

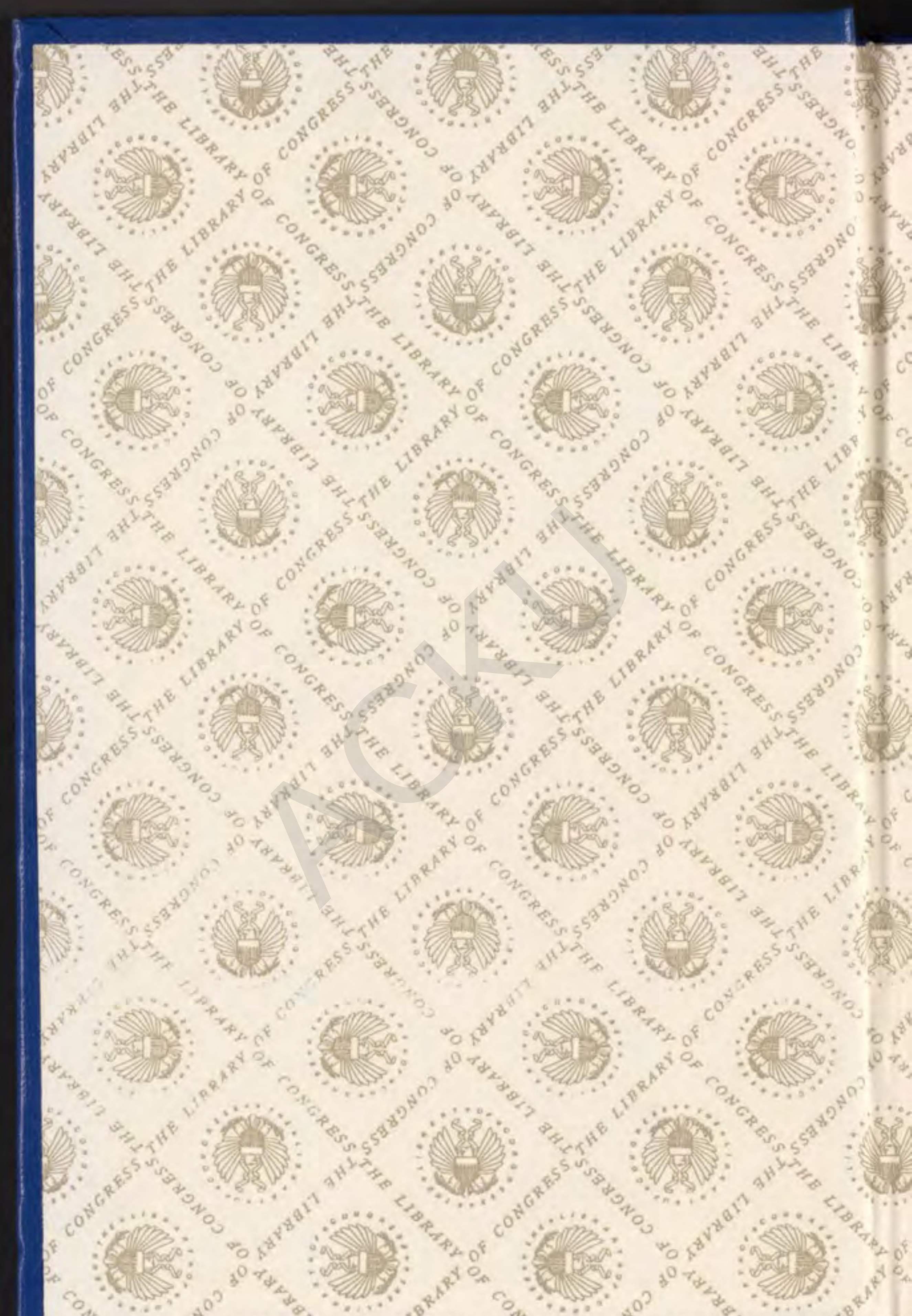


20

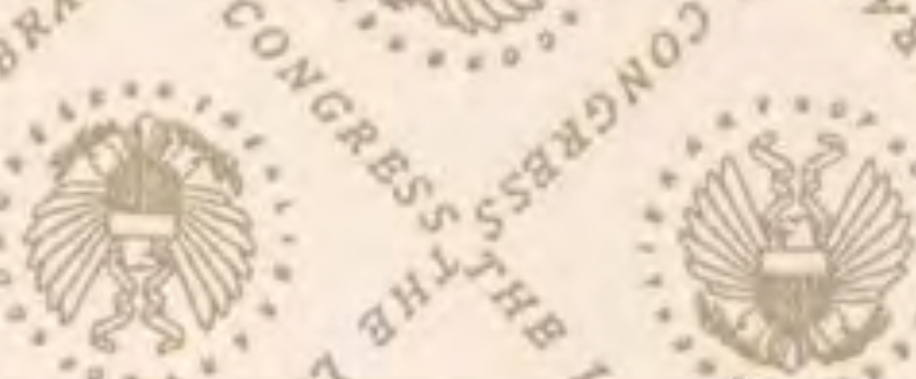

(1) ${ }^{\circ}$

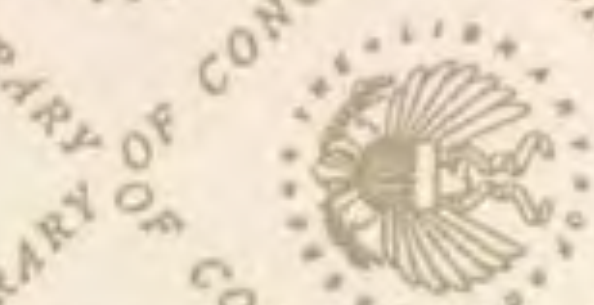

\%

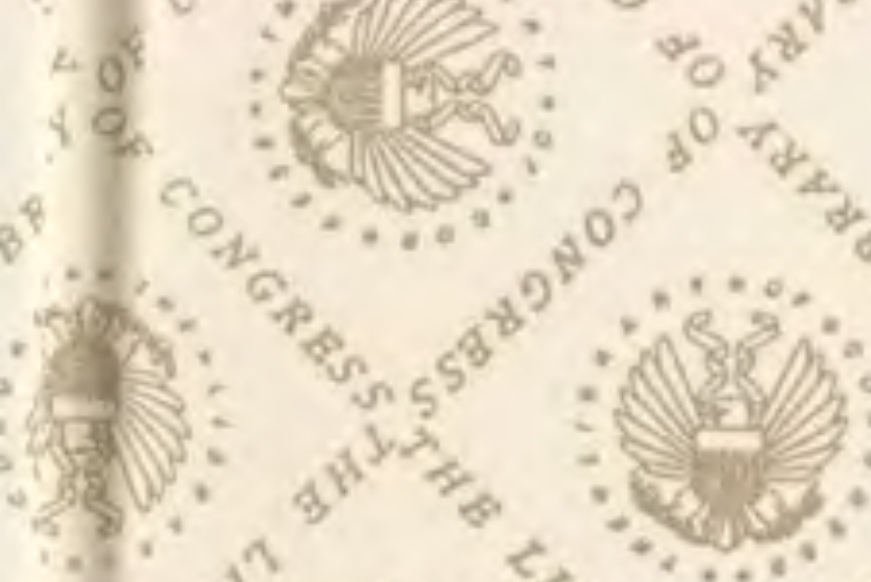

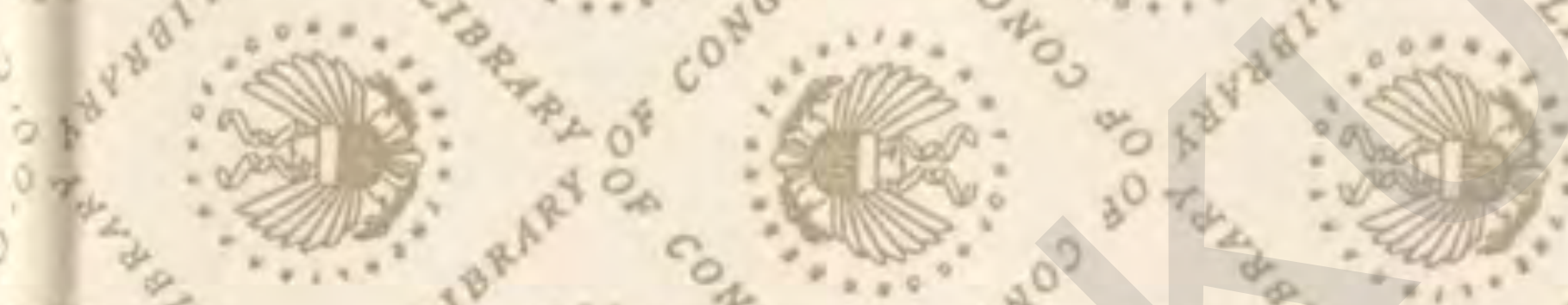

(8)

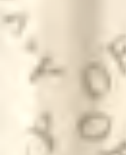

(1) -

(2)

(i)

(1)

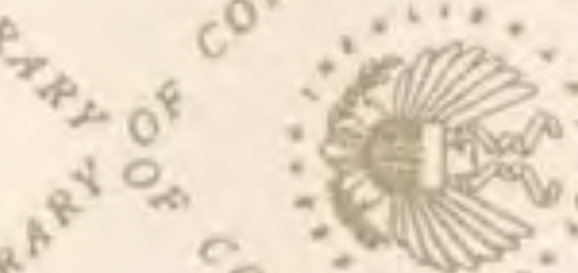

要

81

$\therefore$.

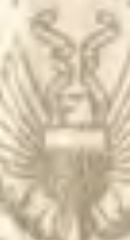

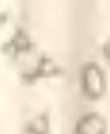

(ve

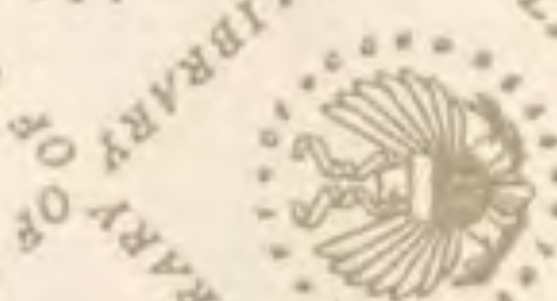

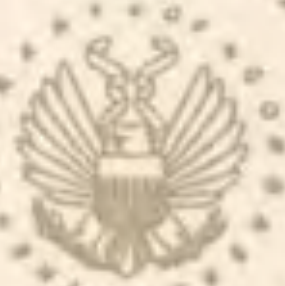

and
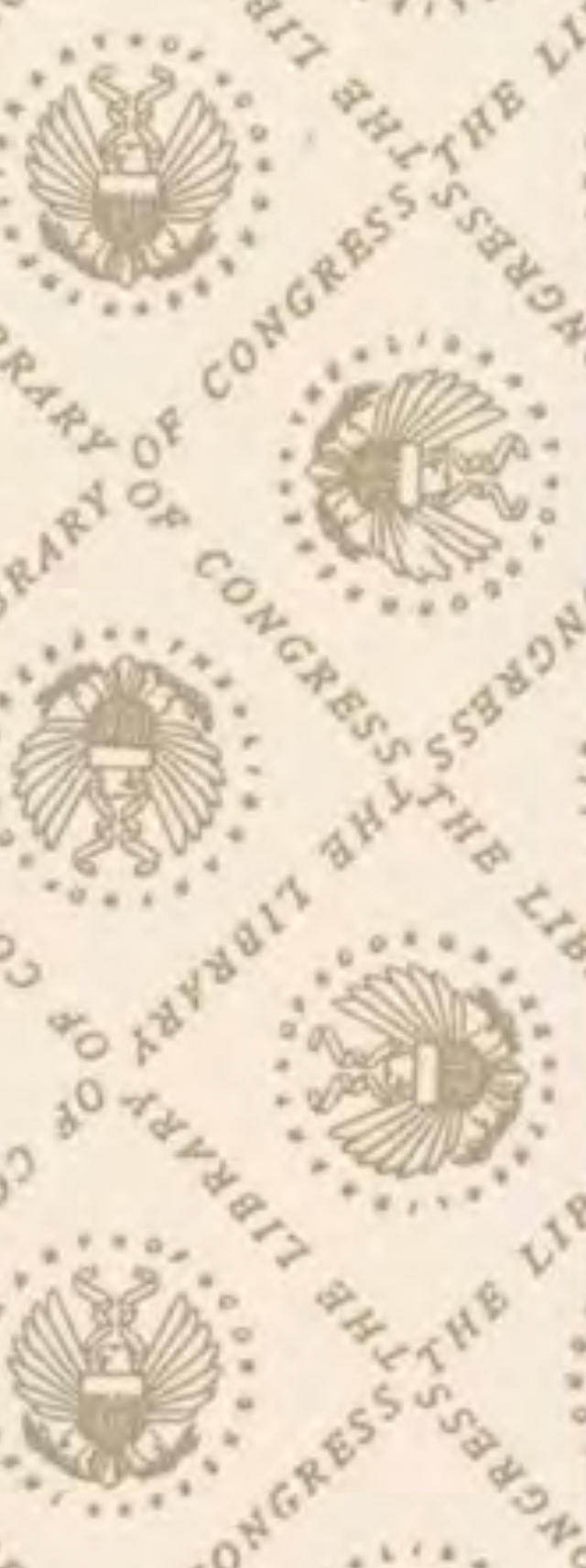

in

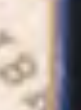






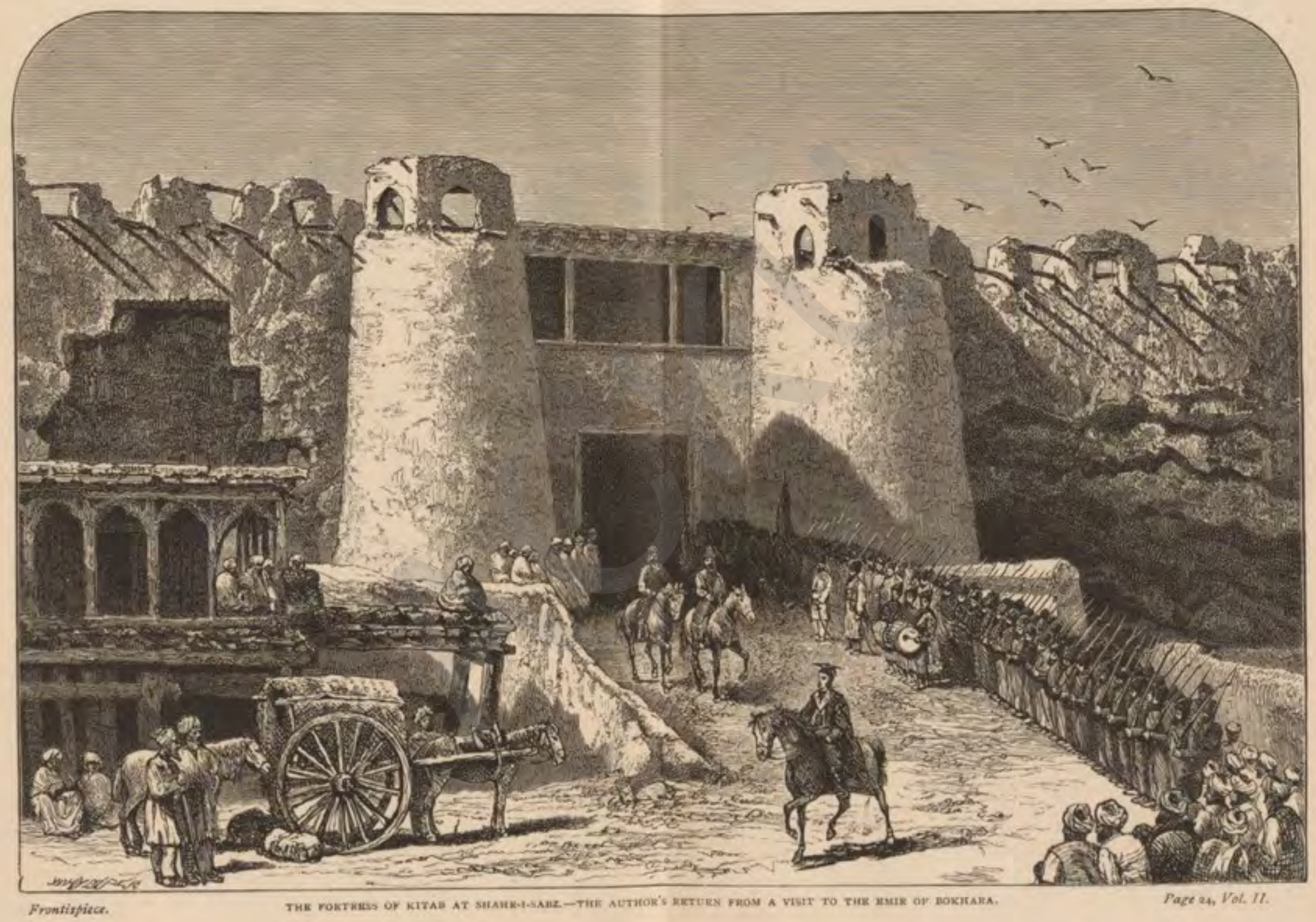





\section{RUSSIAN CENTRAL ASIA}

INCLUDING

KULDJA, BOKHARA, KHIVA $A N D$ MERV

BY

\section{HENRY LANSDELL, D.D. M.R.A.S., F.R.G.S. \\ AUTHOR OF "THROUGH SIBERIA"}

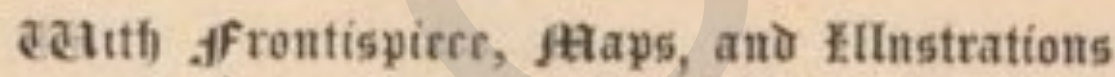

IN TWO VOLUMES..

Vol. II.

Zundon

SAMPSON LOW, MARSTON, SEARLE, AND RIVINGTON I88, FLEET STREET

1885

[All rights reserved.] 


\section{BY THE SAME AUTHOR.}

\section{THROUGH SIBERIA.}

In one Volume, I0s. $6 d$.

LIBRARY EDITION, 2 VOLS., 30 .

For further particulars see p. 685 .

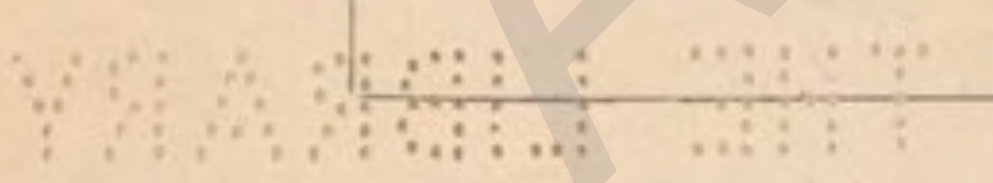

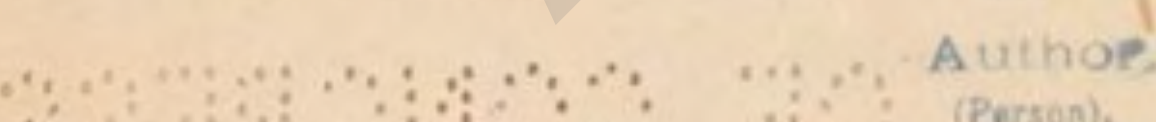

$\therefore \quad \therefore$ :

$12 \mathrm{My}^{\prime} 03$

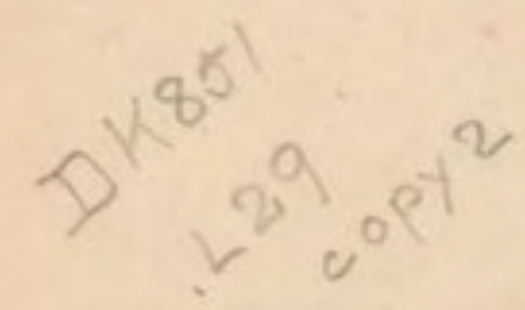




\title{
CONTENTS.
}

\author{
CHAPTER XLV. \\ FROM SAMARKAND TO KITAB.
}

A new country, little visited by Englishmen.-Changed mode of travel. - Tarantass despatched to Karshi. - My retinue.Leaving Samarkand for Kara-Tiube.-Tent lodging in court of a mosque.--Slumbers disturbed.- Journey towards Kitab.Ploughing and threshing.-Forest plantations.-The TakhtaKaracha Pass.-View of Shahr-i-sabz.-Descent to Kainarbulak. - IVelcome from Bokhariot ambassadors. - Kainar refreshments. - Ride to Kitab

\section{CHAPTER XLVI. FROM KITAB TO SHAHR.}

Curious hospitality.-Entertainment by dancing-boys and mountebanks. - Native appreciation of batchas. - Visits from the Emir's court.-Our lodging and spies.-Reception of Bokhariot officers. - Guard of native soldiers. - Dress for an audience with the Emir. - Procession and arrival at the fortress.-The Emir Seid Muzaffar-ed-din.-Various estimates of his character.-Admission to his presence.-My requests and presents.-Refreshment with courtiers.-Princely presents. -Drive to Shahr in the Emir's carriage . . . . .

\section{CHAPTER XLVII. \\ FROMI SHAHR TO KARSHI.}

Historical associations of Shahr.-Visit to the Bek, and his inquiries concerning Kuldja.-Information from courtiers.-Bokhariot weights and measures.--Return of certain presents.--Untrustworthiness of Bokhariot statistics.-Departure from Shahr.The Bekships of Chirakchi, Shir-a-bad, Kobadian, and Kilif,Hissar mountains.-Visit to Bek of Chirakchi.-Burnes at Karshi in 1832 . - Handsome guest-house.-Visit to public bath.-The slave trade in Bokhara.-Visit to Bek of Karshi.Mosques and synagogues . 
CHAPTER XLVIII.

FROM KARSHI TO THE OXUS AND BOKHARA.

Khanate of Bokhara: dimensions, soil, and divisions.-Recent exploration of mountain districts.-Maieff's journeys to Upper Oxus.-Bokhariot recovery of old territory and annexation of new.-Oshanin's exploration of Karategin.-Darwaz.-Bokhariot communications.-Ourdeparture from Karshi.-Kishlaks of semi-nomads. - Khoja-Moburak.-Scamper on my horse "Diotrephes."-Kakir cistern.- "Unfurnished apartments" and oven.-Karaul bazaar.-Lake Kunja.-Stay at Chitarik.Approach to Bokhara .

\section{CHAPTER XLIX. \\ THE CITY OF BOKHARA.}

Bokhara from the earliest times, and afterwards under the Samanids, Seldjuks, and Uigurs.-Bokhara conquered by Jinghiz Khan, Tamerlane, and the Uzbegs. - The Sheibanids, Astarkhanids, and Manghits.-The late Emir Nasr-Ullah.-Visit of Burnes to Bokhara. - Stoddart sent as British envoy. - Concurrent Russian missions. - Conolly enticed to Bokhara and imprisoned. - Stoddart and Conolly killed.-Brave journey of Dr. Wolff.My entry into Bokhara.-Its ancient appearance and customs.Sumptuous lodging and garden.-Bokhariot fruit-trees and horticulture .

\section{CHAPTER L.}

\section{BOKHARA THE NOBLE.}

Bokhara as a place of learning.-Desire to mount a minaret.Paucity of Russian inhabitants and their treatment.-Visits to medresses Kokol-tash and Miri-arab. - Characteristics of Kirghese and Sart music.-Dancing-boys dressed as girls.Misinterpretation of an English song.-Slumbers disturbed by watchmen, dogs, and military parade.-Service in the $F u m m a$ mosque reminiscent of temple worship in Jerusalem.-A Hindu temple.-Gallop round the walls . . . . . . . 86 


\section{CHAPTER LI.}

THE TEWS OF BOKHARA.

My plans concerning the Jews.-Inquiry about the alleged persecutions in Moscow and South Russia,-Russia : how regarded by Western and Eastern Jews.-Oppressed condition of Jews in Bokhara.-Visits to their synagogue, and their sick.Inquiry for Hebrew manuscripts. - Hints concerning their technicalities. -Wonderful manuscript of the Old Testament.Fear of the Jews to receive us,-My letter to the Emir on their behalf .

\section{CHAPTER LII. \\ BOKHARA THE NOBLE (Continued).}

Visit to a primary school.-Method of study.-A ride outside the walls.-Mosque of Namazi-gah,-Visit to the Kush-beggi.The Emir's palace and curiosities.-Conversation with the Kush-beggi and his son.--Some of my requests refused.-Value of presents received.-Visit to the bazaar.-Commerce and trade of Bokhara.-The Righistan.-Bokhara after dark.Standing up for my rights.-Ride towards Katte-Kurgan.-The lepers' quarter.-Fear of punishment.-Return to our lodgings

\section{CHAPTER LIII. \\ SUNDRIES CONCERNING BOKHARA.}

Both guest and prisoner.-Use made of custodians.-Bokhara minerals.-Building materials and garden produce.-Animals and animal products. - The natives and their diseases.-Treatment of the insane.-The rishta, or guinea-worm, and investigations concerning it. - Native method of treatment.Classes of native society.-The Bokhara prisons.-Inquiry as to where Stoddart and Conolly were confined.-Manner of life of the Emir,-His harem

\section{CHAPTER LIV. \\ FROM BOKHARA TO CHARFUI.}

Our generous reception at Bokhara and its cause.-Extra presents to the Emir.-Dr. Schuyler's "Turkistan."-Departure from Bokhara,-End of Zarafshan oasis.-Bokhariot agriculture and horticulture.-Ruins of Peikand.-Approaching Kara-Kul. -Inexperienced postilions.--Lake of Kara-Kul.-The sands of Sundukli.-Our tarantass left behind.-A night's lodging at Betik 


\section{CHAPTER LV.}

\section{CHARYUI.}

PAGK

Departure for the Oxus.-Meeting of Charjui officials,-Our lodging and reception,-Pilau and native bread.-Visit to the Bek,Received with music.-The place of execution, and the prison,-Charjui bazaar and slave-trade. - A Bek's official staff.Administration of the khanate, and taxes.-The governments of the Tsar and the Emir, how respectively regarded by the Bokhariots.-Return from Charjui to the Oxus.- The tarantass regained.-Departure of our two attendants

\section{CHAPTER LVI.}

\section{THE UPPER OXUS.}

Names of the Oxus.-The Englishman Wood, its first explorer.-Its source and issue from the mountains.-Strategical importance of the next reach of 200 miles.-Alleged feasibilily or probability of a Russian invasion of India.-Fords and ferries on the Upper Oxus.-The Oxus at Kilif, and from Khojah-Saleh to Charjui.-Reports on the profitable steam navigation of the Oxus,- The Amu-daria at Charjui,-Our boat for floating down the river

\section{CHAPTER LVII. \\ FROM CHAKYUI TO KABAKLI.}

Prospect of floating 300 miles on the Oxus.-Escort for protection against the Turkomans. - Hydrography of the river.-Journey to Kheradj.--Rough hospitality.--Journey to Ustik.-Description of the river.- Compulsory service of boatmen.-Geological phenomena.-Arrival at Ildjik.- Change of boat and oarsmen.A Bokhariot "Siberia."- Arrival at Kabakli.-Sheep attacked by wolf.-Visit from the Bek

\section{CHAPTER LVIII.}

FROM KABAKII TO PETRO-ALEXANDROVSK.

Hydrography of river to Russian frontier.-Departure from Kabakli. - Ruins on the banks and tugais. - Precautions against robbers. - Fauna of the islands and river banks. - Native information.-Uzbeg notions of a future life.-Singing oarsmen. - The Bokhariot frontier,-Flora of the river islands and banks. -The "Pitniak Curve" and "Lion's Mouth."-A dumb journey thence by horses.-Shurakaneh.-Arrival at PetroAlexandrovsk 
CHAPTER LIX.

PETRO-ALEXANDROVSK AND THE LOWER OXUS.

PAGE

By what route homewards?-The Orenburg and Aralo-Caspian routes.-A social evening at the Governor's house.-Change of weather.-Petro-Alexandrovsk and its institutions.-Proposed desert journey.-Arrival of tarantass.-Distribution of Scriptures.-Results of Bible work in Siberia and Central Asia. -The Lower Oxus and its hydrography: its delta and fall into the Aral.-Fish of the Amu-daria.-Discovery therein of the Scaphirhynchus.-Geological questions concerning it

\section{CHAPTER LX.}

\section{FROM PETRO.ALEXANDROVSK TO KHIVA.}

Departure with the Khivan Consul.-Journey to the Oxus and crossing.-Arrival at Khanki, - Extraordinary sepulchres.Central Asian funerals, - Our lunch and native food.-The Khivan oasis and its dimensions.-Its gardens and principal aryks.-Arrival in Khiva at the house of the Divan-beggi.His antecedents and visit.-Inspection of his premises,-Our visit to the Khan. - Khivan manuscripts and documents.Burnaby's "Ride to Khiva" . . . . . . . 246

\section{CHAPTER LXI.}

\section{THE KHIVAN OASIS AND ITS HISTORY.}

My informants.-Dimensions of the khanate: its soil, geology, and botany.-Khivan melons, and efforts to introduce them into England.-Khivan fauna, inhabitants, revenue, and foreign relations. - Kharezm under the Arabs. - Conquests of Jinghis Khan and Tamerlane.-The Uzbeg khans, and commencement of intercourse with Russia.- - Raids of Cossacks, and expedition of Cherkassky.-Khivan enslavement of Cossacks.-Kazak khans. - Perovsky's expedition and English mediation. Shakespear's conduct of Russian slaves.-Russian capture of Khiva 


\section{CHAPTER LXII. \\ THE KHIVAN CAPITAL AND ITS COLLEGES,}

The sights of the town, including the bazaar.-Central Asian weights, measures, and trade.-Cloisonné turquoise jewellery.Khivan industries. - The medresses of Allah Kuli and Madrahim Khan.-College life.-Classification of students.Character of Muhammadan studies.-The Uzbeg language and kindred dialects, - Russia's responsibility towards Muhammadans.-Pehlivan-Ata mosque and its royal tombs.-Moslem pilgrimages .

\section{CHAPTER LXIII.}

KHIVAN MOSQUES AND THEIR WORSHIPPERS.

Muhammadan religious orders.-Ceremonies of the Jahria Brotherhood.--Superstitious practices.-Dancing dervishes.-Religious condition of Central Asiatics.-Morals of the people.-Fanaticism and indifference.-Their attitude towards the Bible and Christianity. - Importance of missions to Muhammadans, Efforts of "Orthodox" missionaries,-Labours of the Bible Society. - Khiva seen from a minaret.-The winter palace and Fumma mosque.-The prison and gallows.-Home entertainment. - Farewell visit to the Khan.-Hazarasp and its legendary origin .

\section{CHAPTER LXIV.}

\section{FROM KHIVA TO TASHAUZ.}

Departure from Khiva with Khassan the Batchman.-Luggage arbas.-Kosh-ku-pryk and its melons.-Aryk and town of Gazavat.-Russian reconnaissance of Khivan oasis,-Our stay at Shavat.-Amusements of the natives.-Havlis and their supposed resemblance to Scripture " strongholds." -Visit to havli at Manak.-Oil and corn mills.-Hawks for falconry.Mud walls of the havli.-Invitation to stay,-Route to Tashauz

\section{CHAPTER LXV.}

FROM TASHAUZ TO KUNLA URGENY.

Stay in the Khan's palace,-Former condition of Russian slaves in Khiva.-The town of Tashauz.-View from the palace roof.The Khivan climate.-Arrival at Iliali.-Shakhavat aryk to Zmukshir. - The town of Iliali.-A starting-place for the Caspian. - Khivan irrigation. - Our luggage attacked by robbers.-Stay at Ak-tepe,-The Turkoman region.-Accident near Kunia Urgenj 


\section{CHAPTER I.XVI.}

KUNIA URGENY AND NORTHERN KHIVA.

Antiquity of Kunia Urgenj,--Sieges of Jinghis Khan and Tamerlane. -Visits of Jenkinson and other Europeans.-Inspection of -the ruins.- The minarets and mausoleums.-Tombs of Tuirebek Khanim and Sheikh Nejm-ed-din-Kubera.-Khivan communications and routes from Kunia Urgenj.-The town of Hojeili.Settlement, near, of a Mennonite colony. - The town of Kungrad.-Our lodgings at Kunia Urgenj.-Central Asian "home life."-Marriage and divorce.-Life in a royal harem.Seclusion of women,-Need of female missionaries in Central Asia .

\section{CHAPTER LXVII.}

\section{KUNIA URGENF AND PREPARATIONS FOR THE DESERT.}

Delay in getting camels.-A Kirghese court of justice and witnesses. - Kirghese interpreter.-A new servant.-Need of Kirghese literature. - Preparation for the desert; camel cradles; cooking utensils, and provisions.-Arrival of camels and dishonesty of attendants,-Presumptive danger ahead . . . 357

\section{CHAPTER LXVIII.}

\section{FROM KUNIA URGENY TO KUNIA VEZIR.}

Departure from Kunia Urgenj.- - Rest in a Turkoman tent.Forced labour of the Khan.-Dismissal of attendants with presents.-New interpreter and guides.--Our last habitation.Doctoring a Turkoman.- "Turning in " to camel cradles.Rosy's accident. - My ride through the night. - Wells of Karategin.-First caravan breakfast.-Endeavours to hasten the drivers.-Journey in the old Oxus bed.-The dam of Egin Klych.-Ruins of Mashrek.-Pitching our tent opposite Kunia Vezir.-Reference thereto by Abu'l Ghazi.-Jenkinson's forecast.-Routes of other Englishmen from Kunia Urgenj . 


\section{CHAPTER LXIX. \\ FROM KUNIA VEZIR TO SARY KAMISH.}

Order of march and loading camels.-Tragical end of a china basin.-Climbing a camel's hump.-The Oxus bed at Akbugut.-Description of old Oxus bed from Kunia Urgenj.The Butenau plateau and Kazak tombs.-Cliffs of the Ust Urt and traces of Jenkinson.-The Kitchkine-daria.-The pool at Dekche.-Further description of the Oxus bed.-Wells of Sary Kamish.-Correction of Murad for stealing.-Character of guides.-Arrival at Sary Kamish

\section{CHAPTER LXX. \\ SARY KAMISH AND OLD BEDS OF THE OXUS.}

Lakes of Sary Kamish and their characteristics.-Testing specific gravity of water.-Its chemical analysis.-Crossing the lake basin to the Ust Urt. - Jenkinson's alleged "Bay of the Caspian."-Geographical problems respecting the course of the Oxus and Sea of Aral.-Historical discussion and physical investigation.- Testimony of travellers from $1717 .-$ Reconnaissances of Markozoff, Stebnitzky, Glukhovsky, Lupandine, and Petrusevitch.-Four dry Oxus beds.-The feasibility of diverting the Oxus into the Caspian.- The cause of its deflection eastwards .

\section{CHAPTER L.XXI. \\ FROM SARY KAMISH TO KAPLAN KIR.}

Mounting the Ust Urt.-The well Uzun Kuyu.-Saxaul and other fuel.-Bread baken on the coals.-Capture of a gazelle.Remains of sun worship.-Troubles with attendants.-Breakfast on a camel's back. - The wells of Kazakhli.-The bay of Kaplan Kir.-A dry ocean bed.-Kaplan Kir not an island.The wells of Kum-sebshem.-Ascent from the bed of Kaplan Kir 410

\section{CHAPTER LXXII.}

\section{FROM KAPLAN KIR TO KRASNOVODSK:}

Road to well of Seikiz Khan.-Improved prospects, but low spirits. - Search of Bible for illustrative passages.-Lack of domestic comforts.-Revival of hope at sight of Caspian.-Russian itinerary from Iliali to Krasnovodsk.-The pond of Porsu.Gazelles.-The Kara-boghaz and its geography.-A sixteen hours' march.-Oriental customs illustrated.-Fauna of the steppe.-The land tortoise.-Last night on the camel's back.Mouldy bread and tattered garments.-Arrival at Krasnovodsk 


\section{CHAPTER LXXII.}

TURKMENIA.

Turkmenia: its boundaries, area, and surface.-Russian maps with new frontier.-Revision of this and following chapters by M. Lessar.-The Caspian littoral.-The Balkhan, Kuren-dagh, and Kopet-dagh mountains.- The rivers Atrak and Gurgan.Meteorology, flora, and fauna.-The Turkomans : their origin, physiology, and characteristics.-Turkoman tribes: their distribution and sub-divisions.-Habitations, food, and occupations.-Turkoman women

\section{CHAPTER LXXIV. \\ THE TURKMENIAN OASES.}

Oases of Akhal, Attek, Tejend, and Merv.-The Akhal oasis : its dimensions, settlements, and history.-The Attek settlements, history, and hydrography.-The Tejend oasis.-The Heri Rud from Herat to Sarakhs, and below.-The Merv oasis.-The Murgab from Penjdeh.-Unknown country between the Murgab and Heri Rud.-The desert around Merv, and its historical associations.-Merv in the times of Burnes, Abbott, Shakespear, and Wolff-List of Central Asian travellers from the $13^{\text {th }}$ to the rigth centuries

\section{CHAPTER LXXV.}

\section{THE RUSSIAN ADVANCE TO MERV.}

Russo-Turkoman relations from 17 13.-Russian forts on the Caspian seaboard. - Opposition from Kirghese and Turkomans, Russian advance to Kizil Arvat and Chikishliar.-Failures under Markozoff. - Pacification of Yomud Turkomans by Lomakin.-Lomakin's defeats by the Akhal Tekkes.-Skobeleff's campaign and capture of Geok Tepe.-Turkmenia visited by political agents, private adventurers, and a journalist.Journeys of Marsh, Napier, Macgregor, Butler, and Petrusevitch.-O'Donovan's ride to Merv, and extracts from his private correspondence.-Journeys in disguise of Stewart to Khorassan and Alikhanoff to Merv. - Benoist-Méchin's journey from Khiva to Merv . 


\section{CHAPTER LXXVI.}

$M E R V$ AS ANNEXED.

The fortress of Kaushid Khan.-Irrigation and vegetation of the oasis.-Merv Tekkes : their number, divisions, and distribution, with agriculture, manufactures, and trade.-Their religious and moral characteristics. - Their lawlessness at home and atrocities abroad.-Persian slaves.-Submission of Mervis to Russia.Explanations of the Moscow Gazette.-Suspicions of Russian intrigue.-Dependence of Merv on Khiva.-Signs, in $188_{3}$, of coming submission.-Partial opposition to Russian rule.-The present situation .

\section{CHAPTER LXXVII.}

FROM KRASNOVODSK HOMEWARDS.

Descent into Krasnovodsk.-Hospitality of the Commandant.Dismissal of native attendants. - Our rate of travel and itinerary.-Mertvy Kultuk and Kizil Arvat routes.-Visit to Merv abandoned.-The town of Krasnovodsk, and its scanty supplies.-Visit to a Turkoman oba.-Turkoman women and jewellery.-Armenian trading.-Passage across the Caspian.Baku and its oil.-From Baku to Tiflis in a horse-box.-Bible distribution from Tiflis.-Scenery at Batoum.-Voyage to Odessa.-Summary of journey, and farewell

\section{APPENDICES.}

A. The fauna of Russian Turkistan :-

Preface

Mammalia

Aves .

Reptilia .

Amphibia .

Pisces

,

Mollusca .

Araneae .

Crustacea . 
Coleoptera . . . . . . . . 552

Mellifera . . . . . . . . . 562

Sphegidae . . . . . . . . . . 568

Scoliidae . . . . . . . . . 572

Mutillidae . . . . . . . . . . . 575

Formicidae . . . . . . . . 576

Chrysidiformes . . . . . . . . . . 579

Lepidoptera . . . . . . . . . $58 \mathrm{I}$

," of Kuldja . . . . . . . 596

Neuroptera . . . . . . . . . 609

"Odonata . . . . . . 6 6 12

Orthoptera . . . . . . . . 613

Vermes . . . . . . . . 615

B. THE Flora of RUSSIAN TURKISTAN :-

Preface . . . . . . . 618

List of Species . . . . . . . 623

C. Bibliography of Russian Central Asia :-

Preface . . . . . . . . 654

Asia (Central) in general . . . . . . . . 659

Bokhara . . . . . . . . 667

Khiva . . . . . . . . . 668

Khokand . . . . . . . . . . . 670

Kuldja . . . . . . . . . . 671

Siberia-Western . . . . . . . 673

Turkistan . . . . . . . . . . . 674

Turkmenia . . . . . . . . 677

Maps illustrative of Central Asia . . . . . 679

Alphabetical List of Authors . . . . . . 681

GENERAL INDEX . . . . . . . . . 685 


\section{LIST OF ILLUSTRATIONS IN VOL. II.}

PAGE

THE FORTRESS OF KITAB AT SHAHR-I-SABZ-THE AUTHOR'S RETURN FROM A

VISIT TO THE EMIR OF BOKHARA

Frontispiece

ETHNOLOGICAL MAP OF RUSSIAN CENTRAL ASIA, INCLUDING KULDJA,

BOKHARA, KHIVA, AND MERV, WITH AUTHOR'S ROUTE, AND SHOWING

THE LOCALITIES INHABITED BY RUSSIANS, KIRGHESE, TURKOMANS, UZBEGS, TAJIKS, AND CHINESE RACES + * * * To face THE BAZAAR, OR MARKET PLACE, OF KITAB * . . . . * . . 23

SEID MUZAFFAR-ED-DIN, EMIR OF BOKHARA . . . . . . . . 27

RUINS OF TAMERLANE'S PALACE AT SHAHR-I-SABZ, AND REVIEW OF BOKHARIOT TKOOPS

THE COURT MOSQUE AT KTTAB . . . . . . . . . .

TOMB OF ABDULI.AH KHAN AT BAHA-UD-DIN . . . . . . , 70

GROUND PLAN OF THE PRINCIPAL. GUEST-HOUSE AT BOKHARA . . . 8 .

FNCAMPMENT OF BOKHARIOT SOLDIERS . . . . . . . . . . 93

MEDRESSE OF ABDUL AZTK KHAN . . . * . . . . . . . 99

A JEW OF CENTRAL ASIA * , . + . . . . . . . III

A JEWESS OF BOKHARA . . . . . , . . . . . . 113

A TIBETAN COW AND NATIVE KEEPBR * * . . . . . . . $\mathrm{r} 43$

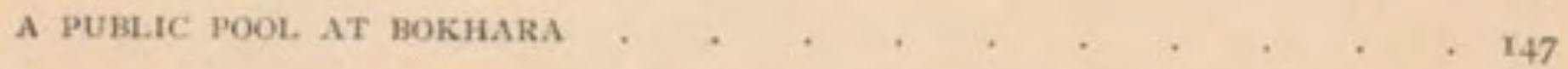

THE AUTHOR IN ROBE OF HONOUR, WITH TURQUOISE BRIDLE, PRESENTED

BV THE BMIR OF BOKHARA . . . , . . . . . . I6r

CRNTRAL ASIAN MUSICIANS . + . . , . , . ., 82

VIEW OF KHIY WITHIN THE OUTER WALL + + . + . + , 253 
SEID MUHAMMAD RAHIM, KHAN OF KHIVA + . . . . . . 260

THE WINTER PALACE OF THE KHAN AT KHIVA + . . . . . 281

THE MEDRESSE MADRAHIM + . . . . . . . . . . 289

THE GREAT MINARET OF KHIVA + . + . + . . . . 291

MINARET OF THE MOSQUE SEID BAI . . . . . . . + . . 306

KHIVAN TAMBOURINE MUSIC . . . . . . . . . . 309

THE HAZARASP GATE AT KHIVA + + . . . . . . . . 3I

A KHIVAN ARBA. . . . . . . . . . . . . $3^{17}$

GROUND PLAN OF A KHIVAN HAVLI . . . . . . . . . . 324

A CENTRAL ASIAN CORN MHL . . . . . . . . . . 325

THE MINARETS OF KUNIA URGENJ + . . . . . . . . 343

THE TOMB OF TIUREBEK KHANIM . . . . . . . . . . 345

A KIRGHESE EQUESTRIENNE . . . . . . . . . . . 360

A KIRGHRSE "FLITTING" . . . . . . . . . . . $388 \mathrm{~V}$

TURKOMAN TENTS NEAR KRASNOVODSK, ON THE SHORE OF THE CASPIAN * 446 THE FORTRESS OF KRASNOVODSK . . . . . . . . . . 497

GOVERNOR'S HOUSE AND STORES AT KRASNOVODSK. . . . . . 498

"OFF sukUM Kall." (From an oil painting by Aivasouski, in the possession of Dr. Lansdell) . 


\section{OBSERVANDA.}

IN proper names the letters should be pronounced as follows:$a$ as in father; $e$ as in there; $i$ as in ravine; $o$ as in go; $u$ as in l $z$ nar; and the diphthongs $a i$ and $e i$ as $i$ in hide. The consonants are pronounced as in English, save that $k h$ is guttural, as $c h$ in the Scotch loch.

Unless otherwise stated :-

I. The dates are given according to English reckoning, being in advance of the Russian by twelve days.

2. English weights and measures are to be understood.

3. Degrees of temperature are expressed according to the scale of Fahrenheit.

The ordinary paper rouble is reckoned at two shillings, its value at the time of the Author's visit ; but before the Russo-Turkish war in 1877 , it was worth between half-a-crown and three shillings.

The Russian paper rouble-(or roo kopecks) equals 2 shillings English.

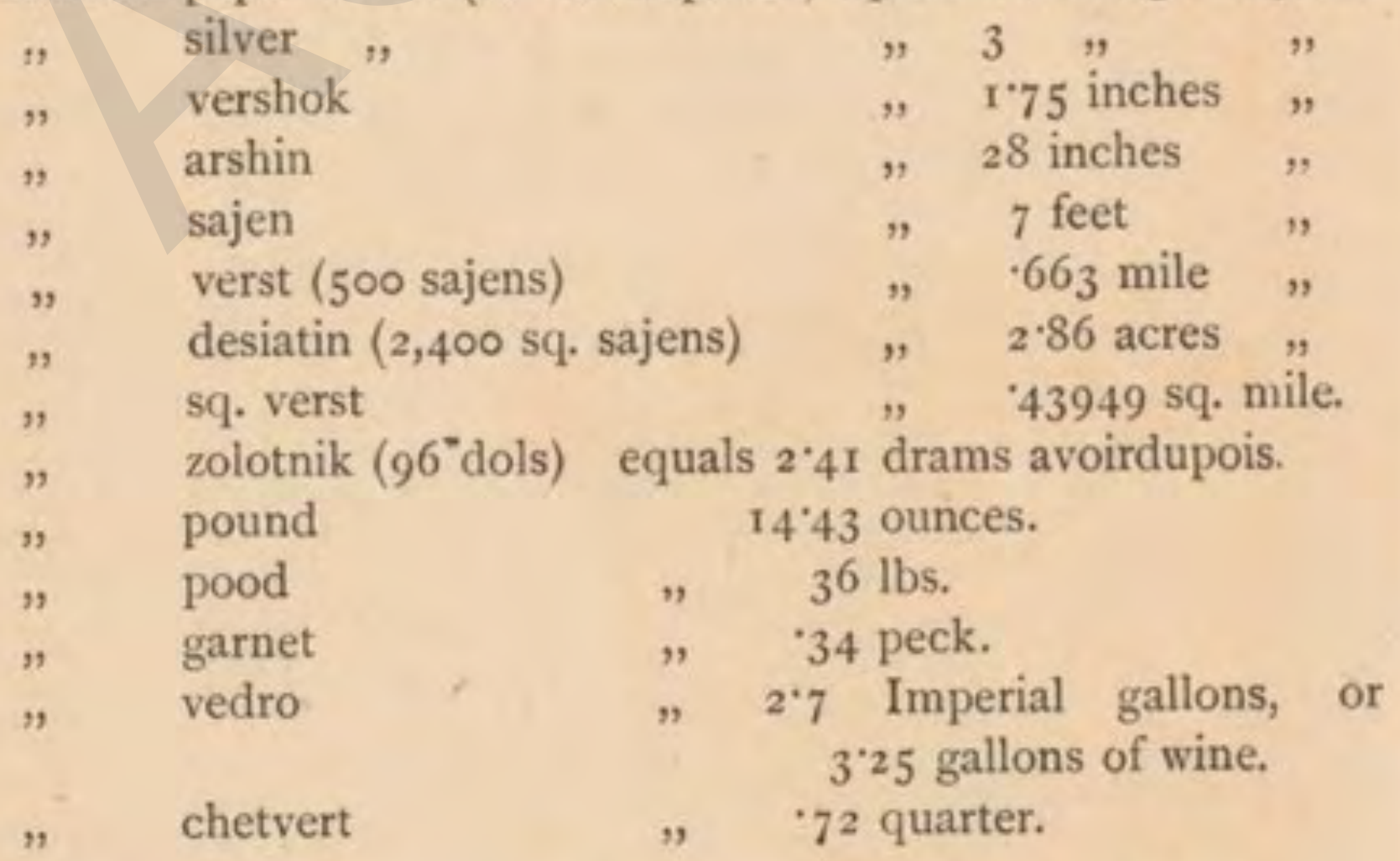

For Asiatic Moneys, Weights, and Measures, see Vol. i., p. 682 


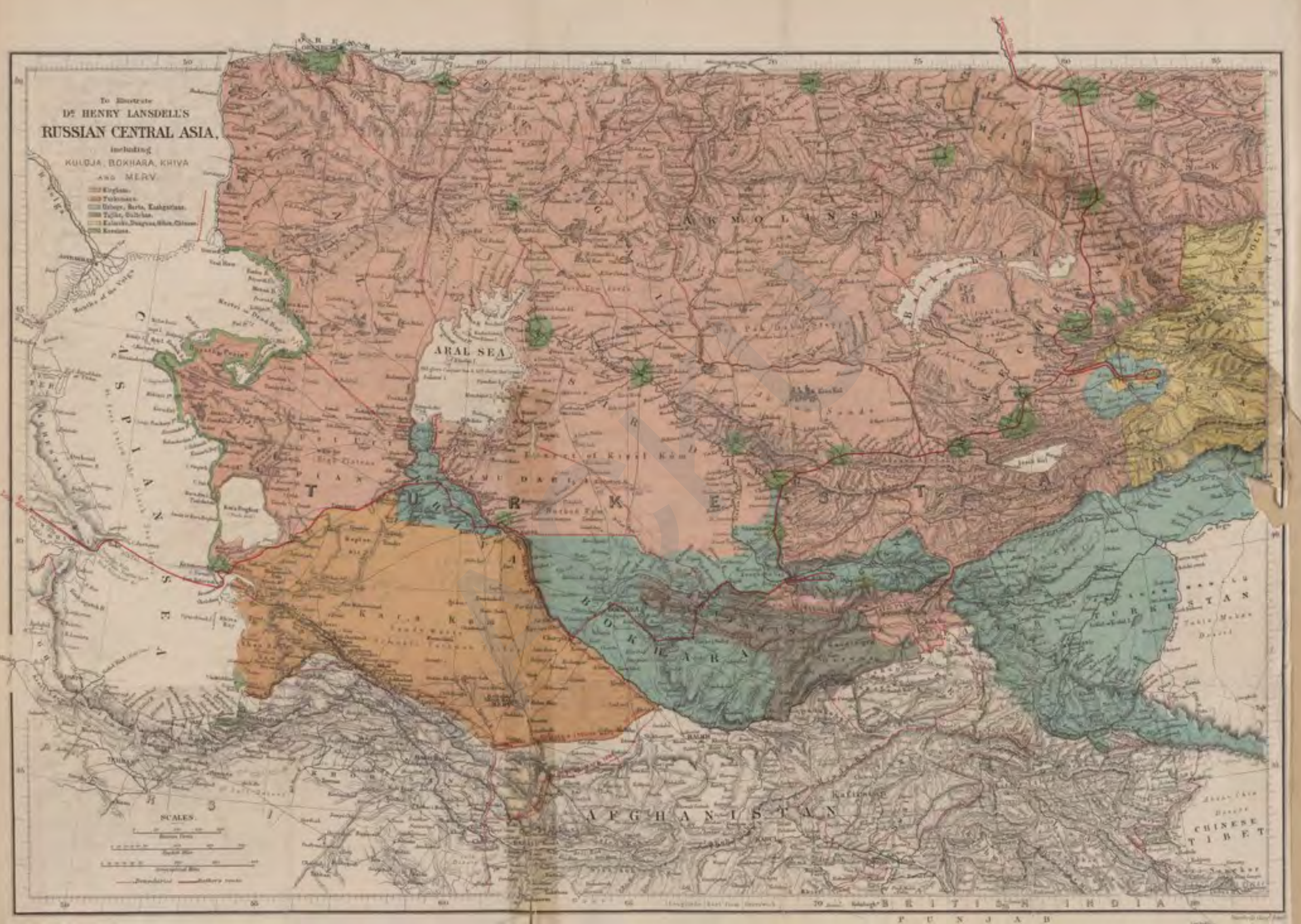




\section{RUSSIAN CENTRAL ASIA,}

INCLUDING

KULDJA, BOKHARA, KHIVA, AND MERV.

CHAPTER XLV.

FROM SAMARKAND TO KITAB.

A new country, little visited by Englishmen.-Changed mode of travel. - Tarantass despatched to Karshi.-My retinue.-Leaving Samarkand for Kara-Tiube.-Tent lodging in court of a mosque.-Slumbers disturbed.- Journey towards Kitab.--Ploughing and threshing. -Forest plantations. - The Takhta-Karacha Pass.-View of Shahri-sabz.-Descent to Kainar-bulak.-Welcome from Bokhariot ambassadors.-Kainar refreshments.-Ride to Kitab.

THUS much in regard to Russian Central Asia, which is the main title of this book. Now we enter on a different district-Bokhara, Khiva, and Turkmenia - and with change of scene comes, in a measure, change of treatment. When preparing to lèave Samarkand I was conscious of making a distinctly new departure. One Russian officer had expressed surprise that I did not travel with a servant. I decidedly preferred not to do so on Russian soil, but now I was to start as a proprietor of horses, with two interpreters and two mounted

VOL. II. 
attendants - a cavalcade of five, that afterwards increased sometimes to a dozen. Further, my tarantass, with all my personal conveniences, was no longer to be the chariot in which we could roll along in comparative ease, but, at the outset at all events, my baggage had to be reduced to a minimum, and myself to take to the saddle. The tarantass was to be sent by a carriage-road through Djam to Karshi, a distance of 94 miles, and it was not easy at first to decide what things were so necessary or so valuable that they must be taken with me; but when all was in readiness there were 16 packages to be placed in the carriage, besides such as could be locked up. The common cart of the country is called an arba, and the man who drives it an arba-kesh. One of these men had undertaken to get my tarantass to Karshi for $£_{4}$, and there await my coming, asking, however, for three-fourths of the pay in advance.

For some reason I did not clearly understand, the arbakesh insisted on taking the wheels off the tarantass and mounting it on an arba. I confess to having some qualms about committing "my little all" to the care of the man, especially in a new country where I should be unable to invoke the aid of a friendly tchinovnik if things went wrong. A happy thought occurred, however, when all was in readiness, respecting the importance attached by Easterns, and for that matter by Russians too, to a seal. Taking light and wax I solemnly sealed up the curtain and hood, in the presence of the arba-kesh and his helper, and then called them in to put each " his mark" to a receipt for the tarantass and its contents. I afterwards heard that the natives were frightened by this formal proceeding, especially as it took place in the house of the 
Governor, and they drew from the transaction precisely the inference I intended, that they had some thing important committed to their charge, and must mind what they were about with it. My tarantass then rolled out of the yard like a miniature locomotive on one of Pickford's trucks, after which, on October 2nd, I placed my foot in the stirrup, as Tamerlane used to say, when leaving Samarkand, and went forth to conquer.

The two djiguitts, named Kolutch and Fazul, were both Uzbegs, and dressed in long robes and white turbans. They were to accompany us, if I pleased, as far as the Oxus, but they were provided with little luggage, for it was all stowed away in saddle-bags. Fazul could speak no Russian, and, so far às information was concerned, was of little service; so I sent him forward to accompany the man who had charge of the sumpter horse, which had been hired from the bazaar at $2 s$. a day to go with us as far as Karshi. Kolutch, the other djiguitt, was a man of more character, and, for an Oriental, had a considerable amount of "go " in him; too much, I fancy, for the natives, over whom he appeared occasionally to lord it, but he was faithful to me and mine. Our Tatar interpreter was one Suleiman Yakooboff, whom we surnamed "Yakoob."

Leaving the Governor's palace, and its kind hospitality, we passed the tomb of Tamerlane, and saw the Russians at work on the exterior of the dome, and then left Samarkand by what used to be the Khoja Akhrar gate, so called after a celebrated saint of that name, but now thrown down. Just beyond there sat a woman by the wayside begging, who rose and lifted her veil, to show the white leprous spots on her face;*

* Like the four leprous men at the entering in of the gate of Samaria, who said, "Why sit we here until we die" (2 Kings vii. 3 ). 
-the last woman's face I was to see for some time, for over the border they were all veiled. Our route lay through suburban gardens, with fruit-trees hanging on either hand over the walls, till we reached the Ankhor aryk, where the steppe commences, with hillocks here and there, but bare and lifeless, except where covered with thorny bush. Our first day's journey was to be only as far as Kara-Tiube, a distance of 21 miles. This was so arranged in order to give us an easy start before entering on the country beyond, which was said to be unusually difficult. We were warned of this at our last lunch at the Governor's house, and heard that some officers had even discussed whether we should accomplish the mountain pass at all; but my national vanity was flattered to hear that one of them said, "Oh, yes, they will succeed, for they are Englishmen; and what the English begin they carry through." It would not have done to break down after this; but as I was not in bed till half-past one the night before, and had risen at six in order to pack, I was not sorry that the first day's journey was to be only an afternoon ride.

About halfway to Kara-Tiube the road crosses a deep ravine with steep banks, and we had been told that the remains of Tamerlane's camp were still visible. Neither Kolutch nor Yakoob had ever heard of them, however; and though we did see certain mounds of earth apparently artificial, I should think them more likely to be connected with former irrigation works than with Tamerlane. Fifteen miles from Samarkand we came to the Russian summer camp, where the soldiers were exercising, and singing as they marched. One of the things that struck me was the ranks of sham men they had put up to shoot at for a 
review on the day following. Yakoob informed us, in proceeding, that the correct thing was for me to go last, and the djiguitt a little distance on ahead ; but, however correct, this had one disadvantage for me, namely, that I caught all the dust kicked up by those preceding me, and against this I soon revolted. Again, it is considered by the Asiatics more dignified for a great personage to let his horse walk or amble than to galop. Yakoob said my stallion had been doing no work of late, and, therefore, begged I would not ride too fast the first day; but my steed was like to a fed horse in the morning, neighing wherever he went, and impatient of restraint; so I let him go. Mr. Sevier's horse took the cue from mine, and we thus frequently left Yakoob and Kolutch for a while behind. We had a fair wheel-road to within 5 miles of our destination, but on reaching the foot of the mountains it became little more than a path, though still practicable for carriages. We mounted the first range of hills, and had from the summit a fine view of the valley beyond, and of the plains we had left behind. Notice of our coming had been sent forward to the chief of the volost, who, as we approached Kara-Tiube, came out to meet us, and conducted us to the courtyard of a mosque, where a tent was put up for our use. We had left Samarkand at 2.15, and completed our 21 miles in $3 \frac{1}{2}$ hours.

Kara-Tiube lies in a hollow among the lower hills of the Samarkand range, and under native rule possessed a frontier fortress. The Emir made it a centre of operations during his war with the invading Russians. The fortifications were destroyed by General Abramoff, in 1868 . I could not help thinking what a change had come over the scene in a dozen years, for I suppose 
that, previous to the advent of the Russians, the Mussulmans from choice would hardly have tolerated the presence of an "infidel" in their midst ; whereas now they were entertaining us in the courts of their mosque.* The tent was nicely carpeted under foot with handsome bands around, though the roof and sides were somewhat the worse for wear-one rent, in fact, being opened to admit light. Yakoob said that he would close it when we were going to sleep. Till then it would help to air the tent, he said, utterly oblivious that there was too much air for my liking already. Here we ate our first meal prepared by the natives, beginning with sweetmeats, and going on through soup, native bread, grapes, and pilau, made of meac and rice.

As we intended to start early next morning, we soon got ready after dinner for bed. I set my alarum, and placed my revolver under the pillow. But, though tired, it was not so easy for me to sleep. Just outside the djiguitts were talking, and sending round their gurgling kalian, or water-pipe, the horses were restless, sundry dogs barking and whining, as well as stallions fighting. My first sleep was disturbed by a rattling of plates, due, it soon appeared, to an intruding tom-cat. I quickly drove him out, and, being thus on my feet, looked outside the tent. There lay Yakoob and the djiguitts asleep and covered, but in the open air, as an ordinary thing, and, all around being quiet, I turned in again, to be disturbed within an hour by another cat getting on the table, knocking over a candlestick, and stopping my alarum. Of course, I blessed every member of the feline race, gave chase

* We were not again lodged in the courtyard of a religious building, but it served to recall the Israelites in captivity, who "made themselves booths, every one upon the roof of his house, and in their courts, and in the courts of the house of God" (Neh. viii, 16). 
again, and re-set my alarum, of which I then heard no more till it awoke me early next morning, not so stiff as I expected to be, and ready to set things astir.

Our second day's journey was to Kitab, a distance of 22 miles over the Takhta-Karacha Pass, for which we set out at half-past seven o'clock. The road threads the defile of Katta-Sai, in which flows a turbulent little mountain stream of the same name. Following the windings of this, and occasionally crossing it, we saw from the road a tiller of the soil, with a yoke of oxen and a plough, that from its primitive form might have served for Elisha the son of Shaphat.* Somewhat further on we saw a good illustration of the threshing-floor, of Ornan the Jebusite. The grain, instead of being thrashed, is trodden out by oxen or horses, on a space specially prepared, termed khirman. In this case two oxen only were employed, and their treading power was economized more ingeniously than pleasantly, I should imagine, to one at least of the pair. One ox was fastened to the off end of a pole, that worked on a pivot in the centre of the floor, a boy holding on to his tail as to a rudder, and thus providing for the circumference of the floor, whilst the second ox, with his hinder parts in the centre and his head tied to his fellow, by means of a crab-like motion trod the central area. $\dagger$

* The saban, or two-pronged plough of Central Asia, is a sharpened block of wood, tipped, it may be, with an iron point, and fastened at a sharp angle to a long pole. On the front of this pole is laid a beam, or yoke, about 7 feet long. Cords are let into this at either end, and the oxen are made fast. The ploughman holds on to a fork, let into the pointed beam, and the implement turns up about 7 inches of earth. In the case I am describing it appeared to be easily guided by one hand through a light soil. Harrowing is effected by means of a comb made of a beam, in which are fastened long wooden teeth. It is drawn by a pair of oxen. In order that the harrow may go deep into the soil, two or three men stand on it, whilst the animals draw it over the field.

+ The oxen were not muzzled (Deut. xxv. 4), and the abundance of 
For some distance the rise towards the pass was very gentle. Before the climbing began in earnest, we called a halt at a poor little uninhabited caravansary, Aman-Kutane, where we ate bread and melons to fortify us for the coming steeper road. Here was one of the plantations mentioned by General Korolkoff, which the Russians place on the mountains to keep the soil from washing down.*

Nor was this the only vegetation. So long as we kept near the stream there were considerable patches of grass, and we passed a collection of mud huts and tents inhabited by semi-nomads who tilled a little ground. Across the stream we saw the women weaving, and a narrow texture stretched on the ground. On losing sight of the stream, we left vegetation behind, and had to climb a narrow path, almost a rude staircase, of stones and boulders, to a height above the sea of about 5,200 feet.

food placed within their reach was reminiscent of the language of Hosea x. 1t., "Ephraim is as an heifer that is taught, and loveth to tread out the corn." I did not see in Central Asia an implement that I observed in the Trans-Caucasus, which made clearer to me a verse in Isaiah, where the prophet says (xli. 15), "Behold, I will make thee a new sharp threshing instrument having teeth." Among the Armenians, I saw in use in 1880 an instrument suggestive of the Latin tribulum (whence our word tribulation), a heavy plank, or threshing sledge, studded on one side with angular, tooth-like pieces of iron and flint, about an inch high. The plank was widened at one end, for a man to stand on, and narrowed and raised at the other for an animal to be attached; and this instrument, dragged over the floor, not only beat out the corn, as did the treading of oxen, but cut up the straw. The whole detritus was then swept in a heap, and tossed into the air by shovelsful, when the corn fell on the earth, and the rest "became like the chaff of the summer threshing-floors," which the wind carried away (Dan, ii. 35).

* The surplus trees raised for this purpose are given to the natives, who readily undertake their culture. The year I was in Samarkand they had distributed $1,000,000$, and in the following spring expected thus to give from $2,000,000$ to $3,000,000$ of saplings. Of the various 
We were now on the crest of the mountains of Kitab, a continuation of the Hissar range, that separates the Zarafshan province from Bokhara. From the broad platform of rock, about 30 paces wide, we looked back on the dry and arid steppe we had crossed from Samarkand, but before us the scene was of a more pleasing character. There lay on either side of the Kashka-daria the twin towns of Kitab and Shahr, called together, from the number of its trees and gardens, Shahr-i-sabz, or "the green city." The beauty of the landscape from this spot had been extolled by Colonel Alexandroff, who lunched with us the day before we started. To an Oriental this view would be, no doubt, exceedingly pretty, and to an European tolerably so ; but it was nothing compared with that obtainable from scores of places in England, to say nothing of mountain scenery in Switzerland or the Caucasus,

We had now to descend by a far steeper track, over bare rocks of granite and gneiss, the path leading by a cornice, excessively sinuous and obstructed, with round stones that rolled down the precipitous slopes. I judged it best to give my horse full liberty to choose trees and shrubs cultivated by the Russians, the General mentioned to me a variety of Poplar (P. alba pyramidalis, also called $P$. boleana), almost unknown in Europe, but common in Central Asia, where it attains, in from 15 to 20 years, proportions fit for building, and is sold from $10 s$, to $16 s$. the tree. Elm is used for making arbas, as also sometimes is almond wood, but not often that of the wild nut. They have introduced also several kinds of conifers, among them Thuya Orientalis, which does not grow so large as in Europe, though it attains to 70 feet. To these may be added the white and black Mulberry ( $M$. alba et nigra), especially the former for silk culture; and many European kinds of fruit-trees, especially Apples and Pears, which attain only moderate perfection, as cultivated by the Sarts, and Raspberries, which I understood the natives do not cultivate at all. More than 12,000 fruit-trees were grafted the year of my visit, and were to be given to the natives. 
his own path, and so did Sevier. It was amusing sometimes to see the creatures after they had chosen a track, and found it more difficult than was anticipated, hark back and try another. I did not, at the time, think of the danger we ran, if a horse stumbled, of breaking one's skull against the jutting rocks on every hand; but when reading from Dr. Schuyler that only one of his party had a sufficiently strong head to make the whole descent on horseback, it occurred to me that we should have done more wisely to dismount and allow the horses to be led. On completing the descent among the rocks, where the path was barely wide enough for two horses to pass, and issuing from the Takhta Karacha defile, the road widened as we approached Kainar-bulak, our first Bokhariot village.

We were now only 7,500 paces, or say five miles, from Russian territory, where one may find the newest outcome of the intelligence of the nineteenth century, yet we seemed to have dropped from the clouds among men and things 3,000 or 4,000 years behind. If what we saw among the Kirghese recalled the days of Abraham, the new experience brought to one's thoughts a number of messengers despatched by one of the kings of Israel. We were met by the Bek, or Governor of the district, also a military officer sent direct from the Emir, with several others, wearing turbans of spotless white, and clad, one in striped silk, another in a robe of cloth of gold, and all mounted on gaily caparisoned horses. They had come to inquire for the welfare of various personages, to receive and welcome me, and put a series of questions respecting my health and my journey. After shaking hands and saluting me with an Aman, the Bek proceeded to ask in stereotype fashion, "Is the Emperor well? Is the 
Governor-General Chernaieff well? and is General Abramoff well?" This was spoken in Turki to Yakoob, who put it to Sevier in Russ, after which it reached me in English. I replied that, when I passed through Petersburg, his Imperial Majesty was well, also that in Petersburg I saw General Chernaieff, who was well, and that General Abramoff, whom we had recently left, was in good health. This principal messenger, having completed his ceremonious inquiries, moved on in front, and the old general or colonel came up to announce that the Emir had sent him to say that he was very glad we had come, that he hoped I was not greatly exhausted by the difficulties of the way, and begged us to take refreshment in Kainar.

Kainar is a kish-lak, or village, as it is usually rendered, though the word literally means winter quarters, just as lai-lak means summer quarters. In summer quarters the habitation used is a tent, but in winter quarters it is often a mud house, which in summer is deserted or turned into a store. In the present instance we were conducted through the yard of what I suppose was the Bek's house, our horses picketed to a circle of posts, and ourselves shown into a room where was a table evidently rigged up for the occasion, and groaning beneath a dozen, if not a score, of trays of grapes, sweetmeats, almonds, sugared nuts, melons, and other kinds of fruit. Upon these I concluded we were to make a meal, and I began the attack, till it appeared these things were only by way of pudding and sweets presented in inverse order to English fashion, and to be followed by more substantial dishes of meat, boiled chicken, and rice. This was a lesson for me, and so was the next performance in clearing the table; for whereas, at home, one is brought 
up to "eat what you please, but pocket none," in Bokhara it is expected that you eat what you can, and pocket the rest. All was to be mine, and I found that Yakoob, the djiguitts, and attendants were ready to accept the remainder as a perquisite, and stow away the same in their bags.

We were left to partake of refreshment alone, and when the envoys subsequently entered, I showed to him who appeared to be master of the ceremonies the letter I had received from General Chernaieff, whereupon he spoke to me about seeing the Emir on the following day. For the information of the Emir our names had to be entered in a book, the hour we arrived, and when we departed, with particulars of our visit. They asked how soon we meant to start for Kitab, whereupon observing that it was 1.45 p.m., I replied, "In I 5 minutes"; but this was contrary to their notions, and they wished to put down 3.0 as the hour of our departure, "so that it might look to the Emir as if we had been well entertained." Not that they cared, however, that we should wait, and our horses were accordingly made ready.

It was five miles further to Kitab, along a carriageable road, through an inhabited district. On starting, our escort increased, and we were preceded by a score or so of horsemen, who smothered us with dust. I begged them, therefore, to go on far ahead. This dispersed the crowd, and we rode along to Urus (or Russian) Kishlak, and beyond we forded the River Kashka. Soon afterwards we approached the mud wall, 53 miles long, which once surrounded Shahr-isabz, and included, besides Kitab and Shahr, several villages, with fields and gardens. These entirely occupied the whole space within the wall. In winter 
a large part of the neighbouring country is under water, and even in the dry season unhealthy swamps abound. We had to approach the citadel of Kitab by a narrow street, with water and mud up to the horses' knees, the Colonel, in cloth of gold, having motioned me to his side to enter the town with something like state. As we passed along, the people rose and saluted the Colonel with a "Salaam aleikum," or "Peace be with you," but not bowing so servilely as at Khokand. Other mounted officials now came to present themselves, and formed a cavalcade that brought us at last to what was to be our lodging. I had read that it was a point of Bokhariot etiquette as to how near one should ride up to a palace or great house before dismounting. My retinue, I observed, alighted outside the street gates, but we were conducted on horseback "right in" the courtyard, and then, having dismounted, were shown into our room. 


\section{CHAPTER XLVI.}

\section{FROM KITAB TO SHAHR.}

Curious hospitality.-Entertainment by dancing-boys and mountebanks. -Native appreciation of batchas.-Visits from the Emir's court. -Our lodging and spies.-Reception of Bokhariot officers.-Guard of native soldiers.-Dress for an audience with the Emir.-Procession and arrival at the fortress.-The Emir Seid Muzaffar-eddin.-Various estimates of his character.-Admission to his presence. - My requests and presents.-Refreshment with courtiers. -Princely presents.-Drive to Shahr in the Emir's carriage.

$\mathrm{O}$ UR house at Kitab was certainly not a mansion, for the principal room measured only about 12 feet by 10. Perhaps lack of space was meant to be atoned for by abundance of air, for there were 6 doors, and over 3 of them unglazed lattices. We learned, however, that hereafter we should be lodged in better guest-houses, but that few embassies came to Kitab. Soon after our arrival we were asked what we should like to do. I replied that we wished to see the town, and that I should be glad if we could find some coins and other antiquities or curiosities. I had been told by the Russians that the shortest space etiquette would allow of our staying at Kitab would be three days, and this was the time I told them when they asked how long I should remain their guest. My answers were reported to the Emir, and his messenger came back to 
say that they thought we should stay at least a week, that my wish for coins should be attended to, and that we could see the town after our audience with the Emir.

On our arrival we had found, as at Kainar, the table laden with trays of sweets and fruits, and, in addition, there awaited me, as a present, at least half-a-dozen loaves of white sugar, and as many boxes of sugarcandy, both imported from Russia. I soon voted my own tea preferable to the green tea drunk by the natives, and, after taking refreshment, found that we were to be entertained that evening by a grand performance of musicians, batchas, and buffoons. At dusk the scene was lighted up with 25 lamps, and we were to sit under a spreading vine that formed a rustic balcony at the back of the house, and from thence to see the fun. Three men, with tambourines, sat near a charcoal fire in a brazier, over which, from time to time, they held their instruments to tighten the parchment. Presently four boys, or batchas, arrived, and were presented to us as the artistes of the evening; and whilst they were drinking tea and eating fruit, the tambourines, increased to five, began to sound and the men to sing. The batchas were dressed in red, flowing robes, with loose, wide trousers, but had their feet uncovered, their most striking peculiarity being their long hair, like that of girls. In the first dance the four boys walked leisurely round and round, keeping time with clappers. In the next they danced faster, clapped their hands, and sang in unison,-love, on the part of the supposed girl, being the burden of their song. In the third dance the lover answered this ditty, and in the fourth the dance was interspersed with somersaults and other antics.

Whilst the batchas were dancing and putting them- 
selves through various movements intended to be graceful, two men carried candles, dodging about to hold them close to the dancers, that their good looks might be admired, the candle-bearers themselves contorting their faces, and disporting themselves like clowns. One of their nonsensical feats, when there was a lull in the dance, was to sit opposite each other and make grimaces, or move the muscles and skin of the face like a rabbit. They brought on next a Persian song and dance with whistles, the batchas snapping their fingers in time, and then striking together a pair of wands.

As the entertainment proceeded, a large crowd, attracted by the sound of the music, pressed into the courtyard and garden, delighted to witness the performance. Their appreciation of the batchas was intense. They offered them tea and fruit, and, when the boys sat, they could hardly have been made more of had they been the first stars of a London season. They seated themselves apart from "the vulgar crowd," near to us, whereupon lights were placed before them, that all might gaze and admire. $\mathrm{He}$ thinks himself a happy man to whom a batcha condescends to offer a bowl of tea, and receives it with expressions of great respect. So, again, if a man offers tea to a batcha, it is counted an honour if it is taken and the cup returned, after tasting, to the owner, but a great indignity if the remainder be handed to another. I gave the boys refreshments, and sent round to the crowd some of our boxes of sugar-candy, which was readily accepted.

We were next entertained with some acrobatic feats, the men bending backwards till their heads touched the ground, and performing several other 
fantastic exercises. After this, a man gave us a Hindu dance, and preparations were made for some rude comic acting, in which were represented various scenes from native life-first a quarrel and law-suit about a scarf. Presently a high priest, or some dignitary amply covered with cotton wool to represent white hair and beard, was carried in on a sort of sedan chair. Whether he was intended to represent the Emir or the Grand Lama I am uncertain, but he was waited upon with great obsequiousness, whilst the musicians kept up vociferous singing and loud beating of tambourines. Presently a supposed dead man was brought in, upon whom the mullah sprinkled water in such abundance as to make the corpse wince, and he then proceeded to count the dead man's debts, supplying himself with a substitute for ink with a nastiness that will not allow of description. At length, by accident or by design, one of the candles set fire to the cotton wool of the judge's hair, and he was about to be enveloped in flames, but which fortunately they were able to put out, and this touch of reality brought the proceedings to an unceremonious close.

I am not aware that the Central Asiatics dance at all as a social amusement, but only as a spectacle. The boys are early trained to it, and continue their profession until the beard grows. The Emir has a staff of them, who, when he stays in Kitab, dance every night from 7 to to in some public place. Rich men also keep them for their enjoyment, and even poor families club together to maintain a corps for their joint amusement.*

* These batchas are also used, though not in all cases, for immora purposes. Vambery alludes to this at the time of his visit to Bokhara, One hears and reads of the Emir having formerly had a male and VOL. II. 
It was nearly midnight before the batchas left our house, and I am not sure that they did not prolong the fun near at hand; but they had put us up bedsteads and pillows at either end of our room, and we were glad enough to get to bed. Next morning they gave us for breakfast fruits, boiled milk and rice with butter, and sour cream. Quite early some courtiers came, saying that the Emir had already asked several times after my health, and his Majesty (or his Highness, as the Russians call him) wished to know whether we were dull, because, if so, he would send some persons to amuse us. I replied that we were not dull, having plenty of reading and writing to do. His spokesman, we were told, was a colonel, and we afterwards learned that he was a very near attendant and minister of the Emir, named Hodja Abul Fais, and one of the most enlightened of the Bokhariots that we met. He had lived seven years in Constantinople, and had travelled to Kief, Moscow, and Orenburg. Both being travellers we compared notes, I telling him of my Central Asian journey, and my former route through Siberia round the world. I offered him a copy of St. Matthew's Gospel in Osmanli Turkish, which he appeared to female harem, and M. Ostroumoff, writing of the characteristics of the Mussulmans of Central Asia, states that, from $1869-7 \mathrm{I}$, out of 103 criminal law-suits brought before the Russians, 25 were traced to the keeping of such boys, to persons having committed murder and 14 robbery to find the money to pay them. Some parents, he says, themselves use or sell their boys as batchas, and one law-suit was brought by a father against a whole family who had thus used his son. Solong as the batchas are young and good-looking they are petted and spoiled, but afterwards they often fall into a life, as Dr. Schuyler says, of caprice, extravagance, and dissipation. They told me that the Emir did not allow women to dance, which probably meant in public, as I heard of them doing in Khokand. Dr. Schuyler, too, speaks of their performing in the women's court; but we saw none throughout Central Asia. Such a practice in public, if not also in private, would be quite contrary to Sunni Muhammadan ideas. 
read fluently. On learning what it was, he said God had given four books to men, of which this was one, whereupon he kissed and accepted it with thanks, putting it away in his breast. He then asked how old I was, guessed me too young by ten years, and was surprised that my beard was so black and without grey hairs."

After the departure of this courtier I walked out to look at our surroundings. Our house stood on a bank some half-dozen feet above the courtyard, with a stream of water running near, the specific gravity of which I tested, and found to be 99 . In the yard and the adjacent open sheds our horses were picketed, whilst on the other side of the house were sunken, muddy flower-beds, watered by irrigation, with chrysanthemums in blossom. Near these beds were dwellings resembling offices, into which I began to pry, when Yakoob came running up in alarm to inform me that I was entering the women's domains. Of course I at once drew back, though so effectually had the fair ones kept out of sight that I had not the least idea there were any on the premises. I fancy however, they had seen me, and I perceived that other eyes were upon us also. Six open doors in one small room I had voted rather too much of a good thing, and closed accordingly the three that gave access to the courtyard, leaving open for light and air those facing the garden and offices. One of the attendants came to ask whether I would not like the opposite doors opened, so that the air might enter, but

* More than once this question was asked in the khanate, and followed by a similar remark. A Russian living in the town of Bokhara told me that the natives are usually grey at 35 , that his brother living there for three years began to get grey at 24 , but that on going back to Russia the grey hairs disappeared. 
I declined, beginning to suspect that what he really wanted was to spy from the yard what I was doing, and this suspicion increased when, chancing to look in the direction of the offices, I saw a man had taken a seat commanding a view of our room, off which he scarcely took his eyes. In the course of the morning a messenger came from the Emir and told us, to our disgust, that his Majesty, having heard how late we got to bed on the previous night, felt sure we must be tired, and so would not see us till the morrow. About midday we said that we should like to go out in the afternoon for a ride, and to see the town, whereupon I discovered that, in addition to being a guest, I was also a prisoner, for they said we must not leave the premises without the permission of the Emir, and this permission did not come.

In the evening we were informed of the arrival of the assistant to the commander-in-chief of the Bokhariot forces, the commander of a battalion, and a guard of honour, 30 strong. There was no need to fear, his Majesty said, but he had thought it better to send us a guard.* We were just finishing our evening meal, and $I$ invited the officers in, and plied them with-not cups, but-bowls of tea, bread, butter, and eggs. Upon these meats the gallant commanders made a vigorous onslaught, and it was not until each had disposed of half-a-dozen basins of tea that they cried "enough," their politeness having come to an end; for I discovered that, according to Bokhariot etiquette, they were bound to keep on eating as long as we kept offering.

I then tried to amuse them by showing them

- To be "valiant men about our bed . . . . every man with his sword upon his thigh, because of fear in the night" (Cant. iii. 8). 
engravings of Central Asia in Madame Ujfalvy's " $D e$ Paris a Samarcand," but the officers seemed somewhat slow in taking in their meaning. It occurred to me afterwards that they were perhaps the first pictures they had ever seen.* To Yakoob, who had been brought up in Russia, all was plain enough, as he looked over the book with pleasure, and interpreted; but it raised a curious question in my mind as to what would be the impression produced on a man's understanding, at 40 years of age, who then saw a picture for the first time.

Next morning we went out to look at our guard of honour. One officer wore a tunic of red glazed calico, a black sheepskin hat, and a sword, and his brother officer carried in his girdle, as indicative of his rank, a battle-axe. The uniforms of the rank and file were of the nondescript character, easily imagined when I add that the Emir's soldiers find their own food and clothes. One soldier had buttons on his coat that had done service in various British regiments, the I Ith among them, whilst their muskets were of all degrees of antiquity, one having been stamped in the year of grace I8oo! The Emir had tweive guns at Kitab, and more at Bokhara, and his army consisted, it was said, of 1 4,000 warriors, of whom 6,000 were cavalry. $\dagger$ If these, thought I, are a specimen of the Sovereign's body-guard, and the pick of his troops, what must the

* The Sunni Muhammadans hold it contrary to their faith to represent anything that has life, whether vegetable or animal, being taught, I believe, that those who paint animals will at the day of judgment have to put life into them. Anyway, not a ghost of a picture of any living thing did I see all through the khanate.

+ Another informant, a courtier, said he thought it was 20 battalions of 1,000 each, and the cavalry as many more; but the Kush-beggi, or Viceroy, told me 15,000, of whom 5,000 were cavalry. All of them are volunteers, who serve from 18 till death, on the munificent pay in the 
rest be like, and would it not have been passing strange if the Russians had not beaten them ?* But whilst I was taking stock of the soldiers, and showing them my revolver, some courtiers came to say that the Emir was ready to receive me, and I had to think of a fitting Court dress.

Dr. Wolff, who escaped with difficulty from the clutches of the present Emir's father, wore his gown and hcod into Bokhara, carried a huge Bible under his arm, and announced that he was the great dervish of England; and he partly attributed his safety to having maintained throughout his ecclesiastical character. I had some thought, therefore, of taking a leaf from his book, and the more so because Russians had told me that the Emir would not distinguish between my clerical coat and that of a Russian merchant, and that all the Russian dignitaries this Asiatic sovereign had seen were in uniform and decorated with medals. This suggested to me that it might be desirable if I could combine in my raiment the splendours of ecclesiastical vestments and military uniform. But where was the Emir? Was he living close by, our house being a part of his palace, or was he a mile off? because, if I were going to get myself up very gorgeously, and his Majesty were

country of $175.6 d$. a month, or, at the capital, of 205 . Another account I heard said ros. a month, that these hired troops are a militia rather than a standing army, of which there was said to be none in Bokhara. The men live at home, and come up for drill occasionally, and when they wish to quit the force, simply give up their muskets and uniforms, and go about their business.

* The natives told me that, at the occupation of Samarkand, the very sight of the Russian soldiers, before they had crossed the river, made the enemy run like sheep. I heard, too, that when a fortress was stormed, the natives entirely gave up hope, and simply sat down, each awaiting his turn to be killed. 



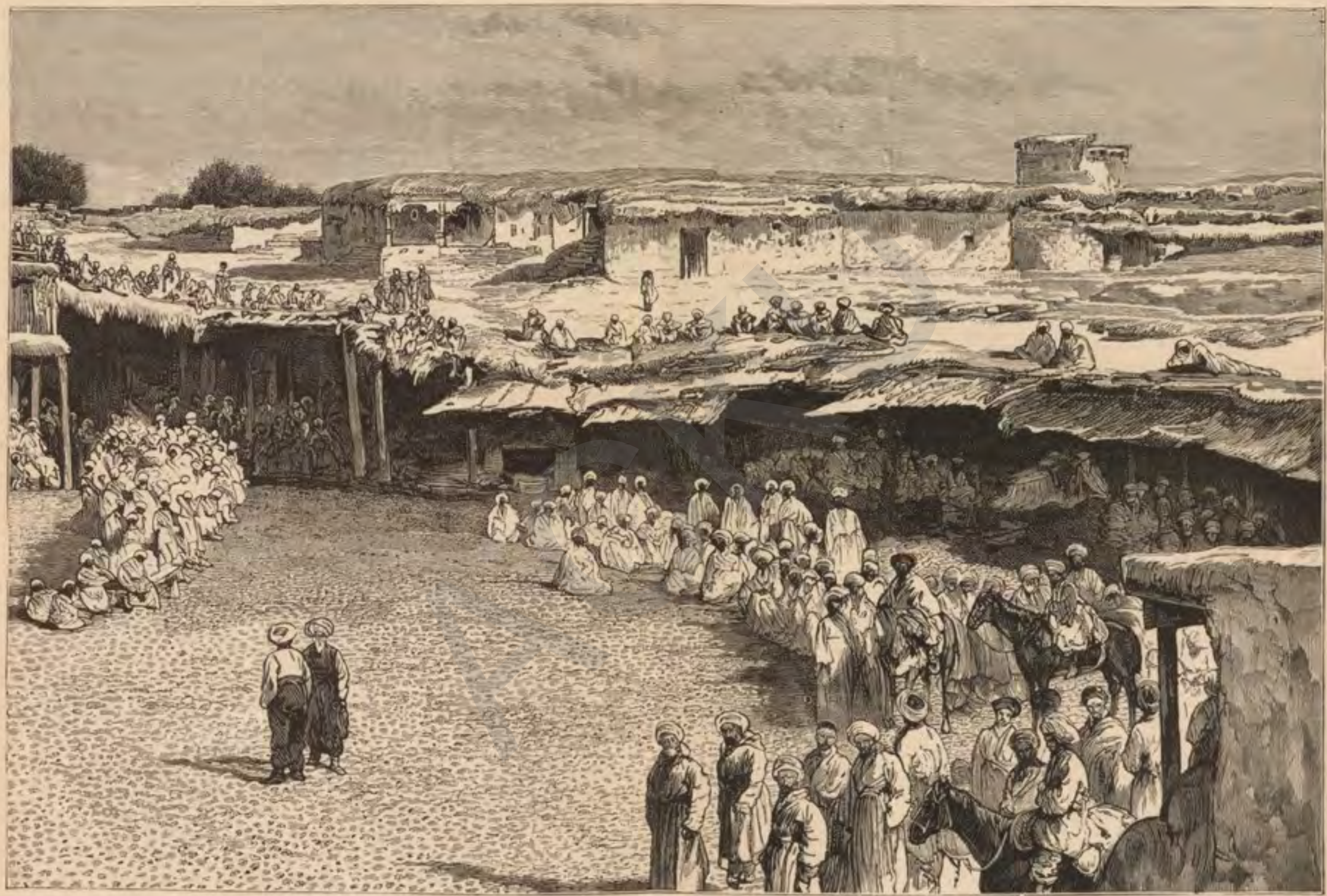



living close by, it might be more convenient to walk. My inquiry had reached the great man's ears, and he seemed to have taken it as a trait of humility on my part that I did not think myself worthy to come mounted to his presence. He therefore sent me a message to say he had heard I talked of walking to the palace, but that he desired I would ride.

So I proceeded to make ready, and first put on my cassock, that did duty when I went to the Court of St. James's. Over this I put on a gorgeous, goldembroidered waistcoat, adapted from a garment I bought in Servia, as a specimen of a Servian gentleman's vest-grand enough for a general-and tied a cincture at the bottom, with ends hanging at the side, and over these I hung my scarlet hood. Fortunately, perhaps, there was no mirror in the room, or my heart might have failed me; but I next put round my neck a Provincial Grand Chaplain's collar of purple and gold, and on this pinned three or four masonic jewels, by way of medals, and slung at the bottom my pocket Bible; after which my costume was completed by a college cap; and thus arrayed I mounted my palfry and sallied forth. My two djiguitts went in front, preceded by a whole bevy of officials, and the two interpreters came after. Of course I looked at the people as we passed through the streets. Need I say that they looked still harder at me, doing my utmost, as I was, to keep my countenance? The boys, not content with a passing glance, ran before, and kept turning round to look, and, in the bazaar, buyers and sellers stopped their bargaining in order to gaze. All went well, however, and we reached the citadel. This is a large artificial mound, surrounded by high clay walls, having an imposing gateway, with a chamber 
above, and a tower on either side. A number of troops were drawn up, who received me with a salute, and we dismounted to be received by two officers at the entrance, one of whom took charge of my presents for his master. We then crossed the first court, and, on entering the second, I caught sight of his Majesty, at a distance, through an open door.

Of him I had read various and somewhat conflicting accounts. Of his father, Nasr-Ullah, there seemed to be but one opinion, and that about as bad as it could well be; but of the reigning Emir, Seid Muzaffar-ed-din, Vambery, in $186_{3}$, spoke rather favourably. ${ }^{*}$

For my own part, I heard stories from Russians and natives alike, to which I shall hereafter refer, that in a manner confirmed both the bright and shady sides of the Emir's character. Meanwhile, knowing that the man I had to deal with was a despot, and remembering his power to hinder or advance my journey, I was

* Vambery says, “The Emir is in the forty-second year of his age, of middle stature, somewhat corpulent. He has a very pleasing countenance, fine black eyes, and a thin beard. In his youth he .... was always distinguished for the gentleness and affability of his manners. He carries out strictly the political principles of his father, and, in his capacity as Mullah and pious Mussulman, is the declared enemy of every innovation. On his accession he had impressed upon his signet the device, 'Government by justice,' and up to the present moment has most scrupulously observed it .... Towards his grandees, who for the most part well merit the treatment they meet with, he is very severe; for although punishing with death even trivial offences in these, he spares the poorer classes. Hence the expression applied to him by the people, and which does him honour, for they say of him that he is a "killer of elephants and protector of mice." "

Ten years later, Dr. Schuyler had a short audience with the Emir, and described him as " tall, stout, with sallow complexion, and small, dark, uneasy eyes, which he kept turning in all directions. His flesh looked very flabby and unhealthy, and his hands trembled constantly throughout the interview, as I have been told from a too frequent use of aphrodisiacs."

Ten years later still, M. Stremoukhof, ex-political secretary of General 
naturally anxious for a favourable interview. I wanted in the first place to extend my travels into parts of the khanate that Dr. Schuyler was not allowed to visit, next to distribute among the Bokhariots my remaining copies of the Scriptures, beginning with the Sovereign himself, and, lastly, I wished to search for manuscripts, and to get all the general information I possibly could.

The Bokhariots have a poetical conceit that a stranger, on being admitted to an audience with the Emir, is so overwhelmed with the brightness of his presence, that he needs an attendant on either side to support him from fainting. I fancy that intercourse with the Russians, who, as conquerors, do not stand upon such nonsense, is breaking down the custom, or perhaps the attendants did not think me a fainting subject. At all events I have no recollection of being supported into "the presence." The courtiers began to bow immediately they turned the corner of the court from whence his Majesty was visible. I had received the hint, however, that I should act as if being presented to my own or the Russian sovereign, and I accordingly reserved my bow till I entered the audience chamber. It was a good-sized room, carpeted

von Kaufmann, gave, in the St. Petersburg Gasette, a less favourable account than either of the preceding, saying, "The present Emir, whose mother was a slave, is an uneducated, unmannerly coward, and an immoral man. He spent his youth among thirty wives, several hundreds of concubines, a whole squadron of batchas, reciters of poetry, jesters, and jugglers. The young Emir's mental faculties could not possibly be developed among the depraved set with whom he associated, and it is now commonly said of him that he has little savat, meaning that he can hardly decipher any document. He is even now accessible only to flatterers, mischief makers, and charlatans. . . . During his father's lifetime the young man put some little restraint upon himself, but when he became Emir he gave full vent to all his worst propensities." 
all over, but without a stick of furniture, except two roughly-made deal chairs with crimson seats. The Emir was perched on one, and, after giving me a feeble shake of the hand, he motioned me to the other. I had seen his portrait at Tashkend, photographed, I think, in 1874 , and from which, I presume, the engravings have been made; but as I had heard his Majesty spoken of as an old man, I expected to find him grey, whereas his hair was black, and, though apparently in debilitated health, he looked, thanks perhaps to cosmetics which he is said to use freely, less than 58 , which I heard was his age.

When I had seated myself, Mr. Sevier and Yakoob stood in front, a few courtiers being behind. The Emir began by saying he had heard that I came from far; he was glad that I had come, and hoped that I had recovered from fatigue.

I thanked him, and said that the Russians had given me permission to go to Petro-Alexandrovsk; would he be so kind as to direct that my tarantass should be taken to Charjui, and then floated down the Oxus?

"Yes."

I then said, "I am an English mullah, and can read Hebrew and Greek. I should very much like to be allowed to see what ancient manuscripts there may be in your Majesty's library.'

Answer: "He had heard that I was interested in antiquities. I might, therefore, search for them where I pleased, and have any I could find; and his men would help me."

Thus far, all promised well, and I went on to say that I had seen prisons and hospitals in many parts of the world, especially in Siberia, and that I should like to to be allowed to see those of his Majesty's dominions. 
Here I suppose I "put my foot in it," for I received no answer. In asking Russians the kind of presents that would be suitable for the Emir, I had been

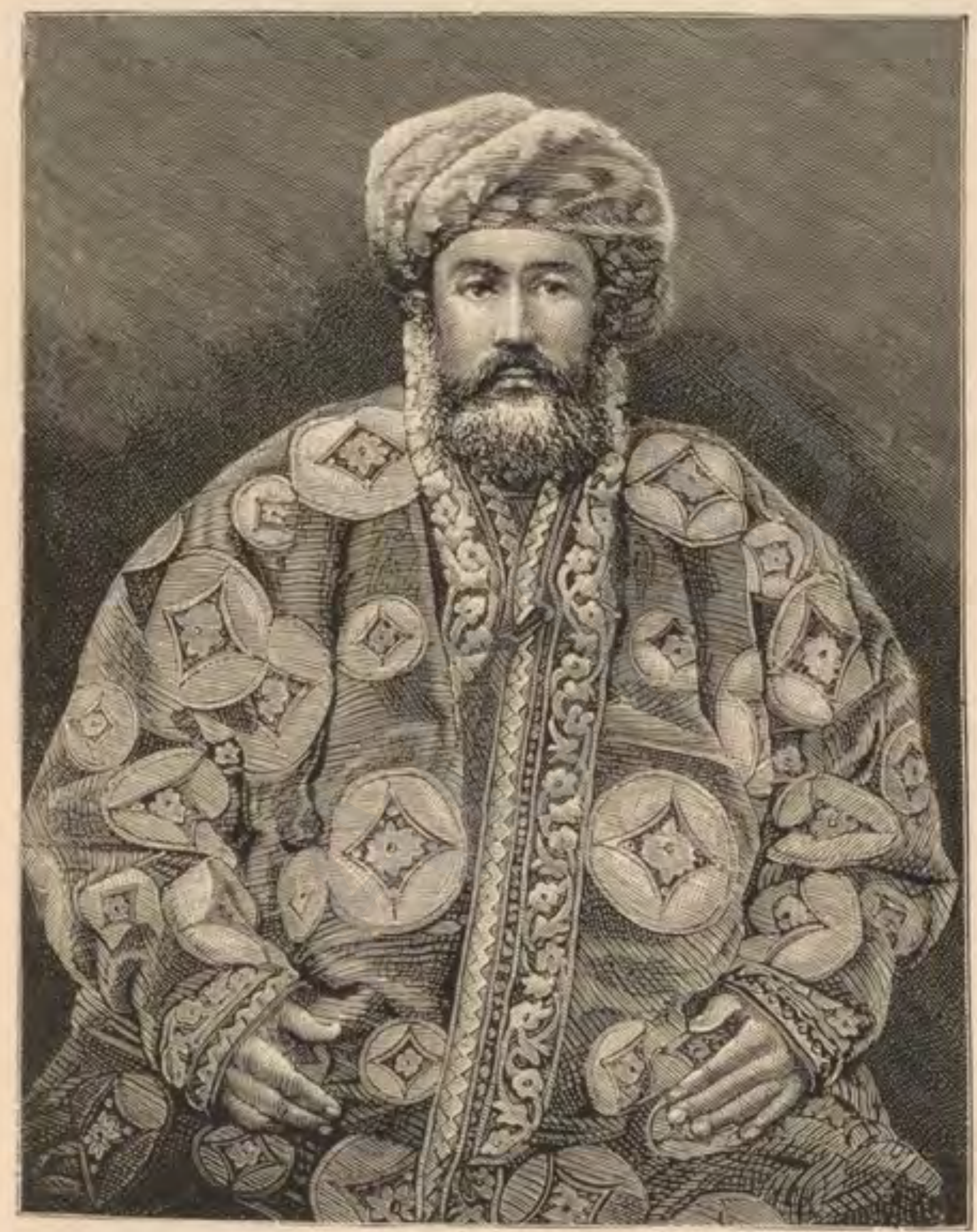

SEID MUZAFFAR-ED-DIX, EMIR OF DOKHARA.

especially advised to offer articles that would be new to him. I was not too well supplied with such things, for I was not sure, on leaving England, that I should get into Bokhara, nor had I previously travelled in coun- 
tries where money was not generally regarded as the best of presents. When, however, no reply came to my request, I pointed to the scarlet raiment on my back, telling his Majesty that such a decoration was worn by our chief mullahs in England; that I had heard he was a mullah, and that I should be gratified if he would accept my Doctor's hood; and then, to make quite sure that among my presents there should be something decidedly new, I added the masonic collar and jewels! He seemed at first not to understand me, until, having called in the aid of his own interpreter, he replied, "Yes"; and again there followed a painful silence.

I was beginning to think him provokingly uninquisitive, and inquired whether he had any questions to ask about England.

Again there came no answer, whereupon I rose.

Then he said he must consider. Did I mean about England, or about my travels?

I answered, "Whichever your Majesty pleases."

"What, then," said he, "is the aim of your travels?"

"Primarily," I answered, "to distribute good books in prisons and hospitals; but, besides that, I am interested in antiquities."

"Now," said he, "I understand your object."

I handed him two of my letters, with accompanying translations in Turki, but he hardly glanced at them, and rather impatiently, I thought, put them aside. We then shook hands, and all literally "backed out" of his presence. We had been told beforehand that refreshment would be provided, of which we partook, in the room of the chief ministers. They said we ate too little, and asked about my costume, one of them having been in Belgrade, the very town where 
my vest was purchased. They had no prisons worth seeing, they said. They used to put prisoners in the stocks, but not now. They were curious to know what were the books we had given to the Emir; they understood our giving books in "the hospitals to cure the sick, but had we, besides, any medicine?" I gave presents of rings and a pocket microscope to these ministers, for which they said they had nothing to give in return ; but they soon came to tell me that the Emir had looked at my presents, and thought them very curious, and, further, they brought into the room to me, as a present, at least a score of changes of raiment, for myself and retainers. These were the robes of honour, or khalats, of which the Russians had told me the Emir would give enough to "bury me." Some were of cotton, of gaudy colours, others of native silk, some few of Russian brocaded satin, like the Russian priests' vestments ; one or two were of Cashmere, and another of pea-green velvet, to envelop me from head to foot ! This, however, was only the beginning of favours, for I was next informed that the Emir had sent me a horse for myself, and another for whomsoever I pleased. Nor was my charger sent without saddle or bridle, for it had both, as well as a saddle-cloth, covering him from mane to tail, and hanging down on either side, two feet from the withers and three feet behind. The saddle-cloth is the handsomest I have ever seen, and is of crimson velvet, embroidered with gold and silver thread and silk of various colours, in seven large foliate patterns, surrounded by a scroll border of similar workmanship, and edged with wide amber and crimson fringe, the whole being adorned by spangles of silver and gold.

The bridle, too, is no less remarkable, being mounted 
with bosses, pendents, and ornaments of turquoise cloisonne work. At the back of the head, on the neck, rests a plate of turquoise work, from which hang on either side 8 strips, similarly jewelled, the reins being of white leather. One of the bridles is now in the British Museum.

I suppose that, had I been an Asiatic, I should have been clothed with one of these robes of honour,* and mounted upon the horse to ride through the street, "like unto the man whom the king delighteth to honour" ; $†$ but I was excused from this, though the trappings were left on the horses, that the people might see, they said, that I had received a present, whilst "the changes of garments were laid upon his servants, and they bare them" (with the horses walking) before me $\neq$

It was well, perhaps, that I did not mount my present, for subsequently gay clothing was found to cover but sorry steeds, and one of them was so vicious that none liked to get near him. One horse was an Arab, 8 years old, the other a Karabair, the two together being valued at $£ 8$ ! We had now done the honours, and were told that we might proceed if we wished; and upon my expressing a desire to hasten forward, the Emir sent us his carriage, drawn by a pair of horses, in which we drove through the market-place, out of the town towards Shahr, and arrived before evening.

* I saw this done on the following day. When sending a watch and chain to the Bek of Shahr, by the hand of Yakoob, the Bek threw over my messenger's shoulders a gaudy robe, in which Yakoob came parading back, thus illustrating, I suppose, the case of Mordecai, who "went out from the presence of the king in royal apparel of blue and white " (Esther viii. ${ }^{5}$ ).

+ Esther vi. 11 .

$\ddagger 2$ Kings v. 23 . 


\section{CHAPTER XLVII.}

\section{FROM SHAHR TO KARSHI.}

Historical associations of Shahr.-Visit to the Bek, and his inquiries concerning Kuldja. - Information from courtiers. - Bokhariot weights and measures.-Return of certain presents.-Untrustworthiness of Bokhariot statistics. - Departure from Shahr.-The Bekships of Chirakchi, Shir-a-bad, Kobadian, and Kilif.-Hissar mountains.-Visit to Bek of Chirakchi.-Burnes at Karshi in 1832.Handsome guest-house.-Visit to public bath.-The slave trade in Bokhara.-Visit to Bek of Karshi.-Mosques and synagogues.

THE carriage that took us from Kitab had been sent from Petersburg by the Emperor as a present, and no one but the Emir had the like in Bokhara. It was not surprising, therefore, that the people gazed hard at the two Englishmen in plain clothes seated in the royal chariot. The distance between the two towns that make up Shahr-i-sabz (pronounced Shakhr-i-sabz) is only four miles, and the route lies through gardens and fields edged with trees, crossing about midway the Ak-daria, an affluent of the Kashka-daria. We soon saw that the people knew far less about driving than riding. Draught horses, they told us, were rare; hence the Emir had lent us two artillery chargers, somewhat large and heavy, and attached to our delicate carriage by ropes intended to draw a cannon, whilst each horse was mounted by a turbaned postilion, who, as he 
walked or at most ambled his horse along, kept smiling at his fellow as if he thought the occasion a novel, if not an important, one. Hence we had a leisurely afternoon drive, and before sunset reached our destination. We were conducted to the house where embassies are received, in which was a large room carpeted, with niches in the wall, and a moderate-sized flower garden outside. We were told that the Bek would receive us in the evening in the Ak-Serai, a reminder that we were on historic ground.* Accordingly, after sunset we went to visit the Bek. At the entrance to the citadel soldiers were drawn up, who presented arms, and we crossed the court where Tamerlane's feet must often have trod; for there stood the ruins of two piers, solidly built of large bricks, of the famous Ak-Serai, or white palace, in which he used to repose after his campaigns. Their height is 140

* Shahr-i-sabz was widely known under its former name of Kesh as the birthplace of the great Tamerlane. Separated from Bokhara by the desert through which we were to travel, and from Samarkand by the easily defensible mountain pass we had crossed, the position of Shahr-i-sabz offered a good area in later days for the formation of an independent government, and it early asserted itself. In the middle of the last century, Rahim Bi, of Bokhara, subdued and held the province for five years, but it revolted. From 1811 to 1836 it had a noted Governor, Daniar Atalik, who successfully held out against Mir Haidar and his son, Nasr Ullah. Nasr Ullah, however, captured the place in $185^{6}$, but it revolted on his death, and his successor, the present Emir, did not at first succeed in obtaining possession of the "green city." Baba Bek was set up as ruler of Shahr, and Jura Kek of Kitab, and with these Muzaffar was obliged to make peace, they giving him precedence and yearly presents, but not allowing his interference in the affairs of the province. These relations were broken in 1866 , on the battle of the Russians and Bokhariots at Irdjar, after which certain rebels against the Emir were harboured in Shahr-i-sabz, and the province again held out successfully against Muzaffar. The final blow to its independence was given by the Russians in 1870 , when Kitab was taken by storm, and Shahr immediately surrendered; whereupon the Russians gave up the province to the Emir of Bokhara, as a proof that they desired no further conquest of his territory. 
feet, and their pure Arabic style and ornamentation in glazed tiles of blue and white porcelain, inlaid in arabesques, and Persian and Arabic inscriptions, make them striking objects. ${ }^{*}$ I was received in a spacious hall surrounded by mirrors about five feet high, and suspected that my reception had been deferred till after dark that I might be dazzled with the (supposed) magnificence.

The Bek, who gave me his name as Astanakul, Parmanatchi, signifying that he was one grade below the highest, sat near me at the table on which refreshment was served. There were also at the table Khoja Abul Fais, and the Emir's interpreter, who had been sent by his Majesty to amuse us during the evening, and I suppose also to learn of us what they could. The Bek was much more communicative than his sovereign, and asked if I had a father and brothers, but made no such inquiry as to mother or sisters, which, according to Bokhariot ideas, would have been unpolite. He wished to know my profession, and that of my father, and inquired for the health of my family. As he appeared to be so chatty, I took the opportunity to ask him, and those at the table, many questions, and to jot down the answers I received. He gave me information also concerning my route, which was to be 60 miles to Karshi, 95 more to Bokhara, and IOI further to Charjui. I asked him to arrange, if possible, that our journey might be expedited, whereupon he summoned his scribe, who wrote a letter at his mouth, which the Bek authenti-

* This is the building of which the Spanish Clavijo tells us the builders had been engaged upon, in 1405 , for 20 years. He speaks of a broad and high entrance to the garden, beautifully adorned with glazed tiles, in blue and gold, as well as handsome galleries and reception halls decorated with gold, azure, silver, and ivory.

VOL. II. 
cated, after hearing it read (not reading it himself), by impressing his seal upon it ;* while the messengers went out to make preparations for our departure on the morrow. When the Bek heard that we had come from Kuldja, that was shortly to be given back to the Chinese, his eyes sparkled, evidently at the thought of the Russians having to disgorge some of their prey, and he inquired particularly how many Chinese there were in Kuldja, and how many versts westward the frontier had been fixed. Before leaving I presented the Bek with an Arabic New Testament, and a portrait of myself, whereupon he asked whether I had given the like to his Majesty. Then, to my surprise, they brought me a present, by desire of the Emir, from the Bek, of more khalats and another Arab horse with saddle and bridle, but not so gorgeously ornamented as the one I had received in the morning.

It was quite dark when our visit was over, and a crowd outside was waiting to escort us back with torches and lanterns. The Khoja and his interpreter accompanied us to our lodgings, where we found a company of batchas, and the people assembled for a performance. I did not decline it, but gave the Khoja to understand that it would be a far greater treat to me than seeing

* Like Shaphan, the scribe, reading before the king ( 2 Chron. xxxiv. 18), or like Mordecai writing letters, sealing them, and sending off messengers in the name of Ahasuerus (Esther viii. 8, 10). The Emir, not reading personally the letter I presented to him, recalls the words of Artaxerxes, "The letter which ye sent unto us hath been plainly read before me" (Ezra iv. 18, 23). The carrying a signet appears to have been customary with dignitaries in patriarchal times in Palestine, if we may so understand the case of Judah (Gen. xxxviii, 18); and later in Persia, for Darius sealed Daniel in the lions' den (Dan. vi. 17 ). So, too, in Judrea under Pilate, who "made the sepulchre sure, sealing the stone" (Matt. xxvii. 66). We read of none of these affixing their sign manual, as it would be with us. 


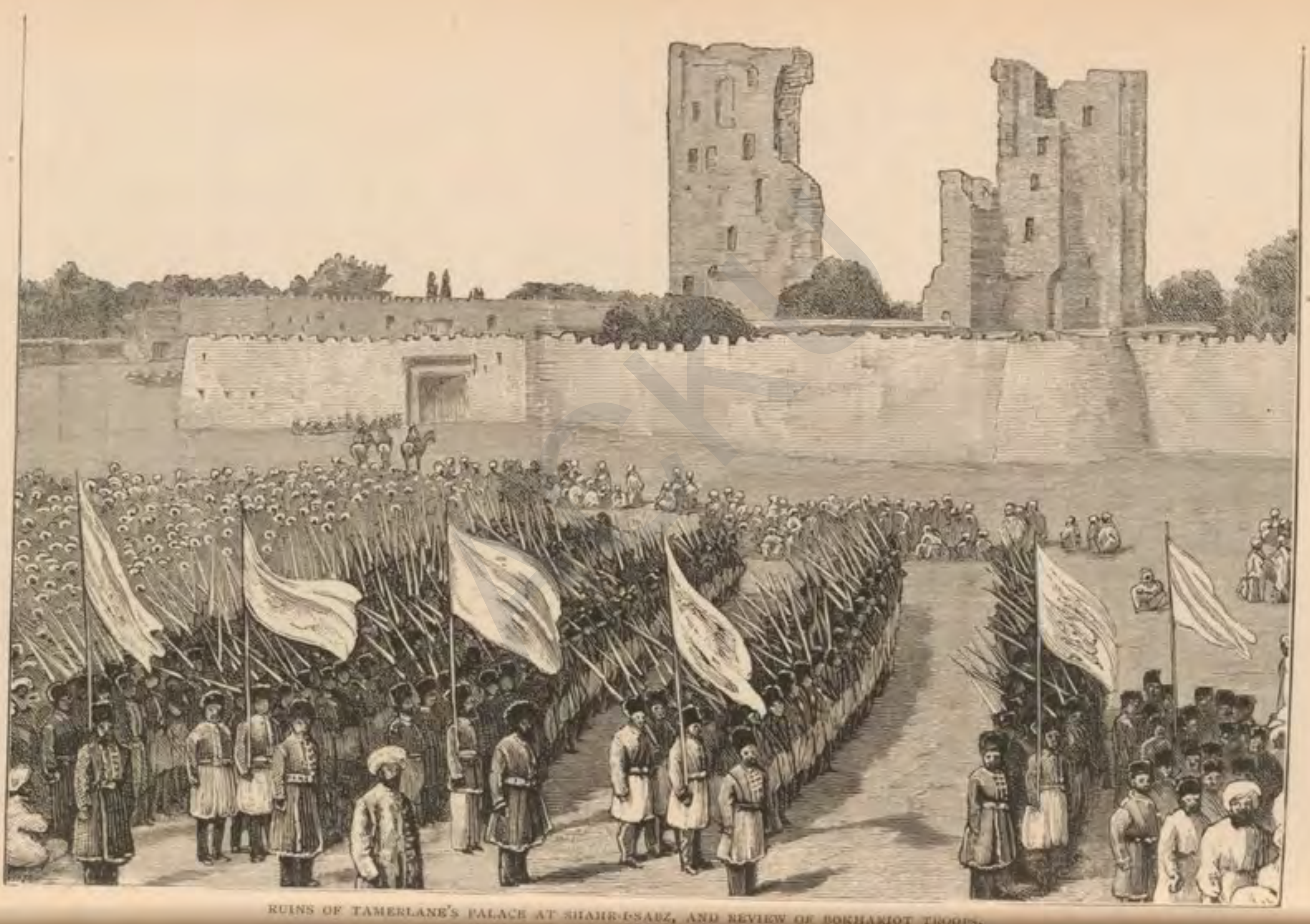


the batchas if he would allow me to question him about the country. He and his interpreter were, I saw, intelligent fellows, and it was an opportunity not to be missed. When, therefore, the batchas were well started with their tomfooleries, we withdrew into the room, to my table and note-book, but left the doors open so that we could see a little and hear only too much of the performance outside. I fear the crowd thought us sadly wanting in taste, and the batchas, determined that we should not lose all the fun, came every now and then putting their heads inside, and bawling, at the top of their voices, some portion of song for our special benefit.

Meanwhile I was plying my visitors with questions, and by them was initiated into the mysteries of Bokhariot weights and measures, among which, in the absence of a recognized standard, the glorious uncertainty of "the rule of thumb" is as nothing."

Among the messages sent me by the Emir was one that they delivered very delicately, and accompanied by some of my presents to him. The Emir feared that I should want again my hood, collar, and jewels, adding what was no doubt true, that I should not be able to get the like throughout his kingdom; and with regard to the illustrated book of travels, it was in a language he knew not, and he had looked at, but could not understand, the pictures. He hoped, therefore, I should not be offended if he asked me

* For instance, they have only one measure of capacity, the chuyeh, for oil and honey, and that seldom used, and of variable size. A tash equals 3 milles, or 12,000 paces, or 18,000 olchines. The olchine was spoken of roughly as equal to the Russian arshin, and measured cubitfashion from the elbow to the end of the forefinger. The kulatch is the distance from the tips of the fingers when the arms are outstretched, whilst the giaz is from the centre of the breast to the end of the fingers. 
to take that back, but as for the religious booksnamely, a Persian Bible and Arabic New Testamenthe accepted and revered them. Here, then, was a rebuke to my worldly wisdom, for (to make confession for once) I did not feel at all sure how this Mullahpotentate, the chief champion of Islam in Central Asia, would be pleased at the idea of my offering him a Christian Bible. On the other hand, the book of travels was gorgeously bound, and full of pictures of his own khanate and of Central Asia, and I thought this would prepare the way for the religious books. I suppose the real reason why he returned the book, with my portrait also, by-the-bye, enclosed, was because of the Sunni Muhammadan law against pictures. Vambery says that in Bokhara, in 1863 , " the unhappy possessor of a portrait of a living human being suffered the extreme penalty of the law," so that his Majesty could hardly keep the pictures in defiance of his own regulations." I do not know whether the law about possessors of portraits has been relaxed. If not, I fear I jeoparded the lives of a good many, for I had taken with me a large number of cabinet portraits, because convenient to carry, and I gave them freely in the khanates. It was not till I was getting towards the end of my stock that I accidentally learned of the objection, and asked Yakoob what he thought would be done with the photographs. He expected that in many cases they would be destroyed. Nevertheless, good Mussulman as he was, I had by this time so far ingratiated myself with him that he seemed to wish for a memento, and, on parting, asked for my

- Burnes wrote, in 1832 , that a merchant had lately imported some pictures from China into Bokhara, but that they were immediately broken, and their value paid by the government. 
portrait for himself. Moreover, no one else but the Emir returned the present.

In the Emir's case, of course, I took back the things without hesitation, expressing the hope that I might be able to find something else to send in their stead (which I did on reaching Bokhara), and asking also the Khoja and his interpreter if there was anything they would like me to send them from England, to

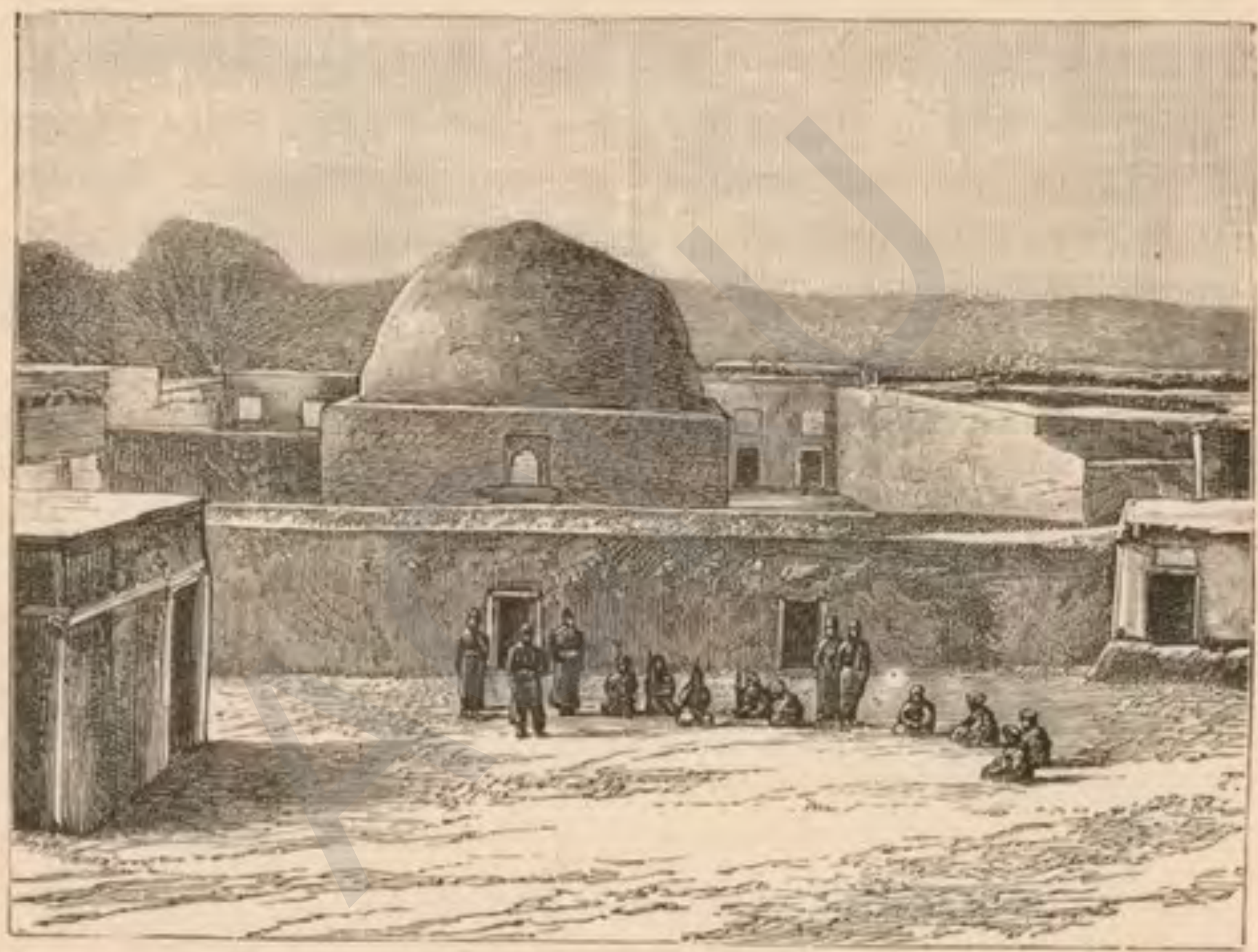

THE COUNT MOSQHE AT KITAB.

which they replied, with Oriental politeness, that they wished for nothing but to please me. I supposed I must have created a favourable impression upon the mind of the Khoja, for before parting he informed me that he was constantly in the presence of the Emir, and took his meals with him, so that, if I had any favour to ask, he was in a position to help me."

* Reminding one of Elijah's words to the Shunamite, "Wouldst 
I had no wish to stay at Shahr, which is said to have 90 mosques and 3 medresses. I secured a photograph of the Court Mosque of Kitab, but it is an insignificant building. Dr. Schuyler suggests a population for Shahr of 20,000 , and mentions 15,000 for Kitab.* I am, however, exceedingly sceptical as to the accuracy of Bokhariot numbers, especially when they mount to four or five figures. I am persuaded that some travellers have supplied us with statistics of population in the khanate, which the Emir himself could not give if his life depended on it. One of the questions I asked at Kitab of my military informant was the population of the khanate, but he could not inform me. The reader will therefore kindly bear this in mind in reference also to my own figures, supplied from information given by the natives.

The Bek sent early next morning to inquire for my health. His present of the previous evening had taken me by surprise, and having subsequently heard that his son was at the Emir's court, though not present when I gave presents to the ministers, I sent to the Bek a watch and chain for his son or any one else to whom he chose to give it. He threw a khalat over

thou be spoken for to the king?" (2 Kings iv. 13); also of various courtly officers who were in "the king's presence"; as David, who "sat with the king at meat" ( 1 Sam. $x x .5)$; "five men of them that were in the king's presence," taken by Nebuchadnezzar (2 Kings xxv. 19): and "seven men of them that saw the face of the king," taken by the Babylonian monarch (Jer, lii. 25); such as had ability to stand in the king's palace, among whom was Daniel (i. 4); and, again, the seven counsellors of Artaxerxes (Ezra vii. 14).

- Mr. Galkin, in 1865 , estimated the population of the bekship at 70,000 of both sexes. More recent authorities have put it at 50,000 , mostly Kanigas Uzbeks, noted for their valour. The same author gives the names of 4 forts and 20 villages and settlements in Shahr-isabz. Kitab lies on a hill, at an altitude of 1,910 feet, but Shahr is in a marshy plain, somewhat lower. 
the shoulders* of my messenger, saying that he would send the watch and chain to his son, after detaching the whistle from the guard for himself, and thanked me.

We left Shahr at 9.20 a.m. in the Emir's carriage, the road to Karshi lying through the Kashka-daria oasis. ${ }^{\dagger}$ We drove slowly for an hour through gardens and cultivated fields, and then came to the open steppe, sandy, but covered with vegetation. Not far from Shahr is the little village of Sharmitan, and six miles from the town is a second village, but we stopped at neither. Several streams were crossed, and on our left we had a distant view of mountains belonging to the Hissar system. $\ddagger$

About a mile before reaching Chirakchi we were

* This giving of raiment reminds one of Jonathan stripping himself of his garments and giving them to David ( 1 Sam. xvii. 54), a custom that lingered in Europe in the sixteenth century, when the Tsar honoured Yermak, the conqueror of Siberia, by sending him a garment from his own wardrobe.

+ Part of the upper portion of the oasis comprises the Chirakchi bekship, where, in 1878 , they reaped thirtyfold crops of corn. The price reached, in 1877 , barley $2 s .6 d$. to $2 s .9 d$. per cwt., wheat $3 s .4 d$. to $3 s$. $7^{d}$. per cwt. Sheep, when lean, cost from $8 s$, to $12 s$., and horned cattle from 255 . to 245 . a head. The latter, however, can be obtained only in small numbers. Cattle are more plentiful in the neighbouring bekship of Hissar, where some 4,000 head are driven weekly to the bazaars. The bekship of Shir-a-bad, further south, is less productive than either of the former, so much agriculture only being developed as suffices for the needs of the people. In the neighbouring bekship of Kobadian there is but little corn sown, silk being the staple produce. The settlement of Kilif on the Oxus does not produce corn, but only vegetables and lucerne. They get corn from Afghanistan in exchange for salt. In the mountain valleys of the Kilif bekship corn is produced, but they lie far from the line between Karshi and the Oxus, or the locality where a post could be established.

† This high range, called Hissar, is a direct prolongation of the Thian Shan, and separates the valleys of the Zarafshan and Kashgardaria from the Amu-daria. The Hissar range, with its offshoots, serves also for the northern boundary of the Bokhara khanate from the 
met by half-a-dozen cavaliers, gaily dressed, who said that the Bek, who was the Emir's son, had sent them to welcome me, and inquire for my welfare. They preceded us to the town, as the place must be termed, since it is surrounded by a wall, otherwise it might be taken for a kishlak with a large bazaar; and they informed us that, it being Friday, the Bek was gone to the mosque, but that on his return he would receive us. We called about two hours later, and found the Bek's house standing almost on the bank of the river. His residence is within a quadrangle, closed in with a high mud wall, and divided into smaller squares, in one of which a row of chambers stretches along the wall. On entering, an official first received my presents, and then we were shown into a room, where sat a youth of I 8, but looking much older, dressed in a khalat of cloth of gold, with a pink turban, edged with gold lace, the grandest get-up I had yet seen, and far outdoing his father, whom we had found plainly dressed. He said that as they had been visited by no Englishmen before, he was glad I had come to see their country.

I asked if he would come to England.

"That," he said, "depends entirely on my father."

He had heard that I was fond of antiquities, and orders had been sent to Bokhara to find them if possible. I suppose, too, he had heard that I was an author, about which I made no secret, and, in fact, in this way explained why I was taking notes, which is a deadly crime in Oriental eyes, and soon laid me

meridian of Samarkand to its eastward boundary on the Pamir, a line of about 300 miles. There are II roads and passes leading over the mountains, some for foot passengers only, and some for packanimals, but none for carriages. The most convenient for communication between the valley of the Upper Zarafshan and the Hissar villages is (considered to be) the Anzob Pass, r 2,00o feet high. 
open to suspicion. I suppose, therefore, he had been primed to say what he afterwards added, namely, that he hoped I should say nothing against their country. I replied, and replied truly, that I should have a great deal to say about the hospitable manner in which I had been received.

I learned that a horseman had arrived from Bokhara from the Kush-beggi, having been only two days on the road. This made us long to be hurried forward, for we had that day accomplished only 13 miles, and were to go no further-a great contrast to our travel in the Russian Steppe, where we expected to do a similar distance in little more than an hour. Moreover, we were poorly lodged in a room about 12 feet by 8 feet, with bare mud walls, not even plastered, wooden pegs stuck in holes to hang our things on, and two rickety bedsteads; and also there was nothing in the town worth delaying our journey for. Chirakchi was formerly a dependency of Shahr-i-sabz, but is now governed by this boy-bek, who, report said, spent his money prodigally, and grumbled at his father because, in his annual migrations from the capital to his summer residence at Kitab, he did not stay with his son on the way.

Several sons, some of them quite young, the Emir has distributed through the khanate as beks or governors of provinces, as at Chirakchi.* I observed, however, that this youth was surrounded with aged

* I presume that the one we saw is the same that Dr. Yavorski, when passing through in 1878 , speaks of as the youngest son of the Emir, so that, if my information were true, the Bek could have been then but 14 years of age. The position and conduct of the Emir illustrates the expression in Psalm xlv, 16, "Instead of thy fathers, thou shalt have children: whom thou mayest make princes in all lands," and Muzaffar thus emulates the example of Rehoboam, who, desiring many wives, "dealt wisely, and dispersed of all his children throughout all 
courtiers, who paid him the utmost deference. After our departure there was sent for my acceptance another caparisoned horse and khalats.

Next morning at 6.30 , soon after sunrise, we started for Karshi, a distance of 47 miles, which I was determined, if possible, to accomplish that day. Several of the authorities accompanied us out of the town, so that our cavalcade numbered fully 20 persons, one of whom. an old man, asked if we could give him a little quinine, which I promised to do when we unpacked at the next station. Our road lay along the valley of the Kashkadaria oasis, descending from an altitude of 1,300 feet at Chirakchi to 800 feet at Karshi. Between Chirakchi and Karatigan the oasis somewhat thins off, but there is everywhere plenty of water, forage, and fuel. About two hours after starting we traversed low flat-topped hills near the river, with plains between us and the stream, and a few yourts surrounded by plots of cultivated land. Further on the road we passed through a better cultivated and more populous district. Wheat and rice fields, cotton plantations and vegetable gardens extended along both sides of the road, whilst the winding river and the snowy summits of mountains in the distance helped to vary the scene. We passed two kishlaks on the right, crossed the river at the village of Karabagh, and were met about halfway to our destination by messengers sent by the Bek of Karshi. At a small place called Chim, or Sham, we stopped two hours for dinner, and then, driving on to within seven miles of Karshi, we were met by another messenger, who invited us to take refreshment, and the countries of Judah and Benjamin, unto every fenced city" (2 Chron. xi. 23). Also the youth of some of the beks, and the condition of Bokhara, is a commentary on Isa. iii. 4, "I will give children to be their princes, and babes shall rule over them." 
provided some excellent figs. We were now approaching a fruitful oasis, noted for the cultivation of tobacco, which from Karshi is as famous in its way as the pomegranates of Shahr-i-sabz and the grapes of Kitab. We then pushed on, and about 7 o'clock on Saturday night, 7 th October, arrived at Karshi.

The first Englishman who visited Karshi, or the ancient Nakhsheb, was Alexander Burnes, in $183_{2}$ (murdered in 1837 at Cabul), who called the place a straggling town, a mile long, with a considerable bazaar, and about 10,000 inhabitants. Vambery, in 1863 , estimated the population at 25,000 , but said that the town was without walls. Khanikoff, however, mentions three concentric walls, and I certainly rode round a good portion of one of them. Khanikoff gives the town a diameter of about 2 miles, and a possible circumference of 6 miles, containing 4 medresses and the grand Friday mosque. There was one place I was delighted to hear of above many others, and that was a public bath, whither we gave notice that we wished to go next morning.

We were lodged at Karshi in a guest-house worthy of the second town in the kingdom. Our room was large and handsome, with painted ceiling and wainscot, carved door and windows, a beautiful carpet, bed coverlets of silk, and a velvet pillow. Soon after our arrival the Bek sent to welcome us, and to offer an entertainment with batchas, but we replied that we were tired, and, having heard them twice, wished to get early to bed. It was then arranged that we should see the Bek next day, and since I intended to spend Sunday in the place, I intimated that one of us was a physician, and would be glad to be of use to any sick there might be in the town. 
Early next morning we started for the bath, and on our way passed through what I supposed to be a part of the bazaar, where the line of shops appropriated to the wool trade is said to be nearly 600 yards long. There are also numerous and well-supplied shops for the sale of butcher's meat, sweetmeats, silk, and tobacco. For the production of silk the district is famous, as also for the manufacture of knives. A kind of raisins prepared by immersing the fruit in hot water, and thence known as Abjosh-i-Karshi, is specially esteemed. The town used to be a market-place for slaves, and we saw in the bazaar some Turkomans, by whom the captives used to be brought for public sale.

On reaching the bath-house I found almost a fac-simile of a Turkish bath I had seen in Constantinople. I had hoped that Sevier and I might get a private room wherein to undress - for this special reason if for no other, that I had around my waist a belt of money, which I preferred should not be seen even by my own native attendants. To my disappointment they ushered us into a public place with a score or so of other bathers in various stages of deshabille. When, however, my wish to be alone was made known, the people were ordered out, and they ran off laughing evidently thinking that my modesty required their absence. Even then Yakoob and the djiguitts remained; so, seeing there was no help for it, I hid my belt in my clothes and entered the bath-room. It looked like a crypt lighted from the tops of domes, and, having placed myself on a hot stone, I had to submit to the well-known kneading and rubbing of the Turkish bath, previous to washing with water. I did not like it nearly so well as the Russian steam bath, though glad of an opportunity of a good cleansing, such as we had 
not had since leaving Samarkand. By the time we returned to the dressing chamber, some more natives had been admitted, and they watched us with not a little curiosity as we finished our toilette and put on our European garments. A tooth-brush appeared to them quite a novelty. I am not so sure about a comb, but, as all the men shave their heads, hair brushes are to them unknown.

Having returned to our house, we went after breakfast to call on Astanakul Bi, Bek of Karshi. He came into the courtyard to meet us, a young man of intelligent countenance, dressed in cloth of gold and white turban, and who, when we reached the hall of reception, seemed somewhat under constraint, and formal in the presence of several older men standing around. I invited him to question me about England, and asked if there was anything he would like me to send him, but in both cases he answered in the negative. His bekship extended, he said, from Chim, on the east, to about 40 miles in the direction of Bokhara." Thinking to draw him out, I told him of my travels, to which he replied that, to be successfully accomplished, such journeys needed brains, and then he added, "You are constantly on the move, and see many persons, whilst we sit still and see nobody." I told him he should come to England, but he replied that without permission he might not so much as leave his bekship. I particularly asked that the remainder of our journey to Bokhara might be accomplished in two days, to which he replied that it rested with ourselves, and should be done. As we bade him farewell,

- The bekship of Karshi consists of the districts of Karshi, Khozar, Shirabul, Sadabad, and Chirakchi, the total of the land revenue given jy Burnes being 32,000 tillahs. 
he accompanied us to the fortress gate, where was said to be a prison, and he told us we might see it. We were conducted certainly to a room in the guard-house, with a fireplace and matting on the floor, lighted from above, which, if it were the prison, was tolerably good for Bokhara ; but one native of our party thought that they were deceiving us, and that the real prison was underground. At the time I did not believe him, though my subsequent experience taught me that he was very likely right. They had no prisoners, they said, just then, the Emir on his last journey having released the few they had. Near the so-called prison was a guard-room, and on the walls were hung old firearms of unknown antiquity, one long blunderbuss affair being supported on legs, and fired with a fuse.

I had, as usual, sent a present to the Bek, and afterwards he sent me some loaves of sugar and boxes of sugar-candy; but the messengers said, in reply to my inquiry for the sick, that there were none! Thus we were disappointed of getting into the houses of the people, as we had hoped to do, to see something of their domestic life. I then asked to be permitted to visit the lepers' quarter, but this the Bek did not dare allow without the permission of the Emir. I next asked that we might be shown the town, thinking that we should possibly see some sick people, and also visit the Jews. Accordingly we were taken to see the chief medresses, of which there are four, and by a roundabout road, outside the walls, we were conducted to a large mosque I have called in my note-book KokChum-Bass, built 320 years ago by Mir Bika, who was made governor of Karshi by Abdullah Khan. It is the oldest building in Karshi, and is chiefly used during the month of Ramazan, and the other great 
Muhammadan festival of Kurban, at which time the adjoining gardens are filled with people, who come not only to pray, but to feast and play. We rode through the gardens, but on approaching the mosque they requested us to dismount, though there was not enough within to repay one for the slight trouble, the nine stone vaults being very plain. The front of the building was ornamented with blue and white tiles formed into texts from the Koran, but the whole of it appeared to be in a very dilapidated condition.

From this Muhammadan temple we asked to be conducted to a despised place, where the Jews meet to worship. It was hardly a synagogue, but rather a shanty, approached through a dirty yard, and the poorest place of Jewish worship I ever saw. It appeared that the Jews came to the town about 40 years ago, and there were usually only from 30 to 40 persons, and of these only 3 or 4 families resident. They had a few old and dirty, but not ancient, books, and I promised to give the man who received me a book in his own tongue if he would come to my lodging. Three came, to whom I gave two Hebrew New Testaments; one to a rabbi, who said he had not seen the book before, and kissed it.

In the evening the Bek again offered us amusement by batchas, but we declined on religious grounds, saying that it was our Sunday, and got off early to bed, intending to leave the next day. 


\section{CHAPTER XLVIII.}

FROM KARSHI TO THE OXUS AND BOKHARA.

Khanate of Bokhara : dimensions, soil, and divisions.-Recent exploration of mountain districts.-Maieff's journeys to Upper Oxus.Bokhariot recovery of old territory and annexation of new.Oshanin's exploration of Karategin.-Darwaz,-Bokhariot communications.-Our departure from Karshi.-Kishlaks of semi-nomads. -Khoja-Moburak. - Scamper on my horse "Diotrephes."-Kakir cistern.- " Unfurnished apartments" and oven,-Karaul bazaar. -Lake Kunja.-Stay at Chitarik.-A pproach to Bokhara.

THE Bokhara khanate, as at present constituted, bears on the map a rough resemblance to a huntsman's horn, of which the outer curve, 800 miles long, formed by the Amu-daria, indicates the southern and western boundaries. The inner curve, 400 miles in length, formed by the Hissar mountains, constitutes a part of the northern boundary, whilst the remainder of the northern frontier, corresponding to the wide mouth of the instrument, and about 250 miles in length, is bounded by the Kyzyl-Kum desert.*

* A straight line drawn from the easternmost part of Darwaz to the north-west corner at Uch-Uchak measures 650 miles, but east of Karshi the average width of the khanate from north to south is 100 miles, and at Katte-Kurgan, where the Zarafshan enters, the width east and west is about 200 miles. Réclus gives it an area barely half as large as that of France. On the north-east the country is bounded by huge mountain chains, but on the north the hills are unimportant, being called after the wells in the valleys. Towards the west and south the surface

VOL. II. 
On arriving at Karshi, midway in the khanate, we were about to turn westward into the plain; but, before describing this part of our journey, a few words must be said about the mountainous region eastwards, which was wholly unknown to science when the last Englishman before me travelled through Karshi, and which had not been explored until within the past ten years.*

The district of Shahr-i-sabz and the adjoining bekships of Hissar and Kulab were explored by Colonel Maieff, who made two journeys in this direction to the Oxus, and M. Oshanin, whom I met at Tashkend, told me of his recent journey into Karategin. Dr. Regel and his companions have been along the part of the Upper Oxus that bounds the west of Darwaz, but M. Oshanin $†$ gave his intelligence concerning this last-named district at second-hand.

Colonel Maieff, in 1875 , took from Samarkand the route I followed as far as Karshi, whence he went to slopes towards the Amu-daria, the plains being broken only by dry clay hillocks from 5 to 20 feet high, and from 6 to 200 yards broad. The soil is almost entirely clay, infiltrated with salt, and covered more or less by shifting sand, sometimes overgrown by tamarisk and saxaul ; consequently cultivation is confined to the river banks. Thus the two physical divisions of the country are the eastern or mountainous, and the western district, a great level plain.

* The two great mountain range; of Eastern Bokhara are those of Hissar and Peter the Great, the latter being the higher, and having the three-headed peak of Sar-i-Kandal, estimated by M. Oshanin at 24,000 feet. This range is crossed by three passes, in that portion lying east of the point where it is pierced by the River Khulias. These passes are open only in summer. The Hissar and Peter ranges are separated by the River Surkhab, an affluent of the Oxus; other affluents further west of the same river being the Kafirnihan and Surkhan.

+ See "Hissar and Kulab," by N. Maieff, p. 326, Geographical Magasine, 1876. "Oshanin's Travels in Karategin and Darwaz," Proceedings of Russian Geographical Society for $188 \mathrm{r}$, Vol. xwii., No. 1. "The Russian Pamir Expedition of $188_{3}$," with map, p. 135 , Proceedings of Royal Geographical Society, 1884. 
Derbent, passing through the famous "Iron Gates."* He reached the Oxus at Chushka-Huzar, where it is 700 feet wide, with three passages near. From ChushkaHuzar his party went on to Baisun, Deh-i-nau, and Karatagh, on the sources of the Surkhan, to Hissar, on the River Kafirnihan. Passing on from Hissar, the expedition came to Kafirnihan, whence Karategin is approached, and Baljuan, whither there was said to be a route of two or three days' journey to Darwaz, but the road is very difficult and across snow ranges. Kulab is situated on a small river of that name, and from this point Maieff's party returned through Kobadian and Baisun to Derbent.

Colonel Maieff's second journeyt was through Chirakchi, Huzar and Shirabad, to Kilif and Kara Kamar ferry, both on the Oxus, and after this he returned to Huzar by the direct road. $\ddagger$ The people would seem to be living in Eastern Bokhara in primi-

* This defile, in the days of Hiouen Thsang, the Buddhist missionary, was closed by double gates, fixed with ironwork, and ornamented with little tinkling bells. Eight centuries later, Clavijo passed through the "Iron Gates," but the gates were gone, and now the defile is called simply the Buzgol-Khan pass. It is difficult to conceive anything more solemn and magnificent than this huge cleft in the frowning rocks hanging overhead-a gloomy, tortuous defile, a mile and a quarter long, varying from 5 to 35 paces wide, and apparently liable to be choked at any moment by a falling rock. Soon after emerging from this defile Derbent is reached. Another town of interest, within 35 miles of the Oxus, is Shir-abad (or "Lion Town"), from whose walls the bookworms say were seen the phalanxes of Alexander of Macedon. The town was then called Shahr-i-Khyber, and was peopled by Tajik fire-worshippers.

† See "Routes compiled by Colonel Maieff on the occasion of his second journey in Bokhara," Gournal of the Imperial Russian Geological Society, $\mathbf{1 8 7 8}$, Part iv.

† Thus from Huzar to the Oxus at Kilif, there exist two principal roads, one about 150 , and the other 100 miles long; but the advantage of the shorter road is cancelled by passing through 45 miles of a tract devoid of fresh water. On comparing the quantity and difficulty of work required for rendering the two roads practicable for wheeled 
tive simplicity, and so ready is their hospitality that Colonel Maieff told me it costs a traveller nothing there for board and lodging.*

On the capture of Samarkand by the Russians, the south-east provinces of the khanate, seeing their Emir beaten, seceded from him. I have already mentioned that Shahr-i-sabz was restored by the arms of the invaders. The Russians also encouraged the Emir in reasserting and extending his authority over the bekships in the Surkhan and Kafirnihan valleys, which he formed into a province or vice-royalty known as that of Hissar.

This arrangement did not last long, the Hissar province being eventually broken up into a number of bekships, of which the rulers are directly responsible to the Emir. Further east were the two poor and insignificant principalities of Karategin and Darwaz, governed at this time by hereditary chiefs, in a manner

traffic, there appears to be little to choose. As regards fuel and forage the shorter road is much the worse. The stations and places on the two routes from Huzar to the Oxus, with distances between in miles, are as follows:-

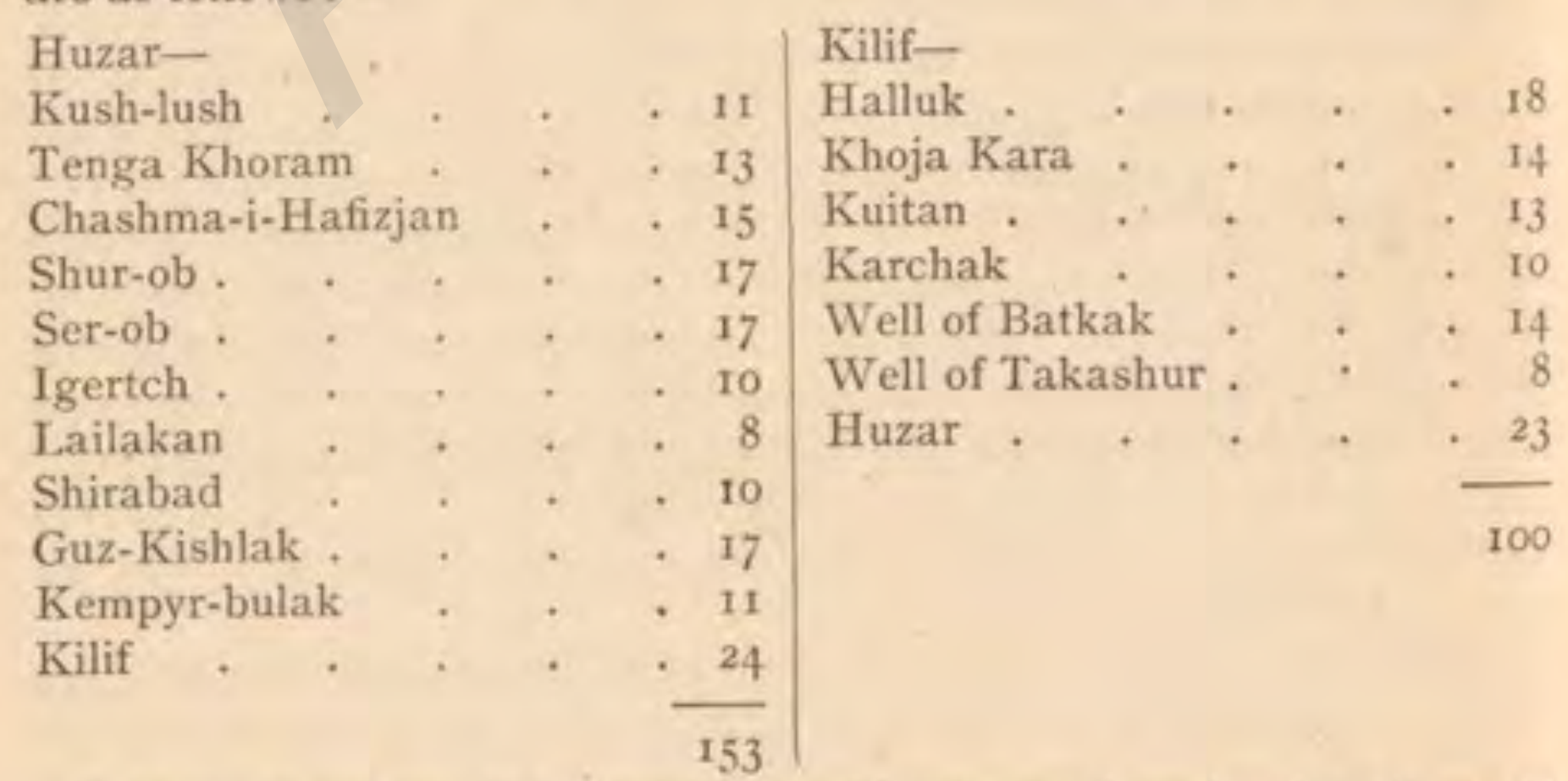

* Here, therefore, the direction would not sound so hard as it would in modern Europe, "Provide neither gold nor silver nor brass in your purses, nor scrip for your journey" (Matt. x. 10). 
independent, but also subject sometimes to Khokand, and at others to Bokhara, as one or the other of these happened to be supreme. Accordingly, after the fortunate campaign of the Emir in Hissar and Kulab in 1870 , Karategin and Darwaz acknowledged themselves his vassals, and their rulers brought nominal presents and came annually to salaam the Emir.* This opened the way, with the Emir's permission, for the Russians to explore another portion of the mountain region towards which British travellers had worked, for many years past, from the south, so that, thanks to the exploration of Dr. Regel to the west, and of Captain Pistiata and others to the east of the Pamir, connection has been established between the Russian labours and the route maps of English travellers.

Karategin lies to the south of Ferghana, along the central course of the Surkhab, a district about 30 miles wide, and extending about roo miles west from Little Karamuk. On the south it touches Darwaz, and on the west the Kulab and Hissar bekships. M. Oshanin entered the territory from the west, near the source of the Ab-i-Gharm, in August 1878 , and recrossed the Russian frontier a fortnight later at Fort Karamuk. His description of the rickety bridges over the Surkhab indicates that a traveller need have good nerves to cross them. There are no carts in Karategin, and the bridges are fit for the passage of one horseman only at a time. They shake at the approach of a man

* The Emir appointed a new Governor of Karategin, who took the title "Shah" like his predecessors, but seven years later he was deposed, and Karategin came completely under Muzaffar-ed-din, who sent there his own Bek to govern the country. The ruler of Darwaz then proclaimed his own independence, and refused to send the Emir the tartuk, or mark of tribute. Thereupon the Bek of Karategin, with a Bokhariot force, subjugated the Darwazis and imprisoned their Khan. 
even on foot, and are never furnished with a hand-rail to prevent one tumbling below.*

M. Oshanin describes Darwaz as a mountainous country, consisting of the valley of the Panja or Upper Oxus from the Shignan border as far as Kulab, and the valleys of the two large rivers Wanj and Khulias. $\dagger$

Thus it will be seen that the means of communication in Eastern Bokhara are exceedingly poor, and they are not grand even in the west. There is no regular postal communication in the country, and when in winter the passes are closed by snow, many of the mountain villages are completely cut off from the rest of the world. The roads practicable for wheeled vehicles are from Karakul through the capital and Katte-Kurgan to Samarkand, whilst from Samarkand carriages can travel through Jam or from Bokhara

- M. Oshanin mentions, among the staple articles of food in this region, crushed mulberries dried in the sun or in an oven. Trade is carried on chiefly by barter, there being little coined money in the country. Grain is sold by measure, the unit being the batman, which here is equal to 15 chashkas or bowls, or 45 tibeteikas, that is capsful; and though this latter must, of course, vary considerably, the measure is adhered to throughout Karategin. Very many of the Karategin Tajiks hire themselves out as porters in the large towns of Turkistan, and as their great strength enables them to carry up to $360 \mathrm{lbs}$., they drive other competitors out of the market. All the routes in Karategin are for pack-animals only, and there is not sufficient forage obtainable for a considerable detachment of soldiers, nor for a large caravan, though the route to Kashgar would do for 30 or 40 baggage animals.

+ Its scattered population consists chiefly of Tajiks, with a few Kara-Kirghese in the uplands. In these regions it is said that grain is the occasional, and dried mulberries the staple, food, whilst the leaves of the mulberry tree, since sericulture is not practised, serve as food for cattle. Gold and iron are exported, the latter being dug from mines near Fort Wanj. M. Oshanin was told that there is a whole mountain of it there! Darwaz, according to all accounts, appears to be a country extremely difficult of access, there being only two practicable roads, except tracks for pack-animals, and footpaths that need long acquaintance to know how to follow them. The chief difficulties appear to lie in the numerous narrow gorges, with almost perpendicular 
itself to Karshi.* But having now pointed out to an ambitious traveller a region where he may win his spurs, and having indicated the roads thither, I shall proceed with my own journey from Karshi.

I directed on Sunday night that we should start next morning at sunrise, in accordance with which I stirred up Yakoob at 4 o'clock, but a delay arose in connection with the tarantass. The men had brought it from Samarkand through Jam, but their experiment of mounting it on an arba had not been a complete success. Fearing that their machine might break down, they had brought a second conveyance, and for some reason had been obliged to break my seals. As my parcels were in full tale, I paid the men off, as also the man who had accompanied us with the sumpter horse, and distributed to them, and to Yakoob and the rest of my suite, presents and khalats. The difficulty that now arose was in harnessing our troika. Had I needed several scores of pack-horses for a large caravan, no doubt they could easily have been hired with saddles complete at a tenga per tash, or about a penny a mile; for Karshi being on the high road from India, and all the imports from the south-east having to pass that way, the local provision for land carriage is considerable; but to procure horse-collars and proper harness, not for an arba merely, but for a Russian tarantass, was not at all so easy. What was more, when sides, where the only thing to be done is to have recourse to skilfully constructed galleries, clinging to the side of the overhanging crags.

* These, however, are not marked on my large Russian map as "chaussée" "roads, but as "great caravan" routes. A communication of this character is indicated as proceeding south from Karshi, through Derbent to the Oxus at Karakamar Ferry, and also branching off from Derbent to Kafirnihan. One other great caravan route leaves the capital northwards, and all the remaining tracks in the country are marked "small caravan routes." 
the harness was forthcoming, no one appeared to know how to put it on, and this business took so long that we were not out of the city till nearly 8 o'clock.

In the suburbs we crossed a long bridge of nine brick arches, spanning the Kashka-daria, and had not got far when messengers came galloping after us, saying that the Bek had only just heard from the Emir that he was to give for myself and Sevier the presents they were now bringing. The gift consisted of pieces of silk and velvet of native manufacture, the latter remarkable by reason of their variegated colours and patterns. Sevier and I decided to ride the first stage, which was pleasant enough, for the road passed through the continuously inhabited district of the Karshi oasis. At first we kept beside the carriage, behind our own attendants and a cavalcade that escorted us from Karshi, but I soon became disgusted at our slow pace. The postilions seemed to have no notion of putting the horses at a respectable trot, and I foresaw that we should be a long time getting to Bokhara, unless I urged them on. Precept seemed to have no effect, so I determined to try the force of example; and, setting at nought their notions of propriety that I should ride in state behind, I told one of the djiguitts to keep with the carriage whilst I galloped on and left them to follow, and thus we reached Kassan.*

Kassan is a large commercial village, situated at the extreme western point of the oasis. Beyond Kassan the steppe begins, with vegetation, however, and kish-

- The stations from Karshi to Bokhara, with distances between in miles, are:

Karshi-

Kassan . . . . . 16

Karaul Bazaar * * * 13

Khoja-Moburak * . 20

Kakir Cistern.

Bokhara . . . . 27

94 
laks here and there-one of them, Maimene, being the residence of the Amliakdar, or tax-gatherer under the Bek. The inhabitants of these kishlaks water their fields by means of aryks, or canals, from the River Kashkadaria, which is full only in early spring, and afterwards becomes narrower and shallower, inclining to the north-west, and seven miles from Karshi it reaches the Maimanak hills, where it is lost in the sands. Together with the Kashka-daria the gardens also disappear, so that we continued on a flat, bare, and waterless steppe, the scrubby vegetable growth consisting of clumps of Issirik grass, used by the Bokhariots for all diseases, and sold in their bazaars. They dry the grass and burn it on coal, the sick man or animal inhaling the smoke. In passing along from Karshi we had seen what I judged to be good specimens of kishlaks, or winter habitations of semi-nomads, for in some cases the whole collection of houses appeared to be deserted, and we were told that the inhabitants were gone to the mountains for the summer, whilst in other cases cultivated places were seen, with the people living by in tents.*

At Kassan, where we arrived about midday, and rested for a couple of hours, we obtained two fresh

* It is interesting to note in the book of Genesis how naturally the patriarchs Abraham, Isaac, and Jacob, pass from nomad to settled life. We do not read that the first ever built a permanent dwelling for a house, but lived in a tent-a nomad pure and simple (unless Gen. xxiii. 2, points to the contrary). Lot, on the other hand, seems to have forsaken the tent on settling in Sodom, so that, when driven by fear to the mountain, he dwelt in a cave, and not in a tent (Gen. xix. 19, 30). Isaac in middle life perhaps had a house (xxvii. 15 ). like a seminomad, and he appears to have died a settler in a town (xxxv. 27). Jacob was "a plain man dwelling in tents" when young (xxv. 27), but on returning from Laban he built a house (xxxiii. 17), though not forsaking the tent (xxxv. 21) till settled in old age in his patrimony, whence he sent out his sons to tend his flocks (xxxv, 27; xxxvii. 14). 
horses, but the third had to go further, our troika being mounted by three turbaned riders. Sevier and I got into the tarantass for the next stage, and after proceeding about half the distance, we passed KaraKum, where is, I think, a dry well, as also near, on the left, the ruins of the town Maimanak. We had no trotting until we approached Khoja-Moburak, which we reached at 6.30 , and found it a village of 60 or 70 houses, affording a resting-place for caravans between Bokhara and Karshi. I cannot say that I was satisfied with having accomplished 36 miles only for a day's journey, and I therefore desired that we should go on to the next station; but our escort said the horses were too tired, and, indeed, the men appeared horrified at the notion of travelling by night in the steppe. I thought at the time this was only an excuse, but experience taught me further on that "perils of robbers" was here a thing by no means to be risked.

The chief man of Khoja-Moburak came out to meet us, and conducted us to a poor but nicely-carpeted lodging, where our room measured about 12 feet by 8 . Here I nearly had an accident, for taking a light to get something out of the tarantass, the man to whom I gave the candle to hold, set fire to the cotton lining of the apron, which fortunately I managed to extinguish quickly, or we might have had serious loss. The inhabitants, however, were determined that we should not suffer from either fire or pillage, for they set Io men to watch the tarantass through the night, and I told Kolutch to sleep inside. I asked a few questions concerning taxes, and was told that from 12 surrounding villages are collected annually 100,000 tengas, or $£ 2,500$, whilst the population, chiefly Tajiks, with a few Uzbegs, was guessed at 100,000 ! I record this, though 
I do not think the figures trustworthy. Colonel Maieff, in a similar case, says he was told by the Amliakdar of Karakia, in the bekship of Chirakchi, that there were sown in his Amliakdarship alone 250 tons of wheat and 125 tons of barley.

As we could not go further the first day from Karshi, I resolved, if possible, to start early the next morning, and was rewarded for turning out by getting my first sight, on October roth, in the direction of the "Great Bear," of the beautiful comet of 1882 , with its enormously expanded tail. The natives said it had been visible for the previous 20 days, and that the world was now coming to an end.* As we drove out of the miserable village of Khoja-Moburak we saw a beautiful sunrise over the barren steppe, and we jogged along a road destitute of anything green, until the postilions wanted, for some reason, to re-arrange their troika; whereupon Sevier and I mounted our horses for a ride. It was a magnificent morning. The wind was fresh, but not much laden with sand. The previous day had been hot, and my minimum thermometer had gone down in the night only to $55^{\circ}$; but at this early hour there was just so much of autumnal freshness in the air as to make it perfect for horseback travel.

My little horse had manifested a strong liking to get before everyone else in the cavalcade, wherefore I named him Diotrephes, and let him have his way. By this time, too, we understood each other pretty well, and I had got firmly into my seat. Upon giving my horse his head, Sevier came on, and Kolutch, not liking to be outstripped, joined in the run. So did several others, and away we scampered

" Illustrating Jeremiah x. 2: "Learn not the way of the heathen, and be not dismayed at the signs of heaven; for the heathen are dismayed at them." 
like a party of huntsmen. Soon we overtook a horseman, who looked round at our approach with dismay, for he had been sent on ahead to the next station to prepare for our coming. He trotted on after another horseman still further ahead, sent on a similar mission. This latter was a stout fellow, well advanced in years, who had packed on his horse a number of carpets and other things for our accommodation, on the top of which he had mounted. He had supposed, doubtless, that we should jog along in the slow fashion that is thought dignified by the Bokhariot officials; but when he discovered that we were upon his heels, he made the most frantic efforts to keep ahead. As seen from behind, the broad back and base of this individual, and his vigorous application of whip, had a most ludicrous effect, and we fairly roared with laughter. With the start he had, he managed to keep ahead for a time; but his whipping was vain, and he was outstripped.

A diversion of another kind now took me aside for a moment, for we saw off the track two small eagles sitting, which did not pretend to rise on our approach. I was minded to get as near as possible, and was allowed to approach easily within pistol shot, and had a good view of one, but I had not my revolver with me, and so could not have secured, a skin, even had I known how to dress it. We met only one or two horsemen during our five miles' run to Kakir, the distance being accomplished in 35 minutes, at the cost, however, of a wide-mouthed bottle with prussic acid, fitted for killing moths, which broke in my saddle-bag. Sevier and I, and a few more, had now reached Kakir, where is a sardaba or cupola-covered cistern, erected in the 16 th century by Abdullah Khan.*

* Burnes tells a story that Abdullah had made a pilgrimage to 
Besides the cistern at Kakir there is a large building that had served as a mosque, but was now used as stables for caravans. It seemed also to serve as a guard-house, for we saw several old matchlocks and firearms of a bygone generation hanging about. After the speed at which we had come we were hot, and it was grateful to turn into the cool corridors of what Kostenko speaks of as a house for the Emir in the event of his crossing the steppe. Already we had noticed raised platforms of earth by the wayside, on which we were told his tent was spread with that of such of his wives as were chosen to accompany him. On passing round the passage we came to a spacious chamber with four windows, that when properly prepared would serve for his Majesty, and, therefore, for ourselves. But as we had outstripped our forerunners, our "furniture" was not come, and we thus had the opportunity of seeing what an "unfurnished" room was like in the East, namely, four bare walls and a mud floor, the chief difference between a furnished and an unfurnished room being, under ordinary circumstances, that one was strewn with carpets and the other not.* The introduction of chairs and tables I took to be quite Mecca, but imbibed an idea that it had not proved acceptable to God, on account of which, and in order to propitiate the Divine favour, he set about the construction of caravansaries and cisterns in all parts of his dominions - a later Uzziah, who "built towers in the desert, and digged many wells"' (2 Chron. xxvi. 10). The cisterns are becoming dilapidated and unfit for use; but there is water still in two of them : in one, three miles from our last station, and in this one at Kakir. This sardaba is 35 feet high to the top of the cupola, and about 25 feet in diameter. The water, approached by steps, was said to be 12 feet deep at the time of our visit, and, when full, about three feet deeper. In winter the cistern is empty, and they clean it, the fresh supply of water being run down from the hills in May.

- This seems to me to throw light upon, though perhaps not exhausting, the meaning of a word in Luke xxii. 12, "He shall show you a

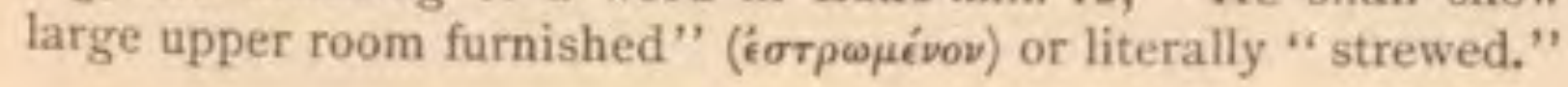


foreign. Those we saw had, for the most part, been made for us, or for Russian visitors, and it was not a little ridiculous on one or two occasions to see our chairs, stowed away with a man on horseback, going before to the next station. As for the tables, they generally consisted of boards put on rickety supports, and covered with calico. The moment we finally quitted apartments we had occupied, our carpets, rugs, etc., were folded up, and the room speedily " unfurnished."

Near the building at Kakir was a small bazaar, but it was not market day, and many of the houses were empty. I busied myself, therefore, whilst the tarantass was coming up, in looking about for objects of interest, and, among others, examined a native oven.*

When at length our carriage came up we had some little to do in starting with fresh horses, for one fell, and had to be taken out. Sevier and I preferred still to ride to the next station, the wind becoming stronger, and our horses being not too tired for another gallop. Yakoob had picked up for us, without my directions, a ragged hanger-on, whom I supposed to be going to Bokhara on his own account, but glad to do so on one of my spare horses, as a recompense for acting as groom and making himself generally useful. This fellow had mounted the savage horse given me by the Emir, and we had a short race; but I soon found that the long-legged creature, vicious as

* It recalled to my mind two passages of Scripture, being like an earthenware crock, laid upon its side and built about, except in front, with earth, into the mouth of which was put the grass or other fuel (Matt. vi. 3o; James i. I I). Yakoob explained to me how they bake the bread; namely, by making cakes of dough about the size and thickness of a captain's biscuit, and then clapping this on the side of the oven, where it sticks till one side is done, the same process being repeated with the other side. Hence a half-hearted person, as "Ephraim, is a cake not turned" (Hosea vii. 8). 
he was, with a rider who knew how to manage him, could hold his own, and more, against Diotrephes.

After passing Kash-sardaba, and some distance before we reached Karaul Bazaar, we saw the latter building standing out against the sky like some lofty Russian cathedral, or medresse. This also was built by Abdullah Khan, for his soldiers, and intended for the great central caravansary of the Karshi steppe. It was used as a guard-house, whence escorts were provided for passengers and caravans. Dr. Schuyler, in 1873 , was provided with a guard in this place, and we heard that 30 soldiers are still kept on the spot, but we neither asked for, nor received, any addition to our company. We saw several old firearms hanging at the entrance, but not promising much help to a besieged traveller. The principal building consists of a square court, surrounded by cloister-looking corridors with vaulted chambers, surmounted by low domes. From within the court are seen four lofty facades, on which there still remain a few coloured bricks to testify of departed grandeur, but the entire building is fast going to ruin.

Near the caravansary is a cistern with what is said to be good water, and also a deep well of brackish, disagreeably-tasting water, to which they were letting down skins to fill, and hauling them up by four men walking away, and drawing the rope over a round piece of wood at the mouth of the well. There were also some small houses, in one of which we made a light meal, and then I insisted on proceeding, so as, if possible, to get to Bokhara that night, a distance of 26 miles. From the Kakir cistern to Karaul Bazaar, and for a mile beyond, there was a continuation of steppe, with some pretence to vegetation here and 
there, so that we had had in all from Karshi about 53 miles of this character to pass through along a level road, the altitude of Karshi being 730 feet, and that of Karaul 660 feet.

Now the character of the steppe changed, the soil became stony and sandy, and all vegetation completely disappeared. We were in a desert pure and simple ; * sand, sand everywhere, and blowing withal in our faces, so that we were glad to get into the tarantass, and shut it up closely to keep ourselves from being covered. This kind of steppe continues over some high ground and beyond the ruins of Sarai-MamaJugarta, and onwards to the salt lake, from whose shore there continues a salt tract almost up to Bokhara. The name of the lake on the map is Kunja-Kul, but the local name was given me as Kulimai. $\dagger$

From the high ground of Mama-Jugarta to Bokhara is only i I miles, but my hopes of getting there that night were to be disappointed, for it was not till 7 o'clock we came to Chitarik, where a djiguitt from the Kush-beggi came out from Bokhara to meet us and apologize, saying that they had received the letter from Karshi to announce our coming only that day at noon; and hence the poor reception made for me at the last two stations. I had, however, put this

- Witnessed to here and there by the bleached bones of horses and camels fallen and left as meat for the fowls of the heaven and for the beasts of the earth (Jer. xvi. 4), to which the eagle flies, hastening to eat (Habak. i. 8).

+ Yakoob said it took its name from kunji, a corner, because the shore is irregular, and mai, fish. They gave me its length as about 6 miles, which, according to my Russian map, is full measure. It was said to be from 25 to 50 feet deep, and frozen in winter to the thickness of a foot, so that camels may cross it. I could hear nothing of boats thereon, but fish is caught with shore nets and sold in Bokhara at from $3^{d .}$ to $5^{d}$. per lb. 
down to my own perverseness in getting ahead of those sent forward to prepare for my comfort. At Chitarik we were put up for the night, and our host brought forth at our evening meal a rather pretty china plate. I had the curiosity to look at the bottom, and, to my amazement, saw written in my own tongue "Real Ironstone China." No Englishman had been along that road, so far as I know, since Alexander Burnes, half a century before, and I wondered how it came there.

The temperature fell during the night to $55^{\circ}$, and at 7.30 we were again on the move. The salt tract soon ceased, and the country began to show signs of life and cultivation. After 5 miles of travel we came to the village of Kagan, where the Bokhariot oasis begins. Although we had not long since breakfasted, we were expected to stop here for tea and refreshments, partly also, I fancy, because our nimble movements rather outran the local arrangements. Henceforward, for the remaining five miles, we drove through fields and gardens, till we stood before a city with a wall great and high, having I I gates, rigorously closed by night, which city, when I had entered, I found one of the most interesting, and certainly the most curious, I have ever seen. 


\section{CHAPTER XLIX. \\ THE CITY OF BOKHARA.}

Bokhara from the earliest times, and afterwards under the Samanids, Seldjuks, and Uigurs.-Bokhara conquered by Jinghiz Khan. Tamerlane, and the Uzbegs.- The Sheibanids, Astarkhanids, and Manghits. - The late Emir Nasr-Ullah.-Visit of Burnes to Bokhara.-Stoddart sent as British envoy.-Concurrent Russian missions. - Conolly enticed to Bokhara and imprisoned.- Stoddart and Conolly killed.-Brave journey of Dr. Wolff.-My entry into Bokhara. - Its ancient appearance and customs. - Sumptuous lodging and garden.-Bokhariot fruit-trees and horticulture.

J OT a little of the interest attaching to the city we had now approached is connected with its history, and without some slight sketch of it my description would be very imperfect. The earliest tradition peoples the country with a Turkish race who had much intercourse, alternately friendly and hostile, with China. The natives even told me that the present walls of Bokhara were built by the Celestials, though I saw not a single sign of it, nor of anything Chinese throughout the city. In seeking for documentary evidence, we cannot, as in the case of Samarkand, fix upon a date for a starting-point so early as the days of Alexander; but it seems pretty certain, according to Gibbon, that in the time of Justinian there was a khakan, or emperor, of the Eastern Turks reigning 
in Mavera-un-Nahr-that is, between the Oxus and Jaxartes-who was overthrown by Naushirvan, from which time the prevailing race and language became Persian. At the beginning of the eighth century came the Arabs, who found the people fire-worshippers and Buddhists, but, at the end of a century and a half, left them Muhammadans. During the Arab occupation, Bokhara, being more or less under the Khalifs, was treated as a part of the province of Khorasan, and had to yield obedience to commands issued from what was then called Mervi-Shah-Djihan, or Merv, the queen of the world.

The rule of the Samanids, who were next masters of Bokhara, commenced about 874 , in the person of a nobleman, named Saman, a ruler of Belkh, and one of the remaining followers of Zoroaster, who, in gratitude for help received from the Viceroy of Khorasan, embraced the creed of Islam. Of one of his successors, Ismail, is told the magnanimous story, that having conquered the generals of Amrubin Leith from Khorasan, instead of taking the whole army prisoners, according to the custom of those days, he loaded the men with presents, and set them free to return home; and when his own people expressed their astonishment, he said, "Why, what would you do with these poor men? Let them go quietly home, and they will never fight us again." Under Ismail, Bokhara became virtually the capital of all the states of Central Asia, Merv included; but the Samanids, who succeeded Emir Ismail until 1004, were, for the most part, helpless puppets, who at length made way for the Seldjuks.

Seldjuk was commander of an army of the Turkish hordes of Transoxiana, under a prince named Pigu, and, being expelled from his native steppe, settled near 
Djend, north of Bokhara, where, with all his followers, he embraced Islamism. Seldjuk acquired some amount of influence by protecting the peaceable inhabitants of the neighbourhood from his heathen kinsmen. $\mathrm{He}$ also took the part of the later Samanids, and gradually obtained the position of one of the independent princes of Transoxiana. His successors, forced to quit Turkistan in $\mathrm{IO}_{3} \mathrm{O}$, conquered Merv five years later, and Khorasan also ; after which the power of the Seldjuks continued till the second quarter of the twelfth century.

The last of the Seldjuks was overthrown by the Uigur Khurkan from the district north-east of Khokand, and Bokhara now became an apple of discord between the Uigur Khurkan in the east, and the princes of Kharezm, or what is now Khiva, in the west. So things continued for nearly a hundred years, when the greatest of Asiatic conquerors arose in the east, born as Temuchin in I 155 .

The progress of Temuchin in subduing the nomads of Gobi was, up to 1206 , comparatively slow. At this date he assumed the new title of Jinghis (or Chingis, Genghis, or Jenghiz) Khan, and soon afterwards subdued all eastern Mongolia, and the country south to the Chinese wall, and the frontier of Tibet. In 12 I8, this Mongol conqueror set off on a campaign against Transoxiana. He was accompanied by his three sons, Jagatai, Oktai, and Djudji, with 600,000 men. Jinghiz himself, with the elite of his army, marched direct on Bokhara. Entering the Friday mosque, he went up the steps of the pulpit, and said to his soldiers, "The hay is cut, give your horses fodder." The Mongols plundered the town, and afterwards set it on fire, so that only a few mosques and palaces of brick remained. 
The garrison, however, in the citadel continued to hold out, nor was it till the moat was literally choked with the corpses of men and animals that the stronghold was taken and its defenders put to death. More than 30,000 men were executed, and the remainder reduced to slavery. Samarkand shared a similar fate, and, in I 220, Merv was sacked by the Mongols, and 100,000 people slain. This Mongolian invasion put an end, for the time, to the intellectual life of Central Asia, and Bokhara and Samarkand never regained their former position. Jinghiz, in 1224 , divided his immense empire, stretching all across Asia, between his three sons; Turkistan and Transoxiana falling to the share of Jagatai, whose descendants ruled the country for nearly i 50 years, towards the end of which time the Turks, who had come west with the Mongols and served them so long as they were powerful, gradually usurped the place of their masters, and the empire of the Djengezids gave way to that of the Timurids.

The house of Berlas planted the flag of independence at Kesh, where, as 1 have said before, the great Tamerlane was born in 1333 , and though he made Samarkand his capital, he often went to Bokhara. The sway of the Timurids lasted barely a hundred years. During that time, however, Bokhara and Samarkand again rose, as I have shown in a previous chapter, to considerable civilization and culture, but with the last of the Timurids in 1506, Central Asia began to gravitate towards the slough of ignorance and barbarism, from which it has never yet recovered itself.

A new dynasty was now arising among the descendants of some of the Turko-Mongol tribes, living in the north-west country between the Volga and Aral. 


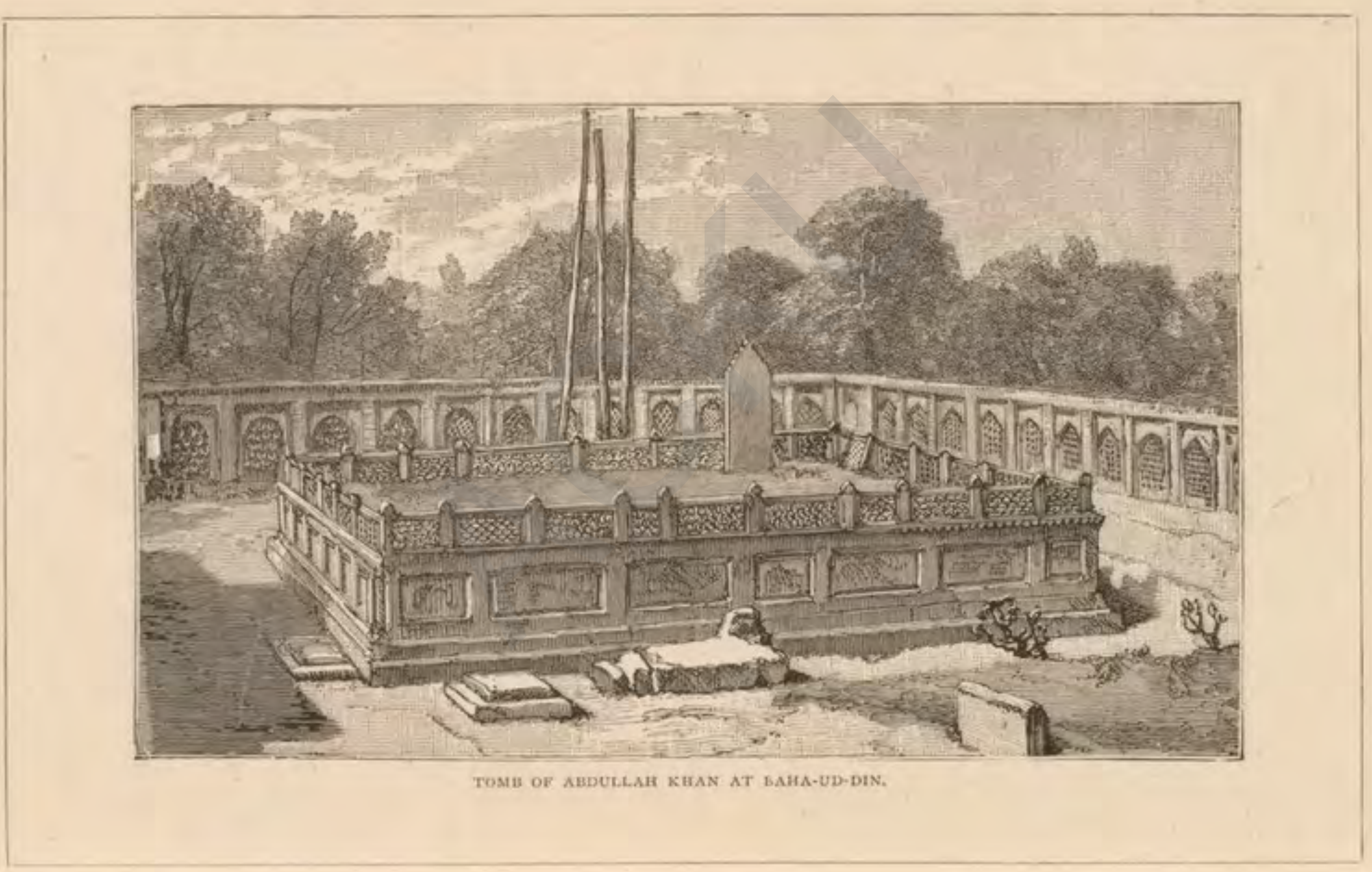


They had assumed the political name of Uzbegs, or Özbegs, in honour of Özbeg, the ninth ruler of the house of Djudji, son of Jinghiz Khan; and when the Muscovite power was beginning to drive out the Tartars from Russia, these Uzbegs gradually retired eastwards under Ebulkhair. Being appealed to for help, they lent their warlike powers to the successors of Timur, who were fighting each other, till, under Sheibani, the grandson of Ebulkhair, Baber, the last of the Timurids, was driven from his throne, and the Uzbegs became masters of Transoxiana. Sheibani was conquered and killed in $1_{5}$ io by Shah Ismail, after which the Sheibanids reigned for nearly a century.

The greatest monarch of this line was Abdullah Khan, born in 1533 . It was during his lifetime that trade relations were proposed by ambassadors sent in $155^{2}$ from Bokhara and Samarkand to John the Terrible; and six years later the English merchant, "Master Anthony Jenkinson," landed at Mangishlak on the Caspian, and having travelled across the Turkoman desert to Bokhara, returned the following year. To Abdullah Khan is attributed the building of many caravansaries, bridges, cisterns, and other works of public utility in Bokhara. The part of the bazaar at Bokhara that is now best preserved was built by him in $1_{5} 8_{2}$, so was the bridge at Kermineh, besides the one I crossed at Karshi. His tomb is near that of Baha-ud-din, the patron saint of Bokhara, a short distance out of the town. His reign, Vambery says, may with truth be called the last ray of the glory which had at various times surrounded the throne of Transoxiana.

The succeeding Sheibanids reigned till 1597, and 
were succeeded by a new line of sovereigns, called Astarkhanids, who maintained their rule for nearly 200 years. Driven from the khanate of Astrakhan on the lower course of the Volga, the Astarkhanids were welcomed in Transoxiana by the Sheibanids, both being descendants of Jinghiz Khan. They helped the ruling dynasty as Sheibani did before them, and with similar results, for they also succeeded to the throne, and retained it till 1737 , when their power was permanently broken by Nadir Shah. The material prosperity of the country declined greatly under the Astarkhanids. Old buildings were suffered to fall into ruin for want of necessary repairs, whilst the buildings of the Astarkhanids themselves were only the college of Yelenktosh, built in $16 \mathrm{Ir}$, opposite the already ruined college of Ulug Beg; a mosque and a college in Bokhara, raised by the wealthy Nezr Divanbeghi in I620; and lastly, two reception saloons, which Baki Mehemmed Khan had built in Bokhara and Samarkand in 1605 . It was under this dynasty that the Italian Florio Benevini arrived at Bokhara on a mission from Peter the Great; and with difficulty made his escape four years afterwards.

The Astarkhanids, in 1784 , were succeeded by the family of Manghit; Uzbegs who came from the wooded country on the left bank of the Lower Oxus, where they helped the Khivans. Some of them were taken into the pay of the Sheibanids, and these settled later in the neighbourhood of Karshi. Here others of their number afterwards rose to power under the later Astarkhanids, with whom they intermarried, and the crown was at length placed upon the head of one Emir Maasum, of the family of Manghit, who passed much of his time in religious meditation, living in retirement 
in the great mosque, and wearing the mantle of a dervish. Later on, however, he turned warrior, laid waste Merv, and transferred its inhabitants that were not killed to Bokhara. It was this prince who revived the office of the Reis-i-Shariat, guardian of the law of religion, whose office it was to pass through the streets attended by police with a whip, to thrash those who could not pass a proper examination in religious matters, or who did not attend to their religious duties. Drinkers of wine and smokers of tobacco were treated in like manner. Emir Maasum was succeeded by his son Emir Said, in $\mathrm{I}_{80}$, who remained a mullah all his life, and at his death, in 1826 , passed on his throne to his son Nasr-Ullah-Bahadur Khan.

I have thus rapidly outlined the history of Bokhara, so that in describing the capital and objects seen in passing through the khanate, references to the past may not seem quite a blank. ${ }^{*}$ We now come to a despot whose name, Nasr-Ullah, father of the present Emir, was well known forty years ago in England in connection with those of Lieutenant Burnes, Colonel Stoddart, Captain Conolly, and Dr. Wolff, and with others who proceeded to Bokhara from Russia. The mutual rivalries of the two nations at that time gave the affairs of Bokhara a wider interest than had been previously felt in Europe. The first English officer who travelled into Bokhara was Lieutenant Burnes. Leaving Peshawur, he passed through Cabul, Balkh, and Karshi, in 1832 , and thence continued to Bokhara by the route described in the preceding chapter. He

" For fuller information see Howorth's "History of the Mongols," and Vambery's "History of Bokhara," from which I have for the most part derived my information; but in connection with the latter should be read the criticism thereon of Professor Grigorieff, translated in Schuyler's work, Appendix II. 
travelled as a private individual, but with documents showing that the British Government was interested in his good treatment. He was suspected, of course, and forbidden to use pen and ink; but on the whole, thanks to the court officials, he was kindly received, and on reaching England published, in 1834 , an account of his travels.

Russia had carried on intercourse with Bokhara, as I have stated, since the middle of the sixteenth century, and in 1820 Russian literature was enriched by books on Bokhara and Khiva, by Muravieff, Meyendorff, and Eversman. Howorth suggests that perhaps the journey of Burnes incited the Russians to send to Bokhara Dr. Demaisons in the guise of a mullah, in I $8_{34}$, and Vitkovitch disguised as a Kazak in the following year, to learn what the Englishman had been about. In 1836 , the Governor of Orenburg asked by letter for the friendship of Bokhara, whereupon an envoy from the Emir was sent to Petersburg to reciprocate these friendly advances, and to say that the English had sent agents to try to open trade with Bokhara.

Russia and England had been for some time intriguing at the Persian court, whence the British Ambassador deemed it prudent, in 1838 , to send Colonel Stoddart as an envoy to Bokhara to endeavour to stop the pillage on the Persian frontier and the capture of slaves, to release any Russian-prisoners he might find at Bokhara, and to make a friendly treaty with the Emir. On his arrival at the gate of the city he was received with distinction; but when, soon after, he refused to conform to local usages and etiquette, rode his horse in the Rhigistan, which none but the Emir then might do, did not dismount when his Majesty 
passed, and finally, when about to be presented to the sovereign, he knocked down the master of the ceremonies, who presumed to feel if he had arms concealed ; after all this the Emir had him let down to an underground prison, 20 feet deep, and kept him there for two months, with two thieves and a murderer. Captain Grover states that this dungeon swarmed with ticks and vermin, specially reared to annoy the wretched prisoners, and that, if no prisoners were there, the vermin were supplied with rations of raw meat. On the second day the executioner descended with an order from the Emir instantly to kill the Englishman if he did not embrace Islamism. Stoddart made the profession of faith ; but at the end of two months, being removed to the house of the Mir-sheb, or head of the police, he announced his return to Christianity, and that his avowal of Islamism was forced from him. He was now informed that one Naib-Abdul-Samut, once in English pay, but expelled from India for his crimes, and now lieutenant to Nasr-Ullah, had been the principal cause of his imprisonment, having represented him to the Emir as a spy. During $1839-40$, Stoddart was alternately in prison and in favour, and after his third imprisonment was removed to the palace, and then to the house of Naib-Abdul-Samut.

Meanwhile some Russians arrived at Bokhara. In August, 1838 , the Emir had sent to the Tsar a present, and asked that some mining engineers might be sent to search his country for minerals. In April, 1839 , a caravan started, but, being threatened on the way by the Kazaks, the Russian officers did not proceed. In I 840 , another mission was sent to the Tsar. In reply to this, Buteneff was charged to proceed to Bokhara, in company with Khanikoff, Lehmann, and others, and 
to compass among other things, if possible, the release of Stoddart. On their arrival the Russian mission was treated very coolly by the Emir, but Stoddart was permitted to live with Buteneff. The Emir even offered Stoddart to return with the Russian embassy, but this he declined on the ground that he had not received orders from his government to withdraw. One principal reason that made the Emir so wavering was the alternation of success and defeat, at that time, of the English in Afghanistan. Matters were further complicated in 1840 by the arrival of the English officers, Abbott, Shakespear, and Conolly, at Khiva. Conolly was ordered to explore Khokand, and apparently also to attempt to checkmate the Russian advance thither. He travelled north of Bokhara, but on receiving a letter from Stoddart, inviting him to go there, he determined, contrary to the advice of his Khivan and Khokandian friends, to go to Nasr-Ullah's camp, and try to persuade him to join with the Uzbeg princes in a league against Russia. The Emir wished to gain possession of Conolly, and at once made him prisoner in the house of Abdul Samut, where he was joined by Stoddart.

The Emir now became very hostile to the English, as well as insulting to the Russian embassy, whom he dismissed, and said that he would send the Englishmen to their country direct. Instead of this, the Afghan campaign having ended in the massacre of the English, from whom he thought he had no longer anything to fear, and embarrassed by requests for the release of his European prisoners from Persia, Khiva, Constantinople, Cabul, and Herat, Nasr-Ullah determined to put Stoddart and Conolly to death, which he did on the 24 th June, 1842. 
A vague report of this reached England, but much uncertainty hung over the matter for some time, whereupon Captain Grover, a friend of Stoddart's, determined to go out to Bokhara to clear up the mystery, and had applied to the Government in London for official papers of protection, when Dr. Wolff, a Christian Israelite and English clergyman, who as a missionary had visited Bokhara in 1831 , and, going on to India, had made the acquaintance of Captain Conolly, issued a challenge, in July, I 843 , to the "brave officers of England," that if one of them would accompany him, or even pay the expenses, and no more, of his journey to Bokhara, he hoped to be able to release the prisoners, whose execution he considered exceedingly doubtful. This led to the formation of a Stoddart and Conolly Committee, and in the following October Dr. Wolff started.

He went supported by letters from the Sultan and others, and on arriving was well received by the Emir, and Abdul Samut told him how and why Stoddart and Conolly had been put to death. The missionary then desired to return at once, recommending that an ambassador should be sent with him to ask pardon of the English Government, and also expressing a wish to redeem some Russian slaves, of whom he heard in Bokhara. Every pretext, however, was put forward to delay the stranger's departure, and, lodged in the house of Abdul Samut, this rascal tried every means possible to extort money from Dr. Wolff, besides doing his best to compass his death as he had done that of the two officers. At length, however, the brave traveller had permission to depart, and after escaping several attempts at assassination, robbery, and poison, he reached London in 1845 . 
I have a dim recollection, as a child, of hearing Dr. Wolff lecture on his travels-I suppose soon after his return-and a better remembrance as a boy of hearing him preach. How little I then dreamed that I should be the next of the Queen's subjects to enter the city of Bokhara! Yet, on October IIth, I882, I found myself approaching the very gate by which I presume Burnes had entered 50 years before. The sight of the crenelated walls, 8 miles round, with holes through which archers might shoot, guarded by a thin clay defence, and supported on triangular beams, struck me as curious indeed for Anno Domini $\mathrm{I} 882$. Everything, however, was in keeping therewith. It was not like a street of Old London, erected in a modern exhibition, or an assemblage arrayed in ancient costumes whilst surrounded with igth century furniture. There came out to meet us, from the Kush-beggi and his son, to conduct us with honour to our lodging, an array of dignitaries, of whom, mutatis mutandis, one might have said, These are the princes which the Emir had: "Azariah the son of Zadok the priest, Elihoreph and Ahiah, the sons of Shisha, scribes; Jehoshaphat the son of Ahilud, the recorder. And Benaiah the son of Jehoiada over the host : and Zadok and Abiathar the priests : and Azariah the son of Nathan over the officers : and Zabud the son of Nathan principal officer, and the king's friend : and Ahishar over the household: and Adoniram the son of Abda over the tribute" ( 1 Kings iv. 2-6; 1 Chron. xviii. 15). One of my difficulties "was to distinguish "Who" from "Which" among these notabilities, for they were all so grand, and their Oriental titles of office were to me, of course, considerably " worse than Greek."*

* Dr. Schuyler mentions his being preceded at Shahr by men running on foot, as Absalom and his brother Adonijah each prepared 50 men to 
What with our own djiguitts, however, one or two who had accompanied us all the way from Kitab, and the cavaliers who came out to welcome us, we mustered a pretty strong party. We had driven nearly to the city gate when it was suggested, Christians though we were, that we should leave the tarantass, and formally enter Bokhara on horsebacka change truly from the treatment accorded to Burnes, who, because a Christian, had to trudge about the city on foot, whilst his Muhammadan servants were mounted. Not the least objection was made later on to our riding in the Rhigistan, of the old law concerning which we were ignorant, and the Russians have sometimes administered a bitter pill to the Bokhariots, in that when embassies happened to be attended by a Jewish interpreter, the Russians do not, of course, suffer him to dismount.

Our cavalcade was marched through the streets, the carriage bringing up the rear, and djiguitts going before to clear the way. I supposed the one immediately before us to be in authority, for a woman, who was not, I think, fully veiled, happening to meet us, he appeared to rebuke her sharply, and she, poor creature, went and turned her face to the wall like a scolded child. Many rose to give our party the Muhammadan salutation, Salaam aleikum, in which, I presume, we, as Christians, were not intended to participate, for the Moslems do not thus salute Christians; but the Jews frequently bowed to us, and paid their respects with an uttered Aman!* run before him (2 Sam. xv. I; 1 Kings i. 5); but I do not remember meeting with an exemplification of this custom in Bokhara, nor of the Egyptian calling before a ruler, "Bow the knee" (Gen. xli. 43). I missed, too, among the many officers of the Emir, a cup-bearer, like Nehemiah (i.ii.)the Bokhariot sovereign, like all Moslems, being a " total abstainer."

* Reminding one of Matt. v. 47, "If ye salute your brethren only. what do ye more than others ?" 
At length we reached the largest of the eight houses set apart for guests, and which proved to be, on the whole, the finest house we entered in the khanate. I was disposed to christen it " the house of Haman," * for it had been the residence of a fallen favourite, one Barat Bek, who, four years previously, was at the head of 5,000 troops, and had enriched himself by withholding their pay. Besides this he drank, and having had the batchas one night, he went out inflamed with strong drink, and insulted not only the people, but the Emir also. His master caused him to be bound and thrown into the Kana-Khaneh, the prison, I believe, where the English officers were confined, out of which the corpse of the man was taken 15 days afterwards, when it was found he had bitten himself to death.

On leaving the street to enter this good specimen of a Bokhariot noble's residence, we rode into a horse yard in the shape of the letter L, bounded on one side with stables, and on another with men-servants' apartments, and two rooms that served, apparently, for men-servants wives. From this yard we rode into a second small court, out of which a screened door led into the women's quarters, and a narrow passage conducted us into the principal court, or square, with a fountain in the midst. The side opposite the entrance was occupied by a raised platform, and four rooms en suite, and a fifth. The centre one was an entrance hall, in which, at the entrance, was a place for ceremonial bathing, with a chamber overhead; on the right was the room of the Bek, and on the left that intended for his guests, whilst further to the left was a small sleeping-room. The other sides of the principal court

- Esther viii. 1. 
were occupied by offices, and rooms for the Bek's officers and attendants. Also on one side of the women's court were two rooms with upper stories and

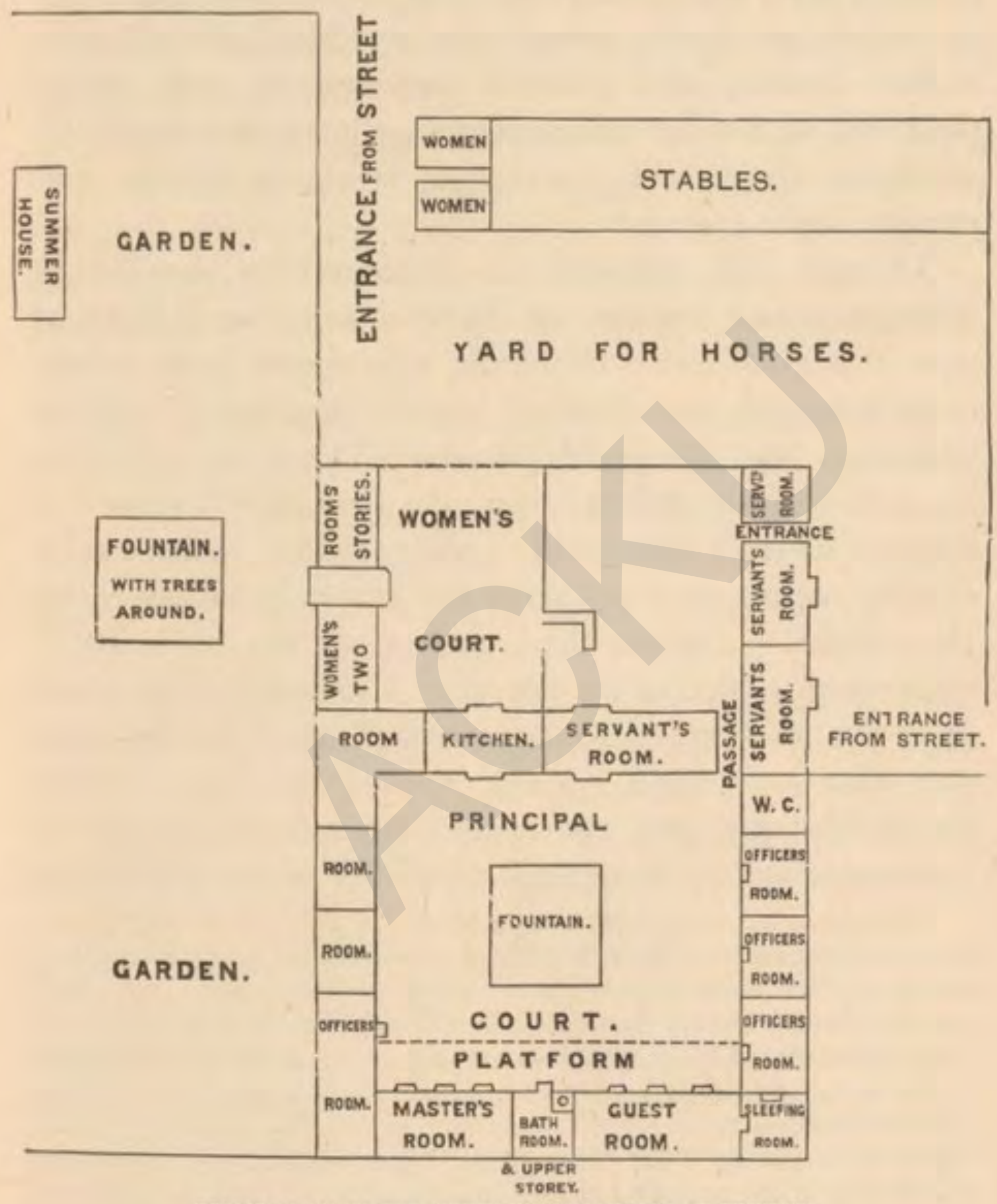

GROUND PLAN OF THE PRINCIPAL GUEST-HOUSE AT BOKHARA.

an entrance hall, opening at either end into the court, or into a splendid garden, where near at hand was a pool with adjacent trees. Somewhat further off was a

vOL. II. 
summer-house, surrounded by bowers of vines, groves of apricots, and clusters of apple, pear, pomegranate, plum, and fig trees, the whole watered by running streams from the Zarafshan. The Bek's own chambers, in which we dwelt, were very spacious, roofed with timber beams, and painted between in red, whilst over the numerous doors were trellised, but unglazed, windows, there being no glass windows in the city except in the palace.*

Though this "house of Haman" is sometimes without guests for two or three months at a time, it was in a good state of repair, our rooms were nicely carpeted, and our comfort closely studied. An old secretary, one Mirza Muhammad Yusuf, appeared to be told off to watch over us-in more senses I suspect than one-and besides him there were sundry messengers to keep up communications with the citadel. As we had arrived in the morning I expressed a desire to see the Kush-beggi the same day, but he begged to be excused until the morrow, and then we might go out to see the city. Thus the Kush-beggi was giving us a mild repetition of the treatment we had received from his master at Kitab

* This building calls to mind the passage in Jer. xxii. $I_{3}-r_{5}$, "Woe unto him that buildeth his house by unrighteousness, and his chambers by wrong; that useth his neighbour's service without wages, and giveth him not for his work; that saith, I will build me a wide house and large chambers, and cutteth him out windows; and it is cieled with cedar, and painted with vermilion. Shalt thou reign, because thou closest thyself in cedar ?" The manner, too, in which the Bek's apartments were cut off from those of his wives recalled the expression, "The king hath brought me into his chambers" (Cant. i. 4). I was given to understand that the Bokhariots do not spend their time continuously, nor even sleep, with their wives always, but about twice a week, so that a particular wife, when desired, is sent for to come,to her husband's chamber. This is not the case, Yakoob told me, among his people, the Tatars of Kazan, who live together, except when the husband has visitors. 
-for though we were guests, yet, disguise it how we might, we were also prisoners. I therefore made a virtue of necessity, set myself to explore every hole and corner of the premises, and then proceeded to a careful examination of this excellent specimen of an Oriental garden.

The first thing that struck me was the enormous size of the apricot-trees, standing like avenues of old English pear-trees, from 30 to 40 feet high, whilst in circumference the first I measured was $3 \mathrm{ft}$. Io in., and the next $5 \mathrm{ft}$. 3 in., the latter being about 40 years old.*

The cherry and peach trees did not strike me as so remarkable. Both are usually grown from the stone. The fruit of the cherry, being acid, is very little used. Peaches are of three varieties, distinguished as red, white, and green. $\dagger$

The vines in the Bek's garden were in some cases allowed to trail, and in others were trained to form colonnades, under which one might walk. In Bokhara are cultivated ${ }_{1} 3$ different kinds, and of these we tasted several. A small, round, greenish variety, called Kishmish, was thought much of, but there were

* The wood is good for fuel only, but the Bek of Shahr had told me they often grow so many apricots that they do not trouble to gather them. They have three sorts in Bokhara, the earliest being ripe towards the middle of June. A second kind, white, is obtained by grafting, one peculiarity in the process being that the scion is first dipped into a bowl of fresh cows' milk. Of a third and reddish kind, the stones are largely prepared as food. The dried apricots, called "Uriuk," of which I had read so much, were to me disappointing, and, till cooked, uneatable.

+ When sown, the stone is put in the earth two fingers deep, before the frosts set in ; water is then let in and allowed to freeze; after that, earth is put over it and left till the following spring, when the young shoots are transplanted at intervals of four paces. The best peaches are said to come from Samarkand. 
larger kinds, the berries of which measured from an inch to an inch and a half in length. The mode of cultivation, however, was to me more curious than their flavour. * Towards the close of summer the bunches are enclosed in bags, and cut off later on to be suspended from the ceilings, and so preserved through the winter as food, but not pressed for wine. Of the manufacture of this I neither heard nor saw anything in Bokhara, unless it were to some insignificant extent among the Jews. $\dagger$

We saw likewise in our garden many dwarf pomegranate and fig trees, planted in what appeared like sunken beds, the muddy-looking soil at the bottom showing that it was so done for purposes of irrigation. $\neq$ The fig-tree requires no peculiar soil, and only two fingers' depth of manure; but as the fruit advances towards maturity, the roots have to be covered with water three days in the week. The crop is usually from 70 to $\mathrm{I} 4 \mathrm{O} \mathrm{lbs}$. from one tree.

- In grafting, the stem being cut, they raise the bark all round for half an inch, though without removing it from its point; they then peel the graft for an equal distance, and fix it on the stem, binding it all round with the bark. The two soon unite, and next year the vine yields fruit. In autumn a trench is made, and the tops of the vine buried under the soil for the winter. The soil chosen for the vine is half clay and half sand, enriched with from one to two tons of manure to the acre. The ground is usually watered twice before budding time, and once towards the end of May, when the earth is completely inundated for 24 or 36 hours. A good crop averages from 40 to 50 tons to the acre.

+ The Bokhariots use the grape for making syrup and vinegar, and for drying into raisins. The last is done by exposing the picked fruit to the sun on the housetop for three or four days, whilst the syrup is made by treading grapes in a cylinder lined with alabaster, refining the juice with pounded clay, and then boiling it to the solidity required.

¥ The pomegranate requires a more sandy soil than the vine, and that it be under water the whole of every tenth day. A tree springing from seed can yield fruit in the fourth year. Bokhara pomegranates are excelled by those of Shahr-i-sabz, where also is a peculiar kind with 
They have two kinds of plums, yellow and black. Of course, by October I ith, we were late for fresh fruit, but I observed some of the siah, or black plums, on a branch suspended in a shop, which, having told Yakoob to purchase, I found particularly well flavoured. From 150 to $200 \mathrm{lbs}$. usually grow on one tree. There were in our garden apple-trees, of which there are in the khanate eight sorts; but none of them autumn fruit. These last are brought from Khiva, especially the town of Hazarasp; but I cannot say much for the flavour of any I tasted in Central Asia, as compared with good sorts in England. Of quince-trees we had noticed abundance at Khokand and elsewhere.*

The various sunken beds, to which I have referred, in the Bek's garden were connected by runnels with the quadrangular pond near the women's apartments, and near this pond were shady trees and two or three flower-beds; but of flowers there were only three or four varieties, and those of the commonest in England. The Bokhariots cultivate flowers only to a very limited extent-the rose, however, among them,- and then not for ornament in the house, but simply to be carried.

Thus we looked thoroughly at our well-stocked garden, and found that its far end almost touched the city wall. I was minded to climb up and look over, but was stopped by barriers and the swampy nature of the ground. We had, therefore, to make ourselves happy in confinement, and wish for the morrow.

small seeds, called bidone, or seedless. The Bokhariot gardeners think the crop improved by the tree being dwarfed.

* They grow on almost any soil, and need little water. The fruit is not eaten raw in Bokhara, but minced meat is mixed with them; the seeds are administered in medicine, the pulp is used in soups, and, once more, boiled guinces are prescribed as good against humours. 


\section{CHAPTER L. \\ BOKHARA THE NOBLE.}

Bokhara as a place of learning--Desire to mount a minaret.-Paucity of Russian inhabitants and their treatment.-Visits to medresses Kokol-tash and Miri-arab.-Characteristics of Kirghese and Sart music.-Dancing-boys dressed as girls.-Misinterpretation of an English song.-Slumbers disturbed by watchmen, dogs, and

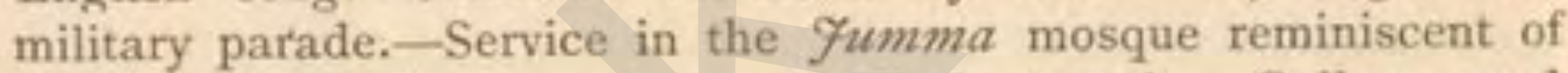
temple worship in Jerusalem.-A Hindu temple.-Gallop round the walls.

I NOTICED, in my Uzbeg interpreter, that, when I he was speaking to the Emir or other native notables, he was careful to add to the word Bokhara, "Al-sherif," or "the noble"; "Bokhara the noble," spoken in a religious sense, being the official name among the Muhammadans for this seat of so-called learning and piety. Accordingly we were all agog to see the University of Colleges and Schools, whither Moslem students are said to come from distant countries, even Siberia, as to a mediæval Oxford. Early on Thursday morning, the day after our arrival, the Kush-beggi sent messengers to inquire for my health, and to say that a considerable amount of business had arrived from the Emir, and, in consequence, that he would not be able to receive us till Saturday morning, but that we might go to see the town. We therefore 
sallied forth on horseback, conducted by the court attendants and our own djiguitts.

I wanted much to mount some lofty building to get a view of Bokhara as a whole, and so, perhaps, by comparison, form an idea of its population; for as we were conducted through the narrow irregular streets, each successive one very like the last, it was hard to trace any plan in the laying out of the city, or to form any estimate of the number of its inhabitants. On approaching the Manari Kalian, or great minaret, I said that I wished to ascend it. This at once flurried my conductors, and at first they tried to put me off by saying "To-morrow." When I objected, they next said that the Emir had taken the key with him to Kitab. Upon this not satisfying me, they urged as an objection that if I went up I should see the women. Not thinking this very dreadful, I still urged my wish to ascend, telling them that if they knew how many of the fair sex there were in England who did not object to be looked at, they would not think I should come for such a purpose all the way to Bokhara. But they said it was contrary to their law. They would, however, send to the Kush-beggi. This having been done, the messenger came back to say that the Viceroy would send to the Emir for permission, and that if his answer should be favourable they would have to tell all the women to hide themselves before I went up, as they had done on the last occasion when a criminal was taken up to be thrown down headlong."

\footnotetext{
- This sounded to me at the time very much like a pack of excuses. Yakoob afterwards said, however, that for me to ascend would be against. Muhammadan law, and I observe Burnes writes that no one but the high priest might ascend this tower (and that only on Friday to call the people to prayers), lest he should overlook the women's apartments in the city.
} 
Accordingly we passed on to the Russian Sarai, or warehouse, and other parts of the town, to present our few private letters of introduction. Since crossing the Bokhariot frontier we had not seen or heard of a single Russian of any grade or calling, nor, so far as I learnt, were there more than the two or three agents of Kamensky and of the Commercial Russian Company, with the wife of one of them, in Bokhara. It seemed almost like calling upon a fellow-countryman in presenting our first letter, to see Kamensky's agent in European clothes, and his wife, the one Russian female in all Bokhara, unveiled, and moving rationally about the house, and not like her oppressed and degraded sisters around. Very pleasant, too, it was, by way of relief from native-made dishes, to stay to lunch, and partake of a meal served in European fashion. We called afterwards at the office of the Russian Company, where I met, oddly enough, an Asiatic, upon whom I had called in Moscow. He had returned by Orenburg, and reached Bokhara some weeks before me. These Russian agents had not, seemingly, a very enviable post, for they are surrounded with Muhammadans, who at first were exceedingly abusive and insulting, not to say dangerous, in the streets, though matters afterwards improved. This improvement was no doubt traceable, in a measure, to European courage. If a Bokhariot chooses to insult, or even strike, a Hindu or a Jew, they must patiently bear it, as the natives knew, and accordingly tried the same with these Russians, though not with a like result; for the agents, without waiting for the interference of the authorities, took the law in their own hands, and administered a thrashing. This made the Muhammadans more careful; but, to show what arrant cowards the Bokhariots were, one of the 
agents said that on a certain occasion, when riding, his horse became restive, whereupon a knot of ten natives frightened the animal and made it run away. Upon this the Russian returned to thrash them, and they set upon him, as he said, to kill him. My informant happened not to have his revolver, which he usually carried, but, taking from his pocket a telescopic aluminium pencil, he solemnly drew and pointed it at them, whereupon they supposed it to be some new infernal machine, and the company fled!

We next went to see some of the medresses, or colleges: first to that called Kokol-tash, for 146 students, and built, they told me, about 300 years ago, though Vambery gives the date I426. I asked what it would cost to erect such a building in Bokhara now, and they thought $\ell_{1}, 250$.* The second medresse in importance is the Miri-arab, concerning which my notes say " I 44 rooms and 230 mullahs." $\dagger$

On returning to our lodging we were entertained in the course of the evening with some native songs and music, as well as dancing-boys. One of the instruments resembled a guitar, 46 inches long, with a sounding-

- The medresse is largely supported by legacies, and in Khanikoff's time the three classes of students respectively received from $\delta_{2}$ to 63 105. a year, whilst the emoluments of the professors amounted to 6240 . This medresse was the same in form as those we had seen in Samarkand, but far less handsome, and consisted of a quadrangular building, with two stories of rooms opening on a court with a few trees and a pool of water, or fountain. The upper rooms were for students, and are sold or let to them, whilst the lower are for instruction.

+ It was built, Vambery says, in $I_{529}$, and its rooms cost from $\oint_{53}$ to $£ 60$, whilst those of the preceding college cost from $£ 65$ to $£ 80$. The natives are fond of fixing the number of their medresses at 365 . Burnes gives them at 366 ; Vambery not more than 80 ; but Khanikoff, " from the Emir's registers on which the grants to them are entered," at ro3. This last authority also gives the number of students in 1840 , when the Emir granted them part of the taxes, and it was found their aggregate amounted to 10,000 . 
board 9 inches by 4 , and might be played with a bow or with the thumb. Another instrument resembled the flageolet, and had something of the hautboy sound, or one between that and a bagpipe. Singing and music appear to hold, according to M. Gotobitzky, a different place among the Sarts and the Kirghese, the latter of whose songs I have partially described. As with the Arabs, so among the Kirghese, a certain class of singers called Oiliantchi are looked upon as were the minstrels of the middle ages. The Sarts, on the other hand, regard their Gafiz, or singers, merely as professionals, who often take a secondary position at a feast (as with ourselves on the evening in question) to accompany dancing-boys.*

Yakoob had endeavoured to raise my anticipations by telling me that some of the batchas would be dressed as dancing-girls. Two of them did assume female costume, wearing a handkerchief round the head and falling down the back. They wore wristlets with tinkling ornaments, and carried small cymbals, wherewith to accompany the tambourines, took short, mincing steps, and shook their hands and heads with rapid motions, now holding up and extending their

* The Kirghese oiliantchis travel from one collection of tents to another, perpetuating their ancient traditions and singing love songs, some of which latter they compose on the spot. The singer draws an eager and attentive audience, which, whenever carried away by the object of the song, or a sudden change of melody, evinces approval by such exclamations of delight as Tchaou ! Barakalla! Their songs are full of feeling and tenderness, and such widespread celebrity do some of the oiliantchis attain that whole auls are eager to do them honour. The theme of Sart songs is invariably the feats of valour of their Palvans, or heroes, or else love adventures; but neither do the contents nor the music of their songs display that uniform originality that characterizes an unmixed people like the Kirghese. The songs of the Sarts, in fact, like their race, are mixed, and exhibit several peculiarities. Some are full of tenderness, the object of affection being a spotless 
outer garment, and so somewhat immodestly dancing, and then kneeling and making motions towards us with their hands. Our choristers favoured us with some prayers or sacred songs in Tajik, one old man screaming up dreadfully high, after which, by way of finale, I asked them whether, as they had done their best to entertain us, they would like to hear a song from me. Upon their replying in the affirmative, I wondered how best to hit their musical taste: whether with something sacred or secular, grave or gay; for the words would in any case be lost upon them. I decided in favour of a rapid movement rather than a slow one, and, without remembering exactly all the words, I sang them "Twickenham Ferry," at the end of each verse of which comes the refrain:

"O hoi-ye-ho, ho-ye-ho, ho-ye-ho, ho!"

I also sang them another song, and had each time a most attentive audience, but was not a little amused afterwards to hear that they had detected the repetition of "O hoi-ye-ho, ho-ye-ho, ho!" and thought that must be a prayer! I wound up the proceedings by lighting a piece of magnesian wire, which caused them no little astonishment, as it had done at Kitab, and after this we retired to bed.

My slumbers, however, were not to be undisturbed, creature, "pure as a star" ; whilst others, on the contrary, breathe a coarse passion and sensuality. The first, probably, are pirated from Persian poets, amongst whom one Gafiz was a Persian luminary, a singer of love, who has given his name to all singers. Again, the Sart music is made to suit the varying theme, being now tender, soft, and pleasant, and then harsh, abrupt, and shrill. The songs of the Kirghese have not this variety, but have a character of their own, and likewise a peculiarity of execution ; for whilst the Kirghese sing in a natural tone, and do not raise their voices, the Sarts do so to the utmost, and often in a falsetto. Lastly, comparing the two peoples, the Sarts sing sometimes by twos in unison, whereas the oiliantchi prefer singing by turns, which enables them to improvise. 
for first we were aroused by " the watchmen that go about the city," who had some dull imitation of a gong or bell wherewith to make us aware of their presence, and then there came into our principal court a howling cur, " returned at evening to make a noise like a dog, and go round about the city."* I sallied forth with a lighted candle, and drove out the dog, but was afraid of going too far in my queer déshabille, lest, being unable, if discovered, to give an account of myself in the vernacular, I might cause the natives to wonder what in the world I was about. The rules concerning keeping at home after sunset are very strict, and the night myrmidons in the pay of the Mir-sheb, or chief policemaster (called Kurbashi in Samarkand), think little of dealing summarily with anyone found in the streets, $\uparrow$ so much so that one of the Russians who had paid us an evening visit, and who left quite early, did not like to go home without one of the Emir's attendants to accompany him. Then, again, early next morning we were disturbed by bugle calls for the practising of the soldiers. Accordingly, when the messengers came after breakfast from the Kush-beggi to inquire for our health, and to ask if I had slept well, I replied that we had been somewhat disturbed by dogs and watchmen, but that on the morrow we should like to see the soldiers practise. Things were better afterwards as regards watchmen and animals, though as

* Psalm lix. 6. I never had so lively an illustration of this last figure as in Constantinople, where every street was monopolized by
ownerless dogs. They did not obtrude themselves much by day, but at night they are unmercifully severe upon any strange dog that trespasses into their particular streets, and are not too nice in barking at, if not even attacking, foot passengers

† Thereby illustrating "The watchmen that went about the city found me, they smote me, they wounded me; the keepers of the walls took away my yail from me" (Cant. v. 7; iii. 3 ). 


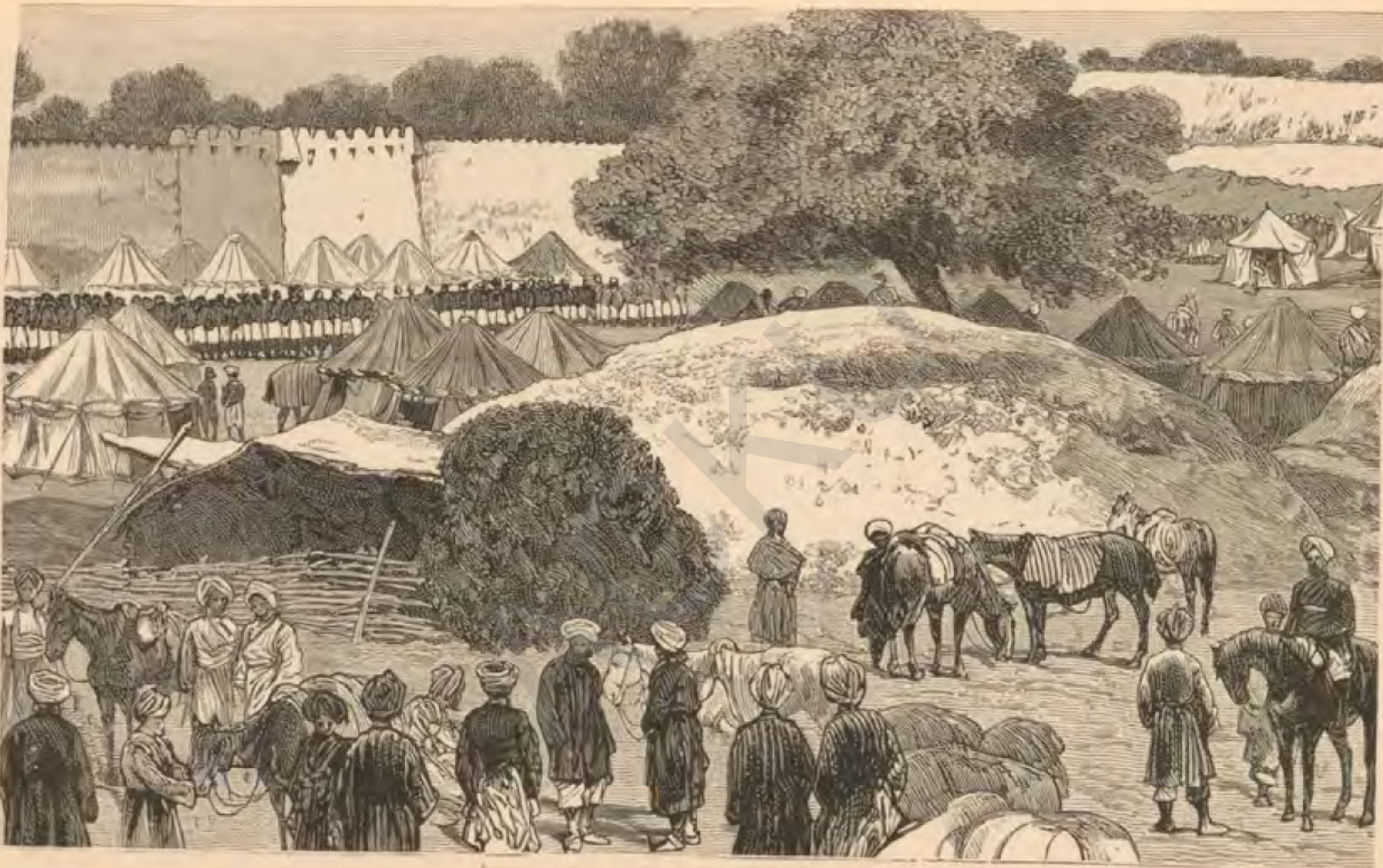

KENCAMPMENT OV MOKHANTOT SOLDIKRS. 
for my seeing the soldiers practise, they put us off by saying that the permission of the Emir must be asked, and pretended that they would exercise no more during our stay. Upon this I twitted the courtiers by telling them that they were ashamed to let us see their soldiers, and that I had heard how badly they were armed. They replied that it used to be so, and that formerly they were a sorry lot, " but now," they adroitly added, "we have seen and learned from the Russians, as the Russians did from the French and English."

I was curious to be present, if possible, at the preaching of a Muhammadan sermon at a chief function on Friday, which is the Moslem Sabbath. Upon inquiry, I was given to understand that the Jumma, or Friday service, would be held at noon in the great mosque, which, in theory, ought to be large enough to hold all the Mussulmans in a city. On the morning, therefore, of the day in question, I asked to be taken, and we sallied forth. I also wished to visit, I said, the synagogue and the Jews' quarter.

By this time I was fully alive to the fact that I was not to be allowed to see too much, and I learned that, from my continual taking of notes, I was suspected of being a spy.* Accordingly our conductors seemed not to be too well pleased at the idea of my seeing the Jumma service, and were leading us off first to the Jews' quarter, which would have brought us to the mosque when the service was over. I detected this, and insisted on going at once to the other building, and, in due time, we rode up to the great mosque Baliand, Buland, or Kelan. The front of it was ornamented with glazed bricks, some of which were fallen

* A very old suspicion attaching to strangers in the East; said Joseph to his visitors, "Ye are spies" (Gen. xlii. 9). 
away, so that the colouring looked worn off. Near at hand was the tall minaret, said to be 200 feet high, ornamented with coloured bricks inlaid in elegant designs. It was the same that I had expressed a wish to ascend. I now looked round the base pretty thoroughly to see, if possible, where the entrance was made, but I failed ; and my conductors were unwilling to further my wishes, and, moreover, began to scheme for keeping me from the service, by proposing that I should go to an upper story of the Miri-arab medresse, which faced the great mosque, and from thence look down upon the Jumma. I counter-manœuvred this proposal by saying that I would ascend to the upper parts of the medresse and see if that would do; for I thought, if they would not let me ascend the minaret, I might perhaps get an extended view of the town from the college, and so checkmate them. I went up accordingly, but found that the view was nothing for my purpose, since it overlooked merely the roof of the palace and fortress, and I therefore came down at once, saying that would not do, and, without further parley, entered the big mosque just before the service commenced. My conductors seemed anxious to put me out of sight, I suppose because I was an "infidel," and they would evidently have liked that, after peeping in, I should withdraw. But I was not minded so to do. Yakoob appeared to take sides against us, and urged that the people would look at us, and thus lose the benefit of their prayers. I simply replied, "Then tell them not to look!" This mild altercation was going on near a corner at the back of the worshippers, when suddenly the mullah's voice sounded. This put an end to all discussion, and the Emir's men, with Yakoob among them, went off to take their places. 
Sevier and I were now left with Kolutch, who remained faithful to us, calling Yakoob somewhat of a hypocrite, for that he had put on in Bokhara a white turban, and was manifesting Muhammadan zeal only to curry favour with the local authorities, whilst at other times and places he did not even observe the stated hours of prayer. As for Kolutch, I suspect that holding the office of a djiguitt in the service of the Russians had not strengthened his Muhammadanism, and, without our asking, he quietly wrapped up a garment for me to sit on, and we all three took our places against the wall, and quietly watched the proceedings.

I do not know whether it was in this mosque that Jinghiz Khan turned loose his dogs of war on the town. They told us it was about 350 years old, but Burnes says that "its cupola, once shaken by an earthquake, was repaired by the renowned Timur," whilst Vambery attributes the building of it to Timur, and its restoration to Abdullah Khan. It is one of the most solid constructions in Bokhara, and as I sat within I felt exceedingly glad that I had declined to be shut out; for the service was wholly unlike any form of Western congregational worship I had seen, and it suggested to my mind what, in some degree, may have been the ancient temple service in Jerusalem. The interior of the great mosque at Bokhara consists of a large unroofed, entirely open court, 300 feet square, and capable of accommodating, they say, 10,000 worshippers. It is surrounded by what Dr. Schuyler calls "a wide, vaulted cloister of brick, two and sometimes three aisles in width," but which I had put down as a succession of colonnades. They brought to my mind the Hebrew Bethesda at Jerusalem 
"having five porches" or stoas.* In front of us, and at the end opposite the entrance, was the pishtak, or tall façade, faced with coloured bricks, and surmounted by a dome over the two arches, forming the sanctuary we had seen in other mosques, where the mullah prays; whilst in front of these arches, and standing a little outside, was a low structure that 1 supposed to be intended for a pulpit or reading place

The service began on a long sustained note, uttered by a mullah from the sanctuary, upon which the men arranged themselves in ranks with strictest precision; all knelt, then rose and stood praying and bowing in silence. Some of the worshippers knelt in clusters of two and three, but always in a line. Looking under one of the covered stoas I saw a man whom I was uncharitable enough to fix upon, in imagination, as the Pharisee, "who went up to the temple to pray." He was clad in a crimson velvet robe, with the purest of white turbans, and had taken "a chief room in the synagogue," whilst a poor fellow with bare feet, whom I thought to be the publican, came in later, took a hindmost place, where, having no costly prayer-cloth on which to perform his devotions, he took off his upper coat, laid it on the ground, and so prayed "standing afar off." As for the behaviour of the congregation, I can only speak of it as most reverential. One or two did now and then look round at the infidel strangers in the corner, showing that Yakoob's fear was not altogether groundless; but their eyes were

"It was not "a high day" when we were there, and I estimated the number of worshippers as not exceeding 500, but one had only to imagine the people pouring into the city by thousands on a festival to be reminded of the place "whither the tribes go up, the tribes of the Lord, unto the testimony of Israel, to give thanks unto the name of the Lord" (Psalm cxxii. 4).

† John v. 2.

VOL. II. 
quickly withdrawn, and the service, as a whole, was, outwardly, far more decorous than that of an average Christian assembly, whether Anglican, Roman, or Greek.

Although at the extreme end and out of doors, as I have intimated, we could hear quite plainly the mullah's words from the sanctuary, and further on in the service some sentences were uttered by another mullah from under one of the stoas on the right, about halfway down. Again all the worshippers stood, then bowed down, and next prostrated themselves to the ground, after which I was told the "Jumma" was finished. Something else was to follow, which I did not make out to be of the nature of preaching, but rather of staying behind for private prayer. The great mass of the congregation began now to move, and with their faces towards the exit, of course they had a full view of the "infidels." The Emir's men were ready, not to say in haste, to take me off, but I had noticed one thing that I was anxious to inspect. It very much resembled a font, and, remembering that Nestorian Christianity had once been known in the land, I wondered whether this object could have come down from those mediæval times. Accordingly, I went up to, and looked around, over, and under it, if perchance there might be on it some Christian emblem or device; but whilst so doing I was quickly surrounded, the crowd looking, I fancied, not too well pleased, so that if ever I felt nervous in Bokhara, it was at that moment, for I thought they might misinterpret what I was doing, and set upon me, as, without provocation, a man assaulted and attempted to kill Dr. Schuyler while examining the shrine of a saint. I did not linger, therefore, over my inspection; but, seeing nothing that led me to suppose 


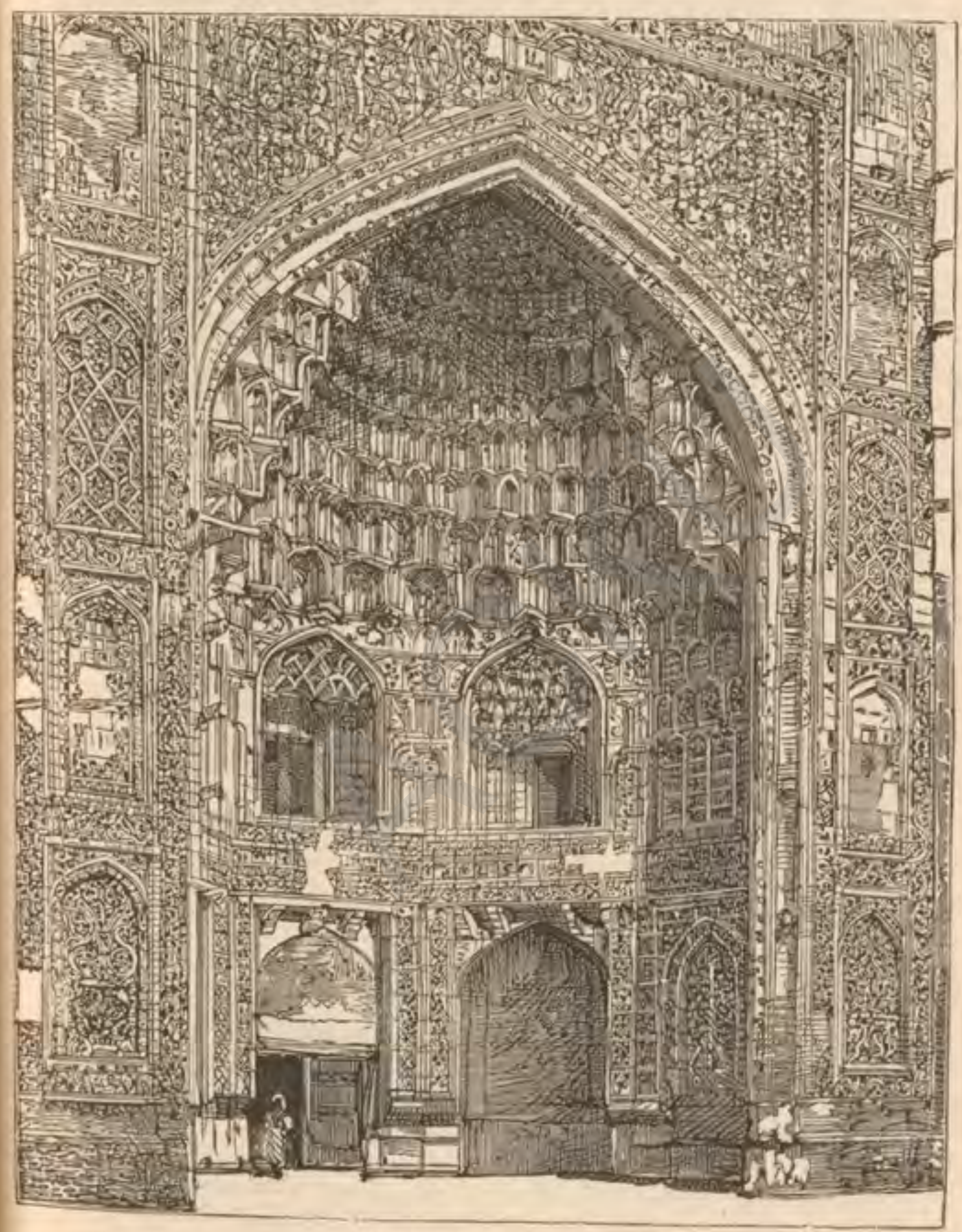

MEDFESSE OY ARUUL AZIZ KHAN.

L. of C. 
the basin to be of Christian origin, I joined my conductors, who took me out of a side door, sent to Fazul to bring our horses there, and hurried us off, seemingly glad to get us away.

There were some few other Muhammadan religious buildings we entered in Bokhara. One I have noted down as the Jumma mosque of Abdul Aziz Khan, said to have been built about 200 years, and to hold 2,000 people. There is also a medresse, named after that same Khan. At the Mosque of Hazret Imlah, I 32 years old, we saw the tomb of the great saint Imlah, whereon were two spear-heads, and above, a pole with a horse-tail suspended. Lastly, at the Hazret Halfa Khu-daidat was a covered cistern, where sick people drink the water for recovery. Pious turbaned Yakoob went down to taste, but, having so done, made a grimace, and said the water stank. We saw comparatively few monumental inscriptions, but at this well, over the door, it was written in Persian that the building stood 71 years, was then destroyed, and rebuilt 28 years ago.

We went afterwards to the Hindu Sarai, somewhat similar to the one we had seen in Khokand.* At Bokhara the Hindus lie under the same disabilities as the Jews. They paint a red circle about two inches in

- At Khokand we found in the priest's house a reading-room, and a temple. In the former was a central seat, or dais, something like a bedstead, also a sacred book, written in Hindustani, laid open, but having a cover with pendants, and a brush of peacocks' feathers to keep off flies. There was a priest and his attendant, who opened for us in the temple the doors of a shrine, in a cupboard, with pictures of Vishnu and offerings of flowers, incense, candy, and apples. When Bishop Alexander, from Vierny, visited them, they said he explained the pictures. There were also stones placed in the altar, said to have been found by saints, but the priest would not suffer me to touch them. He seemed pleased with our visit, and offered us candy and apples. There are about 30 Hindus at Khokand, all usurers. 
diameter on their forehead-whether by compulsion or for glory and beauty I know not-and they wear the black calico cap and girdle of string. Their temple in Bokhara was carpeted, and we found therein a looking-glass, with a musical-box, a lectern, and a cupboard with books; but I doubted whether they had the freedom of religious worship that their coreligionists enjoyed in Khokand.

Since my guides had baffled me in mounting the minaret, whence I might form an idea of the area of the city, I determined to go round its walls, and, therefore, asked to be taken to one of the gates, keeping my counsel till I got outside the portal of the Saleh-Kaneh. Then I told my conductors what I wished to do, whereupon they began to raise objections ; but by this time I was disposed to have my own way. So I gave my horse his head. Diotrephes had not had a gallop all day, and, after creeping through the crowded streets, was quite prepared for a run. Sevier, Kolutch, and Fazul followed, and we soon put space between us and the malcontents, among whom Yakoob stayed behind to curry favour, as we supposed, with the Emir's grandees. This galloping off was very undignified, according to Bokhariot ideas, but we enjoyed immensely the race and the pleasure of being pursued. We passed the Kuale or Karshi gate by which we had arrived, then the Mazar gate that leads to the famous shrine of Boghu-eddin, on to the Samarkand and Imam gates, the Urlan, or Uglan, and Talipaj. By this time the run had given a wet jacket to horses and men. The temperature had been rather fresh in the morning, and Kolutch had put on his best fur-lined khalat. This he now opened, and held up to show me how wet he was, and how his horse's sweat had damaged his 
garment. It became a question, therefore, how long we were to continue, for in about half-an-hour we had compassed 7 out of the I I gates of the city, a distance of about 5 miles, and to continue our flight beyond the Talipaj gate appeared to require our making a détour. I decided, therefore, to re-enter the city, and to finish the circuit, if possible, on the morrow. We had met scarce anyone in galloping round the walls, save one or two persons winding silk, and these looked not a little astonished at our headlong career. Kolutch, before the invasion of the Russians, had lived in Bokhara, and so was able to pilot us back to the embassy, where we had a wash, and calmly awaited the arrival of our custodians. Fortunately, the old fellow, into whose special keeping we appeared to be committed, took the thing pleasantly, and made the best of it. He even complimented us upon our horsemanship, but I said that we thought small things of anything we could do, being accustomed only to caper about in a riding-school, and one of us not that, but that we had heard the Bokhariots were splendid riders, to which he replied that anyhow we held in our horses remarkably well; and so the matter for the present ended, the old man telling us that he had followed us, inquiring at one gate after another whether we had entered. This was not the last unwilling gallop we gave the old gentleman, but we had immensely enjoyed our first, though not without some little fear of rebuke for our insubordination. 


\section{CHAPTER LI.}

\section{THE FEWS OF BOKHARA.}

My plans concerning the Jews.-Inquiry about the alleged persecutions in Moscow and South Russia.-Russia : how regarded by Western and Eastern Jews.-Oppressed condition of Jews in Bokhara.Visits to their synagogue, and their sick.-Inquiry for Hebrew manuscripts.-Hints concerning their technicalities.-Wonderful manuscript of the Old Testament.-Fear of the Jews to receive us. - My letter to the Emir on their behalf.

I HAD looked forward with great interest to what I I might see and learn in Bokhara of the condition of the Jews, and, in crossing Europe, had called on some of the rabbis, telling them of my intended journey, and my willingness to be of use, if possible, to their countrymen, though I was not sanguine that I could do much. "Ah! that's right," said one old Israelite, "they are much oppressed in Bokhara, and stand in need of help." I took occasion also, on some of these visits, to ask concerning the then recent persecutions of the Jews in Russia. I had been present at the Mansion House meeting in the early part of 1882, convoked on behalf of the persecuted, and had been favoured, as I have said, with a letter from the Lord Mayor as Chairman of the Jewish Relief Fund. This letter I showed, so that they might see I was in every way friendly to them and their cause; yet I 
must confess that the accounts from the rabbis' mouths relative to the sufferings of their people seemed much less than the newspapers had led us to believe.

To begin with Moscow. I was told how the troubles there began with the revival by the Minister Ignatieff of old regulations against the Jews, which the authorities had for a long time allowed them to break, though the laws had not been repealed; and further, that the Jews had not suffered personal violence by order, though the police, in some cases, had hastened to drive away from the town some women among others who were sick, and unfit to travel, until a petition was presented to Prince Dolgorouki, the Governor, who thereon manifested his sympathy with the sufferers, and showed a desire to mitigate, as far as possible, the carrying out of the minister's edict. After this, things were less severe. At the same time it could not be denied that the Jews, in certain parts of Russia, suffered under many disabilities. I asked one Jew to tell me succinctly what these disabilities, or some of them, were. To this he replied, "A Jew may not trade in the interior unless a merchant of the first guild, or after being a merchant five years in the provinces. Jewish artisans may dwell in the interior with strangers' passports only, and not as citizens; the police, moreover, allowing them to practise only their own trades. Again, suppose that a man has made a fortune, he may not buy a house and live in the interior. His wife might live there, and be a dressmaker, but if he remains unoccupied, he must go away." By "the interior" is meant Petersburg, Moscow, and certain other localities where, the laws not having been rigorously carried out, many from the provinces had settled unrebuked, and the turning 
out of some two or three thousand of these people at the previous Easter had cost the Jewish community from $£ 500$ to $£ 600$ to send them to their former homes in the provinces. This, however, did not exhaust the list of gravamina. "If a Jew," my informant continued, "has passed the university, he may, in theory, enter the service of the State, but not practically. For instance, only just before, an order had been issued by the Minister of War that among the military physicians the Jewish element should not form more than 5 per cent. Also, on the Exchange, a Jew could not be a broker, and the right to trade in spirits, or make them, is forbidden in the interior, even to Jewish merchants of the first guild. Again, in the interior, Ignatieff had lately ordered that a Jew might not be an apothecary, or manager for an apothecary. The same authority had forbidden to the Jews in the west, for the time being at all events, to buy or even to hire land. Even in Moscow it appeared that the Israelites had not a piece of land of their own whereon to build a synagogue or a school, though this is allowed to Lutherans, and also to Muhammadans. Once more, by Russian law, if in a high school there are a certain number of Jewish children, a rabbi should be allowed to teach them; but this was forbidden in one large town at least that I heard of, and the rabbi not allowed to have them even at his own house. Lastly, the Jews have no rights as a community."*

* It is singular to compare the remains of Christian persecution of the Jews in Russia and the Muhammadan persecution of the Israelites in Central Asia, with a letter written towards the end of the fifteenth century by Isaac Zarphati, a refugee, who then found in Turkey the shelter denied him by Christians in Germany. He says :- "They (the Christians) imagine that their religion is in danger, because the Jews in Jerusalem may, peradventure, purchase the Church of the Sepulchre. For this reason they have issued a decree that every Jew who is found 
I have set down these things as they came to me from Jewish lips, without having had the opportunity of hearing of what explanation they may be capable, or what may be said to the contrary. As we were travelling, one gentleman was heard to say, "These English are greatly shocked about the treatment of the Jews in Russia; but it would not be so if they understood how the Jew money-lenders fleece the peasants when they get them into their hands." This was only an echo of what a Polish nobleman said, when I asked him, in Warsaw, why they disliked the Jews, and he replied, "Because by money-lending they get all power in their hands, and distress their debtors." To which I simply replied, "Then why go to them? The remedy is in your own hands. Don't borrow!" At the same time, it must be remembered that the Jewish element in Russia is comparatively large; and with reference to one prohibition, that of liquor, though the Hebrew is sober himself, he does not object to deal out for gain this curse of humanity, and there are parts where the Jews have got into their hands the grog-shops of the district to the great demoralization and ruin of the people. Whether, in their absence, someone else might not do the same, I am unprepared to say. I simply notice

in a Christian ship, sailing for the East, is to be thrown into the sea .... I proclaim to you that Turkey is a land in which nothing is wanted .... Is it not better to live among Mahomedans than Christians? Here we are allowed to dress in the finest materials.... while in Christian countries you are not even permitted to dress your children in red or blue, without exposing them to be beaten red or blue. Hence you are obliged to walk about like beggars, and in rags ! They invent lying accusations against you ..... They always inflict upon you double punishment... They prohibit the instruction in our schools. And now, O Israel, arise and quit this cursed land!"-See Massoreth-haMassoreth of Elias Levita, by Christian D. Ginsburg, 1867, p. 6. 
what I believe to be the fact. I met one intelligent Russian lady, who began to put things before me from the point of view of the Russian Government; but, unfortunately, our interview was cut short ; and hence, personally, I do not consider that I have heard properly both sides of the question.

When, on my return journey in December, I reached South Russia, I inquired again of the highest authorities and persons most likely to know the truth, and they said things in Odessa had quieted down, and that there was no more persecution there; further, that at the outset the people were not against the Jews, but that the authorities had made them hostile, and that whilst in Balta, Okna, Smeela, and New Prague, there had been much dishonouring of women, it was not so in Odessa, where only one murder had been known. I heard, however, of one authority, the vigorous Prince Dondukoff Korsakoff, going into the streets himself in a riot, and punishing one persecutor with his own fists. English opinion in Odessa went to say that at the very first the newspaper accounts made things out worse than they were, but that the rectification of the error sent the pendulum too far in the opposite direction, and then the English people would not believe enough. I thought perhaps I might see a little into the state of affairs by going to the Russian frontier, where the refugees were gathered, and the committee of relief were sitting. At Odessa they said I should find at Brody a few hundred, or, perhaps, a thousand families. 1, therefore, went out of my way, though sorely pressed, and spent a day in going there, but not to much purpose. I found indeed a committee sitting, at the end of their labours, and a few men, women, and children being brought into the room to be portioned 
off; most of them fairly well dressed, many of them young men with young wives, and most suitable persons to emigrate; but if I am to be candid, I confess to the suspicion, that, whether persecution had anything to do with it or not, such young husbands might be very glad to get away from Russia to avoid military conscription. I presented my Lord Mayor's letter, and was asked to sit down; but the meeting being over in about an hour, I was left to go my way.

Thus much for the Western Jews, who looked upon the Russians as their oppressors; whereas, when I got to Samarkand, the Eastern Jews regarded the Russians as their deliverers, and the Israelites of Bokhara longed for the Tsar to gain possession of them as subjects. I took an early opportunity of securing a private interview in Bokhara with Jews to whom I had letters, but they appeared to be in great fear of being heard or seen talking to me. Formerly, they said, it was death to speak to a Russian, but that now they might do so on matters of business ; but for all that, despised as they were, they did not dare presume to accept my invitation to visit us at the embassy. Vambery speaks of the Jews coming to Bokhara from Kazim and Merv 150 years since, but those on the spot told me 600 or 700 years ago, and that most came from Persia, but some from Tunis, and among

- More than one prophecy respecting the Jews seems fulfilled in their condition in Bokhara, for they are truly "a proverb and a by-word" among the people (Deut. xxviii, 37 ; I Kings ix. 7). They still " dwell alone" (as once in the ghettos of Europe), "not reckoned among the nations" (Num. xxiii. 9), and these verses are still startlingly true: "Among these nations shalt thou find no ease, neither shall the sole of thy foot have rest; but the Lord shall give thee there a trembling heart, and failing of eyes and sorrow of mind: and thy life shall hang in doubt before thee : and thou shalt fear day and night, and shalt have none assurance of thy life" (Deut, xxviii. 65, 66). 
the latter, one named Maiman. This man, or a relative, was here in the time of Dr. Wolff's visit. I heard of him as far off as Petersburg, where he was known to the English Consul through having become a British subject, and a mercantile gentleman has told me that when Maiman came to London he astonished the English merchants by his skilful knowledge of cochineal. Maiman's son, or grandson, was said to speak French, if not English, and I was told at Moscow to inquire for him, but I found that he had been killed in the Russian service. Some of the Bokhara Jews had travelled to Europe, and one spoke a few words of French, but not enough to converse. I showed my letters, and asked the Jews if there was anything that I could do for them,- - an offer they were disposed at first to embrace. They thought I might ask the Emir to release any Jewish prisoners he now has, and this request seemed to be made with reference to a former chief rabbi, who I 5 years before had been arrested, his goods confiscated, himself forced to turn Muhammadan, and then left to serve in the palace, where he is kept a prisoner still, and not allowed to go out of the fortress. But upon further thoughts, they considered that to ask for his release might lead to his being put to death, and that my request was more likely to bring evil than good upon them for their mentioning the matter to me, so that they deprecated my attempting anything on their behalf.

On the Friday, as I have said, I expressed a wish to see the synagogue, reputed to be 500 years old. We passed through a narrow entrance, and came into a room, perhaps 50 feet square, which had no pretence to architectural beauty. There was a reading desk of marble, and on this they began to show me their 
manuscripts and books. I had read in Dr. Wolff's memoir that the Jews of Bokhara had a manuscript of the prophet Daniel, wherein, in Chapter viii. 14, the words "Unto two thousand and three hundred days," read " 2,400" days (which agrees with the Vatican copy of the Septuagint, whilst the Armenian translation reads 2,068), but I could not find this manuscript in the synagogue. They showed me, however, a large number of old torahs, or copies of the law, thrown together pell-mell on a platform or loft, midway between the floor and the ceiling, which I suppose in this case represented their genizah.* Nothing would satisfy me short of being allowed to mount the platform, and see and handle the manuscripts, so that I might convince myself that, as the rabbi asserted, they were not ancient. A ladder was brought, therefore, and up I went, accompanied by one of the Jews who spoke a few words of French, which when my custodians discovered, they were on tenterhooks, lest we should speak privately, and they requested that I would speak all 1 had to say through my interpreter. They also made it apparent to the Jew that they did not like his being on the platform with me. He remained, however, whilst I looked at one or two, which did, indeed, appear to be what I had been told-namely, disused Torahs-though in some cases apparently not much soiled. I found it was customary for persons to leave at their death a sufficiency of money to purchase a new manuscript for the synagogue, and I inferred that this must be a popular form

* It is in such a place the Jews put their copies of the law that are soiled or ritually unfit for use, if only, for instance, a single word be rubbed out by wear. So literally do they interpret the passage, "Ye shall not add unto the word which I command you, neither shall ye diminish ought from it" (Deut. iv. 2). 
of legacy in Bokhara, for I should estimate there may have been 20 or 30 on the loft, covered with dust, and otherwise not inviting to a further search.

There was, moreover, another obstacle to my investigation just then, inasmuch as the Jews had crowded in on the very tiptoe of expectation as to what the foreigners could mean by visiting their synagogue; and when I presented to the rabbi my Jewish letters,

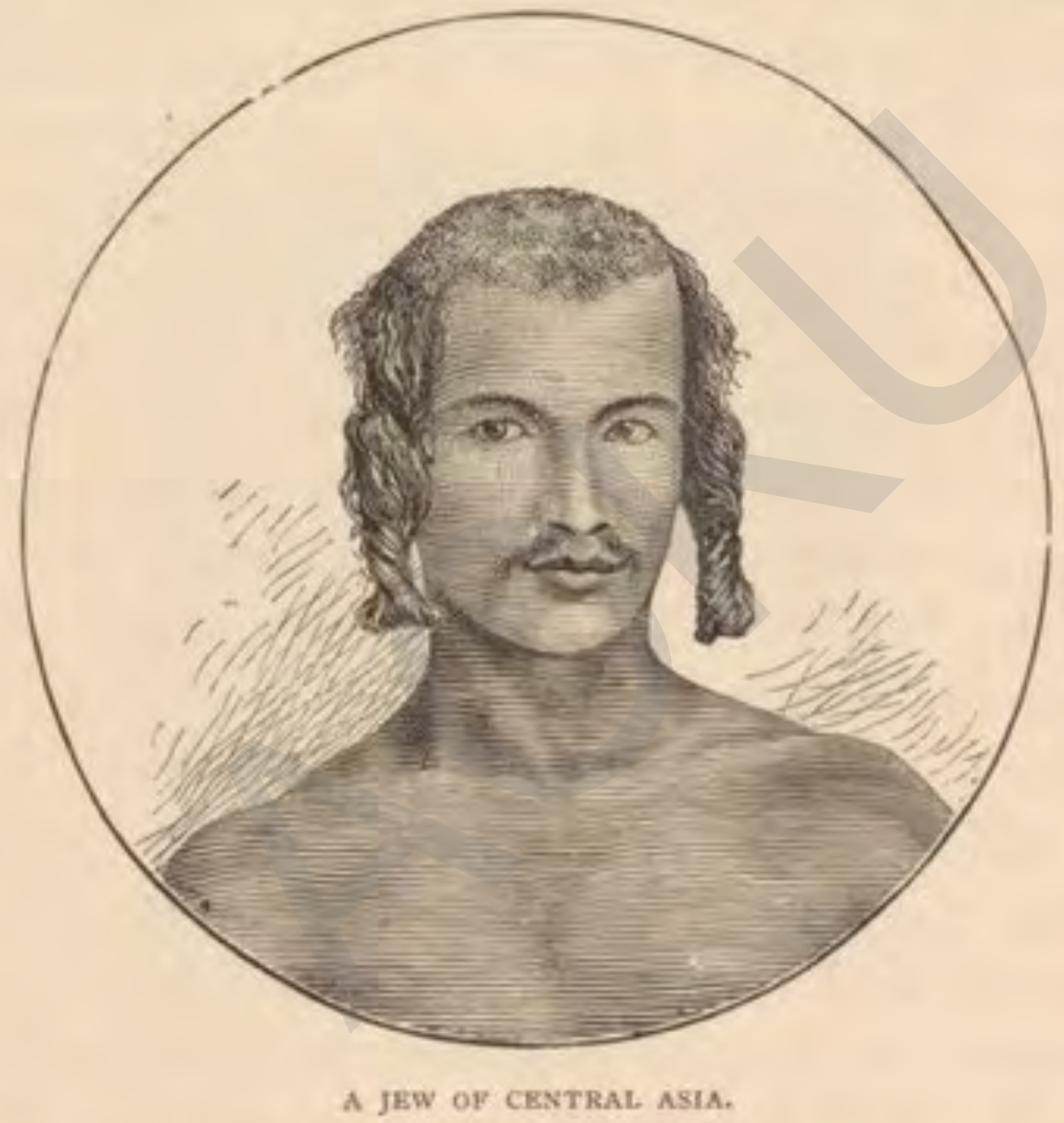

written in "the holy language," they swarmed round, leaving us scarcely breathing-room. Some of the boys with their coal-black eyes were extremely handsome, but of all the crowds I have ever been in, I can remember none like those of the Asiatic Jews at Khokand, Samarkand, and Bokhara. They were not disrespectful or rude, and they made way when I wished to move, but the curiosity depicted on their countenances was most striking. We were, I suppose, 
the first Englishmen they had seen, and that might have gone for something; but I fancy it raised their wonderment more that two guests of the Emir, living in the best embassy in the town, should bring them a letter in their own tongue, come down to their synagogue, and instead of despising them, as did the haughty Muhammadans, be willing to enter their houses and attend their sick - for we had promised so to do. Hence the people had come not in ones and twos, but in crowds, and as we left the synagogue not only did they fill the passage, but some had clambered up to the tops of the walls and the roofs of the houses.

As for our Moslem custodians, all this excitement greatly perturbed them, and it seemed to "grieve them exceedingly that there was come a man to seek the welfare of the children of Israel."* Moreover, when they discovered that the Jews were asking us to their houses, they made efforts to prevent us, by what sort of arguments I do not know, for I cut matters short by addressing our dominus in a few words of round Saxon, telling him to hold his tongue, and speaking in tones that conveyed to him my intention of going, whether he liked it or not. Then, turning to the man who wished our help, I motioned to him to lead the way whilst I and Sevier followed, leaving our guardians to do as they pleased. The crowds again pressed after us-with too much freedom I suppose Kolutch thought for these despised Jews,-for, being quick of temper, and they not heeding his words to keep back, my man assumed the policeman, and began to lay about him with his riding-whip to keep them at a respectful distance. The poor Jews submitted with a disappointed look, as if such treatment were only too common.

\footnotetext{
- Neh. ii, to.
} 
Meanwhile we had arrived with the man whose daughter was sick, the multitude crowding, but there entered only Yakoob and a few more, and the father and mother of the girl. The women were not veiled, and, Englishman like, I offered my hand to the mother, who took it, though I have been since told that it is contrary to rabbinical teaching for a woman to shake hands with a man. Then, looking at the girl, we found her suffering from ophthalmia. Sevier prescribed, or promised medicine, and then we were entreated to go

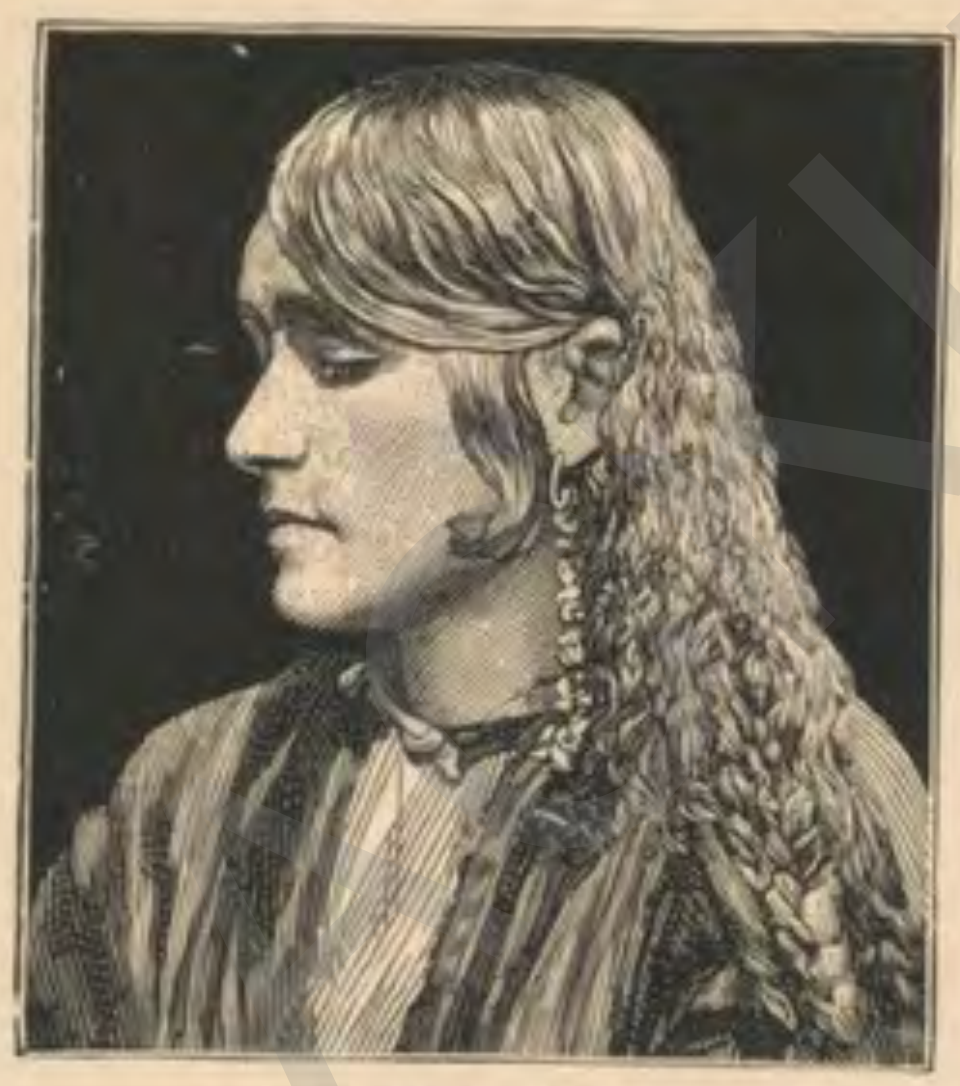

A JEWESS OF BOKHAKA.

to another patient, at some little distance. We went, to find an old rabbi with a paralyzed limb; and when Sevier stooped to examine it, the patriarch was affected to tears, and, placing his hands on Sevier's head, he gave him his blessing. Sevier would have recommended galvanism for his legs and back, but as that was not to be had in Bokhara, he wrote a prescription to be made up at Samarkand. I do not know whether by this time the Emir's men thought they had gone too far, but they must have seen that I

VOL. II. 
was annoyed, and they accordingly proceeded apologetically to explain that with the crowds pressing round they were apprehensive for my safety, and hence their desire that I should not venture into the houses. Fruit was now offered us in the rabbi's house, which we sat down and ate, and talked, hearing nothing, however, of ancient books or writings.

I had thought it possible, before leaving England, that I might find a Hebrew manuscript or two worth bringing home, and not trusting to my slender acquaintance with Hebrew I went to the British Museum and consulted on the subject Dr. Ginsburg, who has spent a quarter of a century in the praiseworthy but thankless occupation of editing the "Massorah," a work that will hand down his name among the learned to posterity, although pecuniarily it promises to be an unrequited labour.* Dr. Ginsburg was kind enough to tell me what kind of manuscripts would be worth buying, and the contrary, also by what signs I might judge approximately as to their antiquity or otherwise. I had also spoken upon the same subject, and received one or two hints from Dr. Albert Harkavy, of the Imperial Library at Petersburg. $\dagger$ Accordingly, I left Petersburg duly

* The price at which the first volume was published did not cover the cost of paper and print, so that Dr. Ginsburg might say, only in a wider sense, as did Jacob ibn Adonijah before him, "This was a labour of love, for the benefit of our brethren, the children of Israel, and for the glory of our holy and perfect law"; and the Times might well admiringly add, "That such a work as this edition of the 'Massorah' should be completed by the unaided labours of one man is, indeed, a singular illustration, unhappily rare in this age, of scholarly enthusiasm and perseverance."

+ The outcome of these hints was somewhat as follows: Buy no Korans or Persian manuscripts; nothing, in fact, but Hebrew, Chaldee, and Syriac. Rolls of the Pentateuch and Esther do not touch; rolls of other books, yes. Manuscripts in book form generally may be examined, even of the Pentateuch: the larger the characters, and the 
primed, and, strange to say, met my first manuscrip at Moscow, recently arrived from Bokhara by the hands of a Jew, who was said to have acquired it at a cost of $£_{500}$. This, they informed me, was about $£ 300$ more than a Hebrew manuscript, with points, of the whole Bible would cost. I began to apply my tests, and fancied that I had made my little learning go a long way, for pointing out to the learned rabbi who showed it me, that $\pi$ and $\pi$ were differently formed, likewise $\boldsymbol{i}$ and , and that consequently the manuscript could not be very ancient, the old bookworm said to his fellow-rabbi in German, which he thought I should not understand, "That's a knowing fellow!"

The manuscript struck me as of singular beauty, by reason of its marvellous illumination and the fineness of the Massoretic writing. When I reached Bokhara I told the Jews I had seen the manuscript, which to them was news. They knew the book. It had been sold by a woman - they thought for $£_{\mathrm{I}} \mathrm{Oo}$ but they did not know whether it had been taken to Constantinople or to Russia. When I arrived in England I chanced to meet Dr. Ginsburg, at the British Museum, and was informing him of the treasure I had met, when I was told that if I would come downstairs I could perhaps see it again. I did so, and there it was! The owner had brought it all fewer divisions between the words, the better; also two columns on a page are better than three; and illuminations add to their value. I might expect sometimes to find the text on leather, because they did not know in remote places how to make parchment, and I should do well to note whether the manuscripts were of Bokhariot origin or foreign. With regard to the forms of the letters, the following were signs of great age, namely, both $\pi$ and $\Pi$, written like the latter, and the same with , and ,; $P$ written without a space between the horizontal line and shaft; $\zeta$ written with an extra long upper stroke; and lastly, final ; written no longer than $r$. 
the way from Bokhara to London, and now it enriches our national collection-a manuscript that has turned out to be of great importance to textual criticism as well as to the art of Jewish illumination.

The peculiarity of the illuminations consists in their exhibiting a mixture not only of French and Flemish art, but of German and Italian, interspersed with decorations of an Oriental character, more especially Persian* At the end, within richly illuminated double borders, and in letters of gold, the writer of the codex describes himself and the distinguished patron for whom it was written as follows: "I, Samuel the Scribe, son of Rabbi Samuel Ibn Musa-peace be upon him!-have written these fourand-twenty books by the help of Him who is enthroned between the cherubim, at the order of the distinguished, etc., Rabbi Joseph, son of the honoured

- The manuscript consists of three volumes large quarto, the first containing the Pentateuch, wherein not only is the first word of each of the five books written in letters of gold, in a beautifully illuminated border, occupying the space of six lines, but every one of the 53 pericopes, into which the Pentateuch is divided, is indicated by a rich illumination in the margin containing the word פר (pericope) in letters of gold. The second volume contains " the Prophets" in the following order: Joshua, Judges, Samuel, Kings, Isaiah, Jeremiah, Ezekiel, Hosea, Joel, Amos, Obadiah, Jonah, Micah, Nahum, Habakkuk, Zephaniah, Haggai, Zechariah, and Malachi. The first page of each of these prophets has a highly illuminated border, and the first word of each book is not only written in letters of gold, but is in a square on a beautiful groundwork of delicate penmanship. Two leaves separate the earlier from the later prophets, and on these are written in the border, in letters of gold, the celebrated Massorah registering the number of verses in the Hebrew Bible; and in ordinary ink the alphabetical list of hapax legomena, or words occurring only once with and once without the letter 1 at the beginning. In volume iii., of 186 folios, the books are in the following unusual order: Chronicles, Psalms, Proverbs, Job, Daniel, Ruth. Canticles, Lamentations, Ecclesiastes, Esther, Ezra, and Nehemiah. After the sacred text are 9 folios, 7 of which are filled with Massoretic and rabbinical lore. 
Rabbi Jehudah, called Alchakim. . . . . I finished the manuscript in the month Kislev, on the sixth day of the week, on the preparation for the Sabbath, in the year of the creation 5243 (i.e., A.D. 1483 ), in Lisbon."

Hence, when I saw the manuscript at Moscow, I was right in my supposition that it was of late date, but Dr. Ginsburg says that even a cursory examination shows that it is a careful copy of an ancient and model codex, and that it in turn was designed for a model.*

Thus I lighted upon what Dr. Ginsburg says, so far as he knows, is "the most richly illuminated Hebrew manuscript of the Old Testament in the world "; and though I did not know its full value until I reached England, I was careful to ask in Bokhara whether there were any more like it. They replied "No." I confess, however, to leaving the city with a regret that I did not make another effort, and search to the bottom

* This is evident not only from the careful and splendid manner in which it is written and illuminated, but from the various readings given in the margins as taken from renowned recensions. The most interesting and important fact, however, is that the manuscript gives, in the Pentateuch, two variations between the Westerns and Easterns, which have hitherto been unknown. On Lev. xxvii. 24 it tells us that the Westerns read מת (maitto), whilst the Easterns have (maotho); and again, in Deut. xvi. 3, we are told that the words "For thou camest forth out of the land of Egypt," etc., which in our Bibles are in the middle of the verse, are the Western division, whilst according to the Eastern these words begin a new verse. In Joshua xxi. the Bokhariot manuscript has the two verses, 36 and 37 in the text, both with vowel points and accents, and remarks against them in the margin, "These two verses are not in the text in the Hillali Codex." This manuscript has also some various readings that are interesting, as for instance in Psalm lxxii. 5, where our version has "They shall fear Thee as long as the sun and moon endure," we are told the Hillali codex reads, "The people of the sun [that is, of the East] shall fear Thee."

The manuscript in the British Museum is numbered "Oriental $2626-8$ " ; but for further information see Dr. Ginsburg's letter to the Athenoum, page 409, March 3 Ist, $188_{3}$. 
the Torahs on the synagogue loft. As a matter of fact we saw none of the principal Jews after our visit on Friday. The Emir's men evidently did not wish us to go into the houses of the people, and the Jews were afraid as to what might be done if they received us. Two Jews came to the embassy on the following day, one with bad eyes, and the other inviting us to his house, but also telling Yakoob characteristically that he had European "clothes to sell." We had neither time nor opportunity to avail ourselves of this offer, but on the Sunday a knot of half-a-dozen Jews and two Jewesses came to the embassy for treatment. Of the latter, one had slight goitre, the other ophthalmia; and, of the men, one had a weak hand, and another dry and chapped fingers.

After this we met no more Jews in Central Asia. I am anticipating a little, but by way of finishing with this subject, I may add it occurred to me after leaving Bokhara, when writing my last letter of thanks to the Emir, that it might possibly do good, to express guardedly to my royal Mussulman host my good wishes for Israel, and I did so in the following words :-

"PETRO-ALEXANDROVSK,

"October 17-29th, 1882 .

"To His Majesty the Emir of Bokhara.

"SIR,

"According to my promise, I hasten to inform your Majesty of my safe arrival here, and once more to express my thanks for all the kindness I have received in passing through Bokhara. I will not weary your Majesty by mentioning the many things that have pleased and interested me, but if I may be allowed to mention one thing that has pained me in my travels in Central Asia, it is the condition of the Jews. 
"I was told in Samarkand that the Jews in Bokhara are placed under restrictions, and on visiting them was sorry to find them so cramped for room, and possessing only one synagogue. May I not venture to hope that your Majesty will be pleased to allow them to build other synagogues if they wish?

"Your Majesty will doubtless remember that the Jews are God's ancient people, to whom $\mathrm{He}$ gave His first written revelation, and Jesus Christ, our great Christian Prophet, was also a Jew. It would therefore be a thing, I am sure, pleasing to the God your Majesty worships, that $\mathrm{His}$ people in your midst should have similar privileges to your other subjects.

"We, in England, and other nations in Europe, used once to place many and severe restrictions upon the Jews, but we are now ashamed of this, and in England we give them full rights with ourselves. I sincerely hope your. Majesty will be pleased, on consideration, to do the same, for I ask this out of love for the people, amongst whom I have friends in England.

"Let me once more thank your Majesty for the splendid hospitality I have received in Bokhara-such as I have received in no other country in the worldand allow me to remain,

"Your Majesty's obedient Servant, "Henry Lansdell."

What fruit this letter bore I have not heard, but thus finished my intercourse with a scattered remnant of that wonderful race, amongst whom I had seen much of interest, by whom I had been kindly received, and on whose behalf I would willingly have done more. 


\section{CHAPTER LII. \\ BOKHARA THE NOBLE (Continued).}

Visit to a primary school.-Method of study.-A ride outside the walls.Mosque of Namazi-gah.-Visit to the Kush-beggi.-The Emir's palace and curiosities.-Conversation with the Kush-beggi and his son.-Some of my requests refused.-Value of presents received.Visit to the bazaar.-Commerce and trade of Bokhara.-The Righistan.-Bokhara after dark.-Standing up for my rights.-Ride towards Katte-Kurgan.-The lepers' quarter.-Fear of punishment. - Return to our lodgings.

A $\mathrm{S}$ we were taking a morning ride during the A Saturday of our stay at Bokhara, I inquired the meaning of a sing-song noise that proceeded from a house we were passing, and learned that it was a school. We dismounted immediately, and, entering, found therein from 25 to 30 scholars, of ages from 6 to 13. It was a good example of one of the maktab or lower schools, just as in the medresses we had seen specimens of the upper schools, of Central Asia. Both are usually attached to the mosques, and maintained on the wakuf or foundation; but if the schools are not so maintained, they are kept up partly at the expense of the people generally, and of the parents of the scholars. The teachers of the lower schools are usually chosen from among the inhabitants of the district in which the school is situated, and who 
are taxed at the rate of from $6 d$. to $1 s$. per house for the teachers' support. The building we entered was small and simple enough - a single room roofed with a dome, having several doors instead of windows, and niches around for shoes, clothes, etc. On the floor, and parallel to the walls, were raised benches, about 14 inches apart, consisting of beams of wood Io inches high. The pupils sometimes sit on these, or, as we saw them, on the ground, their books resting on the beams. Tables or desks there are none.* The pupils sit with their faces towards the centre of the room, in the direction of the teacher, who is in the middle of them, and thus, like Saul of Tarsus, they are "brought up at his feet." $\dagger$ The floor is usually covered with plaited reed mats or simple straw. I asked how much the scholars paid, and found that their fees were partly tendered in kind, and by way of presents; but M. Kühn, who has written upon the subject somewhat fully, $\ddagger$ mentions as an ordinary school fee on beginning from 3 d. to Is. per month, with a present of cakes and raisins.

* I do not remember ever seeing a single native in Central Asia writing at a table. They hold the paper in the left hand. Even the Turks at Constantinople seemed to me only in a transitional stage in this respect, for I observed in the Government offices that, though they had tables before them, on which the ink was placed, the clerks curled their legs under them on the chair, and held in the hand the paper they wrote on,

$\dagger$ Acts xxii. 3 .

In the Turkistan Gazette, Nos. $37,47,48$, for 1876 . The first thing a novice does is to repeat after his teacher:-

"Merciful God, enlighten the heart of Thy slave.

Thy slave is a Mussulman,

Who is thirsting to read the Koran.

He seeks Thy protection,

For he has sinned much."

After this dedication, so to speak, the teacher writes the alphabet, gives the pronunciation of the letters, and frequently hands the boy over to one of his kalfa, or assistants, who are generally senior scholars. 
In these lower schools the most unsophisticated simplicity reigns. There is no division into classes, but by the side of one scholar sing-songing the alphabet is another learning the verses of Khoja Hafiz, or not less loudly reading the Koran. In the school we entered they all read together, swinging their bodies backwards and forwards, though one boy was permitted to read alone for us to hear. I asked about school hours and holidays, and found that the boys are present from six in the morning till five at night, with an interval of two hours at noon. They go on, moreover, all the year round, except Fridays and a week at each of the three Muhammadan festivals. On Thursday each pupil usually brings his teacher a specially prepared cake, and on that day also the studies close at noon, the teacher, before dismissing his pupils, examining their nails, and banging their heads with a book if they are not found clean. But Thursday is also the day for paying off disciplinary scores. Thus, if a boy has played truant, some of his fellows are sent in

After the alphabet, the pupil passes to the abjad, which is an exercise of committing to memory hard words without sense. This done, he has a day's holiday, when he is expected to go home, and return with a present from the parents, and then he proceeds to the study of the Koran. After a certain number of chapters has been studied, a thanksgiving procession is formed, and the pupil goes round, not "with the hat," but a tray, to his friends and relations, who contribute money for the teacher, the procession singing a hymn composed for the occasion. The pupil then passes on to the remaining parts of the Koran, the various steps being attended with feasting and giving of presents. All the instruction thus far has been in Arabic, which the pupil has to acquire by rote, but without understanding it. The boy now goes on to certain books in Persian, and finishes with the verses of Amir Nevai, in Turki, or very zealous pupils are further instructed in Fazul's poetry, written in Uzbeg. After this the boy can remain to perfect his caligraphy, which is generally done by those who are intended for mirzas or scribes, whereas those intended for a college training are taught writing in the medresse. 
search, and, on bringing him back, the culprit is laid on the floor, his feet lifted in a noose, and he is bastinadoed, the right of giving the first blow belonging to his captors, as a reward for finding him. On Thursday, too, the teacher usually shows them the attitudes of devotion, and concludes by reciting a prayer. Education among the Mussulman women is at a very low ebb. There are, nevertheless, in most towns one or two bibi-kalfas, whose duty it is to teach girls, for the most part those of the rich. In the school we entered at Bokhara I had a little conversation with the teacher, and thought to surprise him by saying that in some of our English schools we have as many as a thousand children ; to which he replied with the greatest calmness, as if to give me a Roland for my Oliver, that they had many schools, but only about 25 scholars in each. His was only one of many instances wherein the self-complacency and ignorance of the Asiatics struck me forcibly, for they seemed not to have the least idea that they were behind other people, or needed any improvement.

Remounting our horses we went outside the town, by the Saleh-Kaneh gate as before, but turning now to the right, my intention being to ride round the remainder of the walls; but we stopped awhile opposite the Namazgah gate, at the mosque Namazi-gah, said to be 350 years old, and where prayers are read at the two feasts, Ramazan and Kurban. As this building was tolerably high, though some distance from the walls, I wished to ascend, and did so, our aged "dominus" clambering up to the top after me. We could see several of the prominent buildings standing above the walls, such as the chief minaret, and the blue dome of the Jumma mosque close by, as well 
as the citadel, and the domes surmounting many medresses; but we were too far off to get anything like a view of the whole of the town. We could see a good long stretch of the wall, looking truly ancient, and perhaps rather imposing, with no houses or buildings outside, with battlements and buttresses, which from a distance appear like towers, though not higher than the wall itself. The buttresses are called burj, and are $I_{3} \mathrm{I}$ in number. The wall is 7 miles 980 yards round, 24 feet high, and ro feet thick at the base.* I asked the date of building the wall, and they said "a thousand years ago," and that the population of the city is about $2,000,000$ ! Wolff gives the population at 180,000 , but Khanikoff estimated it between 60,000 and 70,000 . I should judge this to be much nearer the mark, since Khanikoff estimates the area covered by the city to be 1,860 acres, or about 3 square miles.

There were no houses near the mosque, on whose summit we were standing, so I took occasion to twit

* The condition of the walls in Central Asia more than once brought up Scripture analogies. At Aulie-Ata they presented a scene such as Nehemiah (ii. 13) saw when he "went out by night, and viewed the walls of Jerusalem, which were broken down." The rent and cracked walls of Etchmiadzin, in Armenia, reminded me of the derisive expression of Tobiah, "That which they build, if a fox go up, he shall even break down their stone wall " (Neh. iv. 3 ); but I do not remember being struck with a similar multiplicity of cracks in Central Asia, where I think the walls were thicker. Once more, in the so-called Jasper wainscoting of Tamarlane's tomb, we saw an exemplification of Oriental magnificence pictured in the expression, "the foundations of the wall of the city were garnished with all manner of costly stones" (Rev. xxi. 19), or better, perhaps, "I will lay thy foundations with sapphires, and I will make thy windows of agates, and thy gates of carbuncles, and all thy borders of pleasant stones"'(Isa. liv. I1-12).

† The latter, at all events, is a specimen of their ignorance as to high numbers, with which they seem quite unable mentally to deal. Also they love set numbers, saying there are in the city 360 mosques and 360 streets and lanes. 
Mirza Yusuf about his fear that we should overlook the apartments of the women. Then, remounting our horses, I galloped off to finish the remaining gates, namely, Sheikh-Jelal, Kara-Kul, Shir-ghiran, and so entered, as before, the gate Talipaj. This we did in about half an hour, including the stoppage at Namazgah, but the run was not so long as we had had on the preceding occasion. It was an autumnal morning, decidedly cool, not to say cold; so by the time we reached the embassy I told our old gentleman that, as the morning was fresh, I thought he might like a warming, whereupon Fazul, seeing the joke, looked at me, and expressively hid his face in his khalat to laugh. Our custodian took it good-naturedly, however, saying that an occasional gallop was good, since it stirred the blood.

The Kush-beggi had appointed noon as the hour for receiving us, but it was not till some time later he sent, with apologies for delay, to say that he was ready. We therefore paraded through the streets with our retinue and certain of the local dignitaries, and came to the Righistan, or public place. On one side of this is the citadel, or palace of the Emir, built on a square mound, 35 or 40 feet high, and about a mile in circuit, with an area of 24 acres. On this area, surrounded by a high crenelated wall, are built the palace, the houses of the Kush-beggi, and certain of the court grandees and their retinue. At the entrance are two lofty towers, and, looking up, I noticed the clock made by Giovanni Orlandi, who fell into the hands of NasrUllah, and when condemned to death because he would not turn Mussulman, was pardoned on promising to make the despot a machine for measuring time. There were also a few cannons lying about, and, as we drew 
near, we were saluted by the soldiery and sentinels presenting arms. Things had altered, I thought, since the last of my countrymen rode his horse in the Righistan, and since the first was allowed to be there only on foot. For my own part I did not give the matter a thought, and dismounted only at the foot of the inclined way that leads to the palace.

The Kush-beggi (or lord of the Beks) is the chief adviser and confidential officer of the sovereign, the first person in Bokhara after the Emir. He manages all the commerce of the city, and its dealings with neighbouring countries. He sits at certain times on a raised platform under the archway at the entrance of the citadel to transact business with those who enter.* Besides this he is his Majesty's viceroy. The Kush-beggi is the chief representative of authority when the Emir is absent. During this time, in keeping with the Bokhariot idea that the greatest man in a city must always remain at home, the Kush-beggi is said never to leave the town. He was not sitting in the gate at the time we entered, but above, as he usually does, I believe, when

"Just as "Daniel sat in the gate of the king" (ii. 49), so it was "beside the way of the gate" that Absalom said to those who came for judgment, "There is no man deputed of the king to hear thee" (2 Sam. xv. 2, 3). Again, with David in a critical time, "The king stood by the gate side," and confidence was restored when "the king arose and sat in the gate" (2 Sam. xviii. 4, and xix. 8). Moreover, since trials are conducted there, "to turn aside the poor in the gate" meant "to give unjust judgment" (Amos v. I2). "The gate" also served in the East as a place for public buying and selling. Abraham thus purchased Macpelah (Gen. xxiii. 10). Similarly Boaz went to the gate for witnesses to his paying the kalim, on taking Ruth to wife. And in Samaria, after a siege, corn was sold there (2 Kings vii. 1). The gate was a place of debate for the public good. "Hamor and Shechem communed there with the men of their city," etc. (Gen. xxxiv, 20). A "fool openeth not his mouth in the gate" (Prov, xxiv. 7); but the gate was a place for prominent persons, and for Mordecai to refuse there to reverence Haman was particularly insulting to the court 
the Emir is away, and then another officer takes the place of judgment below.

We noticed this portal arrangement in many towns, but at the fortress my attention was attracted therefrom by some curiosities hanging on the walls. Among them was a huge whip, 7 feet long, with a handle of about 4 feet, the thin end of the lash being three inches, the thick end 5 inches, and the middle about 8 inches in circumference. I wondered what it could be for, and was told that it belonged to a former monarch, who, perhaps, used it as a fighting weapon. When some of the courtiers were telling me next day how prisoners were flogged, I asked if this great whip were used for the purpose, whereon they said indignantly that it was made by a lunatic, and presented to Abdullah Khan. This is a less poetic origin than that given by Maieff, who calls it the whip of the hero Rustum, and adds that formerly there were seven of such whips, but the "most religious" Emir NasrUllah distributed six as relics of the past among the dervishes and other holy men of Bokhara. The courtiers added that a snake-like staff, hanging near the whip, belonged to a saint, and, when dipped in water, possessed curative properties. Another thing I noticed in the passage at the entrance to the palace was a narrow shelf on either side, which served as a sleeping place for the guard and attendants.* At length, after passing through some passages, we came to the house of the Vizier.

favourite (Esther iii. 2, v. 9). Job lamented the bright days when "he went out to the gate through the city" (Job xxix. 7). Lot was sitting in the gate of Sodom, when two angels came at even (Gen. xix. 1). Lastly, for Abraham's seed to overcome the nobles and councils of a nation was to possess the gate of his enemies (Gen. xxii, 17).

"Illustrating so naturally 2 Sam. xi. 8, 9. "Uriah departed out of the 
The Kushi-beggi, a man of 60 or 65 , and his son came out to greet us, and we were conducted into the grand man's chamber, that, for a wonder, had two glass windows, and contained a French clock. I knew, as I have said, that I was under surveillance, and that my deeds, if not my words, were reported to the Emir; for while some of the attendants were on one occasion waiting for me outside a house, two of them were reading over their notes, not noticing there was a man near who understood them, and who heard them read the record of my ill-deeds in galloping away from them round the walls, notwithstanding that I was told to go slowly. Remembering, therefore, that my note-taking had brought me under suspicion, I began by telling the Kush-beggi of my travels ; that I was an author, and, therefore, I took notes of what I saw. "He might perhaps have heard of this," I said. Also, I wrote books. I had written about Siberia, and the Emperor of Russia had accepted a copy, as also Count Tolstoy, and had been much pleased. Then I showed him an official letter to this effect from the Russian Embassy in London, together with my letters from General Chernaieff and the Lord Mayor. I added, moreover, that I should perhaps write a book concerning Bokhara; and that I might see their customs, I requested to be allowed to be present at a circumcision, a marriage, and a funeral.

To this he replied that inquiry should be made if there were such things going on, and he would let us know.

king's house, and there went out after him a mess of meat from the king. But Uriah slept at the door of the king's house with all the servants of his lord, and went not down to his house." At Ura-Tiube I observed that a Russian soldier, who was sleeping in the open air, had placed his bedstead close to the front door of the commandant. 
I then asked to be allowed to see the Emir's library, but the old fox replied that his Majesty had taken the key. But I said that the Emir had given me permission, and it was strange there should be any difficulty about the key. He then proposed to send a messenger for it to the Emir, but I disappointedly replied that was of no use, to which he said "Very well!" I inquired about the antiquities promised by his master, but he said the Emir had not written to ask them to find any, although, if I desired it, he would send to the bazaar and have them brought to me. I thought it was of no use to accept this offer, and asked that a mullah should be sent to me who could decipher inscriptions on coins. The Kush-beggi said the man should be sent, but he never came. I next requested to see the two prisons, called the Kana-Khaneh and the Zindan. I could not, he said, without the Emir's permission, nor could I be allowed to ascend the great minaret.

Upon this I changed my tactics, and said I must tell General Chernaieff that when his visitors came to Bokhara they were not allowed to see the things they wished, to which the old man said that they could not do things contrary to their law. "But surely," I said, "it is not against your law for me to see a prison!" He replied that in this case the Emir must be asked; whereupon, finding myself no more successful than before, I told him that if he came to London he would be allowed to see the prisons, and ascend our highest building as often as he pleased. For this he thanked me, and appeared relieved by the remark.

I then invited him to ask me any questions he pleased. He at first declined, until I drew him out

VOL. II. 
by telling him that our Queen was the greatest monarch in the world. "Is she rich ?" he asked. I replied that for her private purse she has $6,000,000$ tengas a year, and that some of our nobles also have as much. On the previous day I had told the Kush-beggi's messengers that so great was our Empire that the sun never set thereon; upon which they pleaded that "surely it must set for a few hours?" Then, discovering that they did not understand the earth's rotundity, although one of them had travelled to Petersburg, I took a melon, and roughly explained it; but I fancied they thought I was "cramming" them. It occurred to me now to repeat my astronomical and geographical lectures to the Kush-beggi, and I again spoke of our Queen as ruling over an Empire on which the sun never sets. Was his Excellency aware, I asked, that the sun did not move round the earth, but the earth round the sun? That, he replied, was their opinion; and I then went on to explain my paradox by stating that the sun was always shining upon some part of our dominions. Further, since they had told me, as a sign I took it of their greatness and importance, that they had eight guest-houses, and received many guests in the course of the year at Bokhara, I told him that we had 10,000 visitors a year come to London. Did he think, I asked, that his son would come? and, in case of such an event happening, I gave him my card, hoping to see him.

During the conversation the festal board had been spread for us with fruit and viands. I had observed that up to the present we had nowhere seen in the khanate any diaper or damask linen, but our napkins had been made by cutting from corner to corner a square of common brown calico, thus making a triangular 
serviette of original design, the table-cloth being usually of white calico. When, therefore, at the Kush-beggi's, I saw on the table a damask napkin, I said to Sevier, "Ah! here is linen at last!" when, upon examining it, I found it was my own napkin, which, with our knives and forks, they had brought up from the embassy, the Kush-beggi, I presume, having no such furniture to his table. I do not remember that the Kush-beggi or his son partook of the food with us, but they sat at the table. I inquired whether arrangements had been made to get us to Charjui in two days, and was answered in the affirmative. I then rose to go, but was pressed to stay longer, whereupon we renewed our conversation, and by way of starting a topic I asked if he remembered two Englishmen named Stoddart and Conolly being put to death at Bokhara, about 40 years ago? He replied that he was then Bek of Samarkand, and he did not remember Dr. Wolff coming to inquire into the matter. He appeared not to like the subject, whereupon I proceeded to administer another potion, that I thought would not be sweet, by asking if he remembered the visit of Dr. Schuyler. He said "Yes," and I reminded him that Schuyler purchased a slave, whereupon both father and son nodded their heads as certainly remembering that, and I added that I was very glad that they had no slavery now. M. Stremoukhoff's assertion that slaves are still bought in the khanate has led me to wish that I had made some inquiries upon the subject, but I heard of nothing of the kind anywhere in the khanate. I had asked, on the day after our arrival, to see the interior of the palace, which was then refused; and now, on leaving the room, I expressed a wish to see more of the building; but again the old fellow said that his 
Majesty's apartments were locked up, and the remaining portion of the palace was occupied by the women. At parting he shook my hand warmly twice, and thanked me for my visit, but I had summed him up as an old fox, who had utterly disgusted me by his want of straightforwardness, whilst his son, who holds the office of Toksaba at the court, or chief of the officers of the second grade, struck me as the greatest nincompoop I had seen in the khanate. The Kush-beggi, however, at Bokhara has great influence with an Emir, especially in the case of the present one, who is said to be very easily led by the opinions of others. I had sent presents for both the Kush-beggi and his son, among other things of a Persian Bible, Arabic New Testament, a watch and chain, india-rubber cushions, a compass, articles for toilet use, etc., in return for which he sent me a piece of silk and four black curly Kara-Kul lambskins.

My presents received had by this time so increased that I was obliged to think what to do with them. I had crossed the frontier with two horses, and now I was the possessor of six! I was given to understand that I need not be at all nice about selling my presents even under the noses of those who gave them; nay, that in all probability the Emir himself would buy the horses again, to present to his next guest. Yakoob and Kolutch valued my four royal steeds to be worth, in all, $£ \mathrm{ro}$, but when a horse-dealer was sent for, he offered only $£ 8$ for the lot! This was rather amusing to one accustomed to English prices, and since I did not know what cattle I might need in crossing the desert, I determined to take two of my presents down the Oxus, and the remaining two I sold for the sum of $68 s$. 
After returning from the Kush-beggi we went to the bazaar, where also we had been several times previously. Were I to speak of the commerce of Bokhara without book, and as it appeared to my limited observation, I should almost be tempted to say that more merchandise crosses London Bridge in an hour than enters Bokhara in a twelvemonth!* M. Petrovsky speaks of the bazaar of Bokhara as five times as large as that of Tashkend, and he estimates the transactions of the Bokhara market at $£_{4}, 000,000$.

Business is carried on in 24 caravansaries and 6 timis, besides the ordinary shops. As in other Asiatic towns, the various kinds of merchandise are sold apart. +

So, again, the various trades are localized in streets, as, e.g., for selling machines for silk-winding, coppersmiths, bakers, $\ddagger$ etc. In the shoemakers' street were skins for sale at half-a-crown each. In the armourers'

* The only statistics I can offer upon the matter are those of M. Petrovsky, who gives the value of 34 items of merchandise passing from Russia through Kazalinsk to Bokhara in $1868-9$ as $\oint_{1} 179,283$; and conversely, the value of 30 items passing from Bokhara to Russia as 6419,341 . Further, concerning goods passing from certain Russian towns through Tashkend to Bokhara, and vice versa, 14 kinds of merchandise exported from Bokhara to the value of $\xi^{864}$, and 8 kinds brought into Bokhara to the value of $\delta^{1}, 402$. But these figures concern only two commercial routes, from the north and north-east, and say nothing of merchandise brought from the south and west, from India, Afghanistan, Persia, and Khiva.

† Khanikoff mentions the following permanent bazaars for various merchandise, thus:-1, kid-boots; 2 , bread; 3 , fish ; 4 , candles ; 5 , fuel ; 6 , flour, barley, and jugara ; 7 , salt ; 8 , charcoal ; 9 , bez; 10, copper and metal wares; 11 , leather; 12 , boots; 13 , bran; 14 , dried fruit ; 15. drugs; 16 , melons; 17, pomegranates and pears; 18, eggs; 19 , milk; 20, horse coverings; 21 , knives; 22, butter; 23 , ropes; 24 , slaves, which last is now abolished, and it should be added that for some articles of merchandise there are more bazaars than one.

¥ So in Jerusalem, Jeremiah was to be given daily a piece of bread out of the bakers' street (Jer. xxxvii. 2I). 
street I secured a capital helmet of mail, a powderflask, and a battle-axe; and, in another street, some rude china inkstands and cups of local manufacture, which have, fortunately, come safely to England, where I presume they are unique in origin, if not transcendent in beauty. Another curiosity I obtained is a woman's veil (called chasman), made in part of horse-hair, and closely resembling the hair-cloth used in England for upholstery, as also a woman's cotton khalat (called pharange), similar in form to that of a man. In wearing it, however, the garment, instead of hanging from the shoulders, does so from the head, the collar being made to encircle the veiled face; and instead of the woman putting her arms into the sleeves, they are pinned together, and allowed to fall down the back. As winter was approaching, we were advised to provide ourselves with fur shubas, or robes, for crossing the desert. We found a serai set apart for this trade. In form the serai was a quadrangular building, very much like a medresse, with the interior resembling a college quadrangle of two stories. The centre was given up to horses and camels, and bales of merchandise, the rooms in the lower story were for warehouses, and in the upper story were rooms approached along a wide gallery, and in each of them fur shubas were hanging for sale. The shubas were lined with various furs, specially that of the jackal, and common ones differed in price from $30 s$. to $63_{3}$ s, there being few of the best kinds. It was probably a little too early in the season to see a large collection. We had a few coins brought to us, but all the fine promises of the Emir and Kush-beggi about searching for antiquities came to little or nothing. I tried to get some native books, and succeeded to a small extent, but only, as 
it were, by stealth, for I saw nothing like a bookseller's shop, and had to purchase through a middle man.

The streets and lanes of Bokhara (which are not named separately, but only as belonging to a certain quarter of the town) are exceedingly tortuous and narrow, varying in width, as Khanikoff says, from 40 inches to 20 feet. It did not need many people, therefore, to give the bazaars a very busy appearance, and everywhere crowds attended us, staring at the strangers, especially when we stopped to make purchases, so that our horses could make way only very slowly. One of the liveliest places was the Righistan, which we first saw on the day following our arrival. On two sides are five mosques and medresses, and on a third side is a pool, around which loungers congregate. Here we dismounted, the better to go in and out among the stalls for the sale of small wares, and afterwards visited several mosques and medresses. Near the Medresse Divan-beggi is a square pool, called Liabehaus Divan-beggi, the sides being of square stones, with 8 steps to the water, and shaded around with mulberry-trees of a century's growth. Here are numbers of tea and refreshment stalls, from which one may see the people drinking, bathing, or performing their ceremonial ablutions in the pool.

After finishing our business on Saturday afternoon, we called again at the Russian serai, which kept us till dusk, so that we wended our way homewards after sunset, and saw the miserable, deserted appearance of the streets by night. There were no street lamps, and the few men about were by no means desirable company, for I heard that lately not a night had passed without a murder or a robbery, and that the 
Emir had issued permission to the people, when they saw a thief on their premises, to shoot him, also that several robbers had been publicly executed. The streets of Bokhara, therefore, were no place for moonlight wanderings, and having reached the embassy we spent a quiet evening, having arranged to visit, on the morrow, the shrine of the patron saint of Bokhara, and, if possible, the lepers' quarter.

Next morning the Kush-beggi sent to felicitate me as usual, and, to my great disgust, added that, as we were to travel on the morrow, we might rest, and not go out that day, which Yakoob interpreted as a small piece of revenge for our galloping round the walls. I was somewhat nettled, feeling that we had not come to be prisoners, but guests, and ordered our horses to be saddled immediately. I then told the messengers that we had made our arrangements, and intended to go to Baha-uddin, to which we hoped the Kush-beggi would not object. Upon this our custodians became perturbed, especially Mirza Yusuf, who, as he saw me about to mount my horse, got in a great fever, and said that they had received many Russian embassies, but that none of the others acted thus, but obeyed what they were told. I replied, "Ah! yes, but you have never had an English embassy before!" and then, declining to wait, I bade him tell his master where we were gone, and if the Kush-beggi had any message to send, to bring it after us. The old gentleman mounted his horse somewhat in dudgeon, and went off hastily, whilst I and my party, and one or more of the Emir's men, sallied forth to the suburbs out of the Samarkand gate on the high road to KatteKurgan.*

* The journey to Katte-Kurgan is a distance of $\mathrm{r}$ ro miles, the whole 
As we rode towards Baha-uddin we passed through gardens, along a broad avenue intersected with ditches, and planted with trees. This road is much frequented by pilgrims on their way to the tomb of the renowned Baha-uddin Nakishbend, who died in $\mathrm{I}_{3} \mathrm{O}_{3}$, and was the founder of an order of dervishes bearing his name, to whom are attributed the origination of those religious extravagancies that distinguish Eastern from Western Islamism. He is looked upon as a second Muhammad, and a pilgrimage to his tomb consequently as nearly equal in merit to a journey to Mecca. Near the shrine of the saint is the tomb of the great Abdullah Khan, a photograph of which I fortunately secured. There is also a sort of college for beggars.

I cannot say, however, that I expected the shrine and its surroundings to repay me for the trouble of the journey. What I really wanted was to visit the poor lepers. I had been taught at Karshi the folly of

being available for carriage use. The stations or villages, with distances between in versts, are as follows:-

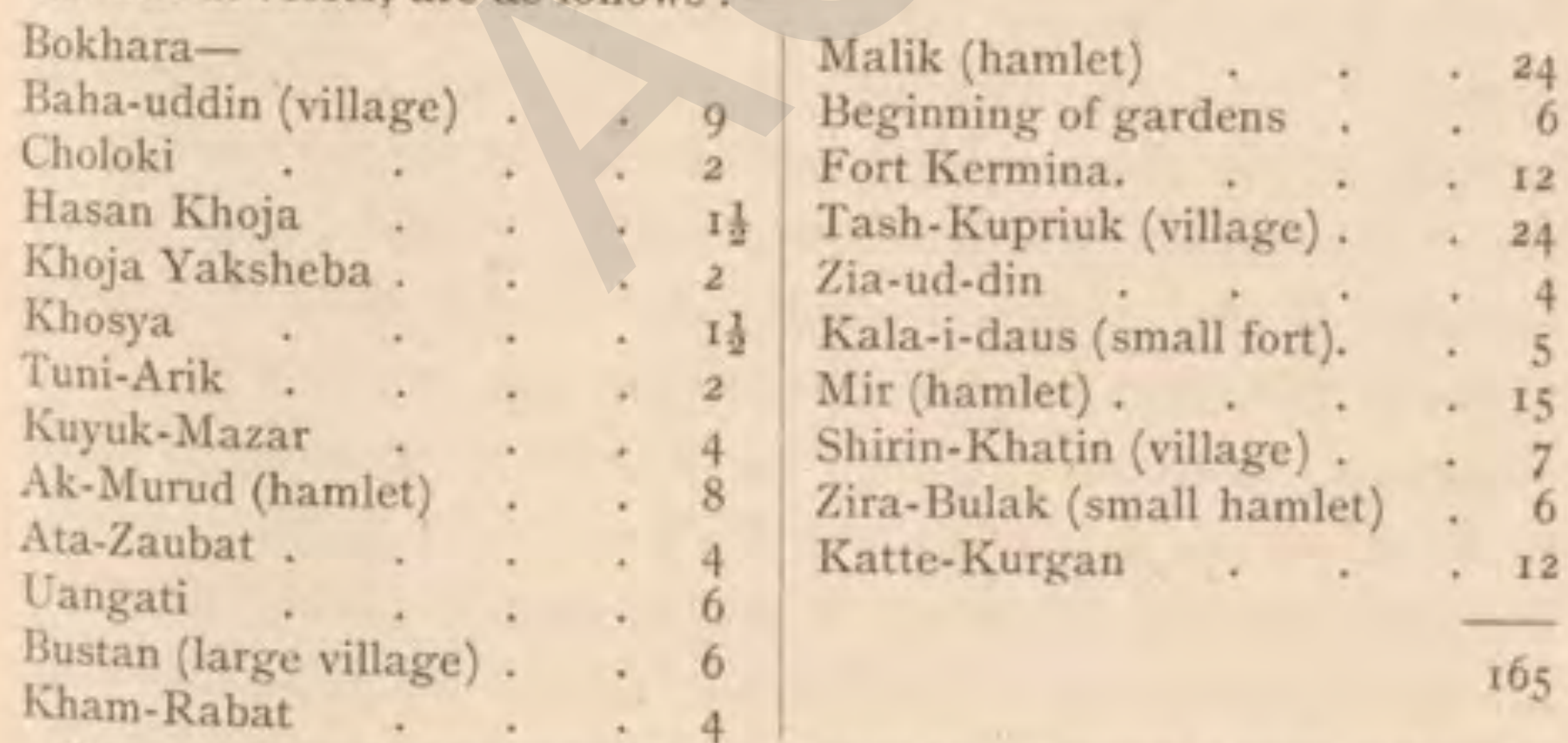

The way from Bokhara to Kham-Rabat lies through a well-cultivated and populated district. Then comes the waterless steppe of Malik, beyond which the traveller again enters gardens before reaching Kermina, the residence of one of the Emir's sons, who is Bek, and after this point the road runs through the beautiful gardens of the Zarafshan valley to the Russian frontier at Katte-Kurgan. 
directly asking to see them, and I suspected that I should get only a refusal if I repeated the request in Bokhara ; but I had heard that we must pass the lepers' quarter in going to Baha-uddin, and hence my zeal to tread the pilgrim's path. I was disappointed, however; for when we reached the Makhau Khaneh, where there were said to be about 150 houses, we saw no single building that invited entrance, nor any people about, though we were given to understand that the lepers were allowed to come into the town and beg.

Meanwhile, the Kush-beggi's messengers had not overtaken us, and now that I had attained, so far as I could, the object of my running away, I began to think what might be the consequences of this breach of discipline. I remembered how Dr. Wolff was harassed in Bokhara, and how this same Kush-beggi, with whom I had to do, had thwarted Dr. Schuyler's desire to go to Charjui, even though he had the Emir's permission. I confess to having felt it a little difficult to know how best to act. If I allowed myself to be dictated to, and treated as a prisoner, I thought it would imply fear, and I had before me the policy of my American predecessor, who would not allow himself to be imposed upon, and found that the more respect he demanded, the more he received. The situation, moreover, gave me a certain sympathy with Colonel Stoddart, who was said to have been unyielding and blunt ; but when a single man is surrounded by all the powers of an Oriental city as he was, and has to hold his own against them, it is not easy always to see what is best to be done. In my own much smaller and less important case, I was fully aware how completely I was in the hands of this unscrupulous Kushbeggi, not indeed to harm me perhaps, but to delay 
me, and vex me more than enough by withholding help for the way. He had prevented my seeing several things upon which I was intent, and had told me numerous falsehoods, so that I had not the smallest respect for him, nor had I reason to believe he would do for me one whit more than he was obliged, or than suited his purpose. Since, however, I had bearded his Excellency, and sent a message to his den, I deemed it might be better to make a virtue of necessity, and turn back to meet the messengers. We did so, and thus came to the embassy without seeing them; and when, later in the day, our old custodian appeared, he said he had trotted round all the city gates, and elsewhere in pursuit,- - a distance, he declared, of 10 miles,-when, failing to hear of us, he had given it up as a bad job, and so returned to the embassy. The old fellow was warm, but happily very good-tempered over it ; and when I inquired by a side wind what the Kushbeggi said to our conduct, it transpired that he was not annoyed, the reason of his order being that they had not taken the proper steps to provide us, on our arrival at the shrine, with refreshments, not to do which to their guests would be a breach of etiquette the Emir might not like if he heard of it. This dispelled my fears, and we spent the rest of the day at the embassy. 


\section{CHAPTER LIII.}

\section{SUNDRIES CONCERNING BOKHARA.}

Both guest and prisoner.-Use made of custodians.-Bokhara minerals. -Building materials and garden produce.-A nimals and animal products.-The natives and their diseases.-Treatment of the insane.-The rishta, or guinea-worm, and investigations concerning it.-Native method of treatment.-Classes of native society.-The Bokhara prisons.-Inquiry as to where Stoddart and Conolly were confined.-Manner of life of the Emir.-His harem.

FROM the hour that I crossed the Bokhara frontier and met the Emir's messengers, I was tly accompanied by officials-not that they did (n) going about we were always attended.* In travelling, there was generally one, often more, of position who went with us a long distance, if not all the way, whilst others were relieved at successive stations. Besides our fixed attendants in Bokhara, some of the higher functionaries came each morning to exchange greetings from the Kush-beggi, and I took advantage of these visits to draw them out by asking questions pre-arranged, and thus, by putting the courtiers and other natives through the same examination, I was able to compare their various answers with information

* The custom of Eastern dignitaries being usually thus attended may perhaps account for Ahimelech's fear on meeting David and saying, "Why art thou alone, and no man with thee?" (i Sam. xxi. r.) 
received from men of European education, both Moslem and Christian.

I asked about their minerals, but I imagine that Lehmann's book, which includes the Zarafshan valley, gives far more information than the natives themselves know.* One man told me he had read in the Turkistan Gazette that gold in small quantities was obtainable on the banks of the Amu-daria, but that the results were so inconsiderable that the search for it was confined to Turkomans and Uzbegs. I obtained in the shops at Bokhara some good specimens of pink salt, one of which I have given to the British Museum. $\dagger$ The Bokhariots have coal, though they do not work it. When Lehmann discovered it near Wairabad, in the Fantagh, the native officials to whom he pointed it out would not believe in its value, and told him derisively that he had better take 500 camel-loads to

* Copper was found by Lehmann near Wairabad as the carbonate, whilst the sulphate, and probably copper pyrites are found in the Karatagh. Copper is found also two days north of Shirabad. Iron exists in the Nuratagh as red and brown ironstone, and as iron glance near Wairabad in clefts of the quartzose sandstone. Irwin reports two iron mines in the Hissar district. Lead (probably galena or sulphide of lead) is found in many places, sometimes along with soorma, or sulphide of antimony. Lead, the natives told me, is to some extent worked. In the hills of Shirabad, and the Wairabad mountain, are found sulphur and saltpetre, which find a ready sale in Bokhara for making gunpowder. They have no precious stones, they said, but Lehmann mentions that turquoises are found in the Nuratagh and in the Butantagh.

† Some of the best is obtained near Karshi, and rock salt is also found in the Nuratagh hills, where each seeker is his own miner. Again, from certain salt springs the water is emptied into a shallow place, and allowed to evaporate, leaving the salt behind. In addition, there are salt lakes, one for instance near Kara-Kul, where, on the shores, red salt is found in crystals. Lastly, there are spots, as at Shurgul, a valley near the lake we saw in coming from Karshi, where the soil is highly impregnated with salt. The sick resort to the west end of this lake for the benefit of the water, which is said to contain iron, salt, and sulphur. 
his Imperial master, the Tsar. They burn saxaul, or charcoal made therefrom, and coarse grasses, called jin-tak and jin-gul, which cost for a donkey-load from $9 d$. to $1 s .3 d$. Dung is little used for fuel in towns, being more valuable as manure.

For building materials I rarely saw stone used, unless for wells or foundations. They have, however, a limited supply of whitish and grey-veined marbles. The whole of the country north of the Amu is covered with limestone. Ordinary houses are built of timber, filled up with intervening mud and stones. The burnt bricks used for building medresses cost from 5 s. to $7 s .6 d$. per thousand. They were said not to have any sun-dried bricks. Potters' clay is found and used, but pottery would seem to be precious, since there is one trade devoted to mending it; and cleverly, too, is this done, even when the vessel has been broken into the smallest pieces.

Concerning the products of their gardens, one man at Shahr-i-sabz told me comprehensively that they had "all kinds of fruits except lemons, oranges, and dates." They grow good peas, but do not eat them green. They use willow bark for tanning, and their chief cures are effected with medicinal plants.

As for the animal kingdom, my informants told me they had in the mountainous portion of the khanate tigers, bears, wolves, deer, and wild boars. To these I may add a very remarkable and peculiarly small breed of goats, covered with a very long and coarse hair, reaching almost to the ground. M. Oshanin saw them in Karategin, and also herds of Yaks.*

- The Dong, or wild Yak (Bos grummiens), as Colonel Yule observes, has till late years been only known by rumour. It is a native of Tibet and high Asia, between the Altai and the Himalayas. Colonel Prejevalsky 
They are in use all across Mongolia, and I have a photograph, lent me by Mr. Delmar Morgan, of a so-called "Tibetan cow" (which I suppose is a crossbreed), introduced by the Russians into Turkistan. The yaks pasture in the coldest parts of Tibet and the eastern portion of Bokhara upon short herbage, peculiar to mountain tops and bleak plains. It remains, therefore, to be seen whether the animal will thrive in the lowlands. During our stay in Bokhara we

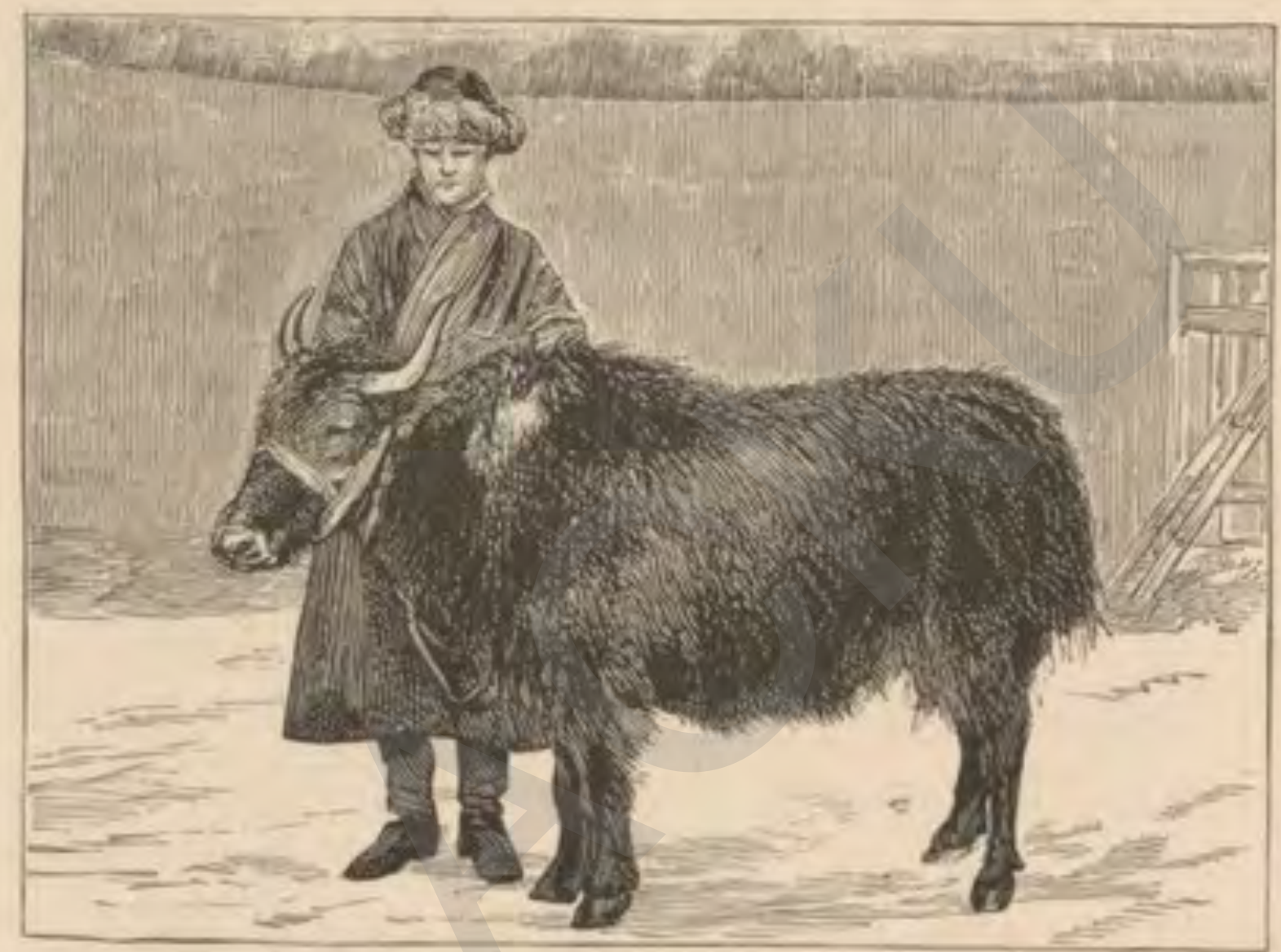

A TIHETAN COW AND NATIVE KEEPER,

drank excellent milk, and Yakoob, finding out my weakness for cream, not only kept us constantly supplied with it for our tea, but made the remainder into butter.

As regards animal products, I learned that the Arab sheep is kept for its wool, which sells at from $3 \frac{1}{2} d$. to shot one south of Koko-Nor, 6 feet high, and in feet in length apart from the tail, which was 3 feet more. The cow yak is considerably inferior in size to the bull, and her horns are small. The animal is capable of domestication, and an extensive variety of crosses with ordinary cattle is produced. 
$4 \frac{1}{2} d$. per lb., whilst the Kara-Kul sheep is reared chiefly with an eye to the black, curly lamb-skins, like Astrakhan fur, which sell for $8 s$. or $9 s$. each. Other pelts they use are those of the wild cat, lynx, and fox, selling at from $7 s$. to Ios. each. A Russian told me the Bokhariots tan leather badly. They soften sheepskin, dye it black and red, and export it over the border, where the Russian soldiers cut it up for trousers. Of whole goatskins they make tursuks, in which to keep the honey they express from grapes. Cocoons of the best silk cost about $6 d$. a lb. Bokhara is one of the chief places in Central Asia for the culture of silk, especially at Vardan Zigi, where the best is produced. In weaving, they use for one kind of warp a silk called tchillah, brought from Afghanistan. Khokand silk is called tafili.

In our wanderings in the khanate thus far, we had met with Tajiks, Persians, Jews, Hindus, Arabs, and Uzbegs. The last were comparatively new to us, for in Turkistan they comprise only 6 per cent. of the entire population. In Bokhara they form the ruling race. The Khan of Khiva and the Emir of Bokhara are both descended from the Min section of the Uzbegs. The Uzbegs have, however, lost their political and tribal importance. Most of them have mixed with the Tajik, Kirghese, and other races, and have settled down and become known as Sarts. Hence, in the bazaar, the crowd did not appear of quite so motley a character as in some other towns we had visited, and in speaking of the natives we usually heard the one general word Sart used as comprehending the whole.

We gave out that any who were sick might come to be treated. The diseases from which the Bokhariots most frequently suffer are fevers, ophthalmia, leprosy, 
piles of various kinds, syphilis, small-pox, and the rishta. Syphilis is treated only with mercury. They practise vaccination, but it is not compulsory, and they have a "pest-house," or rather a village, where those who wish may be inoculated. A boy came one morning, his head being covered with a thick eczema, to whom Sevier simply said, "Go and wash! and then come again." I was not a little struck with the account they gave of their treatment of the insane. They have a special mullah, called Ishan, who is brought to a man when he begins to fail, and who reads over the patient prayers from the Koran for a week or two. If this proves unavailing, the patient is taken to the Ishan's house, tied to a post, and kept on low diet for a couple of months. Thus in the Ishan's yard, not far from the Russian Company's office, in the quartal of Bokhara called Juibar, may be seen a number of these patients chained, or rather picketed, to posts like horses. As a further step they are beaten whilst prayers are going on. If a poor creature does not show signs of pain, his case is thought incurable; but if he is seen to suffer, his recovery is hoped for.* A Russian told me that one of his servants was slightly deranged, but, having gone to the Ishan, appeared to be getting better. "But suppose he does not improve," I asked, "what do you do with him ?"

"He remains there chained, and if regarded as quite incurable, his parents are obliged to take him away and keep him locked up."

"But suppose he has no parents?"

- Is it possible that Prov. xxiii. 35 can have reference to any such custom, wherein the man, apparently in delirium tremens or after a deep debauch, says, "They have stricken me, and I was not sick; they have beaten me, and I felt it not; when shall I awake?"

VOL. II. 
"Then he is turned out, and allowed to run about the town till someone takes compassion on him."

After hearing this it was a comfort to be told by one educated Muhammadan that they had not much insanity, and that he had never even seen anyone raving mad.

The reading of the sufferings of Dr. Wolff, and what I had seen and been warned of in Samarkand, made me specially fearful of the rishta, a well-known disease in Bokhara, Karshi, Jizakh, and Katte-Kurgan. It is also met with in India, Arabia, and Africa, whence with the negroes it was taken to America. This disease is caused by a worm, which develops under the skin in May and August, in the form of a cylindrical body, lengthening at the rate of about an inch in a week, and lying extended, or curled in a lump two inches in diameter. Later on, an abscess appears where the head (as is said) of the parasite lies, and through the opening thus made, especially when the surrounding skin is pressed, the end of the worm appears. Sometimes, however, the skin, lifted by means of a needle, is cut off in layers until the head of the worm is reached and grasped.

The problem now is to extract the animal entire, in which case the wound soon heals. Native specialists, usually barbers, insert a needle under the worm, and one end is drawn out by the fingers of the right hand, whilst those of the left press the affected part, the operation lasting from one to five minutes. Russian medical men wind off the animal on a reel, so much daily as comes out without force, till the whole, commonly three, but sometimes (according to one physician) seven feet in length, is extracted. If, however, the worm should break, and part of it remain 
in the body, illness continues for several months. It was an unsuccessful case of this kind we saw in the military hospital at Samarkand, where the portion of the rishta extracted was given to me. The other parts had come out of the patient of themselves, in numerous places, through painful abscesses.

In appearance the worm is a long, cylindrical body,

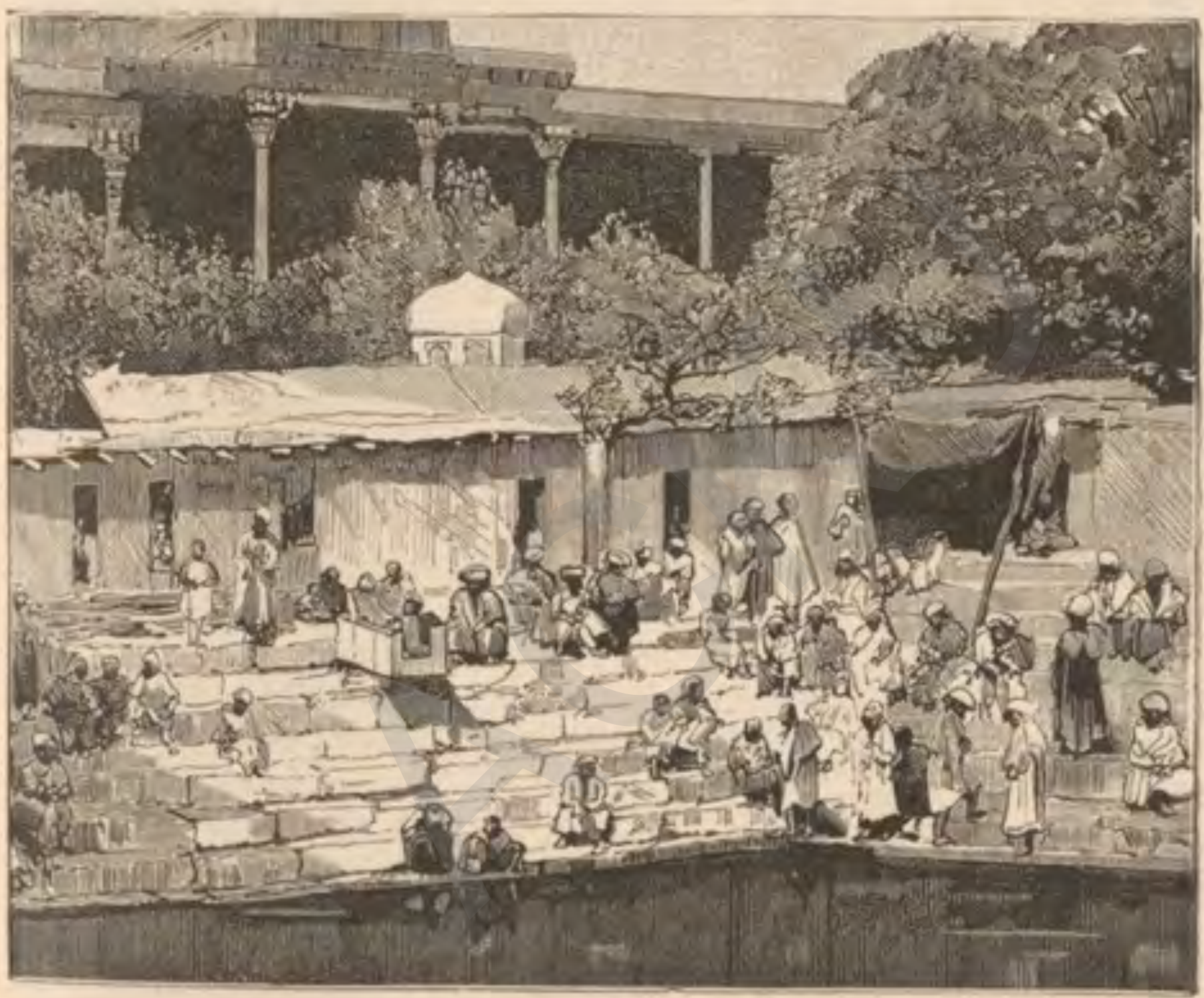

A PUBL.TC POOL AT BOKHARA.

of a milk-white colour, resembling cooked vermicelli, and can be stretched like a piece of elastic. When torn, a milk-white fluid exudes, containing an immense number of minute worms, swimming rapidly, whence it appears this animal is viviparous. Concerning its origin in man, Dr. Klopatoff,* who resided three years at Jizakh, considered that water was the medium by

* Gournal of Health, p. 123 , No. 35,1876 . 
which the parasite was conveyed, entering most likely through the pores of the skin. Fedchenko, on the other hand, came to the conclusion that the germs of the worm are swallowed in drinking the water."

Some persons are, however, I imagine, more prone to the disease than others ; for a Russian told me that his friend, who came to Bokhara in 1876 , had suffered from rishta 8 or 9 times a year, and in the year of my visit 12 times, whereas he himself came a year earlier, had taken no care as to what water he drank, but had not been attacked until $\mathrm{I} 882$. It may readily be supposed that I had no wish to be the first to bring this parasite from Bokhara to England; and, accordingly, * "Compendium of Russian Turkistan," p. 283, Moscow, 1872. His investigations brought to light some very int eresting facts, the first of which was that the germs of the rishta (filaria medinensis) cannot live in very fresh water. This he discovered by accident. Not being at home when the first rishta was brought to him in water, the water putrefied. He detected therein, through the microscope, several living germs; but as the fluid stank, he put therein some fresh water, with the result that all the germs died. Subsequently a fresh rishta was brought to him in water, in which water he noticed two minute crustaceans of the genus Cyclops, and, putting these under the microscope, he saw on each of them several rishta germs. That he was not mistaken, he convinced himself by pricking another rishta in separate water, and out of the aperture immediately many germs exuded (there are millions in each rishta), and then he put the water with these germs into a vessel, seen beforehand to be free from germs, but containing examples of Cyclops, with the result that in a few hours the germs had entered the crustaceans, though how he did not discover.

It then remained to trace the germs onwards. The size of the germ is about $0^{\circ} 65 \mathrm{~mm}$. in length and $0^{\circ} 02$ in width. The animal has a tail about one-third of its length. This, after being in the Cyclops for two weeks, it loses, and also casts its skin, the tail being no longer needed as an organ of motion in the water. The animal now glides like a serpent, and no longer has any rings. It begins also to take in food by means of the mouth, and the sexual organs appear.

Here M. Fedchenko's observations ceased; but he asks, "What becomes of the germs later on ?" and, arguing by analogy from what is known of other worms, he goes on to suggest that the Cyclops enters by drinking into the human stomach, where, under new conditions, a 
on crossing the frontier, I gave up teetotalers' beverage, and drank no longer water-that is, in its natural condition. But neither did I take to wine, but making more tea than we needed, the surplus was kept for consumption cold, and thirst allayed after a meal by melons or fruit.*

The Bokhariots have no hospitals ; but apothecaries and doctors, who profess to know something of medicine, and whose chief method is to read over the patients passages from the Koran. With regard to the increase

further development of the germs takes place, principally of the sexual organs, copulation follows, the males die, and pass out of the abdominal canal, whilst the females work their way and settle themselves in the subcutaneous cellular tissue. Fedchenko then points out that in Central Asia the parasite appears only in those places where the people are forced to use standing water, generally from ponds that are filled by means of a small channel, whilst another similar channel serves for the escape of the superfluous water. In these square ponds or pools, near every mosque, the natives wash, and, when drinking, think nothing of the aquatic animalcula, even Daphnio, that are visible to the naked eye. It is easy for them then to swallow the small grey Cyclops, which can with difficulty be distinguished in the water. Fedchenko adds the curious fact that the Cyclopes avoid moving water, and says that if water in which they are swimming be drawn up a syringe, however violently, they hasten out of the current, and scarcely a single example will be found in the syringe, but only Daphnia, in which it appears the rishta germs do not become developed; so that Fedchenko thinks the natives might in a measure avoid the evil by taking their drinking water, not from the ponds direct, but from the small canals running out of them. The Cyclops would thus be left in the still water.

- The old traveller Jenkinson, who visited Bokhara in 1558 , has the following curious remarks: "The water of the little river that runs through the city is very bad, breeding in the legs of those who drink it worms an ell long, between the flesh and the skin, which, working out about an inch every day, are rolled up and thus extracted; but if they break in the operation the patient dies. For all this inconveniency it is there forbidden to drink any other liquor but water and mare's milk, such as break that law being whipped through the markets. There are officers appointed to search all houses for aqua vite, wine, or braga (as Abul Ghazi calls it); and in case they find any, to break the vessels, spoil the drink, and punish the owners; nay, often, if a man's breath smells with strong liquor, he incurs a good drubbing." 
of the population, men with one wife sometimes have up to 8 children, and with 4 wives, each wife perhaps will have from I to 3 ; or with 2 wives, 8,9 , and 10 children is common. In Bokhara they said the mother, after childbirth, gets up after a week at the longest ; in Khiva, after 4 or 5 days, but sometimes after 2 .

The levelling code of the Muhammadans prevents a very definite classification of the people into grades. After the Emir and his officials, the mullahs take the first social place; but I was told they were not much esteemed, and merchants stand nearly as high. In the city of Bokhara the most influential men are Persians, who were formerly slaves, and who still send their money to their fatherland. I asked various persons, in different localities, what possessions would entitle a man to be considered rich. In Bokhara city, one Mirza Khoort was said to be the richest man, and to possess a million tengas (round numbers again!) - that is, $£_{25}, 000$. Also, I was told of a so-called rich Jewish family, now consisting of 5 brothers, 2 of whom together export annually 200 camel-loads of silk and 1,100 tons of cotton. Passing the suburban residences outside the capital, I was told they were the houses of rich men. I said to Yakoob, "What do you call a rich man ?" He replied, "One who possesses a horse, some cattle, $£_{50}$ in money, and an annual harvest of 25 cwt. of corn." A similar question at Petro-Alexandrovsk elicited the answer, "A man who possesses 4 acres of cultivated land that will yield him 3 tons of wheat, with a horse and a cow" ; but that some possessed 4 or 5 times as much! Thus it would appear that few of the Sarts have what Europeans would consider great riches, and, on the other hand, it must be added that they have little abject poverty. 
As they would not allow me to visit the prisons in Bokhara, I took care to make what inquiries I could about them; and happened to hit upon a man who, when crossing the Steppe; made a vow that if God would bring him safely to the end of his journey, he would spend 7 tengas in bread for the prisoners in the Zindan, i.e., dungeon, or town prison of Bokhara. He was too wise to give the money to the keeper, but, having brought the bread, asked leave to distribute it, whereupon he threw it down to the detained. He said their prison was like the baths we visited at Karshithat is, a chamber entered and lighted from above. I asked him how many prisoners there were; and he replied, "From 300 to 400 "; but I found this was a mere guess on his part, though he said he had heard the same from the Bokhariots, and that some of them had been confined there for 12 years. Each man received, he said, only a cake of bread in the morning, and another at night, whilst 2 prisoners, he said, were let out daily to beg, and, of what they received, half went to the jailer and half among all the prisoners.

My informant added that, if a man be accused of theft by two witnesses, the accused is beaten on one side 75 times with a stick as thick as the wrist, then 75 times on the other side, and lastly 75 times on his stomach, unless he confesses, in which case he is beheaded at once, or perhaps kept for a year and then let off. But if he does not confess he is sent to prison to heal, and then beaten again; and so on four or five times. If then he is not killed, he is allowed to go. Murder is punished by hanging or beheading. I asked if prostitution were punished, as I had heard, with death, and received a reply in the affirmative : that the man's 
throat is cut at the bottom of the great minaret I wished to ascend, whilst the woman, with her head covered, and buried to the waist in a ditch, is shot with a pistol. This was said frequently to happen, but that bribery could often buy off the would-be informer.* This informant corroborated the throwing of certain criminals from the top of the minaret, saying, that about 7 years before, there was a gang of robbers between Bokhara and Katte-Kurgan who were caught, and most of their throats cut, and their bodies thrown in a heap at the frontier, but that the chief was hurled from the tower, the women of the town having received notice to hide themselves. $\dagger$

Thus primed with information, true or false, I took occasion one morning, when the Kush-beggi's messengers came, to ask how many prisoners there were in the Khana-Khaneh and Zindan prisons, to which they replied, "Very few"; for that they did not keep them long, not even for 5 months, but speedily gave them I 50 stripes, or beheaded, or released them. I asked if it were true that in the Khana-Khaneh ticks were kept alive to annoy and prey upon the prisoners. They somewhat indignantly denied it, saying that they had three sorts of prisons, the Ab-Khaneh, Ben-

* With this may be compared the very old law in patriarchal times touching prostitution, by which Judah would have Tamar burnt (Gen. xxxviii. 24), the Levitical law concerning adultery (Lev. xx. 10; Deut. xxii. 22), and the continued existence of some such punishment obtaining at the time of the birth of Christ (Matt. i. 19), though John viii. 5 has it "that such should be stoned."

† Throwing from a height would appear to have long been a recog. nized mode of putting to death in the East, and to remain so still. The men of Capernaum thus led our Lord to the brow of the hill whereon their city was built, that they might cast Him down headlong (Luke iv. 29 ), and in the very year of my travels this was one of the modes of being put to death offered by the Arabs to Professor Palmer and Captain Gill. 
Khaneh, and Khana-Khaneh, representing better class, intermediate, and dark prisons. They also denied that prisoners were sent out into the town to beg; but this last denial was certainly a falsehood, for when we turned back from the lepers' village I asked one of the natives to take us back to the embassy in such a way that we might pass the Zindan prison. I saw that I had asked a hard thing, and at first he said it was more than he dared to do; but ultimately he was better than his word, and, looking up a passage as we rode along, I saw outside a lofty building two prisoners chained together by the neck, and who, on my approach, cried most piteously for alms, which I gave them, as also did Yakoob, whose heart was evidently touched. The building before me. I make no doubt, is the one that Khanikoff calls the "Zindan," saying that it has two compartments, the upper and lower dungeons, the former consisting of courts with cells, and the latter of a deep pit, at least 20 feet deep, into which the culprits and their food are let down by ropes. This latter I suppose to have been the one in which Colonel Stoddart was first placed. As for the Khana-Khaneh, I stood near the door, I was afterwards told, when examining the great whip at the entrance to the citadel, but I did not know it at the time. It was from hence, I imagine, that Stoddart and Conolly were taken to execution, or from the Ab-Khaneh, said by Khanikoff to be also in the palace, but of which I heard nothing.

Of course we heard during our stay in the khanate something of the Emir's manner of life and his family affairs. Much, no doubt, was untrue and exaggerated, but I am not sure that I shall be justified in withholding from the reader the accounts we were told. 
I asked the messengers one morning how his Majesty lived, and they confirmed what I had previously read, that he keeps a very simple table,-if indeed he can be said to keep a table at all who, I suppose, sits on the ground to eat. Also I gathered that he spent but little, his only pleasures being dancing-boys and his wives. I ascertained that his feasting is confined to two occasions in the year, when he invites his officers; and I heard something, too, of wholesale feasts, facsimiles, I should imagine, of those given by David when "he dealt to every one of Israel, both men and women, to every one a loaf of bread, and a good piece of flesh, and a flagon of wine" (or grape cake?) (I Chron. xvi. 3), the last, however, being replaced by the Emir with sweetmeats.* In the palace, certain men who stand in Muzaffar's presence, such as the travelled Khoja we met at Kitab, eat with him, but not at the same table. $\dagger$ "What does the Emir eat?" I asked. They replied, "Much the same as the fare provided for you, unless, perhaps, he might have the very best rice, and his soup a little richer." He has three meals a day, namely, at sunrise, milk, tea, and perhaps meat and meal; his dinner about noon, the time of the midday prayer ; and supper at eight. I thought to draw out the messengers to speak of his intellectual tastes, if he had any, by saying that our Queen spent time in reading. Does the Emir read much? They said that on rising he reads, then transacts business, and afterwards reads again, but that he had not much leisure because of his work. The Emir has several arbas,

* I heard, too, of the Zaketchi, or principal tax-gatherer, inviting the Mussulman merchants once a year at the time of the fast.

† As did Jehoiachin, King of Judah, before Evil-Merodach, King of Babylon (Jer. lii. 3I). 
they said, and, when going away for the summer, takes his books with him. This was in reply to a question of mine fishing for information as to whether there was in the palace any library, or anything that would give me any hope that it might be that of Tamerlane; but when they spoke of taking his books away in an arba, I concluded they must mean his accounts and state documents. His Majesty speaks, I was told, only Turki and Persian.

I imagine it is no uncommon thing for Eastern sovereigns to suffer from scandal respecting their harems, and all the more, perhaps, because they keep them so secluded. Even M. Ujfalvy permits himself to say that, at the taking of Khokand by the Russians, the Khan had 3,000 women! After this it made little claim on one's belief to be told in Samarkand that the Emir had 300 . The number of 300 , however, would not strike an outsider as unlikely in the face of such tales floating about as the following. I learned from a Russian judge that there was brought before him a woman of ill-fame, who professed to have been an inmate in the Enir's harem. She said that when his Majesty went through the streets, the women he met were obliged to stand by the wall and lift their veils, and that anyone whom he saluted was taken to the harem, and there kept for a few months, when, if not pregnant, she was given to wife to one of the officials of the court. In the other case the child had to be her only one, and she remained in the harem for the rest of her life. This story, upon the face of it, is not very likely to be true, for the women go out but little, and then it is chiefly the old ones. So contrary to etiquette is it for young women to go out, that, when necessity compels, they take a stick and creep along like old 
hags. Moreover, on repeating this to at least three persons in the khanate, they had never heard of it, though some of them said that the Emir's wives, after having a child, were usually given to one of his favourites.

I found that the simple question, "How many wives has the Emir ?" elicited some very varying replies. One replied, "Many" ; another, "Thirty for certain"; a third said he did not know, but he supposed that at least two a week were taken by force from the people. Of course all the royal wives must be orthodox Sunnites, so that, if a very pretty Jewess be taken, she is made a Muhammadan; but no instance of this, the Jews told me, has occurred lately. This led to the question, "How are suitable wives obtained, since females in Bokhara are kept so secluded?" The first informant said, "Old wives are paid to go into families, and so discover beautiful girls, who are taken to the harem, and then either allowed to return or made wives of the Emir." This statement was made, however, by an ignorant man, and the report of a second was more rational, that the Emir asked the father's permission, and paid a handsome kalim-more, that is, than the Muhammadan law requires, which is $£ 20$ for a girl, and $£_{\mathrm{I}} \mathrm{o}$ for a widow. Another said that the presents or kalim that he gave were small, and that the parents thought it a grievanee. "But have the parents," I asked, "no right to object?" "Yes," said my informers, "but no two persons in the khanate may marry unless the local authorities approve, though the Emir may be appealed to; and if in his own case the Emir's advances are declined by the father, he forbears to press the matter, but forbids the girl to marry anyone else." Such a case was known to my 
informant at Kermina, where the poor girl, like Jephthah's daughter, "bewailed her virginity," * and cried over her position, so singular in Bokhara, where it is a thing comparatively unknown for "their maidens not to be given in marriage." $\dagger$

Of course these were very delicate subjects upon which to approach the Emir's messengers, especially as my conversation might be reported to his Majesty. Nevertheless, I thought it better to hear their answer to my question, "How many wives has the Emir?" They replied immediately, "Four." I said that I had heard it was 300 , upon which they waxed warm, and said that as a husband I ought to know that one man would be no match for 300 wives! in answer to which, being unmarried, I expressed my ignorance of such matters. "Then," said they, "if you are not married, Mr. Sevier, who is a doctor, ought to know!" They allowed, however, that his Majesty may have had 50 or $60 ; \ddagger$ "but," said they, "never more than four at a time!" and as to how he obtained them, the Emir had some sisters, $\S$ aged wives, or other near relations, and that, when he wished to marry, they told him of girls they knew here or there. To this I added that I hoped they were not offended at my asking, but I thought it better to inquire than to go away with

- Judges xi. 38 .

† Psalm Ixxviii. 63 .

‡ Thus emulating Rehoboam, who took 18 wives and 60 concubines, and begat 28 sons and 60 daughters ( 2 Chron. xi. 21 ).

$\S$ With this may be compared, though only in certain aspects, an old wife seeking a younger for Abraham (Gen. xvi. 3 ), and a mother seeking a wife for her son Ishmael (Gen. xxi. 21). I met with a case of this latter so recently as 1879 , when a Russian mother, whom I saw on the Amur, was said to be looking out for a wife for her son, just finishing college, and who was then to be married as a qualification for ordination to the Russian priesthood. 
erroneous ideas. They thought so too, and said they were not offended.*

Thus I have stirred this sink of impurity, for which I feel an apology to the reader to be due. Yet I have conceived that, in order to paint an accurate picture of Bokhariot life, the preceding paragraphs will convey more meaning than a whole chapter of my own opinions; and if the purity of the domestic hearth be any gauge, in forming an estimate of the happiness of a people, then English men, I think, and certainly English women, will have no reason to envy those of Bokhara.

* The royal harem was spoken of as no abode of bliss, especially with the young mothers, now, according to the testimony of the first witness, set aside, and who emulate the unnatural practices of the Central Asian men (Rom. i. 26). Of course there can be little of what we call family life, and the case of the Emir's daughters is not enviable. Their father marries them to Khojas, who live in the palace as playthings for their wives; but should the wife die, her property is sold, they said, and the husband turned adrift, to become perchance a beggar. 


\section{CHAPTER LIV.}

FROM BOKHARA TO CHARYUI.

Our generous reception at Bokhara and its cause.-Extra presents to the Emir.-Dr, Schuyler's "Turkistan."-Departure from Bokhara. - End of Zarafshan oasis.-Bokhariot agriculture and horticulture. -Ruins of Peikand.-Approaching Kara-Kul.-Inexperienced postilions.-Lake of Kara-Kul,-The sands of Sundukli.-Our tarantass left behind.-A night's lodging at Betik.

A $S$ the time drew near for us to leave "the noble" A Bokhara, I could not but feel that we had been most hospitably treated. Not that I supposed the Emir's conduct to be the expression of his personal regard for me or my country, but of his desire to please the Russians. I had been warned at Samarkand to be very careful not to lose my credentials, for if I did the Bokhariots would be only too pleased to insult me, and then to excuse themselves on the ground that I brought no papers. More than once I asked in Bokhara what would have been done to me had I come to the town without letters. One said we should probably have been sent back to the Russians; and another that we should have been placed in confinement, and the Russian authorities informed. No Europeans, they said, are seen in Bokhara, but Russians, who themselves would have an unbearable time of it, if the Emir had power to oppress; but since he has not, the 
natives are outwardly civil, whilst they curse the infidels at heart, and the Emir is obedient to the Imperial will. The Russians, in fact, call him "Nash Chelovak," or "our man." We were told that if only an ordinary letter be sent from the Turkistan authorities, the bearer is feasted, presented with 3 or 4 khalats, and supplied with money to return, whilst the number of khalats sometimes presented by the Emir to the higher officials at Samarkand and other principal places, it was said, would stock a clothing establishment.

My reception was, therefore, in keeping with the foregoing. One Russian had told me that, having a letter from the Governor-General, I need trouble for nothing; and another had prophesied that the Emir would give me ten times the number of presents that I offered; yet I confess that I was taken aback at the way in which 1 and my retinue were supplied with board, lodging, and attendance, to say nothing of presents. The splendour of my turquoise bridle, embroidered saddle-cloth, and robes of honour, dazzles all who see them, and they are rendered doubly valuable, of course, by the circumstances under which they were received. But besides these additional favours bestowed, it was as if another son of the East had said, "Howsoever, let all thy wants lie upon me." * Nor did I quite see in Bokhara how duly to acknowledge such thorough-going hospitality; but I went carefully through my kit for such things as I could possibly spare, and which I deemed might be acceptable to the Emir. There was first my india-rubber bed and pillows, which I thought might be a comfort to his Majesty's bones in case of illness. Accordingly I showed one of the attendants how to screw on the 
bellows and inflate the bed. This appeared greatly to tickle his fancy, though I doubt whether he had used a screw before. To this I added an excellent filter, to preserve his Majesty, I said, from rishta; a pair of

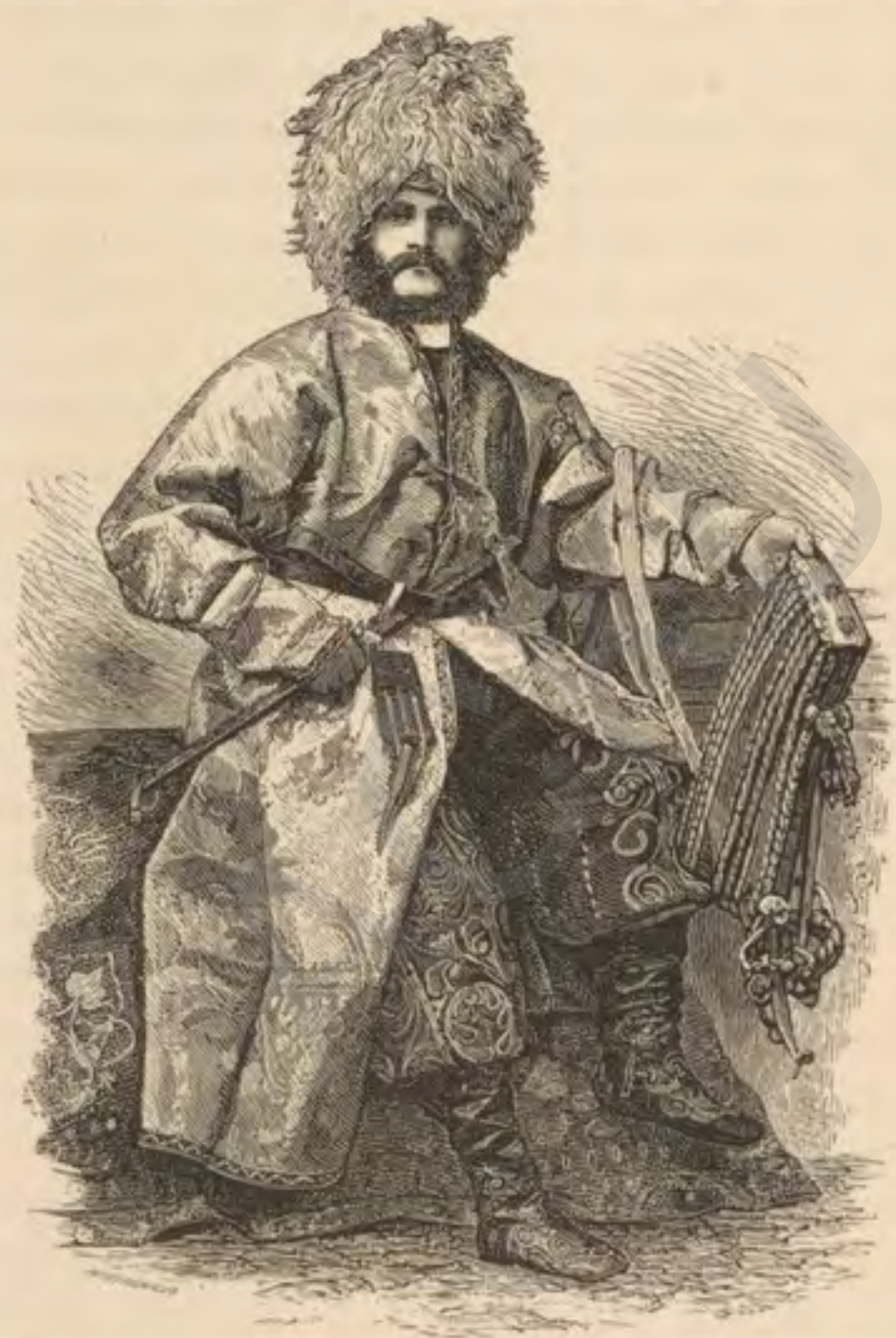

THE AUTHOR IN ROBE OF HONOUR, WIJH TUIEUORE BRIDI., PRESENTED DY THE FMIR OF BOKHARA.

mosquito curtains, the like to which I had seen nothing in the khanate; an electro pepper and salt case, presented to me by Messrs. Langton and Son, whose "travelling requisites" I have found so useful, besides VOL. II. 
an enamelled travelling bottle of their bringing out, that is by far the best I have seen; also a fine damask linen tray cloth, and some smaller articles. These I packed, and wrote a letter telling the Emir that I was to leave on the morrow for Charjui, thanking him heartily for all the kindness and hospitality I had received, and begging him to accept, as a mark of my gratitude, the few things of European manufacture which he would find awaiting his return to the capital. I promised further to write again on finishing my tour through his kingdom, and this letter I sent to the Kush-beggi to forward, as also two post-cards to be sent to the nearest post-office, I ro miles distant. The Emir takes the liberty of reading his subjects' letters, when they have any, and of course he was welcome to study mine.

The post-cards 1 sent were to inform friends of my safety up to date, and that I was now about to plunge into a land comparatively unknown, which I felt all the more because I had no handbook to accompany me. Thus far from Omsk I had been to no place where Dr. Schuyler had not preceded me, and his work had been continually in my hand, as since upon my table. Nor can I take leave of his pages without expressing my increased admiration for his most useful volumes. I have never found his work scamped, but more than once, after reading up a subject, have, on reference to him, found the whole carefully condensed in his notes. But now he was to turn to the right, whilst I went to the left, the latter being the road followed, I suppose, by Burnes, Stoddart, and Wolff.

I directed that we should start at sunrise on October I6th, and sent my parcel to the Kush-beggi, saying I had received so much kindness from the Emir, that I 
wished to offer some more presents. Yakoob, remembering no doubt the khalat given him at Shahr when bearer of a present, asked that he might take the parcel, saying that he had business upon which to speak to the Kush-beggi; but as Yakoob had served us, I thought, half-heartedly in Bokhara, I gave the job to more faithful Kolutch. Whether he received a tip I know not, but the cunning Kush-beggi, unlike the courtiers at Kitab, intimated, without my offering it, that he would be pleased to accept a present from England. I sent him something more of European manufacture, and then prepared to start, Sevier being employed up to the last in attending the sick. One of them, a woman, was considerably taken aback when he applied his ear to her chest with a view to the auscultation of her heart, such treatment by a doctor being evidently unknown in Bokhara.

We were escorted out of the town at 9.20 a.m. by a mirakhur, or captain, of the Kush-beggi and three others of his men, ${ }^{*}$ meeting in the suburbs many of the poor riding in on asses. ${ }^{+}$When well out of the city I turned for a farewell look at its battlements. It was the best specimen of a walled town I had ever seen-the first, strictly speaking, in which I had lodged, but wherein my actions had been so spied upon, that I confess to a

* The Bokhariots are still very observant of the Eastern custom of accompanying or bringing on their way friends, or those whom they wish to honour, as did Abram the angels going toward Sodom (Gen. xviii, 16); and the churches at Antioch and Tyre, the Apostles Barnabas and Paul (Acts xv. 3 ; xxi. 5).

† Some of the asses were laden with earth or sand in bags slung on either side, reminding one of the expression " two mules' burden of earth" (2 Kings v. 17); and now and then we met women, or better said, perhaps, Bokhariot ladies, on white asses, which are more expensive than others, and so the property of the rich. Hence the expression in Judges $\mathrm{V} .10$, "Speak ye that ride on white asses." 
feeling of relief as I left it behind. Our route lay at first through highly-cultivated gardens and fields on both sides of the road. Round the fields were ridges of soil to confine the water when let in to submerge the surface, and certain mounds of earth, rising from the plain, were pointed out to us as being gradually carted away by the natives for the repair of their fields.

We were now approaching the termination of the oasis that extends more or less widely along the Zarafshan valley from Katte-Kurgan past Bokhara to Kara$\mathrm{Kul}$, and we had the opportunity of seeing a little of Bokhariot agriculture. The extent of liyali, or rainwatered land (from Turki liyal, rain), in the north of the khanate is not great, about 40 miles in length only, I was told, between Katte-Kurgan and Kermineh, and there the crops vary a good deal according to the weather. Owing to the mildness of the Bokhara climate the irrigated soil gives two crops in the year. The field that has yielded a crop of winter wheat or barley is sown at the beginning of June, and after the harvest a second sowing takes place of peas, millet, or carrots, or less frequently of sesame, poppy, or lentils. After this second crop is reaped the field is prepared early the next year for the spring sowings. The land thus tilled is allowed to give one winter and two spring harvests before it lies fallow, or shidgar, as it is called. For the spring crops the greater portion of the fields are sown, not only with rice and sorghum, but also with cotton and lucerne, and on small portions of land are grown melons, cucumbers, pumpkins, and onions.

As we passed along I noticed late crops of jugara, bearded wheat, and cotton. Of this last plant I picked some pods, which I brought home. Yakoob 
gave us $£$ I per acre as the price of untilled land, but for cultivated lands three to four times as much. This is a wide difference, however, from the price mentioned by Khanikoff forty years ago, for he says from $\delta_{10}$ to $f^{20}$ per acre. A noticeable feature, as we proceeded, was the number of farmhouses surrounded by walls, usually a dead flat, but sometimes crimped, and crossed with lines, each presenting the appearance of a miniature fortress. They were surrounded by gardens, and other efforts of Bokhariot culture. These orchards form a fair criterion of the wealth of their owners, because everyone who can afford to increase his garden thereby increases his wealth, the silver poplar and willow being about the only trees allowed to grow there that are not fruitbearing.

The gardens are formed of enclosed ground called hazat, the surface being levelled to facilitate irrigation.* Those skirting our way for the first I I miles appeared to belong to men in well-to-do circumstances. Next we came to a salt land, less fertile than the preceding, but such as might be cultivated. At noon we passed the ruins of a large, mud-built castle, once inhabited by a wealthy family, and near this were two small hovels, where a bazaar, so called, held once a week, is visited by half-a-dozen people. I take this to be the ruin marked on the Russian map Shari-Islam, I6 miles from Bokhara, and Dr. Wolff's second stopping-place,

* The vegetables in use at Bokhara are:-beetroot, carrots, radishes, cabbage, onions, cucumbers, peas, lentils, melons, water-melons, and pumpkins. In small quantities are also raised red-pepper, turnips, mushrooms, fennel, and cumin. Melons, water-melons, cucumbers and pumpkins are sown on well-manured soil that has been ploughed over at least ten times. The sowing is done in rows. The growing plants are three times hoed, banked up with narrow ridges round each, and no water allowed till the plant is sufficiently advanced. Later, trenches are made, and water introduced once a week. 
though I found nothing of Jesman-Doo, the first village he speaks of as one "farsang " from the capital. We rode on 3 miles further, passing Khoja-Khairon, and arriving at 12.20 at Yaka-tut, or Jakatut, our worst mishap being that Sevier's horse, which had more than once stumbled, now fell, and pitched his rider over his head. Fortunately, however, he was not much hurt, though he literally "bit the dust." At this our first station we dined, and took leave of our old custodian Mirza Muhammad Yusuf. He had guarded us many nights and days, and I think had done his best to keep us from seeing too much, but he was good-tempered, and put on no airs ; so I gave him a present, and we parted as friends.

We had now before us 21 miles to Kara-Kul, and by way of change we accomplished the greater part of the journey in the tarantass, though not without pains and penalties ; for our postilions were so little accustomed to their work, that they had no notion of avoiding stones or obstructions in the road, but took them all as they came, now going over banks made at the edges of the fields to keep in the water, and now turning the tarantass at right angles instead of a curve, to the imminent risk of an upset. The road, too, varied a good deal, sometimes passing over strips of sand only a few yards wide; next, over an arid steppe; and then through cultivated land and well-ploughed fields of next season's wheat, one of which I recollect appeared as clean as a flower garden.

On the left we passed what was given me as Shahan Khibar. They told us the heaps of ruins were those of an old town destroyed by the Caliph Ali, and soon we came to the half station Peikand, which is mentioned by Wolff. Burnes calls them "the ruins of Bykund," 
and throws light upon them from a history in manuscript he purchased in Bokhara, calling Bykund one of the most ancient cities of Turkistan, the seat of Afrasiab, and of the ancient Turkistan kings.

We stopped at Peikand some minutes only, and a little further on sighted the Zarafshan, no longer the broad, impetuous river we had struggled through at Samarkand, but a feeble, attenuated stream, robbed of its life-giving waters, and narrowed, as I judged, to a width of about 20 feet. The strip of cultivated land on either bank of the Zarafshan gets narrower, being pressed in by the desert ; and as we drove along between the aryks, we came here and there to hillocks of sand, among which we had to wind in and out. Of animal life there was little; but we heard the singing of a lark, and, in addition to the ubiquitous rook, saw a flight of storks.

After driving thus to within a mile of Kara-Kul, we remounted our horses, and there came out to meet us the amliakdar, or tax-gatherer. He was the principal man of the village, and with him were several others, wearing dandy riding boots, of which the height of the heels would vie with those worn by English ladies, only that the point of the Bokhariot heels barely exceeded the size of a sixpence. As I rode along by the side of the amliakdar, my Diotrephes misbehaved himself, stumbled, and came down upon both knees, but, fortunately, I kept my seat, and he recovered himself. We then crossed by a substantial bridge what I supposed to be the Zarafshan, or a large canal diverted therefrom, and about sunset entered KaraKul.

$\mathrm{Kara}-\mathrm{Kul}$ is a village that gives its name to the black, curly lambskins that are exported thence over a 
large portion of Central Asia. We stayed there for the night, and left early next morning, hoping to reach the Oxus in the course of the day. But we did not know what was before us, or we should hardly have brought the tarantass, for it became more and more apparent that neither the roads, the horses, nor the people were accustomed to wheeled vehicles of any kind, and still less to a European carriage. The horsecollars here appeared to have been made for the occasion, and instead of harnessing 3 horses to be driven from the box, the animals were mounted, as before, by 3 postilions, who, in turning a corner, made no allowance for the curve, but struck the vehicle against the wall. Things were not much better when we reached the open country, for they not only went over stones, ruts, and timbers, but, whilst smoking in turn their kalian, occasionally left the road to go across country, through wheat or melon fields, and consequently over the irrigation embankments surrounding them. But worst of all were the horrible bridges over aryks, fortunately then empty, but 8 or ro feet deep, or, at all events, sufficiently deep to make a fall therein a most undesirable event. Sometimes they avoided the bridges by driving down into the aryk, which was bad enough, but not so dangerous as crossing the rude constructions that were never intended for three horses abreast, and had no rails or guards on either side. To make matters a little worse, I could not get my charioteers to see the desirability of fastening the two wheelers to the centre horse, lest in crossing a narrow bridge one of the two outer horses might jib, the other two go on, and the whole concern go to smash. On the previous morning the tarantass did fall into an aryk, and took 20 men to get it out, but happily we 
were then on horseback; and now, with this careless driving, so fully did I anticipate a second edition of the accident, that I unbuttoned the apron, so as to be able to spring out at a moment's notice, as we came to bridges that they seemed not to be approaching with respectful care. I twice jumped clean out, with my heart in my mouth, expecting to see a crash, though, fortunately, my fears were not realized. It was interesting to see messengers, spade in hand, sent on to prepare the way before us, ${ }^{*}$ to exalt the valleys and make low the hillocks, $\uparrow$ so that, thanks to their preceding us, after a drive, the most dangerous I had ever taken, of 16 miles, we came to the end of the cultivated district, and stopped for refreshment at the KishlakKhoja-daulet-bi.

Thirteen miles to the south-west are marked on my Russian map three small lakes, separated by two necks of land, but for which the three would make one narrow lake 25 miles long. They make together, I presume, what is usually spoken of as Lake Kara-Kul, but, as now divided, they are called Sungur-Kul, KarangaKul, and Tenghiz or Denghiz. They would be unworthy of notice, only that, with the exception of the sheet of water we saw in approaching the capital, these are the only lakes in the khanate. They are, moreover, the last home of such of the waters of the Zarafshan as can attain thereto. $\neq$

We were now in the neighbourhood, I presume, of

- Mark i. 2.

† Isa, xl. 4.

I The inhabitants describe the water as malodorous and salt. And thus ends the "gold-strewing " Zarafshan, after giving life in Bokhara to the two bekships of Katireh and Kermineh, to 8 tumens, or smaller districts about the capital, and the capital itself, as also the district of Zia-ud-din, and the tumens of Kara-Kul; or, to take the whole Zarafshan oasis, 32,000 nomad camps, and an area of 1,800 square miles. 
what Burnes calls Meerabad (though I can find no such place), where he was detained for some weeks, and concerning which he makes the interesting remark that Alexander, after a small detachment had been cut up by Spitamenes, followed him to where the Polytimetus, or Zarafshan, loses itself in the sands of the desert. He further quotes a passage from Curtius, speaking of the extensive forests of Bazaria (supposed to be the modern Bokhara), and the towers therein for the reception of the hunters. How things are now changed from a forest to a desert the reader will presently see.

One of the most interesting geological features of Central Asia is its moving sands, a veritable plague to some parts of Ferghana and Bokhara, advancing like a flood, and swallowing up roads, houses, and farms. Whole villages receive notice to quit, or be buried. I have already described what is taking place in Ferghana, and the same has happened also between the Oxus and Kara-Kul, where the cutting down of the saxaul, to say nothing of the forests spoken of by ancient authors, has let loose the sand-dunes, which the wind drives forward to the ruin of the fields.

The belt of sand-hills, on the east bank of the Oxus, from Kerki, or soon after the river leaves Afghan territory all along to the Russian frontier on the north, varies in width from 25 to 40 miles. Burnes speaks of the width of the Sundukli sands, between the Oxus and Bokhara, as varying from 12 to 15 miles, and the height of the hills as 15 or 20 feet. Dr. Capus says 50 feet-a computation, I think, nearer the mark. They gave us the distance from Daulet-bi to the Oxus as 16 miles, and a mile from the station the sand began in good earnest. 
Sevier and I mounted our horses and preceded the tarantass, the attendants asking us not to go too far ahead, lest we should be lost. When once fairly on to the desert we found ourselves amid surroundings the like to which I had never seen before, and would not willingly experience again. The only vegetation was some dwarf bushes, a few inches high, under which ran here and there, like squirrels, the long-tailed marmot, and even these were soon left behind, and the bushes gave place to sand-dunes not unlike those found on parts of our own coasts. The shape of the hills was uniform, each presenting the form of a horse-shoe, the convex side being sloped towards the north, whilst the concave side was precipitous. Sometimes we saw a barkhan had been formed by the increase of a house, with the result that it had continued to grow till the building was buried. Nothing appeared able to stay the advancing scourge, and the desolation of the scene was, in our case, heightened tenfold by a blustering wind, that drove the sand in our faces. As we looked ahead, one bare hill rose above another like waves of the ocean, whilst the tempest blew the sand from their crests like spray, and all this on a scale that strikingly brought to my mind the waves I had seen in crossing the Northern Pacific.

For 7 miles we dragged on to the frontier of the bekship, where we were met by 15 horsemen, come to take our tarantass to the Oxus ; but imagine our dismay when we discovered that they had brought with them only one horse-collar! They asked the party from Kara-Kul to lend them theirs, but they declined, took out their horses, and were making off.

The Amliakdar came to take his conge, and I gave him a present, but it was not till his back was turned 
that we realized our critical position. We were left like a boat in mid-ocean. All around was sand-sand everywhere-and our late protectors had pitilessly bolted. Sevier suggested that they should be forced to return, which perhaps might have been done, with a revolver pointed at them. But it was too late, and we were obliged to turn to our new attendants, who stood discussing what was to be done, for there was not another horse-collar to be had within several miles.

As I stood there listening, the only sign of animal life apart from our company that met my eye was a beetle, bent on taking home a ball of dung ever so much bigger than himself, but which he was skilfully pushing along with his hind legs, running backwards, kicking up his heels, and so availing himself of the wind to further his efforts. I found that my interference was no use, so I left the men to their own devices, whereupon one horse was put in the shafts, and ropes, fastened to the tarantass, were attached to the saddles of the rest, and in this novel fashion the vehicle was dragged along. Of course this was slow work.

I thought, therefore, it would be best for Sevier and me, with Yakoob to interpret, to go forward and send back reinforcements. Moreover, a Russian officer in Samarkand had told me of the terrible difficulty we should have with the tarantass, and had given me a hint not to meddle in the matter. "If," said he, "the Emir gives the order that your tarantass is to be taken to the Oxus, it is their affair, not yours. You had better go on, and leave them to follow." I therefore took the chief man for a guide, and left the tarantass in charge of Kolutch and Fazul. We then tried to gallop on, but that was no easy matter, for 
the sand was so soft that the horses sank at each step half-way to the knee.

Our guide was an old man, but mounted on a good Turkoman horse, and him we followed over little mountains of sand, with clumps of sand-grass visible here and there, also wrecked houses and half-buried villages. This almost lifeless scene was but slightly modified by one or two kinds of birds, and carrion crows feeding on dead horses. As we struggled on, we met scarcely any travellers, and wondered more than enough how they would get the carriage over the barkhans, as high as London houses. It was no small relief when, late in the afternoon, we came to a pool of water, said to be 3 miles from the kishlak Betik mentioned by Burnes. We were now once more in sight of trees and cultivation, and soon reached the house of our guide.

He turned out to be one in authority, Mirza Anvar Gwatchi, but it seemed that we cockney riders had thoroughly tired him out, in addition to which he received a sound rating from his belongings for going off with only one horse-collar. $\mathrm{He}$ at once sent a relief party off, who, by-the-bye, lost their way. Also a boy, whom we had met with a ewer of drinking water, was clever enough to break it, and so it came to pass, as we afterwards heard, that, after making almost superhuman efforts, the horses not unfrequently falling and rolling in the sand in their efforts to get the vehicle over the hills, they could only approach to within 5 miles of the station, where, darkness coming on, horses and riders alike, almost supperless and waterless, and thoroughly tired, lay down on the ground and slept. At $\mathrm{I}$ o'clock in the morning someone reached our station, and more horses were sent, 
with clover and food, so that later on the party consisted of 25 horses, 25 men, and 2 camels, besides our 2 mounted djiguitts. When the tarantass proved too much for the horses, they harnessed a camel to it, but this failing also, the goods were taken out, placed on a camel's back, and so the journey was finished.

Meanwhile, as we heard on our arrival that the river was only a few versts further on, and Charjui just the other side, we determined to stay for the night. This appeared to give our hosts real pleasure, and we had a hearty welcome, though our room was exceedingly poor. It had this mark of distinction, however, that on the wall were stuck two little artistic productions, a few inches square, taken apparently from a traveller's tin of preserves. These were the only pictures I saw on the walls throughout the khanate. One attendant brought in a glass lantern worthy of the occasion, about a foot square and two feet high, and on the level bottom of this he was vainly trying, by letting fall some drops of grease, to make a tall candle stand. I bethought me of a clerical acquaintance, who, when beginning some cottage lectures among the poor of Birmingham, extemporized candlesticks out of turnips. We had no such roots at hand, but, slicing off the top of a melon, I made a hole and stuck in the candle, to the great wonderment of the native, who ran out with a laugh to tell his fellows what the stranger had done; and even Yakoob could not resist coming in to look at the invention, which he called "American." I had no more of my outfit than I had brought on my saddle, so that I need hardly say we lay down in our clothes, and thus finished the most remarkable day's travel I have known, and I certainly shall not soon forget the sands of Sundukli. 


\section{CHAPTER LV.}

\section{CHARFUI.}

Departure for the Oxus.-Meeting of Charjui officials.-Our lodging and reception. - Pilau and native bread.-Visit to the Bek.Received with music.-The place of execution, and the prison.Charjui bazaar and slave-trade.-A Bek's official staff.-Administration of the khanate, and taxes.-The governments of the Tsar and the Emir, how respectively regarded by the Bokhariots.Return from Charjui to the Oxus.-The tarantass regained.Departure of our two attendants.

A FTER a breakfast of rice, milk, and tea, we 1 started from the kishlak Betik at 7.30 to ride to the Amu-daria, leaving directions that the tarantass should not be brought on to the town of Charjui, but shipped in the boat waiting to descend the river. Five miles, we had been told, was the distance to the water, but it seemed much more, for our guide did not appear very well to know the way, and things were not rendered more pleasant from the fact that the weather had now become decidedly cold. Fortunately, I had strapped behind my saddle a Maude shawl, and having folded this around me in what the natives must have thought a queer fashion, we wended our way at first across fields of hemp or flax, and then passed over ground frosted with salt. As we approached the river, we made our roundabout way through acres of 
pampas grass and reeds overtopping our heads, waded some narrow streams, and then came to the famous Oxus.

So primitive in appearance was the boat to take us across, and so high in stern and prow, that one was tempted to think it a relic of the tribes that were crushed by the great commander. The oars were about the thickness of scaffold poles, with blades roped on, Io inches wide by 30 long. Our horses were shipped, and we were rowed across to the opposite bank, where one Mama-sherif, an official called the Toksaba, came to meet us from Charjui. We were taken into a house in the midst of a garden, which in summer doubtless would have been pleasant enough, but crossing the river had not warmed us, and I was sufficiently chilled when they brought us a meal to ask whether they could give us also a fire. They assured us they would do all they could for the comfort of their guests, and shortly brought us "a fire of coals." It was a large brazier or octagonal pan, about 4 inches deep and 2 feet in diameter, filled with glowing charcoal. There was no fireplace in the room, and the floor was nicely carpeted all over, but the brazier was stood in a tray and placed beside us. I cannot pretend there was much heat to be got from it, but we could not stay long, since there remained to be accomplished what they told us was 3 miles, though Burnes calls it six, to the town of Charjui, the question being, I suppose, whether it was half a tash or a whole one.

On setting out they asked that we would not hurry, for it was customary for guests to proceed sedately, to which I rather demurred, saying that I wished to ride myself warm. We passed through fields to within 
about a mile of the town, where we gained the first view of its lofty fortress, whose outline seen from a distance was more picturesque than that of any building I had yet seen in the khanate. I asked the Toksaba the population of the town, and received another illustration of native ignorance when dealing with high numbers. He stated it at 100,000 , and the population of the bekship at a million! after which he added that the place was only a fortress, with a thousand soldiers to keep the neighbouring Turkomans in order. Burnes gives the population as not exceeding 5,000 ; the Russians give the town 6,000 "yards," or domiciles.

Thus we had arrived at Charjui, a distance, according to my reckoning, from Bokhara of 80 miles, but Kostenko calls it 100, from information given by the local staff, though his stations do not appear to be the same as mine. In any case, I suspect the distance is not measured, but taken from the statements of the natives, whose reckoning is by the tash, sang, or farsang, each of which is 12,000 paces, i.e., about 8 versts Russian, or rather more than 5 miles English." We found the town pleasantly situated; the fort occupying a knoll, and commanding a view of the whole neighbourhood. Our house stood by itself, near a stream, and, though not very sumptuous, they appeared to be doing * The stations, with distances between in versts, as given by Kostenko
and myself, are as follows:-

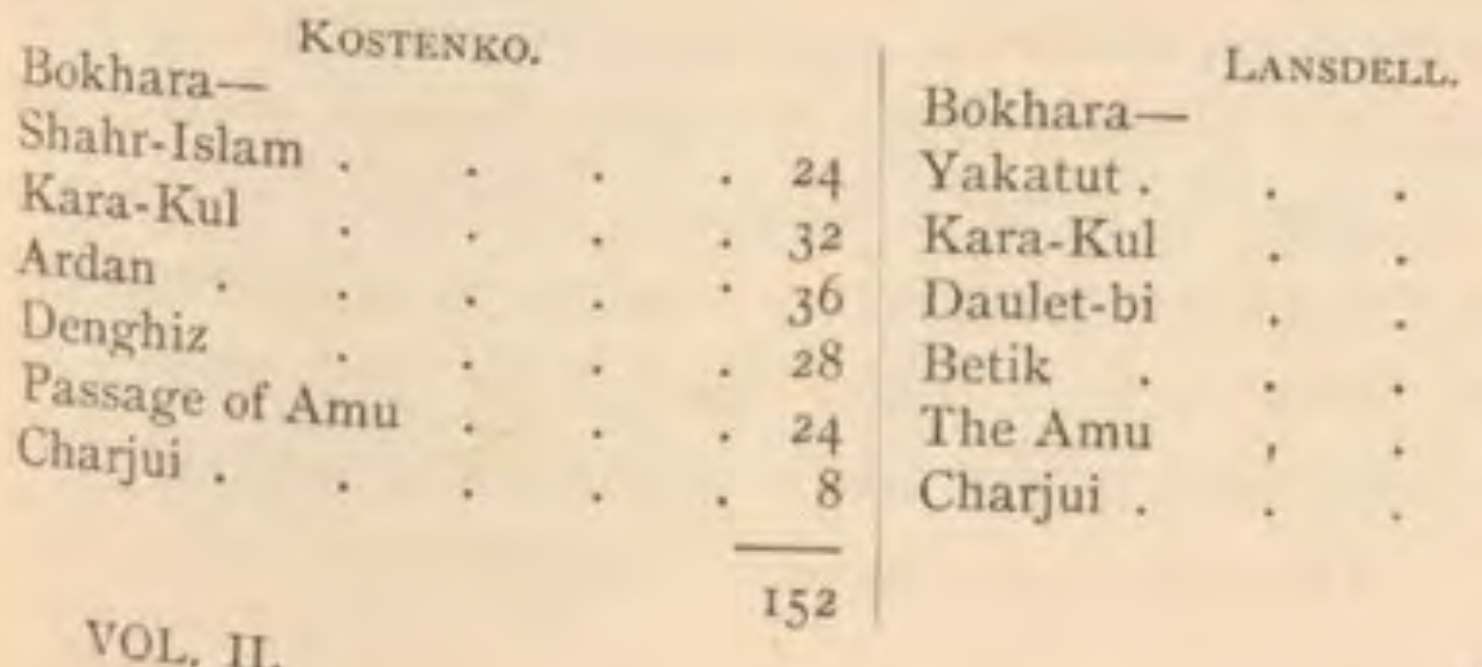


their best to make us comfortable. It was not easy to feel so, however, deprived as we were of most of our toilet gear. But we were not to lack for food, and they had prepared for us such a dostar khan (literally "table cloth") as we had seldom seen. The trays and dishes were so numerous that I made a note of them. They more than covered the table, and were spread likewise on the floor. Our European decimal system was represented by ro loaves of sugar, to packets of tea, Io boxes of sugar-candy, 10 trays of sweets, and Io trays more of parched peas," pistachio nuts, natural and sugared, apricot stones, raisins of four kinds, flour cakes of grape honey and sugar, large and small cakes of bread, eggs coloured red, apples in syrup, almonds, dough-nuts of grape honey and flour, called cantle neshullah, and, lastly, a semi-liquid concoction of sugar and white of egg, that looked tempting, I suppose, to one of the officers talking to us, for in the absence of a spoon he extemporized one by putting in his finger, twirling it round, to make as much as possible stick, and then sucked it dry. They brought us some white fish to eat, which was not bad, but rather salt, and afterwards came pilau.

When extra good pilau is desired, a chicken is cooked in addition to pieces of mutton. This was a blessing to me, for not being fond of fat, or caring for rice, especially when greasy, I usually made my meal from the chicken and native bread. Their bread consists of unleavened cakes (nans), about the size of a large captain's biscuit, though sometimes larger and thinner, perhaps 9 inches in diameter. I think the latter is Persian, but both are made of wheaten flour, and when fresh are tolerably good, and

* Used as food in Persia by Daniel (i. 12). 
much more to my liking than the rye and oaten breads of Russia and the Scandinavian peninsula. It is strictly "daily bread," and a native takes in a supply each morning as regularly as a Londoner purchases milk.* Nans cost 2 poolahs each, or about a penny for five,

Soon after our arrival at Charjui they asked how soon we should like to see the Bek. I replied, "Immediately." Seeing we had not our luggage, they asked whether I had my presents.t I replied in the affirmative, intending to take off the watch and chain I was wearing, and send them in with other articles small in bulk. They then said we should be received in two hours. The Bek proved to be another son of the Emir, and was living in some state in the fortress. At the entrance of the citadel, which resembled the one at Kitab, about I $_{50}$ soldiers were drawn up. We were saluted with a fanfaronade of trumpets and other musical instruments - "plus bruyante qu' agréable," as Dr. Capus puts it-a grander reception than we received from the Emir. Attendants

- The size of these cakes brought to my mind the friend coming at midnight and saying, "Lend me three loaves; for a friend of mine in his journey is come to me" (Luke xi. 6). An English child, accustomed, as I was, to great half-quartern loaves, might naturally wonder at the traveller's appetite, and why he should need so many as three loaves, but the text would present no such wonder to the mind of a Bokhariot boy. May not this also illustrate, and perhaps account for, the amount of "crumbs" that fell from the rich man's table (Luke xvi. 21), as well as the "fragments" of the miracles (Matt. xiv. 20)? The thinness of the bread, moreover, illustrates why we never read in Scripture of bread being cut, but broken, as in the Lord's Supper, and in Lam. iv. 4, "The young children ask bread, and no man breaketh it unto them."

$\dagger$ The common-place manner in which this was asked reminds one of Saul's words to his servant, "But behold, if we go, what shall we bring the man, for . . . there is not a present to bring? What have we?" (I Sam. ix. 7.) 
with white wands ushered us forward, and, finally, a military commander introduced us to his Highness the Bek, a youth of 18 or 19 , perhaps, dressed in a gold brocade and Cashmere turban. I apologized for not presenting myself in courtly apparel, since I had parted company with my tarantass, whereupon he asked us to stay longer. How long had we remained at Kitab, Karshi, and Bokhara? I told him the number of days in each, whereupon he asked why I stayed 3 or 4 days in other towns, and only 2 with him ?* The reason was not far to seek, and I told him that we were already behind our time, that we had a long and difficult journey before us, and we begged in consequence that we might not be detained. $\mathrm{He}$ consented that our journey should be sped. I then requested to be allowed to see the prison, and also to ascend to the top of the fortress or some high place, my object, as before, being to get a bird's-eye view of this wonderful town of " 100,000 inhabitants." To my surprise the Bek consented, after which I invited him to ask me questions. He had none to put, he said, but was willing to listen for an hour if it would please me. This was an unexpected turn of the tables, and I racked my brain for things that would give him some idea of the grandeur of England, but in vain ; for he seemed to have no bump of wonder, or of inquisitiveness, and I gave up trying to enlighten the youth.

On leaving I examined some antiquated cannons lying about in the court, some old matchlocks and muskets hanging near the entrance, and also the

* Resembling on the surface the language of Jeremiah (xiv. 8): "Why shouldest thou be as a stranger in the land, and as a wayfaring man that turneth aside to tarry for a night?" 
musical instruments of the band. Later in the day I secured a wooden pipe, I6 inches long, with an expanding end, like a clarionet, called surnoi:* In addition to the surnoi and other instruments previously mentioned, there is used also in Central Asia the kornoi, a large brass trumpet, 6 or 7 feet long, giving a deep base note. Drums, too, of different sizes are used, made of small earthenware vessels, covered with skins, fastened on by a network of little straps, and played with two sticks. The soldiers appeared amused at my examination of their instruments, and I left them thinking that $\mathrm{I}$ was to be conducted to the top of the fortress.

Instead of this they took me outside the wall to a high place indeed, but whence I could not see the whole of the town, and I was beginning to regret, when my attention was called to an object the surroundings of which far outweighed my disappointment. "That is the gallows," said they, "where we hang the Turkomans-about 30 or 40 in the course of the year." I had the curiosity to ask what they did with the bodies, and their reply struck me at once as noteworthy. "Oh!" said they, "we pitch them in a ditch, or their friends come and take them away." How exactly, I thought, like the case of John the

- It has 7 holes on the upper side and 2 below (one stopped). In the small opening is a brass mouthpiece. Into this fits a brass pipe, called a nil, with a mouthpiece of reed, and close to the mouthpiece a horn disc, serving as a support to the lips of the player. When not played on, the farther end of the pipe is stopped with a metal rod, and two small wooden discs cover the mouthpiece. Attached to the instrument (which may be seen in the ethnographical department of the British Museum) is a copper chain, and hanging therefrom 8 reed mouthpieces. For the mouthpieces, I suppose, would be used in some cases a $\gamma \lambda \omega \sigma \sigma o ́ x o p o \nu$, which also served as a "purse" or cashbox (John xii. 6 ; xiii. 29). 


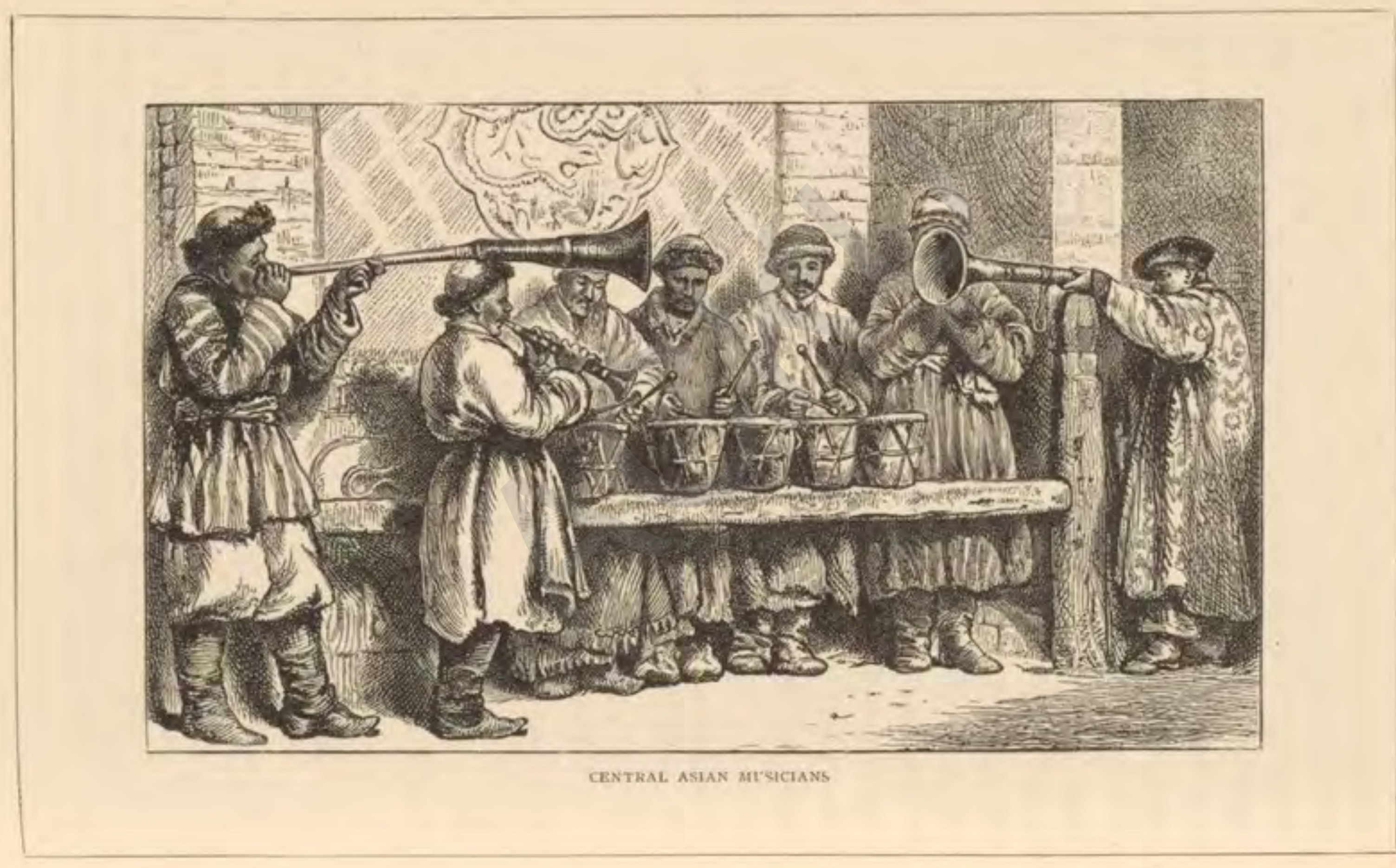


Baptist, when, beheaded by Herod, "his disciples came, and took the body and buried it."* The gallows consisted merely of two posts and a lintel, and after seeing it we went to the prison, into which I managed to get in spite of the Emir's endeavour that I should see none of his jails. He might well be ashamed of them, for this one at Charjui outdid everything of the kind I had seen. It was situated under a chamber at the gate of the fortress, and was about ro feet square by 5 feet high. The one doorway was 3 feet high and 18 inches wide, and through it $I$ crept into the dismal den, which had no window or ventilator, so that, when the door was shut, it was a veritable "black hole" of Calcutta, while the only thing in the chamber was a thick beam down the centre of the earthen floor, wherein the feet of the prisoners might be confined. ${ }^{\dagger}$

* Matt. xiv. 12; Mark vi. 29. The place reminded me also reverently of One greater than the Baptist, for we stood on another Calvary, "a place of execution nigh to the city" (Luke xix. 20), "outside a city wall." As a further illustration it will be remembered that when the Jews wished that their approaching feast should not be marred by the sight of corpses remaining on the cross, they besought Pilate, not that they might be buried, as would be the case with us, but "that they might be taken away " (John xix. 31). The exposure of the dead bodies of the Turkomans is regarded by them as a defilement and an insult, and is evidently the survival of a very ancient custom, just as Jeremiah (xvi. 4) prophesied of his people, "They shall die of grievous deaths: they shall not be lamented, neither shall they be buried; but they shall be as dung upon the face of the earth." So again it was foretold by Jeremiah of Jehoiakim that "his dead body should be cast out in the day to the heat, and in the night to the frost " (Jer. xxxvi. 30), whilst the other custom regarding the deceased's friends throws light on Acts viii. 2, "devout men carried Stephen to his burial," as also it emboldened Joseph of Arimathea, the timid disciple, to prevent desecration of the body of his Lord by undertaking the office of a friend when he went to Pilate, and begged the body of Jesus (Matt. xxvii. $5^{8}$ ).

+ Illustrating exactly Acts xvi. 24, "Who, having received such a charge, thrust them into the inner prison and made their feet fast "

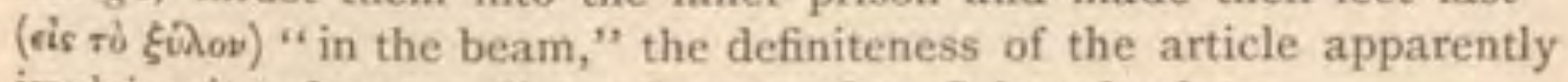
implying it to be an ordinary feature of an Oriental prison. 
Six prisoners were under arrest, wearing iron collars, through the ends of which a chain was passed to secure them all together, and with a spike at the end to fasten into the wall. Most of the criminals, they said, were sent to the capital quickly, but some of the present batch had been confined 3 months, and, to make matters a little worse, we heard next morning that 5 Turkomans had been caught in the Steppe during the night, all of whom had been thrust for the present into the black hole. Thus there would be II persons within 500 cubic feet of air, which is not much more than half the amount allowed to each prisoner in Newgate, where the cells measure I 4 feet long, 8 broad, and 8 high. The only good things I remember about this prison were that it was dry and fairly clean, nor did I detect any unpleasant smell, though the prisoners were said to leave it only when necessity required, and never for exercise. I managed to get into my hands one of their iron collars, and asked where I could get one like it.* They said, "In the bazaar," whereupon I seized the one I had for my collection of prison curiosities, and gave the man the sum he named wherewith to purchase a substitute. $\dagger$

* It is comparatively light, and the iron not so thick as the little finger, but $I$ had seen nothing like it in Europe. Manacles, or chains for the hands, referred to as worn by Jeremiah (xl. 4) and Peter (Acts xii. 7), and perhaps Paul (Acts xxviii. 20), I did not see or hear of among the natives of Central Asia.

+ I had now seen or heard of at least three kinds of prisons in Bokhara illustrative of similar places of confinement mentioned in Scripture. That at Charjui might be compared to the common prison

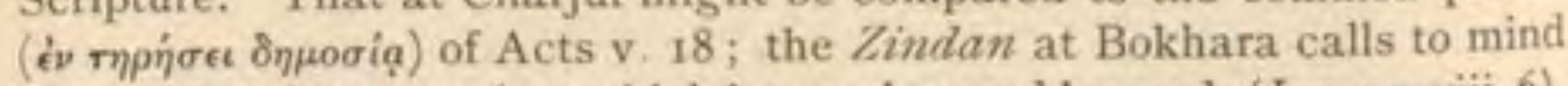
Jeremiah's dungeon, into which he was lowered by cords (Jer. xxxviii, 6), whilst the prison in the palace of the Khan of Khokand, and the Kana Khaneh in the palace of the Emir, remind one how Jeremiah the prophet was shut up in the court of the prison, situated in the King of Judah's house, or that (Jer. xxxii. 2) whereinto Joseph was thrust, under the captain of the guard-a place that is not for ordinary felons, but 
On our way to the prison at Charjui we passed through the bazaar. This used to be a great place for slaves, brought thither by the Turkomans, who kidnapped them from the Persian frontier. M. Stremoukhoff, writing the year after my return in the St. Petersburg Gazette, says, "Although the slave markets in Bokhara are officially closed, and although it is strictly prohibited to trade in slaves, yet slaves are sold and bought with perfect freedom in all parts of the country, and the Emir himself takes an active part in this traffic for the replenishment of his harem, as well as of his coffers."

When on the spot, I did not suspect that the trade was still carried on, but Colonel Stewart tells me that, on inquiry, he learned that whilst there is no buying of slaves in Khiva, yet that Persian girls can be, and are, sold at Charjui, and, as he left the neighbourhood only a few weeks before telling me this, I think it well to state the allegation openly, and with his permission thereby to corroborate the letters of M. Stremoukhoff, which state that this odious trade is not yet completely stamped out in Bokhara.

We found but little gold money current in Bokhara, and were told that it is used chiefly for export, especially to Bombay. For this purpose Russian half-imperials are employed, as well as tillahs. I succeeded in adding to my Bokhariot curiosities from the bazaar at Charjui another kind of skull-cap, and coming out of

where "the king's prisoners were bound" (Gen. xxxix. 20). The Turkomans, when caught on the Persian side of the desert, would appear to fare worse than at Charjui, for less than a week before writing this I met Colonel Stewart, who has been living on the frontier, and who tells me that one Persian prison he came to was a well in a house, down which Turkoman man-stealers and their food were lowered, and the well shut in with a covering at night! 
Bokhara I secured a curious implement for driving donkeys. It consists of a thick handle about 6 inches long, with a goad at the top, and two thick depending chains about the same length, but united at the ends by a ring. I am not aware that the chains are used for striking the animal as with a whip, but rather (as I saw them employed) the chain is made to fall lightly on the shoulder, according as the rider wishes the animal, which is unbridled, to turn to right or left.

On returning to our lodging, it seemed as if the Bek were minded that we should come to no harm in the night, for he sent a guard of 16 soldiers, 4 to each side of the house. I cannot say much for their arms. for they were old enough, and on two of them I found stamped, in my mother tongue, "Wolley, Serjeant, and Fairfax."

I was told that there are 29 beks throughout the khanate, all appointed by the Emir, their duty being to collect the revenues, pay for their personal expenses and those of their officials, and hand the balance to his Majesty. Bokhara and the suburbs for about 25 miles round is under the Kush-beggi, who is chief of all the beks, and also keeper of the Emir's harem. We got a fair idea at Charjui of a bek's staff of officials, which consists of about ${ }_{5} 5$ men, some of whom are mirzas, or secretaries; others are djiguitts, whilst others have no specified duties.*

- Some of their appellations are Divan-beggi, the highest, and Donbashi, the lowest (bashi meaning head, or chief), Toksaba, Isha-bashi, Bi, Datka, Yuz-bashi, Mirza-bashi, Churagassi, Jay-batchi, Karaulbeggi, Mirakhur or captain, Bakaul or cook, and Khazinatchi or treasurer. The Sharvadar is the officer who stands nearest the bek, and presents his food; the Darban, one who stands always at the door to receive orders, which he passes on to the Shagaul, whose duty it is to see them carried out; and, lastly, the Ullaitchi is the master of ceremonies, to introduce dignitaries and visitors. 
I asked about taxes, but got widely-divergent answers in various parts of the khanate. The caravans from India we saw between Karshi and the capital were said to pay duty at two other places in the khanate- on the Amu and at Tash-Kurganbesides Bokhara, at which last it was $2 \frac{1}{2}$ per cent. on their value. At one place they said that out of 10 batmans of harvest they paid 8 for taxes, and at another place 4 , whilst for each acre of clover land they paid from 4 to 6 shillings. According to law, I think I gathered that $2 \frac{1}{2}$ per cent. was the proper tax, but that, as a matter of fact, the beks took more and more, and as much as they pleased.* This, they said, the Emir allowed, but if he saw one getting very rich he picked a quarrel with him, threw him into the Kana-Khaneh, and then, according to Muhammadan law, sold his property in the bazaar, took his money, and turned adrift the bek's wives, with nothing but their clothes. This treatment, however, I was told, sometimes overtakes not only extortionate beks, but also dishonest judges, or Kazis, who are practically the lawyers. ${ }^{+}$About 3 months before my visit 7 Kazis had been dismissed for taking bribes. Their goods were sold, and from the proceeds those who had given the bribes were allowed to reclaim them, the surplus being taken by the Emir.

I was curious to know with what feelings the Bokhariots regard their Emir, and the possibility of

* Reminding one of the publicans, or tax-gatherers, in Judea, who came asking, Master, what shall we do? He said, Exact no more than that which is appointed you (Luke iii. 13); and of Zaccheus, who, when he found he had so done, restored fourfold (Luke xix. 8).

$\dagger$ There is one only for each town, even for all Bokhara. I heard that the chief Kazi at Samarkand, who is elected by the people, makes as much as $£ 1,000$ a year. The Kazis judge petty matters and money affairs. Greater cases are brought to the Kush-beggi and the Emir. 
the occupation of the khanate by the Russians. His Majesty does not, it was said, go out much from his palace, except on Fridays to the great mosque; and, though he is nominally the ruler, yet the real potentates are the Kush-beggi and the beks. It is they, one man said, who ruin the land, the Emir apparently not troubling himself about it, and consequently, since he shows no interest in his people, it is only the mullahs who, out of religious veneration, like him, whilst the rest of the nation hate him. Again, it was said that the people are discontented, but dare not say anything. On the other hand, as compared with some of the inhuman monsters who have preceded him, Muzaffar-ed-din is mild; and hence one man said his subjects liked him because of his negative character, and his doing no harm!

I did not gather that either the Emir or his people had within their breasts a spark of patriotism. I heard on Russian soil, with other chit-chat, that the Emir had more than once asked the Russians to give him a pension, and take his khanate. A native told me also that though the Bokhariots were on the whole satisfied with the Emir, yet at his death, he thought, they would be ready for Russian occupation. Muzaffar had recently been ill, at which time the people were ready even to welcome the Russians, who were liked, he said, at Samarkand, though not at Khokand, but neither, he added, did these last care for their own Khan. Another informant said that, from talks he had had with the people, he fancied the Bokhariots would prefer Russian to native rule. I asked how, under ordinary circumstances, on the sovereign's death the succession would go. They replied that the Emir had several sons (about Io adults, I 5 boys, and a number of 
daughters unknown), and that he who had the strongest party of followers would fight for the throne. Perhaps it was to prevent such a free fight that the Russians quartered a good many troops in Samarkand when the Emir was ill. One native expected in that event that, if the Russians advanced, the Bokhariots would be goaded on by the mullahs to fight. But this was mere supposition on the part of irresponsible persons, and of course it was a very delicate subject for me to approach with the Kush-beggi's messengers. I did, however, make bold to introduce the subject one morning by asking whether the Emir were quite recovered from his illness, and, upon their replying in the affirmative, I intimated that I had heard the people were ready, if his Majesty had died, to welcome the Russians. I thought these courtiers approached the subject like men whose inmost fear was, "The Romans shall come and take away both our place and nation." * They cautiously replied that the people were content with the Emir, and that the Russians would do evil if they came. I ventured to ask, What evil? and they gave the comprehensive reply, first, they would abolish the Muhammadan law in favour of their own; secondly, they would sanction prostitution; and, thirdly, they would bring drunkenness. I believe that in the conquered parts of Turkistan the Russians have to some extent allowed the Muhammadan law to stand, though I could not but feel the truth of the last two objections. ${ }^{\dagger}$

On the evening of our stay at Charjui they offered

* John xi. 48.

† I had heard before that they had no houses of ill-fame, and that if a woman was publicly immoral, and the Kush-beggi heard of it, she was executed. At the same time they did not pretend that there was no secret immorality in Bokhara, as there was, they said, in every country. 
to send us batchas, and I accepted them for the sake of Yakoob and the natives, who were said to have the chance of seeing such performances only when a visitor came; but we did not keep them late, being anxious to get to bed and start early in the morning. Of the three boys, one sang and danced unusually well, and it was amusing to see one stout old man drinking tea, looking admiringly on, and getting heated with excitement.

Next morning I stirred up Yakoob before sunrise, and tried hard to put the Toksaba in a bustle; but it is not easy to hurry Asiatics. The Bek, they said, must be informed of our departure, and this took some time; but when the messenger returned he brought with him presents of khalats, a horse and saddle-cloth for me, and khalats for Sevier. Meanwhile our groom had arrived with the agreeable intelligence that the tarantass was shipped and awaiting us some I I miles off at Ghuzari-Tozakar. This hanger-on also put a scrap of paper into my hand to inform me politely that he wished to quit my service (to which, by-the-bye, I had never engaged him), and return to Bokhara, Yakoob pleading that he had been very useful in taking care of my stud. In due time, therefore, we started once more for the Oxus. It was a bright, fresh morning, too cold by half to think of sedate riding, so, as soon as we reached the fields, I galloped off, leaving those to remain behind who pleased. One of the Bek's djiguitts had no mind to be outstripped, and took care to keep ahead. I followed his fleet horse, and we covered the distance in about an hour and a half.

Arrived at the Oxus, we found a tent put up for us, with bedsteads, in case we had returned to sleep, and Fazul and Kolutch ready to give us the story of 
their difficulties with the tarantass. They had dragged it over the sand barkhans, actually without a scratch or a visible strain, and it was now safely shipped for our departure. Yakoob, by agreement, was to go on with us at least to Petro-Alexandrovsk, whilst Fazul and Kolutch were to return; and the latter asked that I would write a note to General Korolkoff to say how they had served me. I had only one peccadillo to complain of, of which Yakoob had officiously informed me, that when I had sold the two horses at Bokhara, Kolutch had seized the two wooden saddles, sold them for a trifle, and appropriated the money. Accordingly, after giving Fazul his present, and paying the groom with a Cashmere khalat, of which I did not know the value, but was afterwards told it was worth three or four times as much as I supposed, I took Kolutch alone and quietly lectured him. He was distressed on being accused, said he thought the saddles were of too little value to be of importance, and urged that, had he wished to steal, he could easily have done so when in charge of the tarantass. I tried to show him, however, the importance of honesty in trifles, and then wrote a letter saying how well Fazul and he had served us, as indeed they had. This I gave him with his present, and added a pound of tea for each of the three. A crowd had assembled on the bank, who bade us farewell as we pushed off into the stream; but before we commence the descent of the Oxus, I purpose to say a few words on the upper portion of the river. 


\section{CHAPTER LVI. \\ THE UPPER OXUS.}

Names of the Oxus.-The Englishman Wood, its first explorer.-Its source and issue from the mountains.- Strategical importance of the next reach of 200 miles.-Alleged feasibility or probability of a Russian invasion of India.-Fords and ferries on the Upper Oxus.The Oxus at Kilif, and from Khojah-Saleh to Charjui.-Reports on the profitable steam navigation of the Oxus. - The Amu-daria at Charjui,-Our boat for floating down the river.

I Parsi books the Oxus was called Veh-rid, from which Colonel Yule traces Vakhsh, and the classical Oxus; but Colonel Kostenko would trace this last word to the name of what he regards as its head waters, the Ak-Su. In early Muhammadan history its title is $A l-N a h r$ (the river), whence Mawaralnahr signified "beyond the river," or Transoxiana; whilst the name now common in Turkistan, the Amu, appears to be comparatively modern, and of uncertain origin; also, I was told by a native that in Uzbeg books the river is called Bilkandi Frindin. The ancients thought the Oxus one of the rivers of Paradise, whence, probably, the arbitrary name of Jailuun, as it was styled by Muhammadan writers of mediæval times. By whatever name, however, it has been called, the Oxus has long been the most interesting river of Central Asia. In the middle of the sixteenth 
century the first Englishman, in the person of Anthony Jenkinson, crossed the lower part of the stream on his way to Bokhara. It was reserved for another Englishman to trace the Oxus to its source. Lieutenant Wood, in 1838 , ascended the River Panj to a lake, which he named after his then youthful queen, Victoria, 15,600 feet, as he estimated it, above the sea. Hence the Panj, which means five, after a notion that the river is made up of five streams, came to be regarded as the source of the Oxus. But, says Kostenko, the reconnaissances in the southern portion of the Pamir, carried out by members of the English mission under Forsyth in 1874 , and in the northern portion of the Pamir by the Russians in 1876 , have shown that the River Ak-Su, which flows out of the lesser Pamir lake, should be regarded as the principal source of the Amu.

Accepting this correction, then, we have the Ak-Su flowing out of the Oi-Kul, or goose lake, ${ }_{13}$, 100 feet high, and about 30 miles to the south-east of Sari-Kul, or Lake Victoria. After flowing for 120 miles the Ak-Su unites with the Murgab, and $\mathrm{I} 33$ miles beyond, at Kila Wamar, with the Panj. "Beyond Wamar the Amu-daria soon enters, first Darwaz territory, then that of Badakshan, and lastly serves as the boundary which separates the province of Kolab, belonging to Bokhara, from Kunduz belonging to Afghanistan."* The Amu receives its largest affluent from the left in the Kokcha, and, after flowing 143 miles from Wamar, receives its principal tributary on the right, namely, the Surkhab or Waksh, the upper portion of which is

* This portion of the Amu to the mouth of the Surkhab, Kostenko added, is known only from hearsay; but later information concerning the head waters of the Oxus has been given by Mr. Michell in the Proceedings of the Royal Geographical Society for September, 1884.

VOL. II. 
called Kizil-Su, or Red river, and its middle portion Surk-ab, which in Persian bears the same meaning. At this point the river, now 400 miles from its source, emerges from the mountains, acquires a new character, and becomes much better known. Its direction, moreover, soon changes to the north-west.

That which gives greater importance, however, to the next stretch of about 200 miles to the Turkoman frontier, is that here are the principal crossings on the route from Central Asia to Hindustan ; and should the long-talked-of Russian invasion of India ever take place, this part of the Amu would become of great importance as being the point on which I am told the Russian left wing might rest. With regard to the feasibility of such a movement, since Alexander, Jinghiz Khan, and Tamerlane invaded India from the north-west, it would not be complimentary to Russian military skill to say that they could not do the same. Nevertheless, after passing through the country, and especially across the desert, I cannot help thinking that in this region they would have before them what the Americans would call " a big job." To get adequate troops and baggage from Russia to Samarkand is no trifle; and though the distance thence to the Oxus is only about 350 miles, a road for a modern army would have, I presume, to be made from Ghuzar, either I00 or I 53 miles long. Moreover, the Cossack would hardly be content to let blood from his horse and drink that for a meal as did the Mongol soldiers; and from the report of Colonel Maieff upon his routes from Karshi to the Oxus, it would appear that the tracks lie through an unproductive country, where there is little or no pasture for horses, and where the people grow barely enough corn for their own consumption. But 
what strikes my non-military mind as the greatest difficulty would be the getting an army across the desert portions of the route on either side of the Oxus. It took six camels and two horses to run me and my carpet-bag across the Aralo-Caspian desert. What, then, would it take to move an army?

Nor can I express an opinion as to whether the Russians have the least desire to attempt such a thing. No doubt there are Turkistan officers to whom war means medals, promotion, and money, who are quite ready to attempt the invasion of India, or for that matter of Timbuctoo, or any other place, as there are Indian officers who for similar reasons would invade Turkistan. So, again, as during the Crimean War the French and English invaded Kamchatka (and a pretty mess they made of it!), so, in case of another Russo-English war in Europe, a movement by way of diversion might be made upon India, with perhaps similar consequences to the invaders. But I was not led, by anything I saw or heard in Central Asia, to think that there was any preparation or desire for an invasion; and when now and then I broached the subject to Russian officers, it never elicited any suspicious remarks, or was treated otherwise than as a joke. I am, however, neither a soldier nor a politician, so that I had better perchance leave specu lation and continue my description of the river.

Before the river leaves the mountains, at Sharwani, 33 miles above the mouth of the Surkhab, there is an excellent ford that is considered to be the best for 30 miles up or down the stream, and across this ford guns are reported to have been taken for winter forays by the Mir of Kunduz. Also immediately below the town of Hazrat Imam, still above the Surkhab, the 
river is fordable for artillery during six months of the year ; but from a point about 30 miles lower, the stream, having received the Kunduz river on the left, and the Kafirnihan on the right, may be considered unfordable at all seasons throughout the remainder of its course. As for ferries, I see on my Russian map one marked above the Surkhab at Kunda-Ghuzar, and others below, near the mouths of the Kafirnihan, and Surkhan, at the Karakhamar ferry near Chuska Hazar, and at Kilif. Kilif is a village of about 40 houses on the main road from Bokhara to Balkh. It was here that both Timur and Nadir Shah crossed on bridges of boats, the river being only 334 yards wide, and the current not too swift to be crossed by swimmers. The banks, of equal height, are of calcareous schist.

From Kilif to the mouth of the Amu, a distance of about 700 miles, the river has been scientifically surveyed by Russian topographers.*

After the little Shirabad river, flowing into the Amu near Kilif, no more tributaries attain thereto. In the Bactrian plain, that is, after leaving the mountains, the river runs between uninhabited, barren, flat banks formed of loess and alluvial soil deposited by

* In 1876 , Kostenko says, at the request of the Emir of Bokhara, a survey was made from Charjui to Kilif, and levels taken of the country round with a view to the construction of new irrigation canals, but the levelling did not give encouraging results. Thirty-three miles below Kilif is Khoja Saleh, where Burnes crossed in 15 minutes, in a ferry drawn by swimming horses. He gives the width of the river as upwards of 800 yards, and its depth from 7 to 20 feet. The last European author, I believe, who has visited this portion of the Amu, is Dr. Capus, who touched the stream near the mouth of the Surkhan. Dr. Capus claims, and apparently justly, with M. Bonvalot, to have been the first to visit the entire ruins of the Surkhan valley. Termez and Shahr-gulGula, he says, were known, but not the more important group of Shahri-Saman. They took sketches there of the most characteristic substructures, made a map of the vast necropolis of Sisahri-Saman, and took down several legends. 
the water, which holds in suspension also a large quantity of granitic sand. Dr. Capus describes the deposit as of dull sandstone which contains many thin layers of mica. It gives to the Amu a characteristic grey colour, which becomes yellowish where the banks are formed of loess and clay.

Below Khoja Saleh the Amu leaves Afghanistan, and, turning to the north-west, cuts off on the left a riparial strip of Bokhariot territory. West of this is the Turkmenian desert, continuing to the Khivan oasis.*

Concerning the navigation by steam of the Upper Oxus, I was told at Petro-Alexandrovsk that the Russians had proceeded from thence up the river to Afghanistan between April 2oth and May igth (O.S.), and a letter concerning a similar journey appeared in the Russian naval journal called the Yacht. ${ }^{\dagger}$

This was at the time of high water. Another favourable opinion on the navigability of the Oxus is that of General Grotenhielm, who, in the year before $(1877)$, made the journey, he told me, from

- A few poor Turkoman families here and there cultivate a saline soil, and there are a few inhabited points on the road from Bokhara to Maimene at Kerki on the left bank where Vambery crossed. He describes the river at the ferry as twice as wide as the Danube at Pesth, and Kerki as a fortified town. Burnes mentions between Termez or the mouth of the Surkhan and Charjui, nearly 300 miles distant, 15 ferries, few of them having more than 2 boats; but on my Russian map I do not find more than $1 \mathrm{I}$, and I know of 9 only between Charjui and PetroAlexandrovsk. Thirty miles below Kerki is another ferry, and still lower, on the right bank, is Burdalik, whence there is a route north to Bokhara, and east to Karshi. Thirty miles beyond, on the right bank, is Narizim, connected by a route with Karshi; and rather less than this distance, beyond, on the left bank, is the oasis of Charjui.

$\dagger$ It stated that the ss. Samarkand (drawing, I understand, 3 feet of water, and of 24-horse power), commanded by Captain Briukhoff, left Petro-Alexandrovsk on the 26th of August, 1878 , and on the 8 th September, after it had passed the Afghan frontier, at Khoja Saleh, it turned back, returning to its starting-point on the r8th September. In the captain's report it said: "The Oxus presents no difficulties to 
Petro-Alexandrovsk to Charjui in the same steamer, embarking on the 22 nd of March. In his report General (then Colonel) Grotenhielm stated that Captain Briukhoff had demonstrated the navigability of the Amu at a time when it has least water.*

These favourable reports must be accepted with caution, for opinion is by no means all on one side, some authorities considering the difficulties such as to unfit the stream for ordinary navigation. M. Shabashef, who, according to Kostenko, explored some 506 miles of the course of the river, was, from his researches, brought to the conclusion that the establishment of useful navigation of the Amu was absolutely impossible.t Whether or no this may be regarded as a pessimist view I cannot say ; but it may navigation in its upper course; the current is not nearly so strong above as below, the banks are clayey, and fringed with reeds and fruittrees, and the bottom is soft; both sides of the river are densely populated."

* Kostenko remarks, however, that from certain parts of the report, it is evident that the trip could not be called a successful one. On two days, when the weather was bad, a strong wind blew about particles of sand, and so darkened the horizon that it was difficult to see the channel, and the steamer several times grounded, though it was always easily got off. I learn also from the Turkistan Gazette, of 2nd October of that year, that the matter of fuel must be a difficult one. The saxaul forests on the Amu are not so abundant as on the Syr, and for the trip just mentioned no less than 145 tons of saxaul were accumulated, the steamer carrying $3^{2}$ tons, and the rest being sent up stream $I 1$ days in advance, in 11 boats, which deposited, at intervals of 15 to 25 miles, a store of 8 tons on the banks, at Pitniak, Meshekli, Itchke-Yar, UchUchak, Sartarask, Ak-Rabat, Gugerdjeili, and Kabakli. On the first day, in calm weather, the steamer made 47 miles, at the rate of about 5 miles an hour; but from Uch-Uchak, for roo miles, to Kabakli, the river was so full of shallows, and so difficult to navigate, that it took 5 days, and, with other hindrances, the trip occupied 17 days. Even the return journey down stream took 8 days to accomplish 300 miles.

+ His reasons were that the swiftness of the current, in some places 6 miles an hour, would impede the progress upwards of the most powerful steamers the Russians had in Central Asia, and that, if a more powerful class of steamers were built, they must be larger, and so be 
be noticed that, when I was at Petro-Alexandrovsk in I 882, they told me that no steamer had been running for two years, though the Russians had been making experiments in navigating the river since 1874 .

On our arrival at the Amu, approaching Charjui, it was easy to perceive that, in speaking of the width and depth of the river, it was essential to mention the season, for we were pointed to a spot five miles distant up to which the natives said the waters reached during four months of the year.* It is characteristic of a large portion of the river that it has double banks. The inner directly skirt the river at low water, the outer are some distance off, in places as much as three miles, with tugais, or meadows, between. The second unsuitable for what is in many places an extremely narrow and tortuous channel. Further, the narrowness of the channel and its constant shifting would interfere with the towing of vessels, because, at the first grounding, the tow-rope would break. Once more, the unequal and sudden rise of the waters from April to August, and the fall from August to October, making a difference of level of 8 feet, would render the study of such a shifting stream almost impossible, and make regular voyages altogether impracticable.

- Burnes gives the width at Charjui in August as 650 yards. At time of high water, however, the width should be at the ferry 500 sajens, or about 1,150 yards, and in some places 25 and 29 feet deep. I observed. when crossing, that 20 feet from the bank the water hardly covered a man's knees, and further out in the stream it did not appear to be more than io feet deep. If I remember rightly, they pushed with poles all across. Masts and sails are unknown, nor did we see swimming horses attached to a boat to drag it across. The natives, when telling me there were no fords below Charjui, added that they sometimes swim horses across at low water in the narrow parts, putting under them inflated skins on either side. Communication is maintained on the upper river by smaller boats than those I have alluded to, and rafts are used there for the transport of timber and firewood. The fall of the river from Khoja Saleh to Charjui, Burnes estimated at 600 feet, in which he appears to be a long way out, since, according to Russian reckoning, it should be 220 feet, the altitude of the following places in feet being :Kilif, 730; Kerki, 640 ; Burdalik, 580 ; Narizim, 545; Charjui, 510 ; after which, for the next 500 miles to its mouth, the river falls to 167 feet. 
banks are high, those on the east especially so. They are even precipitous. In these cliffs may be found fossil remains, easily reached by the hand. The space between the high and low banks now increases and now diminishes, and sometimes they unite, the river flowing on uninterruptedly between. The native boats are rude, flat-bottomed barges, built of dumpy 6-ft. logs of paki wood, chipped square, and cobbled together with iron clamps. It was in a craft of this kind we were to descend the river from Charjui, a willowbuilt barge, costing about $£_{22}$ in value, 50 feet long. Io feet in beam, and 4 feet deep, drawing perhaps 18 inches of water. The gunwale was just low enough for me to reach over, sponge in hand, and get an apology for a morning wash. Such boats would make an admirable bridge, and the river bed offers excellent anchorage. These Bokhariot boats are said to carry I 50 passengers and 20 tons of cargo, or 20 mounted men with their horses, which I should think close work for a journey, though it might do for a ferry passage. In our own case, we were favoured as the Emir's guests with a boat to ourselves. The tarantass was placed amidships, and abaft were five horses of mine and one belonging to Yakoob, whilst the fore part was occupied by 8 oarsmen, with two as a guard, besides Khudaiar Bek, a Karaul-beggi, to look after us.

Having described now the Upper Oxus from the information of others, I shall proceed to state what I saw myself between Charjui and Petro-Alexandrovsk: amplifying my own observation from certain unpublished Russian information I possess, concerning which I will only say that, when giving measurements of the stream, it is to the season of high water they are to be understood to refer. 


\section{CHAPTER LVII.}

FROM CHARFUI TO KABAKLI.

Prospect of floating 300 miles on the Oxus.-Escort for protection against the Turkomans.-Hydrography of the river.- Journey to Kheradj.- Rough hospitality.-Journey to Ustik.-Description of the river.-Compulsory service of boatmen.-Geological phenomena.-Arrival at Ildjik.-Change of boat and oarsmen.-A Bokhariot "Siberia."-Arrival at Kabakli.--Sheep attacked by wolf.-Visit from the Bek.

THE prospect of floating 300 miles down the 1 Oxus, not in a puffing steamer, but in a fashion as ancient as the days of Noah at least, was to me a new sensation, and one heightened in interest by the recollection that over this part of my journey at all events no Englishman had ever preceded me. The authorities, not content with giving us two guards against Turkoman robbers in the boat, furnished us also with five horsemen to ride along the shore. These latter were presented to us at Guzhari Tozakar, after which they got into a ferry-boat with horses and camels, and crossed to the east bank. The river here, they told us, was 2,000 kadarm in width, or rather less than 2,000 yards.* There were no houses near,

- A kadarm was said to measure If arshines, which would make the breadth about I, 0oo yards less than at the Khandek-li ferry at high water. This ferry is about II miles from Charjui, and I suspect we had been brought there, though Guzhari Tozakar is the name I have entered in my book. 
yet the crossing ferry-boat and the crowd attracted, I suppose to see the foreigners start, made rather a lively scene. We stepped on board at 20 minutes past $\mathrm{I}$, the Muhammadans giving a parting blessing, and stroking their beards as they shouted Allah akbar! (the mighty God!), and Yakshi sagat! (a pleasant journey!)-the former intended, I suppose, for the "faithful," and the latter for us "infidels,"

We soon found ourselves on the bosom of a rapid current, and the wind was also in our favour, but it was rather too cold to be quite pleasant. Faraub and Betik, on our right, were left behind; and on our left, after floating 3 miles, ${ }^{*}$ seven aryks were diverted from the river, going in the direction of Khoja Kala, an inhabited district with 7,000 dwellings. ${ }^{+}$

At 2 o'clock we passed a wide expanse of land, evidently covered in the time of flood, and on the bank were fishing nets. In half an hour trees were visible a mile off on the left, and the depth of the water near the left bank was less than 5 feet. At half-past 3 we were proceeding in a very undignified manner. The wind blew us against the west bank, and the prow and stern being "much of a muchness," with the concern guided by an oar instead of a rudder, the boat was allowed to perform a series of gyrations

* That is, I presume, according to the channel, rather than as it appears on the map, and so hereafter in these minute measurements.

+ For 5 versts more the Oxus continued to run in an undivided channel, and then aryks went off on the right to the villages Alli-li and Alim-dor, the latter with roo houses. For the next 10 versts the river widened to 4,000 yards, with numerous islands, one of them 3 miles long, and then we came to two arms of the river, with an island between and a ferry connecting Khandek on the right and Khandek-li on the left. Five versts more got us clear of islands, the river was again confined to 2 versts in width, and another mile brought us to a ferry opposite the tomb of Sumpana-Bi-baba on the right, with an aryk going off on the left bank in the direction of Boiun-Uzun, with 3,000 dwellings. 
in obedience to the sweet pleasure of the stream $U_{p}$ to four o'clock we had seen only 3 men ashore and met two boats being tugged up the stream. Five o'clock found us still hugging the left bank because of the wind, the only visible reminders of human kind being the banks of aryks. Half an hour later the first small house was sighted on the left bank, and soon afterwards the moon rose, and we floated on till 7 o'clock to Kheradj, where we were to stop the night, thus accomplishing 30 versts only out of the 435 (as measured by the stream), from Charjui to Petro.

What good things they may have prepared for us in the village I know not. We were pointed to a dim line in the far distance, as a haven of rest and refreshment, but on the water's edge there was no tent erected, and not a creature to be seen, and I did not care to go so far away and leave my tarantass to the tender mercies of the first band of Turkomans that might happen to come along. I therefore declined with thanks to go so far, and a fire was made on shore, some Oxus water heated, and we sat in the smoke drinking our classical tea. Afterwards I retired to the tarantass to write my journal, leaving Sevier on the bank with the party round the fire; and as I looked out upon them I could not but be struck with the peculiarity and novelty of the weird picture. Our valiant guard of cavaliers, not a ghost of whom we had seen all day, found us out at feeding time, and swelled the party to about a score. One wore a turban of red, white, and blue; Yakoob had on his Tatar cap and cassock-like robe; Sevier had arrayed himself in European smoking-cap with his fur khalat purchased in Bokhara; and then, far outnumbering these, was the crowd of Uzbegs, with their tanned, swarthy faces. 
They drank tea, and lay round the fire to sleep, whilst Sevier and I arranged ourselves in the tarantass, and thus spent our first night floating down the Oxus.

The next day we managed to accomplish 33 miles* and reached Ildjik. I had read of the rough delights of taking a meal in primitive fashion round a camp fire; but when it came to be realized at breakfast time on the morning of 2oth October, on the muddy bank of the Amu-daria, a great deal of the sentiment vanished. My thermometer had fallen during the night to $7^{\circ}$ below freezing point, and at six o'clock the sun was far from hot, but we battled through a meal by the fire. and at 6.30 pushed off. Matters were not improved by the fact that our oarsmen considered they had now done their duty, for they expected here to have been met by a relay of men and another boat to carry us on. We learned, too, that the reason they had not continued the journey on the preceding evening to Ustik, as they expected to have done, was for fear

* In this stretch of river we passed about a dozen islands, the largest, at our point of starting, being upwards of two versts in length. Two versts also was about the average width of the river for 13 miles, and then, at a point 385 versts from Petro-Alexandrovsk, it contracted to half this width, and so continued for Io versts, when it once more expanded to its former width as far as the aryk leading off to Ildjik. On the left bank we passed Dekhnau with I,00o dwellings, and Guiniuk with 300 , in the neighbourhood of which latter the vegetation of the Charjui oasis appears to come to an end. On the opposite bank it ceased about 15 versts below Kheradj. This place is on one of the roads from Bokhara to Merv, and there comes to it from Kara-Kul, 40 miles distant, a small caravan route, by which travellers cross the river to Dekhnau, and then penetrate the desert. This route, moreover, continues from Kheradj all along our right bank to Petro-Alexandrovsk, though we were rarely within sight of it. The noticeable points or stations up to Ildjik were two places named Kheradj, Godyn (with 20 dwellings), the ruins of Ustik or Ost ; the fort of Ustik and Fort KhojaKanaspi (near which there are in the steppe deposits of impure salt worked by the natives), and Ildjik with 200 dwellings. 
of robbers. Since neither boat nor men were there, I was obliged to be firm, and insist that they should take us forward, promising that if they got us to Ustik by 9 o'clock I would give them a sheep to eatthe cost of the said animal being r $2 s$. At 9.45 we passed, on our right, the ruins of the fortress Ustik, perched like a stork's nest on the top of a mound of conglomerate loess, at the foot of which are some houses enveloped by the sand, whilst from the river we could discern cupolas among the ruins.

Ustik was a place with threescore dwellings, and the residence of a Toksaba, who was unwilling (and perhaps reasonably so) to let us have the only boat he possessed for the service of the ferry. At first he rather gave himself airs, whereupon I took out my pencil and note-book, solemnly asked his name, and wrote "Muhammad Ziphar," threatening to tell the Emir that the Toksaba had declined to carry out his Majesty's orders. This rather frightened him, and he proceeded to explain in some way that he was acting for our advantage, and that he wished our men to take us on to the next station at Kabakli. It had been gradually dawning upon me, though "we were appointed a daily provision of the king's meat," * yet that, by command of the Emir, we were served in travelling with forced labour. I first suspected this with those men who ran off and forsook us coming from Kara-Kul in the Sundukli sands. "They appeared to have been compelled to go a mile," and were certainly not minded to go with us twain. ${ }^{+}$So with our present oarsmen; they had not fulfilled the con-

* Dan. i. 5 .

$\dagger$ Matt. v. 41. A capital illustration of áryapev́w, which is a Persian word, and so, indigenous to the country we were in. In fact, I could not help thinking how closely the Persian customs observed in sending 
dition stipulated for the sheep, but I promised them that, and an additional present to take us on. To this they consented, but unwillingly, the distance by road to the next station, they said, being i I miles.

After leaving Ustik we noticed, at II.45, on both banks, rounded hills of sand and gravel, with the peculiarity that they were flattened on the top, and all at the same height, so that it was suggested whether these flat hill-tops did not represent, in a former geological epoch, the level of the country around, the mounds having been washed to their present form.*

As the day advanced the weather improved; there was less wind, and by 4.20 the thermometer had risen to $64^{\circ}$. We now hugged the right bank, and at half-past six came to Ildjik or Ilchik. The Toksaba had preceded us, and was awaiting our arrival, bent, I

away Ezra and Nehemiah were re-enacted in my own case. "In any place where he sojourneth, let the men of his place help him with silver, and with gold, and with goods, and with beasts "; "let the expences be given out of the king's house " (Ezra i. 4 ; vi. 4). ("Now the king had sent captains of the army and horsemen with me.") " Moreover, I said unto the king, If it please the king let letters be given me to the governors beyond the river that they may carry me over" (Neh. ii. 9, 7). For my part, I did not ask for "a band of soldiers and horsemen to help us," though, when provided, I saw no occasion to decline it; but let me not forget thankfully to acknowledge with Ezra, that "the hand of our God was upon us, and He delivered us from the hand of the enemy, and of such as lay in wait by the way " (Ezra viii. $22,31)$.

- I suppose it is to these Dr. Capus refers when he says that sometimes one sees isolated hills of loess, and knows not how to account for their presence. Perhaps it is hazardous, then, on my part to conjecture, but they remind me of the cap-shaped hillocks of which M. N. P. de Marny speaks on the Lower Oxus. He combats the idea of their origin being due to the action of the waves of an ocean, but says they are due to atmospheric erosion. On the other hand, Major Herbert Wood states that he found the surface of the hillocks near the Aral to be composed of a thin layer of sandstone, showing very distinct ripple marks, which he thinks is some prima facie evidence of the existence of an Aralo-Caspian sea in tolerably recent times. 
fancy, upon extorting money if he could. Perhaps he had heard what I had promised the oarsmen. I had been warned as far back as Samarkand to be very careful, if I hired a barge, to make a bargain before starting. The Toksaba now asked us about paying for the boat. I simply replied that we were the Emir's guests, and were being provided with all things necessary to take us to Petro-Alexandrovsk by his Majesty's commands. To this charge he did not return, though he afterwards endeavoured to have money dealings with me to his advantage, and also tried to deceive me respecting the number of men at his disposal. They had erected no tent, and we had again to eat our supper by moonlight surrounded by Turkomans, whose swarthy faces beneath their sheepskin hats looked grimly fierce in the glare.

Our next stretch of river was to Kabakli, or Karakli, distant 47 miles.* We were promised overnight by the Toksaba that a boat some miles off should be sent for, but in the morning it had not come. We proceeded, therefore, to breakfast leisurely in the open on cream, tea, chicken, bread and butter, and then looked about at some Turkoman boats and rough shelters they had

* Thus far from Charjui we had been running due east and west, but now the river turned, and resumed its normal direction to the northwest, not, however, in a straight line, but in three bends to Kabakli. Opposite Ildjik the river contracted to a verst in width, Io versts further on enlarged to 3 versts, with an island in the middle, and again contracted 5 versts further on, where, on the right bank, was the tomb of Ak-rabat, and on the left the town Moor, with 500 dwellings (which Walker's map, by-the-bye, places on the wrong side of the river), and 2 versts beyond, on the left bank, the ruin of Kyzyl-Bash. Another 8 versts brought us due north of the fortress of Ist-poos, on the left bank, where are said to be half-a-dozen houses and a garrison. About a verst further are ruins of a fort of the same name. For the previous to miles there is vegetation on the left bank, but not on the right, and both banks now become barren. For the next 30 versts the stream continues contracted, for the most part to one verst in width. 
constructed with their oars and poles and pampas grass, one of them having a hawk tied near. Meanwhile our Karaul-beggi, the five horsemen, and the oarsmen wished to return to Charjui, and proposed to take the tarantass out of the boat to be left on the bank till the other boat arrived; but this I forbade, having no wish to find myself stranded on the banks of the Amu. Moreover, I would have preferred to keep the boat we had, and I could not see how the carriage, without mechanical appliances, was to be transferred from one boat to the other. When at length the new craft arrived, it was older and smaller than the one we had, but they called everyone to work, and, to my no little surprise, with their hands lifted the heavy machine out of one boat into the other. The Turkomans had lent their assistance, and I distributed three boxes of sugar-candy, not supposing that such a ragged-looking lot, whose only belongings appeared to be a few bales of tobacco, and those, perhaps, committed to them for transport, would have anything to offer in return; but, to my surprise, they offered a few nice-looking apples from Khiva, the first I had tasted, but of disappointing flavour.

We now dismissed our escort, and at 12.45 put off with only 3 oarsmen and the Toksaba, our two selves and Yakoob, and 5 horses. The quarrelsomeness of our

after which, ro versts above Kabakli, it expands to a width of $2 \frac{1}{2}$ versts by reason of two wooded islands, one of which is 4 versts long. All the way from Charjui to Ist-poos the banks had been of loess and flat, but at a point 330 versts from Petro-Alexandrovsk, and 5 versts further, opposite the ruin of Nar-kiz-kala, on the right hand, there is a stony cliff 2 versts long. There is a similar cliff on the left bank, to versts further, at Mys-ak-tur, or Tashakhur, that I estimated at from 40 to 60 feet high. Five versts further, sand barkhans take up nearly half the river bed opposite a tugai, or spit of land, Djegdiari, the first marked in our course. 
stallions was a constant nuisance. As they could not be tied other than close together, and Yakoob's horse threatened to kick Sevier's, it caused the latter incautiously to spring out of the way, and in so doing, much to his own surprise and ours likewise, to jump into the water. He had therefore to swim until the boat could be brought to land, whence he re-entered, with his courage evidently cooled. At 3 o'clock the right bank was from Io to I $_{5}$ feet high, and at 5.20 we came to sand barkhans, on the same side of the river, from 30 to 40 feet in height. After leaving Ildjik we overtook only one small boat, saw no houses, and only one man on the banks before night came on. The maximum temperature during the day rose to $63^{\circ}$, and the wind had so gone down that, as we drank our tea by moonlight, Sevier sitting on the box with a light and I inside, the candle for a long time was not blown out. They had given out on Thursday, when we left Charjui, that they expected to reach Kabakli in two days, and I had intended there to spend something like a quiet Sunday. Waiting for the boat, however, had hindered us, and I now urged the men to take advantage of the moon, and go on as far as possible during the night. This they consented to do as long as they could see, after which we were to lay to till break of day. Accordingly, after tea, we turned in to rest, our slumbers being soothed by the ripple of the waters, and occasionally disturbed by the shouting of the men, when running on a bank. We stopped for only about 4 hours during the night, and by 8 next morning were opposite the Tash-akhur cliffs on the left bank. Fifteen versts further, beyond two wooded islands, we had on our left the ruins of Sengr Rabat, and on the opposite bank Chidari Kaya

VOL. II. 
in the Saradar or Soratas tugai, and by half an hour before midday we reached Kabakli.

The fame of Siberia as a place of exile is not unknown in Bokhara, and, in imitation thereof, the Emir is said to banish some of his criminals to Ustik, and on the other side of the flood to Charjui and Kabakli, which three places are called à la Bokharienne, Little, Middle, and Great Siberia.*

We had approached Kabakli during the great Muhammadan feast of Kurban-Bairam, to which Yakoob had been looking forward, and the Toksaba asked me to sell him a silk khalat wherein he might attend the mosque in grand array, taking good care, however, to offer me little money and to say that he had no more. When we landed and despatched a messenger to the Bek to announce our arrival, he sent to say that prayers were over, and that he was receiving visits, but that he would shortly send a djiguitt or come himself to see us. Meanwhile a tent was erected for our use in a wood among stunted trees and stalks of pampas grass, one of which last I had the curiosity to cut, and found it measured $17 \mathrm{ft}$. 6 in. in length. This wooded tract of country we had had on our left for half an hour before arriving. Near at hand was a flock of sheep, and during our stay the shepherd came, saying that a wolf had just killed a sheep and

- Dr. Capus speaks of Kabakli as an advanced post of the Bokhariots against the Turkomans of the desert, and, in a letter to the Geographical Society of Paris, mentions 300 or 400 Bokhariot soldiers
kept there to repress the brigands. This looks rather like another version of my Russian information I have given concerning Ist-poos, for 1 can hardly think there would be two garrisons so near together. We did not leave the margin of the river, but the fortress, with crenelated walls 200 yards square, is described as enclosing the habitations of the military, and surrounded by 4 or 5 hovels or saklias, some stalls, a bath, tombs, and a little mosque. 
was making off therewith, but, on being chased, dropped it.* The shepherd said also that the Bek was on his way to us. We had dined in the tent, and it was now well on in the afternoon when the old gentleman arrived, so infirm that one almost wondered at his being able to mount a horse. I had once more to drain my stock of European articles for presents, and I gave him, among other things, my gorgeous, gold-embroidered, Servian vest that had done such good service, a pair of spectacles, a ring, and some English needles. The one burden of my request was that he would send us forward to PetroAlexandrovsk as speedily as possible, and with more oarsmen. He promised to give us two additional men and a mirza to represent himself, adding that, if the men did not bring us there in two days, they should receive five-and-twenty lashes. In the same breath, however, he intimated that in fine weather the journey took three days, whereupon I promised that if in that space of time they brought us there, I would give a present, but that if they failed so to do, I would let him know. I asked if it would expedite matters to have our horses sent by road, but he preferred not to undertake the

* A modern illustration, I thought, of an ancient story: "Thy servant kept his father's sheep, and there came a lion and a bear, and took a lamb out of the flock; and I went out after him, and delivered it out of his mouth " (I Sam. xvii. 34, 35). The Kirghese on horseback hunt the wolf and beat him to death with their riding-whips, and the fighting of men with bears is said to be sometimes done still by the Gilyaks, amongst whom I travelled on the Amur in 1879 . John X. 12 seems to contemplate the shepherd fighting the wolf, even to the laying down his life for the sheep. In the Caucasus, where wolves abound, I learned, in 1880 , that the shepherds provide themselves with wolf-like dogs in large numbers to protect their flocks from beasts of prey, but I am not sure whether or no this practice obtains among the natives of Central Asia. Further down the Amu we saw a shepherd with his flock, but 1 do not remember anything about a dog. I-learned, however, that the Bokhariot shepherds do not lead, but drive their sheep, which would seem to require the employment of canine help. 
responsibility of sending them. All else, however, that I asked he promised to do, and said that we should start early on Monday morning.

We slept that night, if I remember rightly, one in the tarantass and one in the tent, and early next morning were astir. There were provisions, of course, to be taken in. The Bek sent no present, but provided us with fodder for 5 horses, besides 4 live chickens, bread, eggs, milk, cream, and melons. This was much the same as had been provided for us at Charjui. The local cost of clover, I heard, was I $2 s .6 d$. for 100 snaps of an armful each, or, according to the time of year, from rod. to $20 d$. per donkey-load of about II bundles, April being the dearest season. The Bek was spoken of as stingy, but fond of turning a penny, and, though he had sent no present, they said he would purchase the bridles other beks had given me. I had more than I wanted, and offered him two by the hand of the Toksaba, for which he gave me two-thirds of what I asked. I had an offer also at the place for a pair of my horses, but not knowing whether I might not want them beyond Petro-Alexandrovsk, I declined to sell for less than $£_{3}$ each, and took them on. The Toksaba had told us at Ildjik, as the reason for giving us only three men instead of the eight we had had from Charjui, that his men had run away; but we learned at Kabakli that it was a falsehood, for he had only three, of whom one was ill. I cannot say that I liked this official, and I was accordingly glad to give him his conge when he desired to return. 


\section{CHAPTER LVIII.}

FROM KABAKLI TO PETRO-ALEXANDROVSK.

Hydrography of river to Russian frontier.-Departure from Kabakli.Ruins on the banks and tugais.-Precautions against robbers.Fauna of the islands and river banks.-Native information.-Uzbeg notions of a future life.-Singing oarsmen.- The Bokhariot frontier. -Flora of the river islands and banks.-The "Pitniak Curve", and "Lion's Mouth."-A dumb journey thence by horses.-Shurakaneh.-Arrival at Petro-Alexandrovsk.

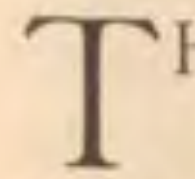

HE journey before us to the Russian frontier beyond Ust-Uchak measured by the bed of the river 113 miles.* We launched forth at 7.10 on a morning cloudy, but not windy, and after rowing 7 miles, passed on our left the ruins of Katta-kala, and after 7 miles more, arrived at io o'clock at the Bish

- Five versts from Kabakli the river contracts to 875 yards, and continues almost without islands for $\mathrm{I}_{5}$ versts more. Afterwards, for 10 versts, it widens to $2 \frac{1}{4}$ versts, enclosing numerous wooded islands. Then comes a course of 25 versts of river (to a point 240 versts from PetroAlexandrovsk) about the same width, with only one large, treeless island, 4 versts long. The banks for 35 versts from Kabakli are of loess and flat, with a few trees on the left. Four versts further, however, the right bank changes in appearance, and presents cliffs of clay for 60 versts, except at the Shurtankali tugai, which is bounded by sand barkhans. On the left bank the clay cliffs do not continue unbroken for so long a stretch. Opposite the tugai just mentioned there is a clay cliff, a verst long; then come flat banks for 4 versts on either side of the ruins of Kitmenchi fortress; a verst beyond that place clay cliffs run again for II versts to the before-mentioned point, 240 versts from Petro-Alexandrovsk. 
Arandjan tugai, with the ruins of Uch-Keran (seemingly also called Kavakli), on the left bank, whilst opposite are two ruined castles, with a legend worthy of the banks of the Rhine.

One is called Kyz-kala, or Maiden fortress, and the other that of her lover, Im- or Djiguitt-kala. Kyzkala is an extensive ruin, situated on the top of a hill about a mile from the river, and enclosing 13 acres of land. We could discern from the river the remains of a gateway, apparently of burnt brick, and we were told that it contains still a bath and a prison. There is a subterranean aqueduct from this ruin to the river, and a well inside the fortress. Even the woodwork may be seen, and the well, being built of baked brick, is admirably preserved. The ruins on the banks of the Amu are said to be of two kinds, namely, fortresses of considerable strength, such as Kyz-kala, for the protection of the frontier, and fortified caravansaries to afford shelter to passing caravans. Somewhat to the south, and near the Amu, is the ruin of the fortress of Djiguitt-kala, anciently enclosing 8, but now 3, acres of land. Here also was visible a cupola over the bath, but both places are uninhabited. The legendary origin of these two was given me as follows : About 400 years ago there lived a princess, who did not wish to be married, whereupon she ran away into the Steppe, and built Kyz-kala, wherein to live in single blessedness. Her lover followed, and erected Djiguittkala near, but to no purpose; for the damsel remained obdurate. Soon, however, it came to pass that she was at a loss for water, and determined to excavate a subterranean way to the river ; but the lover discovered this, and stopped it up, whereupon the princess fled, and her lover after her, and they were never heard of more! 
At I0.15 we came to three boats near the bank, and 8 miles from the lovers' fortresses we passed, on the left hand, the ruins of Eshik-rabat, in a tugai of that name, and, on the opposite bank, Kheik tugai. At I.45 I judged the cliffs on our right to be from 60 to 80 feet high, and half an hour later we passed, on the left bank, a wood of small deciduous trees, within sight of the ruined town of Daiakatyn-kala, said to have been built in the time of Abdullah Khan. The mud walls and a high gateway, apparently of burnt brick, were visible, and on the opposite bank was a stone erected in memory of a hero, who, it was said, used to ride across the river (from Kok-oguz-kala ?) to the town. A little further on were the ruins of a fortress and tomb, named after a saint, one Kitmenchibaba. Opposite is the large Shurtankali tugai, 4 versts along the bank, and on the map is marked the Tekke ferry, the first below the one at Kabakli, where, by the side of the place we landed, we had seen a Turkoman barge proceeding in the same direction as ourselves. At 3.20 , the banks on the right I judged to be from 40 to 50 feet high, and sandy. Yakoob here went ashore to find some large stones, if possible, whereon to rest his kettle in the boat during cooking operations, but he was obliged to return with lumps of earth. At 4.15 we had on our right the Gurli tugai, where we saw a shepherd with a staff indeed, but straight, the Bokhariot staff having no crook. At 5 o'clock we were floating between lofty banks on either side of the river, the right cliff some distance from the water now; though I should suppose, when the river is high, the stream touches both cliffs.

At sunset the men wished to stop. This I endeavoured to prevent, reminding them that my reward 
was offered on condition of their bringing me to PetroAlexandrovsk in three days. They said, however, that the mud banks rendered navigation perilous by night, and they drew to land; but hearing there that the Turkoman boat, that left Kabakli before us, had passed only an hour before, they put off again, caught up the craft, and stopped alongside for the night.*

I suppose that our men sought the company of this friendly Turkoman boat as a precaution against robbers, for we were now in the most dangerous part

- Beyond this point the river for 20 versts widens to $2 \frac{1}{4}$ versts, enclosing several islands, the largest 6 versts long, opposite the Gugerdjli or Kukertli tugai on the flat left bank. Beyond this tugai sand barkhans prevail for 6 versts, and then comes a stony cliff to the river, 3 versts long, near At-Khor-Kaya, opposite Kukerth. Between this cliff and the opposite clay cliff, $2 \frac{1}{1}$ yersts distant, the river contracts to $1,75^{\circ}$ feet, leaving dry a strip of wooded land on the right, 8 versts long. The stream then regains its normal width of 500 sajens, and so continues for 20 versts, where, after a contraction to half this width near the tomb of Dargan-ata (called also Ak-Kala), it expands to nearly 4 versts, the widest part we had seen, and includes its largest island, 8 versts long, called Dargan-baba. Here the long clay cliff on the right ceases. At a point 197 versts from Petro-Alexandrovsk both banks are flat with the ruins of Kyzyl-rabat (called also Urus or Russian fort) on the right, and Ak-rabat on the left. Three versts beyond, the river contracts again, and then rolls on for 20 versts. On the right bank, opposite the ruin, rises a clay cliff a verst long; then comes the Shura tugai, 6 versts long; and afterwards another clay cliff of the same length, called Pik-Suat or Dik-Suat. Opposite to this, on the left bank, ends also in the same latitude a clay cliff extending from within 3 versts of Ak-rabat, which, opposite an island 5 versts long, is called Gerchegen-Tau or mountain. Both banks now continue flat for 5 versts to a point 170 versts from Petro-Alexandrovsk. Then begins the last clay cliff on Bokhara soil, on the right bank, to versts long, near Burlius-ulade tugai, whilst, on the left bank, at a point 168 versts from Petro-Alexandrovsk, are Kara-shir, which is the Bokhariot frontier, and Kichekran-kaya or kala, which is the Khivan frontier. Here the river contracts to less than a verst, and then flows on for 8 versts, with the Kumalapyn tugai on the left; and on the right, at the end of the cliff just mentioned, the ruin of Sertarash. The river now for 25 versts widens sometimes to 4 versts, to the Bokhara Lager, or camp fortess, on the right bank, 135 versts from Petro-Alexandrovsk. The banks for 
of our course.* Our men were evidently shy of travelling after dark. One evening they wished to stop soon after six o'clock, and, in answer to my urging them on, they replied by a threefold argument,that I was in the first place the guest of the Emir; secondly, the guest of the Kush-beggi; and, thirdly, the guest of their own Bek. Consequently, being responsible for our safety, they did not like to venture further for that night. Tekkes, however, were not the only foes we had to fear, for just before going to rest one night, Yakoob came from shore to say they thought there were wolves about, and asked me to let off 2 or 3 pistol-shots to scare them away. I emptied 3 barrels of my revolver into the air. Whether or no the wolves were frightened I know not. The horses were, and it was well they did not take it into their heads to break loose.

We started on Tuesday morning at 6.1 5 , and soon after saw a jackal (they call it shakal) on the left bank. At 8 we breakfasted, on coffee, cream, cold chicken, and

this stretch on either side are flat, except on the left, opposite the fort, where is a stony cliff, 7 versts long, called the Burliu boundary, and opposite to which, a couple of versts beyond the fort, on the other bank, are the three hills called Uch-Uchak.

- When Capus and Bonvalot descended, 12 months before us, they appear to have taken great precautions against the bandits, especially in the neighbourhood of the Tekke ferry, where they avoided shouting and unnecessary noise by day, and the lighting of fire by night. They certainly had good reason to know of the vicinity of robbers, inasmuch as they picked up in their boat two miserable wretches who, leading camels to Bokhara, had been robbed of everything by the Turkomans, and one of their companions killed. After the Khivan war the Russians gave a part of the territory ceded to them to the Emir of Bokhara, on condition that he would establish, on the right bank of the Amu, posts of vigilance and refuge for caravans. The bandits were said, however, to cross the river at the narrowest places on inflated skins, holding their horses' bridles, or sometimes they spied a boat starting, and waylaid it in a difficult part of the stream. 
bread and butter; and at so our head cook came for orders for dinner. I said, "Soup as yesterday; a boiled chicken ; and, for a third course, rice-pudding, with milk and eggs and sugar. To be served at one." We had met, an hour and a half before, a boat with a very rough-looking crew, from whom we had obtained, by borrowing, begging, stealing, or some law of exchange unknown to me, an extra man and a kettle, concerning which latter, when the dinner came, we asked no questions, but ate what was given us. We were now becoming somewhat accustomed to roughing it, and, besides, the weather was becoming more agreeable. My thermometer at Kabakli fell during the night to $37^{\circ}$, but went up next day to a maximum of $70^{\circ}$. whilst on the 24 th October it stood at $80^{\circ}$ in the shade, though I must add that the wind was cold.

At 1 i o'clock we went on shore, near the hut of a solitary fisherman, who, to my surprise, had in his possession a Russian breach-loading rifle, the only one, so far as I remember, that we saw in the Bokhara Khanate. He had shot some wild animals and caught a young hawk, which he sold me. They snare hawks and young eagles by tying a sparrow on a fishing net, in the meshes of which the bird of prey, as he pounces on his quarry, entangles his claws. The numerous islands of the Amu contain abundance of game. The native names of some of these they gave us as Yilbars, Doltaburk, Gawas, Kaiks (or Antilopes), Kashkir (or Wolves), Rabbits, Hares, Wild Boars, and even Tigers. Besides these may be shot Pheasants and Partridges, Geese, Ducks, Swans, Herons, Storks, Falcons, Buzzards, and Ravens, which nest in the cliffs; but of these I cannot say we saw many, though I noted the appearance of Eagles, Magpies, and Wagtails. 
We continued to pass various ruins. Thus, on the left bank, below the Tekke ferry, there was the ruin of the fortress of Shirin Khatun, and, beyond that, of the fortress Pitchke tugai.

I liked the men we had from Kabakli better than any of the previous sets. The old Bek had been not only as good as his word, but better; for, in addition to the three men from Ildjik, who were content to go foward with us, he gave us three oarsmen, also an Issaul(or Yessaul)-Bashi, or centurion, named Hadji Muhammad, and a Mirza, or secretary, Jurabai. The last two, as well as Yakoob, I think, occasionally took their turn at an oar as volunteers, and I made further use of them in calling them to the tarantass, and pumping them with questions. They said the Amu begins to rise in April, is high in May, June, and July, but highest in June, $\uparrow$ and lowest at the end of November. $\neq$ Boats such as ours, they said, could navigate the river at all seasons, but that steamers in winter could not go above Charjui. The water is always muddy, so much so that there was room for doubt, in the absence of a mirror, whether one's face were cleaner or the reverse after a morning wash therein. This was not at all to

* Walker's map has next a place called Deveh Bayun, of which I can learn nothing elsewhere. Then comes, on my Russian map, Svar-djeli, Sad-Djargan-bai, and Buz-Karaul-Khana. Next we came, at noon, to Dargan-ata, or baba, a large fortified place in ruins. On the other bank, but not quite so far, is Kukurtli, a Bokhariot resting-place and refuge for caravans, which strike off from this spot for Kara-Kul, 1 10 miles distant. At half-past twelve we passed, on the right bank, the ruins of Kyzyl-rabat, said by our guides to have been inhabited in the time of Abdullah Khan.

+ Thus it might be said of the Oxus, as of the Jordan, that it "overfloweth all his banks all the time of harvest" (Joshua iii. 15); both rivers being fed by the melting of snow on the mountains about their sources-the Lebanon and the Pamir.

$\ddagger$ All old style. 
be wondered at, however; for, apart from the detritus brought down from the mountains, the stream eats away its muddy margins, and the falling into the water of banks undermined caused a series of detonations that constantly fell upon our ears like the booming of distant guns. Though so muddy, however, the sediment quickly settles, and for cooking purposes we found the water neither unwholesome nor distasteful, though I do not remember drinking it unboiled.

The Mirza carried about him, in a long, narrow, Chinese-looking box, his trade implements, reed pens, ink, penknife (truly so called), and scissors wherewith to cut paper. I was taken with his scissors, which were so made that the hole for thumb and finger were placed not by the side of, but behind, each other, and thus the instrument, when not open, measured barely half an inch at the widest part. He gladly exchanged them for an English pen and pencil case, and I added them to my collection of curiosities. As he was supposed to be educated I asked him sundry questions on religious matters, and among others what were his notions of a future life. He said that as a man dies, so he remains until the resurrection, when, the earth being flat, the dead grow out of it like grass. Then God divides the bad from the good: the bad He sends to hell, and the good to heaven. Heaven is a place, he said, where persons live immortal, and where every wish is fulfilled; but then the Mirza added, what hardly agreed with the foregoing statement, that the creditor there might seek out his debtor, and though he could not demand his money, yet if the debtor were a good man, and the creditor a sinner, the creditor might take away the virtue of all the debtor's good deeds, so appropriating them as to be saved thereby. 
In the course of the day the men asked permission to sing Bokhariot and Turkoman songs, and, of course, we consented. One man, for want of a tambourine, took a basin, and they sang the praises of their heroes, but Turkoman singing is very monotonous.

Our gondoliers told us on Tuesday night that we had made during the day I 2 tashes, as also, they said, I t tashes the day before; but we put little confidence in their statements, since they seemed to reckon pretty much by the rule of thumb. Starting next morning, however, at 6.15 , in two hours and a half we came within sight of Uch-Uchak. The only objects worthy of notice we had recently passed on the banks were at $\mathrm{IO}_{3}$ miles from Petro-Alexandrovsk, the ruin of Shurpak-kala on the right, and on the left the tomb of a saint, Djegerment, beyond which, on the same side of the stream, was a tugai named after him, whilst to miles beyond was a ruin on the right called Eshek-rabat, and 3 miles further the Bokhariot frontier fortified camp. Near this spot, about 2 miles inland, is the small Sardaba Kul, a blue lake, surrounded by a frame of green reeds. Near it passes the diverging caravan route to Bokhara.*

Uch-Uchak derives its name from "three hills,"

- At this spot the river is one verst wide, and so continues for 10 versts to just beyond the ruins of Dagen-ishur, on the left bank. Here, between stony cliffs, for 2,000 feet on the left, and 9,000 on the right, the river contracts to 900 feet. For nearly ro versts it does not widen much, but rushes past It to the Siunuk-tarak tugai on the left, and on the right to Dul-Atlagan and Yastkhy, whence runs a distant line of sand barkhans 7 versts long, ending at the cliff of Ichke-yar (Walker's map, by-the-bye, terms this Nuke-yar, perhaps from the Nukus boundary or district just beyond). Ichke-yar is the Russian frontier fortress, so that henceforward the Oxus runs between Khivan and Russian territory. Below Itchke-yar for 45 versts the stream widens to 2 and sometimes 3 versts nearly to Uch-Tiube on the left margin. The banks are flat, except a clay cliff about 2 versts long on the right bank, 
whereon they fancifully say a kettle might be placed as on a tripod. Here, at 9.45, we went ashore, the centurion's business being to look after a man, who had under cultivation $\mathrm{I}_{3} \mathrm{O}$ acres of linseed, besides other crops. In the previous year he had sowed one batman of seed, and reaped, they said, a hundred batmans, but this year the floods had destroyed his harvest, and he professed to have reaped nothing. Consequently the Bek had told the "Issaul," or centurion, to look at the land. The farmer was found and presented to us, and a very rough object he was, without stockings, and with a skin resembling leather. He was reported, however, to employ 12 men, and lived in the village, socalled, of Uch-Uchak, not visible from the river. For 9 versts beyond the rocky projection at Itchke-yar there runs along the right bank, between the river and the heights, a narrow tugai, which is partly under cultivation, and in other portions covered with excellent pasture. Moreover, on the face of the steep, rocky bank is a narrow foot-path, along which travellers can walk or ride in single file on sure-footed horses. At II.I5 we noticed large sandstones fallen away from the bank, and at 2.30 , in the right-hand cliffs, was exposed a thick stratum of dark-coloured earth. At 3.15 we had, on our left, the Sadivar ruins, and opposite, on the right bank, the ruins of Meshekli, whose clay walls and towers form a small square. At the time of the nearly opposite the ruins of the town of Sadivara or Saudager on the left bank; also at points 85 and 75 versts from Petro-Alexandrovsk there are stony cliffs 2 and 4 versts in length respectively. Opposite the former cliff is Yani tugai on the right bank, and, a verst inland, a line of sand barkhans 5 miles long, having at the south end the tomb of Kurumbet, and at the other, a hill apparently called Zenke-Kurgan, The river in this stretch has many islands, several of them being sandbanks covered at high water, and others being separated from the banks by only a very narrow strip of water. 
Russian invasion, in 1873 , these were said to have been well preserved, and apparently not long deserted. At 4 o'clock the Mirza went on shore, professedly to get melons, but I fancy to execute some other commission. I followed him for some distance, through reeds, long grass, and bushes of tamarisk (called yulgun), but found him going too far, and returned.

This gave me a short opportunity of seeing something of the vegetation on the banks of the Amu. It is poor enough, and generally saline. Where the banks are not inundated one meets with scrub jungle, consisting of Halimodendron Argenteum, Lasiagrostis Splendens, the Wild Djida (Eleagnus Angustifolia), a kind of Poplar (Populus Diversifolia), the Paki, or Shishan tree, Guzan (or Wormwood), Saxaul, Willows, and thickets of Briars. Also, where the banks are inundated for a season, there spring up, on the receding of the water, a few annual plants. These, with the vast beds of pampas grass, and the variegated colours of the tamarisk, afforded occasionally a little relief to what was otherwise a dreary, and I must also add a lonely, landscape, for we saw scarcely any inhabitants.*

The Mirza came at last, bringing melons, which

* Below Charjui I have mentioned towns, and in keeping with my unpublished Russian information have given the number of "dwellings." The word I have thus translated is dvor, which means a yard or court, and so a house or dwelling; but the high numbers sometimes mentioned would lead me to suspect either that the figures are put down from the mouths of natives, and so not much to be trusted for accuracy; or "dwellings" may also include shops, stalls, and perhaps also tents of the district. The distance the floods extend on either side of the river cause the habitations to be built a long way off from our route, but the fewness of boats we saw, and the rarity of human beings led me to think the river banks almost uninhabited; and if Ustik and Kabakli be excepted, this remark as applied from Charjui to the Khivan oasis would, I suppose, be true. 
did not, however, atone for the long time he kept us waiting, so that our two stoppages had been a decided hindrance, and, to make matters a little worse, we ran aground towards evening on a mud bank. Upon this the men first got out and waded about the river to find the channel, and then the horses were taken out. After this, the boat being floated, all were reshipped, and we went on till 2 o'clock. The temperature during the preceding night had sunk to $36^{\circ}$, and rose during the Wednesday to $87^{\circ}$; but a change of weather was coming, and on the Thursday morning a strong wind blew, rendering our progress slow. The temperature of the air did not rise above $65^{\circ}$, and of the water $50^{\circ}$, the specific gravity when I tried it being 96.

We were: now approaching a remarkable portion of the river, termed by the natives "Touja-moujoun," or Camel's Hump, and by the Russians Pitniaksy-louka, or the "Pitniak bend." It is perhaps the sharpest curve of the Amu throughout its course-certainly so after leaving the mountains. The arc measures 13 miles round, and 4 miles across.*

We passed the sand barkhans on the right bank, and

* The stream, continuing in its normal direction to a point 75 versts from Petro-Alexandrovsk, trends during the next 5 versts to the left, till, between the three hills called Uch-Tiube on the left, and the sand barkhan of Ak-pash, or white mouth, on the right, its course is interrupted by a perpendicular eminence rising above the water to a considerable height. In consequence the river turns sharply to the south, almost at a right angle, and for 6 versts from the turn, the right bank is a perpendicular wall. After this the wall is replaced on both banks for some scores of yards by high and almost perpendicular rocky cliffs, and the bed at Piuia Muiun is narrowed to from 1,400 to 1,700 feet. This is the Dahan-i-shir, or Lion's Mouth, through which the river rushes as if enraged by the obstacle. On getting clear of the cliffs it expands to its normal width, and opposite Pitniak makes a détour to the right for 12 versts, finishing the curve at Sheikh-aryk. Subsequently sending off, on the left bank, 5 versts distant, the great 
the tomb of Bazerviak opposite Uch-Tiube, and about 2 o'clock were approaching Pitniak, and, just beyond, on the right bank, the fort Kurtli (built by the Khivans to oppose the Russians in 1873 , and from whence the natives fled on the enemy's approach), when our men told us that we were only 9 miles distant by land (though much further by water) from Petro-Alexandrovsk. It occurred to me to escape the slow journeying by boat, and proceed on horseback, the

Palvan Ata canal, the river curves again, and resumes its normal direction to the ferry that connects Hazarasp and Petro-Alexandrovsk. In the neighbourhood of the "Camel's Hump" are cliffs of millstone grit and conglomerate, as also fossiliferous deposits. On the right bank, from the Lion's Mouth to Sheikh-aryk, are sand barkhans, and on the left, opposite Pitniak, the flat bank is cut by many aryks. In the stream is the small island of Airangi-baba, covered with pyramidal poplars, and almost the only island in the river with long-stemmed trees. Five versts beyond is a rocky cliff, 3.500 feet long, near Ike-gugurdi, and beyond that a clay cliff to Sheikh-aryk, both banks being flat down to the ferry just named. The width of the stream in the great bend varies from 4,000 to 7,000 feet, and, opposite Pitniak, nearly 10,000 feet, whilst at the diversion of the Sheikh-aryk it is 2,800 feet. The depth of the Amu in Russian territory between Meshekly and UchTiube is in some places as much as 12 feet. Near Zenke Kurgan, the line sounded from $1 \frac{1}{2}$ to 7 feet. At the commencement of the Pitniak bend it is about ro feet. Beyond the gardens of Pitniak it diminishes in the middle of the stream to 6 and 7 feet. The bed of the Sheikharyk is to feet deep.

To the foregoing concerning the Amu I may add that Colonel Yule, from observations taken at Khoja Saleh and Charjui by Burnes, computes roughly that the summer discharge of the Oxus is 70,000 cubic feet per second, that is (according to statistics kindly supplied me by the Engineer of the Thames Conservancy), rather more than double the discharge per second of the Thames at London Bridge during the spring ebb, and four times the volume of the same river at Kingston Bridge at the highest flood of 1882 , which happened on October 3 oth. Again, I have the following Russian figures, by Mr. F. B. Dorand, of the dimensions of the Oxus, as measured on July $7 *$ Igth, 1875,2 versts above Pitniak:-

$\begin{array}{lll}\text { Width of stream . } & . & 1,963 \mathrm{ft} . \\ \text { Average depth } & . & 12 \mathrm{ft} .\end{array}$

Average rapidity $\quad: \quad 5 \mathrm{ft.} 6$ in. per second.

Discharge .

VOL. II.

126,140 cubic ft. per second. 
Mirza and Centurion undertaking to bring us there. Accordingly we charged Yakoob to accompany the tarantass, and to bring it, with all our belongings, to Petro-Alexandrovsk, whilst Sevier and I, and the two Bokhariots, were to ride.

I little knew what we were undertaking; but we started in excellent spirits. Our horses, after standing so long in a leaky boat, were delighted to use their legs. The Centurion had asked Yakoob privately, before we started, whether we were fast riders or slow, and, as Yakoob told him unhesitatingly the former, we set off at a dashing pace. Our route at first lay over a desert almost as bad as the sands of Sundukli, save that here and there were bushes of tamarisk, nor did we see any footprints. At length we recognized the tracks of camels' feet, and knew that we had struck the Khiva-Bokhara caravan-route. Then, turning to the left, we entered the cultivated region of Ak-Kamysh, supplied with water by aryks from the right bank of the river beyond the point where we had left it. We passed Turkoman farms with havlis, or fortress-like farm-houses, and had gone on some miles when the Centurion and I, being ahead, missed Sevier and the Mirza. At first I thought nothing of it, supposing they would catch us up, but when this did not happen I began to get uneasy. The Centurion galloped about, but could see nothing of them. At length we mounted a knoll, and saw them coming, Sevier in the gallop having lost his overcoat, and gone back to seek and fortunately to find it. As the afternoon grew, and we had ridden fast, I began to think the 9 Bokhariot miles were uncommonly long ones, and matters were worsened by the fact of our being unable to ask any questions. We could only make signs to our guides, 
who I was afraid did not know the way, and, if they did, could communicate nothing. They kept pointing ahead, and, as the sun began to go down, I saw on the horizon a belt of trees that reminded me of those planted by the Russians at Tashkend and Vierny, and from the nodding of the men we thought we must be within sight of our destination. My Diotrephes sustained his character, and kept on well ahead; but it was bitterly disappointing, when almost dark, on reaching the trees, to find we were not at the end of our journey. Moreover, it now grew cold, and "the fun of the thing" was all gone, to say nothing of want of food.

At length we came to a collection of houses, and could make out from the men that it was Shurakaneh, which is about 5 miles east of the river. It was one of the towns through which Vambery passed, which he speaks of as having a weekly market, as surrounded by an earthen wall, and, though boasting of only a few houses for dwellings, yet consisting of 300 shops. The Turkistan Almanack gives it now only 200 inhabitants. Its distance from Petersburg is 2,500 miles. It was nearly dark when we passed through the bazaar, which looked very small, but remarkably strange, since many of the houses were built in havli fashion, though opening on to the street. The place appeared empty, and we looked in vain for signs of Russians. Presently, beyond the bazaar, we crossed an aryk by a wooden bridge that was unmistakably of European build, and this revived our spirits for a moment, thinking we must be near Petro-Alexandrovsk. But a greater trial of our faith awaited us; when, passing on, we seemed to leave every human being behind, and were making once more for the desert, and to travel there, too, in 
the dark! I confess to not liking this, for the guides were unable to give us any idea how much further we had to go; we were leaving habitations behind for sand in front, and I had heard too much of Turkomans to have unbounded faith in their honesty. It was of no use, however, to object, and I was resigning myself with a heavy heart when the Centurion, going on ahead, saw, from a hillock, something that caused him to exclaim, and very shortly I did so too; for in the distance were visible a row of lighted windows that I knew must belong to houses of Europeans, and it proved to be the windows of the Russian barracks, 4 miles from Shurakaneh, at Petro-Alexandrovsk. It subsequently appeared that the distance we had ridden, instead of being I4, was 40 versts - that is, 27 miles instead of 9. This, however, was soon forgotten, for on presenting my letters we received a welcome from Madame and General von Grotenhielm, the Governor, in whose house we were not sorry to return once more to the comforts of a Russian home. 


\section{CHAPTER LIX.}

PETRO-ALEXANDROVSK AND THE LOWER OXUS.

By what route homewards ?-The Orenburg and Aralo-Caspian routes.

-A social evening at the Governor's house.-Change of weather. - Petro-Alexandrovsk and its institutions. - Proposed desert journey. - Arrival of tarantass. - Distribution of Scriptures.Results of Bible work in Siberia and Central Asia.-The Lower Oxus and its hydrography: its delta and fall into the Aral.Fish of the Amu-daria.-Discovery therein of the Scaphyrhynchus, -Geological questions concerning it.

QUESTION of prime importance to be disA cussed on our arrival at Petro-Alexandrovsk was, "How should we get away again ?" We had lighted for a moment upon an oasis of civilization, but "many miles from everywhere," and so completely desert-locked, that we could not proceed in any direction without crossing hundreds of versts of sand. We were 400 miles west of Tashkend, in which direction there is a route, on Russian territory, followed, I suppose, by Conolly when going from Khiva to Khokand, and striking the Russian post-route at Jizakh. Another route attaining at Perovsk the Tashkend-Orenburg post-track would be by the one just mentioned as far as the Bukan-Tau, and then proceeding north through Irkibai,- the difficult road that was so bravely taken by MacGahan, the corre- 
spondent of the New York Herald, at the time of the Russian conquest of Khiva. Or, once more, if I wished to return by Orenburg, there was the comparatively easy road taken by the late Captain Burnaby on his ride from Khiva. I infer its comparative ease because Madame Grotenhielm told me she accomplished it in the depth of winter. It is very common in Asiatic Russia, when a lady or gentleman is travelling alone, to seek for a poputchik, or companion, which, among other advantages, halves the expense for the hire of horses. Whether Madame had inquired for a poputchik I know not, but she told me that at Kazalinsk, or some preceding station, they had mentioned to her that there was a lady and an English captain, both journeying independently to Petro-Alexandrovsk, and she was asked if she would like a travelling companion. Madame joined the lady ; and thus, whilst the English officer, who was none other than the late Captain Burnaby, was doing his "ride to Khiva," these two ladies, unprotected, were accomplishing a similar thing, but travelling in a tarantass drawn by a camel.

This, I was told, must be my method of progression, and the only one possible if I wished to go forward with my tarantass. The distance to Kazalinsk would be 400 miles, taking, at the least, I I or 12 days, and beyond Kazalinsk was another sandy tract of 180 miles, that must be traversed similarly before coming to a road where horses could speed forward my carriage. Matters, too, just then were made temporarily worse owing to the postal service having broken down through the contractor coming to grief financially. I had heard at Tashkend with what difficulty and expense private horses could be obtained to cover the disorganized portion of the road; and though $\mathrm{I}$ had 
it in my favour that General Chernaieff had recently travelled by the post-road to Tashkend; that the Kirghese would be wandering along the line with their horses to winter quarters; and further, that General Grotenhielm would do all in his power to help me forward,-yet I could not but see that to proceed to Orenburg promised to be a long business.

Besides, I did not wish to return by Orenburg. From the day I left London my heart had been set upon crossing the Aralo-Caspian desert. Some thought the project for me impossible. Another considered it so dangerous, owing to the uncertainty of the Turkomans, who one day may be amicable, and on the next bloodthirsty, that he strongly counselled me not to venture, even though the authorities at Petro-Alexandrovsk should pronounce it safe. The Governor-General at Tashkend offered no opinion, but said General Grotenhielm would advise me. Meanwhile we heard of two parties of Europeans who, as travellers and without a military escort, had accomplished the journey in safety. The first was a doctor, and an engineer, Russians, with an Armenian clerk, who left Petro-Alexandrovsk in March of the previous year, and crossed by the most direct route, past the well Charishli to Krasnovodsk, the 460 miles needed for this being too great a temptation to them, compared with the longer Kazalinsk route, even though people thought it risky, and called them madmen. An account of their journey was published in the Petersburg Vedomost, 23 rd March (4th April), 1882. Sevier translated the account for me as we floated down the Oxus; but, from the hills of sand that were mentioned, it seemed clear we could not cross this way in our tarantass. The second party alluded to con- 
sisted of Messrs. Capus and Bonvalot, who crossed by the same route six months later.

If, then, two Russians had accomplished the journey and two Frenchmen, why not also two Englishmen? The General thought it safe, and, besides the novelty of the route, it promised not only to save me time, but to take us towards the Caucasus, where I was anxious to see how fared, in the prisons and hospitals, the distribution of Bibles I had set on foot there in 1880 , and which I have since learned has been carried out. Another circumstance favourable to my going to the Caspian was that the General was about to despatch his monthly letter to Krasnovodsk, to be forwarded thence to Askabad, and the man who acted as postman could be my guide. This was opportune, and, all things considered, I decided to go, so that the next question was-by what route? The General could send me, he said, to Kizil Arvat, the Trans-Caspian railway terminus, but, as it was so late in the season, he was not sure whether I might not find, on reaching the other end of the line, that the local steamboat to Krasnovodsk had ceased running, in which case I should have to make a land journey of about 80 miles round the bay, with such convenience for transport of baggage as I could get. As this might detain me several days, I determined not to run the risk, but to go instead by a more northerly route.

These questions, so full of interest to us, were discussed over glasses of hot tea in the Governor's house on the evening of our arrival. In riding costume, with high boots, and all in the rough as we came off our journey, we were not highly presentable objects for a lady's drawing-room ; but Madame von Grotenhielm made us welcome, and it was a great treat to me to 
be able once more to speak direct in French to a European, and not through double interpreters as with the Asiatics. Some of the officers of the garrison came in to spend the evening, and among them was a Captain Gidayat Ullah Hadji Mirbadaleff, a native, who had been taken from Bokhara as a boy, educated, and half-Russianized at Orenburg. He played the violin, accompanied by our hostess at the piano, and whilst my ears were thus entertained, my eyes were feasted with amateur photographs of some of the ruins we had seen in descending the Amu, and others of Kunia Urgenj, the ancient capital of Khiva, through which the General said we should pass.

We slept that night near the Governor's house, in the apartments of Captain Mirbadaleff, and as we had not taken off our clothes since leaving Charjui, I need hardly add that we slept soundly. But what a change had come over the scene next morning! The windows were frosted, the ground and water frozen, and the fresh wind of yesterday had increased to a gale, and become so cold, that I thought somewhat uneasily what it would be to cross the desert in such weather. This, they said, was the beginning of winter, for which I had better prepare; and so it seemed, for the soldiers were walking in sheepskins, and civilians with their fur collars turned up, and looking the reverse of cheerful. As I had nothing warmer than a Maude shawl, my Ulster being in the tarantass, the General clothed me in a thick officer's overcoat, and in this uniform, after morning tea at his house, took me to see the "lions."

Petro-Alexandrovsk was not ten years old at the date of my visit, but looked as Russian as other towns of its class, forming a great contrast to the crowded 
houses of the Asiatics. Here was a huge square, big enough for a parade ground, and the domiciles of the few inhabitants were so spread around as to make it quite a journey from one part of the little town to the other. The troops, at the time of my visit, stand in my notes thus: 2 battalions $(1,000), 4$ sotnias $(600)$, and a battery of artillery (350); but my memory does not serve me as to whether the figures in brackets are comprehensive or distributive. The principal building of the place, on one side of the square, is the fortress, with a somewhat imposing gateway, built upon the site of a house and garden once belonging to an uncle of the Khan of Khiva. A wall surrounds the fort, and within are the Governor's house and public offices, besides officers' quarters. Autumn was too far advanced to leave any beauty in the trees and gardens, in which latter generally, at Petro, the rose is the only flower cultivated. But the last rose of summer had long since disappeared, though one could imagine the trees to afford a grateful shade in the earlier part of the year.

We visited first the hospital, with 80 beds. " Each tent of the nomads of the province pays $2 s .6 d$. yearly, for which the local government provides for the repair of roads and bridges, and a hospital, dispensary, and school. The natives, however, find their children too valuable to spare them from work, so that there were in the Sart school only ${ }_{15}$ boys. The girls are not

- There were 4.5 patients, fever being the prevailing disease, though it was said to be less dangerous here than in some parts of Turkistan. One poor fellow with typhus was very ill, and evidently dying. The mattrasses for the soldiers were of straw, for the officers of straw and hair, and in one case of hair only. The rooms were large and airy, one of them containing $8,23^{2}$ cubic feet for 8 patients-1,030 feet for each man-a contrast to the prison at Charjui, that gives less than one-tenth of this ! 
taught at all. Hence only a small proportion of the natives can read. For the Russians at Petro they have a school of two classes, containing 40 scholars.

Besides the foregoing there was in the town a public bath, that we patronized, and, let me not fail to add, a general shop, where we laid in provisions, also a lantern, a pail, and a kettle, for we were now to "do for ourselves" in a very practical sense of the phrase. It was desirable, however, that we should not purchase here such things as we could get in Khiva, because of the trouble of carriage. Shall I add the prices of articles in this out-of-the-way part of the world? Rusks, the staff of life to the desert traveller, cost is. per lb., and biscuits $1 s$. $5 d$.; candles $20 d$. Native articles, however, were cheaper; mutton $3 d$., beef $1 \frac{1}{2} d$. to $2 d$., grapes from 2 to 5 farthings, and butter $2 s$. per lb. Carrots and potatoes, $\frac{1}{4} d$. per lb. We thought we should get potatoes at Khiva, but were disappointed. Eggs cost $\frac{1}{4} d$. each, and cabbages from IOs. to $18 s$. a hundred. Prices of other things, not in our line, were, $3 s .9 d$. per yard for camlet for ladies' dresses; ${ }^{*}$ saxaul for fuel, 16 lbs. for $1 d$.; burnt bricks $30 s$. to $40 s$., and dried $4 s$. to $6 s$. per $\mathrm{I}, 000$. Monthly wages of women-servants at Petro-Alexandrovsk stood at I 4 s., and of a coachman $\ell_{\mathrm{I}}$, each with food; a horse's food costing $\mathrm{I} 4 \mathrm{~s}$. a month.

We had been favoured with some private introductions to officers, and amongst others to Captain Kryloff, whom we visited. He would have liked to accompany us across the Aralo-Caspian desert, but he was ill in bed. Another officer, who proved a valuable acquaint-

\footnotetext{
* This was the finest material of bona fide camel's hair 1 had seen, and very different from the thick camel's hair-cloth made into a prison garment I bought in Siberia, than which the Baptist could hardly have had anything coarser (Matt. iii. 4).
} 
ance, was Lieutenant-Colonel Pevtzoff, who, at the Governor's request, took great pains in equipping us for our journey, provided a small tent, and lent us a couple of water-barrels. We did not fully understand at the time the value of this arrangement, for we must otherwise have taken water-skins, which are not so desirable. A native, too, was presented to us, one Tailly, who usually undertook the carriage of the Governor's monthly despatch to Krasnovodsk.

On the morning after our arrival we were anxiously looking for Yakoob, but no news came of the tarantass all that day, nor was it till Saturday, the day following, about noon, that it arrived, whereupon I sent my promised presents to the men, by the Centurion and the Mirza, and gave them a letter to the Bek. I had now to become salesman, as hitherto a buyer, and to get rid of my tarantass and two of my horses. I was not very canny in selling the animals, for when a man came to look at them I asked only $£ 6$ for the two. He took the better of them, and obligingly told me that I had asked too little. I did better with the tarantass, which had accompanied me for 5,000 miles, for I now sold it for more than half as much again as it cost me. It was cheap, however, even so, to the purchaser at such a distance from the place of manufacture. In fact, I had asked a higher price, and my purchaser, knowing that I must sell, had quietly sent something more than half the sum demanded, saying that I might take the roubles if no one would give more. Being in a corner I was obliged to accept the offer, but it was satisfactory even then to be able to score on the right side.

I had now to make arrangements for the transport of ourselves and baggage across the desert. The 
Governor kindly interested himself, and arranged with the man Tailly that he should go forward and hire camels for us. The next need was a native interpreter, for Yakoob's engagement extended only to Petro-Alexandrovsk. Meanwhile he had improved upon acquaintance, and I was anxious that he should go on to Krasnovodsk. Like a wise man, he took time to consider, and sleep upon it, with the result that on the morrow he decided to go as far as Sary-Kamish. For this he was to have at the rate of $£_{4}$ per month, with everything found, and I promised an additional present. Yakoob bought the remaining horse I had to sell-the vicious Arab, of whom everyone fought shy, for $\ell_{3}$, so that our steeds were reduced to the two I had bought at Samarkand for Sevier and myself, and it only remained to pack four arbas, hired at $8 s$. each, to take our goods before us to Khiva.

On Sunday I asked the Governor's acceptance of 22 New Testaments, and about 100 tracts, the remainder, or thereabouts, of my stock of 5,064 Scriptures and 12,000 other publications, given and sold since leaving Petersburg. I had now been privileged to accomplish my heart's desire in distributing enough copies of the Bible and portions thereof, so that at least one might be placed in every room of each prison and every hospital in Russian Central Asia, the complement to what I had done, three years before, for each prison and hospital in Siberia. I had also left a large number to be distributed to free exiles passing to their remote destinations in the interior. These have been distributed as I wished, and thankfully read on the way, as there is written testimony to show.

I hear that several books have fallen into other, but most suitable, hands. Many of the poorer class 
of Russians, located near Samara, where living is dear, have lately been migrating with their families into Siberia, far beyond Omsk and Tomsk. They are described to me as all decent well behaved people, a great many of them being able to read; and my correspondent says, "It would do one's heart good to see how glad they are of the Bibles, and how carefully they wrap them up." And well they may, for they will perhaps not have the chance of getting more for years to come. The books in quantities for the hospitals and prisons I had to leave with the authorities, and in the case of those who bought I have little to tell, because I was as one deaf and dumb, and I could only hold up the book, and name, or point to, the number of kopecks demanded.

Many will be sceptical, no doubt, as to the ultimate worth of such an undertaking. Its value, however, must not be judged as if it had been done now in England. There was not a Bible depôt in all Turkistan until the year I went there, and the open distribution of tracts, I wot, had never been seen there before. Not that I would seem to forget what has been done in European Russia. As I walked through the Moscow Exhibition I came to a stall whence 300,000 tracts had been distributed in 40 days, and the British and Foreign Bible Society had given 10,000 copies of the Gospels to be similarly distributed there. Again, I was cheered in Ekaterineburg to meet with an agent of the Bible Society, who, in 8 years, had sold 8,079 copies for $£ 23^{8}$. Telling me of his difficulties in so doing, he said he had sometimes striven to incite inquiry by offering to sell a peasant a New Testament for Io kopecks, and, when read, to take it back at the same price. But in this he had not always met with success, 
for so densely ignorant were they, that they preferred to keep the $2 \frac{1}{2} d$. in their pocket, and forego the reading of the book. So, too, I have mentioned an officer at Tashkend distributing Scriptures among his soldiers.

Fallow ground, therefore, is being broken in various parts of the Empire, and I have heard incidentally from travellers, who have been in Siberia after me, that the books I left are exceedingly valued. The 2,498 Scriptures distributed in Siberia and Central Asia by the agents of the British and Foreign Bible Society in 1881 , increased in 1882 sixfold, to 14,638 , and of three causes contributing to this, the Committee were good enough to reckon my efforts as one. I am hopeful, therefore, that my labour has not been in vain, and I am still more hopeful of what is to follow, for the experience of all ages has been that those who submit themselves to the teaching of this book are elevated, improved, and blessed thereby. I strongly urged upon the Committee, in 1879 , the hastening of what they had long been contemplating, namely, the opening of a depôt in Siberia, and, what is better, I have been able to find a Finnish nobleman, who for this purpose was willing to give up his father's home and family, and go into voluntary exile to Irkutsk. A depôt is now opened there; 1,048 copies were sold during the first three weeks, and by the latest report of the Bible Society (for $188_{3-4}$ ) I perceive that Tomsk, Blagovestchensk, Kiakhta, and even Yakutsk are indicated as future centres around which colporteurs may travel with the Word of Life. To have initiated or helped forward such a work, therefore, I count an honour to be remembered through life, and I was thankful for the point attained to at Petro-Alexandrovsk.*

* From the last report I see the circulation from the new Tashkend 
Some weeks after writing the foregoing paragraphs I happened to pick up part of a report of the Bible Society $(1882-3)$, and my eye chanced to fall on the following :-

\section{"A Man of the World ARREsted.}

"A worldly man in a good position, but alienated from God, was in Helsingfors on business, when he received a telegram from his wife, saying that his favourite child was dying, and that if he wished to see her alive, he must hasten home. He set off with his heart full of bitterness against God, so much so that he cried out as he sat in the sledge, 'Thou mayest take my child, but me Thou shalt never have!' The driver was shocked by his language, and cried, ' Such a blasphemer I never met!' Coming to a station where he had to change horses, while he was inscribing his name in the way-book he observed a copy of the New Testament and Psalms on the table, one of the books which we (the British and Foreign Bible Society) have helped to place in each inn, station-house, and passenger steamer in Finland. Almost automatically he opened it, and his eyes fell upon the first verse of the first Psalm, 'Blessed is the man that walketh not in the counsel of the ungodly,' etc.

"The words fastened on his mind, and he could not drive them from his thoughts. As the horses were not ready, he took a turn in the open air, brooding over the words, and when he came to the next station he read them again in the book he found there, and in order to retain them he copied them on a piece of paper. As he thought about them, he felt that 'the way of trangressors was hard,' and began to realize his sinfulness.

"When he came home he learnt that his dear child was gone. Though overwhelmed with sorrow, he sought the Bible for comfort; there was no copy in the house; and he had to send out to procure one, but in its pages he found consolation. He has not only continued to read it, but he makes it the guide of his life."

The reader will understand my thankful surprise on reading this when $\mathrm{I}$ add that the narrator of the story was none other than my friend Miss Alba Hellmann, who put it into my head to go to Siberia; and the words I have italicised represent the distribution of depot, for $188_{3}$, amounted to 3,202 copies, and for Siberia and Central Asia combined, 10,864 copies, besides the circulation effected in Khiva and Bokhara by colporteurs from the Caspian, as will be mentioned hereafter. 
Scriptures in Finland as the outcome of my journey there in 1876 . Here, then, is fruit found after many days, and not a few, I am sure, will join in the prayer that it may be so again and again in Asiatic Russia.

I have intimated that our tarantass arrived on Saturday, but I have omitted to say that it narrowly escaped a watery grave, for the boat ran aground after we left it, and was so damaged thereby that they were obliged to bring forward the carriage in another boat to, I suppose, the ferry connecting Hazarasp and PetroAlexandrovsk, down to which point I have brought my description of the Amu-daria. Two days later, I had to cross the river once more, and say farewell to this noble stream, but I ought not so to do without pointing out the characteristics of the Lower Oxus.*

The whole course of the river below Petro-Alexandrovsk goes through a low-lying country. The basin is covered with bushes, sometimes thickly, the tamarisk being specially abundant, and with this growth below Nukus reeds and rushes intermingle. At Nukus the delta of the Amu begins, so that the waters of the river ultimately reach the Aral Sea by three outlets-the

* The course of the Amu from the Hazarasp to the Khanki ferries, a distance of 13 miles, and for 4 miles beyond, rolls on in one stream with islets, after which, for 16 miles, the Oxus spreads out in some places to a width of 4 miles, with numerous channels and larger islands, on the left, and Sheikh-abbas-Ali on the river lie the towns of Urgenj stream, on the Sheikh-abbas-Ali on the right. Further down the in summer standing is Gurlen, up to which point the banks are flat, and the right bank djeili mountains, gins to be skirted by the rocky ridges of the Sheikhinto the river, forming, opposite the Khivan town of Manghit, project is about 600 yards. town of Kipchak, Seven miles below Manghit is the small Uzbeg same left bank, 40 milesite Lake Khoja on the Russian side. On the nearly opposite is the Russian for, is the Khivan town of Khojeili, and

VOL. II. 
Kuvan-Jarma, or Yangi-Su, the Ulkun-daria, and the Kunia-daria, or Taldik.*

Prior to 1859 , the waters of the Amu reached the town of Kungrad, 66 miles from Nukus, so that Captain Boutakoff took his two steamers, the Perofski and Obrucheff, by the main channel to Kungrad, and passed by the Taldyk and Ulkun-daria to the Aral. In 1859 , the Khivans built dams on the Taldyk and Ulkun-daria. These have completely prevented the entrance there of ships from the Aral. Along the banks of the Taldyk are ruins of forts and traces of canals and engulfed fields; this desolation dating from 1858 , during the war between the Ruler of Kungrad and the Khan of Khiva. Thus the noble Oxus, on which I had floated above Pitniak, where it has a volume of 126,000 cubic feet per second, enters the Aral by three ignoble streams, the river having been drained of half its waters before reaching Nukus.

- The Kuvan-Jarma is now the most important of the branches of the Amu. Eighty-seven miles from Nukus it enters lakes Kungrad and Kara-Teren, emerges, after 17 miles, as the Yangi-Su, or New River, and falls into the Aral 40 miles beyond. This branch of the Oxus was navigated, in 1873 , by some of the Aral flotilla, but with difficulty. It appears that this waterway would be practicable for vessels only in time of flood, since at other times of the year the depth of Lake Kungrad does not exceed a foot. At the mouth of the Yangi-Su shallows abound, and the passage through these, with their 5,6 , and 7 feet of water, is possible only in calm weather and by day. The Amu at Nukus, having discharged about one-sixth or seventh of its water into the Kuvan-Jarma, has still a considerable volume of water for 30 miles further, flowing north-west. Then there begin to diverge to the right four branches, one after the other, and these completely drain the principal stream dry. It is then called the Kunia-daria, or Old River The bed, after being dry for 17 miles, collects from the backwater of several channels, the largest of which is the Sar-Krauk, that enters the Kunia-daria 33 miles above the Khivan town of Kungrad. From Kungrad the Amu reaches the Aral by two channels, the one on the left flowing due north, under the name Taldyk (or Tardyk), and the principal stream to the north-east, called the "Ulkun," or Great-daria 
There is one more subject connected with the Amu that ought not to be omitted-I mean its fish, and especially one species, called the Scaphyrhynchus. Whilst floating down the river, the natives gave me the local names of Amu fish as Songan, Laka, and Znggara. Yalbashi is their smallest, and Nahang their largest, which last sometimes weighs up to $13 \mathrm{cwt}$. They gave me the price of fish at $6 s$. per cwt. At PetroAlexandrovsk they quoted the price of sturgeon at $4 d$. per lb., but from $4 s$. to $6 s$. for a whole fish of from 30 to $40 \mathrm{lbs}$. weight. They have no eels, they said, and do not eat pike, nor the scaphyrhynchus, which last the natives called Tash-bakre, and the Russians Chaklik. It is a kind of sturgeon, and, when discovered in the Syr-daria by Fedchenko, it excited a good deal of interest amongst naturalists by reason of its resemblance to one of the species of North American sturgeons.* The Turkistan fish was at first supposed to inhabit the Syr-daria exclusively, but some time afterwards interest in the matter was heightened by the discovery of another species of scaphyrhynchus, by M. H. Bogdanoff, in the Amu-daria.

The fish belongs to the order Ganoidei, of the family Acipenseridae. One form was found for a long time in the Mississippi only, till Fedchenko unexpectedly brought to light his specimen taken near Chinaz, which has been named after him Scaphyrhynchus Fedchenkoi. This discovery suggested that a similar form might perhaps be found in the Amu, and so it proved. The new species was called Scaphyrhynchus Kaufmanni, + and is especially in-

The Syr-daria species was described by Kessler in the Annals and Magazine of Natural History for October, 1873, and a note was added by Dr. Albert Günther.

+ The Scaphyrhynchus Kaufmanni, according to Bogdanoff, is dis- 
teresting, Bogdanoff points out, from a geological point of view. In the Palæozoic period, he says, the ganoid fishes used to inhabit all the waters of the world in a great number of forms, and composed almost entirely the ichthyological fauna of that period. During the Devonian period this group of fishes

tinguished from the American and Syr-daria species by the following marks. The head is large, equal to one-third of the entire length of the fish. The front is broad and flat, and has the form of an equilateral triangle, with the sides bent out. The bony shields on the "temeni" and between the eyes have sharp spines turned backwards, two pairs in number. On the upper side of the head, near the summit, are from 3 to 5 long, sharp, small hooks. With other scaphyrhynchi similar hooks are found in elementary form, or not at all. The plates over the gills, at each side of the head, have also two hooks. The eyes are very small; the mouth very broad; the bony shields on the head are well seen, and not covered with visible skin as in the American form. The gill covers are broad, and the back border has a soft skin. The body, beginning from the head, gradually tapers towards the tail, without any thickening of the abdominal region as with the American. The rays are fewer in number in the dorsal, pectoral, and ventral fins, than with the other two species of the scaphyrhynchus. The root of the tail is very short; the thread with which it ends is long. The air-bladder is not large, but entirely developed. In the work of Bogdanoff is a table comparing further the Amu, Syr, and American forms. The eyes of the Chaklik are smaller than those of the Syr-daria species, and twice as small as the American; but the mouth, on the other hand, is twice as broad. The largest Chaklik caught by Bogdanoff measured 700 millimetres from the point of the nose to the end of the tail. The natives say they catch much bigger ones. The colour of the fish is very changeable, sometimes blackish, and darkly marked. Some have no markings, but are of yellow tint, through which the pinky colour of the muscles is seen. Up till now, Bogdanoff says, the Chaklik has been found in the Amu only between Ust-Uchak and Nukus. Probably it is to be found in the delta, but not, he thinks, in the Aral Sea. It does not migrate into the canals, nor the lakes, and keeps always at the bottom of the river, choosing places with a rapid current and sand-banks. This, probably, accounts for the natives calling it "Tash-bakre," or "stone ossitrina." Its food is exclusively animal, such as worms, mollusks, and fish.

Besides the two species already mentioned, I am informed on the authority of Mr. Alpheraky, that a third species from Turkistan is now known-Scaphyrhynchus Hermanni, Sem. 
seems to have reached its highest development, and in the strata of this formation are preserved the most numerous remains of its representatives. In the succeeding geological period, this group appears to fall and die out, giving place to the Teleostei, or bony fishes, of numerous forms and widely distributed. At the present time the ganoïd fishes are but of 6 forms, with bony skeletons (that is, sub-order Holostei), and about 20 forms of ganoïds, with cartilaginous skeletons (Chondrostei). To the last belongs the family of these Acipenseridae, consisting of four genera, the Acipenser, Scaphyrhynchus, Polyodon, and Psepharus. This paucity of forms of a once rich group of ganoïd fishes makes every discovery of great value, because each newly-discovered species increases the possibility of tracing the progressive development of the organisms of the group, and also the history of their life in the waters of the world, together with the part they play in nature.

Only three European authors, other than Russians, so far as I know, have travelled the Lower Oxus, namely, Professor Vambery, Mr. MacGahan (who, by-the-bye, was American), and the late Major Wood, each of whom have published their experiences ; and now, having added such information as I can, chiefly from Russian sources, I shall proceed to the description of my journey to the capital of the Khivan Khan. 


\section{CHAPTER LX.}

FROM PETRO-ALEXANDROVSK TO KHIVA.

Departure with the Khivan Consul.- - Journey to the Oxus and crossingArrival at Khanki. - Extraordinary sepulchres. - Central Asian funerals.-Our lunch and native food.-The Khivan oasis and its dimensions.-Its gardens and principal aryks.-Arrival in Khiva at the house of the Divan-beggi.-His antecedents and visit.Inspection of his premises. - Our visit to the Khan.-Khivan manuscripts and documents.-Burnaby's "Ride to Khiva."

E left Petro-Alexandrovsk on Monday morning, October 3 oth, at 7 o'clock, having broken our fast, not with beefsteaks and coffee as an Englishman would before starting for a 40-mile ride, but on tea and biscuits, which is the usual beginning of a Russian day's eating. The ground and trees were covered with rime. Diotrephes was fresh after three days' rest, and he and I soon agreed upon a gallop. Sevier was ready to follow, but the rest of the party lagged. We were escorted by an old Uzbeg whom the General called "the Consul," a djiguitt, and two or three followers, all of them natives. The Consul was a sort of representative of the Khan at Petro-Alexandrovsk, so that when the Russian authorities had any communication to make with his Highness, it was done through this man. The General spoke of him not quite as his lackey, indeed, but he bade me fix the 
time I would start in the morning, and he would then "tell the Consul to be ready to take me," and so on. Accordingly, when I found my attendants lagging, I sent back to urge them to mend their pace; but the Consul sent me word that he was a man of importance, and that to hurry would be beneath his dignity. Whereupon I examined him attentively. He was of more than three-score years, dressed in a blue cloth outer khalat, edged with fur, and two khalats beneath, confined by a girdle with an agate clasp, from which were suspended two knives, a hone, and scissors, the last stamped "London." He wore a very tall, black hat, I think of Kara-Kul lambskin, and out of the top peeped a piece of blue cloth. He was mounted on a tall Turkoman horse, whose tapering neck was encircled, like a lady's waist, with silver straps, the bridle also being mounted with silver and with agate. I had, by chance, spoken to Madame von Grotenhielm of this provoking nonsense about grandees riding sedately, and she had told me that her husband, when accompanied by the Consul, rode ahead at his own pace, and left the old man to follow; which, in this case, was all very well, partly because his Excellency knew the road, and next, being Governor, the Consul could give himself no airs.

In my own case 1 modified the General's plan by riding forward, but frequently turned off the road to look at objects of interest, of which there were plenty in a country where to me almost everything was new. Our route, at starting, lay for 7 miles to the northwest, parallel with the Amu, and about 3 from it. We passed the Cossack cavalry station, and also, a mile after starting, a tower in ruins, a minaret of burnt brick, and adjacent tombs, some of them being partly 
covered with vegetation, whilst others were simply mounds of clay. On coming opposite to the Khanki ferry we turned to the left at right angles, and, crossing four narrow canals, bore down straight to the river, a good part of the way over land that is submerged in time of flood. On a Russian map I have, r 3 versts to the inch, the river's width at the ferry is $2 \frac{1}{2}$ versts, and it took us about an hour to cross. We did not float all the way, but were three times landed on islands that look small in the map, but whose area in each case was sufficiently large to lead me to think, in getting out of the boat, that we had reached the Khivan bank.

When this was really the case we rode across steppe country till 10.45 , and then began the fields, or socalled Khiva "gardens"; this word being applicable in the fashion that one speaks in Kent of hop "gardens," only that the Khivan ones are not a tenth so pretty. The ditches round the fields were skirted by willows, djida, and pollard mulberry trees. At 1 i we reached Khanki, where Vambery spent a night in the Kalanter Khane, or quarter for dervishes, and where Captain Burnaby slept in the house of the governor.

As Diotrephes and I, ahead as usual, approached the town we came to a cemetery, and seeing some of the tombs in a very dilapidated condition, I had the curiosity to dismount and peep within, when, to my surprise, I saw two or three skulls and other bones lying on the surface, as if they had never been put beneath the ground. And this I gathered is sometimes the case.*

* Funerals among the Sarts, it would appear, are not attended with much ceremony. As soon as a person dies, the women of the household collect in a corner, and begin to wail and beat their heads. The apprised neighbours come in, and grief reigns within the house of the deceased, whose acquaintances flock together during the whole of that 
I could hardly believe Yakoob, on his coming up, when first he said this, because in such a hot country it occurred to me that the effluvia of a graveyard would be terrible. But he said that it was so even in Bokhara, where the graveyards do smell offensively in summer. At Samarkand he said the graves are made 6 feet deep, but that at Bokhara, as at Khanki, there is lack of room, and hence the practice alluded to. Moreover, he added that the same vaults are used over again, the bones of the former occupants being pushed into a corner to make way for the new corpse, which might have been the case with the three skulls I saw in one tomb; or, again, it seemed they may have been originally placed there together."

In this graveyard at Khanki the orders of Josiah

day. It was one of these assemblies I had asked to see in Bokhara, Conversing afterwards with Yakoob, I gathered that the probable reason why I bad not been allowed to do so was the propriety of introducing strangers to the presence of women. Yakoob said that we had passed houses in Bokhara where the wailing was audible, whereupon I reproached him for not telling us, but he said he supposed we heard it. On the day after death, the corpse, shrouded in a cloth, is taken to a mosque, whence, after some reading of passages from the Koran, it is borne, in a sort of coffin, to the cemetery, or wherever the testament of the deceased directs. The kinsmen and acquaintances divide amongst them the shroud, and the coffin is brought away again, the body (when not buried) being laid under a clay tomb, of which the ends present the form of an equilateral triangle with the sides bent out.

* May not this illustrate $\mathrm{I}$ Kings xiii. 31 : "When I am dead, then bury me in the sepulchre wherein the man of God is buried: lay my bones beside his bones"; or, again, the hurried thrusting of a corpse into the sepulchre of Elisha (2 Kings xiii. 2I)? Evidently it was this kind of sepulture adopted in the case of Lazarus (John xi. 38,39 ), and not our fashion of putting beneath the ground; so also in the case of our Lord (John xix. 41 ; xx. II).

After a Sart funeral, those collected at the deceased's house listen to the reading of the Koran. The next day the same thing is repeated. The third day, after morning prayer, the mourners go straight from the mosque to the requiems, and again listen to recitations from the Koran, and then, having eaten, disperse. Requiems are repeated for 7 or 10 
could have been easily executed when he "sent and took the bones out of the sepulchres and burned them upon the altar."* By way of explaining why the cemetery was so full, Yakoob said the cost of land at Khanki was as much as $£_{55}$ the acre. This certainly was a great jump from that of Petro-Alexandrovsk, where I heard of a man buying poor land for $12 s$, the acre.

Lunch was prepared for us at Khanki, in a suburban house with farm buildings, and we squatted round a fire on the hearth in the centre of the room. I offered the Consul a glass of my English tea, which won his keenest approbation. They used to get in Khiva Indian tea, but the Russians have practically shut it out of the market by a prohibitive duty. Consequently the natives drink "green tea," as they call it, costing from $3 s$. to $4 s$. a pound, or, if they desire better, black Russian "family" tea. The Consul pronounced, however, "Green tea is good; family tea is better; but that tea would make one as 'fat as a camel "!" I observed on the hearth a curious pair of tongs, so clumsy that I thought to get the like for days. On the occasion of yearly festivals the women collect at the grave, and, with wailings and lamentations, call up memories of the departed. Women are paid to do this, and the Muhammadan just alluded to told me they wail so loudly as to make one run away. This appears to agree with the custom obtaining in the time of the Evangelists, of whom Matthew (ix. 23) records, "He saw the minstrels" (I did not hear of these in connection with Central Asian funerals) "and the people making a noise" ; and Mark employs a stronger term (v. $3^{8}$ ), "them that wept and wailed " (or shouted) "greatly."

Those who assemble at the requiems give alms for the poor and the insane, and the mention thus together of funerals and insanity recalls what they told me at Bokhara, of turning loose the incurably mad. Indeed, one could easily picture neglected lunatic s taking refuge in empty sepulchres, like those I saw, and "coming out of the tombs, exceeding fierce, so that no man might pass by that way " (Matt, viii. 28).

* 2 Kings xxiii. 16 . 
a curiosity, and I asked the Consul whether they could be purchased in Khiva. He said "Yes," or they would make a pair like the English to order; but I told him I was anxious to take the native article, with a view to improving the English taste! This joke tickled the fancy of the old fellow, who had already thawed under the influence of tea, and his tongue wagged apace.

I had made several inquiries concerning the food of the natives, for with this we were to be regaled again for some time. Of course, they eat no pork, and some eat neither hares nor rabbits, though they are not forbidden. Camel, I believe, is forbidden, and in Bokhara not eaten, neither there, they said, are horses, but the Kirghese eat both. Goats would appear to be not much used for food in Bokhara. We heard there of a porridge of rice and milk, and of lapsha, a sort of vermicelli. To these may be added fowls, ducks, and geese, and, near the Oxus, pheasants.*

They gave us at Khanki some gravy soup, which was thought a delicacy, and, after resting for an hour and a quarter, we resumed our journey under a bright sun, but without sufficient power to melt the rime and thin ice on the ponds. About 5 miles from Khanki we passed the ruins of Nakhaia, a small stronghold; then 5 miles beyond, the village Gudja ; and, 3 miles further, another village, Nadubak. For the first hour we had gardens

* It must not be supposed, however, that the people in general feast on these dainties daily. The rich live on pilau. The well-to-do families live on bread and tea daily, but pilau on Thursday and Sunday. Workmen, carters, etc,, have pilau daily, and shopkeepers eat pilmain, or pieces of meat on a skewer, costing a poolah each, and not all off prime joints, but some of liver and inferior parts. They drink a good deal-in summer, ice and honey. The poor make soup out of wheat and other grain, and the poorest eat sorghum. 
right and left, and then came a patch of unoccupied land, needing water only to make it fruitful, as was apparent from the portions of it enclosed and irrigated, giving a lively picture of garden and desert side by side, with only a wall dividing. In my note-book I have marked the road to Khiva as traversing gardens, desert, and steppe, for we saw some of each, though we were supposed to be passing through a rich country.

The Khivan oasis is in some respects unlike any other country I have visited. A well-written article on Khiva, in the "Encyclopædia Britannica," describes the khanate as a fertile oasis, 200 miles long and from 25 to 30 miles wide, stretching along the left bank of the Lower Oxus, between Pitniak and the Sea of Aral, with an area of from 5,000 to 6,000 square miles, or about three-fourths the size of Wales. So far as mere area is concerned these figures are approximately correct, but the reader will have an exaggerated idea of the oasis if he supposes it to consist throughout of gardens and fields. I have before me my Russian map of largest scale, wherein the cultivated soil is coloured green, the sands orange, and the uncultivated land is not coloured at all. On this map the famous gardens of Khiva shrink to very small proportions. They are, in fact, the lands bordering on the aryks and canals; and where the water from these does not reach, there is sandy desert, or barren or unoccupied land."

- I can fitly describe the arable surface of the khanate in connection with its aryks and canals. At Pitniak there is a small patch of green about 8 miles long and $\frac{3}{4}$ mile wide. Ten miles further down the Amu there leaves the river the great Palvan-Ata-aryk, running almost due west, a course of about 50 miles past Hazarasp and Bagat to Khiva. It throws out canals and smaller branches all along this stem, 


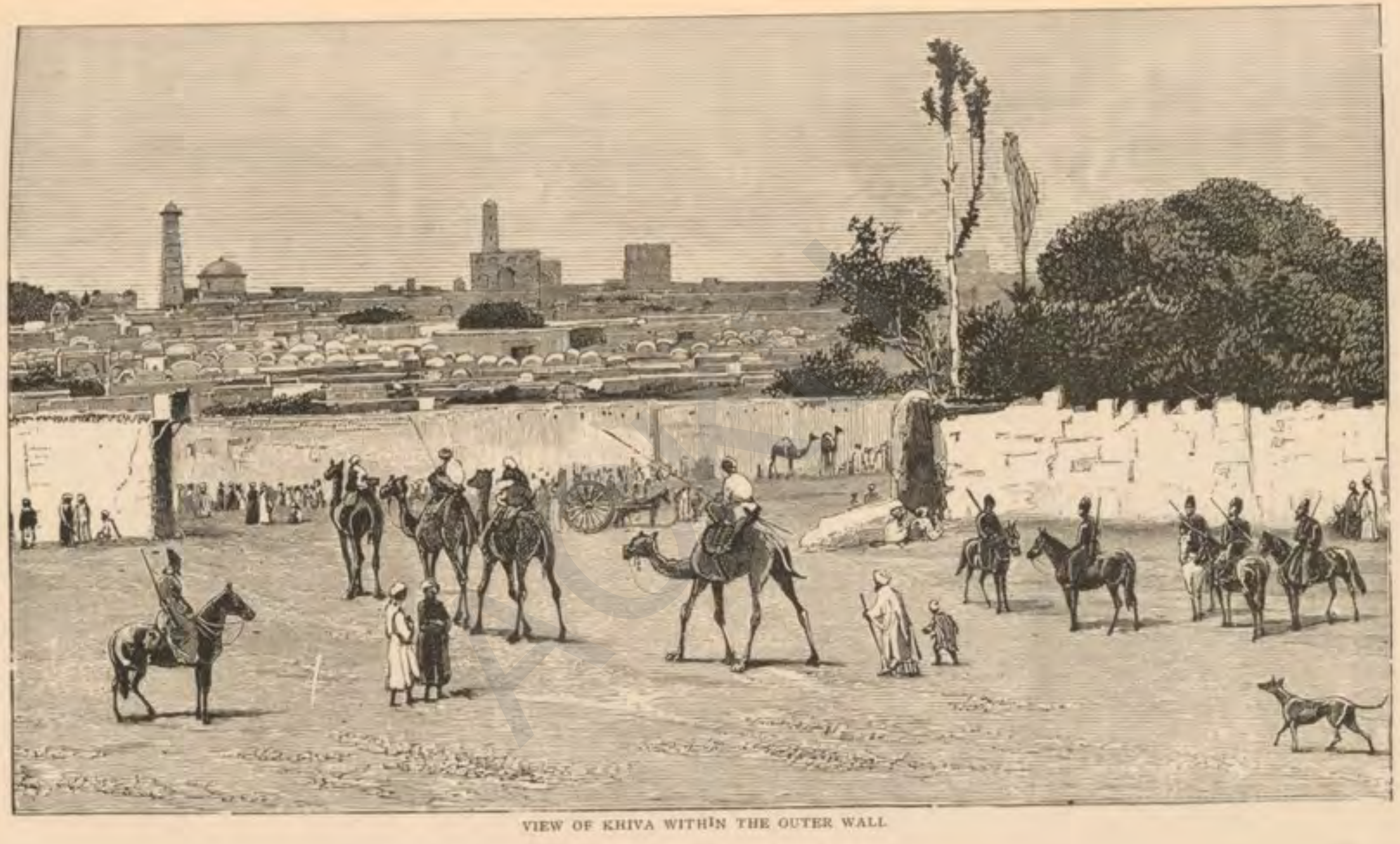


I was reminded of the arid character of the soil by my horse making for a water-trough at the side of the road, which was unhappily empty, and we had to go some distance further, not seeing a road-side pool, or stream, till we came to what they called a Sart station, where water was drawn from a well for our animals. We saw cattle in two or three places near the numerous fortified farm-houses, or havlis, and, as we drew near to Khiva, met a large number of arbas returning from market. At sunset we came in sight of the city, and beholding, with satisfaction, its towers and minarets standing out against a reddened sky, we entered the gates at half-past 5 . They called the distance 60 versts, or 40 miles, but by neither of my maps can I make it more than 50 versts. Captain Burnaby rode between Khiva and Khanki, a distance he calls 60 (but which should be 30 ) versts, in 6 hours, so I suppose we had done fairly well in accomplishing 50 versts in 8 hours, excluding rest, and crossing the Oxus. Any-

like a well-trained espalier tree, till it disappears in the desert, 3 miles west of the capital. This aryk waters a larger area than any in Khiva, an expanse of garden ground, say 45 miles long, and varying from 6 to 12 miles wide. The next large aryk, called Khazavat, or Gazavat, leaves the Amu 5 miles below the Hazarasp ferry, flows off to the north-west past Khanki, Kosh-Kupyr, and Khazavat, and into the desert 70 miles from its source. This aryk is longer than the former, but it gives verdure to a belt of country not usually more than a mile, and never more than 4 miles wide on either bank. The next large aryk, Shakh-abad, leaves the Amu opposite Urgenj, gives off no small canals until it comes to Shakh-abad, then continues north-west past Ambar, Tashauz, and Iliali, and disappears near the ruins of Kokchuk after a course of 80 miles. Between this aryk and the preceding one there is a tongue of sandy desert, varying from 1 to 7 miles wide, and the band of verdure on either bank rarely exceeds 3 miles in width. The foregoing are the largest three of the Khivan aryks; the remaining two, Yarmysh and Klych-niaz-bai, run in a similar direction further north, but present on the map the appearance of bare branches with a few leafy sprigs at the ends, whilst nearly all the land between the Shakh-abad aryk and the Amu is barren or uncultivated. 
how, it was the longest day I had spent in the saddle, and I was thoroughly tired.

They conducted us through many streets, nearly empty at dusk, though, of the few inhabitants that were about, some saluted us, and I observed one man, on recognizing the Consul, formally descend from his horse. After winding about a long time we came to the house-or shall I call it palace?-of no less a person than Matmurad, the Divan-beggi, or prime minister of the Khan. We passed through sundry courts and passages, and entered the guest-room, where I fancy Russian embassies are usually lodged. It was less Oriental, but more comfortable, than the rooms we occupied at Bokhara. The windows were glazed, there was a petchka, and an iron stove, also a table at which one could sit without having to stoop unduly. On this was a Russian lamp, and in the room two clocks, each bearing false witness against its neighbour, and both being many hours wrong. At one end of the chamber was a divan, and in the opposite wall were indented niches containing sundry Russian confections, coffee, wine and champagne bottles. The last agreed with a whisper I heard at Petro that champagne was not tabooed at the most orthodox court of the Khan, Muhammadan though he be. From this apartment a curtained doorway led to what was to be my bedroom. The walls were papered, and adorned with a mirror and Turkoman carpets, the most noteworthy object in the room being a large bedstead, stretching lengthwise all across the room, with a gateway into it. It must have been a peculiar bed, however, whereon I could not have slept that night, and when I awoke in the morning my limbs had not perfectly recovered from the effect of the previous day's exertion. 
Soon after breakfast we received a visit from our old conductor, the Consul, and our host Matmurad, who had thoughtfully spared us a visit immediately on our arrival. This Matmurad, it should be observed, is a man whose name will go down to posterity in the pages of MacGahan and Howorth. At the time of the Russian conquest there was a division of opinion among the Khan's counsellors. Some urged submission, but Matmurad, having headed the militant party, and being very hostile to Russia, was sent a prisoner to Kazalinsk, and thence, as he told us, to Kaluga in Russia, his son Polvan, in his absence, taking his place at court. Subsequently Matmurad was allowed by the conquerors to return, after which he was reinstated as Divan-beggi, " next unto the Khan, and great among the Khivans, and accepted of the multitude of his brethren."

Matmurad asked about my health and requirements, and I told him what things I desired, naming among them some photographs, if possible, of Khiva, which I knew some Russians had taken. He replied, however, that there were none to be had. I then invited him to ask me questions, whereupon he inquired whence I came, whither going, and what the object of my journey ; further, hearing that I had been round the world, he wished to know which country I liked best. Of course I said England, whereupon he asked if the people in England were good and hospitable. I replied truly, "Not more hospitable than here, but better educated," and as to their being good, I quoted one thing in which England is conspicuous above every nation of the world in that she spends yearly more than half a million of money in carrying the means of improvement and reli-

\footnotetext{
- Esther x. 3.
} 
gious enlightenment to the ignorant and heathen parts of the earth. On hearing that I had distributed 50,000 books in Siberia, he asked, "What book?" I then mentioned the Bible, saying that I could give it in Persian and Arabic, but that it was not printed in Uzbeg.

We were then informed that the Khan would receive us in about four hours, and after that we might go and see the city. I therefore asked to be allowed in the interim to look over our host's premises, which had for us this advantage over those we occupied at Bokhara, that they were not apartments occupied by our noble selves merely, but by a great man's family and servants. They told us there were in the establishment the 4 wives and 5 sons of the Divan-beggi, and 100 men-servants and their wives; but so little did the men-servants (the only ones we saw) know of the women's quarters, that they could not tell how many daughters their master had, or even if there were any. MacGahan says that, at the time of the Russian occupation, Matmurad possessed 400 slaves. Within the high walls surrounding the premises were a garden, several courts, and buildings. The houses were new-in fact, not quite finished-and showed unmistakably that the owner had adopted in captivity many Russian ideas. Matmurad's own chamber was entered through an ante-room, devoid of furniture, and almost of light, with a prettily carved door, said to have cost about $£_{3}$. In the chamber was a bath, and a hearth, measuring 68 inches by 40 , wide enough for a bonfire. There was likewise a table, some books, or portions of the Koran, a harmonicon, and a pair of gloves (the only ones we saw in the khanate), whilst on the wall hung bridles, guns and pistols, many of them presents from the Russians. There VOL. II. 
was also a bedstead large enough for two persons, a chandelier, presented by the Khan, a huge glass lantern, big enough for a good-sized clock-case, and, as the acme of Khivan refinement, coloured glass for the windows. In the butler's room were birds in cages, musical instruments, and a board for chess, at which they play skilfully. In the mirza's, or secretary's, room was a Sart scraipka, or fiddle, a poor-looking goldfinch, and a hawk in training for hunting wild sheep. In one of the courts was a tent, erected evidently for a permanency, and intended, in its present position, for a Bek and his scribe, though one could see the convenience of such a thing in Khiva, inasmuch as if the Divan-beggi's business called him to travel in the khanate, he would have a habitation to carry with him.

Thus far we had only seen the winter house, but I was more interested in the summer house, not yet completed. It had an upper story, and an outlet on to the roof, where they commonly sit, and lounge and talk. By mounting the roof we could see that the outer walls were tipped, not with broken glass, but with thorns, and the wall of the women's apartments was pointed out, whilst below us was the garden and a pond, with adjacent trees of karagatch, whose dense shade would make the spot cool and agreeable in summer. The karagatch is used for carvings, especially for the two lofty ornamental pillars, which, in palaces and great houses, support the roof of what I must call the portico, covering the wide gallery or platform in front of the principal dwelling-rooms. A block of timber, to make such a pillar, costs in Khiva from $£_{1}$ to $\ell_{5}$. Our host had given $£_{2}$ for his, and I measured the pedestal 30 inches square, 
whilst higher the greatest circumference was 6 feet 7 inches."

Besides the summer house of the Divan-beggi, we visited, in a different part of the premises, the house or rooms of his eldest son, and other apartments reserved to another son, a good-looking boy of ${ }_{15}$, whose education was not finished, and who showed us one of his copy-books illuminated. Near at hand, tied up in a court, was an enormous ram kept for fighting. It measured 5 feet from the horns to the extremity of its fat tail, 3 feet across the wool on the back, and stood 3 feet high ; but the most interesting part, perhaps, of the premises was the stud yards, a small one for the sons' horses, where they stood in the open, covered with felt from ears to tail, and a larger one for the steeds of the Divan-beggi. Here we saw some good Argamaks, the biggest and strongest of Turkoman horses. One of them cost $\ell_{17}$, another $\ell_{24}$, and the best, under cover in a stable, $£ 45$. The prices of such horses at Petro-Alexandrovsk had been given us as from $\AA_{1}{ }_{5}$ to $\ell_{20}$, and of a cow $\ell_{3}$ ios.

After inspecting our host's premises, we were sent for, about half-past 3 , to see the Khan. Preceded by

* These pillars suggested a partial elucidation of the passage in Judges (xvi. 29) concerning Samson's death. Given a man making sport before these pillars, in a position to be seen best from the roof of the portico, and the adjacent portions of the building; then, having been guided to the pillars (ver. 26 ), he could, sufficient strength being granted, dislocate them quickly one after the other, before bringing down the structure on his own head. This house of the Divan-beggi would be no illustration for the size of the house of Dagon, with the 3,000 men and women stated to be on the flat roof, but it is a question whether this Khivan roof, being covered with people, and the two pillars gone, the whole concern might not collapse. As to the numbers on the roof, I may add that the Jumma mosque, at Khiva, is said to it is to be assumed to 4,000 people, and as it is covered with a flat roof, so it is to be assumed that as many could assemble thereon. 
the Consul and another, we rode outside the inner wall, receiving here and there a salaam, until we came

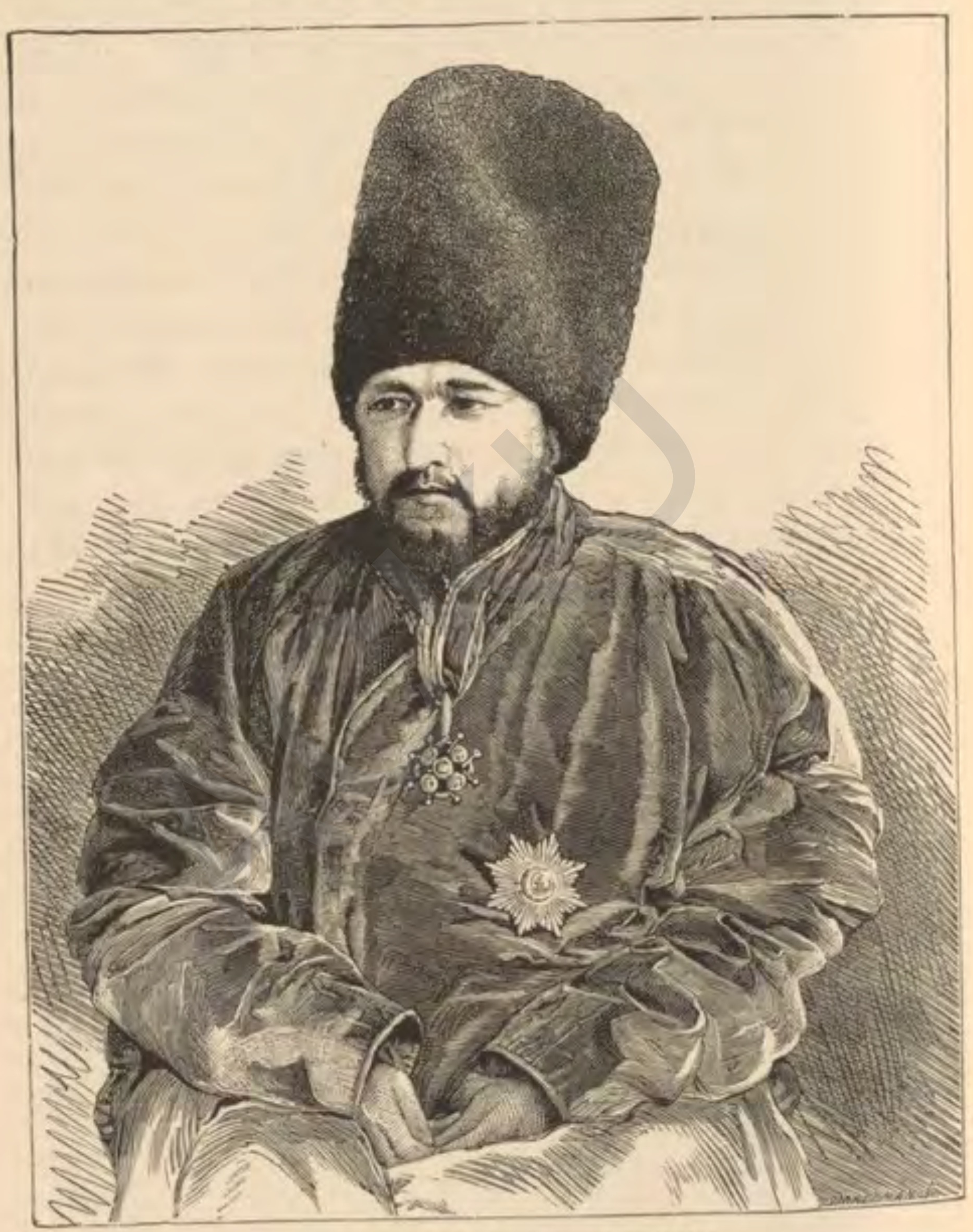

SEID MUHAMSIAD RAIUS, KHAN OF KUTVA.

to the summer palace. The Khan had not yet quitted this building, and a troop of horses were waiting, their riders having gone within, I suppose, on business with 
the Khan, who, according to Vambery, holds public audience for at least four hours daily, and is expected to hear the most trivial cases his subjects bring before him. The number of attendants about the building appeared greater than we had seen about the Emir of Bokhara. The Khan's officers were all in sheepskin hats, clothed in somewhat dowdy garments, and presented a poverty-stricken appearance. We were shown into an ante-room, and then through one court after another, till we came to a room, only partially carpeted and scantily furnished, wherein the most prominent object was a sort of divan or bedstead, covered with a Persian carpet. On this the Khan was sitting, with a sword and revolver before him, and behind were three chairs piled with books. His Majesty shook hands with me, and motioned me to a seat on the couch.

The Khan's age had been given me as 36 , but I should have thought him older. He was dressed in a dark-blue cloth khalat and black sheepskin hat, much like the Consul or any of the others about the court, and he displayed no pretence at grandeur of any sort. He asked whence I came, whether the chief Russian authorities were well, and whether they had been kind and helpful to me; all of which I could answer in the affirmative. Next he asked who was the Sovereign of England, and whether things were going well. I told him Queen Victoria, and repeated the old story about the sun never setting on her dominions, whereupon he told Yakoob privately that he did not believe that; and when he was further informed that the earth went round the sun, his Highness inquired whether it did so straight or upside down, meaning, I suppose, vertically or horizontally. I asked if he had any ancient books 
or antiquities, but he said that those he once had, the Russians had taken.*

Of course I had read Burnaby's "Ride to Khiva," and at Petro-Alexandrovsk had been told that the Khivans sent word of his arrival to the Russians, some of whom remembered the tall life-guardsman being brought to the fortress " a prisoner," as they put it, on his little pony. If this were so, it would seem that the Captain was treated as I had been told I should probably have been at Bokhara, had I come without permission, and this, I suppose, was only in keeping with the Russo-Khivan treaty, which expressly provides that no one is to be allowed to enter the khanate from Russia without a passport.

On reaching Khanki I asked the Consul if he remembered the English Captain, and how it was they gave him up. He did not remember him, and said that for them to give him up to the Russians could not be, for that the Khan was on excellent terms with England, and sent to Herat two years before Khiva was taken, and that the letter was forwarded thence to the English, but no answer was received. I asked Matmurad if he remembered the Englishman coming, but he said "No." When, however, I told

- There were about 300 volumes. They have been described by M. Kuhn, the Orientalist of the Russian expedition. They were taken to the Imperial library at Petersburg, where, I believe, I saw some of them. The works were in manuscript, and historical in character, chiefly translations from Persian into Turki, written, for the most part, under the present Kungrad dynasty. There was also a native work on the history of the Khivan khans; likewise a history of the world, and a history of Khiva from the beginning of time. Besides the books were several diplomatic documents, 20 gold and 5 silver seals belonging to the khans, and about roo dies for striking money. There is a valuable article by Khanikoff on the documents concerning the Khanate of Khiva in the Bulletin de la Société Géographique, p. 282, Vol. xv., 1873 . 
the Khan that the English had been much interested in Khiva by reason of a book written by Captain Burnaby, his Majesty, though not seeming to recollect very clearly, yet inquired if he were still alive, and to what tchin, or rank, the Captain had now attained. I told him that of "Colonel."

He then asked what was my tchin, and was somewhat nonplused when I told him "Doctor of Divinity." He appealed to Matmurad, who was kneeling before him, the only courtier present, and said that was a tchin he had never heard of before.

Seeing that Yakoob had decided not to go so far as Krasnovodsk, 1 mentioned to the Khan our desire to find an interpreter who could speak Russian and Turki; and he said he would find a djiguitt for us who could act in this capacity and accompany us to Krasnovodsk. Tea had been brought during our conversation for the Khan, Sevier, and me. I had observed that Yakoob, on approaching the Emir, had kissed his Majesty's hand, and so he had done with the Khan; but now he received what in the East is considered a great honour, for the Khan, after drinking a portion of his tea, gave to Yakoob the rest. His Majesty frequently called during our interview for the chilim, that was brought by an attendant at a moment's notice, and taken away again after one long whiff had been drawn by his royal master. On the whole, I thought the Khan of Khiva far more intelligent and more interesting than the Emir of Bokhara, and we left his presence with the understanding that, according to Khivan etiquette, we were to see him again before quitting the capital. 


\section{CHAPTER LXI.}

\section{THE KHIVAN OASIS AND ITS HISTORY.}

My informants,-Dimensions of the khanate: its soil, geology, and botany.-Khivan melons, and efforts to introduce them into England.-Khivan fauna, inhabitants, revenue, and foreign relations. - Kharezm under the Arabs.-Conquests of Jinghis Khan and Tamerlane. - The Uzbeg khans, and commencement of intercourse with Russia.-Raids of Cossacks, and expedition of Cherkassky.Khivan enslavement of Cossacks,-Kazak khans.-Perovsky's expedition and English mediation.-Shakespear's conduct of Russian slaves.-Russian capture of Khiva.

T WAS greatly favoured, both in Petro-Alexandrovsk and Khiva, in being brought into contact with men such as the Russian Governor, Captain Mirbadaleff, and the Divan-beggi. Both the Captain and Divan-beggi kindly permitted me to put them through my list of questions, so that, thanks to Mr. Sevier's usual patience and theirs, I gained a good deal of information at first hand concerning native life in Central Asian towns, which, after all, is much of one pattern, whether at Samarkand, Bokhara, or Khiva.

Not that I placed much reliance upon Matmurad's judgment in matters of opinion, or anything requiring abstract calculation, for his answer to my first question as to the length of Khiva from north to south showed that he knew nothing about figures. He replied 100 
tashes, or 530 miles, which was nearly three times too much. The breadth, including the desert, he gave as from 300 to 400 miles, which was nearer, but the inhabited part west of the Amu as 50 miles. As an illustration how unaccustomed the Khivans are to tabulating information, I heard at Petro that the Emperor had desired of the Khan certain statistics respecting the khanate, which the latter was willing to supply, but he utterly failed in the attempt. A calculation more to the point was that of the late Major Wood, who estimated the Khivan area, fertilized by the waters of the Oxus, at a million and a half of acres - an area, that is to say, rather less than that of the county of Lincoln, or about half the size of Yorkshire. The soil of the oasis is of loess, or stiff, sandy clay, with strips and patches of sand. Black mould is seldom seen, but earth is frequently found impregnated with salt. The oasis is generally level. The cliffs and sand-hillocks, which I described coming down the left bank of the Amu, surround the valley of Pitniak in a broad curve, but five miles lower, the sand-hills approach the river again, and accompany it as far as Sheikh-aryk, and then quit it finally, to turn westward and surround the Khivan oasis.

The geological formation of the khanate is principally red sandstone on the south, gradually changing northwards into a firm clay. They work no metals, but have salt and sulphur sufficient for home consumption. The best salt is found in the north. They have building stone, but it is too expensive, Matmurad said, at Khiva, to build a whole house of it, for though sufficient might be quarried without cost, it would have to be conveyed all the way from Pitniak, or I suppose beyond, since he spoke of the distance as 130 miles. 
Hence stone is used only for foundations. Burnt bricks cost $£_{1}$, and sun-dried 2 s., per thousand.

Concerning things botanical, I had expected much in Khivan fruits, especially the melons. They are a most lucrative crop. With good management, Kostenko says, an acre will yield from 10,000 to 14,000 melons, and these, at $1 \frac{1}{4} d$. each, will bring from $£ 50$ to $£ 70$. M. Brodovski says that about Samarkand an acre yields 10,000 melons. The natives hang them in cool chambers to the ceiling, where certain sorts will keep from the time when they are ripe till the following May. Matmurad gave us the price of melons from 12s. to 20s. a hundred. There are, of course, several varieties. I heard of one sort, small as an apple, but pronounced very good; some are a foot and a half long. On their winter melons Matmurad did not appear to set much store, but said that two varieties, ripe at harvest, were sweet as sugar, though they would not keep. My host gave me seeds of five kinds, which, as did Captain Burnaby, I brought to England, hoping that I might be more fortunate than he in raising them. I must say that, after eating Central Asian melons, I have tasted none in England that are by comparison worthy of mention. Those I ate in Constantinople came nearest, and hence, believing that I had real treasures to give, I distributed the seeds to such of my friends and acquaintances as had convenience for growing them.*

- The five kinds were called (1) Kitai (or Chinese); (2) Zamcha; (3) Kukcha, all sown in Khiva in April, and ripen in about two months, or say the beginning of June; whilst the remaining two (4) Sherin-pitchek, and (5) Alikeh, are ready a week or two later. Mr. J. D. Allcroft sent me the first fruit in $188_{3}$, less than a foot long, somewhat pear-shaped, of green flesh, but tasteless, and not juicy-I fear not quite ripe. Earl
Stanhope kindly tried some seeds the same season at Chevening. Mr. Gray, the head-gardener, informs me that one plant was raised of such rampant growth that it ran on a trellis over a space of nearly 200 
Apples were easily obtained in Khiva, and cost from $24 s$. to $30 s$. per cwt., grapes $4 s$. a batman, or $\mathrm{I} d$. per $\mathrm{lb}$., and peaches in the season up to half that price. Of mulberries they take so little account as not to pick them for sale. The Khivans cultivate many flowers, they said, but not peas, and neither Matmurad nor the

square feet, covering half the roof of the glass house, and then would have spread further if permitted. It was planted early in March in an ordinary loam and leaf soil, with bottom heat. For a long time the blossoms, with one exception, did not set, and that one produced a large ovate melon of 10 lbs. weight. Subsequently other blossoms set, and were growing fruit weighing 3 or 4 lbs. each, when unfortunately the plant gave way through rot at the collar, and died. The plant took quite 5 months to grow. The large melon was cut a little too early, and was lacking in the juicy qualities it probably would have acquired had it been left longer on the plant; but the gardener considered it a good melon. Next year three sorts were tried by Mr. A. F. Barron, of the Royal Horticultural Society's gardens at Chiswick; but he did not report very satisfactorily upon them. Of those he tried, one did not fruit, a second produced two long ovate melons, and the third, round fruit. These ripened, the flesh being tender, very juicy, even watery, but not by any means rich. Mr. Barron adds, "They were rather rampant in growth, and did not fruit readily, but the foliage was somewhat destroyed by the hot sun, and this, no doubt, affected the fruit." Mr. Wildsmith, of Heckfield gardens, near Winchfield(Viscount Eversley's), spoke of the "Alikeh" as best of the three kinds he raised, and not so rampant in growth as the other two, but, though speaking of the "Zamcha" as excellent, thought them no better in quality than English melons. The Zameha was tried also at Burghley Gardens (the Marquis of Exeter's), by Mr. Gilbert, who is famous, I am told, for growing melons, and he exhibited from my seed a fruit weighing $\mathrm{I}_{1} \frac{3}{4} \mathrm{lbs}$. at the Royal Horticultural Society's show on September gth last. Another fruit from the same plant, weighing $9 \frac{1}{2} \mathrm{lbs}$., was of green, deep flesh, and though not of very rich or aromatic flavour, was liked for its great juiciness. The appearance of the "Kitai" melon, as reported on from Burghley Gardens, was not flattering, being "precisely like a large vegetable marrow, and of a dark green colour." I sent seeds to my friend Dr. Haughton to be tries in the botanical gardens of Trinity College, Dublin. He committed them to Mr. Burbidge, who distributed some seeds to a few English gardeners, who made melons a speciality. From the correspondence that ensued I learn that Mr. O'Donovan, who penetrated to Merv, thought the introduction of Central Asian melons to Europe so desirable, that he carried some of the seeds in his 
Consul seemed to know what beans were. They grow tobacco, and sell it from $18 s$. to $24 s$. per cwt., but it is not good, and the well-to-do purchase that imported from Karshi and Samarkand. The cultivation of cabbage and potatoes has commenced since the arrival saddle-bags four or five thousand miles, and spoke of them as of marvellous excellence. Mr. Simpson, of Wortley, grew some of Mr. O' Donovan's melons, but they proved insipid and flavourless, or, at best, just passable. $\mathrm{He}$ also tried some of my seeds, of which only one, the Sherin-pitchek, grew, and this he pronounces of the same type as O'Donovan's. Mr. Simpson says, "I gave it a light all to itself, but it was rather straggiing and weak from the first, and could not endure the bright sunshine. It lost its foliage, and the single fruit it bore never ripened properly." It was sent, however, to Dr. Haughton, and thought highly of. Dr. Haughton received, too, a Zamcha melon, grown at Lord Eversley's, weighing ${ }_{4}$ lbs., of which he subsequently told me that, though familiar with American, as well as British melons, he never in his life ate any so fine as this from Khiva. Previously to receiving this information I was becoming dispirited, and thinking that my seeds would turn out no better than those of Captain Burnaby or Mr. O'Donovan. Another trial, however, has been made of the "Alikeh" at Chevening, where the gardener, taught by experience how much space was necessary, planted the melon under a frame with five lights, expecting it to cover the entire area. I saw the plant thus growing on September 5 th. It was not so strong, I was told, as that of the previous year, but it had three halfgrown fruits of fair size. One of these was sent to me, not quite ripe, on October $13^{\text {th }}$, which, upon eating ten days later, I was delighted to be able to pronounce quite equal to those I had eaten in Khiva, and far more delicious than anything $I$ have ever tasted in England. This opinion was shared by others with me at the table. This ovate fruit measured 8 inches long, and was green-fleshed, juicy, sweet, and eatable to the skin. Thus I consider that Mr. Gray and Mr. Wildsmith have demonstrated that two kinds at all events of the Khivan melons can be grown in England. The former considers the Alikeh melons require plenty of heat, and a long season, since English melons planted simultaneously with them ripened six weeks before those from Khiva. This, however, will make the latter valuable for late eating, especially as they have such good keeping properties. I hope, therefore, that English gardeners will learn how to grow these fruits. The great size and robustness of the plants may prevent their having fair play in English houses, but I have given seeds also for outdoor growth in Florida, whence the iruit could easily be sent to the London market, so that if, after all, I do not succeed in getting them on English tables, it will not be for lack of endeavour. 
of the Russians. Both Lieutenants Shakespear and Conolly speak of timber as plentiful in Khiva, which I could hardly confirm now. Logs for rafters cost from $4 s$. to $8 s$, each.

The domestic quadrupeds of Khiva, says the "Encyclopædia Britannica," are Camels, Horses, Asses, Horned Cattle, Sheep, and Goats. Then it goes on to enumerate of wild animals the Hog, Panther, Jackal, Fox, Wolf, and Hare. To these might be added, according to some, the Tiger and Wild Ass, but when the article mentions the Giraffe, I think it is in error. I have met this statement before, and it arises, I think, from a mistranslation of the name of an animal said to exist on the islands in the Aral, that should be the Saiga Antilope. Again, some authors, as Vambery, mention the Lion on the banks of the Oxus, and the Seal in the Aral, but I do not remember meeting any confirmation of either. Birds are represented in the khanate by the Wild Goose, Swan, Crane, Pelican, Duck, Moorhen, Bustard, Pheasant. Quail, Snipe, Partridge, Magpie, Crow, Sparrow. Nightingale, and Lark, besides the domestic Fowl and Pigeon. The fishes include Sturgeon, Sterlet, Bream, Pike, Carp, and Sandre.

I learnt from Matmurad that in the town of Khiva there are scarcely any Tajiks-only about 15 tradesmen-but that Uzbegs predominate, and the rest are Turkomans and Sarts. They have also a few Jewsless, I believe, than half a dozen - and without a synagogue. The northern portion of the khanate is peopled partly by an inconsiderable tribe called Karakalpaks, but I think this was more especially the case when the delta of the Amu, where now they chiefly live, belonged to Khiva. T wo other races are mentioned in the khanate, namely, a few Arabs living about 
Shakhavat, and Kizilbashes, or liberated Persian slaves, about Tashauz, whither we shall presently come. We met also in the north a few Kirghese, more especially of the Adaef tribe, still subject to Khiva. The Uzbegs live, for the most part, on their farms, and busy themselves in agriculture, gardening, silk culture, hunting, and fishing. They are divided into tribes, as are the remaining nomad Karakalpaks, who are for the most part stockbreeders. The Kirghese engage to some extent in the transport of goods by caravan. Major Wood estimated the population of the khanate in 1875 at 300,000 ; Howorth says 500,000 ; but in the absence of data I have not much confidence in these figures, though I have no alternative to offer. The watered portions of the khanate, according to the Major, have a smaller area than that of the county of Lincoln, which in $188 \mathrm{I}$ had a population of 470,000 . After passing through the most populated portions of the khanate (where, by-the-bye, Major Wood did not go), and knowing a little of Lincoln, I should judge that the two areas would not bear comparison for a moment as to density of population, and, consequently, that $\mathrm{Mr}$. Howorth's estimate is too high by at least a half.

The Khan has no army, and the people are not sharply divided into classes. The mullahs, or priests, and khojas, or descendants of the Prophet, pay no taxes, ${ }^{*}$ and furnish no labourers for canal work, but other subjects have to do so.t 1 imagine, however,

* This is the case with the priesthood in Russia, and reminds one of a law promulgated in Persia, touching the priests of the Jews, that " it shall not be lawful to impose toll, tribute, or custom upon them" (Ezra vii. 24).

$\dagger$ Howorth gives, from MacGahan, the Khan's revenue at the conquest as 90,000 tillahs, or $£ 45,000$ (as he reckons it), being derived from customs dues on foreign merchandise, shopkeepers' and traders' 
that the people must be very poor, for I was told that the raising of the Russian indemnity tries them sorely. The Khan was called upon to pay, at the conquest, for the expenses of the war 2,000,000 roubles, or $£ 200,000$, or, in default of immediate payment, to bring $\ell_{15}$,000 a year, and pay interest on the remainder at the rate of 5 per cent. per annum. When I was there he had paid $£_{\mathrm{I}_{55}, 000}$, so that he was still $£_{45}, 000$ in arrears, besides $£_{20}, 000$ interest; and this so distressed him that I heard his Highness intended, on the ground of poverty, to ask the Emperor for a remission.

The foreign relations of the Khivans, other than with the Russians, are, I take it, exceedingly few. As we approached the city, a djiguitt came alongside, and seemed to be dividing the whole of what was the outer world to him into three categories. He wished to convey to me his dislike of the Russians, which he was obliged to do in very simple language, and partly by signs, whereupon he said, "Rom yakshi, Inghiliz yakshi, Urus shaitan!" or something like it, signifying that, "The Turks of Constantinople are good, the English are good, but the Russians are horrible," or "devils," as he had called them before ; and with that he placed his hand on his sword and then drew his fingers across his gorge, signifying that he would willingly cut their throats. But we heard a different story from a very intelligent Kirghese, who said that the Russians, having taken the country, began by putting on a small tax, and then increased it. Some of his people, not understanding this proceeding, had taken fright, and run licences, and land and house taxes. The Karakalpaks paid one sheep in every hundred, a bullock in every twenty, and a camel in every six. The Kazaks who visited the bazaar paid a shilling for every camel or ten sheep, and there was besides a harvest tax. 
away into Bokhara and beyond. When I asked him why they did so, he said, "Because they are fools, and know no better!" and afterwards he said that he considered the Russian intercourse with the Kirghese had been to the advantage of his people. During my interviews with the Khan, his Majesty betrayed great ignorance of foreign countries. He asked which were the greatest powers of the world? Without much time to think, I told him first England, second Germany, third France, fourth Russia, and fifth America; but he thought Russia more powerful, he said, than England.

I said they had a larger army, but we had money to increase ours; that Russia owed us millions already, and came to us when wanting more.

He said yes, he had heard that England was rich; that English people worked very hard, and were so clever that our mechanics after seeing a thing could make another like it.

I showed him a map of the world, with the English possessions coloured red, which seemed to surprise him ; and, as if he thought it our sole vocation in life to annex territory, he inquired what country we should take next, and whether we thought of conquering China. He seemed also to think the Russians were bitten with the same mania, adding that they were never satisfied, but took more and more territory.

Spitzbergen on the map happened to catch his eye, and he asked about that, whereupon I am afraid I puzzled his royal wits, and tested his credulity by telling him that it was dark and light there continuously for periods of eight weeks every year.

Turning from this feeble ruler of the khanate to speak briefly of its history, I may observe that the 
appellation of Khorasm, or Kharezm, has been for long centuries applied to the country south and southwest of the Aral, Quarasmiah, written in cuneiform characters, being found on the ancient monuments of Persepolis. Herodotus, in the fifth century before Christ, terms the same country Chorasmia, it being then one of the Persian provinces over which Darius placed satraps, but nothing material concerning it occurs, says Pinkerton, till it was possessed by the Arabs in 680 A.D. The Chinese knew it as Hua-latze-mu. On the declension of the power of the khalifs the province was probably seized by its governor under them; but we meet with no king of the country before Mamun-ibn-Mohammad, in 995. Later Kharezm fell under the dominion of Sultan Mahmud Ghazni, King of Khorassan, who, in ror6, made it a province of his empire.

Kharezm continued in this condition under the families of Ghazni and Seljuk successively, till upon the death of Malek Shah, or Jelal-ud-din, in I092, Kuthbud-din, then governor, assumed the title of king. Takash, the sixth sultan of this dynasty, firmly established the empire of the Kharezmians by destroying the power of the Seljuks in Persia, whose dominions he added to his own about 1196 . His son, Kuthb-ud-din-Mohammad, extended the empire by the conquest of all Persia and Maverunahr, and was the greatest prince in Central Asia when Jinghiz Khan appeared on the scene in 1219 .

At this time the capital of the kingdom was Urgenj, which was overpowered by Juchi, to whose share of his father's dominions Kharezm fell. Later we find it possessed by Hussein Sofi, of the horde of Kungrat, in whose family it continued till conquered by Timur

vOL. II, 
in 1379. Kharezm continued under the descendants of Timur, a dependency on Khorassan, till that province was subdued by Sultan Shakbakt, commonly called Sheibani Khan. Soon after, Shakbakt was slain by Shah Ismail Sofi, in $1510,{ }^{*}$ and Kharezm once more came under the dominion of Persia. Two years later, however, the inhabitants, revolting against their governors, set up Sultan Ilbars, who, coming with his Uzbegs out of Turkistan, was proclaimed Khan, in 1512 , at Vezir, or Sellizure (i.e., Shehrvezir), and it is his descendants who now have possession of the country.

The history of the Uzbeg Khans of Kharezm has been written by Abul Ghazi, and translated, so that it is quite unnecessary for me to mention all their names, but only the most notable, and those to whom reference may be made hereafter. During the latter half of the sixteenth century reigned Hajim Muhammad, at the time that the first Englishman, in 1558 , entered the kingdom in the person of Anthony Jenkinson, who calls him Azim, and says that all the land between Urgenj and the Caspian was called the land of Turkman, and was subject to Azim Khan and his five brothers. When Jenkinson returned, he took with him four envoys from Hajim Khan to the Tsar, and subsequently, in 1595 , fresh envoys were sent from Kharezm to solicit the friendship of the Tsar Feodor.

Hajim was succeeded by his son, Arab Muhammad, in whose reign, about $1603,1,000$ Cossacks of the Ural, or Yaik, made a descent upon Urgenj, and killed more than 1,000 inhabitants, but were themselves ultimately destroyed. After Arab Muhammad came Izfendiar Khan, and later still, Abulghazi Behadur

* For Sheibani's reign, see Howorth's “"Mongols," ii., 691-713. 
Khan, to whom we are indebted for the history. He succeeded to the Kharezmian throne in 1642 , reigned lawlessly till $166_{3}$, and then resigned his throne to his son, Anusha, with the design of spending the rest of his days religiously, but he soon died. Anusha was followed by his son Erenk, who was poisoned in 1687 , and the conspirators set up in his place Shah Niaz Khan, who, in 1700 , sent an envoy to Peter the Great, asking him to take Kharezm under his protection. Peter complied by letter, and confirmed his friendly message three years later to Arab Muhammad, the next Khan, who was then pressed by Bokhara. Arab appears to have been followed by Haji Muhammad Behadur Khan, who, in 1714 , sent an envoy to Petersburg, offering in grand language to help the Tsir at any time with 50,000 horses, and to allow Russian caravans to pass through his country, a four months' journey to China. The envoy said his master's residence was Khiva, which consisted only of tents and huts, and not fixed, in summer, to one place. This Khan was soon displaced, and succeeded by Yadighar, who had a very short reign, ending in a revolution, the outcome of which was to place on the throne, according to Howorth, an imported Khan, Arank, or Evrenk, a Karakalpak from the old royal house subsisting among the Kunkurats in the delta of the Oxus. Next followed Shirgazi Khan, in whose reign the Khivans came into full contact with the Russians, to the dire loss at first of the latter.

The attack upon Urgenj of the Cossack freebooters just referred to was followed by two subsequent attacks of a similar character, and equally disastrous to the Cossacks. In 1717 , however, Peter the Great having heard of gold in the bed of the Oxus, and wishing 
to open trade relations with India through Turan, as well as to release some Russian subjects in slavery, sent Prince Bekovitch Tcherkassky to examine into the alleged ancient course of the Oxus into the Caspian, and to proceed to Khiva, the Khans of which had already offered him allegiance. Bekovitch surveyed the east of the Caspian, built forts, and marched upon Khiva with 3,000 men. The Khivans feigned submission, induced Bekovitch to break up his force in small detachments, to facilitate their being provisioned, and then slew them nearly all.

During the next I 20 years the tables were turned as between the Cossacks and Khivans, the latter of whom now attacked and plundered their former invaders, seizing caravans, and carrying off Cossacks and other Russian subjects into slavery. Kharezm, during this time, became the great slave market of Central Asia, and as many as 10,000 Russians and Persians were held in captivity there. This led to several Russian envoys being sent. Thus, in 1725 , Florio Benevini, an employé in the Russian Foreign Office, visited Khiva, proceeding thither through Persia and Bokhara, and was well received, Shirgazi being then troubled with the condition of things in Bokhara. Other Russian envoys visited the country during the rest of the century, but none of them were able to bring the Khan to terms, to induce them to stop pillaging and enslaving Russians, or to emancipate those already in bondage. During this period we find Shirgazi succeeded by Ilbars, who, threatened by Nadir Shah, called to his assistance Abulkhair of the Little Horde, and so brought a Kazak monarch to the throne, who initiated a line of Kirghese or Kazak Khans. Abulkhair came, and occupied Khiva, submitted to Nadir 
Shah, and retired to the Steppes. Several insignificant Khans followed: Tagir, Abul Muhammad, Abulghazi II., and Kaip.

Khiva next took to "playing with a Khan," having a sovereign as a toy, but the real power being in the hands of an hereditary Inak, or Inag, who was governor of Hazarasp. It was in the reign of Abulghazi III., son of Kaip, and under the rule of Ivaz Inak, Dr. Blankennagel, a Russian oculist, visited Khiva, in 1793 , with a view to treating the eyes of the Inak's brother, and when he could not cure him, had to escape for his life. Ivaz Inak died in 1804 , and was succeeded by his second son, Iltazar, who, sending the Kazak Khan back to the Steppes, proclaimed himself an Uzbeg Khan. He was succeeded, in 1806, by his brother, Muhammad Rahim Khan, a veritable scourge to the regions around. It was in this reign that Muravieff, in 1819 , landed at Krasnovodsk, to enter into relations with the Turkomans east of the Caspian, and having so done, crossed the desert to Khiva. Muravieff gave a terrible picture of the savagery of the people, declaring that his predecessor, Bekovitch, had been flayed alive, and his skin stretched over a drum.

In 1826 , Muhammad Rahim was succeeded by his son Allah Kuli Khan, who reigned till 1841 , and narrowly escaped invasion by the Russians, for, the Khivan plundering of caravans, and stealing of Russians for slaves still continuing, the Tsar determined to strike a blow at the khanate. In the winter of I $839-40$, General Perovsky started for Khiva with a force of 6,000 men, 10,000 camels, and 2,000 Kirghese attendants. The snow of winter, it was thought, would remedy the want of water in crossing 
the desert in summer, but cold and exposure killed 9,000 of the camels, and two-thirds of the men, and the expedition completely failed.

This untoward event was not altogether adverse to the English diplomacy of that day, and Major Todd, then at Herat as political agent, sent a Kazi to Khiva to draw closer the bonds between that country and England-in other words, to countermanœuvre the supposed Russian advance. The Kazi having reported the success of his mission, Major Todd despatched Captain (now General) Abbott to Khiva. He was instructed to obtain the liberation of the Russian prisoners, and then to go to Astrakhan, and, if possible, secure the liberation of the Khivan merchants detained by the Tsar pending the Khan's refusal to release Russian slaves. Abbott obtained permission for a Russian official to visit Khiva, to take back to Russia all the captives he could find who wished to return, on condition that the Khivan traders were released. Abbott then crossed the Steppe to the Caspian, but, betrayed by his guide, was robbed, treated with great cruelty, and with difficulty made his way to Astrakhan.

Meanwhile, Major Todd having heard a false report that Abbott was dead, sent Lieutenant (afterwards Sir Richmond) Shakespear, whose mission writers have hardly made sufficient of, to complete negotiations. "Lest the Khivans," says Dr. Schuyler, "might take heart by the failure of Perovsky's expedition, it was resolved at once to send another. Before, however, the arrangements for it had been completed, the Khivans saw their danger, and in the summer of 1840 sent an envoy to Russia with 418 Russian captives, and the Khan issued an order forbidding the capture and purchase of Russians." The envoy mentioned thus anonymously 
and ambiguously was none other, it would appear, than Lieutenant Shakespear, who, according to Blackwood's Edinburgh Magazine (for June, I 842, containing Shakespear's journal), was charged with the difficult task of removing, if possible, the causes of hostility by inducing the Russians to withdraw their army, and the Khivans to restore all their Russian slaves. To this latter end the Khan handed over to him the Russians, to each of whom, Shakespear says, he gave a ducat, hired a camel for every two, besides giving the Khan a bill of exchange, endorsed by the Kazi of Herat, which was to be paid him if the long-delayed caravan were not released. Then, taking charge of 416 men, women, and children, he in person marched with them across the desert to the Caspian, and took them to Orenburg, where, on his arrival, 640 natives of Khiva were released by Russian authority, thus making 1,056 persons liberated, Shakespear claims, through English mediation. The English lieutenant then went on to Petersburg, where he received the public thanks of the Emperor Nicholas, and on reaching England was knighted, as he richly deserved, for one of the most brilliant actions of his day. No doubt his so-called mediation was unasked for, and was liable to be looked upon as interference by the belligerents. But it seems hardly a gracious remark I have met with in a Russian account of Perovsky's expedition, that "Shakespear wished to take credit for the release of the Russian prisoners ; these, however, prior to his arrival at Khiva, had been collected and registered by the Russian cornet Aitof." The Russian account adds that the Khan gave each Russian a tillah, a bag of flour, and a camel for every two men, that "Cornet Aitof returned to Orenburg, and the liberated Russians, numbering 
4 I 6 men, followed him on the 3oth October." But if this Cornet (who by-the-bye was not an envoy, but an officer taken prisoner while foraging) had done all the negotiations and work, why were not the prisoners committed to his care? and if Shakespear were merely travelling with the prisoners, and striving to take an active part in the Russian affairs with Khiva, as the Russian account puts it, why should he have received the Emperor's thanks ?*

However this may be, English influence at Khiva was only short-lived. The Shah next pressed for the liberation of his Persian slaves, and Captain Conolly was sent to Khiva to try and settle differences. The Khan received him well, but refused to release the prisoners, whereupon Conolly sent to Cabul, proposing that the slaves should be purchased; and it was whilst his messenger was gone that Conolly, finding himself

* After writing the above, and whilst the sheets are going through the press, I have received from the Rev. Percy IValler, son-in-law of the late Sir Richmond Shakespear, a printed "memorandum of the services of Brigadier-General Sir R. Shakespear," in which I find No. 2., "Translation of a Russian Letter from the Officer commanding the fortress of Nova Alexandroff, on the Caspian Sea, to the Envoy of the Khan Akhun, and to the Englishman Shakespear:

"Commandant at Nova Alexandroffski Fortress, 5th Sept., 1840, No, 1,097 .

"On the 3 oth August inst. you delivered here from Khyva Russian prisoners, in number according to a detailed list, males, females, and children under age, four hundred and sixteen. When you collected them from amongst the Khyvan Turcomans, and others, you gave to each one a ducat, and fifty pounds' weight of flour. On their arrival at this fortress, in answer to my inquiry, they expressed themselves unanimously grateful to you as father and benefactor from the time of their being taken out of bondage, and during the journey from Khyva to this fortress, of which I shall make a report to the Governor-General of Orenbourg, Adjutant-General Peroffsky.

$$
\text { "(Signed) }
$$

LIKHOSHSOSTOFF,

"Commandant of Nova Alexandroffski,

"Colonel of Artillery." 


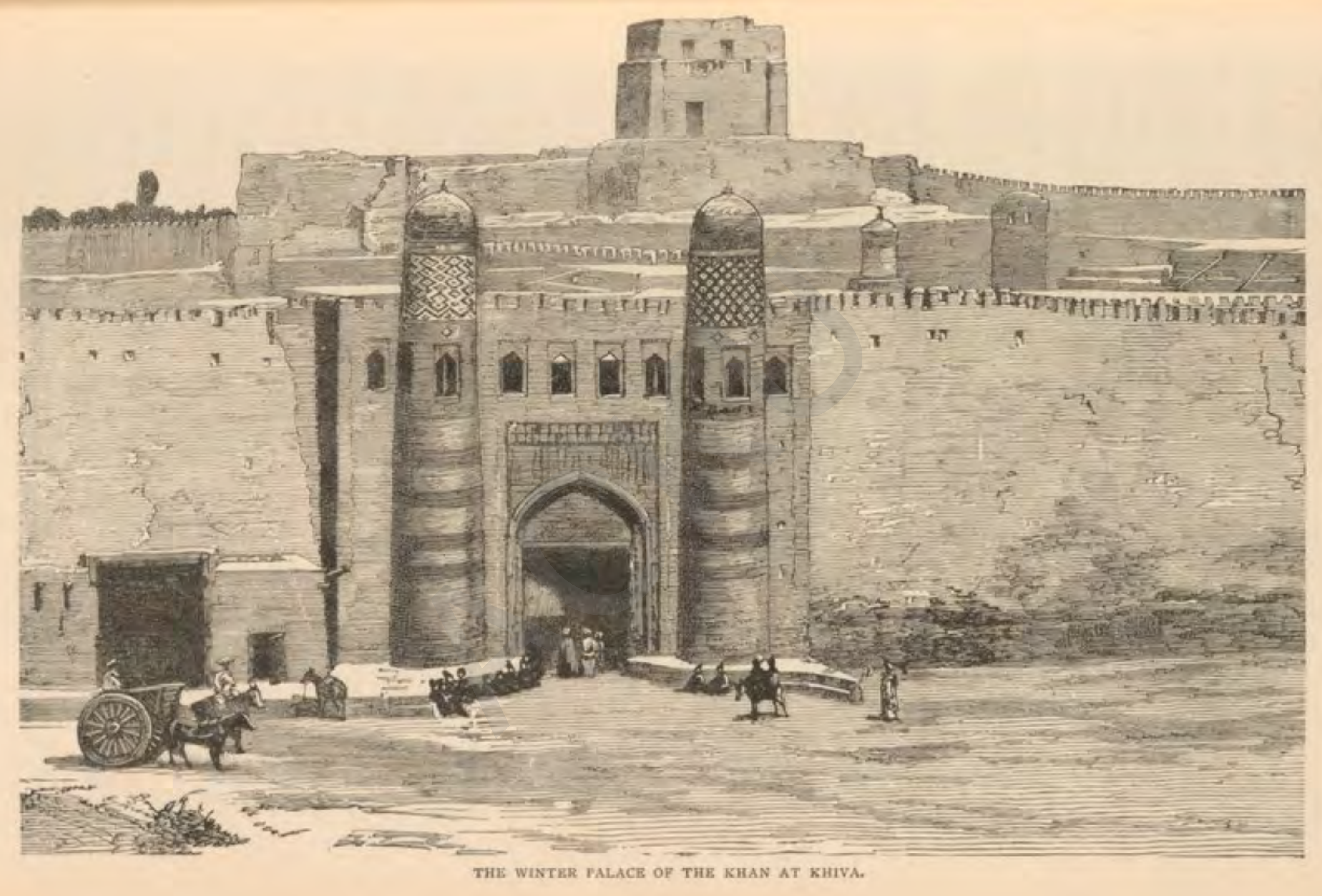


not so welcome at Khiva as at first, went to Khokand, and then to Bokhara, where he was put to death.

Meanwhile the intercourse with Russia and Khiva continued intermittently. With the returning Cornet Aitof was sent a Khivan envoy, and three others followed, though not so far as the capital. With one of them Nikiforof came back to Khiva, but it was not till I 842 that Colonel Danilevski succeeded in making the first treaty between the two countries, and whilst he was at Khiva, Allah-Kuli-Khan died. He was succeeded by his son Rahim Kuli for three years, and Rahim Kuli by Muhammad Amin, who was killed in 1855 . This sovereign was followed by Abdullah Khan for a year; then came Kutlug Murad Khan for three months, and next his grand-uncle, Seid Muhammad Khan, who was reigning when Vambery visited Khiva in $186_{3}$. This monarch was succeeded in 1865 by his son Seid Muhammad Rahim Khan, who is now on the throne, and whose reign has been a disastrous one for the khanate.*

The Russians had pushed down to the edge of the Khivan territory by 1848 , and, in building their forts on the Jaxartes, had deprived the Khivans, if not of territory, yet of tax-paying Kirghese. Moreover, the kidnapping and enslaving of Russian subjects had not ceased, and the Khivans fomented disturbances among the Russian Kirghese. The Russians determined, therefore, to avenge their past disasters, and to effectually humble the khanate. In I869, Krasnovodsk was founded, and in $1871-72$, the country leading to Khiva from Russian Turkistan was thoroughly surveyed, as also the Aralo-Caspian desert, and, in I 873 ,

* For a genealogy of the Khans of Kharezm, see "Howorth" ii., 977 . 
an expedition was organized on a large scale, under the command of General Kaufmann.

The plan of the campaign was to start the force of I0,000 men from three different bases of operations, namely, from Tashkend, Orenburg, and Krasnovodsk, which were distant 600,930 , and 500 miles respectively from Khiva. The campaign has been amply described by Dr. Schuyler; also by MacGahan, who was on the field, entered the city with the troops, and with them took up his quarters in the Khan's winter palace. It suffices, therefore, for me to say that Khiva was occupied by the Russians almost without opposition, and the Khivan territory on the right bank of the Oxus ceded to Russia. The Khan fled, whereupon his brother Ata Jan was temporarily put in his place, but on Kaufmann inviting Seid Muhammad Rahim to return, he did so, and was reinstated.

I am under the impression that Ata Jan was given some sort of ornamental military commission at Petersburg, until, his office being abolished, he returned to Khiva, and was there at the time of my visit, though I did not see him. Having now made these general remarks upon the oasis, and briefly sketched its history, I shall proceed with the description of what I saw and heard and did at the capital. 


\section{CHAPTER LXII.}

THE KHIVAN CAPITAL AND ITS COLLEGES.

The sights of the town, including the bazaar.-Central Asian weights, measures, and trade.-Cloisonné turquoise jewellery.-Khivan industries.-The medresses of Allah Kuli and Madrahim Khan.College life.-Classification of students, - Character of Muhamma. dan studies.-The Uzbeg language and kindred dialects.-Russia's responsibility towards Muhammadans.-Pehlivan-Ata mosque and its royal tombs.-Moslem pilgrimages.

( $\mathrm{N}$ the morning of our third day in Khiva we were taken by the Consul to the sights of the town, and first to the bazaar, the one they seemed proudest of being the Tim, or bazaar proper, where is transacted most of the retail business.* As it was not Monday or Thursday, which are market days, when we were in the Khiva bazaar, I did not see the place to advantage. I searched for a long time in vain for a pair of warm socks, and at last managed to purchase for a rouble two pairs of coarse worsted foot envelopes, like a pair of night socks, and coming up only to the ankles, and with these I was forced to be content. Dreading, too, the cold we had been warned

* Vambery gives the number of shops in the bazaar at about 120 . MacGahan says 300 , and the "Encyclopædia Britannica" 380 , in the town of Khiva. Yani-Urgenj, or New Urgenj, would appear to be the town where most of the Khivan trade is concentrated-the richest merchants, who trade with Russia, Bokhara, and Persia, living there. 
of, I inquired for a sheepskin shub, but could not find one to my taste in the bazaar, so poor was the choice.

From the bazaar we were conducted to the caravansary built in 1823 by Muhammad Rahim Khan, like those I had seen at Bokhara.*

The only statistics of trade I have are those of M. Petrovsky for I868-9, when there were exported from Russia to Khiva, through Kazalinsk, I 3 sorts of merchandise, to the value of $\ell_{11}, 204$, and imported by Russia from Khiva I9 kinds; value $\ell_{29} 2988$.

Their weights and measures in Khiva appear to be as vague as elsewhere in Central Asia, and to have their own peculiarities, for, whilst the batman in Bokhara equals 320 , in Khiva it is only 40 , Russian pounds. $\dagger$ I came to the conclusion there could not be much coinage in Khiva, for when I found that Russian silver money would circulate in the khanate as easily as native coin, I thought it better to get rid of the remainder of my Bokhara tengas, of which I had 550. The equivalent I was to receive was $12 \mathrm{I}$ roubles, or $£ \mathrm{r} 22 \mathrm{~s}$. (though they had cost me $£ \mathrm{r} 3 \mathrm{I} 8 \mathrm{~s}$.), but it was quite a business to effect the exchange, and when I inquired I found that Yakoob had to go to several merchants, changing a few here and a few there, because no one tradesman had sufficient Russian coin to do the whole transaction.

* Most of the business is in the hands of Sarts. The principal trade of the khanate is with Russia. Caravans go to Orenburg in the spring, and to Astrakhan in the autumn. During the year of my visit 800 camels had gone also to Krasnovodsk. With Persia the trade is inconsiderable, but it is larger with Bokhara.

$\uparrow$ It is noteworthy that the word "batman" is used from the Caspian to Kashgaria, though representing a differing capacity in various places. It possibly has some connection with the Hebrew na (Bath), Báros (Luke xvi. 10), which was a measure for oil (Luke xvi, 6), and equivalent to the ephah as a measure for corn (Ezek, xlv. 10, 11, 14). 
This put the finishing touch to the low estimate I had formed of the extent of native Central Asian trade. In the Tashkend bazaar one saw here and there a fair stock of goods, but as we travelled on, it was rare to see a native shop in which the stock might not have been bought, one would think down to the very last stick, for a few hundred pounds. I cannot think we saw a single native building throughout Central Asia in which the contents exceeded in value $£ 2,000$. I do not remember one that struck me as containing half that value, and we certainly saw no silversmiths' or jewellers' shops that displayed half the stock of an English shop in a small town. I am stating impressions rather than facts, received, it must be remembered, sometimes on other than market-days; but when the stock of three or four dealers had sometimes to be brought to enable us to purchase a few representative specimens of jewellery, one soon found that there was little made ready to hand.

I did purchase certainly one set of jewellery in Central Asia that has been much admired, consisting of an Albert chain, locket, and studs of cloisonné turquoise enamel work. I have shown it to Mr. Augustus Franks, at the British Museum, and to the leading art jewellers of Regent Street, and they all called it new to them, and said the like could not be made in London. These things, however, if not ordered, had been made with an eye to Russian demand, and the man told me he was the only maker of them. In fact, the old Biblical custom seemed still to rule, that one takes silver and gold to a smith, as we take cloth to a tailor, whose business it is to make it up.*

- " His mother took two hundred shekels of silver, and gave them to the founder, who made thereof a graven image and a molten image" 
We asked in Khiva to be taken to a silversmith's, and so we were in the strict sense of the word. for there was a workshop with two crucibles of stone to be heated by charcoal fires, two small anvils, and, if I remember rightly, silver in the bar as we had seen at Kuldja, whilst the work the man had in hand was the silvering the handle of a battle-axe, by order of the Khan, to be carried by some new place-man as an insignia of office; but as for getting a collection of Khivan jewellery, it was not apparently there to be had, and I could spend only a shilling for three ear-rings, for the sake of buying something as a souvenir.

I was anxious to form some idea, if possible, of the manufactures of Khiva, and asked to be taken to some of their workshops ; but things were at so low an ebb, that in the coppersmiths' row I could not get a kurgan, or ewer, that was worth bringing away. The Divanbeggi subsequently gave me one for his present, which I was well pleased to have as a souvenir of Khiva. It is small, but prettily graven, though not so finely as some of those we saw at Khokand. They took us likewise to what might by compliment be called a silk factory, where, after crawling through a door 3 feet high, we found a few looms of the roughest description. The Khivan silks, when woven, do not compare well with those of Bokhara and Khokand. I saw them, however, making a thick, red silk, that is sent to Bokhara to be used chiefly for head-dresses of rich Kirghese women. It sells for $£_{\mathrm{I}}$ per Russian pound.

From the caravansary we were taken to see some of the medresses and mosques. MacGahan says there

(Judges xvii. 4); and, once more, "They lavish gold out of the bag, and weigh silver in the balance, and hire a goldsmith; and he maketh it a god" (Isa. xlvi. 6). 
are 22 of the former and 17 of the latter. My notes say " 4 large medresses and many small," The medresse of Allah-Kuli was built by the present Khan's father, about 40 years ago. It is of 2 stories, and has IOO students, they said. That of Kutlug Murad Inag has about roo students. On the square, before the Khan's winter palace, is the Medresse Madrahim, built by the present Khan, with from 60 to 70 students only. Not far distant is the most important medresse in Khiva-that of Muhammad Emin (contracted to Madamin) Khan, which they said was 30 years old. Taken in all, this was about the most complete we had seen, and gave us a fair idea of what many of the medresses in Central Asia must have looked like before they began to fall into ruin. And that is not saying very much : for, to a European eye, they have a dull, unfinished, unfaced look about them that is disappointing. Their photographs flatter them. Several of the Khivan mosques are ornamented with blue and white tiles, interesting, because locally manufactured, but they did not advantageously compare for beauty with those we had seen at Samarkand. This medresse, with 130 cells, has a large quadrangular court, with a well, and is surrounded by cells fitted with hearths, where each student does his cooking-when he has anything, that is, to cook. In one of them I saw a samovar, china teapots, and felts, but for the most part everything looked poverty-stricken. More interesting than this medresse, however, I thought the immense tower without base or capital, which, owing to the death of the builder, Vambery says, but to the lack of funds, as the people told me, remains incomplete, like the Calton at Edinburgh-memorials of men who "began to build and were not able to finish." The Khivan tower was 


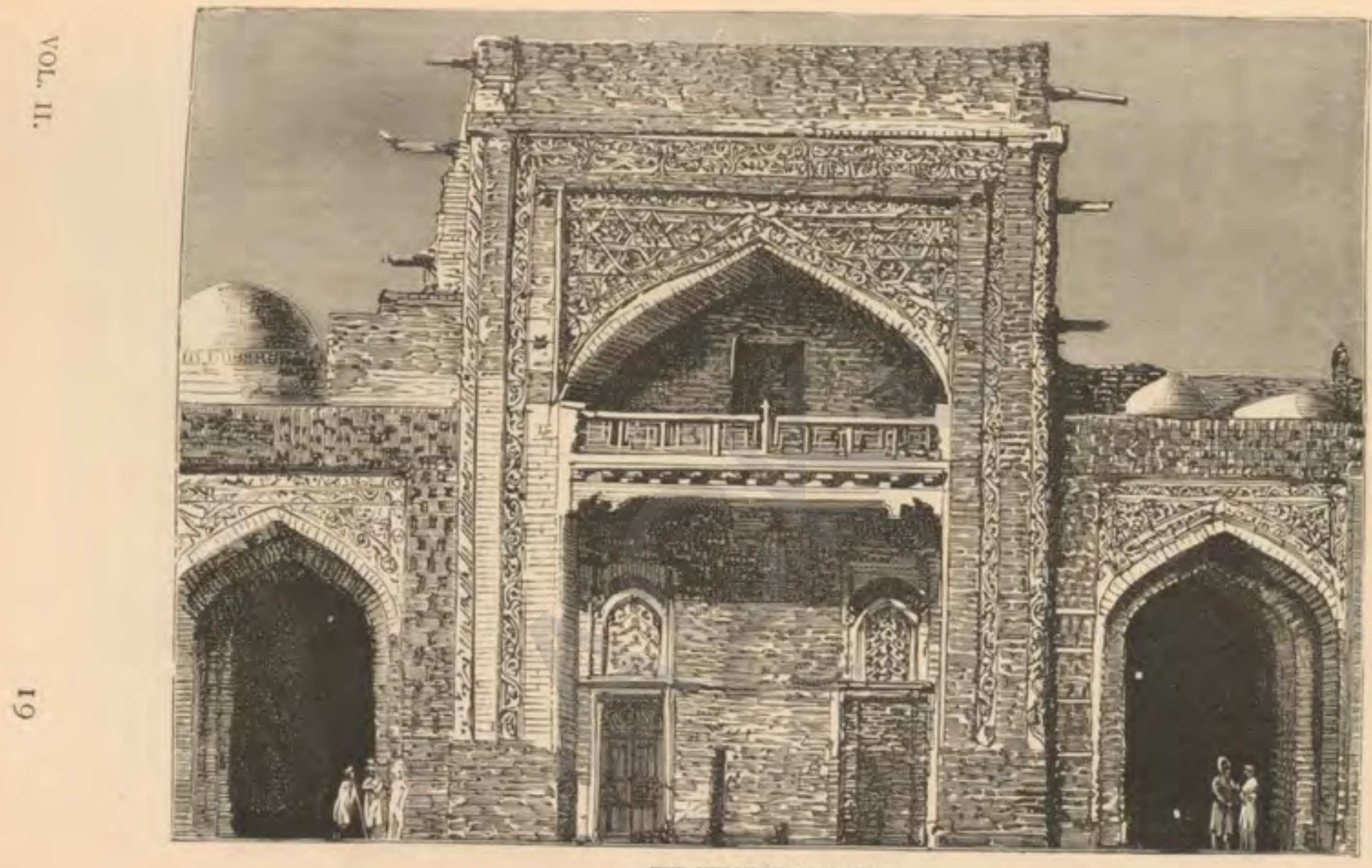

THE MUEDKESSE MLADEAMIM. 
intended for a minaret, at least twice as high as at present, but even now it is the most prominent architectural object in the town, by reason of its prettilybuilt texts from the Koran and ro zones of light and dark blue, green, and brown bricks. I had a great business to measure with my tape its circumference, and found it to be 146 feet, and I also estimated its height to be about the same, and its diameter at the top about $\mathrm{I}_{5}$ feet. This tower and medresse are built of particularly good burnt bricks, which the natives said cost $5 d$. each, meaning thereby, I presume, those coloured.

Having referred to so many Central Asian medresses, I must not omit to say something about the kind of life the students lead in them.*

The course of instruction is not limited as to time. Some of the students stay 30 and 40 years, affirming that if a bird could fly for 30,000 years in a straight line, the distance it traversed would scarcely give an idea of the depth of Muhammadan learning. The prose of that Oriental calculation is that some of the students like so well their cell, in which somehow or other they can generally get a piece of bread-from the foundation, by begging, or a little work-that they do not care to leave.t Of sciences based on facts, of the

- The composition of a college consists of the direction, the teachers, and the students. The mutawali look after the property of the college. The teachers are called mudarises, meaning readers, or teachers, and the students shagirds, or disciples. The last may be of any age from I5 upwards. No special forms, and no standard of knowledge, ate necessary for admission.

† Students are grouped, though not sharply, in three courses. In the lower course they are taught grammar and rhetoric; in the middle, dialectics and metaphysics ; and in the upper, jurisprudence, which also comprises the adoration of God. The student is free to choose, and the majority take jurisprudence, few going through the complete curriculum of study. The method of instruction is to commit to memory. 


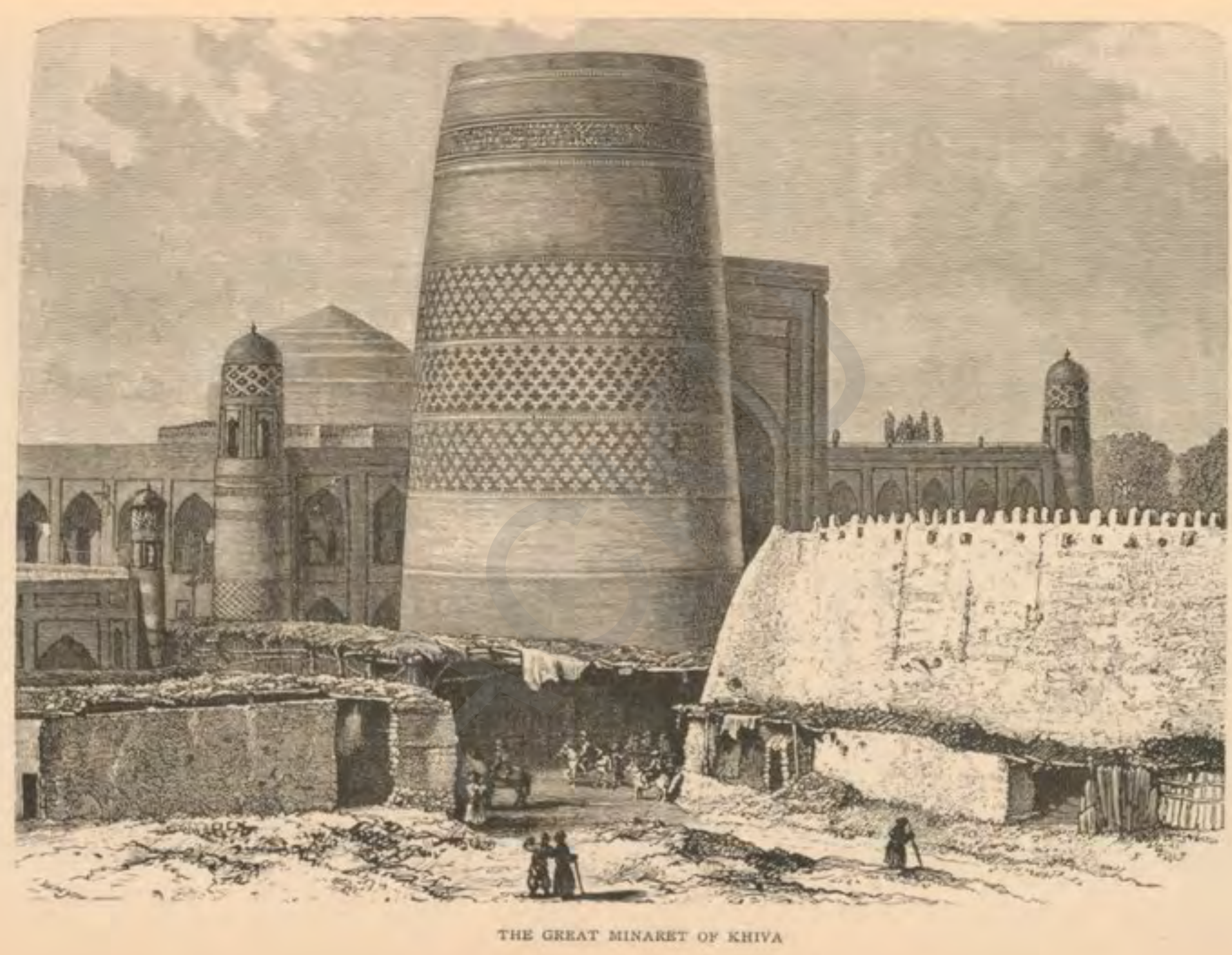


methods of working induction, of physics, chemistry, history, geography, the Muhammadan student hears not the name, nor of modern languages, unless it be Uzbeg and Tajik.*

All roads leading out of the circle of knowledge bounded by religion are cut off from the Muhammadan student. He must know, Kostenko says, only that which the authors of the works he studies knew from 500 to 1,000 years ago. He is taught to disbelieve in ascertained science, the rotation of the planets, the laws which govern physical phenomena, in the forces of nature, in historical facts, in a criticism which would

and then receive comments thereon. A man who can say the Koran from end to end, or, beginning at any part, can go on repeating it, is deemed a scholar, though he may be utterly unable to translate a chapter, and know nothing of Arabic. Many, indeed, study nothing but the Koran for 8 or 9 years.

- I could not hear of such a thing in Bokhara or Khiva as an Uzbeg grammar or dictionary, though they have various books-religious, poetical, historical-printed in this language, and in Tajik, Arabic, and Jagatai Tatar. Professor Vambery published an interesting article "On the Uzbeg Epos" in the Fournal of the Royal Asiatic Saciety for July, 1880. I was told in Bokhara that a Kazan Tatar grammar would do for Uzbeg, and I have seen or heard of " A Sketch of the Turki Language," by Robert B. Shaw, Lahore, 1877, and Calcutta, 1880. There is also the "Chagataische Sprachstudien" of Professor Vambery, and the standard work of Callim Beg, who was an Indian official, taught at Kazan, but who wrote his grammar in English. Captain Mirbadaleff spoke to me of Uzbeg as a branch of Tatar, differing from Jagatai in local expressions and pronunciation, and said there was not so much diversity between Jagatai and Uzbeg as between Sclavonic and Russ. The chief difference, he said, between Kirghese and Tatar is in pronunciation. According to Mr. Howorth, the Turkish dialects are divided into the two great divisions of Eastern and Western. The Uighur and Jagatai are types of the Eastern, and Uzbeg, Kazak, Turkoman, and the so-called Tatar dialects, of the Western. Uzbeg and the dialect of Kazan are deemed very pure forms of Western Turkish. The main shibboleth, distinguishing the Eastern and Western Turkish, is the change of $s$ into $r$. In Tashkend a gazette is printed in Russ and translated into Uzbeg, not purely, but somewhat mixed with Tatar. 
wipe out all elements of fancy. On the other hand, he must recognize that there are seven heavenly spheres, that all the earth is divided into seven climes, and that Mussulmans are destined to rule over all men!

An understanding, bound by the chains of such a slavery as this, says Kostenko, of itself cannot emerge from the mist, nor can it make the existence of man smoother and more reasonable. And then he adds, "To Russian influence in the East is presented a problem important and exalted. It must break the intellectual fetters of Muhammadanism, and turn the people to the wider development of humanity."

This is good, and it is gratifying to see so intelligent a writer as Colonel Kostenko recognizing the responsibility of Russia towards her conquered Moslem subjects, so far as their intellectual needs are concerned. But I hope they will not stop there; for as we pass from the medresse to the mosque, we shall see, I think, that an intellectual reformation alone, even if it could be accomplished, would be utterly insufficient properly to elevate the Muhammadan mind.

The one mosque in Khiva that is worthy of notice is the Hazreti Pehlivan-Ata. It has one large dome about 60 feet high, surmounted by a gilt ball, and covered with green tiles, like some of those in the great tower. There are also two small domes. The building is of kiln-burnt brick, and contains the tomb of the Pehlivan Ahmed Zemchi, patron saint of the Khivans. We approached the interior through a darkened passage, where was shown the tomb of Allah Kuli Khan, and though only about 35 years old, it is already decaying. From beneath the cupola we had rather a pretty view of the tiles with which it is lined, adorned with blue tracery, and interwoven with 
verses from the Koran. This dome, owing to its construction, is said to have peculiar acoustic properties, to which the Khivans attach superstitious importance. There were pointed out to us the tombs of Abul-ghazi Khan and Anusha. MacGahan alludes to the tombs of Muhammad-Rahim, which may agree with one they told me was the present Khan's "grandfather," and another of Shir-Ghazi, the Khan who outwitted Bekovitch. Adjoining the apartment under the dome were two side chapels. In one of them is the tomb, says MacGahan, of Allah-Kuli Khan, who received Abbott, Shakespear, and Conolly, and in the other the tomb of Palvan himself.

I am under the impression that this latter is regarded as particularly sacred and kept locked, but when the door was unfastened, Yakoob, delighted no doubt with the opportunity, went within, and I followed through a cloth-covered door. Within the inner and almost dark chamber was the saint's tomb, but the whole affair looked shabby and dirty; and by the time I had seen this, the information had reached me through my two interpreters that persons were not allowed to go in. Neither at the Shah Zindeh at Samarkand, nor in Khiva, did we come in contact with anything like the crowds that are to be witnessed flocking in Russia to the monasteries of Moscow and Kieff, or in Italy to the holy places of Rome. I am not sure how far this is any indication of the falling-off of Muhammadan zeal, or that it much assists in forming an opinion on the vitality of the Moslem faith in Central Asia; but to this end I shall put together such facts as I have ascertained by inquiry or observation, from which the reader may judge the matter for himself. 


\section{CHAPTER LXIII.}

\section{KHIVAN MOSQUES AND THEIR WORSHIPPERS.}

Muhammadan religious orders.-Ceremonies of the Jahria Brotherhood. - Superstitious practices.-Dancing dervishes.-Religious condition of Central Asiatics.-Morals of the people.-Fanaticism and indifference.-Their attitude towards the Bible and Christianity. -Importance of missions to Muhammadans.-Efforts of "Orthodox" missionaries.-Labours of the Bible Society.-Khiva seen from a minaret.-The winter palace and fumma mosque.-The prison and gallows.-Home entertainment.-Farewell visit to the Khan.-Hazarasp and its legendary origin.

I HAVE already spoken of our attendance at the Friday mosque at Bokhara, where I thought we saw Muhammadanism, so to speak, at its best. We saw something of another religious service in the Shah Zindeh, at Samarkand, that was less pleasing, namely, the excited frenzied worship of the Jahria Brotherhood, as Dr. Schuyler calls them, though the word I have in my notes is the sect Nadamat. The proceedings reminded me of the service of the so-called "howling" dervishes I had witnessed at Constantinople. Neither there nor at Samarkand did I see the service begin, and in both cases we came away before the end. Dr. Schuyler has described their worship with his usual thoroughness, which enables me better to recount what I saw. At Samarkand the mosque was well filled with an audience seated on the floor, 
whilst opposite the entrance, near the kibleh, were I I men, ejaculating prayers with loud cries and violent movements of the body. They recite texts, such as Hasbi rabi jal Allah! ("My defence is the Lord, may Allah be magnified!"); Mo fi kalbi hir Allah ("There is nothing but God in my heart!") ; Nuri Muhammad sall Allah ("My light, Muhammad, God bless him!"); La iloha ill Allah ("There is no God but Allah!"). These words, or some of them, are chanted to various semi-musical tones, first in a low voice, and accompanied by a movement of the head over the left shoulder towards the heart; then back; then to the right shoulder; and then down, as if directing all the movements to the heart. Sometimes I observed a man, more excited than the rest, shout a sentence, throw out his arms, dance, jump, and then slap his left breast with such force as to make the place ring. These texts are repeated several hundreds of times, till the devotees get so exhausted, and so hoarse, that their repetitions sound like a succession of groans, and we could see the perspiration running through their clothes. Some were obliged to give up and rest, whilst others were pushed out by the Ishan, who was conducting, and who called someone else to fill up gaps in the ranks. When their voices have become entirely hoarse with one cry, another is begun. They sit at first in a row, but later on, as the movement quickens, each puts his hand on his neighbour's shoulders, and they form in a group, as Dr. Schuyler says, " in several concentric rings," but which could remind a native of Blackheath of nothing but a group of players during a "scrimmage" in Rugby football, as they sway from side to side of the mosque, leaping about, jumping up and down, and 
crying, Hai! Allah Hai! like a pack of madmen, till the Ishan gives them a rest by reciting a prayer, or a hafiz recites poetry; or again, as at Samarkand, we heard a dervish sing a solo in a fervid, trilling voice.

One curious part of the service, as I saw it at Constantinople, was that persons apparently sick were brought to the minister, to be stretched on the floor, whilst he set his foot on their shoulders, breast, etc. In one case, eight men, women, and children, being laid in a row, side by side, he deliberately planted his elephantine foot on the first, and walked over them all, one woman, I observed, making a terrible grimace as she received his whole weight. After this ordeal they all went up and kissed their benefactor's hand! Besides this, various garments, and vessels, bottles, etc., were brought to him to breathe his holy breath upon, and thus impart his blessing."

I saw also at Constantinople the worship of another order, popularly called by foreigners the "dancing" dervishes. ${ }^{+}$

We did not meet in Central Asia with any such "orderly" dancing, but in the bazaar of Khiva we

- Can the former of these practices be in any way illustrative of an Oriental procedure, as in Isa. li. 23, "I will put it into the hand of them which have said to thy soul, Bow down that we may go over: and thou hast laid thy body as the ground, and as the street, to them that went over" ?

$\dagger$ The square mosque had galleries around, supported by wooden pillars, the centre of the floor being partitioned off for the dancers, Is in number, of all ages, from boys to "greybeards." " They commenced. by walking round in single file, and solemnly and sedately saluting their chief and one another. Having completed a triple circumambula. tion, they stripped themselves of their upper garments, and began to whirl round in their respective orbits with sufficient velocity to cause their kilts, or petticoats, to fly out at right angles to their bodies, therein resembling a troupe of stage dancers, their faces the while being turned upwards, and eyes closed in apparent meditation. They kept this up for a long time, music and singing going on meanwhile with 4 
suddenly came upon a company of dervishes, or Kalendar, from Kashgar, who were prancing about the street. These dervishes, like the Nazarites and the Russian priests, suffer no razor to come upon their head. They wear an extinguisher-shaped cap, a sample of which I would gladly have purchased new, but found they were not to be had, for that each made his own ; and to take one second-hand was more than I dared do! When they saw us strangers they broke up their dance, and were for making off, but I called them back to see their performance. They are dressed in rags, and each carries a wallet, and a drinking vessel shaped out of a gourd. They sing sacred songs in Persian and Turki, shouting as loudly as possible, accompanying the singing with boundings, prostrations, and whirling about.* I noticed that one dervish had in his hand two wooden rods about 16 inches long. To these were attached a ring 4 inches in diameter, and on this ring were 12 smaller rings. This was carried in the hand when dancing, and a jingling made therewith. I bought it, and was glad thus to secure a souvenir of these wild-looking devotees.t

Having heard so much of the fanaticism of the Muhammadans in Central Asia, I made inquiries, so flutes, 3 kettledrums, a tambourine, and 7 singers, the last making strange grimaces in straining their voices in Eastern fashion to the loudest.

* Does this possibly afford some illustration of David's "leaping and dancing before the Lord," on account of which Michal, the daughter of Saul, despised him in her heart? (2 Sam. vi. 16; I Chron. xv. 29).

† Both Vambery and Schuyler speak of their smoking of nasha, or hemp. They are supposed to be great fanatics, and preached hatred and hostility to the infidel till the Russians stopped their preaching in Turkistan altogether. In appearance they looked about the most depraved specimens of humanity we saw in Central Asia. 
as to ascertain, if possible, their religious condition and development. Kostenko says that as a people the Sarts cannot be called religious. Even the mullahs and the kazis know but imperfectly the Koran and the Shariat. The simple folk do not know the most ordinary prayers. On the ordinances of religion, such as the five periods of prayer, ablutions, and the like, the Sarts look as a weary form. Where the officer has been abolished whose duty it was, and in Bokhara still is, to compel the people with sticks to say their prayers and be religious, there the attendance at the mosques is less than one half what it used to be, and Kostenko does not hesitate to say that hypocrisy alone and hope of gain arouse the Sarts to the outward forms of religion. In a paper by M. Ostroumoff on the characteristics of the Mussulmans in Central Asia, he makes many deductions against them upon too slender premises, I think. His facts, however, if true, are noteworthy, for he represents them as not despising a murderer, and given to gambling, which causes many to rob.*

One man, of whom I asked the character of the natives, said: "They are revengeful ; give good words for a favour shown them, but nothing more; very untruthful, utterly untrustworthy in dealing with Russians, and not much better among themselves; very dishonest, and trying to cheat wherever they can." + To this it is only fair to add an extract I

\footnotetext{
* He adds that the houses of ill-fame in Russian Turkistan are mostly supplied with native women, fathers bringing their maiden daughters to sell. I myself heard of one man leaving in such a house for a time, and for the sake of a trifling sum, his own wife. Of course, the natives might retort that it was their conquerors who opened such houses among them, but $\mathrm{I}$ am adducing these alleged facts not for the purpose of instituting comparisons, but rather to describe things as they are.

$\uparrow$ This, from a man living among them, only confirms what Kostenko
} 
have received within the past day or two from a letter by Dr. Vanorden, an American medical missionary, dated Khiva, Dec. I5th, I884. He says :- "In my frequent walks through the city I meet with no rudeness, and not unfrequently I receive the salutation 'Salaam alerkum' from all ages. No weapons are carried. There are no soldiers. If one deviates from the fair way, he is at once reminded that he is a Mussulman and a Turkoman, and not a Kafir, and that it becomes him to be consistent."

As to the fanaticism of the Central Asiatics, I asked the question more than once, "Is Muhammadanism progressing or going back in Central Asia ?" Looking at the tumble-down condition of the medresses and mosques, I should have been rather inclined to think the latter; but I was reminded that if their temples were not grand, neither were the people's houses. Common opinion went to say that there is now less fanaticism than formerly. One man at Bokhara deemed it stationary. He thought they made converts only occasionally, when a Hindu or Jew condemned to death turned Muhammadan to save his life. At Petro-Alexandrovsk I was told the mullahs have little influence among the people, who there are not fanatical, but rather indifferent to religion. Where four houses are near, they elect one of themselves for mullah, and many do not trouble to come in to the town mosques at all.

writes. It should be observed, however, that he affirms certain of the moral sides of their character to produce a favourable impression. The absence of drunkenness preserves them from many vices and crimes, and likewise preserves their strength and health. The Sart discontinues work from Thursday noon till Friday evening. Again, they are kind-hearted, hospitable, and readily help the poor. In every town, he says, there is a society that undertakes the care of the poor and orphans. Consequently there are few beggars among them. 
I certainly observed one marked difference between Constantinople and Samarkand. At the former I had to take off my shoes, and be on my best behaviour. In Samarkand we were not asked for a moment to be unshod, and they made no objection to the Russian officer, who was with me, smoking in the precincts just outside the doorway. We had been told by our Jewish interpreter that if we had seen enough of one part of the ceremony they would go on with the next, and, surely enough, upon the Russian officer intimating that we must be moving, the Ishan did change the form of the service! Dr. Schuyler met with a similar experience in Turkistan, whence he infers that this willingness of Muhammadans to show Christians their rites is not so much a sign of growing liberalism as of indifference.

In passing through the Steppe I sold, as I have said, many New Testaments to the Kirghese, and going through Bokhara I gave an Arabic New Testament, a Persian Bible, or a Turkish Gospel to, I think, every bek whom I met, as well as to the Emir. I asked an intelligent Muhammadan what he thought the natives would do with the books. The Kirghese, he supposed, would simply neglect them, but not destroy them, as he thought would be the case with the mullahs of Khokand and Samarkand. Further, that if the mullahs had known I was coming with such books, though they would have been afraid to offer personal violence, they would most likely have taken measures, he thought, to prevent their distribution. Captain Mirbadaleff said that when, as a boy, he was instructed at Orenburg, and there was a Tatar copy of the Scriptures placed within reach of the Muhammadan scholars, but it was hardly read at all.

* Perhaps it is not to be expected, since I am told by Mr. Hyde 
I asked the Khan of Khiva to accept a Persian Bible and Arabic New Testament, whereupon he inquired what religion they had in England, and whether, like the Russians, they cross themselves in prayer. i replied that we had no pictures or images for religious use in worship, that we did not cross ourselves, and that our religion was in the Bible I had given him. Did we believe, he asked, that Jesus Christ was a prophet or God's Son? I said "Both," whereupon he said to Yakoob, privately, "That is not true"; but when Yakoob asked whether he should translate that reply, his Highness said "No," and ended by observing that each one had his own religion.

I was keenly interested, of course, as to how the Muhammadans would receive any attempts to convert them to Christianity. I say " of course," because I find it extremely hard to understand the position of those who say, "Leave the Muhammadans alone. Their religion is suitable for them. A good Muhammadan compares fairly well with an average Christian. Converts can hardly be made, and, when made, do but follow the example of their Christian masters in eating pork and getting drunk." Now, if this string of objections were true (which it is not), even then I fail to see that a Christian would be released from obedience to the standing orders of his Master to "make disciples of all nations, and preach the Gospel to every creature" (Matt. xxviii. 19; Mark xvi. 15). If one thing be manifest about Christianity, surely it is that it is a proselytizing religion. Its Master was a proselytizer and all $\mathrm{His}$ first followers, and $\mathrm{I}$ am at a loss to see how

Clarke that the New Testament is of no authority to Muhammadans, being held to be corrupt, whilst the genuine teachings of the prophet Jesus are in the last revelation of the Apostle Muhammad. 
any who profess to follow Him can free themselves from so plain a duty.

Russia has no doubt dealt tenderly with the natives of Central Asia in keeping back even her own missionaries, lest to the natives the adoption of the conquerors' religion should seem a matter of compulsion, but this state of things ought not to go on. It is a most hopeful sign in the Russian Church that they are awaking to the duty of sending missionaries to their heathen fellow-subjects ; and I was gratified to be asked by one Russian in Tashkend, how the English managed to get a missionary hold of Asiatics, as he would like to do. Another, a German Russian and a Lutheran, was far from satisfied with the little that is being done for the spiritual good of the Muhammadans. He doubted, however, whether the orthodox missionaries were likely to make much headway among the Moslems, if for no other reason than that their use of pictures in worship is to a Muhammadan an abomination and idolatry,

I was pleased to see, however, from a short notice of Russian missionary work in the Times for 4 th September, 1884 , that at one place a chapel had been built, at the cost of the heathen Kirghese, in which I 20 persons had been baptized; and in the government of Tomsk more than 400 Kirghese, chiefly Muhammadans, are reported to have embraced Christianity. Here, then, is a beginning on the part of the Russians, which I pray God may go on and prosper.

Meanwhile the British and Foreign Bible Society has not been idle, as will be seen from its reports for 1883-4. The brothers Bartsch from the Tashkend depôt, on their way to Khokand, sold to the Kirghese 349 copies of the New Testament in 8 days, and I 
observe that since my visit two colporteurs have made an interesting journey from the Caspian to Khiva, Bokhara, and Charjui. In Khiva they stayed a week, and left it under the impression that the town offers great opportunities for Bible work. Of Bokhara they say, "In this thickly-peopled town even a timid colporteur need not be afraid to work."* In the six months they were away, they sold to the Turkomans, Khivans, Russians, and Bokhariots, 3 I9 copies of the Scriptures, or portions, for i 8 roubles. This for a first journey by two unprotected colporteurs into parts where even I, with the Russians at my back, was warned of danger, I think highly creditable to the agents of the Society, and still more so as their travelling expenses, including the hire of camels, amounted to only $\delta_{27}$ !

Thus Bokhara and Khiva have been approached from the west by these colporteurs; by myself from the south, and on the east the brothers Bartsch went to Samarkand, and wished to go on to Bokhara; but General Ivanoff, though authorizing them to colport among the Russian troops (to whom they sold 330 copies in 5 days), hesitated to let them go on to Bokhara, without telegraphing first to Petersburg, and finally thought it would be safer for them not to go. It is from this side, however, the khanates will be most conveniently worked. $\dagger$ The opinion of the men

* I am informed by the Secretary of the British and Foreign Bible Society, that Dr. Vanorden, writing from Khiva, says :- "The report of your colporteurs as to the quiet of this land I find fully confirmed by my own experiences. It extends even to the animals; for though there are many dogs here, not one barks at the stranger. . . . I am much pleased with the people. It would seem as if they could hardly be Mussulmans, so different are they from others I have met with."

† From the latest information, I learn that the brothers Bartsch went on a tour in the summer of 1884 to the North-East (I presume through Vierny), and met with tolerably good success. "But in the neigh- 
from the Caucasus is, that it is very desirable that Bible work should be taken up by colporteurs from the three centres, Khiva, Charjui, and Bokhara; for, say they, a very large proportion of both sexes, young and old, can read, and there is nothing to hinder work among them.*

But to return whence this excursus began. I found it not so difficult to ascend a minaret in Khiva as in Bokhara. On approaching the Jumma mosque, and seeing its elegant minaret, I expressed a wish at once to go up. They replied at first that the man with the key was absent, which temporary difficulty was overcome by my saying that we would wait till he brought it. We then mounted 90 steps, each about a foot high, and had a capital view of the city. The configuration of the outer wall is that of an oyster-shell with the narrow end elongated and squared. $\dagger$

bourhood of Tashkend the fanaticism of the Muhammadan population, which is easily awakened, has, after the first success, tended greatly to decrease their sales." At Tashkend the Gospel of St. Matthew in Kazan Tatar is finding acceptance, and an agent of the Society, one Jacob Starkel, is stationed near Petro-Alexandrovsk.

"I am glad to notice here the kindness of General Grotenhielm at Petro-Alexandrovsk to the men; also of the Governor-General at Askabad, who gave the colporteurs a recommendation to authorities they might possibly meet. His Excellency charged the leader of the caravan to take due care of them, and made him promise to take them safely to Khiva. So, too, in Askabad, a Russian doctor attended gratis one of the men who was ill, wishing, as he said, to befriend a
colporteur of the Bible Society.

+ Its largest diameter is a mile and a half, its shortest a mile. The wall measures 3,100 fathoms, or 4 miles, in length according to Basiner's map (but they told me 8 miles), is about 25 feet high, the same in thickness at the bottom, but only two or three feet at the top. The wall is pierced by 12 gates, and the whole is girdled by a wide ditch. This wall was built by Allah Kuli in 1842 . Within are visible many fields ings, and fortress-limer palace of the Khan, with other great buildings, and fortress-like farmhouses. There is besides an inner wall, in the shape of a parallelogram, 700 yards long on the eastern and western
sides, and 540 yards broad. VOL. II. 
Below us we could see plainly the winter palace of the Khan near the western gate of the citadel; a large. rambling structure with crenelated mud walls, and having chambers rising above them. On either side of the entrance gateway is a tower, whose top is embellished by coloured bricks, whilst along the cornice of the façade is a row of loopholes. In front of the palace is a square, in which we found some brass cannons mounted on

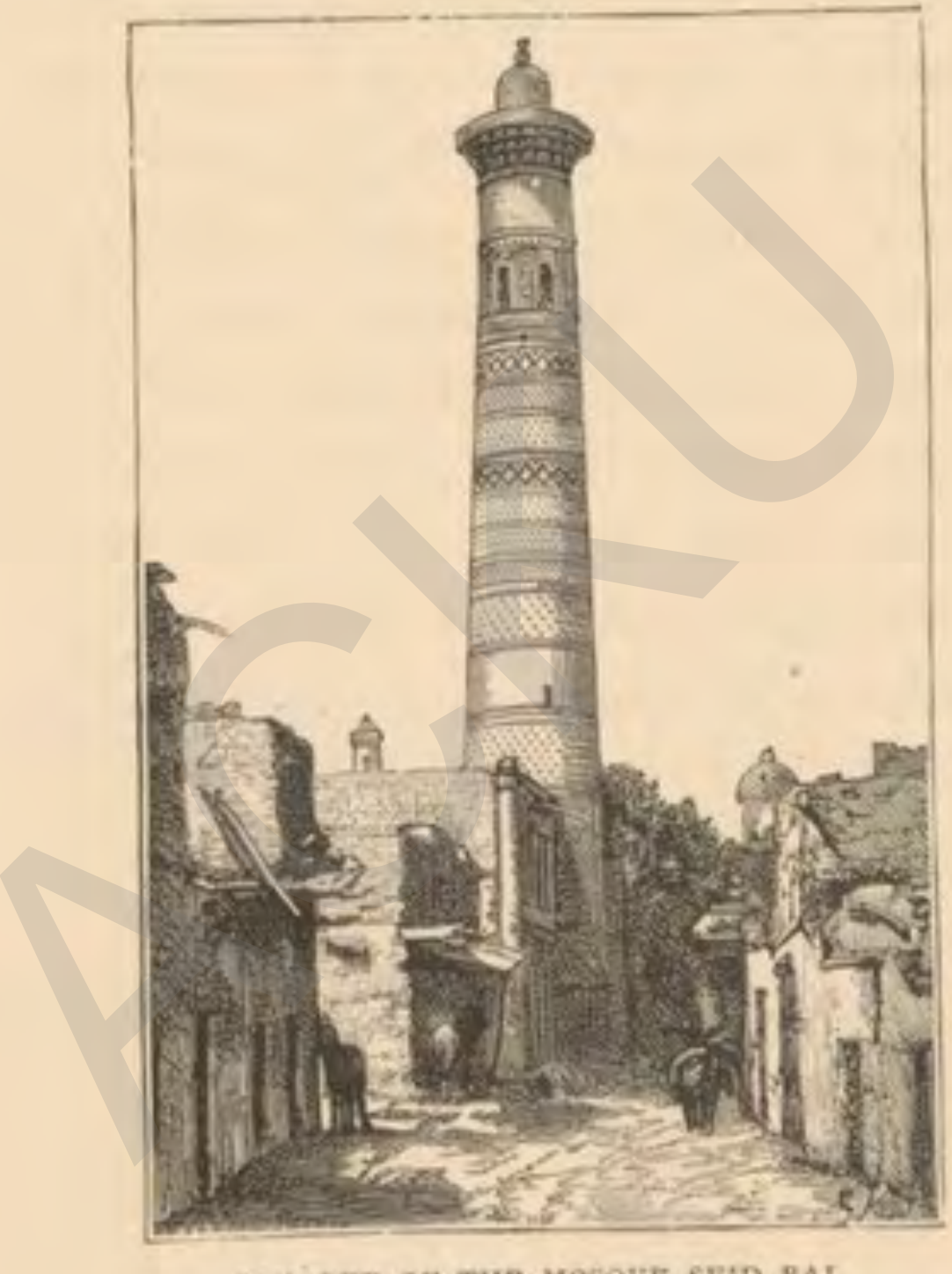

MINAKET OF THR MOSOUE SEID BAL.

carriages with wooden axles, also a mortar, but all of them exceedingly clumsy, whereupon I asked the Consul how, with artillery such as this, they could not manage to keep off the Russians? Later on we asked the Khan to be allowed to see his palace. He said that, had we asked before, we should have done so, but that he was on the point of quitting that very afternoon his summer for his winter palace, and consequently 
we could not go inside. The view of Khiva was no exception to the usual ugliness of an Eastern city as seen from an eminence. We could detect the existence of mosques and medresses by the mud cupolas over them, and we could see well another minaret belonging, I think, to the mosque Seid Bai, almost a facsimile of the one on which we were standing. The big minaret also stood out well, but there were few other buildings sufficiently conspicuous to be worthy of mention. Immediately below us was the flat roof, with two octagonal holes, of the Jumma mosque, where the Khan attends on Fridays, and into which we descended. Anything more bare and ugly as a place of worship it would be hard to conceive, and this was intensified by a forest of upwards of 200 columns or poles, by which the roof was supported.

Dr. Wolff said the population of Khiva was 600,000 at least, including 40,000 slaves. Captain Burnaby guessed it at 35,000. From the top of the minaret I put it down at 5,000 less; but Réclus mentions from 4,000 to 5,000 , which must, I think, be a mistake.

I had somewhat of a tussle about seeing the prison, for when I asked the Consul to conduct me there, he at first declined, whereupon I spoke loudly, insisted, and asked him to send at once to the Khan for permission. At length they brought us round to one of the city gates, beneath which was an arched room, wholly without light, and with a door hardly large enough for Sevier and me to crawl through. We found the prison to be 16 feet long, by $8 \frac{1}{2}$ feet wide, and 6 feet high. It had no flooring and no beam for stocks as at Charjui. There were two Kirghese and two other men, prisoners, all secured to one another at the neck by a long chain, and for the moment they were 
sitting outside before a fire. This was the only prison, they said, in Khiva ; further, that they made short work with malefactors, and decided their cases quickly. The men appeared to be fed truly "with bread of affliction and with water of affliction,"* and after giving them a trifle we continued our round, passing in the course of the day the gallows.

Having thus spent some hours in looking about the town we returned late to lunch upon the inevitable pilau. On the previous day we had heard a story from the cook's dominions anent this dish that was flattering to our nationality. Among the condiments in the niches in our room was some Russian essence or extract of vinegar, and the cooks thinking, I suppose, to give us something recherche, and not knowing the strength of the essence, mixed it freely in the rice, and then discovered that they had spoilt it, whereupon they made some more, but declared that the vinegar must be English, for that the Russians had nothing so strong as that !

We were not called upon for much medical assistance in Khiva. Their chief diseases are fevers and ophthalmia, but they have no leprosy or rishta. Sevier prescribed only for the Divan-beggi, and I think a few of his household, who seemed anxious in every way to make us comfortable.

On our second evening four musicians came to entertain us, one playing a tambour, two others flageolets, and another a tambourine. We had been told by Captain Mirbadaleff to ask Polvan, the son of Matmurad, for a Khivan flute and for written music for the tambourine. The notes he gave me were written on ruled paper, with lines numbered in Arabic up to 19 , though the notes extend only between lines 6 and io. I $*_{2}$ Chron. xviii. 26. 
heard, too, of a stringed instrument called kizhak, a kind of fiddle. Besides the musicians were provided three batchas, who began their dances with clappers or castanets, but they were not so clever as the boys in Bokhara. They had their hair cut short, and appeared to be from 15 to 17 years old. As usual, a small crowd pressed into the room, and squatted against the wall, Tailly among them, to participate in the fun ; but when the, Divan-beggi appeared he speedily turned out the majority and sat down with us. I had intimated to him that I should be thankful for an opportunity to ask him questions about the khanate, so that when they had made a noise for a while, and then asked if I wished for more, I was glad to excuse myself on the ground that I desired conversation with our host. Ugh! said one of the musicians, as if disgusted with our want of appreciation of their talents. After this they speedily left the room, and we fell to-the Consul, Matmurad, Yakoob, Sevier, and I-at such a cross-

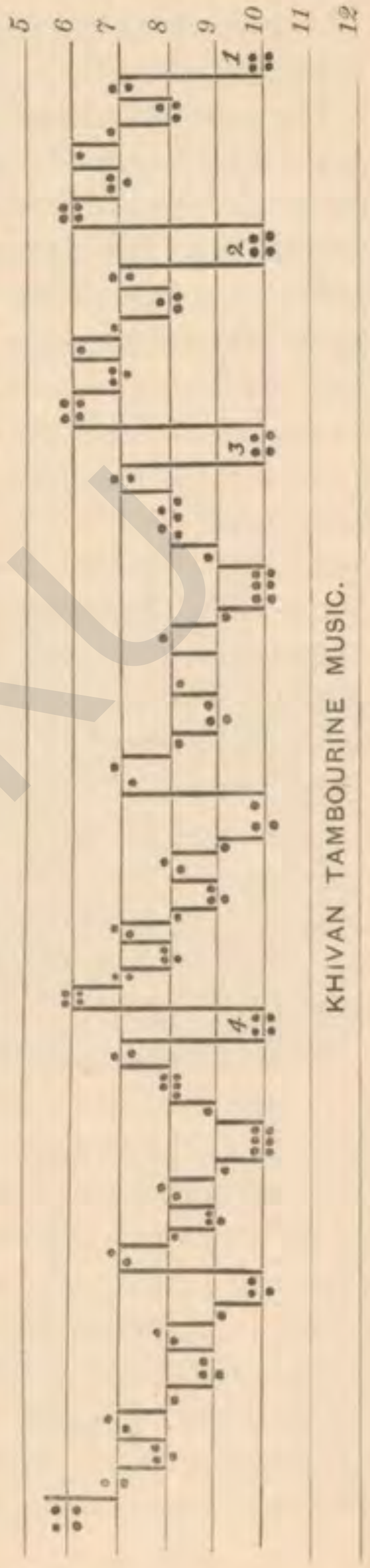


questioning as I think the natives had not often experienced before.

On our last afternoon in Khiva we went to pay the customary farewell visit to the Khan. He received us as before, and seemed rather inclined to talk politics, which, however, is not my forte. He had heard of our war going on in Egypt, and asked whether the affair were cleared up. I had supposed that this war with Muhammadans might have rendered it unsafe for us to travel in Central Asia, but the people seemed to know next to nothing about it, and to care as little. I had heard no news since leaving Samarkand, and not much there, so that I was obliged to explain the situation as best I could. His Highness asked my name and (following in the same interrogative groove as the Bek in Bokhara) my age, and inquired if we had been well entertained in Khiva. This we were able to answer truly in the affirmative, thanks to the hospitality of his Divan-beggi. Before bidding us farewell, he said that he had directed Matmurad to give us men to take our baggage, and that he had also sent to seek for a Russian-speaking djiguitt to accompany us to Krasnovodsk.

Yakoob, who took up his habitation with the servants, and who had not told them that he spoke Tajik as well as Turki, rather amused us that evening by telling us that there had been a discussion going on outside as to whether it would be proper to give us presents from the Khan. It was at length decided in the affirmative, and there came a horse and cloth khalat for me, a similar khalat for Sevier, and a cotton one for Yakoob. Captain Burnaby was informed, he says, that " a khalat or dressing-gown from the Khan is looked upon at Khiva much as the Order of the Garter would be in 
England," at which rate I suppose that I, who had received them in Bokhara by dozens, ought to consider myself "very much knighted."

This honour Tailly seemed anxious also to share, for he cunningly left with Yakoob a limited number of roubles to be offered for the two cloth khalats, telling Yakoob that he wished to take them back to PetroAlexandrovsk, and there to cut a dash, representing

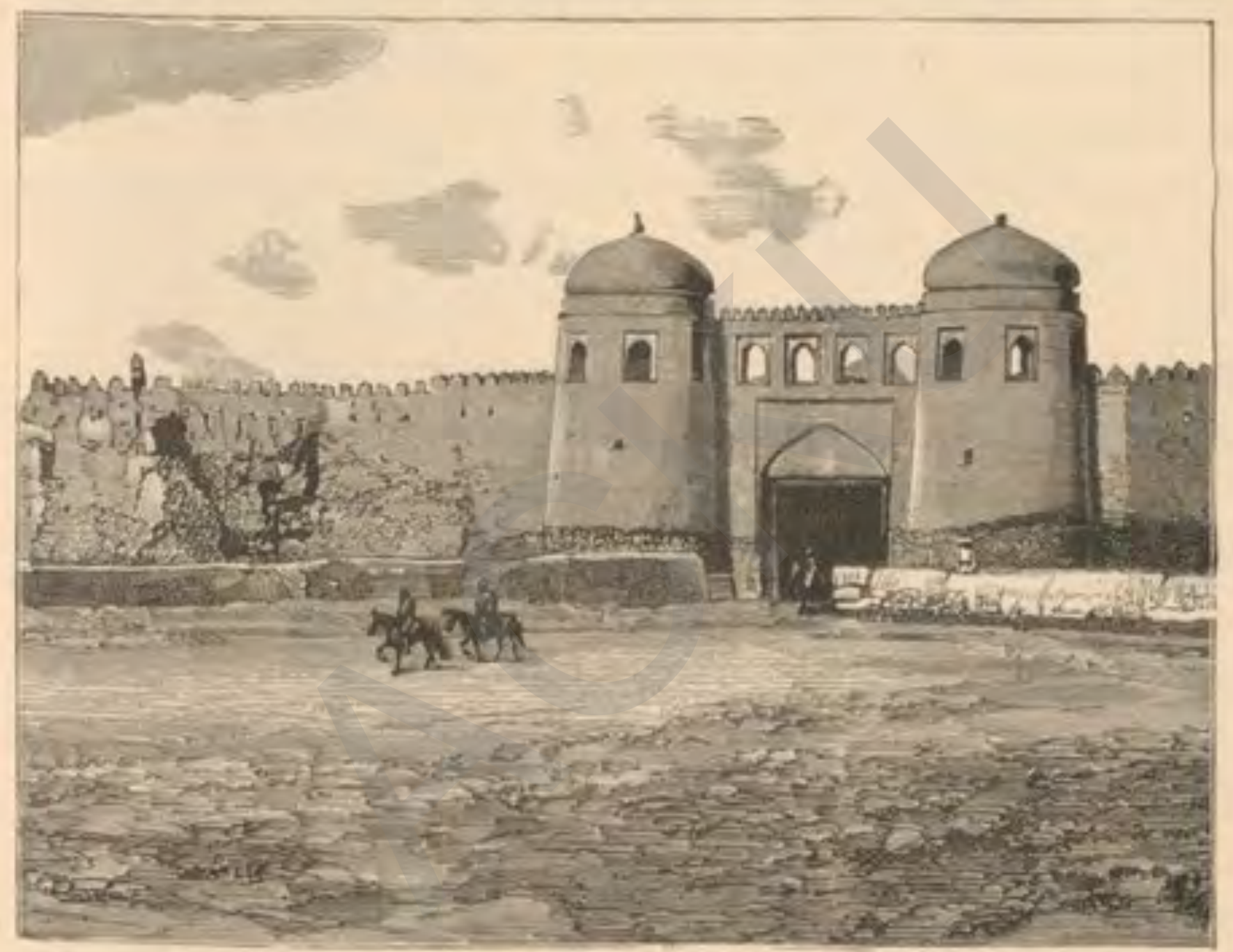

TUE WAZARASP GATE AT KHTVA.

that he had received them as a present for the efficiency with which he had served us. Meanwhile he was cheating us to his heart's content. I had given him at Petro-Alexandrovsk 60 roubles, the very top price he thought he should require to hire the best camels. Now, in Khiva, he came to say that he needed 6 roubles more, and put on the most injured expression when I ventured to doubt his veracity, though his story, as will afterwards be seen, was a concoction. 
I did not hear much of the character and manner of the life of the Khivan Khan, so I can write no scandal about hím. Messrs. Capus and Bonvalot refer to him as a debauchee, but no reports reached me of a fabulous number of royal wives as at Bokhara. The Consul could not tell me how many wives his Majesty had. He had 6 or 7 sons, he said, but of the daughters he knew nothing. General von Grotenhielm told me he had expressed to the Khan a wish to have photographs taken of his wives, and had offered to provide a female operator, but the Khan would not consent. Neither would he agree that one of his sons should be sent to Petersburg to be educated, saying that he loved his children too much to part from them. I think I have read that he has since compromised matters by receiving at Khiva a Russian tutor for his sons.

Whilst talking of Khivan affairs to the Consul, he said he had three wives. I asked if he did not find it exceedingly difficult to manage so many? He looked at the matter, however, in a very practical light. "You see," he said, "I have two houses, one here at Khiva, and the other at Petro-Alexandrovsk, and consequently I have a wife in each, without the trouble of moving her!"

Thus I have described with what fulness I can the city of Khiva, but I must not start northwards without mention of another town in the south, called Hazarasp, approached from Khiva through the gateway of that name-a heavy covered portal ro feet wide by 20 deep, arched over with brick, and flanked by heavy towers with loopholes. The town to which I refer was considered one of the strongest in the khanate, and has an origin lost in legend.

Khiva has been the capital of the khanate apparently 
only since the accession of the Kungrad-that is, the present-dynasty, though it is mentioned by older writers, Ishtakhri, Mokadessi, and Yakut, the last of whom says the natives called it Khivak. The fact that the ambassador told Peter the Great that Khiva consisted only of tents and huts, points to the comparatively modern erection of its buildings. With regard to Hazarasp, however, Khanikoff thinks it was to this place, then called Zariaspe, that Alexander retired for the winter from Samarkand, and Arab geographers of the Ioth century, to whom I have referred, speak of it as a strongly fortified place in their day."

The original fortress is said to have been replaced by the present one, about roo years ago. A part of the wall of the old fortress is said to exist still, and underneath it a Tchile-Khaneh, or hermit's cave, wherein those who have entered have been struck dead or dumb; the last man who did so having seen several figures, and received a box on the ears! The entrance to the cell was then blocked up.

* Popular tradition, says M. Kuhn, records that in olden time there lived four kings - two of them "infidels," and two Mussulmans; the latter, Iskander and Suleiman. Suleiman conquered all the world, tamed every living thing, and subjected to his rule even the inhabitants of the spirit world. On one occasion Suleiman ascended his throne, which by the spirits was lifted in the air, so that he might inspect the entire earth; and then he alighted where now stands Hazarasp. At that period the locality was covered with beautiful meadows and dense forests, through which ran a stream of sparkling water. At the moment of Suleiman's descent a thousand graceful steeds had come to drink. The king ordered the spirits to catch the horses, and when they could not do so, he directed an intoxicating liquor to be put in the stream, which enabled the spirits to fulfil his command, and cut their wings, ever since which time the horse has been the friend of man. Having possessed himself of the steeds, Stleiman caused a fortress to be erected on the spot, and called it "Hazarasp," or a "thousand horses." 
The governorship of Hazarasp formerly belonged to the Inak, or oldest member of the Khan's family, and who came next in dignity to the sovereign."

This governor has his court officials, and the palace of the Inak still stands in the citadel. The Khivan governors of provinces have full judicial authority over everything, the life of criminals excepted, in which case the Khan is appealed to. MacGahan entered Hazarasp with the Russian invaders, and describes the town as he saw it. He speaks of 5,000 inhabitants in the place. It is $1 / 3$ miles from Pitniak, 7 from the Oxus, and 40 from Khiva; and now having mentioned Hanki, Khiva, and Hazarasp, which were regarded as three, we shall now proceed northwards in the direction of Tashauz, which was considered the fourth, of the strongest fortresses in the Khanate of Khiva.

* The office has now somewhat lost its importance, and at the present time there are more Inaks than one; and the ruler of Hazarasp bears a new title, Emir-ul-umer, or "Ruler of rulers." The district has 15 villages, and the town 400 shops. Pitniak and Shura-Khaneh were until recently governed by Inaks during the Kungrad dynasty. 


\section{CHAPTER LXIV.}

\section{FROM KHIVA TO TASHAUZ.}

Departure from Khiva with Khassan the Batchman.-Luggage arbas.Kosh-ku-pryk and its melons.-Aryk and town of Gazavat.Russian reconnaissance of Khivan oasis,-Our stay at Shavat.Amusements of the natives.- Havlis and their supposed resemblance to Scripture "strongholds."-Visit to havli at Manak.Oil and corn mills.-Hawks for falconry.-Mud walls of the havli. -Invitation to stay.-Route to Tashauz.

$\mathrm{O}$

$\mathrm{N}$ Thursday morning, November 2nd, at 9.45 , we said Aman! to Matmurad, our Khivan host, and began our ride to Kunia Urgenj, where Tailly, having left. us on the road, was to meet us again with camels, and start us across the desert. By this means we should pass from the new Kharezmian capital to the old one, and so have seen the principal inhabited points of the khanate. The Consul was setting out to return to Petro-Alexandrovsk, and I confided to him a letter to be forwarded to General Abramoff, informing him that I had now delivered to the Khan the last of his Excellency's letters; also thanking him for the exceedingly kind reception everywhere afforded me, and assuring him that I should take away with me a most agreeable recollection of my tour through his general government. We were now a party of 7 "regulars," besides "volunteers " includ- 
ing the Consul and his attendants, who, on leaving the town, were to turn off to the east, whilst our course was to the north.

We were placed under the charge of Khassan, the old assistant Bek, or more accurately, I think, the batchman, or tax-gatherer, of Kunia Urgenj, and two djiguitts, our luggage having been sent forward by the Khan in 3 arbas. There was more reason now, as will presently appear, than when leaving Samarkand, to be afraid of losing our goods, but I had no means of sealing them up; so, to inspire the arba-kesh with some little sense of responsibility, I wrote in my notebook " 27 packages," as sent from Khiva, and called upon him to affix thereto his sign manual, which he did, " his mark" consisting of a perpendicular stroke, that would, I should think, puzzle any expert in caligraphy to swear to.

I have several times referred to, without describing, the Central Asian vehicle prevailing from Kuldja to Khiva, and called an araba, or arba. Imagine, then, a thick wooden axle, Io feet long, with 2 wheels attached, not quite so high as the big wheel of the "Flying Dutchman" engine-that is to say, about 7 feet in diameter. On the axle a platform is fixed, of two long beams, the hinder parts being interlaced with willow, whilst the front parts serve as shafts. The axle is somewhat curved below, and owing thereto the position of the wheels is slanting, so that the distance between the lower felloes is greater than between the upper, the breadth of the track of the arba being 9 feet. These carts are the only wheeled vehicles used by the natives, and are exceedingly clumsy, but they cannot easily be upset, and can go through water 4 feet deep without wetting the load. 
Our road lay for the first 8 miles through cultivated land, then crossed 2 miles of steppe with a spur of sand-hills on our right. Of the two Englishmen (Captain Abbott and Lieutenant Shakespear) who passed this way before me, the latter mentions a village, about 9 miles north-west of Khiva, called Zaca, where he stayed for a night, previous to receiving into his charge the Russian prisoners on the morrow. This, I suppose, is the place on the map marked Zeikesh, through which we must have passed,

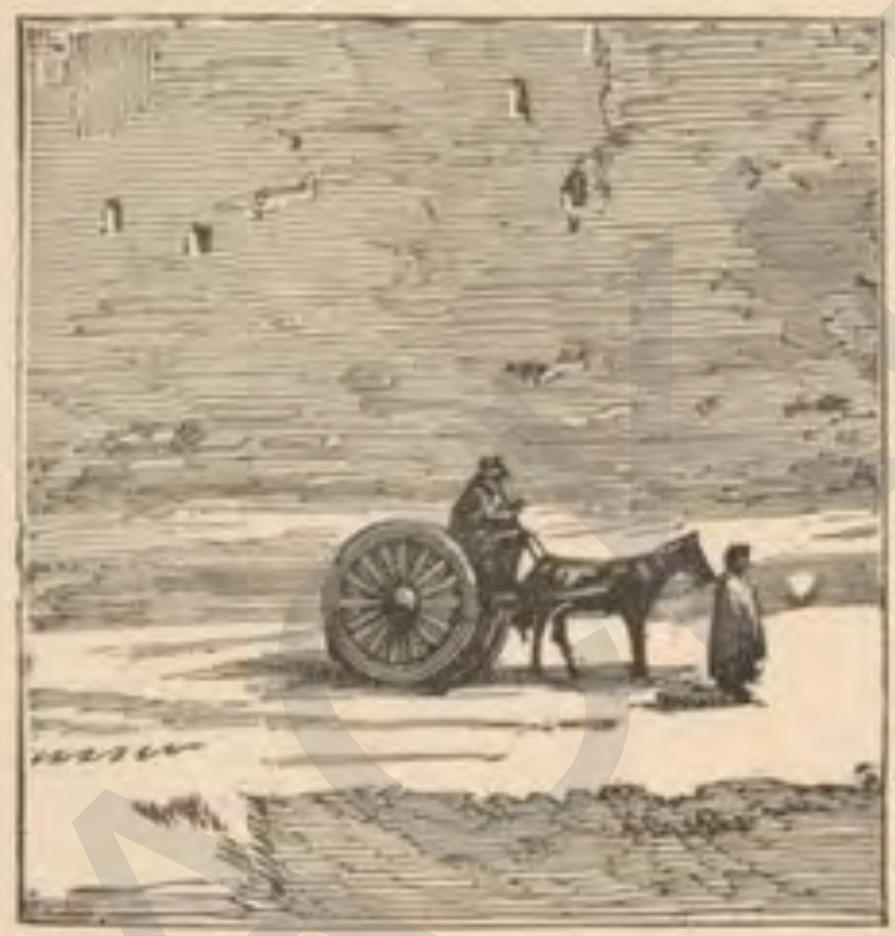

A KHIVAN ARBA.

but without noticing it, as also the village Kanabash, on the canal of that name, a short distance beyond.

At I o'clock we reached Kosh-ku-pryk, I I miles from Khiva, a place marked on the maps as a town, but only a hamlet of less than 20 houses. Here we sat on a platform in the street, in front of a shop, drank tea, and ate bread and melons, taking notice of the dexterous fashion in which the natives cut them up.*

* Drawing his knife from the girdle, the man first cuts off a morsel at each end, slices out a quarter of the fruit lengthwise, and clears away the seeds. Then he deftly passes his knife along lengthwise, just inside the skin, cutting under the pulp about half way across; after 
After the feast, Yakoob asked me for money to pay for it, which, of course, I gave him, though I was still guest of the Khan, as before I had been of the Emir, when everything was found for me. Yakoob told me, however, that had we not paid it was very doubtful whether the refreshment would not have been exacted by the batchman as fruit furnished for the Khan's service. Whilst our horses rested I looked about the village, and in the farmyards, wherein the buildings were commodious, but very rude, the walls being of mud, with timber thrown across for the roof.

Kosh-ku-pryk is watered by the aryk Khazavat, or Gazavat, 30 feet wide and Io deep, according to MacGahan, with a current of 5 miles an hour. It continues ro miles westward to the town of its own name, where a market is held twice a week.* I should observe that during the occupation of Khiva by the Russians, in 1873 , the Orenburg detachment was de-

this he draws his knife across the pulp in skin-deep cuts, half an inch apart, and finally passes the knife along, as before, on the other side, and so releases a number of slices, breaking up the quarter melon. which is not thought too much to give to one person.

* On approaching Gazavat, fields are fewer, and a mile beyond the canal, named Hair-abad, the road leads across a sandy plain, in the vicinity of the Zaikesh, a reedy marsh or lake, 2 miles long and a mile wide, that is formed by the superfluous waters of the Gazavat aryk. This lake is 2 miles distant from the town, under whose walls flows the aryk. On its left bank stands the small fort of Gazavat, erected to defend the place against the Turkomans, about the time, M. Kuhn thinks, of the expulsion of the Golden Horde from the banks of the Volga. He supposes the place to have been first inhabited under Shir-ghazi Khan, or one of the Abul-ghazi Khans, and would derive the name from Ghazi-abad-that is, "pacified - quieted." Uzbegs constitute the chief population, and trace their descent from 4 Kalmuks who settled at Gazavat. Tradition says that the Kalmuks had been of service to the Khan of that day, who gave them hereditary rights in his territory, and placed them over his horses and trappings. On this account they have retained their name of "Altin-djilayou," and they alone have the right to live in the fortress. The remaining inhabitants 
spatched to collect information about the Turkomans, to Kunia Urgenj, whence they marched to Hojeili.*

This detachment passed through Gazavat. So did Shakespear, and, I suppose, Abbott; but, for some reason unknown to me, instead of our turning west from Kosh-ku-pryk, we proceeded north-west to Shakh-abad, or, as it is abbreviated, Shavat. The greater part of our way lay through the sandy desert, Chukur-kum, and after proceeding about 3 miles we crossed an old bed of the Oxus, called "Daudan." $†$

By half-past 3 we had ridden 12 miles more, and reached Shavat, our stopping-place for the night, being now, according to my reckoning, 34 versts, or 23 miles, from Khiva, whereas our conductors wanted to make out that we had travelled 6 parsangs, or 48 versts. No one appeared to be expecting us, and the Bek of the place living at a distance, we were lodged in quarters that were a great "come-down " from the mansion of the Divan-beggi. Our dwelling partook of the features of a farm-house and shop combined, and into our miserable room, with black walls, the light entered only through a hole in the roof, which served also as an outlet for smoke. It struck me that it

are Persians, Karakalpaks, and Tajiks. There are altogether in the town about 300 houses, many being in ruins, and showing traces of the last invasion of the Turkomans in their war with the present Khan. Some Turkomans of the Ushak tribe are settled a short distance from Gazavat, to whose land former Khans extended the aryk, hoping to subjugate them by inducing them to settle to agricultural pursuits. But they became more dangerous than ever, and in all the Khivan revolts the Turkomans of Gazavat were among the most active.

- With them was M. Kuhn, the Orientalist of the expedition, to whom I am indebted for much information of this part of the khanate.

$\uparrow$ The Orenburg division, on their way from Gazavat to Tashauz, had also to cross the Daudan, and whilst the baggage was being conveyed over the bridge, Colonel Glukhovsky was despatched to survey another old channel of the Oxus, called the Urun-daria. 
might usually serve for an apartment-or, better said, a prison-for the women. There were two doors, one leading into a cowshed, and the other on to a shopplatform open to the street, where we drank tea.

As it was fully early, I looked round the town, in this case again consisting of about 12 houses, some with shops, wherein the chief articles of merchandise appeared to be Russian sweetmeats, native tobacco, apples, and melons. One remarkable thing about the place was that the dozen houses had between them at least 6 rams, kept, I presume, for fighting.* This development of the "animal" in the natives, and their readiness to see a fight, came out after dark, when our lamp was suddenly run off with, as I supposed the better to part two dogs that were snarling, whereas I found that the object of the depredators was to incite the animals to fight.

In the course of a few hours the Bek of the district appeared, and an evening meal was prepared, of which the grim and public participation in the open street was not particularly agreeable. Here also Russian candles, such as had hitherto been provided by our native hosts, failed us, and there were furnished the ordinary lamps of the country, not "warranted to burn twelve hours," but that needed frequent replenishing. ${ }^{\dagger}$

We left Shavat next morning at 7.45 , and travelled

* Setting animals, especially rams, to fight appears to be one of the chief sports of the natives of Central Asia. In the rutting season, at the beginning of the year, the camels can be made to fight, and wagers are laid also on the struggles of cocks, partridges, and quails. With these low sports must be coupled that of horse-racing, but the goat-chase does not obtain, I was told, among the Khivans.

† Thus reminding one of the folly of the virgins who carried their lamps, but took no oil with them (Matt. xxv. 3). Again, though our blazing fire (for it was cold) and the light and brightness of our feast were little in themselves considered, yet, compared with the blackness of the street 
all day through a strip of cultivated land, about 4 miles wide, the soil beyond, on the right, being uncultivated, and, on the left, sandy. We came within sight of very little steppe, but passed numerous walled farm-houses, some, however, being in ruins. After riding 4 miles we passed the village Djagatai. The most striking feature of this part of the country is the manner in which the houses are built. The Daudan, which lay about 2 miles on our left, separates the Uzbegs of the Djagatai and Kipchak tribes to the east from the Yomud Turkomans on the west. As it is impossible for the Uzbegs to depend upon the lengthened quiet behaviour of the Turkomans, the Uzbegs have constructed a line of small fortified buildings, stretching between town and town, wherein the inhabitants can take refuge in case of an attack. Numerous single dwellings are also met with in the fields, and these are provided with towers as well, that are guarded. They are called "gullah," Abbott says, and Vambery calls the farm-houses " havli."

I have alluded before to these miniature fortresses met with all the way from Bokhara, and I was particularly interested in them as illustrating a stage of civilization, such as I should not know where else to find in the present day, but which is brought before us in the early years of the Jewish polity.*

beyond, like the streets of Khokand and Bokhara, they helped one to realize the dire simile of being expelled from the brilliancy of a feast, and "cast into outer darkness" (Matt. xxii. 13).

Abrahame said that the Kirghese Steppe took me back to the days of Abraham, the city of Bokhara to the times of Jewish kings, and now this border land of the Uzbegs reminded one of the days of the Judges, and even earlier; for what the Sabaeans were to Job's sons in falling upon their oxen and asses (Job i. 15), and what the Midianites were to the children of Israel when they entered into the land to destroy it
(Judges vi. 5), or the Philistines when they robbed the threshing-floors VOL. II. 
Thus far an opportunity had not offered for me to have a good look at the interior of one of these havli, but at half-past 9 we arrived before an excellent specimen, the residence of a rich bek, with whom we were to rest, and our horses be baited. We had made fair speed in coming, thanks to my having had recourse to a new method of interpreting my desires. I had given the batchman to understand that I wished to get on at a good speed, but he seemed sorely oppressed with dignity, and ambled along at a poor pace, whilst I dared not go ahead, not knowing the way. My importunity seemed to lose all its fervour in passing through the brains of two interpreters; so, finding one of the djiguitts near me, I bawled out in English, "Go on!" and at the same time laid my whip lustily across his horse's flanks. The djiguitt did not understand my language, but his horse did, and I then kept him trotting before me at an improved pace, to show the way, and abundantly soothed his feelings by (I Sam. xxiii. I), that, I take it, the Turkomans have been to the Uzbegs. Hence the children of Israel "made them the dens which are in the mountains, and caves, and strongholds"' (Judges vi. 2). David, the wanderer, would, of course, be familiar with such places, for "he abode in the wilderness in strongholds" (I Sam. xxiii. 14), and hence the comparison he makes after deliverance from Saul, "The Lord is my rock and my fortress . . . my high tower and my refuge" (2 Sam. xxii. $1-3$ ). These similes would appeal more forcibly to an Uzbeg than to an Englishman, whilst, as for " the high tower," the best illustration, perhaps, that I know is in the Caucasus, where ruins still show that a family used to build not merely a high tower, but also provide themselves with a movable ladder, which one having ascended quickly on account of robbers, for instance, could pull up after him, and so be safe from his enemy. On the south-west frontier of Turkmenia, the Persians have been living in such dread of the Mervis, that one sees constantly in the fields and gardens small towers entered by 3 hole just large enough to admit one person at a time. The owner takes refuge there till the departure of the marauders, who do not dare enter. lest the intruder's brains should be battered by a stone. Again, if the word "cities," in 1 Chron. ii. 22, may be understood to mean these 
a gratuity when we reached Manak, as they called the house of the Bek. They affirmed the distance we had ridden that morning to be $2 \frac{1}{2}$ parsangs, but I can make it by the map only about half that distance, namely, 7 miles.

I regarded the visit to Manak as an introduction to another grade of Uzbeg society. At Bokhara we lived as princes, at Khiva with nobles, in some of the travelling stations with the poor; but now we were guests of one of the "landed aristocracy," who had wives and men-servants, and horses and camels, and oxen and asses; who possessed I 50 acres of land here, and 350 more elsewhere, with a yearly harvest of 3,000 batmans, or 50 tons, of corn. I was so interested in the man's castle, with its four clay walls 20 feet high, and round bastions at the corners, reminding me forcibly of so many Oriental expressions, that I proceeded to look over the place thoroughly, and afterwards made a rough sketch of its ground plan. Immediately on the left, at the main entrance, was a platform such as we often saw under a city gate, and adjoining this was a sleeping-room for workmen, whilst a passage between led into a chamber with an oil-mill of severely primitive construction."

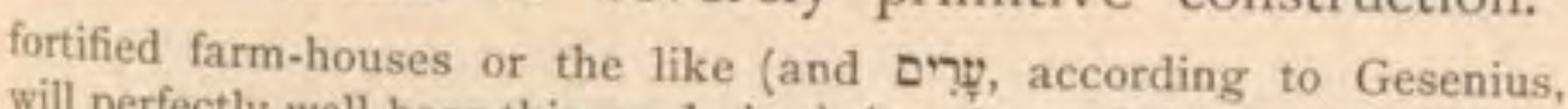
will perfectly well bear this rendering), it reduces Jair's possessions in the land of Gilead to more reasonable proportions, and renders more intelligible the large number of "cities" referred to in the books of Deuteronomy, Joshua, and Judges. Also these havli illustrate, perhaps, words in Gen. xxv. 16. These are the sons of Ishmael ... (whose hand, be it remembered, was to be against every man, and every man's hand against him), by their towns, and by their castles. Again, of the Midianites, "they burnt ... all their goodly castles" (Numb, xxxi. 10); and the same idea re-appears in the New Testament, "When a strong man armed keepeth his palace, his goods are in peace" (Luke xi, 21).

"Reminding one of Job's expression, " which make oil within their walls" (Job xxiv. 11). 
The mill was made out of the trunk of a tree stood on end, and in the centre a hole, 12 inches across at the top, diminishing below. In this hole was placed a heavy beam made to incline and pound against the side the seed of a plant resembling cotton, called bang, with a mixture of flax-seed, for making "kunjut" oil.

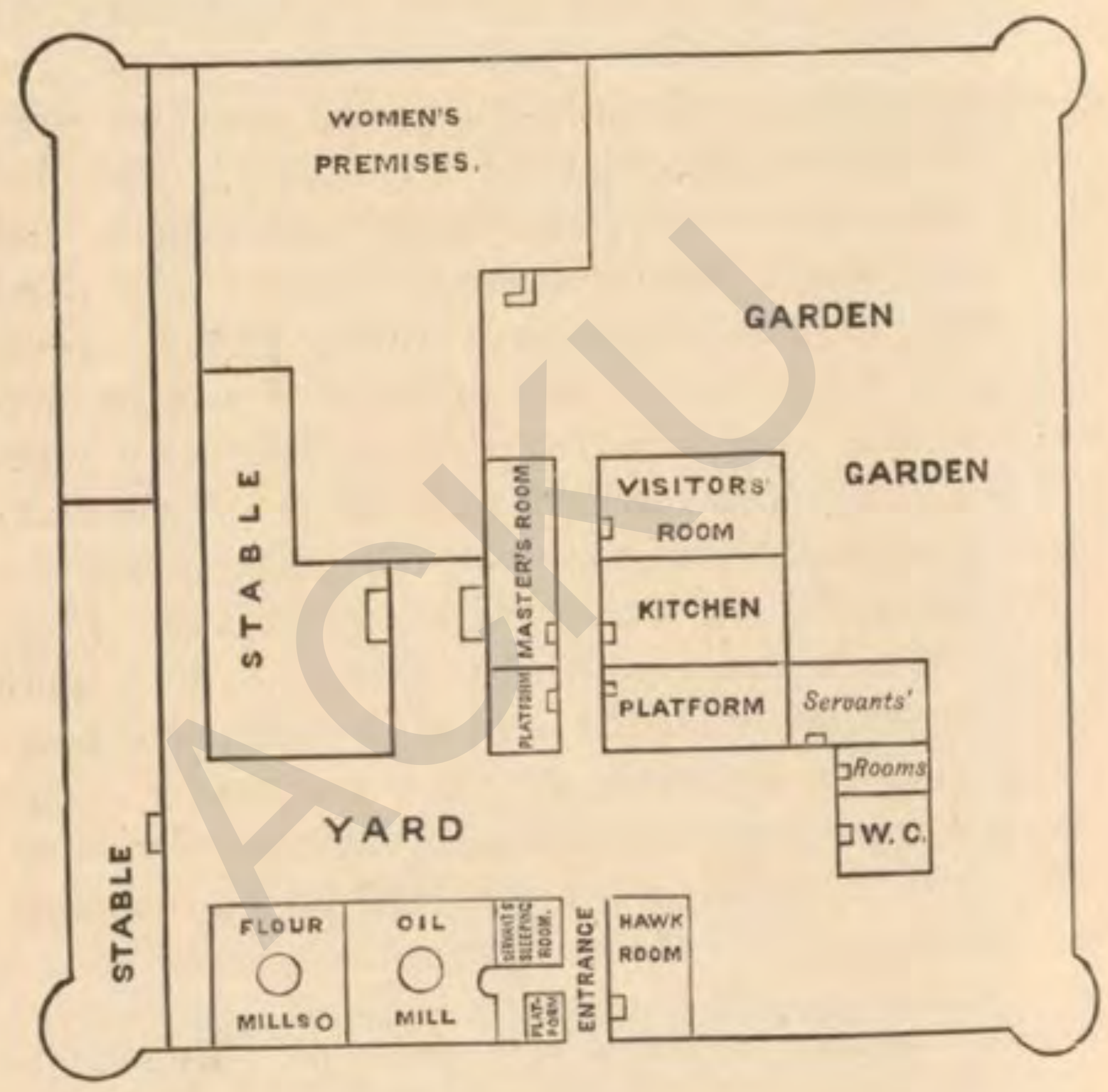

The machine was turned by a horse blindfolded, and padded here and there, so that, in going round the confined space in which it moved, the animal might not rub or bruise itself against the walls. The traces were made of a bent branch of a tree. The oil sold, they said, for 32 tengas, which they called I 2s. Iod. a batman (say $4 d$. per lb.), and is used alike 
for burning, cooking, and in making pilau. Oil-cake sells from $3 s$. to $4 s$. per cwt.

Adjoining the oil-mill was a chamber with two flourmills, the larger, in the centre, to be turned by horse or ass, or, if they were in use, the smaller could be turned by a woman. ${ }^{*}$ In Russian Turkistan, wheat grinding is usually effected by water power on the

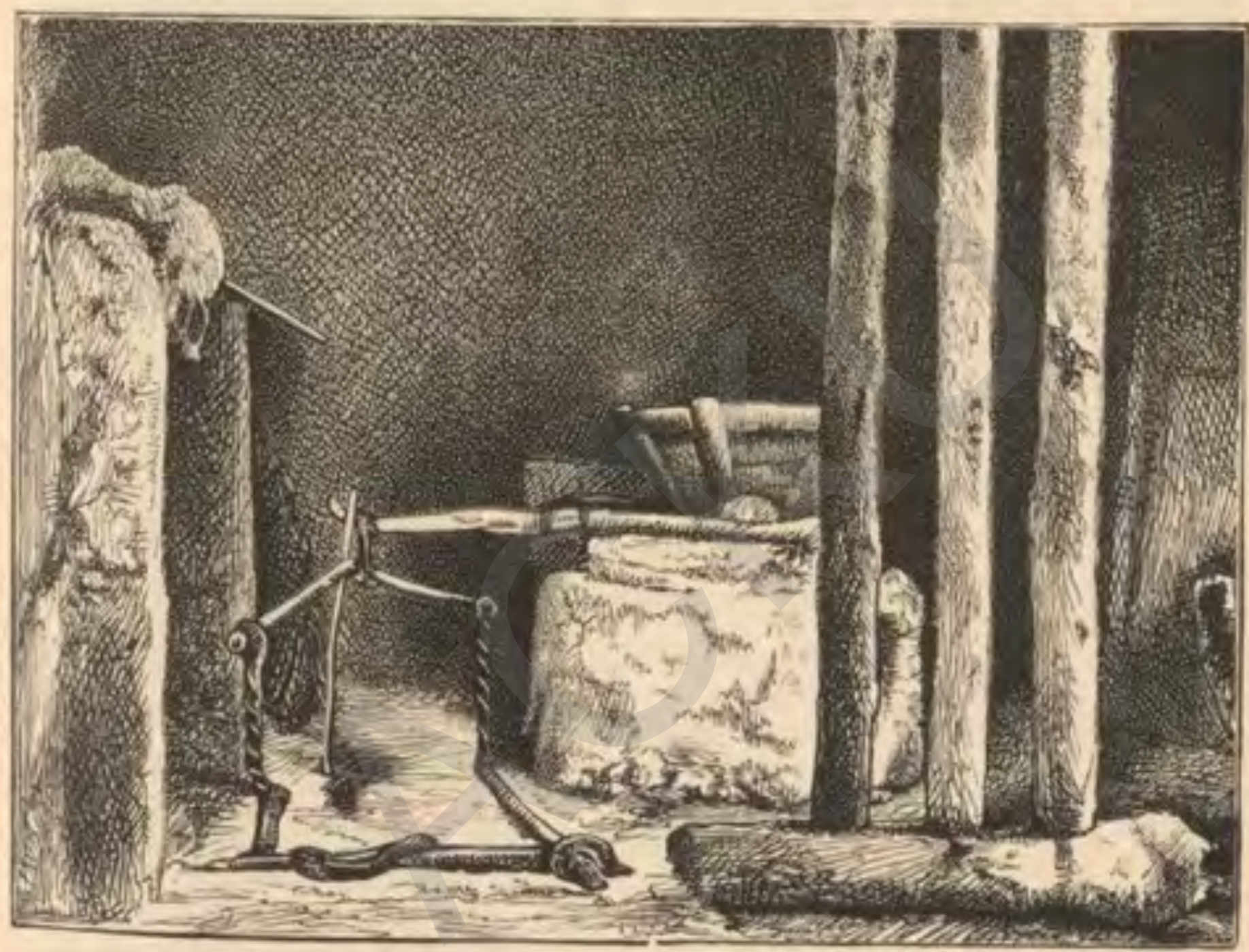

A CENTRAL ASTAN CORN-MTLL.

banks of the aryks, though there are 16 windmills set up at Kazalinsk by Russians. Our host's mill, kept going all day with a horse, would grind $6 \mathrm{cwt}$.

From the flour-mill we went to a stable, which

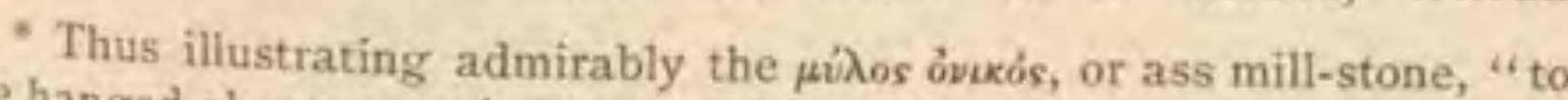
be hanged about a man's neck " (Matt. xviii. 6 ; Mark ix. 42), and the hand mill-stone at which two zoomen shall be grinding (Matt. xxiv. 41). Grinding the mill was a menial occupation for a man, and was reserved for slaves and captives. Hence the Philistines made blind Samson do it (Judges xvi. 2I). One of Jeremiah's lamentations (v. 13) was, "They took the young men to grind," and Isaiah (xlvii. 2) bids the tender and 
appeared to run along the whole side of the havli, and then to another building, wherein were only a few horses, donkeys, cows, and a camel; but there was said to be accommodation in the two stables, or sheds, for a hundred cattle. More novel than these last buildings, however, was a room on the right at our entrance, where our host kept some half-dozen hawks. Hunting by means of the falcon, goshawk, and common eagle, is the favourite sport of the natives." Within the walls of the fortress at Manak was an excellent garden, with rose-bushes, peach and other fruit trees, and standard vines. These, in the absence of leaves, and not looking at them closely, led me to remark to Sevier, "Here at last are filbert-trees," of which, however, we saw none in Central Asia. They told me they make of grapes an intoxicating drink called zaip, but that it keeps only six months. Walking round the garden, I looked carefully at the walls. At a height of 3 feet from the ground these measured 3 feet 8 inches in thickness, and in the delicate daughter of Babylon return to her work: "Take the millstones and grind meal." I found the custom obtaining in 1879 as far east as the Ussuri, where turning the hand-mill in a Cossack's house was the recognized work of the wife.

* The birds of prey themselves are caught simply by stretching a net on short stakes and tying small birds underneath. The hawk, on swooping down, entangles its talons in the net, whereupon the hunter brings him into his tent, feeds him with his own hands on meat for a twelvemonth, and then takes him out to catch other birds. Whilst engaged in the chase the trained bird rests on the left arm of the master, its eyes being covered with a leathern hood. The game is started with a drum, fastened to the master's saddle-bow, the bird's hood is snatched off, and the hawk darts after the quarry. When this is caught, the hunter comes up and releases it, but gives the captor only the head and brains. Should the bird fail in overtaking the game, it is enticed back to the arm of the falconer with meat, which he always carries with him for such an emergency. The hawk I saw in the house of the Divan-beggi, at Khiva, was being trained by means of pieces of cotton-wool thrown on the ground. 
circular towers, or bastions, at the corners, were little chambers, into which I should imagine it would be easier to dig than penetrate through the other parts of the fortress.* We have not, however, as yet entered the owner's residence, which was a house with rooms on either side of a passage, and, adjoining, two rooms for servants. On either side of the passage, at the entrance, was a raised dais or platform, like that at the gateway, only larger, and where I suppose in hot weather much time would be spent. Further in, on the left, was the door of the master's room, and opposite, the door of the kitchen, whilst beyond the kitchen was a room reserved for strangers, called the "guest chamber," Here we were treated to a meal, and the rich bek told us that his fortress cost $f_{120}$ to build. He invited us to stay for a night ; but this I declined for lack of time, and at half-past i I started again.

Within about a mile of Manak are the ruins of the fortress Uiangen, and two miles further is Ambar,- - a mere row of empty stalls, where, as we passed through, they told us a bazaar is held. Other places on the road, beyond Manak, are Kannai, Govozali, Beurak, and Kiatly. Beyond this is Tashauz, where we arrived at half-past three, having accomplished since the morning 23 miles.

" The walls were simply of rammed mud, such as "thieves would

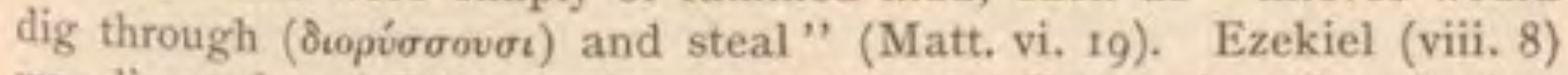
was directed to "Dig now in the wall," and Job (xxiv. 16), referring to the lawless and murderer, says, "In the dark they dig through houses, which they have marked for themselves in the day time," a practice no doubt common enough in the wild country through which we were passing. 


\section{CHAPTER LXV. \\ FROM TASHAUZ TO KUNIA URGENY.}

Stay in the Khan's palace.-Former condition of Russian slaves in Khiva.-The town of Tashauz.-View from the palace roof.-The Khivan climate.-Arrival at Iliali.-Shakhavat aryk to Zmukshir. -The town of Iliali.-A starting-place for the Caspian.-Khivan irrigation.- - Jur luggage attacked by robbers.-Stay at Ak-tepe.The Turkoman region.-Accident near Kunia Urgenj.

O $\mathrm{N}$ arriving at Tashauz we found that the miserable quarters we had left in the morning were to be exchanged for nothing less than a palace at night. The said palace, built in part of brick, was erected by Allah-Kuli Khan, near a pond surrounded with stones, whence the name of the town "Tashhauz," or "stone pond." Let me hasten to say, however, that we were not cradled in luxury, for the palace, though repaired for a stopping-place by the present Khan when he happens to be passing, is in a ruinous condition. When Allah-Kuli erected the fortress, he peopled it and the surrounding neighbourhood with Persian prisoners of war from Khorasan, and with Tajiks from Khiva.

It is rather remarkable that " the first who brought the news that Russian slaves* were to be found in the

- I quote from an article on "Russian Slaves in the Khanates of Central Asia," in the Oriental Church Magazine for September, 1880. 
Central Asian khanates was the English merchant Anthony Jenkinson, who, in $\mathrm{I} 558$, ransomed from Khiva 25 captives." Florio Beneveni reported to Peter the Great that there were 2,000 Russian slaves throughout the khanate. When, however, Nadir Shah conquered Khiva, he gracefully released the Russians detained there, and gave them horses and money to go home. Later on, Russian deserters and criminals, who feared slavery less than Siberia, fled to the Khivans, and the Kirghese kidnapped others.*

The Russian Government made many attempts to get the slaves released, the most successful being the otherwise abortive expedition of Perovsky. The fear this inspired, combined with Shakespear's diplomacy, enabled another Englishman to bring away the largest and last numerous batch of slaves that ever returned to Russia. When Kaufmann's army was approaching Khiva in 1873 , the Khan released 21 captives; but when the Russians entered the khanate they repaid the gracious act of Nadir Shah, and released I 5,000 Persians, or, as MacGahan says, 27,000, and Réclus

* The price of a Russian male slave was twice that of a Persian, but in the case of women slaves Persians were preferred. Many of the deserter slaves held posts in the Khan's army, and had a tolerably easy time of it; but in 1816 , on the advice of a fanatical Khoja, the Khan determined not to feed the "Kafirs" so well, and gave them monthly $40 \mathrm{lbs}$. of wheat mixed with earth. Also they were poorly clad, especially the agricultural slaves. "One day," says Sinowjew, "the Khan's old wife came into the garden. I said to her, 'You must be ashamed to look at us, gracious lady: we are almost the same as naked; why does not the Khan give us some clothes?' What was her answer! 'Why should I be ashamed? Is it not all the same whether I look at you or at a dog, which also runs about unclad?", Of course, there were also instances of cruelty. Jegor Schtich, suspected of exchanging letters with his family in Orenburg, was forced to dig his own grave, and was then buried in it-some say dead, but others, alive! For a third attempt to escape, the wretched slave was left alive for some days skewered on a stake stuck in the ground. 
37,000. Some of them were sent home, but those who chose might stay; and many of the well-cultivated lands we had passed in approaching Tashauz were farmed by Persians, their greater development in civilization being manifest not only in their farms, but in their houses.

The town of Tashauz has three gates: the west, south, and palace gate. We were lodged near the last, and the platform at the entrance, for a guard, or for judicial purposes or public business, was very ample. We went out before dinner to see the town. It has 300 shops and workshops, and one caravansary, admirably suited to persons in search of "cheap lodgings," the rent for a room and shop being $\frac{3}{4} d$. a day, or $20 d$. per month. This was much cheaper than at Aulie-Ata, where, for a place to sleep and accommodation for horses, was charged $2 \frac{1}{2} d$. per diem. We inquired the price of black Turkoman sheepskin hats, seen elevated on poles above the roof of a house, and were told $8 s$. each. I had already provided myself with a white one and a sheepskin coat in Khiva, thinking I should find them useful when crossing the desert and spending the night in the open. Tashauz has in all 400 houses, 6 mosques, and a medresse, and besides the Iranian population there are also some Uzbegs of the Antort-Yuruk tribe. The chief trade of the place is in corn.*

* As time hung upon our hands, before dark I mounted the roof of the palace, and was reminded again of the early days of the Israelites in Canaan, where the cities they took were " fenced with high walls, gates, and bars; besides unwalled towns a great many " (the two categories into which Central Asian towns may still be divided). (Deut. iii. 5.) The spies accustomed to nomad life might well have said of towns such as Tashauz that they were "great and walled up to heaven" (Deut. i. 28; Num. xiii. 28); and as I looked down from the palace I could see on numbers of the roofs, if not actually stalks of flax (which 
We left Tashauz next morning at 8 , the road turning off to the west, and leading still, for the most part, through cultivated land, steppe appearing only here and there. We began to see also ruined houses. The weather had been gradually improving since we left Khiva, where the night before our departure the temperature fell to $33^{\circ}$, the maximum of the previous day being $60^{\circ}$. At Tashauz during the night the minimum was $35^{\circ}$, and I had not ridden far from the town before I found my Ulster too hot, and, after throwing it off, was hardly cool enough. This was pleasanter than the blustering weather we had at Petro-Alexandrovsk, where they had told us that sometimes, on the approach of winter, there comes a day or two of cold as a warning, but passes away, to be succeeded by a sort of "St. Luke's little summer." *

Our road from Tashauz was enlivened by numbers

there may have been), yet of jugara, under which Rahab, as easily as possible, could have hidden the spies. There was not a single building outside the walls of Tashauz, and "the time of shutting of the gate when it was dark" would still be a favourable time for escape, since all the population would be shut within. One had only, therefore, to picture Rahab's house adjoining the wall, and letting her visitors down, to escape over the Oxus some 20 miles distant, to recall to the mind some of the acts in a drama with which we had been familiar from childhood (Josh. ii. 5, 6, 15). Again, the height of such a roof as that of the palace at Tashauz, commanding a view of all the other buildings and gardens near, whilst recalling David's walking upon the roof of the king's house in Jerusalem (2 Sam. xi. 2), might also throw light upon the Bokhariot objection to my mounting the minaret, and their declaring that it was contrary to Muhammadan law to mount a high place overlooking other houses.

* Concerning the climate of Khiva generally, I may add that winter begins in November, as we have seen, and lasts till February. At this season the thermometer sinks to $20^{\circ}$, and the Oxus freezes from 6 to 12 inches. At the end of March the pomegranate, vine, and fig sprout, and early in April are green. Wheat harvest begins early in July, when apricots and plums ripen. The leaves were nearly all fallen as we passed through the khanate. The west wind rages in spring, and 
of Uzbeg and Turkoman farmers, going to market to the town we had left. We passed on the road another place called Manak, and Uigur, the ruins of Goklenkala, or fort, and Karamazy, and after riding 19 miles we came at noon to Iliali.

Iliali, or, as the Turkomans call it, "Dschilandy," or "Djingildi," is so named from Hazret Biliali, who is buried here. The Turkomans claim him as their patron saint, and ascribe to his protection sundry of their victories over the Khivans. When the Russians, in 1873 , bivouacked near his tomb, the Turkomans took it for a good omen, and attacked the invaders.*

The town of Iliali numbers about 160 houses, and a bazaar with roo shops and workshops. The population

the north wind also at times blows strongly. Then dews are abundant, but generally there is little rain, snow, or hail, and violent storms are rare.

* During the occupation of Khiva by the Russians it was thought desirable that the Turkomans, especially the Yomuds, should be chas. tised, and made to pay a part of the war indemnity. Accordingly, Kaufmann demanded of them 300,000 roubles in money, to be paid within 15 days. If not forthcoming, their settlements and families were to be given over to destruction, and their property to confiscation. Immediately General Golovtcheff was directed to encamp near Gazavat, and the commander of the Orenburg detachment to watch the Turkomans from Kyzyl Takir, north of Iliali. MacGahan accompanied the forces of Golovtcheff to Iliali, and has described the carnage. The houses and stacks of corn were given over to the flames, and the inhabitants to the sword, after which the Russians camped near the ruined four-acre fortress of $\mathrm{Zmukshir.} \mathrm{MacGahan} \mathrm{describes} \mathrm{the} \mathrm{fortress} \mathrm{walls}$ 30 feet high, as built of burnt bricks, probably Persian, of a pale-red colour, 6 inches square, and an inch and a half thick. It was at this part of the khanate that the column from Tchikishlar, under Marcozoff, expected to arrive. They failed, however, in crossing the desert to get beyond Ortakuya, but the remainder of the way was investigated by Skobeleff, before the withdrawal of the troops. He left Zmukshir on August 16 th, went as far as Nefes-guli, 6 miles from Ortakuya, and returned on August 23 rd to Khiva. It was from $Z$ mukshir also that Messrs. Capus and Bonvalot hired their camels, and started to cross to the Caspian some months before me. 
is of Sarts, Turkomans, and Persians. Mondays and Thursdays are the market days, and Turkoman corn is the principal merchandise. The fortress, built in its present form about $\mathrm{I} 865$, is in a tumble-down condition, similar to that of many of the houses in the town. It would have been possible for us, and perhaps pleasanter in summer, to have reached our present stage from the Amu by boat on the canals. The Russian doctor and engineer, to whom I have alluded, did so, taking two days from Khanki to Iliali.*

We were taken to a large garden in Iliali, having in the middle a good-sized building, kept, I believe, as a summer house for the Khan when there; the same, I suppose, as that of which Basiner gives an illustration in the excellent account of his journey in 1842 , though doubtless in 40 years the chateau has very much deteriorated. The house could hardly be said to be "furnished" in 1882 , for we had no table, and our food was served so primitively that soup was brought without spoons, and meat without knives and forks. To make matters worse, our own table requisites and baggage had not arrived. There was nothing to be done, therefore, but to drink the soup from the basins. This I remedied for the future by providing myself with a folding-knife, etc., in my saddle-bag.

Our slow-going conductors would have been well content that we should have stopped here for the night, but they had rather alarmed me by saying that the

* They describe their way as lying through gardens, meadows, and trees, past New Urgenj to Tashauz, beyond which to Iliali they found the country less fertile. At Iliali they hired camels, took supplies of flour, potatoes, and corn for the horses, and started for Krasnovodsk. Thus the two Frenchmen and two Russians crossed the desert from points further south than ours. The two colporteurs I have alluded to from the Caucasus, crossing from Askabad to visit Khiva a year after me, struck the khanate at Iliali, and returned thence to Krasnovodsk. 
next day's journey to Kunia Urgenj was to be a long one, and as the day was only half gone I thought it much better to push on as far as possible before night, and so shorten the morrow's ride. They said something about the danger of travelling in these parts after dark ; but I gave less heed hereto than was wise, thinking perhaps it might be merely an excuse. After waiting, therefore, till our luggage arbas arrived, we set out again at 2.30 , leaving them to follow.

For about 10 miles we passed through gardens; cultivation then diminished, and the road traversed clayey, and in some parts slightly saline, soil, trees being seen only here and there on the banks of the large aryks. We crossed several canals, one being the Murat Bai, and another the Kasym. This was impressed upon my mind, because we passed one spot where the aryk had overflowed.* We had been turned from our path by another such flooded place, like a large lake, on the day we left Khiva, and had to go round its edge. I suppose, in the preceding season, water had been unusually abundant, for we saw houses flooded, in some cases to their destruction, in others not, though the inhabitants were driven out. $\dagger$

As darkness came on we were still on the steppe,

- The irrigation of Khiva is accomplished by water-courses, varying from 20 to 150 feet wide, from 10 to 20 feet deep, with a current of about 2 miles an hour. They are of two kinds - the larger, called Arna, which are natural streams from the Oxus, widened and deepened; and Yap, which are canals dug, up to a dozen feet wide, from the Arna, and wherewith the whole of the land under cultivation is covered as with a net.

+ Bearing in mind that this laborious watering by irrigation was what the Israelites had been accustomed to in Egypt, where they seldom saw rain, they would the more highly appreciate the description set before them of the promised "good land, a land of brooks of water, of fountains and depths that spring out of valleys and hills," "not as the land ... where thou sowedst thy seed, and wateredst it with thy 
and met several wild-looking men, which brought to my mind what they had said about danger from robbers. Our little all was entrusted to three men, of whom I knew nothing, who, supposing they were honest, possessed no arms, and, perhaps, not courage enough to defend themselves if they had. These fears were not by any means allayed by the savage aspect of the country we were now traversing, and I was very glad for our personal safety when, at 5.45 , we arrived at a group of houses, where we determined to lodge for the night-not that we were expected, however, so that lodgings had to be sought. When found, we were conducted into a Turkoman's shop, where a bright fire was burning, the smoke getting out as best it could through the roof, which had consisted of leafy boughs now blackened, whilst a confined space was cleared for our accommodation, amid sacks of rice, tobacco, firewood, oil, melons, green tea, and butcher's meat.

They called the place Ak-tepe, and wished to make out that we had covered since the morning 72 versts, or nearly 50 miles. There is no such place on the map as Ak-tepe, but according to them we had ridden

foot " [that is, by removing the irrigation ridges and allowing the water to flow in], "but the land ... drinketh water of the rain of heaven" (Deut. viii. 7 ; xi. 10, 11).

So, again, the floods we passed, and ruined houses suggested, of course, another Scripture resemblance. Judged by the wise and foolish men in the parable (Luke xi. 48), who built their houses upon the rock and earth respectively, the Khivans, with few exceptions, would belong to the latter class, for not only did they seem to me in most cases to build their houses without foundation on the surface, but in a great many cases they placed first a layer of brushwood, and on that they built the wall. I asked the meaning of this feature in Khivan building, and, so far as I could understand, it seemed to be as a remedy against dampness rising in the walls in the time of rain. I perceived, too, in Bokhara waterspouts projecting from the roofs to throw the water clear of the bottom of the walls. 
32 versts from Iliali, which would give for the day 60 versts, or 40 miles, and this was the most we had yet accomplished between morning and evening. For some hours I was anything but comfortable on account of the non-arrival of our luggage, especially as I had therein my papers, note-books, diary, journal, etc., which I was anxious above all things to save, so that I half determined to carry them in future in my saddle-bags. When at length they did arrive, I found that my fears had not been groundless, for, as the carriers came along, two men, also in arbas, met them and asked, "Where do you come from ?"

"From Khiva," they replied; " whence come you?"

"Don't know," said the spokesman. "Where are you going?"

"To Kunia Urgenj," said my man. "And you?"

"I don't know," again he said, and let off his gun.

"What are you shooting at?" said my men. "If you want these goods, you had better come and take them, only remember-they belong to the Russians!"

Whereupon the fellows made off, and my men caught us up at Ak-tepe. I was delighted to hear of their safe arrival, and so thankful that I promised the men an extra present, and determined not to be so venturesome again in pushing on at night.

Nothwithstanding our curious lodging, we were too tired not to sleep well, and next morning, at 8.45, we resumed our journey, through a country wilder than anything we had yet seen in Khiva, where even the green of the tamarisk was of a bluish hue, looking as if covered with dust.*

- This part of the khanate is occupied by Yomud Turkomans, Imralis, Kara-dashli, Goklans, and other semi-nomad tribes. We had passed Kish-dagli, 3 miles after leaving Iliali, and after crossing the 
The general characteristic of this part of our journey was flatness and desolation, with scarce any water, though there were visible numerous traces of old aryks, showing that the land had formerly been cultivated. The Yomuds, we afterwards learnt, were the inhabitants, amongst whom, a quarter of a century ago, agriculture is said to have been highly developed. They used to get their water from a branch of the Oxus called the Darialyk, which then reached as far as Sary Kamish; but during the war of the Turkomans with Muhammad Amin Khan, the Khivans turned the course of the Darialyk by means of dykes, in order to starve out their turbulent Turkoman neighbours, who were thus compelled to move their settlement, and went off to the Balkan mountains, near the Caspian.

Thus we rode along till we saw, a long way ahead, two lofty minarets and other ruins, which I knew to be those of Kunia (or Old) Urgenj, so called to distinguish it from Yengi (or New) Urgenj, near Khiva. I

canal Yarmysh came to Kizil Takir, which appears to be the name of a district, and also of a spot on the road, 9 miles from Kish-dagli, called Kish Kizil Takir, about 2 miles south of a garden of the Divanbeggi. Near this place a bazaar is held on Mondays and Thursdays, where come Turkomans, some singly to buy, but sometimes in bands to rob the tradesmen on the way. Four miles beyond the garden is Goklan-kala, the district being inhabited by Turkomans of the Goklan tribe. Just beyond is Kish-alaly. We had passed several ruined houses and fortresses, or rather fortified camps. Such a fortification consists merely of a walled quadrangle, without barbettes, and only tents within, which, I suppose, Khiva was like when the ambassador told Peter the Great that it consisted only of tents and huts. Leaving Goklan-kala, Kish-alaly is on the left of the road, and on the opposide side Kish-tash-kent. Ten miles beyond the garden of the Divan-beggi is the canal Shakh-murat. Among the many ruins I may mention, in the order we came to them beyond Shakh-murat, Kochev-Mashrik, Allah-Kul-Yakyl to the left, and, opposite, Kurgan Yakyl; again, on the right, a fortified place, Kara Amym, and beyond, Khanavat. There were also beyond Shamrut two gardens, Bogan and Tajik.

VOL. II. 
hurried on to get a good look at them, and was much deceived by finding them so distant. I reached them, however, about noon, and will describe what I saw in the next chapter. Meanwhile, after spending two hours at the ruins, we rode forward a mile or two towards the present town of Kunia Urgenj, the high road passing through a cemetery, where Diotrephes, having got behind, and being as anxious as usual to go ahead, I was letting him trot, when he so completely misbehaved himself as to stumble and roll. I was pitched several feet over his head, my boots coming easily out of the stirrups, so that providentially I was not in the least hurt, and, before I quite knew what had happened, was on my legs helping up Diotrephes, who looked ashamed of himself. This was something, but Yakoob imported a new sentiment into the affair by observing that it was a judgment on us for galloping on holy ground, where the saints were sleeping. He added that some Muhammadans would have got off their horses and walked, but Yakoob himself did not set the example.

On reaching Kunia Urgenj we were supposed to be about 80 miles from the capital, according to Kuhn, but our conductors had told us 107 miles, and this, by measurement of my map, is about right. A very well mounted messenger can do it in $4^{8}$ hours, but an ordinary estaphette takes 3 days. We had been occupied three days and a half. Our arbas came soon after our arrival, so that we had simply to wait for Tailly to bring the camels, and pack our goods for the journey across the desert. 


\section{CHAPTER LXVI.}

KUNIA URGENY AND NORTHERN KHIVA.

Antiquity of Kunia Urgenj.-Sieges of Jinghis Khan and Tamerlane.Visits of Jenkinson and other Europeans.-Inspection of the ruins. -The minarets and mausoleums.-Tombs of Tuirebek Khanim and Sheikh Nejm-ed-din-Kubera.-Khivan communications and routes from Kunia Urgenj.-The town of Hojeili.-Settlement, near, of a Mennonite colony.-The town of Kungrad.-Our lodgings at Kunia Urgenj.-Central Asian " home life."-Marriage and divorce.-Life in a royal harem.-Seclusion of women.-Need of female missionaries in Central Asia.

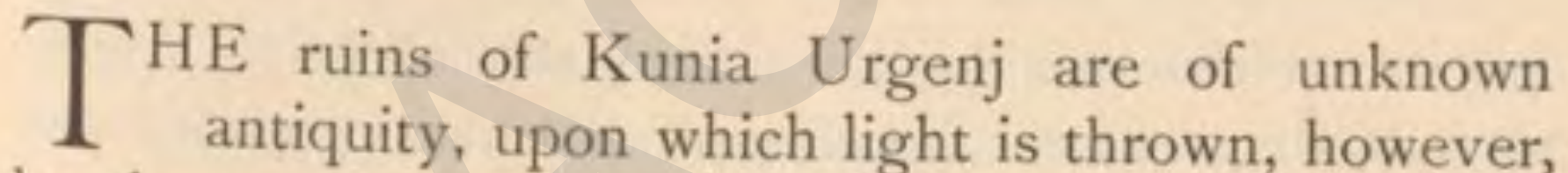
by the annals of Arab and Chinese history. The Chinese knew Kharezm as early as the seventh century of our era, and record several embassies there from the court of the "Celestials." One Chinese author records the capture of Urgenj by the Mongols, and another adds, "The city is still more rich and populous than Bokhara." The Arabs called it Al Jorjania, and also Gurganj.

Tradition ascribes its erection, says Kuhn, to Izud-din, son of Jelal-ud-din, or Djelaletdin, a successor of the Abbasides, whose descendants are said to have ruled the country for 450 years before the reign of Sultan Muhammad, who reigned there when it 
was destroyed by the Mongols. Mokadessi describes it as growing in size, and having four gates. Near the pilgrims' gate was a palace built by $\mathrm{Al}$ Mamun. Ali, son of Mamun, also built himself a palace there, in the square where the sheep-market was held. In 1220 the three sons of Jinghiz besieged Urgenj, summoning the people to surrender. This being without avail, the siege proceeded, and, for lack of stones, says Howorth, the Mongol catapults were served with balls made out of the neighbouring mulberry trees, soaked in water. They fired its buildings with naphtha, and, after 7 days of desperate street fighting, captured it. The artisans and skilled workmen, 100,000 in number, were sent into Mongolia. The young women and children were set aside as slaves, 24 to each soldier, and the rest of the inhabitants massacred. The Mongols then destroyed the city, and submerged it by opening the Oxus dykes.

This was a fatal blow to Urgenj, but the town began to flourish again under the Golden Horde, to which it was subject, and became populous and the site of a bishopric. Ibn Batuta, in his famous journey, found it prosperous in $\mathrm{I} 333$, but in 1379 Tamerlane took it from Yusuf Sofi, caused it to be razed in 1388 , and the ground sown with barley.* Three years later Timur ordered the city to be rebuilt, and the country peopled afresh; but Urgenj seems never to have gained its former prosperity, though we

- Micah (iii. I2) prophesied, "Zion shall be plowed like a field." Such immense armies as those of Tamerlane and Jinghiz required not a little corn for horses, to say nothing of the needs of the soldiers. The most recent instance I have read of a modern army growing corn for its own nourishment is that of the Chinese, who, on their way to Kashgaria a few years since, to put down the insurrection, stopped their march in Mongolia thus to sow and reap. 
read that, in 1393, Antonio Pietro de Malliano succeeded Boniface there as bishop.

Jenkinson was there in $\mathrm{r}_{55^{8}}$. He estimated its mud walls as four miles round, but the buildings within were ruined, save one long covered street or bazaar. He remarks that it had been won and lost four times within seven years by civil wars. Hence there were few merchants, and they so poor that he could not sell above four kerseys. A few years later the further decay of the city was ensured by the Oxus, which, Abul Ghazi tells us, took a fresh course in 1575 . In 1603 Urgenj was plundered by the Cossacks, as I have mentioned. The story that Khassan gave me as we approached the ruins was that the place was destroyed by the Kalmuks, he said about 650 years ago, which would agree approximately with the conquest of Jinghiz Khan, but Howorth mentions another inroad of the Kalmuks under Ayuka, at the end of the seventeenth century.

Abbott and Shakespear yisited the place in 1840 , and Basiner two years later, Vambery also in 1863 , and then, ten years later, came the Russian invasion, when their surveyors overran the country, examined the former beds of the Oxus, and the site of this ancient town.

General von Grotenhielm gave me some photographs, that have done good service for illustrations of the remaining buildings, but he informed me that the ruins awaited the exploration of competent antiquarians.

In approaching the place we could easily trace for a short distance the old bed of the river, on whose banks the city stood. Sandhills abound, however, and the ancient walls are little more than heaps. We had to make a long circuit before we could enter the city area 
so as to examine first the westerly of two tall minarets that are left standing. The base of the tower-or rather the bottom, for it has neither base nor capitalwas surrounded with broken bricks in such quantities that it was not easy to take the circumference. I found it to be 80 feet, but the whole affair looked so tottering as to be dangerous even to approach it. Here and there on its surface are coloured bricks, but hardly sufficient to indicate its former appearance. The eastern minaret, Kuhn says, is higher than the other. I do not know how he reckons; but I measured the circumference on a level with my head as I I 4 feet. The diameter on the photograph measures $\frac{7}{16}$ of an inch and the height $2 \frac{1}{2}$ inches, which would therefore make its altitude about 186 feet. This minaret is in a better state of preservation than the former. Both are built of baked bricks, and the latter is encircled by four convex rings with inscriptions, the letters of which are said by Glukhovsky to be the height of a man. Kuhn calls them Kufic, which they doubtless are, though Mr. Sevier did not readily allow them to be letters at all, until we purchased some old coins found on the spot, when the similarity of the inscriptions was manifest. It is doubtful whether the inscriptions can now be deciphered, because some of the bricks that form them are fallen out. Besides the inscriptions, the zones of coloured bricks are sometimes in mosaic in the form of a scroll, and at others in broken $X$ patterns. Howorth, quoting Glukhovsky, who visited the place in 1873 , speaks of a stately tower or minaret in the shape of a truncated cone, and adds that inside is a winding staircase reaching to the roof, which is quite probable; but, so far as I remember, I could find no entrance, or I certainly should have been eager 
to ascend. In my photograph of the eastern minaret, the summit of the western one only just rises above the horizon, though Kuhn gives their distance apart as only from 700 to $\mathrm{I}, 000$ feet.

What end these lofty towers served is not clear, unless to call the Muhammadans to praver. It seems

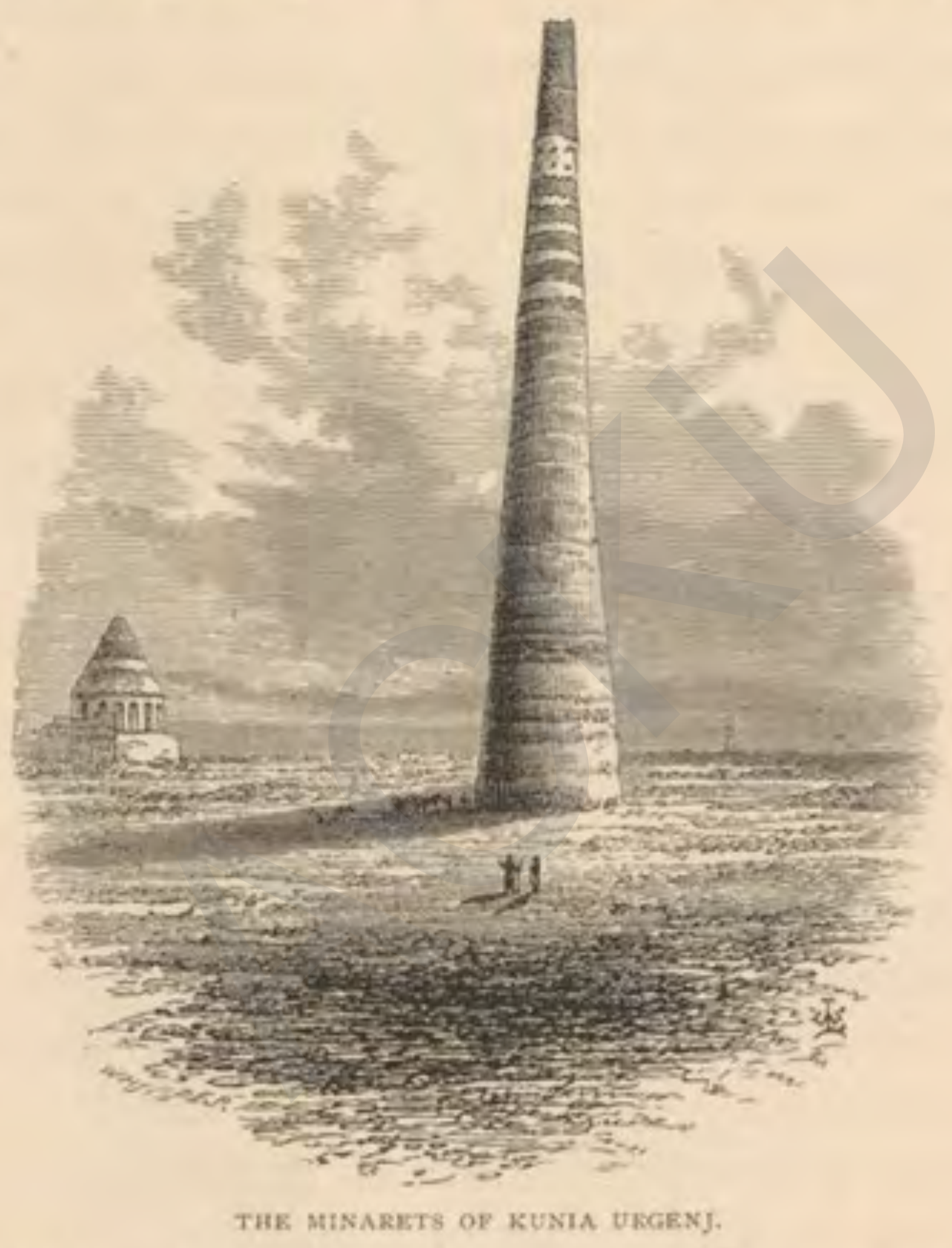

probable that the two belonged to different medresses, though no traces of the medresses remain.

Besides these minarets there are still standing 5 ruined buildings, once ornamented. Some distance west of the first minaret we examined are some walls and an arch, or pishtak, resembling that over the kibleh in a mosque; and this may possibly be the ruins of one of the old palaces of the Kharezmian Shahs. 
They show signs of having been ornamented with coloured tiles. A few minutes' walk south-west of the west minaret is the mausoleum of Sheikh Shurif. It has a conical roof of coloured tiles, supported, as Abbott says, upon a prism of 24 sides, not inelegantly moulded into columns and recesses. The only mosaic ornamentation left consists of pale-blue bricks, with raised letters round the cornice of the edifice outside. The door is a pointed arch, and inside I measured the area as 37 feet square. The interior of the dome was so fashioned as to remind me of a scallop shell. The grave of the Sheikh they showed us outside.

Near at hand we entered a tomb my notes call "Kara Lau Baba, built of burnt brick plastered over." This I suppose to be the same as Kuhn calls the mausoleum of Imam Fakhr-ud-din, where again the blue tiles are found only on the cupola. Nearer the east minaret we entered the tomb of Kara Kapa Baba, where was an old man acting apparently the part of showman, and expecting a gratuity. In Central Asia the showmen at the resorts of pilgrims are, I believe, supposed to be descendants of the departed saints, but as to what are the "notes" of Muhammadan sanctity I am not clearly informed.*

But the most noteworthy of the mausoleums we visited last, namely, that of Tiurebek or Törebeg

- I think it was Colonel Maieff who, at a saint's tomb in Bokhara, asked a native, "For what was this saint famous?" The native replied he did not know, nor probably did anyone else. "Perhaps," he said, " he was a rich man, had a great many sheep, talked very little, and often gave a feast." Again, in answer to my question in Bokhara, "What does 'Khoja' mean, as affixed or prefixed to a man's name?" I was told it meant a saint, and that he would be considered such who had made a pilgrimage to Mecca, so that there could be no lack of sanctity in the case of one of my Bokhariot acquaintances, who had twice made the journey. 
Khanim, a daughter of Djanibek Khan. It is circular in form, with a conical roof, having a wide facade with pointed arch. I presume it is this that Howorth, quoting Glukhovski, calls "a fine ruined palace, containing a large round hall with a vaulted cupola. The hall has a double row of windows, one about 6 feet

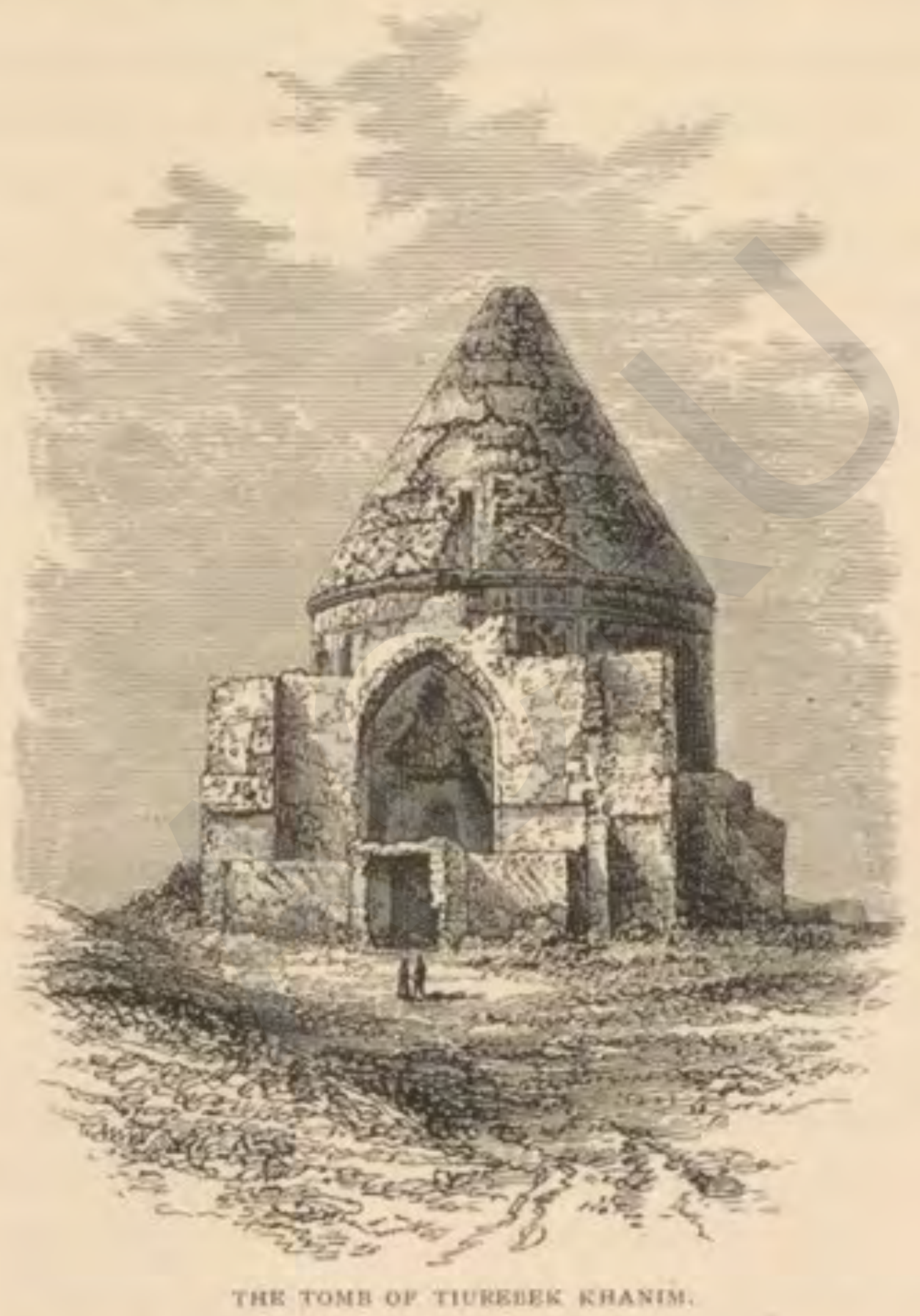

from the ground, consisting of four, and the other, near the dome, of 16 windows: and its walls are decorated with reliefs and arabesques, on which are remains of gilding and colour." We found the building of burnt brick on the exterior, with kashi, or coloured tiles, inserted here and there, sometimes in 
the form of a scroll, at others in that of a medallion, or, again, triangular. The walls of the interior have once been lined with kashi, but now only the roof retains them, and they told me that men sometimes shoot at the tiles out of reach to make them fall, for the purpose of getting off the gold, which did not sound to me very reasonable. One thing noteworthy in this ruin was that the enamelled tiles of the cupola were scarcely damaged at all, as had been the case in other buildings we had seen in Central Asia, and this made it possible, whilst confining the attention to the interior of the roof, to imagine the appearance of the finest buildings of Samarkand in their palmy days. I would have given something for the pocket camera promised to have been sent for me to Tashkend, if only to have secured the pattern of the kashi cupola, which was certainly the most complete thing of the kind we had seen. All the figured enamelled bricks were out of reach, or I am afraid my antiquarian instincts would hardly have kept my fingers from picking and stealing. As it was, I mounted the roof to see if anything could be had, but the bricks, which were rather smaller than English, were not only built with great regularity, but were of marvellous strength. I think I may safely say that I never examined bricks so hard; and when I remarked this to Khassan, he told me, what will probably tax the reader's belief as it did mine, that they were made, or rather wetted, with camels' milk. I took them to be of Persian manufacture, and they more nearly resembled stone than anything I have ever seen. On the following day, upon offering a reward for a few specimens of the coloured bricks, some were brought, and though these are not of the same clay or, at least, of the same burning, 
as those used for building simply, I was glad to obtain a few specimens of kashi from this ancient town of "the Chorasmian waste." Treasure has been found from time to time among the ruins of Kunia Urgenj, and Shakespear adds "mummies," but I have not seen this statement corroborated.

Urgenj, under the name of Kharezm, occurs as a mint place on the coins of the Golden Horde from the reign of Mangu Timur, in 1296 , to that of Pulad at the end of the sixteenth century. I was fortunate enough to secure some coins from this place, certain of which Mr. Poole, of the British Museum, tells me he has not seen before.

Between the ruins of Kunia Urgenj and the modern town, on an aryk, stands the mausoleum of Sheikh Nedjm-ud-din Kubera, built in the form of a double mosque. This was erected, according to all accounts, by order of Tamerlane, and if so, it seems likely that, in ordering the rebuilding of the city, he may have directed the two minarets also to be built. The tomb now spoken of was restored by Muhammad Emir Khan. On the facade are two lines of inscriptionwhite letters on blue ground. Inside is a pair of tombstones, on which are two parallelograms in mosaic, signifying that two persons are buried beneath-the Sheikh, and Yalgaiz Khan, son of the Sheikh Jinghiz Khan. In a line with the slab, at the corner, is a small tiled pillar about 2 feet high (reminding one of the like at Tamerlane's own tomb), said to denote where the head lies. A wooden paling encloses the slab and at its head are several flags. On the north side of this building, and touching it, is a mausoleum, wherein lies buried Piriyar, the father of Palvan Ata, the patron saint of Khiva. Besides these ruins there are numerous 
kurgan, and heaps all round Urgenj. Very few are known even by name, though one remarkable thing is that amongst the débris are found broken pieces of glass, which Kuhn says is not the case among the ruins in the adjoining Syr-daria province, though found at Samarkand, and suggested as being of Chinese origin.

I have thus entered somewhat fully into particulars concerning this former capital of Kharezm and its ruins, because they are the most ancient erections I saw in the khanate. Not, however, that Urgenj was always, or first, the capital, for Arabian geographers (quoted in Howorth) give this honour to Kat, the ruins of which have been found on the right bank of the Oxus, near Sheikh Abbas Vali. Pinkerton gives a list of the provinces, and Vambery of the towns and villages, of Khiva. Of inhabited points there remain two others which should be noticed in connection with the north of the Oasis-I mean Khojeili and Kungrad.

Both were at one time connected with Kunia Urgenj by the Oxus, and communication was by water, but the journey has now to be made by road.* From

* Speaking generally of the land communications of Khiva, one may say there are no properly-made roads, but since my baggage was carted from the Amu to the capital, and thence to Kunia, the reader will have perceived that the tracks are practicable for wheels. They are caravan routes; sometimes exceedingly wide, but often very narrow between the canals, and generally rough. Six of these caravan routes branch out from Khiva : one on the south to Merv; another eastward to Hazarasp; a third to Hanki ; a fourth to the north-east to New Urgenj, and thence all along the west bank of the Amu, touching Gurlen, Manghit, Kipchak, and on to Khojeili and Kungrad; another leaves Khiva on the north-west to Gazavat, and through the district watered by the aryk of that name, to Zmukshir, whence it bifurcates on the left across the desert, and on the right to Iliali. The main road appears to be that we followed, which throws off a branch beyond Kosh Kupyryk, through the modern Kiat to Gurlen; the other continues to Tashauz. Other routes leave it on the right at Iliali, and beyond, but they lead to no large towns. 
Kunia Urgenj radiate three routes: one to the left towards Sary Kamysh; another to the north-west mounting the elevation of the Ust-Urt at Spusk-kumdjul, or Aibugir; and a third route, 20 miles long, to Khojeili. This town was visited by Vambery, who approached it on the third day, floating from Khiva on the Oxus; and Kuhn accompanied the Orenburg division there by land from Kunia Urgenj. The latter describes Khojeili as about a mile from the Amu, in the midst of gardens and not fortified, situated on both banks of an aryk spanned by a bridge. In the suburbs are many havlis, or farm-houses. The town has a large bazaar, 300 shops and workshops, 5 mosques, with as many schools, one medresse, and one caravansary. The proximity of Khojeili to the Amu facilitated the establishment of a fish trade, and, in 1873 . there were a great many boat-loads of dried fish, principally carp and silurus, taken from the neighbourhood to Bokhara, costing at Khojeili from 6s. to gs., and selling at Bokhara from $12 s$. to $18 s$. per cwt., and thence it is carried inland as far as Shahr-i-sabz. "Khojeili" means the "home of Khojas," who abound in the town.*

A propos of Khojeili being a town of saints, I may observe that land in this region has been given for a settlement to a body of Christians, called Mennonites, the party of whom we heard first at Aulie Ata, and in whose track we afterwards followed. ${ }^{\dagger}$ They travelled

Tradition says, according to Kuhn, that 600 years ago a Khoja, named Aliamin, settled here, and in course of time some Kirghese and Uzbegs joined him ; but Howorth would suggest for the place a greater antiquity, and imagines that it may be the site of the ancient Tuk, so often mentioned by Abul Ghazi, who says that from the ramparts of Tuk Urgenj could be seen in the distance to the south-west.

+ Their story, given me in part by one of themselves, is that they are 
in huge European wagons, and when they came to the sands between Karakul and the Amu, we heard that they took the wagons to pieces, and carried them on camels. Sixty-four families floated down the Oxus in 8 boats, which cost for hire $£_{\mathrm{I}} 68$. Some went by land, and at Petro-Alexandrovsk we heard of them in that their demand for potatoes had sent up the price from $2 s .6 d$. to $3 s$. $9 d$. per cwt.

I presume these Mennonites must be settled within a few miles of Khojeili, whence the traveller proceeds to Kungrad, about 70 miles by road, or two days

so called from Simon Menno, a Dutch sectary, who died in 1561 . In consequence of persecution some of the first Mennonites left Holland for Prussia ; and when the Prussians would have forced on them military service, they emigrated to the South of Russia, and settled in the Crimea and on the Volga. In 1874 , when conscription became universal in Russia, about a thousand families emigrated at once to the United States and Canada, but the greater part remained in Russia, having been allowed to serve their time, not as soldiers in the army, but as foresters on the crown lands. Some Mennonites of the Volga, however, about 150 families, having been carried away by one of their number, who declared he had received orders from on high to proceed eastward, went to Turkistan in 1880 and 1881 , and tarried near Tashkend till their destination should be fixed. Schism then divided the camp, some settling at Aulie Ata, but others going on to the Bokhara border, and finally arranging with the Khan of Khiva, who consented to receive them. They are now settled in a small colony on the left bank of the Oxus opposite Fort Nukus; the schismatical party of Aulie Ata, I believe, having joined them.

Their strong point, or prejudice, seemed to be that they would not accept employment of any kind, not even that of a watchman, much less that of a soldier, under any government they consider not Christian. When I asked what government of those existing they considered Christian, my informant said "None!" so that they are tolerably sweeping in their condemnations. At the same time, I observe, they accepted the services of the soldiers sent to protect them by the Emir of Bokhara, whose escort went before them preparing the roads, building bridges, and helping them with food. My informant tells me that they have no ordained priests, but choose ministers among themselves, baptize adults only, and communicate weekly. Some letters respecting these Mennonites appeared in The Friend for 1882 and 1883. 
journey by boat, when the water is sufficiently high. In the course of the river journey one meets with a rapid, or waterfall, in the Oxus, about 3 feet high. Kungrad was visited, in 1858 , by the Russian mission, with E. Kühlewein. So late as the beginning of the present century Kungrad was independent of Khiva, and governed by its own Uzbeg princes. The old inhabitants say that 200 years ago the chief of the Kungrads (of the Karakalpak tribe), Mahomet Nazar Beij, having subdued the neighbouring tribes, built a fortress 20 miles below the present town, on the shores of the Aral, as it then was, and that his successor moved the fortress to its present site, where it was taken and destroyed by Mahomet Rahim Kuli Khan.* The most remarkable building in the town is the old palace of the Khan. The commercial importance of the place diminished greatly subsequently to the year I 860 , after a rebellion of the inhabitants against Khiva. It was inhabited by Karakalpaks, Kirghese, and a few Uzbegs, many of whom, however, have moved away to Chimbai, in the delta, since the Oxus has changed its course further east. There are also some nomads, called Arals, or islanders, from their living in the neighbouring isles.

From Kungrad there are three possible routes to make the ascent of the cliffs of the Ust Urt, the northernmost continuing along the elevated west shore of the Sea of Aral. There is also a route due southwards other than that beside the river, which strikes at right angles, the route I have named coming off the Ust Urt at Aibugir. By this latter Basiner travelled past the ruins of Kyzyl Kala, and so to the modern Kunia Urgenj, where we arrived, as I have said, on

- See Howorth's " Mongols," ii., 1056. 
November 5 th. We found it a poor place-a walled town of 350 houses, a small bazaar, with a hundred shops, 6 mosques, and 2 schools. The town has been populated less than 20 years - that is, since the canal was cut that waters it-and thus, perhaps, accounting in part for the inhabitants knowing next to nothing of the adjacent ruins.

At Kunia Urgenj we were quartered on the Bek, a son of the old Consul who had conducted us to Khiva. Our room was large and carpeted, with a fire in the centre on a hearth, surrounded by a curb, but there were no chairs or tables. The Bek showed us his own room, in which were felts, a niche to hold a book or two, a kurjun, or pair of saddle-bags, and a double-barrelled gun. There was likewise a room set apart for the Batchman, or Assistant Bek, who had accompanied us. In the stables the best Turkoman horse was valued at $£ 20$, and two camels at $£ 10$ and $£ 6$ each respectively. The house was built throughout of mud, at a cost, he said, of about $£ 50$, but that houses so built lasted only about 60 years. I suppose that the Bek had some wives, but not a shadow did we see of one of them; and this reminds me that, though I have introduced the reader to several native houses, I have hardly given a picture of what English people love so much, and call "home life." The simplest way to supply this omission is to say of the natives, "They have none." I must, however, endeavour briefly to sketch what they possess approaching it.

To begin, then, with the marriage union. When a boy reaches the age of $1_{5}$, his parents seek a wife for him, who, it is preferred, shall be at least 5 years older, so that she may know how to manage his household. 
Betrothal among the Sarts is usually effected by means of a professional match-maker, who is consulted as to the amount and nature of the kalim to be paid, which, besides money, consists of various articles of toilette -robes, beshmets, or under-tunics, ear and fingerrings, kerchiefs, likewise sheep, rice, fruit, etc., for the wedding feast. In Bokhara they said the kalim varied according to law from io to I,Ooo tengas-that is, from 5 s. to $£ 25$. Of the dowry the bride is to bring with her, the husband knows nothing till after the marriage, though her father, who, according to the prevailing custom, keeps the greater part of the kalim, is bound to give his daughter a tent, and an entire set of domestic necessaries.

When the kalim has been paid and the weddingday fixed, a money security is set aside by the bridegroom in case he should wish to divorce his wife. After this point is settled the mullah reads a prayer, and asks the bride through a closed door whether she consents to marry such an one, and, on her assenting, the bridegroom is asked the same. The mullah then hands the bridegroom a cup of water, from which he drinks, and returns it to the mullah, who sends it in to the bride. The remaining water is then drunk by those present. At the close of the ceremony, the women conduct the bridegroom to the sleeping apartment, and also the bride, in whose society the man spends his first three days of married life in the home of her parents.

The bride is then brought to her husband's house, and begins her every-day and stay-at-home existence. She goes into the streets only on business, and seldom makes social visits, except now and then for a funeral or a wedding. When her husband goes out she is VOL, II. 
commonly locked up, and this want of confidence between man and wife, and the prevalence of polygamy, constantly leads to unfaithfulness. An educated Muhammadan magistrate told me that he thought polygamy had a most pernicious tendency. The principal crimes at Petro-Alexandrovsk among the Kirghese and Sarts are murders in which a woman is concerned. One of the patients we saw in the Sart hospital there had been fighting about a woman. Captain Mirbadaleff had declined his case, and sent it to the kasi, or native judge. Poisoning would appear not to be common, though a case had recently occurred at Petro-Alexandrovsk, committed with the intention of administering an opiate for a nefarious purpose. Formerly the punishment on a wife for unfaithfulness was very severe, but it is less so now, and the mullah at once gives a divorce.

About Petro-Alexandrovsk not many men have two wives, yet if a man be rich, and his first wife chosen by his parents be old (forty is considered very old), then he not unfrequently chooses for himself, with the aid of a match-maker, a second and very young wife, who by law, however, in Khiva, must not be less than I I (in Bokhara they told me I2) years of age. On the other hand, though a girl has usually to accept the first husband her father finds for her, yet, if not content, she may get a divorce, and then choose her next husband; but, in ordinary cases, if either husband or wife objects, divorce is stayed.

But these are the darker parts of the picture, it may be said. Supposing there is no divorce, and things go on fairly well, what can then be said for home life in Central Asia? In Bokhara I was told men feed their wives badly, giving them tea and bread in the morn- 
ing, and tea and peas in the evening, and on bazaar days condescend to eat pilau with them !

One informant represented to me the harem of the Emir as a miserable place, where they get only 5 lbs. of bread a day, and pilau twice a week. Another account, however, from a man who knew a boy, brother of one of the Emir's wives, said that each woman in the harem had a separate house and maid-servant, with 3 meals a day, of her own choice, and the food was said to be good, because the boy in question; being poor, frequently went to see his sister, and was given a meal. The Emir's wives, I was told, might visit, but they had no amusements, unless, perhaps, they played the guitar, "but quietly, so that no one might hear!" I did not infer, from the little I heard of the Emir's affairs, that he cultivated what we should call "family life." We were told in Samarkand that he has two unmarried daughters, whom he visits once a year, but otherwise has no domestic relations with them.

As I have said, it was only in the case of one or two who came to Sevier for medical advice that I saw a woman's face all through Bokhara and Khiva. I thought, however, that I should like to do so, if only in the case of my hostesses at Khiva, whereupon 1 cautiously approached the subject to Matmurad. I had already invited him to England, and to this I added, "When you come, the first person to whom you will be introduced, after the gentleman, will be the lady of the house. Moreover, I expected, when I returned, that the English ladies would be curious to know what the Khivan ladies are like. Further, I thought it possible that his Khivan ladies might like to know what the English ladies were like. Would he not, then, do me the pleasure to introduce me to his wife?" 
How much these sentences altered their shape in passing through interpreters I know not, but he replied that it would give him pleasure to do so, only that it was contrary to their customs. Moreover, that they were always locked in their chambers, and would be so frightened at the appearance of a stranger that they would drop! And Yakoob afterwards informed me that Matmurad was offended at my asking.

This incident gave me a text on the need of Zenana work and women's labour in the mission field, such as I shall not quickly forget. Here was I with abundance of prestige at my back, a court guest, in the house of a host who seemed desirous to please me in every. thing. Yet I was refused! How, then, can male missionaries, for educational purposes, gain access to Oriental women? and if they are not reached, how shall the children be influenced to advantage?

But what I could not do, or any other Christian man, a Christian woman can do. And here is a field of usefulness for English ladies, which, thank God, some have nobly commenced, but of which others do not yet realize the importance. England would appear to have a contingent of about 700 women missionaries, representing British societies in the mission field abroad. Has Russia, then, no daughters to send to so noble a work in Central Asia? Can girls be found, recklessly to throw away their lives in shooting police officers and promoting the horrible "cause "of Nihilism, whilst none offer themselves to minister in womanly sympathy to their Muhammadan sisters-dark, ignorant, and uneducated? Let us hope that, as the Russian Church has formed a Missionary Society for the employment of men, so another may be formed for lady missionaries to the native women! 


\section{CHAPTER LXVII. \\ KUNIA URGENF AND PREPARATIONS \\ FOR THE DESERT.}

Delay in getting camels.-A Kirghese court of justice and witnesses.-

Kirghese interpreter,-A new servant.-Need of Kirghese literature.-Preparation for the desert; camel cradles ; cooking utensils, and provisions.-Arrival of camels and dishonesty of attendants.Presumptive danger ahead.

SOON after our arrival at Kunia Urgenj, on the 5 th of November, the postman Tailly put in his appearance, but not with camels. He had so easily obtained the money asked on two previous occasions, that he seemed determined, if possible, to exact higher terms. To that end he had fabricated a story I did not believe, and the upshot was that he left us about sunrise on the morning of the 7 th, promising to be back in a few hours with our "ships of the desert." But he did not come till night, when it was too late to start, and thus we were compelled by his machinations to spend three or four days at this our last outpost of Khivan civilization. The place, however, was not devoid of interest, and we had several preparations to make. We saw, too, some fresh incidents of native life, better, perhaps, than when in larger places and under more pretentious patronage.

Our host, being Bek, was, of course, chief magis- 
trate in his district, and during our stay there came from a distance two Kirghese of the Adaef tribe for judgment. Captain Mirbadaleff, at Petro-Alexandrovsk, told me that the cases brought before him amongst the Kirghese and Sarts were, for the most part, robberies, murders, and thefts. The Russians leave the bis among the Kirghese to administer justice after their own customs. In the court of the Bek of Kunia Urgenj the mode of procedure was simple enough. The litigants squatted on the platform near the door of our apartment, told their tale, and the Bek gave judgment. Anything more primitive could not well be; but it was manifest that the judge, being bound by no apparent code, could so easily give unrighteous judgment, that the "glorious uncertainty of the law" was, with the Kirghese, about the only thing certain.*

The prison was not far distant from the Bek's house. I found it " in the gate," - not a dungeon, however, like those we had visited at Charjui and Khiva, but a good-sized room, in what was, I imagine, the house of the keeper of the gate. There was but one

* The autocratic power in the hands of such a judge, and the known corruption of the natives, call to mind "Thy princes. . . every one loveth gifts and followeth after rewards: they judge not the fatherless, neither doth the cause of the widow come unto them" (Isa. i. 23). We had seen one instance wherein a Kirghese widow had preferred to come to a Russian officer with her suit rather than to her own people. The answer she received was one of several incidents that reminded me of the similarity between Russian Central Asia in the present day, and Palestine in New Testament times, in that both had concurrently a law of the people, and a higher law adminstered by foreigners. Had this woman come to General Kolpakovsky she might have used the language of Paul to Agrippa, "I think myself happy because I shall answer this day before thee, because I know thee to be expert in all customs and questions which are among us" (Acts xxvi. 2, 3); whilst, on the other hand, the answer she received was near akin to that of Pilate: "Take ye him, and judge him according to your law" (John 
prisoner, and he was quite ready to receive alms, though, by comparison with the imprisoned at Khiva, he was in easy circumstances.

We saw more of these Adaef or Adai Kirghese in the bazaar, perched aloft on their tall camels, and looking the more conspicuous by reason of enormous woolly hats they wear, made in something of the shape of a baby's hood, the flaps covering the shoulders, by no means elegant in appearance, but a great protection from the cold wind of the Steppe. The Kirghese women also come riding into the town astride of horses or oxen. We came into contact here with a very superior young Kirghese, whom the Khan, according to his promise, had bidden offer himself as our interpreter. Meanwhile, as we did not find him on our arrival, we had been looking about for ourselves; for since Yakoob could not be prevailed upon to go further than Sary Kamish, it became clear that we should have to do our own cooking - an art in which I had not graduated. Yakoob, moreover, had found in the bazaar, one Rosi Muhammad, or Mahmet, a poor-looking Sart, with no very definite calling, and sadly in want of cash, who had once been in a party with some Russian surveyors between Khiva and the Caspian. He could speak a little Russian, and said he could cook. He was willing to go with us as

xviii. 31); or of Gallio, "If it be a question of the law you have among yourselves, look ye to it" (Acts xviii. 15). What the officer really answered was, however, more consıderate. He said, "Go first to your own court, and, if the decision does not please you, come again to me." Further, the case of the two Adaef Kirghese, travelling together to present themselves to the judge, brought out the meaning of a phrase, I thought, in Matt. v. 25: "Agree with thine adversary quickly, whiles thou art with him in the way," lest haply "the adversary deliver thee to the judge, and the judge to the officer, and thou be cast into prison." 
servant for $\ell_{2}$ IOs. and all found, and to make himself generally useful; ornamental he could never be, for his eyes were at cross purposes, he was sadly pitted with small-pox, and looked many removes from one of nature's gentlemen. The Russians at PetroAlexandrovsk had said we should be able to get on without a Turki-speaking interpreter, but I declined the obvious risk; and our short experience between

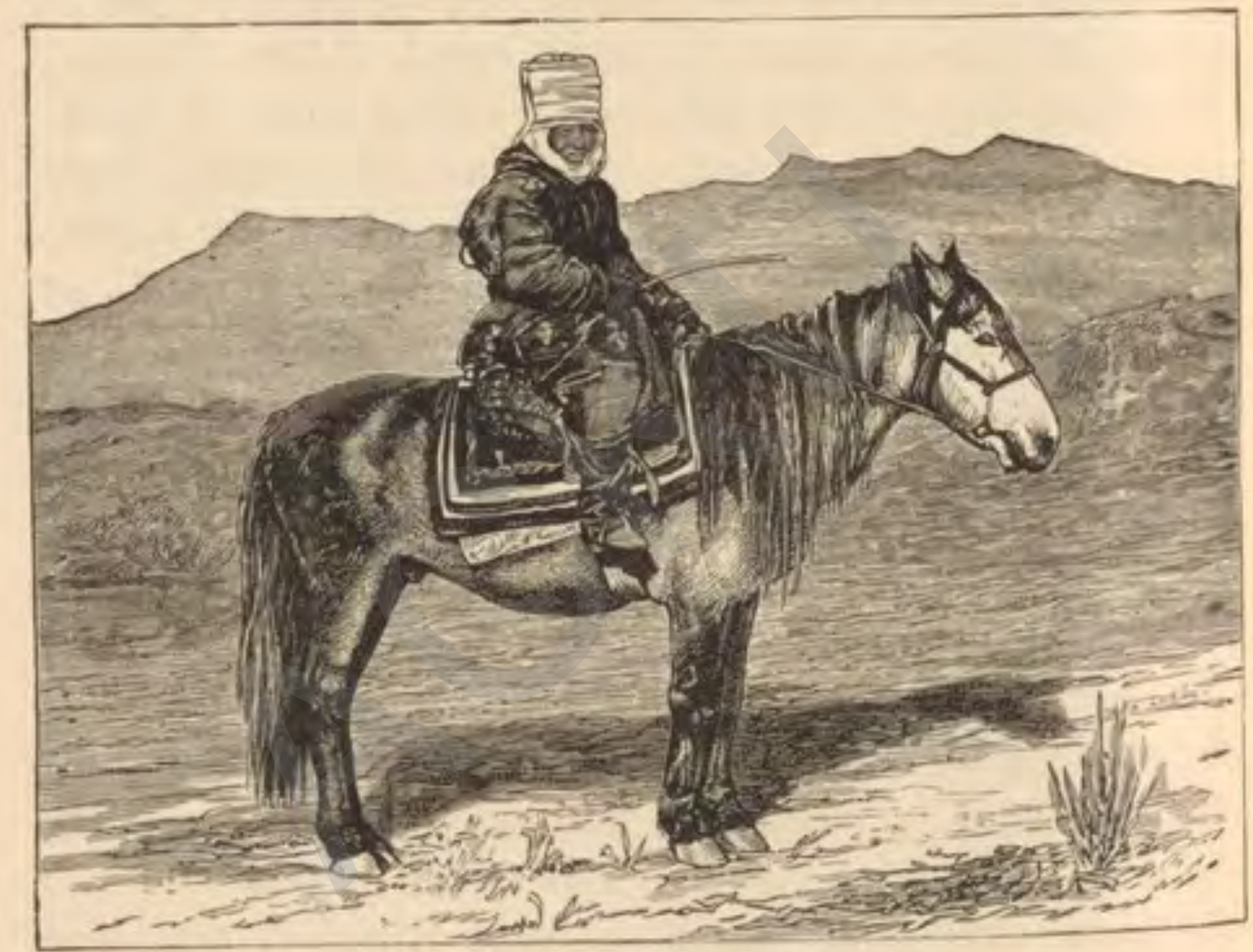

A KIRGHESE EQUESTRIENNE.

Pitniak and the Russian fort, where we had left Yakoob in the boat, warned me that there might be many extremely unpleasant little episodes if unable to say so much as "Yes" or "No" with our guides during a fortnight's journey in the wilderness.

I was inclined, therefore, to settle with "Rosy," as we afterwards flatteringly called him, especially as we heard nothing of the interpreter promised by the Khan. 
Yakoob, however, suggested that we should keep Rosi Mahmet as a reserve, and wait to see if the promised one came, and what he was like. At length, on the afternoon before we started, one Jumagala Mataief arrived from Nukus, concerning whom Yakoob came in to report that he feared he was "too great a swell" to do any cooking. Yakoob had also heard him say that he should not think of asking less than $£ 20$ for accompanying us to Krasnovodsk !

Accordingly, when the grand man was introduced, he appeared in a cloth tunic, respectably dressed throughout, and carrying a watch, with its silver chain dangling from his breast and shoulders. Almost before we had ascertained his powers of interpretation, we had to ask the ignoble question whether he could cook, to which he replied with the Frenchman, who was asked if he could play the fiddle, that "he had never tried," but he was willing to do so.

He said that he had been engaged for 3 years, winters excepted, as one of five interpreters who accompanied Io Russian engineers, engaged in surveying the old bed of the Oxus, with a view to ascertain whether water communication could be again established between the Caspian and the Amu-daria. He had evidently profited by his intercourse with the Russians, and, I should imagine, had proved a faithful servant, for, at the end of his 3 years' service, the principal officer had given him, as a parting reward, the silver watch and chain he now displayed. He appeared, too, to be highly intelligent, and I quite took to him as a man to be depended on ; but the cooking difficulty was too serious, as a mere question of health, to be treated lightly.

We thought it better, therefore, to forego this grand 
interpreter, and be content with Rosi Mahmet, who suddenly increased in value in his own estimation, and asked 20 per cent. more than before, whereupon I clenched matters by writing in my note-book, and bidding him place "his mark" thereto that he agreed to accompany us as servant and interpreter to Krasnovodsk for $\ell_{3}$. We then gave Jumagala Mataief a consideration for the time he had lost in coming to us, and he was content to accept that and our thanks, asking, however, my recommendation, if 1 knew of any one seeking an interpreter, which I promised.

What I saw and heard from him reminded me of much that M. von Ghern had said of the Kirghese at Vierny respecting the desirability of doing more for their mental elevation. Kirghese morals are said to be very bad; conjugal fidelity and virginal purity being alike unknown. Moreover, they appear to have at present no books in their own dialect. The Kirghese New Testament I have spoken of is largely mixed with Tatar, and it seems very desirable that a few simple primers and tracts should be written and translated for them, which, I was told, could probably be done, if someone would bear the expense of printing. Anything written expressly for them would have to be extremely simple, for, of course, the ideas of the natives are very limited, as some of their questions showed, whenever I could get their inquisitiveness sufficiently aroused to ask any. They inquired how far Petersburg was from London, and whether it was surrounded by water, by steppe, or gardens, which I answered; but telling them that the latter city had $4,000,000$ inhabitants seemed to convey nothing to their minds. The batchman asked also about the comet that was just then visible, and upon my explaining the matter, he 
said they had always been taught to look upon such things as supernatural, and portending coming events.

The "coming event," however, with us was that we were about to plunge into the desert, where, even under the most favourable circumstances, we might expect to be many days without seeing house or inhabitant, and so be thrown upon our own resources. We had taken from the newspaper account of the Russian doctor and engineer, who had crossed before us, two or three hints, one of them being the desirability of two cradles wherein to sleep at night on the camel's back. They had no such thing at Kunia ready-made, so we had to call in a native carpenter, whom Yakoob, without my desiring it, and quite unnecessarily, beat down in his price, and the consequence was that, though the cradles came in time, they were so badly made that they threatened not to hold together even to the first halting-place.

Next we were informed that, as the purchase of a horse does not include his bridle, so we had to find all things requisite and necessary for loading our camels and keeping the goods from the effects of the weather. Hence I thought it necessary to purchase several large pieces of felt to cover the baggage, lest it should get wet, and two also to lay at the bottom of our tent. These cost 43 s. Then came rope in large quantities to tie on the loads, and we were specially advised to take one very long piece, because some of the wells were deep. Our two predecessors had taken corn for their horses, and we were enjoined to take also chopped clover, at which Tailly said the horses would turn up their noses, for that we should find plenty of grass on the way. We purchased, notwithstanding, two corn sacks, and a third for a dozen melons and water-melons, 
some of which I judge must have weighed $20 \mathrm{lbs}$, each, though the sackful cost only $2 s$.

Next came sundry humble articles, namely, a round, open saucepan, about 18 inches in diameter, and a wooden soup ladle as big as a saucer, 2 nose-bags for the horses, 2 japanned wooden bowls for soup, and a china basin, which last came to a dreadfully tragic end, as will be described hereafter. In Khiva the price of meat had been given us as $3 d$. per lb., beef rather less, and mutton rather more, so of one or the other we took about $20 \mathrm{lbs}$; ; of chicken we added 8 , at $4 d$. each. Then came the difficult question of eggs. They used to sell in Khiva at 7 for a halfpenny, but, having advanced to 6 for a penny, we took an economical view of matters, and purchased a limited number only. By way of luxuries we secured Io pheasants, the price of which, I had better perhaps add, lest I should be deemed extravagant, was $5 d$. each.

These were our viands, but I have yet to add a bag of rice, onions and carrots, a keg of cream, about $5^{\circ}$ cakes of native bread taken fresh from the oven, and for dessert, apples and grapes, whilst the batchman gave us for his parting present a nicely-packed little box of large pears. These, with some native salt for cooking purposes, finished our list of eatables purchased in Kunia Urgenj, and to this list must be added candles, wooden spoons, and a teapot.

I was glad to secure in Kunia an addition to my curiosities for the British Museum in the shape of an iron pendent, for a horse-collar, formed of a flat plate with loop and staple for attachment. It corresponds to a horse-bell, and flaps against the wooden collar with a ringing sound. More interesting were some coins found in ruins near Kunia, one of which was 
said to be "a thousand years old," - a statement I have not yet verified. I purchased, too, at Kunia some of the common native lamps of Central Asia, which appeared to be for the most part of one form only.

The purchase of these provisions took us from time to time to the bazaar, and gave us a peep at the poor and insignificant modern town of Kunia Urgenj. It is surrounded by a wall with three gates. There are about 350 houses, a small bazaar with Ioo shops, 6 mosques and 2 schools. This was rather disappointing, for we had been told that we could get all that was necessary for the desert journey at this border town, so that we had deferred some of our purchases.

To our disgust, Tailly did not return all day on Tuesday, so that we spent the greater part of the time in packing, and after we were in bed he arrived with a trumped-up story to the effect that on his way one of the hired camels had stuck in a bog, that they had great difficulty in getting it out, and when they did, it was in so disreputable a condition that he did not like to bring it on, and had consequently purchased another in its stead. This was a tissue of falsehoods. At least, the story we afterwards heard from the camel owner was that he brought 5 camels, as agreed, to Kunia Urgenj, but that Tailly said I would not pay for the fifth, and consequently he sent one back. I knew nothing of this, however, until some days afterwards.

Accordingly, on Wednesday morning, I directed the camels to be loaded, and this was accomplished with no little difficulty. They used the rope so lavishly that I thought we should exhaust all the stores in the town. There was no more to be had new, and the second-hand, according to Yakoob's account, kept rising in price. Unsolicited by us, Rosy told us later 
on that Yakoob out of this rope had been making a little harvest for himself. I had received a hint at Samarkand that I must look sharp after Yakoob, for that, although he was not a thief, yet he had his own notions of honesty. Yakoob told us that in one commission we had entrusted to the new interpreter he had overcharged us sufficiently to allow of his purchasing a store of tobacco. For the future, therefore, I sent Yakoob on errands, not thinking that his probable reason for "splitting upon" Rosi was that he might get the business into his own hands.

My costly felts, that I expected would be put over the goods to keep them clean, Tailly coolly folded, and placed beneath the baggage to keep it from rubbing the camels' sides. I rather demurred, thinking that the owner ought to provide that much for his own animals. I urged that I wanted the felts to keep the things from rain. Here no doubt he laughed in his sleeve at my ignorance, as he replied, "We will put them on the top when the rain comes." We did not have a drop all across the desert, and evidently, by Tailly, rain was as little expected as when Samuel called for a storm in harvest. ${ }^{*}$

I confess to being a little disappointed at the look of the camels hired for us. I had given the best price, that he might secure the best animals, which I supposed to be the graceful, long-haired, two-humped Bactrian camel. Instead of this appeared five short-haired, one-humped, gaunt-looking creatures of anything but attractive appearance. I was reconciled, however, to the new animals on Yakoob's telling me that the onehumped (nar tuya) animals are stronger than the twohumped (tuya). Accordingly, when our camels were

* I Sam. xii. 17 . 
loaded, our little string of five filed out of the Bek's yard, and I was somewhat amused at this novel fashion of removing my baggage.

I imagine, however, that there was a serious side to the affair, that my ignorance did not permit me to see, but which seemed to be present to the mind of the Bek. He had, I presume, never before seen two foreigners, comparatively unarmed, starting with three natives only to cross the Turkoman desert. The Russian surveying parties had been escorted by a guard of Cossacks, and the two private parties I have alluded to did not come so far north as Kunia Urgenj. The Bek, too, knew the dangers of the desert better than I, and sent for a man who offered himself as guide; but this did not seem necessary, I thought, since Tailly was supposed to have made adequate provision on this score, and every individual added to the company rendered necessary the taking also of his provision for nearly three weeks.

What were really the Bek's fears, if he had any, I know not, but it looked rather ominous when, just before starting, he asked me for a written statement that I had in safety left him, and been properly treated. I, therefore, formally wrote, "This is to certify that Dr. Lansdell, having received much kindness and attention from the Bek of Kunia Urgenj, leaves to-day for Krasnovodsk, with Mr. Sevier and Rosi Mahmet as interpreters, and under the guidance of (I) Tailly, (2) Nazar Muhammad, (3) Murad, and (4) Yakoob," and then handing this to the Bek, with a slight touch of the feeling with which I suppose a mariner puts a paper in a bottle for what may, perhaps, be his floating epitaph, I mounted Diotrephes and prepared for the start. 


\section{CHAPTER LXVIII.}

FROM KUNIA URGENY TO KUNIA VEZIR.

Departure from Kunia Urgenj.-Rest in a Turkoman tent.-Forced labour of the Khan.-Dismissal of attendants with presents.New interpreter and guides.-Our last habitation.-Doctoring a Turkoman.- "Turning in " to camel cradles.-Rosy's accident.My ride through the night,-Wells of Karategin.-First caravan breakfast.-Endeavours to hasten the drivers.-Journey in the old Oxus bed.-The dam of Egin Klych.-Ruins of Mashrek.-Pitching our tent opposite Kunia Vezir.-Reference thereto by Abu'l Ghazi.-Jenkinson's forecast.-Routes of other Englishmen from Kunia Urgenj.

(N Wednesday morning, November 8 th, at halfpast ro, we left the city walls in a cavalcade of I 4 men. First came three djiguitts, who represented a military escort, and were supposed to be armed, though I forget with what. These, with Tailly and Yakoob, after seeing us well started, were to return on the morrow. Besides, there were a number with us whose presence I did not understand, and also Khassan, the Batchman, and his servant, who were to accompany us as a compliment a short portion of the way. We passed few, if any, gardens, the only cultivated land lying to the right on the banks of the aryk that had been cut to run through the modern Kunia Urgenj. Plunging quickly into the steppe, we again had ruins on either side of the road, as in coming 

from Iliali, but dating only from half a century ago at most. Khassan said they were about 30 years old, and were forsaken when the Turkomans quarrelled with the Uzbeg inhabitants, and the latter fled, their Khan, Madamin, having been killed. Before this civil war, land about Urgenj sold for Ioo tillahs a tanap, or $£_{1} 8$ an acre.

When Khassan bade us farewell we took a parting view of Kunia Urgenj. Its tall minaret was the one reminder we saw in Asia of the spire of an English church, and as it faded away in the distance we said good-bye to fixed habitations for many days. At noon we were taken to the tent of one who was said to be a " rich" Turkoman, where they brought forth melons for lunch, and by half-past 4 we arrived at an oba or collection of Yomud Turkoman tents, in one of which we were to take up our quarters for the night, or, as Yakoob put it in New Testament language, "till the cock crew.", *

In unloading the camels one of the cradles went hopelessly to pieces, but fortunately we found another among the Turkomans. Yakoob came to inquire whether he should cook some of the butcher's meat for a feast to my retinue. I replied "Certainly," but was hardly prepared for their making off with little

* Matt, xxvi. 34. This was not the only answer I received in Central Asia characteristic of a people who have not clocks and watches, or cally divide their so far as I saw, and who, consequently, do not practically divide their day into hours and minutes. One morning I stirred up Yakoob before it was light, whereupon he murmured, "Why, the Nehemiah's men appeared" (iven worked "from the rising of the morning till the stars driver how soon ), so, in the desert, one weary eve I asked the camel in so many hours, heould arrive at the next well, and instead of saying that should have sunk pointed to the evening star, and intimated when there.

VOL. II. 
short of three-fourths of our stock. A tent, belonging apparently to an old man, who shifted elsewhere for the night, was set apart for Sevier and me; Tailly and Rosy paying us visits to settle sundry minor affairs. We had a fire burning, and a piece of green wood was sputtering out sap, which I observed Tailly take with his finger and rub on his eyelids, for the purpose, he said, of " improving his sight."

Next morning we were astir at dawn, and after drinking tea I pleased our old host by presenting him with $8 s$. for our night's lodging. He fairly danced with delight, and vowed that "the Russians," as he called us, were excellent people, for that whereas their Khan exacted from them labour, and gave nothing in return, the Russians paid. I suppose the old man referred to a practice of the $\mathrm{Khan}$, who, when he wants a great work done, such as making a canal or dam, raises a levy.* At the time of the Russian invasion, the Khan directed a levy to be gathered from the districts of Khojeili, Chimbai, and Kungrad, to help the Russian steamers in the Ulkun-daria to ascend the Amu. A certain Yessaul-bashi, who had boasted that he could find the channel for the ships, was authorized to deal as he saw fit with the inhabitants of the delta, and this power he abused by summoning the labourers right and left from their fields in the hope that the unfortunate people would bribe him to let them off, and thus whole villages were fleeced. I know not whether my old host had this sort of thing in mind, or whether he thought that, as we were guests of the Khan, he might expect no payment for his tent and bread and melons; but he appeared very much gratified, and we parted on excellent terms. $†$

* As did King Solomon of 30,000 men (1 Kings v. 13).

$\dagger$ This incident, and what transpired about the melons at Koshkupryk. 
I had now to pay off Yakoob and Tailly, for neither wanted to go any further ; and as they had found me other men to take their places, there was no reason why they should not return together to PetroAlexandrovsk. Accordingly I paid Yakoob what was due, and added a present, and I gave a present to Tailly too, with which they were both pleased. Yakoob had asked for my portrait, and now kissed my hand, and seemed to have become attached to us; but Tailly, I afterwards discovered, was a thief.

The Governor at Petro-Alexandrovsk had given me to understand that Tailly received $\&_{7}$ for taking the post to Krasnovodsk. If, therefore, I chose to take him as my guide, and give him a present, "pour boire," as he said, at the end, I might do so, and this offer I thankfully accepted. Next, to facilitate matters, Tailly was to go forward, and hire for us in Khiva four really good camels, and their owner was to accompany them and us to Krasnovodsk; for which Tailly thought $£ 6$ would suffice. This I gave him, with the understanding that any present to the owner at the end of the journey was to be voluntary on my part. At Khiva he came to us with a story that $£ 6$ was insufficient, and I gave him, as he asked, r $2 s$. more. Again, at Kunia Urgenj he came trying the milch-cow again, but not successfully this time,

as well as sundry other exactions we had seen, helped to remind me of a custom that obtained in Palestine, under the Persians, when the governors were chargeable unto the people, and took of them bread and wine, from doing which Nehemiah refrained because of the fear of God (Neh. v. 15). Long before this time, however, the people were warned when they asked for a king. This shall be the manner of the king. "He will take your sons, and appoint them for himself, for his chariots, his.. and your goodliest young men, and your asses, and put them to his work" (I Sam. viii. I I-I6)-a picture this of Bokhara and Khiva to the present day. 
though at parting I gave him a present of $\ell_{\mathrm{I}}$ for his trouble.

It was interesting, therefore, to compare notes one morning at breakfast with our new men, Nazar Mahomet, who replaced Tailly, and Murad, the owner of the four camels. The latter said he had been paid only $24 s$., and seemed greatly surprised that I had given $33 s$. for each animal. As for Nazar, who lived at Gazavat, Tailly told him that he received $£ 68 \mathrm{~s}$. for carrying the post, which he brought as far as Gazavat, and then sent it on by Nazar, over the greater and the worst part of the way, giving him $£_{3} 4 s$., or only half the spoil, leaving him to find his own camel or horse, or do as best he could. Upon this auspicious occasion, however, Tailly had given Nazar nothing, telling him that I should doubtless give him a present of $£ 5$, and that if 1 did not do so he would.

Then, to complete this little exposé, Rosy informed us, rightly or wrongly, that Yakoob and Tailly stole melons and ropes from me at our first stopping-place, and asked him not to tell. Further, they said that, at Kunia Urgenj, Tailly had threatened to cut them across the face with his whip if they dared to expose him; and as he was a tall, powerful bully, I suppose they thought it better not to provoke him. I knew nothing of this, however, when Tailly and Yakoob left, and we parted with mutual good wishes, the two volunteering the remark to Sevier that they were "well satisfied."

To those who have had much to do with Orientals, I suppose this story will be sufficiently commonplace, and perhaps they will add a caution against believing the informers without sufficient proof. Be that as it may, I was sorry to hear of Yakoob's peccadilloes, 
which, however, if true, I should be disposed to regard leniently, for he had a conscience, and, on the whole, served us well; so that, if I were returning to the country, I would willingly employ him again; though I was not minded to let off Tailly so easily, and took measures to bring him to book.

With Yakoob and Tailly we dismissed, also with a present, the three djiguitts who had escorted us, so that we were now reduced to a party of 5 men. Rosy, after the fashion of the country, had asked for half his pay before starting, had bought a new cloth cap, and otherwise put on a rather more respectable appearance; but we soon found that he was of inferior calibre to Yakoob-a capital trencherman, but by no means industrious, or one that could be left to his own devices. $\mathrm{He}$ was a Sart, and afflicted with the failings of his race. The other two men were blackhatted Uzbegs, brown as berries, but of very different character and temperament, as will be presently seen. I shall speak of the three as Rosy our servant, Murad the camel-owner, and Nazar the postman.

We had started on this our second day from Kunia Urgenj soon after sunrise, and as we went along we passed more ruins, some of them so large that I rode forward to look them over. Also I turned aside here and there to look at the tents of the semi-nomad Turkomans, who tilled patches of land, presenting myself alone, and saluting them with an Aman!one of the few salutations I knew in the vernacular.* At i i o'clock we came to an aul they told us would be

- This phrase, with Salaam aleikum, I observed to be used when two persons met, but I have no recollection of hearing the form of salutation bestowed by a traveller on the road upon a man labouring in the field. I have heard it in Connemara among the Romanists, thus, "God and Mary bless the work!" to which the labourer replies, "And 
the last habitation we should see for some time, and as Nazar had a brother or relation here, they proposed to stop for 5 hours, and then to set off in real earnest. Accordingly we stretched ourselves in the tent of this friendly Turkoman, the master not being at home on our arrival, though a neighbour unceremoniously came in, nominally to pay a visit, but seemingly to stare at us. Meanwhile they prepared a meal for Sevier and me, and when we had eaten it, the master of the tent returned, and took down a leg of mutton wherewith to feast his friends. When cooked, he invited us to partake, but I declined, saying most truthfully that we had just dined, and wanted no more. Here I forgot that being able to eat no more is a mere figure of speech to a Turkoman, and I am afraid that my host either thought me rude, or attributed my refusal to national or religious exclusiveness, for he gave a polyglot grunt that would be understandable in any language, and appeared to be huffed.

Sevier was able to make a good impression, however, by doctoring him. Soon after entering, our host stretched himself on the floor. Then his boy, 8 or 10 years of age, stood on him, and walked up and down his body, as if kneading the patient with the soles of his feet. This was an intended cure for a pain in the stomach I had never before seen, nor Sevier, at any of the three European capitals where he had studied, so he proceeded instead to paint the patient with iodine from the ribs to the loins. For this the man seemed to be grateful, and good-fellowship progressed to such

you, too!" and something of the kind appears to be referred to in Ps. cxxix. 8. They who go by say not so much as "The Lord prosper you! We wish you good luck in the name of the Lord " There is also the case of Boaz and his reapers (Ruth ii. 4). 
a degree that, when the time drew near for us to be moving, the three natives would willingly have stopped for the night. This was precisely what had happened in the case of the Russian doctor and engineer, in whose account we had read that their guide took them as guests to the tent of a friend for two days. I was accordingly ware of the delay, and said "No." Rosy urged that the men did not exactly know the way at night. This difficulty was surmounted by arranging to take a man from the aul as guide. Then our servant further pleaded for a prolonged stay, on the ground that it would be our last stopping-place with fellow "humans," and that our host was such a " right good fellow," with which I agreed, but recommended that they should make haste back and then further cultivate his acquaintance.

When they saw I was firm, they began to load the camels. Hitherto Sevier and I had travelled on horseback, but now we thought it better on starting to "turn in" for the night, and directed the cradles to be prepared accordingly. The other of our new cradles was now pronounced unsound, so as our host happened by a lucky fortune to have an old one at hand, this was patched up and an exchange effected, the articles hitherto placed in the cradles being distributed over the remaining beasts. Now they said that there was too much baggage for 5 camels (the fifth belonging to the postman). It was fully late to find this out, nor was it quite apparent how the defect was to be remedied, for there was only one camel in the oba, belonging to an old woman, who was anything but amiable, and seemed not to like my face, declaring she would not let it to me, though I know not exactly why. Our host began to show us some cheap politeness, 
as I thought, by saying that had he not recently sold his camel, he would have lent it to us gratis, in recognition of Sevier's kindness in doctoring him without charge. I capped this by answering that, if he were really grateful, he might show it by persuading the old woman outside to hire us her camel. This he proceeded with alacrity to do, and for $34 s$. we secured her treasure to accompany us to Krasnovodsk. The owner gave strict injunctions as to its being brought back by our men, and bade them God-speed, but she would not shake hands with me, a Kafir, and evidently was with difficulty persuaded to let her animal go.

About seven o'clock all was in readiness, and Sevier and I were to get into our queer sleeping-cages. Let the reader imagine two narrow wooden crates such as earthenware is packed in, each sufficiently large for a man to lie in when twisted to the shape of the letter S; and let him further imagine them suspended on either side of the huge hump of a kneeling camel. This I am given to understand is to be my sleeping-place for the night, and I accordingly choose my berth on the port-side of this " ship of the desert," first putting into the cradle for a lining a piece of felt, and then two pillows. So far all is well; but inasmuch as my lodging is to be beneath the frosty sky, it seems desirable to multiply my sleeping garments. First I put on, over my ordinary suit, my jackal-lined khalat, enveloping me from head to foot, over that my Ulster, and on my head a sheepskin hat, to say nothing of fur-lined boots kindly lent by General Grotenhielm; and then, getting into the cradle, I cover my feet with my sheepskin coat.

And now comes the tug of war! Nazar asks, are we ready ; bids us hold on! and says to the camel, 
Chu ! whereupon the animal gets up leisurely, first on its hind legs, and in so doing raises our feet to an angle of 60 degrees, thereby threatening to pitch us out bodily. We hold on, however, for dear life, and then comes a lurch from the fore, lifting our heads once more to the horizontal. The fear of danger now is past ; but it is not easy at first to get accustomed to the strange motion caused by the long strides of the camel. When the creature was urged to go quickly, the nearest simile for the cradle I can think of is that of a bottle of physic in the process of being "well shaken before taken"; but when the camel walked leisurely, then one lay as in a boat idly tossed by the billows ; and sleep became possible just as it is in a Russian tarantass, when one is dead tired, cramped, and "used to it."

But we were not the first night to enjoy our slumbers undisturbed. As we went along we passed some men with huge fires making charcoal, and then towards midnight there came a crash and a bellowing from one of the camels which had fallen. The jerk had broken the ropes, and the baggage lay hither and thither, needing new ropes to secure it afresh. But how to get them? We thought of the charcoal burners, and it was suggested that Sevier and Rosy should go back and inquire whether they had any to sell. Sevier took my horse and Rosy the other, whilst I turned in to my cradle again, now on the ground, and went off to dreamland. Sevier, taught by experience, warned Rosy not to gallop his horse, because not sure-footed; but this was not heeded, and presently down went the horse, and Rosy, not getting his foot free from the stirrup, was dragged along and bruised, until the horse got free and ran away. Sevier was 
slightly ahead, and did not at first miss the rider, but when he came back he found him on the ground, calling out, "I'm dead! I'm dead!"

He was brought back alive, notwithstanding, and though sufficiently bruised in tender parts to put him in great pain, he was not seriously hurt, and, on looking out of my queer sleeping-place, I could see Sevier doctoring him up and painting him with iodine by the light of the fire. It was a weird, curious sight. There we lay under a lowering midnight sky, the darkness relieved by the glare of a saxaul fire. The camels were kneeling around asleep, and so were the outstretched drivers, whilst Sevier was busy with his groaning patient in the application of bandages.

When at length the doctoring was over, it was plain that the wounded man could neither walk nor ride on horseback, and the only thing left was that he should occupy one of the cradles, to which end I volunteered to give up mine, and to ride Diotrephes for the remainder of the night. I had to speak sharply to the men to rouse them from their slumbers, especially to Murad, whom I perceived to be not in the least hurried, and to take things a great deal more coolly than suited my anxiety to get forward. Matters, moreover, had not been improved by my having heard, through Rosy, that the men had talked of throwing overboard, in the night, the melons and clover in order to lighten the ship. I saw, therefore, that I must be firm, and I spoke in tones that needed no interpreter to show that I meant to be obeyed, and at length we got under way.

Once started, Nazar and Murad became hilarious, and commenced singing, now in duet, now in solo, but never in harmony, and always in dubious melody. In one of 
his strains Murad's voice, whether intentionally or otherwise, approached perilously near to the braying of a donkey, but he seemed to enjoy it, and it helped to keep me awake. For a time I got on pretty well, sometimes walking and sometimes riding, but the wind was cold; and as we passed ruin after ruin the "Queen of night rose not in clouded majesty, nor v'er the dark her silver mantle threw." Not even an owl swooped by, and the gloom was decidedly uninspiring.

In plain English, I began to get fearfully sleepy and tired, and I had so far the satisfaction of seeing that it was no singular weakness on my part, inasmuch as the local guide, who went on ahead, now and then galloped a little further than usual, and then got off his horse and lay on the ground for a few minutes' sleep till the caravan came up. I did not attempt this, but vainly tried in all sorts of ways to put myself in a posture for horseback sleep. Then I called in the aid of reason, and argued how useful it might be in my experience to have spent one night thus out in the open; what sympathy it would give me in future for policemen, night-watchmen, nurses, and such persons. Other thoughts too, better than of reason's light, came to my aid about self-denial, and " enduring hardness," with sundry other appropriate reflections.

So things went on till Aurora opened the gates of morning, and dawn found us at the four wells of Karategin, or Kara-Kum, in the dry bed of the Oxus. Here we were to draw water for the first time, and to prepare breakfast at a camp fire; so, after directing Rosy to cook a pheasant, I was minded to turn into the cradle for a nap; but sunrise brought vigour to my fatigued limbs, and I could not sleep amid such novel surroundings. My thoughts were speedily taken back 
to the days of Abraham, and the herdmen of Gerar striving with Isaac's herdmen at the well of Contention, ${ }^{*}$

We were upon the verge of doing the same thing, without my knowing it, at Karategin, for a shepherd had come before us to water his flock, and, being " first come," had a right to be "first served." This, however, would not only cause us delay, but by the time his bucket had descended often enough to give drink to a thousand sheep, the water, if there were any left, would be so muddy as to be unfit to put into our barrels. My men represented this to the shepherd, and ominously added that the Englishman carried a revolver, and would certainly shoot him if he did not give way. This impromptu story caused the shepherd to yield, so that I was not called upon to carry out their murderous threat, and Nazar proceeded to get water, drawing it, to my astonishment, in the horses' nosebags! This was the nearest approach I had seen to "holding water in a sieve," but the bags, being made of thick woollen material, answered the purpose admirably. We were also able to purchase some more rope here, and our local guide went back to his aul.

Breakfast went off pretty well for a first occasion. The pheasant was preceded by potage au faisan, and we made an attack upon our Russian bread from Petro-Alexandrovsk. When looking over the hospital there, I had tasted the patients' bread, and was so pleased that I asked the General if the baker might make me a number of loaves, and these we had been saving till we could get no more fresh native nans or bread-cakes. The Russian loaves were now 12 days old, and, truth compels me to add, were getting hard; but we soaked the bread in tea, besides which we

• Gen. xiii. 7 ; xxvi. 20. 
had cream that was wondrously accommodating. On opening the keg at even, the motion of the camel was found to have converted it into "whipped " cream, whereas in the morning the frost of night had given us "iced" cream, and in the middle of the day we had crème au naturel. Then we sliced a melon, and having thus partaken of dejeñner à la fourchette at the somewhat abnormal hour of sunrise, I directed the camels to be reloaded.

First, however, I had a little serious talk with the men concerning despatch. From the very outset, even as far back as Petro-Alexandrovsk, I had found it difficult to get a satisfactory answer from Tailly to the straightforward question, "How many days will it take you to get us from Khiva to Krasnovodsk?" He said about 12 or 14 days, and mumbled out some sort of reckoning, at which the General only laughed, and said the man did not really know. The Russian doctor and engineer had taken $\mathrm{I} 7$ days from Iliali, but in hot weather, and had been compelled to rest, whereas we were going by a longer route, though in a cool month. I gravely put it, therefore, to the men as to how many days it would take them to reach Krasnovodsk from where we were.

They answered "Nine." " Very well," said I. " Then for every day less than nine I will add ten shillings to the present I am thinking of giving you; whilst for every day you take more than nine I shall deduct ten shillings." Remembering also what I had heard of their intention to fling overboard some of my possessions, I informed them that, if they lost any of my belongings, they might expect to have the cost of it deducted from the present. They assented to this arrangement and then we started. 
Our way lay for I4 miles along the Urun-daria, the old watercourse by which the Oxus used to reach the Caspian, so that as we marched along the bottom of its bed with the rising banks on either hand, we had the pleasure of imagining how, in bygone centuries, fishes sported in the space we occupied, and how gallant ships went over our heads with cargoes of Asiatic produce to be transported over the Caucasus to the Black Sea and onwards, for the aristocrats of ancient Greece and Rome. We started to walk in the fresh morning air, but instead of meeting anything to remind us of "the briny deep," or rather fluvial remains, we came upon three or four flocks of sheep and goats, with their shepherd, who was to be our "last man " for many days.

Since my retinue had eaten so ravenously of my butcher's meat, I had offered to purchase a sheep at Karategin, but the shepherd had only one that he cared to sell, and, what was worse, would be paid only in silver, and not paper, which latter circulating medium the country people in Khiva do not take to kindly ; and it certainly would not have been convenient for this unhoused shepherd to carry in his pocket for many days, since he was simply "abiding in the field" with his flock. On the other hand, I could not spare so large a proportion of my Russian coin, lest I might want small change further on, and so negotiations fell through, much, I fancy, to the disgust of Murad, who was hoping for a share of the prospective mutton feast. The second shepherd had shot a fawn, which he sold us for $3 s$. $8 d$., and thus we added venison to our marching larder. We passed three wells, but saw no other reminder of inhabitants, save some arbas for the transport of firewood. At 2 o'clock we came to 
Igin, or Egen-Klych bent-that is, the "bent," or dam, of Egen-Klych, a Turkoman of that name, who built it in $184 \mathrm{I}$, by the help of 100 workmen in 6 months. ${ }^{*}$

We now had the ruin Benam-baladi on the left, and ascending out of the river bed we passed by a ruined fortified place called Mashrek. These ruins have not the character of an ordinary fortress, but consist of a large area surrounded by a shallow moat and a low wall. Within are numerous clay houses, some well preserved, and between them streets and squares. These ruins have been deserted not much more than a quarter of a century - at the same time, in fact, as the ruins we had passed on the previous day, and from a similar cause.

At half-past four, about 3 miles beyond the ruins of Mashrek, we came to what was deemed to be a suitable place to encamp till midnight. Here we pitched our tent for the first time, and were reminded of the kindness of General Grotenhielm in lending it, for it suited our wants exactly. We were offered the use of a larger one, but preferred this yulamaika, its construction and erection being alike simple.

Taking the two pieces of felt from the cradles, we

'It is $\mathrm{I}, 000$ feet long, and the present dyke is still in good preservation; but two previous ones were washed away, the slope being so great and the water at that time so excessive, that it found its way round the dam, and at length rushed 40 miles southwards to Lake Tiuniukli, which it filled, and still poured along an old channel towards Sary Kamish. Some few years before, the Laudan, the most northerly branch of the Amu, had overflowed, and inundated the country between Kunia Urgenj and Khojeili, and entered the Aibughir gulf. But it afterwards made another channel for itself into the old bed of the Oxus, and filled Sary Kamish. I presume it must have been this inundation that Abbott saw in 1840 , and at first thought to be the Aral, but afterwards found it " only the Lake Lowdahn, which receives an arm of the Oxus." One looks in vain now for any water in the direction he indicates, since it is all completely dried up. 
laid them side by side for the tent floor. Next we spread thereon a number of rods, perhaps 8 feet long, and joined at the top so as to stand like a cone, leaving two wider apart than the others for a doorway. Then summoning all hands, we hauled over this cone a huge shape of thick felt, all in one piece, that covered everything, and left a flap for entrance. We next folded other felts and placed pillows for two beds, leaving a space between for the dining arrangements - a change truly from the spacious halls and palaces wherein we had been lately lodged, but amusing enough in its way at first and for a limited time. Rosy was quickly voted a very fair cook. His pheasant soup at even was pronounced excellent by hungry men, whose last meal had been eaten at sunrise, whilst the venison was the best of its kind I think I have tasted before or since.

There was one thing that specially impressed this our first encampment on my mind, in that we could see across a plain, about 7 miles from the camp, but only 3 or 4 miles north of the road we had come, the ruins of a town now called Deu-Kesken, doubtless none other than the ancient Vezir, where the first of the Uzbegs, Sultan Ilbars, was proclaimed Khan, in I512. It is the "Sellizure" of Jenkinson, * who, in $155^{8}$, spoke of it as a castle seated on a high hill, and

* Abu'l Ghazi refers to it as Vezir, six parasangs from Urgenj. Its actual distance in a direct line is 55 versts, or say 7 parasangs, and he adds that there were formerly several towns dependent on Vezir, each having its own governor. It is called in an ancient Jagatai work, Howorth says, Shehr Vezir, probably a corruption of Shehr-i-Vezir, or town of the Vizier. Others, again, call it Kunia, or Old Vezir, as I have done to correspond with Kunia Urgenj. Jenkinson adds that to the south of the castle the land is low, producing a fruit called a "dinie" (this is the native name for what I have called a "melon"). It is very large and full of moisture, the people eating it after meat instead of 
though the residence of the King Azim Khan, yet built of earth, not strong, and making a poor figure. It may have happened, however, that the place was added to in after years, for when Glukhovski's expedition visited it, in 1873 , they were surprised at the fine appearance of the arches, arcades, and façades, and at the extent of the ruins. To us, as the old buildings stood out against the sky on an outlying promontory of the Ust Urt, close to the Chink, or bounding cliff of the plateau, they looked a superior class of ruin altogether to the mud houses and 30-yearold ruins we had passed, and comparable rather with such as we had seen at Kunia Urgenj, to which the town seems to have ranked next in importance.

Jenkinson, so far as I know, is the only Englishman who has ever entered the ancient Vezir, going from and returning to Mangyshlak, though Captain Abbott also, like myself, saw it from a distance, but not apparently from the same spot.* As the sun went down upon this interesting ruin, we retired for a few hours' sleep, and at midnight resumed our journey.

drink (which is precisely what we did). There is another, called "karbus" (which the Russians call arbuz; I have called it a "watermelon," because resembling our fruit of that name); but when Jenkinson calls this latter "the size of a great cucumber, yellow, and sweet as sugar," I should rather have said the size of a large pumpkin. The old traveller then goes on to say, "The water that serveth all this country is drawn by canals out of the Oxus, so that it falleth not into the Caspian Sea, as formerly, and in a short time all that land is likely to become a wilderness for want of water." This has now come to pass, though it was more than 300 years before the forecast was
fulfilled.

* Shakespear's route from Kunia Urgenj lay further north, mounting the Ust Urt at Aibugir, and so reaching the Caspian at Fort Novo Alexandrovsk, or Dasht Gullah, on the bay of Mertvi Kultuk, $487 \frac{1}{2}$ miles from Khiva, whence he started on the 3 rd August, and arrived on IIth September,

VOL. II. 


\section{CHAPTER LXIX.}

\section{FROM KUNIA VEZIR TO SARY KAMISH.}

Order of march and loading camels.-Tragical end of a china basin. -Climbing a camel's hump. -The Oxus bed at Ak-bugut.-Description of old Oxus bed from Kunia Urgenj.-The Butenau plateau and Kazak tombs.-Cliffs of the Ust Urt and traces of Jenkinson. -The Kitchkine-daria. - The pool at Dekche.-Further description of the Oxus bed.-Wells of Sary Kamish.-Correction of Murad for stealing. - Character of guides.-Arrival at Sary Kamish.

W ${ }^{\mathrm{HEN}}$ urging upon Tailly that I was anxious about sunset, let the camels graze for a couple of hours, then collect them for 2 hours' sleep, and go on again at midnight. He thought it necessary to add that we must get up when called, or he could not undertake to get us to our destination in the specified time. He evidently thought he was dealing with feather-bed travellers, whose night and morning views about early rising would not agree, instead of with one who professes to rise at 5 all the year round, and who gets up every morning at the bidding of an alarum. I had taken with me one of these comforts of my life, and before midnight was stirring up the natives, who lay snoring round the fire, by gentle applications of 
shoe-leather. They did not seem to appreciate this disturbance of their "beauty" sleep, but I thought it better from the outset to enforce discipline, and made them stir.

We also lent a hand in loading. I cannot pretend that getting a caravan under way on a dark night is no more uncomfortable than changing carriages at a railway junction; still, both no doubt have their points of interest. Sevier and I always undertook the arrangement of our cradles, which were hoisted by 4 on to the back of the leader camel. Then came the loading of the water-barrels, oval in shape, and resting on short, wide ladders, against the animals' flanks-a great improvement on tursuks, or skins, which communicate, I am told, an ill-flavour to the water they carry. For the loan of these barrels we were indebted also to the kindness of General Grotenhielm. This load was assigned to the animal we had last hired, a she-camel, that gave herself airs like her mistress. So long as the creature was let alone, all was well ; but when made to kneel, whether to be laden or unladen, she whined and roared as if being imposed upon, and tried to get up before she was told. I assumed the function, therefore, of holding her down by the nose, and more than once had to thank merely my own cleverness in not getting my fingers bitten. She was, however, a strong beast, that never flagged. The third animal carried our portmanteaus and bags; the fourth had a sack of barley and fodder for the horses. On the fifth were the tent poles and a strong crate, with our food and live-stock. By this last I mean chickens tied by the legs, and at first suspended by Murad from the top of the saddle, until I saw them suffering, and directed them to be placed in the crate. Even so they voted camel 
travel very fatiguing, and one of them succumbed, though the others were ready, on stopping, for barley and water, until it came to their turn to be eaten. The sixth camel brought up the rear with a bundle on its back as big as itself, consisting of the tent, on the top of which Murad loved to mount, and, if possible, go to sleep, whilst Nazar trudged in front, or rode one of the horses, dragging on the foremost camel of the nose-tied caravan, which had very much the appearance of a Kirghese family flitting, save that we had no cows.

Rosy, though much improved by doctoring, was not yet sufficiently recovered to mount a horse without pain. Accordingly, on leaving Kunia Vezir, Sevier generously gave up his cradle and rode, whilst Rosy and I, on opposite sides, "turned in." Presently we had to "turn out," for about 4 o'clock I heard an ominous cracking of my cradle, and I thought it best to get down.

But how should I make Nazar comprehend? Sevier was not at hand, and Rosy was snoring. Almost the only native word I knew was Yakshi, meaning "All right!" whereas just then I feared things were all wrong, and I vainly called out in Russian, Stoi! or stop. Suddenly remembering the word used by the drivers when they wished the camel to kneel, I shouted Chok! Chok! whereupon the sapient animal went down suddenly upon its knees with a thud. The jerk broke out the side of my cradle completely, and I descended to terra firma with unexpected alacrity.

My head, however, was pillowed on down, and fortunately I was not hurt. Meanwhile, on the other side of the ship things had taken a different turn, explanatory of the pathetic end of the china basin, as 



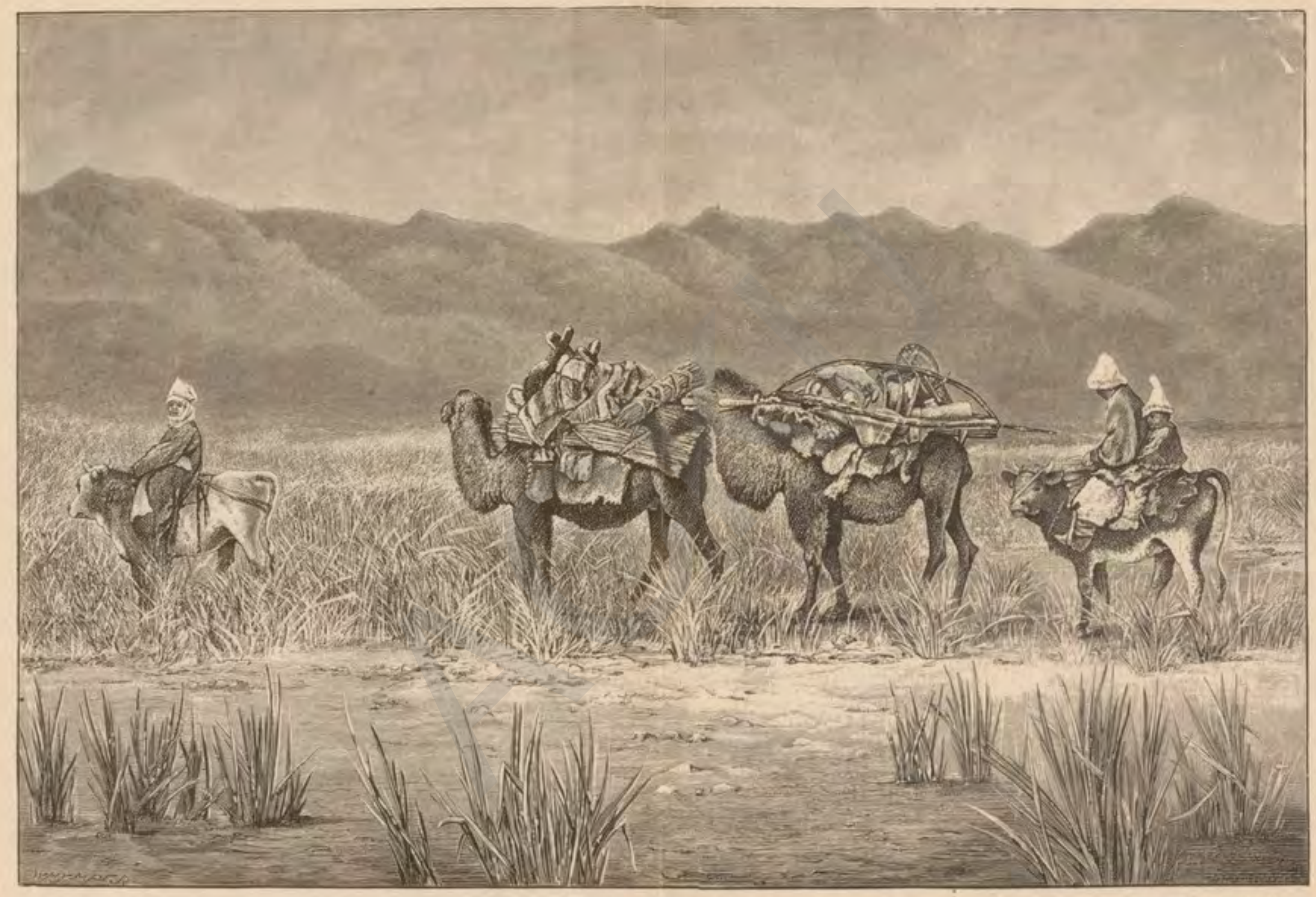

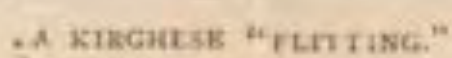

Page 38B, Vol. II. 

recently hinted. We had but one of these useful articles, and fearing to put it into the crate, lest it should be broken, I committed it to Rosy, to carry, as he suggested, in his bosom. Later, however, he transferred it to the interior of his sheepskin hat, and he was enjoying his slumbers when the crash came, and he was pitched out on his head, not to the breaking of his skull, indeed, but to the utter destruction of my china basin!

It took Rosy a few minutes to realize in all its bearings this sudden termination of his dreams, and then I saw that he was disposed to take a serious view of matters. This was the second time his perpendicularity had been inverted, and he now solemnly informed us that if he were thrown upon his head again he would die! This, of course, we deprecated, as we had not yet made sufficient progress in the vernacular, and we accordingly roped up the broken cradle, once more to turn in.

The men suggested, however, that, in deference to the frailty of the broken panier, we should not get in whilst the camel was kneeling, but after it had risen. This was a feat less difficult of accomplishment, no doubt, than climbing an elephant's trunk, but by no means easy. First, Murad was made to tuck his head in the camel's shoulder, whilst I climbed up his back on to the camel's neck, my first landing-stage, after which it remained to struggle over the front of the pack-saddle, and let one's self down into the cradle, the opposite panier being held down till my fellow-rider arrived by the same route, and established the equilibrium.

During the night, after marching three miles, we approached again the bed of the Oxus at Ak-bugut, or white dam, 12 miles from Egen-Klych by the road, but 
many more by the river bed, which in this reach is particularly tortuous. This last remark will hold good of our road, more or less, all the way from Kunia Urgenj.* Ak-bugut is situated at the apex of a bend of the old bed, where the sandy hillocks on the banks are of considerable height, and where the water has dug out a big hole, surrounded by woods and high natural walls. From Ak-bugut our road continued west for 9 miles, when we again crossed the Oxus, the river bed mean-

- As no English author has described this part of the old bed of the Oxus in detail, I ought perhaps to attempt it, especially as I have a Russian account, edited by Professor Lenz, as well as his and Mr. Morgan's admirable papers on the "Old Channels of the Lower Oxus." At the old fort, Ak-kala, opposite the ruins of Kunia Urgenj, the bed is encumbered with sand; but, a few hundred paces below, the banks become so high and steep that a ramp had to be cut for the wheeled traffic of Glukhovsky's expedition. 'On the left bank, within about a mile of Ak-kala, the ground is covered with sand-dunes, and 5 miles off begins the dry, salt, clay steppe, with tamarisks and saxaul. Wheel tracks lead 16 miles south to the ruins of Medemin-kala and Kandumkala, near a lake of the latter name, whence saxaul and salt are obtained. Seven miles from Ak-kala the bed is wide, the left bank high and steep, and the bottom and right bank covered with sand. About 9 miles beyond is the dam of Ushak-bent. Here the banks are lofty, covered with tamarisk, growing 20 feet high. The dam across the bed measures 200 paces, and in breadth about 25 feet on its flattened top, and 40 at the bottom. There still exists a road across the dam to Kandumkala.

Within the next 3 miles, below Ushak-bent, are lakes, or rather reaches, of fresh water, Kara-Kum, Mamuly, and Autsi. Three miles west of this last the bed divides, and forms an elongated island of sand, called Gudalchi; 4 miles further on are the reaches Salak-bent and Nazar-bai, and near to this last the ruins of Baklyk. The reaches derive their names from the constructors of the dam, Salak-bent, 4 miles below.

This dam was constructed about 1843 , in order to raise the water high enough to fill a large, aryk running from the left bank. Two or three hundred men were employed on the works during the winter, each family working ${ }_{15}$ days. All this labour, however, was in vain. The Turkomans, who had dwelt on the banks of the Urun-daria for a century, were troublous subjects to the Khans of Khiva, and were protected by distance and difficult communications. The Khans, therefore, wishing them to settle nearer Khiva, dammed up the Laudan, and so cut off 
while having made a double bend to the south, and for the last 5 miles skirted on the left the Butenau hills, a plateau in the shape of a boot, and having on its northern edge a group of Kazak tombs, one of which bears the appellation Ibrahim Khan, or Ibrahim Ata. Another is that of Ismail Khan, and at the north-west headland that of Mazar Ata.

Thus far from Kunia Urgenj the country on the south had been a level plain, whilst on the north this plain abuts on the Ust Urt plateau, the escarpment or border of which is called in Turki Chink.* West of

their water supply, and forced them to come about Gazavat. Hence the many deserted houses we had seen.

Up to 1862 a certain amount of water came up to Salak-bent, and to Kunia Urgenj for 6 years later. The width of the old bed here is 770 feet. Along each bank runs a channel, and in the middle is a sandbank. The greatest depth of the left channel is ro feet, and of the right 5 feet. Three miles from the mouth of the canal, on the right bank, are the ruins of Sheruana, which must be somewhere left of the spot I passed on the night of Rosy's accident, where also, on the right of the road, three miles north of Sheruana, are the ruins of the fortress, Kalak-kala.

Three miles below Salak-bent is the well Karategin, where we descended into the Oxus bed, and from thence marched along it to Egen-Klych. Below Egen-Klych the channel becomes more tortuous, and contains quantities of loose sand, which the river, however, if it returned, would easily carry away. In the next 13 miles by the river bed to Ak-bugut, or " white dam," are wells in at least 7 places, but deeper than those mentioned before, owing probably to the earlier stoppage of the current.

* The slopes commence at the low plateau Akimen, about a mile north of the well Karategin, and the chink runs along the river bed for 6 or 7 miles, then makes a bend northward, where the hills become known as the Armanzyk range. Three miles further west, and the same distance north of Egen-Klych, is what some would call the southern boundary of the Ust Urt, and four miles westward the promontory whereon we saw standing so proudly the ruins of Old Vezir. Here the perpendicular walls of the chink are 70 feet high, but for 22 miles to the westward, the elevation appears to be less. When we reached the Oxus, west of Ak-bugut, we again had on our right, 6 miles off, the chink running in a south-westerly direction, and forming two headlands, the first called Bish-Tishik (five holes), and the second 
that part of the plateau, called Bish-Tishik, are the ruins of Denki-Kena, and still further west, on the crest of the cliffs, a ruin called Shamaka, of which, says Lenz, we know nothing except by hearsay.

Lenz says that Ibrahim Ata is found on the march route of Jenkinson. This would be natural enough, and the most direct route that I see from Kunia Vezir or Sellizure, as he calls it, to Mangyshlak; and I see no route on my large map connecting Deu Kesken with Aibughir, 17 miles to the north-west, where Shakespear mounted the Ust Urt.

After reaching the Oxus beyond Ak-bugut, and north of the Butenau hills, we stopped at sunrise, on November I Ith, for breakfast, and encamped at sunset at Jedurun, in or near the dry bed called Kitchkinedaria, or "little river," a stream that branches off from the old Oxus bed about two miles from where we last crossed it, and runs parallel thereto, but at a distance of from I to 2 miles, to Sary Kamish.* We were now passing between the Butenau hills on the left, and the Chink on the right, with a valley 8 miles between of friable, clayey soil, mixed with stones. Saline patches were visible, and much tamarisk, and in the morning we passed through a fine wood of saxaul, with white willows here and there in favoured localities.

Aur-Murun (big cape). Between these headlands the cliffs are evidently inaccessible, but to the north of Bish-Tishik the slope is gentler, and to the west of Aur-Murun is a narrow but convenient ramp, after which the cliffs again become steep, and from 70 to roo feet high, as far as the eye can reach, trending off round Sary Kamish.

* The bed of the Kitchkine-daria is 150 feet wide, but filled with sand. Still, its banks are high and steep, and it therefore presents difficulties, though not insuperable, to wheeled vehicles crossing it. The windings of the Kitchkine-daria cover so large an area that the road from Ak-bugut to Dekche crosses it 7 times. At Dekche the bed turns south, but again approaches the road from Dekche to Sary Kamish, and then crosses this road twice. 
On the preceding day we flushed a pheasant, and later saw crows and a finch, and here and there the tracks of sheep, but otherwise few signs of animal life.

On the next morning, November I 2 th, I was in an indulgent mood, gave the men an extra rest, and did not stir them up till 4 o'clock, and by 9 we had reached Dekche. This was now the third day since we had taken water, and the horses were faint from being restricted in drink, and also from finding little on the ground to eat. But at Dekche there was "corn in Egypt," though not easily accessible, for both grass and water were at the rush-grown bottom of a deep gorge in the Oxus bed, and just there the banks were quite imposing.* The right bank, though of clay, obstinately resisting atmospheric influences, was much weatherbeaten, and stood up before us like a cliff, as we scrambled down a narrow path on the opposite bank, to water our animals and refill the barrels.

We thus gained an opportunity of observing one of the many lakes, or reaches, in the old bed of the Oxus. They are not only numerous, but in some cases very deep. That they existed before the river ceased to run is shown by the presence therein of fish. It is to be presumed that a considerable amount of filtration from the Amu and canals goes on under the old bed, by means of which the wells along its course-usually from 4 to 20 feet deep-are supplied. The water in

* After giving off the Kitchkine-daria the bed gradually widens and deepens, At first the right bank is steep, but the left disappears under the sand. A short distance further the bed is like a deep precipice, the outline of the banks being irregular. As the bed approaches the Ust Urt it narrows, the walls are 140 feet high, and the sands on the bottom are replaced by stretches of clear water. This was the case at Dekche, where the width of the Urun-daria (which usually averages from $\frac{1}{4}$ to $\frac{1}{2}$ a mile) is from 700 to 1,050 feet, and the depth, according to Lehmann, at least 210 feet. 
the reaches is rather yellow, but fairly transparent, and sweet, until the meridian of Aibughir is reached, when it begins to be brackish. So, at least, say several writers, adding that, at Dekche, the water is "salt and bitter, and quite unfit for use" ; but we made use of it for all purposes, and I have no recollection of its being particularly disagreeable.

Rosy told us that the Russian engineers stayed at Dekche, with their Cossack escort, for 6 weeks, and we unladed our camels close to the earthworks they had thrown up. The place commanded a good view of the cliffs of the Ust Urt, with well-marked horizontal indentations. As we descended into the gorge the path contracted in one place to a few inches between rocks, and here was cleverly set, not a man-trap, but a smaller one with teeth to catch some luckless gazelle going down to drink. This led us to think there might be Turkomans in the vicinity, in which case it seemed desirable not to leave our baggage unguarded. Murad told us for our comfort that in this very place, three years before, the post had been attacked and robbed; but as he himself had been robbed some ten or a dozen times, he seemed to make little of it. We had seen no habitations since we left the Turkoman's tent, but I have read that in this neighbourhood there are to be found here and there under thickets, subterraneous sheds, deserted in summer, but into which, in winter, cattle are driven on the approach of danger.

On leaving Dekche we proceeded ten miles to the wells of Sary Kamish, in the Oxus bed, where the surface of the water was I 8 feet deep. I did most of the way in the cradle. Sevier gave up his panier all the morning to Rosy, who was much better, though still taking very kindly to the cradle, and perfectly 
content to be treated as an invalid! About 5 o'clock we reached the wells, which are within sight of the great lake ; and here we had to descend so steep a path that the men desired us to get out of the cradles, lest the camel should fall and break its legs. Thus far we had met with no piece of road, I think, whereon our tarantass might not have been drawn, but now it would have been out of the question.*

For some reason unknown to me our men wanted to stop at the wells Sary Kamish only two hours, and then to go rapidly on for a long journey, as they said, on the morrow. This was our fifth day from Kunia Urgenj, and up to this time we had accomplished only about 85 miles, or not much more than I have sometimes posted in Siberia in 12 hours, and I was beginning to get tired of this slow progress. I reminded the men of their probable lessening of the present they hoped to receive; but they did not appear much concerned. An incident now occurred, however, that brought my dissatisfaction to a climax, for, on going to the crate to get half a water-melon we had left uneaten, I found its pinky flesh scooped out and the rind only left. Murad was the culprit, whom Sevier had seen

* From this point the Oxus bed becomes gradually wider, and the ground rapidly falls towards the lake. The banks of the river bed, gradually sinking, remain vertical at first, and then gently and imperceptibly disappear in the banks of the old lake. The ground is sandy, covered with tamarisk and white willows (populus diversifolia), numerous enough to be called woods. The area occupied by the thickets is considerable, and bears traces of former cultivation. Another evidence of this is the fairly preserved system of aryks and canals. The copses become less dense on approaching the lake, finally give place to thick steppe grasses, after which comes a zone of firm, clayey, salt soil; but beyond this, and nearer to the lake, the soil is so spongy as not to support a man on horseback 200 paces from the water, thereby exhibiting signs of being merely a crust over a liquid foundation. 
put in his great black hand, and tear out the luscious morsel. I called him up, and charged him with purloining, whereupon he said that when the crate fell, which it had done early in the day, one of the camels had put his nose into the crate and cleaned out the melon. Sevier, however, witnessed against him, and I gave him a lecture.

But shortly after Rosy came to divulge that Murad had stolen about five-and-twenty, or nearly half, of my native bread-cakes, whereupon I felt that it was high time for me to turn policeman, and to give him something more than sharp words, which by the time they had left me in English, Sevier in Russian, and Rosy in Turki, had lost much of their flavour. I adopted, therefore, a corrective idea from Captain Burnaby's book, and holding up the bag with the remaining cakes before Murad's face, I addressed him in English, and, to make it understandable, I administered on his back two or three sharp cuts with my horsewhip. He wore so many khalats over his well-seasoned hide that I do not think he was much hurt, but under the consciousness of guilt his swarthy face became a few shades darker than before, and Sevier cried out that he acknowledged himself wrong, promising not to offend again ; whereupon I desisted.

I know not whether this narrative may cause some to think that I was forgetting my profession, but I acted advisedly and thought I was right. We were not yet half-way to the Caspian, and if I did not in some way establish my authority, we might have half our provisions stolen. There was no policeman, magistrate, or bek within scores of miles, and I could not rid myself of the thief either by advance or by retreat. I was thankful, therefore, that I had the courage to 
"take the bull by the horns" and administer what the French call une petite correction, and it had precisely the effect that I wished.

Murad slunk off to Nazar, and presently a message came in the plural number to say that, if I scolded and beat them, they would go back, which united action I counter-manœuvred by telling both that they had only to be honest and all would be well, and adding that I was not angry with Nazar. This honourable exception pleased Nazar, and he thanked me, and, what was better, proved himself afterwards true as steel. Murad continued the idle, lazy lout he had been all along, putting his work, when he could, on the others, and wanting to ride when Nazar walked; but I had established my position as master, and he obeyed, so that henceforward we got on better.

After resting three hours at the well, we ascended out of the river bed by a path equally difficult to that by which we had entered. Murad's temper had not quite recovered, and he said at first that they were going back, but made no attempt in that direction, and soon after midnight we came to a land of reeds and rushes. Then the men came to say that the camels were so tired that they must rest, for one of them was ill; also that it was so dark they could not see the way. With regard to the camels I thought it a lie, but as for the other plea, if they did not know the way, certainly I could not tell them, nor blame them, for it was so dark as to surprise me how they could make out the way at all. I gave permission, therefore, to stop and rest till daybreak, when, on opening our eyes, we saw stretched out in the grey light of morning the littleknown lakes of Sary Kamish. 


\section{CHAPTER LXX.}

SARY KAMISH AND OLD BEDS OF THE OXUS.

Lakes of Sary Kamish and their characteristics.-Testing specific gravity of water.-Its chemical analysis.-Crossing the lake basin to the Ust Urt.-Jenkinson's alleged "Bay of the Caspian." -Geographical problems respecting the course of the Oxus and Sea of Aral.-Historical discussion and physical investigation.Testimony of travellers from 1717 . - Reconnaissances of Markozoff, Stebnitzky, Glukhovsky, Lupandine, and Petrusevitch.-Four dry Oxus beds. - The feasibility of diverting the Oxus into the Caspian. -The cause of its deflection eastwards.

I AKE SARY KAMISH, or, as the Turkomans call it, "Betandali Goel," comprises, properly speaking, two elongated sheets of water, united by a narrow and sinuous strait, two-thirds of a mile wide and 7 miles long. They lie from north-east to southwest, and the one we first approached measures 8 miles long by 4 wide, and has several barren islands. Between the two lakes, and almost surrounded by water, is a rocky eminence, on the northern and western sides of which runs the strait. The second lake is ro miles long, and varies from 3 to 6 miles wide. The altitude of the former is said to be a little higher than that of the latter, and the Cossacks of Glukhovsky's expedition found the current of the strait running accordingly. Both lakes are very deep, and their beds are in places firm and sandy, though 
for the most part unapproachable at the edge of the water, whilst their flat and open shores are one mass of salt marshes. The lakes are surrounded by sand, and one easily sees that their surface once occupied a far wider extent than now, especially on the east, west, and south, the shores of the former basin being in some places 8 miles distant from the present lakes. Vegetation exists only on the former shores.

When daylight showed us our whereabouts on the morning of November 13 th, we found ourselves at the north end of the first lake, in a dry portion of its present basin, whence we proceeded in a southwesterly direction, about 3 miles distant from the water, till in the afternoon we approached sufficiently near to the second lake to lead me to ride forward, and attempt to get to the water for the purpose of testing its specific gravity; but within a stone's throw of the margin my horse sank to the knees, and I was obliged to desist. Returning to the caravan for assistance, Nazar brought me to another place, where, tucking up my trousers, I found myself also sinking to the knees within a dozen feet of the water's edge. I dared not undress, because I could see no means of washing off the mud with which I must inevitably be covered on wading out to terra firma. On the other hand, I did not like to be so near the goal and not attain to it. Whereupon Nazar and I plucked some tussocks of a bushy, prickly plant, which was the only vegetation growing near, and, putting these before me step by step, and putting my bare feet thereon, I managed, at the cost of scratching myself, to keep from going down out of all soundings, and to attain to the edge of the lake. The water was clear, but intensely salt-more so than sea-water-and so great was 
its density, that my instrument for the determination of the specific gravity of different waters, and graduated from $0^{\circ}$ to $100^{\circ}$, would not sink below a point which, had the scale been continued, would have read $120^{\circ}$.*

I was fortunate, or unfortunate, as the reader may regard it, in not attempting to bathe in Sary Kamish. A member of Glukhovsky's expedition found a stony beach on the south-east of the upper lake, and, on going in to have a swim, found the water so buoyant that, at roo paces from the beach, he could hardly dive. The sub-strata of the water appeared a greenish yellow, and viscous like oil, with a disagreeable odour, that, in the course of a long walk on the beach, produced in him a sensation of nausea. The buoyancy of the water reminded one of the Dead Sea, which these lakes resemble further in that the natives say they contain no fish. The banks are deserted. Gulls, Woodcocks, and Ducks, however, are sometimes seen flying over the water, and we saw in the course of the afternoon a Magpie and a Dun Crow.

Leaving the water to our left, we crossed a piece of rising ground, and on looking back we had rather a pretty view of the lakes, but the place was barren of trees. We came about 3.30 to a promontory, KakhPular, and to sands on our left of the same name, whilst the sands to the right of the road are called

- Samples of Sary Kamish water, in 5 bottles, were taken by Glukhovsky's expedition, and each submitted to chemical analysis at the Tashkend laboratory, with the following results:- Specific gravity 103 at $5^{\circ}$. In 1,000 cubic centimeters of water there were, in each of the 5 samples, grains of solid matter from $40^{\circ} 9^{2}$ the lowest, to $47^{\circ} \cdot 04$ the

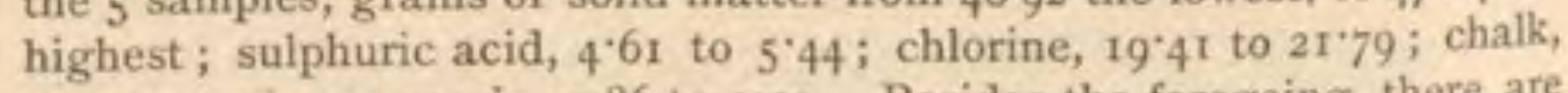
2.03 to $2 \cdot 57$; magnesia, $1 \cdot 86$ to $2 \cdot 09$. Besides the foregoing, there are in the waters of Sary Kamish, in quantities not stated, natron, sulphuretted hydrogen, silica, aluminium, carbonic acid, and organic matter in solution. 
Kyzyl-Kaia. At Kakh-Pular we pitched our tent, as my notes have it, "near what looks like the dried basin of a large lake."*

We started on the morning of November I 4 th, at I, stopped for 3 hours at sunrise, and at half-past 2 arrived at the cliffs, which had long bounded our horizon. I have no note or recollection of the hollow way, or water-course, which, according to my map, we must have crossed, but we noticed particularly at the foot of the cliffs a narrow line of beach, or pebbles, rounded apparently by the action of water, and mixed with sand and shells, which we at first took to be evidence indicative of an ancient sea shore; and as we were mounting a declivity, or natural ramp, in the cliffs, it looked, in common parlance, just as if we were emerging from the sea at low water, across beach washed up by the last tide, on the southern English coast, and mounting the downs, say, at Newhaven or Eastbourne. Then, on looking back from a height, one could think of the vast expanse of land stretching to the horizon as of nothing else but the bed of a former lake or sea.

It occurs to me to add that if at this point Jenkinson emerged from the wilderness after 20 days' journey from Mangyshlak, and if the water then came up to

" This is precisely what the guide to Glukhovsky's expedition informed them, adding that the level steppe extended " to the cliffs of the Ust Urt, and there, at a distance of about a verst from their base, may be seen a long lowland, or rather a flat, hollow way, running parallel to the cliffs, which perhaps served as the former issue of the Oxus flowing from Sary Kamish towards the Caspian." The commencement of the hollow way, the guide said, was about 17 miles from the western bank of Sary Kamish. Subsequent exploration would appear to have confirmed this, for on my Russian map, zo versts to the inch, the Oxus bed leaves the Sary Kamish basin in a westerly direction, about 6 miles west of the southern lake, and then quickly turns at right angles and runs south, parallel to the Ust Urt cliffs, called here Ust-Kaplan-Kir.

VOL. II. 
the cliffs, he may very well be pardoned for mistaking it for a gulf of the Caspian. Muravieff, many years afterwards, called the cliffs " a sea shore," and I could well have done the same, looking only at what was before me.* I fear, however, that I am laying myself open to objection from the general reader, in that I am trying to throw light on the interesting geographical problems belonging to this region, without having stated them. They concern the ancient course of the Oxus, and the condition of the Sea of Aral. Not many years ago it was asserted by Sir Henry Rawlinson and other eminent geographers, that the Oxus has more than once changed its course, flowing now into the Caspian. and now into the Aral, and that the Aral has accordingly fluctuated a good deal at different periods, between the condition of a great inland sea and that of a reedy marsh, and, further, that when the supply of water from those feeders has been entirely cut off for a lengthened period, the Aral has dried up, and

* There is a route indicated on Walker's map that would, bring Jenkinson here from Mangyshlak, with his thousand camels, in about 20 days, and, on reaching this cliff at Sary Kamish, the distance to Sellizure would be just 3 days' journey at 25 miles a day. His statement also, that the Oxus once fell into this gulf, would accord with what anyone may now see of the dry bed, though there may have subsequently been an intermittent flow of water all the way to Sary Kamish; and, lastly, if his report be adduced as a difficulty of the water being fresh, one may fairly suppose this to have been the case when the lake had been supplied from the Oxus only recently through the Urundaria. Besides this $I$ have read nothing to show that the lake may not still have been reached by some of the now dry beds of the Oxus approaching Sary Kamish on the other side. The guide to Glukhovsky's expedition "'showed us the place where the Jity-Muran formerly fell into the eastern angle of the lake, and also, 15 to 20 versts away, the old bed of Iliansky-Daudan, which fell into the old lake, whose limits extended thus far from those actually existing." I shall have presently to refer to another inland bed of a sea, or lake, we came to farther west at another Kaplan-Kir, which no Englishman but myself, and very few Russians, I believe, have ever seen. But suppos- 
disappeared from the map of Asia. In opposition to this it was maintained by Sir Roderick Murchison and others that though the Oxus may at times have partially flowed into the Caspian, yet that the main outlines of the Aralo-Caspian region have not materially varied in historic times, and that there is not sufficient ground for saying the Aral has ceased to exist.*

$\mathrm{U}_{\mathrm{P}}$ to within about 12 years ago the country was closed to scientific observers, and, therefore, the question could be discussed only upon historical grounds, which Sir Henry Rawlinson stated to the effect that from the earliest date, say, from 600 years B.c. to about 600 years A.D., the Sea of Aral is utterly unknown in any Greek, Latin, or Persian writings we possess. The Oxus and Jaxartes are described as running into the Caspian. Further, the Asiatic trade-route of those days is represented as starting from the foot of the Indian Caucasus, or Central Asian mountains, down the Oxus to the Caspian, ascending the Kur, and descending the Phasis to the Black Sea, and thence crossing into Europe.

For the next 700 years, he adds, there is a consensus of testimony exactly in the other direction. The Arabs were then the possessors of the country, and their geographical works invariably represent the Oxus and Jaxartes as falling into the Sea of Aral.

ing for a moment that the Kara-boghaz indented the coast in this direction as far even, say, as Uzun Kuyu, it would be impossible to get a caravan from thence to Sellizure in 3 days. So far, then, as my limited reading upon the subject, and my personal observation, enable me to form an opinion, I think that Jenkinson emerged from the wilderness at Sary Kamish, and mistook this lake for a gulf of the Caspian, as Mr. Howorth also suggests.

- See the question as stated by Sir Henry Rawlinson and Sir Roderick Murchison in the Proceedings of the Royal Geographical Society for 1867 , pp. 114,204 . 
The presumption, therefore, is that from some natural disturbance the rivers had changed their course, and, running into a hollow, probably made for themselves the Sea of Aral.*

During the next 200 years, from $\mathrm{I} 300$ to 1500 , frequent missions were sent from the courts of Europe through Central Asia to Mongolia: and though the routes lay in most cases across the Aral region (Sir Henry even says the route lying across the bed of the Aral), yet not one of the travellers records the existence of the sea. Colonel Yule, however, having examined these records, states there is no ground for saying the route lay across the bed of the Aral, though it may have gone partially round it. ${ }^{\dagger}$

In addition to this negative evidence Sir Henry Rawlinson adduced extracts from a Persian manuscript, containing a geographical account of the province of Khorassan at the beginning of the fifteenth century. In this the writer, speaking of the Lake of Kharezm, or Aral, says: "In all the ancient books the Lake of Kharezm is described as the receptacle of the waters of the Oxus, but at the present date ( $\mathrm{I}_{4} \mathrm{I}_{7}$ ) the lake no longer exists, the Oxus having made a way for itself to the Caspian, into which it disembogues at a spot called Karlawn" (or Akricheh). The same writer states that the Jaxartes, passing into the desert of Kharezm, joins the Oxus, and thus reaches the Caspian.

Next we come to the time of Jenkinson, who, in $155^{8}$, landed on the north-east coast of the Caspian,

* The bed of this sea, it should be remembered, is about 130 feet above the level of the Caspian, so that, if a communication were formed between the two seas, the Aral would naturally be drained.

† See Proceedings of the Royal Geographical Society for $186 \%$, p. 211 . 
travelled for 20 days to a sheet of water, which he called a bay of the Caspian, but which, for reasons already mentioned, I can think of only as Lake Sary Kamish, since the water was sweet, and within 3 days' journey of Sellizure. I myself passed over some miles of the dry bed of this shrunken lake, but supposing that Jenkinson kept along the cliffs to the north, as apparently did Muravieff, to Bish-deshikwells(Dekche?), then both travellers must, in all probability, have seen, as I did, if not crossed, what is now called the Urundaria, and Jenkinson might well have there learned that the river had lately changed its course, and gone back to the Sea of Aral. This change is amply confirmed by Abul Ghazi, who mentions the very year when the river began to return to the Aral, and relates how the Oxus dried up, and formed the present sea.

With regard to the Oxus bed beyond Sary Kamish, the reviewer of Yule's "Marco Polo," in the Edinburgh Review for 1872 , whom I take to be Sir Henry Rawlinson, thinks that when Bekovitch went to Khiva in 1717 , the desiccation of the Turkoman steppe was complete, and that not a drop of the Oxus water at that time flowed to the Caspian ; and when we come to the present century it would appear that the bed south of Sary Kamish was undoubtedly dry, as witnessed by Muravieff, who passed from Balkan Bay to Khiva; from Conolly, who attempted to cross from Astrakhan to Khiva ; and, lastly, by Vambery. All of these came upon the old dry bed.

So much, then, for the historical inquiry, which shows a fourfold change of course.* We come next to scientific investigations of Russian engineers,

\footnotetext{
- Further information may be found in the work of M. de Goeje, the brochure of Professor Lentz, and a paper of Major Wood.
} 
who have had every inducement to go into the question thoroughly ; since, if the Amu could be turned into its old channel and rendered navigable, Russia would have a highway from Petersburg to Afghanistan. As General Grotenhielm laughingly said to me, "When you come to pay us your next visit, and the Oxus is open, you will be able to take your ticket from London Bridge to Petro-Alexandrovsk, in the heart of Asia, and come all the way by water!" meaning, of course, by way of Petersburg, and through the canals to the Volga and Caspian. This practical question occupied the mind of Peter the Great, who sent Bekovitch Cherkassky to Khiva with a view of investigating the old bed of the Amu, and diverting it again into the Caspian; but, as will be remembered, he was murdered, and the data he collected perished with him. Again, Muravieff, in 1819, crossed the old bed of the Oxus at Besh-dishik wells, where he found it 700 feet wide, margined on the north by the chink of the Ust Urt, or "sea shore" as he calls it. On his return journey he crossed the old river bed at the bitter salt spring of Tunuklu, on the parallel apparently of Dakhli wells, 277 miles from Krasnovodsk, where one bank is again steep, and the bottom covered with brushwood, but the channel not so deep as at Besh-dishik. Also, in 1836 , General Blaramberg had the opportunity of exploring the old bed from its mouth, in Balkan Bay, to the Balkan mountains; but it was not till after the occupation of Krasnovodsk, in 1870 , that the Russians commenced to survey the steppes east of the Caspian and the desiccated Oxus bed, their alleged object being to find a good number of roads for the furtherance of commerce with Central Asia. To this end Colonel Markozoff made two re- 
connaissances, the first to the north-east beyond Sary Kamish, to Dekche; the second along the lower portions of the Uzboi (as the natives call this part of the old bed), but reached only to Topiatan.

To this peaceable object was added, shortly after, the necessity of finding routes with wells, along which troops might march for the occupation of Khiva. Colonel Stebnitzky's expeditions, in 1872 , were in part intended to push on Markozoff's work in the Uzboi. He found a good slope all the way from the Caspian to the wells of Igda, a distance of 187 miles, and indications that a great river, from 60 to 70 feet deep, had once flowed there.* In the following year, 1873 , during the Khivan expedition, Colonel Glukhovsky went along the old bed, as I have said before, to Sary Kamish, in the direction I myself travelled, and I have incorporated the principal results of his work in my own account. It was not till 1875 , however, that the topographer M. Lupandine mapped the remaining section of the Uzboi, between Igda and Sary Kamish, so that the entire direction of the old bed was made known, its length from the Amu at Kipchak to Balkan Bay being 500 miles, with a fall of 400 feet.

After this it was proposed, in 1876 , to establish a permanent trade-route from Khiva to Krasnovodsk, along a line drawn by Glukhovsky, which is practically

* At Dso-Yuruk spring the steep sides are composed of regularly stratified steppe lime. From the springs of Burgun, close to the right bank, the stream must have bored its way through horizontal layers of marl and shell-limestone belonging to the miocene formation. From Dso-Yuruk to Topiatan the bed is nearly a mile in breadth. Traces of freshwater shells, however, could nowhere be found, nor ruins, nor traces of irrigation works between the Caspian and Igda. Between Igda and Sary Kamish, however, Lupandine found shells, a Muhammadan cemetery, and 3 old irrigation canals, probably belonging once to a Turkoman aul. Otherwise this central portion of the Uzboi does not differ from the lower in important respects. 
the one I followed; but as there were large tracts without water, and the country was not safe from Tekke Turkomans, it was proposed to build a fort between Kunia Urgenj and Sary Kamish, and to supply it with water by turning back the Amu into its old course, with a view to its reaching as far as Ak-Inish-a spot I9 miles from Uzun Kuyu well. The expedition for preliminary investigations was committed to Colonel Petrusevitch, from whose report it appears that there are in the Khivan oasis alone three old beds of the Oxus, and the Turkomans told M. Stebnitzky it has another dry bed, leaving the Amu at Charjui, and turning westward into the desert.* But this last statement, according to information which I have had within the last few days from Mr. Lessar, is a mistake. $\dagger$

As to the possibility of diverting the Amu into its ancient bed, it is very likely, says Kostenko, if the dams placed in the Laudan and Kunia-daria were

* Of the remaining three, the southernmost, called Tonu, or Sonudaria, takes its rise near Hazarasp, and passing close to Khiva, on the south, makes its way towards the wells of Adji-Kui, but where after that is not known. This channel is said to form the southern boundary of the Khivan oasis from Hazarasp to Mount Bishik-gir. The channel next further north, called the Daudan, or Darialyk, begins near the town of Hanki, runs past Kosh-Kupyr (where, it will be remembered, I alluded to crossing it) and Iliali, and then to Lake Tiuniukli (throwing off an arm, however, to the east, before reaching the lake), and beyond to Sary Kamish. The northernmost and best known of the three is the Urun-daria, composed of two branches - one, called the Laudan, issuing from the Amu between the Kipchek and Khojeili hills, running southwest; and the other, called the Darialyk, leaving the Amu at Urgenj, proceeds north-west, joining the Laudan about $\mathrm{I}_{3}$ miles above Kunia Urgenj, past which the united stream, called the Urun-daria, or Kuniadaria, runs to Sary Kamish. The distance from the confluence of the two rivers to Sary Kamish is 133 miles, and it is the same distance from Sary Kamish to Igda.

+ See Proceedings of the Geographical Society, $188_{3}$, p. 430 ; and Compte rendu, p. 299, of the Geographical Society of Paris, 1883 . 
removed, that the water would pass along the Urundaria as far as Sary Kamish. But beyond this it is hardly to be expected the Amu would have strength to clear for itself a passage to the Caspian, for first it would have to fill the entire basin of Sary Kamish, the level of which in 1877 was found to be 42 feet below the Caspian ; and, secondly, it would have to scour for about 330 miles the old bed, which, in places, is completely choked with sand. Further, in consequence of the slight elevation of the Aral over the Caspian, the small amount of water in the Amu near its mouth, and, lastly, the sandy nature of the soil, it would be difficult, nay, almost impossible, so to contrive that the Amu should again find its way to the Caspian. When we arrived at Krasnovodsk, the Commandant told us that the Russian expedition, which surveyed the old bed of the Oxus, found a depression that would take all the water of the Oxus and Aral to fill, and this was subsequently confirmed by surveyors we met, just come from the steppe.

The cause of the deflection of the Oxus is unknown, but all combines to indicate that the direction of the lower course of the Amu has been subject to changes which have followed one regular law, namely, of inclining to the right from the south-west, by turning its main channel in a semicircle. So that the present Taldik and Ulkun-daria may be expected to dry up, as have the Urun-daria and Laudan, and that the Amu will enter the Aral by its easterly branches only.

Having now thrown what little light I can upon some of the problems concerning the ancient course of the Oxus, I shall proceed on my way to the Caspian. 


\section{CHAPTER LXXI.}

FROM SARY KAMISH TO KAPLAN KIR.

Mounting the Ust Urt.- The well Uzun Kuyu.-Saxaul and other fuel. - Bread baken on the coals. - Capture of a gazelle.-Remains of sun worship.-Troubles with attendants.-Breakfast on a camel's back. - The wells of Kazakhli, - The bay of Kaplan Kir.-A dry ocean bed.-Kaplan Kir not an island. - The wells of Kum-sebshem. -Ascent from the bed of Kaplan Kir.

$\mathrm{W}^{\mathrm{E}}$ ascended from the lacustrine bed of Sary Kamish at half-past 2 on the afternoon of November I4th, to make for Uzun Kuyu, or "deep well," 27 miles distant. After toiling up a hill we found ourselves on an immense table-land, bounded on the side of the lake with cliffs, that still bore traces of being water-worn. The receding waters had left a long, narrow line of beach, and shells similar to those found at Krasnovodsk on the shore of the Caspian, and, as we passed over them, I hoped that now we might be about half-way on our journey, but to our great disappointment we were told that it was not so. We could soon see, however, that we had attained to a very different tract of country - an excellent specimen of a level steppe, where there was not a hill to be seen all round, nor was the line of the horizon cut by so much as a tree, hardly a bush, but the surface was covered with a coarse, scrubby vegetation. The soil 
was not saline, but stony, though the stones were not rounded like those in the bed of the lake. Our men had asked to stop at midday to bake their bread, whereupon I gave them some of mine, and insisted upon their going on. Thus we continued marching till 9 in the evening, hoping to reach the well at Uzun Kuyu ; but, failing to do so, we stopped till an hour past midnight to rest, for which I was quite prepared, having spent 8 hours in the saddle that day.

Before daybreak the men judged us to be near Uzun Kuyu, but said they could not find the well in the dark; and at sunrise this was seen to be perfectly reasonable, for there was no erection to mark the spot, and we might have easily walked by, or, for that matter, into it. This was one of the deep wells of which we had been forewarned. I reckoned it $\mathrm{I} 8 \mathrm{o}$ feet, but Markozoff I 33 feet, to the water. Accordingly, Nazar did not straddle over the top, as in other cases ; but, finding a stake placed athwart the well, he let down his nosebags, and then fastened the rope to a camel to draw them up. The water, containing sulphuretted hydrogen, had a disagreeable smell and taste, with a specific gravity indicating on my hygrometer 102 degrees.

With this deterioration of water there came another change in our lot. Thus far we had made our fires of saxaul, the well-known fuel of Central Asia. At PetroAlexandrovsk, General Grotenhielm gave me a piece of this singular wood, about the thickness of the thumb, but grown into a knot, the size of a double fist, and as curiously intertwined as if it had been rope. East of Sary Kamish we passed through little forests of it, the trees being 12 or 14 feet high, and it was curious to find that, though so hard as to defy the cutting of a switch with a pocket-knife, yet one could break off 
great boughs thicker than one's wrist. On our first evening upon the Ust Urt there were only dwarfed clumps of saxaul, about as high as a gooseberry-bush, and these, strange to say, we could break off at the root, so that the collection of sufficient fuel was an easy task. But Rosy had told me that we should have no more saxaul; and when I asked what we should do, he replied that "I should see" at Uzun Kuyu. And truly I did so, for he had gone on a little ahead, had ignited an immense lump of horse and camel dung, and this was to be our fuel for the rest of the way.

It was no part of my business to feed Nazar and Murad, and, that we might be quite clear upon this point, I asked them, before we left Kunia Urgenj, if they had plenty of their own provisions. They replied that they had a bag of flour, but they hoped I should give them what we left of the mutton. This was a contrast, truly, to the many things I was taking! They had, indeed, the advantage of new bread instead of stale, in that they wet flour in a wooden dish, and then baked the dough in the ashes of the fire. I did not taste the cake thus "baken on the coals," like that of Elijah in the wilderness; * but after our bread robbery, when provision was running short, I asked them to feed Rosy also on native bread, in exchange for other things. This they said they would do, and graciously added that, if our bread supply ran out, we should have some of theirs. This, so far, was obliging; and so long as the bread was cooked in wood ashes, one, perhaps, might eat it, failing anything else; but when I saw them cook their bread in precisely the same way, putting it uncovered

$$
\text { * I Kings xix. } 6 \text {. }
$$


into fuel of dung, I am afraid it lessened my confidence as to having a store to fall back upon."

An unexpected opportunity occurred of adding to our larder at Uzun Kuyu; for Sevier, wandering about after breakfast, came upon an empty well, about io feet deep, with a funnel-shaped mouth, the sides of which bore vegetation. He had the curiosity to go near and look in, and saw, to his surprise, at the bottom a Persian gazelle. It was quite young, of exquisitely graceful form, and, when it saw us, made frantic but vain efforts to spring out of its prison-house. Our camels had drunk nothing since the third day, and I would not have the natives told till they had watered them and filled the barrels, lest their hunting propensities should be excited and we should lose time; but, when all was ready, I pointed out to our men the captive. Nazar immediately volunteered to be let down to secure the little beauty, which it seemed the height of cruelty to kill. Something was said about bringing it alive to London, but it was manifestly out of the question, so the grim office of the butcher was entrusted to our butler Rosy. I watched him particularly, and observed that he looked up to the part of the heavens whence the sun was shining, and turned the animal in that direction. Then Murad (who was standing by) and he stroked their beards, and apparently uttered a prayer, after which Rosy cut the animal's throat. I afterwards noticed Rosy, when killing a chicken, do the same, but I fancied they seemed rather ashamed of it, and not willing to explain the matter. $t$ I observed further that Rosy,

- The preparation of bread in this way manifestly throws light upon the manner in which Ezekiel (iv, 12-15) was commanded to prepare his bread, as prefiguring coming scarcity.

$\dagger$ It struck me as a possible remnant of the very ancient sun worship 
before cutting the gazelle's throat, scooped out a hole, and then covered up its blood. I asked why he covered the blood, and he said, "For good luck, that we soon may catch another.*

Before leaving Uzun Kuyu I took Nazar to task about what I considered the slow progress we were making. I also lectured Rosy for his idleness and putting his work upon others. In fact, I found that Nazar was at once the best servant and the weak man of the three, for he allowed the other two to impose upon him. He said he was perfectly willing to hasten; but Murad was the lazy fellow, who had told Nazar that, having received his money beforehand, he did not want his camels hurried, and cared not to push on.

This was plain speaking, though not intended for me, and I determined that Murad should not have it all his own way. If I set him to lead the camels, and allowed Nazar to rest in one of the cradles, Murad dawdled so tantalizingly that I took the camel string out of his hand, and on horseback, or walking, led the

to which, perhaps, Job alludes (xxxi. 26, 27), and Ezekiel (viii. 16), who saw 25 men, with their backs towards the temple of the Lord, and their faces towards the east, who worshipped the sun : the same idolatry that was forbidden to the children of Israel (Deut. iv. I9), and punishable with death (xvii. $3-5$ ).

- Whether this had any religious origin I know not; but Dr. Hermann Adler tells me the Jews act similarly in obedience to the command in Leviticus xvii. 13: "Whatsoever man there be . . . which hunteth and catcheth any beast or fowl that may be eaten; he shall even pour out the blood thereof, and cover it with dust." Maimonides supposes that one of the reasons of this command was to prevent the Israelites from assembling round the blood to eat meals as was the custom of idolatrous nations. Rosy looking up to the sun and uttering a prayer recalls Ezekiel xxxiii. 25, "Ye eat with the blood and lift up your eyes toward your idols."

As a matter of anthropological interest I ought to mention, perhaps. that the natives of Central Asia appeared to be most particular in 
caravan myself. Nazar quickly pronounced me an able camel-leader, and said that if I continued in office we should make excellent headway.

Thus we travelled from Uzun Kuyu towards the next wells at Kazakhli, the road continuing along the level elevation of the Ust Urt over excessively hard soil, almost devoid of vegetation, but never so bare that the camels could not find food. We rested as usual, and started again at midnight. Soon afterwards we missed Rosy and Murad, who rode the horses, whilst Nazar, on foot, led the caravan, and Sevier and I were "in bed." The sun rose and gilded the plain, but nothing could we see of Rosy or Murad. To lose the caravan in such a spot, and without provisions, would mean almost certain death, and I began to wonder whether I should have to go back to look for their corpses-and not only for them, but my journal also, which, for safe keeping, I had placed in my saddle-bag.

Then came breakfast time, when we were to try an experiment. Nazar, who seemed inclined to push on, had pointed out, and truly, how much time we wasted by stopping to cook breakfast, and said, on the $15^{\text {th }}$, that if we halted only once a day, we might get to Krasnovodsk in about 4 days more. We resolved, therefore, not to stop, but to eat this meal comfortably on the camel's back. The pack-saddle was extemporized into a table, cold pheasant was served from

covering up all facal matter. All the way from the Bokhariot frontier, and through Khiva to the Caspian, I did not once see faces lying about. "Earth-closets" were everywhere used, and I do not remember ever to have met with an offensive smell. Even out in the desert, mothers did for their infant children what they were too young to do for themselves, and the Turkomans had thoroughly adopted the spirit, if not the letter, of Deut, xxiii, 12-14. 
the cradle as a sideboard, and cold tea drunk from my enamelled bottle. We had besides, venison, bread biscuits, apples, and pears, all which may read very well, and savour perchance of romance, for it caused us at first to laugh, but in reality it was intensely disagreeable. The sand blew in our plates, the shaking was enough to upset one's digestion for a week, and for 12 hours matters were not brightened by the prolonged absence of the two deserters. At last we saw some fresh horse-tracks, and about noon came upon our men near Kazakhli.

According to my map we should have passed, since leaving Uzun Kuyu, two pools of sweet water. Perhaps it was at the latter of these they stopped for us, since Rosy had kindled a fire, and he muttered some sort of excuse that they had gone forward to prepare for us : but I have no recollection of seeing any water till we came to the Kazakhli wells, two in number, about I 20 feet deep, and containing water with specific gravity of $102^{\circ}$, and saline, but such as both camels and horses drank. We did not linger at the well, though my attention was attracted to a gully, widening into a ravine, running away therefrom, having cliffs on either side, with the earth near the surface hanging in stalactites, and the bottom descending so rapidly, that I was minded to ride along it, to see whither it led; but the camels were started in another direction, and I followed, meaning to advance to the top of the hill and look down. I did so, and shall not easily forget the sight, for it amply repaid me for crossing the desert. The ruins of Kunia Urgenj had been interesting, so had the old bed of the Oxus and Sary Kamish, but I had heard of these beforehand.

Not so with the landscape of what I am disposed to 
christen the "Bay of Kaplan Kir," though I have in my notes the words "Ku-yurt-nu-Kurrah," the meaning of which I have forgotten.*

A short distance beyond the well Kazakhli there suddenly burst upon our sight an enormous bay, or horse-shoe depression, apparently of the sea, bounded on the right by a cliff, trending away westward for 30 miles to the well Dirun, or Dirin, and on the left for a greater distance towards the south, whilst the western walls of the bay were formed of the cliffs Begendjalri Kir. Within this depression was the well of Kumsebshem, our next point to make for, and 23 miles from Uzun Kuyu. $†$

But what struck me as so remarkable were the manifest tokens of the locality having been once a

"I have already used the word "Ust," or East Kaplan Kir, as we came up out of the basin of Sary Kamish. The place we had now arrived at our men called "Kaplan Kir," and my Russian map says, "Obryv Kaplan Kir," i.e., the "steep place or cliff" of Kaplan Kir, which word seems to be used, as by Vambery, further south, of various parts of the cliffs forming the edge of the Ust Urt, or elevated plateau lying between the Aral and the Caspian, and which, at Uzun Kuyu, is 52 miles wide. Across this plateau, it will be remembered, we were now passing.

† To Markozoff's detachment, when on the march, no less than to ourselves, the precipice of Begendjalri appeared as a separate ridge, or precipice, of a separate plateau from that of Kaplan Kir; but it turned out subsequently that Begendjalri Kir and Kaplan Kir unite, or, at least, almost touch, leaving a strait between, and form the western wall of the Kum-sebshem depression, which is, therefore, nothing less than a scoop out of the general elevated plain. It has the shape of an elongated ellipse, whose western end is compressed to a narrow pass 3 miles long, having at its western extremity the well Dirun. The longer axis of this ellipse, with a direction of W.N.W. to E.S.E. from the well Dirun, measures, according to Markozoff, from 33 to 37 miles in length, and the smaller one, traversing the well Kumsebshem, from 13 to 17 miles. Its south-west border, Begendjalri, becomes gradually lower, and at last sinks in the sands eastwards; but the eastern side, Kaplan Kir, is broken, and off it lies, about midway from north to south, and 6 miles east of the cliff, the well Dakhli.

VOL. II. 
lake, or a bay of the sea, though now completely dried up. One may occasionally be taken to an English hill-top, and be told by some geological friend that the prospect before you was once under water, and, in deference to his learning, you accept the information, albeit that trees and grass and corn are growing on every hand; but at Kaplan Kir, when I peeped over the cliff, as one might do at Ramsgate, I saw places hollowed out by the billows in the face of the limestone, and the marks left by the water-rills. Nor was this all; for the chalk was worn away into colossal spires, columns, and minarets, into pillars and turrets, and buttresses and towers, as white and clean as if the tide had only recently gone down. There were caves and grottoes, and coves and caverns in which, by the aid of imagination, one could see the fishes, perhaps, of a former geological epoch swimming about just as one sees their modern types in the rocky tanks of the Brighton Aquarium. The water was the one thing wanting. I will not venture the hyperbole that I could almost "smell the briny," or trace any remains of sea-weed; but the phenomenon was so remarkable, and unlike anything I had seen elsewhere in Europe, Asia, or America, that, like Columbus discovering a new world, I became, in my little way, quite excited.

We descended into the bed by a natural ramp, so steep that the cradles had to be unoccupied, and our horses led; and when we reached the bottom, about a mile from Kazakhli, and skirted the northern shore, we had on our right an elevation that brought to my mind Shakespeare's Cliff at Dover, whilst, a little further ahead, rose out of what was once the sea another St. Michael's Mount, lying off the coast of Cornwall. 
The cliff on our right, rising about 300 feet, needed no geologist to see that it was formed of three sharplydefined strata - the uppermost of earth, the centre of limestone, and the lowest of sandy clay. The face of the cliff was not every where uniform. Here and there were natural caverns, and between what I have imaginatively called Shakespeare's Cliff and St. Michael's Mount, huge masses of the upper stratum had been hurled below. The cliffs had a well-defined water-mark all along their face, above which they were generally inclined, but perpendicular below it. The sandy plain, whereinto we had descended, was what the Russians call a solonchak, or salt steppe, which had on it a poor, scrubby vegetation.*

We encamped in this supposed sea-bed, where the vegetation was so scanty and distasteful to our horses that they would not touch it. On the next morning, at 8 o'clock, we came to the wells of Kum-sebshem. Here were "twelve wells of water," but not "threescore and ten palm trees," and we "encamped there by the waters." $\dagger$ There was not a vestige about these wells to give a clue to their age. They were well built, and for the most part in good repair. There was a little grass about the place, and the water was good, so that whilst the men were watering the camels and replenishing the barrels, we made some tea; but

\footnotetext{
* The prospect brought to one's mind "The sea saw it, and fled"; "He rebuketh the sea, and maketh it dry, and drieth up all the rivers" (Psalm cxiv, 3 ; Nahum i. 4), - a fact seen here on a large scale. All around was a flat plain, marked with the whitey deposits of salt, like those we had seen in the bed of Sary Kamish; and the only signs of animal life, after a Jackdaw who paid us a visit at the well, were the chirping of a chance bird, hills thrown up by Ants, and the Marmots, which undermined " the parched places in the wilderness, in a salt land and not inhabited" (Jer. xvii. 6).

+ Exod. xvi. 27 .
} 
the camels were not all unpacked, which proved afterwards to have been a mistake. These wells were 100 feet higher, according to my aneroid, than the place where we last encamped, but we marched in the seabed another 4 miles, and then at I I o'clock ascended 300 feet out of its bed, on to the hill Begendjalri Kir. the cliffs running from N.W. to S.E.

The coming out of the bed was as remarkable as descending into it, for towards the top of the ramp the chalky cliffs were worn into resemblance to a chain of snow mountains, that I fancifully called the "Bernesc Oberland," with crevasses here and there, and wellmarked rifts, caused apparently by the running of water. Here, too, jutting out beyond a promontory. was another "St. Michael's Mount." On reaching the top, I turned round to gaze at this wonderful landscape. Diotrephes did not appreciate the scenery a bit, for the caravan was gone on, and the loneliness of the desert had given him a strong aversion to being left behind, or getting far away from his companions. I made him stand, however, whilst I vainly asked myself what it all meant. When had the voice gone forth to the waters, Be dry ?*

And what waters were they? salt or fresh? A bay of the Caspian, or the remains of the great Central Asian Sea, that geologists talk of ? These are questions 1 am incapable of answering. I can only say that this Bay of Kaplan Kir was the fourth point of interest in my desert journey, and from its entire unlikeness to anything I had ever seen, it reconciled me to the fatigues of the waj, and made me thankful to have been the first Englishman to gaze upon this remarkable scene.

* Isa. xliv. 27. 


\section{CHAPTER LXXII. \\ FROM KAPLAN KIR TO KRASNOVODSK.}

Road to well of Seikiz Khan.-Improved prospects, but low spirits.Search of Bible for illustrative passages.-Lack of domestic comforts.- Revival of hope at sight of Caspian.-Russian itinerary from Iliali to Krasnovodsk.-The pond of Porsu.-Gazelles. - The Kara-boghaz and its geography.-A sixteen hours' march.Oriental customs illustrated.-Fauna of the steppe.-The land tortoise.-Last night on the camel's back.-Mouldy bread and tattered garments.-Arrival at Krasnovodsk,

[ EAVING Kaplan Kir, we next passed along a L level elevation for about 7 miles, and then mounted to the highest part of the neighbouring hills, called Begendjalri Kir, where we came to another flat steppe, without bushes, and only a scrubby vegetation, in the midst of which we encamped at sunset. The direct path would have brought us along the hills to the pool Dungra, of bad, bitter, salt water, overgrown with reeds, 39 miles from Kum-sebshem. But this path, though shorter, was said to be trying to the camels' legs, and, rather than risk breaking them, our men, starting afresh at midnight, turned off the principal road about I 3 miles short of Dungra, and brought us before sunrise on the 18 th to the well Seikiz (or eighth) Khan, so named after the present Khivan ruler. Our route from the main road to the well, where we drew water, was 4 miles to the north-west; now it turned 
I 9 miles towards the south-west to the well Tuar. At 10 o'clock we descended 200 feet into the bed of a river, or sea, with banks washed into various forms, apparently by the action of water. This brought us to a plain, bounded by distant cliffs. We then remounted to a higher land, 250 feet above the sea level, and camped, hoping on the morrow to attain to Tuar.

In certain respects our journey was rather more endurable here than on some portions of the way. The route was not quite so monotonous and lifeless, for we saw several game birds, and among them what was called the Wild Hen. It is rather larger than a pigeon, runs very fast, and is shy. They get them near Krasnovodsk in the rocks, and sell them from $8 d$. to $10 d$. a brace. Marmots abounded, but not with the squirrel-like tails we had seen in Bokhara On one occasion we stirred up a solitary Owl, and further on saw a few Jackdaws, but not many small birds. Once, too, we scared from her form a frightened Hare. The weather, moreover, now was perfection. My pocket thermometer in the sun stood at $75^{\circ}$, and the temperature was sufficiently warm to induce me, in riding by day, to throw off my great coat. I always slept, however, in the cradle in my furs, and was not much incommoded by cold, though my sheepskin hat and the furs about my face were unpleasantly wet.

But with all this I am bound to say our spirits were somewhat low. It was now our eleventh day since leaving Kunia Urgenj, and we had not yet come in sight of the Caspian. The novelty of camel travelling had worn off, and the journey promised to be longer than I anticipated. Things moved, as I thought, so slowly. When I left Samarkand, or soon after, I found that I had exhausted, or nearly so, all my books that I 
brought with me to read. Ordinarily in England, when going for only an hour's journey, I no more think of starting without something to read than without my purse, and I wondered how I should employ my thoughts on this long, slow journey. I cross-questioned Tailly severely whether some means could not be invented by which I might gallop on horseback the allotted day's journey, and have my tent put up so as to do some writing and arrangement of my notes, whilst the camels were walking on their leisurely way. But he said a horse could not carry the tent, and a camel could not keep up with the horse, so that he could contrive nothing. Preparation, therefore, for literary work seemed out of the question.

The idea occurred to me, however, that I might glance through my pocket-Bible, and mark therein all the passages on which light or illustration could be thrown from incidents in my 10 years' travels. The print of my Bible was too small, and the shaking of the camel too great, to allow of my doing much in the cradle, but I often adopted another plan. I galloped forward a good distance in front of the caravan, to some herbage if possible, that Diotrephes could crop, and then, whilst he was nibbling, I sat reading till the caravan had come up and passed, and was nearly out of sight, by which time my horse was impatient to catch it up again. By thus economizing my time, and using up odd moments, I managed to glance through the Old and New Testaments, and marked therein more than 500 passages.

But besides the weariness of mind incident to such slow travelling, the fatigue of body was not small, and the lack of ordinary domestic comforts began to be very trying. Our clothes had not been off for a long 
time-and as for a good wash, how was it possible with water at such a premium, that between the wells I had to look sharply after the men, or they refrained from giving enough to the horses? A pint and a half or a quart of water in my india-rubber basin had to be sponged over my face and neck before dinner, then to serve for the hands, and my ablutions for the day were over! Sevier, one evening, looked at the matter philosophically, and calmly debated whether under such circumstances it was worth while to wash at all, which certainly our men did not do the whole time we were with them.

Then there was the crawling about our tent on all fours, like quadrupeds, rather than standing erect as lords of creation, to say nothing of soup in wooden bowls, tea made out of brackish water that occasionally curdled the cream, and sundry other inconveniences not nice to mention. These things had to be encountered before lying down, after which, if the horses did not fight, or the men make a noise, we managed to get perhaps four or five hours' sleep, till my alarum warned me I must stir up the men, or who could say when we should start, or whether we should not have our provisions run out before the end of our journey?

A revival of our hopes awaited us on the morrow. We did not start till five from the depression, wherein is situated the well Tuar, nor did we take water there. It was found by the Russian doctor and engineer to be black, though sweet, and to increase the thirst, nor did boiling it, or the addition of lemon extract improve it. At sunrise, or about seven o'clock, we mounted the Tuar hill, and so emerged from the marine or lacustrine bed wherein we had travelled. We then ascended the hill Sary Baba, 250 feet higher, when lo! we espied 
the blue waters of the Caspian! I doubt if the Greek soldiers, returning from their Asiatic campaigns, were more pleased with the sight of the Euxine than were we with the Kara-boghaz gulf, and like them we shouted, "The Sea! the Sea!" We were a long distance, however, from the end of our journey, and, on looking at my great map, I doubted if we should get to Krasnovodsk in three days as the men said we should, especially as the Russian doctor and engineer before us, on reaching Tuar from Iliali through Charyshly to Dakhli, had taken 5 days from Tuar to Krasnovodsk.* But it was a great refreshment to see the Caspian.

Our road now continued in a south-westerly direction, over hilly ground; but before we descended from the hill Sary Baba, to an altitude of 300 feet above the sea, we passed a Muhammadan tomb of one Arsariboa, killed in battle, I suppose with the Russians. There was a hero's flag-pole erected, and something like ornamentation round the grave, but no trace of any building near it. I thought it more like a Shaman Buriat than a Kirghese Muhammadan grave.

About noon, with the thermometer at $75^{\circ}$, we came to Porsu, called also, I think, Portokup, I9 miles from Tuar, and situated at the foot of the hills Togus-tepe. Here is a pond of rain-water, which the Russian doctor Their itinerary was briefly as follows :-Leaving Iliali on the 26 th
May (O.S.), they stayed two days with guide. 28 th: Took 5 skins, each
of 8 gallons, of Amu-daria water for a party of 5 men, 8 camels, and 3
horses, and set out. 29 th: By 7 a.m. had marched in all 33 miles,
passed a fort, and at dusk entered, because of the heat, a pass with a
well of salt water. On the hills were sand barkhans, as high as five-
storied houses in Petersburg. 30 th : At 10 a.m. came to another fort.
3 rst: Road over sands and hilly. Came to a pool of slime-covered
water, making tea like fatty chocolate. In the evening mounted hills.
June Ist: A well of good water. 2nd: The well Charyshly, and the dry
bed of the Oxus. Here they rested till the morrow. 3rd: Started at
9 a.m. 4th: Road over hillocks with trees. Mounted Kaplan Kir 
and engineer in June pronounced good, but in November our men rejected it. The pond is situated in a hollow, approached by a narrow path, down which the deer descend to drink. Murad, knowing this, went foward, thinking to cut off the retreat of any that might be at the bottom, but he was not sharp enough. We saw a herd, perhaps a score in number, small, and of similar species to the one we had caught, which was, I believe, the ordinary Persian gazelle; but I do not think we saw any of the saiga antilope, a native of these regions. Captain Abbott saw the saiga further north, and describes it as a singular animal; and the specimen, shown to me at the Natural History Museum at South Kensington by Dr. Günther, does not belie the description. The natives call both kinds, I believe, "Kaik," and as we saw the little creatures bounding away on our approach, it was not difficult to perceive the aptness of the simile which described the Gadites "as swift as the roes upon the mountains."* Of Wild Asses we saw none, though a Wild Boar one night approached the caravan, and startled the horses.

Our road continued for many hours, on the 19 th, in sight of the Caspian, and at 3 o'clock we mounted a hill, on whose top my aneroid stood at 650 feet above the sea. On these hills we camped, and from thence could see the white cliffs of a bay, and other hills of chalk inland, where evidently the water had once attained to. Over some of these we had traversed up and down as if crossing arms of the ocean.

plateau. The air dry. Had to wet the mouth every five minutes. At II p.m. came to bitter well Dakhli. 5 th: Stopped at bitter well Dungra. Road hilly. 7 th: Same character of road. 8th: Without water for the camels, so had to rest. At Tuar found water black, but sweet. 9th: Saw the Caspian. 1oth: Arrived at Demerdjan. 11th: Well Suili. 12th: Well Sumaili. 13th: Well Burmak and then south to Krasnovodsk.

$* 1$ Chron, xii. 8. 
This "Kara-boghaz," or "Black Gulf," has certain points of geographical interest. It is an immense oval, with an area of 6,000 square miles, bounded on the west by two thin strips of sand, and between these there runs from the Caspian a narrow strait from 200 to 800 yards wide, and only about a yard deep. The current flows through at the rate of from 3 to 4 miles an hour. The cause of the current is that the surface of the bay gives off so much by evaporation as to need continual replenishing from the Caspian. Whilst giving off water by evaporation, however, the salt remains, and permeates the remaining water to such a degree that no animal, they say, can live in it.*

At an hour after midnight we started on the 2oth, and marched till 5 next evening- 16 hours without a halt, at the end of which our horses, not to say ourselves, were exceedingly tired. The route lay over a steppe country, with occasional depressions, and the latter part was not without anxiety, for Murad lagged behind, and for many hours was out of sight, so that I began to think quite seriously what legal responsibilities I might be involved in for not going back to search, if I arrived at Krasnovodsk without him.

The fact was, he had loitered behind and gone to sleep, having probably first muddled his torpid brains by long whiffs from his kalian pipe. This smoking instrument usually has a long stem from the gourd which holds the water; but our men appeared to have

- Réclus adds that fishes drawn in by the current become blind in five days, and that seals, which used formerly to visit the bay, are seen no longer, He further gives a calculation that the bed of the Kara-boghaz receives daily 350,000 tons of salt, or as much as they consume in all Russia in six months; and that when, by storms or slow deposit, the strait hereafter shall become choked up, the Kara-boghaz will quickly diminish in extent, leaving its former shores transformed into immense fields of salt. 
made a travelling pipe (such as could be slung in a bag on the camel), omitting the long accessories. At first they took the liberty of stopping the caravan, in order to light up their pipe and take a whiff, " turn about."

But this had one disagreeable result with the camels, and demoralized them, in that, rather than stand still, they took it into their heads to lie down suddenly, which sometimes snapped the ropes, and brought about other inconveniences. Further, when I was in the cradle, my nostrils were defiled with the smell of their coarse, common tobacco, which I abominate, and I bade them not stop the caravan, and gave orders that, if they must smoke, the lighting of the pipe should be entrusted to one of the two men who were not leading the camels.

It consequently often fell to Murad's lot; and after the others had taken their one or two long whiffs, Murad would take the kalian and lag behind to finish the pipe. I imagine the fumes had on this occasion soothed him into 40 winks, from which he did not wake apparently for some hours, though at last he sneaked up like a naughty child, as we came to a halt, and, without saying a word, proceeded to put up the tent. No doubt he was very tired, like the rest of us.

I had by this time come to the conclusion that never before in my life had I been so weary of a journey as this. Crossing America by railway was a mere bagatelle in comparison, nor could I say otherwise even of traversing the Siberian expanse. Our last pheasant had been eaten the night before, and we had only one chicken left. Of the 8 we purchased, 2 died, and 3 were lost, stolen, or strayed. One or two "came to table" minus a leg, sauced with the excuse that it had been maimed on the way-the truth being, I suppose, 
that Murad had taken the absent member from the pot. One night he told Rosy to put more water to the soup. "For then, don't you see," said he, "we shall get more?" Our butcher's meat had long since vanished. The men had eaten it all, and the captured venison I tasted only once. It had become rather too high, though why I know not, so that too was transferred for the benefit of their "braxy" appetites, as well as our pickings, and the teapot with sugar. Hence, by comparison with their sack of flour and nothing else, they were faring sumptuously every day, and Murad's not wishing to hurry was understandable.

Meanwhile Sevier and I were ardently longing for the end of the journey, when we might take off our clothes again, and once more perform some very necessary ablutions. At the same time I am bound to say I gained an idea of tent life and Eastern travel, and saw exemplifications of Oriental customs, for which, as a Bible student, I shall always be thankful.* We encamped on the 2oth at the well of Demerdjan, near

\footnotetext{
Thus, over how much land we passed where it was as if the decree had been pronounced, "The land shall be utterly emptied and utterly spoiled" (Isa. xxiv, 3). "The whole land thereof is brimstone, and salt, and burning, that it is not sown nor beareth, nor any grass groweth therein " (Deut. xxix. 23). I could never before understand so vividly the expression of Moses concerning " all that great and terrible wilderness" (Deut. i. 19), or how, in the desert, "the soul of the people was much discouraged because of the way" (Numb. xxi. 4). Certainly, the passage in Hagar's life, when she wandered in the wilderness of Beersheba, with the same food only as taken by our men, with her water-bottle spent, and her child laid down to die (Gen. xxi. 14, 15), might have happened easily enough in the desert we crossed.

Of course, I had always been taught how wrong it was for the Israelites to murmur in the wilderness, and to long after the flesh-pots of Egypt, the cucumbers, and the leeks and onions, and melons (Numb. xi. 5). All this I had accepted without question in plentiful England; but when, in the Aralo-Caspian, our last melon was gone, I could not help thinking that, if the melons of Egypt were as good as
} 
some conical hills of the same name. At this place we took water for the last time, and found it so salt as to curdle our Swiss milk, though earlier in the season it is said to be slightly bitter, but good. Here we struck the main route between Krasnovodsk and Mangyshlak; and as this was one of the wells at which Murad had once been robbed of a camel, he suggested that someone should watch against the Tekke Turkomans whilst the others slept.*

We did not rest long, however, for at one o'clock in the morning we started again, and continued all day on the 2 Ist, till sunset, over a steppe country with the accustomed coarse vegetation. On the previous day I had seen the cast skin of a hedgehog, and now I found on the steppe several shells of tortoises. The latter were interesting, because we were attempting to carry two of the like (Homopus Horsfieldii, Gray) in a comatose state to the Zoological Gardens of London.

They were given to me in Tashkend by M. Oshanin, who expected them to sustain the journey those from Khiva, their longing was very much like human nature, whether B.C. or A.D.

So, again, this journey made me familiar with more incidents and necessaries of travel of which I knew before only by reading, as "the camel's furniture" upon which Rachel sat (Gen. xxxi. 34)-great pack-saddles which, in our case, the animals wore as we did our clothes, without their being taken off. The action of one of Joseph's brethren. who opened his sack to give his ass provender in the inn (Gen. xlii. 27), was precisely what we had to do nightly; and after seeing the coarse stuff eaten by the camels, and the inferior herbage given to Central Asian cattle, I understood better than before the prosperity implied in Isa. xxx. 24 , when the oxen and young asses were to eat clean provender which had been winnowed with the shovel and with the fan. No doubt many of these things are simple enough to Westerm readers already, and they do not perhaps need much illustration, but I can never now read these passages without my thoughts going back to my journey.

* Reminding one of " those that are delivered from the noise of archers in the places of drawing water" (Judges v. i1). 
without food, founding his opinion concerning the extraordinary vitality of the animal upon what M. Bogdanoff had previously done when he sent a tortoise in a box by slow transport at the end of May from PetroAlexandrovsk to Petersburg. The box went to Kazan by mistake, and did not reach Petersburg till the middle of November, but the animal was alive and well, having eaten nothing apparently for 7 months.

In the present case, two were placed in a box with a little hay, and the box put on the seat of the tarantass. We constantly heard them scratching, as if desirous of making their winter bed, and before we had advanced far on our journey they appeared to have gone to sleep. Crossing the desert I trembled for their slumbers, for the shaking they were getting on the camel was enough, one would think, to wake the dead. How long they lived 1 do not exactly know, since it was not till we looked at them as we approached Odessa that they were found to have departed this life-victims, alas! of the spirit of enterprise, and I had no spirit of an alcoholic character wherein to preserve their remains.*

At nine o'clock in the morning we arrived at Suili, with 11 deep wells of bad, bitter water, and near

- An officer at Samarkana had gravely assured me that it would be absolutely necessary to mix "a little red wine" with the desert water as a corrective for health's sake; but I did nothing of the kind. I have often met with the idea that, when travelling abroad, it is advisable to put wine in drinking-water as a precaution. My experience, however, which may go for what it is worth, is quite in the opposite direction. I have been an abstainer from alcoholic drinks for about a quarter of a century. In the summers of eight years I must have travelled from sixty to seventy thousand miles, generally rapidly, round the world, through Central Asia, and to all the capitals of Europe except Oporto and Madrid. Ordinarily I have used no filter, nor taken any special precautions (Bokhara excepted), and, I am thankful to say, have never suffered in consequence. Judging, therefore, from my own case, my opınion is that, when travelling, persons in ordinary health need not fear to drink the water in common use. 
to each a tank, about 7 feet long by 4 wide, hewn out of the limestone. Here, too, is a cemetery, but we did not stay, hoping to get to Krasnovodsk on the morrow. We could reach that place by one of four roads. The Russian doctor and engineer went nearly due west, to the well Burnak, I 3 miles north of Krasnovodsk. Our men, however, chose, I think, a road of their own, over a trackless steppe.

Approaching the Caspian, our guides pointed out a shepherd's tent, or hut, put together in the clumsiest fashion, in which, like the shepherds of Bethlehem, they spend many weeks, day and night, watching their flocks,"

By sunset, however, we had seen no one. We stopped for two hours to eat, but did not sleep, because Sevier thought he had seen that the steamer left for Baku on the evening of the following day. So we pushed on, the night being unusually temperate, so that my fur clothing, as I lay in the cradle, became inconveniently warm. About 2 o'clock on the morning of the 22 nd we had to "turn out of bed " whilst the camels descended a ramp from a cliff 200 feet deep into the plain, and afterwards, an hour or two before daylight, our men stopped for fear of losing their way.

We breakfasted as usual, in all its discomfort and awkwardness, on the camel's back; and as our bread was now 24 days old, I thought we could adopt the language of the Gibeonites to Joshua (ix. 12, I3): " This our bread we took hot for our provision out of our houses on the day we came forth . . . but now, behold, it is dry and it is mouldy"; to which we could also add, "These our garments . . . are become old

\footnotetext{
- Cant. i. 8; Luke ii. 8.
} 
by reason of the very long journey." Both were true, and the latter especially of Sevier, concerning whom I must tell no tales; but his riding all the way on a wooden saddle (now preserved for coming generations in the British Museum) had played terrible havoc with his pantaloons, so that I doubt if any dealer in "old clo" " would have bid for them other than as curiosities of travel. Neither of us, thanks to the toughening of our hides, had suffered from what the doctors call "abrasion of the epidermis," which was more to Sevier's credit than mine, since it was his first attempt at horsemanship.

After breakfast on this eventful morning, I was lying idly in the cradle, when two natives appeared, the first we had seen for 12 days. They were Turkomans, but apparently not robbers; and whilst I was taking stock of them Sevier bade me look round. I did so, and there, from the top of a hill, at half-past io o'clock, I looked down upon Krasnovodsk. My sense of relief was great, and if ever words came from the heart, it was then as I exclaimed, " Thank God!"

I felt that we had something to thank Him for. We had travelled in safety over 400 miles of country where many a man has been murdered or enslaved; at the mercy of our native attendants, who might easily have played us false; unhindered by mishap to man, horse, or camel-save in the case of Rosywhilst, in my own case, I had not been constrained so much as to open my pill-box. But with all that, it had been the most trying journey of my life. My horse had become thin, and so had I ; and thankful as I am to have taken the journey once, I wish, unless duty calls thereto, never to take such another.

VOL. II. 


\section{CHAPTER LXXIII.}

\section{TURKMENIA.}

Turkmenia: its boundaries, area, and surface.-Russian maps with new frontier.-Revision of this and following chapters by M. Lessar. - The Caspian littoral. - The Balkhan, Kuren-dagh, and Kopet-dagh mountains. - The rivers Atrak and Gurgan.Meteorology, flora, and fauna.-The Turkomans; their origin, physiology, and characteristics.-Turkoman tribes : their distribution and sub-divisions.-Habitations, food, and occupations.Turkoman women.

I AVING brought the reader across the northern 1 portion of the land of the Turkomans, I proceed to give some account of Turkmenia as a whole; of the country, that is, extending from the Caspian to the Oxus, except Khiva. Turkmenia is bounded on the north by a straight line drawn from the Caspian at Mertvy Kultuk-that is, "Dead" (or, as it has been lately renamed, Tsarevitch) Bay-to a point on the Khivan frontier midway between Kungrad and the Sea of Aral; whilst on the south it touches Persia and Afghanistan. The southern frontier, beginning at the mouth of the Atrak, proceeds along that river to Chat, and then continues eastwards between the Atrak and Sumbar rivers to the mountains 50 miles north-west of Askabad. It then descends to the south-east along the mountains to Sarakhs. 
From Sarakhs the southern Turkmenian boundary, though it has never been surveyed, has been drawn in both Russian and English official maps, in a tolerably straight line, to Khoja Saleh on the Upper Oxus. North of this line is Turkmenia, and south of it Afghanistan. This frontier, moreover, has in a measure been recognized by Russia, since her foreign minister, M. de Giers, instructed Prince Lobanow to endeavour to induce the British Government to assist in formally and definitely laying down the boundary "from Khoja Saleh to the Persian frontier in the neighbourhood of Sarakhs." * England agreed to the joint Commission, and in August, 1884 , some of her Commissioners started; but a Russian map had been issued by Ilyin, of Petersburg, at least four months previously (of which I have seen a copy printed in England, dated April, 1884), pushing the boundary 100 miles further south, up the Heri Rud, to the 35 th

- Whilst this and my remaining chapters were passing through the press, I had the privilege of making the acquaintance of M. P. Lessar, sent as Imperial Russian Commissioner to London in connection with the arrangement of the Afghan frontier question. Being very desirous of writing accurately and impartially, I made bold to ask his Excellency's revision of my four chapters on Turkmenia, and to this, notwithstanding great pressure of official duties, he kindly consented. His remarks are not numerous, and are short. I have therefore given them in my notes, and for the most part verbatim. Concerning the above quotation from Central Asian Correspondence, No. I (1884), p. 14, his Excellency says:- "Only maps, designed to explain treaties, can serve as documents to determine a frontier. Others, even when edited by official departments, are not always made with the necessary attention, and with sufficient local knowledge, but often on the basis of inexact reconnaissances. It was so with this little-known country; the frontier on the official English map (General Walker's) in different editions being differently indicated. In 1873 Sari-Yazi and Pul-i-Khatun are shown as outside of Afghanistan." "Also, approximate expressions (e.g., ' in the neighbourhood of Sarakhs') used in the preliminary negotiations cannot be taken as the recognition of any frontier line." 
parallel, then proceeding about 20 miles south of Penjdeh, by a curve between that place and Meruchak on the Murgab, and afterwards continuing to Khoja Saleh. I am not aware that this map carries any official authority; but another map, from the Military Topographical Department of the Russian General Staff, had reached England by the beginning of March, 1884 , with the frontier similarly altered. This latter map is dated $188_{3}$; but, on close inspection, a tiro may see that the old frontier has been erased by hand, and the new substituted frontier lithographed.

Straight lines from Mertvy Kultuk to Khoja Saleh, and to the mouth of the Atrak, measure, respectively, 800 and 550 miles, whilst the breadth of Turkmenia at its widest, say from the mouth of the Atrak to the town of Khiva, is 430 miles. The only estimate of its area I have met with is that of Kouropatkin, who mentions 9,000 German (or 197,000 English) square miles. Thus it will be seen that Turkmenia is about as large as France.

The country, as a whole, consists of the plains in the east and of hills in the west. The western portion includes the elevation in the north called the Ust Urt, and in the south the mountain chain stretching to the south-east, under the various names of the Great and Little Balkhans, the Kuren-dagh and Kopet-dagh, whilst the eastern portion is entirely flat, the lowest part being the dry bed of the Oxus The Chink, or scarped edge of the Ust Urt, on the east, west, and south, looks, when seen from the lowland, as if rising, as many think it once did, from the sea. It constitutes, in a measure, an ethnological line of limitation between the Kirghese and the Turkomans (Grodekoff, in his ethnological map of Turkmenia, makes it nearly so); 
the Kirghese not passing to the lowlands, and few of the Turkomans ascending to the highlands. Hence some would call the Chink the northern boundary of Turkmenia.

On the west of Turkmenia is the Caspian littoral, more than $\mathrm{r}, \mathrm{OOO}$ miles long. *

Extending in a south-easterly direction from Balkhan Bay is a mountain range 270 miles long, broken in two places, and first by the old bed of the Oxus. The part of the range between this first break and the Caspian is called the Great Balkhan. The second part, situated between the two breaks, is known as the Little Balkhan. Beyond the second break, southwards to half the entire length of the mountain system, the range is called Kuren- or Kioren-dagh, whilst the most southerly part is called the Kopet-dagh, or Daman-i-Kuh (skirt of the hills). +

The Kopet-dagh is joined from the south by the

* The northern portion of this line is Kaidak Bay, whose eastern coast is walled by the steep declivities of the Ust. Urt, and bounded by a margin of lowland only a few miles wide. Next thereto is the flat, sandy, saline, and partly reedy shore of the Buzachi peninsula, extending to the high projecting spit of Cape Karagan. From this last point the shore turns south, and as far as Karaboghaz Gulf it is composed of limestone rocks, almost washed by the sea. Gradualiy declining in height as they proceed southwards, these rocks merge into the sandy steppe, except on the north coast of Balkhan Bay. The most southerly portion of the Caspian littoral at the estuaries of the Atrak and Gurgan rivers is a reed-grown flat.

† A recent English traveller in this region, Mr. A. Condie Stephen, speaks of the Great Balkhan as the most imposing in appearance of the mountain ranges of Turkmenia. The higher portion of its southwestern face is precipitous, the crest being estimated at 5,300 feet above the sea.

From 25 to 30 miles south of the Great Balkhans lie the Little Balkhans, a low, bleak ridge, not mounting higher than 2,200 feet. The Balkhan mountains have a length of about 130 miles, and are rarely wider than 30 miles. They are composed of molluscular limestene and laminated rock. Springs are found in the defiles, but the little grass 
ramifications of the Elburz range, which crosses the north of Persia and Khorassan. Between the northern spur of this range, the Kopet-dagh, and the Caspian, is a mountainous triangle, its apex being the point of junction of the Elburz and Kopet ranges. The sides are the two ranges referred to, and the base is the eastern coast of the Caspian from Balkhan Bay to the mouths of the Atrak and Gurgan.

The lack of water in Turkmenia is very marked. There are in the eastern portion certain districts of 130 square miles-about as large, that is, as Rutlandshirepossessing only one well of fresh water. The mountain systems of the Kuren-dagh and Elburz are of considerable extent, but give rise to only two small rivers, the Atrak and Gurgan, and a few rivulets.

that grows there is frequently bitter. There are cherry and fig trees, barberry bushes, and small conifers growing up to 3 o feet high.

The Kuren-dagh has an average height of from 1,500 to 2,000 feet, for a distance of about 50 miles, to the neighbourhood of Kizil Arvat, where it joins the other range called the Kopet-dagh. Mr. Stephen found at Kizil Arvat pieces of calcareous rock, such as abound in the Kopet-dagh, composed entirely of "marine shells," thereby proving, he observes, the submarine origin of the Central Asian desert. On the

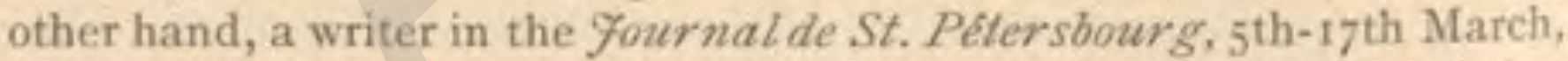
1876 , says of the earthy formation about Topiatan in the Uzboi that there is to be found a profusion of fresh-water shells, "which no one coulả mistake for sea shells."

The Kopet-dagh is about 40 miles wide at its rommencement, but narrows towards the south. It presents a bolder appearance than the Kuren-dagh. Its elevation is greater, the height increasing as it extends, like a wall, southwards. One summit, overlooking the Germat Valley, has been estimated at between 7,000 and 8,000 feet in altitude, but the average height of the range Mr. Stephen supposes to be not more than from 3,000 to 4,000 feet.

As seen from the Trans-Caspian railway, the Little Balkhans and Kuren-dagh are bare of trees, with few protuberances or abrupt declivities. In the Kopet-dagh, however, soon after leaving Kizil Arvat, clumps of trees are observable half-way up the mountains. The northern slope of the Kopet-dagh Mr. Condie Stephen thought to be from 30 to 35 degrees. 
The Atrak takes its rise in the mountains of Handoo Kuh, at an elevation of 5,800 feet, and, flowing in a westerly direction for 190 miles, reaches the Russian frontier at Chat, or, more properly, Chat-i-Atrak, where the Atrak receives its one affluent from the north, the Sumbar. From Chat the Atrak runs southwest, about 50 miles in a deep stream, from 40 to 70 feet wide, between precipitous banks from 30 to 100 feet high, to Baiat-hadji, the stream being fordable only at a few places by horsemen when the water is low.*

Below Baiat-hadji the Atrak resumes a westerly course, and, 40 miles beyond the ferry Chelte Alum, empties itself by several mouths into the Hassan Kuli Bay of the Caspian.

The River Gurgan, I 30 miles long, runs parallel with the Atrak at a distance of 30 or 40 miles, and between

- From information gathered in 1874 by General Lomakin, it appeared that from Chat the bulk of the Atrak waters were formerly made to flow to the north-west, irrigating the country to the Bugdaili wells, on the road towards Krasnovodsk. The soil may still be cultivated after a little spring rain, and without irrigation./ The whole of the mountainous triangle alluded to, watered by the Atrak and Gurgan, abounds in pasture grounds and fertile valleys. In this region are extensive ruins of an ancient city (Mestorian), that was built of burnt brick. There are several minarets among the ruins, and the Turkomans continue to use the bricks. The traces of numerous canals show that this deserted country once teemed with life, but the district has been depopulated by the slaughter or captivity of its inhabitants.

† A great many canals are cut from this lower part of its course, but only those on the south are now used for irrigation. The current of the Atrak does not exceed two miles an hour, and its water, though muddy, is fresh, except at its mouth, where, when the river is shallow, neither horses nor camels will drink it, because the saline banks impart a bitter salt taste. Small Turkoman boats ply for a few miles up the Atrak, in which are taken carp and sandre; and on the shores of the Hassan Kuli Bay is, or was, a collection of 200 tents, where the Turkomans build their flat-bottomed boats. Here, too, was established, in 1835 , a Russian fishing station. 
low banks, except at its sources. Its breadth is about the same as that of the Atrak, but it is shallower and fordable in many places. The traces of a large wall of burnt brick are discernible here and there along its right bank. This is Kizil Alan, said to have been built by Alexander the Great.

To the south of the Gurgan, and forming the frontier of the Astrabad province, flows, through a swampy, reed-grown valley, the Kara-Su river. It has a length of 40 miles.

The climate of Turkmenia is continental, and presents extremes of temperature disproportioned to the latitude of the country. The south of the desert is warmer than the centre. The seasons also present remarkable variations, caused by the winds. *

These differences of climate produce a corresponding variety of vegetation. Describing his journey from Krasnovodsk, Mr. Condie Stephen noticed, before reaching Kizil Arvat, the growth of little more than camel-thorn and saxaul. From Kizil Arvat to Geok Tepe the same continued, with the addition of willows, wheat, barley, maize, millet, and melons; whilst beyond, as far as Gavars, or Gyaurs, he adds nut, mulberry, apricot, and peach trees; rice, cotton, and grapes.

* The north-easterly gales cause a fall in the temperature, and, being dry and violent, they raise clouds of dust, which, impregnated with saline particles, is hurtful to the eyes. The westerly winds from the south and south-west, blowing from the Caspian, render the air damp, and, in September and October, bring clouds with heavy and continuous rains. This last remark, however, applies more especially to the parts south of the mountains, since little rain or snow falls further north. The winter varies a good deal. In $1880-8 \mathrm{I}$ it was so mild that the besiegers of Geok Tepe hardly required great-coats. The following winter was almost Siberian, the Michailovsk Gulf being frozen, and snow on the plain lying from 2 to 3 feet deep, whilst the mountain roads were for weeks impassable. M. Lessar observes that surveying can be best 
At Krasnovodsk, at the end of November, I purchased apples, medlars, and sweet lemons - the last, if not all, being imported from Astrabad. The lemons were very insipid, even to one just come from the desert, but the medlars were good.

Again, the country between the Atrak and Gurgan grows rice and cotton, also walnuts and lemons, and even the sugar cane.

Amongst the fauna of Turkmenia may be mentioned Wolves and Jackals, and in the reedy marshes waterfowl abound. North of the mountains Mr. Condie Stephen observed Eagles, Vultures, Hawks, Bustards, Grey Crows, Pin-tailed Grouse, and Larks; besides Flamingoes on the shores of the Caspian. The Tarantulas are large, and there is found in the desert a great Lizard, measuring from 2 to 3 feet long. Mr. O'Donovan, writing to me before I started, said, "You ought, of course, to go well armed. If you are anything of a sportsman, you will find plenty of amusement on the slopes of the mountains between Persia and the Turkoman country - Partridge, Fowl, and Wild

done during September and October, since the temperature is then cool, and the sky generally clouded. In March and April cold nights are prevalent. The most abundant rain falls early in spring, at which time the deserts can be conveniently traversed in all directions. M. Lessar speaks, I presume, of the region about Merv, and I should take what he says of autumn to hold good of the part I crossed between PetroAlexandrovsk and Krasnovodsk. In 1877 , at Petro-Alexandrovsk, the mean, maximum, and minimum temperatures were: July, $82^{*} \cdot 4$. $103^{\circ} 3,62^{\circ} 4$; August, $77^{\circ} \cdot 2,103^{6} \cdot 5,57^{4} \cdot 7$; September, $69^{\circ} \cdot 8,99^{\circ} \cdot 1$, $48^{\circ} \circ$; and October, $52^{\circ} \cdot 3,79^{\circ} 7,28^{\circ} \cdot 9$; whilst at Krasnovodsk for the same four months the mean, maximum, and minimum temperatures registered: July, $88^{\circ} 7,99^{\circ} 9,79^{\circ} 5$; August, $86^{\circ} \cdot 4,100^{\circ} \cdot 9,72^{\circ} 5$; September, $75^{\circ} \cdot 2,94^{\circ} \cdot 5,61^{\circ} \cdot 3$; and October, $61^{\circ} \circ, 79^{\circ} 3,50^{\circ} \cdot 2$. I collected meteorological statistics of the year preceding my visit from several places in Central Asia, and to these I have added some few others for the purposes of comparison, thus : *

$$
\text { - See pages } 44^{2-3} \text {. }
$$


Boar abounding in almost incredible numbers, as well as Antilopes, Wild Ass, and Leopard." In the south, M. Lessar describes the ground as everywhere undermined by Porcupines and other animals. He mentions, too, as of frequent occurrence, White Anthills. Along the line of railway the ants attack the timber-work, though they have not yet touched the sleepers. In the desert there is almost no fauna, not

METEOROLOGY OF CENTRAL ASIA, I881,

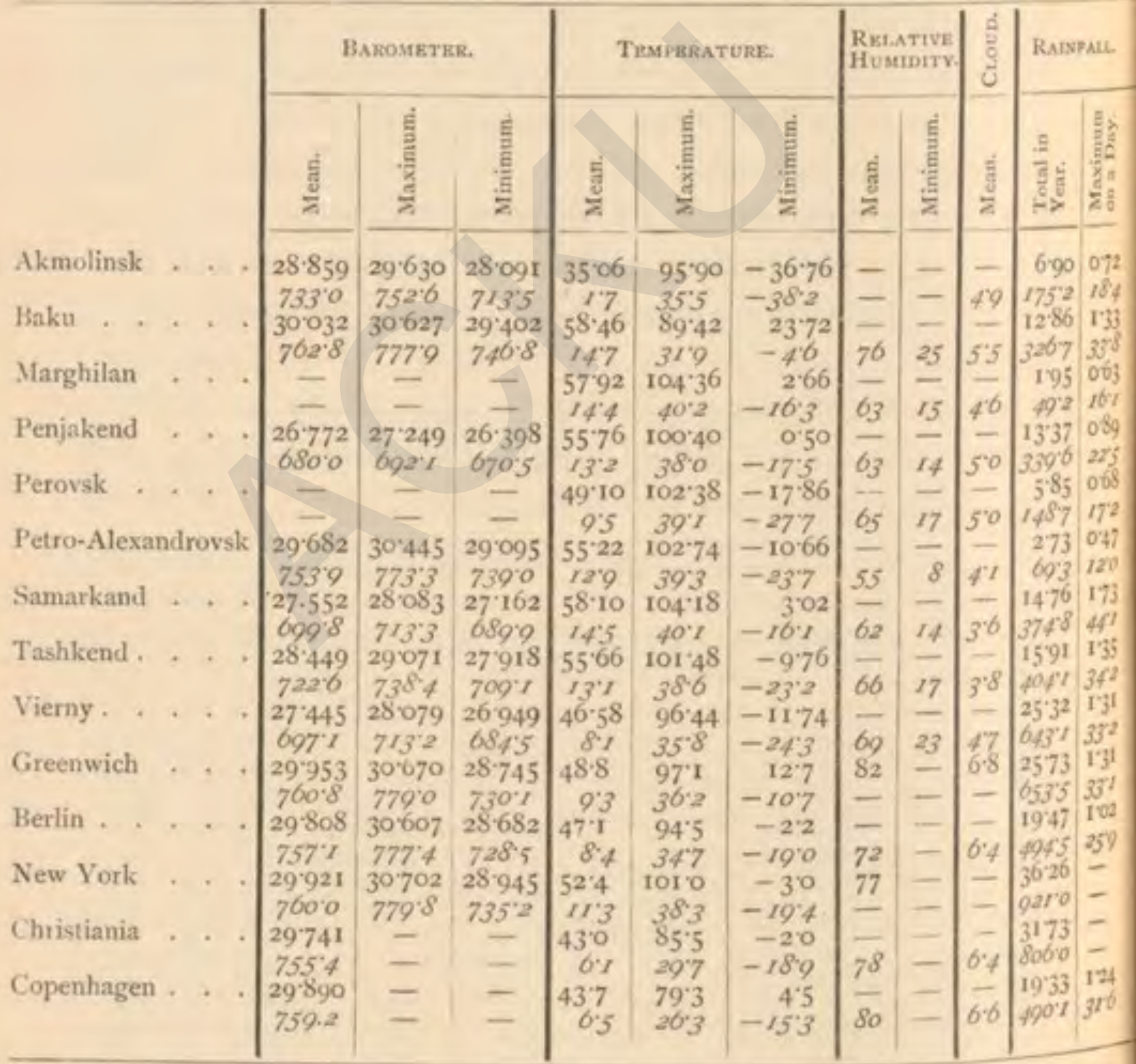

N.B.- The readings of the BAROMETEK (corrected to the temperature o Centigrade or 32 and RATNFal. in inches and millimetres. For Crovd, ro equals a completely covered shy. represented by $\mathbf{I} 00$. 
even Wolves, so that the Turkomans can pasture their sheep without fear round the wells, down which the few birds visible fly for their supply of water.

Turkmenia is peopled by the Kirghese of Mangysh-lak, the garrisons of the Russian forts, and the Turkomans, the last being of uncertain origin. Their ancestors are said to have been driven from Mangysh-lak at the beginning of the last century. Ferrier

COMPARED WITH THAT OF SOME OTHER PLACES.

Nianask of Davs wiтh

\begin{tabular}{|c|c|c|}
\hline 랠 & 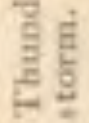 & $\frac{\vec{H}}{0}$ \\
\hline- & - & \\
\hline 2 & 12 & 88 \\
\hline- & - & - \\
\hline- & 9 & 52 \\
\hline - & 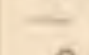 & - \\
\hline- & 8 & 530 \\
\hline- & 7 & 120 \\
\hline- & - & - \\
\hline- & 9 & 97 \\
\hline- & 5 & 134 \\
\hline- & 2 & 158 \\
\hline- & - & 1 \\
\hline 2 & 14 & 156 \\
\hline - & - & - \\
\hline$t$ & 23 & to3 \\
\hline 2 & 8 & 77 \\
\hline - & - & \\
\hline 3 & $I t$ & 30 \\
\hline- & & \\
\hline- & - & - \\
\hline $\bar{c}$ & - & - \\
\hline 6 & 16 & 44 \\
\hline 9 & 7 & 48 \\
\hline
\end{tabular}

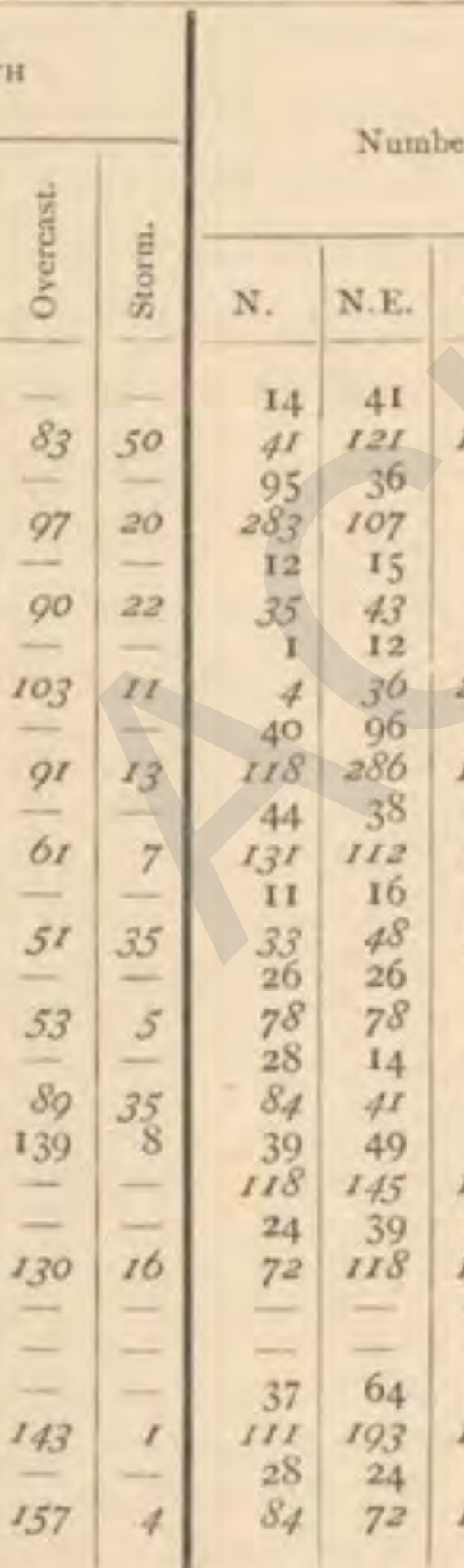

DiRection of Wind.

Number of Daily and Tri-daily Observations. \begin{tabular}{l|l|l|l|l} 
E. S.E & S. S.W. W. N.W. Calm.
\end{tabular} 34
100 \begin{tabular}{l|r}
3 & 51 \\
8 & $\times 53$ \\
\hline
\end{tabular} \begin{tabular}{|l|l|l|l|l|l}
27 & 36 & IO4 & 44 & I4 & 49 \\
\hline
\end{tabular} 43 27 
considers that the Turkomans, Uzbegs, and Kirghese are of common origin; but, so far as my experience goes, I think that whilst I could easily distinguish a Kirghese by his broad Mongol face from either of the other two, I could not easily discern between a Turkoman and an Uzbeg.*

Of the numerous divisions and sub-divisions of the Turkomans, Petrusevitch gives a long account; but Grodekoff, having sifted previous information (which he publishes in a condensed form), gives an ethnological map of Turkmenia, apportioning the country to 10 groups, with a total $1,170,000$ souls. $t$ The Yomuds are made to extend from Khiva all across the Ust Urt south of the route I travelled, to the Caspian, and southward along the sea-board to Persia. The Tekkes extend from the old Oxus bed at Igdy, and from Kizil Arvat, southwards to Afghanistan. On the Oxus about Khoja Saleh are the Ersaris, whilst south of Khoja Saleh, about Andkhoi, and on the upper waters of the Murgab, both in Afghan territory, are

* In appearance the Turkomans are usually dark. Some few are air, and others even sandy, says the Baron Benoist-Méchin, but I cannot say that I saw any of the last. Blue eyes, he adds, are not uncommon, and in many families, especially among the women, one discovers the pure Turkish type, that is, verging towards the Mongol. The men are generally tall, robust, fierce, and often wild-looking. They are, he says, exceedingly brave, and a life of plunder is the one that suits them. They are true to their word, and their guest is sacred till he leaves their tent, and then they murder him if it suits them. When not engaged in plunder they are extremely idle, lying about their tents playing chess, at which they are skilful, or gossiping, till a fresh opportunity of pillage excites them to action. By way of contrast I may add that two days before writing these words, I received a communication from Tiflis, quoting a letter from an American doctor, now in Khiva, who says of the Turkomans he had met, "For fair and kindly dealing 1 have met with no such people in the East."

† Yomuds, 150,000; Emrali, 50.000; Sakar, 15,000; Tekke, 300,000; Ersari, 150,000; Goklan, 3r,000; Alieli, 250,000 (?); Chaudor, 86,000; Saryk, 65,000 ; and Salor, 12,500. 
the Alielis and the Saryks. ${ }^{*}$ The Salors are scattered along the Murgab in small settlements from Penjdeh to beyond Merv. $\dagger$

With the Yomuds I came into personal contact, both in Khiva and at Krasnovodsk. In fact, my limited experience of Turkoman life was drawn principally from them, and the few others I met in Khiva or on the Oxus.

Without reference to their particular tribe, all Turkomans are included in two classes - the Chomur, or settled, and the Charva, or nomads. The two classes consort amicably, a father sometimes being one, and his son the other, or the same man sometimes becomes a nomad when prosperous, and a settler when impoverished.

Their habitation is almost always the tent, which closely resembles that of the Kirghese. I noticed, however, in the Krasnovodsk aul I visited, or rather oba (for this is the Turkoman word for a collection of tents), that the reed matting the Kirghese place round the tent inside, the Turkomans placed outside, and wainscoted the interior with a piece of striped cloth or carpet. Further, this matting was bound on the

- This distribution of the Turkomans indicates, to a certain extent, their gravitation to the various states around them, though some are in a greater degree of dependence than others. The Ersari are dependent on Bokhara, and Russia claims the allegiance of about ninetenths of the Yomuds; but Khiva holds sway over a few of them-also, and some of the Chaudors, whilst the allegiance of the Yomuds in the extreme south with that of the Goklans is claimed by Persia. Petrusevitch gives the Goklans 4,000 tents, and says they pay a yearly tribute to the Shah of 6,000 tumans, or, say, $\oint^{2}, 700$. The most independent were the Tekkes, recently conquered and incorporated by Russia, and of whom I shall speak hereafter.

+ M. Lessar here writes as follows :-

"The Saryks live on the middle waters of the Murgab in only two places: Penj-deh and Yul-utan, the distance between them being inhabited. There are no Salors on the Murgab. In 1857 they were driven away by the Saryks, and migrated to Zur-abad in :Persia." 
exterior with broad bands, some of velvet about 9 inches wide. These bands are handsomely worked, so that I saw them cut up for chair-backs and other furniture in the drawing-room of the Governor's house at Petro-Alexandrovsk. I tried to get a piece at Krasnovodsk, but could only find a soiled second-hand specimen, and that very dear.

The usual food of the Turkoman is unleavened bread, the dough being kneaded in a wooden trough or upon a dried skin, and then baked on the hearth by covering it up in wood embers, the simplest, surely, of

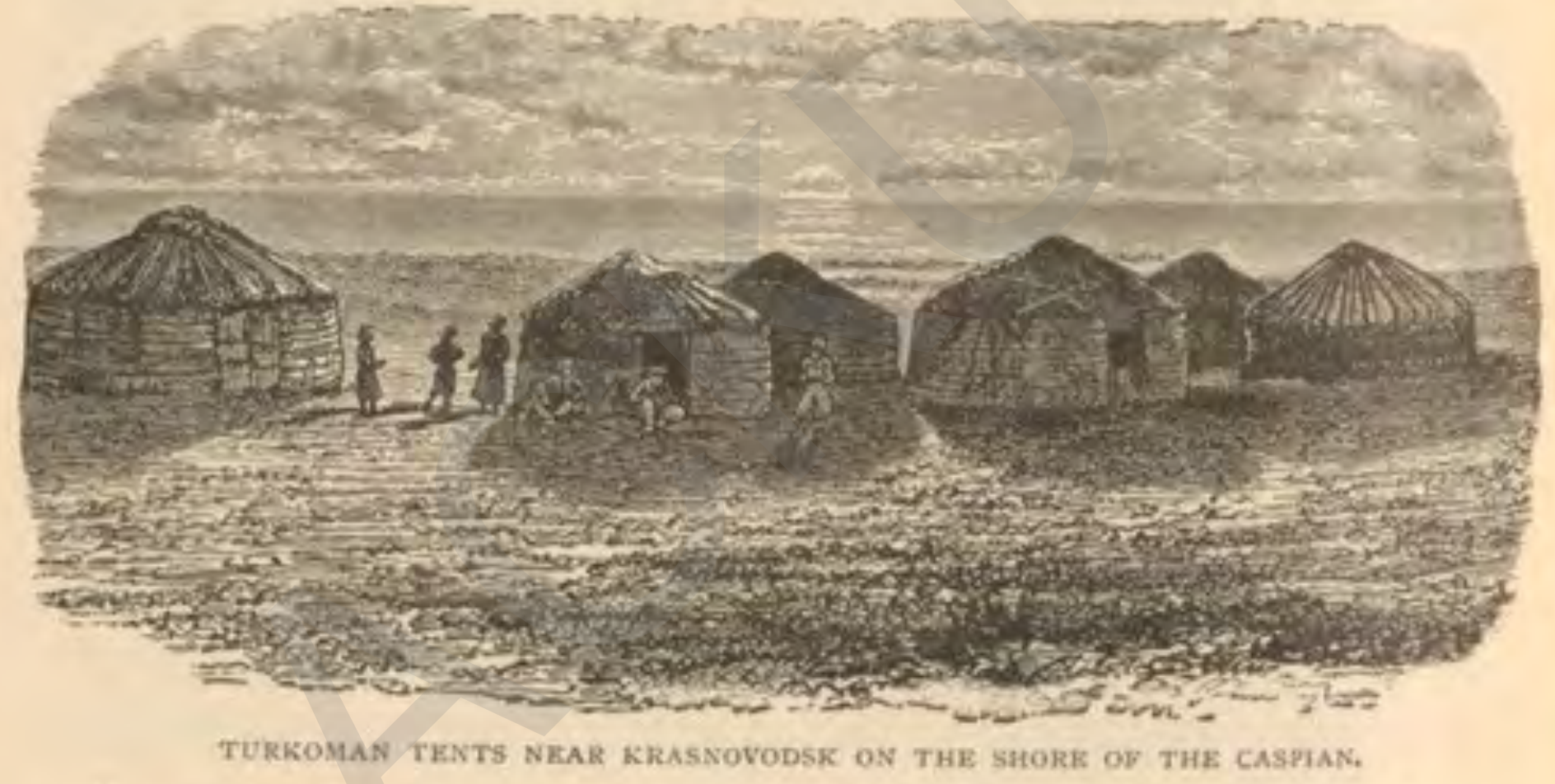

all methods of cooking, and such as I saw in full force amongst my attendants, crossing from Khiva. The Turkomans also eat meal with oil or clarified butter, and I saw in preparation another kind of food called yarma, consisting of bruised wheat and sour milk.* Melons are said to be the staple food of the Tekkes: pilau and soup on special occasions. $\dagger$

* The wheat was bruised in a stone mortar with a stone pestle. I had never seen corn thus treated, but it seemed to me to illustrate Prov. xxvii. 22, "Though thou shouldest bray a fool in a mortar among whest with a pestle" ; and, perhaps, Isa. xxviii. 28 , "Bread corn is bruised."

+ M. Lessar tells me the Turkomans do not eat fish from the Murgab and Tejend, supposing that it causes fever. 
The dress of the Turkoman is like that of the Uzbegs. Women being kept less in seclusion than amongst the Uzbegs, I was able to examine their jewellery, which was for the most part of silver. Their bracelets were in the shape of the letter C, 2 inches wide, and perhaps a quarter of an inch thick, weighing, I suppose, up to half a pound. Some wore in the ears gold rings, 3 inches in diameter, for which they asked as much as $f \mathrm{r}$, but $\mathrm{I}$ did not observe any worn in the nose. I bought of them some studs of native workmanship, a finger-ring, and a child's anklet.

The women showed us amulets worn round the neck, and valued in some cases up to $f_{2} \mathrm{O}$. I observed a charm similar in character tied round the neck of the Turkoman camel we hired.

Besides the ornaments just mentioned I noticed silver tengas sewed in rows on babies caps, and one young mother wore her hair in long braids behind, with dangling ornaments attached, whose tinkling could be heard as she moved about.

As to the occupation of the settled Turkomans, they nearly all engage in agriculture, and some few in sericulture. Those I saw at Krasnovodsk were chiefly fishermen, but some were engaged in the transport of goods by caravan. The carpets and felts made by the Turkoman women are well known. I saw some of the latter in various stages of manufacture. In one house in Krasnovodsk, tufts of coloured wool were strewed over a floor of reeds, previous to being wetted and pressed, and in a tent were three women kneeling, and pressing simultaneously upon a bundle of felt they rolled to and fro over matting, whereon loose wool was laid, which, being wetted, stuck to and thickened the roll as it passed over. 
I thought the women better-looking than their Kirghese sisters, their cheek-bones not being so wide and prominent, and their features more European. Of course they are uneducated. In the last tent we visited on the Khivan side, the young wife reminded me of one of the native women of the Caucasus, who, when I entered her room, stood behind a pillar, hiding herself like a shy child.

I was desirous of examining a bundle of trinkets dangling at the back of my Turkoman hostess, but she appeared afraid of my doing so ; and when her husband playfully held her by her tresses, she began to cry and struggled away. Presently, when she entered our tent, I noticed she was crying again, and, asking the cause, found myself the unintentional offender. I had observed on her child's cap two Khivan tengas, said to be old. These I bought of the husband as coins, at the price he asked, and they were cut off. Hence her tears. I could hardly suppose her numismatic sensibilities wounded, and I therefore offered her more money, whereupon her tears dried, and she cheered up like a pacified child. I purchased in this tent a pair of silver earrings, which they said were of genuine Turkoman workmanship. The charm on the baby's cap they would not sell, saying that the child would be ill without it !

Having now glanced at the northern portion of Turkmenia, with its Yomud inhabitants, I shall proceed to what I have to say of the southern portion, peopled chiefly by the Tekkes. 


\section{CHAPTER LXXIV.}

\section{THE TURKMENIAN OASES.}

Oases of Akhal, Attek, Tejend, and Merv,-The Akhal oasis: its dimensions, settlements, and history.-The Attek settlements, history, and hydrography.-The Tejend oasis.-The Heri Rud from Herat to Sarakhs, and below,-The Merv oasis. - The Murgab from Penjdeh.-Unknown country between the Murgab and Heri Rud.-The desert around Merv, and its historical associations.-Merv in the times of Burnes, Abbott, Shakespear, and Wolff.-List of Central Asian travellers from the 13th to the 19th centuries.

T

HE southern portion of Turkmenia, with the exception of four oases, consists of a desert. These oases are those of Akhal, Attek, Tejend, and Merv.

The Akhal oasis is a long, narrow tract of country, lying between the Kopet-dagh mountains and a range of undulating sand-hills. Locally the region goes by the name of Arkatch. It is somewhat bare, though intersected by 17 perennial streams, varying in breadth from 2 to 18 feet, and running from the Kuren-dagh. Its length is about 170 miles, its breadth 14 in the centre, but diminishing towards the extremities. The Akhal area is estimated at 3,000 square miles, or about the extent of North Wales.

A series of native forts and strongholds, 43 in number, with about 50 villages or settlements, are established along the valley from Kizil Arvat at the voL. II. 
northern end to Gavars, or Giaurs, in the south. The inhabited points, each in the form of a square, surrounded by a small rampart with moat, and environed by gardens and cultivated fields, are situated on the banks of the rivulets. About 30 miles from Kizil Arvat, to the south-east, is Bami, and, 70 miles further, midway in the oasis, is Geok Tepe. This was formerly the capital, or, at least, the rallying point for the Turkomans of the Akhal.

About 50 miles further south is Askhabad, the Russian capital. From hence to Geok Tepe is the part of the oasis best adapted for cultivation, and here are many gardens. Within 20 miles of Askhabad are Annau with 200 , and Gavars with 600 , dwellings. Petrusevitch estimates the population of the Akhal at 30,000 tents. Petrusevitch informs us, on the authority of the Governors of Budjnurd and Kuchan, that Akhal was occupied by the Tekkes about 170 years ago, during the reign of Shah Tamasp, and that up to the beginning of the present century they kept within the limits of this oasis. The increase of population, and the impossibility of spreading into the desert, seeing that all depended upon the water supply from the mountains, forced the Akhal Tekkes to seek fresh lands to settle upon. Accordingly, in about the third decade of the present century, about 10,000 families of them, under Oraz Khan, migrated to the lower course of the Heri Rud river, about 50 miles east of Gavars. There they erected the fort of Tejend, from which the course of the Heri Rud below Sarakhs was renamed Tejend- or Tajand-daria.

The second oasis I have mentioned, called the Attek, or mountain base, extends from Gavars to Sarakhs. The present Sarakhs is a Persian fortress 
on the west bank of the river, and was intended originally to dominate the neighbouring Salor and Merv Turkomans. It is surrounded with a clay wall merely, and contains 600 or 700 soldiers, who pass their time, according to the Baron Benoist-Méchin, sleeping and drinking. The fort stands in a plain far away from the mountains, and the Baron speaks of its having no raison d'être for the Persians now, since it is surrounded by a Turkoman population. Nearly opposite, but three and a half miles distant on the east of the river, are the ruins of Old Sarakhs. In this neighbourhood, M. Lessar says, are the lands best adapted for cultivation along the whole course of the Heri Rud. Beginning, however, our description of the Attek at the north, we have Baba-durmaz, 47 miles from Askhabad, and on the Russian frontier. M. Lessar speaks of this place as uninhabited. Only two points, he says, in the Attek, Luftabad and Shilgian, are peopled by Shiite Persians, subjects of the Shah. The other points are occupied by Turkomans; but all this population, according to M. Lessar, is of very recent origin.*

- In the middle of the last century a portion of the Akhal was including by the Emrali tribe, and the country towards the south-east, including the neighbourhood of Geok Tepe and Askhabad, formed been driven -grounds of the Alieli tribe. The Tekkes had at that time the inhen from Mangyshlak to Kizil Arvat, and commenced despoiling tinuing for abouts of the Akhal country, these hostile relations conEarly in the present century the Tekkes gained the supremacy.

the Emrali to Mehna and Cha the Kardashli tribe retreated to Khiva, Afghanistan, and the remainder to Alieli to the northern frontier of century ago, Allah Kuli, Khan to Küren and Abiverd. About half a Emralis to Khiva, whence they of Khiva, took away the Alielis and grounds; but the Persians they returned in 1855 to their old camping. after the Khivan campaign, that them back, and it was only in 1873 , Attek, and built the present inhabitants settled in the the Attek has taken place also fort. The migration of the Tekkes to 
The inhabitants of the Attek live chiefly in mud huts, but to some extent in tents. Formerly each settlement consisted of a fort, or " kala," within whose walls stood the mud huts of the inhabitants; tents were pitched outside the fort, and these, when in danger, were removed into the kala. At present, at Chacha, all the new buildings are of clay, and the number of tents decreases with the pacification of the country.

As regards the important question of water in the Attek, the quantity is limited, and the streams are wide apart. There is also in this oasis another disadvantage, in that considerable portions of the streams are in the territory of the Persians, who are thus able to cut off the water from the Turkomans. +

Along the whole extent of the Attek there is a population of about 7,000 Alieli and Tekke Turkomans. It is only at Kurren and Kakha that there is a settled population. All the inhabitants of the Attek are engaged in agriculture and horticulture. Great

* M. Lessar says: "Here, as also in Akhal, a watch-tower was, a short time ago, the necessary appurtenance of every field. The towers are either round or square, with a small aperture at the base sufficiently large to admit the passage of the human body. When robbers appeared on the scene, the people working in the fields crawled into the tower, and, closing the entrance with heavy stones, remained there till the marauders disappeared.

+ The following are the watered and inhabited places of the Attek. At Baba-Durmaz the water, though slightly salt, is good for drinking purposes. At Artyk, 11 miles further south, are 20 tents. Luftabad and Küren, 3 miles from Artyk, and the succeeding settlements as far as Kakha, are supplied with water from the Rud-Khan, or Rudbar river, which takes its rise in the Allah-Akbar mountains, and is the finest river in the oasis. Here water is abundant. Between Luftabad and Kakha are about 500 tents, Kakha, with 650 tents, is the largest settlement in the oasis. Dushak, 14 miles beyond, has 160 tents j Mehna, 29 miles further, has 130 tents; Chacha, ir miles beyond, 70 huts. These last two settlements, M. Lessar says, suffer much from the Persians who deprived them of water. From Chacha to Sarakhs, a distance of 37 miles, there is no water. 
poverty prevails, and no trade originates there, whilst the bazaars of Luftabad and Kakha are more than sufficient for the whole of the Attek. No great increase of the inhabitants can be expected, because the Attek cannot supply the means of existence for a dense population, and there is no inducement for further migration thither of the Merv and Tejend Tekkes.

The third oasis I have named is that of the Tejend, on the lower Heri Rud. That river rises in the mountains near Kabul, waters the Herat plain, passes the Afghan fortress Chorian, or Ghorian, to Kusan, and thence onwards to Sarakhs forms the boundary between Afghanistan and Persia. On the parallel of Mashad the Heri Rud is joined by the Kashaf from the west, and near the confluence is Pul-i-khatun, up to which point Russian troops penetrated in 1884 . After a course of about 250 miles the river forces a channel through the mountains south of Sarakhs. Beyond this point the Heri Rud receives the name of Tejend, runs into the Turkoman desert, and is lost, on the parallel of Askhabad, in the swamps and lakes formed by the spring floods. For a few miles below Sarakhs both banks are Turkoman. The settlements of the Tekkes along the Tejend are concentrated north of Karybent, and in the direction of Alaman Chungul.

The slopes of the aforesaid mountains are dotted over with pistachio-trees, and the mulberry is occasionally met with, whilst the edges of the river are in some spots covered with almost impenetrable willow bushes and reeds. Grass, M. Lessar says, is abundant everywhere and of good quality, and the water of the Heri Rud, though not clear, is wholesome.

* At Daulatabad, 10 miles above Sarakhs, the river divides into several branches, in consequence of which in the dry season the water 
We come now to the Merv oasis, situated east of the Tejend towards the end of the River Murgab. This river rises in the Safed Koh or White Mountains in Afghanistan, and has a course of about 200 miles, running parallel with, and at a distance of 120 or 140 miles from, the Tejend. At Penjdeh, or Panjdeh, about 120 miles north of Herat, where the Kushk, or Kuk, falls into the Murgab, the river is, in December, a deep stream of pure water about 60 feet wide, flowing in a channel, worn to the depth of 30 feet into the clay soil. The valley at Penjdeh is about 9 miles wide, but narrows to three-quarters of a mile at Yulutan. Here the stream, 50 yards wide, is deep, and flows at about five miles an hour. The valley is bounded by sandy hills, rising to 600 feet above the river level. These hills gradually broaden out and sink into the plain of Merv.

The valley of the Murgab from Penjdeh to Yulutan

does not reach Sarakhs. Canals, however, are brought thus far, and even 7 or 8 miles beyond. Below Sarakhs the river flows on in one stream, from 100 to 150 feet broad, the water being high from January to March. O'Donovan swam the stream in February, at a place north of Kangali-Guzar. Lieutenant Alikhanoff, when travelling as a merchant, crossed the Tejend at Karybent dam, where, in the middle of February, the river had a breadth of 70 , and a depth of $5 \frac{1}{2}$ feet. During six weeks caravans can cross the stream only at Alaman-Chungul, to which point the Tejend proper does not reach, the water being conducted there and beyond by canals. In April the stream at many points is not more than 4 feet deep, and in June and July it may be crossed anywhere, when the steepness of the banks permit. The river inundates the country only when the dam above Herat is destroyed. In summer the Tejend ceases to have any current, and may be said to consist mostly of long lakes, fed, in the opinion of the natives, by springs, or perhaps by subterranean prolongations of some of the streams that flow from the Persian mountains towards, though none so far as, the Tejend. This opinion is founded on the fact that the water in these lakes is cold, and does not dry up in the hottest summer, which would hardly be the case if they were mere accumulations of water in deep holes of the river bed. 
was once a well-populated district, as is shown by its now ruined vineyards and deserted fields. Abbott and Shakespear, about 1840 , travelled from Herat to Merv along the Kushk and Murgab; but the country between the Murgab and Heri Rud was unknown to science till, in I 882-3-4, M. Lessar travelled there.*

Along the Upper Murgab are the Saryk settlements of Bala Murgab and Penjdeh. Further south the Afghan Djemshidi and Teimurs occupy the slopes of the Paropamisus. West of the Murgab to the Heri Rud there is scarcely a single inhabited point, and all the forts along the Kushk are in ruins. Even among the neighbouring natives this intermediate district is known only to the "Sirdars," or leaders of robber-bands, and neither caravans nor travellers have for a long time risked venturing into this district, from fear of encountering Saryk or Merv raiders.

So recently as $188_{3}$, the Baron Benoist-Méchin, in proceeding from Merv to Sarakhs, speaks of the approach to the Tejend as the most dangerous part of the route, by reason of robbers, and how he camped a few miles from the spot where an engineer and four of his Cossack escort had been recently murdered.

All around the Merv oasis is desert, which long served better than fortifications to protect the plundering Turkomans from retribution, whether from Persia, Afghanistan, Bokhara, or Khiva. This surrounding desert, however, varies in its nature. That to the north, north-west, and east, is sandy and arid; but the south, as I have said, is a tract of a different kind, which shows traces of irrigation in the remote past, one canal in particular, the Kara-i-ab, extending 40 miles in the direction of the Tejend. This tract of country

* Proceedings of the Royal Geographical Society, January, $188_{3}$. 
has been celebrated in Eastern history as a fertile land,* No less than four towns have existed at different epochs known as Merv, and the remains of each were said by Conolly to be distinguishable. When Abbott visited Merv in 1840 , it consisted of a hundred mud huts, wherein lived a few Khivan officials. The village belonged to the Saryk Turkomans; but they were driven further up the Murgab by the Tekkes, who began to settle in the Merv country about 1830 . The Tekkes destroyed these mud huts, and in 1860 they commenced to build a large fortress, Kaushid Khan

*It is at Merv, Balkh, and Seistan, that Iranian history begins. The Zendavesta says, "Mouru, the strong and pure," was the third land of profusion "which 1, Ormuzd, have created." I observed that Turkomans, with whom I came in contact, spoke of Merv as "Mowr." Merv was a flourishing city in the ancient province of Margiana, comprised in the empire of the Parthians. Alexander passed through Margiana, and Antiochus, son of Seleucus Nicator, ruled on the Murgab. In 420 A.D. the archbishopric of Merv was made a metropolitan See. Two centuries and a half later, the Arabs captured Merv, at which time, says Colonel Stewart, the Salor and Saryk Turkomans were in the land. From Merv, as their capital, the lieutenants of the Khalifs ruled Khorassan.

Mokanna, the veiled prophet of Khorassan, began to promulgate his doctrines a century later at Merv, whence he fled to Bokhara, which khanate in 903 became the dominant state in Central Asia, and the mistress withal of Merv. In the eleventh century, the town was surrounded, by princes of the Seljuk dynasty, with stately palaces, groves, and gardens. The tomb of Sunjur Shah, who in the twelfth century conquered all the country between the Oxus and Jaxartes, still remains there in ruins. In the next century, Tului, the son of Jinghiz Khan, twice took Merv, and put to death, it is said, 700,000 inhabitants. This was the fourth time that the city had been desolated.

In 1505 the Uzbegs occupied the place, but were conquered five years later by the Persians. Two and a half centuries afterwards, however, the Emir of Bokhara killed the Persian governor, and again the Uzbegs gained the ascendency. They razed the town of Merv to the ground, destroyed its dam, and, in 1794 , deported 40,000 of the people to Bokhara. From this time, properly speaking, there has been no such city as Merv, and what few buildings there were, served under the Bokhariots as a place of banishment for criminals.

Merv was taken next by Muhammad Rahim (1806-26), who placed there a few Khivans, considering it an advantageous point whence to 
Kala, on the eastern bank of the most westerly branch of the Murgab, a walled enclosure to contain, the Tekkes said, 50,000 tents. Accordingly, when Merv is now spoken of, Kaushid Khan Kala is meant thereby.

I have mentioned the name of Abbott as visiting Merv in 1840 . Another Englishman, Alexander Burnes, had preceded him in 1832 , not to mention Dr. Wolff's first visit in the previous year. In the same year as Abbott, Shakespear passed through Merv, travelling from Herat to Khiva, and in 1843 Sir Taylour Thompson visited the place on his way to Khiva. In 1844 Dr. Wolff a second time went there on his journey to and from Bokhara, but after this no Englishman went to the place for nearly 40 years.* An unfortunate Frenchman, De Blocqueville, attack the Persians, and to keep in subordination the Turkomans. It was then seized by the Emir Nasr-Ullah of Bokhara, but he did not hold it long, and the Khivans once more made themselves its masters. In order to eject them the Bokhariots incited the Turkomans to attack the Khivans, which the Turkomans did, and in 1846 massacred the greater portion of their rulers.

After this date the Khan of Khiva frequently led his soldiers across the desert, and laid waste the fields and pastures about Merv, but not to much purpose. The last expedition of Muhammad-Emin to Merv and Sarakhs, in 1855 , ended in his total defeat, and the exhibition of his head as a trophy at Teheran. After this, in 1861, a Persian army, led by Hamza-Mirza, came against the enclosure now called Merv, but the Tekkes drove back the Persians with immense loss.

- It may perhaps be of use if I add a list of the travellers to Central Asia up to 1850 , which $I$ bave found in a translation from the Russian of a narrative of the military expedition to Khiva in 1839 , the list being much fuller than any I have seen elsewhere, and containing many names quite unknown, 1 believe, in English literature.

During the $13^{\text {th }}, 14^{\text {th }}$ and $15^{\text {th }}$ centuries occur the following records of travels:-Desborough Cooley ("Histoire génér. de Voyages," Traduct. Franç.); Abel Remusat ("Mémoire sur les Relations des Princes Chrétiens avec les Empereurs Mongols "); and Averve ("Notices sur les Anciens Voyages en Tartarie,") an unknown Englishman in 1243, and the following monks: Benedict, Lawrence, John Planicarpin, Aszelin, 
was taken there as prisoner about twenty years ago. Several Europeans, however, have been there in the present decade, and recently the eyes of all Europe have been attracted to Merv in consequence of its

St. Quentin, Alexander, Albert, Guichard, Longjourel, 1245 to 1267 ; the monk Andrew, 1248; Ruisbruque, 1253; Nicholas and Matthew Paolo, 1250-60; Marco Paolo, 1271-1295; Highton (?), 1254: Ricold de Montécroce, 129o; John de Montécroce, 1288 to 1307 ; Odesico Mateneci, 1317 ; John de Caro, 1330 ; Jourdan Cataliani, 1330; Pascal de Victoria and Juan de Mariniolli, $1339-53$; Francesco Pegoletta, 1335: Mandeviile, 1322 to 1355; Arigo, 1374; Gomez de Satomajor and Herman Sanitz, 1393; Gonzales de Clavijo, 1403 ; Schiltberger, 1395 to 1427 ; Conti, 1424 to 1449; Joseph Barbaro, 1471 ; Ambrose Contarini, 1473 : Bartem, 1502 to 1508 .

In the 16 th and 17 th centuries occur the following:- Jenkinson and Johnson in $155^{8}$; Jenkinson in 1561 ; Aldcock and Chiny (?) in 1564 ; Edwards and Johnson, 1565 ; Edwards and Chapman, 1568 ; Borough, Edwards, Turnbull, Talboys, and Hasasde, from 1579 to 1581 ; Nirberri (?), 1582 ; Kichel, 1585 to 1589 ; Kakasch and Dectander, 1602 ; Benedict Goes, 1603 ; Tesseiro, 1604 ; Stell and Crofter, 1615 ; Posère, 1621 ; Garcia Silva, $162 \mathrm{t}$; Piestro de Lavalli, 1614 to 1626 ; Olearius, Krusius, and Herbert, 1628 to 1641 ; Mandeilo and Fleming, 1636 to 1638 ; John de Lucca, 1637; Anderson, 1641 to 1650 ; Tavernier, 1645 to 1670 ; Shardan, 1666,1669 , and 1673 to 1677 ; Heidenfeldt, 1680 ; Struiss. 1645 to 1670 ; and Kempfer, 1684 .

Among those who visited Central Asia in the 18th and 19th centuries, and the accounts of whose travels are more or less known, are :-Meyer, 1703 ; Truschinski, 1713 ; Bucholtz, 1714 to 1717 ; Volynski, 1718 ; Beneveni, 1718; Werden, Soimonoff, and Prince Urusof, 1719; Likharef, 1720 ; Soimonoff, 1722 ; Harber, 1722 and 1723 ; Bruce, 1723 ; Soimonoff and Dolmatof, 1726 ; Dubrovin, 1729 ; Harber, 1731 ; Tevkelef, 1731; Urgumef, 1732; Miller, 1734; Kushelef, 1735; Miller, 1739; Thompson, 1740; Moravin, 1741; Gladishef, 1742; Miller, 1743 ; Elton, 1743 ; Lerche, 1747 ; Reigelmann, 1750 ; Rukavkin and Maksulof, 1753 ; military expedition, 1767 ; Gordayef, Tokmachef, and Panin, 1764; military expedition, 1767 ; Pallas and Kraft, 1769; Gmelin, 1770 ; military expedition, 1771 ; Lozitch and Inokhdusef, 1769 to 1771 ; Islenief, Lepekhin, Rytchkof, Falck, and Sokolof, 1771 ; military expedition, 1774 ; Tchernishof, 1780 ; Efremof, $1774-1782$; Noinof, 1871 ; military expedition, 1784,1785 , and 1790 ; Herman, 1790 ; Sivers, 1791 ; Blankenagel, 1793; Chevkin, 1794; Snegiref, 1745; Idanof, 1796 ; Pospelof and Burnashof, 1800 ; Gaverdooski, 1803 ; Telckerzam. 1805 ; Klaproth, 1807 ; Kolodkin, $1809-1817$; Nazarof, 1813 ; Kishuevski, 1806 to 1815 ; expedition to Svinsovi Mountains, 1814 to 1815 ; 
incorporation by Russia. This brings us, however, to a new chapter in the history of Turkmenia, once more conquered by a European power.

Bystrinski, Zavialof, Meushenin, Losef, and Leshof, 1817 ; Burnashof, I818; Muravief, 1819; Negri, Meyendorf, and Eversmann, 1820; Siberian Line Surveys, 1820 to 1830 ; Levshin, 1820 to 1822 ; Muravief, 1821 ; Berg, 1822 ; Bronevski, Grigorief, and Gorski, 1823 ; Jemchujnikof, 1823 and 1824 ; Berg, Lemm, and Eversmann, 1825 and 1826 ; Tafayef and Yagmin, 1825 ; Bassargin, $1823,1824,1825$; Eichwaed and Ladyjinsk, 1826; Meyer, 1826; Engelhardt and Helmersen, 1826; Reconnaissance from Semiarsk Outpost to River Chu, 1827 ; Helmersen and Hofmann, 1828 ; Humboldt and Rose, 1826 ; Survey of Orenburg region, 1830 to 1850; Lenz, Larin, and Karelin, 1830 ; Parrot, 1831 ; Karelin, from 1831 to 1832 ; Fedorof, 1832 to 1837 ; Helmersen, 1833 ; Reconnaissance of territory of Siberian Kirghese, 1832 to 1841 ; Habel, Vasilief, and Demaisons, $18_{34}$; Sozi and Vitkevitch, 1835 ; Lessing, 1833 to 1836 ; Helmersen, 1835 ; Karelin, Telkner, and Blaramberg, 1836 ; Caspian expedition, 1836 and 1837 ; Homer de Hell, 1836 to 1840 ; Jacob Khanikof, 1836 to 1840 ; survey of territory of Inner Kirghese Horde, 1836 to 1839 ; Mansurof and Danilefski. 1837 ; Vitkevitch, 1837 and 18,38 ; Lehmann, 1838 ; Eversmann, Leman, Bodisco,'Shirkof, Nicholas Khanikof, Khiva expedition, and Vasilief, 1839 ; Kovalefski and Herrngrosz, 1839 and 1840; Reichenberg, 1840 ; Romanof, Blaramberg and Nikiforof, 1840 ; Butenef, Leman, and Nickanyof, 1840 and 1841 ; Karelin, 1840 to 1842 ; Dal, $183_{2}$ to 1841 ; Danilefski and Basiner, 1841 and 1842 ; Gentz and Schrenck, 1840 to 1844 ; Murchison, 1841 ; Sokolof, 1842 ; Ivanin and Leman, 1846 ; Jerebtsof, 1847 ; Butakof, 1848 and 1849 ; surveying corps, 1850 . 


\section{CHAPTER LXXV.}

\section{THE RUSSIAN ADVANCE TO MERV.}

Russo-Turkoman relations from 1713 .- Russian forts on the Caspian seaboard.-Opposition from Kirghese and Turkomans.-Russian advance to Kizil Arvat and Chikishliar.-Failuresunder MarkozoftPacification of Yomud Turkomans by Lomakin. - Lomakin's defeats by the Akhal Tekkes.-Skobeleff's campaign and capture of Geok Tepe.-Turkmenia visited by political agents, private adventurers, and a journalist.- Journeys of Marsh, Napier, Macgregor, Butler, and Petrusevitch.-O'Donovan's ride to Merv, and extracts from his private correspondence.- Journeys in disguise of Stewart to Khorassan and Alikhanoff to Merv.-Benoist-Méchin's journey from Khiva to Merv.

I PURPOSE to give in this chapter a brief account of the Russian approach to Merv, and of recent travel thither. The Russians first entered into relations with the Turkomans during the reign of Peter the Great, when, in $\mathrm{I}_{71} \mathrm{3}$, these nomads offered to aid the Russians in occupying the lands along the Oxus, where the Tsar expected to find gold. Two years later the Kalmuk Khan, Ayuk, after coercing the Turkomans into obedience, acknowledged himself a vassal of Russia; but it was not till ${ }_{1} \mathrm{SO}_{3}$ that the Abdal tribe of Turkomans were granted a document taking them under Russian protection. In 1811 two deputations, representing 6,000 families, repaired to Astrakhan, seeking Russian protection. Similar over- 
tures were repeated in $181_{3}, 1820,1837$, and 1840 , and, 16 years later, the Turkomans of Alexander Bai asked the Russians to establish a fortress on their coast, offering even to build it themselves. More recently, however, says M. Veniukoff, the Turkomans endeavoured to frustrate all attempts of the Russians to establish themselves on the east coast of the Caspian.

The first Russian forts erected in Turkmenia were on Cape Karagan, in the Bekhtyv Bay, and on the Krasnovodsk spit, in $1715-16-17$, but they were all abandoned after the failure of Bekovitch's expedition to Khiva. Officers were sent, in 1819 and 1821 , to choose a site for a fort, but the next Russian military settlement was not founded until 1833 , in Mertvy Kultuk (now Tsarevitch Bay), and called Novo Alexandrovsk. It was to this spot Abbott and Shakespear travelled in 1840 , but the fort was abandoned 6 years later, and a new one erected on the Mangyshlak peninsula.

In 1859 a large reconnoitring force was sent to the east coast under Dandevil, but was attacked by Turkomans, so that the survey of the Balkhans could not be carried out. A site was selected, however, at Krasnovodsk for a new fort, after which Dandevil proceeded south by vessel to Ashurada and to Hassan Kuli Bay, where he bombarded a Turkoman settlement. He also stormed and took Chikishliar, but made no lodgment on that part of the coast.

Ten years later a Russian expedition laid the foundation of the stone fort in Krasnovodsk Bay, and in the following year established 3 military positions somewhat further south. The invaders were then able to push an expedition 130 miles inland to 
Kizil Arvat, and in the following year to effect two reconnaissances towards Sary Kamish, after which, in I $87 \mathrm{I}$, Chikishliar, near the mouth of the Atrak, was occupied, and made the principal head-quarters of the Trans-Caspian forces.

The Russians had now planted themselves at four points in the country of the Turkomans, - namely, Mangyshlak, Krasnovodsk, Chikishliar, and on the island of Ashurada in Astrabad Bay, but not entirely without opposition. In 1870 the Kirghese of Mangyshlak besieged the invaders there, and next year the Turkomans attacked Michailovsk further south. In retaliation for this latter the Russians pushed across the desert and destroyed the fortress of Kizil Arvat. In the autumn of $187 \mathrm{r}$ Colonel Markozoff descended to Chikishliar, with a view of collecting camels for the projected occupation of Khiva, but the Turkomans opposed him, and dammed up the River Atrak.

In 1872 , therefore, a joint expedition was undertaken against the Akhal Tekkes. One party advanced under Stolietoff from Krasnovodsk to Kizil Arvat, and the other under Markozoff up the Atrak to Khoja or Kodsh Kala, somewhat furthers outh. The Turkomans fled, and the Russians invaded the Akhal oasis as far as Beurma, burning tents and seizing sheep; and after this Markozoff marched north to Igdy, but was driven by the Tekkes back to Krasnovodsk.

The next year, 1873 , was memorable for the taking of Khiva. One Russian detachment, it may be remembered, marched from Mangyshlak, and reached its destination. The other, under Markozoff, was to start from Chikishliar, and pass through Kizil Arvat and Igdy ; but, before setting out, Markozoff, on account 
of the incessant raids of the Persian Turkomans, crossed the Atrak, thereby invading Persian territory, and punished them. He then set out for Khiva, but his troops were overcome by heat and fatigue, and, harassed by the Turkomans, had to retreat. In the following autumn the Steppe was formed into a military district, to be governed from the Caucasus, and Lomakin was appointed first Governor-General of the Trans-Caspian. The district then lay north and south between Tsarevitch Bay and the Atrak, and extended eastwards to the possessions of Khiva, if indeed the whole arrangement were not an invasion of Khivan territory; for the Khan remonstrated against the foundation of the Krasnovodsk fort as an infringement of his rights.

In 1874 and the following year Colonel Ivanoff fought with the Turkomans of Khiva, and routed some Merv Tekkes who approached Pitniak. Meanwhile Lomakin was negotiating, but not successfully, with Sofi Khan, the ruler of Kizil Arvat, for the establishment of Russian authority in the Akhal. Lomakin next determined to reconnoitre the ancient bed of the Oxus from the Caspian to Sary Kamish. He succeeded as far as Igdy, but had then to return, receiving, however, on the road, expressions of friendliness from the Caspian Turkomans, the Yomuds of the Atrak, who agreed to help the Russians and to watch their marauding neighbours the Tekkes.

The following year the Tekkes informed the Yomuds that, if they entered into vassal relations with the Russians, they should be exterminated, whereupon Lomakin, to protect his allies, sent a small detachment to establish itself at Kizil Arvat, but the Tekkes drove it back.*

* To this M. Lessar writes:- "The Tekkes never drove them back, 
In 1877 Lomakin set out with a stronger detachment for the same purpose, but the Russians were again repulsed, to attempt next year to reach the Akhal by a new road; for Lomakin now made his way up the Atrak and the Sumbar as far as Kodsh Kala, where he entrenched himself. So fiercely was he besieged, however, by the Tekkes, that he had once more to retire, and Russian prestige in the Akhal sank almost to zero.

It was determined, however, that the contest should be renewed in 1879 , and another campaign was begun under Generals Lazareff and Lomakin. Lazareff died early in the campaign at Chat, whereupon Lomakin assumed command, and marched into the Akhal country as far as Denghil Tepe, which he besieged, firing upon men, women, and children, for many hours ; but he was so successfully withstood that the besiegers had to retreat, and Lomakin was superseded in command of the army by General Tergoukasoff, and in the administration of the Trans-Caspian province in the following year by General Petrusevitch.

In 1880 Tergoukasoff resigned his command, and was succeeded by General Muravieff; but in the month of May there came to Chikishliar, as commander of the active army across the Caspian, General Skobeleff, who, whilst Petrusevitch was preparing a railway inland from Krasnovodsk, reconnoitred the Akhal as far as Geok Tepe. This fortress, he considered, could be taken only by a regular siege.

Extensive preparations were accordingly made, and, in December, Skobeleff for the second time came to the neighbourhood of Geok Tepe. A second recon-

but the detachment went there each time to punish the tribe, and, having so done, returned." 
naissance showed the Tekkes to be gathered in force at Yangi Kala, Denghil Tepe, and Geok Tepe, within about a mile of each other. The Russians were from 8,000 to 10,000 strong, and the Tekkes, it is said, about 30,000 - but the latter, of course, badly armed and totally unaccustomed to European strategy. The invaders drove the foe from the first two positions, and appear to have been left to occupy the third. Victory was not gained, however, with the ease of battles in Turkistan, for, in capturing Geok Tepe, the Russians lost more men, Mr. Marvin estimates, than in all the previous sieges in Central Asia since 1853 .

However this may be, the terror inspired throughout the land by the taking of Geok Tepe, in $188 \mathrm{I}$, had not died away when I approached the Turkomans in 1882. Of this I had proof when on the Oxus; for when I asked some Turkomans if it would be safe to cross their Steppe, they replied that the Russians had given the Tekkes such a thrashing that probably we should not be meddled with; and the prediction proved true, for, as I have said of the Turkomans near Khiva who shot at our luggage drivers, when dared to take the goods, with the warning that they were Russian, they decamped. As for our route further on, we were subsequently told that, since the fall of Geok Tepe, the Turkomans had left the northern part of their country and gone further south. Beyond all doubt, therefore, it was owing to the success of the Russian arms that we kept our property and travelled in safety across Turkmenia.

This brings me to the mention of other travellers, who have entered or aproached the country during the past 12 years. The Russian encroachments in Turkmenia attracted to its vicinity at least three classes of VOL. II. 
travellers-political agents, private adventurers, and newspaper correspondents. Captain Marsh, in 1872 , rode through Khorassan from the Caspian to the Indus, and afterwards told his story in "A Ride through Islam." In the following year, a visit was made to the Perso-Turkoman frontier by Colonel Valentine Baker, accompanied by Lieutenant Gill and Captain Clayton. They failed, however, in reaching either Merv or Herat, but visited the upper waters of the Atrak, as described in Baker's "Clouds in the East."

The foregoing were private travellers, but in 1874 Khorassan was visited by Captain the Hon. G. Napier, who made his way to Kalat-i-Nadiri, on the Perso-Turkoman frontier, and thence travelled up to Astrabad. Afterwards he returned to Teheran, and wrote his secret and confidential report for the English Government, by whom he had been sent. He made a second journey in 1876 .

In 1875 another English officer, Colonel C. M. Macgregor, set out upon his own responsibility, thinking to ride from India to Russia through Afghanistan; but he was forbidden to do so by his Government, and when he had gone round by the Gulf of Persia, and approached to within 5 miles of Herat, he was thence sent back to Persia. He was next on the point of starting for Merv when he received orders from Teheran prohibiting his leaving Persian territory, so that his account was confined to a "Journey through Khorassan."

In the spring of 1876 , Captain F. W. H. Butler spent his leave on the Perso-Turkoman frontier, disguised as a Chinaman. On returning to India, and informing the Government of what he had done, Lord Lytton, in the following year, sent him to 
ascertain the condition of things at Merv. He wrote a report for the Government, concerning which, how ever, very little that is trustworthy has been made public.

The years 1876 and 1878 saw a Russian explorer in Turkmenia, and on the Persian frontier, in the person of General Petrusevitch, in whose report are amply described the parts of Turkmenia between the Uzboi and Persia, and also the north-eastern provinces of Khorassan.

Thus far it will be seen that all the English travellers I have mentioned were military officers, who hovered about the border, but not one of whom penetrated into Turkmenia. The honour of doing this first, of late years, was reserved for a brave civilian, in the person of $\mathrm{Mr}$. O'Donovan, who, in I88 $\mathrm{I}$, boldly rode into Merv, under circumstances that excited no little admiration. As correspondent of the Daily News, he had started from the Caucasus to accompany the Russian expedition against the Akhal Tekkes; but upon the death of Lazareff, Turgoukasoff objected to his presence, and he withdrew into Persian territory at Astrabad. Nor upon Skobeleff's advent to power could O'Donovan obtain the needed permission. Upon this he set off to watch the Russian operations from the enemy's side; but, failing to get into Geok Tepe, he determined, at all costs, to enter Merv.

He set out from Mehna on 28th February, the journey involving a ride of 120 miles in 24 hours, and on his arrival he was treated, first with suspicion as a spy, then with honour as a guest, next with confidence as a doctor, and lastly with respect as a chief. After five months' residence, though secretly watched, he 
succeeded in making his escape, and was the first European to describe in detail "The Merv Oasis." His book was not ready, I think, when I left England, nor did I ever meet Mr. O'Donovan; but as I intended myself, if possible, to go to Merv, I wrote to ask him for useful hints. He has since perished with the army of Hicks Pasha in the Soudan ; but his reply is before me, and I take pleasure in recording the kindness with which he sent me a letter of three sheets answering my questions.*

\section{O'Donovan was an Irishman. The next traveller}

- Some parts of his letter are of sufficient general interest to warrant my printing them. He wrote from "Dinard, Ile et Vilaine, France, 17 th June, 1882,"' and said :-

"The journey from the Caspian to Samarkand had best be commenced by rail from Krasnovodsk. The railroad is completed, I think, as far as Yengi Sheher, in the Akhal Tekke. Then you can procure horses and camels, and proceed either through Merv or Bokhara. I would recommend the route through Merv, especially if you can establish yourself in the good graces of the Russians, who by this time are doubtless all-powerful in that district. At this crisis, however, you will find it very difficult to persuade the Russians that your mission has nothing to do with politics.

"Between the eastern terminal of the Trans-Caspian railway and Samarkand I know of no way of travelling except by horses and camels. The people of the country, excepting when travelling in caravans, generally prefer horses. The only difficult piece of ground you will have to cross, if you proceed by way of Merv, is that between the Tejend and Murgab rivers, owing to its being in summer a waterless district. During the rainy season there will be abundance of water-too much of it sometimes.

" $\dot{A}$ propos of water, it would be well to bear in mind that as soon as you get eastward of Merv, and especially at Bokhara, it is absolutely necessary to avoid drinking water from tanks or rain-pools, without first causing it to be boiled, for in such waters the germs of the Rishta, or guinea-worm, invariably abound ... A large percentage of the members of caravans coming from Bokhara are infected in this way.... .

"The language spoken by the people inhabiting the district between the Caspian, Merv, and the Oxus is primitive Turkish, bearing the same relation to the modern Osmanli spoken at Constantinople that the language of Chaucer does to our latter-day English. Should you 
to be mentioned is a Scotchman, with whom I have the privilege of being acquainted. I mean Colonel Stewart, of the $5^{\text {th }}$ Punjaub Infantry, who took upon himself in I880 to visit the Turkoman frontier; and, that he might mix freely among the people, assumed the disguise of an Armenian horse-dealer of Calcutta. In the bazaar at Muhammabad he chanced to meet O'Donovan, who told him he "spoke English wonderfully well for an Armenian," but did not detect his dissimulation; nor was it until some time afterwards, Colonel Stewart told me, that he made himself known be acquainted with Constantinople Turkish, you will acquire the Turkish of Central Asia in a very short time. If you have anyone with you who can speak Persian, you will get on well enough with the better classes of the community. Among the nomadic peoples, however, Turkish will be absolutely necessary. . . .

"When I was at Merv, I bought from a Jewish merchant of the place, named Matthi, a copy of the New Testament* printed by one of the Bible Societies in the language of the nomadic TurkomansJagatai Tatar. I believe you can get any number of them in London, for it was there that the copy I saw was printed. For general distribution in Central Asia, the Scriptures printed in the Turkish of Azerbaijan (West Caspian provinces), and which resembles as nearly as possible the language of Bokhara, would be requisite. $\dagger$

"The dangers of travel in Central Asia have been, since the time I travelled there, immensely lessened by the Russian advance. They consisted principally of the attacks upon the caravans crossing between

"ODonovan's mention of the sale of the Scriptures by a Jew is noteworthy, for Colonel Stewart told me that, whilst on the Turkoman border, he met with a Jew who was not only selling the New Testament, but had read it, and to such purpose that, quite apart from Christian teaching, he had become convinced that Jesus was the Messiah, and he asked Colonel Stewart for directions as to how he might carry out his desire to become a Christian - an incident from which I drew hope that the reading of my distributed Bibles, though unaccompanied by human teaching, will, with God's blessing, produce like fruits.

$\dagger$ Mr. O'Donovan is, I think, not quite accurate in some of his retnarks about the Scriptures. The Gospel of St. Matthew, known as Bassett's version, has been printed in Jagatai Tatar, by the British and Foreign Bible Society, but the remainder of the New Testament has not yet been translated, and I have heard nothing elsewhere to lead me to suppose that the Turkish of Azerbaijan would be better for the khanates than Jagatai. In fact, Dr. Vanorden, writing from Khiva, speaks of the Kirghese New Testament he met with there as "'about the same as the people speak in Khiva." Again, "The language spoken here, though Turkish, is quite different from that spoken in the Caucasus. 
to the brave correspondent. The Colonel watched the course of events till ten days before the fall of Geok Tepe, and then returned. Not, however, in his case to have altogether unacknowledged his self-imposed mission, for it was shortly after determined by the Government to send him back to Khorassan as an accredited agent, " the only English pioneer in Central Asia," Mr. Marvin says, "who has been rewarded with any official recognition of his services." Russia, on the other hand, he adds, as a rule, well rewards her explorers. I know not now

Krasnovodsk and Khiva or Bokhara by the Akhal or Merv Turkomans. In travelling by caravan at present, however, I should say there was no danger. Small parties of nomadic shepherds, who occasionally take to the road, as chance offers, do not dare to attack any considerable number.

"As I presume your principal travelling will be done in company with caravans, you must regulate your speed according to that of laden camels. In summer the caravans almost always halt during the entire day, commencing their march at sunset, and continuing up to a couple of hours after sunrise. I think you will find from 25 to 35 miles a day a safe average to count upon, especially the lower number of miles; for, every three or four days, the caravan bashi halts for an entire 24 hours, with a view of allowing the camels and travellers on foot, of whom there are always many, to repose.

"The cost of travelling will vary immensely in the localities through which you will pass. It will be dearer to march with a caravan than if you travel alone with your servants, for the demand occasioned by the arrival of a large number of animals sends up the price of forage very considerably. At Astrabad the food of each horse cost me 2 francs a day. At Meshed it was $1 \frac{1}{2}$, in Dereghez 1 franc, and in Merv but half a franc. For a fowl you pay on the average about 1 franc, and the price of pilau, and yaghourt (or coagulated milk) is very small indeed. but varies immensely. The wages of a servant-board wages-are 40 francs per month. This is good pay, and for it you ought to find a man well able to cook, and superintend your affairs generally. A groom need not cost you more than 25 to 30 a month. With 3 horses and 2 servants, your ordinary expenses should not exceed to, or at most 12 francs a day; but you will find at the end of 12 months, between being cheated by your servants, and making presents to local dignitaries, 20s. per diem will be a satisfactory average," 
how far these remarks are correct, but I remember that M. Ujfalvy draws a contrast between the liberality of Russia towards her explorers compared with his own Government in France.

Colonel Stewart returned to Khorassan in $188_{3}$, after reading a paper at the Geographical Society upon "The Country of the Tekke Turkomans." He is appointed on the Afghan Frontier Commission.

The appointment of Governor bestowed on the next traveller to Merv seems rather to illustrate the alleged liberality of Russia towards her explorers. It was natural enough, after O'Donovan's adventure, that the Russians should wish to go to Merv too; whereupon, in February, 1882, a caravan was despatched, under Kosikh, a trader representing the firm of Koushin and Co., of Moscow, with Lieutenant Alikhanoff disguised as his clerk and interpreter, and Ensign Sokoloff as another clerk - a similar plan, it will be observed, to that enjoined by Peter the Great, when ordering a party to proceed to Yarkand, to find out and seize the gold mines; or, again, like their plan in sending Valikhanoff, disguised as a Khokand merchant, with a caravan to Kashgar, in 1859 . In Alikhanoff's case a Russianized Khivan was sent on before, secretly to arrange for the reception of the caravan, the arrival of which caused a sensation; but the people were assured that its objects were purely commercial, gifts were distributed, and permission was obtained for the caravan to remain a few weeks in the oasis.

During this period the officers took advantage of every opportunity to examine the situation and survey the fortress of Kaushid-Khan. The Tekkes, however, were suspicious, and the reports of their plots to murder the Russians caused the trader to wish to depart, 
leaving his goods on credit with the Tekkes. The whole party then returned to Askhabad, and the public knew nothing of the affair till, months afterwards, Alikhanoff published his adventures in the Moscow Gazette.

Alikhanoff was followed a few months later by another disguised officer, Lieutenant Naziroff, of whose successful ride from Askhabad through Merv to Charjui I first heard on the 2oth September, at the dinnertable of the Governor-General at Tashkend. I had asked about the possibility of my proceeding from Charjui to Merv, but the Russian authorities said it would be madness for me to attempt it, for that they regarded the journey just accomplished by Naziroff, who was an Asiatic speaking the language, as no small feat, and that they had no means of guaranteeing my safety beyond Charjui.

This information was volunteered to me in Tashkend without reserve, and further particulars were given me at Samarkand, when writing notes.*

Besides these last two officers, it appears that M. Lessar also went to Merv, and from thence to Khiva, and back again to Kizil Arvat. $†$ This brings me to

- A portion of a private letter from a high functionary to another of nearly equal rank was read to me, and to this effect: "You know that Naziroff passed safely from Meshed through Merv to Bokhara in native costume, and, knowing the language and customs, went with a caravan together with Turkoman pilgrims returning from Mecca. There were many, and from different districts. Not knowing that he was a Russian officer, they were open with him, and told him that they would like to be in the Zarafshan province, where the authorities cared for the people, entered into their needs, and do not wrong them; but they did not make the same remark about the other pro. vinces."

+ Since I wrote thus, M. Lessar has told me that he went openly in Russian runiform in August and November, $18 \mathrm{~S} 2$, and was both times well received by the Mervis. From Merv he went to the Amu-daria, 
the last two Europeans who visited Merv during its independence.

More than once I have referred to two French travellers, M. de Mailly-Chalon and the Baron BenoistMéchin, who had made a remarkable journey from Japan through Southern Manchuria to Vladivostock, and then proceeded by the Siberian post-route to Tomsk, whence, striking south, they had reached Vierny, and were, at the time of our arrival there, in the Thian Shan mountains. They afterwards proceeded to Samarkand, which they left to follow our track, three months later, to Khiva.*

At Khiva they stayed two-and-fifty days, hoping for some way of proceeding direct to Merv. For a long time the General at Petro-Alexandrovsk would not take the responsibility of giving them permission to go, until by a lucky opportunity there came an embassy of Merv Tekkes under Kara-Kul-Khan to meet General Chernaieff at Khiva, and to ask him to send a delegated Khivan to govern the turbulent Tekkes. The French travellers eagerly seized this unexpected opportunity, and, with the consent of the Russians, proceeded with the returning embassy. $\dagger$

near Charjui, to Khiva, and thence to Durun in Akhal (published in the Proceedings of the Russian Geographical Society, and in Petermann's Mittheilungen). On comparing notes as fellow-travellers over the same steppe, I found that M. Lessar's journeys had been more arduous than mine; for that, whilst my party had never more than three days' journey without coming to a well, M. Lessar sometimes went five days and six, so that in one case, if not more, his horses died.

* Proof-sheets of the Baron's communication addressed to the Geographical Society of Paris, on 2 Ist March, 1884, respecting their journey from Samarkand, are before me. From them I gather that their reception in Bokhara was as kind as ours, but they were not so fortunate as we in being able to descend the Amu by boat, because the river was frozen, and they had to journey by horses for 10 days, first on the west bank to Ildjik, and then on the opposite bank to Petro-Alexandrovsk.

$\dagger$ The caravan consisted of about 85 camels and $15^{\circ}$ horsemen. 
The length of their route the Baron states as 370 miles, but observes that there is a route followed sometimes by couriers and camel caravans, shorter by 90 miles. Of the two routes, Abbott followed the shorter, and Shakespear and Taylour Thompson the longer, in I 840 and 1842 , since which time probably no European, except M. Lessar and the two Frenchmen, has been over either. Our travellers stayed in Merv for three weeks, and then passed on, leaving the oasis that has so often changed masters, to begin a new period of its history, and, from having belonged to an Alexander more than 2,000 years ago, to pass to another Alexander in the person of the Emperor of Russia.

Leaving Khiva on the $5^{\text {th }}$ of May by Pitniak, they followed the west bank of the Amu comfortably, to a spot called Kougar-chin, or Kurganchin, within about 30 miles of Kabakli. Then began the difficult part of their journey, when on the 12th May they struck into the desert, and, after 42 hours, had ridden 75 miles to the well Chelganak; their way lying over undulating sandhills covered with saxaul, and scanty thin grass which grows in spring. On this the Turkoman horses were sup. ported almost entirely during the journey. The well, 80 feet deep, had brackish water, and not sufficient in quantity without digging deeper. At length, on the 16 th, they resumed the journey, the heat being almost insupportable, and the chief declaring that it was absolutely necessary, on account of the horses, to get to the next well, Chashmah, as quickly as possible. This involved crossing two tongues of sand, each 2 or 3 miles wide, in which the horses sank to the houghs. The stage was accomplished in 27 hours, a distance, the Baron says, of 110 kilometres; but this looks like a mistake, since it would involve a caravan of camels doing 68 miles in 27 hours, which, 1 take it, is out of the question. The distance on my Russian map does not exceed 25 miles. This well was situated at the extremity of the bed of the Murgab, and further south wells increased in number, and vegetation became more general. Traces appeared of former cultivation, and on the 21st of May, after 17 days' journey, they entered Merv. 


\section{CHAPTER LXXVI.}

\section{MERV AS ANNEXED.}

The fortress of Kaushid Khan.--Irrigation and vegetation of the oasis. -Merv Tekkes: their number, divisions, and distribution, with agriculture, manufactures, and trade. - Their religious and moral characteristics.-Their lawlessness at home and atrocities abroad.-Persian slaves.-Submission of Mervis to Russia.-Explanations of the Moscow Gazette.-Suspicions of Russian intrigue.-Dependence of Merv on Khiva.-Signs, in $188_{3}$, of coming submission.-Partial opposition to Russian rule.-The present situation. $1 \begin{gathered}\mathrm{HE} \text { journeys of O'Donovan, Alikhanoff, and } \\ \text { others have served to remove many false im- }\end{gathered}$ pressions, and to give us a fair idea of Merv as it is, namely, a huge fortress, called Kaushid Khan Kala.

The "Kala" forms, as Benoist-Méchin says, "a truncated cone," of which the base is wanting, for it is finished only upon three sides. In those sides, moreover, are numerous breaches. ${ }^{*}$

The fort, built in a loop of the river, is protected on

"The history of this is that when, in 1873 and subsequently, the Russians were supposed to be coming, the divisions of Turkomans were summoned in haste, each to perform a certain part; but the Saryks, to whom the fourth side was allotted, did not answer the summons before the fear of invasion was over.

The enclosure is about 2 miles long by 1 mile wide at the bazaar. The length of the walls Alikhanoff gives as about 3 miles, and he speaks of the profile as frightful, the earthwork being 80 feet thick at base, tapering to 30 feet at summit, and 35 feet high. There is no regular 
two sides by the Murgab, which here is 50 paces wide. The depth in some places reaches 23 feet, but in others horses can ford it.*

The Merv country, Alikhanoff says, is not a natural oasis, but the soil and vegetation are the same as from the Attek to the Oxus. The entire expanse, he says, excluding, of course, the sandy patches, might be made to have the same aspect as Merv, if watered. In fact, canals exist on all sides, showing that at one time the land, which now is a waste, was cultivated. $\dagger$

The ground is very fertile, and is covered with crops of wheat, sorghum, sesame, rice, cotton, and barley. The gardens produce abundance of melons, which are considered good enough to be exported to Deregez, and even to Mashad, where rich people send them to one another as presents. The Merv gardens sometimes swarm with red beetles, called kekene; these, like ditch, but inside and out is a broad and shallow excavation, formed by digging away the earth for the wall. There are in all 8 openings or gates. It was constructed mainly to afford shelter to the surrounding population in the event of an enemy appearing.

- Benoist-Méchin gives the width of the river as from 80 to roo paces near the fortress, and nowhere fordable (I suppose in spring). There were, until recently, 3 bridges, but only one now remains. Across the river, where it enters the oasis, Kaushid Khan built a dam. Here the stream, 80 yards wide, is not fordable, the water being raised to make it flow over the adjoining country, giving a difference of level between the Upper and Lower Murgab of 7 feet. This dam, called Kaushid Khan bent, diverts the water among the two sections of the oasis by means of two main canals, the Otamish and the Tokhtamish. The small remainder of the water flows along the natural channel, whilst each of the two canals distributes water through about 50 leading arteries, and these in turn feed hundreds of smaller leats.

† Like the Khivan oasis, that of Merv consists of a clayey plain, intersected here and there by sands. It is about 40 miles broad and long, with an area consequently of 1,600 square miles, or the size of the county of Kent. The river divides the expanse in two almost equal parts, north-east and south-west. The whole of the land between the canals is surrounded by clay walls. Merv is far from being as well cultivated as Khiva, for the Tekkes are both unskilful and idle. 
locusts, destroy the entire melon crop. It was so in I88I. There is also a disease called sheere, which causes the plant to wither. The fruits grown at Merv are apricots, grapes, and mulberries.

Alikhanoff estimates the number of the Mervis at 46,000 kibitkas, or 230,000 souls. Of this number 36,000 tents belong to the Tekkes, whom Kaushid Khan brought with him from Sarakhs to conquer the oasis. As conquerors they exercised authority over the land and canals. The remaining 10,000 tents consist of casual arrivals from the Akhal tribe, the Saryks, Salors, Ersaris, and others, with 26 Jewish families. All this remnant, except the Jews, who only trade, hire land and water from the sovereign tribe.

The Merv Tekkes are divided into the Otamish, formed of the two clans Sitchmaz and Bakshi, and the Tokhtamish, formed of the Vekil and the Beg.*

About 6,000 tents of the Beg tribe, Colonel Stewart says, are generally pitched near Kaushid Khan Kala, where each chief has a guest-house of mud or sunburnt brick, but they themselves live either in tents or, in places where reeds are plentiful, in reed or mat huts, similar, I suppose, to those I saw on the banks of the Oxus, and which can be carried away on camels. They struck me as the poorest of habitations, and inferior by many degrees to a felt tent. The semisettled population generally is disposed around Merv

* The Otamish occupy the south-west, and the Tokhtamish the remainder. These clans are further subdivided into 17 branches. The Saryks are divided into those of Yulutan and Penjdeh, the latter declaring themselves Afghan subjects, and foes of those of Yulutan [M. Lessar says :- " Foes of the Tekkes of Merv, but not of the Saryks of Yulutan "], who number, according to some, about 4,000 tents, but Petrusevitch says 6,500 , or $1_{3}, 000$ in all. The Salors are mingled among the Tekkes. 
at a distance of about a day's ride in groups of two or three hundred tents.

The principal occupations of the people are agriculture and cattle rearing, omitting plunder, which until recently was the chief pursuit of the Turkomans.*

A few artisans are to be found, such as smiths, bootmakers, saddlers, and silver workers, but, says Alikhanoff, they are all inferior workmen. Colonel Stewart, on the contrary, says they make very good gunpowder, and are clever in manufacturing false Persian money, with which they flood the bazaar in Muhammadabad. Both authors agree, however, respecting the carpets of the Turkoman women. They are similar, the Colonel says, to the ancient Persian carpets that fetch so high a price, and cannot now be made in Persia (though I have seen some good ones in the Colonel's own collection). He adds that their felts, and the rough cloth they manufacture from sheep's wool, are far superior to any made in Persia, and they also weave a thick material of the appearance of alpaca, that is costly. In fact, he declares everything the Turkomans make, except their coinage, is good.

On Tuesdays and Saturdays a market is held at Merv in the square between the fortress and the river, where 7,000 or 8,000 men assemble, but no women. $\dagger$

The Turkomans are Muhammadans of the Sunni

- The population owns 242 flocks, or about 160,000 sheep, and 26 herds, or, say, 7,800 camels, to which Alikhanoff adds 11,500 horsesthat is, one to every four tents-25,000 donkeys, and 46,000 cattle.

With regard to agriculture, he adds that two-thirds of the population sow a tchooval (250 lbs.) of wheat to every tent. Wheat yields 20 -fold, and sorghum from 200 to 300 -fold. The people use large quantities of sesame oil with their food, but half the seed whence it is expressed is brought from the Tejend and Attek. Cotton is exported to the extent of 100 camel-loads, but silk is only slightly cultivated.

+ The crowd circulate about roofless enclosures, wherein, on the bare 
division, but are guided more by custom than by the precepts of the Koran, unless it be the injunction which enjoins war upon Kafirs. The Persians being Shias are regarded as foes, which fits in with the Turkomans' love of taking them into slavery. When Shias, however, are not to be had, they sometimes take Sunnis, and torture them into saying, in the presence of witnesses, that they are Shias, and then enslave them. Also they give a portion of their spoils for religious purposes. The ishans, or priests, are few, and have little influence. Mr. Condie Stephen was shown a Turkoman place of worship, about $\mathrm{I}_{5}$ feet long, at Annau, but I do not remember reading of another. Near the fort at Merv, however, is a boys' school, with five or six houses for the mullah teachers.

Alikhanoff certainly does not give the Mervis a good character. In addition to their being pilferers and thieves, he says they are liars and gluttons. "No matter how much sugar and how many biscuits are served up with the tea, whatever is left is carried off in the visitor's pocket without any ceremony." I am a little surprised at his making this last remark, because, as I passed through Bokhara, it was expected that my servants should take away all that was left, and they had looked forward to it as their perquisite, so that when taking refreshment with Alikhanoff the Mervis would seem to have followed local usage.

ground, traders expose Moscow chintz, Persian sugar, opium, green tea, dried melons, tobacco, Bokhariot samovars, and cotton, but, except a few carpets, little that is of home-make or valuable. Here trade the Jews, who are treated better than in Bokhara, each for a consideration being taken under the protection of some powerful Turkoman. Kostenko gives the following prices of produce in Merv: A batman (1) poods, or 45 lbs. Eng.) of flour costs $5 d$., or, say, Is. per cwt. ; wheat $10 d$.; millet $10 d$. ; rice $3 s$. ; a sheep $8 s$.; and a cow $18 s$. 
The same writer adds: "They are frightfully envious; they have no notion of decency or shame; and, finally, among all the Turkomans there is not a people so unattractive in every respect, morally, as the Tekkes of Merv. Further, the licence of individual will is carried to an extreme. Perpetual quarrels exist between the branches of the various clans, and there is an utter absence of any organization to keep a check upon disorder."

This brings me to speak of their government, concerning which a short and easy method would be to say, "They have none." They acknowledge no authority, and every Turkoman is supposed to be free. All that they respect is force and deb, or custom, and in bowing to custom each tries to forward his own interests without regard to those of the community. The common welfare makes them combine to a certain extent for the regulation of the water supply, and also in time of war. Each clan is divided into families, that elect a person called a khetkhoda, who acts representatively, says Colonel Stewart, in matters of policy, though only according to the wishes of the clan. Merv has about two dozen khetkhodas.

In some of the clans one family has rendered itself more powerful than the others. Such is the family of Kaushid Khan, and such was the family of Nur Verdi among the Vekil clan. In times of danger the khetkhodas elect some person, who, by family influence and resoluteness of will, obtains paramount power for a time. About I 868 Nur Verdi Khan enjoyed absolute power in the Akhal, till, wearied with the incessant dissensions of his people, he abdicated and retired to Merv. He was the leader of the resistance 
against Lomakin in 1879 , but died in the winter of that year, and was succeeded by his son Makhdum Kuli Khan. Makhdum Kuli Khan was another instance of supreme power vested for a time by the Akhal Tekkes in an individual. Thus, in a certain fashion, the people might be said to have elected for themselves aksakals and khans. Some of these could exercise influence, but they could not enforce the execution of any regulation.

Without laws at home, the Merv Tekkes were many degrees worse than lawless in their forays abroad. Previous to the establishment of Russian settlements on the Caspian the Turkomans were complete masters of the Steppe, and attacked, not merely individuals and caravans, but entire villages on the borders of Bokhara, Khiva, and especially North-Eastern Persia Northern Khorassan was devastated by them, and on the east side of the Heri Rud alone, out of 460 villages, less than 20 now remain. So recently as 1878 an immense body of Merv Tekkes approached within 5 miles of Mashad, that has a population of 70,000 , and laid waste a village of 500 families. On such occasions the raiders take away as many men and women as suits them to keep or sell for slaves, and the rest they usually kill, or sometimes maim by cutting off hands or feet. The cattle are driven away, and everything else of value is carried off.

Colonel Stewart says, "No one in England has any conception of the fearful sufferings of the slave trade that has been carried on by the Turkomans." He believes the number of slaves in Bokhara, Khiva, and Turkmenia itself, a few years since amounted to more than 100,000. I observe the Baron Benoist-Méchin estimates, on what he considers good information, that

VOL. II. 
within the last 40 years the Turkomans took away from Persia about 200,000 captives. ${ }^{*}$

Such, then, was Merv, and such the character of its people when Russia, by the conquest of the Akhal, became its near neighbour. The steppe was so unsafe between Mashad and Charjui that a caravan could not travel without a military escort, and the raids on Persia continued, to say nothing of the pillage of Turkomans under Russian protection. Accordingly there was no lack of seers who prophesied that Russia must sooner or later take Merv. As I passed through Central Asia I did not hear much about it among the Russians, but the Khan of Khiva seemed to think so.

By the journeys of Alikhanoff, Lessar, and Naziroft, it will have been seen that the Russians had become acquainted, through practised eyes, with the routes converging upon Merv from the three Russian military centres of Askhabad, Petro-Alexandrovsk, and Samarkand. This reminds one, of course, of the attack upon Khiva concurrently from north, east, and west, but I am not aware that any active preparations for war had begun, or that the capture of the oasis had been determined upon; but if it had, the Russians were spared the trouble of fighting, and England was

* The sufferings of the slaves, says Colonel Stewart, while being carried off are terrible, as they are lashed on a horse's back behind their captors, and allowed little rest till they reach the oba. Then they are heavily ironed, a ring being passed round the neck and one round each leg. From these rings there are chains fastening the legs together, and a long chain from the neck ring, which is fastened to a tent peg. The Colonel saw prisoners fastened in this Turkoman manner at Muhammadabad. Alikhanoff, in 1882 , found Persian captives in Merv, who had been kept in chains since 1860 , with the hope that friends would ransom them. The Baron Benoist-Méchin, on the other hand, in the following year, saw none in chains. He says, however, they affirmed that in the previous year a thousand slaves were chained every evening, and that there remained 20,000 slaves throughout the oasis. 
suddenly surprised in 1884 with the information that the Tekkes of Merv had spontaneously given themselves up to be subjects of the Tsar!

The Russian Official Messenger, February 2nd (14th), published the following telegram, addressed to the Emperor by General Komaroff, chief of the TransCaspian region, dated 3 Ist January (O.S.) :-

"I am happy to inform your Majesty that an assembly held this day at. Askhabad, of the Khans of the four Turkoman tribes of Merv, each one of them representing 2,000 tents, declared themselves unconditionally subjects of your Majesty, confirming the same upon solemn oath taken on behalf of their own selves, and on behalf of all the people of Merv. This decision, according to the statement of the Khans and delegates, was arrived at by the Turkomans of Merv, because they were assured of their incapability of governing themselves, and were convinced that your Majesty's powerful government could alone establish and maintain order in Merv, and ensure its prosperity."

So much for the telegram. The Moscow Gazette of February 27 th (March 1oth) thus explains the circumstances of the submission :-

"Captain Alikhanoff, charged with a communication to the elders of Merv from the officer commanding in the Trans-Caspian region, on arriving at Merv, established himself in the tent of Yusuf Khan. Yusuf Khan (aged 17) is the younger brother of Makhdum Kuli Khan, who fought with Tykma Sardar in defence of Geok Tepe. The meeting at which it was resolved to offer the allegiance of the Mervis to Russia was held in the dwelling of Yusuf Khan's mother.

"The population of Merv consists of two tribes, sub-divided into four branches. The Khans of these four branches joined in the deputation. The oasis of Merv is divided into 24 sections of canals; each of these sections has 2,000 tents, and these sections were represented on the deputation by 24 elders. The deputation was thus a thoroughly representative one. The deputies, 28 in number, proceeded with Captain Alikhanoff to Kolibend, on the Tejend river, where a Russian detachment under Colonel Muratoff was encamped. The petition of the people of Merv to be included among the subjects of his Imperial Majesty was here presented. It was written in the Tatar dialect, on an immense sheet of parchment (the size of a newspaper sheet), and was signed by all the deputies. Accompanied by Colonel Muratoff, the deputies [were] marched to Askhabad, reaching the Russian head-quarters on the $25^{\text {th }}$ 
January (o.s.) They presented a fine spectacle in their gorgeously brocaded robes.

"The oath of allegiance was administered to them on the $3^{1 \text { st }}$ of January (o.s.) All the superior officers in the Trans-Caspian region were assembled at the residence of the chief commanding officer.

A Tekke Mullah from Geok Tepe came upon the scene with the Koran, when the 24 (sic) Turkoman deputies ceremoniously entered the hall. General Komaroff greeted them, and addressed the Turkomans, who were offering their allegiance, in glowing terms. The oath was administered to the Khans according to law, the deed was drawn up, and the signatures were appended. All the documents referring to the annexation of Merv have been brought to St. Petersburg."

According to information subsequently furnished by the English and Indian newspapers, ${ }^{*}$ the course of events is represented somewhat as follows: In November, 1883 , the Persians on the border, suffering from the raids of the Mervis (some put it vice versâ) asked help of the Governor, Komaroff, who sent troops to intimidate the Mervis, but with orders to stop short of Merv by 100 miles, whilst Alikhanoff, with a small guard, went on to Merv, with a letter to one of the Khans. Alikhanoff is said then to have recommended the submission of the alarmed Mervis, naming as terms that they should renounce slavery in future, liberate their slaves, and give up their Persian booty. To this they are said to have agreed, and to have liberated. among others, 37 Russian subjects. Further, a number of representatives accompanied Alikhanoff on his return journey, and gave in their submission.

Some weeks afterwards, according to Indian news, and before the representatives had returned, a Turkoman who had been at Merv says that certain Khans, Baba and Kajjar, did not acquiesce in the submission, and that when the Russians again approached

- See Times for roth March, 3rd April, and 12th May, 1884; Standard, 8th March ; Morning Post, 24th April ; and Pioneer Mail, 14th May, 1884 . 
(to take possession?) they halted, as before, at a distance, and induced the two malcontents to appear. To Baba Khan they gave a khalat and 600 tomans $(£ 275)$, and offered the like to Kajjar Khan, who would not accept, but summoned his tribe, and, in a skirmish with the Russians, lost three or four men before they were dispersed, when further opposition was seen to be useless.

These accounts have given rise to the suspicion that Alikhanoff summoned the chiefs, and by mendaciousiy representing the Tajand force to be the advanced guard of a great army, induced them to proceed to Askhabad and submit; or, in milder words, that the elders of Merv were coerced, cajoled, and menaced into submission rather than that the people of Merv made a voluntary offer of allegiance to Russia - that the thing in fact was planned by the Russian authorities.

I cannot deny there are some grounds for this suspicion, and, in the absence of fuller information, it is a weak point in Russia's armour that we are not told the contents of the letter that Alikhanoff carried. On the other hand, the evidence against Russia does not appear to me conclusive. If any other testimony has been given that Alikhanoff coerced, deceived, cajoled, or menaced-it has escaped me. It has been said that from the fact that no maslakhat or medjliss was convened at Merv, it may be denied that the elders thereof acted in a representative capacity. But is this inference quite safe? Because, in the scanty information that has reached us, we are not told of a meeting having been convened, are we justified in assuming that none was held? or, supposing that no meeting were held, and in the face of Colonel Stewart's information that "these families have each a person 
called a Khetkhoda, who acts for the family in matters of policy," are we justified in taking for granted that the 24 elders and 4 Khans were not acting in a representative capacity?

I suspend my judgment, however, on another ground, inasmuch as it seems to me that the submission of the Mervis was precisely what might have been expected. Coming events had been casting numerous shadows before them. I have shown in a previous chapter that, ever since the reign of Peter the Great, certain clans or families of Turkomans have from time to time seen it to be to their advantage to place themselves under Russian authority. Internal dissensions caused the Kirghese to do the same, till one horde after another was absorbed. So with the Turkomans, amongst whom all writers agree in saying there was neither law nor order, and consequently no security for right against might. Before Russia conquered Khiva, the Mervis were, to a certain extent, under the Khan; and they evidently tried to cling to Khiva to the last.

In one of my interviews with the Khan, his Highness asked me to whom Herat belonged.

I replied, "To Afghanistan."

Then he asked whether Merv belonged to Russia or to England.

I said that it belonged to neither, but was supposed to be independent.

"Once," he said, "it was independent, but the Khivans took it 60 years ago," and it was only on the coming of the Russians that their allegiance had been disturbed, but that lately the Mervis had sent to him wishing to pay taxes, and he had sent a man to receive them. Accordingly he argued that Merv belonged to him, and as he belonged to Russia, Merv must 
belong to Russia too. This was a logical sequence, from which there was no escaping, and, therefore, I laughingly replied that if his Majesty had no objection I had none.

A few days later we met an intelligent native, who confirmed, in a measure, the foregoing by saying that two years previously ( 1880 ) a hundred men from Merv came to the Khan asking him to rule them. The Khan received them, and gave them presents, and, like a good vassal, sent them on to the Russian authorities at Petro-Alexandrovsk, by whom they were also well received. The deputation then, returning to Khiva, showed their true character by robbing the Sart inhabitants and making off. In the following year they deputed others to ask pardon; and before this the Khan had sent a representative, but up to the time of our conversation the Mervis had paid no taxes.

This was at the beginning of November, 1882, and I now learn from the paper of the Baron BenoistMéchin, that at the beginning of May--just six months afterwards-another embassy came from Merv under Kara-Kul-Khan, chief of the Begs. This chief, says the Baron, had heard of the intended coming of General Chernaieff to Khiva, and had set out to meet him. He wished to obtain from him a delegated Khivan to govern the turbulent Tekkes. The envoy was appointed, and the two Frenchmen travelled with him to Merv. And what was his reception?

The Baron says: "Kara-Kul-Khan was, at the time of our stay at Merv, the strongest and most renowned chief in the country. He had acquired great notoriety by his forays and his expeditions before becoming a political chief. His raids were celebrated in all the steppe, and even Khiva had seen him beneath her 
walls. In spite of the popularity he enjoyed, however, he was far from obtaining from his people absolute obedience; and when Kara-Kul-Khan wished to instal their newly-imported governor from Khiva, he saw well that this fresh attempt at government would quickly share the fate of others. Discouraged, and in despair, he came to tell us he saw well that nothing but Russian bayonets would bring such a turbulent population to reason, and went so far as to speak of his countrymen as robbers and brigands.

" This conversation, among others we had with him and with other Turkomans, witnessed to so great a laxity in the existing state of things, and to such a lack of any government whatever, that, after our arrival, in the month of July, we did not hesitate to write to General Chernaieff, it seemed to us that the Merv oasis would submit without fighting at no distant date." Within six months it had come to pass, and the Baron adds, " The event, happening more quickly than we supposed, has shown us to be right."

In face, then, of these considerations, I see no need for Russian coercion or duplicity; nor do I see much to be surprised at if, in marching to take possession, the troops were attacked.*

It is extremely unlikely that there were no dissentients in Merv. At the taking of Tashkend, one party promised to open the gates to the invaders, but another party opposed them. Even in the little town

* Private information from an officer who was present has reached me (but at second or third hand), that the Russians approached Merv with about 600 troops, and that every night the Turkomans hovered round and harassed them to such a degree that the soldiers, wearied with being kept so on the alert, began to talk of going back. But one night the Turkomans did attack the Russians, who fired a volley and emptied 50 saddles, after which the Turkomans troubled no more! 
of Hazret the inhabitants shut their gates against their own returning warriors, and in favour of the invaders. So, again, I was told by one native that had the Emir died during his recent illness, the Bokhariots were ready to welcome the Russians ; but on speaking to another native, he said, "No, they should fight." And thus it may very well have been at Merv, though 1 offer this only as a suggested corroboration of the newspaper accounts, together with certain considerations that have not been made public so fully before. Whether my suggestions are right, time perhaps will show.*

Meanwhile the Russians are beyond Merv, and a question of interest is-What next? Will Russia conquer India? There are in England some wise heads who think she will attempt it, and their opinions are not to be lightly treated. When looking at the question from the Upper Oxus, and the possibility of an invasion of Afghanistan from Samarkand, the undertaking presented itself to my mind as attended with colossal difficulties, suggested in part by my own little experience in crossing the desert. But if the approach be from the Caspian, these difficulties vanish now that the Russians are masters of Merv, and the country between it and Herat carefully surveyed. There is already a railway from the Caspian to Kizil Arvat, and there is no reason of a physical nature why it should not be continued on shortest notice to Sarakhs. M. Lessar says there is no

'As a final note M. Lessar adds:- - "I have made remarks about certain facts, and in no wise touched upon the political side of the question. I think it, however, indispensable to say that with many things in the four chapters (Ixxiii.-lxxvi.) I disagree, especially with regard to the occupation of Merv.

$$
\begin{aligned}
& \text { (Signed) " P. LESSAR, } \\
& \text { " woth March, 1885." }
\end{aligned}
$$


serious ascent along the whole of the route he surveyed. Indeed, all the way from Askhabad to Sarakhs there are only some seven miles of road "where, in constructing the railway, it would be necessary to make use of the shovel," and then only because of a few sand hillocks, which occur midway between Annau and Gavars.

The distance from the Caspian to Kizil Arvat is 144 miles, and the railway cost, M. Marvin says, $£ 648,000$. From Kizil Arvat to Askhabad is 135 miles more, and from thence to Sarakhs, according to M. Lessar, an additional 186 miles, beyond which it is only 200 miles of easy country to Herat. The cost of continuing the line to Sarakhs, M. Marvin estimates at about a million and a quarter of money, and nearly another million to Herat; in all, $\oint_{2}, 192,000$. In other words, the length of the extension to Sarakhs would be the distance from London to Penzance, and its cost not so much, I presume, as was required for making the line from London to Brighton.

The railway, however, is needed for nothing but strategical purposes, and need not be considered at present if Russia is content to remain at Merv. There she has abundant scope for what she considers her mission of civilization. Nor is this a mere empty expression. After seeing Bokhara and Khiva under Asiatic rulers, and Tashkend and Samarkand under Europeans, I should be false to my convictions if I withheld my opinion that the natives have been gainers by Russian conquest. Hence, now that Merv is annexed, if there are any who would rather see it revert to its old condition of lawlessness, slavery, and blood, I confess 1 am not one of the number; but what may be the bearing of this upon political questions, I leave to others more competent to decide. 


\section{CHAPTER LXXVII.}

FROM KRASNOVODSK HOMEWARDS.

Descent into Krasnovodsk,- Hospitality of the Commandant.-Dismissal of native attendants.-Our rate of travel and itinerary.Mertvy Kultuk and Kizil Arvat routes,-Visit to Merv abandoned. -The town of Krasnovodsk, and its scanty supplies.-Visit to a Turkoman oba.- Turkoman women and jewellery.-Armenian trading.-Passage across the Caspian.-Baku and its oil.-From Baku to Tiflis in a horse-box.-Bible distribution from Tiflis, Scenery at Batoum.-Voyage to Odessa.-Summary of journey, and farewell.

L RASNOVODSK was in a measure familiar to me by name, from its frequent recurrence in Trans-Caspian affairs, and I had expected to find it of urban proportions. The part we looked down upon, however, on the memorable morning of the 22 nd November, reminded me rather of an English coastguard station, with a miniature pier alongside. But in truth we viewed it from a considerable height, for Krasnovodsk lies on an arid flat below towering rocky cliffs, down whose precipitous scarp we were to crawl by a sinuous path, somewhat similar to that by which I descended into the Yo-Semite valley. The camels would have to be led slowly, and as we were under the impression that the steamer we could see at the pier was to leave that morning, there was no time to lose ; so I suggested that Sevier should come with the 
camels, whilst I trotted forward to act the postman in delivering the Governor's letter.

I think Diotrephes was pleased to get back to human habitations, for, tired as he was, he galloped famously towards the fort, though it required all my horsemanship, especially as I had lost my whip, to induce him to step over some tram rails that were new to him. Wishing to give the poor animal a drink of good water at the first moment possible, I rode into the yard behind the Commandant's house; but I fear I cut a sorry figure, for my unkempt appearance and few words of Russian elicited only scanty deference from the orderly I addressed.

I made my way into the office of Colonel Charitonoff, but found no French-speaking clerk to whom I could communicate who I was and whence I hailed, nor could I do much better with the Colonel himself till Sevier arrived, though my letters immediately secured me hospitality. This, we were given to understand, would have awaited us, whether we had letters or not.

The camels were led into the yard, and the patient, soft-eyed creatures knelt for the last time to be relieved of our burdens, after which, on dismissing the natives, I paid Rosy his balance, made Nazar a present of most of my equipment and remaining provisions for desert travel, and gave him a letter to General Grotenhielm, to return with the tent and barrels so kindly lent us. Afterwards, on telling the Colonel how long the journey had taken us from Kunia Urgenj-14 days to do 403 miles,-to our surprise he said that caravans following the same route usually took 20 days, and 1 have recently been informed that Dr. Vanorden was 25 days on the road 
from Krasnovodsk to the Khivan border.* The Times correspondent with the Afghan Frontier Commission reported that the average rate of marching from Nushki to Kuhshan ( 770 miles), "including halts, was over 15 miles a day," and he adds, "This, I think you will admit, is a very remarkable rate of marching." Since, therefore, our average, including halts, amounted to about double this rate throughout. I suppose 1 ought to have been more thankful than I was at the time.

We had come by what was, I suppose, the easiest road for us ; but had there been steam communication with Mertvy Kultuk, we heard of a road thither which was said to be fit for vehicles and to have pasture for both camels and horses. The Times of August 22nd, I $88_{3}$, gave a description of this "New Route to Central Asia," lying between the Caspian and Kungrad, a distance in all of 295 miles, over which the longest portion destitute of water does not exceed 30 miles. Some have talked of making a railway in this direction to connect the Caspian with the Oxus. There is, however, as usual in Russia, an awkward difficulty in the way, for the Bay of the Caspian is so shallow that large

* Our itinerary from Khiva to Krasnovodsk was as follows :-

Nov, 2 Khiva

"2 Shakhavat

" 2 Ambar

" 3 Tashauz .

$" 4$ Iliali

3. 5-8 Kunia Urgenj 60

", 10 Karategin wells of 40

") 10 Mashrek ruins . 28

3. 10 Halting Place . 5

n. Io Ak Bugut. . 13

II Jeduruntha

(hait) . 14260

" 12 Dekche . 8268

i.e., 764 versts in 17 days' travelling, or 45 versts (or 30 miles) per day.

\section{Versts.}

Nov. 12 Sary Kamish + 17285

„13 Kaplan Kir

, 15 Uzun Kuyu

" 16 Kazakhli . . $147 \quad 432$

, 17 Kum-sebshem . 38470

" I8 Seikhis Khan . $40 \quad 510$

„19 Tuar. . . 54564

" 19 Portokup . $\quad 34 \quad 598$

,2 20 Demerjan . 72670

", 2 I Suili . . . 24694

" 22 Krasnovodsk . $70 \quad 764$ 
vessels cannot approach within 20 or 30 miles, so that when General Chernaieff officially opened the new route, and arrived at the coast, the steamer for which he had telegraphed was not to be seen, and he had to gain the open sea in a fishing boat before he found a vessel to take him to Astrakhan.* I have already spoken of the shallowness of the Lower Oxus also, so that there are several obstacles to be overcome before water communication can be made extensively available.

We found that the smaller steamer, or rather tug and barge, had not ceased plying for the season between Krasnovodsk and the railway terminus at Mikhailovsk, as we feared at Petro-Alexandrovsk might be the case; for it must be borne in mind that, when one reads of the Trans-Caspian railway from Krasnovodsk, this is a figure of speech, and would-be travellers from the large steamers have to disembark at this place and be taken across the bay some 50 miles in a smaller craft, there being no other regular means of communication. Hence we were told we could have reached Kizil Arvat from Khiva in five days, and have come on to Mikhailovsk in a few hours. We should by this means have peeped into the Akhal oasis, where I was informed there were at that time between Krasnovodsk and Askhabad 10,000 rifles, about 2,000 cavalry, and 5 or 6 batteries of artillery.

Also, we should have been within 400 miles of Merv, but I had decided not to go thither, for I had already exceeded my limit as to time, and surveying officers were coming off the steppe, thereby implying that the

* Concerning other parts of the Caspian shore, Hasan Kuli Bay, where the Atrak disembogues, is only 3 feet deep, and choked with reeds. From Tuik Karagan spit to Balkan Bay, however, there is a good depth of water, the best anchorages being in Alexander, Kinderli, Balkan. and Michael Bays. 
season for outdoor work was over. I was told that I might be some time at Kizil Arvat before I found a suitable guide to take me a journey on which I might have to battle with the elements as well as the Turkomans; and, finally, I could not learn that, when I reached Merv, there would be anything special for me to see or do, since I had no more books to distribute. Whilst, therefore, I was thankful to have come thus far, and by the way that I did, I determined to turn my back upon Asia, and telegraphed to London, for $6 d$. a word, my return to civilization thus: "Arrived through Bokhara down Oxus and across Aralo-Caspian desert from Khiva-telegraph, if necessary, to Tiflis," to which place I had now to make my way as quickly as possible.

But it was not so easy to get across to Baku at a moment's notice. The summer steamers had ceased plying, and the boat we saw waiting was to proceed south to the Persian coast. We had time, therefore, to look about Krasnovodsk, which we soon voted a sorry place. In 1877 , a correspondent of the Golos wrote:- "Krasnovodsk has now grown almost into a town, has become populous, and very animated "; but if so, it must have since come down in the world, for my note-book gives the population as only 400 Persians and Armenians, and 1,000 Russians, of whom 800 were military.

Besides this, I think I never saw a town for which nature had provided so scantily, and my non-strategic mind was puzzled to know why the Russians had built their fort in such a place, where the population, if left to their own resources, must speedily starve. There are no wells of good water, and they have, consequently, to distil it from the Caspian at the rate of 16,000 gallons 
a day. There are also two engines at Mikhailovsk for a similar purpose, one of which distils 260,000 gallons, and the other half this amount per diem, to be sent along the line to waterless places in the desert. Moreover, there was not a blade of grass to be seen. There was a solitary cow tethered before a bundle of hay, and a few bushes planted in what was meant to be a public garden, but I cannot recall the sight of a single tree throughout the place.

It might be said, in fact, of Krasnovodsk as of Tyre and Sidon, that "their country was nourished by the king's country," * for almost everything had to be brought from Baku, Astrabad, Astrakhan, or adjacent parts of the Caspian. Hence provisions were dear. They had no pheasants, as at Khiva; beef cost $3 d$. a pound, mutton $2 \frac{1}{2} d$., and eggs from $4 s$. to $6 s$. a hundred.

One thing in which Krasnovodsk seemed to be rich was mineral oil in its various forms. About 30 miles distant is the island of Cheleken, where are said to be 3,000 springs of naphtha, that supply the fuel for the distilling engines. I was also informed of naphtha works on the Kizil Arvat line. Large supplies of mineral wax have been discovered on the north of the Little Balkans, for the carriage of which a branch line has been constructed. There is at Krasnovodsk a grotto of alabaster, and salt obtained from the islands and lakes is exported for about $6 s$. a ton.

The only other produce of the place I remember hearing of was fish, caught by Turkomans of the Shikh tribe, living by the sea, a mile or so outside the town. To visit their collection of tents gave us something to do on the second afternoon of our stay. The 
Colonel provided us a native for interpreter and guide, and we galloped off to the oba. It was by no means a large one, and the cause was speedily to be traced to the horrible practices of the Tekkes, who had made a raid upon this tribe some time before, and taken from them nearly everything that was valuable.* The tribe was said to number 200 tents, of which there were about 70 in this neighbourhood. There were not many men at home, but, introduced by our guide, the women did not object to our entering the tents, and looking at what we pleased, including their own

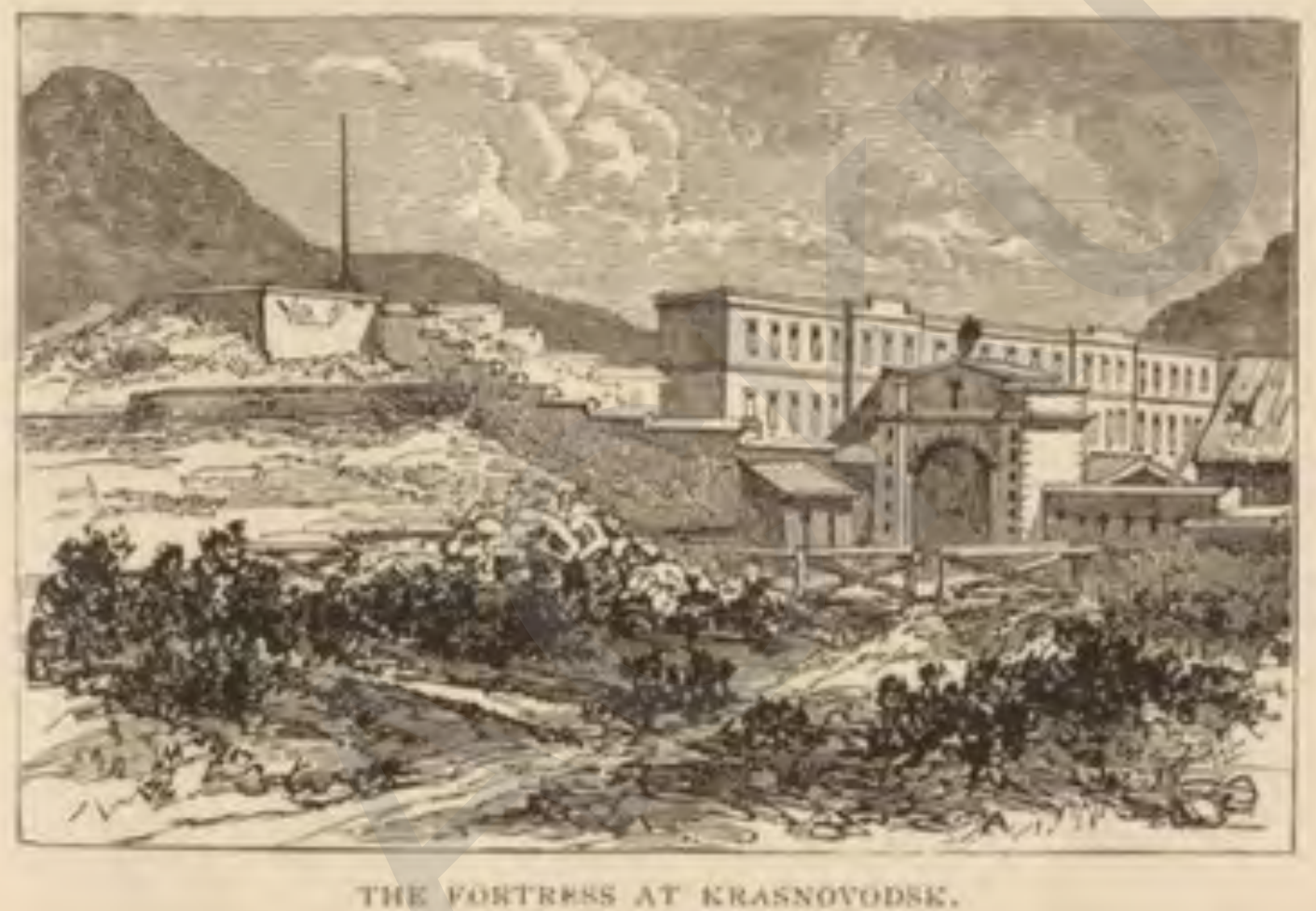

jewellery. Most of this latter was of silver, but in the first tent we entered the woman had a pair of gold earrings, for which she asked £io. Near another tent was a large stone mortar with a stone pestle, for cleaning corn, they said, before it was ground, but I

* Reminding one of the troublous times in Israel, when " there was to peace to him that went out, nor to him that came in ... and nation was destroyed of nation, and city of city" ( 2 Chron. xv. 5, 6)-a state of things with which Jeremiah (xlix. 29) was familiar when he prophesied, "Arise ye, go up to Kedar, and spoil the men of the East ; their tents and their flocks shall they take away: they shall take to themselves their curtains, and all their vessels, and their camels."

VOL. II. 
believe for bruising it aiso, whilst in a third was a child amusing himself with a bird tied by a string.* We managed to purchase a few curiosities from these nomads ; but the guide, seeing our bent, said he would take us to some Turkomans who were living in houses at Krasnovodsk.

We therefore returned, and saw something of the town. The most striking object is the fortress on the seashore, a large rectangular space, enclosed on the three sides by a high, well-built, stone wall, and having

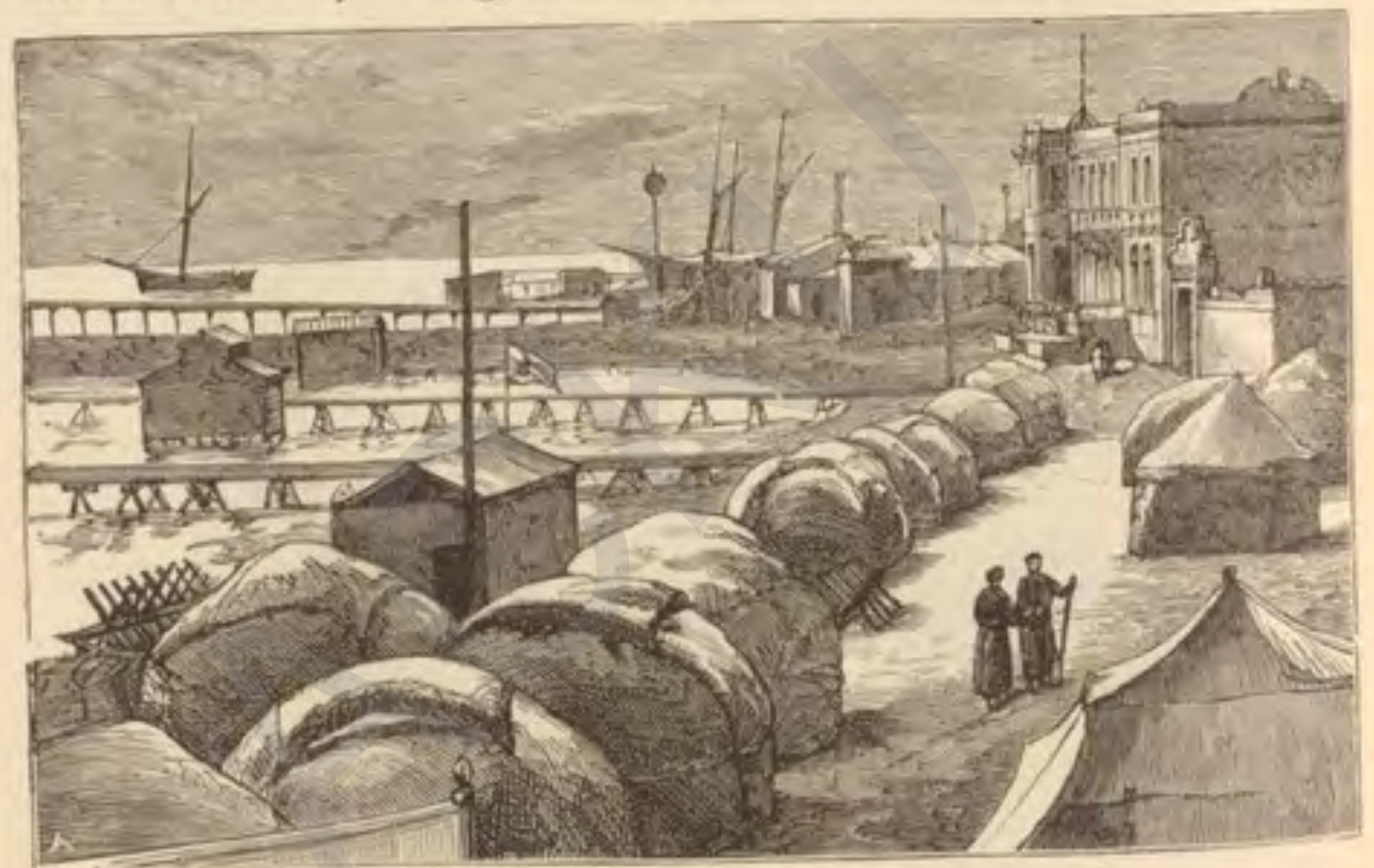

GOVERXOR'S HOUSE AND STOKRS AT KRASNOVODFK.

within it the Government offices, officers' houses, and small barracks. The place gave one the idea of a depôt for stores, which are sometimes packed under the useful Kirghese kibitka, side by side with the less bulky Russian linen tent. Some of the boats on the shore I noticed were of very primitive make, with flat bottoms, and simply cut out of the trunk of a tree.

* A child's plaything, as old as the time of Job (xli. 5), "W Wilt thou play with him as with a bird ?" ; or, as Rénan translates:"Joueras-tu avec lui comme avec un passereau? L'attacheras-tu avec un fil pour amuser tes enfants?" 
The Turkomans, Persians, and Armenians live without the fortress in flat-roofed, stone houses. Into some of these we were led through narrow passages, and shown a variety of massive but coarsely-made jewellery, chiefly in the form of amulets worn on the breast. We had an opportunity also during our stay of seeing something of the keenness of the Armenians, who in commercial transactions outwit even the Jews. I intimated that I wished to sell my two horses, whereupon some Armenians came to offer me for them 50 s. each. I deferred the immediate acceptance of the offer, thinking I might have further need of them, whereupon the fellows came on the morning of the day I was leaving to say that they could give now only 40 . each; but rather than be taken advantage of thus, and remembering that I might need them in Baku, I determined to take them across the Caspian. Rosy and Nazar called the day after our arrival, to say that they had secured some freight for a homeward passage, and nominally to bid us good-bye, but hinting also that a little more sugar, etc., would be acceptable. On giving it, I enjoined upon Nazar to take care of the letter to the Governor, upon which he swore in Oriental fashion, pointing to his head, ${ }^{*}$ and set off to recross the desert.

We started on the evening of the 24 th. I brought my baggage and steeds on board the Kumo, bound for Baku, and it seemed to savour somewhat of home when I found that the boat was built in London, and had done service first on the coast of Finland, and subsequently had been brought viâ Petersburg, through the canals to the Volga, and so into the Caspian. The first mate, too, though a Russian baron, had been in

" "Neither shalt thou swear by thy head" (Matt. v. 36). 
English service, and I was glad to hear him speak the English tongue. Several engineers, who had been engaged in surveying about Askhabad, were on board, one of whom had met O'Donovan. Indeed, I met two or three Russian officers who knew this hero of Merv.

We had to wait for the arrival of the ferry-like boat tugged from Mikhailovsk, full of cattle and passengers, and it was not until two in the morning that we started. We were at sea all next day, making a smooth passage of 190 miles, and landed at Baku early on the morning of the $26 \mathrm{th}$. The long and sometimes robberhaunted post-road from Tiflis had prevented me in I 880 o from travelling to see the "eternal fires " of Baku, and I was devoutly hoping that the railway would now be opened, so as to obviate the disagreeables of about 400 miles' journey by telega.

We went to Dominique's Hotel "Italia," and found that a train was to start in two days, but that tickets were not purchasable, and that it was difficult to obtain a pass. My way, moreover, was not made smoother from the fact that some Englishmen who had preceded me had had the bad taste to accept a free passage, and then to write to the papers complaining of the slowness of the administration. I went, however, to Baron Hübsch, the Governor, and, having presented my credentials, was told that matters should be arranged for us.

Monday was now left to visit the oil-wells at Balakhane, and the monastery of the fire-worshippers at Surakhane. The latter is empty, the last priest, I heard, having contracted a habit of paying less attention to fire than to fire-water. As for the wells, enough has been said elsewhere, and it hardly concerns 
the subject of my book except perhaps in this way. The supply of oil in this region is said to be practically inexhaustible, and should there be a demand for it in Persia and India, and its export sufficiently developed, it would give a commercial, instead of a strategic, motive for extending the railway to Sarakhs.

On Tuesday we arrived at the Baku station, as directed, at noon, with rather more than a quarter of a ton of luggage, in I9 parcels, but we did not start till half-past six; and as we were packed in a third-class carriage, with a crowd of all sorts and conditions of men, women, and children, some of whom smoked, and others snored, I cannot pretend that I slept well the first night. Better by far to have been in my tent in the wilderness! Improvements awaited me, however, next morning, for among the passengers to whom I had been introduced was M. Immanuel Nöbel, a son of the "oil king" in these parts, and his local influence had secured for him the luxury of a horsebox! This he invited me to share, so that we were now in clover, having in common our provisions and tea-pot.

The time expended on the 350 miles was nearly as long as it took me to cross America, because we sometimes had to halt for an engine that had met with an accident, or for a ballast train to be unloaded; but with all this the journey was not longer, and was more comfortable, not to add more economical, than if we had travelled by post. I was very thankful, therefore, for the convenience when on the Saturday morning early we were awakened with the intelligence that we had arrived at Tiflis.

Here I made my way to the depot of the British and Foreign Bible Society, where a letter had been 
received only the night before from the Government authorities respecting a request I made to the Grand Duke Michael in I 880 to be allowed to place New Testaments in the prisons and hospitals of the Caucasus, so that every prisoner and hospital patient might have at hand a copy in his own language. His Imperial Highness had granted my request at once, and I 2 months afterwards information had been sent me in England that, to carry out the scheme, 1,910 copies would be needed in the Russ, Polish. Armenian, Grusinian, Tatar, Turkish, Hebrew, Arabic, Persian, Greek, German, Italian and French languages. The Committee had kindly made the grant, and the letter just arrived was to indicate where the books would be placed, and to whom they should be sent. All, therefore, seemed to be proceeding correctly, though not very rapidly, and there was nothing for me to do in the matter but to wish the local agent God-speed in his work, and get forward to the Euxine.

I had telegraphed from Baku that my money should be sent from Tashkend to Tiflis, and this, after some little difficulty, I managed to get on the Saturday. Speaking of money, I may add that I made the acquaintance of Herr Bayern, a naturalist and antiquarian, who had a magnificent collection of coins, and who, when I showed him my few, congratulated me on having secured some from Central Asia, both rare and valuable, but I have not yet had time to get them properly determined.

We left Tiflis on December 4th, and, arriving that night at Poti, opened our umbrellas for the first time since the previous $\mathrm{I} 7 \mathrm{th}$ of August. The weather, however, was now broken, and on going next day to Batoum we had to wait there because of storms in the 
north of the Black Sea, before we could start for Odessa. Our delay, however, was much brightened by the kindness and attention of $\mathrm{Mr}$. Peacock, in having obtained whose services as Vice-Consul Her Majesty's Government may think themselves fortunate. He knows the Caucasus thoroughly, and speaks I dare not say how many of its tongues. Oddly enough, I had met his brother at Krasnoiarsk, in Siberia, and my portrait had already preceded me to the Consulate, as one of a party returned from a Siberian gold mine.

We had a fine view from Batoum of the North Caucasian chain of mountains, snow-capped all along, with the two peaks of Mount Elburz standing above the rest; and when, after leaving Batoum, we came opposite Sukum, I was specially interested in the view, because I am fortunate enough to possess an oilpainting by the celebrated Russian sea painter, Aivazovsky, "Off Sukum Kali," that was given me by the artist when he made his début in London, in $188 \mathrm{I}$.

Our steamer was the Puschkin, the finest for its size I have ever travelled in. The captain had been ordered, however, by telegram, to call at all the ports round the eastern coast, so that our progress was not rapid, though it gave us an opportunity of seeing something of Kertch and Sevastopol, which latter I had visited before. At length, on the morning of the

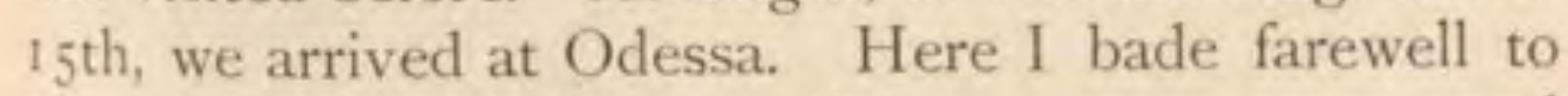
$\mathrm{Mr}$. Sevier, to whose patience, perseverance, and efficiency not a little of my success was due. He was to go to Moscow, whilst 1 , that night, thanks to help received at our Consulate, entered the train for London, and arrived on December 2 Ist. 


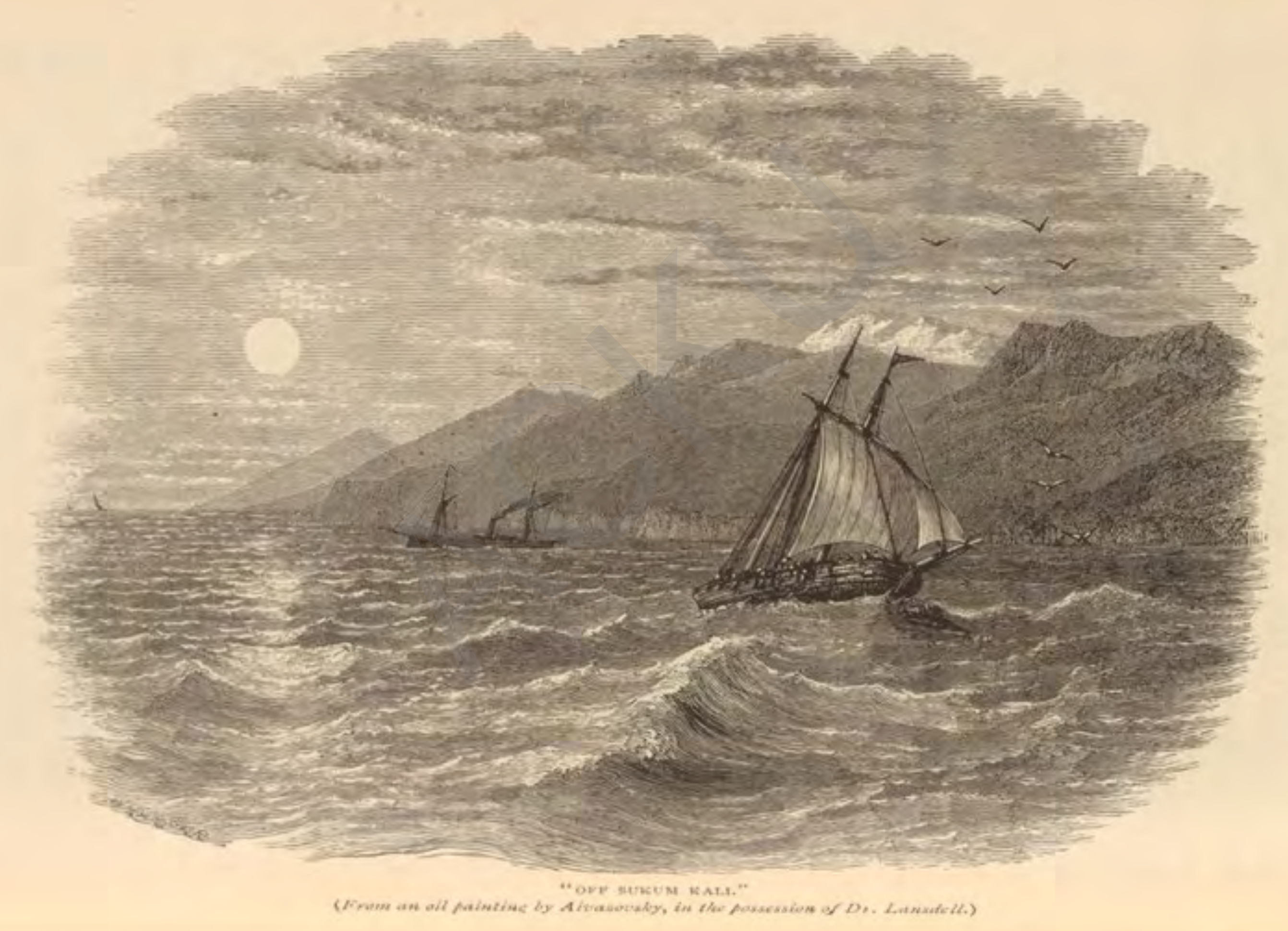


Thus ended my journey of 1 2,000 miles, during which I was absent from England 179 days, and slept in my clothes half the nights. I was somewhat exhausted by the desert journey, but not so much as I have been by writing this book, which has far exceeded the limits. I anticipated. I commenced it with the thought that, having acquired information possessed by no other Englishman living, it was in a measure incumbent on me to offer it to the public. That duty I have attempted to fulfil, and now I leave the results in higher hands. As my going to Siberia was followed by that of other labourers in the same field, so it has been already in Central Asia; and if the publication of my books shall, by throwing light upon little-known parts of the world, tend in any way to their further evangelization and conquest for Christ, I shall deem that my labour and expenditure of time in writing are justified. I have then only to thank the reader who has had patience to follow me to the end, and to bid him a kind farewell! 


\section{APPENDIX A.}

\section{THE FAUNA OF RUSSIAN TURKISTAN.}

I AM conscious of acting somewhat rashly in attempting to put together the information I have gathered respecting the fauna and flora of Russian Central Asia, because I know that to do it properly requires a larger amount of scientific knowledge than I possess. My case, however, is this. Before I had quite decided whether to make the present work a chatty book of travel, or to attempt something more solid. I went to the British Museum to ask what information they possessed of the zoology of Turkistan. A pile of Fedchenko's books was shown me, said to be full of valuable information, but lost to the major part of the scientific world, because written in Russian. That the books were beautifully illustrated only made the matter more tantalizing; but as the names of the species, and in some cases their descriptions, were in Latin, I began to examine them.

Just about this time I chanced to meet Mr. W. H. Cromie, who has translated several articles from the Russian for periodical literature, and who kindly volunteered to help me. At first I thought to avail myself of his services only to the extent of one or two introductions in Fedchenko's work, which, when put into English, promised to furnish general data for embodiment in my text. The translation, however, sped so well, that ere long the majority of the introductions were done, when it occurred to me that it might be of service to add them, with their accompanying lists of species, as appendices.

On consulting Professor Newton, of Cambridge, Dr.Günther, 
of the British Museum, Dr. Sclater, of the Zoological Society, Mr. Dresser, F.Z.S., Mr. MacLachlan, F.R.S., and other naturalists, they all commended the idea, and, what was better, several volunteered assistance. Thus encouraged by their sympathy, and further helped by $\mathrm{Mr}$. Cromie, the work was continued, and other naturalists communicated with. The result is that I am able to place before the reader in a narrow compass a certain amount of information upon the fauna and flora of the country I travelled through, which may perhaps be of some little use, until better is forthcoming. I have also been careful to indicate, when possible, where more and fuller information may be found.

Until within the last thirty years, it will be remembered, Turkistan was all but unknown to science, and autoptic writers upon its fauna and flora even now may be counted on one's fingers. Among zoological writers we have Prjevalsky, Severtsoff, Fedchenko, Alpheraky, Finsch, Oshanin, and Bogdanoff; and we will speak of these first.

If we approach the country, as the Russians entered it, from the north-east, then of the latest naturalists we have Dr. Otto Finsch, who journeyed up the Irtish, and continued southwards to Ala-Kul. Although his book is not strictly zoological, he touches a good deal upon the forms of animal life he met with, and I have embodied much of his information, when it concerns my own route.

Proceeding south to the Kuldja district, and the surrounding mountains, we have Colonel Prjevalsky's "Journey from Kuldja to Lob-Nor," wherein occur several items of zoological information, but they are not tabulated. In the case of M. Alpheraky we are more fortunate. This gentleman penetrated to the Yuldus plateau to study the Lepidoptera of the region, and captured 12,000 specimens. He has been good enough to send me in manuscript his list of 377 species, which is given furthur on.*

Proceeding westwards, we come to the regions travelled by a famous naturalist, M. N. A. Severtsoff, who, in 1867 ,

" For a list of Vertebrata observed by him, as well as further remarks upon his Lepidoptera, see Vol. i., p. 247. 
explored the Thian Shan as far as the sources of the Narin, and afterwards published his "Vertical and Horizontal Distribution of Turkistan Animals." The portions relating to the Mammals and Birds were translated, the former into English in the Annals and Magazine of Natural History, and the latter into German in Cabanis' Journal für Ornithologie. Mr. Dresser also published some notes on Severtsoff's birds in the Ibis. In October and November, 1877 , and from July to September, 1878 , Severtsoff investigated on the spot the zoology of the Pamir and the Alai. An account is given in the Ibis of his "Birds of the Pamir Range," the species of which are added to the list given hereafter. He likewise published, at Tashkend, two papers in Russian on "New Species of Turkistan Birds," and "Characteristics of the Vertebrate Fauna of the Pamir " in the Notes of the Turkistan Section of the Imperial Society of Frends of Natural History, Anthro. pology, and Ethinograpliy. I sent to this eminent naturalist my proof-sheets which bear his name in this appendix, but, before receiving his reply, news reached me from Russia, that in February last he lost his life through the breaking of the ice when crossing the Don.

There remain to be mentioned three names of zoological writers. First, that of M. B. Oshanin, who showed me his fine collection of Hemiptera, and who has published a paper of 64 pages on the Hemipterous fauna of Turkistan, also in the Notes of the Imperial Society of Friends of Natural History, etc, at Tashkend. Then follows that of M. N. Bogdanoff, whose "Account of the Fauna and Flora of the Khivan Oasis and the Kizil-Kum Desert " had been published in Russian at Tashkend a month or two before my arrival. I am indebted to this author for my information concerning the Scaphirhynchus.*

I have reserved, however, to the last the greatest author on the fauna of Turkistan, namely, Professor A. P. Fedchenko, who was sent to Turkistan as chief of a scientific expedition by the Imperial Society of Friends of Natural History, Anthropology, and Ethnograplyy, of Moscow. This society

$$
\text { + See Vol. ii., p. } 243 .
$$


drew up "Instructions for the Expedition," the preface to which sets forth the origin of the work, by whom to be done, at what cost, and on what points various societies and specialists offered suggestions or asked information. There were also enumerated lists of such fauna and flora as were known to exist in the region, with catalogues of books pertaining thereto, as well as those on its geology and ethnography.

Fedchenko's travels extended at intervals from 1868 to $187 \mathrm{r}$. In his first journey he and Madame Olga Fedchenko arrived at Samarkand, in January, 1869 , and by April had collected 7,800 zoological specimens of 1,700 different species. His explorations were on that occasion confined, for the most part, to the Zarafshan valley, whence, in the following October, he returned to Moscow.

In the spring of 1870 he started again, accompanied by Madame Olga Fedchenko, and joined the military scientific expedition to the upper waters of the Zarafshan, and to Lake Iskander-Kul. Returning in September to Samarkand, he commenced winter work, and in October completed his collection of fishes, his great prize being a specimen of the Scaphirlyynchus. In the spring of $187 \mathrm{I}$ he made a tour into the Kizil-Kum desert, and then prepared for his greatest journey, through the khanate of Khokand, where he passed along the Alai range, taking a general survey of the country traversed, and making an entomological collection, whilst Madame Fedchenko devoted herself to gathering botanical specimens. He then returned to Moscow, having collected during his travels more than 57,000 specimens, including more than 5,000 species of animals. His routes are well indicated on a map in Petermann's Mittheilungen for 1874 , and among the early fruits of these journeys appeared, in the Turkistan Annual for 1873 , his "Remarks on the Fauna and Flora of the Zarafshan Valley."

Among the vertebrates he collected was a species of mountain sheep (Ovis vignei, Blyth), not previously found in Turkistan.

In the steppe, between Samarkand and Katte-Kurgan, he found a fine specimen of Eryx jaculus, David, a serpent, 
described by Lichtenstein under the name of Boa tartarica. Almost all the serpents found by Fedchenko were non-venomous, except a species the natives call "Chagyri-gilinn," of the family of Pit-vipers (Trigonocephalus halys), from the neighbourhood of Kasalinsk, and the common adder of Europe (Vipera berus), which he found only once, near Tashkend, Of Lizards he found in the mountains of Shahr-i-sabz Stellio Lelimanni, Strauch (n.s.), Ablepharus Brandtii, Strauch, observed previously by Lehmann during his short excursion to Western Asia. J. J. Skorniakoff found another lizard in the mountains south of Samarkand, which is extremely interesting and little known. It seems to be Euprejis princeps, found in the Trans-Caucasus, and described by Eichwald.

The fishes of the Zarafshan are especially noticeable. It appears that of fifteen species found therein, not less than five, and those among the most frequently recurring, belong to the genera Schisothorax and Oreinus, which are met with in numbers in Kabul, Kashmir, Nepaul, and in the rivers of the Himalayas. To the genus Schisothorax also belongs the "Marinka," remarkable for its poisonous eggs.

Among the invertebrates were found many more new forms, constituting 50 per cent. in some of the groups of insects. Judging by comparison with known species, there appears in Fedchenko's collection a predominance of the forms, with certain deviations, of Southern Europe, Asia Minor, and parts of Africa.

Among the remarkable representatives of Coleoptera may be mentioned the beetle Copris tumulus, the largest specimen of which is an inch and three quarters long.

Sawflies are not numerous in the Zarafshan valley; but some of them are interesting because of their extreme likeness to the European species, though, compared with the typical forms, they are different in colouring. One form is particularly remarkable. With a normal male, related to the group Selandriide, is a female without traces of wings. Affected by this absence of wings, the thorax undergoes important changes, and appears greatly swollen, and all the females generally have the appearance of little bags. Its 
relation to this family is astounding, as this is the only known example of the wingless form in the whole family of sawflies. All the other specialities of structure, however, as well as the wings of the male, confirm it.

Among the Orthoptera must be mentioned two Locusts (Pachyptilus migratorius and P. cinerascens), and another called "Prus" (Caloptenus italicus). Ravages of the locust are complained of in the neighbourhood of Perovsk, and of the Prus in the Zarafshan valley, where the latter is known to the Tajiks under the name of "Malaga," and to the Uzbegs as "Chaurtke."

Of Arachnida, a class very rich in representatives, the Tarantula (Lycosa singoriensis, Lackm.) are remarkable from the fact that in different places in the valley Fedchenko found forms, which in Europe are met with in countries far apart from each other, and have been reckoned as different species. The most widely-distributed form is that with the lower part of the abdomen quite black; next comes the form with coloured edges, and finally that with the lower part almost entirely orange.

The Scorpions are identical with those met with in TransCaucasia (Androctonus caucasicus, Nordm.). Galeodidae are represented by two very well-defined species (Solpuga araneoides, Pall., and $S$, intrepida, Duf.). The distribution of the latter is remarkable. First found in Spain, it was seen later by Wagner on the Indersk mountains, on the Urals, and afterwards by Fedchenko in the Zarafshan valley, besides which, specimens of this Harvestman are found in the collection of insects sent by General Kolpakovsky from Vierny. The animal is reckoned poisonous, and its bite has in certain cases been followed by death, although nothing is yet known of its poison apparatus.

The Karakurt (Latrodectes lugubris) does not live in the Zarafshan valley, and is known only in a few localities of Semirechia. There is also a form of Myriopoda reckoned venomous, viz., a Scolopendra, constituting a new species.

Among the invertebrate animals subjected to special investigation were the ris/uta* and the silk-worm. With

- For some account of his investigations on the riskita, see Vol. il., p. 148. 
respect to the disease of the latter, Fedchenko showed the presence therein of small particles called after their discoverer Cornalia, causing a disease termed pibrine. These particles were found by him in the eggs, larvæ, and moths brought from Samarkand. The rishta, or guinea-worm (Filaria medinensis), is found in other places: in Egypt, Arabia, and India; but in Central Asia it occurs much farther north.

Fedchenko's investigations showed that the germs with which the whole body of a rishta (taken out of a man) is filled, having fallen into water, enter into small crustaceans of the genus Cyclops, live in them a long time (more than a month), lose their colour, change their external form, and begin the development of sexual organs. The cyclops may easily be imbibed in drinking water, as it is very small and colourless, and the further progress of the parasite is clear; the sexual organs of the rishtas are developed in the intestinal canal; the females, after fecundation by the males, make their way to the sub-dermal tissues, where they attain final development, i.e., become filled with living germs, and at the same time grow to about $3 \frac{1}{2}$ feet in length. All th is proces of passage and growth occupies about twelve months; so that the rishta only manifests itself in the body of a man in the following year.

These remarks from the Turkistan Annual are interesting as written by Fedchenko himself, but they are, of course, the merest drops of what he intended to be a coming shower.* When he returned to Russia with his immense collections he summoned to his aid several specialists, to whom respectively he committed his specimens for description under his own editorship.

The desire of the Seciety of Friends of Natural History appears to have been that in each section or subject should appear not only Fedchenko's collections, but every species known in Turkistan, with a short and pithy description of

* Madame Fedchenko has been good enough to send me a list of her late husband's papers and other publications, 34 in number, and most of them in Russian. Many appeared in the Turkistan Gasette for 1870-71 ; reference will be found to others in Mejof's "Bibliography," and to transtations in the bibliography attached to this work. 
each, comparisons also being made with the fauna of neighbouring countries. It was further made a prime matter that everything as far as possible should be described in Russian (new species, however, in Latin), the Society having in view the publication of a work that might serve every inquiring Russian as a handbook and foster a taste for the study of Natural History.

This work, so well conceived, extensively planned, and energetically begun, was, alas! like so many things in Russia, never successfully completed. The zealous and indefatigable Fedchenko, of whom all speak so highly, lost his life in 1873, on the Col du Géant, Mont Blanc; and the chief of the enterprise being thus taken away, the work has languished. As it now stands, various sections of Fedchenko's "Puteshestive v' Turkestan," or "Travels in Turkistan," have appeared as follows: A Fourney to Khokand, by A. P. Fedchenko; Flora of Turkistan, I., Primulaceae et Liliaceae, by Regel; Astragalus et Oxytropis, by Bunge; Descriptiones plantarum novarum, by Regel ; Mammals, Birds, Reptiles, and Fishes, ${ }^{*}$ by Severtsoff; Fishes, by Kessler; Mollusca, by von Martenst; Crustacea, by Ulianint; Araneae, by Kronebergt; Coleoptera, Parts I. and II., by Solsky; Mellifera, I. and II., by Morawitz; Sphegidae, Mutillidae, and Chrysidiformes, by Radoszkovsky ${ }^{\dagger}$; Scoliidae and Orthoptera, by De Saussuret; Formicidae, by Mayrt; Lepidoptera, by Erschofft; Neuroptera, by MacLachlant (Odonata by Brauert); and Vermes, by Krabbet; whilst as an appendix to the "Travels" is published an album of fourteen lithographed views of Russian Turkistan by Madame Fedchenko.

I accordingly have given $\mathrm{Mr}$. Cromie's translations of the various introductions, omitting here and there local or ephemeral matter, and have added the lists of species, from which I trust that naturalists will be able to gather some idea of the Turkistan fauna as a whole; whilst those

\footnotetext{
- This included Fedchenko's materials, but is entitled "Vertical and Horizontal Distribution of Turkistan Animals."

† Authors, marked thus, have kindly revised proof-sheets of their respective articles as given hereafter, and $\mathrm{I}$ am greatly indebted to Madame Fedchenko, who has looked through almost the whole of the appendices on Fauna and Flora.

VOL. II.
} 
who desire it may obtain further information from the originals. My own remarks hereinafter are enclosed in brackets and signed $[H . L$.$] .$

\section{VERTICAL AND HORIZONTAL DISTRIBUTION OF TURKISTAN ANIMALS.}

BY N. A. SEVERTSOFF.

Edited by A. P. Fedchenko and L. P. SabanaefF.

\section{Explanation :-}

Vertical distribution :-

Plains (1).-From $600^{\prime}$ to $1,000^{\prime}$ above the sea, comprising salt plains.

Downs (2).-From $3,000^{\prime}$ to $4,000^{\prime}$, comprising cultivated districts and grassy steppes.

Hills (3).-From $4,500^{\prime}$ to $8,000^{\prime}$ or an average of $6,000^{\prime}$, comprising larch woods, apple and ash groves.

Mountains (4).-From $8,500^{\prime}$ to $10,500^{\prime}$, comprising juniper, fir, and birch districts.

Peaks (5).-From district of Alpine grasses up to the snow-line.

\section{Horizontal distribution :-}

N.E. (I.)-Semirechia : comprising the districts of Kopal, Vierny, Issik-

$\mathrm{Kul}$, the rivers Ak-sai and Upper Narin.

S.E. (II.)-Semirechia south of Issik-Kul, about Son-Kul and Chatir$\mathrm{Kul}$; the rivers Susamir, Jumgal, and Lower Narin, flowing south from the Alexandrovski mountains, with others flowing north, namely, the Chu and Talas.

N.W. (III.)-The West Thian Shan about Tashkend, comprising the Upper Aris, Chirchik, and Keles; the Kara-Tau mountains, and the Lower Syr-daria to Lake Aral.

S.W. (IV.)-The Zarafshan Valley, Steppe between the Syr-daria and the Kizil-Kum Desert, and district about Khojend.

s signifies sedens, or settled. $\quad \mathrm{R}$ signifies rare.

$$
\begin{array}{lllll}
\text { s signifies } & \text { sedens, } & \text { or settled. } & \text { C } & \text { common. } \\
\text { t " } & \text { transvolans , passing. } & \text { erraticus ", migratory. } & n & \text { new. } \\
\text { n " } & \text { nidulans , breeding. } & s & , & \text { species. } \\
\text { a " } & \text { aestivus " summer. } & & & \\
\text { h " } & \text { hyemalis ", winter. } & & &
\end{array}
$$

I have inserted the letters and words at the heads of columns as conveying more to the eye than the figures in the original. The English names of Severtsoff's Mammals, Reptiles, and Fishes have been inserted by Dr. Günther. $-H$. L.] 
MAMMALIA (Mammals).

Mammals.

\begin{tabular}{|c|c|c|} 
I. & II. & III. \\
N.E. & S.E. & N.W \\
\hline & S. \\
\hline s & s & s \\
s & & s \\
s.C. & s.C. & s.C. \\
s.C. & & \\
\hline
\end{tabular}

1. Vesperugo turcomanus [spor.] Titrcoman Bat

2. " serotinus Serotine do,

3. " blythi, Wagn. Indian Pipistrelle $4 . "$ akokomuli, Temm.

5. Plecotus auritus .

6. $"$ leucophreus, $\dot{n}, s$.

Long-eared Bat s.R.

7. Rhinolophus euryale? [spor.] Horseshoe Bat

8. Sorex pulchellus ?

9. " leucodon $\}$.

II. Urens Luscouritus . Long-eared Hedgerog

II. Ursus lenconyx (U. isabellinus? Horsf.)

12. Meles taxus, Gulo borealis (?)-clauved Bear

13. Foetorius putorius, var. eversmanni.

Eversmann's Polecat
4.
15. C.

15. " ermineus . Stoat or Ermine s.C. 8.C. 5.C.

10. Mu', gale, Pall .

17. Mustela foina

Common Weasel

18. " intermedia, $n$

19. ", martes

20. Lutra vulgaris

21. Canis lupus

- Beech Marten

22. " alpinus.

23. " familiaris

24. " vulpes

25. " melanotis

26. "n corsak

27. Felis tigris

28, "n irbis

29. " jubata

Chectah

Lynx

32. " manul

Pine Marten

- Common Otter

Wolf s

- Northern Wild Dog s

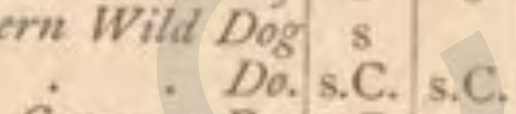

Common Fo. s.C. S.C. s.C.

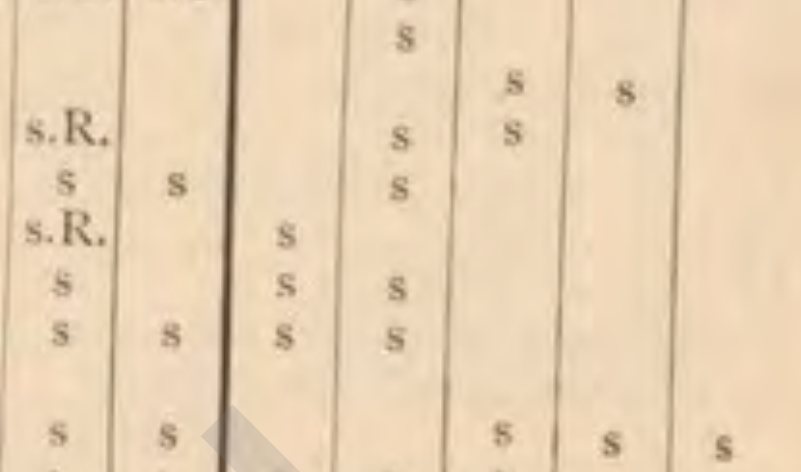

35." catus domesticus Domestic Cot

34. Aretomys baibacinus, Brndt. . Bobac

35. " caudatus . . Long-tailed Marmot

36. Spermophilus fulvus . Souslik

37. " leptodactylus Siender-toed do.

38. " brevicauda, Brdt. I Short-failed 32. (mugos:

12. Arvicola aryalis

41. " leucura

45. Jus" gregalis

B major (M. T. S.C. s.C. s.C.

(n.s.) Aryan .Mouse s ". ." decumanus

W. Cricetus songarus Hamster

$$
\text { [Souslit }
$$

\begin{tabular}{l|l|l|l} 
[Souslik & 5 & 5 & 5
\end{tabular}

\begin{tabular}{|c|c|c|c|}
\hline 2. $\frac{2}{E}$ & 3. & 4. & 5. \\
\hline 8 & & & \\
\hline
\end{tabular}

\begin{tabular}{l|l} 
IV. & I. \\
S.W & 递 \\
\hline
\end{tabular}




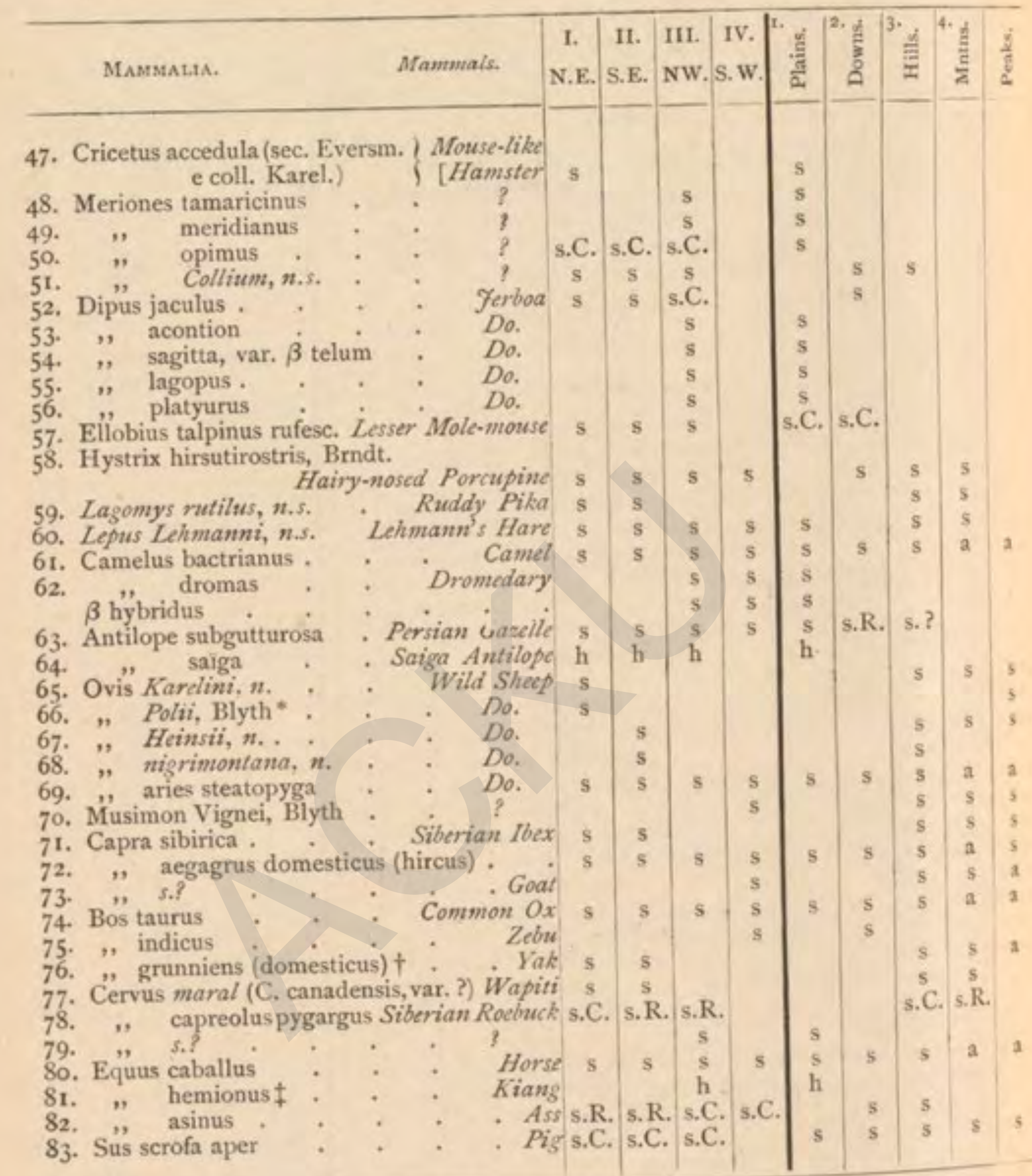

* For illustration see Vol. i., p. 245. + For illustration see Vol. ii., p. 143. † For description see Vol. i., p. 150 . 


\section{AVES (Birds).}

Abbreviations : - vic. $=$ victitat $;$ spor. $=$ sporadice ; reg. $=$ regio.

[The English equivalents and the Pamir column have been given by Mr. Henry Dresser. - H.L.]

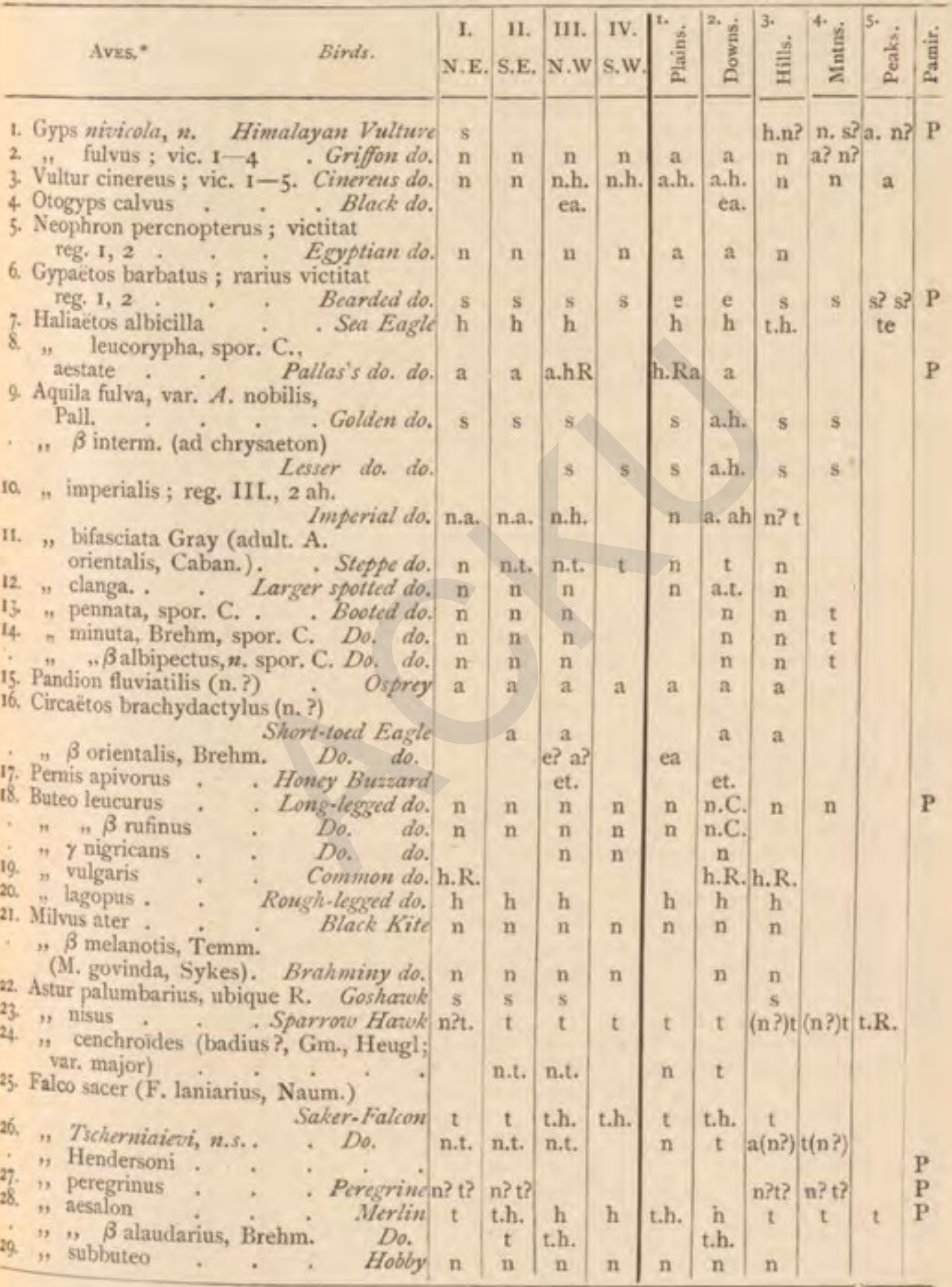

* For summary in English see Vol. i., page 415. 


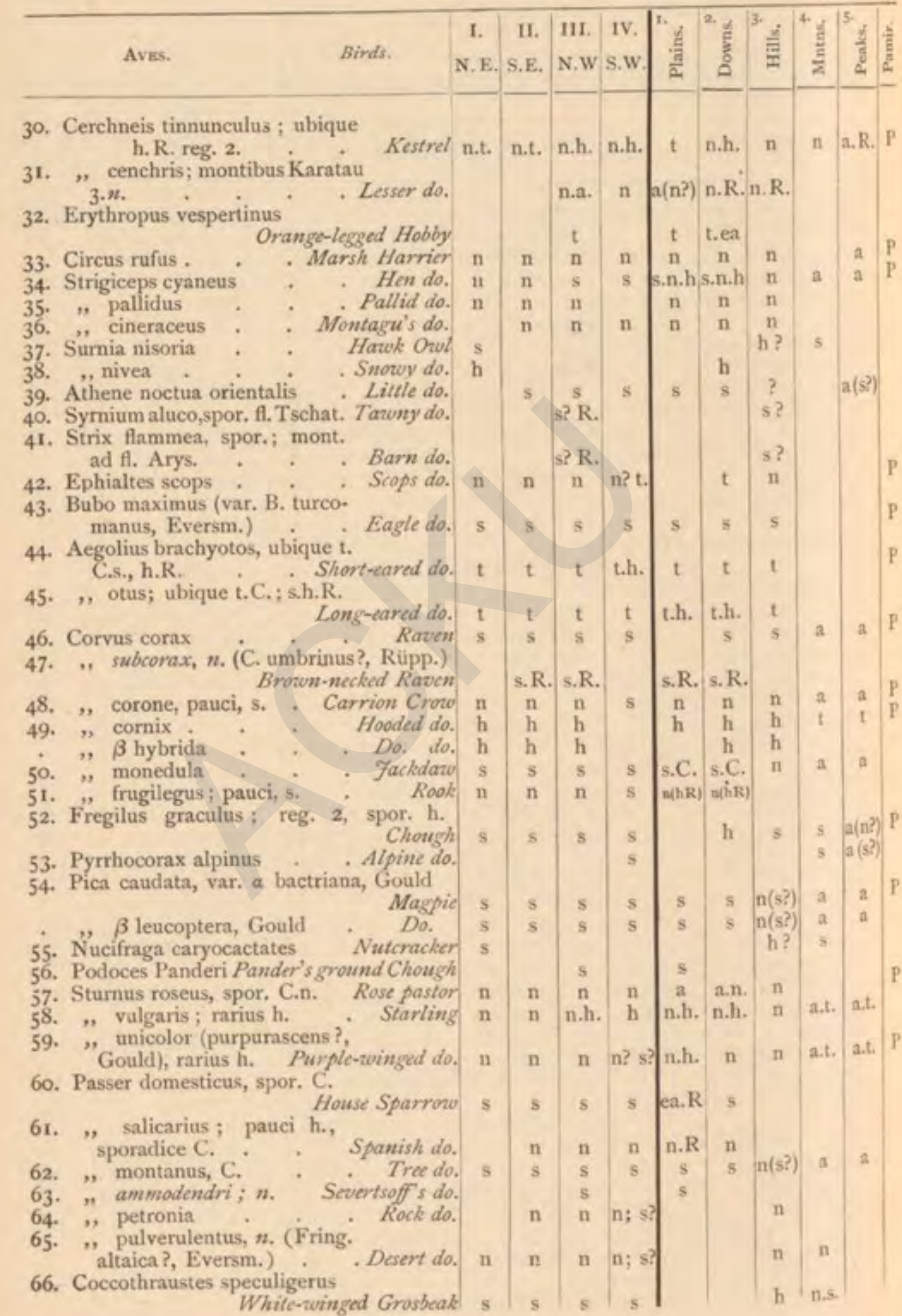


75. Carduelis orientalis Himalayan Goldfinch n.h. n.h. n.h. n.h. 76. „, europaeus . European do. n? h. n? h n? h.

77. Oraegithus pusillus, Pall.

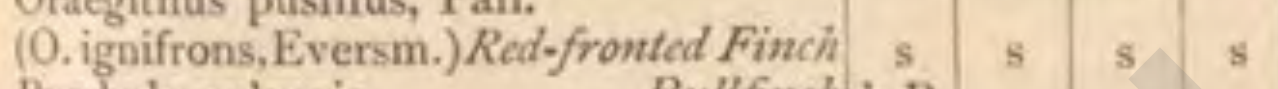
78. Pyrrhula vulgaris . Bullfinch h.R. 79. "nepalensis (an s.?) Browun do. h.R. 80. Uragus sibiricus (spor.)

81. Carpodacus rubicilla, Güld.

\section{Siberian Rosefinch h.n.}

(C. caucasicus, Pall.) Caucasian do. $\mathrm{s}$

82. ,hodochlamys, Brdt. Red-mantled do. n.h. n.h. h.R. s

83. ", rerythrinus

, mongolicus

4. Erythrospiza incarnata, $n$. . Rose do. s \& h.t.R h.t.

85. ", phoenicoptera, Schl.

Bonap.; spor. Scarlet-winged do. s 4 \& 5 s 86. „, obsoleta, spor. C. Desert do.

87. Emberiza cioldes, Brdt. (an $n . ?$ )

88. Whate-browed Bunting t.C. t.C. h.R. 88. " cia. . . Meadow do. t.C.u t.C.n h.n. h.n.

89. ", hortulana . . Ortolan n n n

90. "caesia. Cretzschmar's Bunting n n

9r. , citrinella ; prope fl. Syr-

daria h. R.

Yellowo do.

92. ", caniceps . White-capped do.

., huttoni

93. ", pithyornus (an $n .8)$ : Pine do. t.C. t.C. h

94., schoeniclus . . Reed do. h.t. h.t. h.t.

. " " $\beta$ minor

95. ", pyrrhuloides; reg. 3 , Issyk-

Kuil, an s.? Large-billed do, do, s s s

96. ," miliaris

97. ", pusilla.

. Little do. t.R.

$\begin{array}{lllll} & \\ \text { srunniceps Brown-headed do. } & \mathrm{n} & \mathrm{n} & \mathrm{n}\end{array}$

99. ", aureola, ad fl. Syr-daria

aestate visa Yellow-breasted do.

100. Plectrophanes nivalis. Snow do.

h.R.

10. Turdus merula Blackbird n.h. n.h. n.h.

102. "atrigularis Black-throated Thrush n.h. n.h. h

103. ", mystacinus, n. (Bechsteini, ?

Naum.) - Black-throated do.n.h. n.h. h 
Aves.

Binds.

I. II. $11 \mathrm{I} . \mid$ IV.

N.E. S.E. N. W S.W.

104. Turdus ruficollis, Pall. (non Radde)

ubique R. Red-breasted Thrush t t h t.h. t.h.

105. „, pallens, Pall., urbe Vierny visus.

ro6. ,y viscivorus

Pale do.

107. ", pilaris

108. ", iliacus, ubique R. . . Rectwing

I09. Myophone Temminckii

Yellow-billed Whistling Thrush

110. Petrocichla cyane

111. ", saxatilis

112. Saxicola oenanthe

113. ", squalida, | S. isabellina, Ripp.,

Eversm.

$\beta$ saltator (

Ir4. "leucomela, Pall.

non Temm.

Bluc do.

Kock do.

Wheatear

(S. morio, Ehrb.) Eastern picd Chat n.t. n.t. n.t. n , $\beta$ lugens, Licht., Heugl.

(leucomela, Temm.). Isabelline Cha n.t. n.t. n.t.

115. ", monacha, Brehm ; in rupestrís

116. ", talas, $n$.

117. ", melanogenys. n.s. Black-cheeked do

118. "syenitica, Heugl.

119. Saxicola salina, Eversm

(S. deserti, Rüpp.)

,, $\beta$ xanthomelaena, Ehrb.,

Heugl.

Black-throatcd do.

121, , rubicola

Winchat n.t. n.t. n.t.

" $\beta$ indica, Gould Eastern Chat n.t. n.t. n.t. n.t.

122. ", Hemprichi, Ehrb.;

spor. R. White-tailed do. n $\mathrm{n}$ n

123. Lusciola luscinia, $\beta$ Hafizi, $n$.

Persian Nightingale n.C. n.C. n.C. n

,, $\gamma$ philomela, Pall.

Thrush do.

n.t. n.t.

124. ,, aèdon, Pall.(philomela. Bst.) Do. do.

, $\beta$ infuscata, $n$.

Do. do.

t.n. $t$

t.n.

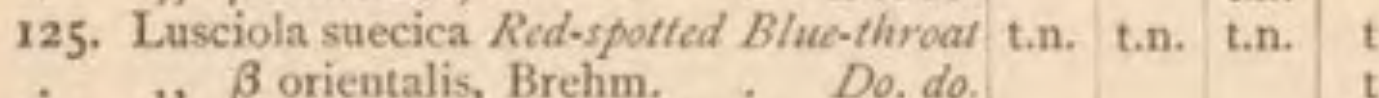

126. ", rubecula; urbe Chimkent

h.R.

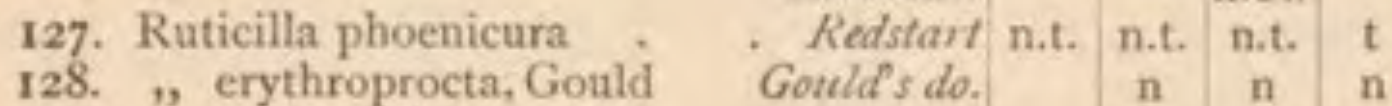

129. ", erythrogastra, Güldenst.

III.hR. Güldenstadi's do. n n t.h. n.h.

130. ,, erythronota, Evers. Eversmann's do. n.C. n.C. h.n ? h.n. „1. aurorea?, Pall. (e coll.

Karelin.) . . Reeves' do. n ?

131. "lugens, n. . Bluc-headed do. n

132. Calliope Ballionii, n. (C. pectoralis?,

Gould) White-tailed Kuby Throat n

t. R.

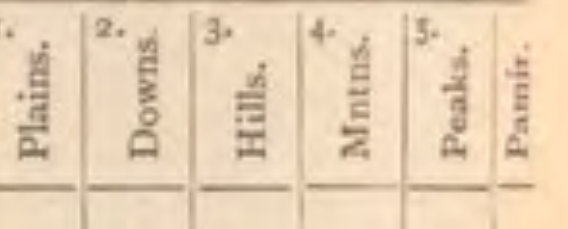

$\begin{array}{lllll}\text { h } & \text { h } & n & n\end{array}$

t.h. t.h.

t.h. t.h. 
133. Irania albigula, $n$. (Bessonornis gutturalis, Guer.?) White-throated Robin Chat 134. Sylvia nisoria

135. "l, cinerea.

Barred Warbler n.t.

136. , curruca.

White-throat do. n

"minuscula

- Lesser do. $\mathbf{n}$

137. " magnirostris, $n$. Large-billed Warbler

138. ", orphen .

Orphean do.

139. ", mystacea, Mén. (subalpina?

Temm.)

Subalpine do

140. Atraphornis aralensis, Eversm. Desert do.

141. Aëdon galactodes, var, familiaris,

Mén.

Grey-backed do.

- " plumbeitarsus

142. Ficedula superciliosa, Cab,

143. "Middendorffi, Meves $=$ Phyl

Yellow-bronved do. loscopus viridanus Middendorff's do.

" " $\beta$ hypolaina, $n$. Do. do.

", " $\gamma$ intermedia, $n$. Do.

144 , obscura, n. (Phylloscopus

indicus, Jerd.) , (Phylloscopus

45. , fiulvescens, $n$. (Ph. tristis) Siberian Chiffchaff t.C.

146. Salicaria turdoĩdes; spor.

Thrushlike Warble

147. ", arundinacea?

148. ", brevipennis, n. (Hypolais

caligata, Licht.). Reed do. n

149. , capistrata, $n$. (Acrocephalus agricola, Jerd.) . . Paddyficld do.

150. Salicaria palustris (?) . . Marsh do.

151. "macronyx, n.s. . Do. do.

152. "curhyncha, n.s. (Acrocephalus

dumetorum, Blyth) Blyih's Reed do.

153. "s sphemura, n.s. (Acrocephalus dumetorum, Blyth) . Do. do.

154. " gracilis, $n$. (Acrocephalus

agricola, Jerd.) . Paddyficld do.

155. " obsoleta, $n$.

Padabootad do.

156. „, pallida, Ehrenb, Eversm.

(Hypolais caligata, Licht.) Booted do.

157. "tamariceti, n.s. (H. pallida,

Ehr.). Olivaceous do.

158. $n$ modesta, $n$. (A. agricola.

Jerd.) . Faddyfield do,

159. " concolor, n.s. (A. dumetorum.

Blyth) Blyth's Reed do.

1to. ," scita, Eversm. (Iduna salicaria,

Kays, non Pall.) H. caligata, Lich.

161. Cettia firsia, n.s.

Booted do.

16. " albiventris, $n$

Cetti's do.

163. ", scalcutris, $n$.

Do. do.

Do. do.

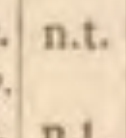

n.t. n

\begin{tabular}{cc|c|c} 
n.t. & n.t. & n.t. & \\
n & n & n & n \\
n & n & n & n
\end{tabular}

n.t.

(n)

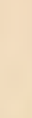




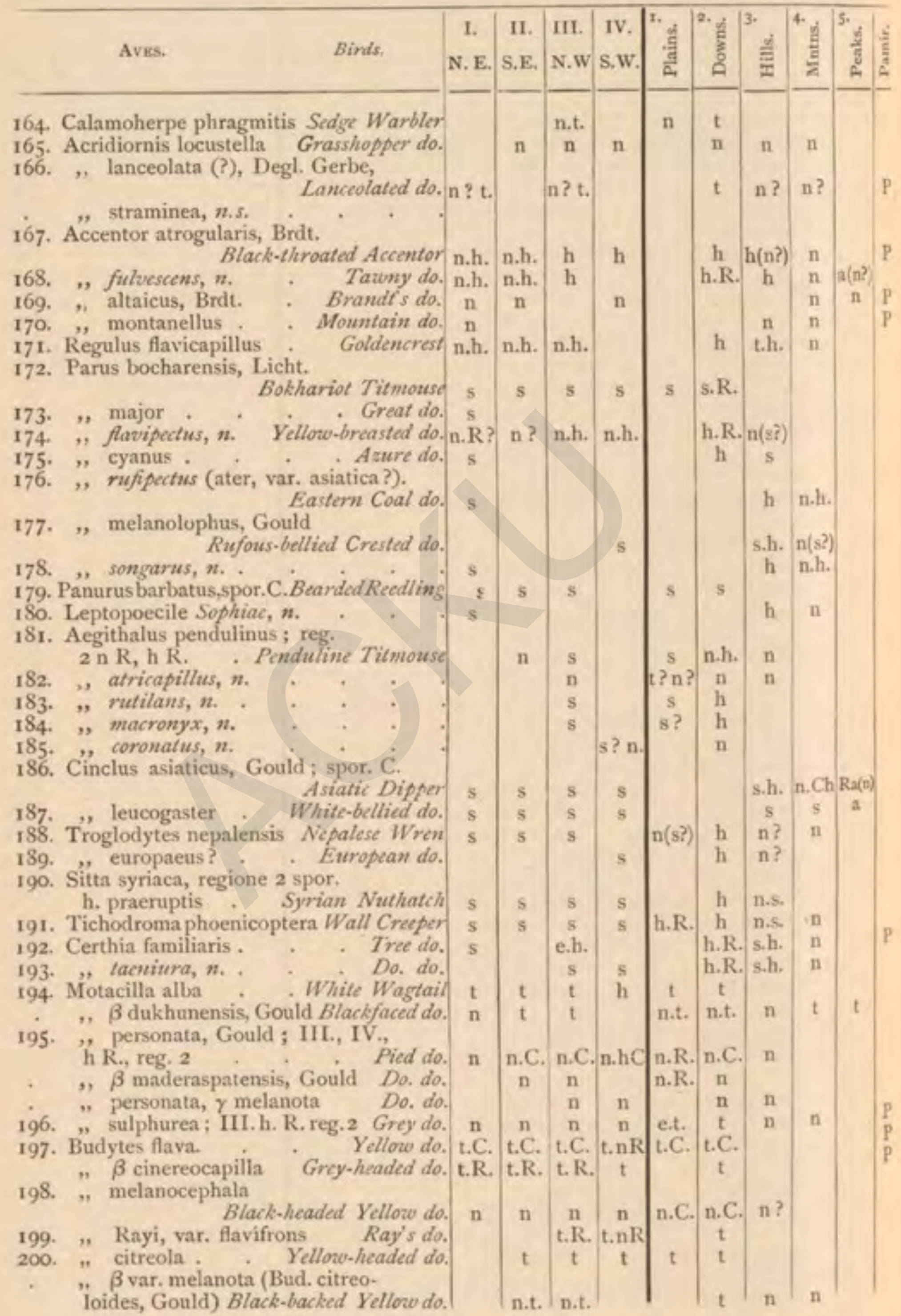




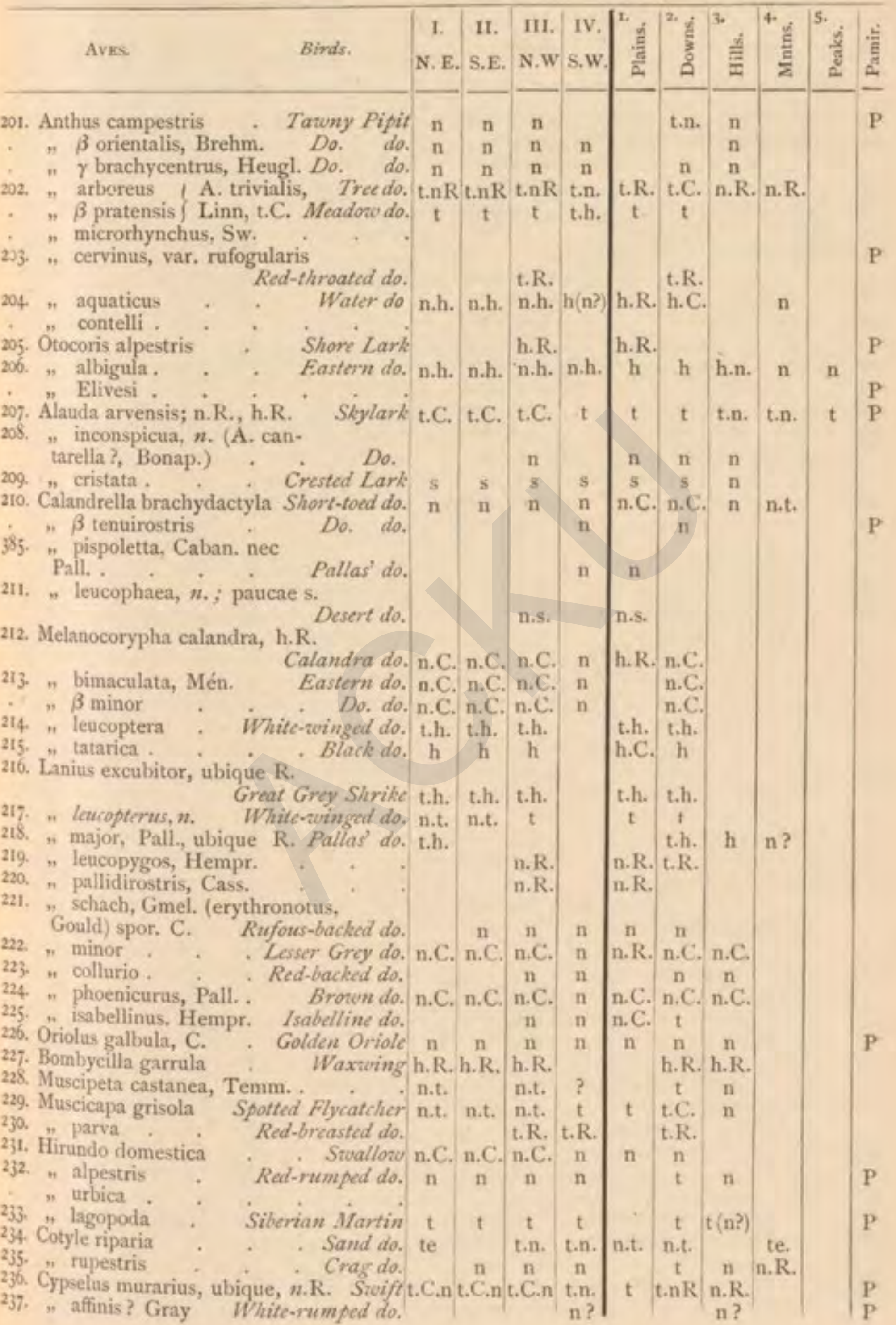




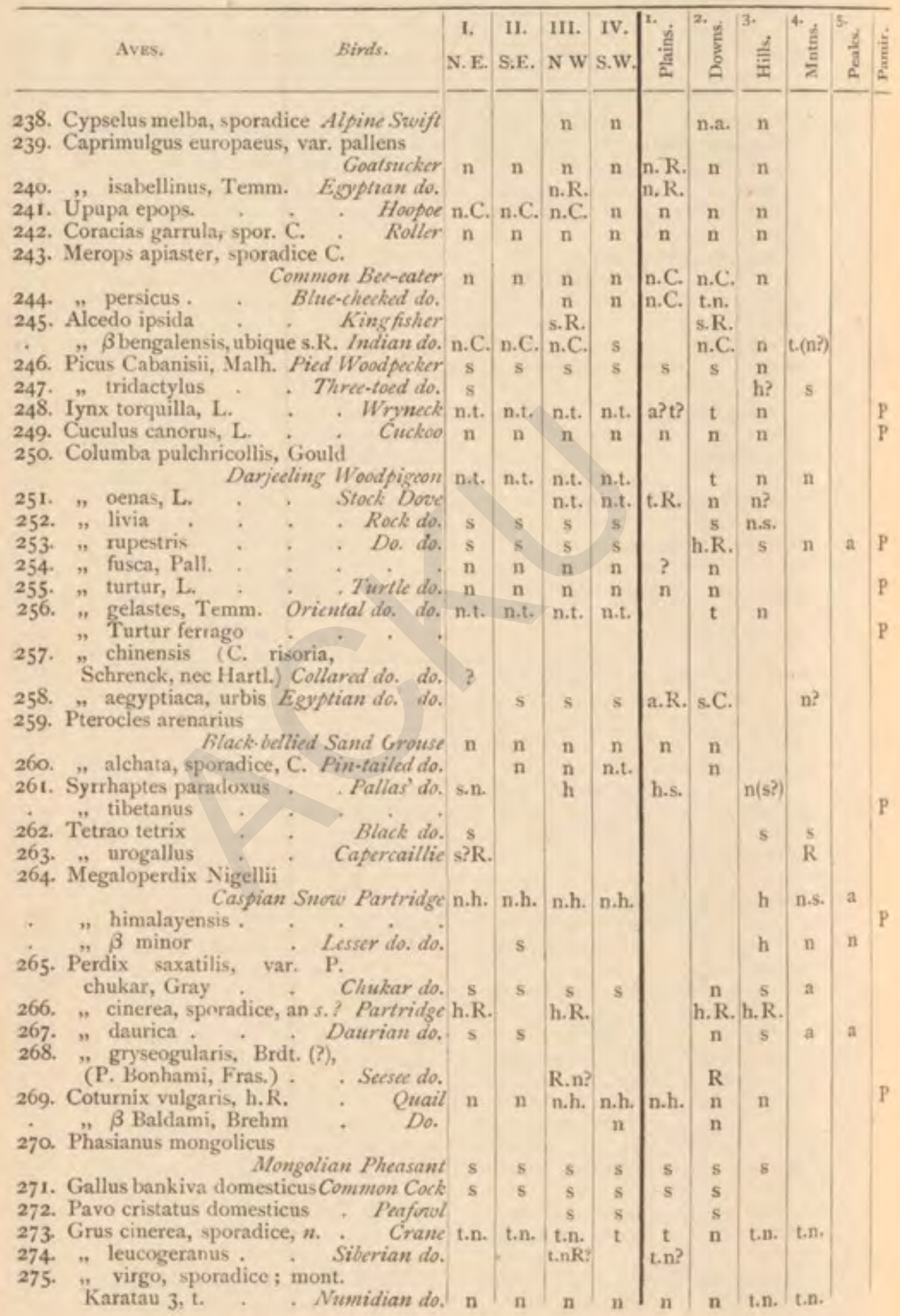




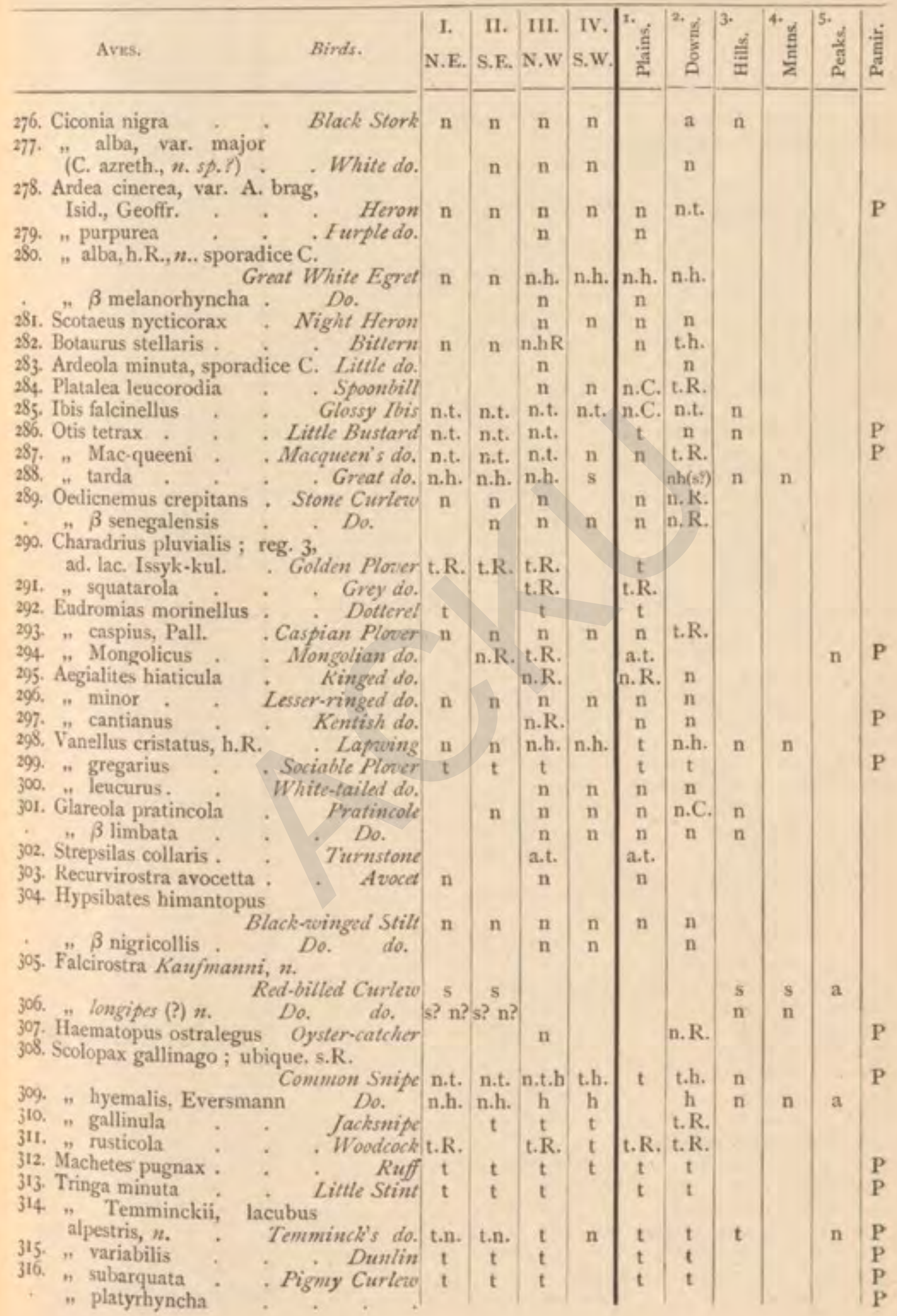


Aves.

Binds.

\begin{tabular}{|c|c|c|c|c|c|c|c|c|c|}
\hline $\begin{array}{c}\text { I. } \\
\text { N. E }\end{array}$ & $\begin{array}{l}11 . \\
\text { S.E. }\end{array}$ & $\begin{array}{l}111 . \\
\text { N.W }\end{array}$ & $\begin{array}{l}\text { IV. } \\
\text { S.W. }\end{array}$ & 鄫 & 2. & 捛 & ․ & 5. & 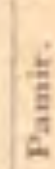 \\
\hline
\end{tabular}

317. Calidris arenaria : : Sanderling 3t8. Phalaropus angustirostris

Red-necked Phalarope

"fulicarim

319. Actitis hypoleucos Common Sandpiper

321. "fuscus

322. " calidris

323. " stagnatilis

324. "ochropus; h.R.

325. " glareola,

Terchia cinerea Spotted Redshank

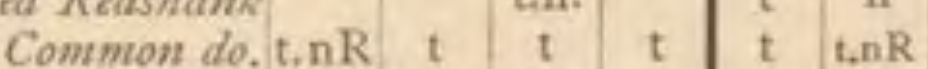

Pond Sandpiper n

- Green do.

Wood do.

326. Limosa melanura ; n. R., h.R.

Black-tailed Godwit

327. Numenius arquatus . . Curlews

328. Rallus aquaticus, spor. C. Water-rail

329. Crex pratensis

330. Gallinula pusilla .

331. " pygmaea

332. " porzana.

333. " chloropus

(Porphyrio?)

Corncrake

Little Crake

Baillon's do.

Spotted do.

334. Fulica atra, sporadice

335. Podiceps minor; urbe Tschim.

kent, fontis C.

Moorhen

. ?

. Liltle Grebe

336. " auritus . . Eared do,

337. " cornutus, lacu Son-Kul, n.Stavon. do.

338. " rubricollis . Red-necked do.

339. " cristatus Great-crested do.

340. Pelecanus onocrotalus Roseate Pelican

341. Carbo phalacrocorax, var.

continentalis : Cormorant

342. " pygmaeus

Little do.

343. Larus canus .

Winter Gull

344. " cachinnants; reg. 3 , ad

lac. Issyk-Kul. Siberianherring do.

345. $"$ argentatus; n. R. ? locis

lacustris

Herring do. , brunneicephalus ?

346. Gavia ichtyaëtos Great black-headed do.

347. " ridibunda

348. " minuta .

349. Sterna caspia

350. ", anglica .

351. " hirundo .

Black-headed do.

351." ". hinuta.

353. Hydrochelidon niger

354. "leucopareius

355. Cygnus olor; reg. 3, Issyk Kul ; III. s. R. .

- Litrle do. Caspian Tern Gull-billed do. Common do. - Little do.

Black do. Whiskered do.

356. , musicus, ubique n.R. reg. 3 , Issyk-Kul.

357. "Altumi, Homeyer, ubique,

Hooper wh. t.h. t.h. Beavick's Swarn t.h. t.h. t.h.

t.R. T.R.

t.R. t.R

n $n$

n

n. $\mathrm{n}$.

$\begin{array}{lll}t & \text { n.hR } & \text { t.n. }\end{array}$

n. R. 
358. Anser Middendorffii, $n$. (A. grandis, Midd., nec Pall.) . Larger Goose 359. " segetum; III. h., reg. 2 ; t. reg. I Bean do. 360. "obscurus, Brehm : Do. 36r. " cinereus; III. h. R., reg. 2

362. albifrons, R. White-fronted do. 364." ruficollis : Red-breasted do. 365. "S Skorniakovi, $n$. . Painted do. 366. Anas rutila, sporadice Ruddy Sheldrake 367. " tadorna.. Common do. 368. ") boschas, h. R.

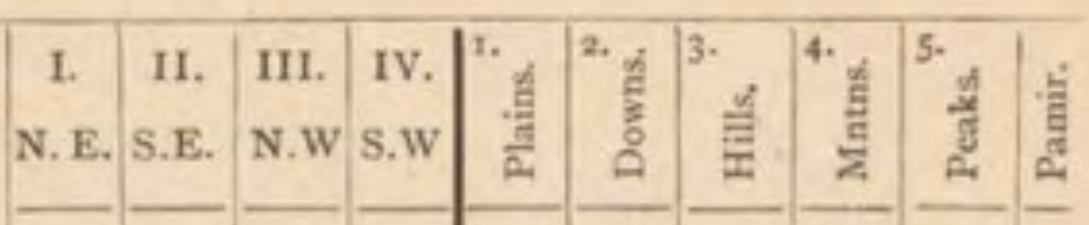
369. " strepera, ubique h. R., reg. I, 2

Gadivall

370. " querquedula . . Gargany n

371. " crecca .

372. " clypeata . t.h.

373. "penelope ; III, 2, h ? . Widgeon t $\mathrm{t}$ t $\mathrm{h}$ 374. „, acuta; lacu Issyk-Kul, $n$. ? Pintail 375. Fuligula fusca 376. " cristata .

Velvet Scoter 377. " ferina; reg. $\mathrm{r}$, h. R. Poshard

378. " leucophthalma White-cyed Duck n 379. " rufina . Red-crested Pochard n

380. n clangula; reg.1,h.R. Golden-eye Duck h.t. 381. " mersa . White-headed do. n.t. n.t. 382. Mergus merganser

38. 3 albellus . Red.breasted Mergansern.th. n.th.

394. Phoenicopterus roseus, Pall. Flamingo Cum Cal. pispoletta, 385 spec. (pag. $5^{2} 3$ ). 
REPTILIA (Reptiles).

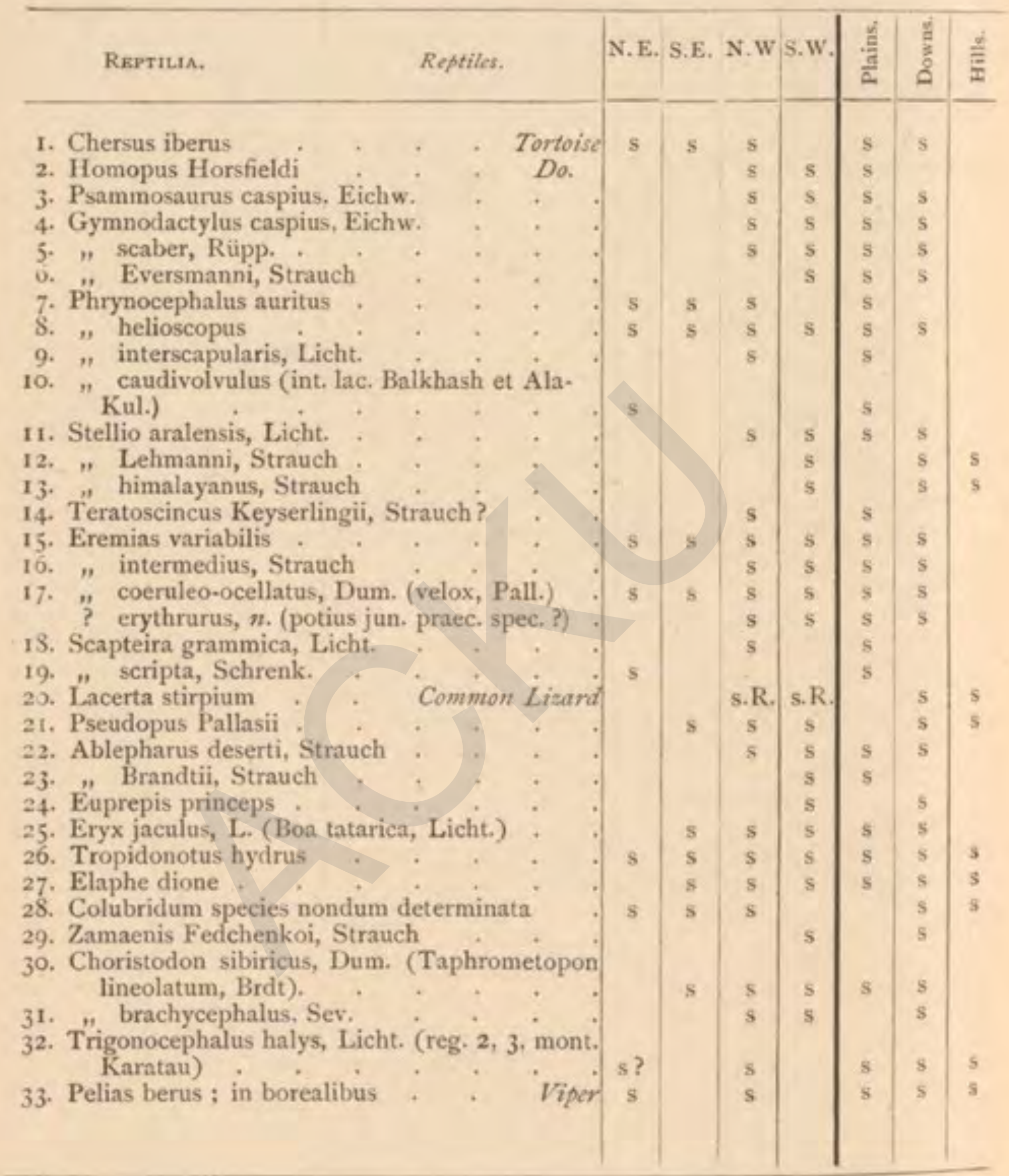

I have borrowed M. Strauch's definitions of Turkistan reptilia from Fedchenko's report on his first expedition (Pro. Soc. Friends of Nat. Hist., Vol. iii., Part I). Fedchenko also communicated to me unpublished definitions of Stellio himalayanus and Zamaenis Fedchenkoi.

Of reptiles I myself found only Scapteira grammica, S. scripta, and, perhaps, Phrynocephalus interscapularis. The Gymnodactylus Eversmanni, Stellio Lehmanni, S. himalayanus, Euprepis princeps, Ablepharus Brandtii, which I did not obtain, are evidently peculiar to 

the S.W. district, which is more definitely characterized by southern
reptiles.

Eremias erythrurus is distinguished from $E$. velox only by its colour and smaller size; the scales and dorsal marks generally are almost identical. Fedchenko considers $E$. erythrurus as a young $E$. velox. But the distribution appears to me different. In the eastern part of Turkistan, commencing from Aulie-Ata, and even Chimkent, I did not meet with $E$. erythrurus, but there were multitudes of $E$. velox. Afterwards, at Khojend, I did not see the very young small specimens of the latter species, which is in favour of Fedchenko's opinion.

AMPHIBIA (Amphibians).

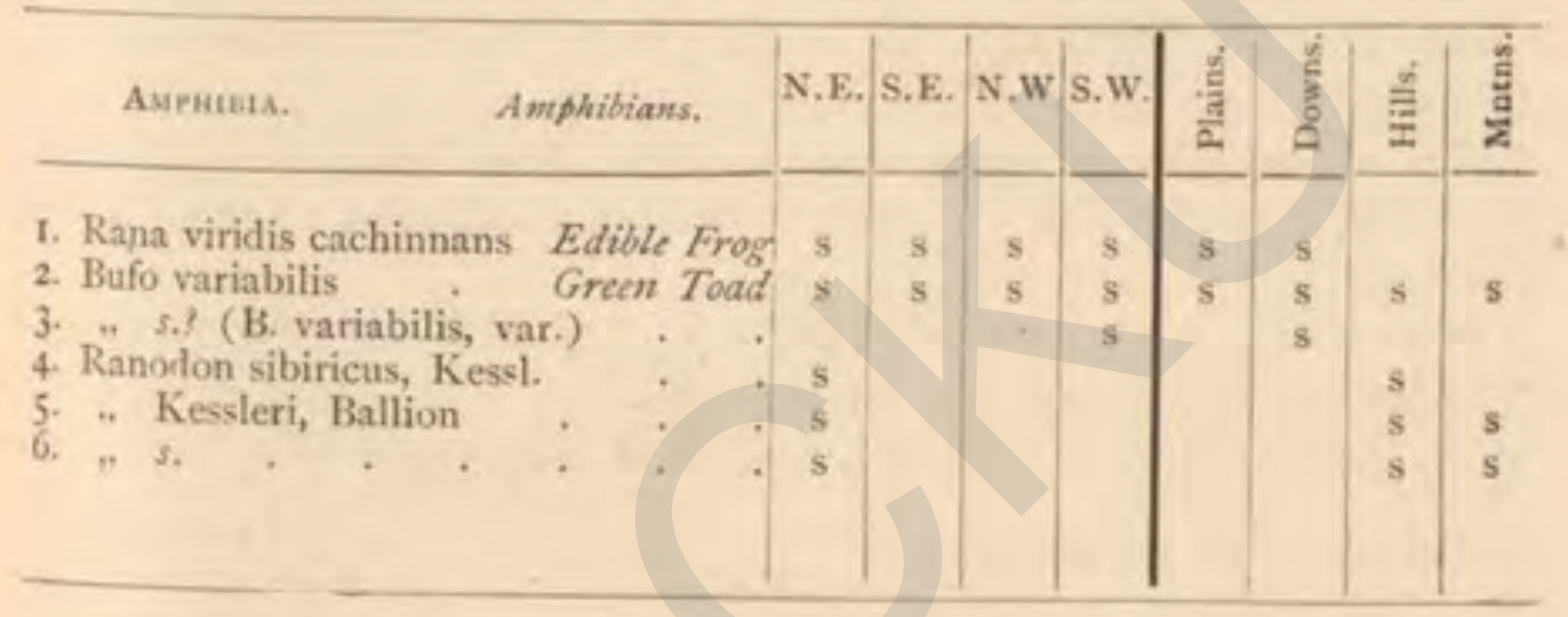

The difference of the conditions regulating the vertical distribution of Reptilia and Amphibia may be remarked in the above lists. The former require heat, the latter moisture, especially the Urodela (genus Ranodon), which, therefore, appear in Central Asia only near the mountains, living in spring-basins, and in marshes near water of very low temperature, not more than $45^{\circ}$ to $48^{\circ}$ in summer. Ranodon $s$. (No.6) was obtained in the marshes on the small Almatinka river, near Vierny, at about $6,000^{\circ}$. Two specimens were presented to me by General Kolpakovsky, and given for definition to Mr. Ballion, who described $R$. Kessleri. The remaining two species are from the northern Ala-Tau. I consider it probable that they might be found higher than $6,000^{\prime}$, in the region of firs. It is no less probable that at this latter altitude, especially on the Kegen table-land, a few reptiles may be found. 


\section{PISCES* (Fishes).}

THE vertical distribution of Turkistan fishes cannot so well be expressed as that of Mammals, Birds, Reptiles, and Amphibia. The chief water systems of the region are those of the Aral, the Balkhash, and the Upper Tarim. There are other systems of second grade, of which the more important are those of the Issyk-Kul, the Chu, Talas, and Zarafshan. The last three, however, might be added to the Aral system.

The principal ichthyological districts of the region are also three (those of $\mathrm{I}$, the Marinka-Schizothorax-and Osmanoff-Oreinus et Diptychus; 2, the Carp, the Silurus and Barbel, together with the Marinka; and 3 , the Aral Sturgeon); but each of them consists of parts of the different water systems, and, on the other hand, the Syr-daria, at different portions of its course, belongs to all three ichthyological districts.

In the following list each of the ichthyological districts is designated by a Roman figure, and the distribution of each species in the districts by an Arabic figure, showing the place of finding, thus:-

\section{Mountain District:-}

I, Tributaries of Balkhash; 2, Upper Chu; 3, Talas; 4, Tributaries of Naryn; 5, Aksai ; 6, Mountain streams of Zarafshan; 7, Upper Surkhab.

\section{Middle District :-}

8, Balkhash; 9, Issyk-Kul ; I0, Chu, below Tokmak; 11, Lower Arys and Chirchik; 12, Springs at Chimkent; 13, Zarafshan, below Penjakend; 14, Sources of Zarafshan; 15, Syr-daria at Khojend; 16 , Springs at Khojend.

\section{Lower District:-}

17. Syr-daria at Chinaz; 18, Syr-daria at Perovsk and below; 19 , Lower Amu-daria ; 20, Aral Sea.

The italics denote species peculiar to Central Asia; almost all the new ones have been described by Kessler. The species marked with an asterisk are common also to the Caspian and Black Seas.

* [For another List of Fishes, by Kessler, sce p. 533.-H. L.] 


\begin{tabular}{|c|c|c|c|}
\hline Fishes. & I. & II. & III. \\
\hline 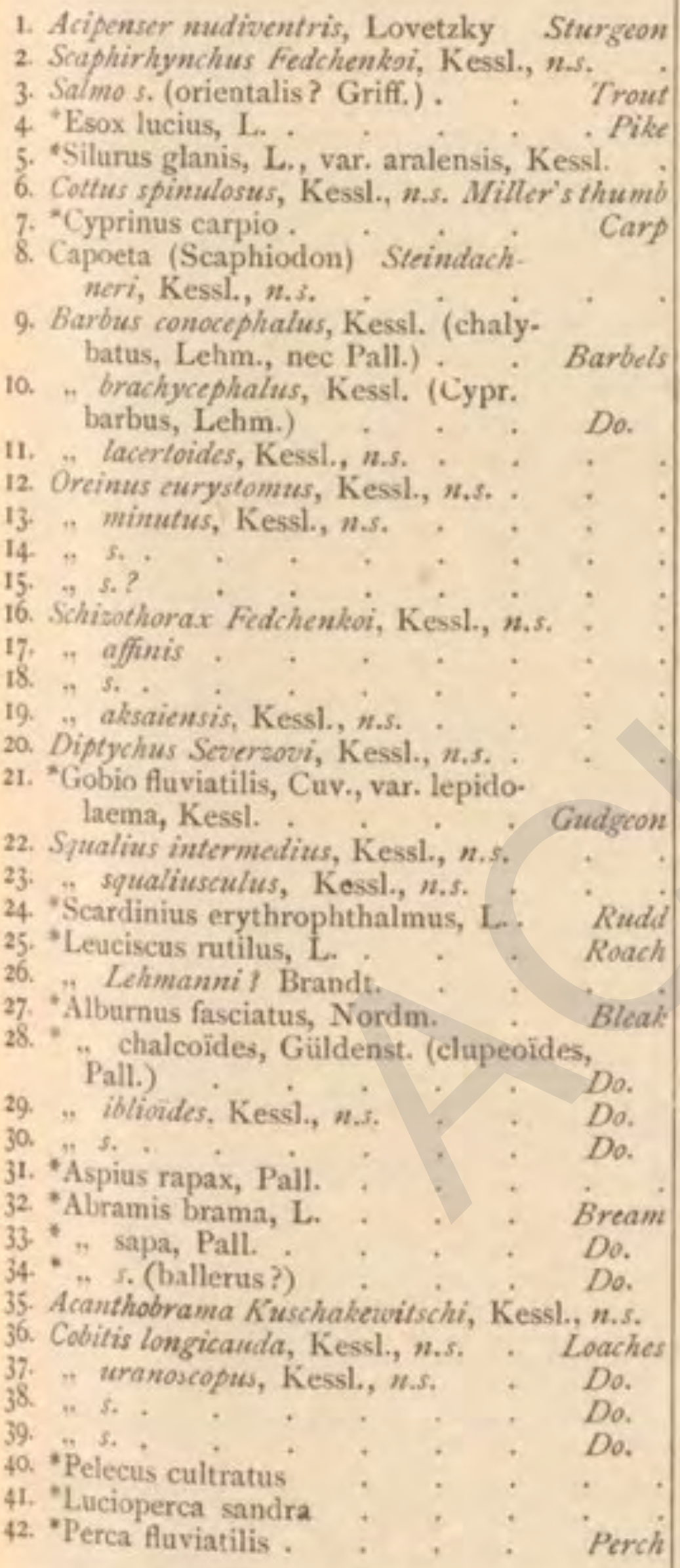 & $\begin{array}{c}6 \\
6 \\
1,4 ? \\
5,4 ?\end{array}$ & $\begin{array}{c}{ }^{*} 13,15,16 ? \\
14 \\
15 ? 16 \\
{ }_{15}+16 \\
13 \\
13 \\
15 ?{ }^{13}+16 \\
13 ?\end{array}$ & $\begin{array}{c}17,18,19 \\
17 \\
* 17,18,19 \\
* 17,18,19,20 \\
17,18,19,20\end{array}$ \\
\hline
\end{tabular}

To the above list, besides certain fishes of Fedchenko's second collection, which have been described by Kessler, should probably be added Issyk-Kul Bream and Roaches, some species of Oreinus, Schizothorax, and Diptychus from the mountain streams, the majority 
of which are uninvestigated, and various small Cyprinidae, from the Balkhash and Chu, so that the total number of species of Turkistan fishes may exceed 50 .

The species inserted in the list show the remarkable ichthyological specialties of the region, and that there are in it at least two ichthyological districts, their differences being clearly defined, although Carp (Cyprinidae) predominate in both.

Almost all of the 11 species of the mountain district (I) are peculiar thereto; the Balkhash Marinka, marked with an ? in the list, has not been scientifically determined, and may, on closer study, prove to be a separate species, distributed in the lower parts of the Balkhash tributaries, but not in the mountains.

Of the 22 species of the middle district (II) to were also found in the lower district (III); but probably the Caspian Alburnus (fasciatus et chalcoides), which was only found in the Zarafshan valley, also lives in the lower district, so that the species peculiar to district II probably consist of rather less than one-half of all its fauna.

Of the 18 species in the lower district (III) 7 or 8 only are peculiar thereto, so that this district (III) is much less distinct in its fishes from district II than are both (II and III) from the upper district (I). Not a single species is known to be really common to districts I and II, much less to I and III.

There have been found 26 species peculiar to Central Asia; all of them were in the upper district ; 14 out of 22 were in the middle district : and 5 out of 18 in the lower district, and all of European genera-forms like to Ponto-Caspian. Of the latter, 12 were actually found in the lower district, and probably there are more; 14 or 15 are mentioned in the list; there were 8 in the middle district, but not one in the upper (I).

There are three ichthyological faunas in the Turkistan region not having any common species between them, and not corresponding with the districts, as these have more or less a mixture of two or even of all three different faunas.

A. Ancient Central Asian fauna-principally in the upper district,

B. New Central Asian fauna, of which the majority of species are in the Middle district, the minority in the Lower.

C. Ponto-Caspian, of which the majority of species are in the Lower district, the minority in the Middle.

Although these three faunas do not possess any species in common, the degree of their differences are far from uniform. The ancient Central Asian may be considered as quite original, while the new Central Asian is rather an altered part of the Ponto-Caspian fauna, in which, for all its species, are found corresponding and closely. related forms, partly met with even in Turkistan waters, and unchanged there.

This shows that the new Central Asian fauna was geologically separated at a recent epoch, on the division of the former AraloCaspian basin into the present waters, while the ancient Central Asian fauna consists of the remnant which escaped, being driven by newet fauna into the mountain streams. .... The local varieties of the Silurus glanis aralensis and Gobrio fiuviatilis lepidolomus show that the evolution of a new Central A sian fauna from geographically sepa. rated parts of the Ponto-Caspian still continues. 


\section{PISCES (Fishes).}

BY K. F. KESSLER.

THIS article is intended to serve as a guide to the further investigation of the Ichthyological fauna of Turkistan. To this end are inserted [in the original] concise descriptions of all the species of fishes thus far found in the country, with the distinctive characters of the genera, families, and orders to which the species mentioned belong. The new species of fishes collected by A. P. Fedchenko on his first journey to Turkistan, and also the new species obtained in the same country by Severtsoff and Kushakevitch, have already been described by me in an article entitled "Ichthyological Fauna of Turkistan," which appeared in the Proceedings of the Imperial Society of Friend's of Natural History of Moscoav, in 1872 .

During his second journey in Turkistan, Fedchenko found only four new species: Aspius esocinus, Cobitis elegans, Salmo oxianus, and Scaphirhynchus Fedchenkoi (a detailed description of which also is included in the above-mentioned article). But these species are very interesting in many respects. Aspius esocinus by its elongated body and flattened head constitutes a very remarkable form of the genus Aspius, which up to the present has only had three representatives-one in S.E. Europe $(A$, rapax $)$; another in W. Asia $(A$.vorax $)$; and the third in China (A. spilurus). Salmo oxianus, discovered in the Kizil-su, in the Alai, appears in Turkistan as the sole representative of the numerous family of salmons. Scaphirhynchus Fedchenkoi [of which the only other species of the same genus known to us (Scaph. rafinesquii) belongs to North America] is of great importance, not only from a zoological, but also from a biological point of view, on account of the extreme smallness of its eyes and the rudimentary condition of its air bladder.

The little fish described by me in an article on the "Ichthyological Fauna of Turkistan," and called Schizothorax minutus, was ascertained to be a young specimen of Schiz. eurystomus, as, however, had been already supposed. In the last collection made by Fedchenko, there were, speaking generally, many young fishes of the genera Barbus and Schizothorax, which enabled me to convince myself of the fact that the rows of teeth, with which many species of these genera are furnished, on the hinder side of the large bony ray of the dorsal fin, are, among young fishes, at first very large and not numerous, but afterwards gradually increase in number and at the same time become comparatively smaller.

For the description of each species of fish the so-called characteristic formula has been introduced by me; i.e., a series of numbers which indicate how many hard and soft rays are found in each of the fins, and also how many scales are found on the lateral line, how 
many rows of scales are above the lateral line, and how many below it. For example, the characterizing formula for the bream, $A b r u m i s$ brama, is written thus :-

P. I/ $15-17$; V. 28 ; D. $3 / 9-$ IO ; A. $324-26$; C. 19 ; Lateral line $50 \frac{12-14}{-8} 55$;

and means that in that fish each of the pectoral fins contains $t$ hard and from $15-17$ soft rays; each of the ventral fins 2 hard rays and 8 soft; the dorsal fin 3 hard rays and 9 or 10 soft rays; the anal fin, 3 hard and from 24 to 26 soft rays; the caudal fin, 19 full rays (besides the small upper and lower incomplete rays), and also that there are on the lateral line, commencing from the upper part of the branchial crevices to the base of the caudal fin, from 50 to 5.5 separate scales; between that line and the base of the dorsal fin, from 12 to 14 longitudinal rows of scales; and between that line and the base of the ventral fins, 7 or 8 rows of scales. It is here necessary to remark that to the hard rays in the dorsal and anal fins are also added, in front, little incomplete rays, often very minute, and almost rudimentary. The characterizing formula of fishes is often of the utmost importance in the recognition of the species to which they belong; it sometimes happens that a single one of these formule is sufficient for the determination of the species, particularly in the carp family.

In deseribing the species, I have referred to the following works, besides the above-mentioned "Ichthyological Fauna of Turkistan" : -

I. Günther, A., "Catalogue of the Fishes in the Collection of the British Museum," 8 vols. 1859-70.

2. Pallas, P.S., "Zoographia Rosso-asiatica," 3 vols., 4to. 1831 . In this are described, more or less satisfactorily, all species of Russian fishes, which were known to Pallas, and it remains up to this day the principal source of information regarding Russian Ichthyology.

3. Kessler, K., "Description of the Fishes met with in the Waters of the St. Petersburg Province." 8vo, 1864. In it are to be found detailed descriptions of many of the species of fishes which also belong to Turkistan.

The Ichthyological Fauna of Turkistan is composed half of European and half of Asiatic forms ; and these are, in their turn, divided into several categories. As regards European species, some of them (Perca fuviatilis, Gobio furviatilis, Leuciscus rutilus, Abramis brama, Scardinius erythrophthalmus, and Cobitis taenia) are remarkable for the wideness of their distribution, being met with in the waters of almost the whole of Europe; and others (Licioperca sandra, Silurus glanis, Cyprinus carpio, Abramis sapa, Aspius rapax, Pelecus cultratus, Alburmus chalcoides, Alburnus fasciatus, and Acipenser schipa) belong to the number of fishes characteristic of Eastern Europe, inhabiting principally the waters of the Pontine and Caspian basins. To the European forms should also be added: Cottus spinulosus, exceedingly like Cottus gobio, Alburnus taeniatus, very like the species A. fasciatus, and A. bimaculatus, and Salmo oxianus, allied to $S$. trutta and $S$. fario. All these European forms belong principally to the lower course of the Syr-daria, Amu-daria, and part of the Zarafshan.

To the Asiatic forms are related species of the genera: Capoeta, Barbus, Schizothorax, Diptychus, Acanthobrama, and partly also to the genera Alburnus (A. iblioides), Aspius ( $A$. esocinus), and Cobitis (C. Iongicauda, $C$. uranoscopus, $C$. dorsalis, $C$. elegans). Certain 
representatives of the genera Barbus and Cobitis are, in fact, met with in Europe, particularly in the S.E, but all the said genera are preeminently Asiatic. The genera Schizothorax and Diptychus, which are characterized by a slit sheath on the posterior part of the belly, belong exclusively, as far as at present known, to the high mountainous countries of Central Asia. Thus, for instance, the only species of the genus Diptychus (viz., Diptychus maculatus, Steind.) known up to the discovery of the Turkistan species, was found in Tibet at the altitude of 11,200 feet. And the Turkistan species (Diptychus Severzovi) was also obtained by Severtsoff in the rivers Ottuk and Aksai, at the altitude of 10,000 feet. Representatives of the genera Capoeta and Acanthobrama were previously found almost exclusively in the rivers of W. Asia, Syria, Anatolia, and Persia.

On each journey, however, the most interesting Ichthyological discovery of Fedchenko was the Scaphirhynchus Fedchenkoi which inhabits, it appears, the Syr-daria exclusively. The interest of this find has been further increased by the discovery of a third species of Scaphirhynchus by M. N. Bogdanoff, in the Amu-daria. From this it seems that each of the two great rivers emptying into the Aral Sea (as also the River Mississippi) has its separate representative of the genus Scaphirhynchus, while almost all the other fishes met with in the lower parts of the Syr-and the Amu-daria respectively, so far as is known, do not differ according to locality, but belong to the same species. It may, therefore, be anticipated that in course of time other species of the genus Scaphirhynchus will be discovered in the rivers of E. Turkistan and China (as not long ago was discovered, in the river Yang-tse-kiang, a species of the genus Spatularia, the third genus of sturgeons, viz., Spatularia gladius, Martens).

Of the 38 species of fishes, known to us up to the present in Turkistan, no less than 25 belong to the carp family, which, therefore, may be regarded as completely predominating. This family is also very rich in representatives in the rivers of S. Europe, W. Asia, and the E. of India, but does not predominate over all the other families to such a degree, as in Turkistan. The small number of representatives of the Silurus (one species) and Salmonidae (one or two species) families is also very characteristic of the Turkistan Ichthyological fauna, as the said two families are very rich in species in almost all other mountain countries.

It is very probable that of the fishes inhabiting the Syr-daria and Amu-daria many live in the Aral Sea, but this sea remains uninvestigated. It is only known that the fishermen on the islands of the Aral catch small sturgeons, silurus, and carp. There is but one species of fish from the Aral Sea in Fedchenko's collection-Pelecus cultratus. Meanwhile, it would be of the highest interest to know whether other sorts of marine fishes besides the small sturgeon exist in the Aral Sea, and whether there are not preserved in it descendants of those species which once inhabited the ancient Pontine-Caspian-Aral basin. Thus, for example, it is very unlikely that there are in it no representatives of Gobius, which are so characteristic of the Black and Caspian Seas. 


\section{TELEOSTEI.}

ACANTHOPTERI. Percomei, Cuv.

\section{Perca, L.}

I. Perca fluviatilis, L. Perch.

II. Lucioperca, Cuv.

2. Lucioperca sandra, Cuv. Pike-Perch.

Cataphracti, Cuv.

III. Cottus, L.

3. Cottus spinulosus, Kessl. Miller's Thumb.

PHYSOSTOMI, MÜLLER.

SiluroIdeI, Agassiz.

IV. Silurus, L.

4. Silurus glanis, L.

CyprinoldeI, Agassiz.

V. Cyprinus, L.

5. Cyprinus carpio, L. Carp.

VI. Capoeta, Cuv.

6. Capoeta Steindachneri, Kessler.

VII. Barbus, Cuv.

7. Barbusconocephalus, Kess.)

8. ." lacertoides, "Barbuls.

9. .. brachycephalus,., I

VIII. Schizothorax, Hæckel.

10. Schizothorax aksaiensis, Kessler.

iI. . Fedchenkoi, ",

12. .. affinis, ",

13. .. eurystomus, ,"

IX. Diptychus, Steindachner.

14. Diptychus Sewerzowi, Kessler.

$$
\text { X. Gobio, Cuvier. }
$$

15. Gobio fluviatilis, Cuv, Gudgreon XI. Abramis, Cuvier.

16. Abramis brama, L. Bream
17. Abramis sapa, Pallas.

XII. Acanthobrama, Hæckel.

18. Acanthobrama Kuschakewitschi, K. XIII. Pelecus, Agassiz.

19. Pelecus cultratus, L.

XIV, Alburnus, Rondelet.

$\left.\begin{array}{l}\text { 20. Alburnus chalcoides, Güld. } \\ \text { 21. " iblioides, Kessl. }\end{array}\right\}$ Bleaks.

22. " fasciatus, Nordm.

23. $"$ taeniatus, Kessler.

XV. Aspius, Agassiz.

24. Aspius rapax, Pallas.

25. " esocinus, Kessler.

XVI. Scardinius, Bonaparte.

26. Scardinius erythrophthalmus, L Rudd.

XVII. Squalius, Bonaparte.

27. Squalius intermedius, Kessler.

28. ." squaliusculus, ,.

XVIII. Leuciscus, Rondelet.

29. Leuciscus rutilus, L. Roach.

SALMONOIDEI, HECKEL. XIX. Salmo, L. Trout.

30. Salmo oxianus, Kessler.

ESOCINI, HACKEL. XX, Esox, L.

31. Esox lucius, L. Pike.

ACANTHOPSIDES, HECKEL. XXI. Cobitis, L.

32. Cobitis longicauda, Kessl.

33. " uranoscopus, ,"

34. ". dorsalis, ", Laarhes.

35. ". elegans, ",

36. " taenia, L.

\section{GANOIDEI.}

Chondrostet, MǗlier.

XXII. Acipenser, L. Sturgeon. 37. Acipenser schipa, Lovetzky.

XXIII. Scaphirhynchus, Hæckel. 38. Scaphirhynchus Fedchenkoi, Kessler.

$$
\text { ADDENDA. }
$$

I. Perca Schrenkii, Kessler. Perch.
2. Barbus platyrostris, Kessler. Barbel. 3. Schizothorax orientalis, , 4. " argentatus, , 5. Diptychus Dybowskii, ,

\section{Diplophysa.}

6. Diplophysa Strauchii, Kessler. 7. " labiata, " 


\section{MOLLUSCA (Mollusks).}

By EduARD von MARTENS (Professor in the University of Berlin).

THE following description of Turkistan Mollusca is based chiefly upon the materials collected by Fedchenko, and in addition there have been included from the same region those very few species which were known to science previously, viz., three species collected by P. P. Semenoff in the Thian Shan, and one which was known, thanks to Messrs. Middendorff and Baer, from the Sea of Aral.

In the definition and determination of species, I have constantly had in view that the matter referred to a country in which we might expect perfectly new and peculiar forms, as well as many of the most widely distributed European ones, and also such as are now known in the farther parts of Asia. I have, therefore, considered it necessary to carefully compare each of the species of Mollusca collected, first with representatives of the European fauna, and afterwards with those made known to us from the Himalayas by English students; and, if I did not find constant and unvarying characters, I did not hesitate to consider the species as known; there are, however, many new species which for the present may be considered as peculiar to Turkistan.

The naked Mollusca (Limax, A malia) have been investigated and described by F. D. Heinemann, of Frankfurt-on-the-Maine, and the small fresh-water Mollusca (Corbicula minima, and Pisidium) by S. Clessin, of Dinkelscherben, as they had for a long time specially occupied themselves with these genera; they are consequently responsible for the distinctness of the new species here described.

There can be no doubt that in the more mountainous parts of Eastern Turkistan many land Mollusca will yet be discovered; it is very astonishing, for instance, that in the whole of that region we have not found a single species of the genus Clansitia. 


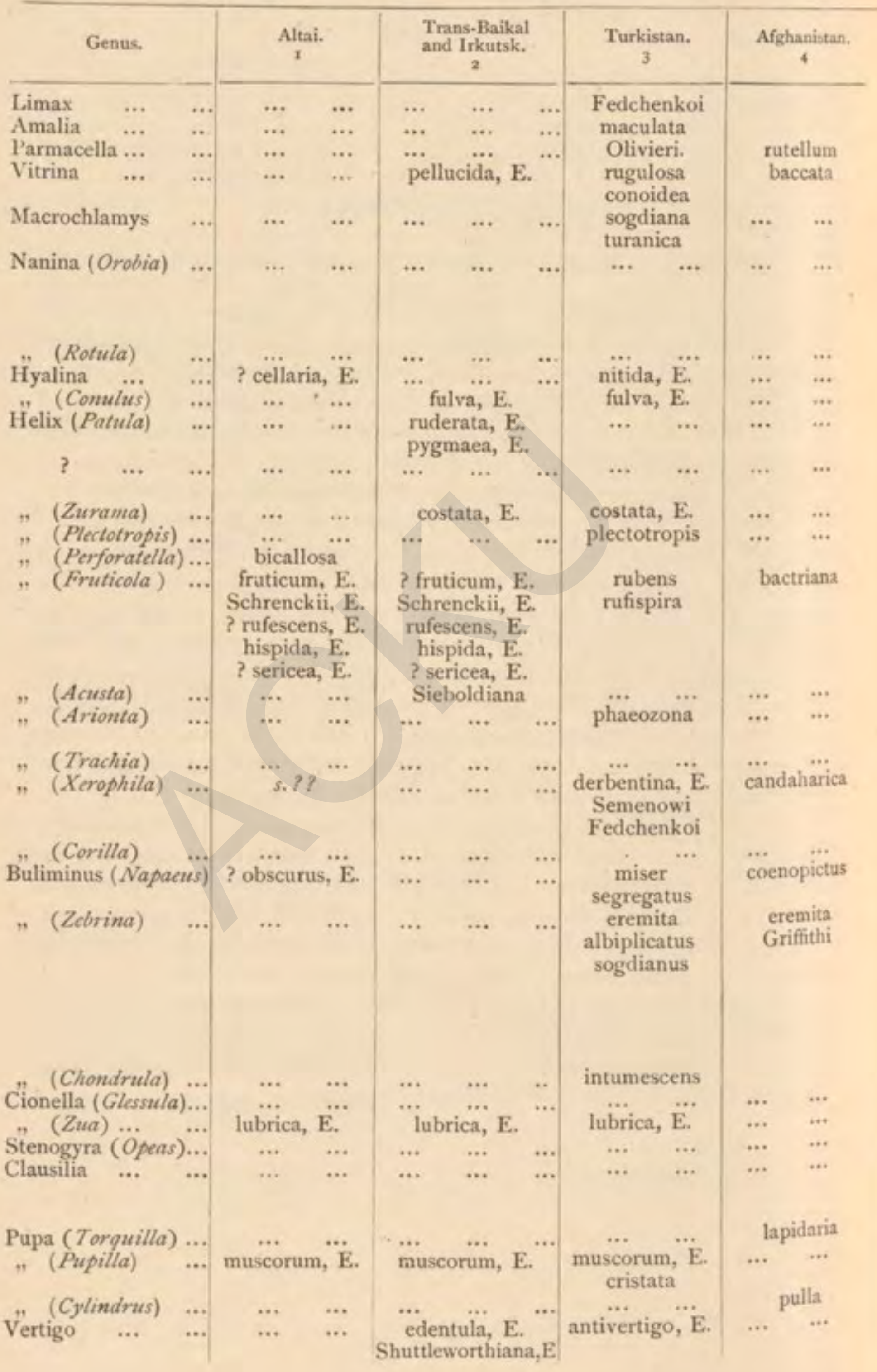




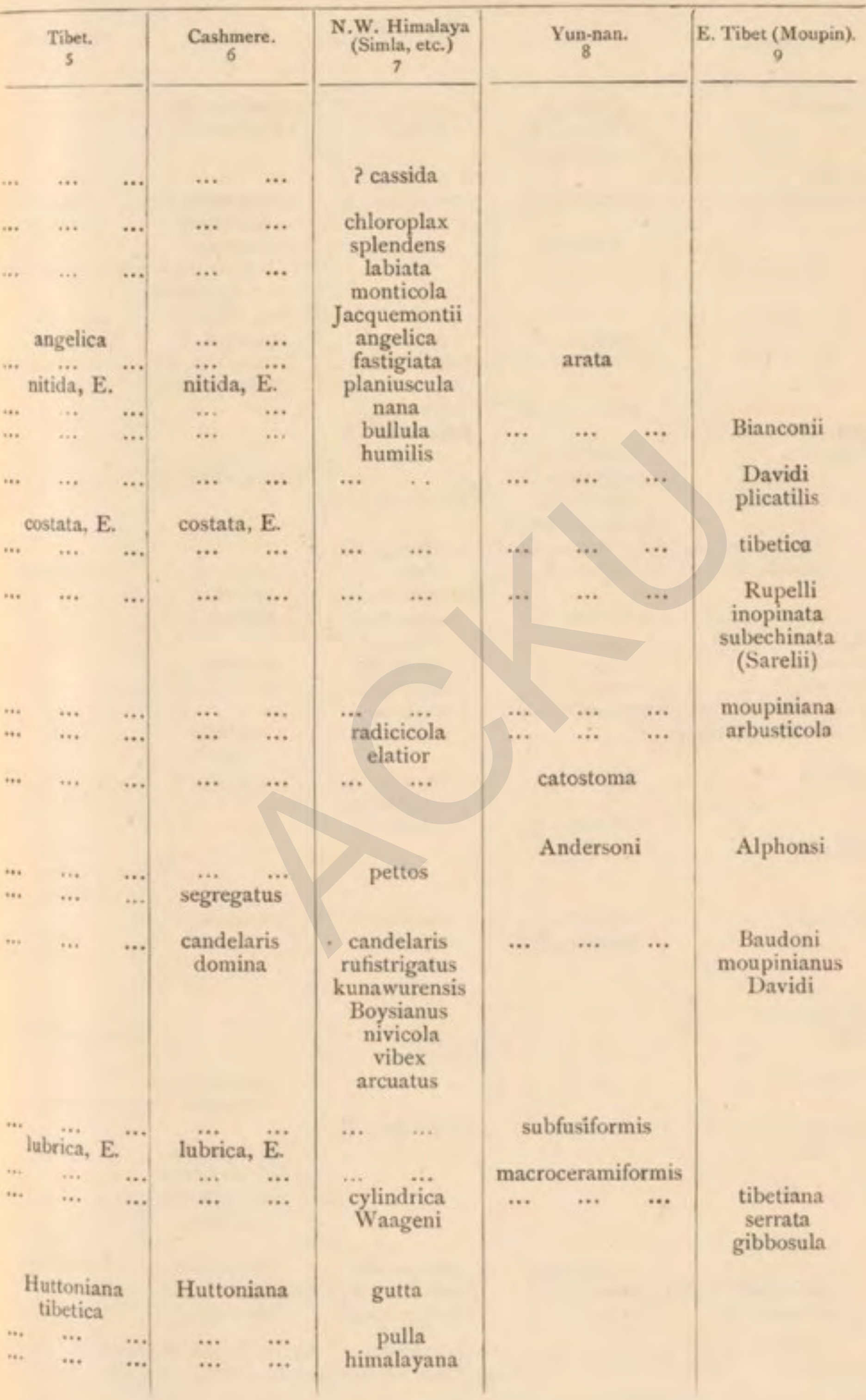




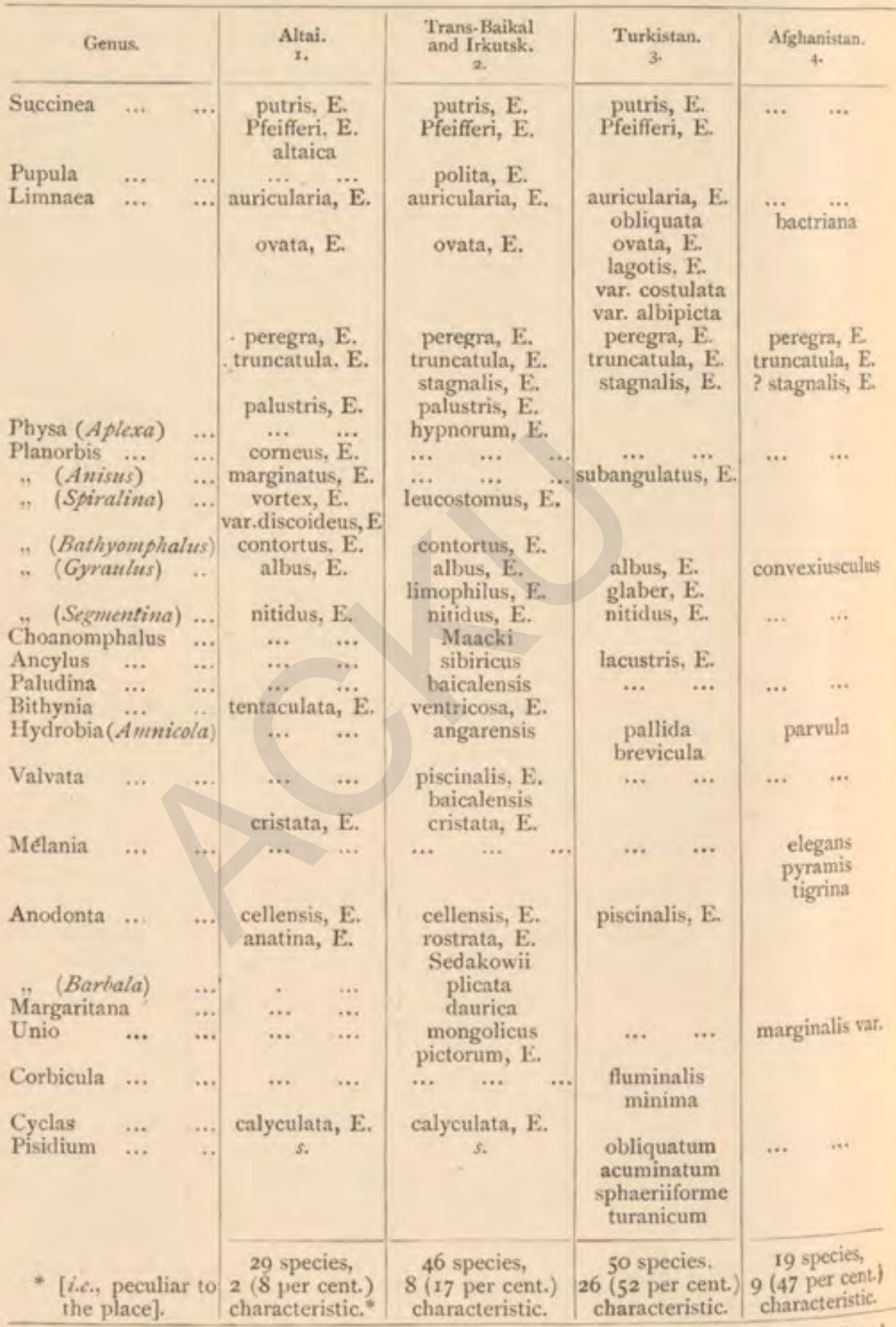

Of these there are known only in various parts of Central Asia, 99 species. Found also in India, to the south of the Himalayas, 11 species; in India and China, 1 species; in China or Japan, 3 species ; in Asia Minor, but not in Europe, 2 species. 
APPENDIX A.-MOLLUSCA.

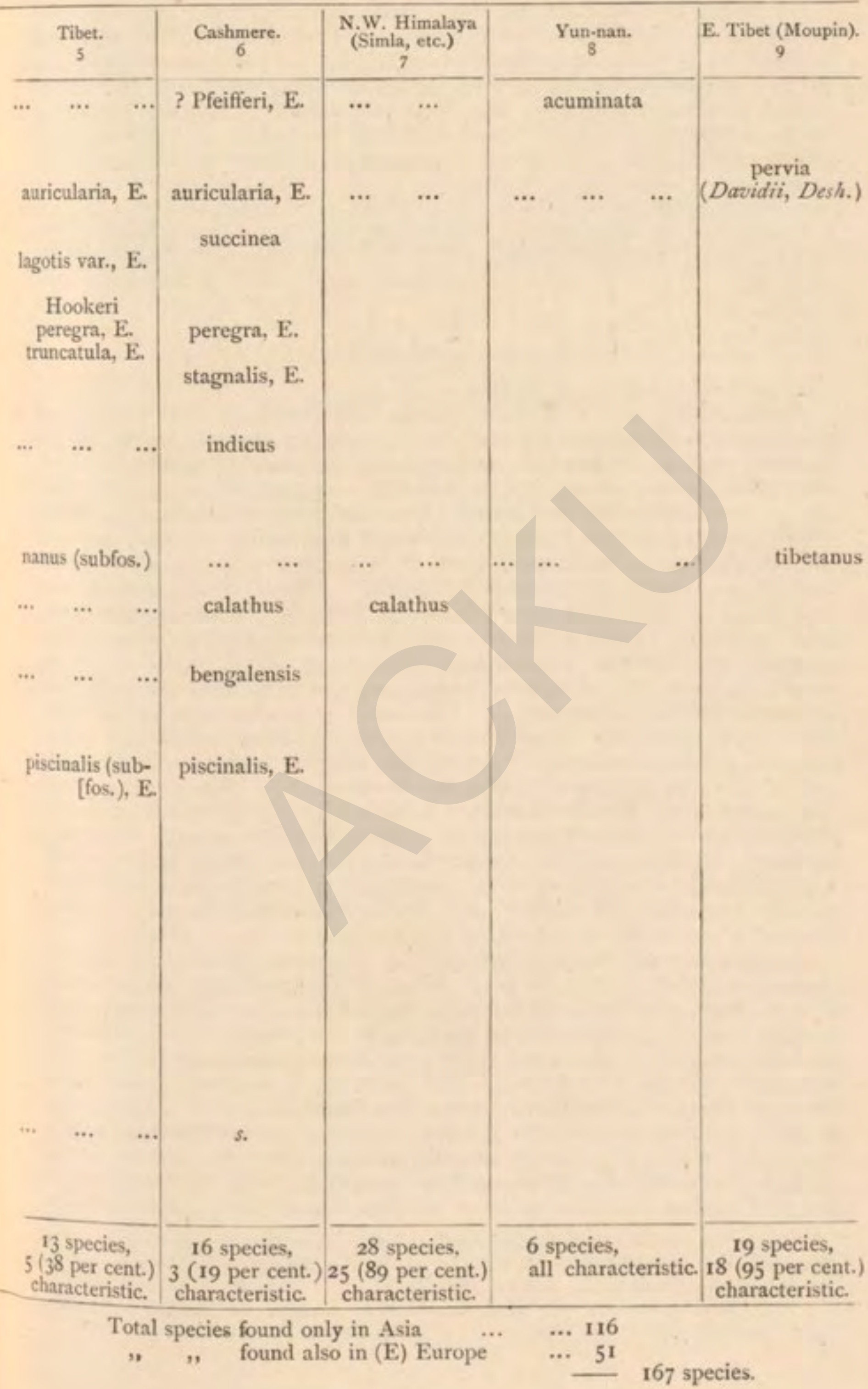


[Professor von Martens, having revised the foregoing, informs me that considerable additions to the Mollusca of Turkistan and the adjacent regions have been made by the collections of Dohrandt (1875), and Barbot $(1876)$ in Khiva; of Prjevalsky, in Mongolia ; and Dr. Albert Regel, in Kuldja (1878).* The Professor received another collection made $(1873-79)$ by Colonel Kushakevich in the Southern Ala-Tau, Khokand, and Pamir.t He is good enough to forward me a new table, thus:-

\begin{tabular}{l|c|c|c|c|c|c|c|c}
\hline & Khiva. & Samarkand. & $\begin{array}{c}\text { III. } \\
\text { Ferghana. }\end{array}$ & $\begin{array}{c}\text { IV. } \\
\text { Kuldja. }\end{array}$ & $\begin{array}{c}\text { V. } \\
\text { Ala-Tau. }\end{array}$ & $\begin{array}{c}\text { VI. } \\
\text { Yuldus }\end{array}$ & $\begin{array}{c}\text { VII. } \\
\text { Kashgar. }\end{array}$ & VIII. Ladak. \\
\hline Total No. & 4 & 18 & 26 & 20 & 4 & 5 & 9 & 7 \\
Peculiar sp. & I & 3 & 9 & 8 & 0 & 0 & 2 & 1 \\
Europ. sp. & I & 7 & 6 & 0 & I & 3 & 3 & 5 \\
\hline
\end{tabular}

with general remarks, as follows : $-H . J$.

Land Mollusca.-This table shows very distinctly the scarcity of land snails in the desert plains (i., vii., viii.), as opposed to the larger number and more peculiar forms in the mountain regions (iii., iv.). The total number of species in this list is 53 , of which 33 are, as far as we know, peculiar to Central Asia as here understood; on the other hand, 11 species are also generally distributed in most parts of Europe, but all of small size, most of them being also found in Siberia and North America (circumpolar species). Most of the genera and sub-genera, and exactly those which are richer in species, are European, and generally characteristic of the Palaearctic region (Fruticicola, Xerophila, Zebrina. Chondrula); but many of the species, chiefly in Fruticicola, are somewhat abnormal, and may form hereafter the types of distinct subgenera. Vitrina is characteristic of northern and alpine countries; Succinea is a cosmopolitan genus; one of the species, $S$. Martensiana, is one of the largest and most intensively coloured in the genus. Parmacella is peculiar to Western Asia and the shores of the Mediterranean. Trachia is, to some extent, a type of Eastern Asia. Macrochlamys is a more tropical genus. The total absence of Clausitia is very remarkable, as this genus is very richly represented in South-Eastern Europe, and it is also tolerably well represented in India and China. Its absence gives a decidedly northern feature to the fauna of the whole of Central Asia.

Fresh-water Mollusca.-Among the fresh-water Mollusca, the predominant feature is the large number of air-breathing species which live in stagnant water, and the paucity, and almost total absence, of the genera living in running water, for example, Neritina, Unio, Melania, and Melanopsis. The same is the case in most northern regions; for example, Siberia and Canada and also, to some extent, in Central Europe, whereas in Southern Europe the case is reversed. Also in the Alps of Central Europe the genera Limnaea and Pisidium (and in some places also Planorbis) extend further north than the rest of the fresh-water Mollusca. If we omit the species found in Lake Aral, which are all Caspian and belong to a peculiar fauna, the number of fresh-

* [ Von Martens has published another volume, incorporating this additional information on the Mollusca of Central Asia, in the M/emoires de IAcid. Imf. It St. Pliershourg, tome xxx., No. 11,1882 .]

+ [See Sitsungsberichte der naturforschenden Finenude in Berlin, July, 1882 PP. IO$_{3}$ and 107.$]$ 
water species contained in our list is 39 , the larger half of which-22are somewhat generally distributed in Europe; others are Siberian (Planorbis sibiricus), or Chinese (Limnaea pervia), or peculiar to South.Western Asia and Northern Africa (Corbicula fluminalis), and the few which are peculiar are all of small size (Hydrobia, Pisidium), and exhibit no striking differences from European species. Some varieties of Limnaea are characterized by exceptional thickness of the shell (L. auricularia, var. obliquata ; lagotis, var. solidissima); they live in elevated lakes with stony bed: others are characterized by white markings (lagotis, var, albopicta). The scarcity of Mollusca in running water may be due to the low temperature and stony bed of the rivers, just as it is in Switzerland.

\section{ARANEAE (Spiders).}

\section{By Alexander Kroneberg.}

IN the collection brought by Fedchenko's expedition, the Araneae are important, and the more interesting, because up to the present we have had almost no information concerning this portion of the fauna of Turkistan. I can find in the literature only two references to the forms found in Turkistan, both of them in the great work of C. Koch (" Die Arachniden," etc.), wherein are described Tarantula obsoleta and Calliethera tricincta from Bokhara. The latter species is found in Fedchenko's collection. Our knowledge is a little fuller in this respect with regard to the fauna of the countries adjacent to Turkistan, which resemble it in character and climate, namely, the Caspian steppes, Kirghese steppes, and Southern Siberia. Besides the large tarantula (Trochosa singoriensis, Laxm.), which is generally distributed over the whole of Southern Russia, Pallas describes in his "Travels," and in "Spicilegia Zoologica," the "Krestorik" (or Cross-spider, i.e., with a cross on its back), Argiope Brummichii, Scop. (speciosa, Pall.), and A. lobata, Pall, known by their remarkable form and colouring in Southern Europe, from the Caspian steppes and Upper Irtish. The tchim mentionedin his " Travels," which is known to the Kalmuks by its stinging horned cattle, may, in the opinion of Motschulsky (Bull. de Mosc., 1849), be related to Lycosa infernalis, Motsch., or to Latrodectus lugubris, Id.

It is difficult to recognize the spiders of which Lepechin speaks in his journal. The large Krestovik, found by him near Kamyshin on the Volga, and called Ar. bicornis, was afterwards described by Krinitsky in the Bull. de Mosc., 1837 , No. V., p. 78, under the name Ep. Lepechini, and is probably Ep. angulata or regia. Another species, met with in the Urals under the bark of trees, and named by Gmelin Ar.alba, is probably related to Thomisus onustus (abbreviatus) or vatius. Eichwald ("Fauna Casp. Caucas.") confined himself to the Arg. Lobata and Brunnichit mentioned above.

If we add to these a few more spiders described by Keyserling and L. Koch from the environs of Sarepta, we have, as a general total for the whole cis-Caspian steppe country, and Turkistan, only 10 or 12 species, which certainly does not permit us to form even an approximate idea of the character of the local fauna and its relation to the faunae of neighbouring countries.

The collection sent to me principally consisted of the materials col- 
lected in Turkistan and the Khanate of Khokand, with the addition of some species received by Fedchenko from the neighbouring localitiesOrenburg, Semirechia, and Kuldja. The total number of species amounted to 180 , of which 146 appeared to be recognizable; of that number ror were already known, and 45 were new.

As all the species already described, which were found in Turkistan, are related to the forms distributed over Central Europe and the countries surrounding the Mediterranean, and as among the new species there is not one tropical form, the list of spiders here given has quite a European character. It is, however, necessary to remark that, judging from the data in our possession concerning the fauna of Central and Southern Europe, this list, in all probability, does not represent more than one-third of the species to be met with in Turkistan. The labours of faunistic naturalists of late years have disclosed, particularly in Southern Europe, an unexpected wealth of forms, and there is no reason to suppose that Turkistan is poorer in this respect than the western countries. As regards North-Western and Central Europe -Westring (1862) enumerated 308 species in Sweden; Blackwall (1863) 304 in Britain, not reckoning those afterwards described by Cambridge; * in Central Europe, Menge (1866) took at least 350 species in East Prussia alone; Italy has, according to Canestrini and Pavesi ("Catalogo sistem.," 1870), 485 species. $\dagger$

Quite as rich, apparently, are the southern and eastern shores of the Mediterranean. In dry and stony Syria and Palestine, Cambridge succeeded in collecting, in the course of two months, not less than 300 species, half of which appeared to be new. This large percentage, and the constant increase in the number of species in European lists, show that the figures quoted above are very far from representing the whole of this portion of the fauna of the said localities. Doubtless, therefore, in time, the list of Turkistan spiders will be materially increased, and it is also very probable that in the southern portion, in Balkh, Kunduz, etc., certain forms will be found of a tropical character, similar to those found by Cambridge in Syria, though in a very small number, notwithstanding that their distribution towards the north does not, in this country, meet with such important natural obstacles as, in Southern Turkistan, are presented by the Hindu Kush and the mountains on the Persian frontier.

Of the 16 families to which, according to Thorell ("On European Spiders," p. 42), the European spiders belong, all except two groups (Urocteoidae and Filistatoidae), very limited in number, have their representatives in Turkistan. The 146 species known there (including one undescribed Cyrtauchenius) belong to 55 genera, which constitute approximately one half of the total of European genera (according to Thorell, 120). Among them are not found many of those semi-tropical genera, such, for example, as Argyrodes, Scytodes, Heteropoda, Ctenus, etc., which belong also to the Mediterranean fauna, not to speak of purely tropical forms. The species are distributed in such a way that after deducting 45 new ones, of the remaining ror species 15 were

* [In 1880, the Rev. O. Pickard Cambridge (who has been good enough to look over this article for me) was acquainted with 518 British spiders. - H. L.]

+ As far as regards European Russia, the country nearest the region in which we are interested, we have only the incomplete lists of Nordmann for Finland, Grube for the Baltic governments, and Simashko for the environs of St. Peters. burg. But judging from what Nordmann says, and from materials in my possession, not less than 400 species of spiders are met with in European Russia. 
known up to this time exclusively in Northern and Central Europe 56 belong also to the Mediterranean fauna, and 30 to the latter alone.

The following are common to Turkistan and Central Europe :-

1. Linyphia nebulosa, Sund.

2. Erigone bicuspidata. Menge.

3. " livida, Blackw.

4. ." fuscipalpis, Koch.

5. Singa pygmaea, Sund.

6. Drassus villosus, Thor.

7. Gnaphosa variana, Koch.

8. Xysticus sabulosus, Hahn.

9. Xysticus bifasciatus, Koch.

ro. " luctuosus, Blackw.

11. .. acerbus, Thor.

12. Artanes pallidus, Walck.

13. + paecilus, Thor.

14. Philodromus elegans, Blackw.

15. Lycosa herbigrada, Blackw.

Of the species of the Mediterranean fauna there are found in Turkistan :

I. Argiope Brunnichii, Scop.

2. Iobata, Pall.

3. Epeira regia, C. Koch.

4. Victoria, Thor.

5. Theridium punicum, Lac.

6. Latrodectus erebus, Sav. et Aud.

7. $"$ conglobatus, C. Koch.

ช. Dictyna consecuta, Cambr.

9. Drassus lutescens, C. Koch.

to. Melanophora conspicua, L. Koch.

II. Gnaphosa exornata, C. Koch.

12. (f) Gnaphosa rufula, L. Koch.

13. Chiracanthium italicum, Canestr.

I4. " Seidlitzii, L. Koch.

15. Misumena villosa, Walck.

I6. Xysticus brevitarsis, Sim.

17. Thanatus Albini, Sav. et Aud.

18. (?) Cyrtauchenius Walckenaeri, Luc.

19. Tarentula narbonensis, Latr.

20. $"$ albo-fasciata, Brullé.

21. Trochosa singoriensis, Laxm.

22. Oxyopes gentilis, C. Koch.

23. Palpimanus gibbulus, Duf.

24. Eresus imperialis, Duf.

25. Ballus rufipes, Sim.

26. (?) Euophrys intenta, Blackw.

27. Philaeus haemorrhoicus, C. Koch.

28. Menemerus indistinctus, Cambr.

29. Heliophanus rufithorax, Sim.

30. Calliethera tricincta, C. Koch.

Of the new species belonging to the genera distributed almost exclusively over the Mediterranean district there are also, Zodarium bactrianum, Hersiliola pallida, Cteniza ferghanensis, Eresus tristis, and Er,arenarius, and, in addition, one Cyrtauchenius. Finally, to the number of forms with Southern European character may be added, Meta dentipalpis, Theridium tuberculatum, Amaurobius longipalpis, Sparassus sericeus, Xysticus lugubris, and the large species of tarantula, Tarentula alficeps, fulviventris, and latifasciata. The remainder have a more uniform character, if we do not reckon the comparatively large numbers of certain species of the family Drassoidae, for example, Drassus, Melanophora, Chiracanthium, as a special distinguishing feature of the eastern part of the Mediterranean province.

Thus the Turkistan fauna of spiders, so far as we now know, appears to be composed of representatives of both divisions of the European fauna, with a slight predominance of South European forms. Although the apparent preponderance of the latter, partly the consequence of the very limited materials, is in itself unimportant, the presence of many characteristic southern genera, as Argiope, Latrodectus, Zodarium, Hersiliola, Eresus, Palpimanus, together with certain Theraphosoidae (Mygalidue), and the large Sparassus and Tarentula, at once clearly shows the connection between Turkistan and the Mediterranean province. In any case, our acquaintance with the spiders of the Steppe fauna is still too incomplete to enable us to say definitely whether it constitutes a simple continuation of the Mediterranean fauna towards the east, or a special faunistic province, bearing the same relation to it as the Central European.* - A certain peculiarity of its character may be recognized in the comparative
VOL. II. 
With regard to the distribution of the species known previously in Turkistan itself, our observations do not enable us to draw any conclusions whatever, the more so, as the European fauna in this respect has hardly been touched. From the comparison of the localities it is not evident, for instance, whether the Central European forms met with in Turkistan belonged principally to any known zone, or whether the sharp contrast in the nature of the lower and Alpine zones, or steppe and cultivated zones, is accompanied by the predominance of known typical forms of spiders. It is necessary, however, to direct attention to certain facts connected with vertical distribution. On the banks of the Iskander-Kul, at 7,000', were found not only Epeira patagiata, Linyphia hortensis, "Theridium sisvphium, Misumena vatia, and Thomisus onustus, but in much higher localities not a few species were also met with. Thus in Autchi pass, at an elevation of $7,500^{\prime}$ to $11,200^{\prime}$ were collected Erigone bicuspidata. Theridium albomaculatum, Lycosa palustris, Xysticus cristatus, and Philaeus haemorrhoicus, and of the new species, Drassus breviceps, menticola, and Lycosa velox; in the Kichi-Alai, higher than 9,000', were found Lycosa palustris, $X$. cristatus, and Heliophanus truncorum, and on the Jiptyk pass at $8,60^{\circ}$, Latrodectus conglobatus.

The evident incompleteness of our information concerning Turkistan spiders was also the cause of my departure from the plan laid down of giving a table for the definition of genera and species. For the European genera, which up to the present have been met with in Turkistan, there exists already a very detailed table in the work of Prof. Thorell, of Upsala ("On European Spiders," by T. Thorell, Upsala, 4to, $1869-70$ ), a work which I have followed in the systematic arrangement of the species enumerated below :-

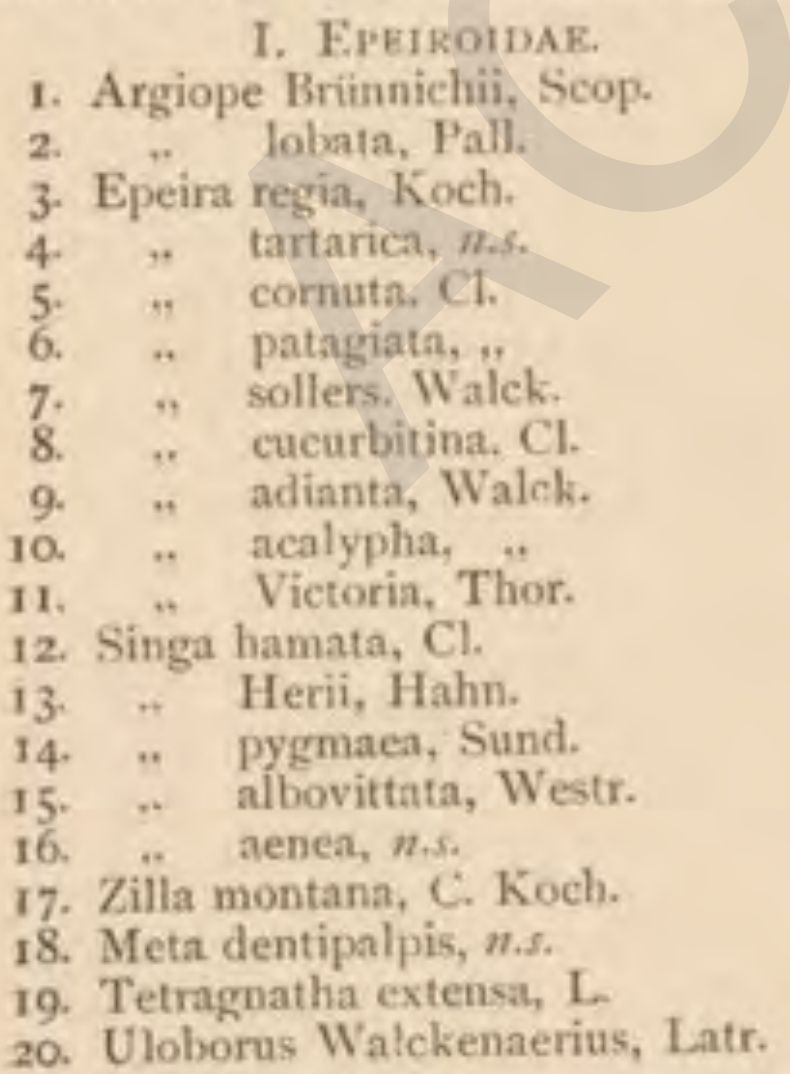

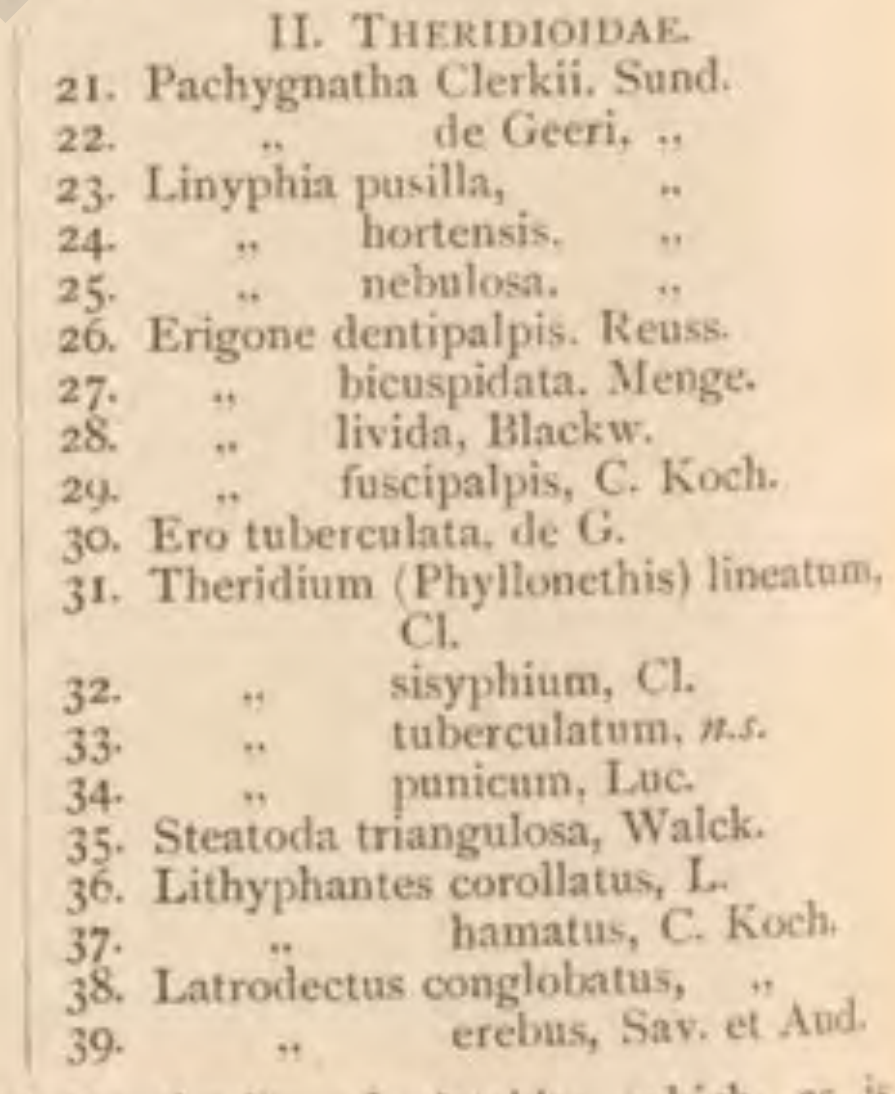

poverty of Turkistan representatives of the family of Attoidae, which, as is known, is extremely rich in species in Southern Europe, N. Africa, and Syria. and, further, is composed of forms not so easily escaping the attention of collectoras the small Linyphia, Erigone, and others. Judging from what I have succeede in collecting in the steppes of S.E. Russia and the eastern part of the Caucasus. these localities also, in an important degree, fall short of the numerous Attoidac of Western countries. 
III. SCYTODOIDAE. 40. Pholeus Forskålii, Thor. IV. ENyomat. 41. Zodarium bactrianum, n.s. V. HersILIOIDAF.

42. Hersiliola pallida, n.s. VI. Agelenotdae.

43. Dictyna arundinacea, L.

44. " consecuta, Cambr.

45. Amaurobius longipalpis, n.s.

46. Caelotes major, n.s.

47. Agelena labyrinthica, CI.

VI1. Drassoidar.

48. Clubiona maracandica, n.s.

49. Chiracanthium carnifex, Fabr.

50. .. nutrix, Walck.

51. * italicum, Can. et Pav.

52. " $\quad$ Seidlitzii, L. Koch.

53. . . brevidens, n.s.

54. Micaria pulicaria, Sund.

55. $" \quad$ pygmaea, n.s.

56. $"$ modesta, n.s.

57. Drassus villosus, Thor.

58. " loricatus, L. Koch.

59. ". lutescens, C. Koch.

60. .. rufescens, n.s.

61. . breviceps, n.s.

62. .. monticola, n.s.

63. ". Fedehenkoi, n.s.

64. Melanophora Petiverii, Scop.

$65 . \quad$ ". conspicua, L. Koch.

66. ".. jaxartensis, n.s.

$67 . \quad$.. fuscimana, n.s.

68. .. hamipalpis, n.s.

69. picea, n.5.

70. Gnaphosa variana, C. Koch.

$71 . \quad . \quad$ exornata, .".

72. " rufula, L. Köch.

VIII. DYSDEROIDAE.

73. Dysdera aculeata, n.s.

74. " tartarica, n.s.

IX. Theraphosoidan.

75. Cteniza ferghanensis, n.s.

76. Cyrtauchenius Walckenaeri, Luc.

$\mathrm{X}$. ThomisoidaE.

77. Sparassus sericeus, n.s.

78. .. oculatus, n.s.

79. Artanes pallidus, Walck.

$80.0 \%$ poecilus, Thor.

81. Philodromus aureolus, $\mathrm{Cl}$.

$8_{2}$. . elegans, Blackw.

$8_{3} . \quad$ fallax, Sund.

$8_{4}$. ". pictus, n.s.

85. . humilis, n.s.

86. Thanatus oblongus, Walck.

$87 . \quad$.. arenarius, Thor.

88. .. Albini, Sav. et Aud.

89. Thomisus abbreviatus, Walck.

90. Misumena vatia, $\mathrm{Cl}$.
91. Misumena lateralis, C. Koch.

92. $"$ villosa, Walck.

93. Diaea dorsata, Fabr.

94. " globosa, ..

95. Xysticus cristatus, $\mathrm{Cl}$.

96. ". bifasciatus, C. Koch.

97. " luctuosus, Blackw.

98. .

99. " sabulosus, Hahn.

100. " brevitarsis, Sim.

101. .. concinnus, n.s.

102. .. lugubris, n.s.

XI. Lxcosomat.

103. Lycosa herbigrada, Blackw.

104. .. palustris, L.

105. . velox, n.s.

106. .. orientalis, n.s.

107. . concolor, $n .5$.

108. .. aculeata, u.s.

rog. Tarentula trabalis, CI.

ro. .. fabrilis. .,

111. .. albofasciata, Brullé

II2. .. latifasciata, n.s.

I13. .. narbonensis, Latr.

1 I4. .. alticeps, n.s.

115. .. fulviventris, n.s.

116. Trochosa ruricola, De G.

I17. $"$ terricola, Thor.

I18. $*$ cinerea, Fabr.

I19. $\quad$ singoriensis, Laxm.

120. Dolomedes fimbriatus, Cl.

121. Ocyale mirabilis, CI.

\section{OXYopoidaE.}

122. Oxyopes lineatus, I $-a t r$.

123. . gentilis, C. Koch.

XIII. EResoidae.

124. Palpimanus gibbulus, Duf.

125. Eresus cinnabarinus, Oliv.

126. " tristis, n.s.

127. ". imperialis, Duf.

128. " arenarius, n.s.

XIV. AтTOIDAR

129. Leptorchestes hilarulus, C. Koch.

130. Epiblemum tricinctum, ",

131. Heliophanus truncorum, ",

132. .. flavipes, Hahn."

133. . nitens, C. Koch.

134. ". rufithorax, Sim.

135. Ballus rufipes, Sim

136. Marpessa obscura, n.s.

137. .. marginata, n.5.

138. Menemerus indistinctus, Camor

139. Euophrys intenta, Blackw.

I40. . ocellata, n.s.

14I. Philaeus haemorrhoicus, C. Koch.

142. Attus floricola, C. Koch.

143. . albo-zinctus, n.s.

144. .. elegans, n.s.

145. Aelurops ater, n.s.

I46. .. variegatus, n.s. 


\section{CRUSTACEA.}

\section{By V. N. Ulianin.}

THE following pages contain the results of the examination of part of the Crustacea collected by Fedchenko, viz., Amphipoda, Isopoda, Copepoda, Phyllopoda, and Cladocera. Ostracoda will form the subject of another part of the "Travels in Turkestan."

The Copepoda Fedchenko proposed to treat himself, and consequently devoted special attention to creatures of this order. During his travels he, whenever possible, submitted the specimens of this order that he collected to a more or less detailed preliminary investigation. To such preliminary, but in the majority of cases very minute, investigation were also submitted all species of the genus Cyclops collected by him. There only remained for me to verify his remarks, in part to complete them, and prepare from them the descriptions of the species of that genus furnished by myself. In this I have received great assistance from the beautiful and remarkably detailed drawings of entire specimens of Cyclops and also of many details, prepared from fresh specimens, by Madame Fedchenko, under the supervision of her husband.

[These drawings are added in the original. $-H . L$. ]

I have endeavoured to compile the present list as a handbook, with synoptical tables. With the aid of these tables, the distinguishing marks of the new forms described by me, and of forms previously defined, are easily seen.

In all there are 51 species enumerated in the present volume $(2$ Amphipoda, 9 Isopoda, 17 free-living Copepoda, 2 parasitic Copepoda, 2 Phyllopoda, and 19 Cladocera), of which 17 are new (1 Amphipoda, 7 Isopoda, 8 Copepoda, and I Cladocera). Doubtless there is to be found in Turkistan a much larger number of species of Crustacea, and much remains to be done by future investigators of that country to complete the present list.

The land Crustacea are represented in the collection by only one genus, Porcellio, the multitudinous species of which are, as is known, scattered over the world. It is very probable that in Turkistan there are to be found certain other genera of Porcellionida very common in Europe (viz., Ligidium, Philoscia, and Platyarthrus), which are distributed over the whole of Central and Southern European Russia. The absence of species of these genera in Fedchenko's collection may easily be explained, partly by the mode of life of creatures related to these genera (species of the genera Philoscia and Ligidium always live solitarily and somewhat concealed), and partly from their small size (Platyarthrus).

Neither one cause nor the other is sufficient to explain the absence from the Turkistan collection of the genera Armadillidium and Armadillo 
the first of which inhabits the whole of Central (part of Northern) and Southern Europe, the second being principally distributed over South Europe. The species of the two above-named genera always attain a considerable size, and are always found in large numbers dispersed ove $r$ limited areas. The consequence is that in localities inhabited by the species of these genera, some of the first are always caught by the collector, and they are always represented in collections by numerous specimens. The absence of representatives of these genera in the Turkistan collection appears to me, therefore, a very weighty evidence that they really do not inhabit Russian Central Asia. The absence of the genera Armadillidium and Armadillo from the Turkistan fauna is also partly confirmed by their distribution in other countries. The species of the genus Armadillidium in the west of Europe extend tolerably far towards the north; many of them are found in the northern part of the British Isles, in North Germany, Denmark, and even in Southern Sweden. As we advance towards the east the northern limit of distribution of genus Armadillidium trends rapidly southwards, and within the limits of European Russia, so far as 1 can judge from my rather extensive collection of Porcellionidae, it does not extend beyond the north of Kief and the neighbouring provinces.

As regards the species of the genus Porcellio, found in Turkistan, they decidedly ought to be added to the number of the species living in the so-called Mediterranean region. Of the two species found by Fedchenko in Turkistan, which had been already described, one (Porc. ornatus, M.-E.) was previously found in the environs of Carthagena, and the other (Porc. Laevis, Latr.), though it is also distributed over the whole of Central Europe as is shown by me in its place, principally belongs to Southern Europe, where only it attains its full development. The Turkistan specimens are similar to those dwelling in Southern Europe along the shores of the Mediterranean and neighbouring seas, and are, like these, distinguished from the Central European forms by the constantly larger size, and also by certain constant differences in the colouring of the body. Of the species of Porcellio described by me as new, Porc. Fedchenkoi is extremely like that, described by Brandt, from Southern European Russia (Porc. Pallasii); Porc. elegans is extremely like that inhabiting the Trans-Caucasus and Persia (Porc. Klugii, Bdt.), and that common in the whole of North Africa (Porc. Réanmurii, Aud.); Porc. maracandicus is very near that described from Andalusia (Porc. glaber, Koch); Porc. asiaticus is doubtless allied to that described from South Europe by Stein (Porc. longicornis). The foregoing considerations, together with the fact that the forms foreign to the Mediterranean province, though very common over the whole of Central Europe including Central European Russia (Porc. convexus, Dg., Porc. scaber, Bdt., Porc. pictus, Bdt.), are not found in Turkistan, induce me to characterize the land fauna of Crustacea as not very different from that of the Mediterranean province.

It is almost impossible to treat in a satisfactory manner the freshwater fauna of Crustacea, not only because the materials collected by Fedchenko constitute only a certain proportion of all the Crustacea dwelling in fresh-water in Turkistan, but also in consequence of the paucity of materials for comparison. The fresh-water Crustacea of only very few parts of Europe have been investigated at all completely.

Fedchenko, during his travels, found no species of Astacus 
(crayfish), and came to the conclusion that they are non-existent in Turkistan, as in West and North Siberia."

The fresh-water Gammarus is represented by the ordinary G. pulex, distributed over the whole of Europe.

Fresh-water Isopoda were not found by the expedition. Asellus, which is so common in European fresh waters, does not appear to be found in Turkistan.

Of 19 Copepoda found, two are the common fish parasites of Europe (Lamproglena pulchella and Argulus foliaceus); the remaining 17 species belong to three genera common to Europe-Diaptomus, Can. thocamptus, and Cyclops. The genus Diaptomus is represented in the collection by two new and rather remarkable species; only one species of the genus Canthocamptus was found, which is common all over Europe. Finally, of the 14 species of the genus Cyclops found, 5 species are widely distributed over Central and Northern Europe ( $C$. signatus, viridis, tenuicornis, serrulatus, and phaleratus), 2 were previously found only in the Scandinavian peninsula and Denmark (C: affinis, Sars, and crassicornis, M.): I (C. Clausii, Heller) was observed only in the Tyrol, and the remaining 6 are new, more or less resembling European species.

Of the two species of Turkistan Phyllopoda, one (Branchipus ferox) is largely distributed over all Southern Europe, and the other (Estheria dahalacensis) lives along the shores (northern as well as southern) of the Mediterranean, and the waters lying near it.

The last section included in this paper-Cladocera-contains 19 species. Of these 15 are more or less common in the whole of Western Europe. Three species had already been found only in the Scandinavian peninsula and Denmark (two species of Ceriodaphnia and Pleuroxus hastatus), and there is but one new species belonging to the interesting section of the genus Daphnia (designated by Schödler Hyalodaphiza), representatives of which were previously observed in North Germany, Denmark, Seandinavian peninsula, and Central European Russia.

As is evident from the foregoing, it is difficult to say, from the data at present in our possession, to what extent the Turkistan fauna of fresh-water Crustacea differs from that of other localities. All that we can say, confidently, is that among the Crustacea living in the fresh waters of Russian Central Asia, a very large number of West European species is found, and that the new species, described by me, are, in the majority of instances, very like the commonest in Central and Southern Europe.

With regard to the two Crustacea taken in the Aral Sea, one of them appears to be a new species, described by me under the name Gammarus aralensis; the other-an Ergasilus - unfortunately, was lost, so that the species remains undescribed. The unimportant number of Crustacea brought from the Aral Sea by the expedition cannot on any account be taken as an evidence of special security of crustaceans there.

* [Madame Fedchenko informs me, however, that the Astacus bas since been found in Turkistan, as communicated by Major N. A. Maieff to the Moscow Society of Friends of Natural History; and that the full description of the species, or rather variety, which proved to be new and somewhat different from the six species hitherto known in Russia, has been given by Shimkevich in the Zoolegischer Anseiger, 1884.-H. L.] 


\section{AMPHIPODA.}

Gammarus, Fabr. Fresh-water shrimps.

1. Gammarus pulex, Degeer.

2.,$\quad$ aralensis, n.s.

ISOPODA. Woodlice.

Porcellio, Latr.

1. Porcellio Fedchenkoi, n.s.

2. ". elegans, n.s.

3. " ornatus, M.-Edw.

4. , ". latus, n.s.

5. " maracandicus, n.s.

6. .. asiaticus, n.s.

7. " laevis, Ltr.

8. ,. marginatus, n.s.

9. .. orientalis, n.s.

ENTOMOSTRACA. Waterfficas

COPEPODA, M.-EuW.

Calanidae, Dana.

Diaptomus, Westw.

1. Diaptomus asiaticus, n.s.

2. $"$ affinis, n.s.

Harpactidae, Dana.

Canthocamptus, Westw.

1. Canthocamptus minutus, Claus.

Cyclopidae, Dana.

\section{Cyelops.}

1. Cyclops signatus, Koch.

2. " viridis, Jurine.

3. . tenuicornis, Claus.

4. $"$ vicinus, n.s.

5. " Fedchenkoi, n.s.

6. " Sarsii, n.s.

7. $"$ crientalis, n.s.

8. " serrulatus, Fischer.

9. " alaiensis, n.s.

10. $\rightarrow$ affinis, Sars.

It. "Clausii, Heller.

12. " phaleratus, Koch.

13. ". Kanfmanni, n.s.

14. " crassicornis, Müller.

Ergasilidae, Burm.

Ergasilus, Nordm.

1. Ergasilus, s.
Dichelestidae, M.-Edw.

Lamproglena, Nordm.

1. Lamproglena pulchella, Nordm.

Argulidae, Burm.

Argulus, Müller.

I. Argulus foliaceus, Lin.

BRANCHIOPODA.

PHYLlopoda.

Branchipus, Schaeff.

I. Branchipus ferox, M.-Edw.

Estheria, Straus.

I. Estheria dahalacensis, Straus.

Cladocera, Ltr.

1. Sida, straus.

I. Sida crystallina, O. F. Müller.

II. Daphnia, Sehödler.

1. Daphnia Schaefferi, Baird.

2. $"$ pulex, Degeer.

3. $"$ vitrea, n.s.

Simocephalus, Sehödler.

1. Simocephalus vetulus, O. F. Muiller.

2. exspinosus, Koch.

Scapholeberis, Schödler.

1. Scapholeberis mucronata, O. F. Miull. Ceriodaphnia, Dana.

1. Ceriodaphnia laticaudata, Müll., P.E.

2. " pulchella, Sars.

Moina, Baird.

I. Moina brachiata, Jurine.

Macrothrix, Baird.

1. Macrothrix laticornis, Jurine.

Bosmina, Baird.

I(?). Bosminal ongirostris, O.F. Müller.

Acroperus, Baird.

1. Acroperus leucocephalus, Koch.

Alona, Baird.

1. Alona quadrangularis, O. F. Müller.

2. "lineata, Fisch.

Pleuroxus, Baird.

I. Pleuroxus aduncus, Jurine.

2. " $\quad$ trigonellus, O. F. Müller.

3. " hastatus, Sars.

Chydorus, Leach.

I. Chydorus sphaericus, O. F. Müller. 


\section{COLEOPTERA (Beetles).}

\section{By S. M. Solsky.}

[THE first part in the original contains the description of 352 species, distributed among 114 genera, belonging to to families. Of these 43 species were not found in Fedchenko's collection, but they were introduced by Solsky because they belonged either to Turkistan or the adjacent regions. There were $6 \mathrm{r}$ species which appeared to be quite new to science, one of them claiming recognition as a new genus. To the description of all new species, and also of certain others previously known but insufficiently described, is added in the original a tolerably complete diagnosis in Latin, where also those of the formerly known species of which Solsky had seen original specimens are designated by an asterisk. The first part constitutes approximately one-third of the work undertaken by Solsky, which he believed to embrace in all as many as 1,000 species. The second part contains the description of 178 species, distributed among 55 genera, belonging to 14 families. Of this number 49 species and one genus proved to be new. In the second part, also, are commenced synoptical tables which will serve for the definition of the families and genera to which belong the species he described.

Solsky intended, in the third part, to write a general preface, but did not live to complete his manuscript. A few sheets only were printed, 1 am informed by Madame Fedchenko, who has been good enough to copy them for me, and they are placed at the end of the following list. Mr, Robert MacLachlan, F.R.S., has pointed out to me, however, concerning these species, unpublished elsewhere, that nothing is more troublesome in systematic zoology than the publication of names only without descriptions; and seeing there are many new species in this addenda, I have, in deference to his suggestion, struck out the specific names for the new species, and left the generic name with n.s. only. Solsky's description of some new Turkistan species was published by his friend, M. Erschoff, in the Hor. Soc. Ent. Ross.

Madame Fedchenko further informs me that in a previous article in the Hor. Soc. Ent. Ross., Vol. viii,, pp. 133 and 165 , Solsky gave a full description (in French) of :-

Curculionides: (1) Alcides Chaudoiri, Guér.

Longicornes: (2) Pachydissus sartus, n.s., and of many Staphylinides. $-H . L$. $]$ 
I. CICINDELETAE.

\section{Cicindela, $\mathbf{L}$.}

I. Cicindela decempustulata, Ménétr.

2. " turkestanica, Ballion.

3. " maracandensis, $n . s .$, Slky.

$4 . \quad$ lacteola. Pall.

5. " Fischeri, Adams.

6. ". melancholica, Fabr.

7. $"$ sublacerata, n.s., Solsky.

8. $"$ descendens, Fisch,

9. "Kirilovi, ,

II. CARABIDAE,

Group I. OMOPHRONINI.

1. Omophron, Latr.

1. Omophron rotundatus, Chaud.

Group 2, Elaphrin!.

2. Notiophilus, Dumer.

I. Notiophilus sublaevis, n.s., Solsky.

Group 3. Carabint.

3. Nebria, Latr.

1. Nebria psammophila, n.s., Solsky.

2. " limbigera, n.s., ",

\section{Carabus, L.}

1. Carabus Fedchenkoi, n.s., Solsky.

2. " Stschurovskii, n.s., ,"

3. "Kaufmanni, n.s.,

\section{Calosoma, Web.}

Section 1. Calosoma.

I. Calosoma sycophanta, L.

2. "turcomanicum, Motsch.

3. " sericeum, Fabr.

Section 2. Callisthenes, Fisch.

I. Callisthenes Kuschakewitschi, Ball.

2. " usgentensis, n.s., Solsky.

Group 4. DRYPTINI.

6. Polystichus, Bonelli.

1. Polystichus vittatus, Brull.

Group 5. BRAchininI.

7. Brachinus, Web.

1. Brachinus psophia, Dej.

2. " brevicollis, Motsch,

3. " graecus, Dej.

8. Mastax, Fisch.

1. Mastax thermarum, Stev.

Group 6. LeBIIN1,

9. Cymindis, Latr.

I. Cymindis Andreae, Ménétr.

\section{2. " accentifera, Zubk.}

3. in decora, Fisch.

4. " quadrisignata, Ménétr.

5. "rufescens, Gebl.

6. " Mannerheimi. Gebl.
10. Glycia, Chaud.

I. Glycia tricolor, Gebl.

2. " cingulata, ,

3. . flavipes, M.5., Solsky.

4. " bicolor, n.s., ",

5. " anthracina, n.s., ,

11. Demetrias, Bonelli,

I. Demetrias unipunctatus, Germ.

12. Blechrus, Motsch.

1. Blechrus plagiatus, Duft.

2. ". maurus, Sturm.

3. " minutus, Motsch.

13. Metabletus, Schm.-Goeb.

I. Metabletus fuscomaculatus, Motsch.

2. $"$ parallelus, Ballion.

3. $"$ obliquesignatus, Solsky.

\section{Lamprias, Bonelli.}

t. Lamprias cyanocephalus, L.

2. $"$ festivus, Faldrm.

\section{Lebia, Latr.}

I. Lebia trimaculata, Gebl.

2. " cyathigera, Rossi.

3. " crux minor, $\mathbf{L}$.

4. " turcica, Fabr.

\section{Tetragonoderus, Dej.}

I. Tetragonoderus intermedius, n.s., Sky.

Group 7. Ditomin.

17. Aristus, Latr.

I. Aristus punctulatus, Chaud.

2. " tenuesculptus, n.s., Solsky.

18. Ditomus, Bonelli.

I. Ditomus calydonius, Rossi.

2. " chodschenticus, Ball.

19. Carenochyrus, $n . g$, Solsky.

1. Carenochyrus titanus, n.s, Solsky.

20. Chilotomus, Chaud.

I. Chilotomus chalybaeus, Fldrm.

Group 8. Scaritini.

21. Scarites, Fabr.

1. Scarites bucida, Pall.

2. " eurytus, Fisch.

3. " Fisrheri, Zubk.

4. " cylindronotus, Fldrm.

5. $"$ salinus, Pall.

6. $n$ persicus, Chaud.

22. Dyschirius, Bonelli.

I. Dyschirius cylindricus, Dej.

2. $\quad$ ovicollis, n.s., Solsky.

3. " $"$ dimidiatus, Chaud. 


\section{Clivina, Latr.}

I. Clivina collaris, Herbst.

2. "Ypsilon. Dej.

Group 9. Chlaenirni.

24. Chlaenius, Bonelli.

I. Chlaenius spoliatus, Rossi.

$\begin{array}{rll}2 . & " & \text { caspicus, Motsch. } \\ 3 . & " & \text { extensus, Eschsch. } \\ 4 . & " & \text { tenuelimbatus, Ball. } \\ 5 . & * & \text { chrysothorax, Kryn. } \\ 6 . & " & \text { Schranki, Duft. } \\ 7 . & " & \text { flavicornis, Fisch. } \\ 8 . & " & \text { Steveni, Quensel. } \\ 9 . & " & \text { semicyaneus, } n-s ., \text { Solsky. } \\ \text { to. } & " & \text { holosericeus, Fabr. }\end{array}$

Group 10. Licinisi.

25. Licinus, Latr.

I. Licinus depressus, Payk.

Group 11. Cnemacanthini.

26. Dioctes, Ménétr.

1. Dioctes Lehmanni, Ménétr.

27. Broscus, Panz.

1. Broscus asiaticus, Ball.

Group I2. Harpalini.

28. Anisodactylus, Dej.

I. Anisodactylus signatus, Illig.

29. A cinopus, Dej.

I. Acinopus striolatus, Zubk.

30. Dichirotrichus, Duval.

1. Dichirotrichus ustulatus, Dej.

2. $"$ microclerus, n.s., Slky.

3. " discicollis, Dej.

31. Pangus, Ziegl.

1. Pangus brachypus, Stev,

2. $\quad$ externepunctatus, n.5., Slsky.

3. $n$ intermittens, n.s.,

4. " diversopunctatus, n.s., ,",

32. Harpalus, Latr.

Section 1. Ophonus, Zicgl.

1. Ophonus tataricus, Ménétr.

2. ., cycloderus, n.s., Solsky.

3. " chlorizans, n.s., "

Section 2. Harpalus,

I. Harpalus ruficornis, Fabr.

2. $"$ griseus, Panz.

3. $\quad$ anisodactyliformis, n.s.,

4. " distinguendus, Duft.

5. $"$ viridulus, n.s., Solsky,

6. ". calceatus, Duft,
7. Harpalus tenebrosus, Dej.

8. .

9. ". serripes, Quensel.

ro. $" \quad$ picipennis, Duft.

33. Acupalpus, Latr.

1. Acupalpus dorsalis, Fabr.

34. Stenolophus, Dej.

I. Stenolophus abdominalis, Géné.

2. " marginatus, Dej.

3. " morio. Ménétr.

Group 13. Pterostichini.

35. Pterostichus, Erichs.

Section 1. Poecilus, Bonelli.

1. Poecilus punctulatus, Fabr.

2. " laevigatus, Ménétr.

3. $"$ cupreus, L.

$4 . \quad n \quad$ longiventris, n.s., Solsky.

5. . Karelini, Chaud.

6. " janthinipennis, n.s., Slsky.

7. " deplanatus, Ménétr.

8. " $\quad$ leptoderus, n.s., Solsky.

9. " carbonicolor, H.S., "

Io. "laevicollis, Chaud.

Section 2. Lagarus, Chand.

I. Lagarus vernalis, Panz.

Section 3. Umaseus, Ziegler.

I. Omaseus niger, Schaller.

Section 4. Argutor, Megerlc.

I. Argutor stricticollis, n.s., Solsky.

\section{Zabrus, Clairv.}

I. Zabrus gibbosus, Zimm.

\section{Amara, Bonelli}

Section 1. Bralytus, Steph.

I. Bradytus apricarius, Payk.

Section 2. Cyrtonotus, Steph.

I. Cyrtonotus caucasicus, Motsch.

2. " intermedius, "

Section 3. Amathitis, Zimm.

1. Amathitis microdera, Chaud.

2. "songarica, "

\section{Section 4. Celia, Zimm.}

I. Celia erratica, Duft.

2. " ambulans, Zimm.

3. " picina, n.s.. Solsky.

4. " testicola, Zimm.

Section 5. Anara, Zimm.

I. Amara rufipes, Dej.

2. " similata, Gyll.

3. " famelica, Zimm.

4. " trivialis, Gyll. 
Group 14. AnchomeniNi.

38. Taphoxenus, Schauf.

1. Taphoxenus Goliath, Zubk.

39. Pseudotaphoxenus, Schauf.

I. Psendotaphoxenus substriatus, Ball.

40. Calathus, Bonelli.

1. Calathus ambiguus, Payk.

2. " melanocephalus, $\mathrm{I}$.

41. Taphria, Bonelli.

1. Taphria nivalis, Panz.

42. Dolichus, Bonelli.

I. Dolichus flavicornis, Fabr.

43. Anchomenus, Erichs.

I. Anchomenus turkestanicus, Ball.

2. .. do-salis, Mitll.

Group 15. TRECHINI.

44. Trechus, Clairv.

I. Trechus minutus, Fabr.

Group 16. BE M BIDIINI.

45. Tachypus, Lacord.

1. Tachypus flavicornis, n.s., Solsky.

46. Tachys, Schaum.

1. Tachys anomala, Kolenati.

2. * tetraspila, n.s., Solsky.

3. .. testacea, Motsch.

4. . brevicornis, Chaud.

47. Bembidium, Latr.

1. Bembidium inserticeps, Chaud.

2. " " posterius, Gemm., Hrld.

3. .. furidicorne, n.s, Solsky.

4. ,. lampros, Herbst.

5. . $\quad$ cupreolum, n.s., Solsky.

6. " glaciale, Heer. platypterum, n.s., , , rugiceps, Chand. hamatum, Kolenati. tenellum, Erichs. quadriplagiatum,Mtsch. cardiaderum, n.s., slky. piceocyaneum, n.s., ,, ovalipenne, n.s., , , ustum, Quens. bisignatum, Ménétr. parallelipenne, Chaud. fasciatum. dilutipenne. n.s., Solsky. abbreviatum, n.s., , insidiosum, n.s.. , marginipenne, n.s., ,", quadripustulatum, Dej.

\section{DYTISCIDAE.}

Group 1. HALIPLINI.

1. Cnemidotus, nlig.

I. Cnemidotus caesus, Duft.

2. Haliplus, Latr.

I. Haliplus ruficollis, D. Geer.

2. maculatus, Motsch.

Group 2. HYDROPORINI.

3. Oxynoptilus, Kiesw.

I. Oxynoptilus cuspidatus, Kunz.

4. Hydroporus, Clairv.

1. Hydroporus inaequalis, Fabr.

2. " $\quad$ fractilinea, $n$ s., Solsky.

3., enneagrammus, Ahr.

4. " $"$ geminus, Fabr.

5. " $\quad$ tetragrammus, Hochh.

6. " $\quad$ parvicollis, Schaum.

7. " $\quad$ airumlus, Kolenati.

8. *. steppensi, Motsch.

9. $v$ planus, Fabr.

Group 3. CoLymberini.

5. Noterus, Clairv.

1. Noterus sparsus, Marsh.

\section{Laccophilus, Leach.}

I. Laccophilus variegatus, Sturm.

2. .. testaceus, Aub.

3. .. obscurus, Panz.

7. Rhantus, Lacord.

I. Rhantus vibicicollis, Hochh.

\section{Agabus, Leach.}

I. Agabus bipustulatus, I.

2. " conspersus, Mrsh.

3. " $\quad$ amoenus, $n . s$. . Solsky.

4 . abnormicollis. Ball.

Group 4. Dytiscini.

9. Trogus, Leach.

1. Trogus Gotschii, Hochh.

10. Eunectes, Erichs.

I. Eunectes punctatus, Zubk.

11. Hydaticus, Leach.

I. Hydaticus cinereus, $\mathrm{L}$.

2. " grammicus, Germ.

\section{GYRINIDAE.}

1. Gyrinus, Geoffr

I. Gyrinus concinnus, Klug.

2. .. distinctus, Aub. 
V. HYDROPHILIDAE.

Group I. HYDROPHILINI.

1. Hydrophilus, Geoffr.

1. Hydrophilus piceus, L.

2. Hydrochares, Latr.

I. Hydrochares caraboides, L.

3. Hydrobius, Leach.

1. Hydrobius fuscipes, L.

2. " chalceolus, n.s., Solsky.

4. Philhydrus, Sol.

1. Philhydrus testaceus, Fabr.

5. Laccobius, Erichs.

I. Laccobius alutaceus, Thoms.

2. " decorus, Gyll.

3. . grac lis, Motsch.

6. Berosus, Leach.

t. Berosus spinosus, Stev,

7. Limnebius, Leach.

1. Limnebius truncatellus. Thunb.

Group 2, HeLophorini.

8. Helophorus, Fabr.

I. Helophorus subcostatus, Kolenati.

2. . dorsalis, Marsh.

3. $"$ granularis, Lin.

9. Ochthebius, Leach.

1. Ochthebius bicolon, Kirby.

Group 3. S PHAERIDIINi.

10. Cyclonotum, Erichs.

I. Cyclonotum orbiculare, Fabr.

11. Cercyon, Leach.

1. Cercyon quisquilium, L.

12. Sphaeridium, Fabr.

I. Sphaeridium bipustulatum. Fabr.

VI. STAPHYLINIDAE.

Group 1. Aleochariv1.

\section{Falagria, Munh}

1. Falagria thoracica, Curtis.

2. .. obscura, Grav.

3. ". gratilla, Erichs.

\section{Leptusa, Kraatz.}

I. Leptusa picipennis, n.s., Solsky.

3. Aleochara, Grav.

1. Aleochara crassiuscula, Sahlb.

2.,$\quad$ lanuginosa. Grav.

3. " sareptana, Fvl. i. litt.

4. " spissicornis, Erichs.

4. Myrmedonia, Erichs.

I. Myrmedonia drusilloides, Solsky.
5. Tachyusa, Erichs.

I. Tachyusa cavicollis, Solsky.

6. Homalota, Mnnh.

I. Homalota labilis, Erichs.

2. $"$ plana, Gyll.

3. " immersa, Erichs.

4. " analis, Grav.

5. " $"$ suecicola. Thoms.

6. " fusca, Sahlb.

Group 2, Tachyporint.

7. Tachinus, Grav.

I. Tachinus rufitarsis, Hochh.

2. " laticollis, Grav.

3. " discoideus, Erichs,

8. Tachyporus, Grav.

I. Tachyporus chrysomelinus, L.

2. $"$ hypnorum, Fabr.

3. $\quad$ armeniacus Klti.

4. .. scitulus, Erichs.

9. Bolitobius, Leach.

1. Bolitobius pullus, Solsky.

Group 3. StaphYLiNiNi.

Section a. Quediiformes.

10. Heterothops, Kirby.

1. Heterothops melanocerus, Solsky.

Section b. Staphylinimi.

11. Creophilus, Kirby.

1. Creophilus maxillosus, L.

12. Leistotrophus, Perty.

1. Leistotrophus sibiricus, Gebl.

13. Ocypus, Kirby.

1. Ocypus picipennis, Fabr.

2. " fuscoaeneus, Solsky.

14. Physetops, Mnnh.

1. Physetops tataricus, Pall.

15. Philonthus, Leach.

1. Philonthus rotundicollis, Ménétr.

2. " atratas, Grav,

3. .. varius, Gyll.

4. .. ebeninus, Grav.

5. " $\quad$ longicornis, Steph.

6. $\quad . \quad$ bipustulatus, Panz.

7. ". discoideus, Grav,

8. rubellus, n.s., Solsky.

9. " micans, Grav.

Io. " nigritulus, Grav.

II. " salinus, Ksw.

12. formosus, Motsch.

I3. " velatipennis, Solsky.

I4. .. dimidiatipennis, Erichs

15. ", procerulus, Grav, 
Section c. Xantholinini.

16. Platyprosopus, Mnuh.

1. Platyprosopus elongatus, Mnnh.

Group 4. PAEDERINI.

17. Lathrobium, Grav.

1. Lathrobium elongatum, L.

2. " concolor, Motsch.

18. Dolicaon, Cast.

t. Dolicaun pullus. Solsky.

19. Cryptobium, Mnnh.

1. Cryptobium fracticorne, Payk.

20. Stilicus, Latr.

1. Stilicus prolongatus, n.s., Solsky.

2. " capitalis, Gemm.. Hrld.

21. Sunius, Leach.

1. Sunius lithocharoides, n.s.. Solsky.

2. " fasciatus, Hochh.

3. " neglectus, Maerkel.

22. Scopaeus, Erichs.

1. Scopaeus breviventer, Sperk.

23. Paederus, Grav.

1. Paederus cephalotes, Motsch.

2. $n$ riparius, $\mathbf{L}$.

3. " fuscipes, Curtis.

4. "albipilis, Solsky.

Group 5. STENIN1.

24. Stenus, Latr.

t. Stenus guttula. Míll.

2. " aereus, Solsky.

3. . ater, Mnnh.

4. - buphthalmus. Grav.

5. " micros. n.s., Solsky.

6. n aterrimus, Erichs.

7. " bifoveolatus, Gyll.

8. " solutus, Erichs.

9. $\quad$ tumidulus, n.s., Solsky.

Group 6. OxyTelint. 25. Bledius, Leach.

I. Bledius hinnulus. Erichs.

2. " tricomis, Hrbst.

26. Platystethus, Mnnh.

1. Platystethus cornutus, Grav.

2. " morsitans. Payk.

3. ". spinosus, Erichs.

4.4 capito, Heer.

27. 0xytelus, Grav.

1. Oxytelus piceus, Linn.

2. " nitidulus, Grav.

28. Zonoptilus, Motsch.

1. Zonoptilus pennifer, Motsch.

\section{Ancyrophorus, Kraatz.}

1. Ancyrophorus sericinus, n.s., Solsky-

Group 7, OMALIN I.

30. Omalium, Grav.

I. Omalium apicicorne, $n . s$, Solsiky.

2. " taschkentense, $n, s .$, ,"

3. " $\quad$ turanicum, n.s., "

31. Anthobium, Steph.

I. Anthobium fulvipenne. N.3. Solsky.

\section{PSELAPHIDAE.}

1. Ctenistes, Reichb.

t. Ctenistes palpalis, Reichb.

2. Bryaxis, Leach.

1. Bryaxis longicornis, Leach.

\section{SILPHIDAE.}

1. Necrophorus, Fat:

I. Necrophorus hunator. Fabr.

2. Silpha, L.

1. Silpha sinuata, Fabr.

2. ." ferrugata, n.S.. Solsky.

3. " turkestanica, Ball.

4. .. costata, Ménétr.

5. .. obscura, L.

\section{Choleva, Latr.}

I. Choleva fuscipes, Ménétr.

2. $n$ scitula, Erichs.

\section{Agyrtes, Fröhl.}

1. Agyrtes ferrugineus, n.5., Solsky.

\section{ANISOTOMIDAE.}

1. Hydnobius, Schmidt.

I. Hydnobius punctatus, Sturm.

\section{SCAPHIDIIDAE.}

1. Scaphium, Kirby.

1. Scaphium quadraticolle, n.s., Solsky.

\section{HISTERIDAE.}

\section{Hister, L.}

1. Hister turanus, n.s.. Solsky.

2. * quadrimaculatus, L.

3. " quatuordecimstriatus, Gyli.

4. . binotatus, Erichs.

5. .. planulus, Ménétr.

6. ". smyrnaeus, Mars.

7. .. finietarius, Hrbst.

8. " purpurascens, ,

9. .. quadrinotatus, Scriba.

ro. .. falsus, n.s., Solsky.

I1. " bimaculatus, L. 
2. Careinops, Mars.

1. Carcinops pusjo, Ménétr.

3. Saprinus, Erichs.

1. Saprinus maculatus, Rossi.

2. " interruptus, Payk,

3. " externus, Fisch.

4. . biguttatus, Stev.

5. .. ornatus, Erichs.

6. " semipunctatus, Fabr.

7. . nitidulus, ,"

8. ,. gangeticus, Mars.

9. .. aeneus, $\mathrm{Fabr}$.

10. " cribellatus, Mars.

II. ". chalcites, lllig.

12. ", sparsutus, n.s.. Solsky,

13. ". Mersinae, Mars.

14. " ovillum, n.s.. Solsky.

15. .. lateristrius, n.S., ,.

4. Gnathoneus, Duv.

1. Gnathoncus rotundatus, Hllig.

2. .. disjunctis, n.s., Solsky.

5. Teretrius, Erichs.

I. Teretrius picipes, Fabr.

XII. PHALACRIDAE.

1. Phalacrus, Payk.

1. Phalacrus corruscus, Payk.

2. Olibrus, Erichs.

1. Olibrus bicolor, Fabr.

2. " liquidus, Erichs.

3. ., affinis, Sturm,

4. " oblongus, Erichs.

XIII. NITIDULIDAE,

Group I. BRACHYPTERIN t.

1. Brachypterns, Kugell.

1. Brachypterus canescens, Motsch.

2.. dilatitarsis, u.s., Solsky.

3. , gravidus, Illig.

Group 2. Nitidulinae.

2. Nitidula, Fabr.

1. Nitidula latiplaga, $n$., , Solsky,

2. .. carnaria. Schall.

3. Meligethes, Kirby.

I. Meligethes xanthopus, n.s., Solsky.

2. " vulpes, n.s., ",

3. . lutra, ns., ",

4. .. distinctus, Strm.

5. $\quad$." tristis. $\quad$ planiusculus, Heer.

\section{TROGOSITIDAE.}

1. Trogosita, L.

1. Trogosita mauritanica, L.
XV. COLYDIIDAE.

1. Aglenus, Erichs.

1. Aglenus brunneus, Gyll.

\section{CUCUJIDAE.}

1. Silvanus, Latr.

1. Silvanus surinamensis, L.

\section{CRYPTOPHAGIDAE.}

1. Telmatophilus, Heer.

I. Telmatophilus sparganii. Ahrens.

2. Cryptophagus, Hrbst.

1. Cryptophagus acutangulus, Gyll.

2. " fumatus, ".

3. $\quad . \quad$ cellaris, Scop.

$4 . \quad$ validus, $\mathrm{Krtz}$.

5. " $\quad$ recticollis, n.s., Solsky.

6. .. bactrianus, n.5., "

3. Atomaria, Steph.

1. Atomaria dilutella, n.5. Solsky,

\section{LATHRIDIIDAE.}

1. Monotoma, Hrbst.

1. Monotoma brevipenne, Kunze.

2. " quadrifoveolata, Motsch.

\section{Lathridius, Hrbst.}

I. Lathridius minutus, $\mathrm{L}$.

2. " parallelipennis, n.s., Slky.

3. Corticaria, Mrsh.

I. Corticaria badia, Mnnh.

2. " quadrimaculata, Mnnh.

XIX. THORICTIDAE.

1. Thorictus, Germ.

I. Thorictus castaneus, Germ.

XX. DERMESTIDAE.

1. Dermestes, I.

1. Dermestes dimidiatus, Stev.

2. " vulpinus, F.

3. $\quad$ Frischii, Kugel.

4. " $"$ elegans, $n . s .$, Solsky.

5. . coronatus, Stev,

\section{Attagenus, Latr.}

I. Attagenus angustatus, Ball.

2. ". simulans, n.s., Solsky,

3. " byturoides, n.S., ",

4. " pictus, Ball.

5. " suspiciosus, n.s., Solkky.

6. ". fasciolatus, n.s., ,"

\section{Megatoma, Hbst.}

1. Megatoma conspersa, n.s., Solsky 


\section{Trogoderma, Latr.}

I. Trogoderma versicolor, Creutz.

2. $"$ ormata, n.s., Solsky.

\section{Anthrenus, Geoffr.}

1. Anthrenus pimpinellae, Fabr.

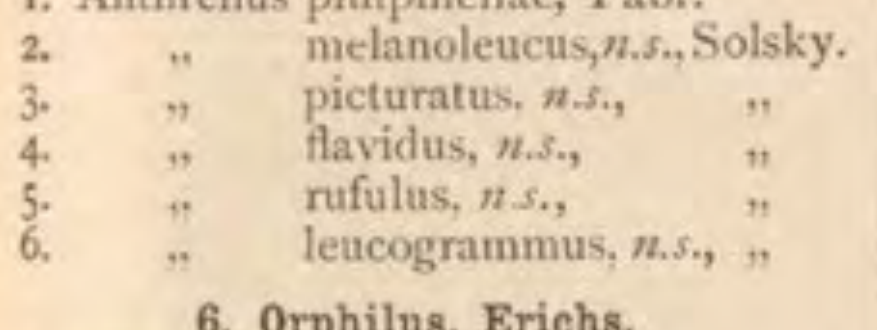

I. Orphilus glabratus. Fabr.

\section{BYRRHIDAE.}

\section{Curimus, Erichs.}

1. Curimus asiaticus, n.s., Solsky.

\section{PARNIDAE.}

\section{Parnus, Fabr.}

1. Parmus fuscipennis, n.s., Solsky.

\section{Dryops, Oliv.}

1. Dryops longus, $n, s .$, Solsky.

\section{Helichus, Erichs.}

1. Helichus asiaticus, n.s., Solsky.

XXIII. HETEROCERIDAE.

\section{Heterocerus, F.}

1. Heterocerus parallelus, Kryn.

$$
\begin{array}{lll}
2 . & . & \text { flexuosus, Steph. } \\
3 . & " & \text { laevigatus, Fabr. } \\
4 . & " & \text { sericans, Kiesw. }
\end{array}
$$

\section{SCARABAEIDAE.}

\section{Group I. CoprINI.}

\section{Scarabaeus, L.}

I. Scarabaeus sacer. I.

\section{Gymnopleurus, Illig.}

I. Gymnopleurus aciculatus, Gebl.

2. + flagellatus, Fabr.

\section{Synapsis, Bates.}

I. Synapsis tmolus, Fisch. de W.

\section{Copris, Geoffr.}

1. Copris hispanus, L.

2. " lunaris, ",

\section{Onitis, Fabr.}

1, Onitis humerosus, Pall.

2. .. Pamphylus, Ménétr.

3. 1 moeris, Pall.

4. .. sterculius, Ba.1.

\section{Onthophagus, Latr.}

1. Onthophagus amyntas, Oliv.

3.

4.

5.

6.

7.

8.

9.

10.

\section{Oniticellus, Serv.}

1. Oniticellus flavipes, Fabr.

2.

\section{Group 2. AphoJisn.}

\section{Aphodius, Illig.}

1. Aphodius erraticus, L.

2. ". ubterraneus, L.

3. . haemorrhoidalis, $\mathrm{L}$.

4. $"$ fimetarius, L.

5. $n$ foetens, $\vec{F}$.

6. .. granarius, L.

7. $\quad$ punctipennis, Hrld,

8. .. immundus, Creutz.

9. . varians, Duft.

Io. " Kraatzi. Mrld,

II., plagiatus, $I_{\text {. }}$

12. ¿. niger, Panz.

I3. " nitidus, Ball.

14. " brunnetus, Klug.

I5., melanostictus, Schm.

16. " $"$ nigrivittis, n.s., Solsky.

17. " conspurcatus, L.

18. $"$ quadrisignatus, Brull.

19. " pusillus, Hrbst.

20. ", quadriguttatus, Hrbst.

21. " Kisilkumi. n.s., Solsky,

22. $"$ gregarius. Hrld.

23. $"$ semipellitus, n.s., Solsky.

24.

25.

26 .

27.

28. lunifer, n.s., circumductus, n.s., , Edgardi, ns., luridus, Fabr.

. pecari, ,"

\section{Plagiogonus, Muls.}

I. Plagiogonus praeustus, Ball.

10. Ammoecius, Muls.

1. Ammoecius discolor, n.s., Solsky.

\section{Mendidius, Hrld.}

I. Mendidius bidens, Ball., i. litt.

12. Psammobius, Heer.

t. Psammobius caesus, Panz.

2. .. variolosus, Klti. 
Group 3. ORPH N INI. 13. Ochodaeus, Serv.

I. Ochodaeus cornifrons, n.s., Solsky.

14. Codocera, Eschsch.

I. Codocera ferruginea, Eschsch.

Group 4. Hy BosoRin 1 . 15. Hybosorus, MeLeay.

I. Hybosorus Illigeri, Reiche.

Group 5. GEO R R PINI.

16. Bolboceras, Kirby.

I. Bolboceras Radoszkovskii, n.s., Slky.

17. Geotrupes, Latr.

Section 1. Ceratophyus, Fisch de $W$.

I. Ceratophyus Ammon, Pall.

Section 2. Geotrupes, Muls.

I. Geotrupes impressus, Gebl.

2. " foveatus, Mrsh.

18. Lethrus, Scop.

1. Lethrus brachiicollis, Fairm.

2. " apterus, Laxm.

3. " politus, n.s., Solsky,

4. " scoparius, Fisch. de W.

5. " turkestanicus. Ball.

6. " laevigatus,

7. " longimanus, Fisch. de W.

8. " Karelini, Gebl.

9. " crenulatus, ,"

ro. " tuberculifrons, Ball.

[The following is the unpublished portion of Solsky's thind part.-H. L.]

25. Lachnosterna, Hope.

1. Lachnosterna holosericea, Ménétr.

2. " porosa, Fisch.

26. Pectinichelus, Ball.

I. Pectinichelus rhizotrogoides, Ball.

27. Rhizotrogus, Latr.

I. Rhizotrogus, n.s., Solsky.

2. " pulvereus, Knoch.

3. " Myschenkowi, Ball.

28. Amphimallus, Muls.

t. Amphimallus solstitialis, L.

2. " glabripennis, Ball.

29. Polyphylla, Harr.

1. Polyphylla hololeuca, Pall.

2. " adspersa, Motsch.

3. " irrorata, Gebl.

4. " n.s, Solsky,
Group 6. Trogrnt.

19. Trox, Fabr.

I. Trox granulipennis, Fairm.

Group 7. Glaphyrint.

20. Glaphyrus, Latr.

I. Glaphyrus oxypterus, Pall.

2. " varians, Ménétr.

21. Amphicoma, Latr.

I. Amphicoma chalybaea, Fald.

2. $", \quad$ analis, n.s., Solsky.

3. " Kuschakewitschi, Ball.

4. . dubia, n.s., Solsky.

5. " $\quad$ clypeata, n.s., "

Group 8. Melolonthini.

22. Hoplia, Illig.

I. Hoplia paupera, Kryn.

2. " detrita, n.s., Solsky.

23. Serica, McLeay.

1. Serica euphorbiae, Burm.

2. .. arenicola, n.s., Solsky.

24. Oxycorythus, n.g., Solsky.

1. Oxycorythus Morawitzi. n.s., Solsky.

[End of Part II. in original.]

30. Melolontha, $\boldsymbol{F}$.

I. Melolontha afflicta, Ball.

2. .. $n$ s., Solsky.

3. . pectoralis, Germ.

31. Pachydema, Cast.

1. Pachydema oblonga, Fisch. de W.

Grump 9. RUTEIiNi.

32. Phyllopertha, Steph.

r. Phyllopertha glabra, Gebl.

2. n.s., Solsky

3. " variabilis, Ball.

33. Anomala, Sam.

1. Anomala diluta, Motsch.

34. Pharaonus, Blanch.

I. Pharaonus, n.s., Solsky.

2. " n.s., ,"

35. Adoretus, Cast.

1. Adoretus nigrifrons, Stev.

2. 4 n.s., Solsky.

3. " comptus, Ménétr. 
Group ro. Dynastini.

36. Pentodon, Hope.

1. Pentodon mongolicus, Motsch.

2. " quadridens, Gebl.

37. Oryetes, Inlig.

1. Oryetes latipennis, Motsch.

Group II. Centonini.

38. Stalagmosoma, Burm.

1. Stalagmosoma albella, Pall.

39. Oxythyrea, Muls.

1. Oxythyrea cinctella (Stev.), Schaum.

40. Tropinota, Muls.

1. Tropinota pilosa, Brull.

41. Cetonia, Fabr.

1. Cetonia afflicta, Gor. et Perch.,var. C chalybaea, Solsky.

, Bogdanoffi, Solsky.

" interruptocostata, Ball.

" n.s., Solsky.

,. Karelini, Zubk.

" n.s., Solsky.

". sibirica, Gebl.

", marginicollis, Ball.

, Zubkoffi, Fldrm.

, fasciata, Fisch. de WV.

XXV. BUPRESTIDAE.

Group I. JULODHNAE.

1. Julodis, Eschsch.

1. Julodis variolaris, Pall.
Group 2. BUPRESTINI.

2. Psiloptera, Sol.

I. Psiloptera argentata, Mnnh.

3. Capnodis, Eschsch.

I. Capnodis Henningi, Fldrm.

2. " excisa, Ménétr.

3. " parumstriata, Ball,

4. " miliaris, Klug.

5. " $\quad$ tenebricosa, Hibst.

4. Coeculus, Cast G.

I. Coeculus sibiricus, $\mathrm{F}$.

5. Dicerca, Eschsch.

I. Dicerca aenea, L.

6. Melanophila, Eschsch.

1. Melanophila decostigma, F.

7. Anthaxia, Eschsch.

I. Anthaxia, n.s., Solsky.

2. " kollari, Mars.

3. " deaurata, Gmel.

4. " bicolor, Fldrm.

5. " auriceps, Mén.

6. " n.s., Solsky.

7. ", n.s., ,"

8. " venerabilis, Mars.

\section{Acmaeodera.}

1. Acmaeodera, n.s., Solsky.

$\begin{array}{lll}2 . & " & \text { n.s., }, " \\ 3 . & " & \text { n.s., }, " \\ 4 . & " & \text { n.s., }, " \\ 5 . & " & \text { n.s., } \\ 6 . & " & \text { lugens, Cast. G. } \\ 7 . & " & \text { Boryi, Brullé. }\end{array}$




\section{MELLIFERA (Bees).}

\section{By Dr. Ferdinand Moravitz.}

Fruchenko hoped to treat the Apidae section himself, but oniy succeeded in finishing the determination and description of the greater part of the species of the genus Anthophora. With what ardour he worked, and to what extent he devoted himself to the labour of investigating the Apidae, his observations show. He did not confine himself to the examination of the external peculiarities only of these insects, but observed also certain of their internal organs, especially the sexual organs, intending to explain the relation between their different forms, and to attempt a genetical morphology. For this purpose he made ready a number of microscopic preparations, but did not succeed in completing them, leaving only very disconnected observations.

The bees collected by Fedchenko form a very rich collection. Other travellers in Turkistan collected no bees, and, therefore, the country may be called, in this respect, unexplored, Lehmann, who went as far as Bokhara and Samarkand, sent to the museum of the Academy of Sciences only seven species of bees, collected by him in the environs of Orenburg, and near Fort Novo Alexandrovsk, which were described by Erichson in ' Ménétriès' Catalogue des Insectes recueillis par feu M. Lehmann." Eversmann, who had also travelled in Turkistan, did not, it seems, then collect any Apidae. Though in his work ("Fauna Hymenopterologica Volgo-Uralensis," Bull. de Mosc., 1852) he often mentions that other species inhabit not only the country between the Ural and Volga, but beyond the Ural, yet all the specimens seen by me were not collected in Turkistan, but, as is shown by the localities marked on their tickets, near Indersk, Orsk, Irkutsk, and even Kiakhta. Thus the whole literature of Turkistan bees is limited to the work of $O$. K. Radoszkovsky, who received some species from Fedchenko, and described four new species from the environs of Samarkand (Hora Soc. Entomol. Rossica, tomus viii.).

The genus Anthophora is included in my work as the special labour of Fedchenko. I have only had to verify the determination of all the species, to compile diagnoses, grouping, and synoptical tables, and give short descriptions of certain species, the majority of which had been already described by other entomologists. I must here remark that Fedchenko did not separate Saropoda from Anthophora, and I have followed his plan, as Saropoda is only distinguished from $A$ uthophora by its maxillary palpi consisting of five, and those of Anthophora of six, joints: but the last joint of the labial palpi of Saropoda is not turned away from the preceding one, as it should be in Anthophora. Belonging, however, to the latter genus we find a tolerably large number of transitory species, having a special arrangement of palpi, which do not correspond with either Saropoda or Anthophora. For instance, Anth. magnilabris, montivaga, velocissima, and ruficornis have all the labial palpi with the last joint not turned aside; in magnilabris, montivaga, and velocissima the maxillary palpi consist of five, and in ruffcornis of four joints. We observe, however, a like difference in the palpi among the species of other genera of mellifera; for we rarely find among Megachile or Osmia two species having a perfectly identical 
arrangement of palpi. Among other genera the maxillary palpi do not exist at all, as in Pasites, and, therefore, it is impossible to ascribe to them any important signification, as in the absence of other important distinguishing marks, they do not serve as generic characters.

\section{APIDAE GFINUINAE.}

A. SCopulipenes.

\section{(A. Sociales.)}

A pis, Linné.

I. A pis mellifica, L.

\section{Bombus, Fabr.}

2. „. terrestris, L.

3. " " leucopygus, n.s.

4. . montanus, Lepelet.

5. " fragrans, Pallas.

6. " laesus, n.s.

7. " mendax, Gerstäck.

8. " hortorum, L.

9. " altaicus, Eversm.

10. "Fedchenkoi, n.s.

\section{Apathus, Newman.}

11. Apathus Rossiellus, Kirby

$$
\text { (2. Solitariac.) }
$$

\section{A. ANThOpHORIDAE.}

Anthophora, Latr.

12. Anthophora parietina, Fabr.

13.
14.
15.

16. Heinemanni, $n$.s., Fed.

17.

18.

Kochi, n.s., ,

Clessini, n.s., , ,

Bogdanowi, n.s., ",

Freimuthi, n.s., ", atricilla, Eversm.

Oschanini, n.s., ,,

Kronebergi, n.s., ,

bifasciata, n.s., ,"

personata, Erichson.

Kessleri, n.s., Fedch. similis, n.s.

Uljanini, n.s., Fedch. Fedchenkoi, Radoszk.

Olgae, n.s., Fedch. magnilabris, n.s., ,. Sichelii, Radoszk." liturata, Lepel. monacha, Erichs. Strauchi, n.s., Fedch. muscaria, n.s., ", clavicornis, n.s. tarsidens, n.s., Fedch. Kaufmanni, n.s., , gracilipes, Mor. Saussurei, n.s., Fedch. Solskyi, n.s., "

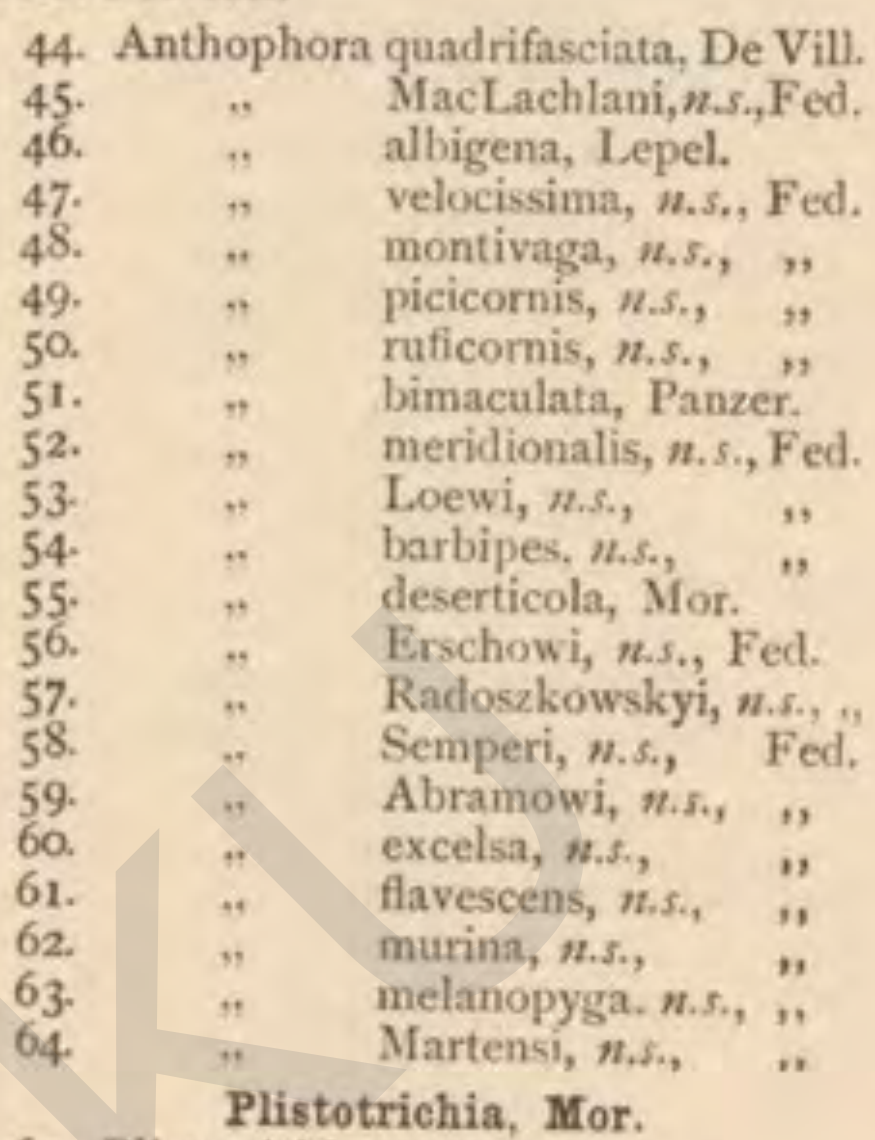

65. Plistotrichia compacta, n.s.

Tetralonia, Spinola.

66. Tetralonia vernalis, $n . s$.

$67 . \quad$ spectabilis, n.s. ruficollis, Brullé. transitoria, u.s. tricincta, Erichs. distinguenda, n.s. intermedia, n.s. mastrucata, n.s. Radoszkovskyi, Mor. vestita, n.s. rufescens, n.s. albo-rufa, Radoszk. malvae, Rossi. nana, Mor. ruficornis, Fabr. desertorum, n.s.

Eucera, Scop.

83. Eucera melanocephala, n.s.

84. " $" \quad$ tibialis, n.s.

85. " hirsuta, n.s.

86. $" \quad$ similis, Lepel.

87. " proxima, n.s.

88. " clypeata, Erichs.

89. $n$ pusilla, n.s.

9o. " caucasica, Mor.

91. $"$ tegularis, n.s.

92. " subrufa, Lepel. pollinosa, Lepel. 
93. Eucera tomentosa, n.s.

94. " ferghanica, n.s.

95. . . sogdiana, n.s.

96. .. melaleuca, n.s.

97. ." melanostoma, n.s.

Melitturga, Latr.

98. Melitturga clavicornis, Latr.

B. ANDRENOIDES.

Xylocopa, Latr.

99. Xylocopa valga, Gerstäck.

roa. .. Amedaei, Lepel.

IOI. ". turanica, n.s.

I02. .. signata, n.s.

103. "n hellenica, Spinola.

Ceratina, Latr.

104. Ceratina ferghanica, n.s.

105. . cyanea, Kirby.

Camptoprium, Spinola.

106. Camptoprium samarkandum, Rad. 107. mirabile, n.s.

\section{Rophites, Spinola.}

108. Rophites vitellinus, n.s.

109. $"$, orobinus, n.s.

110. " clavator, n.s.

111. $"$ atrocoeruleus, n.s.

i12. " canus, Eversm.

\section{Dasygastrae.}

Heriades, Latr.

113. Heriades clavicomis, n.s. Osmia, Panz.

114. Osmia longicornis, n.s.

II5. " subcornuta, n.s.

16. ". fulviventris, Panzer.

117. " prasina, \#.s.

is. " melanocephala, n.s.

119. "Fedchenkoi, n.s.

120. " maxillaris, n.s.

121. "t rufispina, n.s.

122. .. simplex, n.s.

123. " melanogastra, Spinola.

124. ". sogdiana, n.s.

125. " coerulescens, Linné.

126. ." cyanescens, n.s.

127. , indigotea, n.s.

128. " dilaticornis, n.s.

129. ". leucogastra, n.s.

130. ". agilis, n.s.

131. ." singularis, n.s.

132. " atro-alba, n.,

I33. " robusta, n.s.

134. difficilis, n.s.

135. " serrilabris, n.s.

136. . adunca, Panz.

137. ". rufimana, n.s.

138. .. furcula, n.s.

139. " caularis, n.s.
I40. Osmia proxima, $n .5$.

141. " simplicicornis, n.s.

I42. ". tenuicornis, n.s.

143. " abbreviata, n.s.

144. " brachyura, n.s.

145. " latipes, n.s.

146. " ruficrus, $n . s$.

147. . ruficornis, n.s.

148. " rufopicta, n.s.

149. " tridentata, Duf. et Perris.

150. " rufo-hirta, Latr.

I5I. ", montivaga, Mor.

152. " acanthophora, n.s.

153. "falcata, n.s.

Lithurgus, Latr.

154. Lithurgus monoceros, Eversm. 155. " tibialis, n.s.

156. " " maximus, Radosak.

\section{Megachile, Latr.}

157. Megachile muraria, Fabr.

158. $\quad, \quad$ asiatica, n.s.

159. $"$ difficilis, n.s.

160. " desertorum, n,s.

161. 1 derasa, Gerst.

162.

163. ". grisescens, $n$.s.

I64. " Saussurei, Radoszk.

165. " caucasica, Lepel.

I66. $\quad " \quad$ villipes, $n, s$.

167. " argentata, Fabr.

168. .. communis, n.s.

I69. .. imbecilla, Gerst.

170. " apicalis, Spinola.

I71., terminata, $n . s$.

172. " maritima, Kirby.

I73. " lagopoda, Linné.

174. nitidicollis, $n, s$.

175. $"$ basilaris, n.s.

176. "nandibularis, N.s.

177. $" \quad$ viridicollis, $n . s$.

178. " multispinosa, n.s.

179. $"$ sanguinipes, n.s.

180. " pulchella, n.s.

\section{Anthidium, Latr.}

181. Anthidium forcipatum, n.s.

182. " laterale, Latr.

I83. , Fedchenkoi, n.s.

r84. ", limbiferum, n.s.

185. " $"$ ruficorne, n.s.

I86. ." rubiginosum, Lepel.

I87. " $"$ oblongatum, Latr.

188. " diadema, "

189. " punctatum, "

190. .. obscuratum, n.s.

191. " cingulatum, Latr.

192. florentinum, Fabr.

193. $n$ nigrinum, n.s.

194. " callosum, n.s. 
195. Anthidium unicum, n.s.

196. .

197. .. cribratum, n.s.

D. CuculuinaE. (1. Stelidac.)

Stelidomorpha, n.g.

198. Stelidomorpha nasuta, Latr.

Stelis, Latr.

199. Stelis phaeoptera, Kirby.

Dioxys, St. Farg. et Serv.

200. Dioxys cruenta, Gerst.

201. .. rufipes, n.s.

202. .. formusa, n.s.

Coelioxys, Latr.

203 . Coelioxys sogdiana, n.s.

204. .. brevis, Eversm.

205. 4. coronata, Först.

206. ".$\quad$ robusta, n.s.

207. " pulchella, Mor.

208. ... argentea, Lepel.

209. .. conoidea, Illig.

210. " recurva, Schenck.

211. . tricarinata, n.s.

212. $n$ rufescens, Lep.

213. " acuminata, $\mathbf{N}$ yland.

\section{(2. Melectidae.)}

Melecta, Latr.

214. Melecta plurinotata, Brullé.

215. ". luctuosa, Scop.

216. " corpulenta, n.5.

217. $"$ fuscipenois, u.s.

Crocisa, Jurine.

218. Crocisa affinis, Mor.

219. " picicornis, n.s.

220. .. ramosa, Lep.

221. " major, $n . s$.

222. " aberrans, n.s.
Epeolus, Latr.

223. Epeolus variegatus, Linné. 224. " transitorius, Eversm.

225. ". ruficornis, n.s.

Ammobates, Latr.

226. Ammobates nigrinus, n.s.

Phiarus, Gerst.

227. Phiarus abdominalis, Eversm.

Pasites, Jurine.

228. Pasites maculatus, Jur.

Nomada, Fabr.

229. Nomada ferghanica, n.s.

230. " Fedchenkoi, n.s.

231. " $\quad$ subvirescens, n.s.

232. " $\quad$ sulphuripes, n,s.

233. " tripunctata, Mor.

234. " Jacobeae, Panz.

235. " rufiventris, Kirby.

236. . . desertorum, n.s.

237. " vernalis, n.s.

238. 4t discicollis, n.s.

239. " succincta, Panz.

240. " subcornuta, Kirby.

241. .. sarta, 2. .

242. " fucata, Panz.

243. " zonata, ,

244. robusta, Mor.

245. " strigicollis, n.s.

246. ." aurantiaca, n.s.

247. $n$ ruficollis, n.5.

248. " $\quad$ obburdinensis, n.s.

249. flavilabris, "t.s.

250. " nigricollis, n.s.

251. . bifida, Thoms.

252. . minuta, Fabr.

253. " cinnabarina, Mor.

254 " ferruginata, Kirby.

255. " furva, Panz.

\section{ANDRENIDAE.}

1. Acutilingues.

Melitta, Kirby.

256. Melitta leporina, Panz.

257. " melanura, Nyland.

Andrena, Fabr.

258. Andrena rufina, $n, s$.

259. " fulvicrus, Kirby.

260. ". quadrifasciata, n.s.

261. " leucorhina, n.s.

262. "labialis, Kirby.

263. " bairacumensis, n.s.

264. ". sarta, n.s.

265. " combinata, Kirby.

266. " incisa, Eversm.

267. " funebris, Panz.

268. ." proxima, Kirby,
269. Andrena sordida, n.s.

270. " planirostris, n.s.

271. . acutilabris, n.s.

272. ", urmitana, $n .5$,

273. . fulvescens, Smith.

274. , Taraxaci, Giraud.

275. $"$ sogdiana, n.s.

276., oralis, $u . s$.

277. " maculipes, n.s.

278. " convexiuscula, Kirby.

279. " $\quad$ rufilabris, n.s.

280. . nitidicollis, n,s.

28 r. .t lucidicollis, $n . s$.

282. " majalis, n.s.

283. " laeviventris, n.s.

284 . .. parvula, Kirby, 
285. Andrena dentiventris, Mor.

286. $" \quad$ tuberculiventris, n.s.

287. " $\quad$ Ferichenkoi, n.s.

288. $\quad$ ravicollis, n.s.

289. " punctiventris, n.s.

290. " aulica, n.s.

29r. " comparata, n.s.

292. ", ferghanica, n.s.

293. " " combusta, n.s.

294. $"$ analis, Panz.

295. " nupta, n.s.

296. " hieroglyphica, n.s.

297. " $\quad$ turkestanica, n.s.

298. " Lepeletieri, Lucas.

299. " fuscosa, Erichs.

300. " pilipes, Fabr.

30t. " thoracica, ,"

302. " $"$ infirma, n.s.

303.

304.

305.

306.

307.

308.

309.

3 ro.

311.

312.

313.

314.

315.

3 I6.

317.

3 IS.

319.

320.

$32 \mathrm{t}$.

322 .

323.

324.

325 .

326.

327. Nomioides parvula, Fabr.

328. $" \quad$ turanica, n.s.

329. .. parviceps, $n . s$.

330. $"$ jucunda, Mor.

Balictus, Latr.

331. Halictus leucopus, Kirby.

332. " $\quad$ annulipes, n.s.

333. " Smeathmanellus, Kirby.

334. " rhynchites, n.s.

335. " flavipes, Fabr.

336. " meridionalis, Mor.

337. $"$ varipes, n.s.

338. " $\quad$ croceipes, $n .5$.

339. "

340. " mucoreus, Eversm.
341. Halictus cariniventris, n.s.

342. " sogdianus, n.s.

343. " $\quad$ aprilinus, n.s.

344. $"$ desertorum, n.s.

345. $"$ fuscicollis, n.s.

346. " $\quad$ nasica, n.s.

347. " $\quad$ fucosus, n.s.

348. " sexcinctus, Fabr.

349. " fulvipes, Germar.

350. $"$ quadricinctus, Fabr.

351. " determinatus, n.s.

352. " minor, n.s.

353. " $\quad$ palustris, ns.

354. ,, modernus, n.s.

355. " funerarius, n.s.

356. ". longirostris, n.s.

357. ". major, Nyland.

358. " leucozonius, Schenck.

359. . scutellaris, n.s.

360 . zonulus, Smith.

361. " fulvitarsis, n.s.

362 . $\quad$ trifasciatus, n.s.

363. " quadrinotatus, Kirby.

364. " melanarius, n.s.

365. $\quad$ xanthopus, Kirby.

366. " equestris, n.s.

367. , $\quad$ ferghanicus, n.s.

368. " cylindricus, Fabr.

369. . $\quad$ picipes, n.s.

370. ,. obscuratus, N.3.

37 I. , cingulatus, n.s.

372. albitarsis, n.s.

373. . maculipes, n.s.

374. . marginellus, Schenck.

375. $\quad$ laevinodis, n.s.

376. " pauxillus, Schenck.

377. " $\quad$ limbellus, n.s.

378. ",$\quad$ nigrilabris, n.s.

379. " vulgaris. n.s.

380. " nigripes, $n .5$.

$38 \mathrm{r}$. " pectoralis, n.s.

382 . * punctulatus, K'rby.

383 . " gracilis, Mor.

384 .. hyalinipennis, n.t.

385 . " $\quad$ minutissimus, Kirby.

386. $n$ atomarius, $n .3$.

Sphecodes, Latr.

387. Sphecodes fuscipennis, Ciermar. 388. $"$ rufithorax, n.5.

389. $\quad$ " gibbus, L.

390. $\quad$. pectoralis, n.

$391 . \quad . \quad$ nigripennis, $n$. .

392. . . subquadratus, Smith.

393. .. similis, Wesmail.

394. ". puncticeps, Thoms.

395. .. Geoffrellus, Kirby.

\section{Nomia, Latr.}

396. Nomia diversipes, Latr. 
APPENDIX A.-MELLIFERA.

$5^{67}$

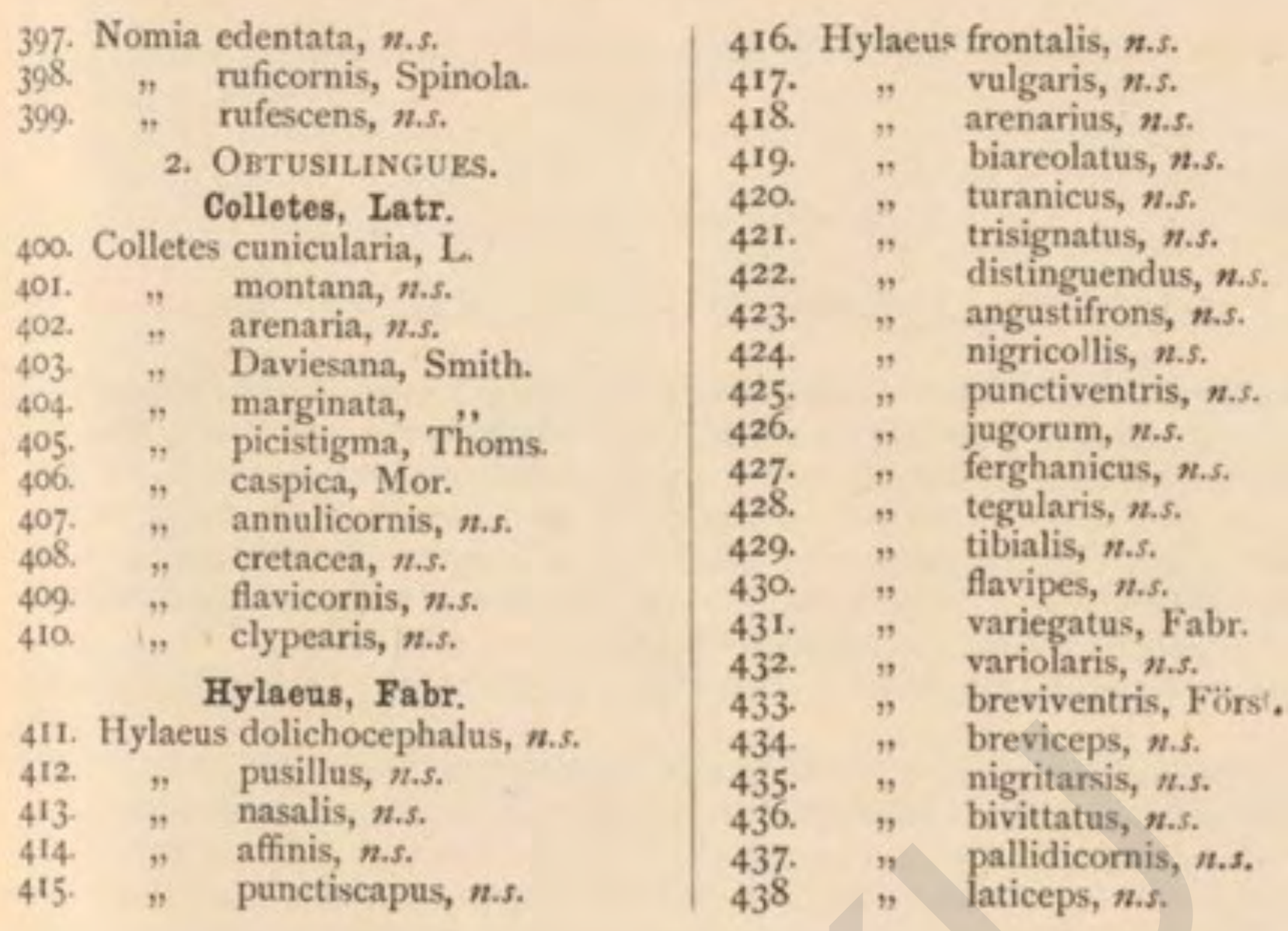




\section{SPHEGIDAE, ETC.}

\section{BY O. KERTZ RADOSZKOVSKY.}

IN carrying out the wish of Fedchenko regarding tables, I was obliged to take as a handbook Dahlbom's work ("Hymenoptera Europæa," tom. i., Sphex in sensu Linnaeano, Berolini, 1845 ) as the only one in which all the Sphegidae groups are reduced to a general system, though there exist incomplete separate monographs on certain genera of this group, for instance, Spher, Aysson, Oxybelus, and Crabro. I myself have added three new genera :-Kaufmannia, Oxybeloides, and Olgia.

In the collection described, 1 found the following distribution of genera :-

The family Sphegridae has not many representatives. Of the genus Sphex 6 species were collected. of which 3 were new; and amongst them, $S$. Stschurofskit is remarkable for its beauty. The American genus Podium has a representative in the Central Asian fauna.

The family Pompilidae is very characteristic: Aporus has 2 new, and I known, species; Salius, 3 new; Ceropales, out of 4 species, 3 are new; Pompilus, of 16 species, 8 are new; Priocnemis, of 7 species, 2 are new. In this family some Egyptian species are found.

In the family Larridae the very rare Egyptian genus Gastrosericus is met with. In Palarus, P. histrio has been, up to the present, found only in Egypt. Tachytes, of II species, 6 are new. If Savigny's drawings in "Exp. d'Egypte" were coloured, I have no doubt that among them would be found species identical with several described by me. Astata included I known and 3 new species, with very beautiful representatives among them. From the want of literature on this family the difficulty of drawing a line between the species and the varieties is increased, and not a little labour is incurred in the separation of species nearly related to one another. A trustworthy sketch of the geographical distribution of many of the species is quite impossible.

The family Nyssonidae was well represented. Alysson has 2 new species. Stizus, of 11 species, 47 are new. Among them, S. Fedchenkot, $S$. rufiventris, $S$. lutescens, are remarkable for their beauty and size. $S$, nigricornis is in great quantity, and must be very common in the locality where they were found. Hoplisus, 4 known, and 2 new species, which do not differ much from European forms, are remarkable for their beauty and shape. The new genus Kaufmannia is remarkable for its resemblance to the genera Ceramius and Paragia. Nysson has 4 new species, of which $N$. grandissimus is the largest species of this genus known up to the present; the remaining three species are remarkable for their beauty. Enthomosericus has a new, remarkable, and very rare species.

Bembex might be expected to have many representatives in the country. Of 11 species found, 7 are new. The majority of the new

* Dahlbom and Lepeletier each described 17 species.

$\div$ Dahllom described $\mathbf{I} 4$ in all ; Lepeletier $\mathbf{I}$ species. 
species are remarkable either for their structure or beauty; $B$. dilatata is remarkable for the shape of the front tarsi: $B$. bicolor, and $B$. femoralis, are remarkable for the shape of the intermediate legs.

Philanthidae is very rich. Philanthus has 2 new, beautiful representatives. Of 25 species* of Cerceris 14 are new. The majority resemble Egyptian species in their colouring.

The family Pemphredonidae is very poor, both in the number of genera and species.

Lastly, the family Crabronidae, with the exception of Oxybelus, is very poor. Oxybelus has many representatives, to (sic) new, and 6 known species.t Amongst them, very beautiful and characteristic forms are met with ; 0 . Savignii, previously only known as Egyptian, serves as another of the clearest evidences that the sands of Kizil-Kum and the sands of Egypt have similar inhabitants, at least among the insects of the groups treated by me. A comparison of the flora of these two localities might lead to more precise conclusions regarding their similarity.

Notwithstanding the monographs of Gerstäcker and Chevrier on the genus Oxybelus, the determination of species of this genus, and particularly the identification of the males, presents no little difficulty. However, in order to avoid misunderstanding and possible errors, I must explain that in determining the species, as well as in identifying the males, I adopted, as a principal basis, the study of the shape of the spine of the metanotum, and the scales of the postscutellum, and then compared the place and time in which the females and males were taken.

The remarkable new genus Oxybeloides differs from the foregoing by the absence of the spine of the metanotum in the male and female.

Crabro has 2 new species.

As a concluding observation it may be remarked that the valleys of Ferghana and the Zarafshan do not present much speciality. Their fauna resembles that of the Mediterranean Sea. Kizil-Kum alone, appearing as a separate part of Asia, abounds in new species and even genera, sharply distinguished from known species both in the form of the body and in the beauty and size of the individuals. Almost all that were found in the Kizil-Kum were new, but at the same time the undoubted similarity between the species belonging to the Kizil-Kum and the Egyptian sands is remarkable.

I. Sphegidar.

1. Miscus, Jur.

1. Miscus campestris, Latr.

\section{Ammophila. Dlb.}

I. Ammophila sabulosa, Lin.

2. Heydeni, Dlb.

3. ". holosericea, F.

4. " rubra, Sich.

3. Mimesa, Shuck.

1. Mimesa unicolor, Dlb.

2. ". atra, "
4. Psammophila, Dlb.

I. Psammophila atrocyanea, Eversm.

2. . affinis, Kirby.

3. . viatica, $\mathrm{L}$.

5. Pelopaeus, Latr.

I. Pelopaeus destillatorius, DIb.

2. -. tubifex, Ltr.

3. " violaceus, $\mathrm{F}$.

I. Podium Maracandicum, n.s., Rad.

7. Sphex, Lin.

1. Sphex Stschurowskii, n.s., Rad.

* Dahlbom described 29 species in all ; Lepeletier 22.

† Dahlbom described 18 ; Lepeletier 15 species. 
. Sphex subfuscata, Dlb.

3. .. desertorum, Eversm.

4 maxillosa, $\mathrm{F}$.

5. " Sirdariensis, n.s., Rad.

6. ", conica, n.s., ",

\section{Enodia, Dlb.}

I. Enodia albisecta, Lep.

2. "micans, Evers.

\section{IL. POMPILIDA .}

\section{Aporus, Spin.}

I. Aporus testaceus, n.s., Rad.

2. " ater, n.s., ",

3. " nigritulus, $\mathrm{KI}$.

\section{Salius, Ltr.}

1. Salius niger, n.s., Rad.

2. " micans, n.s., ,

3. ", albo-notatus, "n.s., Rad.

11. Ceropales, Latr.

I. Ceropales Solskii, n.s., Rad.

2. " Bogdanovii, n.s., Rad.

3. " nigra, n.s.,

4. " histrio, $\mathrm{F}$.

12. Agenia, Schiödt.

1. Agenia punctum, F.

13. Pompilus, Latr.

1. Pompilus viaticus, $\mathrm{F}$.

2. " argenteo-fulvus, ,.s, Rad.

3.,$\quad$ quadripunctatus, F.

4. " testaceus, n.s., Rad.

5. " vagans, n.s.,

6. $"$ sugillatus, $\mathrm{K} 1$.

7. $"$ trivialis, Dlb.

8. " spissus, ,

9. " consobrinus, Dlb.

10. " pulcher, $\mathbf{F}$.

II. " niger, n.s., Rad.

12. " maculatus, n.s., Rad.

13. " ruficeps, Eversm.

14. " albo-fasciatus, n.s., Rad.

15. ., rufiventris, n.s., ,.

16. ". Kizilkumii, n.s., , ,

17. Anoplius notatus, Lep.

14. Priocnemis, schiödt.

I. Priocnemis rubellus, Eversm.

$\begin{array}{lll}\text { 2. } & \text { variabilis, Ros. } \\ \text { 3. } & \text { nigriventris, Costa. } \\ \text { 4. } & \text { flavus, Eversm. } \\ \text { 5. } & \text { fuscus, F. } \\ \text { 6. } & \text { " } & \text { Zarafschani, n.s., Rad. } \\ \text { 7. } & \text { ". } & \text { Moravitzi, n.s., }\end{array}$

III. LARRIDAE.

15. Miscophus, Jur.

I. Miscophus niger, Dlb.

16. Gastrosericus, Spin.

I. Gastrosericus Maracandicus, n.s., Rad.

\section{Palarus, Latr.}

I. Palarus flavipes, Latr.

2. "histrio, Spin.

\section{Tachytes, Panz.}

I. Tachytes pompiliformis, Panz.

2. " vaga, n.s., Rad.

3. " Maracandica, n.s., Rad.

4 , Kizilkumii, n.s.,

5. " unicolor, Panz, Dlb.

6. . " obsoleta. Ross.

7. $\quad " \quad$ tarsina, Lep.

8. " incerta, n.s., Rad.

9. " oraniensis, Lep.

10. " micans, ns., Rad.

II. - fugax, n.s., ",

19. Larra, Latr.

I. Larra anathema. DIb.

20. Astata, Latr.

I. Astata maculata, n.s., Rad.

2. " frontalis, n.s., ,"

3. " quadripunctata, n.s., Rad.

4 " boops, van. d. Lind.

IV. NYSSONIDAE.

21. Olgia, n. g., Rad.

1. Olgia modesta, n.s., Rad.

22. Alysson, Jur.

I. Alysson Maracandensis, n.s., Rad.

2. " incertus, n.s.,

\section{Stizus, Latr.}

1. Stizus Fedchenkoi, n.s., Rad.

2. " nigricornis, Duf.

3. " rufiventris, n.s., Rad.

4. " lutescens, n.s., ",

5. " Eversmanni, n.s., ,,

6. " Kisilkumii, n.s., ",

7. .. Uljanini, n.s., ",

8. " fulvipes, Eversm.

9. " unifasciatus, n.s., Rad.

10. " concolor, Eversm.

I1. "\# tridens. F.

\section{Harpactus, Shuck.}

I. Harpactus formosus, Jur.

2. $"$ lunatus, Dib.

\section{Hoplisus, Dlb.}

I. Hoplisus punctulatus, Costa.

2. " quinquecinctus, $\mathrm{F}$.

3. * rufo-nodis, n.s., Rad.

4. " laticinctus, Lep.

5. ". luxuriosus, n.s., Rad.

6. " $\quad$ latifrons, Dlb. 
26. Kaufmannia, n.g., Rad.

1. Kaufmannia Maracandica, n.s., Rad.

\section{Nysson, Latr.}

1. Nysson grandissimus, n.s., Rad.

2. " argenteo-fasciatus, n.s., Rad.

3. " castaneus, n.s..

4 ." incertus, n.s.,

28. Enthomosericus, Dlb.

1. Enthomosericus Kaufmanni, $\pi$.s., Rad.

\section{Bembecidae.}

29. Bembex, Fabr.

1. Bembex dilatata, n.s., Rail.

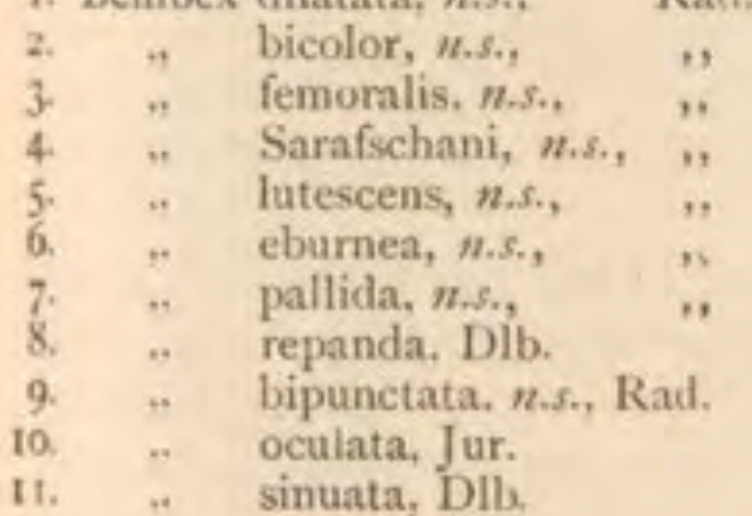

\section{PHILANTHIDAE.}

30. Philanthus, Latr.

I. Philanthus triangulum, Fabr.$$
3
$$

\section{.. Kokandicus, n.s. Rad.}

Kizilkumii, n.s.,

31. Cerceris, Latr.

1. Cerceris acuta, n.s., Rad.

\begin{tabular}{|c|c|c|}
\hline 2. & & \\
\hline 3. & 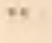 & siruariensis, n.s., Kad. \\
\hline 4. & t" & Ferreri, Van d. L. \\
\hline 5. & * & labiata, Fabr. \\
\hline 6. & " & octo-notata, n.s., Kad. \\
\hline 7. & s & rufo-nodis, n.s., \\
\hline 8. & " & Maracandica, n.S., ,.. \\
\hline 9. & n & maculata, n.s., \\
\hline a. & " & Freymuthi, "7.5., \\
\hline I, & " & mixta, n.s., \\
\hline 2. & "* & quadripunctata, n.5., Kat \\
\hline 3. & " & arenana, Lin. \\
\hline 4 & ". & pardeo-pieta, nis., Kad. \\
\hline 15. & " & solskn, n.s., \\
\hline I6. & "n & sabulosa. Panz. \\
\hline 17. & " & vagans, u.s., Rad. \\
\hline \$ & $"$ & nobilis, \\
\hline 9 & " & dorsalis, Eversm. \\
\hline 20, & " & conigera, Dlb. \\
\hline 21. & $"$ & quadricincta, Panz. \\
\hline 2. & $"$ & albo-fasciata, Ross. \\
\hline 23. & " & variabilis, Dlb. \\
\hline 24. & $"$ & capito, Lep. \\
\hline & ") & elegans, Eversm. \\
\hline
\end{tabular}

\section{Pramiredonidae.}

\author{
32. Stigmus, Jur.
}

1. Stigmus minutissinus, n.5., Rad.

33. Passaloecus, Shuck.

1. Passaloecus parvulus, n.s., Rad.

2. . Turionum, Dlb.

34. Diodontus, Curt.

1. Diodontus minutus, Fabr.

35. Cemonus, Jur.

I. Cemonus unicolor, Fabr.

2. .. lethifer, Dib.

36. Pemphredon, Latr.

1. Pemphredon lugubris, Fabr., Dlb.

VIII. CRABRONIDAE.

37. Trypoxylon, Latr.

1. Trypoxylon figulus, Lin.

38. Oxybeloides, n.g., Rad.

I. Oxybeloides fasciatus, n.s., Rad.

39. Oxybelus, Latr.

1. Oxybelus Fedchenkoi, n.s., Rad.

2. Sarafschani, n.s., R.,

3. " " parvulus, n.s., ".

$4 . \quad$.. elongatus, n.s., ,

5. ". Maracandicus, n.5., ,

6. ".. Kizilkumii, n.s., ,

7. .. Solskii, n.s., ",

8. .. eburneus, n.s., ".

9. ., canaliculatus n.s., ,"

10. " albo-pictus, n.S., "

11. . Savignii, Spin.

12. ., bipunctatus, Oliv.

13. " pugnax, "

14 " I4-notatus, Jur.

15. .. latro, Oliv.

16. .. mandibularis, Eversm.

40. Rhopalum, Kirby.

1. Rhopalum clavipes, Lin.

\section{Crabro, Latr.}

1. Crabro sexcinctus, Fabr.

2. " alatus, Panz.

3. " vagus, Lin.

4. ". urophori, n.s., Rad.

5. " spinipectus, Dlb.

6. ". varus, Panz.

7. " (Thyreopus) filiformis, Rad.

8. " do. Cljanini, n.s., ",

\section{Lindenius, Lep.}

I. Lindenius albilabris, Fabr.

2. "Panzeri, V. d. Lin. 


\section{SCOLIIDAE.}

\section{By H. De Saussure.}

To this family, as we understand it, belong the Hymenoptera Heterosyna, with the exception of Formicidae and Doryllidae. They may be called Heterogyna Solitaria, as they do not live in communities and have only two sexes, or Heterogyna Parasitica, by reason of the majority, if not all of them, being parasites of other insects.

We take, consequently, this family on the same basis as Lepeletier de St. Fargeau, not separating Thynnii from it as does F. Smith; for we view the family of Scoliidae as a natural group, not capable of being split up.

If it were necessary to separate any group from this family, we would prefer to act thus with Sapygii rather than Thynnii, as their legs are not armed but smooth, and both sexes are alike; but these insects are clearly related to Scoliidae by the construction of their thorax, and by their appearance generally.

Turkistan Scoliidae belong chiefly to the fauna of the Mediterranean basin. Among them are found all the eastern species of this basin, but the species (or varieties of form) mostly peculiar to the west are absent ; such, for example, as Scolia flavifrons, Fabr., bidens, L., interstincta, Kl., hirta, Schr., insubrica, Ross, Elis sexmaculata, and ciliata, Fabr. Instead of Scolia Ravifrons the corresponding eastern species, Sc. haemorrhoidalis, is met with in Turkistan, and instead of Elis sexmaculata is found $E$. tartara.

The species generally distributed over the whole basin, as $S c$, maura and quadripunctata and Elis villosa, are also met with in Turkistan. Species purely African are absent from the Turkistan fauna, though certain of them are distributed along the shores of the Mediterranean (Elis collaris), or in Egypt (Elis thoracica, F., Scolia mendica, Kl., acculta, Sauss., dispar, Kl., Elis aliena, KI., etc.). This absence from Turkistan of African species may, it seems, be explained by the fact that they belong to the torrid zone, and cannot endure the winter of the Asiatic steppes.

In the collections brought from Turkistan there are none of certain species described by former authors as belonging to the East; but from data in our possession we may conclude that these species probably exist in the province, and will be found there on further investigation, as for instance Scolia bifasciata, Rossi.

The species (Sc. varicolor, Luc.) belonging to Barbary is also wanting there.

Besides these species of the Mediterranean basin, several others are met with peculiar to Asia (Scolia Vollenhoveni), and also several 
new species, which are evidently characteristic of the fauna of Central Asia.

The family Scoliidae has been very imperfectly known up to the present, and there exists no complete work on the subject, which is explained by the important difficulties connected with the dimorphism, as well as by the comparative rarity of very many species in collections.

Of a large number of species, and also of certain genera, only one of the sexes has been previously known, and it is impossible to discover the other sex until we happen to take both in copula. A priorisuppositions are in many cases quite insufficient to enable us to ascribe known females to males, and, evidently, suppositions on like bases would most probably be incorrect. Thus, for instance, who could have thought that two genera so different as Meria and Plesia have males with similar characters?

Among species with wingless females, the latter retain the larval form, quite distinct from the same form of winged males, and as in the absence of wings it is impossible to observe those characters offered by the neuration, in cases where only the wingless female is known, there remains almost no character whereby we might connect the sexes, or decide with exactitude to which genus a given species belongs.

Even the neuration of the wings does not always serve as a character, as is evident from the following:-In Scolta the wing of the male is always different from the wing of the female, at least in the form of the cellula radialis. Among the males of Plesia the neuration of the wings is analogous to, but not identical with, that of the females. In Meria the neuration of the wing of the female has nothing in common with that of the male.

In a series of genera these anomalies are combined in the most various ways. Thus in Plesia and Meria the males are almost identical, while in Cosila and Merra, on the other hand, the females are almost identical, and the males are different. The genera are distributed quite differently according as we turn our attention to males or females. (This fact is specially evident with regard to Thynnii, among which the differences in form of the females do not at all correspond with those genera, which are established on the basis of the males.)

A classification, therefore, is much retarded by the difficulties naturally resulting from these anomalies. Generally speaking, among hymenopterous insects, it is necessary to base the description on the females, as the characters of that sex are marked with greater clearness. When the females are wingless, one is compelled to turn to the males to observe the neuration of the wings. In our investigation of this family it appears, as will be seen from the foregoing, that there is a new difficulty, chiefly consisting in the fact that the males of known genera are all similar to each other, while amongst the females the generic differences are clearly noticeable.

In the attempt at classification undertaken by us in the present work, 
we have made use of many characters which have not hitherto received due attention. Experience has shown us that not one of these characters, taken separately, can serve as a basis for classification, because many of them are combined, in the most opposite ways, with other characters. This evidently indicates that the family in question consists of several parallel, or rather diverging, series, having points of contact, in which are repeated the same modifications, by which corresponding types are formed in different series.

\section{SAPYGII. \\ Sapyga, Latr.}

I. Sapyga clavicornis, Lin.

2. " exornata, Gerst.

MUTILLIDAE,

Methoca, Latr.

I. Methoca ichneumonoides.

Myrmosa, Latr.

1. Myrmosa melanocephala, Fbr.

2. " Radoszkowskyi, n.s.

Mutilla, Lin., F.

Fedehenkia, n. gen.

1. Fedchenkia grossa, n.s.

$$
\text { Scoliae. }
$$

Scolia (Sensu latiore).

$$
\text { Scolia, Lin. }
$$

Triscolia, Saussure et Sichel.

1. Triscolia haemorrhoidalis, Fabr.

Discolia, Saussture it Sichet.

2. Discolia erythrocephala, Fabr.

3. " flaviceps, Eversm.

4. " quadripunctata, Fabr.

5. " infuscata, Klug.

6. " bifasciata, Rossi.

7. " unifasciata, Cyrill.
8. Discolia maura, Fabr.

9. ". Vollenhoveni, Sauss
10.

\section{Elis, Fabr.}

Trielis, Saussure at Sichel.

1. Trielis Fedchenkoi, n.s.

2. .. tartara, n.s.

3. . villosa, Fabr.

Dielis, Saussure at Sichel.

4. Dielis annulata, Fahr.

\section{Myzine, Latr.}

Plesia, Latr.

1. Plesia Fedchenkoi, n.s.

Tiphia, Fabr.

I. Tiphia morio, Fabr.

2. " 3. minuta, n.s.

Meria, Illig.

I. Meria tripunctata, Rossi.

2. " tartara, n.s.

3. " radialis, n.s.

4 . "Timurella, n.s.

Pseudomeria, Saund.

I. Pseudomeria Swanetiae, Radoszk.

2. ". Tamerlanella, n.s. 


\section{MUTILLIDAE.}

\section{By O. KeRTz RadoszKovsky.}

OF the number of insects of this genus collected by Fedchenko, there are 5 species belonging to the European fauna $-M$ : quinque fasciata (Greece), cephalica (Greece and Russia), rufipes, montana (Europe), lugubris (Russia, Hungary, Spain)-; 4 species of the fauna of the Mediterranean basin-M. Tunensis (Spain, Algeria, Persia), Hottentota (S. Europe, Algeria, Egypt), arenaria (Spain, Caucasus, Persia, Mongolia), rubrocincta (Algeria) - 3 species purely African- $M$. continua (Egypt, Senegal), decorata, and ornata (Egypt)-; 3 Central Asian species-M. bicolor, desertorum (Sungaria, Syr-daria), crenata (Sungaria)-; and 3 new species undescribed.

The species $M$. decorata and ornata were first collected by Savigny; their females are represented in his excellent drawings "Description de l'Egypte,"' Hyménoptères (Planches sans texte), but the males were unknown. The males and their females were collected by Fedchenko: $-M$. decorata in Zarafshan valley and near the Syr-daria, and $M$. ornata along the Syr-daria and in the Kizil-Kum.

As we have, in the monograph "Mutilla," published by Radoszkovsky and Sichel, in Horce Societ. Entomolog. Rossice, tome vi. p. 139 $(1869)$, a very complete description [in French] of the species of this genus then known, we borrow thence descriptions of the species met with in Turkistan, but previously known in other countries. In the description of new species found in Turkistan we always refer to the said work [in the original].

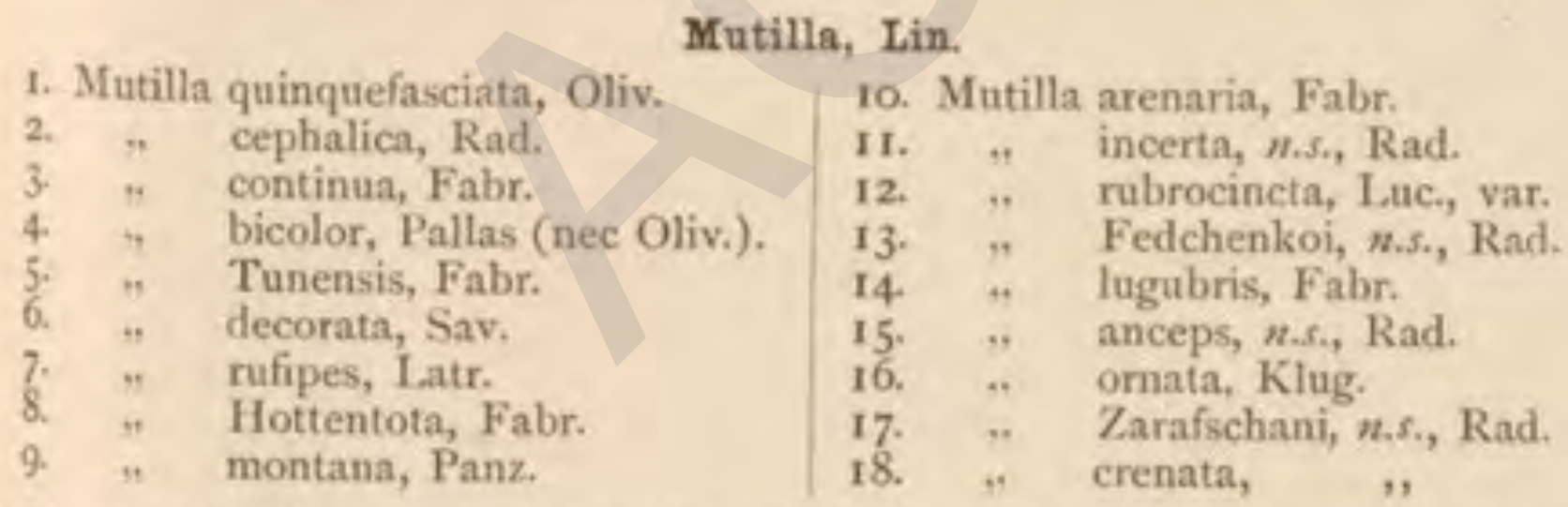

In returning the proof of the above, General Radoszkovsky is good enough to inform me that ( $\mathrm{r}$ ) five years ago Captain Bolosoglo made an entomological expedition to Turkistan, and found some new species, among which is a remarkable Habropoda Bolosoglyi, n.s.. Hymenopt. A pidae ; (2) quite recently General Komaroff has made scientific explorations between Askhabad and Merv, and among the Hymenoptera collected about Askhabad (the description of which is in the press) are the following Mutillidae :-

Agama Blakii, g.

, Komarovi, n.s,

". Askhabadensis, n.s.
Agama Kokpetica, n.s.

Tricholabiades, $n . g$.

$" \quad$ asiaticus, $n . s,-H . L$. 


\section{FORMICIDAE $(A n t s)$.}

\section{By Dr, Gustay Mayr, of Vienna.}

THE zoological investigations of Fedchenko have brought forward very interesting results in the family of Formicidae, and the rich materials collected by his indefatigable activity have the more value because collected in a country the Formicidae fauna of which was totally unknown, and even from the neighbouring countries we were acquainted with only a very small number of species.

It was anticipated that the Formicidae of Turkistan would differ little from those of Europe, as the boundary line between Europe and Asia is long, though, on the other hand, the Urals present a certain obstacle to the distribution of species. Moreover, the climatic conditions of Turkistan do not very markedly differ from European, while important obstacles are met with on the road from Turkistan to tropical Asia; and, finally, the known Siberian species were identical with European.

Of 36 species collected by Fedchenko in Turkistan only 7 are new, the remainder inhabiting Europe. Of the latter, Lasius niger and alienus, Formica truncicola, pratensis. rufibarbis, cinerea, and fusca, Tapinoma erroticum, Myrmica laevinodis, ruginodis, rugulosa, scabrinodis, and Lobicornis, Letramorium caespitum, and Solenopsis fugax are distributed over almost the whole of Europe ; Plagiolepis pygmaea and A phaenogaster structor inhabit Central and Southern Europe; Camponotus sylsaticus and marginatus. Cataglyphis viatica and cursor, Acantholepis frauenfeldi, Tapinuma nigerrimum, Bothriomyrmex meridionalis, Aphaenogaster barbara, Pheidole pusilla, and Cremastogaster sordidula, on the contrary, only inhabit Southern Europe, and only certain of these species are distributed towards the north as far as the middle of Central Europe. Cataglyphis albicans was previously known only from Spain, and Cardiacondyla elegans from Naples and Portugal.

Hence it is evident that the Formicidae fauna of Turkistan is very similar to that of South Europe, but distinguished from it by 7 new species. However, this is not astonishing, as the mean temperature of summer in Turkistan differs little from the mean summer heat in Southern Europe, and in this case only proves once more that, in general, countries with summers alike have greater similarity with regard to fauna and flora than countries lying under identical isotherms with different summers. This peculiarity is evident with regard to Formicidae, because, for example, in Italy and Turkistan they have an identical summer; and though the winter in Turkistan is long and cold, it does not appear to have much influence over the ants, which are protected therefrom.

Up to the present very few species wern known from Siberia,* viz., Camponotus ligniperdus and herculeanus, Formica exsecta, rufa, pratensis, sanguinea, rufibarbis and gagates, Myrmica laevinodis, lobicornis, and granulinodis. Of these only Formica pratensis, rufibarbis, Myrmica laevinodis and lobicornis inhabit Turkistan.

" Mayr, "Beiträge zur Ameisenfauma Russlands," p.87, Stett. Ent. Zeit., 18j9. 
From the Kirghese Steppe I received Cataglyphis cursor, which also inhabits Turkistan.

From Mongolia I know only Formica gagates and rufibarbis, the latter of which inhabits Turkistan.

The Formicidae of Persia, with the exception of Cafaglyphis viatica, are yet unknown; in Asiatic Turkey, principally in Asia Minor, Syria, and the peninsula of Sinai, are known the following, the greater portion having been described by me :-Camponotus sylvaticus with variegatus and aethiops, pubescens, Kiesenwetteri, robustus, sericeus, lateralis,: Prenolepis nitens, Plagiolepis pygmaea, Lasius alienus, brunneus, flavus, Formica gagates, fusca, Cataglyphis viatica, bombycina, albicans, Acantholepis Frauenfeldi, Liometopum microcephalum, Tapinoma erraticum, Aphaenogaster barbara, structor, striola, splendida, subterranea, testaceo-pilosa, rufotestacea, dentigera, Myr. mica scabrinodis. Leptothorax angulatus, Nylanderi, Tetramorium guineense, caespitum, Monomorium Salomonis, gracillimum, torense, Pheidole sinaitica, Solenopsis fugax, Cremastogaster scutellaris, sordidula, and inermis.

From the Caucasus and Georgia are known to me:-Plagiolepis pygmaea, Lasius niger, brunneus, Formica exsecta, pratensis, subrufa, Cataglyphis viatica, cursor, Ponera contracta, Aphaenogaster barbara, structor, Myrmica rubida, ruginodis, scabrinodis, Tetramorium caespitum, Pheidole pallidula and Cremastogaster sordidula, of which approximately three-fifths are found in Turkistan.

Certain of the species inhabiting Turkistan and Europe are also found in North America, viz., Camponotus sylvaticus, marginatus, Lasius niger, alienus, Formica truncicola. fusca, cinerea, rufibarbis, Myrmica ruginodis, scabrinodis, Lobicornis and Solenopsis fugax. The only species known in Europe and N. America, but not previously found in Asia, is Lasius umbratus.

European species which live in trees and woods,-as, for example, Camponotus ligniperdus and herculeanus; the genus Colobopsis, so common in European woods; Formica rufa, which makes high conical ant-hills; Liometopum microcephalum, which in Southern Europe makes such exquisite constructions in hollow trees; or Lasius fuliginosus, which builds similarly; and, finally, the genus Hypoclinia - appear to be in most cases absent from Turkistan.

Of the new Turkistan species Ischnomyrmex rhaphidiuceps is specially interesting. Up to the present, of this genus were known :1. longipes in Singapore, Borneo, and Celebes; I. exasperatus, the native country of which is unknown; and I. Longiceps in Australia.

As two of these species inhabit countries between the tropical and subtropical zones of the southern hemisphere, it is the more remarkable to meet with species of this genus in the temperate zone of the northern hemisphere, and it may be presumed that they have existed here since the tertiary period.

To the characteristics of Turkistan Formicidae $I$ may add that I do tot know of any country in which transitory forms between two species, and pale-coloured varieties, are so frequently met with.

As the new Turkistan species are described [in the original] in detail,

"Smith, in "List of Hym. coll. by Lord, 1871," includes Camponotus ligniperdus in the number of species inhabiting Arabia, but very probably he has mistaken some other for that species.

VOL. II. 
I have, for the definition of known species inhabiting Europe, referred to :-

Mayr, "Die Europäischen Formiciden," Wien, r861 ; and

Forel, "Les Fourmis de la Suisse," Zürich, 1874.

In the following description I have quoted only the principal synonyms; others are to be found in Mayr's "Formicidarum Index synonymicus," in the Verh. d. k.k, zool. bot. Ges. in Wien, 1863, pp. 385-460.

\section{Camponotus, Mayr.}

I. Camponotus sylvaticus, Oliv.

$$
\begin{array}{lll}
\text { 2. } & \text { " } & \text { Fedchenkoi, n.s. } \\
\text { 3. } & \text { " } & \text { marginatus, Ltr. }
\end{array}
$$

2. Plagiolepis, Mayr.

I. Plagiolepis pygmaea, Ltr.

$$
\text { 3. Lasius, } F \text {. }
$$

I. Lasius niger, L.

2. " alienus, Foerst.

\section{Formica, L.}

1. Formica pratensis, De Geer.

2. " truncicola, $\mathrm{Nyl}$.

3. ", rufibarbis, $\mathrm{F}$.

4. " cinerea, Mayr.

5. " fusca, L.

6. $"$ aberrans, n.s.

5. Cataglyphis, Foerst.

1. Cataglyphis viatica, F.

$\begin{array}{lll}2 . & " & \text { cursor, Fonscol. } \\ \text { 3. } & \text { albicans, Rog. } \\ \text { 4. } & n & \text { pallida, n.s. }\end{array}$

6. Acantholepis, Mayr.

1. Acantholepis Frauenfeldi, Mayr.

\section{Tapinoma, Foerst.}

1. Tapinoma nigerrimam, Nyl.

2. ", erraticum, Ltr.

8. Bothriomyrmex, Emery.

1. Bothriomyrmex meridionale, Rog.
9. Ischnomyrmex, Mayr. I. Ischnomyrmex rhaphidiiceps, n.s.

10. Aphaenogaster, Mayr. 1. Aphaenogaster barbara, L. 2. structor, Ltr.

\section{Myrmica, Ltr.}

I. Myrmica laevinodis, $\mathrm{Nyl}$.

$$
\begin{array}{lll}
\text { 2. } & \text { ruginodis, , } \\
\text { 3. } & \text { rugulosa, ", } \\
\text { 4. } & \text { scabrinodis, ", } \\
5 . & \text { lobicornis, ", }
\end{array}
$$

12. Leptothorax, Mayr.

13. Tetramorium, Mayr.

1. Tetramorium caespitum, L.

14. Monomorium, Mayr. I. Monomorium barbatulum, n.s.

15. Cardiocondyla, Emery. I. Cardiocondyla elegans, Emery,

16. Pheidole, Westw.

1. Pheidole pusilla, Heer.

17. Solenopsis, Westw. 1. Sole nopsis fugax, Ltr.

18. Cremastogaster, Lund. I. Cremastogaster sordidula, $\mathrm{Nyl}$. 2., subdentata, nis.

[In returning proof of the above Dr. Mayr informs me that his work on the Ants of Turkistan has been translated into Dutch, and published in Tijdschrift voor Entomologic, xxiii. deel, p. 17-40 (1879-80), - H. L.] 


\section{CHRYSIDIFORMES.}

\section{BY O. KeRtz RadoszKovsky.}

THE species of this group, generally very beautiful, are very like each other in their metallic colours as well as in their form. A definition of the differences of the species of each genus presents much difficulty. The descriptions of Fabricius, Latreille, and Klug, and even of Lucas, are so general and incomplete, that, notwithstanding the beautiful drawings, it is often impossible to say to what species the described and figured specimens of a given genus belong. Spinola first began to describe separately the more characteristic parts of the body; from his descriptions the identification is more practicable. Then Dahlbom published his monograph ("Hymenoptera Europæa," tom. ii., Chrysis in sensu Linnæeano, Berolini, 1854). He paid particular attention to the minutia of all parts of the body, to the form of the frontal depression, to the form of the third ventral segment, and the armature of the extremity of that segment, besides other parts of the body. Dividing the whole family into sharply-distinguished groups, he gave synoptical tables for the definition of the genera and species. With the aid of these tables and detailed descriptions, very often illustrated by most excellent drawings, the definition of each species is fully possible.

Regarding the work of Dahlbom as a model, and so far unique, for the true definition of species of the family Chrysididae, I have followed the system adopted by him, as far as possible, in the description of new species, As to species already known and described I have restricted myself to a Latin diagnosis, inviting the reader to turn to Dahlbom's work for further details. It should be remarked, however, that notwithstanding the most minute description of a species, the change of colour of its body depending upon local and climatic conditions, the transition from blue to greenish-blue, and from golden-green to golden-red, may often give rise to doubt, and lead to the fabrication of a supposed new species. For this reason, as far back as 1866, I considered it useful to add to Dahlbom's descriptions explanatory coloured drawings of all Russian species in my possession. For the same reason I give [in the original] drawings of all the species collected in Turkistan, of which drawings did not exist. This will also be useful, because, if a species identified by me is, though very similar to, yet really distinct from, the species to which 1 referred it, an exact correction of my error will, at any time, be possible.

In the materials collected by Fedchenko 1 found 5.3 species, belonging to the division Chrysidiformes, among which are 2 new genera and 15 new species. I am sorry that the locality of the very remarkable new genus Polyodontus is unknown; it was received from the Orenburg museum without designation as to where it was found. 
I. Clemptidae, Dli. 1. Cleptes, Latr.

I. Cleptes Morawitzi, n.s.

II. Elampidak, Dlb.

1. Omalus, Panz.

2. Omalus auratus, Dlb.

3. ", pusillus, Fabr.

4. " coerule is, de Geer.

5. ", aeneus, Panz.

2. Elampus, Spin.

6. Elampus ambiguus, Dlb.

7. " truncatus, ,

8. ", femoralis, Evers.

3. Holopyga, Dlb.

9. Holopyga ovata, Pall.

Io. " Bogdanovii, n.s.

III. Hedychridae, DlB.

1. Hedychrum, Latr.

II. Hedychrum incrassatum, Spin.

12. ", lucidulum, DIb.

13. ", Erschovi, n.s.

14. ", rutilans, Meger.

15. " flavipes, Evers.

16. ", Solskyi, n.s.

IV. ChrysididaE.

1. Chrysis, Fabr. Group I.

17. Chrysis vagans, n.s.

18. " varicornis, Spin.

19. " uniformis, Dlb.

Group 2.

20. " Fedchenkoi, n.s.

21. " versicolor, Spin.

22. " foveata, Dlb.

Group 3.

23. " cyanea, Lin.
Group 4.

24. Chrysis maracandensis, n.s. 25. " indigotea, Duf.

26. ", dentipes, n.s., Rad.

27. ", nitidula, Fabr.

28. ", soluta, Dlb.

29. " Ehrenbergi,

30. " palliditarsis, Spin.

31. " orientalis, Dlb.

32. ", diversa, ,"

33. " $"$ speciosa, n.s.

34. ", soror, Dlb.

35. " $" \quad$ kokandica, n.s.

36. " sinuata, Dlb.

37. ", cyanopyga, .,

38. " " superba, n.s.

39. ,, rutilans, Oliv,

40. ", analis, Spin.

4I. " Kessleri, n.s.

42. " Grohmanni, Spin.

43. " armena,

44 ", Uljanini, n.s.

45. " impar, Dlb.

46. ", ignita, Lin.

Group 5.

47. , pulchella, Sp.

48. " micans, Rossi.

49. " " sabulosa, n.s.

2. Stilbum, Spin.

50. Stilbum calens, Fabr.

3. Polyodontus, n.g., Rad.

51. Polyodontus Stchurovskyi, n.s.

V. Euchroeidae, DlB.

1. Euchroeus, Latr.

52. Euchroeus quadratus, K1.

2. Brugmoia, n.g., Rad.

53. Brugmoia pellucida, n.s., Rad.

VI. Parnopidae, Dlb.

Parnopes, Fabr.

54. Parnopes carnea, Ross. 


\section{LEPIDOPTERA (Butterfies and Moths).}

\section{BY Nicholas G. ERSCHOFF.}

THE Lepidoptera collected by Fedchenko serve as the chief, but not the whole, of the materials for the following remarks $:^{1}$ for I made use of certain information concerning the lepidoptera of Turkistan contained in the works of Ménétriès "and Eversmann."

It appears that the total number known at present in Turkistan, and included in my work, is 367 species, of which 122 are species of Microlepidoptera.

The Lepidoptera furnished to me by Fedchenko, Golike, and Dobujinsky, were collected in the eastern part of the Syr-daria province, in Khokand, and in the Zarafshan valley, between $66^{\circ}$ and $73 \frac{1}{\circ}^{\circ}$ long. E. from Greenwich, and $39^{\circ}$ and $43^{\circ} \mathrm{N}$. lat. The species described by Messrs. Ménetriès and Eversmann, though collected somewhat further east, and perhaps to the north, are included by me in the list, on account of the very great probability that they are also to be found in the province whence were obtained the collections described in the present work.

The Syr-daria and Zarafshan provinces present a very great variety in the character of localities; we find in them a transition, in a horizontal direction, from almost barren, sandy waste to the most fruitful oases, and, vertically, from the level of the sea to the perpetual snowline. Golike and Dobujinsky collected in the oases, the former at Hazret or Turkistan city, and the latter at Samarkand, while Fedchenko's expedition visited localities of diversified character. Since the various localities appear to present important differences in the character of their fauna, I have considered it necessary to cite the place where the Lepidoptera collected in Turkistan have been found.

The month and day (old style) of capture by the expedition is given for each specimen, because they furnish interesting data concerning the time of the appearance of the various forms in Turkistan. They indicate the occurrence sometimes of two broods of such forms, which in Europe appear in one brood; as, for example, Spintherops spectrum, Esp., Lithocolletis comparella, Z., and others. Finally, we see from them that in Turkistan a certain number of Lepidoptera fly even in the winter months, since we find that five species were collected in February, three in January, and three species even in

'In Fedchenko's collection there were in all 321 species, i.e, $\frac{7}{8}$ of all the forms here enumerated. Of these, 86 species, i.e. $27 \%$, appeared to be new. Specimens of these, as well as of all animals collected by the expedition, are preserved in the Zoological Museum of the Imperial University of Moscow. Besides those collected by Fedchenko, there were others in the collection, caught by Myshenkoff, Lovitsky, and Veltsin.

" "Description des insectes recueillis par feu M. Lehmann." Some Lepidoptera found in Bokhara are described here, of which four species were not found lyy the expedition, namely, Argyraspila succinea, Esp., Ligia ciliaria, Mén.. L. similiaria, Mén., and Margarades unionalis, $\mathrm{Hb}$.

${ }^{3}$ Of those enumerated by Eversmann there have not been found since:-Polyom, Alhananthis, Ev., Lyc. Elvira, Ev., Agrotis fallax, Ev., Agr. acuminifera, Ev., Hadena lirghisa, Ev., H. abrupta, Ev, described in the Bulletin de la Sociate Impiriale des Naturalistes de Moscou, 1854 and 1856. 
December-Spinth. cataphanes, var. ligaminosa, Ev., Ceratophora radiosella, m., and Lith. comparella, Z.

The present list contains a large number of new forms. I do not consider it advisable to reckon them as peculiar to Turkistan, as, probably, they are distributed throughout the neighbouring countries. But the fauna of these conterminous countries is little known, a circumstance which renders difficult the formation of an opinion concerning the degree of completeness of the collections made in Turkistan, and as to what species may yet be found there.

The territories adjacent to Turkistan are almost entirely uninvestigated: only a few species from Kopal and Sungaria are known. Several of them are mentioned in a forthcoming work,' and to some Lepidoptera, of which Eversmann speaks, he assigns a very indefinite habitat, namely, the Kirghese Steppe. To a certain degree Mangyshlak and Krasnovodsk furnish an exception. In June, 1870. A. Becker, of Sarepta, found in Mangyshlak I6 species, which are enumerated in the Bulletin de la Sacieté Impériale des Naturalistes de Moscou, part I., 1870, p. 126. On account of its small extent, the collection of Becker was not, in any way, characteristic of the fauna of Mangyshlak, and the majority of Mangyshlak species appeared in Fedchenko's collection. Only 5 of these species are not yet found in Russian Turkistan, 4 of which, it may almost positively be said, ought to be met with there, viz, :-Naclia punctata, var. famula, Frr., Lithosia unita, $\mathrm{Hb}$., Orgyia dubia, Tausch., and Thalpochares respersa, $\mathrm{Hb}$. As regards the fifth species, - Phorodesma (Ligia, secundum Becker) plusiaria, B., -its being found in Mangysblak may be doubted, and it may be taken for granted that there is an error in the locality assigned. In 1872, Mr, G. Christoph collected at Krasnovodsk, but 1 only saw a few of his insects and heard of others. Almost without exception, the whole of them are met with in Russian Turkistan; the only species wanting are :-Lycaena Christophi, Stgr. in litt., Psyche quadrangularis, Chr., Axiopena maura, Eichw., Agrotis promuba, L., and Heliothis nubigera, H.S., but, in my opinion, there should be no doubt as to the finding of these latter in the Syr-daria province.

I think it sufficient here to compare only the diurnal Lepidoptera of the Turkistan fauna with the number of species known on the whole European territory, and in certain of the better investigated countries of the Mediterranean province, since, of all divisions of Lepidoptera, Rhopalocera is the one which has been best investigated, both in European territory and Russian Turkistan, where they constitute $21 \%$ ( 76 species) of all the species there known.

The diurnal Lepidoptera of Europe [and the adjoining countries]. according to the latest catalogue of Dr. O. Staudinger, number in all 456 species, consequently the 76 species known in Turkistan constitute $17 \%$.

In Greece, according to 0 . Staudinger, ${ }^{2}{ }_{130}$ species, or about $281 \%$, are met with; in Amasia and Tokat, according to J. Lederer and J. Mann, " ${ }^{162}$ species, or about $36 \%$; in Brussa with Olympus,

- Mention is not made of the following which were taken in Sungaria, and described by Eversmann in the Bulletin de M/oscou for $1843,1846,1848$, and I851:-Parnassinus Delphinus, P. Clarius, Lycacna Pherdiades, Coenonympha Sumbeca, Callimorpha Menetriesii, Eprone acummaria, Gnophos stemmataria, Sengaria mollicularia, and Cidaria flaria. Certain of these will probably be found, at is future date, in Russian Turkistan.

For notes 5-11 sec original, p. 3 (in German and French). 
according to J. Mann, " 133 species, or about 29\%; in Anatolia, according to J. Lederer, ${ }^{*} 7^{2}$ species, or about $15 \frac{1}{2} \%$ n Syria, also according to $\mathrm{J}$. Lederer, " 82 species, or about $18 \%$; in Trans-Baikal, Amur, and Sea-coast provinces, according to $\mathrm{O}$. Bremer and $\mathrm{E}$. Ménétriès, ${ }^{10}$ are numbered 157 species, or about $35 \%$; and finally, in the Altai, according to the list of J. Lederer. " 121 species, constituting about $27 \%$, are found. Taking the average of species for each of these countries at $27 \%$, we see that the $17 \%$ of diurnal Lepidoptera in Turkistan only constitutes about $\frac{2}{3}$ of the normal figure. From this we may conclude with great probability that the number of diurnal Lepidoptera inhabiting Turkistan should exceed 120 .

With regard to nocturnal Lepidoptera or moths, it is decidedly impossible, even approximately, to form any trustworthy opinion, as of 2.397 European Heterocera known to me, 169 species are found in Turkistan, and of 3,213 Microlepidoptera only 122 species; besides, the above quoted seven localities with regard to Heterocera are too little investigated to permit of the formation of any opinion whatever.

Concerning the character of the fauna of Turkistan Lepidoptera, the collections made there permit some deductions, but only very general ones, to be drawn. In all there are known 367 species in Turkistan. Of these, 92 , or $25 \%$, constitute new species, and 14 , or $4 \%$, appear there in new forms, some of which will in the future probably be regarded as independent species, and 25 species, according to present information, must with the new species be recognized as peculiar to the fauna of Turkistan.

The remaining 235 species, or about $64 \%$ (29 of them appear new to the Lepidoptera of the Russian Empire), represent forms already known in other parts of Europe and Russia. As the percentage of general European species is very great, and as the new and chiefly characteristic species do not, from their facies, belong to exotic forms, we may suppose that the fauna of Turkistan belongs to the so-called "fauna of the European territory." According to the calculation of Dr. Standinger, the fauna of the European territory is spread over from 500,000 to 800,000 square miles, and to it (in addition to 180,000 square miles of Europe proper) belong, the whole of N. Asia, extending southwards, in the eastern part, as far as Manchuria, and in the west as far as the south of Persia; Armenia and Asia Minor; Algeria and Tangiers; Greenland, Labrador, and certain other parts of North America. The comprehension of such a vast extent under a general appellation is fully justified by the general character of the fauna of these countries, and the great resemblance of the individual species.

The fauna of Turkistan furnishes certain new proofs of the general correctness of thus extending the European territory, as in it are found such species as Colias Nastes, var. cocandica, $m$,, almost identical with a type living in Labrador ; Limenitis Lepechini, m., similar to the Californian L. Lorquinii, B.; Spilosoma melanostigma, m., similar to the N. American $S$. acrea, Dr.; Thestor Fedchenkot, m., represents the genus known previously in the south of Spain and N. Africa; Smerinthus Kindermanni, Ld, various species of Syntomida, and many other forms now known in the western part of Asia Minor.

Respecting the position that the fauna of Turkistan should occupy in the fauna of European territory, it may be without hesitation assigned to the south, or so-called Mediterranean province. The 261 known species, or $71 \%$ of the whole fauna of Turkistan, as is seen from 
the list, represent a mixture of the species of Asia Minor with S. European and Steppe species of the Volga and Ural.

Besides the above-named species, the following are particularly interesting from a geographical point of view :-Plusia Hochenwarthi, Hochenw., previously found only in Lapland, Scandinavia, Switzerland, and Labrador; Hypena revolutalis, Z., first found in Caffraria, then in Syria and Persia ; Phasiane Rippertaria, Dup., only to be found elsewhere in Provence, in the south of France; Eurycreon mucosalis, H.S., allotted to the Balkan Peninsula; and Staintonia medinella, Stgr., known only in Andalusia; but all now found in Central Asia.

I should further mention the Himalayan Colias Eogene, Feld., found by the expedition at a great height in the Khokand mountains; and two species of Heterocera, of the exotic genera Syneda $(S$. Langi, m.) and Azelina (A. maracandaria, m.).

These forms seem to indicate that the fauna of Turkistan tends towards the exotic, but Colias Eogene must be regarded as most probably a form spread over the upper zone of the whole central portion of mountainous Asia, and the species of Symeda and Aselina, on account of their peculiar character, do not quite belong to the exotic forms. Besides these three species there are no others which would authorize us to class the fauna of Turkistan as tending towards the Indian or Malayan fauna.

Concerning the distribution of the Lepidoptera known in Turkistan among various localities and zones of altitude, the following catalogue compiled by me will furnish information. As is seen from this catalogue, the species collected by Fedchenko, within the borders of the country, have a very unequal distribution. An important difference exists, not only in a vertical direction in the zones of altitude, but also in a horizontal direction. The cause of the latter is not the climatic difference alone, but the difference in the general physical conditions of the various localities of Turkistan. The watered cultivated zone, the clay steppe, and the sandy steppe of Kizil-Kum present so much difference in regard to the conditions which influence animal life, that necessarily the fauna must present differences in composition. These differences are expressed in the catalogue, where the original characteristic localities are arranged in separate columns. The catalogue also shows in which of the other countries are distributed those of the forms found in Turkistan which were earlier known. These dati present, without doubt, a good base for further operations in the same direction. I consider it premature, however, to make now, on these foundations, general deductions concerning the relations of the faunx of the different localities of Turkistan among themselves, or concerning the relations of the fauna of these localities to the faunz of other countries of the European territory. I consider it sufficient to say here, that of the 46 species found in the sands of Kizil-Kum, 12, or more than $26 \%$, appear peculiar to them; in the clay steppe, of 38 species 3 , or $8 \%$; in the border zone, oases, and hilly country, of 284 species, 58 , or about $20 \%$; in the mountains from 4,500 ' to $8,000^{\prime}$, of $4 \mathrm{I}$ species, 6 , or about $15 \%$; and finally, in the mountains from 8,000 to $13,000^{\prime}$, of 28 species collected there, 8 , or about $281 \%$. Comparing these general figures, we see clearly that the Kizil-Kum and the mountains from $8,000^{\prime}$ to $13,000^{\prime}$, or Alpine zone, are the most peculiar provinces as regards fauna. The border zone, oases, and hilly country, or cultivated zone, is the richest as regards the number 
of forms there met with, and in addition is not wanting in peculiar forms: the mountains from $4,500^{\prime}$ to $8,000^{\prime}$, or sub-Alpine zone, appears less peculiar, and the clay steppe very poor both in the number of species taken there, and as regards peculiar forms.

The following list of species is compiled on the system adopted by Messrs. Staudinger and Wocke ("Catalog der Lepidopteren des europaaischen Faunengebiets," Dresden, 1871). In the matter of synonyms I have considered it sufficient to limit myself, on this occasion, to quotations from the first author and references to the works where they are inserted; more detailed indications may be found in the above-quoted catalogue of Messrs. Staudinger and Wocke. I also referred to the best known figures of the species, and if the species was described in the "Fauna Lepidopterologica Volgo-Uralensis" of E. Eversmann, I have made quotations from it, as the only tolerably full work which treats of the fauna of Russian Lepidoptera.

Columns $1-5$ give the distribution of Turkistan Lepidoptera :1. (Plains.)-Kizil-Kum sands from $700^{\prime}$ to $800^{\prime}$ above the sea.

2. (Downs.)- Steppes from $750^{\prime}$ to $2,000^{\prime}$ above the sea.

3. (Hills.)-Damp places, such as the banks and adjoining meadows of the Syr-daria; oases, or watered and cultivated places; and hilly districts from $750^{\prime}$ to $4,500^{\prime}$ above the sea.

4. (Mountains.)-Districts from $4,500^{\prime}$ to $8,000^{\prime}$ above the sea.

5. (Peaks.)-Mountains from $8,000^{\prime}$ to $13,000^{\prime}$ above the sea.

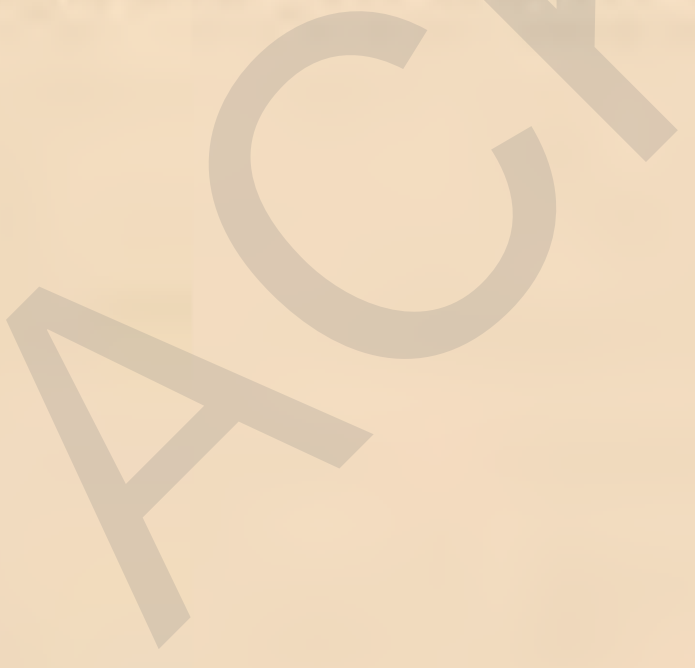




\section{RHOPALOCERA. \\ Papilionidae.}

1. Papilie Machaon, L. . Nick. 3. Parnassius Apollonius, Ev. 5. " " Actius, Ev.

6. ". Mnemosyne, L. Eur., except S.W., Altai, As. Minor

\section{Pieridae.}

7. Aporia crataegi, L.

8. Pieris brassicae, L.

9. " rapae, $\mathrm{L}$.

to. ", Callidice, Esp.

II. ", Leucodice. Ev.

12. ", Daplidice, L.

var. I., Bellidice, O. European territory, except Northern

, II., raphani, Esp. Persia

Europe, Siberia, Persia, Asia Minor

$$
\text { " " European" Alpine territory }
$$
Sungaria, Persia, California 13. Colias Nastes, B. var, cocandica, Ersch. Polar America, Labrador 14. " Erate, Esp.

15. Eogene, Feld.

16. Rhodocera rhamni, var. farinosa, Z.

S. Russia and Siberia Himalayas Asia Minor
Europe, Siberia, N. Africa Persia

\section{啇}

\section{Lycaenidae.}

17. Thecla mirabilis, n.5., Ersch.

18. "lunulata, n.s., Ersch.

19. Thestor Fedchenkoi, n.s., Ersch.

20. Polyommatus Solskyi, n.s., Ersch.

21. ". Thersamon, Esp. S.E. Europe. W. Asia, Persia - et (var. II.) Omphale, Klug. . Asia Minor 22. " dispar, Hw.. . [Brussa 23. $\quad$ var. rutilus, Werneb. - C. S S.E. Eur. Altai,
Phlaeas, L. Whole of Europe et (var. 1I.) Eleus, F. Southern parts of Europe 25. Cigaritis Acamas, Klug. S. Kînghese Steppes, Syria, Persia 26. Lycaena baetica, L. _. S.W. Europe, W. Asia, Persia 27. " aegon, Schiff. Europe, Asia Minor, Persia, Siberia

28. ", Argus, L. et var. maracandica, Ërsch.

20. "Zephyrus, Friv. Turkey, Grece, Caucasus, Asia Minor 30. ". Elvira, Ev.. . . . Southern Kirghese Steppes 31. " Baton, Bgstr. . C. and S.F. Eur., W. Asia, Persia 32. ", Tengstroemi, n.s., Ersch.

33. " ". Astrarche, Bgstr. . European territory, except the north 34. "Eros, O., var. candalus, H.S. Mountains of Asia Minon

35. $\quad$ " Icarus, Rott. European territory, excepi Polar regions

36. " Damon, Schiff., var. Damone, Ev. E. Russia and Persia

37. " Argiolus, L. European territory, except Polar regions 38. " prosecusa, n.S., Ersch.

39. ", semiargus, Rott.

40. "Jolas, O. S S.E. Germany, Hungary, S. France, [Turkey, N. Spain, Asia Minor] 


\section{Nymphalidae.}

41. Limenitis Lepechini, n.s., Ersch.

42. Vanessa Egea, Cr., ab. I-album. Esp. S. Europe, W. Asia, Persia 45. " urticae, L.

var, turcica, Stgr. Asia Minor, S. parts of Eur. Turkey 44 cardui, L. . * Cosmopolitan 45. Melitaea arduinna, Esp., var. rhodopensis, Frr. Caucasus, Asia 45. " Phoebe, Knoch, var. aetherea, Ev. . E. Russia 47. "Didyma, O. France, Germ, Hung., Stvituer, E. Russia et var. Neera, F. v. W. . . . E. Russia et var. caucasica, Stgr.

48. " Athalia. Rott.

Europe, Siberia, Asia Minor

49. Angynis Euphrosyne, L. $N$. and C. Europe, Caucasus, Siberia
50. Sarthenie, Bkh., aberr. Surope 51. " Pales, Schiff. . N. and Alpine Europe 52. " Latona, L. . . European territory, except $N$. 53. ". Niobe, L. . . Do. cxcept extreme $S$, and $N$ et ab. Eris, Meig.

54. " Pandora, Schiff.

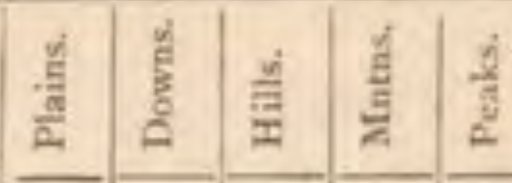

55. Arge Japygia, Cyrilli.

var. Suwarovius, Hbst.

Satyridae.

56. Erebia maracandica, n.5., Ersch.

57. Satyrus Briseis, L. C. and S. Eur., N.Afr., Asia Minor, Persia 55. " Heydenreichi, Ld. . . Altai

59. " anthe, O. . S.E. Russia, Siberia, Caucasus, Persia et var. Hanifa, Nordm.

60. "Kaufmanni, n.s., Ersch.

61. "Actaea Esp., var. parthica, Ld.

62. Pararge Eversmanni, F. v. W. . * : Pungaria

63. "Maera, L., var. Adrasta, Hb. "S

4. Epinephele Dysdora, Ld. . . . . . Persia

65. " narica, Hb. . . Steppes of S.E. Russia

66. " Amardaea, Ld., var. naubidensis, Ersch. . Persia

67. " Lycaon, Rott. Europe, cxcept N., Siberia, W. Asia 65. " interposita, n.s., Ersch.

. Coenonympha Nolckeni, n.s., Ersch.

70. " Pamphilus, L. European territory, $\operatorname{except} N$. [Europe, and S.E. Siberia

\section{Hesperidae.}

71. Spilothyrus alceae, Esp. S. So C. Eur., Sibcria, N.Afr, W. Asia t2 et var. australis, Z. . . . S. Europe 72. $"$ altheae, $\mathrm{Hb}$.

73. Syrichthus alveus, $\mathrm{Hb}$

var. baeticus, Rbr. . S.W. Europe, Italy, Syria

var. alpina, Ersch.

C. Europe, Asia Minor, Persia

Poggei, Ld.

S. Syria 3. H " orbifer, Hb. S.E. Europe, Altai, Amur, W. Asia 10. Hesperia Thaumas, Hufn. C. and S. Europe, Asia Minor, [Persia, N. Africa 


\section{HETEROCERA.}

SPHINGES.

\section{Sphingidae.}

78. " euphorbiae, L.

8a.,$\quad$ Alecto, L.

81. Smerinthus Kindermanni, Ld.

82 .

83. Macroglossa stellatarum, L.
77. Deilephila zygophylli, $O$.

79. ", livornica, Esp.

S. E. Russia, N. Fersia C. and S. Europe, Asia Minor S. Europe, N. Africa, W. Asia * Greece, $W$. Asia leti, Bienert. . Asia Minor leti, Bienert. . $\quad$ Asia Minor European territory, except $N$.

\section{Sesiidae.}

84. Sesia chrysidiformis, Esp. var. turanica, Ersch.

\section{Zygaenidae.}

85. Ino tenuicornis, Z.

Hungary, Sicily, Turkey, Asia Minor

86. , Geryon, $\mathrm{Hb}$.

var. chrysocephala, Nick. . Sziviss Alps, Austrian Mntns. 87. , obscura, $Z$.

88. Zygaena pilosellae, Esp. Asia Minor

var. nubigena, Ld. Europe, Alpine territory, Ircland 89. " " sogdiana, n.5., Ersch. .

go. ", truchmena, Ev. .

91. ", Olivieri, B., var. . Cancasus. Asia Minor

92. ", cocandica, n.s., Ersch. et var. minor, Ersch.

\section{Syntomidae.}

93. Syntomis bactriana, n.s., Ersch.

94. ", maracandina, n.s., Ersch. . et var, cocandica, Ersch. .

\section{Bombyces.}

\section{Nycteolidae.}

95. Sarothripa musculana, n.S., Ersch.

\section{Lithosidae.}

96. Lithosia lutarella, L. var. pallifrons, Z. N. and C. Eur., Dalmatia, Greece

\section{Aretiidae.}

97. Deiopeia pulchella, L.S. Europe, Asia Minor, India, N. Africa 98. Nemeophila russula, L. Europe, Altai, Siberia, Asia Minor 99. Arctia guttata, n.s., Ersch. too. ", spectabilis, Tausch. 101. Spilosoma fuliginosa, L., var. fervida, Stgr. . Asia Minor 102. ", turensis, n.S., Ersch.

103. ", melanostigma, Ersch.

Io4. ", menthastri, Esp.

Europe, Siberia, Asia Minor Cossidae.

105. Cossus campicola, Ev. 
106. Phragmatoecia castaneae, Hb. .

$$
\text { var. albida, Ersch. }
$$

107. Hypopta caestrum, $\mathrm{Hb}$.

. C. and S.E. Europe

S. Europe, Kirghiese Steppe

\section{Liparidae.}

109. Leucoma flavosulphurea, Ersch. 110. Ocneria dispar, $L$.

iII. " sartus, n.s., Ersch.

C. and S. Europe

\section{Bombyeidae.}

112. Bombyx castrensis, L. Europe, Asia Minor, Persia, Altai * 113. Lasiocampa sordida, n.s., Ersch.

\section{Notodontidae.}

114. Harpyia erminea, Esp.

115. Pygaera anachoreta, F. . N. and C. Europc, Italy, N. Spain,

\section{Noctuae.}

116. Acronycta centralis, n.s., Ersch.

$117 . \quad "$ psi, L. . . Europe, Siberia, N.W. Africa 118. Bryophila maeonis, Ld.

119. Agrotis nomas, $n, s$, Ersch.

120. "l flammatra, F Seviterland, $S^{\circ}$ Europt Asia Minon

121. ", simulans, Hufn. . N. and C. Europe, Altai *

122. " fugax, Tr. . . E. Austria, Hungary, S. Russia

123. " fallax, Ev. . . . S. Kirghese Steppe

124 " scripturosa, Ev.

125. ", foeda, Ld.

126. " exclamationis, $\mathrm{L}$.

127. ", solida, n.s., Ersch.

128. ", tritici, L.

var. aquilina, Hb. C. Eur., S. Russia, Caucas., Siberia

120. " acuminifera, Ev. . . . S. Kïghese Steppe

130. " conspicua, Hb. . S. France, Italy, S.E. Russia,

[Caucasus, Altai, Siberia, Persia]

131. "ypsilon, Rott. - . Europe, W. Asia, E. Siberia

${ }^{132}$ " segetum, Schiff: - : All Europian territory

133. ", Golickei, Ersch.

134. Mamestra siri, n.s., Ersch.

135. " Leineri, Frr., var cervina, Ev. S. Russia, Caucasus

136. "t trifoiii, Rott. European territory

137. " irrisoria, n.s., Ersch.

138. "sodae, Rbr. S. Europe

139. " chrysozona, Bkh. S. Stved., C. \& S. Eur., As. Min.

140. ", serena, F., var. obscura, Stgr. . European Als

14. Luperina immunda. Ev.

142. Hadena kirghisa, Ev.

143. " abrupta, Ev.

144. ", furva, $\mathrm{Hb}$. . Ural, Altai

S. Kinghese Steppe

N. and C. Europe, Pyrences, [S. Russia, Altai, E. Siberia

45. "I abjecta, Hb. N. \& C. Eur., Asia Mi., Altai, E.siheria

140. " lateritia, Hufn. . $N$. and C. Europe. Siberia

147. " leucodon, Ev. : . S.E. Russia and Siberia

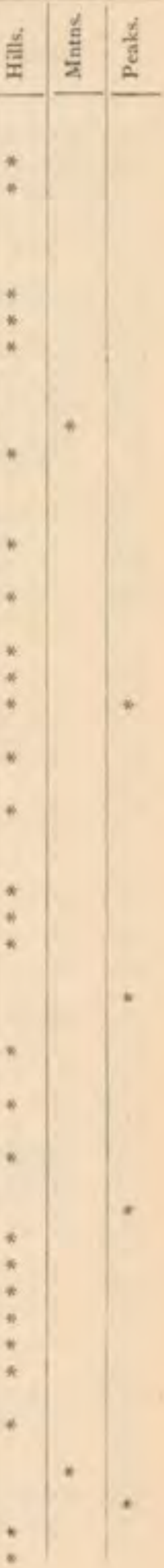


148. Mycteroplus didymogramma, n.s., Ersch.

149. Calamia phragmitidis, $\mathrm{Hb}$.

150. Argyrospila succinea, Esp.

Eur. Ural, Cancasus, Asia Minor

152. " vitellina, Hb. . . S. Europe, Asia Minor, Persia

153. ", Bogdanovi, n.s.. Ersch.

154. Amphipyra tragopogonis, L. Eur., Asia Minor, Persia, Altai

155. Hiptelia miniago, Frr.

156. Dyschorista suspecta, $\mathrm{Hb}$.

157. Scoliopteryx libatrix, L.

S. E. Russia, Altai

158. Xylomiges conspicillaris. I

159. Calophasia Christophi, n.s., Ersch.

160. Cucullia boryphora, F, v. W.

16r. ", argentina, $\mathrm{F}$.

162. Plusia gutta. Gn. . S. Europe, Siberia, Asia Minor, Pasia

163. " circumflexa, L. . . S. Europe, Asia Minor, Altat

164. " ni, Hb. . Hungary, S. Europe, Asia Minor

165. ", Hochenwarthi, Hochw, Sivilier., Lapd., Srueden, Labra.

166. Heliothis jugorum, n.s., Ersch.

167. " dipsaceus. L. . . All European territory 168. ". peltiger, Schiff. C. and S. Eur., Asia Minor, N. Afr. 169. ", Feildi, n.s., Erseh.

170. Chariclea delphinii, L.

171. Acontia Hueberi, n.s. Ersch.

172. ", lucida, Hufn. S. Europe, Altai, Asia Minor, N. Africa

173. " luctuosa, Esp. " " 174. Thalpochares pallidula, H. "S. S. Kirghese Steppe, Asia Ainor

175. ", gratiosa, Ev. . . .. S. Kirghese Steppe

176. ", griseola, Ersch. + . S. Kirghese Siefpe, Persia

177. Phothedes kisilkumensis, n.s., Ersch.

178. ", secuinda, n.s., Ersch.

179. Agrophila trabealis. Sc. C. S-S. Europe, Allai, Asia Minor et var. nigra, Ersch. .

180. Metoponia subflava, n.s., Ersch.

181. \# ochracea, n.s., Ersch.

182. Euclidia munita, $\mathrm{Hb}$.

183. ", mirifica, n.s., Ersch.

184. Syneda Langi, n.s., Ersch.

185. Pericyma albidentaria, Frr.

186. Acantholipes regularis, $\mathrm{Hb}$.

187. Leucanitis rada, B.

188. , ", sesquistria, Ev.

189. " $\quad$ cailino, Lef.

190. ", panaceorum, Mén.

191. ", cestis, Mén.

192. ", flexuosa, Mén.

193. ", spilota, n.s., Ersch.

194. Pseudophia syriaca, Bugnion

195. Catocala elocata, Esp.

196. " puerpera, Giorna S. Europe, Asia Minor, E. Siberia

197. " neonympha, Esp. . S.E. Russia, Caucasus, Aitai

198. Spintherops spectrum, Esp. S. Europe, As. Minor, N. Africa

..$\quad$ et var. phantasma, Ev. . Caucasus, Siberia

199. " cataphanes, Hh., var. ligaminosa, Ev. Cautas. Altai

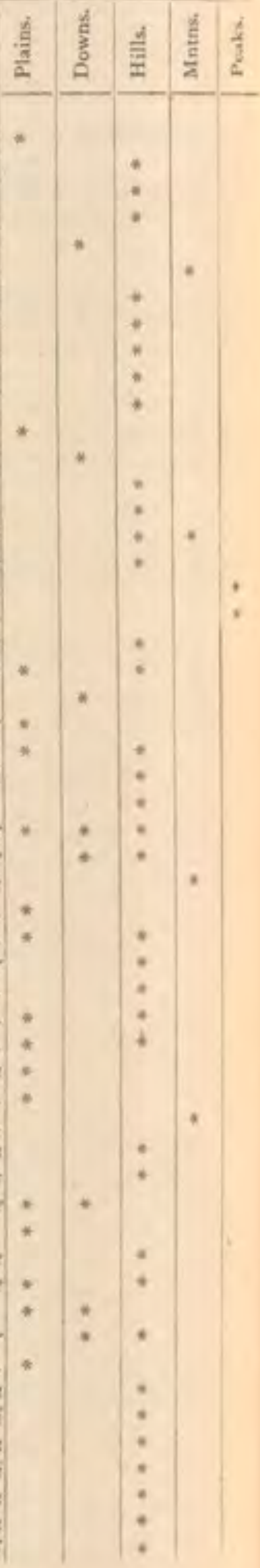




a

200. Spintherops, glebicolor, n.\$., Firsch.

201. ", dilucida, Hb. S. Europe, As. Minor, N.W. Africa 202. Toxocampa craccae, F. . . S. Europe, Asia Minor, Altai 203. Hypena ravalis, H.S. * . . S.E. Russia, Asia Minor 204 ", revolutalis, Z. . . . Asia Minor, S. Africa

\section{Geometrae.}

205. Pseudoterpna pruinata, Hufn. C. \& S.E.Eur., Catalonia, Itaiy 206. Phorodesma smaragdaria, F. . Europe, Siberia, Asta Minor 20\%. Eucrostis herbaria, Hb., var. advolata, Ev. . S. E. Russia 208. Nemoria pulmentaria, Gn. S. Europe, Cancasus, Asia Minor 209. Acidalia rufaria, Hb. Cen. \& Nrn. parts of S. Eur., As. Minor 210. " straminata, Tr. Finland, C. Europe, Dalmatia * 211. ", degeneraria, Hb. England, S.E. Europe, Asia Minor 212. " adulteraria, n.s., Ersch.

213. " halimodendrata, n.s., Ersch.

214. " Beckeraria, Ld. . . S.E. Europe, Caucasus 215. " marginepunctata, Göze. C. \& S. Eur., Altai, As. Mino 216. ", flaccidaria, Z. S. Russia, Caucastes, Asita Minor 217. ", ornata, Sc. $\quad$ Europe, Asia Minor, N.W. Africa 218. Timandra amataria, L. Europe, Siberia, Caucasus, Asia Minor 219. Stegania dalmataria, Gn. . . S. E. Russia 220. Azelina maracandaria, $n . s .$, Ersch. 221. Himera Stschurovskyi, n.s., Ersch. 222. Elicrinia subcordaria, H.S. 223. Hibernia occataria, n.s., Ersch. 224. Biston cinerarius, n.s., Ersch. 225. Boarmia repandata, $\mathbf{L}$. 226. " cocandaria, n.s., Ersch.

Europe, Siberia, Asia Minor 227. " consonaria, Hb. C. Europe, Kirghese Steppe, Amur 228. Gnophes Iveni, n.s., Ersch.

229. Phasiane Rippertaria, Dup., var.

S. France 230. Eubolia arenacearia, Hb. Austria, S. E. Russia, Asia Minor et var. flavidaria, Ev. . . S. E. Russia

231. Eusarca terrestraria, Ld.

232. Ligia turanica, n.s., Ersch.

233. " ciliaria, Mén. .

234. similiaria, Mén.

235. Sterrha anthophilaria, Hb, albidaria, Ersch -

2j6. Lythria purpuraria, L. et var. rotaria, $\mathrm{F}$.

237. Lithostege griseata, Schiff. C. Europe, S. Russia, Asia "Minor 238. ". Staudingeri, Ersch. 239. Anaitis excelsata, n.s., Ersch. 240. .'. plagiata, L.

241. Cidaria Fedchenkoi, n.s., Ersch.

242. " fluviata, Hb. .

243. ", polygrammata, Bkh. 244. Eupithecia innotata, Hufn. 45. " pumilata, Hb. *

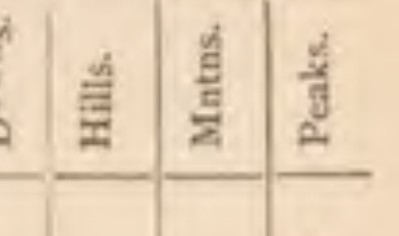




\section{MICROLEPIDOPTERA.}

\section{PYRALIDINA.}

\section{Pyralididae.}

246. Cledeobia consessoralis, n.s., Ersch.

247. $\quad, \quad$ armenialis, Ld.

Cancastus, Asia Minor

248. $\quad$ infumatalis, n.s., Ersch.

249. Hypotia cribellalis, n.s., Ersch.

250. Aglossa pinguinalis, L., var. asiatica, Ersch. . Cosmopolitan 251. Asopia costalis, F. . C. and E. Europe, Amur, N.W. Africa 252. ", farinalis, L. . Cosmopolitan 253. Talis quercella, Schiff. S.E. Europe

254. Scoparia incertalis, Dup. S. Europe, except Russia, Asia Minor 255. Aporodes floralis, Hb. . . S. Europe, Asia Minor, Persia 256. Ephelis cruentalis, Hb. - + . . Turkey, Asia Minon 257. Emprepes pentodontalis, n.s., Ersch.

258. Anthophilodes baphialis, Stgr.

259. Tegostoma comparalis, Hb. - . S. Russia, Asia Minor

Griece, S. $\dot{E}$. Russia, Egypd

260. Aeschremon disparalis, H.S. . . S.E. Russia, Asia llinor

26r. Botys falcatalis, Gn.

262. " sanguinalis, L

Alps of C. and S. Furope

263. ", fractilinealis, n.s., Chr. in lit. . Turkmenia, Persia

264. ", monialis, Ersch. . . Caurasus

265. ", cespitalis, Schiff., var. intermedialis, Dup. . S. Europe

266. ", polygonalis, $\mathrm{Hb}$, var. meridionalis, Wk.

267. " nubilalis, Hb. - . . C.and S. Europe, Sïkeria 268. "rubiginalis, $\mathrm{Hb}$.

269. Eurycreon nudalis, $\mathrm{Hb}$. . . ". . . Europe 270. " sticticalis, L. Europe, exceptextreme N., Siberia 271. ", mucosalis, H.S. - - European Turkey 272. " clathralis, Hb. S. E. Russia, Caucasus, Asia Minor 273. " verticalis, L. . - C. Europe. S. Russia, Amur 274. Nomophila noctuella, Schiff. . . European territory 275. Orobena frumentalis, L. . C. \& S. Eur., Siberia, Asia Minor 276. Margarodes unionalis, $\mathrm{Hb}$. . . . . . S. Europe 277. Hydrocampa nymphaeata, L. . . C. Eurvpe, Amur, Syria

能

\section{Chilonidae.}

278. Scirpophaga praelata, Sc.

279. Schoenobius gigantellus, Schiff.
280. C. Europe, S. Russia
forficellus, Thunb. C. Eur., N. W. E. S. E. Russia 281. mucronellus. Schiff. 282. Chilo "phragmitellus, $\mathrm{Hb}$. .

". C. Europe, N.W. Russia

\section{Crambidae.}

283. Crambus craterellus, Sc, var. cassentiniellus, Z. S. Eur.,.As. Min. 284 inquinatellus, Schiff. . . Europe, Syria, Persia. 285. ", perlellus, Sc.

var. Warringtonellus, Staint. N. Europe, Caucasus 286. Eromene ocellea, Hw. - England, S. Europe, Asia Minor 287. " funiculella, Ev.. . . Kirghese teppe. 
288. Dioryctria gregella, Ev.

289. Nephopteryx rhenella, Zk.

290. ", Dahliella, $\mathrm{Tr}$

291. Pempelia semirubella, Sc.

var. sanguinella, Hb. . C. and S. Europe, Siberia

292. " cyriella, n.s., Ersch.

293. " " obliteratella, n.s., Ersch.

294. " campicolella, n.s., Ersch.

295. " nucleolella, Moesch.

296. , livorella, n.s., Ersch.

297. Gymnancyla barbatella, n.s., Ersch.

298. Eucarphia lixiviella, n.s., Ersch.

299. Epischnia sareptella, H.S.

joa. Myelois deserticola, Stgr.

jor. " rhodochrella, H.S., var. delicatella, Moesch.

$302 . \quad$ " convergens, n.s., Ersch.

303. " urbicella, n.s., Ersch. .

304 " cribrum, Schiff. .

305. " vestaliella, n.s., Ersch.

306. ", albistriga, n.s., Ersch.

$30 \%$. " liturosella, n.s., Ersch.

j08. ", Tengstroemiella, n.s., Ersch.

309. Alispa acervella, n.s., Ersch.

310. Euzophera oblitella, L. S.W. Europe, S.E. Germany, Sarcpia 31. Homoeosoma sinuella. F.

312. ", dealbatella, n.s.. Ersch.

313. Anerastia lotella, Hb.

314 , 3 ablutella, $Z$.

315. Ephestia elutella, Hb.

C. and S. Europe, Altai, Syria

S.E. Russia, Siberia * Europe, cxcept extreme $N$. $S$. Europe, Asia Minor

$$
\therefore \quad: \quad \vdots
$$

, Sarepta

\begin{tabular}{|c|c|c|c|c|}
\hline$\frac{\text { 道 }}{\frac{\text { nd }}{2}}$ & हैं & 蛋 & $\frac{\mathrm{E}}{\mathrm{E}}$ & है \\
\hline
\end{tabular}




\section{Atychidae.}

330. Atychia minutula. n.s., Ersch. .

\section{Tineidae,}

331. Hapsifera luridella, Z.

. Greece, Asia Minor

332. Tinea cloacella, $\mathrm{Hw}$.

C. Europe, S.E. Russia, Sardinia

333. " fuscipunctella, $\mathrm{Hw}$.

Europe. Brussa

334. ", colonella, n.s., Ersch.

335. ", longipennis, n.5., Ersch.

336. ", (?) caerulipennis, n.s., Ersch.

337. Tineola macropodella, n.s., Ersch.

\section{Acrolepidae.}

338. Acrolepia exsuccella, n.s., Ersch.

\section{Hyponomeutidae.}

339. Hyponomeuta padella, $\mathrm{L}$.

Plutellidae.

340. Eidophasia Messingiella, F. v. R. England, Gcrmany, Brussa 341. Plutella cruciferarum, Z. .

All European territory

\section{Gelechidae.}

342. Psecadia pusiella. Roemer. C. \& S. Eur, W. Siberia, As. Minor 343. " distigmatella, ns., Ersch. . Caticastis, Brissa, I ersia 344. De" chrysopyga, Z. S. Europe,

345. Depressiria homochroella, n.s., Ersch.

347. Bryotropha glebicolorella, n.s., Ersch.

348. Parasia lappella, L. . Europe, except extreme $N$.

349. Ceratophora radiosella, n.s., Ersch. .

350. Cladodes (?) biareatella, n.s., Ersch.

351. Megacraspedus exoletellus, n.s., Ersch.

352. Pleurota aorsella, Chr.

353. Oecophora bisinuella, n.s., Ersch.

\section{Gracilaridae.}

354. Gracilaria stigmatella, F.

355. ", phasianipennella, $\mathrm{Hb}$.

var. auroguttella, Stph. . Europe, except extreme $N$.

Coleophoridae.

356. Coleophora alcyonipennella, Koll.

N.W. Russia, C. Europe,

[Italy, Brussa

\section{Lavernidae.}

357. Laverna decorella. Stph, var.

C. Europe

358. " (?) tetrazonella,, s., Ersch.

\section{Elachistidae.}

359. Butalis capitalis, n.s.. Ersch.

360. ", tabideila. H.S.

var. inquilinella, Ersch.

36t. Staintonia medinella. Stgr.

362. Heliodines Roesella. I. 
APPENDIX A.-LEPIDOPTERA.

595

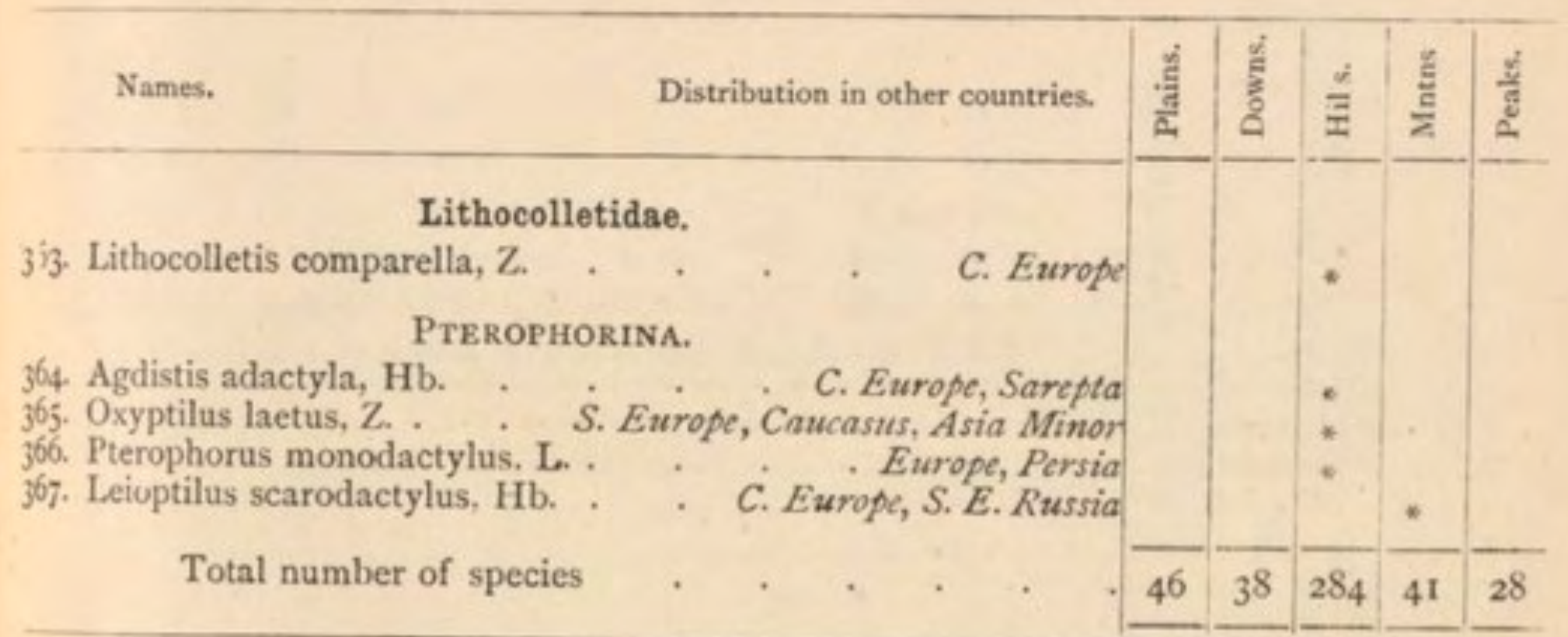


KULDJA LEPIDOPTERA.

[The following is a list of species, with their vertical distributions, collected by M. Serge Alphéraky, of Taganrog, in 1879 , in the district of Kuldja and the surrounding mountains, and here revised by him. The species are described (in French) in Hore Societatis Entomologice Rossice, 1881, p. 334; 1882, pp. 15, 156.-H. L.]

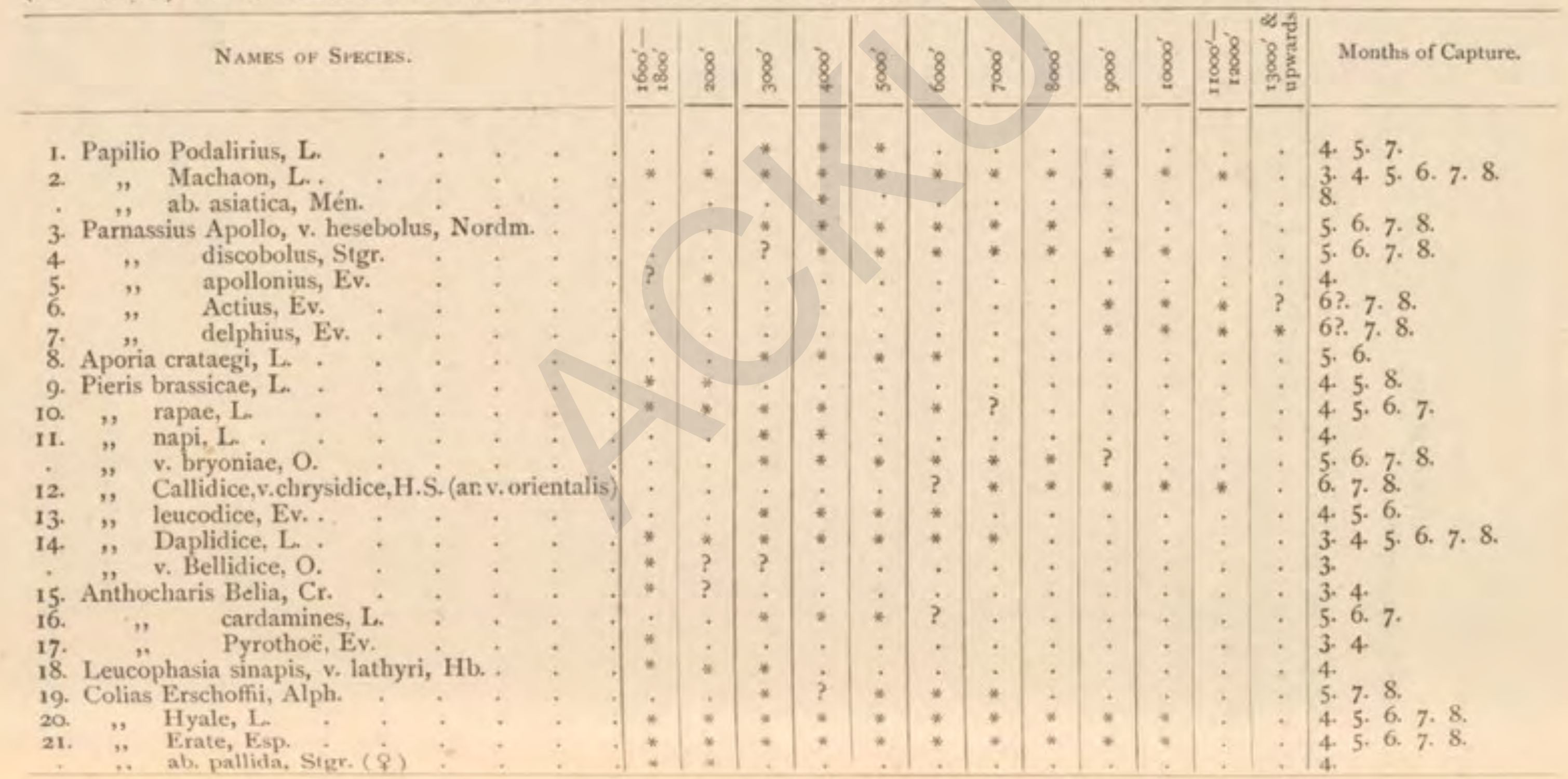




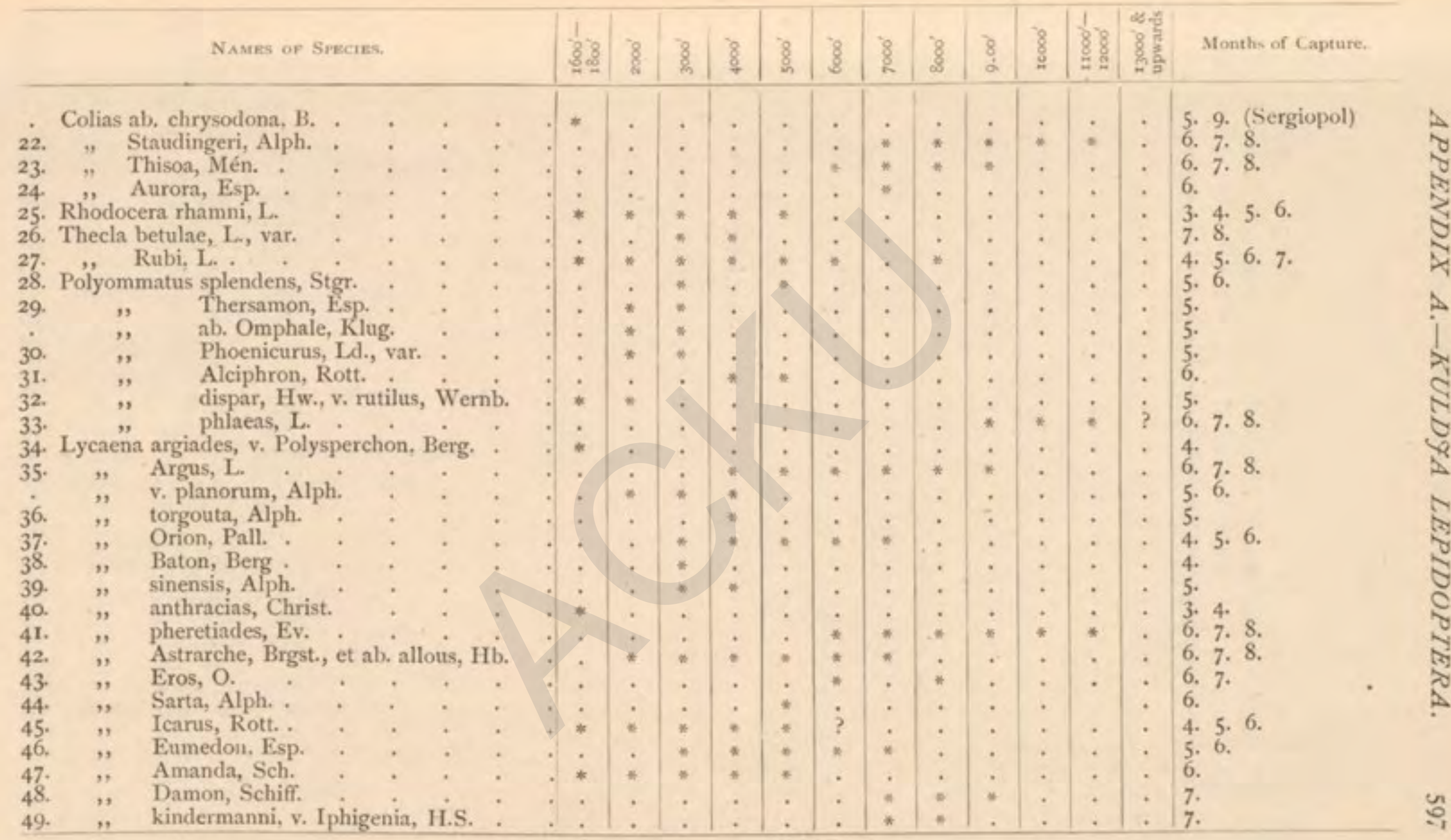




\begin{tabular}{|c|c|c|c|c|c|c|c|c|c|c|c|c|c|c|c|c|c|c|}
\hline & & NAMES OF SrEcies. & & & & 88 & 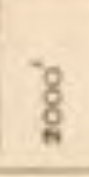 & $\frac{8}{2}$ & $\$$ & $\frac{8}{8}$ & 8 & :̊̊ & $\begin{array}{l}8 \\
8\end{array}$ & $\frac{8}{8}$ & $\frac{8}{8}$ & $\begin{array}{l}80 \\
8 \%\end{array}$ & 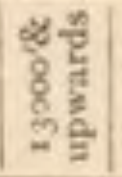 & Months of Capture. \\
\hline $\begin{array}{l}50 . \\
51 . \\
52 . \\
53 . \\
54 . \\
55 . \\
56 . \\
57 . \\
58 . \\
59 . \\
60 . \\
61 .\end{array}$ & 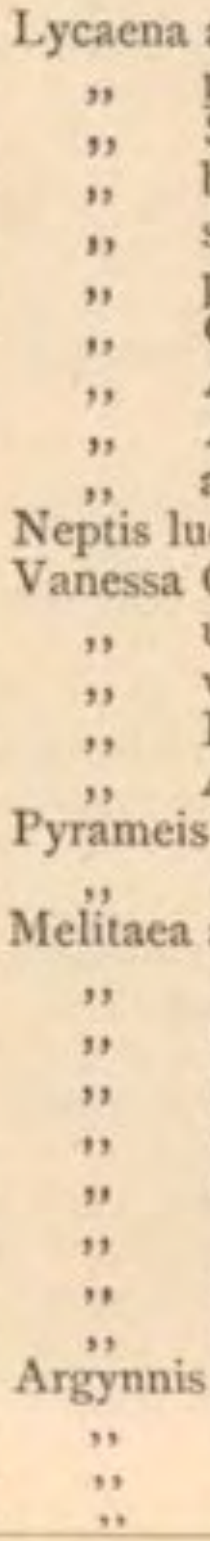 & $\begin{array}{l}\text { argiolus, L., var. } \\
\text { prosecusa, Ersch. } \\
\text { Sebrus, B. } \\
\text { buddhista, Alph. } \\
\text { semiargus, Rott. } \\
\text { persephatta, Alph. } \\
\text { Cyllarus, Rott. } \\
\text { Alcon, F. } \\
\text { Arion, L. } \\
\text { ab. ? cyanecula, Ev. } \\
\text { lucilla, F, v. Ludmilla, F } \\
\text { C-album, v. interposita, } \\
\text { urticae, L. } \\
\text { v. turcica, Stgr. } \\
\text { Io, L. } \\
\text { Antiopa, L. } \\
\text { is Atalanta, L. } \\
\text { cardui, L. } \\
\text { aurinia, v. asiatica, Stgr } \\
\text { Cinxia, L. } \\
\text { arduinna, Esp. } \\
\text { ab. rhodopensis, Frr. } \\
\text { Phoebe, v. sibina, Alph } \\
\text { didyma, v. dalmatina, } \\
\text {, v. ala, Stgr. } \\
\text { fergana, Stgr. } \\
\text { solona, Alph. } \\
\text { is hegemone, Stgr. } \\
\text { Pales, v. graeca, Stgr. } \\
\text { Ino, Esp. } \\
\text { Latona, L. }\end{array}$ & $\begin{array}{l}\vdots \\
\vdots \\
\vdots \\
\vdots \\
\text { H.S. Stgr } \\
\vdots \\
\vdots \\
\vdots \\
\text { Stgr. } \\
\vdots \\
\vdots\end{array}$ & $\begin{array}{l}\vdots \\
\vdots \\
\vdots \\
\vdots \\
\vdots \\
\vdots \\
\vdots \\
\vdots\end{array}$ & $\begin{array}{l}\vdots \\
\vdots \\
\vdots \\
\vdots \\
\vdots \\
\vdots \\
\vdots \\
\vdots \\
\vdots \\
\vdots \\
\vdots \\
\vdots\end{array}$ & $\begin{array}{l}* \\
* \\
* \\
\vdots \\
\vdots \\
\vdots \\
\vdots \\
\vdots \\
\vdots \\
\vdots \\
\vdots \\
\vdots \\
\vdots \\
\vdots \\
\vdots \\
: \\
\vdots \\
\vdots \\
\vdots \\
?\end{array}$ & $\begin{array}{l}* \\
\vdots \\
\vdots \\
\vdots \\
\vdots \\
\vdots \\
\vdots \\
\vdots \\
\vdots \\
\vdots \\
\vdots \\
\vdots \\
\vdots \\
\vdots \\
\vdots \\
\vdots \\
\vdots \\
\vdots\end{array}$ & $\begin{array}{l}* \\
\vdots \\
\vdots \\
\vdots \\
\vdots \\
* \\
\vdots \\
* \\
* \\
* \\
* \\
\vdots \\
\vdots \\
\vdots \\
\vdots \\
\vdots \\
\vdots\end{array}$ & $\begin{array}{l}\vdots \\
\vdots \\
\vdots \\
\vdots \\
\vdots \\
\vdots \\
\vdots \\
\vdots \\
\vdots \\
\vdots \\
\vdots \\
\vdots \\
\vdots \\
\vdots\end{array}$ & $\begin{array}{l}\vdots \\
\vdots \\
\vdots \\
\vdots \\
\vdots \\
\vdots \\
\vdots \\
\vdots \\
\vdots \\
\vdots \\
\vdots \\
\vdots \\
\vdots\end{array}$ & $\begin{array}{l}: \\
\vdots \\
\vdots \\
\vdots \\
\vdots \\
\vdots \\
\vdots \\
: \\
: \\
\vdots \\
\vdots \\
\vdots \\
\vdots \\
\vdots \\
:\end{array}$ & $\begin{array}{l} \\
\vdots \\
\vdots \\
: \\
\vdots \\
: \\
: \\
: \\
\vdots \\
\vdots \\
:\end{array}$ & $\begin{array}{l}\vdots \\
\vdots \\
\vdots \\
* \\
\vdots \\
\vdots \\
\vdots \\
\vdots \\
\vdots \\
\vdots \\
\vdots \\
\vdots \\
\vdots \\
\vdots \\
\vdots\end{array}$ & $\begin{array}{l}\vdots \\
\vdots \\
\vdots \\
\vdots \\
\vdots \\
\vdots \\
\vdots \\
\vdots \\
\vdots \\
\vdots \\
\vdots\end{array}$ & $\begin{array}{l}\vdots \\
\vdots \\
\vdots \\
\vdots \\
\vdots \\
\vdots \\
\vdots \\
\vdots \\
\vdots\end{array}$ & $\begin{array}{l}\vdots \\
\vdots \\
\vdots \\
\vdots \\
\vdots \\
\vdots \\
\vdots \\
\vdots \\
\vdots \\
\vdots\end{array}$ & $\begin{array}{l} \\
\vdots \\
\vdots \\
\vdots \\
\vdots \\
\vdots \\
\vdots \\
\vdots \\
\vdots \\
\vdots\end{array}$ & 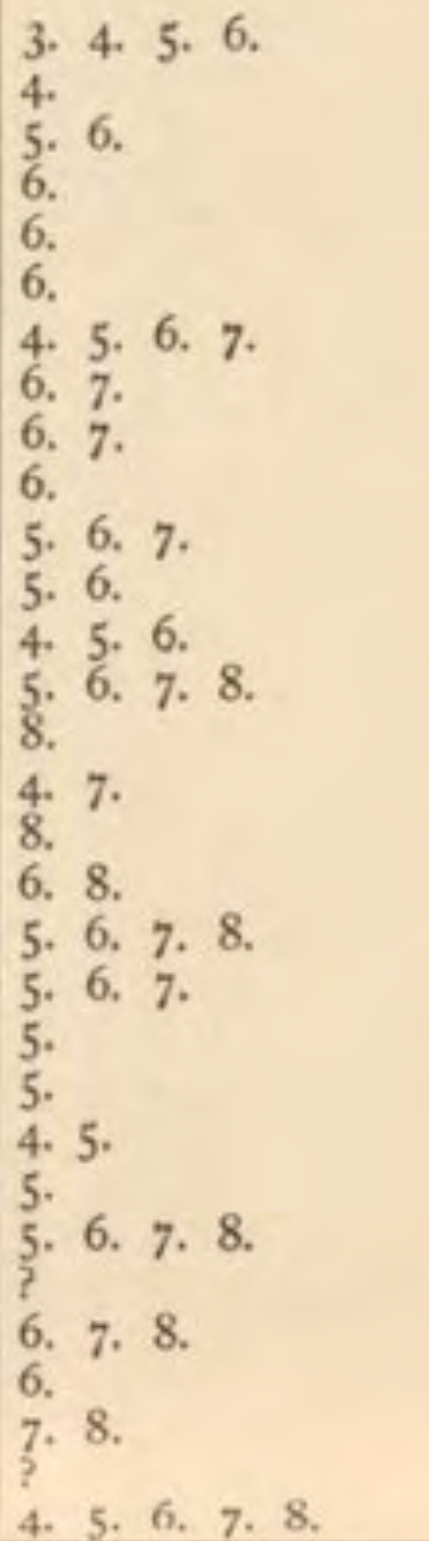 \\
\hline
\end{tabular}


78. Argynnis Aglaia, L. .

79. " Niobe, L., v. orientalis, Alph.

8o. " $\quad$ Adippe, L., var.

8r. ", Paphia, L., var.

83. Melanargia Suwarovius, Hrbst.

84. Erebia turanica, Ersch.

85. , kalmuka, Alph.

86. , sibo, Alph.

87. Oeneis Tarpeia, Pallas

88. Satyrus Briseis, L.

89. ", Anthe, v, enervata, Alph.

. " , ab. analoga, Alph.

" Autonoë, Esp.

91. " Regeli, Alph.

92. " Arethusa, Esp.

93.

94. Pararge Eversmanni, F. v. W.

95. Epinephele Dysdora, Ld., var.

96. naricina, Stgr.

96. ", kirghisa, Alph.

97. ", 9 lycaon, Rott., et var.

99. " $\quad$ interposita, Ersch.

100. ", sp.? (naubidensis, Ersch. ?)

I01. Coenonympha mongolica, Alph. .
I02. Iphis, Schiff., v. mahometana, Alph.

102. ", pamphilus, L.

", v. lyllus, Esp.

104. Spilothyrus Alceae, Esp.

105. Spilothy Alcellum, Hi.

\begin{tabular}{|c|c|c|c|c|c|c|c|c|}
\hline 8 & 8 & 8 & 8 & 8 & 8 & $\begin{array}{l}88^{\circ} \\
8 \\
\end{array}$ & $\begin{array}{l}8 \\
8 \\
\text { s. }\end{array}$ & Months of Capture. \\
\hline * & * & * & * & $*$ & * & - & - & 5. 6.7.8. \\
\hline * & * & * & * & - & - & - & - & 5. 6.7 .8$. \\
\hline - & . & - & * & - & . & - & . & 6. 7 . \\
\hline - & - & - & - & - & - & - & . & 7. 8. \\
\hline : & $\therefore$ & . & - & - & - & - & . & 6. 8. \\
\hline * & * & * & $\therefore$ & : & : & - & - & 5. 6. 7. \\
\hline * & 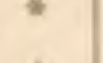 & 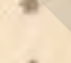 & ( & * & : & $\therefore$ & - & 5. 6.7 .8 \\
\hline . & : & i & : & * & * & * & - & $\begin{array}{l}0.7 .8 . \\
6.7\end{array}$ \\
\hline . & * & . & . & . & . & . & . & ? \\
\hline , & . & - & - & - & - & . & . & 7. 8. \\
\hline - & - & - & . & - & - & - & - & 5. 8. \\
\hline - & : & - & - & - & - & - & - & 5. 8. \\
\hline ; & ? & * & * & : & $\therefore$ & - & - & 8.7. \\
\hline : & $?$ & - & * & - & " & . & - & \\
\hline . & : & - & * & - & - & : & : & 7. 8. \\
\hline - & * & $\dot{.}$ & . & i. & . & . & . & 7. 8. \\
\hline . & - & . & . & . & , & . & - & 5. \\
\hline - & . & - & . & . & . & - & - & 5. \\
\hline - & - & - & - & - & . & . & - & 5. \\
\hline - & var. & - & . & - & - & - & - & 4. 5.7. \\
\hline - & * & : & • & - & 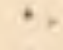 & * & - & 5 \\
\hline - & * & . & - & * & - & - & - & 7. \\
\hline : & : & : & - & * & - & - & : & \\
\hline * & 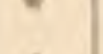 & . & ${ }^{\circ}$ & : & - & ; & : & 0.7 .8 \\
\hline 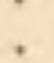 & ; & : & . & . & . & . & : & 4. 8 \\
\hline * & * & * & * & * & * & * & \# & 5. 6. 7. 8. \\
\hline * & . & , & * & • & - & . & - & 4. \\
\hline * & * & . & ? & . & - & . & . & 5. 6. $7.8 ?$ \\
\hline
\end{tabular}




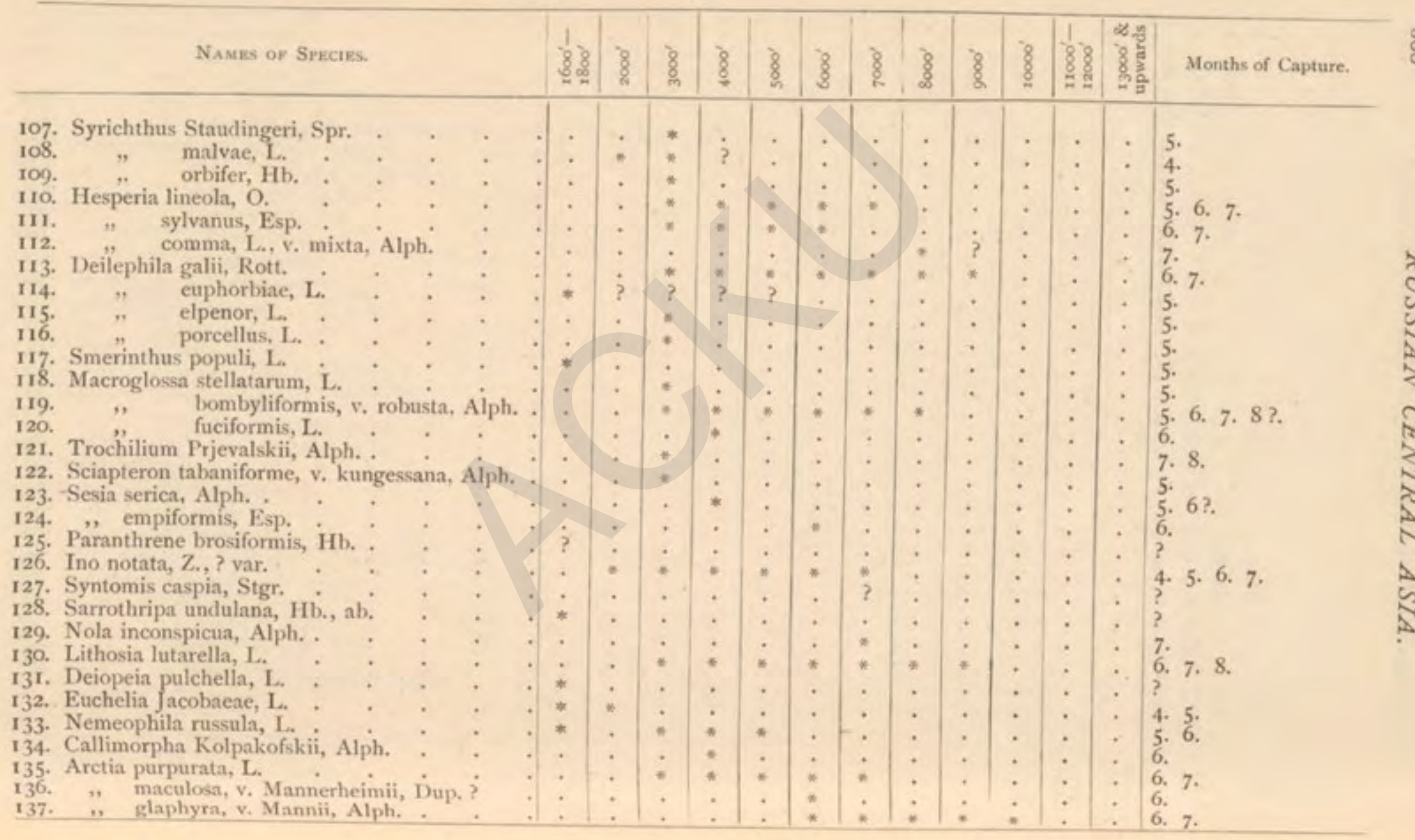


138. Arctia Erschoffii, Alph.

139. ", spectabilis, Tausch.

I40. Spilosoma fuliginosa, L. (var.)

141. , turensis, Ersch.

142. " urticae, Esp.

143. Cossus mongolicus, Ersch,

144. Phragmatoecia castaneae, $\mathrm{Hb}$.

145. Endagria, n.s.

146. Epichnopteryx Flavescens,' Heylaerts

147. Fumea rouasti, ${ }^{2}$ Heylaerts

I48. Orgyia flavolimbata, Stgr.

150. Porthesia kargalika, Moore

151. Bombyx castrensis, L.

152. ," neustria, L.

154. Prievalskit, Alph.

155. Pterostoma palpina, L.

156. Cymatophora or, F.

157. Simyra nervosa, F., et ab.

158. Arsilonche albovenosa, Götze

I59. Acronycta centralis, Ersch.

160. Nephelodes? intricans, Alph. .

I6r. Agrotis obscura, Brabm.

162. ", trigonica, Alph.

r63. ,, C-nigrum, L.

I64. ", albifurca, Ersch.

165. ", Scaramangae, Alph.

166. , , Juldussi, Alph.

167. ," Stentzi, Ld.

168.

," musiva, Hb.

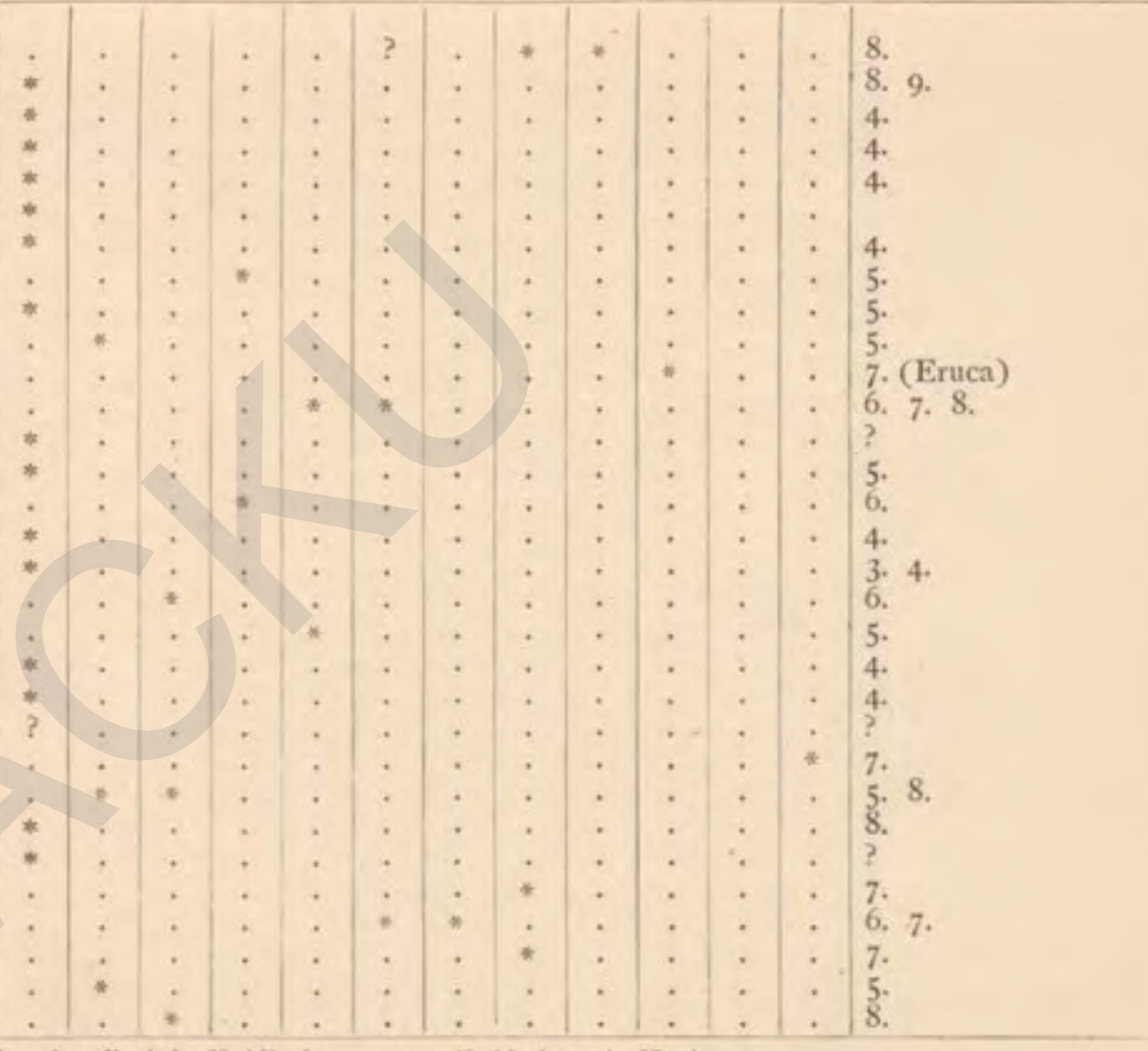


169. Agrotis flammatra, $\mathrm{F}$.

170. ", fennica, Tausch.

171. " polita, Alph.

172. ", umbrifera, Alph.

173. ", signifera, F., v, orientis, Alph.

174. 2 scripturosi, Ev.

175. ", rava, H.S., v. mus, Alph.

176. ", exclamationis, L.

177., tritici, $\mathrm{L}$.

178. ", basigramma, Stgr.

179. " conspicua, $\mathrm{Hb}$.

180. ", confusa, Alph.

I81. " segetum, Schiff,, v. pallida, Stgr.

182. ". kungessi, Alph,

183. Charaeas graminis, L., v.? megala, Alph.

184. Mamestra contigua, Vill.

185. ," dissimilis, Knoch.

186. ", pisi, L., v. pallens, Stgr. .

187. ", khorgossi, Alph.

188. ", aliena, Hb.

189. " oleracea, L.

190. " vicina, Alph.

191. ", dianthi, Tausch.

192. ", trifolii, Rott.

193. " cavernosa, Ev.

194. ", reticulata, Vill.

195. " chrysozona, Bkh.

197. Dianthoecia proxima Alph. Dan, Ev.

197. Dianthoecia proxima, H H. vicane

198. " irregularis, Huri cr.

\begin{tabular}{|c|c|c|c|c|c|c|c|c|c|c|c|c|c|}
\hline * & " & * & . & . & . & . & . & - & - & - & - & 5. & \\
\hline * & . & * & . & . & . & . & . & . & . & * & • & 8. & \\
\hline * & . & - & . & . & . & . & . & . & - & . & - & 5. & \\
\hline . & * & - & . & . & - & . & . & . & . & . & . & 5. & \\
\hline * & * & . & . & . & . & . & . & . & . & . & . & 5. & \\
\hline * & . & - & . & - & . & . & . & . & . & . & - & & 4 \\
\hline . & . & , & . & . & . & . & * & . & - & . & . & 7. $8 ?$. & \\
\hline * & . & * & . & . & - & . & - & . & . & . & - & 4. & \\
\hline . & . & * & . & - & . & . & . & - & - & . & - & 8. & \\
\hline . & * & . & . & . & . & . & . & . & . & . & . & 8. & \\
\hline * & $*$ & . & . & . & - & . & . & . & . & . & - & 5. & \\
\hline . & - & - & . & . & - & . & " & . & . & . & - & 7. & \\
\hline * & . & - & . & - & - & . & . & . & + & . & - & 4. 5. 8 . & \\
\hline . & - & - & * & * & * & * & * & * & . & - & - & 6. 7. & \\
\hline - & . & - & . & * & - & * & * & * & . & . & - & 6. 7. & \\
\hline . & . & . & - & - & * & - & . & . & - & - & - & & \\
\hline * & . & - & . & . & - & - & . & - & - & . & - & $?$ & \\
\hline . & . & - & * & - & - & - & - & . & . & . & - & 5. & \\
\hline * & - & - & - & - & - & - & . & - & . & . & . & 3. 4. & \\
\hline$*$ & . & . & . & • & . & . & . & . & + & . & - & $?$ & \\
\hline$\star$ & : & * & * & $\cdot$ & , & . & $\cdot$ & . & . & . & - & $\begin{array}{l}? \\
6 .\end{array}$ & \\
\hline * & . & . & . & . & $\cdot$ & * & . & . & ${ }^{\circ}$ & 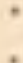 & 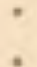 & ? & \\
\hline * & . & . & . & . & . & . & . & . & * & . & . & 4. & \\
\hline * & - & . & . & . & . & . & . & • & . & . & - & 7. & \\
\hline . & - & . & $\star$ & - & . & , & . & - & * & . & - & 6. & \\
\hline * & - & . & . & . & . & . & . & . & . & . & . & 5. & \\
\hline * & . & - & . & . & . & . & . & . & . & . & - & 3. 4. & \\
\hline . & . & - & . & . & * & . & . & . & . & . & - & 6. & \\
\hline$\therefore$ & : & : & : & : & . & . & : & : & : & : & : & $\begin{array}{l}6 . \\
7 .\end{array}$ & \\
\hline
\end{tabular}




\begin{tabular}{|c|c|c|c|c|c|c|c|c|c|c|c|c|c|c|c|c|c|}
\hline \multicolumn{5}{|c|}{ NAMES OF SrECIES. } & 88 & 8 & \& & 8 & 8 & 8 & 8 & 8 & 8 & 8 & $\begin{array}{l}88 \\
88 \\
\end{array}$ & 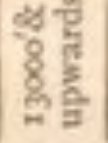 & Months of Capture. \\
\hline 200. & Dianthoecia? picturata, Alph. & & . & . & . & * & $\ldots$ & . & . & . & . & . & . & . & - & . & 5. \\
\hline 201. & Heptapotamia Eustratii, Alpl & & . & . & * & . & . & . & . & - & . & . & . & . & . & . & 9. \\
\hline 202. & Polia centralasiae, Stgr. . & . & . & . & , & . & . & . & . & . & . & * & . & . & . & . & 7. \\
\hline 203. & Luperina virens, v. immacula & $\mathrm{ata}, \mathrm{St}$ & & . & . & . & * & . & . & . & . & . & . & . & . & . & 7. \\
\hline 204. & Isochlora viridis, Stgr., v. vir & ridissi & $\mathrm{na}, \mathrm{St}$ & tgr. & . & . & . & . & . & * & * & * & * & . & . & . & 7. \\
\hline 205. & Hadena arschanica, Alph. & . & . & . & . & . & . & . & . & * & . & . & . & . & . & . & 6. \\
\hline 206. & ", furva, $\mathrm{Hb},$. . & . & . & . & . & . & . & . & . & * & . & * & . & . & . & . & 7. \\
\hline 207. & ", abjecta, $\mathrm{Hb}$. . & $\cdot$ & . & $\therefore \quad$. & . & . & * & . & . & . & . & . & . & . & . & . & 8. \\
\hline 208. & " lateritia, Hufo., v. ex & xpalle & scens, & Stgr. . & . & . & . & . & . & * & . & . & . & - & . & - & 7. \\
\hline 209. & , gemina, Hb., ab. ren & mis'a, & Tr. & .. & . & . & * & . & . & . & . & . & . & . & . & . & 6. \\
\hline 210. & Hydroecia nictitans, Bkh. & . & . & . & * & . & . & . & . & . & . & . & . & . & . & . & $?$ \\
\hline 211. & , micacea, Esp. & . & . & . & . & . & * & . & . & . & . & . & . & . & . & . & 8. \\
\hline 212. & ", songariae, Alph. & . & . & . & . & . & - & . & . & . & . & . & . & . & . & . & 7?. 8. \\
\hline 213. & Tapinostola extrema, $\mathrm{Hb}$. & . & . & . & * & . & . & . & . & . & . & . & . & . & - & . & 5. \\
\hline 214. & Calamia lutosa, $\mathrm{Hb}$ & . & . & . & . & . & * & . & . & . & . & . & . & . & . & . & 8. \\
\hline 215. & Argyrospila succinea, Esp. & . & . & . & . & . & . & . & . & * & . & . & . & . & . & . & 7. \\
\hline 216. & Leucania zeae, Dup. & . & . & . & . & , & - & . & . & . & . & . & . & . & . & . & 7. \\
\hline 217. & ," dungana, Alph. & . & - & . & . & . & - & . & * & * & * & • & - & - & . & - & 6. 7 . \\
\hline 218. & conigera, $\mathrm{F}$. & & & . & . & . & . & . & . & * & * & . & . & . & . & . & 6. 8. \\
\hline 219. & ," . lythargyrea, v, argy & ritis, & Rbr. & & . & . & . & . & . & . & . & - & . & $*$ & . & . & 7. \\
\hline 220. & Caradrina Morpheus, Hufn. & &... & & . & . & . & . & . & . & . & . & . & . & . & . & ? \\
\hline 221. & , quadripunctata, v, M & Ienetri & esii, K & Kretsch. & & . & - & . & . & . & . & - & . & - & . & . & 7. \\
\hline 222. & albina, Ev, . & . & . &. & * & * & . & . & . & . & . & . & . & . & . & . & 5. \\
\hline 223. & ", lenta, Tr. . & . & . & . & - & . & . & . & . & . & . & . & . & . & . & . & ? \\
\hline 224. & Amphipyra tetra, F. & . & . & . & * & . & . & . & . & . & . & - & . & - & - & - & $?$ \\
\hline 225. & Taeniocampa gracilis, F. & . & . & . & * & . & . & . & . & . & . & . & . & . & . & , & 4. \\
\hline 226. & n. incerta, Hufn. & . & . & . & * & . & . & . & . & . & . & . & . & . & . & . & 3. \\
\hline 227. & Hiptelia Staudingeri, Alph. & . & . & . & , & . & * & . & . & . & . & - & . & . & . & . & 8. \\
\hline 228. & Xanthia fulvago, ab. flavescer & $\mathrm{ns}, \mathrm{E}$ & & . & . & . & . & 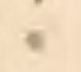 & . & . & . & - & . & . & , & . & 8. \\
\hline 229. & Xylomyges conspicillaris, L. & . & . & . & * & . & . & . & . & . & . & . & . & . & . & . & $?$ \\
\hline 230. & Cucullia dracunculi, $\mathrm{Hb}$. & . & . & . & * & . &. & . &. & . & . & . & . &. & + & . & $?$ \\
\hline
\end{tabular}




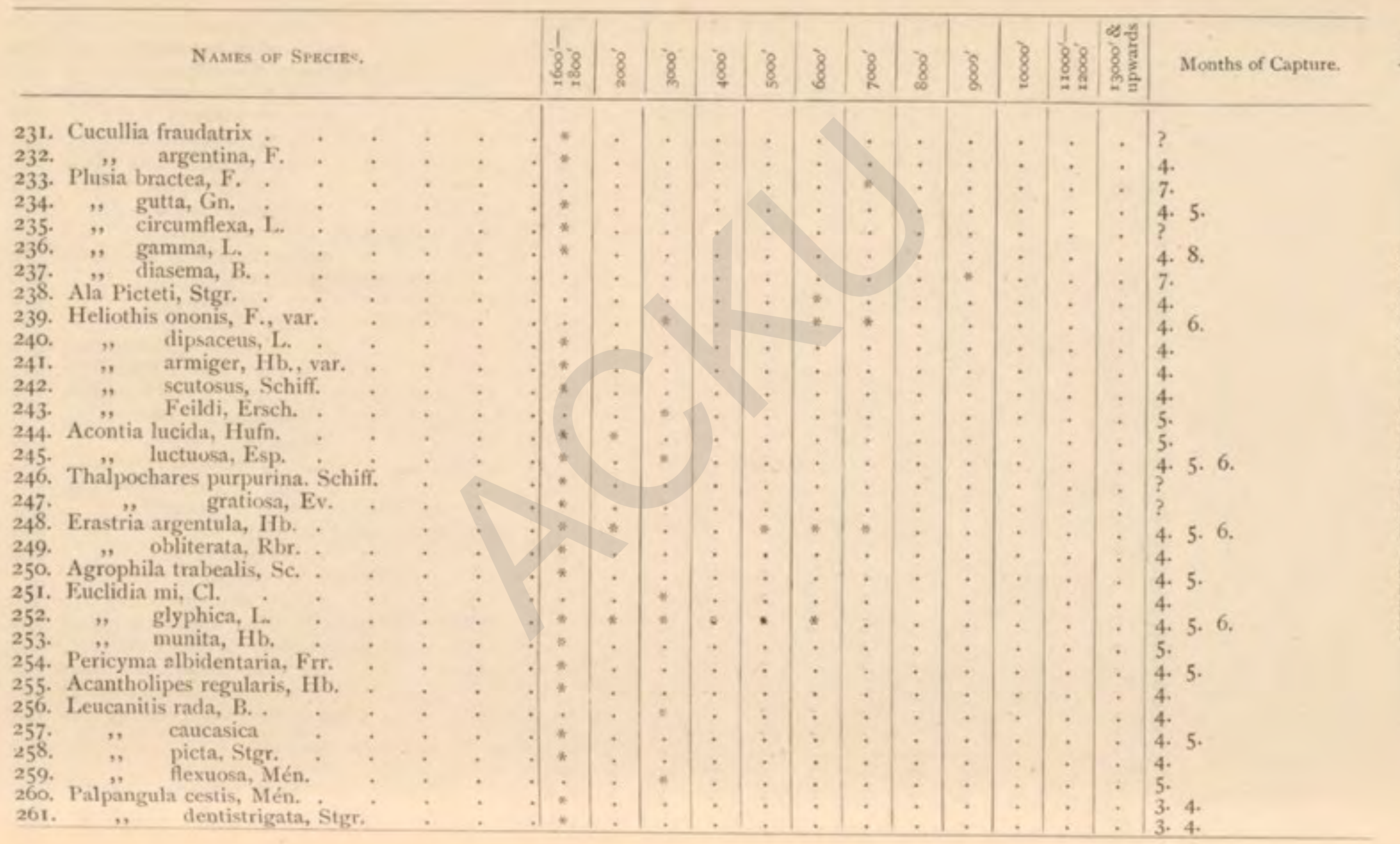


262. Palpangula fractistrigata, Alph.

263. Catocala fraxini, L.

264. ", elocata, Esp.

265. " nupta, L., var.

" puerpera, Giorna

267. ", neonympha, Esp.

268. Spintherops spectrum, v. phantasma, Ev.

269. ", maculifera, Stgr. (in litteris)

270. ", dilucida, $\mathrm{Hb}$

271. Eccrita ludicra, $\mathrm{Hb}$.

272. Toxocampa craccae, F.

273. Hypena diagonalis, $\mathrm{Alph}$.

274. " rostralis, I.

275. ", obesalis, $\mathrm{Tr}$.

276. Rivula sericealis, $\mathrm{Sc}$.

277. Geometra vernaria, $\mathrm{Hb}$.

278. Phorodesma smaragdaria, $\mathrm{F}$.

279. ", fulminaria, L. v. correspondens, Alph.

280. Kucrostis herbaria, Hb, v. advolata, Ev.

281. Nemoria viridata, L.

282 . " porrinata, F.

$283 . \quad$ pulmentaria, Go.

284. Thalera fimbrialis, $\mathrm{Sc}$.

285. Acidalia humifusaria, Ev,

286. ", trilineata, Sc.

287. ", sericeata, $\mathrm{Hb}$.

288. " pallidata, Bkh,

289. ", pecharia (?), Stgr.

290. ", tessellaria, B.

291. ", rubiginata, Hufn. 


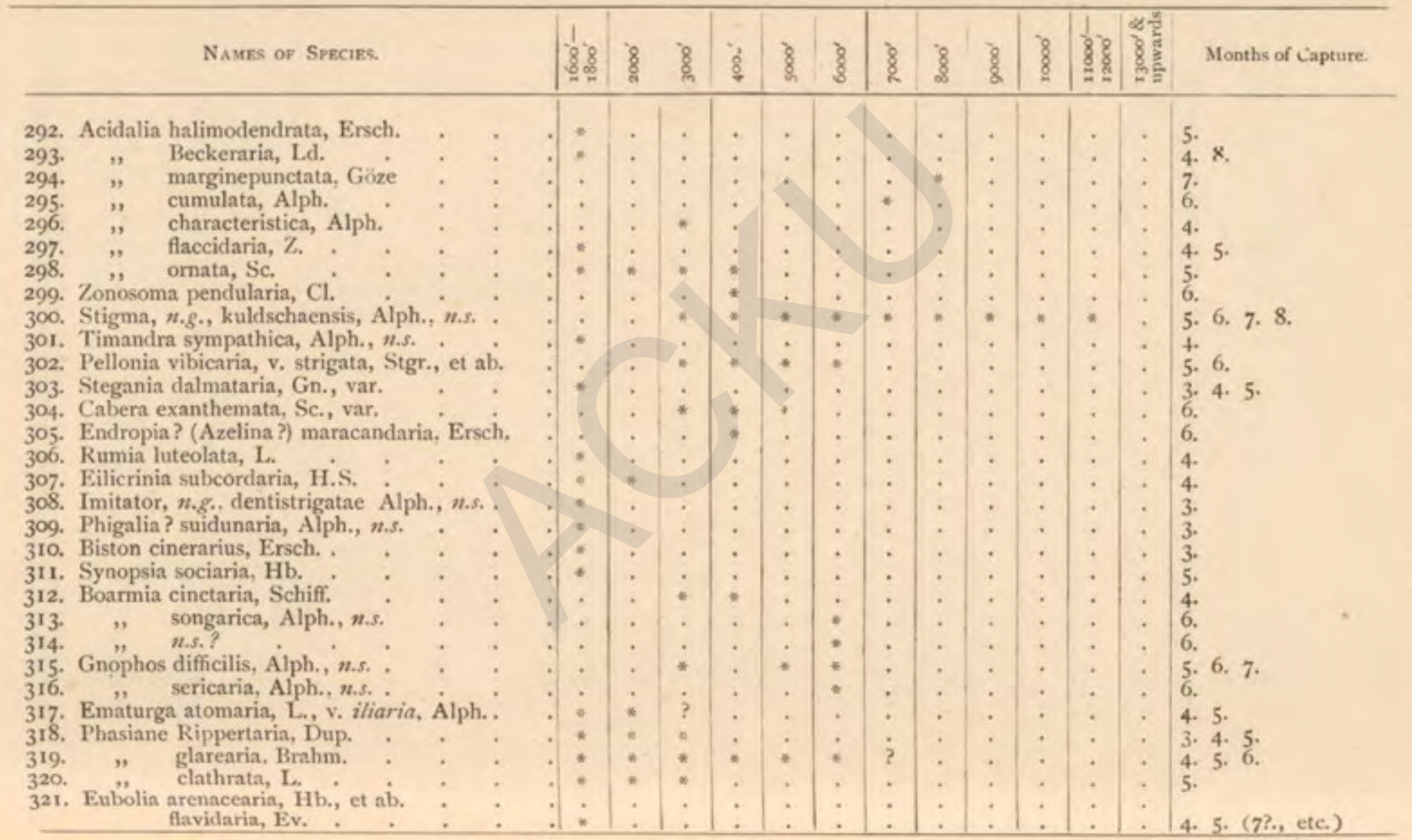


322. Eubolia murinaria, $\mathrm{F}$.

323. Scodiona belgiaria, Hb., v. favillacearia, itb,

324. Scoria lineata, Sc.

325. Aspilates mundataria, $\mathrm{Cr}$.

326.

327., gilvaria, F., v. orientaria, Alph.

328. ", insignis, Alph.

379. Eusarca Staudingeri, Alph.

330. Ligia? turanica, Ersch.

331. Heliothea iliensis, $\mathrm{Alph}$, .

332. ", Christophi, Alph.

333. Sterrha alhidaria, Ersch., v. gegenaria, Alph.

3.34. Lythria purpuraria, L.

var. Gen. I., rotaria, F.

335. Ortholitha junctata, Stgr.

336. ", sinensis, Alph.

337. . " sartata, Alph.

338. Minoa murinata, Sc., v. monochroaria, H.S.

339. I.thostege flavicornata. Z.

$340 . \quad$ " duplicata, $\mathrm{Hb}$.

341. ", farinata, II ufn.

342. ". Staudingeri, Ersch.

343. Anaitis plagiata, L.

344. Lobophora carpinata, Bkh.

345. Triphosa incertata, Styr.

346. Scotosia instabilis, Alph.

347. ,y ? pulchrata, Alph.

348. Kuldscha, $n_{g}$. Staudingeri, Alph.

349. Cidaria ocellata, L.

350. variata, Schiff. 


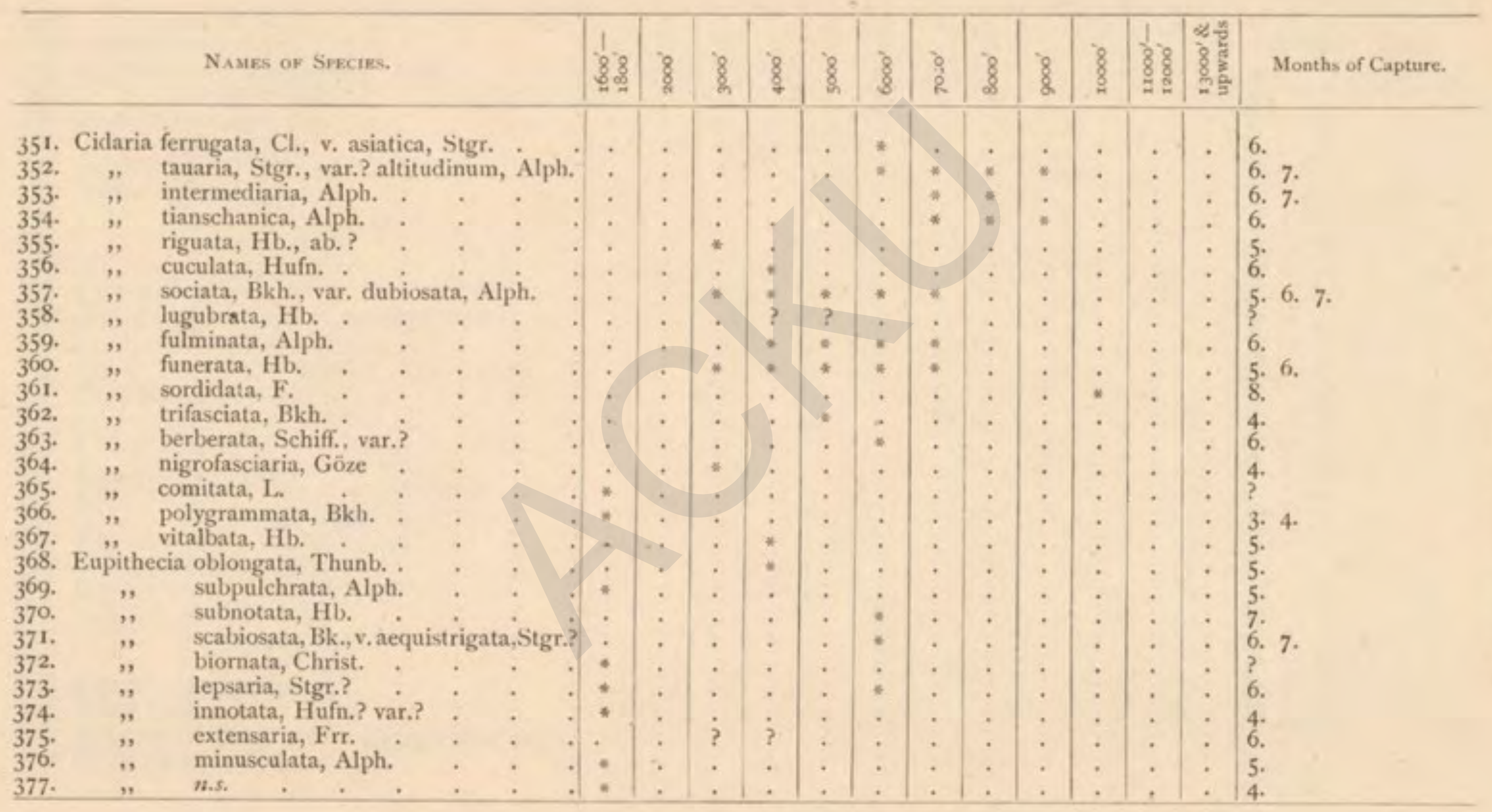




\section{NEUROPTERA.}

By RoBert MacLachlan, London.

THE collection of Neuroptera made by Fedchenko affords a tolerably well defined indication of the character of the Neuropterological fauna of the Turkistan countries, which up to the present has remained almost entirely uninvestigated.

Notwithstanding the fulness of this collection, it is certainly impossible to draw from it any conclusions regarding the number of species to be found in those regions; and in order that such conclusions should be possible, we require more continuous and special investigations by persons not burdened with the diversified and fatiguing labours always connected with travel in unknown countries.

The character of the Turkistan Neuroptera, so far as we may judge from the materials collected by the expedition, is decidedly European; a great many of the species collected in Turkistan are not only European, but even West-European species. This similarity of the Turkistan to European fauna is, however, less sharply defined than that of the Siberian Neuroptera, which I had occasion not long ago to investigate. In the Turkistan collection there is an important number of new species which belong to European genera. On the other hand, in that collection is remarked an unimportant mixture of the Indian element, which is shown in a species of the genus Idricerus, family Ascalaphidae, and a species of the genus Dinarthrum of the family Trichoptera. Representatives of these genera have, up to the present, been found only to the south of the Himalayas. This unimportant mixture of Indian forms does not, however, really alter the thoroughly marked European character of the collection.

There are as many as 36 species of Planipennia in the collection, of which 17 are new. Doubtless the most remarkable of all the species of this family is the above-mentioned new species of the genus Idricerus. Another species of the same family is common in Eastern EuropeAsc. Kolyranensis. Myrmeleonidae are represented by 15 species,* of which 7 are new (in that number one new genus).

The presence in the collection of Gymnocnemia variegata, a very rare species inhabiting Italy and Greece, is very interesting. Among the Chrysopidae the representative of the new genus Chrysopisca is very remarkable. The flemerobizda are comparatively few. The genus Mantispa is represented by one new species. Of the interesting genus Dilar, one specimen is found in the collection belonging, perhaps, to the species described from Turkey. Of the Panorpidae, Sialidae, Raphididae, and Nemopteridae, there are none at all in the collection.; The prominent speciality of the collection, with regard to Planipennia, is without doubt its richness in Myrmeleonidae.

More than one half of all the specimens of Neuroptera collected by the expedition belong to the Trichoptera, of which there are in the In addition to the species enumerated below, there is Acanthaclisis occitanica,
Ramb. from Kuldja, accidentally omitted from the list.

+ One specimen of Borcus was taken by Fedchenko in the environs of Samarkand, in the early spring of 1869 . This specimen was unfortunately destroyed during the transit of the collection from Moscow to London.

VOI. II. 
collection as many as 40 species, in the majority of instances new. One is struck with the small number of species of Phryganeidae and Limnophilidae in the collection, and by the predominance of species of the genus Hydropsyche, which generally live in slowly-running water. As many of the localities visited by Fedchenko are exceedingly elevated, it is difficult to explain the large number of Hydropsyche found by him, and the almost total absence from the collection of Rhyacophila, which live, as is known, generally near swiftly-running water. " The examination of the vast materials collected by Fedchenko, belonging to Trichoptera, cost me great labour. Notwithstanding my wish to treat in detail as far as possible all the materials sent to me, I have unfortunately been obliged to leave some species of Trichoptera undefined and undescribed.

The family Ephemeridae is represented in the collection by about 80 specimens, belonging to the genera Baêtis, Cloêon, Heptagenia, Leptophlebia, and Centroptilum. A detailed description of the species I consider impossible, on account of the specimens being greatly changed by drying. Eaton, who also saw the Turkistan Ephemerae, similarly declined to make a description from dry specimens. One species, the identification of which is certain, is the common European Leptophlebia marginata, L.

Of Psocidae one species of Caecilius, is found in the collection, and one wingless species, apparently an undeveloped Clothilla.

On taking up the examination of the Neuroptera collected by Fedchenko, I foresaw that the Perlidae would present the greatest difficulty to me, as even the largest European species are yet far from being sufficiently investigated, not to speak of the multitudinous small forms. Not having yet decided to undertake a monograph on the Perlidae of the British Isles, I was very doubtful of my ability to properly treat those of Central Asia. In the course of time, on a closer acquaintance with the collection, I quite convinced myself that I should act very wisely in confining myself to the indication of the probable number of species in each genus, and only in a few exceptional cases permit myself to describe certain new forms. Altogether in the collection there are more than 180 specimens of Perlidae, all belonging to European genera. The greater portion of the Perlidae collected by the expedition belong to the genus Nemoura, and to the little-known allied forms.

Finally, the Termitidae are represented in the collection by some incompletely developed specimens, which I am not in a position to determine.

\section{NEUROPTERA, s, str.}

\section{PLANIPENNIA.}

MVRMELEONIDAE.

1. Greagris, Hagen.

1. Creagris plumbeus, Olivier.

\section{Gymnocnemia, Schneider.}

1. Gymnocnemia variegata, Schneider.

3. Maracanda, MacLachlan, n. gen.

1. Maracanda amoena, MacLachl., N.s.

\section{Formicaleo, Brauer.}

1. Formicaleo tetragrammicus, Falir.

2. " lineatus,

5. Myrmecaelurus, Costa, Hagen.

1. Myrmecaelurus trigrammus, Pallas.

2. " major, MacLach., $n$, s 3. Lachlan, nist.

* In Turkistan mountains there are exceedingly few rivers, compared with European mountains, the cultivated zone being watered by slowly-running canals. Does not this explain the fact which struck the author? - Editor's note. 
6. Macronemurus, Costa.

1. Macronemurus paulus, MacL Lach., n.s. 2.

7. Myrmeleon, Lin., Hagen.

1. Myrmeleon Ulianini, MacLach., n.s.

2. " fanaticus, ," , Ascal.aphIDAK.

1. Idricerus, MacLachlan.

I. Idricerus sogdianus, MacLachl., n.s. 2. Ascalaphus, Fabr. (sens, str.).

I. Ascalaphus kolyvanensis, Laxm.

\section{MANTISPIDAE.}

1. Mantispa, Illig.

1. Mantispa scabricollis, MacLach., n.s.

\section{Hemeromitidak.}

1. Hemerobius, Lin.

4. Hemerobius nitidulus, Fabr.

2. " $\quad$ orotypus, Wallengren.

3. " humuli, Lin.

4. ". $\quad$ subnebulusus, Stephens,

5. " conspurcatus, Mac

Lachlan, n.s.

". triangularis, MacLch., n.s.

OSMYLIDAE.

1. Dilar, Rambur.

Chrysopidae.

1. Chrysopa, Leach.

1. Chrysopa vulgaris, Schneider.

2. " microcephala, Brauer.

3. " aspersa, Wesmael.

4 " abbreviata. Curtis (?)

5. " dasyptera, MacLachl., $n .5$.

6. $" \quad$ centralis,

7. " sogdianica,

" sybaritica,

Fedchenkoi,

",

2. Chrysopises, ",

2. Chrysopisca, MacLachlan, n. gen.

L. Chrysopisca minuta, MacLach., n.s.

\section{Contopterygidar.}

1. Coniopteryx, Haliday.

TRICHOPTERA.

Phryganeidae.

1. Agrypnia, Curtis,

I. Agrypnia Pagetana, Curtis.

\section{LIMNOPHILIDAE.}

1. Colpotaulius, Kolenati.

I. Colpotaulius asiaticus, MacL Lach., n.s.

2. Limnophilus, Leach.

1. Limnophilus (Chaetotaulius) striola, Kolenati.

2. Limnophilus (Goniotaulius) subnitidus, MacLachlan, n.s.
3. Stenophylax, Kolenati.

1. Stenophylax pilosus, Pictet, Brauer.

4. Apatidea, MacLachlan, n. gen.

I. Apatidea elongata, MacLachlan, n.s.

2. " copiosa, ",

Skricostomatimae.

1. Dinarthrum, MacLachlan

I. Dinarthrum pugnax, MacLach., n.s.

2. Maniconeura, MacLachlan, n. gen.

I. Maniconeura penicillata, MacL., n.s.

3. Mormonia, Curtis,

1. Mormonia (?) parvula, MacLach., n.s.

4. Brachycentrus, Curtis.

I. Brachycentrus maracandicus, Mac Lachlan, n.s.

\section{LEPTOCERIDAE.}

1. Leptocerus, Leach.

1. Leptocerus cinereus, Curtis.

2. " bifasciatus, Olivier.

2. Triaenodes, MacLachlan.

I. Triaenodes interna, MacLachl, n.s.

3. Setodes, Rambur.

I. Setodes similis, MacLachlan, n,s.

2. " paula, ," ,,

HYDROPSYCHIDAE.

1. Hydropsyche, Pictet.

1. Hydropsyche erythrophthalma, Mac

Lachlan, n.s.

2. $"$ carbonaria, MacL, n.s.

3. " ardens, ", ,

4. " straminea, " "

2. Psychomyia, Latreille.

I. Psychomyia usitata, Maclachl., n.s.

3. Wormaldia, MacLaehlan,

1. Wormaldia occipitalis, Pictet.

4. Ecnomus, MacLachlan.

1. Ecnomus tenellus, Rambur (?)

RHYACOPHILIDAE:

1. Rhyacophila, Pictet.

2. Glossosoma, Curtis.

1. Glossosomadentatum, MacLach., n.s.

3. Agapetus, Curtis.

1. Agapetus bidens, MacLachlan, n.s.

2. " tridens, ," ,

3. " cocandicus, ," ,

4. Beraes, Stephens.

1. Beraea dira, MacLachlan, n.s.

HYDROPTILIDAE.

1. Agraylea, Curtis.

1. Agraylea pallidula, MacLachlan, n.s. 


\section{PSEUDO NEUROPTERA.}

TERMITIDAE.

EPHEMERIDAE,

t. Leptophlebia marginata, Lin.

$$
\text { Psocidae. }
$$

PERLIDAF.

1. Dictyopteryx, Pictet.

I. Dictyopteryx Olgae, MacLach., n.s.

\section{Perla, Geoffroy.}

I. Perla cocandica, MacLachlan, n.s.

2. " cadaverosa, ," ",
3. Chloroperla, Newman, Pictet.

4. Isopteryx, Pictet.

I. Isopteryx montana, Pictet.
2. "tripunctata, Scopoli.
3. " curta, Maclachlan, n.s.
5. Capnia, Pictet.

6. Taeniopteryx, Pictet.

I. Taeniopteryx maracandica, Mac Lachlan, n.s.

7. Nemoura, Latr., Pictet.

1. Nemoura variegata, Olivier.

2. " ornata, MacLachlan, n.s.

\section{ODONATA.}

By DR. F. BRAuER, of Vienna.

\section{LiBelLutidie.}

Libellulinae.

1. Libellula, $\mathrm{L}$.

1. Libellula quadrimaculata, $\mathrm{L}$.

2. Libella, Brauer.

I. Libella brumnea, Fonsc.

2. " albistyla, De Selys

3. Crocothemis, Brauer.

1. Crocothemis erythraea, Brullé.
4. Diplax, Charp.

I. Diplax pedemontana, Allioni.

2. " depressiuscula, De Selys.

3. " Fonscolombii, ",

4. " meridionalis, ",

\section{Aeschnidae.}

Aeschninae.

1. Aeschna, Fabr.

I. Aeschna affinis, Vanderl.

\section{Anax, Leach.}

1. Anax formosus, Vanderl.

2. " parthenope, De Selys.

\section{Gomphinac.}

3. Cordulegaster, Leach.

1. Cordulegaster insignis, Schneider.

4. Gomphus, Leach.

1. Gomphus flavipes, Charp.
5. Ophiogomphus, De Selys.

1. Ophiogomphus serpentinus, Charp.

6. Onychogomphus, De Selys.

1. Onychogomphus flexuosus, Ramb.

\section{AgrionidaE \\ Calopteryginae.}

1. Calopteryx, Leach.

I. Calopteryx splendens, Harris.

$$
\text { Agrioninae. }
$$

2. Lestes, Leach.

I. Lestes virens, Charp.

2. " barbara, Fabr.

\section{Sympyena, Charp.}

I. Sympycna fusca, Vanderl.

2. " paedisca, Brauer, non Eversm.

4. Erythromma, Charp.

1. Erythromma viridulum, Charp.

5. Ischnura, Charp.

I. Ischnura pumilio, Charp.

2. " senegalense, Ramb.

\section{Agrion, Fabr.}

1. Agrion pulchellum, Vanderl.

2. " cyathigerum, Charp.

[There is no introduction to Odonata in Fedchenko's work, but there exists an article in German (giving the localities of the species, and a full description of Sympycna paedisca, Eversm.), entitled "Verzeichniss der von Fedtschenko in Turkistan gesammelten Odonateo,' bearbeitet von Prof. Friedr. Brauer, in the Verhandlungen der kaiserlichköniglichen zoologisch-botanischen Gesellschaft in Wien. Jahrgang 1880 , xxx. Band, Wien, $188 \mathrm{r}$; and p. $75,1882 .-H . L$. 


\section{ORTHOPTERA.}

\section{By H. De Saussure.}

THE collection of Orthoptera made by Fedchenko in Turkistan is so far complete that it enables us to give a pretty clear idea of the character of the Orthopterous fauna of these hitherto little investigated regions. The mingling therein of European species with Indian forms is surprising, as also the comparatively small number of species, the distribution of which is limited to Turkistan and the neighbouring countries.

The species most common in Western and Central Europe are through Russia and the Cis-Caucasian steppe distributed as far as Turkistan, where they apparently attain their extreme limit towards the east, and constitute the chief and fundamental element of the local fauna of Orthoptera.

Other species, which appear only in South Russia, and extend as far as Turkistan (Fischeria brachyptera, etc.), apparently have the steppe as the centre of their distribution; from the Caspian Sea, as from a centre, these forms are distributed over European Russia, Siberia, Turkistan and Asia Minor.

There are much fewer Indian than European species in the Turkistan fauna, which may be explained by the difference in climate of India and Turkistan. The non-European species found in Turkistan are those exclusively belonging to S. Asia (Hierodula), which have either only reached Turkistan, or are distributed further to the West-to the Caucasus, and Asia Minor.

With these South-Asiatic species others from more distant countries, particularly from Africa, are mingled. Such forms, for instance, as Mantis sacra and the genus Oxythespis, proper to Senegal, extending to Turkistan probably through Central and West Africa and Arabia, are especially remarkable.

The Orthopterous fauna of Turkistan presents a very strange resemblance to the European fauna ; it is particularly like the fauna of South Russia, and contains a large quantity of West-European species. It is distinguished not so much by forms exclusively peculiar to it, as by the concurrence of species which are not found together in other conntries. This fauna, together with that of the Caspian, South-Siberian and Aral steppes, and probably that of Asia Minor, might be called the "fauna of the Asiatic steppes."

The species treated of below by me were chiefly collected by Fedchenko. Further, I have included the material in my possession relative to Turkistan Orthoptera, collected by Colonel Kushakevitch, and forwarded to me by Mr. Moser. In the list given by me are also included the species described by various authors from the countries lying near Turkistan, and which it is necessary to regard as belonging to the same fauna.

\section{DERMATOPTERA.}

\section{FORFICULINA, Earwigs.}

1. Labidura, Leach.

I. Labidura riparia, Pall.

2. Labia, Leach.

1. Labia minor, L.
3. Forficula, L., et auet.

I. Forficula auricularia, L.

2. " biguttata, Latr.

3. " decipiens, Gené.

4. " Fedchenkoi, n.s., Sauss. 


\section{ORTHOPTERA \& str.}

I. Blattina. Cockroaches.

1. Ectobia, Stephens.

1. Ectobia lapponica, L.

2. Aphlebia, Brunner de W.

I. Aphlebia tartara, n.s., Sauss.

3. Loboptera, Brunner de W.

I. Loboptera tartara, n,s., Sauss,

4. Blatta, L., et auet.

1. Blatta germanica, L.

5. Periplaneta, Burm.

I. Periplaneta (Stylopyga) orientalis, L.

2. $" \quad$ tartara, n.s., Sauss.

6. Polyphaga, Brullé.

I. Polyphaga aegyptiaca, L.

\section{MantodeA.}

1. Hierodula, Burm.

1. Hierodula tentidentata, Sauss.

\section{Mantis, L.}

1. Mantis religiosa, $\mathbf{L}$.

2. " sacra, Thunberg.

\section{Ameles, Burm.}

I. Ameles alata, Sauss.
2. "Wagneri, Kittary.
3. " ? pusilla, Eversm.
4. Iris, Saussure.

I. Iris oratoria, L.

5. Fischeria, Sauss.

1. Fischeria baetica, Ramb.

$\begin{array}{lll}\text { 2. } & \text { caucasica, Sauss. } \\ \text { 3. } & \text { brachyptera, Pall. } \\ \text { 4. } & \text { " } & \text { Moseri, Sauss. }\end{array}$

6. Oxythespis, Sauss.

I. Oxythespis Turcomaniae, Sauss.

7. Empusa, Illig., et auct.

2. Empusa pennicornis, Pall.

III. PhasmodeA.

1. Bacillus, Latr.

I. Bacillus Rossii, Fabr.
IV. GryllodeA. Crickets.

Gryllotalpit.

1. Gryllotalpa, Latr., et auct.

I. Gryllotalpa unispina, n.s., Sauss.

2. " vulgaris, Latr., et auct.

2. Tridactylus, Oliv.

I. Tridactylus tartarus, Sauss.

2. " variegatus, Latr.

3. " digitatus, Coqueb.

4. " Savignyi, Guér.

5. " $"$ fasciatus, Guér.

\section{Gryllii.}

3. Gryllus, L., et. auct.

1. Gryllus pipiens, Dufour.

2. " capensis, Fabr.

3. " desertus, Pall.

4. " domesticus, L., Latr., et auct.

5. " Cerisyi, Serv,

6. " campestris, L.,Latr., et auct.

7. " melas, Charp.

8. " $\quad$ tartarus, n.s., Sauss.

9. " frontalis, Fieb.

Io. $"$ tomentosus, Ev.

\section{Nemobius, Serv.}

1. Nemobius tartarus, n.s., Sauss.

2. " lineolatus, Brulle.

\section{Oecanthii.}

5. Oecanthus, Serv.

1. Oecanthus pellucens, Scop.

\section{Locustidae.}

1. Onconotus, Fisch. de W.

t. Onconotus Laxmanni, Pallas.

2. Ephippigera, Serv.

I. Ephippigera taurus, Eversm.

2. " vacca, Fisch. de W.

3. Odontura, Ramb.

I. Odontura serricauda, Fabr.

4. Phaneroptera, Latr.

I. Phaneroptera falcata, Scopoli.

\section{Saga, Charp.}

I. Saga serrata, Fabr. 


\section{Xiphidium, Serv.}

I. Xiphidium fuscum, Fabr.

\section{Locusta, Fabr.}

I. Locusta cantans, Fuessly.

2. " viridissima, Lin.

3. " caudata, Charpentier.

4. " thoracica, Fisch. de W.

\section{Gampsocleis, Fisch. Fr.}

I. Gampsocleis glabra, Herbst.

\section{Thamnotrizon, Fiseh. Fr.}

1. Thamnotrizon cinereus, Lin. 2. " tartarus, n.s., Sauss.
10. Decticus, Serv.

Platycleis, Fieber.

1. Decticus (Platycleis) griseus, Fabr.

2. .. " intermedius, Serville.

3. " " montanus, Kollar.

4. " " Trockii, Kittary.

5. " " bicolor, Fisch. de W.

6. " " vittatus, Eversm.

7. " " brevipennis, Charp.

8. " " " Fedchenkoi, n.s., Sauss.

9. " " " brachypterus, Lin.

10. " " Tamerlanus, $n, s .$, Sauss,

I1. " $"$ striatus, Kitt.

Decticus, sens. str.

12. Decticus albifrons, Fabr.

13. " verrucivorus, Linn.

[M. de Saussure, who has kindly revised the above, informs me that his second part of Orthoptera cannot yet be printed.-H.L.]

\section{VERMES ( Worms).}

BY DR. H. KRABBE, of Copenhagen.

\section{Cestodes (Entozoa, Intestinal Worms).}

IN the collection of intestinal worms made by Fedchenko, there were 140 bottles with Cestoidea. About 40 of them contained badly preserved or imperfect specimens, but among the others might be distinguished and determined 47 species, of which 14 were new. The new species were obtained from those animals regarding which there were either no known Cestoidea special to them, or they were little known previously. In man and the domestic animals were found those which infest them in Europe.

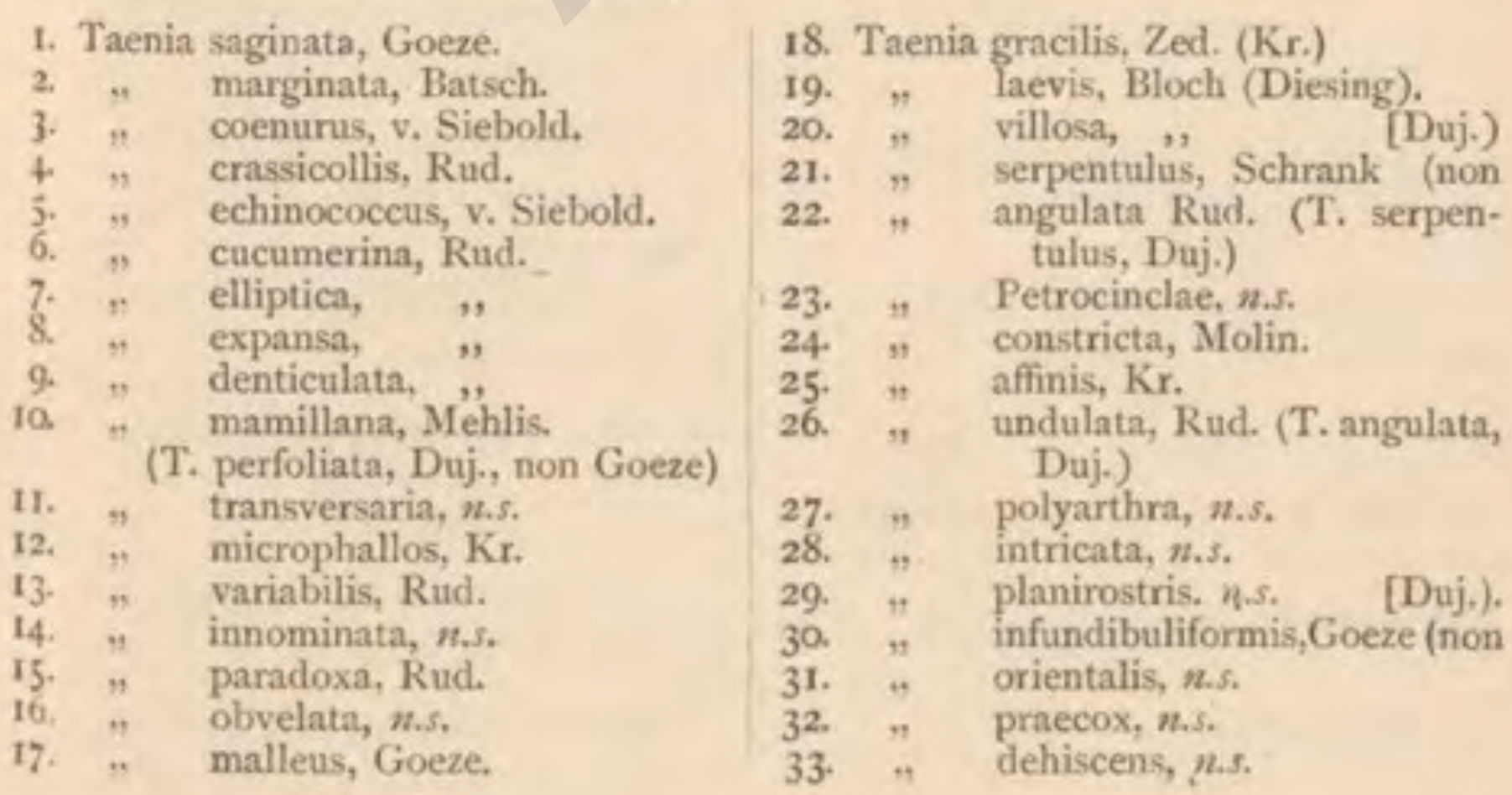


34. Taenia Caprimulgi, n.s.

35. " cesticillus, Molin.

36. $"$ tetragona, ,

37. " Urogalli (T. tumens, Mehlis; T. microps, Dies.).

38. " crassula, Rud. (incl. T, sphe-

39. " perlata, Goeze.
40. Taenia mastigophora, n.s.

41. " megalops, Nitzsch.

42. " truncata, n.s.

43. " Pseudopodis, n.s.

44 " osculata, Goeze.

45. Bothriocephalus latus. Rud.

46. Bothridium s.

47. Ligula s.

List of the species (of Cestodes) found in Turkistan, in man and various animals. Mammat.ia.

Homo. Man.

1. Taenia mediocanellata.

45. Bothriocephalus latus.

Canis familiaris. Dog.

\section{Taenia marginata.}

3. " coenurus.

6. $"$ cucumerina.

Felis catus. Cat.

4. Taenia crassicollis.

7. elliptica.

Equus caballus. Horse.

ro. Taenia mamillana.
Bos taurus. $O x$.

9. Taenia denticulata.

Ovis aries. Shecp.

2. Taenia marginata (Cysticercus).

5. " echinococcus (scolex).

8. $"$ expansa.

Capra hircus. Goat.

2. Taenia marginata (Cysticercus).

8. " expansa.

Aretomys, s. Marnot.

I1. Taenia transversaria.

\section{AVES.}

Anas. Duck.

17. Taenia malleus.

I8. " gracilis.

19. " laevis.

36. " tetragona?

41. " megalops.

Genus et spec. ignot.

14. Taenia innominata.

$$
\text { Scolopax, s. Snipe. }
$$

15. Taenia paradoxa.

Vanellus cristatus, Lapaing.

12. Taenia microphallos.

13. " variabilis.

Gallus domesticus. Fowl.

30. Taenia infundibuliformis.

35. " cesticillus.

36. " tetragona.

Perdix graeca. Greek Partridge. 37. Taenia (Urogalli ?)

Megaloperdix Nigelli. Nigell's Snow. Parkridge.

20. Taenia villosa.

37. " Urogalli.
Pterocles alchata. Sand-Grouse, 16. Taenia obvelata.

Columba livia. Rock-Dove.

38. Taenia crassula.

Columba turtur. Turtle-Dove. 38. Taenia crassula.

Upupa epops. European Hoopoe. 28. Taenia intricata.

Corvus cornix. Hooded Crow. 21. Taenia serpentulus.

26. " undulata.

Corvus frugilegus, Rook.

25. Taenia affinis.

Corvus monedula. Fackdaz.

21. Taenia serpentulus.

24. " constricta.

Pica caudata. Maspic.

24. Taenia constricta.

Alauda cristata. Crested Lark. 22. Taenia angulata. 
Alauda, s.

29. Taenia planirostris.

Petrocincla cyanea. Blte Rock-Thrush. 23. Taenia Petrocinclae.

Turdus viscivorus. Mistletoe Thrush. 22. Taenia angulata.

\section{Turdus, s.}

26. Taenia undulata.

Cinclus aquaticus. Dipper.

27. Taenia polyarthra.

33. " dehiscens.

\section{Agama sanguinolenta.}

42. Taenia truncata.
Caprimulgus, s. Goatsucker:

34 Taenia Caprimulgi.

Saxicola oenanthe. Whealcar:

31. Taenia orientalis.

Ruticilla erythrogastra. Red.bellied Redstar\%.

32. Taenia praecox.

Falco cenchris. Lesser Kestrel.

39. Taenia perlata.

Milvus ater (Milvus melanotis ?) Black Kitc.

40. Taenia mastigophora.

REPTILIA.

\section{| Pseudopus Pallasii \\ 43. Taenia Pseudopodis.}

PISCES.

Silurus glanis, Silurvs.

44. Taenia osculata.

[In returning the proof of the above, Dr. Krabbe is good enough to inform me that his part of Vermes collected by Fedchenko embraced only the Cestoidea, and that the Nematoidea, Irematoda, and Acanthocephala have been described by Dr. von Linstow, of Hameln, in Germany, and published in the Archiv für Naturgeschichte, ${ }_{188}$.

M. Grube, of Breslau, undertook the description of certain other worms, external parasites of birds (Pediculina), etc. He did not survive, however, to complete his work for the "Travels in Turkistan," though Madame Fedchenko informs me that, after his death, the description of the parasites was published in some German periodical of Natural History.-H.L.] 


\section{APPENDIX B.}

\section{THE FLORA OF RUSSIAN TURKISTAN.}

I N considering the flora of Turkistan,- -if we start, as with its fauna, from the north-east, we begin with the Russian botanist Sivers, who at the end of the last century penetrated to the Tarbagatai mountains. We have next Ledebour, who, in 1826 , travelled up the Irtish to Lake Zaisan, and 14 years afterwards published an enumeration of plants in "the whole Russian Empire." Dr. Schrenk also, from $I 840$ to 1843 , collected plants in Sungaria in the Tarbagatai, Ala-Tau, and about the Ala-Kul, which were described first by Fischer and Meyer, and afterwards by Schrenk, to the number of 937 species. Further, in $184 \mathrm{I}$, the neighbourhood of the Ala-Kul, and the upper courses of the Lepsa, Sarkan, and Baskan rivers, to the snow line in Eastern Sungaria, were visited by Karelin and Kiriloff, whose collection numbered 932 species.

Thus matters remained until Semenoff, in 1857 , crossed the Ili, and pushed on to the northernmost range of the Thian Shan, called the Trans-Ili, or Southern Ala-Tau. His collection of plants of 1,234 species was described by Regel and Herder, and to this I shall presently recur. Ten years later a journey was made further to the south by OstenSacken, and as a result about 250 botanical species were described by Ruprecht in 74 pages of the Memoirs of the Academy of Sciences in Petersburg.

If next we approach Turkistan from the north-west, we have Alexander Lehmann crossing the Urals, and proceed- 
ing to the Aral Sea, Bokhara, and Samarkand, and returning through the Kirghese Steppe $(1839-42)$. His plants, numbering 1,523 species in cxv, orders, were described by Bunge in $1850-52$. Further west we have an enumeration of plants collected by Gr. Karelin, in Turkmenia and Northern Persia - a simple list extending to 973 species. Two other names occurring in connection with plants in Turkmenia are Grodekoff, who gave "two small lists of plants" ; and Maloma, who adds a list of plants to his description of the route from Krasnovodsk to Dekcha. There should also be noticed Borszov, who published in 1865 his "Materials for the Botanical Geography of the AraloCaspian," in an appendix to vol. vii. of the Journal of the Academy of Sciences, at Petersburg.

Fedchenko's name, though not so great in flora as in fauna, must not be omitted in connection with the botany of Turkistan, for when he came back with his 5,000 species of animals, he brought also 1,800 species of plants. Under his direction, attention was turned first to the scientific investigation of plants cultivated in Central Asia, and more especially such as had a practical value, of which there were more than $70 .^{*}$ The bulbs and seeds he brought were planted, to the number of 100 species, in the botanical garden of Moscow University, with satisfactory results. One volume of Fedchenko's "Travels in Turkistan " consists of "Descriptions of new and rare plants collected by Madame Fedchenko," by E. Regel ; there is another on "Astragali," by Bunge ; and a third on "Primulaceæ et Liliaceæ," by E. Regel.

A more recent traveller, who has been further than Fedchenko to the south and west, is Dr. Capus, who is now publishing his "Indications sur le climat et végétation du Turkistan " in the Annales des Sciences Naturelles.

But the name that stands above others in Central Asian botany, as Fedchenko's does in zoology, is that of Regel - father and son. The father, E. Regel (who has kindly looked over this preface for me) is Director of the

* I have alluded to most of them in vol. i., chap. xxxii, as also in chap. xxxvii., p. 557 , to some of the list of plants and vegetable products of Turkistan drawn up by the Committee in the "Instructions" to the Expedition. 
Botanical Gardens in Petersburg, and the son, Dr. Albert Regel, a district surgeon in Turkistan. In 1879 , Dr. Albert Regel made a famous journey beyond the Russian border to Turfan. He has explored botanically the regions east of Kuldja, also Semirechia, Sungaria, the entire Thian Shan, and all the Ala-Tau, the districts about Tashkend and Samarkand, Eastern Bokhara as far as Darwaz, Shignan, etc., and west as far as Merv. Whilst the younger Regel has thus widely gathered, the elder Regel has given descriptions of Turkistan collections. He published, in 1875 , "New Plants Growing in the Turkistan Region," and later have appeared several monographs (Rosaceae, Berberideae, etc.) from his pen in the Gartenflora, the Transactions of the Botanical Gardens of St. Petersburg, and the "Description of new and rare Turkistan plants collected by Madame Fedchenko, as well as by Korolkoff, Kuschakewicz (who visited the Pamir), A. Regel, and Krause" ; but a complete list of the plants of Central Asia has yet to be compiled."

For the present it will be seen that our available information concerning the Turkistan flora is more fragmentary than that relating to its fauna; and accordingly, when I went to Kew to ask for a list of plants that would give some idea of the flora of Russian Central Asia, I was told that no such list existed, and that, were I a botanist, it would take me two years to make one. I found, however, at the Linnean Society's library, which was most kindly placed at my service, the list of Semenoff's plants as described by Regel and Herder. I was told that the list was so far representative that it might probably be used for a foundation by anyone desiring to make a fuller list, and I therefore give it below.

ENUMERATION OF PLANTS COLLECTED BY P. SEMENOFF, NORTH AND SOUTH OF THE ILI, IN 1857 .

BY E. REgel AND F, vON HERDER.

SEMENOFF's journeys touched three extensive districts:-(A) The Northern, or Sungarian Ala-Tau; (B) The Southern, or Trans-Ili AlaTau; and $(C)$ The Thian Shan, about Issik-Kul.

* Madame Fedchenko informs me that she has commenced to make a list of her Turkistan plants, which, though not more than half done, numbers 940 species. 
(A) The Northern Ala-Tan at its western extremity sinks into the broad low country of the Steppe, which extends at an altitude of between 1,500 to 500 Paris feet to the Balkhash basin. The highland proper extends easterly to the low country between the Ala-Kul and $\mathrm{Ili}$, and has a central crest with an average height of $6,000^{\prime}$, with

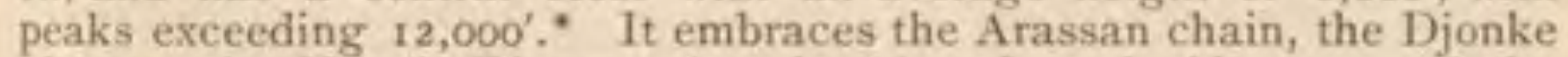
plateau, the Kopal, Djangys Agach, Altyn-Immel, Alaman, and the Kalü chains. Only three, however, of the numerous rivers and streams of this district reach the Balkhash Lake, the others losing themselves in the extensive sandy downs and reed marshes of the Steppe.

(B) The Southern Ala-Tau, between the Ili depression and the Issik-Kul plateau, rises at a distance of about 40 miles south of the Ili, as a colossal range, the central portion of which reaches high above the snow line. Its crest has an average height of 8,000 ', and its peaks of nearly 15,000 '. This mountain chain, of about 130 miles in length, consists of two about equally lofty, parallel, crystalline-formed crests, which in the middle are joined by a bold granitic cross-yoke. The interval between the crests is filled with layers of sedimentary stone trending from east to west. The upper part of these strata is formed of mountain limestone, the lower of silicious and clay shales, probably belonging to the transition period of the mountain range. The most important section of this chain is the Talgarnyn-Tal-Choku, which attains a height of 14,000 '. To the west of this mountain are situated the Keskelen and Almaty passes, to the east the Chinbulak and Maibulak passes, all of them at a height of from 7,000 ' to $10,000^{\prime}$. The most important rivers of this district, and southern tributaries of the $\mathrm{Ni}$ are the Chilik with its confluent the Jenishke, then the Talgar rising in the Talgarnyn-Tal-Choku, with the two Almaty rivers.

(C) The portion of the Thian Shan visited by Semenoff is separated from the southern Ala-Tau by a plateau about 50 miles broad and 150 long, in which there is spread out the basin of the Issik-Kul. The climate of the surrounding plateaus is considerably rougher than that of the low country of the Ili, which is not to be wondered at, since the Thian Shan attains an average height on its crest of $1 \mathrm{~s}, 000$, and on its peaks of nearly 20,000 Paris feet Fine mountain streams, more than 40 in number, rising in the southern Ala-Tau and in the Thian Shan, run straight across these valleys, and transform the usually sterile Steppe soil into fertile arable land. Amongst the streams may be mentioned the Kokdjar, the Karkara, the Tüb, the Turgen-Aksu, the Kachka-su, the Zauku, the Sary-Djas, and a few sources of the Naryn. All the mountain spurs on both banks of the lake consist of crystalline rocks, namely, granite and syenite, which are themselves generally overlaid with a sedimentary conglomerate. The main crest of the Thian Shan again is not uniform throughout its whole length, but appears between the Sary-Djas gorge and the easterly sources of the Naryn to fork out, and run further to the west in two parallel crests, separated by the important longitudinal valley of the Naryn. Amongst the most important of the passes of this range of mountains which Semenoff visited, is the Zauku pass, the absolute height of which reaches $10,430^{\prime}$, and the Kokdjar pass attaining a height of 10,800 feet.

In all three districts $(A, B, C$.) may be clearly distinguished five (and if the snow zone is included, six) natural zones:-(i) The Steppe sone, south of the Balkhash Lake, of $500^{\prime}$ to $1,500^{\prime}$, occasionally 2,000 feet,

- Paris feet ( $1_{1}^{2}$. English), and so throughout this appendix on Flora. 
includes the best winter stations of the nomads, in consequence of its mild climate, and the almost total absence of snow. This zone possesses quite the characteristic flora of the Aralo-Caspian depression in its Halophytes, Artemisias, Astragals, Tamarisks, ete. (2) The cultivated sone of from $1,500^{\prime}$ to $4,000^{\prime}$ contains the finest arable lands, In its herbaceous plants this zone has much more resemblance to those of the European, Russian, and West Siberian lowlands. Nevertheless, amongst them occur also some genuine Asiatic forms, such as Sopkora alopecuroides, Rheum cuneatum, etc. (3) The Pine-tree zone of $4,000^{\prime}$ to $7,600^{\prime}$ contains timber suitable for fixed settlements. The Pimus Schrenkiana is a characteristic of this zone. The remainder of the tree vegetation consists of Populus tremula, $P$. suaveolens, Betula microphylla, Sorbus Aucuparia, and some species of Salix. (4) The Alpine meadow zone of from 7,600 to 9,000 includes the healthiest, and for the nourishment of cattle the richest, summer stations of the nomads. Of bushes there are found $f u n i p e r u s$ Pseudosabina, Caragana jubata, some Spireas and Potentillas. The Alpine plants consist not only of its own peculiar descriptions, but also of the Altai, Caucasian, European, and even Himalayan forms. (5) The High Alpine and glacier zone, from 9,000' to II,200', contains the following distinguishing high Alpine plants:-Oxygraphis glacialis, Hegemone lilacina, Ranunculus altaicus, sar. fraternus, Draba pilosa, stellata, etc. (6) The snow zone from the line of perpetual snow ( 11,200 feet) up to the tops of the mountains.

[In the following lists, the Rev, W. W. Tyler has kindly supplied the English equivalents, and after each order the number of species therein found respectively in Central Asia and (bracketed) in Britain. "By comparison of these," Mr. Tyler remarks, " it is interesting to note how orders represented by numerous species at home may be looked for in similar proportions in Turkistan." It should be remembered, however, that the figures relating to Great Britain are furnished by many labourers working for many years, whereas the Central A sian list represents the collection of one traveller only, during one journey, and must, therefore, be regarded as incomplete. Bearing this in mind, however, it may be noticed from the materials before us that the number of orders found in Great Britain, but absent in Turkistan, is about 25, whereas the number of orders found in Turkistan, but absent in Britain, is only 9: and each of these contains a very limited number of species. Many hundreds of Lichens, Mosses, Hepatica, etc., found in great Britain, are barely mentioned in the Cryptogamous plants of Semenoff's lists, which latter, it may be observed, contain several plants new to science. It should also be added that one locality only is given here to each species or variety named, whereas in the original there are sometimes several; and varieties of a species, often numerous in the original, ate here usually confined to one line.-H. L.]
A. Northern Ala-Tau.
B. Southern Ala-Tau.
c. Thian Shan, about Issik. Kul.
P. Pass or passes.
R. River.

M. Mountain.

Ch. Chain.

V. Valley.

St. Steppe. 
1.-RANUNCULACEAE 69 (49), Crowfool Family.

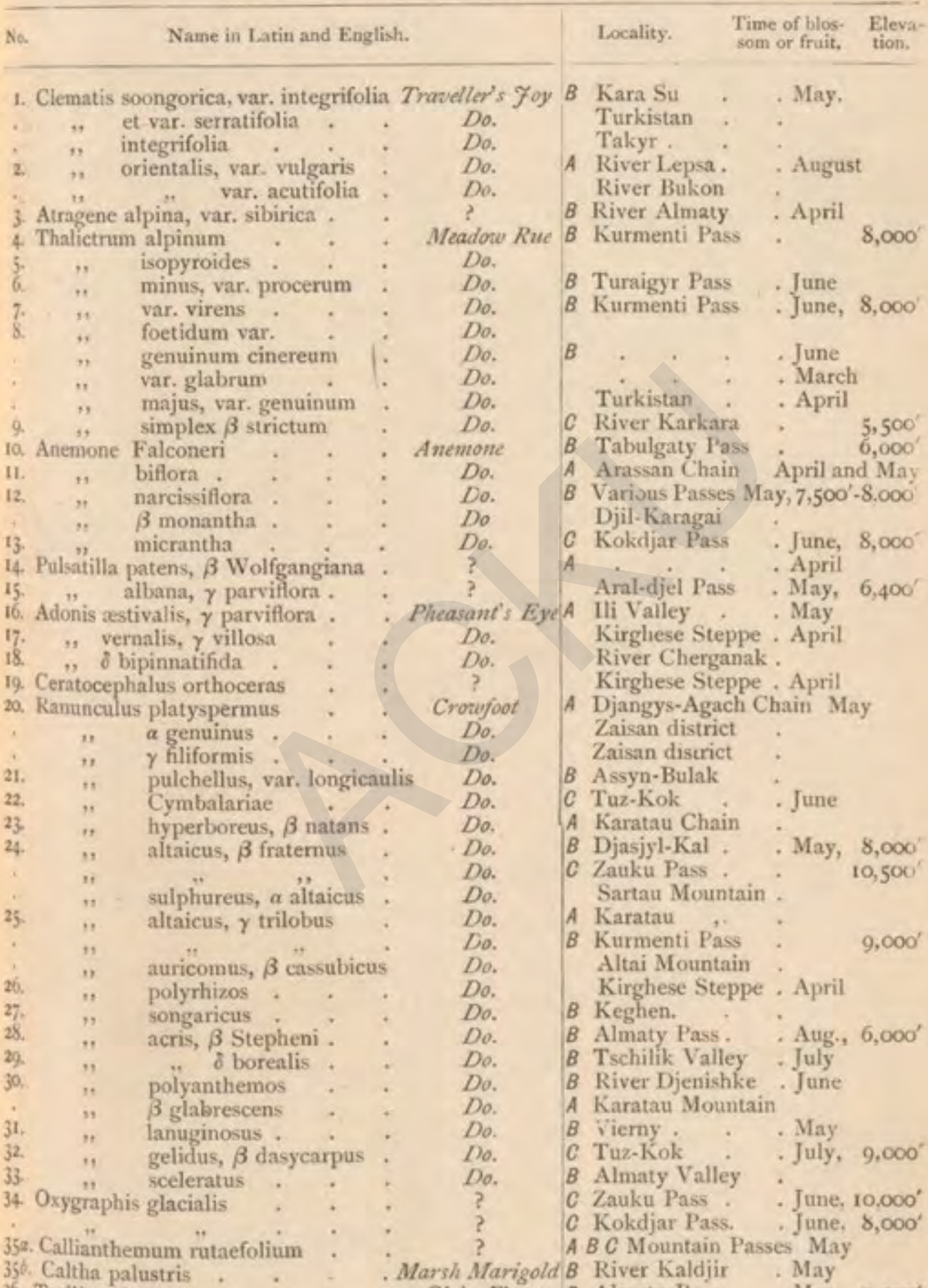




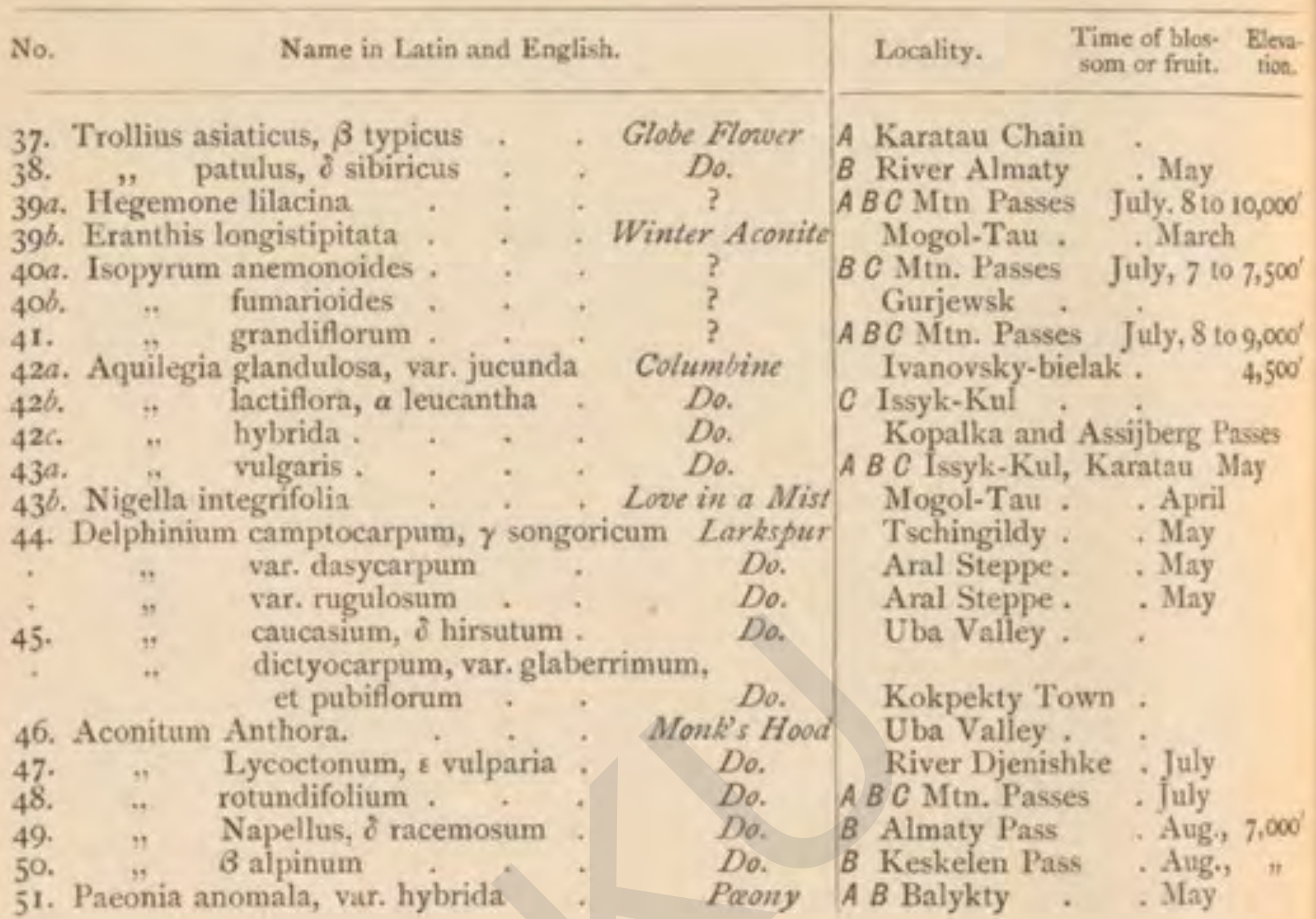

\section{II,-BERBERIDEAE 5 (2), Barborry Family.}

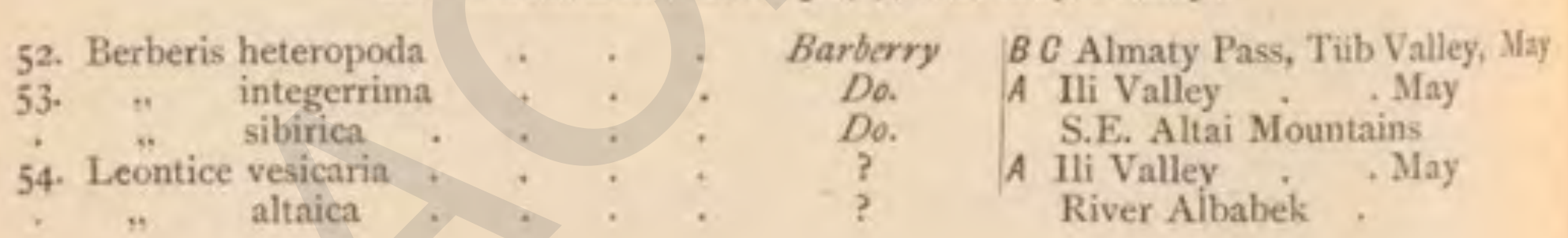

\section{Ib.-NYMPHAEACEAE 1. (3), Water-lily Family.}

34. Nymphaea Basniniana - . . Waler Lily. | River Kokpekty

\section{III. -PAPAVERACEAE 12 (10), Poppy Family.}

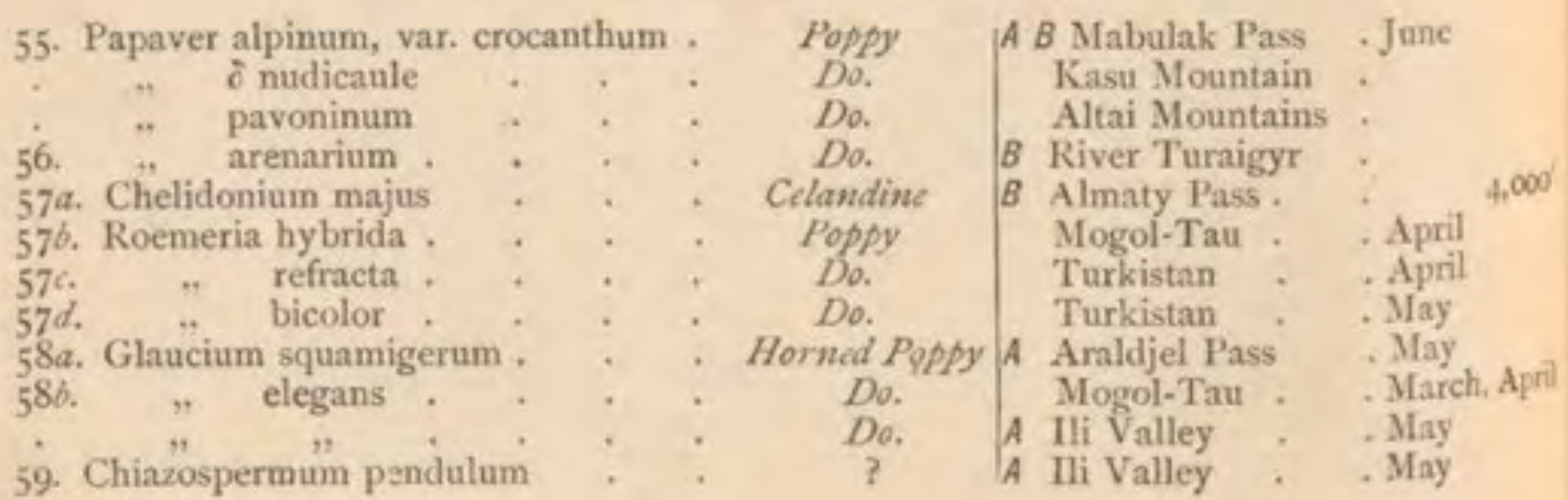




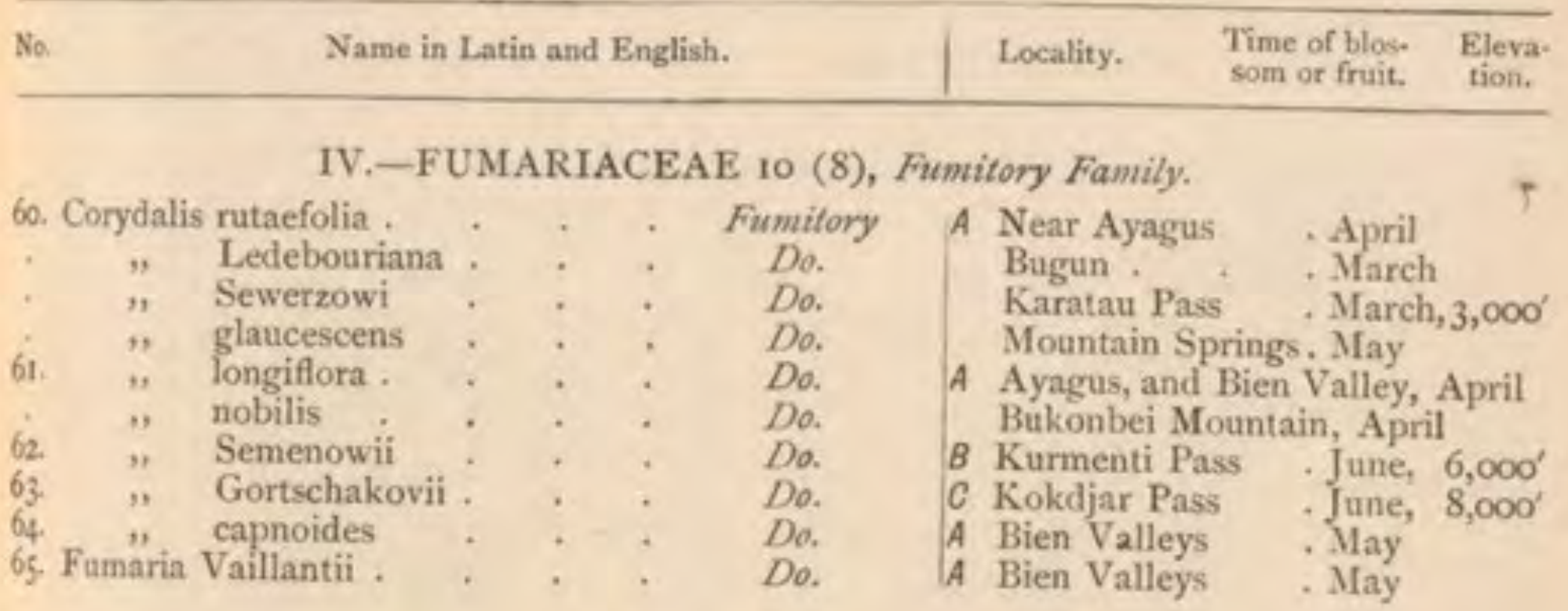

\section{CRUCIFERAE 129 (73), Mustard Family.}

66a. Barbarea vulgaris, var. arcuata ¿6h " $\beta$ stricta. 60. Nasturtium palustre 660. Matthiola runcinata 66 . 67. Turritis glabra

68. Arabis fruticulosa. 69., pendula 70. Cardamine impatiens 71. Parrya parviflora

71. Parrya stenocarpa

n nudicaulis, L., $\beta$ linearifolia. " flabellata

72. Meniocus línifolius .

73. Farsetia spathulata .

74. Berteroa incana

75. Psilonema dasycarpum

46. Alycsum longistylum .

76. Alyssum minimum .

77. " Szovitsianum

$\begin{array}{ccc}77 . & \text { alpestre, } a \text { tortuosum } \\ & , & a \text {. microphyllum }\end{array}$

78. Draba pilosa," $a$ oreades

79.,$\quad$, y commutat

repens, var. legitima

, Wahlenbergii

" lacten

" stellata, $\alpha$ nivalis

" , $\beta$ hebecarpa

" rupestris, a leiocarpa

" hirta, $\boldsymbol{a}$ leiocarpa, var.

" ineana, L., $\gamma$ hebecarpa

\%. " nemorosa, var

Aprin 87a. " , " $\beta$ hebecarpa .

87. Cochlearia grandiflora -

VOL. II.

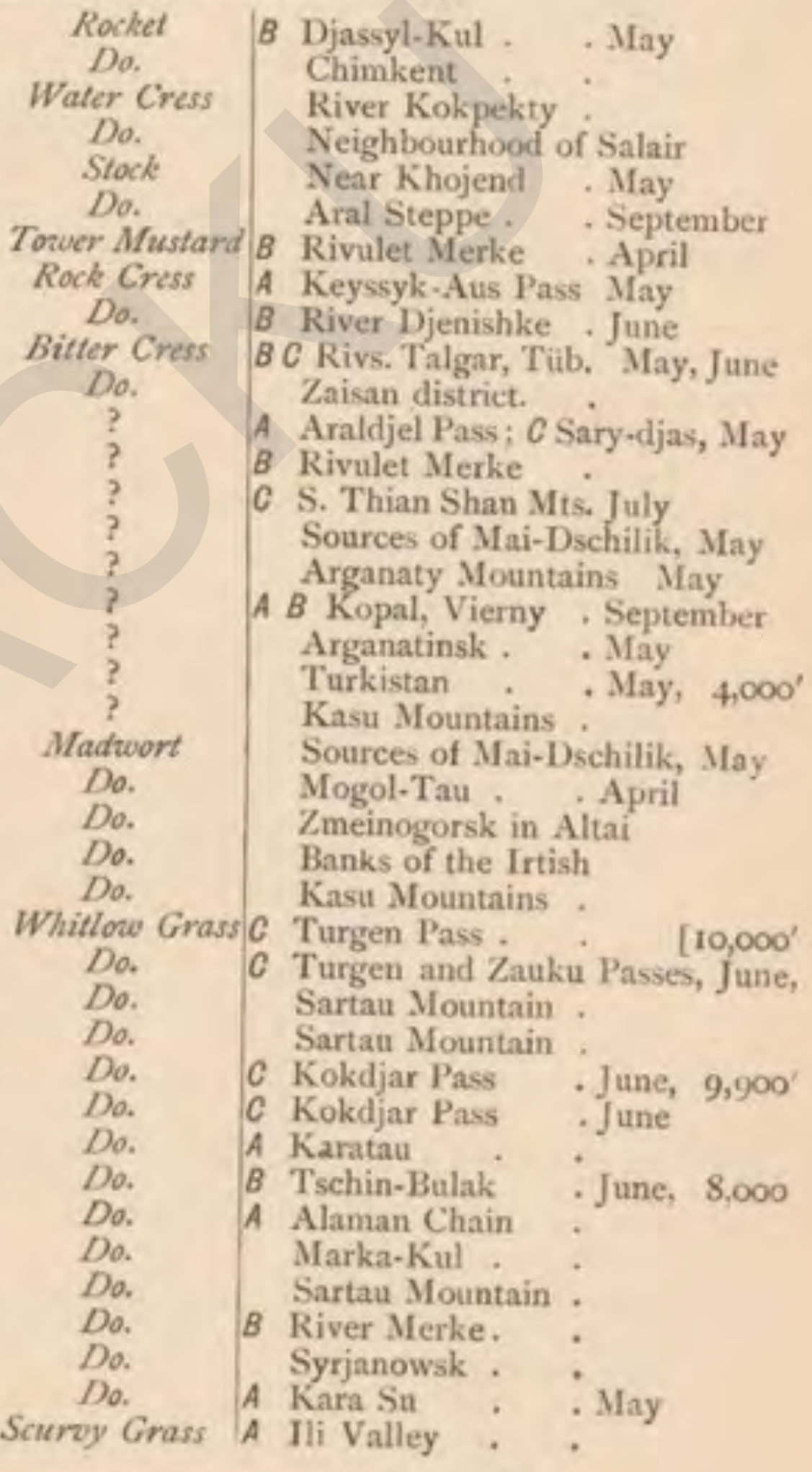




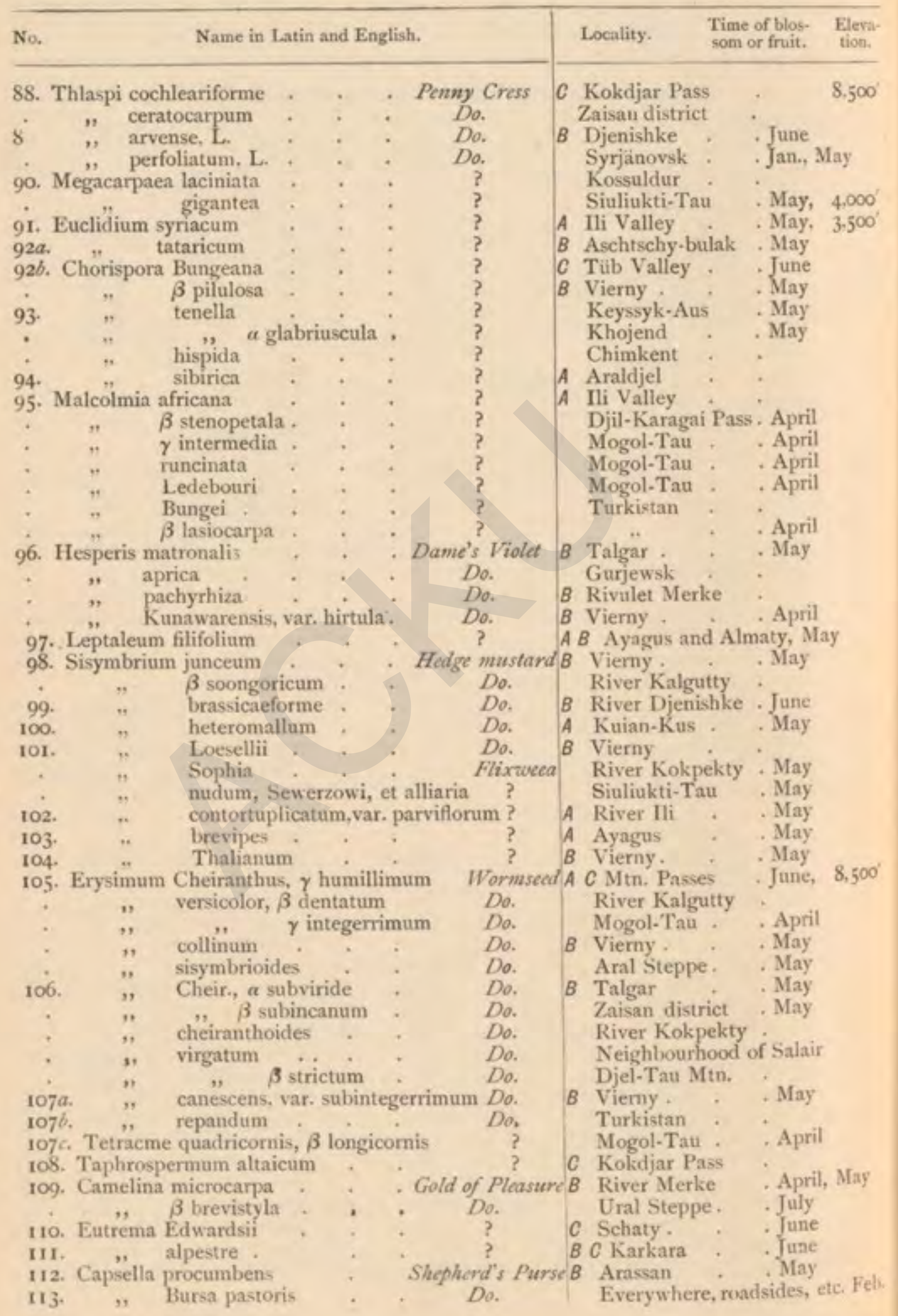


No.

Name in Latin and English.

Locality.

Time of blos- Elevasom or fruit. tion.

114. Hutchinsia pectinata, $\gamma$ densiflora . Rock Hutchinsia C Kokdjar and Keskelen Passes, " calycina, var. incana
,$\quad$, var. pectinata alba, $a$ typica

15. Lepidium Draba, $\beta$ longistylum ", coronopifolium var.

116. $"$ latifolium, $\beta$ acutum

117. $"$ ruderale

i18. ", perfoliatum

". latifolium, y platicarpum

", amplexicaule

cordatum Do.

, crassifolium . . . Do.

" Aucheri, $\beta$ Borszczowi .

Physolepidium repens

Aethionema sagitlatum .

Hymenophysa pubescens

I19a. Isatis sibirica

$$
\begin{array}{ll}
, & \text { laevigata } \\
, & \text { tinctoria, } \mathbf{L} \\
, & \text { emarginata } \\
, & \text { minima }
\end{array}
$$

I196. Pachypteris multicaulis

$$
\text { " } \quad \boldsymbol{\beta} \text { dasycarpa }
$$$$
\text { . }
$$$$
\gamma \text { leiocarpa }
$$

120a. Goldbachia laevigata

$$
\beta \text { adscendens }
$$

1206. Tauscheria desertorum, $\alpha$ lasiocarpa

$$
\text { 120. Sterigma tomentosa }
$$

I20d. Lachnoloma Lehmanni

120e. Spirorhynchus sabulosus

120f. Brassica Besseriana

120g. Bunias cochlearioides

120/. Eruca sativa

120i. Crambe Sewerzowi Do.

\section{Do. \\ Do. \\ Do.}

Pepper Wort A Karatau . July

Do. Mogol-Tau . . May

Do. $\quad B$ Almaty . June

Do. $\quad B$ Almaty

Do. A Near River Lepsa May

Do. Zaisan district

Do. River Kokpekty .

Do. Dolon Kara Mts.

Do. Mts. of Tort-Kel . Sept., 3,500'

Do. Aral Steppe

Chimkent Karatau : May-July

Dyer's Woad Kinghese Steppe ,

Do. River Kokpekty .

Do. $\quad B$ River Talgar

Do.

Do.

?

$\frac{f}{?}$

Mtns. of Syr-daria May

Aral Steppe, Kara-Kum, May

A River Ayagus Mogol-Tau . April

District of the Syr-daria, June

B Turaigyr Chain. May, 6, 100' Chimkent . May

Aral Steppe . . April

Khojend . May

Djus-Agach . July

Mogol-Tau . April

Aral Steppe. . May

Kirghese Steppe - May

The Black Irtish [May

Khojend, Bugun, . Jan., Feb., Spur of Kcharli-Tau, May

\section{VI.-CISTINEAE I (6), Rackrose Family.}

121. Helianthemum soongoricum - . Rock-rose | A B Ili Valley, Turaigyr 2 to $4,000^{\prime}$

\section{VII.-VIOLARIEAE 9 (8), Violet Family.}

122. Viola Gmeliniana, $\beta$ glabra .

123a. , hírta

123b. " montana, a elatior

124. $"$ canina, var. rupestris

125. "biflora, $\beta$ acutifolia

126. "uniflora

126.
" grandiflora.

tricolor
Violet, Pansy C Zauku Pas

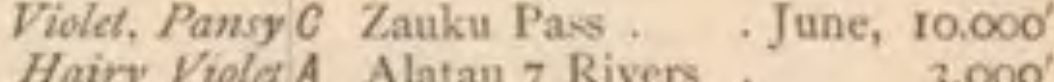
$\begin{array}{cl}\text { Violet } & \text { Alatau } 7 \text { Rivers } \\ \text { On heath lands }\end{array}$

Do. Syrjänovsk

Dog Violet A Arassan - . May, 3,000' Do. BC Almaty, Zauku. May, June

Do. $\quad$ Zarevno-Alexandrovsk

Do. A B C Mtn. Passes May, 7-9,000

Heartiease Village Mjakoticha 


\begin{tabular}{|c|c|c|c|}
\hline No. & Name in Latin and English. & Locality. & $\begin{array}{l}\text { Time of blos- } \\
\text { som or fruit. }\end{array}$ \\
\hline
\end{tabular}

VIII.-DROSERACEAE 2 (4), Sundewo Family.

127. Parnassia palustris. . + $\quad$ ( Grass of In Marshlands . August

128. " Laxmanni, var. subacaulis f Parnassus A B C Streams . . 5,500-8,000"

\section{IX.-POLYGALEAE I (3), Milkwort Family.}

129. Polygala vulgaris, $\beta$ comosa . . Milkwort | BC Turaigyr

\section{X.-SILENEAE 30 (25), Pink Family.}

I30. Dianthus campestris, $\beta$ glaber

131. ,, alpinus, var. Semenovii

132. ,, crinitus

133. , ,

$\therefore$,

134.

135. Gysophila

136. " acutifolia, var. Gmelini .

137. " $"$ paniculata

138. , $"$ altissima

139. Vaccaria vulgaris

140. Silene inflata var.

r41. , graminifolia var.

142. ", repens

143. "Otites, var. Wolgensis

. " , var. parviflora .

144. ", lithophila

145. ", holopetala .

146. ", multiflora, et var.

147. ", Semenovii .

148.

149.

150.

$150 a$.

$15 \mathrm{I}$.

152

152. Ly' saxatilis

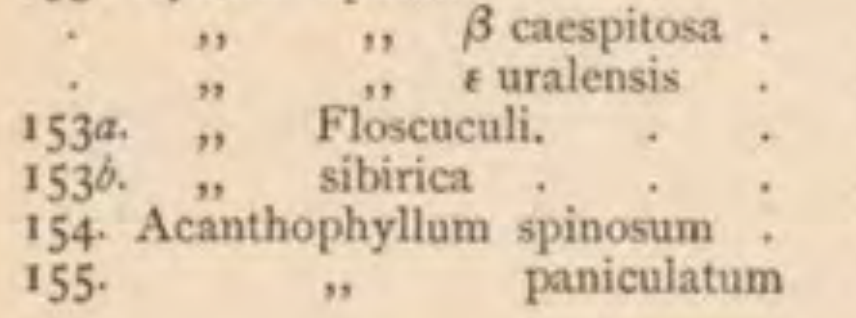

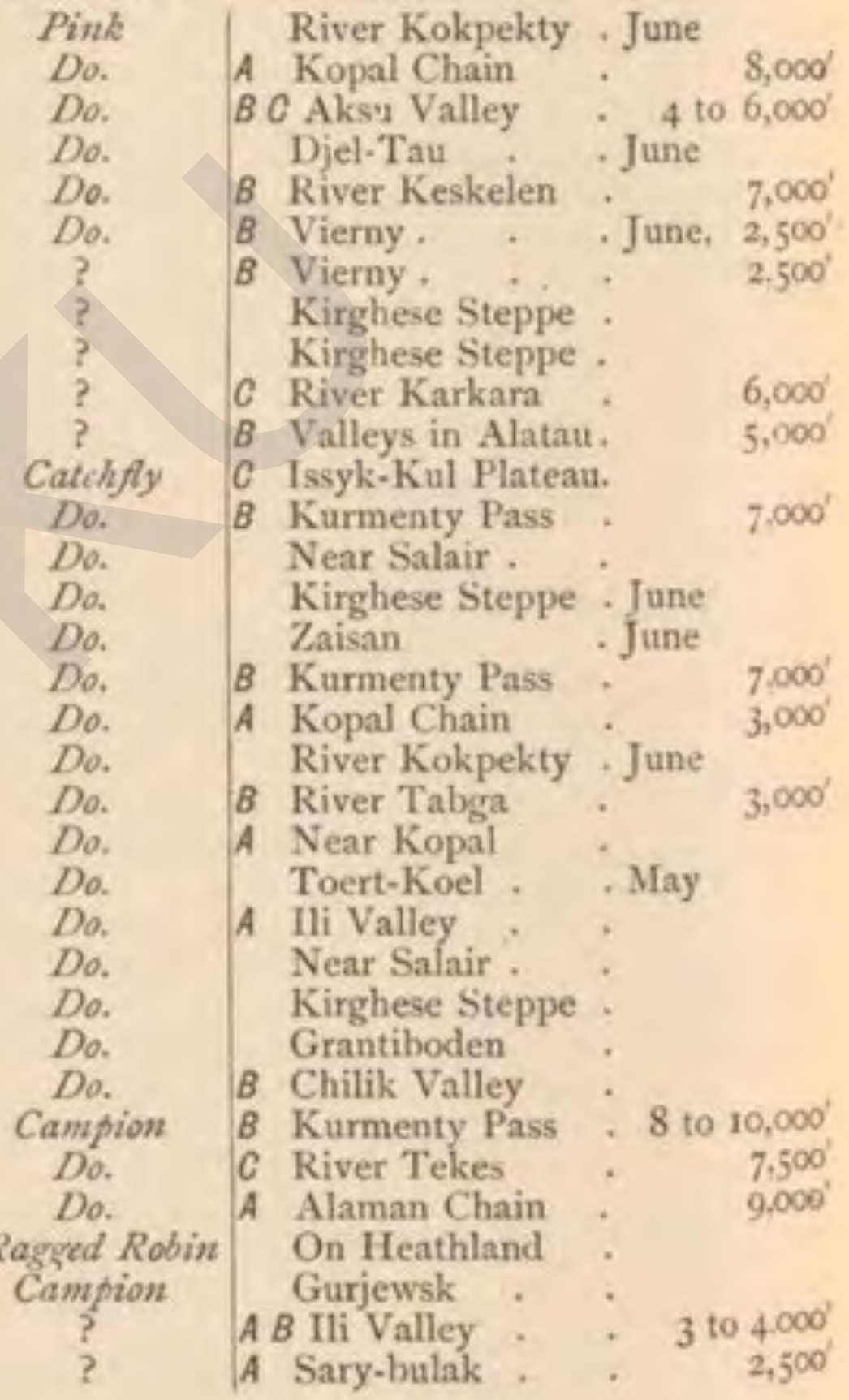

\section{XI.-ALSINEAE 22 (38), Chickiveed Family.}

156. Sagina Linnaei

157. ", globulosa .

158. ", verna, $\beta$ vulgaris, var. micropetala

", " var. macropetala

, alpestris var.

159. Alsine biflora, $\beta$ carnulosa

160. " Villarsii, $\boldsymbol{\beta}$ psilosperma
Pearlwort | Tarbagatai Mtns. . June Do.

Do.

Do.

Do.

Sandwort

Do.
B River Chilik

A Kopal Chain

Ivanovsky Snow Mnts.

A B Kopal Chain

Kurmenty Pass . June

River Zauku 


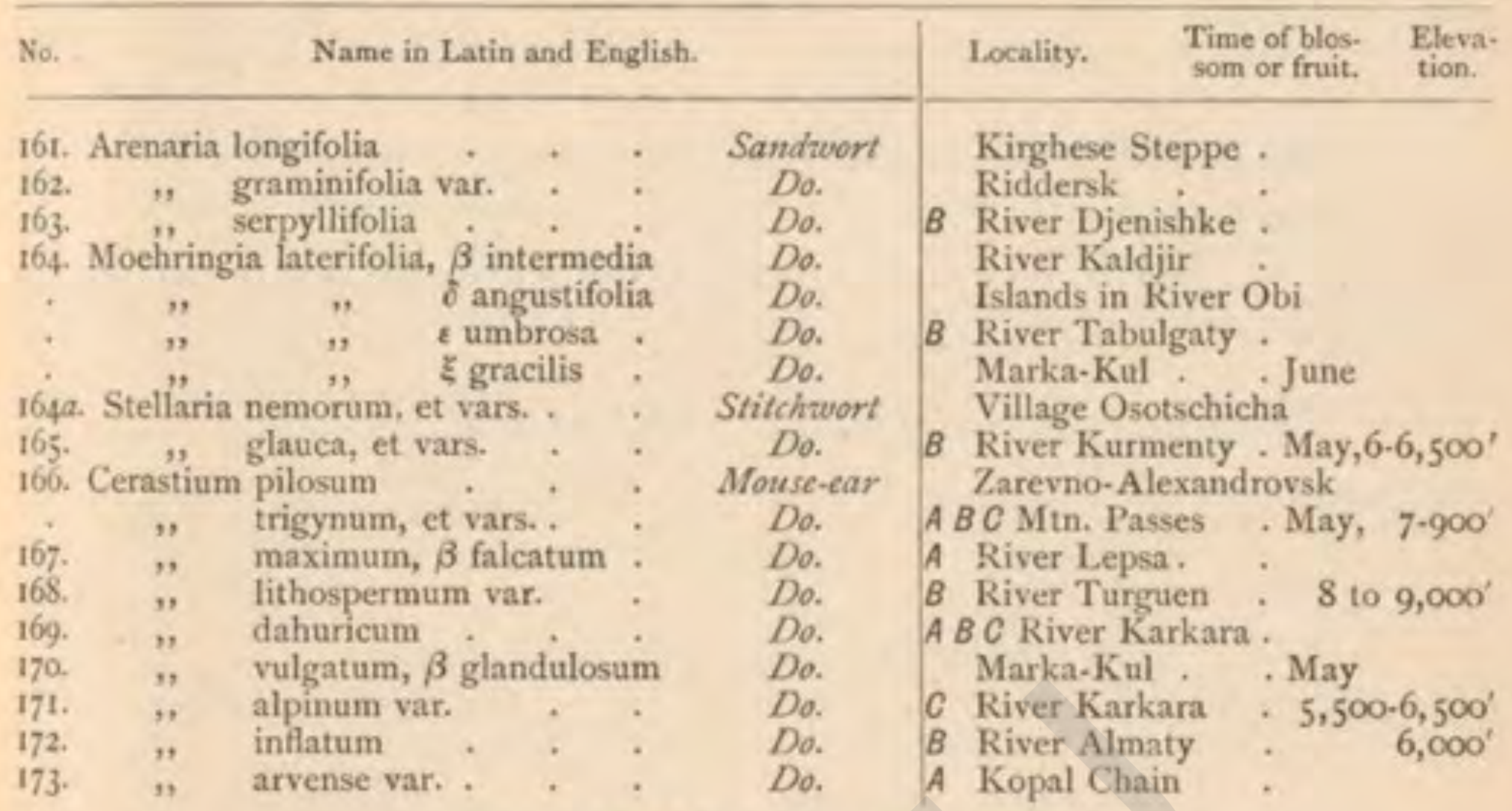

XII.-LINEAE I (5), Flax Family.

174. Linum perenne Flax | $B$ River Almaty

7,500

$$
\text { XIII-MALVACEAE } 5 \text { (8), Mallow Family. }
$$

175. Lavatera thuringiaca - . . Tree MalloalB Vierny. . . June, 3,000 176. Althaea officinalis . . . Marsh Mallow B Near Vierny - 3,000'

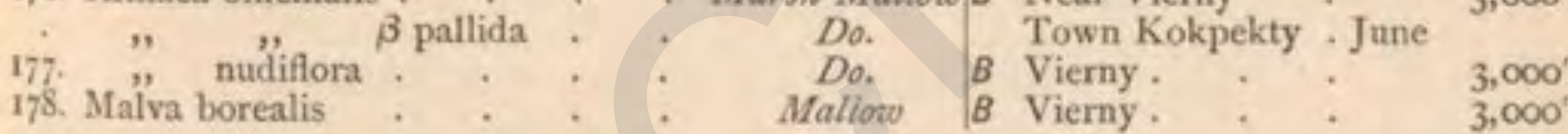

XIV.-HYPERICENEAE 5 (13), St. \%oh's Wort Family.

179. Hypericum Asycron . . . St. Fohn's Wort Uba Valley .

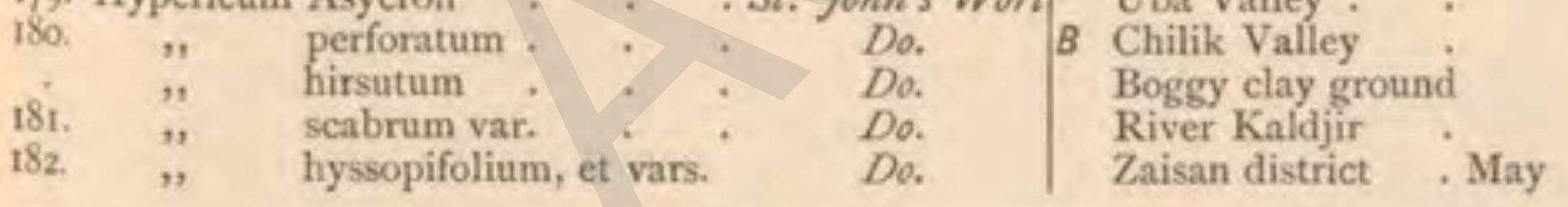

XV.-ACERACEAE I (2), Maple Family.

183. Acer Semenovii . . . . Maple I B Almaty Valley . 3 to 4,000

XVI.-GERANIACEAE Io (16), Cranesbill Family.

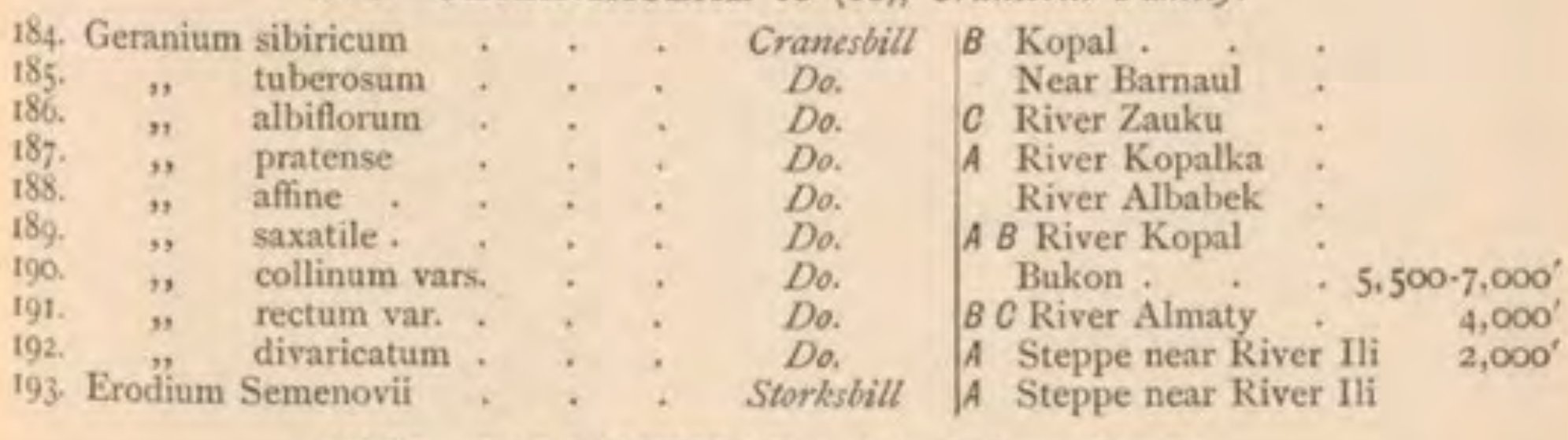

XVII.-BALSAMINEAE I (2), Balsam Family.

194. Impatiens parviflora vars. . . Balsam | A B Mtn. Passes . 4 to 5,000' 


\begin{tabular}{l|ll}
\hline No. Name in Latin and English. & Locality. & $\begin{array}{c}\text { Time of blos- Eleva: } \\
\text { som or fruit. }\end{array}$ \\
\hline
\end{tabular}

XVIII.-ZYGOPHYLLACEAE 4 (o), Bean, Caper, and Guiacum Fanily.

195. Zygophyllum brachypterum . . ?

macropterum . : ?

196. Tribulis terrestris .

197. Zygophyllacea (incog.).

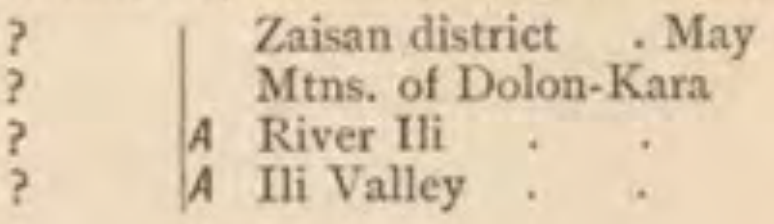

XIX.-RUTACEAE 3 (o), Rue Family.

198. Peganum Harmala

$?$
$?$

A Ili Valley

199. Haplophyllum Sieversii

200 .

latifolium

A B Near River Lepsa $\mathbf{1}, 500-3,500$

XX.-DIOSMEAE I (o), allied to Rue Family.

201. Dictamnus Fraxinella

? Near the River Kaldjar

XXI.-CELASTRINEAE I (2), Spindletree Family.

202. Euonymus Semenovii . . . Spindletree ; $B$ River Djenishke

\section{XXII.-RHAMNEAE 2 (2) Buckthorn Family.}

203. Rhamnus catharticus

Buckthorn $\mid B$ River Turguen

204. Nitraria Schoberi. Zaisan Plateau

\section{XXIII.-PAPILIONACEAE 124 (78), Pulse Family.}

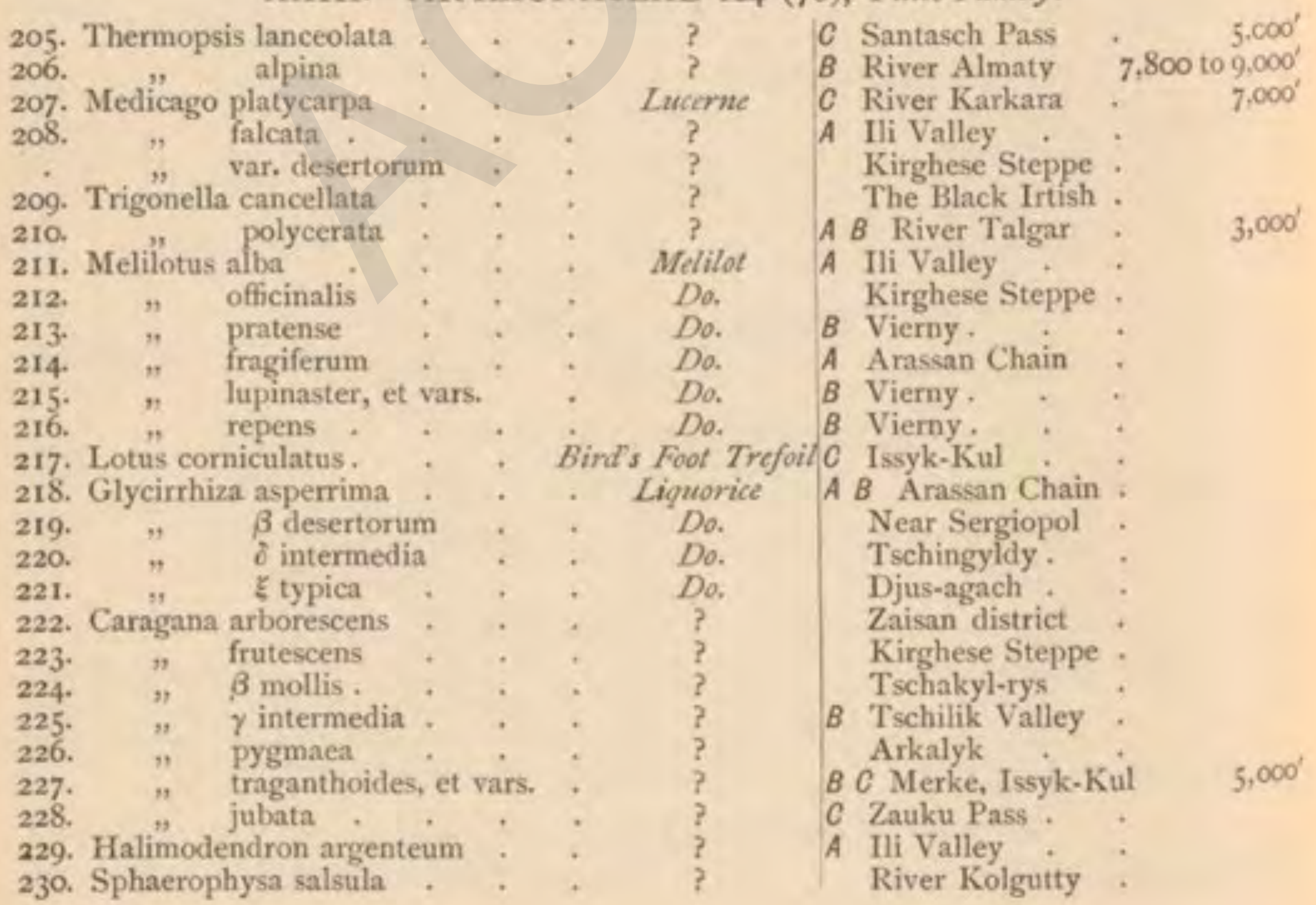




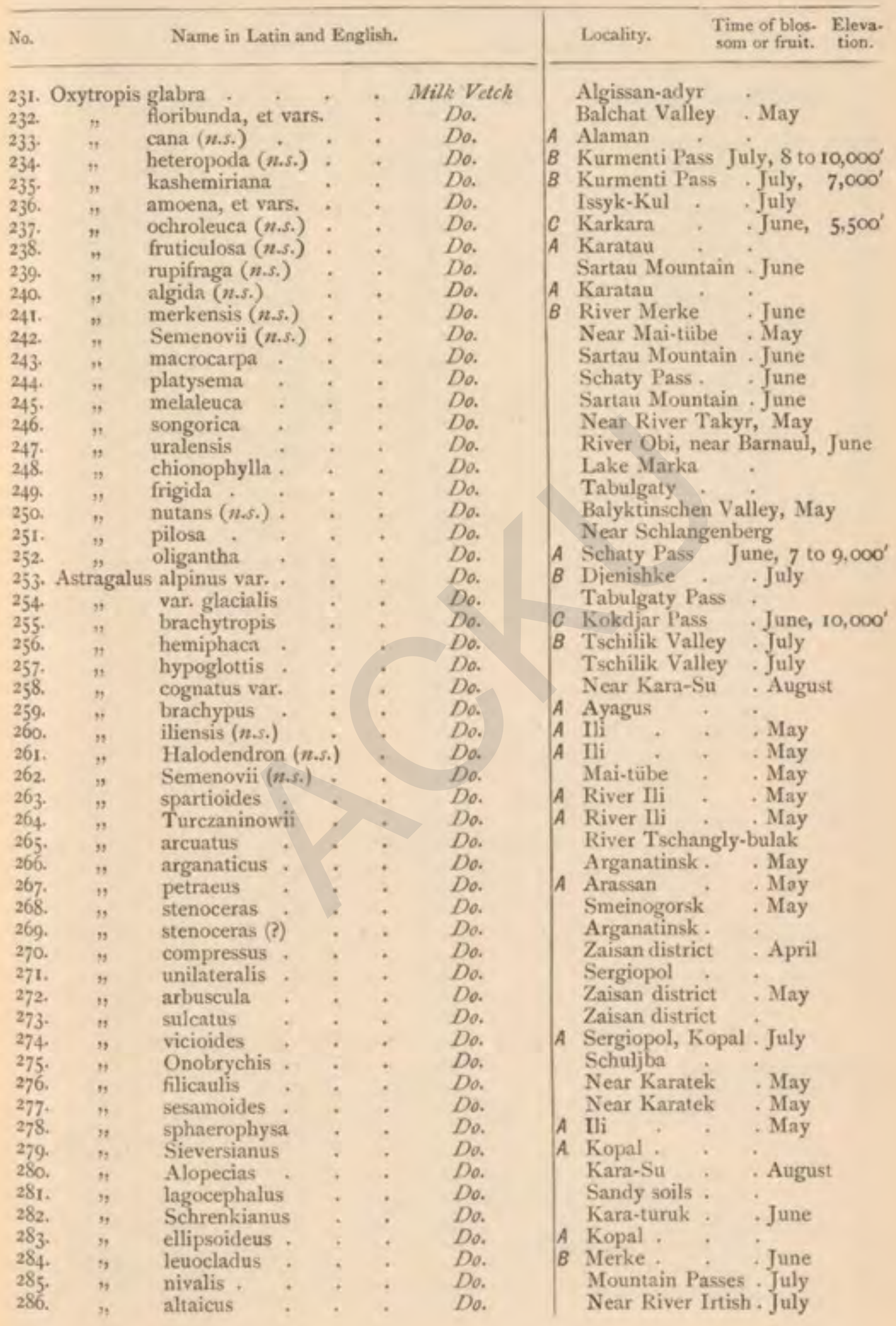




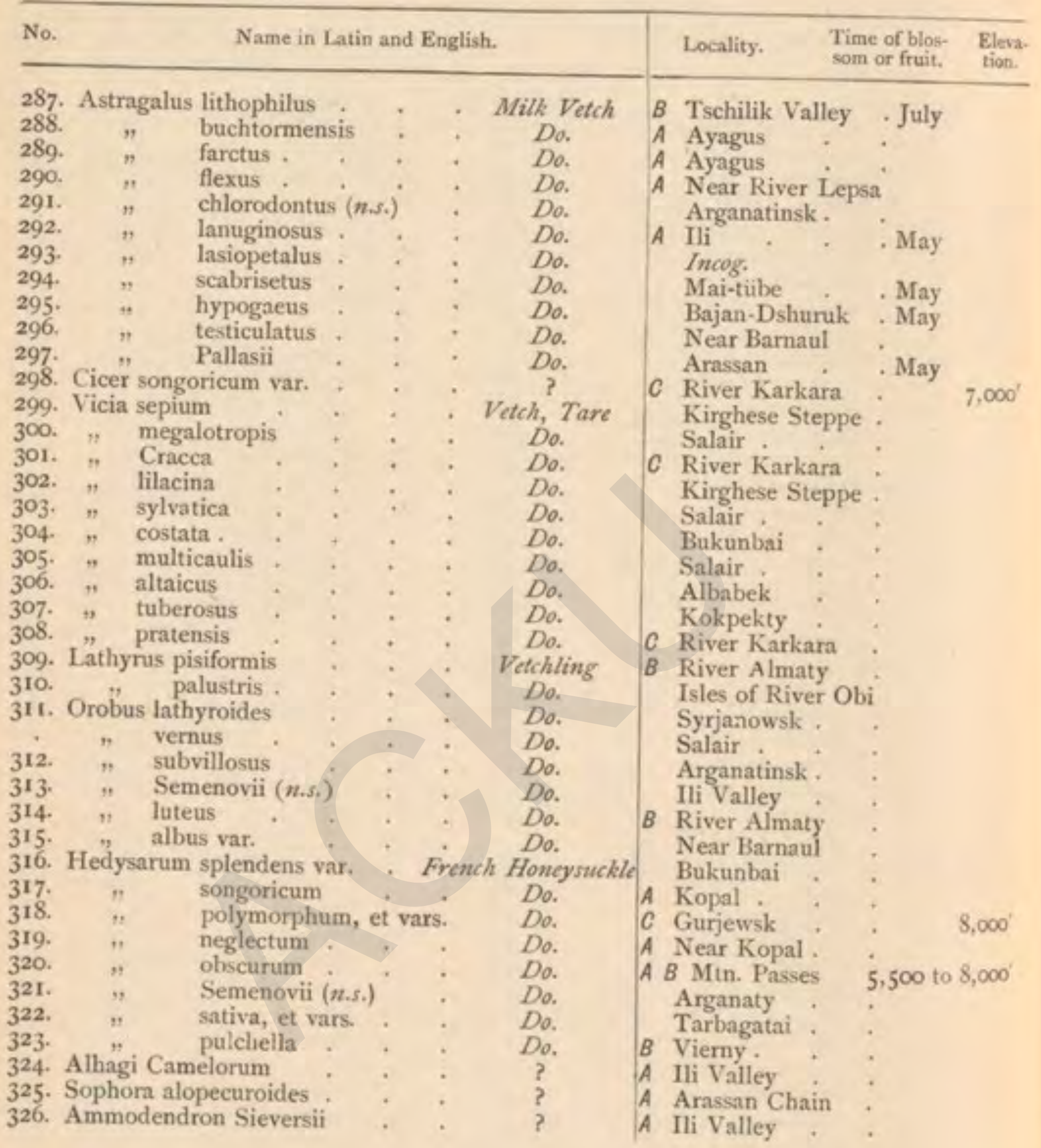

\section{XXIV.-AMYGDALEAE 4 (4), Almond and Plum Family.}

327. Amygdalus nana .
328. Prunus Armeniaca:

329. " prostrata var.

330. " Padus

\begin{tabular}{l|l}
$\begin{array}{l}\text { Almond } \\
\text { Cherry }\end{array}$ & $\begin{array}{l}\text { District of Zaisan } \\
\text { Do. }\end{array}$ \\
Do. & A B Keyssyk-Aus \\
District of Zaisan Mountain
\end{tabular}

XXV.-ROSACEAE 47 (93), Rose Family.

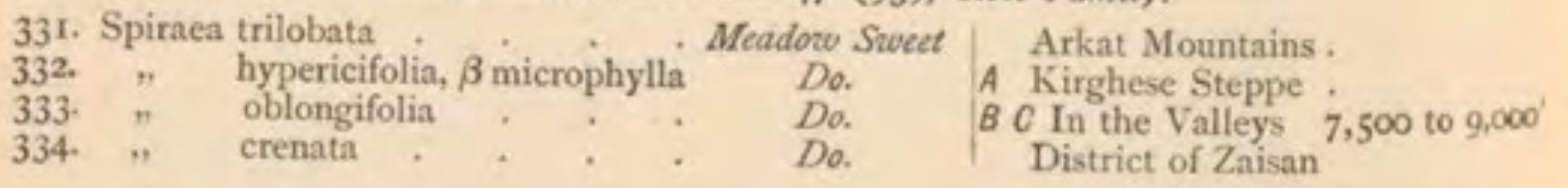




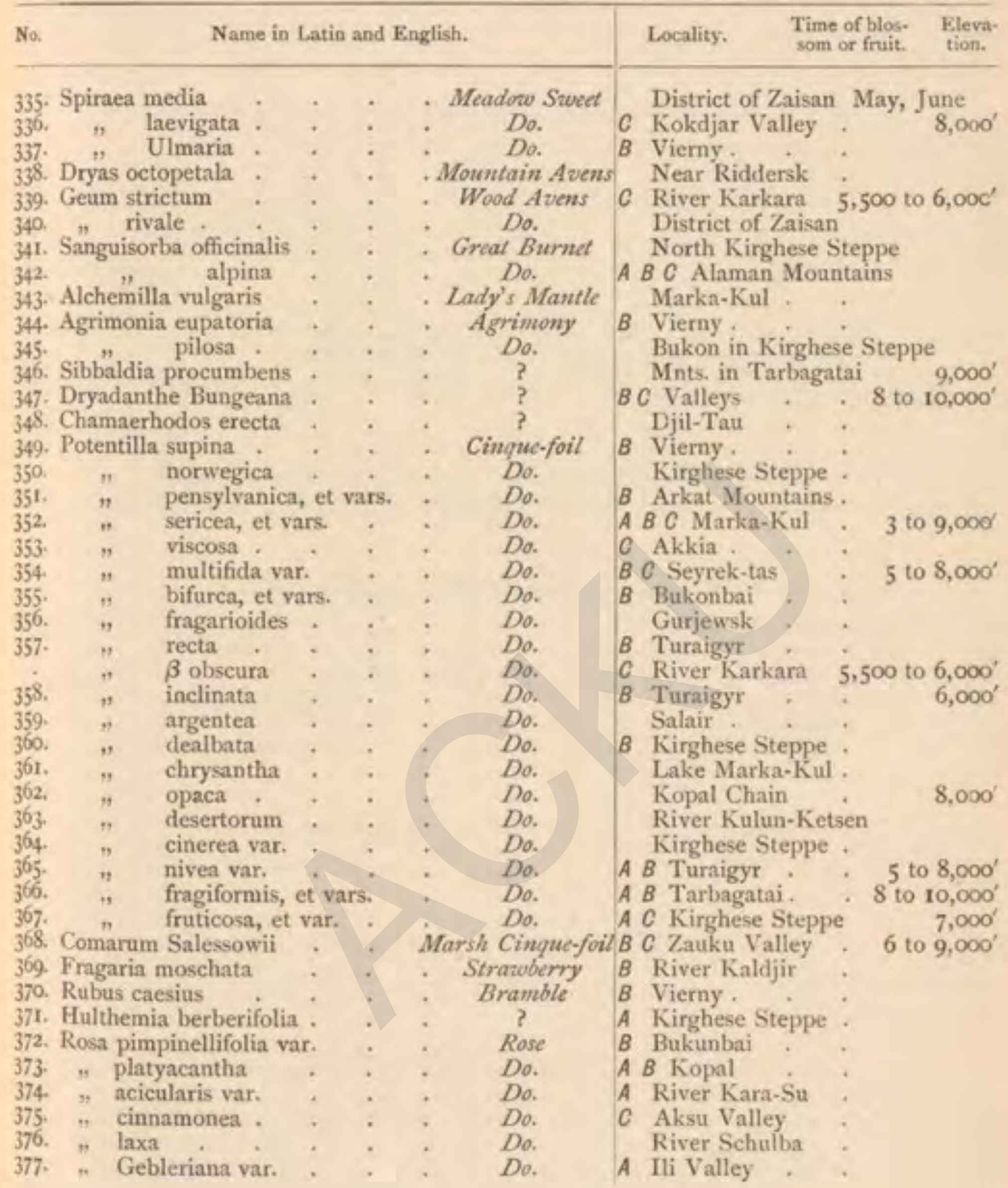

XXVI.-POMACEAE 7 (II), Apple and Pear Family.

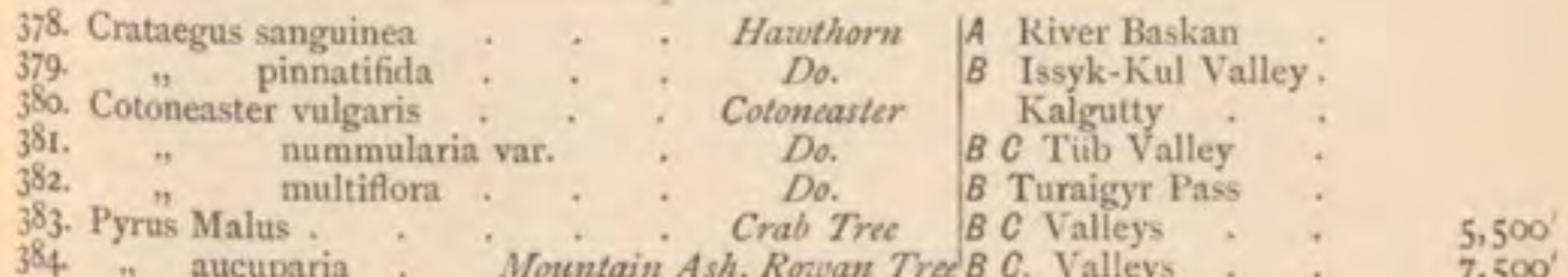

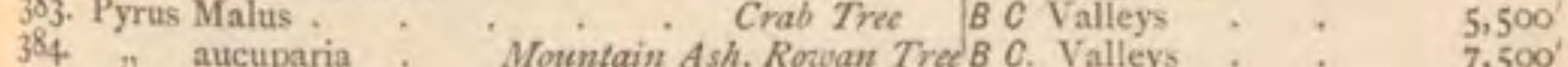




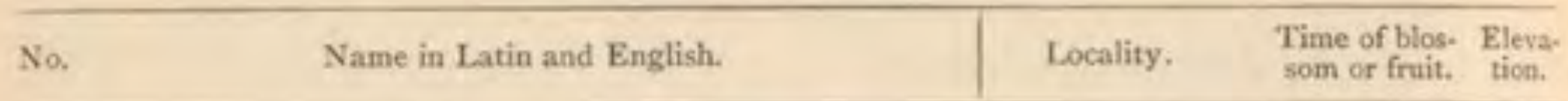

\section{XXVII. - ONAGRARIAE 5 (17), Evening Primrose Family.}

385. Epilobium angustifolium . . Willow Herb B Chilik Valley

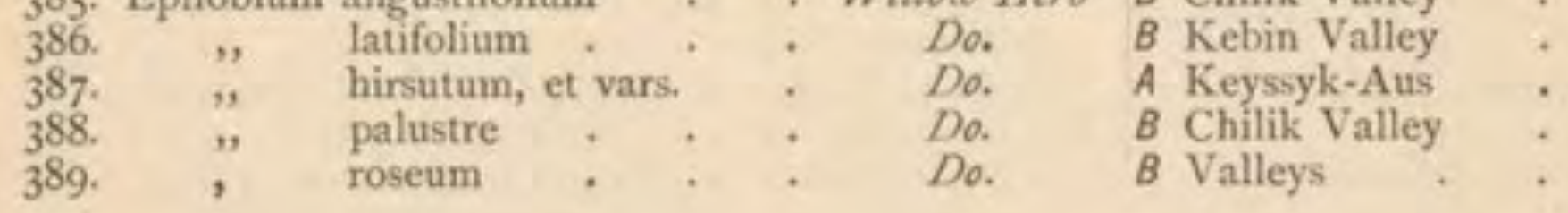

XXVIII.-HALORAGEAE I (4), Allied to Evening Primrose Family, but aquatic; sometimes called Mare's Tail Order (Balfour).

390. Myriophyllum verticillatum . . Water Milfoil | Kirghese Steppe .

XXIX.-LYTHRARIAE I (3), Loosestrife Family.

391. Lythrum virgatum . . . Loosestrife | Kirghese Steppe .

XXX.-TAMARISCINEAE 6 (I), Tamarisk Family.

392. Myricaria alopecuroides

393. ," davurica

394. Tamarix elongata .

395. " $\quad$ laxa $\quad$ Pallasii var.

396. " $\quad \begin{aligned} & \text { Pallasii } \\ & \text { 397. }\end{aligned}$

\begin{tabular}{c|l} 
? & A River Bion : \\
C & Kokjar Pass : \\
Tamarisk & A Ili Valley $:$ \\
Do. & Kirghese Steppe : \\
Do. & A Ili Valley \\
Do. & Ili picket-station :
\end{tabular}

XXXI.-PORTUlaceaE I (I), Purslane Family.

398. Claytonia Joanneana

| Ivanovsky Bjelok .

XXXII.-PARONYCHIEAE 1 (I2), Knotwort Family.

399. Herniaria glabra

. Kupture Wort | Jil-Tau

XXXIII.-CRASSULACEAE 14 (15), Stonecrop Family.

400. Umbilicus affinis

\begin{tabular}{|c|c|c|c|}
\hline 401. & " & Lievenii & . \\
\hline 402. & , & leucanthus & . \\
\hline 403. & , & spinosus & . \\
\hline & " & platyphyllu: & \\
\hline & $" \because$ & alpestris & $i(i=)$ \\
\hline & Sedum & quadrifidum & (n.s.) \\
\hline & ," & gelicum . & . \\
\hline & ", & coccineum . & . \\
\hline & " & Rhodiola var. & - \\
\hline & ", & purpureum & \\
\hline & " & Ewersii & + \\
\hline & , & hybridum & \\
\hline
\end{tabular}

Naveluort
Do.
Do.
Do.
Do.
Do.
Do.
Stonecrop
Do.
Do.
Do.
Do.
Do.
Do.
Do.

A Jil-Tau :
A Tamgaly-tas:
A Arassan :
Kirghese Steppe :
B Jassyl-Kul :
A Kopal Chain.
B Keskelen Pass
Ivanovsky Bielok:
B Turguen-basch
C Zauku Valley C Zauku Valley : 8,500'

Ivanovsky Snow Mountains

A Tamgaly-tas.

Salair

A Kopal Chain

A B Jil-Tau
6,000 $8,000^{\circ}$ 


\begin{tabular}{l|l}
\hline No. Name in Latin and English. & Locality. \\
som or fruit. & $\begin{array}{c}\text { Time of blos. } \\
\text { tion. }\end{array}$
\end{tabular}

XXXIV.-GROSSULARIEAE 5 (4), Gooseberry and Currant Family.

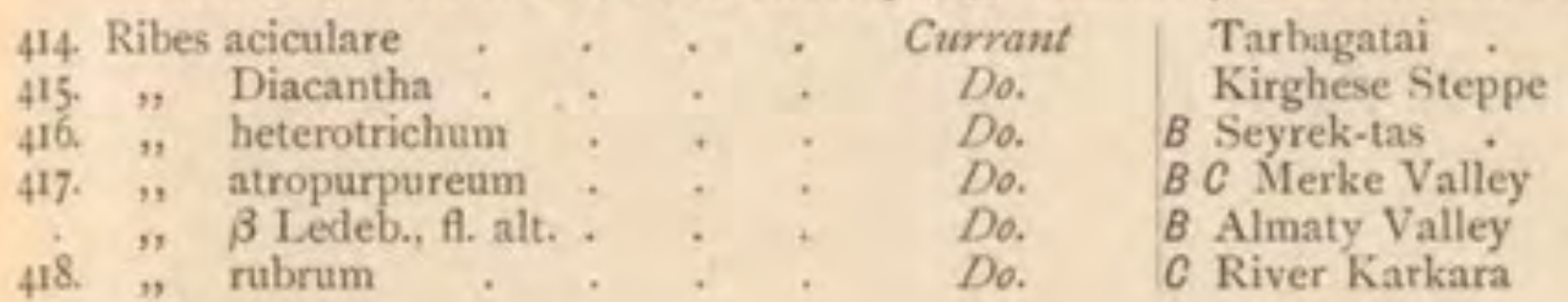

XXXV.-SAXIFRAGACEAE 6 (22), Saxifrage Family.

419. Saxifraga flagellaris

420. ". hirculus

421. " ". crassifolia

422. ," punctata

423. ", sibirica

424 Chrysosplenium nudicaule
Saxifrage

Do.

Do.

Do.

Do.

$A B C$ Mtn. Passes . 8 to 11,000

$A B$ Turaigyr Chain : 6 to $8,000^{\prime}$

Ivanovsky Snow Mountains

Ivanovsky Snow Mountains

A B C Mtn. Passes . 7 to $9,000^{\prime}$ -Golden Saxifrage B C Mtn. Passes . 9 to I1,000

XXXVI.-UMBELLIFERAE ${ }_{4} 6$ (69), Parsley Family.

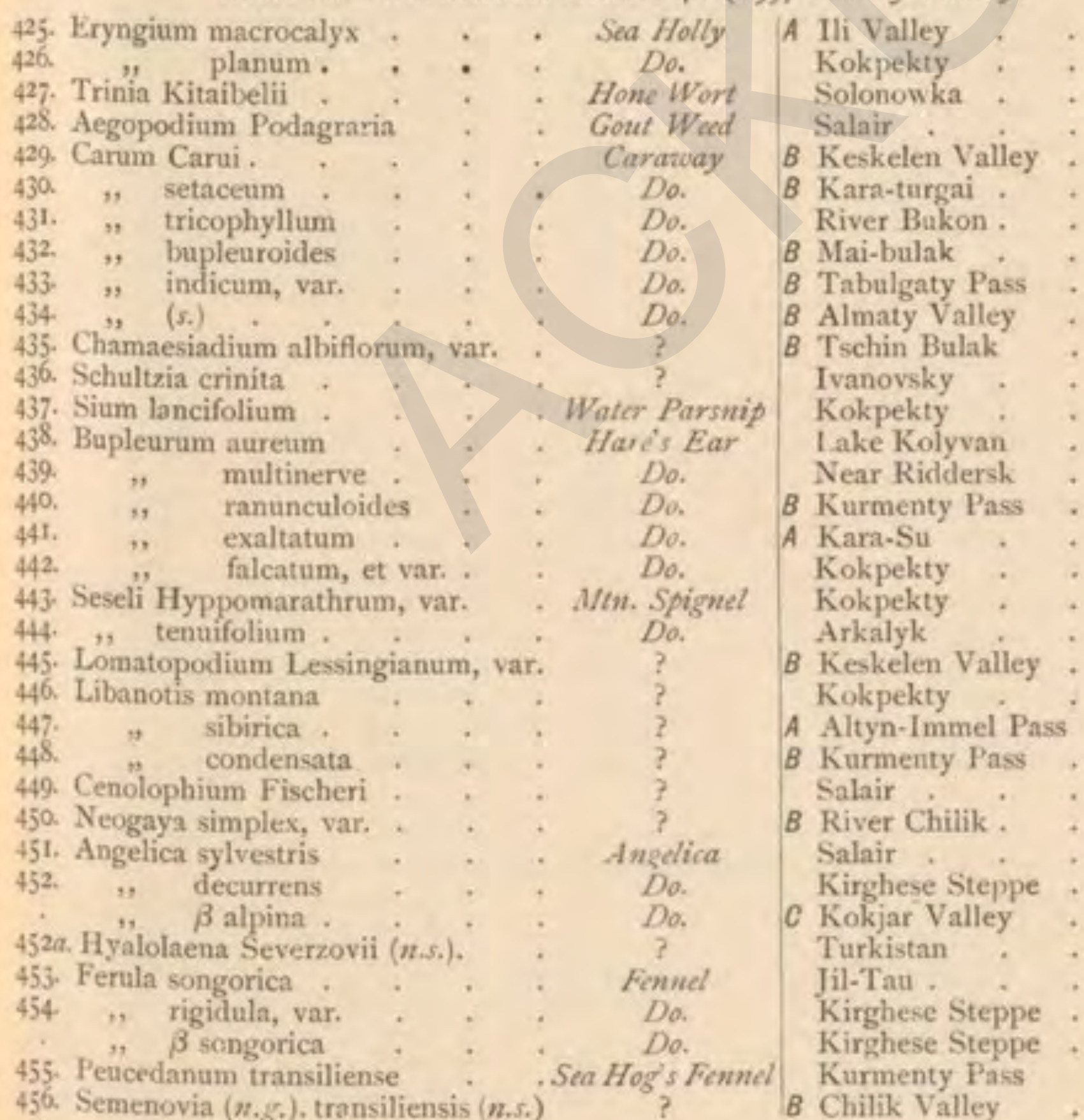

$7,500^{\prime}$ 


\begin{tabular}{|c|c|c|c|c|c|c|c|c|}
\hline No. & \multicolumn{4}{|c|}{ Name in Latin and English } & & Locality. & \multicolumn{2}{|c|}{$\begin{array}{l}\text { Time of } \\
\text { som or }\end{array}$} \\
\hline 457. & Heracleum dissectum . & . & . & Cono Parsnip & & River Bukon & & \\
\hline $45^{8}$. & Pachypleurum alpinum . & . & . & $?$ & & Marka-Kul & . & + \\
\hline 459. & Daucus carota & . & . & Carrot & A & Vierny . & . & + \\
\hline & Scandix pinnatifida, var. & . & & Hepherd's Nealle & $B$ & Ili Valley & + & \\
\hline 461. & Anthriscus sylvestris . & . & - & Chervil & $B$ & Vierny & & . \\
\hline 462. & , nemorosa : & . & . & Do. & & District of $Z$ & Zaisan & \\
\hline 463. & Chaerophyllum Prescottii & . & + & Rough Chervil & & Jil-Tau : & $\cdot$ & \\
\hline 464. & , sphallerocar & pus & . & Do. & $B$ & Kurmenty I' & Pass & \\
\hline 465. & Cachrys odontalgica & . & . & $?$ & & Kinghese St & teppe & - \\
\hline 466. & , macrocarpa & . & - & $?$ & $A$ & Kara-Chek & $\because$ & . \\
\hline 67. & Pleurospermum austriacum & + & + & $?$ & & Salair . & & \\
\hline 88 & Aulacospermum anomalum & . & . & ? & $B$ & Keskelen V & Valley & \\
\hline 469 & Schrenkia vaginata & . & - & ? & C & Kokjar Vall & & \\
\hline
\end{tabular}

\section{XXXVII.-CAPRIFOLIACEAE 9 (5), Honeysuckle Family.}

470. Adoxa moschatellina . . . Moschatel 471. Viburnum Opulus. . . . Gudder Rose 47. Viburam Operalas.

473. , Xylosteum

" $\quad \beta$ macrocalyx.

474

-,

475 .

$47 \dot{6}$

477.

478 .

\section{hispida}

$\beta$ hirsutior $\gamma$ alpina . caerulea, var. $\beta$ villosa.

"

, microphylla, humilis Karelini .

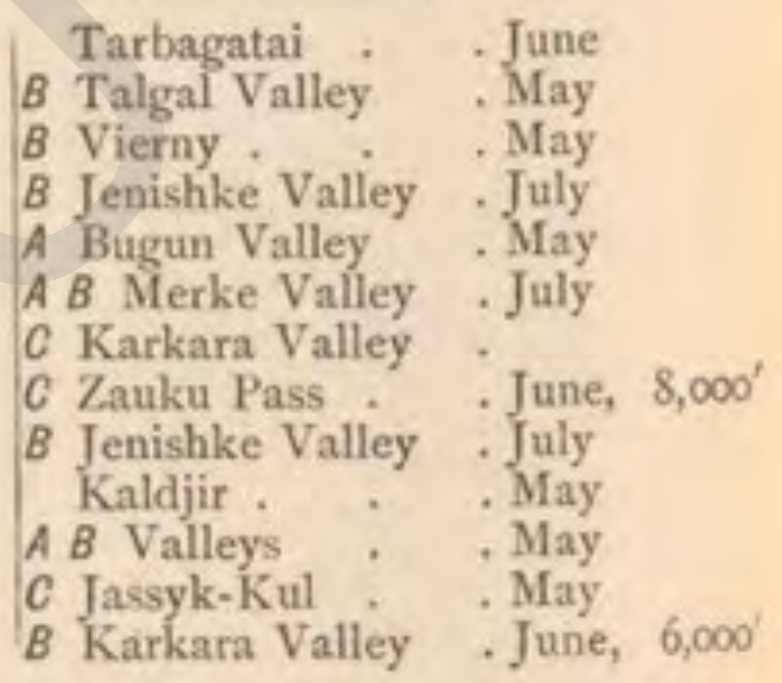

\section{XXXVIII.-RUBIACEAE 10 (2I), Madder Family.}

479. Asperula Aperine

480., humifusa, var.

48r. Galium saxatile, var.

482. ", rubioides, var. .

483 .

484.

485.

486.

487.

488 .
Woodruff Do.

Bedstraw

Do.

Do.

Do.

Do.

Do.

Do.

Do.
A B Mai-Bulak.

$B$ River Almaty

B Ak-kia. Kokpekty

B Vierny :

ground June. July

A Chilik . . June - Salair

$B$ Almaty Valley

$C$ Sary-jas glacier

B Mountain Spurs. June
. May, June

July, 8,000

June

$9,000^{\prime}$

\section{XXXIX,-VALERIANEAE 7 (10), Valerian Family.}

489. Patrinia sibirica

490.

491. Valerianella plagiostephana .

492. Valeriana tuberosa

493.

494

495.

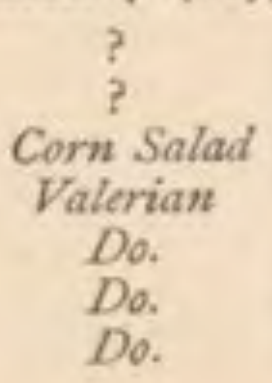

Ivanovsky Snow Mountains B Turaigyr . June A Keyssyk-Aus . May District of Zaisan . May C Zauku Pass - June, 9 to 10,000 A Keyssyk-Aus . May A B Talgar Valley . May, 5.300 


\begin{tabular}{l|ll}
\hline No. Name in Latin and English. & Locality. $\begin{array}{c}\text { Time of blos- } \\
\text { som or fruit. }\end{array} \begin{array}{c}\text { Eleva. } \\
\text { tion. }\end{array}$
\end{tabular}

XL.-DIPSACACIEAE 6 (6), Tcasel Family.

496. Morina kokanica

497. Dipsacus azureus .

498. Cephalaria syriaca

499. Scabiosa caucasica, et var.

$500 . \quad$ Olivieri.

50r. "

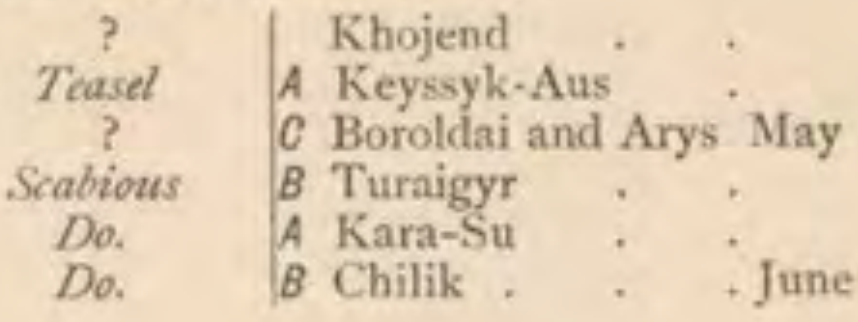

XLI.-COMPOSITAE 23 (15), Composite, or Sunflowier Family.

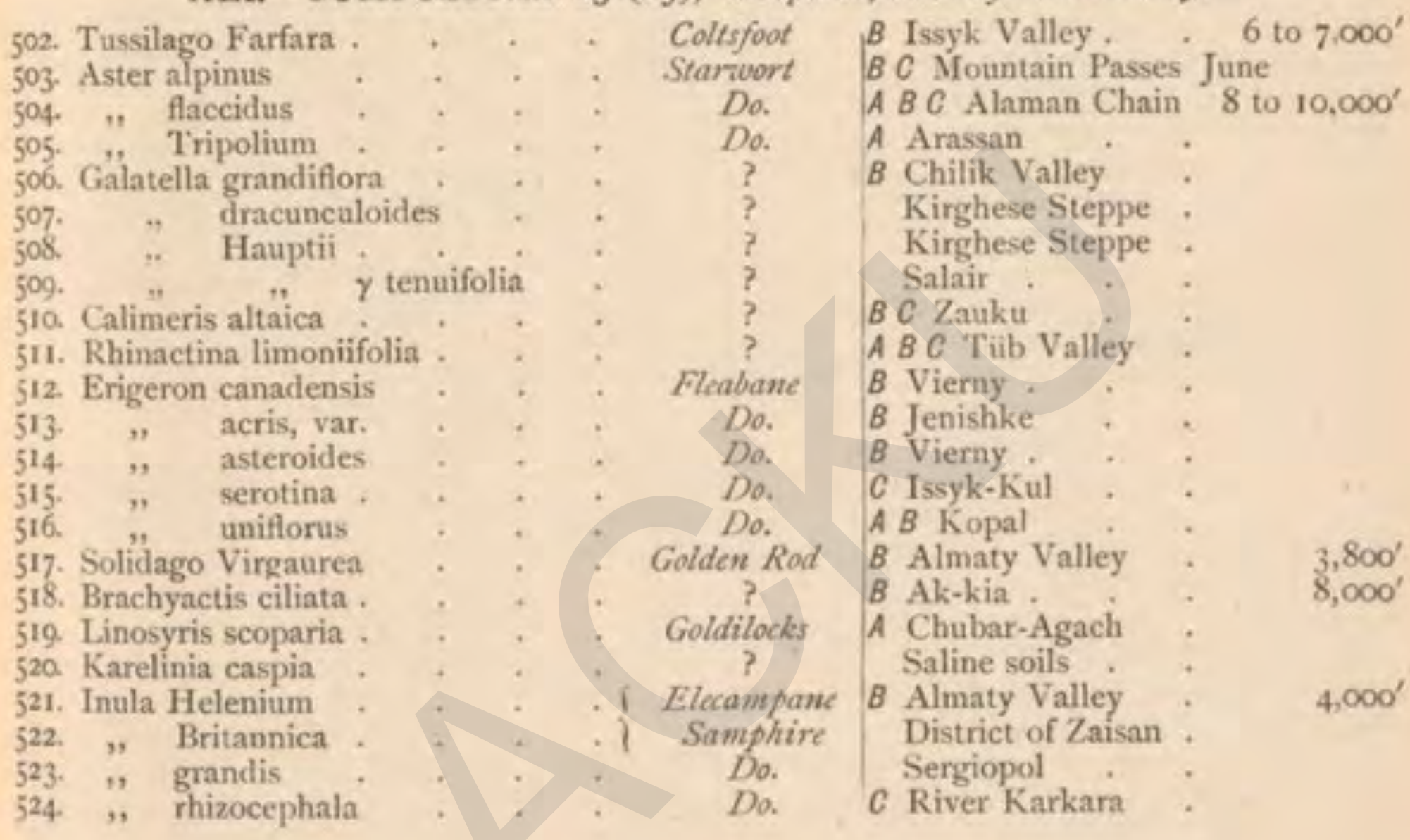

XL.II,-SENECIONIDEAE $53(48)$, Groundsal Family.

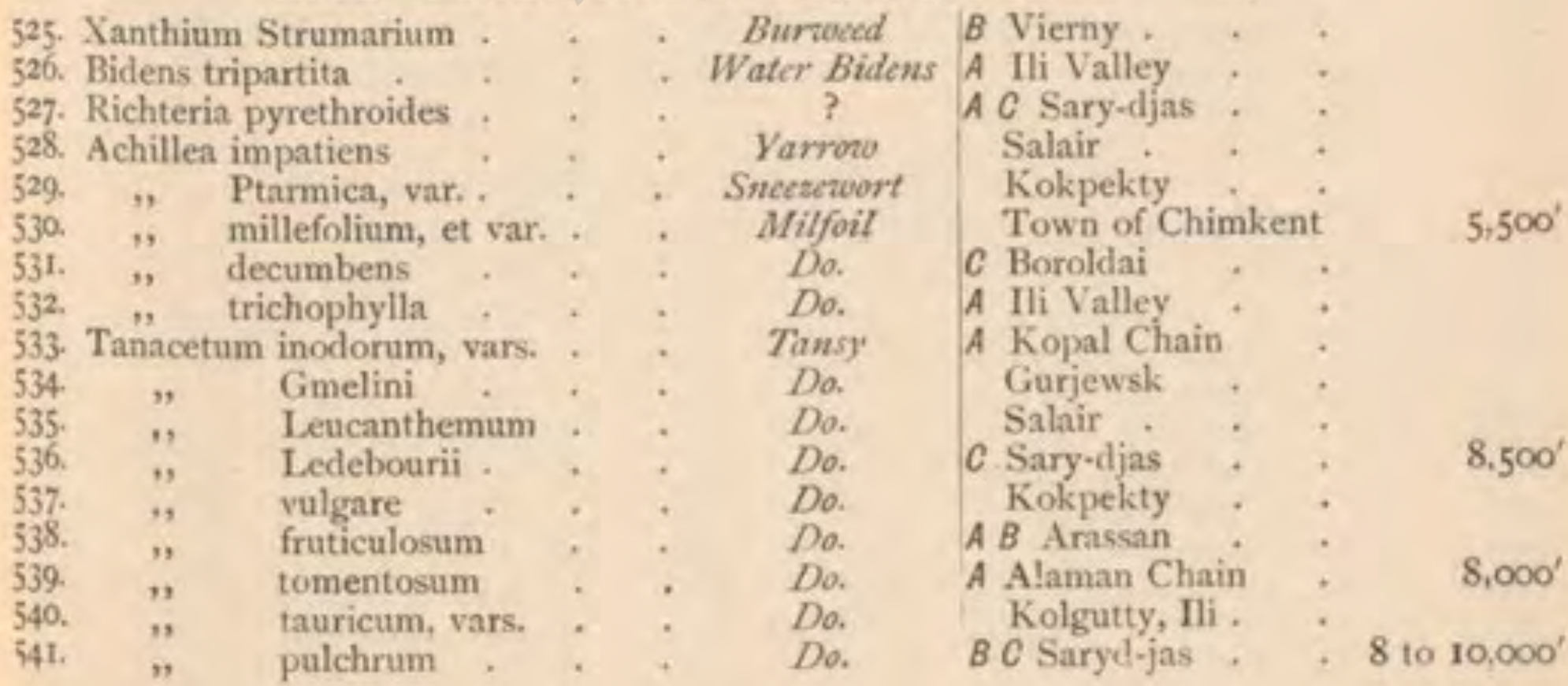




\begin{tabular}{|c|c|c|c|c|c|c|c|c|c|c|}
\hline No. & & Name in Lati & $\mathrm{n}$ and $\mathrm{F}$ & Eng & lish. & & Locality. & & $\begin{array}{l}\text { ime of blos: } \\
\text { om or fruit. }\end{array}$ & $\begin{array}{l}\text { Eleta- } \\
\text { tion. }\end{array}$ \\
\hline 542. & Tanacetum & alatavicum & . & . & . & Tansy & B Seyrek-tas & - & . & \\
\hline 543 . & " & transiliense & & . & , & Do. & BC Valleys & . & +6 to 7 & $7, \infty 00^{\prime}$ \\
\hline 544 & , . & Semenovii & $(n . s)$. & & . & Do. & $B$ Seyrek-tas & . & . & \\
\hline 545. & Artemisia & Dracunculu & & . & - & Wormwoood & B Kurmenty & - & . & 7,000 \\
\hline 546. & " & glauca var. & & . & + & Do. & Salair & $\dot{.}$ & $\dot{M}$ ountains & \\
\hline $\begin{array}{l}47 . \\
8 .\end{array}$ & , & commutata & var. & - & * & Do. & $\begin{array}{l}\text { Ivanovsky S } \\
\text { B Ienishke }\end{array}$ & now & Mountains & \\
\hline 48. & , & scoparia & , & - & , & Do. & $\begin{array}{l}B \text { Jenishke } \\
\text { A Ili Valley }\end{array}$ & . & , & \\
\hline 49. & " & Oliveriana & * & . & . & Do. & $\begin{array}{l}\text { A Ili Valley } \\
\text { Ili Valley }\end{array}$ & - & . & \\
\hline 550. & $"$ & maritima & $\therefore$ & , & + & Do. & $\begin{array}{l}\text { Ili Valley } \\
\text { Kinghese Ste }\end{array}$ & inne. & : & \\
\hline : & ", & $\begin{array}{l}\text { 3 Lerchean: } \\
\eta \text { monogyn: }\end{array}$ & & $\vdots$ & $\dot{*}$ & $\begin{array}{l}\text { Do. } \\
\text { Do. }\end{array}$ & $\begin{array}{l}\text { Kinghese Ste } \\
\text { Ala-Kul }\end{array}$ & eppe & : & \\
\hline 551. & " & juncer & . & . & . & Do. & A Keyssyk & . & . & \\
\hline 52. & $n$ & sacrorum v: & & + & , & Do. & B Chilik Valley & & . & \\
\hline 553. & , & pontica var & & - & , & Do. & Salair & & . & \\
\hline 54. & ", & vulgaris & . & . & + & Do. & B Valleys & & . & \\
\hline 55. & " & annua & - & . & . & Do. & B Almaty Valle & & . & \\
\hline 56. & ", & sericea & . & . & + & $D$ & B Turguen Pass & & . & \\
\hline 57. & , & rupestris & . & . & . & Do. & B Kebin Valley & & . & $7,500^{\prime}$ \\
\hline $5^{8}$. & " & frigida & + & . & . & Do. & Arkalyk & . & . & \\
\hline 559. & yon & Sieversiana & & . & & Do. . . & Salair & . & . & \\
\hline 560. & Helichry: & m anatolicun & & - & $E v$ & asting Flowe & C Boroldai & - & . & \\
\hline 561. & $\begin{array}{c}\text { Gnaphaliu } \\
\qquad,\end{array}$ & $\begin{array}{l}\text { m sylvaticum } \\
\beta \text { s subalpin }\end{array}$ & $\mathrm{um}$ & $\dot{.}$ & & $\begin{array}{l}\text { pot Cud Weat } \\
\text { Do. }\end{array}$ & $\begin{array}{l}\text { Gurjewsk } \\
B \text { Kurmenty } \mathrm{Pa}\end{array}$ & & . & $3.000^{\prime}$ \\
\hline 562. & , & dioicum & . & & & Do. & Sartau & . & . & \\
\hline$\therefore$ & $n$ & $\beta$ corymbo & ssum & & & Do, & Gurjewsk & , & . & \\
\hline 563 & , & leontopod & um & & & Eddaciss & BC Karkara & . & 6 to & $9.000^{\circ}$ \\
\hline $\begin{array}{l}564 \\
565\end{array}$ & Filago arve & ensis : & 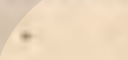 & + & - & Cudroced & B River Talgar & & . & \\
\hline $\begin{array}{l}565 . \\
566 .\end{array}$ & Ligularia a & altaica & . & . & & $?$ & Takyr & - & . & \\
\hline $\begin{array}{l}500 . \\
567 .\end{array}$ & Aronicum : & $\begin{array}{l}\text { nacrophylla } \\
\text { altaicum }\end{array}$ & . & $\dot{.}$ & & $\begin{array}{l}? \\
?\end{array}$ & $\begin{array}{l}\text { A Kopal, Arass } \\
\text { A Kopal Chain }\end{array}$ & & : & \\
\hline 568. & Doronicum & oblongifolit & in var & & & ppard's Bane & A B C Kopal & & + & $6000^{\prime}$ \\
\hline $\begin{array}{l}569 . \\
570 .\end{array}$ & $\begin{array}{l}\text { Cacalia h } \\
\text { Senecio }\end{array}$ & & . & & & ? & Ulba Valley & . & . & \\
\hline $\begin{array}{l}570 . \\
571 .\end{array}$ & & lgaris var. & + & & Gro: & ndsel, Ragzw & B Jenishke & . & * & \\
\hline $\begin{array}{l}571 . \\
572 .\end{array}$ & $\begin{array}{ll}\ddot{\prime} & \text { sul } \\
, & \text { pr }\end{array}$ & $\begin{array}{l}\text { bdentatus } \\
\text { aealtus }\end{array}$ & : & ; & : & $\begin{array}{l}\text { Do. } \\
\text { Do. }\end{array}$ & Marka-Kul & & ; & $3,000^{\prime}$ \\
\hline 573. & " Jas & cobea & . & . & - & Do. & $\begin{array}{l}\text { Kokpekty } \\
\text { Koknaty }\end{array}$ & & . & \\
\hline 74 & sib & oiricus & * & & & Do. & $B C$ Turaigyr & . & , & \\
\hline 75 & pal & ludosus. & . & . & & Do. & B Chilik Valley & & & \\
\hline 76 & , ner & morensis & . & & & $D_{o}$ & Ivanovsky S & now & Mountains & \\
\hline 577. & Cineraria c & campestris & . & . & & irsh Flea Wort & Jel-Tau & + & . & \\
\hline
\end{tabular}

\section{XLIII.CYNAREAE 93 (93), Thistle Family.}

578. Acanthocephalus amplexifolius 579. Echinops Ritro

580. $"$ sphaerocephalus

581. Saussurea pygmaea, et vars.

582 . " $\quad$ pycnocephala

$58_{3}$. ", coronata var. .

584

585.

586.

587.

588 .

589.
,

, latifolia.

, discolor

, salicifolia, et vars.

rigida

, Semenovii $(u, s$.
", crassifolia
? $\quad$ M Merke

? Sandy soil

B Almaty Valley : $\quad 4,500^{\circ}$

Alpine Sazu-wort A B C Kopal Chain + 5 to 8,000 Do. $\quad B$ Jenishke

Do. $\quad$ B Lepsa

Do. Arkalyk

Do.

Do.

Do.

Do.

Do.
Salair

A B Tarbagatai : $\quad 3,000^{\prime}$ Arkalyk

A Ili valley 


\begin{tabular}{|c|c|c|c|c|c|c|c|c|}
\hline \multirow{2}{*}{$\begin{array}{l}\text { No. } \\
590 .\end{array}$} & \multicolumn{5}{|c|}{ Name in Latin and English. } & \multirow{2}{*}{$\begin{array}{c}\text { Locality. } \\
\text { C Sary-djas }\end{array}$} & $\begin{array}{l}\text { Time of blos- } \\
\text { som or fruit. }\end{array}$ & \multirow[t]{2}{*}{$\begin{array}{l}\text { Eleva. } \\
\text { tion. }\end{array}$} \\
\hline & aussurea sorocephala & . & - & & ne Satu-zwort & & . & \\
\hline & ," glacialis & . & - & & Do. & C Sary dias Glacier & + & $10,000^{\prime}$ \\
\hline & Cousinia tenella . & . & + & . & $?$ & Ili Valley . & . & \\
\hline & " uncinata .. & . & . & . & $?$ & B Almaty Valley & , & $4,800^{\prime}$ \\
\hline & Semenowii & . & . & & $?$ & Turuk & . & $3,000^{\prime}$ \\
\hline & affinis . & . & - & & $?$ & A B Ili Valley. & . 1,500 & $3,000^{\prime}$ \\
\hline & platylepis & , & - & & $?$ & A Ili Valley & $+\quad-1$ & $2,000^{\prime}$ \\
\hline 7. & carpa & . & . & & ? & A River Tetayan & . & \\
\hline & $\beta$ s & . & - & & $?$ & A River Lep & $\cdot x_{1}$ & \\
\hline 8. & Sew & . & . & & $?$ & Chirchik & . July & \\
\hline & jides & . & . & & ? & C Near Bugun. & . & \\
\hline & ns, et & var. & - & & ? & Afghar & . & \\
\hline & scario & . & . & . & $?$ & Afghanistan . & , & \\
\hline 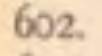 & buphthalmoid & des & . & & $?$ & Afghanistan . & . & \\
\hline 03. & n anthacantha & . & . & & $?$ & $\operatorname{stan}$. & . & \\
\hline t. & Ancatha igniaria . & . & * & & ? & Steppe & . & \\
\hline & Crupina vulgaris . & . & . & & ? & B Almaty Valley & - & $3,000^{\prime}$ \\
\hline 6. & Amberboa & . & & & $?$ & Ili Valley & & \\
\hline & Centaurea pu & . & . & & Knapro & Ili Valley & 1,500 & $0.2,500^{\prime}$ \\
\hline 8. & , ruthenica & . & - & & Do & B River Jenishke & , & 5,500 \\
\hline & glastifolia & . & - & & Do. & hese Steppe & . & \\
\hline & sibirica, et v: & var. & . & + & Do. & 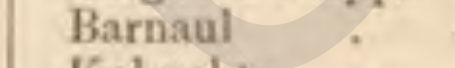 & . & \\
\hline " & Scabiosa, et & var. & . & & Do. & ty & . & \\
\hline . & , squ: & . & . & . & Do. & A $\mathrm{Kau}$ & . & \\
\hline . & Onopordum A & & 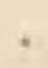 & & Cotton This & elen Pass & . & $3,000^{\prime}$ \\
\hline & Carduus & , & & - & bistle & of Zaisan & & \\
\hline & Cirsium lane & . & . & & & Valley & . & $2.500^{\circ}$ \\
\hline . & ," nidular & . & . & . & Do. & Pass. & . 9 to 1 & $10,000^{\prime}$ \\
\hline 1) & "Seme & . & + & . & Do. & Pass. & 7 to & 7.500 \\
\hline & $"$ arven: & & . & & Do. & Steppe & $\cdot$ & \\
\hline 19. & r., acitu & & . & + & Do. & Kirghese steppe & & \\
\hline 20. & Echinais Siv & & & & $?$ & Ili Valley & I to & $2,000^{\prime}$ \\
\hline . & Acroptilon I & . & . & & $?$ & A Kara-Su , & . & \\
\hline & des & . & & & $?$ & Near Iwanow Sno & ow M & \\
\hline 23 & Alfredia cen & . & & & $?$ & Quarries of Salair & & \\
\hline & * acantholepis & . & . & . & $?$ & $B C$ Mountain Passes & . 6,5 & $-8,000^{\prime}$ \\
\hline 24. & nivea & . & & . & ? & A Kopal Chain & & 3,000 \\
\hline : & Serratula corot & . & & & Sarw-wo & Quarries of Salair & & \\
\hline 20 & ", lyratifolia & . & . & & & $B$ Mai & . & \\
\hline & bens & . & . & & Do. & C Tekes. & . & $8, \infty 0^{\prime}$ \\
\hline & , et var. & . & - & & & $C$ and Kirs & pe & $5,000^{\prime}$ \\
\hline 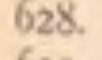 & disse & • & * & & & se Ste & & \\
\hline 29. & ," tenuifolia & . & - & & & B $\mathrm{Me}$ & . & \\
\hline 30. & Jurinea suffruticosa & . & + & * & Do. & A Ka & & 8,000 \\
\hline 31. & $\mathrm{pa}$, et & th var. & . & . & Do. & C Tasma . & $=4,5$ & $5.8,000$ \\
\hline 32. & s. & . & & & Do. & C Bugun . & $+1,300$ & $0.2,000$ \\
\hline . & $\mathrm{Ci}$ & $\therefore$ & & & $r y$, Chicory & B Vierny . & & $2.500^{\prime}$ \\
\hline c & $\mathrm{Ac}$ & & - & & & District of Zaisan & - Jun & \\
\hline . & Tragopogon pra & * & . & & Goat's $E$ & k Valley & & $6 \cdot 7.000^{\prime}$ \\
\hline &, flo & . & & & Do. & Tau & . & \\
\hline & $\boldsymbol{\beta}$ caespito: & osus & - & & Do. & uchan . & + & \\
\hline & " ruber. & $\cdot$ & . & & Do. & Kirghese Steppe & . & \\
\hline & rzonera purpurea & . & . & & Scoranera & B River Jenishke & 4 to & $8,000^{\prime}$ \\
\hline & $" \quad \quad \boldsymbol{\beta}$ subincana & & * & & Do. & B River Merke, & . & $4,000^{\prime}$ \\
\hline & $"$ " & & - & & & Mountains & 4 & \\
\hline & $\boldsymbol{\beta}$ linearifoli & & . & & Do. & Barnaul, Susun & & \\
\hline
\end{tabular}




\begin{tabular}{|c|c|c|c|c|c|c|c|c|c|}
\hline \multirow{5}{*}{$\begin{array}{l}\text { No. } \\
640 . \\
641 .\end{array}$} & \multicolumn{5}{|c|}{ Name in Latio and English. } & Locality. & \multicolumn{2}{|c|}{$\begin{array}{l}\text { Time of blos. } \\
\text { som or fruit. }\end{array}$} & \multirow{2}{*}{$\begin{array}{c}\begin{array}{c}\text { Eleva- } \\
\text { tion. }\end{array} \\
8,500^{\prime}\end{array}$} \\
\hline & Scorzonera $\gamma$ intermedis & & & & Scorsonera & $B C$ Mountain 1 & Passes, & & \\
\hline & , Marschallia & & & & Do. & $B C$ Vierny & & . & $2,500^{\prime}$ \\
\hline & tuberosa $\beta$ & . & & & Do. & Kly in Zaisa & in Mou & untains & \\
\hline &,$\quad \gamma$ crispa & . & ${ }^{*}$ & & Do. & B Keyssyk-Au & 8. $\quad$ & . & \\
\hline 642. & Picris hieracioides & . & & & Yellone Succory & Kokpekty & . &. & \\
\hline 643. & Lactuca undulata & & & & Lettuce & A Ili & . & . May & \\
\hline 644. &,$\quad$ viminea, var. $\beta$ & & & & Do. & A River $11 \mathrm{i}$ & . & 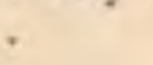 & $2,000^{\prime}$ \\
\hline 645. & $"$ songorica. & • & & & Do. & B River Assy & . & - & $5.000^{\prime}$ \\
\hline 646. & Chondrilla juncea $\beta$ & . & & & $?$ & A Ili Yalley & & - & $2,000^{\prime}$ \\
\hline 647. & , brevirostris & , & " & & ? & Chinguildy & & - & \\
\hline 648. & Taraxacum officinale & . & & & Dandelion & District of $Z$ & aisan. & . & \\
\hline 649. & , caucasicum & & & & Do. & Kly & & . & \\
\hline$\therefore$ & $\beta$ glabrum & $\dot{m}$ & & & Do. & C Sary-djas G] & acier. & * & $9,000^{\prime}$ \\
\hline 650. & glaucanthun & $\mathbf{n}$ & & & Do. & guildy & & . & \\
\hline 651. & "Steveni . & inlus & & & Do. & djas G1 & acier. & 8,50 & $0-9,900^{\prime}$ \\
\hline $65^{2}$. & Streptorhamphus hispid & $\begin{array}{l}\text { lulus } \\
\text { ica }\end{array}$ & . & & Hawol's Beard & Tamgaly $\mathrm{Pa}$ & & • & 1.200 \\
\hline $\begin{array}{l}653 . \\
654\end{array}$ & $\begin{array}{c}\text { Crepis rigida, } \beta \text { songori } \\
\text { tectorum }\end{array}$ & ic: & & & $\begin{array}{l}\text { Hawok's Beard } \\
\text { Do. }\end{array}$ & $\begin{array}{l}\text { Kirghese St } \\
\text { Gurjewsk }\end{array}$ & ерpe & . & \\
\hline $\begin{array}{l}654 . \\
655\end{array}$ & $\begin{array}{l}\text {, tectorum } \\
\text {, multicaulis }\end{array}$ & : & & & $\begin{array}{l}\text { Do. } \\
\text { Do. }\end{array}$ & $A$ B Tekin-Bul & ok & . & to $7,000^{\prime}$ \\
\hline & , $\beta$ congesta . & + & & & Do. & C Sary-djas & & . & $9,000^{\prime}$ \\
\hline 656. & ", sibirica . & . & & & Do. & C Karkara Pla & teau & . & $06.000^{\prime}$ \\
\hline 657. & ,, lyrata .. & • & & & Do. & Quarries of & Salair. & . & \\
\hline $65^{8}$. & Heteracia Szovitsii & . & & & ? & A Zailijsay Pic & uet. & $\mathbf{I}, 80$ & $0-2, \infty 00^{\prime}$ \\
\hline 659. & Sonchus oleraceus. & . & & & Sonothistle & Quarries of & Salair. & - & \\
\hline 660. & ", arvensis var. & & & & Do. & B River Alma & & . & \\
\hline $\begin{array}{l}661 . \\
662\end{array}$ & Youngia diversifolia & & & & & South Altai & . & : & \\
\hline $\begin{array}{l}662 . \\
66_{3} .\end{array}$ & $\begin{array}{c}\text { flexuosa } \\
\text { Mulgedium azureum }\end{array}$ & & & & Sowthistle & $B$ River Alma: & & . & $7, \infty 000^{\prime}$ \\
\hline 664 & " tataricum & & & & Do. & B River Almat & & . & 5,500 \\
\hline$\cdot$ & ," $\quad \beta$ floccosum & & & & Do. & Kokpekty & . & * & \\
\hline & $\gamma$ integrum & & & & $\begin{array}{l}\text { Do. } \\
\text { Do. }\end{array}$ & River Ili & Salair & . & \\
\hline 660. & Hieracium vulgatum & & & & $\begin{array}{l}\text { Hawwiveed } \\
\text { Do. }\end{array}$ & C Karkara Pla & Salair. & 6,50 & $\infty 0 \cdot 7,500^{\prime}$ \\
\hline $\begin{array}{l}667 . \\
668 .\end{array}$ & $\begin{array}{ll},, & \text { umbellatum } \\
,, & \text { virosum }\end{array}$ & & & & Do. & B Almaty Vall & & . & $5,500^{\prime}$ \\
\hline
\end{tabular}

\section{XLIV.-CAMPANULACEAE 10 (15), Campanula Family.}

\begin{tabular}{|c|c|c|c|c|c|c|c|c|c|c|}
\hline 669. & Glossocom & ia clematidea & & . & 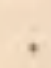 & $?$ & B C River Mer. & & & \\
\hline 670. & Phyteuma & argutum & . & . & . & Rampions & c Chirchik & . & . July & \\
\hline & , & Sewerzowi & . & , & . & Do. & Turkistan & . & $-\quad 1$ & \\
\hline & Campanul: & a sibirica & & . & , & Bell-Flonoer & S. Altai & & & \\
\hline & , & glomerata & & . & • & Do. & B Quarries of S & Salair & & 4,000 \\
\hline & $"$ & rapunculoid & $\operatorname{des} \beta$ & * & - & $\begin{array}{l}\text { Do. } \\
\text { De. }\end{array}$ & B C Issyk-Kul & & & $4,000^{\prime}$ \\
\hline & 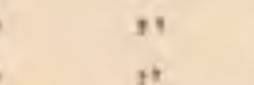 & $\begin{array}{l}\text { Steveni, et } \\
\text { rotundifolia }\end{array}$ & vars. & $\dot{.}$ & : & Hair Bell & Quarries of: & Salai & . Ju & \\
\hline & s & Sewerzowi & & isare & - & $?$ & $\begin{array}{l}C \text { Boroldai } \\
B \text { Ak-kia. }\end{array}$ & - & - & $6.000^{\prime}$ \\
\hline
\end{tabular}

XLV.-PYROLACEAE 3 (6), Winter Green, or Fyrola, Family.

679. Pyrola rotundifolia

680. ", secunda

$68 \mathrm{r}$. Moneses grandiflora

\section{Winter Grecn A Kopal Chain . . \\ Do. $\quad B$ River Almaty}

Do. $\quad B$ River Almaty
7,000 6.500 $6,500^{\prime}$ 


\begin{tabular}{l|l} 
No. Name in Latin and English. & Locality. $\begin{array}{c}\text { Time of blos- } \\
\text { som or fruit. }\end{array}$ \\
\hline
\end{tabular}

XLVI.-PRIMULACEAE 16 (18), Primrose Family.

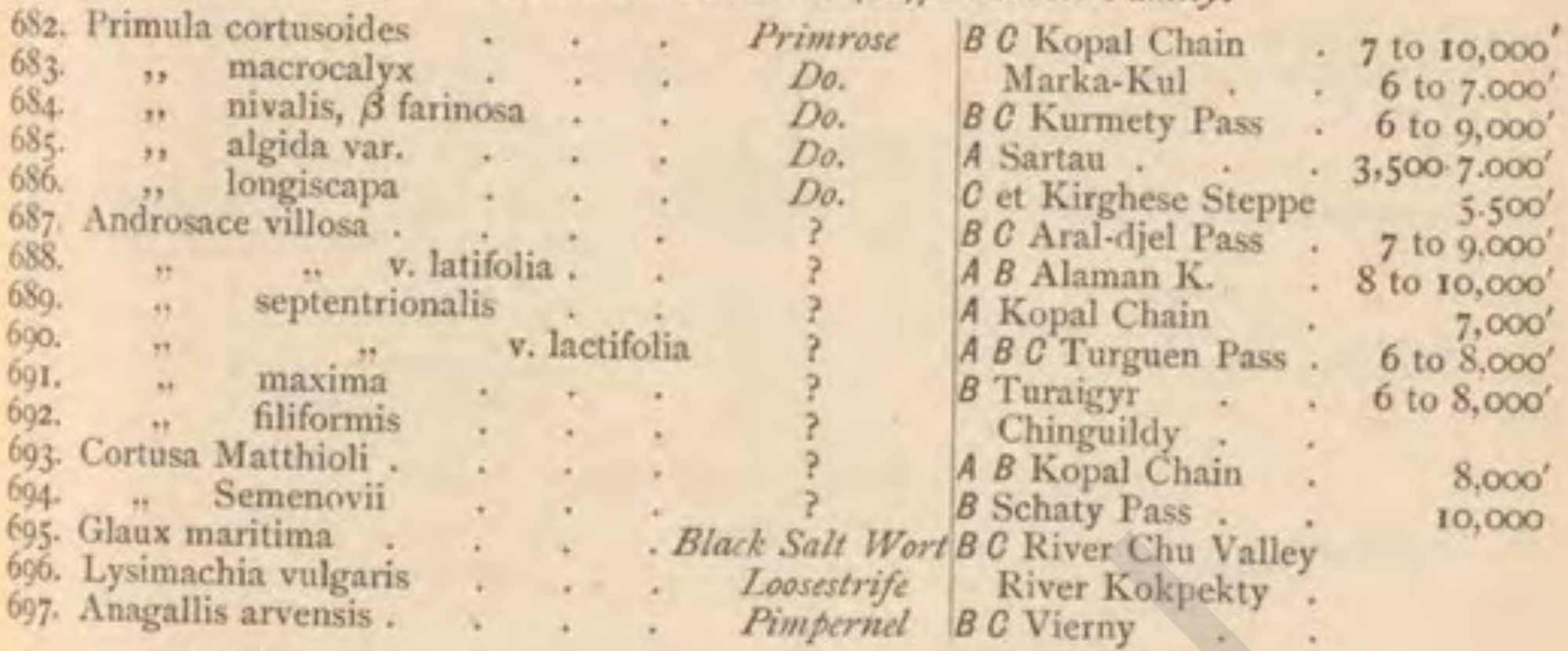

XLVII,-OLEACEAE I (2), Olive Family.

698. Fraxinus potamophila ( $n$. s.)

Ash Tree |A Ili, Bugun . 1 to $2.500^{\prime}$

XLVIII.-APOCYNACEAE I (2), Dogbane and Perizinkle Family.

699. Apocynum venetum . . . Fly Trap | Kirghese Steppe .

\section{XLIX.-ASCLEPIADEAE 2 (o), Milkweed Fanily.}

700. Cynanchum acutum

701. $\quad$ " $\beta$ longifolium :

Chinguildy

Mountains of Dolonkara

\section{L.-GENTIANACEAE 20 (14), Gentian Family.}

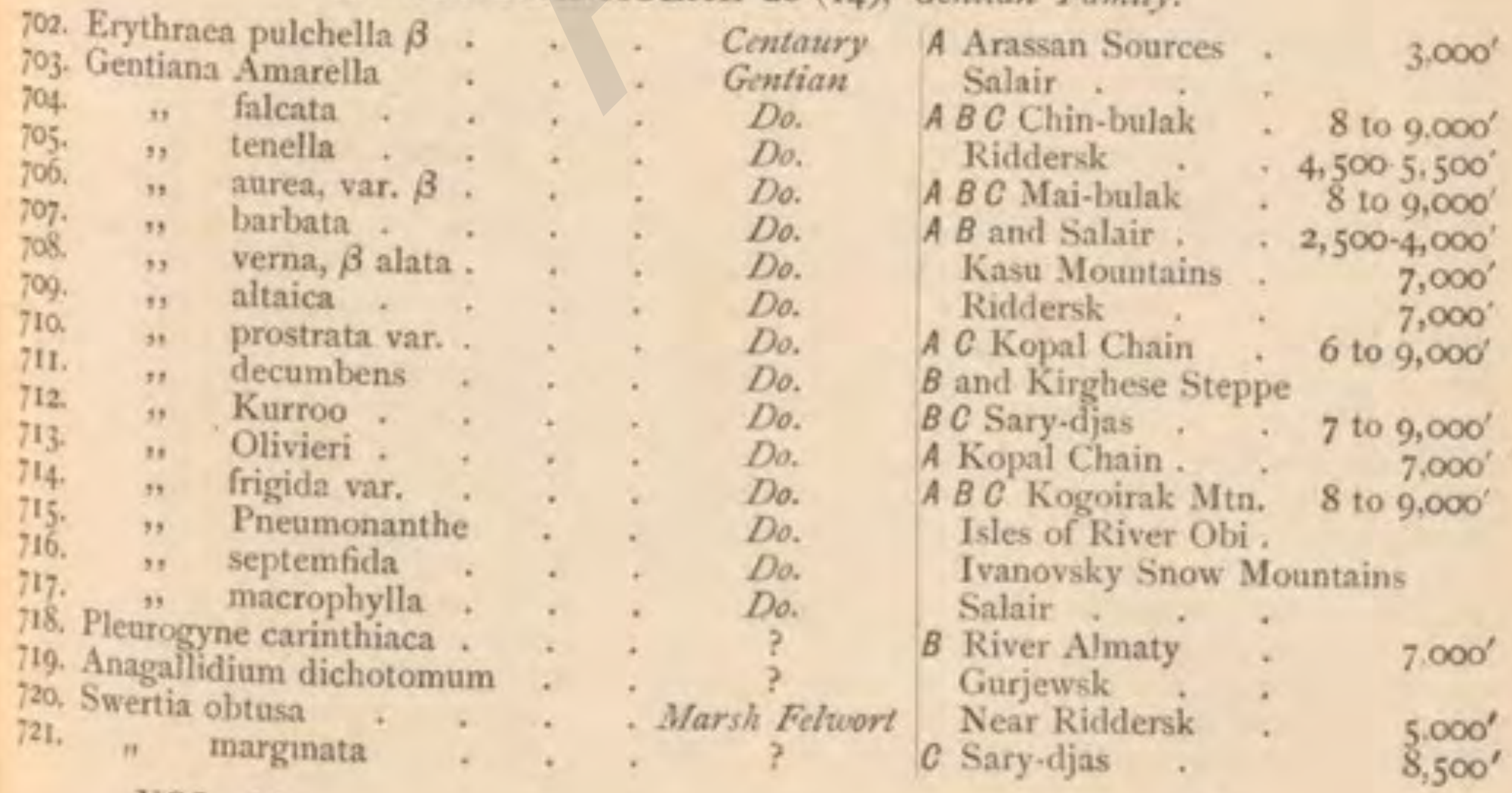

VOL. II. 


\begin{tabular}{l|ll}
\hline No. Name in Latin and English. & Locality. & $\begin{array}{c}\text { Time of blos. Eleva- } \\
\text { som or fruit. }\end{array}$ \\
tion.
\end{tabular}

\title{
LI.-POLEMONIACEAE 2 (1), Polemonium Fanily.
}

722. Phlox sibirica

\author{
Phlox \\ Gurjewsk
}

723. Polemonium caeruleum . . Facob's Ladder B C Turaigyr

\section{LII.-CONVOLVULACEAE 6 (3), Convolvulus Family.}

724. Convolvulus Gortschakovii . . Bind Weed

725. " . . . Do.

726. ", subsericeus . Do.

727. " Pseudo-Cantabrica . Do.

728. "N Semenovii (n.s.) Do.

729. ", arvensis var. . . Do.

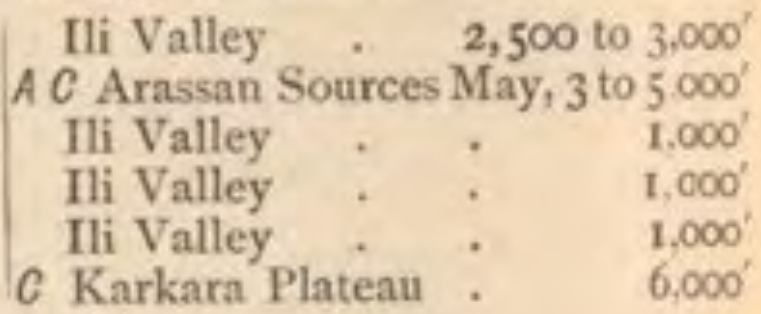

\section{LIII,-CUSCUTEAE 2 (4), Dodder Family.}

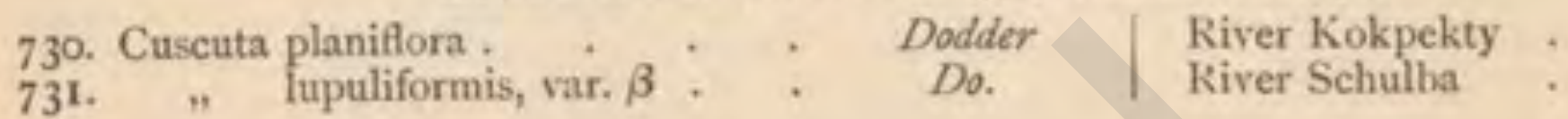

\section{LIV,-BORAGINEAE 35 (26), Borage Family.}

732. Heliotropum europaeum var.

733. Nonnea picta

734. Anchusa italica

735. " myosotidiflora.

736. Onosma echioides, et vars.

737. " Gmelini .

738. " simplicissimum .

739. Lithospermum officinale

740. Pulmonaria mollis .

741. Arnebia cornuta

742. . perennis

743. Myosotis palustris

744. " caespitosa

745. $"$ silvatica.

. $\quad \boldsymbol{\beta}$ alpestris

stricta

747. Eritrichium villosum, et vars.

748 . $\quad$. sericeum

749.,$\quad$ rupestre

750. " pectinatum .

751. $"$ pedunculare

752. Echinospermum Redowskii, et vars. Prickly Samphire 753. $"$ microcarpum, et vars, Do.

754 . " $\quad$ deflexum . . Do.

754

755.

756.

757.

",

,

,

",

Do.

barbatum . . $D o$.

Lappula

758. Heterocaryum rigidum

759. Asperugo procumbens

760. Cynoglossum officinale .

76r. ", viridiflorum

762. Solenanthus circinatus

763 . ". nigricans, et vars.

764. Rindera tetraspis

765. " echinata

766. Rochelia lesocarpa
Heliotrope $A$ and Kinghese Steppe

A B Kayssyk Pass. I to 4,000 Alkant Zarevna-Alexandrovsk May

Do. Zarevna-Alexandrovsk May Kirghese Steppe .

Bala Kaldjir

$B$ River Merke.

A Karatal Valley

Marka-Kul

A Ili Valley

C River Tekes.

Zaisan district June Quarries of Salair. June Kirghese Steppe . May, June

A Kopal Chain. . 7,000

$B$ Turaigyr Pass $\quad 8,000^{\prime}$

A B C River Tekes : $\quad 7,800^{\circ}$ Gurjewsk

Zmeinogorsk

B Tabulgaty Pass

The Black Irtish

Salair

A B C Turkistan

$C$ and Zaisan Mountains

Quarries of Semenowsk

Sergiopol

Kokpekty : July, August

Do.

Madwort

A Ili Valley

$A$ and Turkistan

Hound's Tonguc River Kokpekty

Do. $\quad B$ River Assy

? A River Lepsa.

BC Karkara : 4 to $6.000^{\prime}$

$A$ and Kirghese Steppe

Boroldai

River Koldjir . 


No. Name in Latin and English. $\mid$ Locality. $\begin{gathered}\text { Time of blos. } \\ \text { som or fruit. }\end{gathered}$

LV,-SOLANACEAE 6 (5), Nightshade Family.

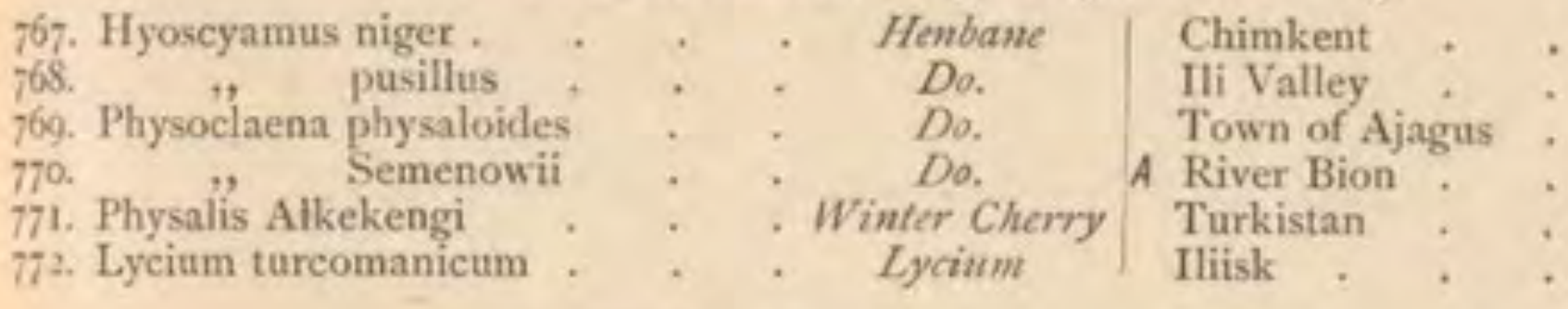

LVI. SCHROPHULARIACEAE 50 (55), Figwort Family.

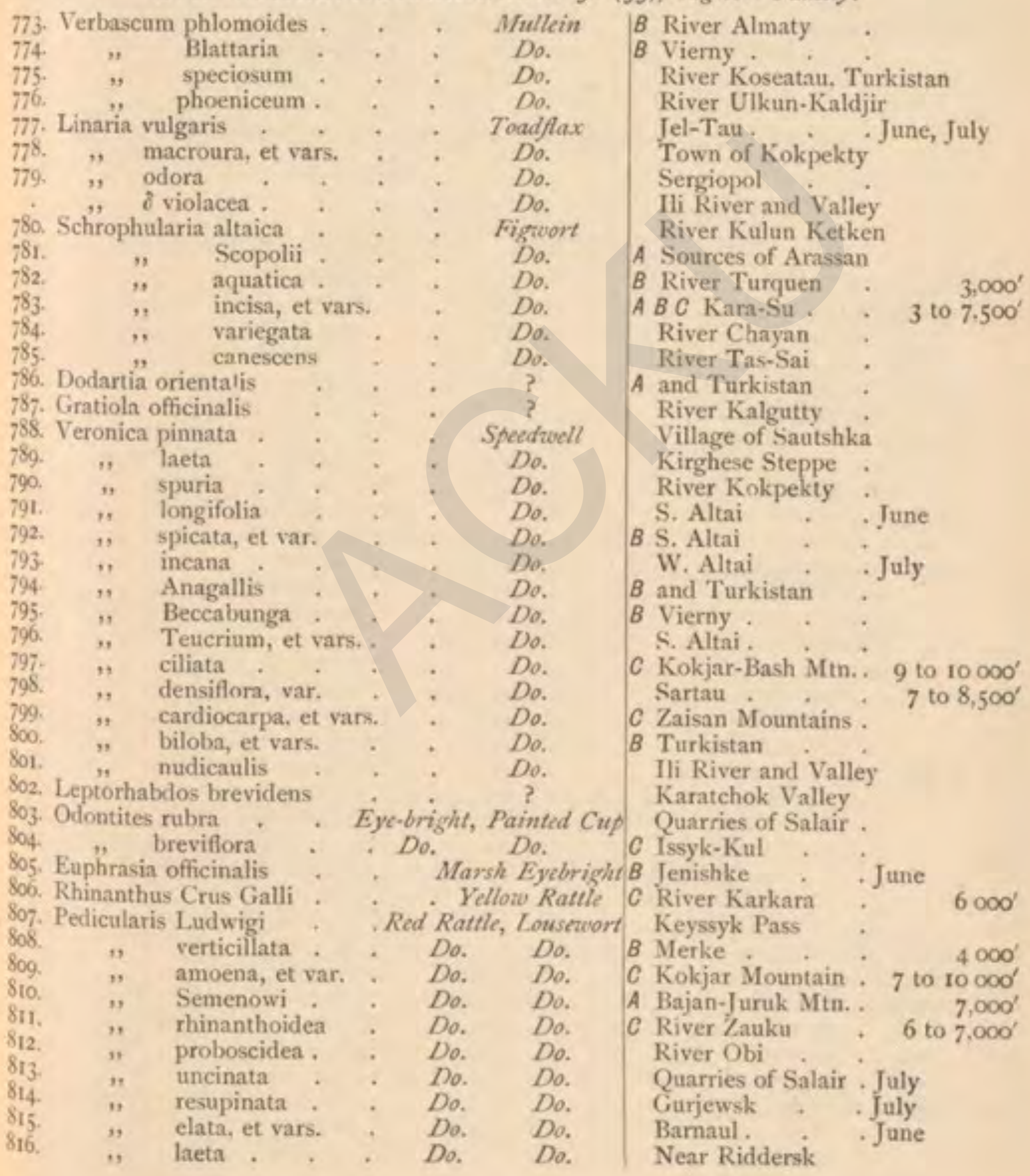




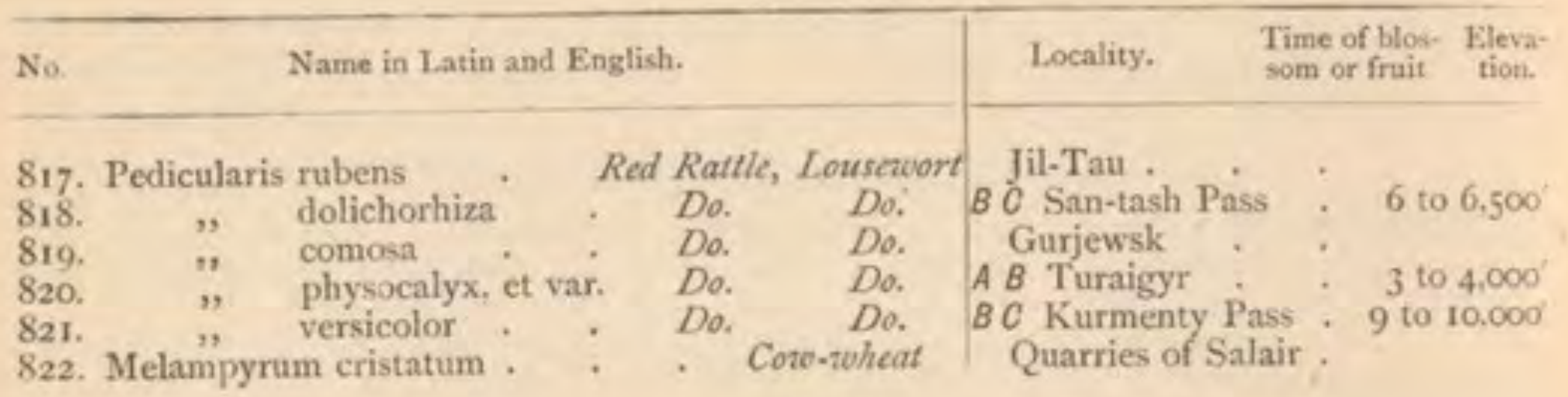

LVII.-OROBANCHACEAE 4 (II), Broom Rape Family.

823. Philipaea salsa

824 . Orobanche amoena

825 ammophila

826 .

cernua

\section{Broom Rape \\ Do. \\ Do.}

A River Lepsa.

A River Ili

Zaisan district

A Kyssyk Pass.

LVIII.-SELAGINACEAE 1 (o), Globularia Family.

827. Gymnandra borealis var. . . ? ABC Zauku Pass

LIX.-LABIATAE 50 (57), Labiate, or Mint, Family.

828 Elsholtzia cristata .

829 . Mentha sylvestris .

830. " arvensis

83 r. Lycopus exaltatus .

832 . Origanum vulgare

833. Thymus serpyllum, et vars. . .

834 . Hyssopus officinalis var.

835. Salvia Sclarea

836. $\quad$ sylvestris

837. Ziziphora clinopodioide

$\delta_{38}$. , tenuior.

839. Nepeta lavandulacea

840 ." densiflora

841. ", nuda.

842 . "Glechoma

843 ", ucranica

844 . Dracocephalum stamineum

845

846 .

847.

848.

849 .

850.

851 .

852 .

853 .

854. Lallemantia Royleana.

imberbe

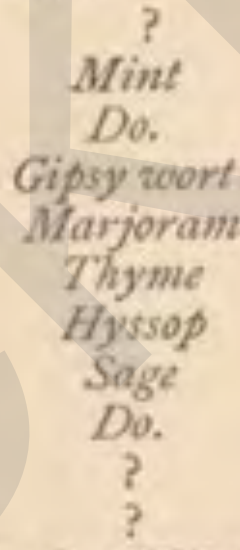

Ground Ivy

?

Dragon's Head

integrifolium

nutans .

alpina .

peregrinum

heterophyllum

Ruyschiana . $\gamma$ alpinum

855. Prunella vulgaris var.

856 . Scutellaria alpina var.

857 . $" ~ o n$ ontalis var.

858. " " Severzovii.

859. " galericulata .

860. Betonica officinalis var.

861. Stachys sylvatica

862. " palustris var.
Cat Mint

Do.

Do.

Do.

Do.

Do.

\author{
Gurjewsk \\ Vierny . \\ B Almaty Valley . 4 to 6,000 \\ Ili Valley \\ B Chilik \\ A B Mai-Bulak: \\ Ulba Valley in Altai \\ Boroldai . May \\ A River Kokpekty \\ A B C Karkara Plateau July \\ River Chilik. \\ Gurjewsk \\ B Tabulgaty Pass \\ C Issyk. Kul \\ Takyr \\ Salair \\ April \\ 5 to 6.000 \\ $5,000^{\prime}$
}

C Zauku Valley

7 to 8,000

A B Kopal Chain

A C Tekes Valley

A B River Talgar

6 to 8,000

2 to $2,500^{\prime}$

River Takyr.

$A B$ and Marka-Kul . 6 to $8,000^{\circ}$

Do.

Do.

Do.

Do.

Do.

?

Self Hea

Skull Cap

Lo.

Do.

Do.

Betony

Wound wort

Do.
A B Turguen Pass 7,500 to $8,000^{\circ}$

$C$ and Kinghese Steppe Zarevno-Nikolaievsk

C River Karkara $\quad 6,000$ Ili Valley Chirchik Barnaul.

A C River Tib . May, 1 to 5,000 Chimkent . May

Salair

Chirchik

Salair

District of Zaisan 


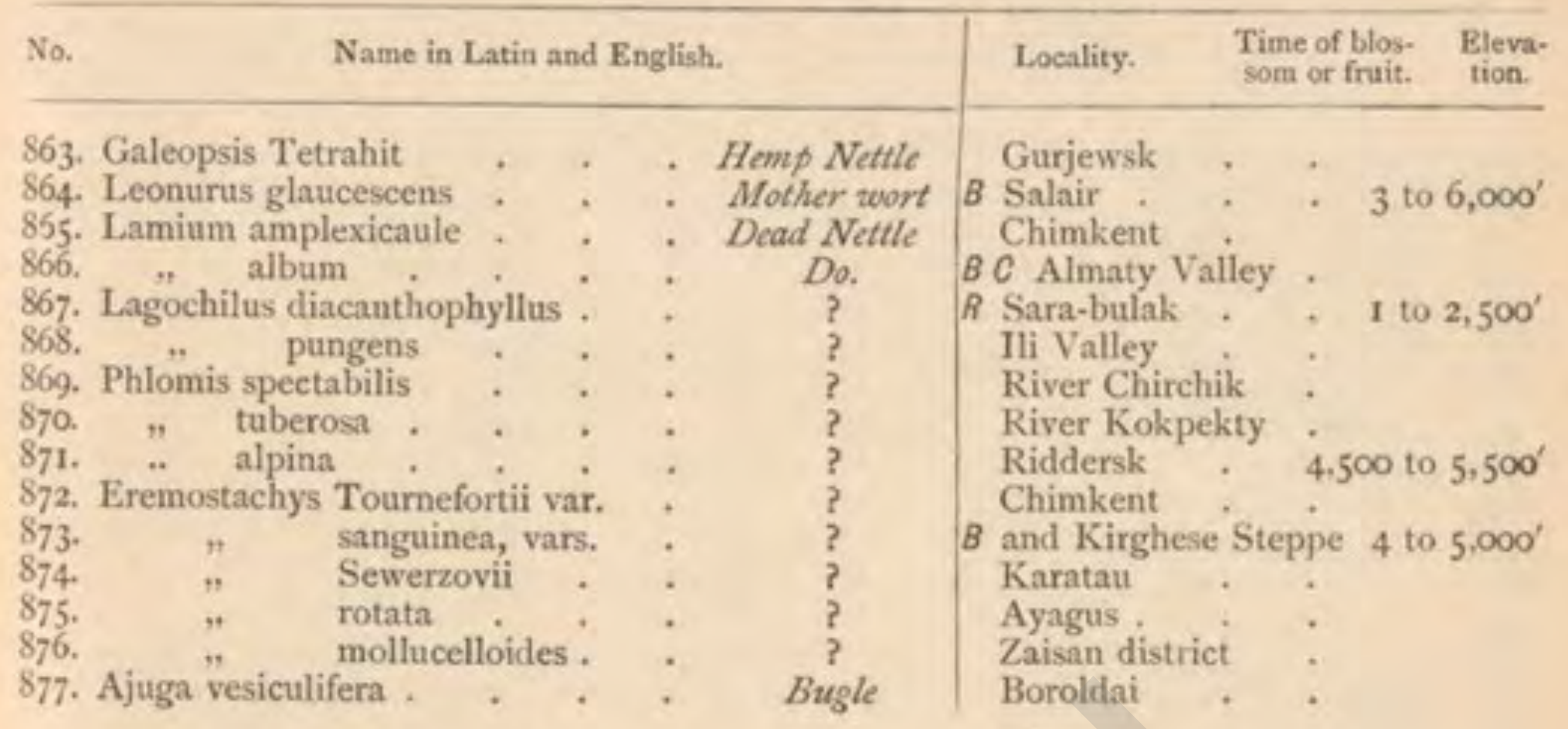

\section{LX.-PLUMBAGINACEAE II (7), Leadwort Family.}

878. Acantholimon diapensioides
879. Hohenackeri $\beta$

LXI.-PLANTAGINACEAE 6 (6), Plantain Family.

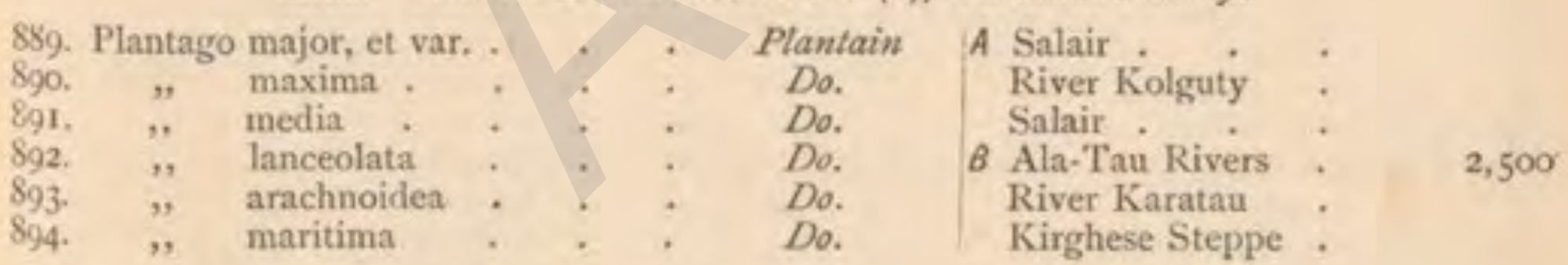

\section{LXII.-CHENOPODIACEAE 34 (28), Goosefoot Family.}

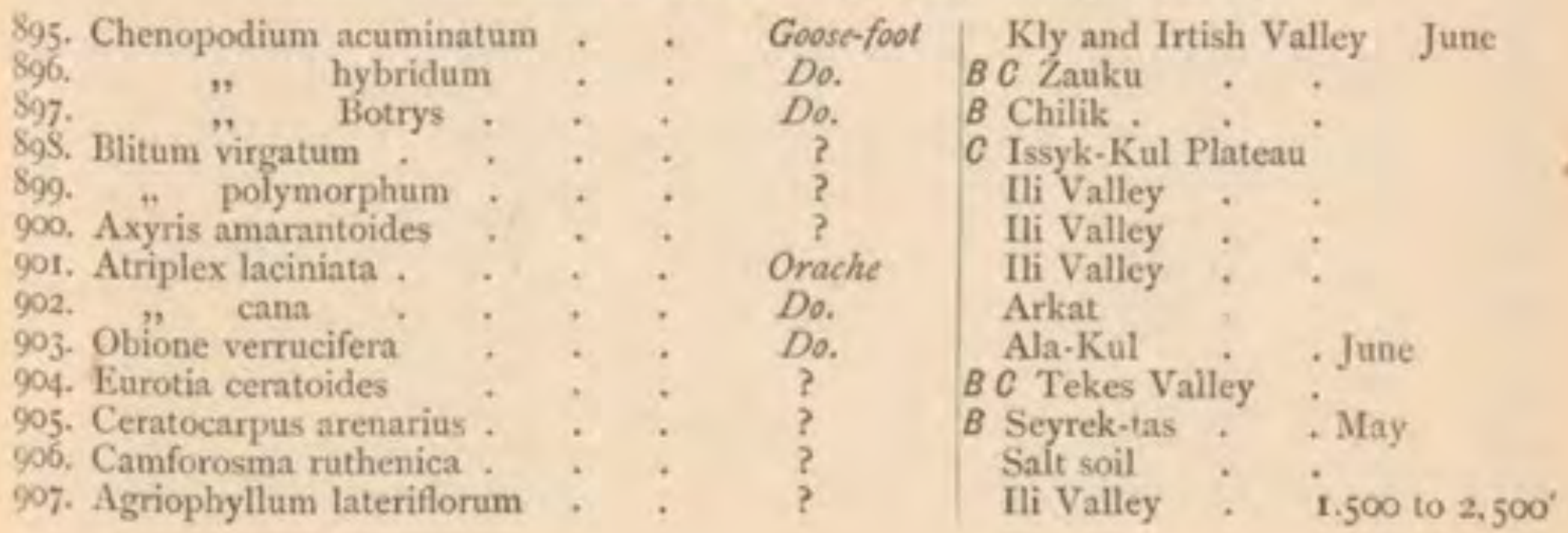




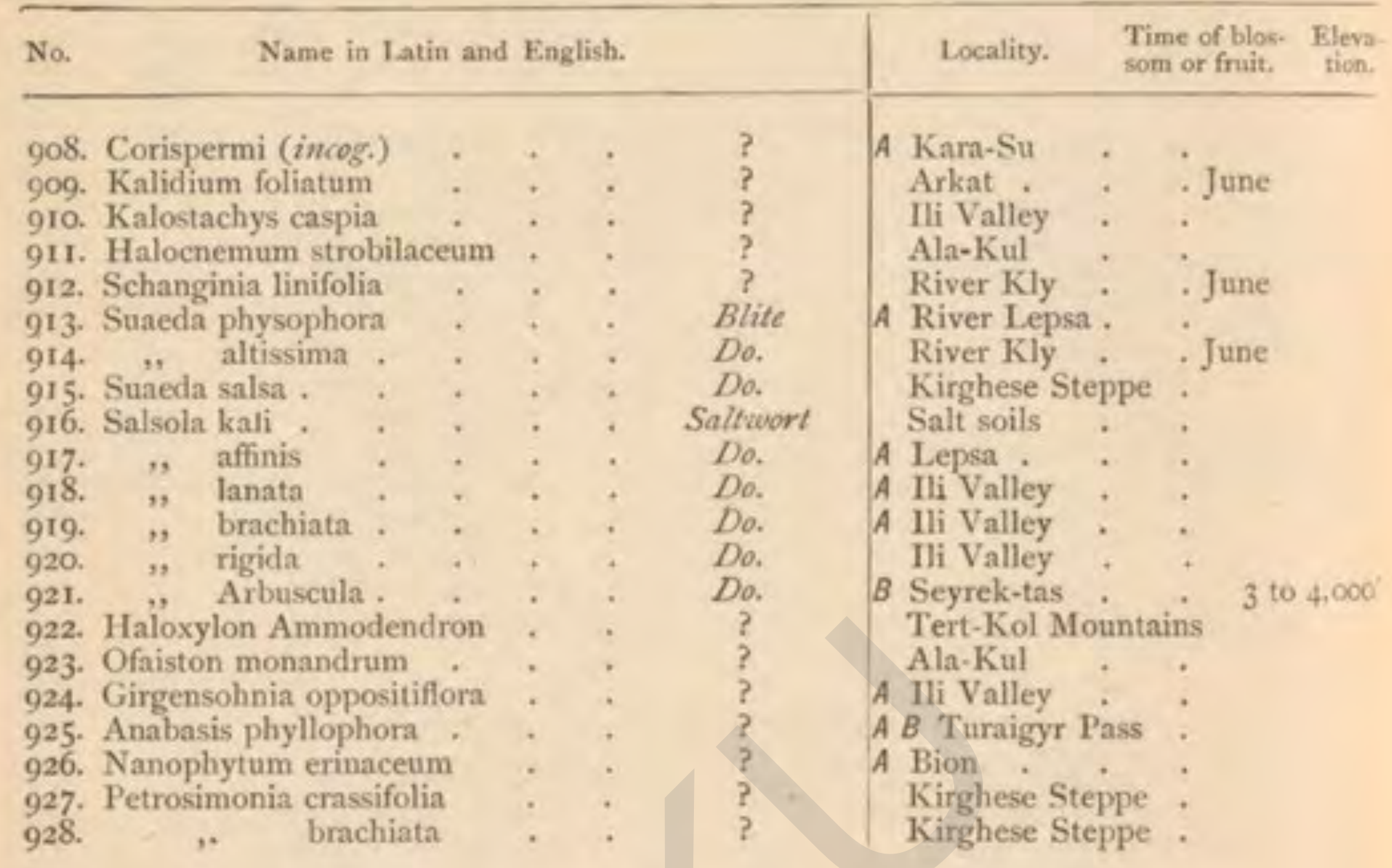

\section{LX11I-AMARANTACEAE 1 (1), Amaranth Family.}

929. Amarantus paniculatus

\section{Amaranth | A S. of Kopal}

\section{LXIV.-POLYGONEAE 25 (29), Buckioheat Fanily.}

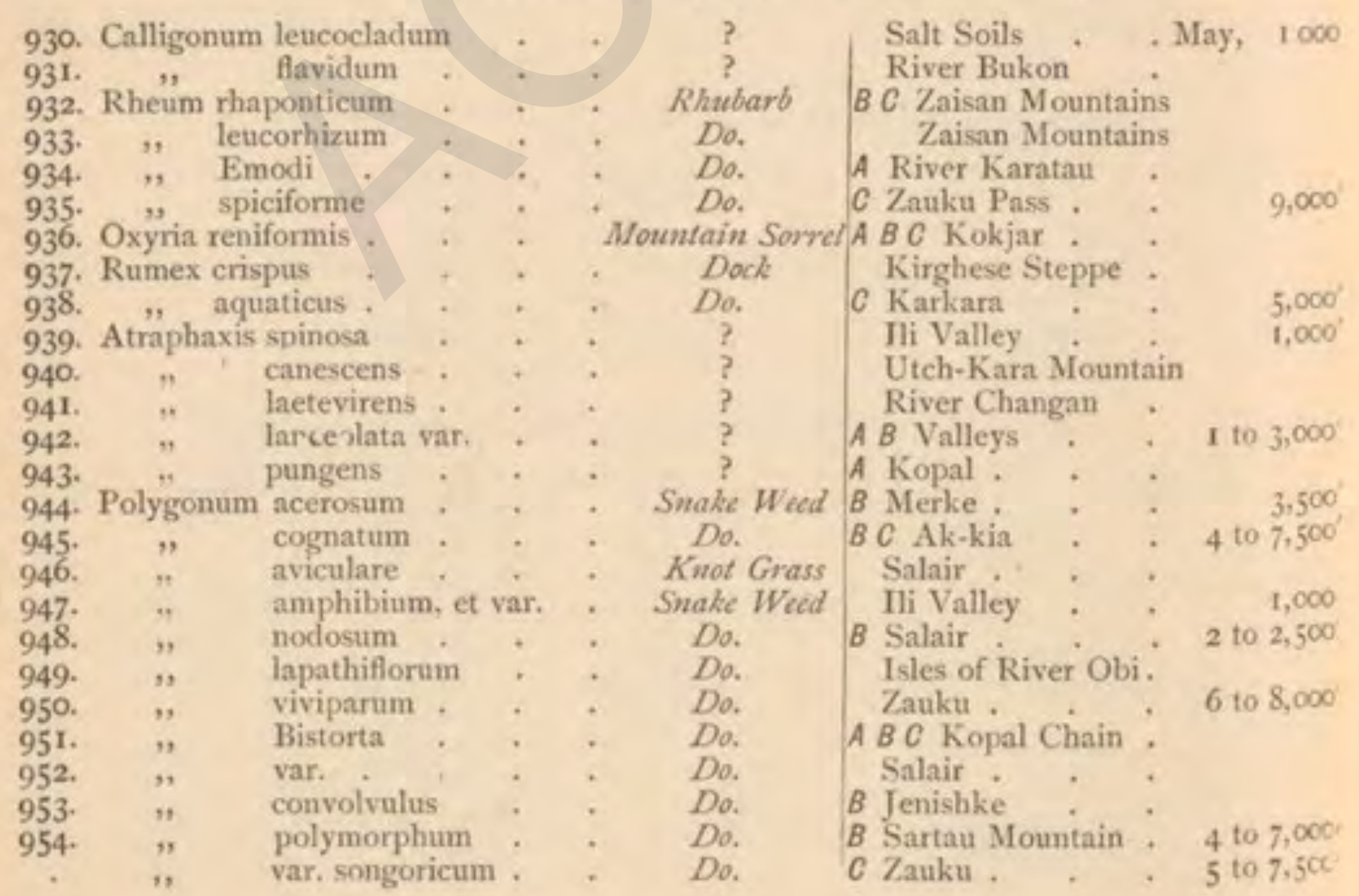




\begin{tabular}{l|l|l}
\hline No. Name in Latin and English. & Locality. & $\begin{array}{c}\text { Time of blos. } \\
\text { som or fruit. }\end{array}$ \\
\hline
\end{tabular}

LXV.-SANTALACEAE 3 (2), Sandalwood Family.

955. Thesium multicaule . Flax-leaved Tond Flax B Seyrek-tas . 4,000

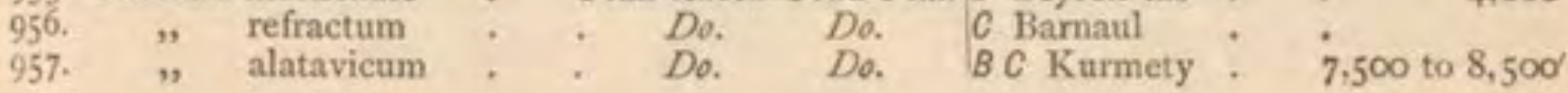
LXVI.-THYMELAEAE 3 (2), Mesereum Family. 958. Daphne altaica Daphne Ulba Valley.

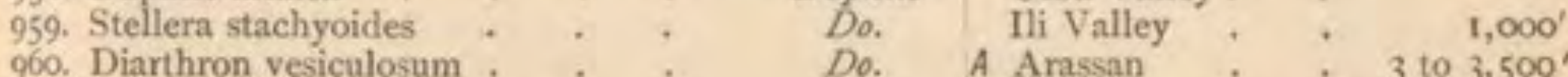

\section{LXVII.-ELAEAGNEAE 2 (1), Oleaster Family.}

961. Elacagnus hortensis

Oleaster | Turkistan

962. Hippophaë rhamnoides

Sea Buckthorn C Issyk-Kul Plateat

1,000 3 to 4,000

LXVIII.-EUPHORBIACEAE 16 (17), Spurgetworts.

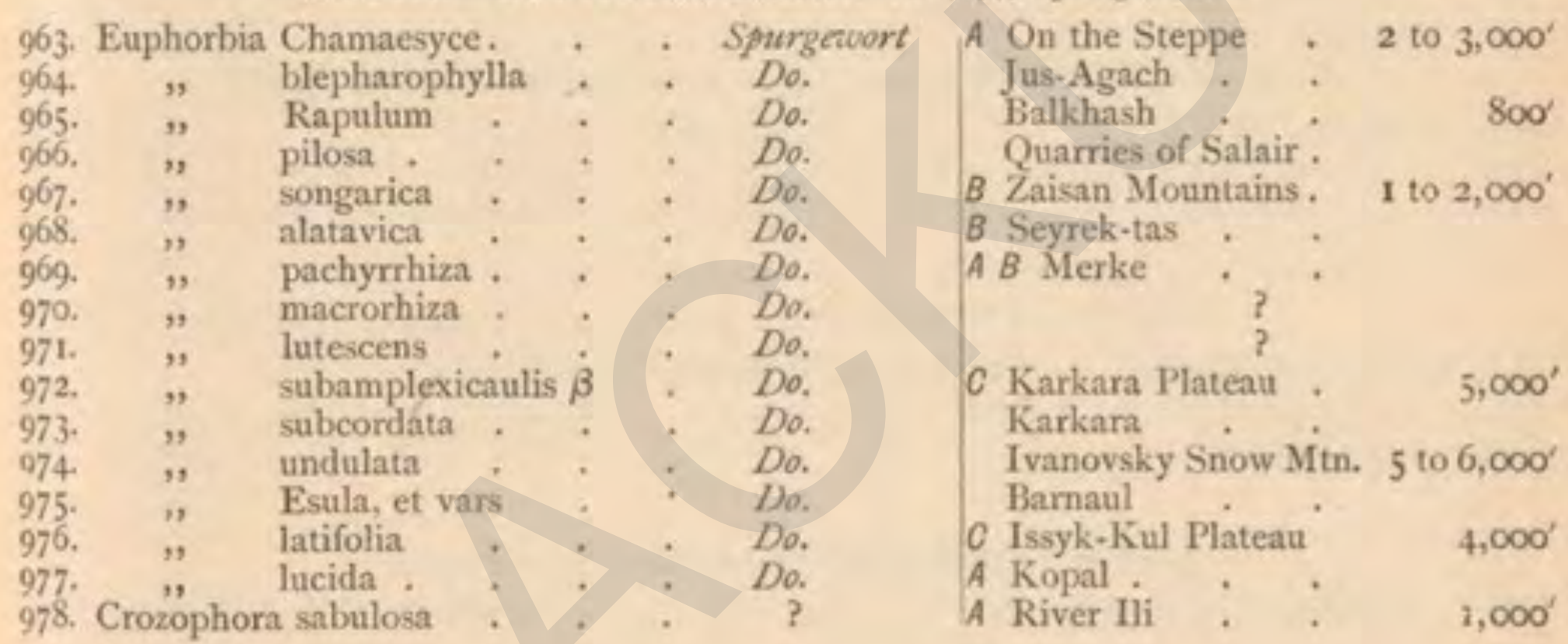

\section{LXIX.-SALICINEAE 13 (37), Willow Family,}

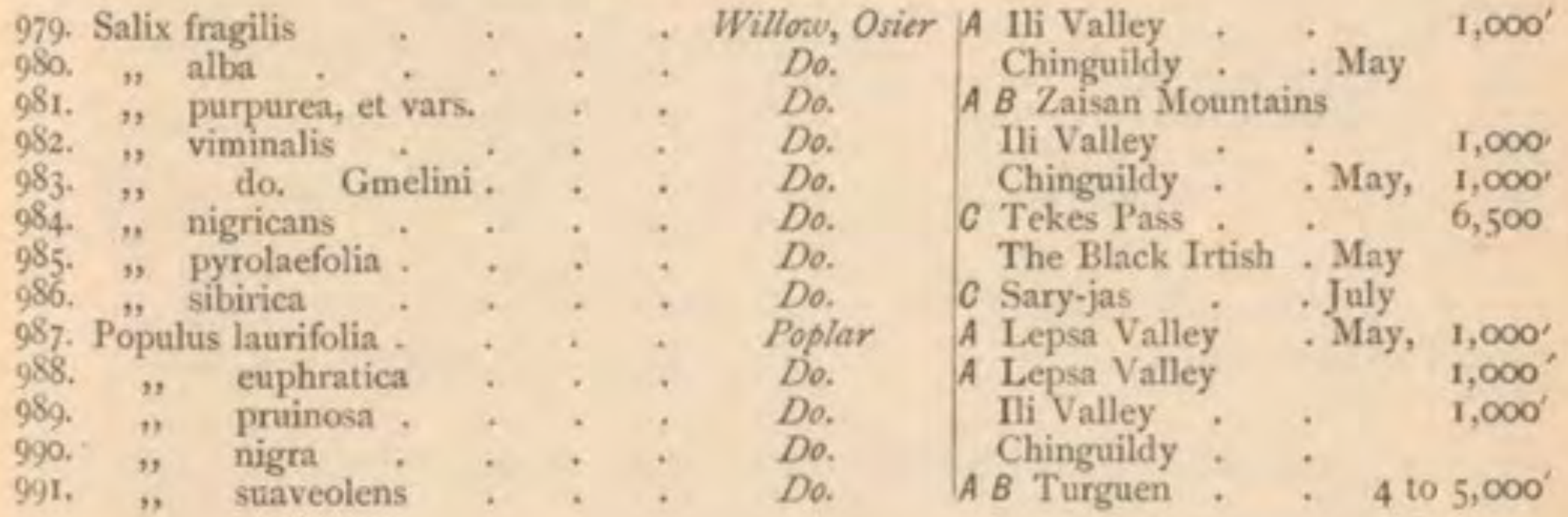

LXX-CANNABINEAE I (o), Hemp Family.

992. Cannabis sativa . . . Hemp | A BC Zaisan July, 1,500 to 7,500 


\begin{tabular}{|c|c|c|c|}
\hline No. & Name in Latin and English. & Locality. & $\begin{array}{l}\text { Time of blos: } \\
\text { som or fruit. }\end{array}$ \\
\hline
\end{tabular}

LXXI-URTICACEAE 2 (6), Nettle Family.

993. Urtica cannabina . . . Stinging Nettle B C Mai-bulak . 994. Parietaria micrantha . . Pellitory C Zauku Pass-. 3.500 to 5,000'

LXXII.-BETULACEAE I (9), Birch Family.

995. Betula alba, et var . . . Birch |C River Takyr

$5,000^{\prime}$

LXXIII,-GNETACEAE I (o), Tointed För Family.

996. Ephedra vulgaris . . . ? | B Turkistan . . 3 to 5,000

LXXIV.-ABIETINEAE (1), Fir and Pine Family.

697. Abies Smithiana . . . . Spruce Fir BC Marka-Kul

698. Pinus Ledebourii . . . . Fir. Barka-Kul

699. " sylvestris . . . Do. Sandy soils.

5 to 6,800

800

LXXV.-CUPRESSINEAE 3 (2), Yew, Juniper, Cypress Family.

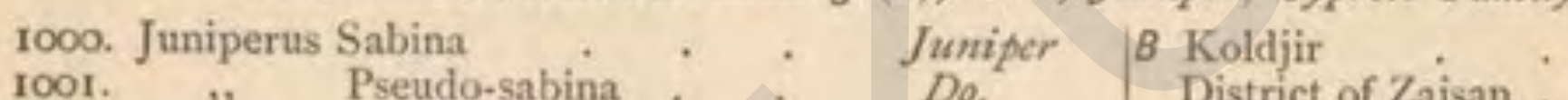

\begin{tabular}{ll|l} 
roo2. & Do. & $\begin{array}{l}\text { District of Zaisan . } \\
\text { nastrict of Zaisan . }\end{array}$
\end{tabular}

4 to 9,000

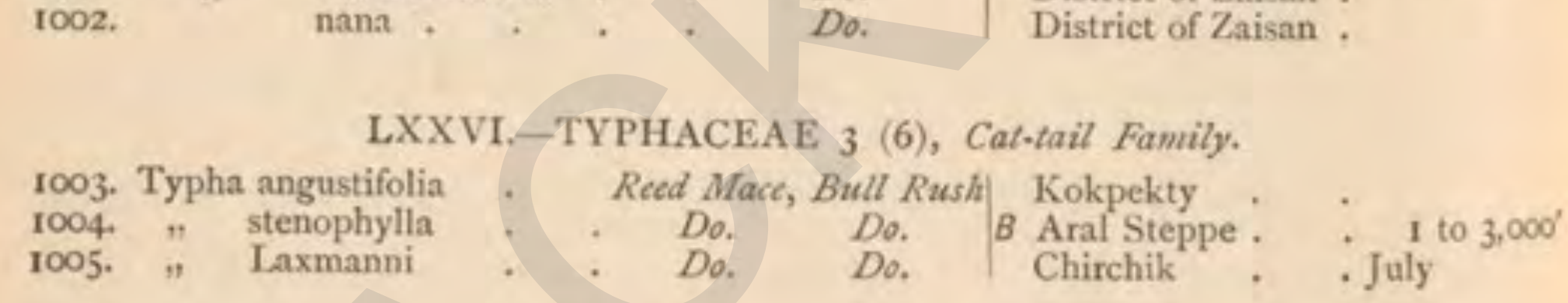

\section{LXXVII.-AROIDEAE I (3), Anum Family.}

1006-7. Eminium Ledebouri. ? ? | Boroldai . . May

\section{LXXVIII.-NAIADEAE 6 (3), Pondweed Family.}

1008. Naias major

? Aral See

roo9. Ruppia maritima $\vdots \quad$ : Tassel Pond Weed

roro. Zannichellia palustris . . Horned Pond Weed

IOI. Potamogeton natans . . . Pond Weed

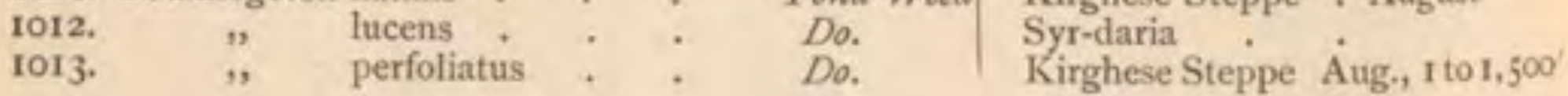

\section{LXXIX.-JUNCAGINEAE I (3), Allied to Water-Plantain Family.}

1014. Triglochin maritimum

Arronu Grass | Mai Chilik . . May

\section{LXXX.-ALISMACEAE 4 (5), Water-Plantain Family.}

1015. Alisma plantago, et var. . .Water-Plantain Aral Steppe . . June 1016. "ranunculoides. Do. BC Plateaus. July, 5 to 6,000

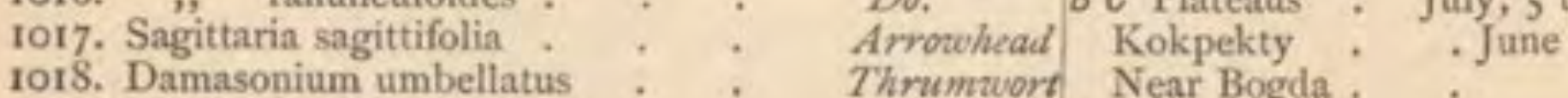




\begin{tabular}{l|ll} 
No. Name in Latin and English. & Locality. & $\begin{array}{c}\text { Time of blos- } \\
\text { som or fruit. }\end{array}$ \\
\hline
\end{tabular}

LXXXI.-BUTOMACEAE I (I), Flowering Rush Family.

1019. Butomus umbellatus . . Flowering Rush | Kokpekty . June

\section{LXXXII.-ORCHIDEAE 6 (42), Orchis Family.}

to20. Orchis latifolia, et vars.

Orchis BC South Altai

1021. " incarnata .

1022. Gymnadenia conopsea .

1023. Plantanthera viridis, et vars.

1024. Goodyera repens .

1025. Cypripedium macranthum ,

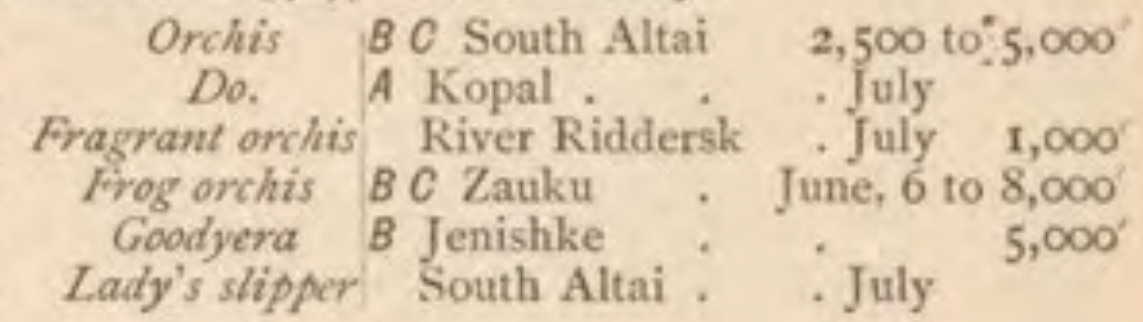

LXXXIII.-IRIDEAE 11 (6), Iris Family.

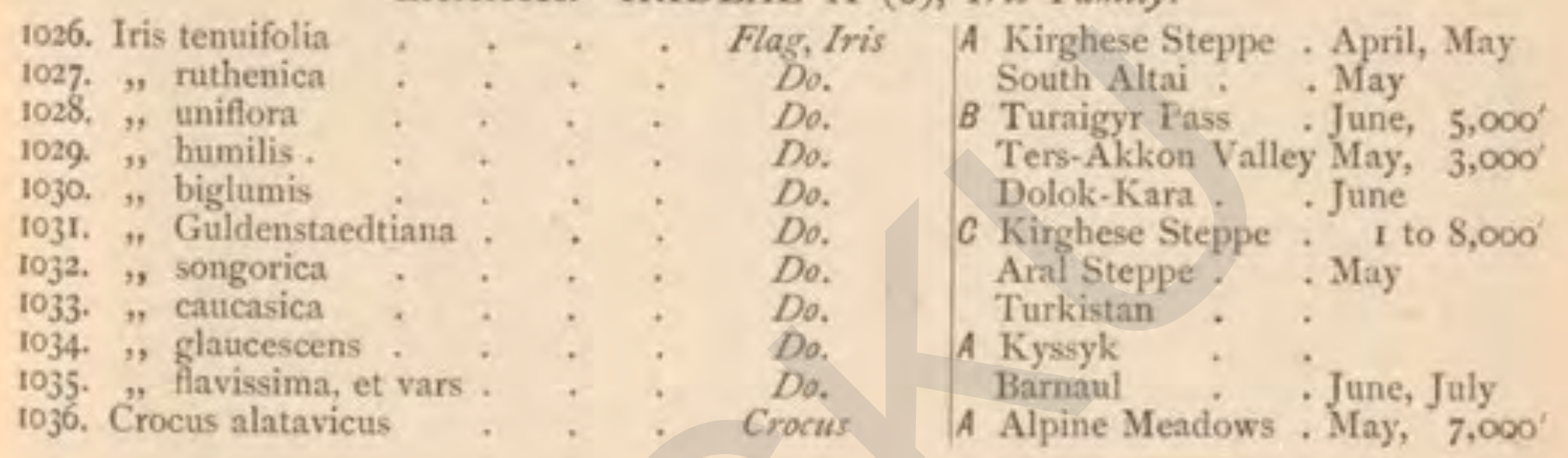

LXXXIV.-AMARYLLIDEAE 2 (5), Amaryllis Family.

1037. Ixiolirion tataricum, et vars. . Mountain lily $\mid B$ Turkistan . May, 2 to 3,000 1038. Lycoris Sewerzowi

ntain $l i l y \mid$
?

LXXXV.-SMILACEAE I (7), Smilax Family.

1039. Polygonatum Sewerzowi . Solomon's seal $\mid$ Turkistan . . May

LXXXVI.-IILIACEAE $5^{8}$ (23), Lily Family.

1040. Erythronium dens canis, et vars.

104I. Tulipa Gesneriana

Tritip

Do.

Do.

Do.

1043. ", altaica, et vars.

1044. " sylvestris, et var.

1045. Orithyia heterophylla

1046. Gagea lutea

1047. " filiformis .

1048. ", minima

1049. ," Liottardi .

1050. ", chlorantha

1051. " bulbifera

1052, Lloydia serotina

1053. Fritillaria minor

1054. "ruthenica.

1055. " verticillata.

1056.

1057 .

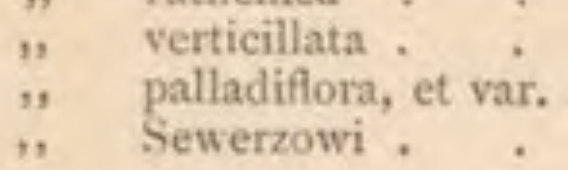

" palladiflora, et var.
Ivanovsky Snow Mtn. July, 6,000 Kirghese Steppe , April Kara-Kum Steppe May

A B C Talgar May, June, I to 6,000 $A B C \mathrm{Kgb}$. St. May, June, 1 to 5,000 $B C$ Tekes Pass July, 7,500 to 8,000 Star of Bethlehem Marka Lake. May, June

Do. Marka Lake. May, June

Do. Kinghese Steppe . April, Møy

Do. A Aral . May, 6,000

Do. A In the Steppe. May, 2,000

Do. A Kirghese Steppe May, 3,000

? AC Aral. May, 6 to 7,000'

Fritillary Kokpekty: April

Do. A Kirghese Steppe April, 2 to 3000 '

Do. $\quad$ On heath lands April

Do. $\quad A B C$ Issyk-bash May, 7 to 9,000

Do. Kara-Tau . May 


\begin{tabular}{|c|c|c|c|c|c|c|c|c|c|}
\hline \multirow{2}{*}{ No. } & \multicolumn{6}{|c|}{ Name in Latin and English. } & \multirow{2}{*}{$\begin{array}{l}\text { Locality. } \\
\text { Kirghese Ste }\end{array}$} & $\begin{array}{l}\text { Time of blos- } \\
\text { som or fruit. }\end{array}$ & \multirow{2}{*}{$\begin{array}{r}\begin{array}{r}\text { Elera. } \\
\text { tion. }\end{array} \\
1,000\end{array}$} \\
\hline & Rhinop & petalum Karelin & & . & . & $?$ & & eppe . May, , & \\
\hline 1059. & Lilium & martagon & & . & & Turk's cap Lily & Strauchern & . June & \\
\hline 1060. & Allium & Schönoprasum & & - & & Garlic & BC Kokjar I & June, 6,500 to & 8,000 \\
\hline $106 \mathrm{I}$. & , & atrosanguineur & & . & & Do. & $B C$ Almaty & - July, 5 to 7 & $7,500^{\prime}$ \\
\hline 1062. & $"$ & sabulosum & . & . & 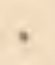 & Do. & Anal Steppe & June & \\
\hline 1063. & , & caeruleum & - & . & - & Do. & $B$ In the Stepp & . June, & $2,000^{\prime}$ \\
\hline 1064. & , & Pallasii . & . & . & 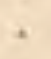 & Do. & Chinguildy & May & \\
\hline 1065. & $"$, & rubellum & , & . & . & Do. & Boroldai & May & \\
\hline 1066. & ", & stenophyllum & . & . & - & Do. & Dolon-Kara & - May, & $1,000^{\prime}$ \\
\hline 1067. & , & moschatum & - & • & + & Do. & B On rocks & 5,500 to & $6,000^{\circ}$ \\
\hline 968. & , & callidictyon & . & . & . & Do. & Syr-daria & . & \\
\hline 669. & " & subtilissimum & - & - & . & Do. & Kirghese Ste & eppe . Aug,, 1 & $1,000^{\prime}$ \\
\hline 1070. & , & obliquum & . & - & - & Do. & C Kiver Karka & ara June, : & 5.500 \\
\hline IO7I. & , & alataviense & . & - & . & Do. & $B C$ Tekes Pass & $5 s$ July, 5,500 to & 7,500 \\
\hline 1072. & $"$ & Semenovi & . & · & - & Do. & $B C$ Santash $\mathrm{Pa}$ & ass & \\
\hline 1073. & ", & Steveni var. & · & - & , & Do. & B Kirghese Ste & . Aug., & 4,000 \\
\hline 1074 . & ", & paniculatum & - & - & . & Do. & River Ural & Aug. & \\
\hline 1075. & ", & strictum . & • & - & - & Do. & 8 Salair. & - Aug, , & $6,000^{\prime}$ \\
\hline 1076. & $"$ & lineare . & * & - & * & Do. & Kokpekty. & - June & \\
\hline 1077. & $"$ & flavidum & - & • & - & Do. & Tarbagatai & 6 to & 7,000 \\
\hline 1078 & $"$ & nutans & - & - & * & Do. & On clay soil & . July & \\
\hline 1079. & , & angulosum & * & * & 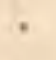 & Do. & Kokpekty & - June & \\
\hline 1080. & ", & inderiense & . & - & & Do. & Bugun . & . May & \\
\hline 1081. & " & tataricum & • & - & & Do. & Aral Steppe & May & \\
\hline 1082. & ", & Oreoprasum & - & & & Do. & $B$ On rocks & . Aug., & 4,000 \\
\hline $\begin{array}{l}1083 . \\
1084\end{array}$ &, & $\begin{array}{l}\text { platyspathum } \\
\text { caspium . }\end{array}$ & & & & $\begin{array}{l}\text { Do. } \\
\text { Do. }\end{array}$ & A Kopal Chain & Aug, 7 to & $8,000^{\prime}$ \\
\hline $\mathrm{IOS}_{4}$ & , & $\begin{array}{l}\text { caspium . } \\
\text { Iliense }\end{array}$ & & $\dot{0}$ & & $\begin{array}{l}\text { Do. } \\
\text { Do. }\end{array}$ & Syr-daria & May & \\
\hline 1085. & , & $\begin{array}{l}\text { Iliense } \\
\text { tulipifolium, et }\end{array}$ & ivar. & & . & $\begin{array}{l}\text { Do. } \\
\text { Do. }\end{array}$ & Ifi Valley & + May, & 1,000 \\
\hline 1086. & $"$ & $\begin{array}{l}\text { tulipifolium, et } \\
\text { Sewerzowi }\end{array}$ & & . & ; & $\begin{array}{l}\text { Do. } \\
\text { Do. }\end{array}$ & A Ili Valley & May, & $1,000^{\prime}$ \\
\hline 1087 & $"$ & $\begin{array}{l}\text { Sewerzowi } \\
\text { Akaka }\end{array}$ & . & & & $\begin{array}{l}\text { Do. } \\
\text { Do. }\end{array}$ & Boroldai & . May & \\
\hline 1088. & $"$ & $\begin{array}{l}\text { Akaka } \\
\text { oreophilum }\end{array}$ & & 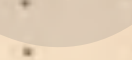 & & $\begin{array}{l}\text { Do. } \\
\text { Do. }\end{array}$ & Khokand Mo & ountains May & \\
\hline I089. & "' & $\begin{array}{l}\text { oreophilum } \\
\text { us altaicus, et v }\end{array}$ & var. & . & 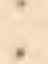 & Do. & $B$ On marl soil & Is Aug, 6 to & 7,000 \\
\hline 1090. & Eremur & $\begin{array}{l}\text { us altaicus, et y } \\
\text { gia Aucheriana }\end{array}$ & & . & . & $?$ & $B C$ Almuty & June, 1,200 to & $5,000^{\circ}$ \\
\hline IOgI. & Henning & $\begin{array}{c}\text { gia Aucheriana } \\
\text { robusta }\end{array}$ & . & . & . & $?$ & A Kara-Tau & . May, , & 3,600 \\
\hline 1092. & & $\begin{array}{c}\text { robusta } \\
\text { soogdiana }\end{array}$ & : & . & & $?$ & B Talgar. & June, 2 to & $3,000^{\prime}$ \\
\hline 1093. & Selonia & $\begin{array}{l}\text { soogdiana } \\
\text { callis flava }\end{array}$ & & . & . & $\stackrel{?}{\text { Hemerorallis }}$ & Turkistan & May & \\
\hline 1094. & Hemero & callis flava & & & & Hemerocallis & Barnaul & - May, J! & Iune \\
\hline 1095. & Asparag & gus trichophyllt & & r. & & Asparagus & A Kirghese Ste & eppe . May, A & August \\
\hline 1096. & " & werticillet, & & & . & $\begin{array}{l}\text { Do. } \\
D_{0} \text {. }\end{array}$ & Zaisan Moun & ntains . May & \\
\hline 1097. & " & verticillatus & & & & Do. & Bogdo. & & \\
\hline
\end{tabular}

\section{LXXXVII-MELANTHACEAE I (o), Colchicum Family.}

1098. Veratrum album . . . White hellebore | B Tabulga Lake .

6,000

\section{LXXXVIII.-JUNCEAE 6 (32), Rushes.}

1099. Luzula campestris

1100. ", communis

IOI. ", lamprocarpus .

$1102 . \quad "$ bulbosus, et vars.

1103. ", bufonius

1104. ", Tenageja .
Wood rush BC Mtn. Passes July, 8 to 9,000 Do. Karkara Plateau? $\quad 5,5000$ Do. $\quad B$ In marshy places 3,500 to 4,000 Do. C Zaisan Mtns. June, 8 to 9,000 Do. C Karkara Plateau. July, 5,500 Do. Kirghese Steppe. August 
LXXXIX. - CYPERACAE 30 (104), Sedges.

\begin{tabular}{|c|c|c|c|c|c|c|c|c|c|}
\hline 105. & Cyper & & & . & . & Galingale & $B$ In sandy soils & Aug., & 2,500 \\
\hline & Eliocha & aris acicula & & . & . & Spike rush & Kirghese Steppe & . Aug. & \\
\hline 07. & & palustr & & . & . & Do. & B Turaigyr & - June, & $4, \infty 00$ \\
\hline 108. & c. & angyrol & lepis & & & Do. & Syr-daria & - July & \\
\hline 10. & & 5 Tabernae & monta & & & $\begin{array}{l}\text { Club rush } \\
\text { Do. }\end{array}$ & $\begin{array}{l}\text { Syr-daria } \\
\text { Town of Koknekt }\end{array}$ & $\begin{array}{c}\text { Augus } \\
\text { ty Tune }\end{array}$ & \\
\hline i1. & $"$ & maritimu & is $\beta$ & & : & Do. & Town of Kokpekt? & ty June & \\
\hline & Isolepis & is Holosche & oenus. & & . & Do. & Kirghese Steppe, & Turkista & in May \\
\hline 3. & Eriophe & iorum $\mathrm{Ch}$ & & & . & Cotton grass & B C Tekes Pass July, & $, 8,500$ to & $09,5 c$ \\
\hline 114. & , & angus & stifo & um & - & Do. & Sartau. . & - June & \\
\hline & Carex s & stenophyila & & . & . & Sedge & C Kly & April, & $8, \infty$ \\
\hline 16. & $"$ & physodes & . & - & . & Do. & Aral Steppe & May & \\
\hline & " & & . & . & . & $D$ & r Ural . & April & \\
\hline 18. & $n$ & vulpt & . & . & . & $D$ & Valleys, & May, & \\
\hline If & $"$ & & & . & & Do & $B C$ Karkara Jul & 5,500 to & \\
\hline 20. & " & & . & . & . & $D$ & $c \mathrm{Za}$ & & \\
\hline $2 \mathrm{I}$. & I & nigi & . & - & . & D & $A C$ & July, 7 to & \\
\hline & $\Rightarrow$ & frig & . & . & - & D & A C Zauku & July, $6 \mathrm{t}$ & 08,5 \\
\hline 123. & $"$ & & . & - & . & $D$ & c Kyzyl-jars & June & \\
\hline 24. & " & & . & . & . & & rshy soils & July, & \\
\hline 2 & , & Oede & . & . & . & $D$ & & & $1, \infty$ \\
\hline 26. & $\because$ & & - & - & . & $D c$ & C Tasma & . June, & 4,5 \\
\hline & " & & . & . & . & $D$ & n Mountains & August & \\
\hline 128. & n & nitida & & & & $D$ & Tau . . & . August, & $6, \infty$ \\
\hline 29. & " & punctata & & & - & $D$ & B Chilik. & June, & $2,5^{\circ}$ \\
\hline & & & & & & & Zaisan Mountains & May & \\
\hline 31.2 & " & acut & irs, & & . & $D$ & Mountains & June & \\
\hline 3. & n & nuta: & & & . & $D$ & ara Pass & . July, & \\
\hline & " & & & & & & -Kul . & . July, & 00 \\
\hline 34. & n & vesicaria & & & & Do. & Zaisan Mountains. & June, & \\
\hline
\end{tabular}

\section{XC.-GRAMINEAE 91 (123), Grasses.}

1135. Psilurus nardoides

1130. Aegylops squarrosa

1137. Hordeum bulbosum

1138.

1139. ". pratense

1140. Elymus crinitus

1141. " sibiricus .

1142. " giganteus

1143. ", lanuginosus

1144., dasystachys var.

$1145 . \quad$, junceus, et vars.

$1146 ., "$ aralensis .

1147. Secale fragile

1148. ", cereale

1149. Triticum prostratum

$1150, \quad, \quad$ orientale $\beta$

1151.,$\quad$ cristatum

1152. ,, fibrosum.

1153. ." desertorum

1154 . $"$ repens
Sedge

Do.

Barley

Do.

Do.

Lyme grass

Do.

Do.

Do.

Do.

Do.

Do.

Rye grass Do.

Wheat

Do.

Do.

Do.

Do.

Do.
A Kirghese Steppe . Aug., 2.500

$B$ In the Steppe . June, 2,500 Aksa .

Turkistan

C Kirghese St. Aug., 4,500-6,000 Turkistan

BC Chilik . July, $5,500-6,000$

$C$ Zaisan Mountains. July. 6000

$B$ Vierny . . Aug., 2,000

Caspian Steppe . Sept.

$B$ Chilik Valley . June, 2,500

Aral Steppe . Oct.

Aral Steppe . Nov.

Aral Steppe

Ili Valley . May, I 000

B Zaisan Mnts, July 2,500-4,000'

Kirghese Steppe. Sept.

Aral Steppe . Oct.

B South Altai . . June, 2.500' 


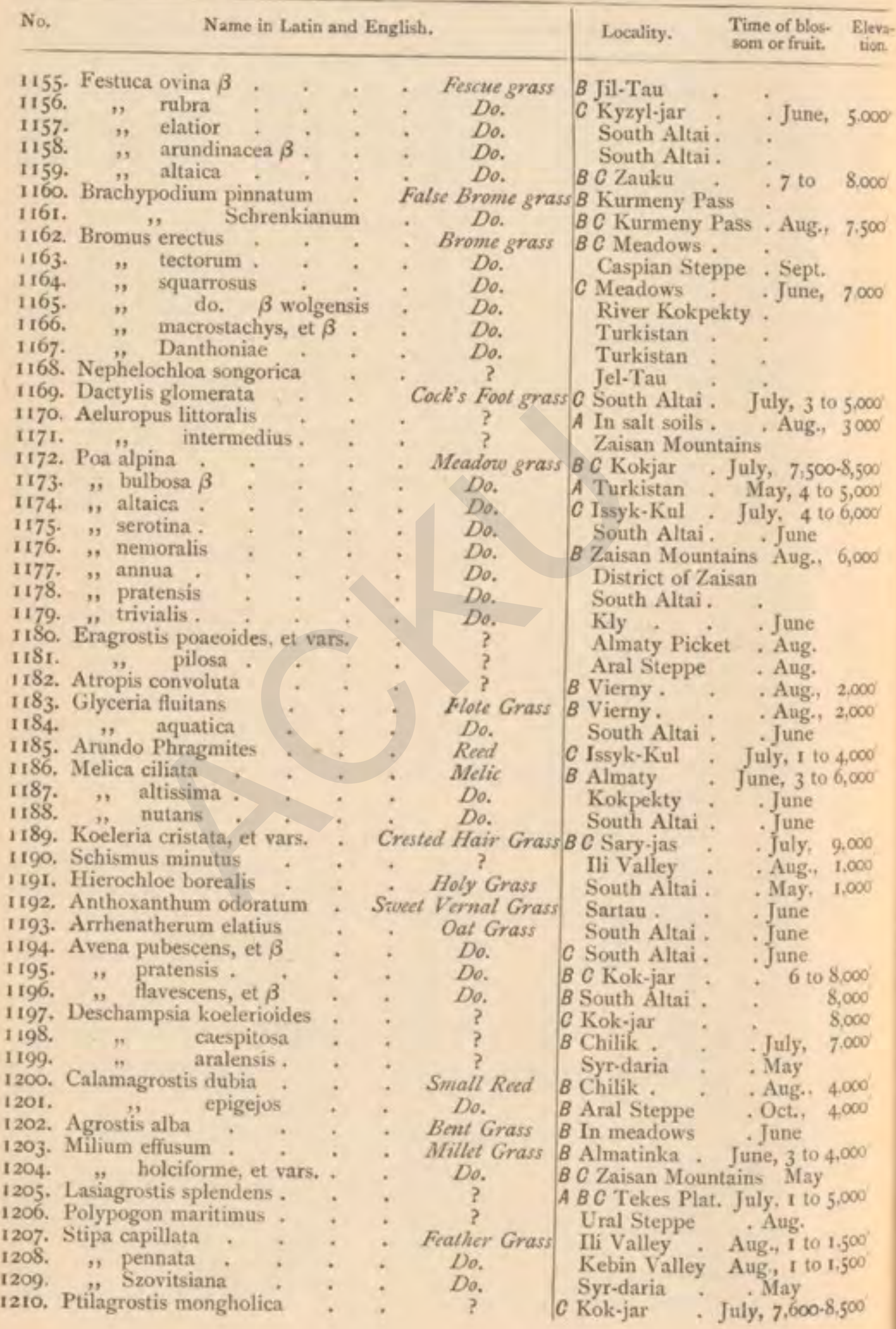




\begin{tabular}{|c|c|c|c|c|c|c|}
\hline No. & Name in Latis & $n$ and & English. & Locality. & $\begin{array}{l}\text { Time of blos- } \\
\text { som or fruit. }\end{array}$ & $\begin{array}{l}\text { Eleva- } \\
\text { tion. }\end{array}$ \\
\hline 1211. & Aristida pungens & & . ? & Kirghese Ste & eppe. & \\
\hline 1212. & Cynodon dactylon $\beta$ & : & Dog's Tooth Grass & Caspian Sea & ppe. & \\
\hline 1213. & Digraphis arundinacea & & ? ? & Zaisan Moun & ntains Aug. & \\
\hline 1214. & Phleum asperum . & . & Cat's Tail Grass & $B$ Vierny & . Aug, & $2,000^{\prime}$ \\
\hline 1215. & , Boehmeri & . & - Do. & C South Altai & . July, & 5,500 \\
\hline 1216. & ", alpinum & - & Do. & B C Sartau & 5 to & $8,000^{\prime}$ \\
\hline 1217. & Alopecurus ruthenicus & & Fox Tail Grass & B Turaigyr & June, & $4,000^{\prime}$ \\
\hline 1218. & $\begin{array}{l}\text { geniculatus } \\
\text { Crypsis Borszczowi }\end{array}$ & & Do. & Chinguildy & May & \\
\hline $\begin{array}{l}1219 . \\
1220 .\end{array}$ & $\begin{array}{c}\text { Crypsis Borszczowi } \\
\text { " alopecuroides }\end{array}$ & . & $?$ & Aral Steppe & Sept. & \\
\hline 1221. & , schoenoides & 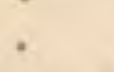 & ? & Ili Valley & Aug., & $\mathbf{I}, \infty 0^{\prime}$ \\
\hline 1222. & ". aculeata. & - & ? ? & Caspian Ste & ppe . Aug., & $1, \infty 0^{\prime}$ \\
\hline 1223. & Setaria viridis . & ${ }^{\circ}$ & - Rough Panick Grass & Zaisan Mour & ntains Aug., & 3,800 \\
\hline $\begin{array}{l}1224 . \\
1225 .\end{array}$ & An" italica & - & - Do. & B Kokpekty & . Aug, & 2,000 \\
\hline & & & - & B Vierny. & . Aug, 2 to & $4, \infty 00^{\prime}$ \\
\hline
\end{tabular}

XCI.-BALANOPHOREAE I (o), Allied to the Grasses.

1226. Cynomorium coccineum . . ? Ili Valley . June, 1,000'

\section{XCII.-CRYPTOGAMAE (8-80), Flowerless Plants.}

1227. Equisetum elongatum . . . Horsetail | Ural Rivers. . Aug., Sept. 1228. Lycopodium Selago . . . Club Moss Riddersk . . 7,000. 1229. Polypodium vulgare . . Polypody Arkat Mountains . May, 1,200 1230. Woodsia glabella, et $\beta$. Woodsia A Zaisan Mountains. June, 8,000' 1231. Asplenium septentrionale . Forked Spleemwort Kirghese Steppe . May, 1,200' 1232. Chara foetida var. . . . Chara Town Ayagus . 1,300' 1233. Fontinalis antipyretica - Greater Water Moss River Bukon - June

1234. Marchantia polymorpha 


\section{APPENDIX C.}

\section{BIBLIOGRAPHY OF RUSSIAN CENTRAL ASIA.}

SHORT description of the method in which the A following lists of books have been compiled will be interesting, I trust, to general readers, and perhaps useful also to any who may attempt the like hereafter. Remembering that "as extensive a knowledge as can possibly be obtained of all literature bearing upon his subject is nowadays the first requisite for an author attempting a standard work," I made my way to the British Museum, asking for books upon Russian Central Asia. By the courtesy of Dr. Bond and $\mathrm{Mr}$. Garnett, I was taken to the modern books of geography and travel in Asia, in the general library, and found myself before 12 presses, some 30 feet high, each containing about 18 shelves a yard long, or as many volumes, say, as would fill a shelf 600 feet in length. These I examined, my amanuensis meanwhile copying the particulars of all such books as treated of the aforesaid region; after which departmental libraries of the Museum were looked through. A similar process was repeated subsequently on various occasions at 80 shelves of the library of the Royal Society, 30 at the India Office, and so on, until I had visited four-and-twenty libraries.*

As a next step, I proceeded to search various library

* British Museum :

General Library.

Department of Oriental MSS.

Department of Coins.

Zoological Department.

Ethnological do.
Natural History Museum :

Mineralogical Department.

Geological do.

Botanical do.

Cambridge University Library.

India Office Library 
catalogues * and bibliographical works, $†$ taking as a help certain catch-words, $\neq$ under which it was expected might be found the information required, and in this way I prosecuted the search, finally, to the indexes of periodical publications and the transactions of learned societies. $\$$

The result these researches brought to my net was nearly 700 titles, which were copied, so as to give as far as possible the author's name; title of book or article, date of the

United Service Institution Library.

The Royal Society Library.

Royal Asiatic do. do.

Royal Astronomical do. do.

Royal Geographical do. do.

Anthropological do. do.

Geological do. do.

- The London Library Catalogue. Royal Geographical Society do. do. London Institution do. do.

East India Company's do. do.

Manchester Free do. do.

† Watt's "Bibliotheca Britannica."

The English Catalogue.

Leypoldt's American Catalogue.

Porter's "Hand-list of Bibliographies in the British Museum."

Publications of Caucasus branch of Russian Geographical Society.

Zuchold's "Bibliotheca historico-geographica."

Ternaux Compans, "Bibliothèqu Asiatique."

Denis and Pincon's "Manuel de Bibliographie."

Jackson's "Liste de bibliographies géographiques."

‡ Such as: Asia (Central), Bokhara, Kalmuks, Ferghana, Ili, Jaxartes. Kirghese,

Khiva, Khokand, Kopal, Kuldja, Omsk, Oxus, Samarkand, Semipolatinsk,

Siberia (West), Steppes, Syr-daria, Tajiks, Tashkend, Turkomans, Turkistan, Uzhegs, Vierny, Zarafshan.

$\$$ Index to Publications of the Acadeny of St, Petersburg.

" Journal of the Royal Geographical Sociely.
" $\quad$ Petermann's Geographische Mittheilungen.
" $\quad$ Behm's Geographisches Fahrbuch.
" L'Ann'e glographique.
" The Zoological Record.
" $\quad$ Oricutal Church Magasine.

Linnean Society's Library.

Meteorological do. do.

Zoological do. do.

Society of Antiquaries do.

Kew Gardens Library.

The London do.

Boston Bates Hall Library Catalogue.

Mr. Wylie's do. do.

Boston Athenaum do. do.

Boston Public do. do.

New York State (Subject Index) do. do. Lorenz, Catalogue de la librairie française.

Mejow's "Recueil du Turkestan."

Catalogue des Russica.

Record of Translations relating to

List of Russian books at the Fisheries Exhibition.

List of books in :-

Howorth's "History of the Mongols."

Hutton's "Aryan to Cossack."

Marvin's "Merv,"

Yule's "Marco Polo." 
information or travel; name of editor or translator ; name of series or periodical; place and date of publication. The titles were then classified under the 9 heads of I, Central Asia in general ; 2, Bokhara ; 3, Khiva ; 4, Khokand ; 5, Kuldja ; 6. Siberia (Western) ; 7, Turkistan ; 8, Turkmenia ; and 9, Maps,-the only Map-room searched, however, being that of the Geographical Society. After this the titles under each heading were arranged chronologically, not necessarily according to the year of publication, but with regard to the date when the information was obtained. Each title was then numbered from the commencement, and cross-references inserted.

In this manner has been compiled what is, I hope, a tolerably complete bibliography of English books on Russian Central Asia, with the addition of a still larger number in French and German, and a few in Russianthese last being for the most part those in my own possession, or in the London libraries. Further information concerning Russian books is to be met with in the excellent bibliography of Mejow, which gives 1,397 titles, not only of books, but of pamphlets, papers, and even newspaper articles upon Central Asia in general, and Turkistan in particular.

It would be ungracious on my part to omit the expression here of my thanks for the unbounded courtesy, kindness, and attention shown to me by the London librarians and their assistants; and this applies not only to libraries where I had the right of entrance, but to librarians upon whom I had no claim whatever.

I was gratified to learn from a Russian acquaintance in Petersburg, who had officially visited the principal libraries of Europe, that he considered ours in the British Museum the best, and I have met with the writings of a French bibliographer, who speaks highly of London librarians. England, indeed, has reason to be proud of its libraries and librarians, but, by way of " practical conclusion," I wish to point out that we are in one respect pitiably - I had almost said unpardonably--poor, for, rich as our literature is, we have not a subject catalogue thereto. If one asks a librarian, "Have you a book by such an author?" "Yes" or "No" is speedily forthcoming: 
but if one asks, "Have you a book on such a subject?" the librarian is either dependent on his own resources, or on reference to a number of incomplete bibliographical works.

The inquirer, therefore, if he be a careful writer, must make a bibliography for himself, and what that means, the reader may judge from what has preceded. To collect the 700 titles in the following list cost me about 30 journeys to London, visits (sometimes several) to 24 libraries, examining the books on a quarter of a mile of shelves, a search through Io library catalogues, 19 bibliographical works, and 8 indexes to publications some of which extended over half a century! Now if this were requisite for a comparatively small topic like "Russian Central Asia," let the reader judge what amount of labour would be needful for an ordinary subject.

What a boon, then, might be bestowed upon literary men, and through them, be it remembered, on their readers, and what glory added to our literature, if some generous patron of letters, assisted by enthusiastic volunteers, would compile, at first, perhaps, a subject catalogue of English books. There is now in course of preparation an English dictionary that, when completed, will be the most thorough, by far, in any language, in the prosecution of which the editorial staff is assisted by hundreds of volunteers. Could not a like effort be set on foot in the interest of bibliography? Could not some benefactors be found to bear the expense of the editorial staff? Many a fortune has been bequeathed or given for a less worthy object, the title of the work might perpetuate the name of the donor, and abundance of voluntary help could be enlisted. Financially, such a work might not probably pay, because of the limited number of copies that would be sold, but its accomplishment would be a crown to our literature to the end of all time.

Not that such a bibliography, however, would leave nothing more to be desired. There would yet remain the much-needed universal index to English literature. The Times newspaper has, if I mistake not, promulgated an autocratic law, with which for one I heartily sympathize, that it will review no book that has not on the title-page

VOL. II. 
honestly printed the date of publication. Orie could almost wish that the Times, and every other publication, would decline to review any book (within certain limits) that has not an index; for no author, speaking generally, who writes a thousand pages of closely printed and perhaps valuable matter, is justified in not providing his reader with contents of chapters that he may see where he is going, or with an index to show whence he has come.

Things are improving, however, in this respect, and authors may be relieved of much tedious labour by placing their works in the hands of professional index-makers. There has been formed also a society, called the Index Society, the object of which is to make and publish indexes to valuable books now without them. The society has already issued one or two valuable works, notably, " A Guide to the Literature of Botany," and "An Index to Titles of Honour," but for lack of funds it can do but little.

I gladly mention this in case any who read these lines should be disposed to send the society help in money, or the offer of honorary assistance in making indexes, or doing anything towards the suggested bibliography of English literature. Communications will be thankfully received by the Secretary, Mr. W. T. Riseley, Offices of the Index Society, 8, John Street, Adelphi, London, W.C.

Meanwhile I append my bibliography, arranged chronologically.

\section{ABBREVIATIONS.}

J.R.G.S., Fournal of the Royal Geographical Society.

P.R.G.S., Proceedings of the Royal Geographical Society.

P.G.M., Petermann's Geographische Mittheilungen.

I.K.I.R.G.O. $\left\{\begin{array}{c}\text { Izvestia (i Zapiski) Kavkazskago otdiela Imperatorskago } \\ \text { Russkago Geographicheskago Obstchestva (Notes, }\end{array}\right.$

Z.K.I.R.G.O. [also Memoirs] of the Caucasian section of the Imperial Russian Geographical Society).

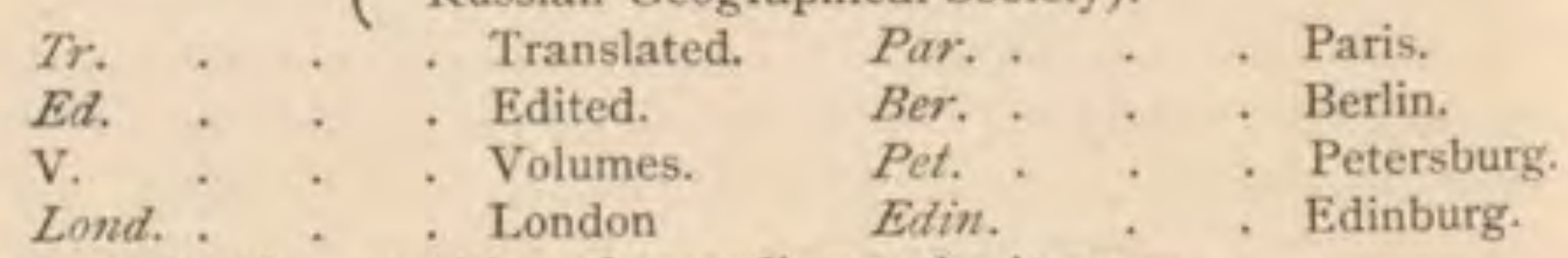

signifies repetition of preceding author's name.

[ ] Square brackets enclose the known or supposed dates of travel, or when the information was acquired. 


\section{ASIA (CENTRAL) IN GENERAL.}

\section{'FROM EARLIEST TIMES TO 1700.}

1. Hiouen Thsang. Mémoires sur les contrées occidentales traduits du Sanscrit en Chinois en l'an [648]: et du Chinois en François par M. Stanislaus Julien.

1858

2. Assemani. Bibliotheca Orientalis. Vol. iii., part ii. (for an account of the Nestorian Church).

3. Yule, Henry. Notes on Hwen Thsang's account of the Principalities of Tokháristán. Maps.

4. Mir Ali Shir (poetically called Nevai'i). Khamsah Nevai'i (the five Poems of Nevaiii). Oriental MSS,, British Museum.

5. Nevai'1, Glossary to the Poems of. Oriental MSS. in British Museum.

6. Dughlat, Mirza Haidar. Tarikh Rashidi (with MS. translation). Oriental MSS., British Museum.

7. Fazl Ullah Khan. Turki Vocabulary explained in Persian.

8. Mirza Mohammed Mehdi Khan. Tarikhi Nadir Shah [1260]. Teheran, 1844

9. Sheikh Kemaleddin Abdurrezak. Matlaa es Saadein [1423-1482]. Oriental MSS., British Museum.

10. Tudela Benjamin Rabbi. Travels through Europe, Asia, and Africa [11601173]. Pinkerton's Voyages, vol, vii.

11. - Purchas' Pilgrimes, vol. ii.

12. Harris, vol. i.

$1625 \cdot 6$

13. Bergeron, Pierre. Voyages faits principalement en Asie dans les xii., xiii., xiv., et Xv. siècles, par Benjamin de Tudele, Jean du Plan-Carpin, N. Ascelin, G. de Rubruquis, Mare Paul, Haiton, J. de Mandeville, et Ambroise Contarini.

14. White's Translations of the Institutes of Timour.

15. Stewart, C. Timour's Memoirs. Tr.

16. Polo, Marco. The Travels of a Venetian [in the 13th century] . . a a description of remarkable places in the Eastern parts of the world. Tr, W. Marsden.

17. - The Travels of. Edited by Hugh Murray.

18. - Tr., Henry Yule.

19. Le livre de. Rédigé en Français par Rustician de Pise.

Rubruquis, William de. The Journ de East part of the worlde [1253]. Hakluyt's Voyages. London, r859

21. Clavijo, Ruy Gonzalez de. Narrative of his Embassy to the Court of Timour $[140,3-6]$. Tr., C. Markham. Hakluyt Society's Publications. Lond. 1859

22. Schiltberger, Johannes. Reisen des K. F. Neumann. Mrtich, 1859

23. - The Bondage and Travels of. . . Tr. by J. B. Telfer, for the Hakluyt Society.

London, 1879

24. Baber, Memoirs of [1558]. In Turki, text edited by N. Ilminski. of Kazan.

25. - Tr. by Erskine, with Introduction. London, 1826

26. - Nameh Djagataica. Ed, N. Ilminsky. Casami, 1857

28. Courteille, Pavet de la. Tr. of Babernameh. $\quad 1827$

29. - Dictionnaire Turk-Orientale. (To facilitate reading works of Baber, Abul Ghaxi, et Mir-Ali-Shir-Nevai'i.) Paris, 1870

30. Evliya Effendi. Travels in Europe, Asia, and Africa [in 17 th cent.]. 1834-50

31. Feynes, Sieur de. Voyage fait par terre depuis Paris jusqu'à la Chine. 1630

32. Dmitrovskiy, N. V. Bibliographicheski Ukazatel sochineniy o srednei Asii (Bibliographical Index to Publications relating to Central Asia, printed in Russia in the Russian Language) [from 1692]. Turkistan Annual, No. 3, PP. $181-250$. 


$$
\text { 1700-1800. }
$$

33. Sherefeddin Ali Zezdi. Zafer nameh (Book of Victories). Tr. into French by Petis de la Croix.

36. Histoire de l' Asie Centrale, depuis les dernières années du rẻgne de Nadit Châh [1740-1818]. Tr., Charles Schefer. Paris, Leroux, 1876

37. The Genealogical History of the Tatars.

38. - Shedjre-i-Turki (Turkish Genealogy). Pub. by Romanzoff. Kasan, 1825

39. - Bahâdûr châni sistôria Mongolorum et Tatarorum (Hlistory of the Djagatai Language of the I8th century), de C. Frähn. Casani

40. Defremery. Histoire des Samanides.

Paris, 1845

41. Strahlenberg. Description of North and East of Europe. London, $173^{\circ}$

42. General History of the Turks (History of the Tatars) and the Empires founded by them in Tatary and Lower Asia. Book I. London, 1759

43. Pallas, P. S. Voyages en differentes provinces de l'empire de Russie. Tr., Peyroine. 5 Tomes. Faris, $1785-93$

44. Landres, Frey de. Histoire des découvertes de Pallas, Gmelin, etc. $1781-7$

45. Mosheim, L. Historia Tartarorum Eeclesiastica. Helmstadi, 1791

46. Campbell, Donald. Journey overland to India.

1795

47. Abu-Taleb-Khan. Travels in Asia, etc. [1799-1813]. Tr. Stewart. 1814

\section{$1800-1850$.}

48. Ali-Bey. Voyage en Afrique et en Asie [1 $\left.8 \mathrm{O}_{3}-7\right]$.

49. Ephremov, F. \$. Stranstvovanie Philippa Ephremova v Kirghizskoi stepi, Bukhariy, Khivii, etc. (Travels of P. Ephremoff in the Kirghese steppe, Bokhara, Khiva, etc.) Kasan, I811

50. Price, D. Chronological retrospect or memoirs of the principal events of

Muhammadan history.
51. Mir Izzut Ullah. Voyage dans l'Asie Centrale [1812]. Klaproth's Mag. Asiat.

52. - Travels in Central Asia in the years [1812-13]. Tr. by Captain Henderson. Calcutta, 1872

53. Murray, H. Historical account of Discoveries and Travels in Asia. Edin., 1820

54. Ritter, Karl. Allegemeine vergleichende Geographie. Berlin, 1822.59

55. Marsden, William. Numismata Orientalia Illustrata. The Oriental Coins, ancient and modern, of his collection described, etc. London, 1823

56. Morier. The Adventures of Haji Baba.

57. Senkovski, M. Joseph. Supplément à l'histoire générale des Huns, des Turcs, et des Mongols, etc. St. Petersburg, I824

8. Klaproth, Julius. Mémoires relatifs à l'Asie. Paris, 1824

59. - Magasin Asiatique, ou Revue Géographique et historique de l'Asie

59. - Centrale et Septentrionale.

60. - Notices sur les troubles survenus récemment dans l'Asie Centrale. Nour. Journ. Asiatique, i.. pp. 147, 319 ; Journ. Asiatique, X., p. $310 . \quad$ I827

61. Rémusat, J. P. A. Mélanges Asiatiques. Paris, 1825

62. Fraehnii, Ch. Recensio numorum Muhammedorum. Academiae Imp. Scient. Petropolitanae. Inter prima academiae Imp, srecularia edita.

Petropoli, 1826

63. Ledebour, C. F. von. Reise durch die Soongarische Kirgisen-steppe (and Atlas to his travels).

64. - Flora Rossica, sive enumeratio plantarum in totius Imperii Rossici.

65. Davis, Sir F. Notices of Western Tartary. Transac. R.Asiat. Soc. London, 1829

66. Miles, The. Shajout ul Atrak; or, Genealogical Tree of the Turks and Tartars.

London, 1830

67. Rosenmialler. Biblical Geography of Central Asia, 2 vols. London, 1836

68. Levshine, A. J. Opissanie Kingiz-Kazachikh ord i stepei. (Description of the hordes and steppes of the Kirghese Kazaks.) St. Petersburg, 1832 
69. Levshine, A. J. Description des hordes et des steppes des Kirghiz-Kazaks. Tr. par Fevry de Pigny, revue par E. Charrière.

70. Descrizione delle Orde dei Kirghizi-Kazaki.

Paris, 1840

Milan, 1840

71. Heeren, A. H. L. Historische Werke. Historical Researches into the Politics, etc., of the Asiatic nations of antiquity.

Oxford, $1832-40$

72. Helmersen, G. von. Reise nach der Kirgisen Steppe [1835]. I841

73. Coquilles marines trouvées dans les sables de Karakum (German), $23-25$.

74. Baer. K. E., and Helmersen, G. R. Beiträge zur Kenntniss des Russischen Reiches und der angranzenden Länder Asiens. St. Petersburg, I84I

75. Perovski, General. Narrative of the Russian Military Expedition to Khiva under General Perovski [1839]. Tr. J. Michell. Calculta, I867

76. Prichard, James Cowles. On the Ethnography of High Asia. London, 1839

77. Hagemeister, Jules de. Essai sur les resources territoriales et commerciales de l'Asie Occidentale, le caractère des habitans, leur industrie, et leur organisation. Beiträge zur Kenntniss d. Russ. Reiches. St. Pdersburg, 1839

78. Nève, Félix. Exposé des guerres de Tamerlan et de Schahrokh dans l'Asie Occidentale.

Bruxelles, 1840

79. Wilson, H. H. Ariana Antiqua: Antiquities and Coins of Afghanistan. 1841

80. Urquhart. Diplomatic Transactions in Central Asia. 184I

81. Baer, K. E. von. Klima der Kirgisen steppe. $\quad 1840$

82. Zimmermann. Geographische Analyse der Karte von Inner Asien. Berlin, 1841

83. Memoir of the countries about the Caspian and Aral Seas, Tr, by Capt. Morier.

London, 1840

84. Leonhard, Gustav. Handworterbuch der topographischen Mineralogie.

85. Finn, James. The Orphan Colony of Jews in China.

Heidelberg, 1843

London, Wertheim, 1843 ; Nisbet, 1872

86. Brandt, J. F. Observations sur le Cervus pygargus de Pallas [Lu le 14 Juin, 1844]. Bull. Phys. Math. Acad. St. Pet., Tom iii., pp. 280-1.

87. Basiner, T. F. J. Naturwissenschaftliche Reise durch die Kirgisensteppe und Khiva.

St. Petersburg, 1848

88. Buchanan, Claudius. Christian researches in Asia. With notices of the translation of the Scriptures into the Oriental languages. London, 1849

Sg. Khanikoff, N., and Tolstoi, P. List of positions in South-western parts of Central Asia determined astronomically (in Russ).

90. - Spisok mest v Severo-zapadnoi chasti Srednei Asii. (List of positions in north-western parts of Central Asia.) St. Petersburg, 1855

91. Bichnrin, J. Sobranie Sviedienii o narodakh, obitavshikh v Srednei Asii v drevniia vremeni. (Collection of information concerning the peoples dwelling in Central Asia in ancient times.) St. Petersburg, 185I

$1850-1860$.

92. Lelewel, Joachim. Géographie du moyen âge.

Bruxelles, 1852

93. Bunge. Beitrag zur Kenntniss der Flora Russlands und der Steppen Central Asiens, Alexandri Lehmann, Reliquiæe botanice.

94. Nebolsin, P. Ocherki byta Kalmykov Khoshoutovskago ulusa. (Sketches of the life of the Kalmuks of the Khoshout tribe.) St. Petersburg, I852

95. Abriss des Russischen Handels mit dem mittleren Asien. P.G.M., 215.

96. Golovin, Ivan. Russia and Turkey, and their destiny.

97. Gould, J. Birds of Asia. Published by Author.

1857

0. Geographische Notizen. Zur Botanischen Geographie und Orographie 55 Central Asien. P.G.M., 163. 1855

99. Nosche1, A. Bemerkungen tiber die naturhistorischen, insbesondere die geognostisch-hydrographischen Verhältnisse der Steppe zwischen den Fliksen Or und Turgai, Kumak und Syr-daria. Mit enem Vorwort und Bemerkungen von G. von Helmersen-Beiträge zur Kenntniss d, Russ. Keiches. 
100. Taylor, Bayard. Cyclopredia of Travel. New York and Cincinnati, 1857

101. - Central Asia, Amer. Geo. Soc, p, 59. 1863.4

102. - Central Asia. New York, 1874

103. Abich, H. Beiträge zur Paläontologie des Asiatischen Russlands, (From the Memoirs of the Academy of Sciences of St. Petersburg.) St. Pet., 1858

104. St. Martin, V. de. Mémoire Analytique sur la carte de l'Asie Centrale. 1858

\section{0-1870.}

105. Lyde, Samuel. Asian Mystery in the history of the Ansaireeh. London, 1860 106. Trade Routes of Central Asia. Tr, from the Russian Nautical Magazine, July.

107. Morley, W. H., and Lees, W. Nassau (Editors). The Tarikhi Baihaki. Published in the Bibliotheca Indica. Calcutta, 1862

108. Radloff, W. Kurzer Bericht ubber eine Reise in den Altaí [186r] . Bull. de

I'Acad. de St. Petersburg. p. 534.

rog. Kurzer Bericht iber eine in [1862] untemommene Reise in der Östlichen Kirgisen-steppe. Bull, de l'Acad. de St. P., p. 415. 1863

110. - Bericht uiber eine in [1863] unternommene Reise in den ostlichen Altai. Bull. de l'Acad. impér. de St. Petersburg, p. $26 \quad 1864$

III. - Die Hausthiere der Kirgisen. Zeitschrift fuir Ethnologie, Band 3. 4. Berlin, $1871-2$

II2. Kirghise. Journal Asiatique, Oct., p. $309 . \quad 1865$

113. Khanikoff, $\mathbf{N}$. de. Mémoire sur la partie méridionale de l'Asie Centrale.

Paris, 1861, and P.G.M., p. 38,1863

114. Kitto, J. Cycl. of Bib. Lit., vol. i., p. 756. Article on "Eldad Ben Malchi"

(with reference to Jews in Cush). Edinburgh, 1862

115. Berg, Ernst von, Repertorium der Literatur über die Mineralogie, Geologie.

Palæontologie, Berg-und Hüttenkunde Russlands bis zum Schlusse des xviii.

St. Petersburg, 1862

116. Gerstfeldt. Der Verkehr Russlands mit Westasien [Geschrieben, 1862.]

Beiträge zur Kentniss d. Russ, Reichs.

117. Benjamin, J. B. Eight Years in Asia.

118. Vambéry, Arminius. Travels in Central Asia [1863]. London, 1864

119. - Voyage dans J'Asie Centrale [1863]. Tour du Monde, p. 33. 1865

120. - Voyage d' 'un faux Derviche dans l'Asie Centrale. Tr. par E. D. Forgues.

121. - Do. do. Edition abrégée par J. Bélin de Launay. Paris, 1877

122. - Geschichte Bocharas oder Trans-Oxaniens. Stuttgart, 1872

123. - Sketches of Central Asia. Tondon, 1868

124. - Skizzen aus Mittelasien. Leipsig, 1868

125. — Reise in Mittelasien [ 1863 ]. Leipsig, 1873

126. - Central Asia and the Anglo-Russian Frontier question : a series of political papers. Tr. by F. E. Bunnett. London, 1874

127. "Russia and her Dependencies." Fraser's Mag., April. 1864

128. Davies. A copy of Mr. Davies's report of the Trade of Central Asia. Ordered by the House of Commons to be printed, 17 Feb. 1864

129. Zaleski, B. La vie des steppes Kirghises-descriptions et contes. Paris, 1865

130. Veninkof, M., and Captain Valikhanof. The Russians in Central Asia, their occupation of the Kirghise Steppe, and the line of the Syr-Daria, their political relations with Khiva, Bokhara, and Kokan: also descriptions of Chinese Turkestan and Dzungaria. Tr. by J. and R. Michell. London, 1865

131. The Pamir and the Sources of the Amu-Daria. Tr. by J. Miohell. J.R.G.S., p. 248 .

132. Les plus récentes explorations russes en Asie. I. M. Rheinthal à Kash gar; II. M. Nikitin à Khokand. Russische Revue. St. Petersburg, 1876

133. - Notes on Lake Issyk-Kul and the River Koshkar. Tr. by J. Mitchell. J.R.G.S., p. 560 .

134. - Die Russische-asiatischen Grenzlande. Tr. by Von Krahmer. 
I35. A British Subject. Russia, Central Asia, and British India. London, 1865

136. Articles on Central Asia :-Journal de St. Petersburg, $16 \mathrm{July,} 3$ Dec., 1865; 28 Feb., 1867; 14 Oct., 1 and 21 Nov., 1869; 8 Jan., 16 May, 7 July, 18 Oct., 1871 ; 21 Nov., 19 Dec., 1872 ; 23 Jan., 7 Feb., 1873.

137. Marthe, F. Aus dem Kirgisenlande. Aus dem Russ. Zeitschrift der Gesellsch, der Erdkunde.

Berlin, 1866

138. Jardot, Al. A. Révolutions et migrations des peuples de la haute Asie. 1866

139. Khanikoff. Note sur le voyage dans l'Asie Centrale d'un officier Allemand au service de la compagnie des Indes orientales. Bull. de Soc. Géog. I869

140. - On the subject of Sir H. Rawlinson's criticisms of "MS. Travels of the Anonymous German Traveller in Central Asia." P.R.G.S., No. 6.

141. Yule, Henry. Cathay and the Way Thither. London, 1866 142. Gobineau, Comte de. Les religions et les philosophies dans 1'Asie Centrale.

Paris, 1866

143. Central Asian Question from an Eastern standpoint [1866]. London, 1869

144. T. L. (Robert Michell). Letters on Things as they are in Central Asia. Times of India.

145. Vereschagine, Basile. Voyage dans l'Asie Centale [1867-8]. Tour du
$\begin{array}{r}1866-72 \\ \text { Toumes of }\end{array}$ Monde, p. 193.

146. Von Chodschend nach Samarkand. Globus, No. 8.

1873 1868

147. Des travaux géographiques des Russes dans le Turkestan et dans la haute Asie [1867-8]. Annales des Voyages. No. 7. 1860

I48. Schlagintweit, R. Die Bewohner Turkistan's. Internationale Revue, 1868

149. Die neuesten Russischen Forschungen in Central Asien. P.G.M., p. r6r.

I50. Thonnelier, M. Jules. Dictionnaire géographique de l'Asie Centrale, offrant par ordre alphabétique les transcriptions en caractères Mandchoux et Chinois des noms géographiques.

I5I. Smythe, P. E. F. W. Articles and Notes upon Central Asia and Russia. In his selection, $v, 2$. 1869

152. Behm, E. andWagner, H, Die Bevölkerung der Erde. Areal undBevölkerung, Gebietsveränderungen. Zählungen und Schätzungen aus den Jahren [1869, 1870, und 1871]. P.G.M., Ergänzbd., vii., 1871-2. Gotha, 1872

153. Wagner, H. Die Bevölkerung der Erde. Allgemeine Betrachtungen und historische Ruickblicke. Erlăuterungen zur Uebersichtstabelle. P.G.M., 1873-4.

154. Bell, Evans, The Oxts and the Indus. London, Trubner, 1869 and 1874

155. Trench, Captain F. The Russo-Indian Question. Britain. A series of papers [1870-8]. London, Chapman and Hall.

157. Romanovski, M. Notes on the Central Asiatic Question. Tr., R. Michell.

Calculla, 1870

158. Pumpelly, R. Across America and Asia.

159. Behm, E. Geographisches Jahrbuch [1870-2]. Gotha, 1874

$$
\text { 1870-1880. }
$$

160. Sarauw. Russlands kommerzielle Mission in Mittelasien. Leipaig, 187

161. Bretsehneider, E. On the knowledge possessed by the ancient Chinese of the Arabs, and the Arabian Colonies and other Western countries mentioned in Chinese books.

162. - Notices of Medizeval Geography and History of Central and Western Asia from Chinese and Mongol writings. $\quad 1876$

163. Chinese Mediaval Travellers to the West. London, 1875

164. Forsyth, D. Memorandum on Trade with Central Asia, 13th March, 1871. Printed by India Office. $\quad$ I871

165. Sehepelew, A. Recognoscirung des Musart Passes P.G.M., p. 400.1872

166. Russia and the Central Asian Khanates. Allgemeine Zeitung, No. 325. 1872

7. Palgrave, William G. Essays on Eastern Questions.

London, 1872 
I68. Maieff, N. A., and V. H. Trotsky, Edited by. Russkii Turkestan. Sbornik izdannyipo po povodu Politekhnicheskoi vystavki. (Russian Turkistan, vol. i., Geographical statistics and miscellany, published in connection with the Polytechnic exhibition; vols ii., iii., Articles on Ethnography, Arts, Kural economy, Natural History, and Turkistan military affairs.)

Moscoto, 1872 Geography, Journey to the source of the River Oxus. With essay on Geography of the Valley of the Oxus by Henry Yule. London, 1872

170. Schayler, Eugene. Turkistan. Notes of a Journey in Russian Turkistan, Khokand, Bukhara, and Kuldja, London, 1877

171. Elwes, H. J. Geographical distribution of Asiatic Birds. Pro. of Zoolog. Soc., p. 6 r 5 .

172. Neue Werke tiber Centralasien. Die "Grensbolen."

173. The Central Asian Question. Fraser's Magazine, Nos. 45 and $47 . \quad 1873$

174. Kessler, K. F. On a remarkable Fish of the family of Sturgeons (Scapli. rhynchus). Annals and Mag. of Nat. Hist., October, p. 269. 1873

175. - Ichthyology of Central Asia. Pisces 3. Zoological Record, 1879

176. Nouvelles recherches concernant l'Ichthyologie de l'Asie Centrale, $2 \mathrm{~S}_{2}-3$ ro (in German), Bull. Acad. St. Pet, xxv.

177. Travaux de l'expedition Aralo-Caspienne. Les poissons vivant et se trouvant dans le bassin ichthyologique Aralo-Caspio-Pontique. I. K.I.R.G.O., Bull. Acad. St. Pét., vol. xv.

178. Gunther, Albert. Notes on the Scaphirhynchus. Annals and Mag. of Nat. Hist., No. 7o, October. 1873

179. Petrovaky, N. Th. Materialy dlia torgovoi statistiki Turkestanskago Kraia. (Materials for Trade Statistics of Turkistan.) Tashkend, 1873

ISo. Goldsmid, Sir F. J. Central Asia and its question. London, 1873

181. Lerche, P., Fried. von Hellwald. Die Russen in Centralasien. Augsburg, 1873

182. Hellwald, F. von. The Russians in Central Asia. A critical examination down to the present time of the Geography and History of Central Asia. Tr. by Theodore Wirgman.

183. - Central Asien. Landschaften und Volker in Kashgar, Turkestan, Kasheh, und Tibet.

184. Nashi sosiedi v srednei Asii. Khivi i Turkmeniyi.

185. Just, Leopold. Bolanischer Fahresbericht.

186. Terentief. Statistiscal sketch of Central Asia (Russ.).

187. - Russia and England in Central Asia (Russ).

188. do. Tr. by F. C. Daukes.

Leipsig, 1875

St. Patersburg, 1873

Berlin, 1873

1874

St. Pet., 1875

Calcutta, 1876

189. Clarke, F. C. H. Steppe Campaigns. Tr. from the Russian. London, 1874

190. Rialle, Girard de. Memoire sur l'Ásie centrale, son histoire, etc. Paris, 1874

191. Instructions anthropologiques pour 1'Asie Centrale. Bull. de la Soc. d'Anthropol., April, June.

192. Vincent, C. E. Russia's Advance Eastward.

London, 1874

193. [Long, Rev. James.] Russia and England in Central Asia. New York, 1874

194. St. Martin, V. de. Explorations Russes. L'Année Géographique. Paris, 1874

195. Aberigh-Mackay, G. R. Notes on Western Turkestan. Calcutha, 1875

196. Spencer, Herbert. Descriptive Sociology. Asiatic Races, No. V. Edited by Duncan.

London, 1875.8

197. Brooke, Sir V. On Asiatic Sheep. Pro. of Zoolog. Soc., pp. 509.526. 1875

198. Recent Russian Explorations in West Mongolia. Markham's Geog. Mag. 1875

199. Debelak. Julius. Die Central-Asiatische Frage. W'icn, 1875

200. Bogdanowitch, B. Exposé de la question relative au Chemin de fer de la Siberie et de l'Asie Centrale.

Paris, 1875

201. Stuart, A. Le chemin de fer Central-A siatique projeté par MM. Ferd, de T.esseps et Cotard. L'Explonatewr, October, November. 1875

202. Regel. E. Botanischer Fahresbericht, p. 734 Berlin, 1874.5

203. - Descriptiones plantarum novarum et minus cognitarum. Tom ii., fasciculus iii., iv , v.. vi., vii. (and supplement), viii. (and supplement), ix. (Description of new Plants in the Turkestan region). Petrofolis. $1875-8$ 
204. Regel, E. Alliorum adhuc cognitorum monographia. Fetropolis, 1875

205. Towle, G. M. The Russians in the East. The Atlantic Monthly, July, 1875

206. Hutton, James. Central Asia from the Aryan to the Cossack. London, 1875

207. Brodowsky, M. Cotton of Central Asia. Journ. Amer. Geog. Soc.,p. 395. 1875

208. Poole, Stanley Lane. The Coins of the Eastern Khaleefehs. Ed. by Reginald S. Poole. London, 1875

209. - and R. S. The Coins of the Mohammedan Dynasties in the British Museum. London. I876

210. - Coins of Mongols in British Museum. London, 1881

2II. Paquier, J. B. Le Pamir, Étude de Géographie Physique et Historique sur l'Asie Centrale.

212. L'Asie Centrale à vol d'oiseau. Paris, 1881

213. - Les exportations russes et anglaises dans l'Asie Centrale. Bull. Soc. de Géog, de Paris. $\quad 1876$

2I4. Maieff, N. Hissar and Kulab. Markham's Géog. Mag. 1876

215. Mejow, V. J. Recueil du Turkestan, comprenant des livres et des articles sur 1'Asie Centrale, etc. 2 Tomes $\mathrm{I}-150,15 \mathrm{I}-300$. St. Petersburg, 1878-84 216. Ujfalvy, Charles de. Voyage du Capitaine Kouropatkine en Kashgarie. Nouvelles du Colonel Prjévalsky. Bull. Soc. Géog.,pp. 651-66r. 1877

217. - Leçon d'ouverture d'un cours de Géographie Historique et Politique de l'Asie Centrale [ 1878$]$.

218. Les Bachkirs, les Vêpses, et les antiquités Finno-ougriennes et Altaĭques,

2rg. - - etc. Atlas des étoffes, bijoux, aiguières, etc., de l'Asie Centrale. Paris, r880

Paris, 1880

220. Ujfalvy, Madame de. D'Orenbourg à Samarcand [1876-8]. Tour du Monde. 1879

221. L De Paris à Samarcand, le Ferganah, le Kouldja, et la Sibérie occidentale.

222. Kostenko. The Russian Expedition to the Alai and Pamir [1876]. Tr. by R. Michell from the Russian Irvalide, P.R.G.S., p. 122. 1876-7, and J.R.G.S., p. 17. 1877

223. Baker, Valentine. Clouds in the East. Travels and Adventures on the PersoTurkoman frontier. $\quad$ London, 1876

224. Howorth, Henry H. History of the Mongols. London, 1876

225. Regel. A. Reisen in Central Asien [1876-9], with Map. P.G.M. $\quad 1879$

226. - Reiseberichte vom Kaschthal im Thian Shan. Gartenflora. I881

227. Mouchketoff, I. Les volcans de l'Asie Centrale. Bull. de l'Acad. de St. $\begin{array}{lr}\text { Petersburg. } & 1877\end{array}$

228. Solfataras of Turkestan. Neues Jahrbuch für Mineralogie, Geologie, und Paleontologie. Jahrgang, 1876, p. 516. Stuttgart, 1876

229. Les richesses minérales du Turkestan Russe. Paris, 1878

230. Cahun, Léon. La bannière bleue. Aventures d'un musulman, d'un chrétien, et d'un paièn à l'époque des croisades et de la conquête mongole. Ouvrage illustré de 73 gravures. Paris, 1877

231. Wild, $\mathbf{H}$. Annalen des Physikalischen Central-Observatoriums (Herausgegeben von). Jahrgang 1877 und 1881 . St. Fetersburg, 1878 and 1882

232. Tomaschek, Wilhelm. Centralasiatische Studien, I., Sogdiana. Wien, 1877

233. Recueil d' itinéraires et de voyages dans l'Asie Centrale. Paris, Leroux, 1878

234. Villeroi, Bernard de. A Trip through Central Asia. Calculla, 1878.

235. Faweett, R. H. Routes in Asia. Section iii. Being ... routes in Khiva, Bokhara, Khokand, Yarkand, and Russian Turkestan. Calculla, 1878

236. Latham, R. G. Russian and Turk from a geographical, ethnological, and historical point of view.

237. Parliamentary Reports [1878-8o]. (Correspondence with Russia respecting Central Asia.)

238. Martens, M. F. La Russie et T'Angleterre dans l'Asie Centrale. Gand, 1879

239. - Russia and England in Central Asia. Ridgway, 1879

240. England and Russia in Central Asia. (A review). Oriental Church Maga. sine for December. Nete York, 1879 
241. Das Quellengebiet des Oxus. With Map. P.G.M., p. 9. 242. Verne, Jules. The Exploration of the World.

\section{$1880-1884$.}

243. Regel, Edward, Gartenflora.

Shutgart, 1880

244. Vsepoddanneishiy otchet voennago ministerstva [r88o]. St. Petersburg, 1882

245. Vseobstshii Kalendar za 1882. (Russian calendar for 1882.) St. Petersburg.

246. Vambery, A. On the Uzbeg epos. J. R.Asiat. Soc., New Ser., xii., p. 365. 1880

247. Boulger, D. C. Central Asian Portraits.

248. Pochtovy dorojnik Rossiiskoi Imperii. (Post-road book of the Russian Empire).

249. Russian Slares in the Khanates of Central Asia Oriental Church Meg for Sept. New York, 1880

250. Street, Rev. Owen, The changes in the Physical Geography of the ancient home of man in Central and Western Asia. J. Amer. Geog. Soc., p. 193,

25I. Lentz, P. E. Zapiski Imperatorskago Russkago Geographicheskago Obshestva. (Notes of the Imperial Geographical Society). St. Petcrsburg, 1881

252. Staudinger, 0. Beitrag zur Lepidopteren Fauna Central Asiens. Entomologische Zeitung, October, p. 393. Stettin, 1881

253. Wild, H. Die Temperatur Verhältnisse des Russischen Reiches, St. Prt., I881

254. Réelus, Elisée. Nouvelle géog. universelle. vi. L'Asie Russe. Paris, r88I

255. Middendorf, A. de. Einblicke in das Ferghana Thal. Mém. de l'Acad. de St. Pet., VII Série, tome xxix.

St. Petershurg, 1881

256. Imbanlt-Huart, Camille. Recueil des documents surl'Asie Centrale. Par, 1881

257. Frost, Thomas. Modern Explorers. London, 1882

258. Capus, G., and G. Bonvalot. Reise in Central Asien. P.G.M. 1882

259. - I.es narcotiques dans l'Asie Centrale. Revue Scientifique, No. 24

[16 Juin, 1883]. Paris, Germer, Ballière, et Cie., 1883

260. La Musique chez les Kirghese et les Sartes de l'Asie Centrale. Revue d'Ethnographie.

26r. - Sur les plantes cultivées qu'on trouve à l'état sauvage ou subspontané dans le Thian-schan occidental.

262. Bonvalot, Gabriel. En Asie Centrale. De Moscon en Bactriane. Faris, 1884 26́3. Nolde, Baron Ed, Th. Piteinoe dielo i aktsiznaya sistema. (The Drink question and Excise system.) St. Petersburg, 1882

264. Keane, Augustus H. Asia, Edited by Sir Richard Temple. With Ethnological Appendix. London, 1882

265. Daubrée. Présentation d'un mémoire de Tchihatchef sur les deserts de l'Asie et l'Afrique. Bull. de la Soc. Géog. de France. Paris, 1882-3

266. Bulletin de la Soc. Imp. des Naturalistes de Moscou [1882]. Mosc., 1882 267. The Russians in Central Asia. The Athenxum. No. 2,204.

268. Entfernung der Nachtlager unserer Karawane auf dem Wege von Orenburg nach Chiwa, mit zwei Hodometern gemessen. Beiträge zur Kentniss des Russ. Reiches. Band 15.

269. Verzeichniss der auf dem Wege von Orenburg nach Chiwa gesammelten Pflanzen. Beitrïge zur Kentniss des Russ. Reiches. Band 15.

270. Berezin, P. Sheilianiada. (Text with Russian translation.)

271. Opissanie Turetsko-Tatarskikh rukopissei. Stati ii, iü., iv. (v. Jurnal Ministerstva Narodnago prosveshchenia, ch. 1., liv., and lix. Djagataiskiia rukopissi). (Description of Turco-Tatar MSS., ii., iil., and iv., Journal of Ministry of Public Instruction, vol. 1., liv., lix., Djagatai MSS.)

272. Dorn, B. Rapport sur des monnaies et manuscrits orientaux envoyés aus Musce Asiatique par M. Khanikoff, 513-536. Bull. Acad. St. Pet., I.

273. Manuscrits Orientaux offerts en don au Musée Asiatique par M. Ie Général Kaufmann. 262-276. (German). Bull. de l'Acad. de St. Pet, xx.

274. Edwards, H. Sutherland. The Central Asian Question.

275. "England." The Central Asian Question. A series of letters reprinted from the Friend of India.

London 
276. Geographisches aus Mittelasien. No. 23 Beilage zur Allgemeinen Zeitung, 1870 277. Hammer, Joseph von. Geschichte der Goldenen Horde.

278. - Geschichte der Ilkhanen.

279. Karazine. Traduit du Russe par Tatiana Lvoff et Augustin Teste. Scènes de la Vie Terrible dans l'Asie Centrale.

Paris

280. Le pays où l'on se battra. Voyage d'un Russe dans l'Asie Centrale, Par.

281. Lejean, Guillaume. La Russie et l'Angleterre dans l'Asie Centrale.

282. Ala-eddin Ata Melik Djuveini. Tarikhi Djhankusha. Imperial Library at Vienna.

283. Ebu Bekir Mohammed bin Djafar un Narshakhi, Kitab-i-Narshakhi (book of Narshakhi) under the title of Kitab-i-Akhbar-i-Bokhara (book of news of Bokhara).

284. Said Rakim. Tarikhi Seĩd Rakim. MS. in possession of Professor Vambéry.

285. Munshi Sadik Mirza. Dakhme-i-Shahan. MS, in possession of Professor Vambéry.

286. Mehemmed Yusuf. Tarikhi Mekim Khani. Asiatic Society.

\section{BOKHARA.}

1517-1850.

287. Jenkinson, A. [1517-84.] Voyages and Travels, vo], vii.

288. - [1517-84.] Hakluyt, vol. i.

280. - Purchas, vol, iii.

290. - Travels in Bucharia. Pinkerton's Collection of Travels. 1808-1.

291. Meyendorff, Baron G. Journey to Orenburg [1820]. Tr. by E. F. Chapman. Calcuita, 1870

292. - - (revu par M. le Chevalier Amédée Jaubert). Voyage d'Orenbourg à Boukhara. $\quad$ Paris, 1826

293. — Journey of the Russian Mission from Orenbourg to Bokhara. Tr.

Madras, 1840

294. Eversman, Edouard. Reise von Orenburg nach Buchara. With Preface by Dr. H, Líchtenstein. Berlin, 1823

295. Tychsen, T. C. De numis Graecis et barbaris in Bochara nuper repertis.

Goettügen, 1823.7

296. Wolff, Joseph. Journal of Missionary labours [1827-38].

297. - Travels and Adventures.

298. - Narrative of a Mission to Bokhara [ $1843-5]$.

299. Burnes, A., Travels. Edinburgh Review, Jan., I 835 .

300. Travels into Bokhara, 3 vols.

London, 1860

London, 1860
London, 1845

Helmersen, Gregoire. Nachrichten iiber Chiwa, Buchara, Chokand, und

den l.ordwestlichen Theil des chinesischen Staates. Beitr., T. I1., Pub.

Acad. St. Pet.

1839

302. Khanikoff, N. Description of the Khanate of Bukhara (Russ.), St. Pet., 1843

303. — Bokhara : its Amir and People. Tr by De Bode. Lond. 1845

304. - Samarcand. Tr. par P. Voelkel. Bull. Soc. Géog., xvii., p. 295. 1869

305. Cartes du Turkestan russe. Bull. Soc. Géog. 1877

306. Grover, Appeal to the British Nation. 1843

307. - Bokhara Victims. London, 1845

\section{$1850-1870$.}

308. De Tassy, Garein. Notice sur une carte routière de Mesched à Bokhara par M. Sedillot. Extrait du Bull. Soc. Géog. Taris, 1852

309. Feisalin, Mustava. Nachrichten über Buchara. Kokand, u. 5. W.. von dem Kaukasischen Tartaren..., der diese Gegenden mehrfach besucht. P.G.M., p. 214. 1857

310. Veliaminof-Zernof, Wladimir. Notice sur un poignard Bonkhare. Bull, hist. phil. Acad. St. Pet., T. xvi., pp, I84-9, and Melanges asiatiques, T. iii., pp. $576-83$. 
311. Véliaminof-Zernof, Wladimir. L'Emir Haidar de Boukhara et ses trois fils, Bull. hist. phil. Ácad. St. Pet., T. xvi., pp. $275 \cdot 83$, and Mélanges asiatiques, T. iii., p. 361 .

312. Description de quelques monnaies de l'oulons de Djaghatai, de Khiva, et de Khokand, pp. 207-18. Bull. de l'Acad. Imp. St. Pet., II. La [I3 Avril, r86o]. Melanges asiatiques, iv., pp. 137-52.

313. Kokan, Bokhara, and Afghanistan, Articles on. Punjab Report for 1860-61.

3r4. Vambéry, A. Eine Anekdote aus der Geschichte Bocharas, Westermann's Illustrirte Monatsschrift, No. I.

315. - History of Bokhara.

1871 On Maieff's Journey from Samarkand to Shahr-i-sabz and Bokhara. Tr., Markham's Geog. Mag., April. 1875

317. Beschreibung von Samarkand. P.G.M., p. 224.

318. Gavazzi, M. Alcune Notizie raccolte in un viaggio a Bucara. Milano, 1865

319. Tatarinov, A. Semimassiachniy plen v Bukhari. St. Petersburg, 1869

320. Gloukhovskoy, M. Captivité en Boukharie. Tr. par P. Voelkel. Bull. Soc. Géog., p. 9.

1868

\section{$1870-1884$.}

32I. Kostenko, L. Puteschestvie v Bukharu Russkoi missii [187o]. Petersb., 188,

322. Description of the Joumey of a Russian Mission to Bokhara [1870]. Tr, by R. Michell.

323. Abramof, General. The Principality of Karategin. Tr., J.R.G.S. 187t

324. Lenz, R. Unsere Kenntnisse über den früheren Lauf des Amu-Daria. Mém. Acad. St. Pet., $7^{e}$ série, T. xvi., No. 3. P. 158, P.G.M. 1871

325. Yavorsky, J. L. Puteshestvie Russkago Possolstva po Affiganistanu i Bukharskomu Khanstvu v [1878-9]. (Journey of the Russian Embassy through Afghanistan and Khanate of Bokhara.)

326. - Russian Mission to Cabul [ 1878 ]. Tr. by R. Michell.

327. Oshanin. Erforschung von Karategin [1878], with Map. P.G.M., p. 210. 1882

328. - Travels in Karategin and Darwaz. Tr. from Pro. of Russ, Geog. Soc. for I88I, xvii., I. By Major Walter E. Gowan.

329. Marshall, L, Routes compiled by Col. Maieff, in his second Journey in South Bokhara in [1878]. Tr. from Jour. of Imp. Russ, Geog. Soc., part v., of 1878 . London

33o. Bonvalot, G., et Capus, G. De Bochara à Krasnovodsk. Société de Géographie. 3 Fev., No. 3, et 3 Nov., p. $449 . \quad$ I882

331. The Mennonites. The friend, pp. 32, $8 \mathrm{r}, 163,21 \mathrm{I}, 253$ (1882), $180\left(188_{3}\right)$,

332. Poole, Stanley London, $1888_{3}$ Poole, Stanley L., and Reginald S. Catalogue of Oriental Coins in the
British Museum. The Coinage of Bukhara (Transoxiana). London, 1882

333. Eyries. Bukharie, J.R.G.S., vol, xiv.

334. Sur les affaires de Boukharie. Jour. de St. Pet., pp. Ir4 et rr5.

335. Captivité en Boucharie. Bull. de la Soc, Géog, Paris, 1861, vol. ii. ; 1865, I., p. 438 ; 1868 , Sep. p. 265.

336. Ivanoff, The Kussian Pamir Expedition [1883]. Tr., P.R.G.S. Lond., 1874

\section{KHIVA.}

\section{$1717-1850$.}

337. Cherkaski, A. Bekovitch. The Russian Military Expedition to Khiva [17 17]. Tr. by R. Michell, London R.G.S.

338. Mehemmed Salih of Kharezm. Sheibaninameh. Imperial Library, Vienna. 339. Riza, Qouly Khan. L'Ambassade au Kharezm. Tr. C. Schefer, Paris, I879 340. Khanikov, N. A. Poyeasdka iz Orska v Khivu i obratno [1740-41]. (Journey from Orsk to Khiva and back.)

St. Petersourg, 1851

341. Lockhart, W. S. Muravieff's Journey to Khiva through the Turcoman country [18r9-20].

Meyendorff. Sce 29I-3. 
342. Mouraviev, M. N. Voyage en Turcomanie et a Khiva [1819]. Paris, 1823 343. Route de commerce d'Ástrakan à Khiva. Journal Asiatique, vol. iv. ${ }_{1824}$

344. Shakespear, Richmond. Journey to Khiva. Blackwood's Mag., June.

345. Conolly, Arthur. Journey to the North of India overland from England through Russia, Persia, and Afghanistan.

346. Travels. Edinburgh Review, July, 1844 .

Helmersen. Sec 72, 74, 301.

347. Ivanov, N. P. Khivinskaya Ekspeditsiya [1839-40]. St. Petersburg, 1873

348. Vigne, G. T. A personal narrative . . with notices of . . Khiva, etc. I840

349. Rukavkin, A. Puteshestvie iz Orenburga v Khivu. (Travels from Orenburg to Khiva.)

Basiner, T, F. J. See 87 .

350. Butakoff, A. Survey of the Sea of Aral [1848-9]. J.R.G.S., p. 93. 1853

35r. - The Delta and Mouths of the Amu-daria or Oxus, Tr. by R. Michell. P.R.G.S., P. 113 , and J.R.G.S.

I866-7

352. A bbott, James. Journey from Heraut to Khiva [1840]. Lond., 1856 and 1884

$$
\text { 1850-1870. }
$$

353. Beschreibung des Chanats Chiwa. P.G.M., p. 213. 1857

354. Kühlewein, G. Rélation d'un voyage à Khiva. Journ. de St. Pet., 8, 9. and 1o Ang., 1861. P.G.M., p. 366.

Vambéry. See $118-21,123-5,246,654$.

355. The Sea of Aral and the Russians in Central Asia, Colburn's Nezu Monthly Magazine, No. I, 122.

1868

\section{0.}

356. Rawlinson, Sir H. C. On Trade Routes between Turkestan and India. P.R.G.S., xiii., p. 10.

357. - England and Russia in the East. A series of papers on the Political and Geographical Condition of Central Asia. London, 1875

358. - Notes on Khiva. P.R.G.S., p. 162. $1872-3$

359. Ignatieff, General (probably written by). Advantages to Russia of possession of Khiva. Russkii Mir ( 7he Russian World), June. 1873

36o. Rèclus, E. Note rélative à l'histoire de la mer d'Aral. Bull. Soc, Géog. Août.

361. Kostenko, L, F. Die Stadt Chiwa im Jahre [1873]. P.G.M., p. 121. 1874

362. Khiva en [1873]. Tr. du russe par M. Guyard. Bull. de la Soc. de Géog., Nov., pp. 469-492.

363. - De Khiva au fort de Kasala.

1874

364. - Le Globe de Geneve, 1875

364. Von Chiwa nach Fort Kasala am Syr-Daria. P.G.M., I874

365. Lerche, P. Khiwa oder Kharezm. Seine historischen und geographischen Verhältnisse. Mit einer Karte von Khiwa. St. Petersburg, i873

366. Schmidt, Emil. Lerche, P. Die Expedition gegen Chiwa im Jahre [1873]. Russ. Revue, Band vi. St. Petersburg, 1874

367. - Die Russischen Expeditionen $[1874]$ in die Niederung des Amu-Darya. Russische Revue, pp. 225-247. Si. Petersburg, 1875

368. Zerbs, Anton. Die Russische Expedition gegen Chiwa [1873]. Wien, 1875

369. Soliman, Hauptmann. Positionsbestimmungen in Chiwa und am Aral-See, [1873]. P.G.M., p. 35 .

370. Niemann, Hauptm. A von. Die Russische Expedition nach Ch7 P.G.M., p. I6r.

371. Le Khiva en Mars [ 1873 ]

372. Blaramberg, Gen. von. Der Feldzug nach Chiwa [1873]. P.G.M. I874

373. Stumm, Hugo. Mit der Russischen Armée gegen Chiwa [1873]. P.G.M., p. 281.

374. Aus Chiwa

375. - Der Russische Feldzug nach Chiwa.

376. — Russia's Advance Eastwards.

Berlin, 1873

Berlin, $\mathbf{1} 875$

London, 1874 
377. Kolokoltzof, Col. Expédition de Khiva [1873]. Le Globe, Journ. Géog. de la Soc, de Genève, xiii., pp. $24 \cdot 40$.

378. Veninkof, Col. Khiva $[1873]$. Bull. Soc. Géog., April and June.

379. Suavi-Effendi. Le Khiva en [1873]. Paris, 1873

38o. Saint-Martin, V. de. Géographie du Khanat de Khiva. 13. L'Année Geographique. $\quad$ Paris, 1874

38r. Khanikoff, Nicholas de Les documents sur le Khanat de Khiva, Bull. Soc. Géog., March, pp. 282-94. 1873

382. Roesler, Robert. Die Aralseefrage. Wien, 1873

383. Traub, Paul. Khiva et le Prince Bélouidek. Héros de la Perse. 1874

384. Spalding, H. Khiva and Turkestan. Tr. from Russ. I.ondon, I874

385. Ker, David. On the Road to Khiva. London, 1874

386. The Mineral Wealth of Central Asia as bearing on Russian progress. Geog. Mag, January, p. 4. 1875

387. MacGahan, J. A Journey to Khiva. Bull. Amer. Geog. Soc. 1874

388. Campaigning on the Oxus, and the Fall of Khiva. Jondon, 1874

389. Kiepert, $\mathbf{H}$. Das Tiefland von Chiwa, mit dem Delta des Amu-Darya, Nach russischen und von Lieut. H. Stumm gesammelten Materialen. Berl. 1875

39o. Paget, John C. Khiva and the Eastern Question. St. Fames's Mag., 1875

391. Tillo, A1. A. von. Notice sommaire sur le nivellement Aralo-Caspien.

392. Wood, Herbert. Notice sur une cause probable du changement cours de l'Amou Daria. Genteve, 1875

393. - The Aralo-Caspian Depression. Geog. Mag., May. London, 1876 394. West Turkestan and adjoining countries. (The shores of Lake Aral, 395. $\frac{\text { Geological Exploration in the Amu-Daria District. Geng. Mag, }}{\text { January. }}$

396. Burnaby, Frederiek. A Ride to Khiva. Kondon, 1876

397. Howorth, Henry H. The Basins of the Caspian and the Aral. Corre. spondence, Geog. Mag., April, p. Io6. London, 1876

398. Das Nivellement zwischen dem Aralsee und dem Kaspischen Meere. P.G.M., p. 3 Io.

399. Burnand, F. C. The Ride to Khiva, Punch. 1877

400. Morgan, E. D. Old Channels of the Lower Oxus. J.R.G.S., 1878

40I. Koenen, A. von. Ueber die unter-oligocaene Tertiaerfauna vom Aralsee. Veliaminof Zernof See 312.

\section{0-1884.}

402. Amu Daria, Hydrometric Measurement of the. Orient. Church Mag., Oct. New York, i $88 \mathrm{i}$

403. Bogdanoff, M. N. Account of the Fauna and Flora of the Khivan Oasis, and the Kizil Kum Desert (Russ.).

404. C[larke], F. C. H. Khiva. Art. in Encycl. Britannica. Londont

405. Meteorologische Beobachtungen, angestellt während der Reise von Orenburg bis Taschhaus. Beiträge zur Kenntniss des Russ, Reiches, Band, 15.

406. Zimmermann. Khiva. Tr. by Morier. London, J. Madden

\section{KHOKHAND.}

\section{3-1870.}

407. Singh, Sodi Hukum. History of Khokand. Ed. Charles Ellison Bates.

\begin{tabular}{l} 
Lahore, 1878 \\
\hline .
\end{tabular}

408. Nazaroff, Fxpedition to Khokand [18r 3 and 1814$]$ ].

St. Pet.

409. Klaproth, J. Voyage à Khokhand [ $181_{3}$ et 1814], par Ph. Nasarow. Mag. Asiat., I.

4ro. Notices géographiques et historiques sur Khôkand, et autres pays. Klaproth's Mag. Asiatique, vol. i., p. $8 \mathrm{r}$. 
Helmersen. Sec 72-4, 99, 3or.

Veliaminoff-Zernof. See 312.

Punjab report. Sce 313 .

4II. Report of a Joumey to Kokan. Selections from Records of Government of India. No. xxxix. Calcutta, 1863

412. Osten-Sacken, P. R. Les paysages inconnus de 1'Asie Centrale. Annales des voyages, No. 3. 1870

413. Expedition to the Trans-Naryn Country in [1867]. Tr. by E. D.

Morgan, P.R.G.S., p. 221, 1869 ; J.R.G.S., p. 250.

1870

414. - und Ruprecht, F. J. Sertum Tianschanicum. Botanische Ergebnisse einer Reise im mittleren Thian-schan. Mém. de l'Acad. Imp. de St. Pet.

415. Michell, Robert. The Jaxartes, from Russian sources. I.R.G.S., p. 420 i869

$$
\text { 1870-1884. }
$$

416. Fedehenko, A. Reise in Kokan und zum Nordende des Pamir, [1871]. P.G.M., p. 16r.

417. - Reise während $[187 \mathrm{r}]$ im suidlichen Greenzgebirg von Kokan. Tr. F. Marthe. Zeitschr d. Gesellsch. f. Erdk.. Bd. vii.

418. - Travels in Khokand, and to the Upper Waters of the Jaxartes. P.G.M.

419. Travels in Khokand, Aug. Geog. Mag. 1874 Kann Alon, 1873

420. Kuhn, Alexander von. Province of Ferghana. Tr. by F. Henvey. Simla, 1876

421. Vambery. A. Russian Campaigu in Khokand. Markham's Géog. Mag., r876 Veniukoff, $S_{e c}$ 130-134.

422. Michell, R. Ferghana. Markham's Géog. Mag. 1876

423. Weil. La campagne des Russes dans le Khanat de Khokand [1875-6]. Journal des Sciences Militaires. Paris, 1876

424. Severtsoff, $\boldsymbol{N}$. Journey in Ferghana and the Pamir [1877-8]. From a trans, by Alexis Lomonossof. P.R.G.S., p. $499 . \quad 1880$

425. - New species of Turkestan Birds (Russ). Notes of Turkestan section of Soc. of Friends of Natural History, etc, vol. i. Tashkend, 1879

426. Birds of the Pamir. Nis, 5 th series, i., p. $48 . \quad$ I883

427. Ujfalvy, c. de, Excursion scientifique dans le Ferghana. Bull. Soc. Géog.,

$\begin{array}{ll}\text { August, pp, I90-193. } & 1877\end{array}$

428. - Notes sur le Ferghana. Bull. Soc. Géog., October, pp. 425-9. 1877

429. - Le Kohistan, le Ferganah, et Kouldja. Paris, 1878

430. Atlas Anthropologique des Peuples du Ferghanah. Paris, 1879

431. Capus, G. Les sables du Ferganah. Archives des Missions scientifiques et littéraires. 3e série, tome viif.

Paris, 1882

\section{KULDJA.}

\section{2-1850.}

432. Gaubil. Journal de la Mission Chinoise chez les Tourgouth Tartares. [1712]. Soc. Observ. Math., etc., I., Pp. 148-175.

433. Amiot. Monument de la transmigration des Tourgouttes [1712]. Mém. Conc. I., pp. 40I-418.

434. Unkowsky, J. Neueste Historie der östlichen Kalmiickei. Miiller's Samml. Russ. Gesch., I., p. 123.

435. De Guigne's Hıstoire générale des Huns, iv., p, I0z Paris, 17532

436. Pesterev, Jegor. Remarques sur les peuples qui habitent la frontière chinoise, sur les Tatars tributaires de la Russie, et sur les Soïotes et Mongols soumis à la Chine [177r-81]. Klaproth's Magasin Asiat., vod. i., p. 123. 1825 437. Bergmann. Nomadische Streifereyen unter den Kalmuken. 4 v. Riga, 1804 438. Voyages chez les Kalmucks, Traduit de l'Allemand. Chatillon, 1875 439. Timkowski, George. Travels of the Russian Mission through Mongolia to China [1820-21]. 
440. Pontimstev, M. Voyages de Bukhtarminsk à Gouldja ou Ili [181r]. Klaproth's Mag. Asiat., vol. i., p. $173 . \quad 1826$

441. Trautvetter. Enumeratio plantarum sungoricarum a Dr. Schrenk annis [1840-43] collectarum. Bull. Nat. Moscou, i., i., 1860: ii., iv., p.937. 1866

442. Karelin et Kirilow. Enumeratio plantarum in desertis Sungoriæe orientalis et in jugo summarum alpium Alatau anno [184r] collectarum. Bull Nat. Moscou, i., ii., iii. p. 933 .

1842 .

$1850-1870$.

443. Zwick, H. A. Grammatikder West-Mongolischen, d. i., Oirat od. Kalmitkischen Sprache.

Danauesch., 1852

444. Atkinson, T. W. A Journey through some of the highest Passes in the Ala Tau and Ak Tau Mountains, P.R.G.S., p. 127. 1858-7

445. - Mrs. Recollections of Tartar Steppes. London, 1863

446. Semenoff, P. P. First Ascent of the Thian Shan in [1857]. With Map. Tr. by John Michell. T.R.G.S., p. 356. I86 $\mathrm{r}$

447. - Djungaria and the Celestial Mountains. Tr. by J. Michell J.R.G.S.,

448. P. 213. $\begin{array}{r}1865 \\ \text { Forschungsreisen in den Transilischen Alatau und zum Issyk-kul. }\end{array}$ Zeitschrift d. Gesellsch. f. Erdkunde. Berlin, 1869

449. - Narrative of an Exploring Expedition from Fort Vernoye to the Western Shore of Issik-Kul. Tr. by E. D. Morgan. J.R.G.S., p. 311.1869

450. Regel, E. et Herder, $\mathbf{F}$. Enumeratio plantarum in regionibus cis-et trans: iliensibus a Semenovio, anno [1857] collectarum anctoribus. Acta Horti Petropolitani.

Mosizua, 1864

451. Der Fluss Ili als künftige Wasserstrasse nach dem westlichen China. P.G.M., p. 407 .

452. Sabir, C. de. Le pays des sept rivières et la contrée trans-ilienne. Mémoir. Société de Géog. $\quad$ Paris, 1861

453. Molloy, Captain. Narrative of the Tungani Insurrection in Eastern Turkestan in [1863].

454. Michell, Robert. Eastern Turkestan and Dzungaria, and the Rebellion of the Tungans and Taranchis.

455. Temperatur-Beobachtungen in Kuldscha. P.G.M., p. III. I865

456. Die Seenzone des Balchasch-ala-kul, und das Sieben-Stromland mit dem Ilibecken. P.G.M., pp. 73, I63, 393.

457. Motchoulski, V. de. Coléoptères rapportés de la Sungarie par M. Séménof,

458. pp. 30I-14. Mém. de l'Acad. de St. Pétersbourg. des Kirghises. Bull. de l'Acad. Imp. St. Pet., ii., Pp. 513-44.

\section{$1870-1884$.}

459. Cordier, Henri. Catalogue of the Library of the North China branch of the Royal Asiatic Society (including the Library of A. Wylie). Shanghai, 1872 460. Bibliotheca Sinica. Dictionnaire bibliographique des ouvrages relatifs i 1'Empire Chinois. Publications de l'école des langues $x$. Paris, 1878

461. Dilke, Ashton. On the Valley of the Ili. P.R.G.S, vol. xviii., p. 246. 1874 462. Mollendorff, P. G., and 0. F. von. Manual of Chinese Bibliography, being a list of Works relating to China. Shanghai, Kelly \& Walsh. London, 1876 463. Prjevalsky, N. M. Reise von Kuldscha iber den Thian-Schan an den Lob-Nor und Altyn-Tag [1876 und 1877]. Gotha, 1878 464. - From Kulja across the Tian Shan to Lob-Nor. Tr. by E. D. Morgan. Including Notices of the Lakes of Central Asia. London, 1879 465. - Expedition fromKuldja to Lob-Nor. Orient. Ch. Mag, March.

66. New York, 1879 466. Regel, A. Meine Expedition nach Turfan [1879]. P.G.M., p. 27, Band x. 1881 467. Pantussoff, N. Sviedienia o Kuldjinskom Raione za [1871-7]. Information on Kuldja. Kasan, r881 
468. Statisticheskia sviedienia po Semiriechenskoi oblasti i Kuldjinskomu raionu za 1878 (Statistics of Semirechia and Kuldja). In Manuscript; unpublished. Ujfalvy. Sec 429 .

469. Clarke, F. C. H. Kuldja. P.R.G.S., p. 489 .

470. Morgan, E. D. A Journey through Semiretchia to Kuldia [1880] P. G. ${ }_{1880}$

47 I. Alpheraky, Serge. Lepidopteres du distriet de Ko [isjo], P.R. Societatis Entomologice Rossice, Tom, xvi., 1881; xvii. St. Pet., 1882
Sorse

472. Kuropatkin, A. N. Itinerary of the route followed by the Russian Embassy to Kashgaria [1876]. By W. E. Gowan.

473. - Kashgaria. Tr. by W. E. Gowan (London, E. Thacker). Calcutta, 1882

\section{SIBERIA-WESTERN.}

\section{FROM EARLIEST TIMES TO 1850.}

474. De la Croix, Pétis. Life of Gengis Can. 475. Purchas. Relation of two Russe Cossacks Travails out of Siberia to Catay.
Vol, iii.

476, Ides, E. Ysbrand. Driejarige Reize naar China 1619

477. - Journal of an Embassy to China. Amsterdam, 1710

478. 'Three years' Travels from Moscow overland to China. London, 1706

De Guignes. Sce 435 .

479. Coxe, William. Account of the Russian Discoveries between Asia and

America, to which are added the Conquest of Siberia.

480. Meiners, C. De antiquis monumentis in Siberia australi existentibus. In

Goettingener Ges, d. Wiss. Comm.

481. Humboldt, A von Personal Narratives of T795-8

[I799-1804] Tr. by W. MeGillivray of Travels to ... Asiatic Russia

482. [1799-1804]. Tr. by W. MeGillivray.

483. - Asie Centrale, Recherches, etc.

484. and Graf G. von Cancrin. Im Ural und Altai.

485. Yazykov, D. J. Sobranie puteshestvii k Tataram. Leipaig, 1869 among the Tatars.)

(Collection of Travels

486. Rose, Gustav. Mineralogisch-geognostische Reise St. Petersburg, 1825 Altai, und dem Kaspischen Meer.

48. Fedorow. W. Vorlanfige Berichte ausgeriihrten astronomisch-geographische von itim . . . in West Siberien

488. Jones, Sir W. W. 1838

488. Jones, sir W. Works. Vol. i., 4to edition, Discourses on the Tatars.

489. Notices des manuscrits de la Bibliothèque du Roi. Vol. xiii., p. 291. Paris, 1838

490. Bonyard, E. H., und C. A. Meyer. Verzeichniss der am Saissan-nor und am Irtysh gesammelten Pflanzen. Besonderer Abdruck. Mémoires de 1'Acad. Imp. St. Pet., tom iv.

491. Fischer, F. E. L., et C. A. Meyer. Enumeratio plantarum 1841 Sehrenk lectarum.

492, - History of Siberia. German.

Petropoli, 1841

493. Middendorff, A. T. von. Voyage scientifique dans la Sibérie occidentale. 1844

\section{0-1884.}

494. Atkinson, Thomas W. Oriental and Western Siberia.

494. Atkinson, Thomas W. Oriental and Western Siberia.
495. Abramof, N. Semipalatinsk. With Table of Meteorological Observations, 496. J.G.S., p. 555 .
1862 496. - Nor Tsai-san and its Neighbourhood. P.R.G.S., 1864-5, $\begin{array}{r}1862 \\ \text { and } \\ 1865\end{array}$

497. Cherkassoff, A. Zapiski Okhotnika Vostochnoi Sibiri, 1856-63. St. Fot., 1867 498. Ujfalvy, c. Excursions en Dzoungarie. Bull. Soc. Géog., Dec., p. 638.

499. — Le Syr-Daria, le Zérnfchâne, le pays des sept-vivières, etc. Paris, 1877

500. - Atlas archéologique des antiquités Finno-Ougriennes et Altaiques de la Russie, de la Siberie, et du Turkestan. Paris, 1880
P

VOL. II. 
501. Obzor Akmolinskoi oblasti za [1380]. (Review of the Akmolinsk Oblast)

Omsk (not published), i881

502. Obzor Semipalatinskoi ; oblasti. (Supplements to the Reports of the Governor of the Semipolatinsk Oblast for [1879-80, and 1881$]$. Not published.

503. Finsch, 0tto. Reise nach West Sibirien im Jahre [1876]. Zool, Botan. Soc. of Vienna.

504. Pamiatnaia knijka Zapadnoi Sibiri (Calendars for Western Siberia) for [1880 and 1881 ]. Omsk, I881 82

505. Yadrintseff, N. M. Sibir kak kolonia. (Siberia as a Colony.) St. Pet., 1882

506. Laharpe. Sibérie. Voyages de Gmélin, vol. viii.

507. Lansdell, Heary. Through Siberia [1879]. 2 vols. London, 1882

508. - do. I vol.

London, 1883

\section{TURKISTAN. \\ 1650-1850.}

509. Abulfeda. Chorasmix et mawralnahre, hoc est, regionum extra fluvium Oxum descriptio. From the original Arab, and Lat.

London, 1650

510. Astley, T. Vol. IV. Collection of Voyages. Descrip. of Turkestan. 1745-7

511. Milman, H. H. Samor, Lord of the Bright City : an heroic Poem. 1818

512. Old Bed of the Oxus, Nouveau journal Asiatique. December, 1833 Perovski. See 75.

513. Yagmin, A. Kirghiz Kaisatzkiya Step i ikh jiteli. (The Kirghese Kazak Steppes and their Inhabitants.)

514. Burslem, Rollo. A Peep into Toorkistan.

St. Ptcosburg, 1845 London, 1846

515. Lal, Mohan. Journal of a Tour through Panjab . . Turkestan (in company with Lieut. Burnes).

516. - Travels in ... Turkestan.

Calcutta, $1834 ;$ London, 1846

$1850-1870$.

517. Ferrier, J. P. Caravan Joumeys in . . Turkestan, London, 1846

518. Maksheev. Opisanie nizoviev Sir-Daryi. (Description of the Lower Syr. daria.) St. Pctersburg, 1856

519. Maksheeff, Kapition. Beschreibung des Aral-Sees. P.G.M., P. 213. 1857

Véliaminof-Zernof, Wladimir. Sec 312.

520. Golubef, A. Brief Sketch of the Results of the Issyk-Kul Expedition. Tr. by John Michell. J.R.G.S., p. 366.

521. Ostroumoff, N. Istoricheskii ocherk narodnago obrazovaniia. (Historical account of the National Education in the Towns and Forts of the former Syr-daria line and Turkestan Oblast [1860-67].) Tashkend, 1881

522. Characteristics of the Mussulmans in Central Asia. Moskovskoe Pravoslavnoe Obozrenie (Orthodox Rev.). August. 1880

523. Kitarskie Emigranty. (Chinese Emigrants in the Semirechia oblast of the Turkistan region and the spread among them of orthodox Chris. tianity.) Kasan, 1879

524. Marthe, F. Russische wissenschaftliche Expeditionen im Jahre [1864 und 1865] in Turkistan. Zeitschrift fiir Allgemeine Erdkunde. Berlin, 1867

525. Lobysevitch, Théodore. La ligne militaire du Syr-Daria. St. Petersburg, 1865

526. Paschino, P. J. Turkestanskii Krai [1866]. St. Petersburg, 1868

527. Das Land Turkestan [1866]. P.G.M., p. 117.

528. Poltaratsky. The Country between the Tchou and Syr Rivers (Russ). Zapisky Imp. Russ. Geog. Soc., I. 1867

529. The Country between the Tchou and Syr Rivers. Tr. into French by P. Voelkel. Bull. Soc, Géog., December, p. 433 . Faris, 1869

530. - Voyage du général .... et du baron 0sten-Sacken, dans le Turkestan Russe, Annales des voyages, No. II. 1868

53I. Kazantseff, Blia, Opisanie Kirgiz-Kasakof. (Description of the Kirghix Kazaks.) St. Petcrsburg, 1867 
Osten-Sacken. See 412-414.

Michell, R. See 144, 222, 351, 415, 454, 533, 538, 562 .

532. Die Turkestanische Industrieausstellung in St. Petersburg. Globus. 1869

533. Miehell, R. Notes on the ruins in Samarkand. Tr. from Fedchenko's description of the Valley of the Zerafshan [1869]. P.R.G.S., P. 393. 1870-71

534. Fedchenko, A. P., Edited by. Puteshestviye v Turkestan (Travels in Turkistan). Vols xi., parts I-7; xix., 8-10; xxi, I1-13; xxvi., 14-16 ; xxxiv., 17-18; also vol. iii., part 2 (Instructions for the Expedition); and ix., part I ; X., I and 2 ; and xiv., for various works on fauna, flora, etc, of Turkistan, as :-Mammals, Birds, Reptiles, and Fishes, by Severtsoff; Fishes, by Kessler; Mollusca, by Martens ; Crustacea, by Ulianin ; Aranene, by Kroneberg ; Coleoptera, by Solsky ; Mellifera, by Morawitz; Sphegidae, Mutillidae, and Chrysidiformes, by Radozkovsky; Scoliidae and Orthoptera, by Saussure ; Formicidae, by Mayr ; Lepidoptera by Erschoff: Neuroptera, by MacLachlan; Odonata, by Brauer ; and Vermes, by Krabbe; in Isvestia Imperatorskago Obshchestva Lubitelei Estestvoznaniia. (Transactions of the Imperial Society of Friends of Natural History, Anthropology, and Ethnography.) Tomes i.-xxxviii. Moscow 535. - Sketch of the Zarafshan Valley. J.R.G.S., 1870

536. - Reisen in Turkestan. P.G.M., p. 201. 1870-71

537. - Topographical Sketch of the Zarafshan Valley. Brit. Assoc. Report, xl.,

538. - Notes on Map of Maghian. By R. Michell, J.R.G.S. P. 1870

539. - Das Gebiet des Oberen Amu und die Orographie Central Asiens. With Map. P.G.M.
1874

540. Adamoli, Jules. Das Thal von Samarkand und der dortige Seidenbau. Nach brieflichen Mittheilungen. Dentsch bearbeitet von W. Koner. Zeitschrift der Gesellsch. für Erdkunde. I870

541. Turkestan Gazette, January, 1871. Statistics of the Province of Central Asia ;

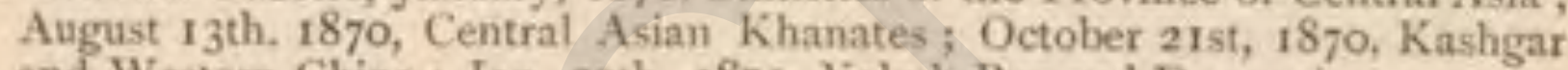
and Western China : Jan. 29th. 1871, Yakub Beg and Dunganis.

\section{$1870-1880$.}

542. Lerche, $\mathbf{P}$, Das russische Turkestan. Russ, Revue,

543. Petzholdt, Alex, and Lerche, P. Turkestan auf Grundlage einer im Jahre [1871] unternommenen Bereisung des Landes geschildert. Leipaig, 1874

544. Umschau im Russischen Turkestan, nebst einer allgemeinen Schilderung des "Turkestanschen Beckens."

545. Maieff, N. A. Material dlia statistiki Turkestanskago Kraia. (Turkestan Annual), vol. i. St. Petersourg, I872

546. - do. do. Vol. ii.

547. - do. do. Vol. iii.

548. - do. do, Vol, iv.

549. - do. do. Vol, v.

$\begin{array}{lll}" \prime & " & 1873 \\ " & " & 1874 \\ ", & ", & 1876 \\ ", & " \prime & 1879\end{array}$

550. The Saturday Review. Articles on Central Asia, January 18"th, 1873; February Ist, 1873; April 5th, 1873; April 26th, 1873; May Ioth, 17th, and $31 \mathrm{st}, 1873$; June 28 th, 1873 ; August 2nd and 9 th, 1873 .

551. The Pall Mall Budget. Articles on Central Asia, January 2nd, Ioth, and 17th, 1873; February 14th and 21st, 1873; April 2nd and 25th, 1873; November 7 th, 1873 ; December 5 th, 1873 ; May 8 th, 15th, and 29th, 1874 ; June 12th, 1874 ; July 1oth, 1874 .

552. Notix uber das im Jahre [1873] in Turkestan beobachtete Temperatur Maximum. Russ, Revue.

553. Alphabetical Index to the contents of the Turkestan Annual for the years $1872,1873,1874,1876,1879($ Nos, r, 2, 3, 4, 5), and of the Turkestan Kalendar for 1880 ,

Simla, $188_{3}$

554. Regel, E. Descriptiones plantarum novarum in regionibus Turkestanicis a el. viris Fedjenko, Korolkow, Kuschakewicz et Krause collectarum. Fasciculi 1.-VIII. Petropoli, 1873 
555. Regel, E. Descriptiones plantarum novarum et minus cognitarum in regionibus Turkestanicis crescentium, II, and III. Transactions of Botanical Gardens of St. P'etersburg, p. 289 .

556. - A. P.G.M., p. 155.

557. Das russische Turkestan. Die "Grensboten," No. 25. 1873

558. Vambery, A. The Steppes to the North of Bokhara. Geog. Mag., 1873

559. Nachrichten tiber das Klima von Turkestan. P.G.M., p. 434 1873

560. Severtsoff, N. A. Puteshestviya po Turkestanskomu Kraiu. St. Pet., I873

561. - Erforschung des Thian-schan Gebirgssystems [1867] nebst kartographischer Darstellung desselben Gebietes und der Seenzone des BalkashAlakul und Sieben-Stromlandes. Nach den Originalen und offiziellen russischen Aufnahmen von A. Petermann Gotha, 1875

562. - Journey to the west portion of the Thian Shan. [1867]. Tr. by $\mathbf{R}$ Michell. I.R.G.S. 1870

563. Vertical and Horizontal Distribution of Turkestan Animals [1873]. Tr. in Annals and Magazine of Natural History, Oct. I.ond., r876

564. - Vertical and Horizonal Distribution of Birds. Tr. into German, pp. 321-89, Oct., 1873; 403-47, 1874; 58-104, 168-200, 1875. Cabanis, Journal für Ornithologie.

565. - Letter with corrections of article on Birds in Cabanis' journal, pp. 420-3I, vol, iii,, 1875. "Stray Feathers." London

566. Dresser, H. E. Notes on Severtsoff's Fauna of Turkistan (Turkestanskia Jivotnyia), pp. 77, 171, 319, 410. "The Ibis."

567. De Marny, N. P. B. Geological Explorations in the Region of the Amu Daria. Markham's Geog. Mag, December, p. 362 . London, 1857

568. Daly. Russian Expedition to Turkestan. Bull. Amer. Geog. Soc. $1874-6$

569. Index to the contents of the Turkestan Gazette from 1874 Simla, 1883

57o. Lubomirski. Un nomade Safar-Kadgi. Les Russes äSamareand. Par, 1874 Spalding. See 384 .

A berigh Mackay. Sec 195.

571. Hochstetter, Ferd. v. Asien, seine Zukunftsbahnen, seine Kohlenschätze Eine geog. Studie. $\quad V_{i c n}, \mathrm{IS}_{76}$

572. Iwanow, D. Die Russen in Turkestan. Nach Skizzen Deutsch von A. v. Drygalski. Stuttgart, 1876

573. Khoroshkhin, A. P. Shornik statei kasaiushchikhsia Turkestanskago kraia (Collection of papers relating to the Turkestan region). St. Pet., 1876

574. Kiepert, $\boldsymbol{H}$. Turan oder Turkistan, zu C. Ritter's Erdkunde, zum dritten Mal neu bearbeitet.

Berlin, 1876

575. Die Sande Kara-Kum, in ihren Beriehungen zur Eisenbahn. P.G.M. 1878 Ujfalvy. See 427-30, 498-500.

576. Piankoff, B. Turkestanskii Kalendar za [1880]. Tashkent, 1879

577. Oshanin, B. Materials for the Hemipterological Fauna of Turkistan. Notes of Turkistan section of the Society of Friends of Natural History, etc. (Russ),

Tashkend, 1879

578. Zapiski Turkestanskago otdiela I. O. (Notes of the Turkestan Section of the Society of Friends of Natural History, etc.), vol. i.

Tashkend, $\mathbf{1} 879$

1880-1884.

579. Kostenko, L. Turkestanskï Krai, 3 vols. (Turkestan region.) St. Pet, 1880 580. Capus, G. Das Jagnau-Thal und seine Bewohner. P.G.M. ${ }_{188}$

58r. - Sables mouvants et colonnes de brèche du Turkestan. La Nature, p. 343, April 26th, 1884. Paris

582. Indications sur le climat et la végétation du Turkestan. Annales des sciences naturelles, Botanie, vi, série, tome xv., xvi., xvii., xviii.. Nos 4.6. Paris, $1883^{-4}$

583. Dragendorf. Ueber den jetzigen Zustand der Volksmedecin in Turkestan.

584. Beschreibung des Landes Turkestan. Allgemeine Historie, etc., vol. vii.

585. Nachrichten aus Turkestan. St. Pet. Zeitung, 214. Rigasche Zeitung, 64. 
586. Motivirovannaya Zapiska o Amu-Daryinskom Otdielie sostavlennaya po programe prikaza po General-Gubernatorstvu, No. 36 (Notes concerning the Amu-Daria District for the General Governor). In MS., umpublished.

587. La défense de Samarkande. Fournal de St. Pil., No. I8I.

588. La prise de Samarkande. Fournal de St. Pet., No. 116.

589. Bulletin militaire. Nouvelles du gouvernement général du Turkestan du 15 Avril. Fournal de St. Pet., No. 117.

590. Sobolef. Geography and Statistics of the Zarafshan District (Russ.)

\section{TURKMENIA.}

\section{FROM EARLIEST TIMES TO 1870.}

Clavijo, R. G. de. See 21 .

Muravieff. See 342 .

591. Bode, Baron de. Otcherk Turkmenskoi zemlii i yugo-vostochnago prebrajia Kaspiiskago moria (A Sketch of the Turcoman Land and South-East Littoral of the Caspian Sea in [ $18_{37}$ and 1848$]$ ). Otechestvennyia Zapiski (Annals of the Fatherland), July, August, September. St. Petersburg, 1856

592. Michell, $\mathbf{R}$. Memorandum on the Country of the Turcomans. giving an account of the Russian Occupation of the East Coast of the Caspian.

593. Quelques apercus sur les Turcomans à l'orient de la mer Caspienne. Nouvelles Annales des Voyages et des Sciences géographiques. Faris, 1852

594. Karelin, Gr. Enumeratio plantarum quas in Turcomania et Persia boreali collegit. Bull. Natur. Hist., p. 14I.

Zimmermann. See 83, 598, 662.

595. De Hell, Xavier H. Les Steppes de la Mer Caspienne, etc. Paris, 843

596. Travels in the Steppes of the Caspian Sea.

597. Pushchin Kaspieskoe more Hidrondon, 1847 dlia plavania (The Caspian Sea irografitcheskoe opisanie i rukovodstvo hook for Navigation). Rnesian Hydrograghical Description and Hand.

598. Humboldt, H. A., und Carl Zimmdrographical Department. $1854-77$ Inf des Oxus Aimmermann. Denkschrift tiber den untern

599. Borszezow, E1, Compte rengas Haff des Caspischen Meeres. Berlin, 1845 pendant E1, Compte rendu géneral sur les résultats botaniques, obtenus pendant un voyage dans les régions Aralo-Caspiennes [ I857 $_{57}$ et 1858]. Bull. phys, math., Pp. $471-479$. Acad. de St. Pet., T. xvii. Lu le 7 Jan. 1859

600, - - Die pharmaceutisch-wichtigen Ferulaceen der Aralo-Caspischen Wüste.

601. Die Aralo-Caspischen Calligoneent 1860

602. Abich, H. Ueber eine im Caspischen Meere erschienene Insel nebst Beiträgen zur Kenntniss der Schlammvulkane der caspischen Region, Mém. l'Acad. Imp., 7. série, tome vi., No. 5. St. Fetersburg, 1863 Vambéry. See 118-121, 123-5, 654-5.

603. Route de Merv..... à Samarcand. Journ. Asiat., p. 263, and p. 92. 1865.72

604. De Blocqueville, Henri de. Quatorze mois de captivité chez les Turco. mans. Tour du Monde, p. 225.

605. Mielgunow. Turkmenien und die Insel Aschurade. Archiv für Wissensch. Kunde von Russland.

606. Unter den Turkomanen. Globus.

1866

607. Koschkul, M. F. de, Compte rendu des travaux [1869-70] dans les environs de la baie de Krasnovodsk. Tiflis, 1875, 188

\section{0-1883.}

608. Koschkul, M. F. de. Tableaux statistiques sur la production de pétrole dans la presqu'ile d'Apchéron, vol. vi., p. 5. Tifis, 1875 and $188 \mathrm{I}$

609. Markozoff, Col. Reconnaissances avec le detachment de Krasnovodsk ... [1871]. I.K.I.R.G.O., vol, i., p. 85. Tifis, is 73

610. Stebnitzky, M. J. Report on his Journey [1872] in Central and Southerm Turkomania. Tr. by E. D. Morgan. J.R.G.S, P. $217 . \quad 1874$ 
611, Stebnitzky M.J. Les steppes des Turcomans. Bull. Soc. Géog., p.457. 1871 612. Nouvelles reconnaissances dans les steppes Turcomanes. Notice préliminaire sur l'expédition scientifique executée [1872]. I.K.I.R.G.O., vol i. Tïfis, 1873

613. - Observations sur les pays des Turcomans, Mémoires Z.K.I.R.G.O., vol. viii.

614. Data of Turcoman Steppe [1875]. Tr. by Robert Michell.

615. Sievers, G. Die Russische militarische Expedition nach dem alten Oxus. Bette, dem Kjurjandagh Gehirge und dem Atrek [1872]. P.G.M. 1873

6r6. Les Turcomans Yomouds. Extrait de la Revue Militaire russe, Jan. [1872]. Bull. Soc. G6́og., July, p. I58 ; Sept., p. 319. I87I

6r7. Stumm. Grabstätten der Turkmenen. Nach Skizzen von Lieut. Tafel, P.G.M., p. I8.

1873

6r8. Du plateau de l'Oust-Ourt et de l'ancien cours de l'Oxus. I.K I.R.G.O., vol. iii.

6r9. Rawlinson, G. Ethnic affinities of the nations of West Asia. In Herodotus Hist., v, I. 1858

620. - The Sixth Great Oriental Monarchy, or the Geography, History, and Antiquities of Parthia. $\quad$ London, 1873

621. Grodekoff, N. J. Deux petites listes de plantes recueillis en [1873] pendant la marche du détachement du Manghychlak de Kinderli a Khiva. I.K.I.R.G.O., vol. iii.

622. The Tytis I880-8I.) 4 vols. Leconnaissance of the Uzboi (Russ.). I.K.I.R.G.O., vol. iv., No. 1 .

624. Nouvelles sur la population Turcomane entre l'ancien lit de l'Amou Daria et les limites septentrionales de la Perse. I.K.I.R.G.O., vol. vi., pp. 5 I-57

625. The Oxus Expedition, Geog, Mag, pp. 313•4 7iffis, 1879-81

626. Blaramberg, Gen. Lieut, v. Die Untersuchung des alten Bettes des AmuDarja (Oxus). P.G.M., p. 23. 1874

627. - Die Ruinen der Stadt Mestorjan. P.G.M., p. I6. I876

628. Petrusevitch, Nicholas. The Turcomans, Tr. by R. Michell.

6z9. - Preliminary Report on the Investigation of the Darialyk (Uzboi) and the country between the Amu-daria and Sary-Kamish (Russ), I. K.I.R.G.O., vol. v., p. 241 . $\quad$ Tifis, 1877.8

630. Turcoman Steppe in [1875]. Tr. from Jour. de St. Pèt., No. 55, 28 Feb. - II Mar.

631. De Goeje, J. Das alte Bett des Oxus Amu-darja. 1876

632. The Amu-Darya Expedition. Markham's Geog. Mag., Pp. 262, 264. 1875

633. Die Russische Amu-Darja Expedition. P.G.M., p. 361. 1875

634. Précis des travaux publiés au Caucase sur la géographie de ce pays. Tifis, 1875

635. Do, do. depuis 1875 . Tifis, I881 Wood. See 392-5.

636. Murray, J. Wolfe. A List (translated into English) of the Publications of the Caucasian section of the Russian Imperial Geographical Society. MS, in possession of the Royal Geographical Society. London

637. Mémoires de la section Caucasienne de la Société Imp. de Géographie. Tiffis Bonvalot. See 258, 262, 330 .

Capus. See $258,330$.

638 . Tietze, Dr. Bmil. Ueber einen kurzen Ausflug nach Krasnowodsk im west-

lichen Turkestan. Jahrbuch der K.K. Reichsanstalt, Bd. 27, p. 1. ${ }_{1877}$

639. Organization du pays Transcaspien. I.K.I.R.G.O., vol, v., pp. 302-17. Tiflis

640. Do. do. Trans, in Russische Revue, p. 447 (German). I879

641. Kuropatkin, Captain. Turcomania and the Turcomans. (From the

Russian Military Journal, Nos. 9 and ro of 1879 .) Tr. by R. Michell. 1879

642. O'Donovan, E. The Merv Oasis [1879-81]. London, 1882

643. - Merv: a Story of Adventure and Captivity. Condon, 1883 
644. O'Donovan, E. Merv and its Surroundings. P.R.G.S., May, June. 645. Die Turkmenen. P.G.M., p. 325.

\section{$1880-1884$.}

646. Marvin, C. The Eye-witnesses' account of the disastrous Russian Campaign against the Akhal Tekke Turcomans.

647. - Merv, the Queen of the World.

648. - The Russians at Merv and Herat.

649. - The Russian Advance towards India.

650. - Grodekoff's Ride from Samarcand to Herat.

651. - The Russian Railway to Herat and India.

652. - The Russian Annexation of Merv.

653. Reconnoitring Central Asia. London, 1884
654. Vambery, A. The Turcomans: their Past and Future. Journal of the Royal London, 1880 London, 1881
London, 1883 London, 1881 London, 1881
London, 1880 United Service Institution, No. cv.

655. Die Turkomanen und ihre Stellung gegenüber Russland.

656. The Akhal Tekke Oasis and Ways of Communication with India, Orient. Ch. Mag., Oct.

New York, 1881

657. Helmersen, G. v. Zur Geologie der Aralo-Kaspischen Niederung. Bull. de

658. l'Acad. de St. Pétersbourg, tome xxviii., May. $\begin{array}{r}\mathrm{I}_{3} 8_{3} \\ \text { et Jakowlew. Sur la géologie de la dépression Aralo-Caspienne. }\end{array}$ Bull. de l'Acad. de St. Pet., tome xxviii., No. 3, pp. 364-79.

659. Notice sur Ak-tau et Kara-tau montagnes dans la presqu'lle de

660. Mangyschlak. Bull. de l'Acad. Imp. de St. Pet., xiv., pp. 529-35. Aralo-Caspienne (German). Bull. de T'Acad. Imp. des sciences de St. Iétersbourg, $x \times v_{\text {., }}$ pp. 513-49.

661. Maloma, M. Description de la route de Krasnovodsk aux puits Dektcha. Annexe:-Catalogue de plantes, etc. I.K.I.R.G.O., vol. viii. Tiffis, 1873

662. Zimmermann, C. Denkschrift uber den untern Lauf des Oxus zum Karabugas Hafen.

663. St. Martin, Vivien de. L'Oxus (Amu-daria). Ėtudes et investigations. L'ancien lit, etc., etc., sur L'Asie Centrale.

664. Loupandine. Description de la partie de l'Ouzboi entre Bala-Ichem et Sary-Kamyche. I.K.I.R.S.O., vol, iv.

665. Bakoulin. Piesni u Turkmenakh i poet Makhdum-Kuli. (The Songs of the Turkomans and their poet Makhdum Kuli.) I.K.I.R.G.O.

666. Kurze Zusammenstellung der Untersuchungen in der Turkmenen-Steppe in der Richtung von Krasnowodsk nach Chiwa.

667. Honinski. Sur la langue des Turkmènes, I. Bull. de 1'Acad, de St. Pet., Pp. $563-71$.

\section{MAPS ILLUSTRATIVE OF CENTRAL ASIA.}

\section{(Chiefly in the Library of the Royal Geographical Society of London.)}

\section{FROM EARLIEST TIMES TO 1870.}

668. Spruner, Dr. Karl von. Historico-Geographical Hand Atlas, London, 1861

669. Yule, H. Asia in the first half of the [fourteenth century] to elucidate Cathay and the way thither.

670. Maas, A. Nova tabula maris Caspii et Regionis Usbeck.

671. Gússefeld, F. L. Carte de l'émpire de Russie et de la grande Tartarie dressée avec soin. Les Herit. de Homann, l'an

672. Balbi, Adrien. Atlas Ethnographique du Globe.

673. Plan von Samarkand und Umgebung [184r].

674. Johnston, A. K. The Physical Atlas. 1786

Paris, 1826

675. Boutakoft, Capt. Karta Aralskago Moria. (Map of the Aral Sea.) I850 
676. Pochtovaya karta Aziiatskoi Rossii. (Post-Map of Asiatic Russia.) St. Petersburg, A. Ilyin, 185

677. Telegraphnaya karta Rossiiskoi imperii. (Telegraph Map of the Russian Empire.)

678. Karta Aziiatskoi Rossii. (Map of Asiatic Russia) [1860],

679. Severzoff N. A. und Osten-Sacken. Karte der neuesten Russischen Forschungen im Thian-Schan System, besonders der Reise zwischen Issyk-Kul und Kaschgar. P.G.M., p. 200.

1867

$1870-1884$.

680. Severtsof, N. A. Karta vysot i rastitelnosti Turkestanskago Kraya. (Map showing Altitudes and Vegetation of Turkistan.) 1872

681. Petermann, A. Plan von Chiwa nach russischen Quellen. P.G.M., I873

682. Regel, Dr, A. Karte von Reisen in Central Asien [1876-79], sowie der Routen von Kuropatkin, [1876-77], und Prjevalsky, [1877]. P.G.M., 1879

683. Fedchenko, A. Reise nach dem Pamir Plateau [1871]. P.G.M., 1874

684. Das Gebiet des Oberen Amu und die Orographie Central Asiens. With Map. P.G.M., p. 157.

685. Lusillin. Karta Zakaspiiskago Kraia Khivy, i prilejasheikh stran. Map the Trans-Caspian region and adjoining regions of Khiva.) 1873

686. - Map of Turkestan, showing Russian Boundaries. I875

0schanin. Sse 327 .

Regel. See 225, 466, 556.

687. Faunthorpe, J. P. An Elementary Physical Atlas.

688. Spruner-Menke. Hand-atlas fuir die Geschichte des Mittelalters und der neneren Zeit. Gorha, Perthes, 1880

689. Chavanne, J. Ethnographische Karte von Mittelasien. Deutsche Rundschan für Geographie und Statistik, p. 196.

1880

6go. Walker. Map of the Kuldja District and the Rnsso-Chinese Frontier in Turkestan. P.R.G.S., vol. ii., P. 529. 1880

691. - Turkestan and the countries between the British and Russian dominions in Asia. Mapped on the basis of the surveys made up to [1881]. Scale, $\mathrm{I}$ inch $=32$ miles. Dehra Dun, September, I88,

692. Turkestan and parts of Adjacent Countries. (In Syriac, Greek, and Latin.)

693. Kaspiiskoe More. (Russian Chart, with surroundings of the Caspian.)

694. Swalenburg. J. B. Greenhough. Nova descriptio geographica Tartarica Tartary (Russian Empire in Asia) with ethnological matter.

695. Weller, E. Botanical Map showing the distribution and limits of Cultivation of some of the principal Plants most useful to man.

396. - Zoological Map showing the distribution and rauge of some of the prncipal members of the Animal Kingdom.

697. Ethnographicheskaya karta Aziiatskoî Rossii. (Ethnographical Map of Asiatic Russia.)

698. Ethnographical Map of the World, showing the Geographical distribution of the varieties of man. With diagrams showing the occupation of all nations. and distribution of man according to religious belief.

699. Arrowsmith, J. The Country between the Aral and Caspian.

700. The Caspian Sea, Khiva, and the surrounding country.

701. Karta Turkestanskago voiennago okruga, sostavlena prí Turkestanskom voenno-topographicheskom otdiela y [ 1877$]$ goduei po noveishim sviedieniiam. Scale, 1 English inch -40 versts.

702. Blackie, W. G. Comprehensive Atlas and. Geography. London, i883 


\title{
LIST OF AUTHORS,
}

\author{
WITH REFERENCE NUMBERS TO THEIR WORKS IN THE \\ FOREGOING BIBLIOGRAPHY.
}

Abbott, J, 352

Aberigh-Mackay, 195

Abich, H., 103, 602

Abramof, General, 323

Abramof, N., 495, 496

Abu Taleb Khan, 47

Abul Ghazi, 34

Abulfeda, 509

Adamoli, J., 540

Ala-eddin Ata Melik Djuveini, 282

Ali Bey, 48

Alpheraky, S., 47 1

Amiot, 433

Arrowsmith, J., 699, 700

Ascelin, N., 13

Assemani, 2

Astley, T., 510

Atkinson, T. W., 444. 494

Atkinson, Mrs, 445

Baber, 24-27

Baer, K. E., 74-8I

Baker, V., 223

Bakoulin, 665

Balbi, A., 672

Basiner, T. F. J.. 87

Bates, C. E., 407

Behm, E., 152, 159

Bell, E., 154

Benjamin. J. B., 117

Berezin, P., 270, 271

Berg, E., II 5

Bergeron, P., $\mathbf{I}_{3}$

Bergmann, 437, 438

Bichurin, J., 91

Blackie, W. G., 702

Blaremberg, Gen. von, 372. 626,627
Bogdanoff, M. N., 403

Bogdanowitch, E., 200

Bonvalot, G., 258, 262, 330

Bonyard, E. H., 490

Borszczow, El, 599-60I

Boulger, D. C., 247

Brandt, J. F., 86

Brauer, 534

Bretschneider, E., I61-63

Brodowsky, M., 207

Brooke, Sir V., 197

Buchanan, Claudius, 88

Bunge, 93

Bunnett, F. E., 126

Burnaby, F, 396

Burnand, F. C., 399

Burnes, A., 299, 300

Burslem, Rollo, 514

Butakoff, A., 350, 351, 675

Cahun, Leon, 230

Campbell, D., 46

Cancrin, G. von, 484

Capus, G., 258.26r, 330, $431,580-82$

Chapman, E. F., 291

Charrière, E., 69

Chavanne, J., 689

Cherkaski, Bekovitch, 337

Cherkassoff, A., 497

Clarke, F. C. H., r 89 , 404,469

Clavijo, Ruy Gonzalez, 21

Conolly, A., 345,346

Contarini, Ambroise, 13

Cordier, H., 459, 460

Courteille, Pavet de, 28, 29

Coxe, W., 479

Crealock, H. H., I56
Daly, 568

Daubrée, 265

Daukes, F. C., 188

Davies, 128

Davis, Sir F.. 65

Debelak, Julius, 199

De Blocqueville, H., 604

De Bode, 303, 591

Defremery, 40

De Geoje, J., 631

De Guigne, 435

De Hell, X. H., 595, 596

Delacroix. Petit, 33, 474

De Launay, J. B., 121

De Mandeville, J., 13

De Marny, N. P. B., 567

De Pigny, Fevry, 69

De Pise. Rustician, 19

De Rubruquis, G, 13, 20

De Tassy, G., 308

Dilke, Ashton, 46I

Dmitrovsky, N. V., 32

Dorn, B., 272. 273

Dragendorf, $58_{3}$

Dresser, H. E., 566

Drygalski, A. von, 572

Dughlat, Mirza Haidar, 6

Duncan, 196

Ebu Bekir Mohammed bin Djafar un Narshakhi, $28_{3}$

Edwards, H. S., 274

Elwes, H. J., 171

Ephremov, F. S., 49

Erschoff, 534

Erskine, 25

Eversman, Edouard, 294

Evliya Effendi, 30

Eyries, 333 
Faunthorpe, J. P., 687

Fawcett, R. H., 235

Fazl, Ullah Khan, 7

Fedchenko, A., 416-19,533. $534-39,683,684$

Fedorow, W., 487

Feisalin, Mustava, 309

Ferrier, J. P., 517

Forsyth, D., 164

Finn, James, 85

Finsch, O., 503

Fischer, F. E. L., 491, 492

Forgues, E. D., 120

Feynes, Sieur, $3 \mathbf{I}$

Frähn, de C., 39, 62

Frost, Thomas, 257

Gaubil, 432

Gavazzi, Modesto, 318

Gerstfeldt, 116

Gloukhovskoy, M., 320

Gobineau, Comte de, I42

Goldsmid, F. J., 180

Golovin, Ivan, 96

Golubef, A., 520

Gould, J., 97

Gowan, W. E., 328, 472, 473

Greenhough, J, B, 694

Grodekoff, N. J., 621, 622

Grover, 306, 307

Giinther, A., 178

Guissefeld, F. L., 671

Guyard, M., 362

Hagemeister, J. de, 77

Haiton, 13

Hammer, Joseph, 277, 278

Hauptmann, A., 370

Heeren, A. H. L., 71

Hellwald, $F$, von, $181-83$

Helmersen, G. von, 72-74, $99,301,657.660$

Henderson, 52

Henvey, F., 420

Herder, Fy 450

Hiouen Thsang, I

Hochstetter, Ferd. v, $57 \mathrm{I}$

Honinski, 667

Howorth, H. H, 224, 397

Humboldt, A., 48r-84, 598

Hutton, $J_{+}, 206$

Ides, C. Ysbrand, 476-78

Ignatieff, General, 359

Ilminski, 24, 26

Imbault-Huart, C., 256

Ivanoff, 336

Ivanov, N. P., 347

Iwanow, D., 572
Jakowlew, 658

Jardot, Al. A., 138

Jaubert, Amédé, 292

Jenkinson, A., 287-90

Johnston, A. K., 674

Jones, W., $4^{88}$

Julien, M. Stanilaus, 1

Just, Leopold, I85

Karazine, 279, 280

Karelin, 442, 594

Kazantseff, Elia, 531

Keane, A. H., 264

Ker, D., 385,386

Kessler, K., 174-77, 534

Khanikoff, N., $89,90, \mathbf{I I}_{3}$, $139,140,302.5,340$, 381

Khoroshkhin, A. P., 573

Kiepert, H., 389 , 574

Kirilow, 442

Kitto, J., II4

Klaproth, J., 58, 59, 60, 409

Koenen, A. von, 401

Kolokoltzof, Col., 377

Koner, W., 540

Koschkul, Fn, 607, 608

Kostenko, 222, 321, 322,

$36 \mathrm{r}-4,579$

Krabbe, 534

Kroneberg, 534

Kiblewein, G., 354

Kuhn, A. von, 420

Kuropatkin, A. N., 472 , $473,64 \mathrm{r}, 682$

Laharpe, 506

Lal, Mohan, 515, 516

Landres, Frey de, 44

Lansdell, H., 507,508

Latham, R. G., 236

Ledebour, C. F., 63,64

Lees, W. Nassau, I07

Lehmann, A., 93

Lejean, G., 281

Lelewel, Joachim, 92

Lentz, P. E., 251

Lenz, R., 324

Leonhard, Gustav, 84

Lerche, P., $181,365,366$, 542,543

Levshine, A. J., 68, 69, 70

Lichtenstein, H., 294

Lobysévitch, Théo., 525

Lockhart, W. S., 341

Lomakin, 623

Lomonossof, A., 424

[Long, James,] 193
Loupandine, 664

Lubomirski, 570

Lusillin, 685,686

Lvoff, Tatiana, 279

Lyde, Samuel, 105

Maas, A., 670

MacGahan, J. A, 387,388

MeGillivray, W., 48r

MacLacblan, 534

Maieff, N. A., 168, 214 . $329,545.9$

Maksheev, 518, 519

Maloma, M., $66 \mathbf{i}$

Markham, C., 21

Markozoff, Col,, 609

Marsden, W., I6, 55

Marshall, L., 329

Martens. 534

Martens, M. F., 238, 239

Marthe, F., 137, 417, 524

Marvin, C., 646-653

Mayr, 534

Mehemmed Salih, 338

Mehemmed Yusuf, 286

Meiners, C., 480

Mejow, V. J., 215

Meyendorff, Baron, 29I-3

Meyer, C. A., 490, 49I

Michell, J., 75, I30, 13 I. $133,446,447,520$

Michell, R., I30, 144, 157 . $222,322,326,337,351$, $415,422,454,533,538$, $562,592,614,628$

Middendorf, A.. 255, 493

Mielgunow, 605

Miles, The, 66

Milman, H. H., 5II

Mir Abdoul Kerim Bot. kbary, 35-39

Mir Ali Shir, 4

Mir Izzut Ullah, 51, 52

Mirza Mobammed Mehdi Khan, 8

Möllendorff, O. F, 462

Möllendorff, P. G., 462

Molloy, Captain, 453

Morawitz, 534

Morgan, E. D., 400, 413 , $449,464,470,6$ ro

Morier, $56,83,406$

Morley, W. H., 107

Mosheim, L., 45

Motchoulski, V., $457,45^{8}$

Mouchketoff, I., 227-29

Mouravieff, M. N., 342

Munshi Sadik Mirza, 285

Murray, $\mathrm{H}_{+}, \mathbf{1 7}, 53$ 
Murray, J. Wolfe, 636

Nazaroff, 408

Nebolsin, P., 94, 95

Neumann, K. F., 22

Nevai'i, 5

Nève, Fêlix, 78

Niemann, 370

Nolde, Ed. Th., 263

Noschel, A., 99

O'Donovan, E., 642-44

Oshanin, 327, 328, 577

Osten Sacken, 412-14, 530, 679

Ostroumoff, N., 521-23

Paget, John C., 390

Palgrave, W. G., 167

Pallas, P. S. 43

Pantussoff, N., 467

Paquier, J. B., 211-13

Paschino, P. J., 526, 527

Perovski, General, 75

Pesterev, Jegor, 436

Petermann, A., 561, 681

Petrovsky, I79

Petrusevitch, N., 628-29

Petzholdt, A., 543, 544

Peyroine, 43

Piankoff, B,, 576

Plan-Carpin, Jean du, 13

Polo, Marco, 13, 16-19

Poltaratsky, 528-30

Poole, R. S., 208-10, 332

Poole, S. L., 208-10, 332

Poutimstev, M., 440

Price, D., 50

Prichand, J. C.. 76

Prjewalsky, N. M., 463-65, 682

Pumpelly, R., 158

Purchas, 475

Pushchin, 597

Radloff, W.. 108-I2

Raduzkovsky, 534

Rawlinson, G., 619, 620

Rawlinson, H. C., 356-58

Réclus, E., 254, 360

Regel, A., 225, 226, 466 , 556,682

Regel, E., 202-4, 243, 450, 554, 555

Rémusat, J. P. A., 6I

Rialle, Girard de, I90, r9I

Ritter, Karl, 54

Riza Qouly Khan, 339

Roesler, Robert, $3^{82}$
Romanovski, M., 157

Rose, Gustav, 486

Rosenmiiller, 67

Rukavkin, A., 349

Ruprecht, F. J,, 414

Sabir, C. de, $45^{2}$

Said Rakim, 284

St. Martin, V. de, 104, $194,3^{80}, 663$

Sarauw, 160

Saussure, 534

Schefer, Charles, 36

Schepelew, A., 165

Schiltberger, J., 22, 23

Schlagintweit, R., $\mathbf{1} 48$

Schmidt, E., 366, 367

Schrenk, 49I

Schuyler, E., 170

Sedillot, M., 308

Semenoff, P. P., 446-9

Senkovski, Joseph, 57

Severtsoff, N., 424-6, 458, $534,560-65,679,680$

Shakespear, R., 344

Sheikh Kemaleddin Abdurrezak, 9

Sherefeddin Ali Zezdi, 33

Sievers, G., 615

Singh, Sodi Hukum, 407

Smythe, P. E. F. W., I51

Sobolef, 590

Soliman, Hauptmann, 369

Solsky, 534

Spalding, H., 384

Spencer, Herbert, 196

Spruner, K. von, 668

Spruner-Menke, 688

Staudinger, O., 252

Stebnitzky, M. J., 610-14

Stewart, C., 15, 47

Strahlenberg, 4I

Street, O., 250

Stuart. A., 20I

Stumm, Hugo, 373-76, 389, 617,618

Suavi Effendi, 379

Swalenburg, 694

\section{T. L, 144}

Tafel, Lieut., 6r7

Tatarinov, A, 3I9

Taylor, Bayard, I00-102

Telfer, J. B., 23

Temple, Richard, 264

Terentief, I86-88

Teste, Augustin, 279

Thonnelier. Jules, I50

Tietze, Emil, $63^{8}$
Tillo, Al. A.. 391

Timkowski, G., 439

Timour, 15

Tolstoi, P.. 89, go

Tomaschek, W., 232

Towle, G. M., 205

Traub, Paul. $38_{3}$

Trautvetter, 44I

Trench, F., 155

Trotsky, V. H., 168

Tudela, B. Rabbi, I0-13

Tychsen, T. C., 295

Ujfalvy, Charles de, 2 I 6 . $219,427 \cdot 30,498 \cdot 500$

Ujfalvy, Madame, 220, 221

Ulianin, 534

Unkowsky, J., 434, 435

Urquhart, 8o

Valikhanof, 130

Vambery, A., 118.26, $246,314^{-17}, 421,55^{8}$, 654,655

Veliaminoff-Zernof, W. 310-12

Veniuk of, 130-34, 378

Vereschagine, B., 145, 146

Verne, Jules, 242

Vigne, G. T., 348

Villeroi, Bernard de, 234

Vincent, C. E., 192

Voelkel, P.. 304, 320, 529

Von Krahmer, 134

Wagner, H., I52, 153

Walker, 690, 69I

Weil, 423

Weller, E.. 695. 696

White, 14

Wild, H., 23I, 253

Wilson, H. H., 79

Wirgman, Theodore, 182

Wolft, J., 296-98

Wood, H., 392-95

Wood, John, 169

Yadrintseff, N. M., 505

Yagmin, A., 513

Yavorsky, J. L., 325, 326

Yazykov, D. J., 485

Vule, H., 3, 18, 14I, 169. 669

Zaleski, B., 129

Zerbs, Anton, 368

Zimmermann, $\mathrm{S}_{2}, 8_{3}, 406$, 598, 662

Zwick, H. A., 443 


\section{ANONYMOUS,}

Akhal Oasis and India, 656 Ili, 45I

Akmolinskoi oblasti Ob. zor, 501

Amu-daria, 402

Kara-Kum, 575

Khiva en Mars, 371

Amu-daria Expedition, 632 633

Amu-DaryinskomOtdielie, 586

Aral, Sea of, 355

Kokan, Articles on, $3^{1} 3$

Kokan, Journey to, $41 \mathrm{I}$

Manuscrits, 489

Aralsee, Nivellement, 398

Astrakhan I Khiva, 343

Aziiatskoi Rossii Karta, 678

Mennonites, 331

Merv à Samarcand, 603

Meteorologische Beobachtungen, 405

Mongolia, Russian Explorations in, 198

Balkhash, 456

Boukharie, Affaires, 334

Boukharie, Captivité en, 335

British Subject, 135

Caspian Sea, 693

Caucase, Travaux publiés au, 634,635

Caucasienne, Mémoires, 637

Central Asia, Articles on, I 36

Centralasien, Neue Werke uiber, $\mathbf{1} 7 \mathbf{2}$

Central Asian Question. I43, I73

Central Asia. Russians in, 267

Central Asian Routes, 106

Chiwa, 353

England and Russia, 240

"England," Central Asian Question, 275

Geographischesaus Mittelasien, 276

Geographische, Notizen, 98

Naturalistes, Bull. Soc. des, 266

Notices géographiques sur Khokand, 410

Old Bed of Oxus, 241, 512

Orenburg nach Chiwa. 268. 269

Oxus Expedition, 625

Pall Mall Budget, 551

Parliamentary Reports, 237

Post Map of Russia, 676

Post-road Book, 248

Recueil d'itinéraires. 233

Russia and Central Asian Khanates, I66

Russia and Dependencies. 127

Russia, Ethnographical Map of. 697

Russia, Telegraph Map of, 677

Russian Calendar, 245

Russian slaves, 249

Russische Forschungen, World, Ethnographical 149
Samarkand, $587,588,673$

Saturday Review, 550

Semipalatinskoi, 502

Semiriechenskoi, 468

Sibiri Zapadnoi, 504

Srednii Asii, 184

Temperatur - Beobachtun. gen, 455

Trans-Caspian, Organiza. tion du, 639, 640

Travaux Gengraphiques, 147

Turcoman Steppe, 630, 656

Turcomans Yomouds, 616

Turoomane, Population, 593,624

Turcomanen, Unter den, 606,645

Turkestan, 557, 584, 589, 692

Turkistan Annual, Indes to, 553

Turkestan Gasette, 541

Turkestan Gasette, Index to. 569

Turkestan, Klima von, 559

Turkestan, Nachrichten aus, $5^{8} 5$

Turkistan Temperatur, 552

Turkestanische Industrie. ausstellung, 532

Turkestanskago Karta, 701

Turkestanskago Zapiski, 578

Turks, History of the, 42

Vsepoddanneiskiy otchet, 244

Map of, 698 


\section{GENERAL INDEX.}

Volume 1. is to be understood unless otheravise mentioned.

Aввотт at Kunia Urgenj, ii. 341 - Merv, ii. 457

Abdul Aziz Khan, Mosque of, ii. 100 Abdullah Khan, ruler of Bokhara, ii. 7I - Tomb of, ii. 71, 137

Ablutions in the desert, ii, 424

- of Bokhariots, ii. 135

Aborigines of Zarafshan province, 541

Abramoff, Gen., Dining with, 471

- Victories over Bokhariots, 625

Abu'l Ghazi's description of Vezir, ii. 384

- Khair, Submission of, 404

Accident to Author, ii. 338

- Rosy, ii. 377

- - Sevier, Mr., ii, 160

- Tatar yemstchik, 363

Accoucheurs among Kirghese, 359

Acquaintances at Omsk, 62

- - Tiumen, 27

Acrobats at Kitab, ii. I6

- in Kuldja, 243

Adai Kirghese at Kunia Urgenj, ii. 359

Administration of Amu-daria province, 436

Adventure on railway at Perm, 18

Adventures on Turkoman frontier, ii. 466

Afghanistan to Petersburg. Highway from, ii. 406

Afghans of Zarafshan province, 544

Afrasiab-Kaleh, Ruins of, 564

Agalmatholite ornaments, 353

Agriculture of Amu-daria province, 434

- Bokhariots, ii. 164

- Constantinovsk, 359

- Kirghese, 314, 338

- Kuldja nomads, I92

- Merv, ii. 478

- Semipolatinsk, 97

- Semirechia, 165
Agriculture of Vierny, 278

- Zarafshan province, 608

Agriculturists in Semipolatinsk, 315

Aivazovsky. M., Oil-painting by, ii. 504

Ak-bugut, Bed of the Oxus at, ii. 389

-Wells at, ii. $39 \mathrm{r}$

Ak-Kend, Post-station at, 196

Ak-Mesjed, Russian capture of, $6 \mathrm{I} 7$

Ak-rabat, Tomb of, ii. 207

Ak-Serai palace at Shahr, ii. 32

Ak.Su river, ii. 193

Ak-tepe, Arrival at, ii. 335

- Robbers near, ii. 336

Turkoman's shop at, ii. 335

Akhal oasis, Area of, ii. 449

- - Dimensions of, ii. 449

- History of, ii. 450

- - Settlements of, ii. 449

-.. Tents of, ii. 450

- Troops in, ii. 494

- Tekkes, expedition against, ii. 462

Akhmed Yasavi, Mosque of, 391

AkmolinsK. Administration of, 50

- Agricultural produce of, $5 \mathrm{I}$

- Animals of, 52

- Area of, 42

- Books for, 65

- Business in, 54

- Climate of, 50

- Cossacks in, 66

- Crime in, 57

- Distilleries in, 55

- Fires in, 54

- Houses in, 54

- Industries of, 54

- Introduction to Govenor of, $4 \mathrm{I}$

- Medical staff in, 53

- Minerals of, $5 \mathrm{I}$

- Population of, 42 
Akmolinsk, Province of, 42, 46

- Punishment for personal offences, 351

- Rivers of, 47

- Russian population in, 53

- Surface of, 47

- Tobacco plantations in, 52

- Towns of, 53

- Uyezds of, 50,51

- Visit to Governor of, 64

Ala-Kul, Altitude of; 177

_- Desiccated lake-bed near, 177

- - district, Fauna of, 147

- - Mammalia of, 149

- lake, Description of, $\mathbf{I}_{46}$

- - Fish in, 148

- Lizards near, 148

- - Onithology of, 147

Ala-Tau mountains, 268

_- Morgan, Mr. D., on, 185

- - Scenery of, 270

Alabaster grotto at Krasnovodsk, ii. 496

Alai expedition in Ferghana, 512

- plateau, 492

Alexandrof mountains, 361

Alielis of Turkmenia, ii. 445

Aliken's hotel at Vierny, 27I

Alikhanoff, Lieut., at Merv, ii. 471

Alim-Kul, Death of, 511,621

- Defeat at Khokand, 5 Io

- - by Khudaiar Khan, 5 Io

- - - Russians, 510

- Disaffection against, 510

- Regent of Khokand, 5 to

- Waning influence of, 510

Alim-Tu, Russian defeat of Taranchi rebels, 627

"All's well that ends well," ii. 139, 505

Almatinka, Schools at, 279

Alpheraky, M.. on Kuldja Lepidoptera, 247 , ii. 596

- - Vertebrata, 247

_- Yuldus sheep, 247

Altyn-Immel and Kuldja, Stations between, 190

- Arrival at, 188, 266

- pass, 189

_- Villages near, 187

Alum manufacture in Kohistan, 537

Aman-Kutane caravansary, ii. 8

Amphibians of Central Asia, ii. 529

Ayu-Daria Province, 425

- - Agriculture of, 434

- Area of, 42

_ - Boundaries of, 425

- Children's diseases, 433

- - Climate of, 432

_ - Difficulties of the nomads, 435

_ - Dimensions of, 425

_- Diseases of military, 433
AMU-DARIA Province, Divisions of, 434

- - Geology of, 426

_ - Health of population, 433

- - Hydrography of, 428

- - Increase of cultivation, 434

- - Innabitants of, 433

- - Karakalpaks in, 433

- - Kyzyl-Kum steppe, 426

- - Meteorology of, 432

- - Mountains in, 426

__ Ophthalmia among natives, 433

- - Population of, 42

- - Revenue of, 437

_- Russian administration of, 436

- - Statistics of habitations in, 433

_- Taxes in, 436

- - Temperature of, 432

- - Towns of, 398

Amu river, Aground in the, ii. 224

- - at Charjui, ii. 199

Kabakli, ii. 213

- Nukus, Delta of, ii. 241

Banks of, ii. 199

Bokhariot frontier camp, ii. 221

Branches of, ii. 242

"Camel's Hump" on, ii. 224

Cliffs on, ii. 200

- Detonations on, ii. 220

- Fall into Aral Sea, ii. 241

- Fauna of islands, ii. 218

- Fish of, ii. 243

- Flooding of, ii. 223

- Flora of banks of, ii. 223

- Fossil remains on, ii. 200

- Game on islands of, ii. 218

- Ganoid fishes of, ii. 245

- Journey to Kabakli, ii. 209

- Kishak gates on, ii. 241

- Legend of Kyz-kala fort, ii. 214

- Linseed farming on, ii. 222

"Lion's Mouth" on, ii. 224

Muddiness of, ii. 219

- Native boats on, ii. 200

- - information on, ii. 219

- Navigability of, ii. 198

- Pitniak curve on, ii. 224

- Precaution against robbers, ii. 216

- - Restiveness of horses, ii. 209

- Ruined towns on, ii. 215

- Ruins on banks, ii. 214

- Scaphirhynchus in, ii. 243

- Singing boatmen on, ii. 221

- Steamers on, ii. 242

- Strategical importance of, ii. 194

- Temperature on, ii. 224

- Tugais on, ii. 215

- Vegetation on banks, ii, 223

- Wolf scare on, ii. 217

Amulets of the Turkomans, ii. 447 
Amusements at Karshi, ii. 48

- Shavat, ii. 320

- of the Taranchis, ii. 208

Angren river, 478

Animal life in a sea-bed, ii. 419

- - - the desert, ii. 172,393

- products of Bokhara, ii. 143

Animals of Akmolinsk, 52

- - Bokhara, ii. I42

- Khivan khanate, ii. 269

- Merv, ii. 478

- Semipolatinsk, 94

- Turkistan, ii. $5^{14}$

Antiguities at Samarkand, Purchases, 611

- in Tashkend museum, 455

- of Lake Issik-Kul, I59

- Samarkand, 563

- Sergiopol, 145

Antiquity of Khojeili, ii. 349

- Kunia Urgenj, ii. 339

Ants of Turkistan, ii. 576

Apothecaries of Bokhara, ii. 149

Appendices revised by Mad. Fedchenko, ii. 513

Apples of Khiva, ii. 267

Aqueduct at Kyz-Kala, ii. 214

Arab capture of Merv, ii. 456

Arabs of Zarafshan province, 544

Aral Basin, Depression of, 385

- Sea, Ancient course of Oxus, ii. 402

- Bed of, ii. 404

- - Derivation of name, 429

- Dimensions of, 429

- - Disappearance of, ii. 403

- Fall of Amu into, ii. $24 \mathrm{I}$

- Fauna of islands, 430

- Fluctuation of, it. 402

- Geological changes of, $3 \mathrm{~S}_{5}$

- Geographical problems of, ii. 402

- Harbours of, 429

- Islands of, $43^{\circ}$

- Navigation of, 409

- Oxus junction with, ii. 2.42

- Reduction of, 431

- Russians on, 409

- Shores of, 430,432

- - Winds of, 429

Aralo-Caspian region, Historical discussion on, ii. 403

- - Murchison, Sir R., on, ii. 403

- - Rawlinson, Sir H., on, ii. 403

- - Travellers in, ii. 404

- Route, ii. 231

Arasan sulphur baths, 186

Arbas for luggage at Khiva, ii. 316

Archbishop of Tobolsk, Visit to, 36

Arendarenko, M., Kindness of, 6 ro

Argamak horses at Khiva, ii. 259
Arganatinsk, Arrival at, ${ }_{178}$

Aris river, Deseription of, 420

- Journey along the, 420

Aristocratic mariner, ii. 499

Armenian literature, $58_{3}$

- trading at Krasnovodsk, ii. 499

Armourers street in Bokhara, ii, I 34

Arms of Charjui soldiers, ii. I86

- Kirghese, $3 \mathbf{I} 3$

- Turkistan troops, 602

Army of Bokhara, ii. 21

- Jinghiz Khan, ii. 68

Arrest of Author at Chusovaia, 20

Art among the Kalmuks, 244

- of Jewish illumination, ii. 116

Artillery of the Khivans, ii. 306

Artisans of Kuldja, 243

- Merv, ii. 478

- Semipolatinsk, ro4

Artists, Chinese, 262

Aryks of Khiva, ii. 252

Asia (Central.), Amphibians of, ii. 529

- Ants of, ii. 576

- Bees of, ii. 562

- Beetles of, ii. 552

- Bible-work in, ii. 237

- Bibliography of, ii. 654

- Book scarcity in, 584

- Chronology of, 677

- Coins of, ii. 502

- Colleges of, 586

- Colporteur work in, ii. 304

- Crustacea of, ii. 548

- Divorce in, ii. 353

- Earth closets in, ii. $4 \mathrm{I} 5$

Fishes of, ii. $53^{\circ}$

- Fortresses of, ii. $32 \mathrm{I}$

- Fuel of, ii. 4II

- Funerals in, ii. 250

- Gardens in, 480

- Geological features of, ii. 170

- History of, 120

- Home life in, ii. 352

- Jewellery of, ii. 286

- Jews of, 446,520

... - Maps of, ii. 679

- Marriage in, ii. $35^{2}$

- Meteorology of, ii. 442

- Mineral wealth of, 380

- Mollusks of, ii. 537

- Money of, 682

- Mongol invasion of, ii. 69

- Pilgrim showmen in, ii. 344

- Pioneers of, 287

- Polygamy in, ii. 354

- Prisons of, 661

- Routes to, 10, ii. 493

- Russian trade in, 462

- Scoliidae of, ii. $57^{2}$ 
Asta (Central), Seclusion of women in, ii. 355

- Slaves in, if. 329

- Sphegidae of, ii. 568

- Spiders of, ii. 543

- Sports of natives, ii. 320

- Statistics of, 117

- Submarine origin of desert, ii. $43^{8}$

- Timurid sway in, ii. 69

- Trade of, ii. 286

- Travellers in, ii. 457

- Unfaithfulness of wives in, ii. 354

- Walls in, ii. 124

- - Weights and Measures, 682 , ii. 285

_- Zenana work needed in, ii. 356

Asiatic commerce, ii. 133

- Jews' synagogue, 446

- policy of Russia, 620

- Scriptures, 454

- Tashkend, 438, 457

Asiatics (Central), Character of, ii. 299

- Fanaticism, of, ii. 300

- Ignorance of, ii. 123

- Morals of, ii. 299

- - Religious condition of, ii. 299

- - indifference of, ii. 300

Askhabad, Official kindness to colporteurs at, ii. 305

Astarkhanid rulers of Bokhara, ii. 72

Astronomy at Samarkand, 565

Asylum at Semipolatinsk, $1_{3} 8$

- for aged at Tashkend, $45^{\circ}$

_- orphans at Samarkand, 600

Atkinson's travels in Semirechia, 289

- - Sungaria, 290

Atrak river, ii. 439

- Fish of, ii. 439

- Turkoman boats on, ii. 439

Atrocities of Merv Tekkes, ii. 48 I

Attek oasis, ii. 450

- - History of, ii. $45 \mathrm{I}$

- Hydrography of, ii. 452

- Lessar, M., on the, ii. 451

- Settlements in, ii. 452

Attendants, Dismissal of, ii. 371

- in desert, Troubles with, ii. 414

A vire-ATA, Arrival at, 363

- Barber's shop at, 365

- Bazaar at, 364

- Capture by Russians, 619

- Cemetery at, 366

- Dearness of timber at, 365

- Departure from, 414

- Discontent among Kazaks, 509

- Domestic animals, Value of, 419

- Kirghese manufactures at, 364

- - wares at, 364

- Lodgings at, ii. 330

- Market at, 364

Auliz-AtA, Market-prices, 365

- Mennonites in, 421

- Ornithology of district, 415

- - Scriptures for, 443

- Tomb of, 366

- Walls of, it. 124

- and Tashkend, Stations between. 4I 4

Aurora Borealis in Turkistan, 377

Author pitched off camel, ii. 308

- visited by Germans at Tashkend, 452

Author's desert ride in the night, ii. 378

- entry into Bokhara, ii. 78

- fall near Kunia Urgenj, ii. $33^{8}$

- fear of retribution at Bokhara, it. 138

- guard of honour at Kitab, ii. 21

- itinerary, $\mathrm{xxx}$

- journal in danger, ii. 415

- journey, Antecedents of, 3-5

- Cost of, 4

- Danger of, 8

- Summary of, ii. 505

- leadership of caravan, ii. 414

- letter to Emir for Jews, ii. 118

- plans concerning Jews of Bokhara, ii. $\mathrm{IO}_{3}$

- presents from Bek of Charjui, ii. I90 - - Emir of Bokhara, ii. 29

- Kush-beggi of Bokhara, ii. 132

- to Emir, ii. 28,160

- religious aims, 6,7

- surveillance in Bokhara, ii. 128

Aves of Turkistan, ii. 517

Ayaguz founded by Russians, 288

BAнA-UD-DIN, Ride to, ii. 137

- Tomb of Abdullah Khan at, ii. 71

Baian-aul, Mines near, 74

Baikof's mission through Sungaria, 124

Baker, Col. Valentine, on Turkoman frontier, ii. 466

Baku, Arrival at, ii. 500

- Eternal fires of, ii. 500

to Tiflis in a horse-box, ii. 501

Balakhane, Oil wells at, ii. 500

Balkhan mountains, ii. 437

- Fruit-trees on, ii. 438

-. Springs in, ii. 437

- Stephen, Mr. A. C., on, ï. 437

Balkhash lake, Dimensions of, 179

- Fish of, 180

- Harbour of, 180

- Shores of, 180

- Tributaries of, 179

- View of, 178

- Water of, iso

Balloting for Kinghese judges, 349

Bandits on the Amu river, ii. 217

Barabinski Tatars, Submission of, 12 ; 
Barat Bek, Death of, ii. 80

Barber's shop at Aulie-Ata, 365

Barkhans at Patar, 516

Barracks at Khokand, 525

- Samarkand, 60I

Tashkend, 468

Bartsch Bros, among Kirghese, ii. 303

Bashkirs, Submission of, 402

Basiner at Kunia Urgenj, ii. 341

Batchas, or dancing-hoys, 2 ro

- at Bokhara, ii. 89

- Charjui, ii. 190

- Karshi, ii. 48

- Khiva, ii. 300

- Kitab, ii. 15

- Shahr, ii. 34

Batchman of Kunia Urgenj, ii. 316

Bath at Karshi, ii. 45

- - Petro-Alexandrovsk, ii. 235

Bathing pools at Bokhara, ii. 135

Batoum, Scenery at, ii. 504

Bayern, Herr, of Tiflis, ii. 502

Bazaar at Aulie-Ata, 364

- - Bokhara, ii. 133

- Charjui, ii. 185

- Kakir, ii. 62

- Karaul, ii. 63

- Karshi, ii. 45

- Khiva, ii. 284

- Khokand, 522

- Kunia Urgenj, ii. 259

- Merv, ii. 478

- Samarkand, 604

- Suidun, 262

- Tashkend, 458 , ii. 286

- Vieray, 278

- near Kish Kizil Takir, ii, 337

"Bearding the lion," ii. 139

Beasts of prey in Kuldja, 257

"Beauty" sleep in the desert, ii. 337

Bed of Aral Sea, ii. 404

- Kitchkine-daria, ii. 392

- Oxus at Ak-bugut, ii. 389

- - Description of, ii. 393-95

- - Length of old, ii. 407

Bedroom of Author at Khiva, ii. $25 j$

Beekeeping in Kopal, 185

- Lepsinsk, 185

- Sarkun, 185

- Semipolatinsk, 102

- Semirechia, 185

- Sergiopol, 185

- - Vierny, 185

Eeer of the Kirghese, 338

Beershops in Turkistan, 607

Bees of Turkistan, ii. 562

Beetles of Turkistan, ii. 552

Beg tribe of Tekkes at Merv, ii. 477

Begendjalri Kir, Camping at, ii. $42 \mathrm{I}$

VOL. II.
Begendjalri, Precipice of, ii. 417

Begging by the wayside, ii. 3

Bek's official staff at Charjui, ii. I86

Beklar Bek medresse at Tashkend, 458

Benoist-Méchin, Baron, Journey, ii. 473

on the Turkomans, ii. 444

Betik. Welcome lodging at, ii. 174

Betrothal among the Sarts, ii. $3 ; 3$

Beverages of the Kirghese, 337

Bibi-Khanum medresse, 575

- - Architecture of, 575

- Miraculous lectern in, 576

Tombs in, 577

Tomb of, 577

Wife of Tamerlane, 564

Bible, Comfort of, ii. 240

- Distribution, 27, ii. 232, 301, 502

- Mubammadan attitude towards, ii. 302

- Presentation to Emir of Bokhara, ii. 37

- searching in the desert, ii. 423

- Society at Ekaterineburg, ii. 238

- - Irkutsk, 28, ii. 239

_ - Tashkend, 453

- - Tiflis, ii. $50 \mathrm{~T}$

- Author assisted by, 5

Work of, ii. $238,240,303$

- work in Central Asia, ii. 237

- - - Siberia, ii. 237

Biblical customs among Kirghese, 301

Bibliography of Russ. Cent. Asia, ii. 654

- Turkistan, 470

Bill of fare at Charjui, ii. 178

Birds of Khiva, ii. 269

- - prey at Manak, ii. 326

- Turkistan, 415, ii. 517

Birthplace of Tamerlane, ii. 32

Births in Semipolatinsk, 108

Blaramberg, Gen., on old bed of Oxus, ii. 406

Boat-building at Hassan Kuli, ii, 439

Boatmen, Compulsory service of, ii. 205

Boats at Krasnovodsk, ii. 498

BOKHARA after dark, ii. 135

- Agriculture of, ii. I64

- Animal products of, ii. 143

- Animals of, ii. 142

- Apothecaries of, ii. 149

- Approach to, ii. 65

- Area of, ii. 124

- Armourers' street in, ii. 134

- as a place of learning, ii. 86

- Astarkhanid rulers of, ii. 72

"Astonishing the natives" of, ii. 91

- Author's entry into, ii. 78

- - fear of retribution, ii. 138

- - letter to Emir for Jews, ii. 118

- - ofter of assistance to Jews, ii. 109

- - presents to Emir, ii. 160

- Bathing-pools of, ii. ${ }_{3} 35$ 
BoкнаRA, Bazaar of, ii. 133

- Bibliography of, ii. 667

- Book scarcity in, ii. 134

- Bribery in, if. 152,187

- British envoy sent to, ii. 74

- Building materials in, ii. 142

- Burnes' visit to, ii. 73

- Capital punishment in, ii. 152

- Caravan routes, ii. 55

- Caravansaries in, ii. I33

- Cistern at Halfa Khu-daidat, ii. 100

- City of, History of, ii. 66

- Clock and towers at, ii. 125

- Coal at, ii. I4I

- Colporteurs in, ii. 304

- Commerce of, ii. 133

- Conolly imprisoned at, ii. 76

- - killed at, ii. 76

- conquered by Jinghiz Khan, ii. 68

- Conversation at court, ii. 154, 189

- - with Kush-beggi, ii. I28

- Crops of, ii. I64

- Curiosities of, ii. 127

- - purchased in, ii. 134

- Custodians in, ii. 140

- Dancing-boys at, ii, 89

- Danger of wealth in, ii. 187

- Departure from, ii. 163

- Deserted streets at night, ii. 92

- Desire to mount a minaret, ii. 87

- Divan-beggi medresse, ii. 135

- Doctors in, ii. 149

- Earliest people of, ii. 67

- Eastern, Hospitality of natives, ii. 52

- Education in, ii. 120

- Emir of, Audience with, ii. 26

- - Character of, ii. 24

- - Children of, ii. 188

- - Conversation with, ii. 26

- - Description of, ii. 24

- - Drive in carriage of, ii. 30

- - Harem of, ii. 155

- - Hospitality of, if. I60

_ - Hostility to England, ii. 76, 77

- - Insults to Russians, ii. 76

- Manner of life of, ii. 153

$\ldots \ldots$ Palace of, ii. 125

_- Presents for, ii. 27

- - - returned by, ii. 36

- - to Author, ii. 29 .

- - Schuyler's description of, ii. 24

_ - Scriptures accepted by, ii. 37

- - Stremoukhof's account of, ii. 25

_ - Submission to Russia, 625

_ - Vambery's description of, ii. 24

- - Wives of, ii. 156,355

- Espionage of Author at, ii. 94. 128

- Farm-houses in, ii. 165

- Fate of a fallen favourite, ii. 80
BoKнARA, Feasting at, ii. 154

- Female seclusion in, ii. 156,355

- fired by Mongols, ii. 68

- Frontier camp of, ii. 221

- Fruit-trees of, ii. 82

- Fuel at, ii. 142

Furs at, ii. 134

- Gallop round walls of, ii. IOI

- Garden produce of, ii. 142

- Gardens of, ii. I37, I65

- Gates of, ii. 101

- Graveyards of, ii. 249

- Guest and prisoner at, ii. 140

- Guest-houses in, ii. 8o

- Gunpowder manufacture in, ii. 141

- Harvests of, ii. 164

- Hebrew MSS. in, ii. 114

- Hindu disabilities in, ii. 100

- Sarai at, ii. 100

- History of, ii. 66

- Horse-dealing in, ii. 132

Horticulture at, ii. 85,165

- Immorality in, ii. 189

- Irrigation of, ii. 165

- Jenkinson's journey to, ii. 71

Jewish legacies in, ii. Ito - manuscripts at, ii. 110

- torahs at, ii. IIo

- Jews of, 521, ii. 103

- - Interview with, ii. $\operatorname{los}$ Synagogue at, ii. 109

- Judges in, ii. 187

- Jumma mosque at, ii. 95

- Kamensky's agent at, ii. 88

- Khanate, ii. 49

_-Dimensions of, ii. 49

Divisions of, ii. 50

- Mountains of, ii. 50 Soil of, ii. 50

- Khudaiar Khan a refugee in, 509

- Kokol-task medresse in, ii. 89

Kush-beggi, Visit to, ii. 125

- Land value at, ii. 165

Lecturing the Kush-beggi, ii. I 30

- Lepers' quarter at, ii, 138

- Life in Emir's harem, ii. 355

Lunatics in, ii. 250

- - Treatment of, ii. 145

- Manghit rulers of, ii. 72

- Medresses of, ii. I35

- Visits to, ii. 89

- Military encampment at, ii. 93

- Milk and cream at, ii. I43

- Minerals of, ii. 14I

- Miri-arab medresse in, ii. 89

- Moslems frustrated by Author, ii. 112

- Mosque of Abdul Aziz Khan, ii. 100

- - Hazret Imlah, ii. 100

- Mosques of, ii, 135. 
Bokhara, Musical entertainment at, ii. 89,90

- Namazi-gah mosque, ii. 123

- Nasr-U1lah, late Emir of, ii. 73

- Native society in, ii. 150

- Natives and their diseases, ii. 144

- Official letters of Author, ii. I28

- Opinions (Native) of Emir's government, ii. 188

- Orchards of, ii. 165

- Patron Saint of, ii. $7 \mathbf{I}$

- Perils of Dr. Wolff in, ii. 77

- Perquisites at, ì. 479

- Persian Jews in, ii. 108

- Persians in, ii. 150

- Pillage of, ii. 68

- Pink salt at, ii. 141

- Population of, ii. 124

- Increase of, ii. 150

- Presents to Author, ii. 132

- - Kush-beggi, ii. 132

- Prison torture at, ii. 75

- Prisons of, ii. I5I

- Prostitution in, ii. 151

- Public pool at, ii. $\mathbf{1 4 7}$

- Punishment for theft, ii. 15I

- under Manghit rule, ii. 73

- Rebellious attitude of Author, ii. 136

- Religious buildings in, ii. 100

- duties compulsory, ii, 73

- Reticence of Kush-beggi, ii. I29

- Ride outside walls, ii. 123

- Righistan of, ii. 125, 135

Rishta disease in, î. 146

- Robbery in, ii. 135

- Russian agents in, ii. 88

- - attempt to release Stoddart, ii. 76

- intercourse with, ii. 74

- missions to, ii. 75

- spies at, ii. 74

- warehouse at, ii. 88

- Sacred singing in, ii. 91

- Samanid rulers of, ii. 67 - Scarcity of monumental inscriptions,
ii. 100

- Schools in, ii. 120

- Seldjuk rulers of, ii. 67

- Sevier's attention to the sick, ii. 163

- Sheibanid rulers of, ii. $7 \mathbf{I}$

- Shoemakers' street in, ii. 133

- Sick Jews visited by Author, ii. 113

- Silk culture at, ii. I44

- Singing and dancing at, ii. 89

- Skin-dressing at, ii. 144

- Slaughter of defenders, ii. 69

- Slavery in, ii. 185

- Slumbers disturbed at, ii. 92

- Smokers punished in, ii. 73

- Splendid garden at, ii. 81
Bokнara, Stalls in, ii. I 35

- Stations to Charjui, ii. 177

- - Katte-Kungan, ii. 137

- Stoddart, Col., at, ii. 74

- compelled to embrace Islamism, ii. 75

- imprisoned at, ii. 75 killed at, ii. 76

- Streets and lanes of, ii. 135

- Subjects' letters read by Emir, ii. 162

- Suburbs of, ii. 137, 165

- suing for peace, 624

- Sumptuous lodging at, ii. So

- Suspicious hospitality at, ii. 82

- Tanning at, ii. 144

- Taxes in khanate of, ii. 187

- the Noble, ii. 86,120

- Trade of, ii. 133

- Tunisian Jews in, ii. 108

- "Twickenham Ferry" in, ii. 91

- Uigur rulers of, ii. 68

- under Abdullah Khan, ii. II

- Unnatural practices in, ii. 158

- Uzbeg rulers of, ii. 71

- Vegetation at, ii. 165

- Vocal entertainment by Author, ii. 9 I

- Walls of, ii. 124

- Water of, ii. 149

- Weaving in, ii. I 44

- White asses at, ii. 163

Wine-drinkers punished in, ii. 73

Wolff's journey to, ii. 77

Bokhariot ambassadors, Welcome from, ii. 10

- army, ii. 21

- boats, ii. 200

- bodyguard at Kitab, ii. 20

- communications, ii. 54

- conceit, ii. 25

- conquest of Ferghana, 506

courtiers, Presents to, ii. 29

cowardice, ii. 88

- criminals banished to Merv, ii. 456

cunning, ii. 129

curiosities, ii. 185

defeat at Uchum, 625

- Zerbulak, 625

- by Gen. Romanovsky, 622

diseases cured by Issirik grass, ii. 57

dislike of ruler, ii. 188

- entry into Tashkend, $62 \mathrm{I}$

etiquette, ii. 13

- at Kitab. ii. 20

- evacuation of Khokand, 507

exiles, ii. 2 ro

ignorance, ii. 124

life in the harem, ii. 155

manuscripts, ii. 115

negotiations for peace, 624 
Bokhariot officers, Reception of, ii. 20 - opinions of Russian rule, ii. I88 rebellion at Karshi, 625

- refuge in Smarkand, 623

- seizure of Khokand, 507

- shepherds, ii. 211

"Siberia," 210

- statistics, Untrustworthiness of, ii. 39

- subjugation of Darwazis, ii. 53

- taxation, ii. $5^{8}$

- troops, Cowardice of, ii. 22

- trophies seized in Tashkend, 622

- village, ii. ro

- weights and measures, ii. 36

Bolosoglo, Capt., Entomological expedition of, ii. 575

Book scarcity in Bokhara, ii. 134

- - Central Asia, $5^{84}$

Books at Pavlodar, Sale of, 70

bought by Muhammadans, 73

— for Akmolinsk, 65

- distribution, 26

_- Languages of, 27

- _ Number of, 27

- exiles in Tobolsk, 29

-Omsk, 65

_- Russian exiles, 6

- Semipolatinsk, $\mathbf{1} 44$

- - hospitals, I44

- Sergiopol, 143

- Tiumen, 29

- presented to Jews at Karshi, ii. 48 Sale of, 38

- on steamboat, 33

- Thankfulness of exiles for, 28

Borokhudzir, Cotton-growing at, 194

- Fortress of, 193

- Fruit at, 194

- Nursery at, 193

- Ruined towns near, 195

- valley, Chinese emigrants in, 194

Boroldai table lands, 484

Botanical garden at Pishpek, 360

- specimens in Tashkend museum, 456

Botany of Khiva, ii. 266

Boundaries of Amu-daria province, 425

- Syr-daria province, 383

- Turkistan, 370

- Turkmenia, ii. 434

Brass-work at Khokand, 522

Bravery of Dr. Wolff, ii. 77

Breach v. Observance, ii. 138

Bread at Charjui, ii. 1; 8

- baking in the desert, ii, 4I2

Breakdown at Kara-Su, 267

- near Moldabavsk, 363

_ - Sam-Su, 353

Breakfast on a camel's back, ii. 415

Breweries, 55
Breweries in Turkistan, 607

- - Western Siteria, 55

Bribery in Bokhara, ii. 152,187

Bridge at Ilisk, 267

British Museum, Presents for, 275

Brodowsky, M., on cotton culture, 195

Brody, Jewish refugees at. ii. 107

Buddhist idols at Tashkend, 456

- temple in Kuldja, 230

Bugs or Hemiptera, Study of, 455

Building materials at Bokhara, ii. 142

Buildings in Kuldja, 243

-- of Asiatic Tashkend, 440

- Khojend, 550

Bukan-Tau mountains, 426

Bukhtarminsk, Trading-place of, 131

Burnaby, Capt., at Khiva, ii. 262

Burnes, Alex., at Bokhara, ii. 73.

- - Karshi, ii. 44

- - Merv, ii. 457

Business in Akmolinsk, 54

Butcher's shrine at Samarkand, 588

Butenau plateau, ii. 39 I

Butler, Capt. F. W. H., on Turkoman frontier, ii. 466

Butterflies of Turkistan, ii. $58 \mathrm{i}$

Buzgol-Khan pass at Derbent, ii. 5 I

"Called Back," Siberian prisons criticised in, 636

Camel accident in the desert, ii. 377

- amulets in Turkmenia, ii. 447

- Breakfasting on the back of a, ii. 415

- caravan at Sari-bulak, 187

- cart of Kirghese, 140

- cradles at Kunia Urgenj, ii. 363

- loading at Kunia Urgenj, ii. 365

Camel's Hump on the Amu, ii. 224

Camels, "Demoralization" of, ii. 428

- Hire of, ii. 365

Camp of Russians near Samarkand, ii. 4

- Tamerlane, ii. 4

Campaign against Khiva, ii. 283

- of Skobeleff in Turkmenia, î. 464

Campaigns of Tamerlane, 562

Camping at Begendjalri Kir, ii. 421

- in a sea-bed, it. 419

- - sight of the Caspian, ii. 426

- - the desert, ii. 383

Canals at Merv, ii. 476

- near Koplan-Bek, 423

- - Sary Kamish lake, ii. 407

- of Khiva, ii. 252

- Zarafshan, 535

Capital punishment in Bokhara, ii. 152

Capture of gazelle at Uzun Kuyu, ii. 413

- Khiva by Russians, ii. $28_{3}$

Caravan on a watercourse, ii. 382

- routes in Bokhara, ii. 55 
Caravan routes of Syr-daria province, 390 - travelling in a sea-bed, ii, 420

Caravans, Taxation of, ii. 187

Caravansaries in Bokhara, ii. 133

Caravansary at Khiva, ii. 285 of the Karshi steppe, ii. 63

Carlyle on Work, 4

Carnage at Iliali, ii. 332

Carpet manufacture at Merv, ii. 478

Carpets of the Turkomans, ii. 447

Carriage of Emir, Author's drive in, ii. 30

Carts of natives at Khiva, ii. 316

Caspian, Camping in sight of the, ii. 426

- Colporteurs from the, ii. 240

- Jenkinson's alleged bay of the, ii. 402

- Littoral of the, it. 437

- Passage across the, ii. 499

- seaboard, Russian forts on, ii. 461

- sighted from the desert, ii. 425

Cathedral at Moscow, 15

Cattle at Chirakchi, ii. 40

- Hissar. ii. 40

- breeding in Semipolatinsk, IOI

- of Kirghese, 316

- diseases, 319

- in Kuldja, 243

- Semirechia, I66

- Zarafshan province, 545

- losses by storms, 319

- market at Vierny, 276

- of Merv, ii. 478

- - the Steppe, 316

- Turkistan, 420

- sheds in the desert, ii. 394

- - of the Kirghese, 319

- stealing among Kirghese, 412

Caucasians in Turkistan, 392

Caverns at Kaplan Kir, ii. 419

Cemetery at Aulie-Ata, 366

- Khanki, ii, 248

- Suili, ii. 432

- Tobolsk, 35

- near Kunia Urgenj, ii. 338

- Sary Kamish lake, ii. 407

Cereals of Turkistan, 483

Ceremonies of Jahria Brotherhoud, ii. 295

Cestodes of Turkistan, ii. 615

Character of Kirghese, 308

Charitonoff, Col., Hospitality of, ii. 492

Charjur, Amu-daria at, ii. 199

- Arms of soldiers, ii. 186

- Arrival at, ii. 177

- Batchas at, ii. 190

- Bazaar at, ii. 185

- Bek's official staff, ii. 186

- presents to Author, ii. I90

- Bill of fare at, ii. 178

- Bread at, ii. 178

- Curiosities of, it. 185
Charjur, Fortress of, ii. 177

- Gallows at, ii. 18I

- Lodging near, ii. 176

- News concerning tarantass, ii. I91

- Night guard at, it. 186

- officials, Meeting of, ii. 176

- Parting with attendants at, ii. 191

- Pilau at, ii. 178

- Population of, ii, 177

- Prison at, ii. 183

- Reception of Author at, ii. 179

- Slave-trade at, ii. I85

- Start for the Oxus, ii. 190

- Trumpets and drums at, ii. 18I

- Visit to Bek of, ii. 179

Chastisement in the desert, ii, 396

Château at Iliali, ii. 333

Cheleken, Naphtha springs at, ii. 496

Chemical analysis of Sary Kamish water, ii. 400

Cherkassky on old bed of Oxus, ii. 406

Chernaieff, Gen., in Turkistan, 619

- Supersession of, 622

Chess-playing among Turkomans, ii. 444

Chickens at Kunia Ürgenj, ii. 364

Chikishliar, Russian capture of, ii. 46r

Childbirth among Kirghese, 359

Children of the Emir of Bokhara, ii. I88

- Kirghese, 360

Chimgan, Sanatorium at, 450

Chimkent, Cultivated land in, 42 I

- Derivation of name, 422

- Discontent among Kazaks, 509

- district, Geology of, 422

- Houses in, 421

- Khokandian defeat at, $6 \mathbf{r 9}$

- Population of, 421

- Russian conquest of, 620

- Scriptures for, 443

- uyezd, 42I

China basin. Tragical end of a, ii. 389

China, Jewish migration to, 521

- Jews in, Traditions of, 594

Opium-smoking illegal in, 26r

Chinaz, Syr river at, 387

Chinchakhodzi, Arrival at, 264

- captured by Russians, 627

- Dungans at, 200

- Station at, 199

Chinese anxiety for Scriptures, 236

- bazaar, Visit to a, 239

- Christians in Kuldja, 230

- coins, 240

- commissariat officer at Kuldja, Visit to, 235

- curiosities in Vierny, 275

- emigrants in Borokhudzir valley, 194

- Gospels in Kuldja, Sale of, 236

- Governor at Suidun, Visit to, 257 
Chinese in the Ili valley, 257

- influence in Khokand, 503

- junks on Lake Zaisan, 131

- Massacre of, 203

- p'ai fang at Suidun, 204

- paintings, 262

- police-master, Visit to, 234

Chirakchi bekship, ii. 40

- Departure from, ii. 43

- Poor lodging at, ii. 42

- Presents from Bek of, ii. 43

- - to Bek of, ii. 4 I

-- Price of corn at, ii. 40

- Sheep and cattle at, ii. 40

- Visit to Bek of, ii. $4 \mathrm{I}$

- Welcome by Bek of, ii. 4I

Chirchik river, 478

Chitarik, Arrival at, ii. 64

Cholera in Turkistan, $53^{8}$

Choristers of Jewish Synagogue, 592

Christian persecution of Jews in Russia, ii. 105

work for women in Cent. Asia, ii. 356

Christianity, Muhammadan attitude towards, ii. 302

Chronology of Russ. Central Asia, 677

Chrysidiformes of Turkistan, ii. 579

Chu river, Description of, 359 Fish of, 359

Chuchai, House-building at, 517

Chulak hills, Route over, 266

Chupan-Ata hill, 564

Church music on steamboat, 40

Chusovaia, Arrest of Author at, 20

Cistern at Hazret Halfa, ii. 100 Kakir, ii. 60

Citadel palace at Samarkand, 577

Civilization, An oasis of, ii. 229

Clayton, Capt., on Turkoman frontier, ii. 466

Cliffs at Kaplan Kir, ii. 418

- of the Ust Urt, ii. 392

- on the Amu-daria, ii. 200

- Upper Oxus, ii. 208

Climate of Akmolinsk, 50

- Amu-daria province, 432

- Ferghana province, 495

- Khivan khanate, ii. 331

- Khojend, 550

- Kohistan, 538

- Kopal, r59

- Kuldja, 224

- Marghilan, 497

- Osh, 497

- Pamir, 493

- - Semirechia, I59

- - Sergiopol, r 59

_- Tashkend, 449, 467

- the Steppe, 44
Climate of Turkistan, 371

- - Turkmenia, ii. 440

- Vierny, 271

Climbing a camel's hump, ii. $3^{89}$

Clock and towers at Bokhara, ii. 125

Coal at Bokhara, ii. 141

- mines in Ili valley, 198

- near Khojend, 515

Coinage at Kunia Urgenj, ii. 347

- in Khiva, ii. 285

Coins found near Kunia Urgenj, ii, 364

- of Central Asia, ii. 502

Chinese, 240

College life in Khiva, ii. 290

- of Ulug Beg, ii. 72

- Yelenktosh, ii. 72

Colleges of Central Asia, 586 Samarkand, $5^{86}$

Colonization of Semirechia, 292

- the Ili valley, $2 \mathrm{O}_{3}$

Colporteurs among the Kirghese, ii. $3 \mathrm{O}_{3}$

- at Askhabad, it. 305

- Iliali, ii. 333

- from the Caspian, ii. 240

- in Bokhara, ii. 304

- Khiva, ii. 304

Comet, Kirghese notions of a, ii. 364

- visible at Khoja-Moburak, ii. 59

Commerce of Bokhara, ii. 133

Communications of the Steppe, 46

Conceit of Bokhariots, ii. 25

Concert among the Kinghese. 341

Conflagrations in Akmolinsk, 54

Conolly, Capt, at Khiva, ii. 280

- - imprisoned at Bokhara, ii. 76

- - killed at Bokhara, ii. 76

Conquests of Jinghiz Khan, ii. 273

- Tamerlane, ii. 274

Constantinople, Muhammadan worship at, ii. 297

Constantinovsk, Agriculture at, 359

Conversation with Bek of Shahr, ii. 33

- courtiers at Bokhara, ii. 154

- Khan of Khiva, ii. 261, 272, 302 , 3 IO, 486

Kush-beggi of Bokhara, ii. 128

Cooking utensils, Purchase of, ii. 364

Copper-mining near Kuldja, 199

Coppersmiths Row in Khiva, ii. 287

Corn at Chirakchi, Price of, ii. 40

- mill at Manak, ii. 325

- stores in Ust-Kamenogorsk, 316

- Zaisan district, 316

Coronation-stone at Samarkand, 577 - of Tamerlane, 564

Cossack colonists in Semirechia, 292

- fisheries on Lake Zaisan, 91

- gardening, roo

- plundering at Kunia Urgenj, ii. 34I 
Cossack population of Akmolinsk, 66

_-Semipolatinsk, 66

- raids on Urgenj, ii. 274

- service, 113

- settlers in Semirechia, $\mathbf{1} 66$

Cossacks, Arms of, 602

- enslaved by Khivans, ii. 276

- in Turkistan, 60I

- Uniforms of, 603

Cotton cultivation at Borokhudzir, 194 - Merv, ii. $47^{8}$

- of Cent. Asia, M. Brodowsky on, 195 - statistics, I95

Counterfeit coin at Merv, ii. 478

Court of Justice at Kunia Urgenj, ii. 358

- visitors at Kitab, ii. 18

Courtine of Catherine II. in Petersburg, 645

- Cells for military officers, 648

- Garden exercise in, 648

- Library for prisoners, 647

- - Prisoners' rooms, 647

- - Trial chamber, 647

- - Visitors' room, 646

Cowardice of Bokhariots, ii. 22, 88

Cradle accident in the desert, ii. 388

Crazy bridges at Kara-Kul, ii. I68

Creeds in Vierny, 280

Crevasses of Kaplan Kir, ii. 420

Crime among Kirghese, 411

- at Petro-Alexandrovsk, ii. $354,35^{8}$

- in Akmolinsk, 57

- Kuldja, 236

- Kirghese idea of, 347

Criminal exiles in Ili valley, $25^{8}$

Cromie, Mr. W. H., Translation work of, ii. 506

Crops in Turkistan, 484

- of Bokhara, ii. 164

- Zarafshan province, 545,608

Crustacea of Turkistan, ii. 548

Cufic inscription on Kok-tash stone, 579

Curiosities at Tashkend, $45^{8}$

- for British Museum, 275

- from Kunia Urgenj, ii. 364

- in Tashkend Museum, 455

- of Bokhara, ii. 127

- Charjui, ii. 185

- purchased in Bokhara, ii, 134

Curiosity hunting among the Sibos, 213

Custody, Release of Author from, 24

Custums of the Dungans, 209

- Kinghese, 364

DAItY BREAD at Charjui, ii. 179

Daily Netes Correspondent, Merv, ii. 467

Dancing boys, or Batchas, 209

- - at Bokhara. ii. 89

- Kitab, ii. 15
Dancing boy3 dressed as girls, ii. 90

- dervishes at Constantinople, ii. 297

- - Samarkand, ii. 295

Darkness in the desert, ii. 397

Darwaz, Iron mines near, ii. 54

- Oshanin's description of, ii. 54

Darwazis subjugated by Bokhariots, ii. 53

Daudan, Crossing the, ii. 319

Death of M. Fedchenko, ii. 513

- - M. Severtsoff, ii. 508

- rate in Tashkend hospital, $45^{\circ}$

Deaths in Semipolatinsk, 108

Debtors and creditors in heaven, ii. 220

Decapitation of Muhammad-Emin, ii, 457

Deflection of the Oxus, Cause of, ii. 409

Dekche, Arrival at, ii. 393

- Urun-daria at, ii. 393

De Marny on Kyzyl-Kum geology, 426

Demerdjan well, il. 429

Demoralization of camels, ii. 428

Dependence of Merv upon Khiva, ii. 486

Derbent, Iron Gates defile near, ii. 51

Dervishes at Khiva, ii. 298

DESERT, Ablutions in the, ii. 424

- Animal life in, ii. 393

- around Merv, ii. 455

"Beauty" sleep in, ii. 387

- Bible-searching in, ii. 423

- Bread-baking in, ii. 412

- Breakfast in, ii. 380

- Camel accident in, ii, 377

- - loading in, ii. 387

- Camping in, ii. 383

- Caspian sighted from, ii. 425

Cattle-sheds in, ii. 394

- Character of guides, if. 397

- Correction of Murad for stealing, ii. 396

- Cradle accident in, ii. 388

- Dangers of, ii. 23I

- Darkness in, ii. 397

- Dessert in, 340

- Discipline in, ii. $3^{87}$

- Doctoring in, ii. 378

- Fatigue of travelling in, ii. 423

- Forty winks in, ii. 428

- Game-birds of, ii. 422

- "Good-luck " in, ii. 414

- Hurrying drivers in, ii. $38 \mathrm{r}$

"In bed " in, ii. 415

- Inconveniences of travelling in, ii. 424

- Jackdaws in, ii. 422

- Krasnovodsk sighted from, ii. 433

- Lack of comforts in, ii. 423

- locked, ii. 229

- Low spirits in, ii. 422

- Marmots in, ii. 422

- Order of march in, ii. $3^{87}$

- Pastime in, ii. 423

- Perils of, ii. 172 
Desert, Preparation for crossing, ii. 363

- Rate of travel, ii. 492

- Reeds and rushes in, ii. 397

- Revival of hopes in, ii. 424

-- Robbers in, ii. 394

- Ruins in, ii. 383 .

- Saxaul fires in, ii. 411

- Sheep and goats of, ii. 382

- Sleeping in, ii. $\mathbf{1 7 3}$

- - cages in, ii. 376

- Slow progress in, ii. 395

- Submarine origin of, ii. 438

- Subterranean sheds in, ii. 394

- Temperature in, ii. 422

- Troubles with attendants, ii. 414

- "Turning policeman" in, ii. 396

Ups and downs of, ii. 422

- Venison in the, ii. 382

Weariness of mind in, ii. $4: 3$

- Wild hens in, ii. 422

Deserts of Syr-daria province, 384

Desiccated lake-bed near Ala-Kal, 177

Desiccation of Turkoman steppe, ii. 405

Dessert in the desert, $34^{\circ}$

Detonations on the Amu, ii. 220

Diet of prisoners at Omsk, 662

Difficulties of desert journey, ii. 172

Dinner among the Kinghese, 339

- in a Turkoman tent, ii. 374

"Diotrephes," Misbebaviour of, ii. 338

- return to civilization, ii. 492

- Scamper on, ii. 59

Disabilities of Jews in Russia, ii. 104

Disappearance of Aral Sea, ii. 403

Discipline in the desert, ii. 387

Diseases among Kirghese, 307

- in Semipolatinsk, 116

- Tashkend, 449

- of Bokhariots, ii. 144

- cured by Issirik grass, ii. 57

- Khivans, ii. 308

Dishonesty of attendants, ii. 311,365 , 371,372

Dispensary at Tashkend, 450

Distilleries, 55

in Turkistan, 607

Distribution of books, etc., 229, 235, $279,469,670,671$, ii. 232 , 301

- Scriptures, etc., 6, 19, 26-29, 38, $65,68,263,442,443,454,466$, $529,611,665$, ii. 237 .

- Turkoman tribes, ii. 444

Divan-beggi medresse at Bokhara, ii, 135

Divinity and medicine conjoined, 18

Divisions of Turkoman tribes, ii. 444

Divorce among the Kirghese, 328

- in Central Asia, ii. 353

Djan-Bulak, Unruly horse at, 487

Djiguitts engaged by Author, ii. 3

Djus Agach, Miserable station at, $\mathbf{1 7 5}$ Doctoring a cradle, ii. 389

- Turkoman, ii. 374

- in the desert, ii. 378

Doctors in Bokhara, ii. I49

Dog-fighting at Shavat, ii. 320

Dolgorouki, Prince, Sympathy with Jews, ii. 104

Domestic animals in Turkistan, 420 comforts in desert, Lack of, ii. 423

- expenses in Tashkend, $46 \mathrm{I}$

Dress of Taranchis, 207

Dresses of Kirghese, 312

Drink traffic in Turkistan, 607

Drive of Author in Emir's carriage, ii. 30

Driving in danger, ji. 168

Droshky drive in Vierny, 272

Drugs, Purchase of, 18

Drums and trumpets at Charjui, ii. 181

Drunkenness of Turkistan troops, 603

Dungans at Chinchakhodzi, 200

- Jarkend, 196

- Customs of, 209

- defeated by Taranchis, 203

- Description of, 209

- Insurrection against China, 626

- Mosque of, in Kuldja, 232, 255

- Music of the, 210

Number of, 209

- Origin of, 208

- Rebellion of, $2 \mathrm{O}_{3}$

- Shopkeepers in Kuldja, 240

Vehicles of, 210,263

Dungeons at Bokhara, ii. 153

Dust-storms in Ferghana province, 496

Dwellings in Kuldja, 253

Dyeing-plants in Turkistan, 483

"EARLY to bed and early to rise," ii. $3^{56}$

Earth-closets in Central Asia, ii. 415

Earthquakes at Tashkend, 468

- in Turkistan, 378

Eastern sovereigns, Scandal concerning, ii. 155

Eatables at Kunia Urgenj, ii. 364

Eating-houses at Vierny, 278

Education among the Kinghese, 358

at Samarkand, 600

- Vierny, 279

- in Bokhara, ii. 120

- Zarafshan province, 600

- of Turkistan troops, 603

Egen-Klych, Dam of, ii. $3_{3}^{8}$

Eggs at Kunia Urgenj, ii. 364

- in Khiva, ii. 364

"Ehbi" wind in the Steppe, 181

Ekaterineburg, Arrival at, 26

Bible Society's agent at, ii. 238

Elburz and Kopet ranges, ii. 438 
Election among the Kirghese, 346

- Kirghese ruttianism at an, 350

Emigration from Kuldja, 256

EMIR of BoкнARA, see Bokhara.

Enamelled bricks at Samarkand, 587

Enamelling, Remarkable, at KhojaAkhrar medresse, $5^{82}$

Encampment at Jedurun, ii. 392

- of Bokhariot troops, ii. 93

English attempts at growing Khivan melons, ii. 266

- ingratitude, ii. 500

- mediation in Khiva, ii. 278

- perseverance, ii. 4

- trade competition in Turkistan, 464

Enterprise, Author's, Danger of, 8

- Victims of the spirit of, ii. 431

Entertainment at Kitab, ii. 15

- - Shahr, ii. 34

Entomological expedition of Bolosoglo, ii. 575

Epidemics in Zarafshan province, $53^{8}$

Ersaris of Turkmenia, ii. 444

Erschoff, N. G., on Turkistan Lepidoptera, ii. $58 \mathrm{I}$

Escort from Kunia Urgenj, ii. 368

- on the Oxus, ii. 201

Etchmiadzin, Walls of, ii. 124

Etemal fires of Baku, ii. 500

Ethnographical specimens in Tashkend museum, 455

Ethnography of Ili valley, 206

Ethnology of Ili valley, 206

- - Semirechia, 162

- Turkmenia, ii. 144

- Zarafshan province, 541

Etiquette at Kitab, ii. 20

Evening audiences aboard ship, 2

Exaggeration of newspapers, 25

"Example better than precept," ii. 56

Excise duties in Semipolatinsk, 112

- statistics, 56

Execution of Bokhariots, ii. 69

- stone at Samarkand, 579

Executions in Bokhara, ii. 152

Exhibition at Moscow, 14

- - Tract distribution in, ii. $23^{8}$

Exiles from Bokhara, ii. 2 Io

- in Tobolsk, Books for, 29

- Russian, Books for, 6

Expeditions in Turkmenia, ii. 461

Exploration of the Oxus, ii. 193

- - Thian Shan, 294

Explorations of Bolkhara mountains, ii. 50

- - Fedchenko, 492, ii. 509

- Kostenko, 493

- Maieff, ii. 50

- Oshanin, ii. 50

- Osten-Sacken, 297
Explorations of Poltoratzky, 297

- Regel, ii. 50

- Severtsoff, 494

Exports from Khokand, 523

- Kuldja, 242

- of Semipolatinsk, IO7

- Tashkend, 46r

FACTORIES in Kuldja, 242

Fairs at Tashkend, 462

- of Semipolatinsk, 105

Falconry at Manak, ii. 326

Fanaticism of Kirghese, 344

- Muhammadans, ii. 298

Fancy goods of Tashkend, 459

Fares between Tiumen and Semipolatinsk, 37

Farm-houses at Bokhara, ii. 165

- near Khiva, ii. 254

- - Shavat, ii. 321

Farming on the Amu, ii. 222

Fatigue of desert travelling, ii. 423

Fauna of Ala-Kul district, 147

- Amu islands, ii. 218

- banks of Lake Zaisan, 91

- Ferghana province, 499

- Khiva, ii, 267

- Omsk, 8o

- Pamir, 494

- Russian Turkistan, ii. 505

- Semirechia, 160

- the Steppe, ii. 430

- Turkmenia, it. 441

Favours, Official, 12

Fazul, Author's native servant, ii. 3

Feast of Tabernacles at Samarkand, 589

Feasting among the Kinghese, 339

- at Bokhara, ii. 154

- in a cemetery, 367

Fedchenko, M., Explorations of, 492

- Fatal accident to, ii. 513

- Madame, Appendices revised by, ii. 513

- on Turkistan Zoology, ii. 506

- Travels of, ii. 509

Feeding-time on the Oxus, ii. 203

Feline obtruders in tent, ii. 6

Felt manufacture at Krasnovodsk, ii. 447

Felts of the Turkomans, ii. 447

Female missionaries, Need of, ii. 356

- seclusion in Bokhara, ii. 156

- - Khiva, ii. 355

Ferghana province, 490

- Alai plateau, 492

- Area of, $42,49 \mathrm{r}$

- Baber, ruler of, 502

- Bokhariot conquest of, 506

Climate of. 495

- Dust-storms in, 496

_- Explorations of Fedchenko, 492 
Ferghana province:

- Explorations of Kostenko, 493

- - Severtsoff, 494

Extension under Narbuta, 504

- Fauna of, 499

- Form of, 490

- Geology of, 497

- Gharm-sol in, 496

- Independence of, 504

_ Kara-Kul lake, 495

- Lakes of, 494

- Madali and his conquests, 504

- Minerals of, 497

- Pamir mountains, 492

- _ Climate of, 493

_- _ Fauna of. 494 Flora of, 494

- Petroleum in, 498

- Pilgrimages in, 500

- Population of, 42

Rivers of, 493

Scriptures for, 443

Size of, 490

- Skobeleff in, $5 \mathrm{I} 2$

- Subjection to China, 503

- - Surface of, 49I

_ - Tobacco culture in, 499

_ Towns of, $398,499,501$

_ - Turquoise in, 497

- Vegetation of, 497

Ferns of Zarafshan province, 609

Ferries on the Upper Oxus, ii. 196

Ferry-boat on the Oxus, ii. 176

Festivals of the Sarts, ii. 250

Feuds of the Kinghese. 294

Fever at Petro-Alexandrovsk, ii. 234

Fevers in Tashkend, 449

Field for female missionaries, ii. 356

Fifty-shilling tea ! 264

Fighting ram at Khiva, ii. 259

Finland, Bible-work in, ii, 240

Finsch, Dr., on fauna of Ala-Kul, 147

- Tukistan Zoology, ii. 507

Fire-worshippers at Surakhane, ii. 500

Fires in Akmolinsk, 54

- Semipolatinsk, 115

Fish at Khojeili, ii. 349

- Krasnovodsk, ii. 496

- in Ala-Kul lake, 148

- Irtish river, 79

Zaisan lake, go

- of Amu-daria, ii. 243

- - Price of, ii. 243

- Asia (Central), ii. 530

- Atrak river, ii. 439

_ Balkhash lake, 180

- Chu river, 359

_ Issik-Kul lake, I59

- Khivan khanate, if. 269
Fish of Turkistan, ii. 243,530 - Zarafshan river, ii. 510

Fisheries on Lake Zaisan, 91

Floating down the Oxus, ii. 200

Flora of Amu banks, ii, 223

- Omsk, 80

- Pamir, 494

- Russian Turkistan, ii. 618

- Turkmenia, ii. $44^{\circ}$ Zarafshan province, 557

Flour mills at Manak, ii. 325

Fogs in Turkistan, 377

Food at Karategin, ii. 54

- Khanki, ii. 251

— of the Kalmuks, 215

- - Kirghese, 337

_- Turkistan troops, 603

- Turkomans, ii. 446

Fording the Zarasshan river, 559

Fords of Upper Oxus, ii. I95

Forest plantations, ii. 8

Forests of saxaul, ii. $4 \mathrm{II}$

- Semipolatinsk, 93

- Semirechia, 160

Fort Vernoe, 270

Fortress at Manak, 326

Krasnovodsk, ii. 498

Petro-Alexandrovsk, ii. 234

- of Borokhudzir, 193

- Charjui, ii. 177

- Hazarasp, ii. 313

- Iliali, ii. 333

- Kaushid Khan, ii. 475

- Zmukshir, ii. 332

Fortress Prison in Petersburg, 640

- Admission difficult, 640

- Courtine of Catherine II., 642

- Eye-witnesses' testimony, 651

_- Misremresentations concerning, 642

- Newspaper criticisms on Author's visit, $64 \mathrm{I}$

- Ninetecnth Century on, 657

- Statements of ex-prisoners, 652

- - Troubetzkoy bastion, 64I

- - Visits to prisoners, 644

Forts along Irtish river, 127

- erected in Steppe, 408

- - Syr-daria province, 409

- of Turkistan, $60 \mathrm{I}$

"Forty winks" in the desert, ii. 428

Fossil remains on the Amu-daria, ii. 200

French travellers at Merv, ii. 473

Frontier camp of Bokhariots, ii. 221

- of Turkmenia, ii. 435

Fruit at Borokhudzir, I94

- - Vierny, 277

- of Khiva, ii. 266

- Kuldja, 223

- Merv, ii. 477 
Fruit-trees at Manak, ii, 326 - - in Turkistan, 480 - - Turkmenia, ii. 440 - - of Bokbara, ii. 82 - on the Balkhan mountains, ii. 438 Fuel at Bokhara, ii. 142 - of Asia (Central), ii. $4 \mathrm{II}$ - the Kirghese, 352

Funerals among the Sarts, ii. 248

Fur trade at Khokand, 523

Furniture at Kakir, ii. 62

Furs at Bokhara, ii. 134

Gaieties at Tashkend, 452

Gallop round walls of Bokhara, ii. tor

Gallows at Charjui, ii. 18I Khiva, ii. 308

Galtchas of Zarafshan province, 54I

- Customs of, 542

- Domestic life of, 542

- Government of, 542

Tribes of, 543

Game birds of the desert, ii. 422

- on the Amu, ii, 218

Games of the Kinghese, 556

Ganoid fishes of the Amu, ii. 245

Garden of Kush-beggi at Bokhara, ii. 8I produce of Bokhara, ii. 142

Gardening at Bokhara, ii. $8_{3}$

- by Cossacks, 100

in prisons, 668

Gardens of Asia (Central) 480

- Bokhara, ii. 137, 165

- Iliali, ii. 333

- Khiva, ii, 252, 337

- Khojend, 550

- Kuldja, 224

- Merv, ii. 476

- Petersburg prisons, 645,648

Gates of Bokhara, ii. IoI

- Tamerlane, 555

- Tashkend, 424

Gazavat, Aryk and town of, ii, 318

- Houses at, ii. 318

- Inhabitants of, ii. 318

- Turkomans of, ii. 319

Gazelle captured at Uzun Kuyu, ii. 413

Gazelles at Porsu, ii. 426

Gazette in Tashikend, ii. 292

Gelun. Clerical functions of a, 217

- Duties of a, 216

Geluns among the Kalmuks, 215

- Tents of the, 216

Generosity of M. Ignatoff, 27, 32, 33

Geographical problems concerning Aral Sea, ii. 402

- Oxus, ii. 402

Geography of Kara-boghaz gulf, ii. 427

Geok Tepe, Russian capture of, ii. 465

Geok Tepe, Russian losses at, ii. 465

- Skobeleff at, ii. 464

Geological changes of Aral Sea, 385

- features of Central Asia, ii. 170

- formation of Khivan khanate, ii. 265

- phenomena on the Oxus, ii. 206

-questions concerning the Scaphirhynchus, ii. 244

Geology of Chimkent district, 422

- - Ferghana, 497

- Kohistan, 537

- Kyzyl-Kum steppe, 426

- Thian Shan mountains, 155

- Turkistan, 378

- Zaisan neighbourhood, 91

German visitors at Tashkend, 452

Germans in Tashkend, 448

Gharm-sol in Ferghana, 496

Ghern, M., at Vierny, 274

Gill, Lieut., on Turkoman frontier, ii. 466

Gilyaks, Men and bear fights among, ii. 211

Ginsburg, Dr., on Hebrew MSS., ii. II $_{4}$

Glaciers of Thian Shan range. 155

Glaisher, Mr., Instruments lent by, 8

Glukhovsky's reconnaissance of old Oxus bed, ii. 407

Gluttony of the Kirghese, 338

Goats of the Kirghese, 317

Gods of the Sibos, 212

Goitre at Khokand, 546

- Remedies for, 547

- Treatment of. 547

Goklans of Turkmenia, ii. 445

Gold in Turkistan, $3^{81}$

- mining in Semipolatinsk, 103

Golden Horde, Russian conquest of, 401

"Good luck" in the desert, ii. 4I 4

Gorge in the Oxus bed, ii. 393

Governors of Khivan provinces, ii. 314

Granary of Tashkend, 478

Grand Duke Michael's reception of Author, II

Grapes of Khiva, ii. 267

Grave of Gen. von Kaufmann, 448

Graveyards of Bokhara, ii. 249

Great Balkhan mountains, ii. 437

- Horde, Submission of, 288

Grodekoff on the Turkomans, ii. 444

Grotenhielm, Gen. von, Hospitality of, ii. 232

- - kindness to colporteurs, ii. 305

Guest and prisoner at Bokhara, ii. 140

- house at Karshi, ii. 44

Guides in the desert, Character of. ii. 397

Guinea-worm in Bokhara, ii. 146

Gunpowder manufacture in Bokhara, ii. $14 \mathrm{I}$

- Merv, ii 478 
Gur-Emir mausoleum, 566

- History of the, 570

- Relics of the, 571

- Tombs in the, 567

Gurgan river- ii. 439

Gypsies of Zarafshan province, 543

HABITATIONs in Amu-daria province 433 - of Semirechia, 164

- - Kirghese, 310

- Taranchis, 208

- Turkomans, ii. 445

Handoo Kuh mountains, ii. 439

Harbour of Lake Balkhash, 180

Harbours of Lake Aral, 429

Harem of Emir of Bokhara, ii. 155

- - Life in the, ii. 355

- Khan of Khokand, i1, I55

Harkavy, Dr. A., on Hebrew MS's, ii. 114

Harvest tax at Khiva, ii. 271

Harvests of Bokhara, ii. 164

Hassan Kuli Bay, Boat-building at, ii. 4.39

Havli at Manak, Interior of, ii. 327

- Walls of, ii. 326

Havlis near Shavat, ii. 321

Hawks for falconry at Manak, ii. 326

- Training of, ii. 326

Hazarasp gate at Khiva, ii. 3 I I

- Governorship of, ii. $3 I_{4}$

- Hermit's cave at, ii. $3^{1 / 3}$

- Population of, ii. $3 \mathrm{I} 4$

- Town of, ii. 312

- Tradition concerning, ii. 313

Hazret Halfa Khu-giadat, Cistern at, ii. 100

- Imlah, Mosque of, ii. 100

- Russian conquest of, 620

Head-dresses of Kirghese, ii. 287

Heaven, Debtors and creditors in, ii. 220

Hebrew MSS. at Bokhara, ii. 114

- - Ginsburg, Dr., on, ii. 114

- Harkavy, Dr., on, ii. 114

- Hints concerning, ii. 114

_ Wonderful specimen of, ii. $\mathbf{I I}_{5}$

- patriarchs, Kirghese resemblance to, 299

- pronunciation at Samarkand, 595

Help of Bible and Tract Societies, 5

Hemiptera seen at Tashkend, 455

Herds of the Kirghese, 322

Heri Rud river in Turkmenia, ii. 453

Hermit's cave at Hazarasp, ii. 313

Highway from Petersburg to Afghanistan, ii. 406

Hindu disabilities in Bokbara, ii. 100

- Sarai at Bokhara, ii. 100

Hindus at Khokand, ii. 100

Hindustan, Route to, ii. 194

Hints concerning Hebrew MSS, ii. 114
Hissar, Cattle at, ii. 40.

mountains, 535 , ii. 40

Historical discussion on Aralo-Caspian region, ii. 403

History of Akhal oasis, ii. 450

- Attek oasis, ij. 451

- Bokhara, ii. 66

_- Ili valley, 201

- Kalmuks, I25

- Khivan oasis, ii. 264

- Khojend. 549

- Khokand, 502

- Maracanda, 560

Hodjas among Kirghese, 346

Holy Communion in a Roman Catholic chapel. 228

Home comforts at Petro-Alexandrovsk, ii. 228

- entertainment at Khiva, ii. 308

- life in Central Asia, ii. 352

Horse-box, Travelling in a, ii. 501

- dealing in Bokhara, ii. 132

- racing in Khiva, ii. 320

Horses at Khiva, Cost of, ii. 259

- Petro-Alexandrovsk, Cost of, ii. 259

- Sale of, ii. 236,237

Horticulture at Bokhara, ii. 85,165

Hospital at Khokand, 525

- Petro-Alexandrovsk, ii. 234

- Tashkend, 448 patients at Samarkand, 599

- statistics of Semipolatinsk, 116 Tashkend, 449

Hospitality at Kainar, ii. II - Khojend, 513

- Krasnovorlsk, ii. 492

- Manak, ii. 327

- Russian consulate at Kuldja, 221

- of Eastern Bokhariots, ii. 52

- Grotenhielm, Gen. von, ii. 232

- Putimsoff, Col.. $4^{89}$

- the Sarts, ii. 300

- Sibos, 214

Hospitals at Samarkand, 596, 593 of Semipolatinsk, Books for, $1+4$

Hotel at Vierny, 275

"Nicolaeff" at Tashkend, 424

House-building at Chuchai, 517

- of Khokand merchant, $53^{\circ}$

- rent in Tashkend, 461

Household commodities in Tashkend, 461

Houses at Iliali, ii. 332

- Tashauz, ii. 330

- in Akmolinsk, 54

- Chimkent, 421

- Kuldja, 253

- Russian Tashkend, 440

- - Semipolatinsk, 114 
Houses in Vierny, 272

- of ill-fame in Russ. Turkistan, ii. 299 - Kunia Urgenj, ii. 352,365

Hubsch, Baron, Kindness of, ii. 500

Hungry Steppe, 477

Huzar to the Oxus, Stations from, ii. 52

Hydrography of Amu at Kabakli, ii. 213

- - Amu-daria province, 428

- Attek oasis, ii. 452

- Oxus, Lower, ii. 241

- - Upper, ii. 202

- - Steppe, 44

- Tejend onsis, ii. 453

ICHTHYOLOGY of Turkistan, ii. 530 Idols of the Kalmuks, 2 I8

\section{- - Sibos, 212}

Igda, Wells of, ii. 407

Iginchas among the Kirghese, 3I 5

Ignatoff, M., Generosity of, 27, 32, 33

Ignorance of Asiatics, ii. 123

- Bokhariots, ii. 124

Ildjik on the Oxus, ii. 206

- Dismissal of Oxus escort, ii. 208

- Journey to, ii. 204

Ini Kalmuks, Religion of the, 217

- province ceded back to Chinese, 629

- Population of, 201

- Roads of the, $20 \mathrm{I}$

1 li river, Crossing at Kuldja, 224

_ - with Cossack escort, 225

- - Steam navigation attempted, 252

Ili valley, Cheapness of labour in, 198

- Chinese in, 257

- - criminals in, 258

- Colonization of, 203

- - Description of, 190

- Ethnography of, 206

- Ethnology of, 206

- - History of, 201

- Iron-mines in, 199

- Kalmuks of, 214

- Khambi in, 258

- Manchu of, 257

- Military colonists of, 211

- Minerals of, 198

- Mining in, 198

_- Mountains of, 190

- Rebellion in, 203, 626

- Russian annexation in, 626

- occupation temporary, 627

- Sibos of, 211

- Solons of, $2 \mathrm{II}$

- Taranchis inhabiting, 206

- Tchampani in, $25^{8}$

Torgouts in, 214

Variety of races in, 206

Iliali, Arrival at, ii. 332

- Carnage at, ii. 332
Iliali, Cháteau at, ii. 333

- Colporteurs at, ii. 333

- Fortress of, ii. 333

- Gardens of, ii. 333

- Houses at, ii. 332

- Khan's residence at, ii. 333

- Market days at. ii. 333

- Population of, ii. 333

Shops of, ii. 332

Ilisk, Bridge at, 267

Illustrated Scripture texts, see Index, p. $\mathrm{xxy}$

Immorality in Bokhara, ii. 189

Import trade of Kuldja, $24 \mathrm{I}$

Imports of Khokand, 523

- Semipolatinsk, ro7

_- Tashkend, 461, 462

Imprisonment of Conolly at Bokhara, if. 76 Stoddart at Bokhara, ii. 75

India, Will Russia conquer? ii. 489

Indian tea at Khiva, ii. 250

Industries of Akmolinsk, 54

- Khiva, if 287

- Kuldja, 242

- Samarkand, 605

- Vierny, 278

Industry of Semirechia, 164

Inexperienced postilions, ii. 166

Inhabitants of Gazavat, ii. 318 Khiva, ii. 269

- Kungrad, ii. 351

Turkistan, 370

Zarafshan province, 544

Inheritance among the Kirghese, 330

Insanity at Bokhara, ii. $25^{\circ}$ - Treatment of, ii. 145

Instruction in Khivan colleges, ii, 290

Instruments, Meteorological, lent by Mr. Glaisher, 8

Insurrection in Khokand, $5 \mathbf{1 2}$

Insurrections of Kirghese, 408

Interior of havli at Manak, ii. 327

- Kirghese tent, $33^{6}$

- Turkoman's tents, ii. 445

Interpreter at Kunia U rgenj, ii. 359

- Selecting an, I6

- Yakoob, ii. 3

Interview with Governor of Tobolsk, 35 - Jews in Bokhara, ii. 108

- Khan of Khiva, if. 261

- Russian Minister of Interior, I I

Intoxicants at Manak, ii. 326

Introduction to Governor of Irkutsk, 18

Introductions at Tiumen, 30

- Vierny, 276

- Scientific, $\mathbf{1} 3$

Inundations of the Steppe, 88

Invalid telegraphist at Konur-Ulen, I91 
Iranian history, ii. 456

- population of Tashauz, ii. 330

Iranians of Turkistan, 392

Irjar, Rout of Bokhariots at, 622

Irkutsk, Bible Society's Depôt, 28, ii. 239

- Introduction to Governor of, 18 Iron Gates defile at Derbent, ii. 5I - mines in Ili valley, 199

- near Darwaz, ii. 54

Irrigation at Bokhara, ii, 165

- of Khiva, ii. 334

- Merv oasis, ii. 476

- - the Kirghese, 98

- Turkmenia, ii. 439

- Zarafshan province, 536

- works at Jarkend, 264

Irtish river, 85

- Consolidation of Russian power on, 124

- Fish of, 79

- Forts along, 127

- Russian influence on, 124

Scenery on, 87

- Tributaries of, 88

- Voyage up, $3^{8}$

- Steppe, Character of, 79

- Russian occupation of, 120

- trade with natives, 124

Ishrat Khana palace at Samarkand, 579

Iskander-Kul lake, 535

Islamism among the Kinghese, 343

Islands of the Oxus, ii. 20.4, 24I

- - Fauna of, ii. 218

Issik-Kul lake, Antiquities of, 159

$$
\text { Depth of, } 15^{8}
$$

_ - Dimensions of, 158

Fish of, 159

Origin of, 157

- Proposed Mission at, 172

Shores of, 158

- Roads to, 354

- Semenofi's expedition to, 295 Veniukoff's survey, 297

Issirik grass, Diseases cured by, ii. 57

Ist-poos, Fortress of, ii. 207

Itinerary from Khiva to . Krasnovodsk, ii. 493

- of Author, xxx.

- Rassians from Iliali to Krasnovodsk, ii. 425

Ivanoft, Gen., Governor of Samarkand, 565

- Information concerning, 612

_- Victory over Turkomans, ii. 463

JACKDAws in the desert, ii. 422

Jahria Brotherhood, Ceremonies of, ii. 295
Jakatut, Inexperienced postilions at, ii. 166

Jarkend, Dungans at, 196

Irrigation works at, 264

- Solons at, 196

- Taranchis at, 196

Jasper wainscoting at Tamerlane's tomb, ii. 124

Jedurun, Camping at, ii. 392

Jenkinson, A., at Kunia Urgenj, ii. 34I - - Sary Kamish, ii. 402

- - in Kharezm, ii. 274

Jenkinson's alleged "Bay of the Caspian," ii. 402,405

- journey to Bokhara, ii. 71

Jewellery at Khokand, 522

- in Central Asia, ii. 286

- of the Turkomans, ii. 447,497

Jewish manuscripts at Bokhara, ii. 1 to

- migration to China, 521

- persecution at Odessa, ii, I07

- quarter of Samarkand, $5^{89}$

- refugees at Brody, ii. 107

Jews at Karshi, Books presented to, ii. 48 - in Asia (Central), Information concerning, 446, 520

Bokhara, 52I, ii, $\mathrm{IO}_{3}$

- Astonishment at Author's visit, ii. 111

- Author's inquiry for Hebrew MSS., ii. II 4

- letter to Emir on behalf of, ii. 118 offer of assistance to, ii. 109 plans concerning, ii. $\mathrm{IO}_{3}$ Condition of, ii. 108

- from Persia, ii. 108 - Tunis, ii. 108

- Interview with, ii. 108

Prophecy fulfilled, ii. 108

- Torahs of, ii. 11C

Visit to sick, ii. I/ 13

- China, Tradition of, 594

- Khiva, ii. 269

- Merv, ii. 479

- Moscow, ii. 104

- - Alleged persecution of, ii, 10.4 - Russia, Disabilities of, ii. 104

- - Liquor traffic among, ii 106

__ Money-lenders among, ii. 106

- Samarkand, Hebrew pronunciation of, 595

_ - Traditions of, 594

Persecution of, ii. 105

quarter at Samarkand, 589

synagogue at Bokhara, ii. 109

- - Karshi, ii. 48

- Khokand, 519

__ Tashkend, 445 
Jinghiz Khan, Army of, ii. 68

- Bokhara conquered by, ii. 68

- Conquests of, ii. 69,273

- Descendants of, ii. 72

- - Sieges of, ii. 340

- Sons of, ii. 68

Jizakh, Khudaiar Khan at, 510,511

- Klopatoff, Dr., at, ii. I47

- Road from Tashkend, 477

Russian capture of, 623

- march to, 622

- Scriptures for, 443

Joot amongst Kirghese cattle, 318

Joss-house in Kuldja, 232 .

Journey across desert, Rate of travel, ii. 492

- along the Aris river, 420

- Author's reasons for, 3,5

- Cost of, 4

- - Object of, 6

- through sandy desert, ii. 171

- to Kitab, ii. 7

Journeys of M. Semenoff, 296

Judges and judgments of Kirghese, 347

- Balloting for, 349

- Election of, 347

- in Bokhara, ii. 187

- salaries among Kirghese, 348

Jumma mosque at Bokhara, ii. 95

- - Interior of, ii. 96

- - - Service in, ii. 95

- Khiva, ii. 259,307

Justice, Court of, at Kunia Urgenj, ii. 358

KAвAKL., Arrival at, ii. 210

- Departure from, ii. 213

Presents to Bek of, ii. 211

- Provisioning boat at, ii. 212

- Visit from Bek at, ii. 2 II

-Wolves among sheep at, ii. 210

Kainar, Descent to, ii. 9

- Refreshments at, ii. 11

Kakir, Bazaar at, ii. 62

- Cistern at, ii. 60

- Furniture at, ii. 62

- Native oven at, ii. 62

- "Unfurnished apartments" at, ii. 61

Kalbinsk mountains, Gold industry in, 103

Kalim of a Kirghese bride, 323

Kalmuk art, 244

Kalmuks at Kuldja, 243

- Characteristics of, 2 I4

- Destruction of Urgenj by, ii. 341

- Domestic concerns of, 215

Family life of, 218

- Food of, 215

- Foreign influence among, 220
Kalmuks, Geluns among, 215

- History of, 125

- Idols of, 218

- Marriages among, 218

- of Ili valley, 214

- Semirechia, 162

- Opposition of, to Russians, 126

- Ostroumoff, M., on the, 215

- Prejevalsky, Col., among the, 244

- Religion of, 217

- Russian treaties with, 128

- School in Vierny, 170

- Superstition of, 220

- Zangs among the, 215

Kamensky Brothers, carriers, 473

- Agent at Bokhara, ii. 88

Kaplan Kir, Ascent from bed of, ii. 420

- - Bay of, ii. 417

- Caverns at, ii. 419

- Cliffs at, ii. 418

- Crevasses of, ii. 420

- First Englishman at, ii. 420

- Phenomenon at, ii. 418

Kara-boghaz guif, ii. 427

- - Geography of, ii. 427

- - Salt-fields of, ii. 427

- Chukum, Street-sleeping in, 549

- Kirghese, Origin of, 304

- Revolt of, 512

- Kul, Arrival at, ii. I67

- Crazy bridges at, ii. 168

- Danger of roads near, ii. 168

- Journey to, ii. 166

- lake, 495 , ii. 169

- Salt-lakes near, ii. $14 \mathrm{I}$

- Su, Breakdown at, 267

- - river, Length of, ii. 440

- Tiube, Arrival at, ii. 5

- Slumbers disturbed at, ii. 6

- Tent lodging at, ii. 5

Karagatch trees at Khiva, ii. 258

Karakalpaks, Characteristics of, 434

- in Amu-daria province, 433

- Khivan khanate, ii. 269

Karakol, Prisoners at, 670

Karamazar mountains, Minerals in, 515

Karamuk Fort, M. Oshanin at, ii. 53

Karategin, Dimensions of, ii. 53

- Food at, ii. 54

- Oshanin's exploration in, ii. 50

- Routes in, ii. 54

- Tajiks, Strength of, ii. 54

- Trade of, ii. 54

- Wells of, ii. 379

Karaul, Altitude of, ii. 64

- Bazaar, ii. 63

-guard-house, ii. 63

Karkaraly, Mines at, 74

Karshi, Arrival at, ii. 44 
Karshi, Altitude of, ii. 64

- Batcha amusements at, ii. 48

- Bazaar at, ii. 45

Bokhariot rebellion at, 625

- Books for Jews at, ii. $4^{8}$

- Burnes at, it. 44

- Caravansary, ii. 63

- Departure from, ii. 55

- Districts of Bekship, ii. 46

- Entertainment at, ii. 44

- Guest-house at, ii. 44

- Journey to, ii. 43

- Kishlaks at, ii. 57

- Kok-Chum-Bass mosque at, ii. 47

- Population of, ii. 44

- Presents from Bek of, ii. 47, 56

- to Bek of, ii. 47

- Public bath at, ii. 45

- Revenue of Bekship, ii. 46

- Scarcity of harness at, ii. 55

- Shops at, ii. 45

- Slave-trade at, ii. 45

- Stations to Bokhara, ii. 56

- Steppe, Character of, ii. 64

- Synagogue at, ii. 48

- Tobacco cultivation near, ii. 44

- Visit to Bek of, ii. 46

Welcome of Bek of, ii. 44

Kashgar, Roads to, 354

Valikhanoff at, ii. $47 \mathrm{I}$

Kashka-daria oasis, ii. 40

Kassan, Arrival at, ii. 56

Kastek, Journey to, 353

Katte Kurgan, Ride towards, ii. 136 Russian occupation of, 625 Scriptures for, 443

Kaufmann. Gen. von, Governor Turkistan, 624

- Expedition against Khiva, ii. 283 Grave of, 448

Victory over Bokhariots, 625

Kaushid Khan, Fortress of, ii. 475

Kazak discontent, 509

Khans, ii. 276

- tombs on Butenau plateau, ii. $39 \mathrm{I}$

Kazakhli. Journey to, ii. $4^{15}$

wells, ii. 416

- - Depth of, ii. 416

- Specific gravity of water, ii. 416

Kazalinsk, Population of, 390

-Scriptures for, 443

Kazan, Russian conquest of, 402

Tatars of, 401

Kazi of Samarkand, ii. 187

Kazis in Bokhara, ii. 187

Keles river, 422

Kessler, K. F., on Ichthyology of Turkistan, ii. 533

Khambi in the Ili valley, 258
Khana-Khaneh prison in Bokhara, ii. 152

Khanate of Bokhara, ii. 49

Khanikoff, M.. on Khiva, ii. 26?

Khanki, Arrival at, ii. 248

- Cemetery at, ii. 248

- Land at, Cost of, it. 250

- Lunch at, ii. 250

- Native food at, ii. $25 \mathrm{I}$

- Tombs at, ii. 248

- Villages near, ii. 251

Khans abolished in Syr-daria province, 407

Kharezm, Conquests of Jinghiz Khan, ii. 273

Tamerlane, ii. 274

Jenkinson in, ii. 274

lake, ii. 404

Slavery in, ii. 276

- under the Arabs, ii. 273

Uzbeg Khans of, ii. 274

Kheradj, Journey to, ii. 203

Khrva, Ánnexation by Russia, 629

- Arbas at, ii. 3 I 6

- Arrival of Author at, ii. 254

Artillery of, ii. 306

- Aryks of, ii. 252

Author's presents from Khan, ii. 310

- Batchas at, ii. 309

- Bazaar of, ii. : 84

- Bedroom of Author at, ii, 255

- Benoist-Méchin, Baron, at, ii. 473

- Bibliography of, ii, 668

- Birds of, ii. 269

- Botany of, ii. 266

- Burnaby, Capt., at, ii. 262

of - Canals of, ii. 252

- Caravansary at, ii. 285

- Carts of the natives, ii. 316

- Climate of, ii. 331

- Coinage of, ii. 285

- College life in, ii. 290

- Colporteurs in, ii. 304

- Communications of, if. 348

- Conolly, Capt., at, ii. 280

- Conquest by Russia, 629

- Consul of Khan of, ii. 246

- Coppersmiths' Row in, ii. 287

- Departure from, ii. 315

- Dervishes at, ii. 298

- Diameter of city, ii. 305

- Dimensions of, ii. 265

- Diseases of, ii. 308

- Divan-beggi, Antecedents of, ii. 256

_ _ - House of, ii. 255

_ - Interview with, ii. 256

- - Premises of, ii. 257

- - Servants of, ii. 257

- 
KHIVA, Divan-beggi, Stud-yards, ii. 259

- E Wives of, ii. 257

- Eggs in, ii. 364

- Engiish mediation in, ii. 278

- officers at, ii. 76

- Entertainment at, ii. 308

- Farms near, ii. 254

- Fauna of, ii. 267

- Female seclusion in, ii. 355

- Fighting ram at, ii. 259

- Fish of, ii. 269

- Forced labour of Khan, ii. 370

- Fruits of, ii. 266

- Gallows at, ii. 308

- Gardens of, ii. 248,252

- Geological formation of, ii. 265

- Governors of provinces, ii. $3^{14}$

- Hazarasp Gate at, ii. $31 \mathbf{I}$

- Horses, Cost of, ii. 259

- Hostilities against Russia, 615

- Imports and exports of, ii. 285

- Indian tea at, ii. 250

- Industries of, ii. 287

- Inhabitants of, ii. 269

- Irrigation of, ii. 334

- Jews in, ii. 269

- Journey from Petro-Alexandrovsk, ii. 247

- Jumma mosque at, ii. 259, 307
- Karagatch trees at, ii. 258

- Kaufmann's expedition against, ii. $28_{3}$

- Khan of, Attendants of, ii. 26i

- Character of, ii. 3 I 2

- Conversations with, ii. 272,302, 310,486

_- Disastrous reign of, ii. 282

- - Farewell visit to, ii. 310

- - Flight of, 629 , ii. 283

- - Indemnity to Russia, ii. $27 \mathrm{I}$

- - Interview with, ii. $26 \mathrm{I}$

- - Library of, ii. 262

- - Officers of, ii. $26 \mathrm{r}$

_- Prime Minister of, ii. 256

_- Recall of, 629

- - Reinstatement of, ii. 283

- - Revenue of, ii. 270

- War expenses of, ii, 271

- Khans of, ii. 275

- Lessar, M., at, ii. $47^{2}$

- Luggage arbas at, ii. 316

- Manufactures of, ii. 287

- Manuscripts of, ii. 262

- Meat, Price of, ii 364

- Medresses of, ii. 288

- Melons of, ii. 266

- Cultivation in England, ii. 266

- Meteorology of, ii. $33^{1}$

Minaret of, ii. 290

- Money-changing in, ii. 285

VOL. II.

Krtva, Mosques of, ii. 288

- Musicians of, ii. 308

- Passport compulsory at, ii. 262

Pehlivan-Ata mosque at, ii. 293

- Perovsky's expedition against, ii, 277

- Population of, ii. 307

- khanate, ii. 270

- Prison at, ii. 307.

- Quadrupeds of, ii. 269

- Russian capture of, ii. 283

- - designs on, 628

- Shops of, ii. $28_{4}$

- Sights of the town, ii. 284

- Silk factory at, ii. 287

- Silversmith's shop in, ii. 287

- Slavery in, ii. 278

- Soil of, ii. 254,265

- Souvenirs of, ii. 287

- Taxes in, ii. 270

- 'Tcherkassky's expedition to, ii. 276

- Timber at, ii. 269

- to Krasnovodsk, Itinerary from, ii. 493

- Tobacco cultivation at, ii. 268

- Tombs of royalty at, ii. 293

- Trade of, ii. 285

- Tradesmen of, ii. 269

- Treaty with Russia, ii. 282

- 'Turkomans' horses at, ii. 259

- View from a minaret, ii. 305

- Walls of, ii. 305

- Weights and measures of, ii. 285

- Wild animals of, ii. 269

- Winter palace of Khan, ii. 281, 306

Khivan Consul accompanies Author, ii. 246

- defeats at Merv, ii. 457

- documents and seals, ii. 262

- enslavement of Cossacks, ii. 276

- logic, ii. 487

- oasis, Dimensions of, ii. 252

- - History of, ii. 264

- occupation of Merv, ii. 456

- slaughter at Merv, ii. 457

Khivans, Foreign relations of the, ii. $27 \mathrm{I}$

- Sports of the, ii. 320

Khoja-Akhrar medresse, $5^{82}$

- - Tradition of, 582

- Moburak, Comet of 1882 visible at, ii. 59

- Lodging at, ii. 58

- Sunrise at, ii. 59

- Village of, ii. 58

Khojeili, Antiquity of, ii. 349

- Fish at, ii. 349

- Havlis at, ii. 349

- Mennonite colony at, ii. 349

- Shops of, ii. 349

- Town of, ii. 349

KHoJEND, Approach to, 489 
Khojend, Arrival at, $489,513,549$

- Boundaries of, 550

- Buildings of, $55^{\circ}$

- Climate of, $55^{\circ}$

- Coal-mines near, 515

- Derivation of name, $55^{\circ}$

- Divisions of, 549

- Gardens of, $55^{\circ}$

- History of, 549

- Hospitality of Nachalnik, 513

- Mountains on Khokand road, 515

- Population of, $55^{\circ}$

- Scriptires for, 443

- Stations to Khokand, 514

- - Samarkand, 55I

- Storming of, 623

- Summer heat at, 550

- Syr river at, 387

- Trade of, 551

- Walls of, 550

KHOKAND, Accession of Khudaiar Khan, 508

- Alim Kul, Regent, 5 ro

- _ Defeat of, 510

- Annexation by Russia, 512

- Author's arrival at, 517

- Barracks at, 525

- Bazaar at, 522

- Bokhariot seizure of, 507

- Departure from, 548

- Diseases of, 547

- Exports from, 523

- Fur trade at, 523

- Goitre at, 546 Causes and remedy, 547

- Harem of Khan, ii. 155

- Hindu usurers at, ii. 100

- History of, 502

- Hospital at, 525

- House of native merchant at, 530

- Houses near, 517

- Imports of, 523

- incorporated by Russia, 629

- insurrection against Khudaiar, 512

- Jewellery of, 522

- Jews' synagogue at, 519

- Khudaiar proclaimed Khan, 508

_ Reign of, 511

- Lepers' hamlet at, 528, 539

- Marionettes at, 524

- Mulla Khan, ruler, 509

- Murad Bek medresse at, 524

- Mussulman $\mathrm{Kul}$ as ruler, 507

_ - Defeat and death of, 509

- Palace of Khan, 525

- Paper manufactory at, 524

- Population of, 524

- Prices of furs at, 523

- Priest's house at, ii. 100
KHok.ND, Prison at, 525, 672 in a palace, 529

- Puppet-show at, 524

- Religious war against Russia, 512

- Residence of M. Ushakoff, 518

- Revolt against Khudaiar, 511

- of prisoners at, 673

- Routes from Peshawur to, $53^{2}$

- Russian war with, 298

- Sart ascerdency at, 500

- Scripture distribution at, 529

- Seclusion of women in, 530

- Shah Murad, Death of, 510

- Shir Ali, Reign of 507

- Stations to Osh, $53 \mathrm{I}$

- Streets of, 517

- Suppression of the Khanate, 512

- Trade of, 523

- Turbulence of Kipchaks, 507, 512

- Sarts, 507 under Chinese influence, 503

- Vishnu pictures at, ii. I $\infty$

- Walls of, 524

Khokandian advance to Syr-daria, 614 - defeat at Aulie-Ata, 6r9

- - Chimkent, 619

- - Turkistan, 619

- by Russians, 617

- fortresses, 615

- hostilities against Russia, 615

- subjugation of Kirghese, 615

- subservience, 519

Khorassan, Col. Stewart at, ii. $47^{1}$

Khudaiar Khan, Accession of, 508

- - at Samarkand, 510

- Bokhariot assistance, $5 \mathrm{IO}, 5 \mathrm{II}$

- Defeat of, 509

- - driven to Bokhara, 509

- Recall to Khokand, 510

- Retirement to Jizakh, 510

-.. - Return to Khokand, 5 I I

- Revolt against, $5 \mathrm{II}$

- - rusticating at Jizakh, 5 I I

- - Treaty with Russia, 511

- Trickery of, 508

- Victory over Alim Kul, 5 ro

Kibitkas in Turkistan, 434

- of the Kirghese, 3 I5

Kidnapping in Persia, ii. 185

Kilif Bekship, ii. 40

- The Oxus at, ii. ro6

- Village of, ii. 196

Kindness to enemies, ii. 67

Kipchak, Uzbeg town of, ii. 241

Kipchaks, Slaughter of, 509

- Turbulence of, $507,5^{12}$

KIRGHESE acconcheurs, 359

- agriculture, 314,338

- Appearance of, 306 
KIRGHESE, Arms of, 313

- at Suigati, Visit to, 333

- anl moving, $32 \mathrm{I}$

- Authorities on the, $30 \mathrm{r}$

- batyrs, 112

- beer, $33^{8}$

- beverages, 337

- Biblical customs among, $30 \mathrm{r}$

- birching for offences, 347

- books, Demand for, 282

- Cattle-breeding of, 316

- - diseases, 319

- Joot among, 318, 319

- - sheds, 319

- - stealing among, 4I2

- Character of, 308

- Childbirth among, 359

- children, 360

- Christian creed explained to, 345

- Colporteurs among, ii. 303

- concert, 341

- Conscientiousness of, 309

- Court of Justice, ii. 358

- Customs of, 364

- Dinner among the, 339

- Diseases of, 307

- Divorce among, 328

- Dresses of, 312

- education, 358

- election, 346

- equestrienne, ii. 360

- Etymology of name, $3 \mathrm{O} 2$

- Fanaticism of, 344

- Feasting among, 339

- Feuds of, 294

- Fines for murder, 347

- Food of, 337

- Fuel of, 352

- Gluttony of, 338

- goats, 317

- governing authorities, 310

- Habitations of, 3 IO

- Head-dresses of, ii. 287

- Herds of, 322

- Hodjas among, 346

- idea of crime, 347

- - future state, 345

- Iginchas, 315

- in Khivan Khanate, ii. 270

- insurrections, 408,617

- interpreter at Kunia Ưrgenj, ii. 359

- interrogatories, 341

- irrigation, 98

- Islamism among, 343

- Judges, Balloting for, 349

- Judgments of, 347

- Salaries of, 348

- Kalim of a bride, 323

- Kazaks, Origin of, 305
KIRGHESR Kazaks, Russian subjection of, 403

- Khivan exactions on, 615

- Khokandian subjugation of, 615

- kibitkas at Krasnovodsk, ii. 498

- in Syr-daria province, 315

- kidnappers, ii. 329

- labour, Cheapness of, $\mathrm{IO}_{3}$

- Land distribution among, 411

- laws, 411

- language, 357

- law of inheritance. 330

- laws, 350

- literature, Dearth of, ii. 362

- Location of, 309

- love-making, 324

- manufactures at Aulie-Ata, 364

- marriage customs, 322

- memorials, 336

- mothers, 360

- Muhammadan grave at Sary Baba. ii. 425

- mullahs, Ignorance of, 346

- mythology, 357

- Native courts of, 112

- nomads, 319

- nomenclature, 360

- notions of a comet, ii. 364

- - - saint, 366

- Numbers of, 303

- occupation of Sungaria, 285

- Occupations of, 314

- offerings at tombs, 367

- oiliantchis, ii. 90

- opinions of New Testament, 357

- opposition to Russians at Mangyshlak, if. 462

- Ormaments of, 313

- Patron saint of, 391

- Physique of, 306

- Poetry of, 341

- politeness, 339

- Polygamy among, 322

- Possessions of, 316

- prisoners at Khiva, ii. 307

- proverbs, 342

- punishments, $347,350,412$

- racing games, $\mathbf{5 5 6}$

- Ranks among, 3 IO

- religion, 343

- Kostenko on, 343

- religious feasts, 367

- resemblance to Hebrew patriarchs, 299

- riddles, 342

- rings, 357

- robbers, Suppression of, 286

- ruffianism at elections, 350

- schools, $35^{8}$ 
KIRGHESE, Scriptures purchased by, ii. 303

- Shamanism among, 343

- sheep, 317

- Slavery among, 357

- Songs of the, 342 , ii. 90

- sorcery, 359

- steppe, Primeval character of, 300

- Sub-divisions of, 303

- submission to Russians, 285

- Taxation of, 4 10

- Tents of, 333

- Interior surroundings, 336

- Testaments, 281

- Tombs of, $31 \mathrm{I}$

- traditions, $157,177,357$

- trials, 346

- Troitzky, M., among the, 344

- Trousseau of a bride, 326

- Turbulence of, 406

- Usury among, 316

- Voting by ballot, 349

- Wanderings of, 319

- wares at Aulie-Ata, 364

- Weapons of, 313

- wedding ceremonies, 326

- - festivities, 327

- Wives of, 340

- wolf-hunting, ii. 2 I $\mathrm{t}$

Kish Kizil Takir, Bazaar near, ii. 337

Kishak Gates on the Amu, ii. 24I

Kishlak, Meaning of, ii. II

Kishlaks of semi-nomads at Karshi, ii. 57

Kiskilenskaia, Stone ornaments at, 353

KITAB, Acrobats at, ii. 16

- Arrival of Author at, ii. 13

- Batchas at, ii. 15

- Bokhariot etiquette, ii, 20

- Court visitors, ii. 18

- Dancing-boys at, ii. 15

-Dress for audience with Emir, ii. 22

- Entertainment at, ii, 15

- Guard of native soldiers, ii. 20

- Hospitality at, ii. 14

- Journey to, ii. 7

- Lodging at, ii. 14, 19

- Mountains of, ii. 9

- Mountebanks at, ii. 15

- Population of, ii. 39

- Procession to visit Emir, ii. 23

- Reception at, ii. $\mathbf{3}$

- - of Bokhariot ofticers, ii. 20

- Refreshments at, ii, 15,28

- Ride to, ii. 12

- Spies in Emir's palace, ii. 20

Kitchkine-daria, Banks and bed of, ii. 392

Kiziak as fuel, 352

Kizil Arvat, M. Lessar at, ii. 472

- - Railway at, ii. 489

Kizil Arvat route, ii. 494

- Russian advance to, ii. 462

Klopatoff, Dr., at Jizakh, ii. 147

Kobadian bekship, ii 40

Kohistan, Alum manufacture in, 537

Climate of, 538

- district of Zarafshan, 537

- Geology of, 537

- Population of, 538

Kök-Bari, Game of, 556

- Chum-Bass mosque at Karshi, ii. 47

Kokine-Sai, Coal mines at, 515

Kokol-tash medresse in Bokhara, ii. 89

Koktash at Samarkand, 564

- Inscription on, 579

- Legendary history of, 577

- Uses of, 578

Kolpakovsky, Gen., Complaisancy of, 362

- Entry into Kuldja, 627

- Popularity of, 362

Kolutch, Author's native servant, ii. 3

Komaroff, Gen., Explorations of, ii. 575

Konur-Ulen, Invalid telegraphist at, I9I

Kopal, Arrival at, 187

- Beekeeping in, 185

- Climate of, 159

- Description of, 187

Foundation of, 289

- Prisoners at, 670

Kopet-dagh mountains, ii. 437 Trees on, ii. $43^{8}$

Koplan-Bek, Canals near, 423

Koran of Othman, $5^{82}$

- Study of the, ii. 292

Korolkoff, Gen., Hospitality of, 608

- - Visit to, 566

Korsakoff, Prince Dondukoff, Pugnacity of, ii. 107

Kosh-ku-pryk and its melons, ii. 317

Kostenko, Capt., Explorations of, 493

- on Aral Sea, $43^{2}$.

_ Kirghese religion, 343

Krabbe, Dr. H., on Worms, ii. 6r5

Krapotkine, Prince, on Siberian prisons, 637

Krasnovonsk, Alabaster grotto at, ii. 496

- Armenian trading at, ii. 499

- Arrival at, ii. 433

- Attendants dismissed at, ii. 492

- Boats at, ii. 498

- Descent into, ii. $49 \mathrm{I}$

- Felt manufacture at, ii. 447

- Fish at, ii. 496

- Fortress at, ii. 497

- Good-bye to attendants at, ii. 499

- Governor's house at, ii. 498

- Hospitality of Commandant, ii. 492

- Itinerary from Khiva to, ii. 493 
KRASNovodsk, Jewellery of Turkoman KULDJA, Oil factory in, 242 women, ii. 497

- Kirghese kibitkas at, ii. 498

- Mineral oil at, ii. 496

- Nomad euriosities of, ii. 498

- Population of, ii. 495

- Provisions at, ii. 496

- Russian establishment at, ii. 461

- Salt exportation from, ii. 496

- Scanty supplies in, ii. 495

- sighted from desert, ii. 433

- Situation of, ii. 491

- Stores at, ii. 498

- Town of, ii. 495

- Turkoman tents at, ii. 496

-Water distillation at, ii. 495

Kroneberg, A., on spiders, ii. 543

Kryloff, Capt., Visit to, ii. 235

Kuhn, M., at Kunia Urgenj, ii. 319

KULDJA, Acrobats at, 243

- Arrival at, 205, 221

- artisans, 243

- Beasts of prey in, 257

- Bibliography of, ii. 671

- Book distribution at, 235

- Books, Sale of, 236

- Buddhist temple in, 230

- Buildings in, 243

- Cattle in, 243

- Chinese Christians in, 230

- Officer, Visit to, 235

- Police-master at, 234

- Climate of, 224

- Crime in, 236

- Crossing the $\mathrm{Ili}, 224$

- Dungan mosque in, 232, 255

- shopkeepers in, 240

- Emigration from, 256

- Exports from, 242

- Factories in, 242

- Fish of, 247

- Fruit of, 223

- hatred of Chinese, 254

- Hazardous drive near, 224

- Holy Communion among Romanists, 228

- Hospitality at Russian Consulate, 221

- Houses in, 253

- Imports of, 241

- Industries of, 242

- Joss-house in. 232

- Kalmuks, Visit to, 243

- Kolpakovsky, Gen., Entry of, 627

- Lepidoptera, 248 , ii. 596

- Mammalia, 247

- Market-place in, 255

- Minerals of, 198,199

- nomads, Agriculture of, 192

- Statistics, 192

- Opium exported from, 257

- smoking in, 261

- Population of, 233

Prices in, 238

- Province, Towns of, 398

- Religions and races, 234

- Reptiles of, 248

- Restaurants in, 241

- Roman Catholics in, 225

- Russian Church in, 227

- occupation of, 205

- rule preferred, 254

- Schools in, 232

- Shop-street in winter, 240

- Speculating in house property, 258

- statistics, 243

- Sunday in, 221

Taranchi bazaar in, 223

- gardens in, 224

mosque in, 232

- Taranchis in, 208

- Trade in, 239

- Transitional state of, 205

- Vegetables and fruit, 239

Vegetation in, 257

- Vertebrata, 247

Kum-sebshem, Wells of, ii. 417, 419

Kumo steamship, Journey on, ii. 499

Kungrad, Inhabitants of, ii. $35 \mathrm{I}$

- lake, Shallowness of, ii. 242

- Routes from, ii. $35 \mathrm{I}$

- Town of, ii. 351

KunIa-UraenJ, Abbott at, ii. $34 \mathrm{r}$

- Accident to Author near, ii. 338

- Antiquity of, ii. 339

- Arrival at, ii. 338

- Attendants, Dishonesty of, ii, 365 - Dismissal of, ii. 371

- Basiner at, it. 341

- Batchman of, ì. 316

- Bazaar at, ii. 359

- Bek's fears for Author's safety, ii. 367

- Camel cradles at, ii. 363

- - loading at, ii. 365

- Camels, Delay in obtaining, ii. 357

- Hiring of, ii. 365

- Cemetery near. ii. 358

- Chickens at, ii. 364

- Coinage at, ii. 347

- Coins found near, ii. 364

- Cossack plundering of, ii. 341

- Court of Justice at, ii. 358

- Curiosities from, ii. 364

- Danger ahead! ii. 367

- Departure from, ii. 368

- Eggs at, ii. 364

- Erection of, ii. 339 
Kunia-UkgenJ, Escort from, ii. 368

- Houses of, ii. 352, 365

- Interpreter and guides, ii. 373

- Jenkinson at, ii. 341

- Journey to, ii. 334

- Kalmuk destruction of, ii. 34I

- Kirghese at, ii. 359

- Kuhn, M., at, ii. 3 I9

- Land value at, ii, 369

- Lodgings at, ii. 352

- Luxuries at, ii. 364

- Mausoleums of, ii. 344, 347

- Meat at, ii. 364

- Minarets of, ii. 342

- Mosques at, ii. 365

- Native life at, ii. 357

- Parting view of, ii. 369

- Pheasants at, ii. 364

- Photographs of, ii. $34 \mathrm{I}$

- Prison at, ii. $35^{8}$

- Provisions at, ii. 364

- Purchases at, ii. 363

- Rope scarcity at, ii. $3^{65}$

- Routes from, ii. 349

- Ruins of, ii. 339

- Schools at, ii. 365

- Shakespear at, ii. $34 \mathrm{I}$

- - Route from, ii. 385

- Shops of, ii. 365

- Sieges of Jinghiz Khan, ii. 340

- Starting for the Desert, ii. 367

- Tamerlane's siege of, ii. 340

- Tax-gatherer of, ii, 316

- Tomb of Tiurebek Khanim, ii. 345

- Vambery at, ii. 341

Kunia Vezir, Camping opposite, ii. $38_{3}$ - Jenkinson's description of, ii. 384 Kunja lake, ii. 64

Kurama, Vegetation of, 478

Kuramas in Turkistan, 394

Kuren-dagh mountains, ii. 437

Kush-beggi of Bokhara, Conversation with, ii. 128

- Presents from, ii. 132

-

- Reticence of, ii. I29

- - Visit to, ii. 125

Kutban-Kul lake, 494

Kyz-Kala, Legend of, ii. 214

- - Subterranean aqueduct, of, ii. 214

Kyzyl Kum Steppe, 426

- - Geology of, 426

_- Marshes of, 426

_- Mountains of, 426

- - Sands of, 426

Labour, Cheapness of, in Ili valley, 198 Lai-lak, Meaning of, ii. II Land at Bokhara, Value of, ii. 165
Land at Khanki, Cost of, ii. 250

- Kunia Urgenj, Value of, ii. 369

- - Petro-Alexandrovsk, Cost of, ii. 250

- communications of Khiva, ii. 348

- distribution among Kirghese, $4 \mathrm{II}$

- laws of the Kirghese, 411

- mollusks of Turkistan, ii. 542

- of Seven Streams, 15I

- revenue of Semipolatinsk, 112

- tortoises of the Steppe, ii. 430

Language of the Kirghese, 357

Languages of books for distribution, 27

Lake Ala-Kul, Description of, 146

- - Fish in, 148

- - Lizards near, 148

- - Ornithology of, 147

- Issik-Kul, Origin of, 157

- Yamyshef, Fortress at, 127

- Zaisan, 89

- Chinese junks on, 13 I

- Cossack fisheries on, 91

- - Fauna of banks, 91

Lakes in old bed of Oxus, ii. 393

- the Steppe, 44

- of Ferghana province, 494

- - Semirechia, 157

Last rose of summer, ii. 234

Law, "Glorious uncertainty" of, ii. $35^{8}$

Lawlessness of Merv Tekkes, ii. 480

Laws of the Kirghese, 350

Lawyers in Bokhara, ii. 187

Leaders of Kirghese rebels, II 2

Lectern, Miraculous. 576

Lecturing the Kush-beggi, ii. 130

Legacies of Bokhariot Jews, ii. 110

Legend of Kyz-kala fortress, ii. $2 \mathrm{I}_{4}$

Legends of Shah-Zindeh mosque, 572

Lepers at Khokand, 528, 539

- quarter near Bokhara, ii. ${ }_{13} 8$

Lepidoptera of Alpheraky, M., 248

- Kuldja, 248 , ii. 596 Turkistan, ii. $5^{81}$

Leprosy in Samarkand, 54I

- - Turkistan, 540

- Zarafshan province, $53^{8}$

Lepsa, Prisoners at, 670

- river, Description of, 183

Lepsinsk, Beekeeping in, 185

- station, r82

Lessar, M., Chapters on Turkmenia revised by, ii. 435

- - Journeys of, ii. $47^{2}$

- on the Attek oasis, ii. 451

- - _ Saryks, ii. 445

Letters and favours, Official, 12

Libraries searched for Bibliography, ii. 654

Library at Tashkend, 470 
Library at Vierny, 279

- of Khan of Khiva, ii. 262

_- Tamerlane, 582

Linseed farming on the Amu, ii. 222

"Lion's Mouth" on the Amu, ii. 224

Liquor traffic among Jews in Russia, ii. 106

- - in Turkistan, 607

Little Balkhan mountains, ii. 437

Littoral of the Caspian, ii. 437

Lizards near Ala-Kul lake, 148

Loading camels in the desert, ii. $3^{87}$

Lodging at Aulie-Ata, ii. 330

- Bokhara, ii. 80

- Khoja-Moburak, ii. $5^{8}$

- Kitab, ii. 19

- Kunia Urgenj, ii. 352

- Tashauz, ii. 330

- near Charjui, ii. I76

Logic of the Khan of Khiva, ii. 487

Lomakin, Gen., and the Yomud Turkomans, ii. 463

- - Defeat of, in Turkmenia, ii. 464

London, Return of Author to, ii. 504

- to the Urals, ro

Love-making among Kirghese, 324

Lovers' fortresses on the Amu, it. 214

Low spirits in the desert, ii. 422

Laggage attacked by robbers, ii. 336

Lunatics in Bokhara, ii. 250

Lunch at Khanki, ii, 250

Lapandine, M., on bed of Oxus, ii. 407

Luxuries at Kunia Urgenj, ii. 364

Macgregor. Col., on Turkoman frontier, ii. 466

MacLachlan, R., on Turkistan Neuroptera, ii, 609

Madrahim medresse at Khiva, ii. 289

Maieff, Col., Assistance from, 456

- Explorations of, ii. 50

- Routes of, ii. 51

Mammalia of Ala-Kul district, 149

- Kuldja district, 247

- Semirechia, 160

- Turkistan, ii. $5^{15}$

Manak, Hawks at, ii. 326

- Corn-mill at, ii. 325

- Fruit-trees at, ii. 326

- Garden at, ii. 326

- Havli at, ii. 323

- - Interior of, ii. 327

- - Walls of, ii. 326

- Hospitality at, ii. 327

- Intoxicants at, ii, 326

- Oil-mill at, ii. 323

- Ruins near, ii. 327

- Uzbeg society at, ii. 323

Manchu, Massacre of, 203
Manchu of the Ili valley, 257

Manghit rulers of Bokhara, ii. 72

Mangyshlak, Opposition to Russians at, ii. 462

Manufactures of Khiva, ii. 287

Manuscript of Old Testament, ii. II5

Manuscripts of Bokliariot Jews, ii. 1io

- Tamerlane, $58_{3}$

Maps of Central Asia, ii. 679

Maracanda, History of, 560

March along old bed of Oxus, ii. 391

Marching in a sea-bed, ii. 420

Marghilan, Climate of, 497

Marionettes at Khokand, 524

Market at Aulie-Ata, 364

- days at Iliali, ii. 333

- - Samarkand, 605

- prices at Aulie-Ata, 365

Markozoff, Reconnaissances of, ii. 406

- Turkmenian failures of, ii. 462

Marmots in the desert, ii. 422

Marriage among the Kalmuks, 2 I8

- customs among the Kirghese, 322

- in Central Asia, ii. 352 Semipolatinsk, ros

Marsh, Capt., on Turkmenian frontier, ii. 466

Marshes of Kyzyl-Kum steppe, 426

Martens, Prof, von, on Turkistan mol. lusca, ii. 537,542

Mashrek, Ruins of, ii. $3^{8} 3$

Massacre at Merv, ii. 456

- of Chinese, $2 \mathrm{O}_{3}$

- Khivans at Merv, ii. 457

L- Manchu, 203

Massoretic writing, ii. 115

Matmurad, Prime Minister of Khan, ii. 256

Mausoleum of Nedjm-ud-din-Kubera, ii. 347

Mausoleums of Kunia Urgenj, ii. 344

Maievsky, Col., Visit to, 253

Measures of Central Asia, 682

Meat at Khiva, Price of, ii. 364

- Kunia Urgenj, ii. 364

Mechanics in Semipolatinsk, 104

Medical staff of Akmolinsk, 53

Medicine and divinity conjoined, I8

Medresse at T'ashauz, ii. 330

- of Shir-Dar, 586

- Tillah-Kari, 586

- - Ulug-Bek, 585

Medresses of Bokhara, ii. 89, 135

- Khiva, ii. 288

- Samarkand, 564, 586

Melons at Vierny, 277

- of Khiva. ii, 266

- - Attempted cultivation in England, ii. $\mathbf{2 6 6}$ 
Melons of Kosh-ku-pryk, ii. 317

Memorials of the Kirghese, 336

Men and bear fights, ii. 21 I

Mendicant prisoners at Bokhara, ii, I53

Mennonite colony at Khojeili, ii. 349

Mennonites in Aulie-Ata, 42I

- of the Volga, ii. 350

-Persecution of, ii. 350

Merchandise of Khokand, 522

Merchant at Khokand, Visit to, $53^{\circ}$

Merke, Author's delay at, 362

Mertvy Kultuk route, ii. 493

Merv, Abbott at, ii. 457

- Agriculture of, ii. 478

- Alikhanoff, Col., at, ii. 471

- Animals of, ii, 478

- Arab capture of, ii. 456

- Artisans of, ii. 478

- as annexed, ii. 475

- Bazaar of, ii. 478

- Beg tribe of Tekkes at, ii. 477

- Benoist-Méchin, Baron, at, ii. 474

- Bokhariot criminals banished to, ii. 456

- Burnes, Alex., at, ii. 457

- Canals at, ii. 476

- Carpet manufacture at. ii. 478

- Cattle of, ii. 478

- Cotton cultivation at, ii. 478

- Counterfeit coin at, ii. 478

- Daily Neros correspondent at, ii. 467

- Dependence upon Khiva, ii. 486

- desert, Historical associations, ii. 456

- Dissentients in, ii. 488

- French travellers at, ii. 473

- Fruit of, ii. 477

- Gardens of, ii. 476

- Gunpowder manufacture at, ii. 478

- Jews of, ii. 479

- Khivan defeats at, ii. 457

- occupation of, ii. 457

- Lessar, M., at, ii, 472

- Manufactures of, ii. 478

- Massacre at, ii. 456

- - of Khivans at, ii 457

- Mongol sacking of, ii. 69

- Moscone Gazette on submission, ii. 483

- Murgab river at, ii. 476

- oasis in Turkmenia, ii. 454

- Area of, ii. 476

- Irrigation of, ii. 476

- Occupations of Tekkes, ii. 478

- Population of, ii. 477

- - Vegetation of, ii. 476

- O'Donovan, Mr., at, ii. 467

- Otamish Tekkes of, ii. 477

- Persian siege of, ï. 457

- Population of, ii. 483

- Produce of, ii. 479
Merv, Rulers of, ii. 480

- Russian advance to, ii. 460

- Shakspear at, ii. 457

- Slavery in, ii. 479

- Submission to Russia, ii. 482

- Suspicious movement of Russians at. ii. 485

- Tekkes, Distribution of, ii. 477

- - Divisions of, ii. 477

- Number of, ii. 477

- Tomb of Sunjur Shah, ii. 456

- Trade of, ii. 479

- Uzbeg occupation of, ii. $45^{6}$

- Visit to, abandoned by Author, ii. 495

- Wolf, Dr., at, ii. 457

Mervis, Moral characteristics of. ii. 479

- Religious characteristics of, ii. 479

Meteorological instruments lent by Mr. Glaisher, 8

- observations in Turkistan, 374

- tables of Turkistan, 376

Meteorology of Amu-daria province, 432 - Central Asia, ii. 442

- Khiva, ii. 331

- Omsk, 48,49

- Pamir, 493

- - Semipolatinsk, $\mathbf{r}_{37}$

- Tashkend, 469

Miankal island, 535

Midnight intruders, ii. 6

Military buildings of Semipolatinsk, I I4

- encampment at Bokhara, ii. 93

- hospital at Khokand, 525

- - Semipolatinsk, 1 15

- notions, ii. 194

Milk and cream at Bokhara, ii. 143

Minaret of Khiva, ii. 290

Minarets of Kunia Urgenj, ii. 342

Mineral oil at Krasnovodsk, ii. 496

- springs near Zaisan lake, 92

Minerals near Sergiopol, 145

- of Akmolinsk. $5 \mathbf{I}$

- Bokhara, ii. $14 \mathrm{I}$

- Ferghana, 497

_- Ili valley, 198

- Karamazar mountains, 515

- Turkistan, 379

Mines at Karkaraly, 74

- near Baian-aul, 74

- of the Steppe, 74

Miniature fortresses, ii. $32 \mathrm{I}$

Mining in the Ili valley, 198

Minister of Interior, Interview with, 11

Miri-arab medresse in Bokhara, ii. 89

Mirza Akhmet, Bek of Tashkend, 509

- Khoort, Croesus of Bokhara, ii. 150

- Yusuf, Parting with, if. 166

Misbehaviour of " Diotrephes," ii. 338 
Mission proposed at Lake Issik-Kul, Muhammad, Rosy, as Author's servant, 172

Missionary work of Russians, ii. 303

Missions to Mongolia, ii. 404

- Muhammadians, ii. 303

ii. 359

- Emin, Decapitation of, ii. 457

Muhammadan monuments, $580-595$

- persecution of Jews, ii. 105

Moldabavsk, Breakdown near, 363

Mollnsks of Turkistan, ii. 537

Money arrangements at Tashkend, 473

- changing at Khiva, ii. 285

- - Samarkand, 6 ro

- lending Jews in Russia, ii. 106

- of Central Asia, 682

Mongol invasion of Central Asia, ii. 69

Mongolia, Missions to, ii. 404

Mongolians in Turkistan, 392

Monumental inscriptions scarce in Bokhara, ii. too

Monuments of the Muhammadans, 5 So

Moonlight suppers on Oxus, ii. 203, 206

Morals of Asiatic people, ii. 299

Moravitz, Dr. F, on bees, ii. 562

Morgan, Mr. Delmar, at Sergiopol, 145

- on Ala-Tau range, 185

- - the "Ehbi "wind, 18I

Moscow, Arrival at, 14

- Cathedral at, 15

- Exhibition at, 14

- Gospel distribution at, ii. $23^{8}$

- Gasette on Merv submission, i. $48_{3}$

- Jews in, ii. IO4

Moslem pilgrimages, ii. 294

Moslems frustrated by Author, ii. 112

Mosque at Karshi. ii. 47

- of Abxlul Aziz Khan, ii. 100

- Akhmed Vasavi, 39 I

- Hazret Imlah, ii. 100

- Namazi-gah, ii. 123

- Shah Zindeh, 571

Mosques at Bokhara, ii. 135

- Khiva, ii. 288

- Kunia Urgenj, ii. 365

- Samarkand, 586

- Shahr, ii. 39

- Tashauz, ü. 330

Mothers, Kirghese, 360

Moths of Turkistan, ii. 581

Mountains of Eastern Bokhara, if. 50

- - Ili valley, I90

- Kitab, if. 9

- Kyzyl-Kum Steppe, 426

- Semirechia, 152

- Syr-daria province, 384

- Turkmenia, ii. 437

- Zarafshan province, 533

Mountebanks at Kitab, ii. 15

Mud walls of havli at Manak, ii. 326

Muhammadabad, Stewart and O'Donovan at, ii. 469

- studies at Khiva, ii. 290

- tomb at Sary Baba, ii. 425

Muhammadans, Attitude towards Christianity, ii, 302

- Books bought by, 73

- Fanaticism of, ii. 298

- Missions to, ii. 303

- Religious orders of, ii. 295

- Russia's responsibility towards, ii. 293

Mulberries at Khiva, ii. 267

Muila Khan, ruler of Khokand, 509

Mullahs, Ignorance of Kirghese, 346

Murad Bek medresse at Khokand, 524

Muravieff on old bed of Oxus, ii. 406

Murchison, Sir R., on Aralo-Caspian region, ii. 403

Murgab river, ii. 454

- - at Merv, ii. 476

- valley at Penjdeb, ii. 454

- - Desolation of, ii. 455

Museum at Russian Tashkend, 44I

- Tashkend, 455

Mushketoff, M., on geology of Thian Shan, 155

Music at Khiva, ii. 308

- Petro-Alexandrovsk, ii. 233

- of the Dungans, 210

- - Sarts, ii. 91

Musical entertainment at Kitab, ii. 15

- reception of Author at Charjui, ii. 179

Mussulman Kul, ruler of Khokand, 506

- Defeat and reath of, 509

Mussulmans, Characteristics of, ii. 299

Mutillidae of Turkistan, ii. 575

Mythology of Kirghese, 357

Nachar.NiK of Khojend, Hospitality of, 513

Nakshbendi, Religious order of, 582

Namazi-gah mosque, ii. 123

Names of the Oxus, ii. 192

Naphtha springs at Cheleken, ii. 496

- works on the Kizil Arvat line, ii. 496

Napier, Capt. Hon. G., on Turkoman frontier, ii. 466

Nass-Ullah, late Emir of Bokhara, ii. 73

National Exhibition at Moscow, I4

Native boats on the Amu-daria, ii. 200

- carts in Khiva, ii. 316

- dispensary at Tashlend, 450

gain by Russian rule in Turkmenia, ii, 490 
Native house near Khokand, 517

- houses in Kuldja, 253

- ignorance at Petro-Alexandrovsk, ii. 234

- society in Bokhara, ii. 150

Nau, Surrender to Russians, 623

Navigation of Aral Sea, 409

-Upper Oxus, ii. 197

Naziroff, Lieut., in Turkmenia, ii, 472

Neuroptera of Turkistan, ii. 609

New Siberian steamer, 32

- Testament, Kirghese opinions of, 357

Newspaper exaggeration, 25

Night guard at Charjui, ii. 186

- time in Bokhara, ii. 135

Nibilistic cunning, 25

Nineteenth Century on Russian prisons, 675

Nocturnal visitors, ii. 6

Nogai Bi, Possessions of, 356

Nomad curiosities at Krasnovodsk, ii. 498

- population of Kuldja, 192

Nomads of Kuldja, Agriculture of, 192

Nomenclature of the Kirghese, 360

Northern Lights in Turkistan, 377

Nukus, Delta of the Amu at, ii. 24 I

- Meteorology of, 432

Number of books for Author's distribu. tion, 27

Numbers of the Kirghese, 303

Nuratagh hills, Rock salt of, ii, $14 \mathrm{r}$

Nursery at Borokhudzir, 193

OASEs of Turkmenia, ii. 449

Object of Author's journey, 6

Observanda, xxxii

Observatory at Russian Tashkend, 44t

- Samarkand, 564

- Tashkend, 467

- of Ulug Bek, $5^{85}$

Occupations in Russian Tashkend, 44I

- of Kirghese, 314

- Merv Tekkes, ii. 478

- Turkomans, ii. 447

Ocean, Dry bed of, ii. 4 I 8

Odessa, Arrival of Author at, ii. 504

- Jewish persecution at, ii. 107

- - - English opinion on, ii. 107

- Parting with Mr. Sevier at, ii. 504

O'Donovan, Mr., in Turkmenia, if. 467

- killed in Soudan war, ii. 468

- Letter of, 468

Offerings at Kinghese tombs, 367

Officers club at Tashkend, 451

- of Khan of Khiva, ii. 261

Official letters and favours, 12

Otticials, Over-zealousness of, 24

Oil factory in Kuldja, 242

- mill at Manak, if. 323

Oil painting by M. Aivazovsky ii. 504

- wells at Balakhane, ii. 500

Oiliantchis, or singers, ii. 90

Old Testament, Wonderful MSS. of, ii. 115

Omsk, Acquaintances at, 62

- Arrival at, $4 \mathbf{I}$

- Books for prisons at, 65

- Cossack school at, 134

- Decline of, 60

- Departure from, 66

- Description of town of, 59

- Fauna of, 8o

- Flora of. 80

- Kirghese school at, $35^{8}$

- Meeting the Governor-General of, 76

- Meteorology of, 48,49

- Prison at, 661

- Diet in, 662

- Schools in, 63

- Visit to Acting-Governor, 64

- Visits to inhabitants, 63

- and Semipolatinsk, Stations between, 66

Opium exports from Kuldja, 257

- smoking in Kuldja, 26r

Orchards at Bokhara. ii. 165

Orenburg, Forts erected at, 404

- Kirghese, Taxation of, 410

- road, Towns on, 389

- routes, ii. 229

- Ship-building at, 409

Oriental customs illustrated. ii. 429

- duplicity, ii. $37^{2}$

- garden at Bokhara, ii. 83

- oath-taking, ii. 499

- politeness, 519

- worship, ii. 297

Origin of Kara-Kirghese, 304

Ornaments of Kinghese, $3 \mathbf{I}_{3}$

- - the Turkomans, ii. 447

Ornithology of Ala-Kul district, 147

- - Aulie-Ata district, 415

- Turkistan, 4I5

Orography of Semirechia, I51

Orphan asylum at Samarkand, 600

Orthodox Christian Brotherhood: Kalmuk school, 170

- - Rules of. 169

Orthoptera of Turkistan, ii. 6r3

Osh, Climate of, 497

Oshanin, M., of Tashkend Museum, 455

- Collection of Hemiptera, 455

- - Description of Darwaz, ii. 54

- Explorations of, ii. 50, 53

- Presents from, 456

Osten-Sacken, Baron, Explorations of, 297

Ostroumoff, M., on Mussulman characteristics, ii. 299 
Ostroumoff, M., on the Kalmuks, 215

Otamish Tekkes of Merv, ii. 477

Othman, Koran of, 582

Oven at Kakir, ii. 62

Overcrowding in prisons, 672

Over-zealousness of officials, 24

Ovis Polii : remarkable sheep, 244

Oxus river, Author's arrival at, ii. 176

- - bed at Ak-bugut, ii. 389

_ - Description of, ii. 393-395

_ _ Glukhovsky's reconnaissances of, ii. 407

- - Russian survey of, ii. 406

_ _ Stebnitzky's reconnaissances of, ii. 407

- Course (Ancient) of, ii. 402

- - Fourfold change of, ii. 405

- Deflection of, ii. 409

- Delta of, ii. 24I

- Dimensions at Pitniak, ii. 225

- Discharge of, ii, 225

- Diversion, Feasibility of, ii. 406

- Feeding-time on, ii. 203

- Ferry-boat on, ii. 176

- Floating down, ii. 200

- Geographical problems, ii. 402

- Junction with Aral, ii. 242

- Lower, Basin of, ii. $24 \mathrm{I}$

- - European authors on, ii. 245

- Hydrography of, ii. $24 \mathrm{I}$

- - Islands of, ii. 241

_ _ Towns on, ii. 241

- Names of, ii. 192

- Old bed, Description of, ii. 390

- - Journey in the, ii. 382

- - L Lakes in, ii. 393

- - - Length of, ii. 407

- - Lupandin, M.. on, ii. 407

- - Petrusevitch, Col., on, ii. 408

- Primitive boat on, ii. 176

- Reconnaissances of Col. Markozoff, ii. 406

- Source of, ii. 193

- Stations from Huzar to, ii. 52

- Upper, Change of boats on, ii. 208

- - Clifis on, if. 208

- - Compulsory service of boatmen on, ii. 205

- - Dismissal of escort at Ildjik, ii. 208

- - Escort of Author on, ii. 201

_- Extortion of Toksaba, ii. 207

- - Ferries on, ii. 196

- - Fords of, ii. 195

- - Fortress of Ist-poos, 207

- - Geological phenomena, ii. 206

- Hydrography of, ii. 202

- - Islands in, if. 204

- - Journey to Ildjik, ii. 206
Oxus river, Upper, Journey to Kheradj, ii. 293

- - - Ustik, ii. 205

_- Moonlight suppers on, ii. 206

- - Navigation of, ii. 197

- - Scarcity of fuel on, ii. 198

- - Survey of, ii. 196

- - Tomb of Ak-rabat, ii. 207

- - Turkoman boats on, ii. 207

- - Villages on, ii. 202

- - Wood, Lieut., on, ii. 193

PADERIN, M., Hospitality of, 221

Palace at Samarkand, 566

- of Emir of Bokhara, ii. 125

- Khan at Tashauz, ii, 328

_- - of Khokand, 525

Pamir mountains, 492

- Climate of, 493

- Fauna of, 494

- Flora of, 494

- Meteorology of, 493

Panj river, ii. 193

Pantussofi, M., Distrib. of books by, 667 - - on crime in Kuldja, 236

Paper manufactory at Khokand, 524

Parasites in Turkistan, ii. 615

Parkes, Sir H., Encouraging opinions of, 2

Parting with Mr. Sevier at Odessa, ii. 504

Pastime in the desert, ii, 423

Patar, Shifting sauds at, 515

Patron saint of Bokhara, ii. 71

Pavlodar, Arrival at, 70

- Cheapness of provisions at, 71

- Sale of books at, 70

Peaches of Khiva, ii. 267

Peculiarities of Turkistan rivers, 385

Pecuniary assistance, 4

Pehlivan-Ata mosque at Khiva, ii. 293

Peikand, Ruins of, ii. 166

Peujakend, Scriptures for, 443

Penjdeh, Valley of the Murgab at, ii. 454

Peril of riches in Bokhara, ii. 187

Perils of the desert, ii. 172

- - - road, ii. 168

Perm, Arrival at, 17

- Departure from, 19

- Police examination of Author at, 22

- Railway adventure at, 18

- Return of Author to, under arrest, 21

Perovsk, Scriptures for, 443

Perovsky, Gen., Expedition against Khiva, ii. 277

Perquisites, ï. 12

- at Bokhara, ii. 479

Persecution of Jews in Odessa, ii. 107

- - Central Asia, ii. 105 
Persecution of Jews in Russia, ii. 105 - Mennonites, ii. 350

Persia, Prison in, ii. 185

- Slaves from, ii. 185

Persian architecture at Samarkand, 582 - Jews in Bokhara, ii. ro8

- siege of Merv, ii. 457

- slaves in Khivan khanate, ii. 270

- - Turkmenia, ii. 482

Persians at Merv. Defeat of, ii. 457

- in Bokhara, ii. I50

Peshawur routes to Khokand, 532

Peter the Great, Aggressiveness of, 127

Petersburg, Departure for, II

- Favourable reception at, $1 \mathrm{I}$

- Fortiress prison in, 640

- to Afghanistan, Highway from, ii. 406

Petro-Alexandrovsk, Bible Society Agent near, ii. 305

- Colporteurs at, ii. 305

- Crime at, ii. 354,358

- Departure from, ii. 247

- Fever at, ii. 234

- Fish at, ii. 243

- Fortress at, ii. 234

- Home comforts at, ii. 228

- Horses at, Cost of, ii. 259

- - Sale of, ii. 236,237

- Hospital at, ii. 234

- Journey to Khiva, ii. 247

- L Land at, Cost of, ii. 250

- Meteorology of, 432

- Native ignorance at, ii. 235

- Provisions at, ii. 235

- Public bath at, ii. 235

-.. Schools at, ii. 234

- Scripture distribution at, ii, 237

- Shopping at, ii. 235

- Social evening at, if. 233

- Tarantass arrival at, ii. 236

- Sale of, ii. 236

- Town of, ii. 234

- Troops at, ii. 234

- - Visit to Capt. Kryloff, ii. 235

- Wages at, ii. 235

- Weather at, ii. 233, 331

_- Welcome at, ii. 228

- Winter preparations at, it, 233

Petroleum in Ferghana, 498

Petrovsky, M., on Bokhariot commerce, ii. 133

- - Turkistan trade, 462

Petrusevitch, Gen., in Turkmenia, ii. 467 - - on old bed of Oxus, ii. 408

- - the Turkomans, ii. 444

Pevtzoff, Lt.-Col., Assistance of, ii. 236

Pheasants at Kunia Urgenj, ii. 364

Photographs of Kunia Utrgenj, ii. 341

Physiology of Turkomans, ii. 444
Picture worship, ii. 303

Pictures, Superstition regarding, ii. 2 1,37

Pilau at Charjui. ii. 178

Pilgrim showmen in Central Asia, ii. 344

Pilgrimages in Ferghana, 500

Pillage of Bokhara, ii. 68

Pink salt at Bokhara, ii. 141

Pioneers of Central Asia, 287

Pisces of Kuldja, 247

Pishpek, Botanical garden at, 360 Prisoners at, 670

Pitniak, Dimensions of Oxus at, ii. 225 - curve on the Amu. ii. 224

Plants collected by Semenoff, ii. 620

Plants of Turkistan, 482

- Zarafshan province, 557

Ploughing and threshing, ii. 7

Poetry of the Kirghese, 341

Police examination of Author at Perm, 22 Politeness of Orientals, 519

- - the Kirghese, 339

Political agents on Turkoman frontier, ii. 466

Poltoratzky, Col., Explorations of, 297

Polygamy among the Kirghese, 322

- in Central Asia, ii. 354

Pomerantzoff, M., on Tashkend temperature, 469

Pond of Porsu, ii. 425

Pools at Bokhara, ii. 135

Poppy culture in 'Turkistan, 257

Population of Asiatic Tashkend, $44^{\circ}$

- Bokhara, ii. 124

- Increase of, ii. 150 Charjui, ii. 177

- Chimkent, 42I

- Hazarasp, ii. 314

- Ili province, $20 \mathrm{I}$

- Iliahi, ii. 333

- Karshi. ii. 44

- Kazalinsk, 390

- Khiva, ii. 307

- Khivan khanate, ii. 270

- Khojend, 550

- Khokand, 524

- Kitab, ii. 39

- Kohistan, $53^{8}$

- Krasnovodsk, ii. 495

- Kuldja, 233

- Merv, ii. $48_{3}$

- - oasis, ii. 477

- Russian Tashkend, 441

- - Samarkand, 605

- Semipolatinsk, 107

- Semirechia, 164

- Shahr, ii. 39

- Shurakaneh, ii. 227

- Tashauz, ii. 330

- Tashkend, 399 
Population of the Steppe, 45

- Turkistan, 370

- - - according to races, $39 \mathrm{r}$

- - city, $39 \mathrm{r}$

- - Density of, 396

- - Locality of, 397

- Vierny, 274

- - Zarafshan province, 544

Porsu, Gazelles at, ii. 426

- Pond of, ii. 425

- Temperature at, ii. 425

- Wild boar at, ii. 426

Post-house "chambre de toilette," 175

- office statistics of Semipolatinsk, 339

- roads in Semipolatinsk, 14I

- - Syr-daria province, 391

- station at Ak-Kend, 196

Postal communication in Semirechia, 292

Posting service in Semipolatinsk, 141

Precipice of Begendjalri, ii. $4 I 7$

Prejevalsky, Col., among Kalmuks, 244

- - on Turkistan zoology, ii. 507

Present from Chinese Governor Suidun, 263

- to Bek of Karshi, ii. 47

- - - Shahr, ii. 30

Presents for Emir of Bokhara, ii. 27

- from Bek of Chirakchi, ii. 43

- - - Charjui, ii. 190

- - - Karshi, ii. 47,56

- - - Shahr, ii. 34

- Emir of Bokhara, ii. 29

- returned by Emir, ii. 36

- to Bek of Chirakchi, ii. 4t

- - Kabakli, ii. $2 \mathrm{II}$

- Bokhariot courtiers, ii. 29

- Kush-beggi of Bokhara, ii. 132

Priest's house at Khokand, ii. I00

Prison at Charjui, ii. 183

- Karakol, 670

- Khiva, ii. 307

- Khokand, 525, 672

- Kopal, 670

- Kunia Urgenj, ii. 358

- Lepsa, 670

- Omsk, 66r

- Pishpek, 670

- Samarkand, 606, 673

- Semipolatinsk, 664

- Tashkend, 671

- Tokmak, 670

- - Vierny, 666, 668

- dungeons at Bokhara, ii. 153

- Fortress, in Petersburg, 640

- gardening, 668

- gardens, 645, 648

- in Persia, ii. 185

- literature, 662

-Overcrowding in, 672
Prison revolt at Khokand, 673

- statistics, 665

- torture at Bokhara, ii. 75

Prisoners' diet at Omsk, 662

- rooms at Petersburg, 647

Prisons in Russia. Exaggerations, 663

- - Nineteenth Century on, 675

- Semirechia, Report on, 667

- of Bokham, ii. 151

- Omsk, Books for, 65

_- Russian Central Asia, 661

- $-\ldots$ Overcrowding, 672

- Semipolatinsk, Books for, 144

- - Siberia, Criticisms in "Called Back," 636

- Do we know the truth? 630

- Doubts concerning, 63I

Opinions of residents, 634

- Prince Krapotkine's censure and its value, 637

- Supposed preparations for visit to, 631

at - - Supposition examined, 632 4 Swedish testimony, 635

Prostitution in Bokhara, Punishment for, ii. 151

- Turkistan, ii. 299

Project of Author considered hopeless, 8

Proverbs of the Kinglese, 342

Provincial statistics, Russian, 96

Provisions at Krasnovodsk, ii. 496

- Kunia Urgenj, ii. 364

- Pavlodar, Cheapness of, $7 \mathrm{t}$

- Petro-Alexandrovsk, ii. 235

- Tara, Cheapness of, 40

- Tashkend, 46I

- for Turkistan troops, 603

Public bath at Karshi, ii. 45

- corn stores in Ust-Kamenogorsk dis. trict, 316

- Zaisan district, 316

- houses in Zarafshan province, 607

- library at Russian Tashkend, 44I

Publications, Religious, Distribution of, 6

Punishment for personal offences at Akmolinsk, 351

- theft in Bokhara, ii. 151

Punishments among Kirghese, 347

Puppet-show at Khokand, 524

Purchase of a tarantass, 17

- - - telega at Tiumen, $3 \mathrm{I}$

- - drugs, 18

Puschkin steamer, To Odessa in. 504

Putimsoff, Col, Hospitality of. 489

QUADRUPEDS of Khiva, ii. 269

Quarrels of stallions on the Amu, ii. 209

RACES inhabiting Semipolatinsk, 94 
Races inhabiting Vierny, 274

Racing games of the Kirghese, 555

Radoszkovsky, O. K., on Turkistan Chrysidiformes, it. 579

- _ - Mutillidae, ii. 575

- _ - Sphegidae, ii. 568

Railway adventure at Perm, is

- at Kizil Arvat, ii. 489

Rain scarcity in Turkistan, 372

Ram-fighting at Shavat, ii. 320

Raskolnik fanatic in prison, 664

Ratepayers in Semipolatinsk, 109

Rawlinson, Sir H., on Aralo-Caspian region, ii. 403

Rebellion in $\mathrm{Ili}$ valley, 203

Reception by Grand Duke Michael, I1 - room at Kitab, ii. 26

Reconnaissances of bed of Oxus, ii. 406

Recruiting statistics, 114

Recruits on the march, 74

Red river, ii. 194

Reeds and rushes in the desert, ii. 397

Refreshment stalls in Bokhara, ii. I35

Refreshments at Kainar, ii. 11

- - Kitab, ii. 15

Refusal of Author's requests in Bokhara, ii. 129

Regel, Dr., Exploration of, ii. 50

Release of Author from custody, 24

Religion of the Kalmuks, 217

- - Kirghese, 343

Religions and races of Kuldja, 234

— of Semipolatinsk, 108

_- Vierny, 280

Religious aims of Author, 6, 7

- beliefs in Russian Tashkend, 441

- character of Author's journey, 3

- Tract Society, Help of, 5

Reptiles of Kuldja, 248

Restaurants in Kuldja, 241

Revente of Amu-daria province, 437

_- Khan of Khiva, ii. 270

Revolt of prisoners at Khokand, 673

Riches among Bokhariots, ii. I50

Riddles of the Kirghese, 342

Ride outside Bokliara, ii. I23

- to Baha-uddin, ii. 137

- Kitab, ii. 12

- Petro-Alexandrovsk, ii. 226

- towards Katte-Kurgan, ii. 136

Riding and racing, ii. 59,62

- with dumb guides, ii. 226

Rifle practice at Samarkand, 604

Righistan of Bokhara, ii. 125, 135

Rings worn by Kirghese, 357

Rishta disease in Bokhara, ii. 146

- - Treasment of, ii. 146

- Fedchenko's investigations of, ii. 512 Rivers in the Steppe, 44
Rivers of Akmolinsk, 47

- Ferghana province, 493

- Semipolatinsk, 84

- - Semirechia, 156

- Turkistan, 385

- Turkmenia, î. 439

Roads of Ili province, $20 \mathrm{I}$

- - Syr-daria province, 389

- Zarafshan province, 545

- to Issik-Kul, 354

- Kashgar, 354

Robbers in the desert, ii. 394

- - Tejend oasis, ii. 455

- Luggage attacked by, if. 336

- on the Amu. Precautions against, ii. 216

Robbery in Bokhara, ii. 135

Rock salt in Nuratagh hills, ii., 141

Roman Catholic request for religious service, 227

- Catholics in Kuldja, 225

Romanovski, Gen., Victory over Bokhariots, 622

Rope scarcity at Kunia Urgenj, ii. 365

Rosy, Accident to, ii. 377

Roubles, Value of, xxxii

Route over Chulak hills, 266

- to Hindustan, ii. 194

- Tashauz, ii. 327

Routes from Kungrad, ii. 351

- to Central Asia, Io

Ruffianism at Kirghese elections, $35^{\circ}$

Ruins in the desert, ii. $3^{8} 3$

- near Borokhudzir, 195

- Tokmak, 356

- of Bibi-Khanum medresse, 575

- Peikand, ii. 166

- on Amu banks, ii. 214

- Taldyk banks, ii. 242

Rulers of Merv, ii. 480

Russia, Asiatic policy of, 620

- Disabilities of Jews in, ii. ro4

Russia's responsibility towards Muhammadans, ii. 293

Russian advance to Merv, ii. 460

— - - the Syr-daria, 400

_ - Trans-Ili region, 290

- agents in Bokhara, ii. 88

- annexation, 402

- - of the Steppe, 287

- attempt to release Stoddart, ii. 76

- camp near Smarkand, ii. 4

- Central Asia, Bibliography of, ii. 654

- - Definition of, 42

- - History of, 120

- - Prisons of, $66 \mathrm{I}$

- church in Kuldja, 227

- conquest of "Golden Horde," 401 
Russian exiles, Books for, 6

- fishing station at Hassan Kuli, ii. 439

- forts in Turkmenia, ii, 46I

- Government. Bokhariots on, ii. 188

- hospital at Kuldja, Book distribution in, 235

- influence on the Irtish, 124

- inhabitants of Turkistan, 393

- intercourse with Bokhara. ii. 74

- invasion of India, Feasibility of, ii. 194

- itinerary from Iliali to Krasnovodsk, ii. 425

- maps of Turkmenia, ii. 435

- march on Tashkend, 620

- missionary work, ii. 303

- missions to Bokhara, ii. 75

- occupation of the Irtish, 120

Administration of new territory, 134

Export trade with Chinn, 133

Frontier fortified, $I_{3}$ I

Submission of Kalmuks, 127

- Tatars, 123

Trade at Semipolatinsk, 132

- on the Irtish 124

Trading-place of Bukhtarminsk, $\mathbf{I}_{3} \mathbf{I}$

-Ust-Kamenogorsk, I $_{3} \mathbf{I}$

Treaties with Kalmuks, 128

- occupation of Turkistan, $6 \mathbf{r}_{4}$

- population in Akmolinsk, 53

- prisons, Nineternth Century on, 675

- provincial statistics, 96

- reconnaissance of Khivan oasis, ii. 318

- rule in Turkmenia, Native gain by, ii. 490

- Samarkand, 596

- slaves in Khiva, ii. 278

- spies at Bokhara, ii. 74

- subjection of Kirghese Kazaks, 403

- survey of old Oxus led, ii. 406

- Tashkend, 440

- Trade in Central Asia, 462

- Turkistan, Flora of, ii. 618

- Prostitution in, ii. 299

- war with Khokandians, 298

- warehouse at Bokhara, ii. 88

Russians on the Aral Sea, 409

Russo-Turkoman relations, ii. 460

SAINT, Kirghese notion of a, 366

- Saviour's Cathedral at Moscow, 15

Saint's tomb at Khiva, ii. 294

Sairam lake, Road to, 200

Salaries of Kirghese judges, 348

Sale of books at Taldi-Kuduk, 175

- - on steamboat, 33

- Scriptures in Kuldja, 236

Salors of Turkmenia, ii. 445
Salt deposits in Turkistan, 537

- exportation from Krasnovodsk, ii. 496

- fields of the Kara-boghaz, ii. 427

- lakes near Kara-Kul, ii. 141

Samanid races of Bokhara, ii. 67

Samara, Migration from, ii. 238

Samarkand, Ancient ruins of, 563

- Antiquities of, 563

- - Schuyler, Dr., on, 564

- Ujfalvy, M., on, 564

- Arrival of Author at, 559

- Astronomical instruments at, 565

- Attendants for journey, 610

- Barracks at, 601

- Bazaar of, 604

- Bibi-Khanum medresse, 575

- Bird's-eye view of, $58 \mathrm{r}$

- Bokhariot refuge in, 623

- Butcher's shrine at, 588

- Chupan-Ata hill, 564

- Citadel of, 601

- - palace at, 577

- Colleges of, 586

- conquered by Jinghiz Khan, ii. 69

- Conquests of, $56 \mathbf{I}$

- Dancing dervishes at, if. 295

- Decline of, 562

- Departure from, ii. I

- Devastation by nomads, 563

- Dimensions of, $58 \mathrm{I}$

- Distribution of Seriptures at, 611

- Education at, 600

- Enamelled bricks at, 587

- Endowment of medresses a:, 586

Execution stone at, 579

- Executions at, $56_{3}$

- Foundation of, 560

- Gur-Emir at, 564

- - mausoleum, 566

- Horse-buying at, 610

- Hospital for military, 596

- Hospitals for natives, 598

- Industries of, 605

- Interpreter necessary at, 610

- Ishrat Khana palace at, 579

- Jews' quarter at, $5^{89}$

- Hebrew pronunciation of, 595

- Tribes of, 595

- Kazi of, ii. 187

- Khoja-Akhrar medresse, 582

- Khudaiar Khan at, 5 Io

- Kindness of M. Arendarenko, 610

- - Gen. Ivanoff, 612

- Koktash stone at, 564, 577

- Koran of Othman, 582

- Korolkoff, Gen., Visit to, 566

- Legend concerning Tamerlane, 570

- Leprosy in, $\mathbf{5 4 1}$

- Library of Tamerlane, 582 
SAMARKAND, Market days at, 605

- Medresses of, 564,586

- Money-changing at, 6 ro

- Mosques of, $5^{86}$

- Observatory at, 564, 585

- Orphan asylum at, 600

- Palace of Governor, 565

- Patients in hospital, 599

- Population of, 605

- Prison at, 606, 673

- Cleanliness of, 675

- Lavatory arrangements, 675

- Purchase of antiquities, $6 \mathrm{rI}$

- Rifle practice at, 604

- Russian camp near, ii. 4

- capture of, 625

- Sart disease at, 596

- Schools of, 593,600

- Scriptures for, 443

- Shah Zindeh mosque, 564, 57 1, 573

- Shir-Dar medresse, $5^{85}$

- Shrines of, 588

- Spastic paralysis at, 599

- Suburban gardens of, ii. 4

- Synagogue of Jews, 592

- Tamerlane's burial-place at, 564

- - capital, 562

- Telegraphing to London, 6r2

- Tillah-Kari medresse, $5^{86}$

- Trade of, 604

- Tradition of Jews, 594

- Vegetation near, ii. 8

- Visit to Jew's house, 589

- - Jewish Rabbi, 593

- Weavers and their products, 606

Sam-Su, Breakdown near, 353

Sanatorium at Chimgan, $45^{\circ}$

Sand floods at Patar, 515

Sands of Kyzyl-Kum Steppe, 426

- Shifting, ii. 170

Sandstorm on the Steppe, 181

Sandy surroundings, if. 171

Sarakhs, Heri Rud river at, ii. 453

Sari-bulak, Camel caravan at, 187

Sarkan, Beekeeping in, 185

- Missionary operations in, 169

Sart bazaar, Visit to, 240

- curiosities at Tashkend, $45^{8}$

- Disease, Cause of, 598

- - Characteristics of, 597

- Treatment of, 598

- pastime of Kök-Bari, 556

- school at Petro-Alexandrovsk, ii. 234

Sarts, Ascendency of, in Khokand, 509

- Betrothal among the, ii. 353

- Festivals of the, ii. 250

- Funerals among the, ii. 248

- Hospitality of the, ii. 300

- Music of the, ii. 91
Sarts, Songs of the, ii. 90

- Turbulence of the, 507

Sary Baba, Tomb at, ii. 425

- Kamish, Arrival of Author at, ii. 397

- Jenkinson at, ii. 402

- lakes, ii. 398

- - Canals near, ii. 407

- - Cemetery near, ii. 407

- Crossing the basin of, ii. 400 - Saxaul forests near, ii. 411

- Water of, Buoyancy of, ii. 400

_ - Chemical Analysis of, ii. 400

- - - Specific gravity of, ii. 399

- Wells of, ii. 394

Saryks of Turkmenia, ii. 445

- Lessar, M., on the, ii. 445

- Settlements on Upper Murgab, ii. 455

Satinsk, Dr., on Sart disease, 599

Saussure, H. de, on Orthoptera, ii. 613 Scoliidae, ii. 572

Saxaul, Fires of, ii, 411

- Forests of, ii. 411

Scandal concerning Eastem Sovereizns, ii. 155

Scaphirhynchus, Geological questions concerning, ii. 244

- in the Amu river, ii. 243

Scenery at Batoum, ii. 504

- of the Ala-Tau range, 270

School at Samarkand, 593

- for Cossacks at Omsk, ${ }_{3} 34$

Schools at Almatinka, 279

- Kunia Urgenj, ii. 365

- Petro-Alexandrovsk, ii. 234

- Tashkend, 466

- Vierny, 279

- in Bokhara, ii. 120

- - Method of study in, ii. I21

- Kuldja, 232

- Omsk, 63

- of Samarkand, 600

- Semipolatinsk, 138

- Semirechia, 172

- - the Kirghese, $35^{8}$

Schuyler, Dr., on Muhammadan worship, ii. 295

- Samarkand antiquities. 564

Schuyler's description of Emir of Bokhara, ii. 24

"Turkistan," ii. 162

Scientific explorations of Gen, Komaroff, ii. 575

- introductions, 13

Scoliidae of Turkistan, ii. 572

Seripture analogies, ii. $\mathbf{1} 24$

- distribution at Khokand, 529

- - Samarkand, 6I

_- Tiumen, 29

- in Tobolsk, 29 
Scripture illustrations, see Index, p. xxv Scriptures bought by Muhammadans, 73 - Chinese anxiety for, 236

- sold to Kirghese, ii. 303

Sea-bed, Animal life in a, ii. 419

- Camping in a, ii. 419

- Marching in a, ii. 420

Seikiz Khan, Road to, ii. $42 \mathrm{I}$

- Well of, ii, 421

Seldjuk rulers of Bokhara, ii. 67

Self-esteem of Khivan Consul, ii. 247

Semenoff, M., Expeditions of, 295, 296

- on Thian Shan mountains, 152

- Plants collected by, ii. 620

Seminary for training schoolmasters, 465

SEMirol.ATINSK, Accidental deaths in, I 17

- Administration of, 1 I I

- Agriculture of, 97

- Agriculturists in, 315

- Animals of, 94

- Area of, 42

- Arrival of Author at, 82

- Artisans in, 104

- Asylum at, 138

- Beekeeping in, 102

- Births in, ro8

- Books for hospitals, 144

- - prisons, 144

- Cattle-breeding in, ror

- Cereals grown in, 98

- Cossack population of, 66

- Criminal statistics, 665

- Deaths in, ro8

- Departure of Author from, 141

- Diseases in, 116

- Economy of, 96

- Etymology of, 136

- Excise duties in, 112

- Exports of, 107

- Fairs of, 105

- Fires in, 115

- Forests of, 93

- Gardening in, 100

- Gold-mining in, $\mathrm{ro}_{3}$

- Governor's repurt, 97

- Harvest statistics, 99

- Hospital statistics, I I6

- Houses in, 114

- Imports of, 107

- Industry of, 103

- Land revenue, 112

- Local products of, 106

- - rates in, II 2

- Location of population, 109

- Marriages in, ros

- Mechanics in, 104

- Meteorology of, 137

- Military building, 114

VOL. II.
SEMIPOI.ATINSK, Military hospitals of, 115

- Personal liabilities in, $\mathbf{I I}_{3}$

- Population of, 42, 107

- Post-office statistics, 139

- - roads in, $\mathbf{1 4} \mathbf{I}$

- Posting service in, 14I

- prison, 664

- Birching in, 664

- Books for, 665

- Morality of inmates, 664

- Raskolnik fanatic in, 664

- province, Dimensions of, 83

- Public buildings of, 114

- health of, II5

- Races inhabiting, 94

- Ratepayers in, Io9

- Religions of, 108

- Rivers of, 84

- Scarcity of bread in, 140

- Schools of, I $_{3} 8$

- Situation of, 136

- Taxation in, III

- Towns of, 95

- Trade of, 105, 132, 139

- Traders at, 286

- Vaccination in, 117

- Violent deaths in, ${ }^{1} \mathbf{I} 7$

- Visit to Governor of, 137

- Wild animals of, 94

- and Omsk, Stations between, 65

Semirech1A, Agriculture of, 165

- Area of, 42

- Atkinson's travels in, 289

- Beekeeping in, 185

- Books distributed in, 671

- Boundaries of, $\mathrm{I}_{5} \mathrm{I}$

- Cattle in, $\mathbf{1 6 6}$

- Civil administration of, 291

- Climate of, 159

- Colonization of, 292

- Cossack settlers in, 166

- Dimensions of, $15 \mathrm{I}$

- Educational affairs of, 172

- Ethnology of, $\mathbf{1} 62$

- Fauna of, 160

- Forests of, 160

- Habitations of, 164

- Industry of, 164

- Kalmuks of, 162

- Lakes of, 157

- Mammals of, 160

- Mountains of, 152

- Orography of, 151

- Orthodox Christian Brotherhood, 169

- Population of, 42,164

- Postal communication in, 292

- prisons, Official report of, 667

- Voluntary committees, 668 
Semirechia province, Towns of, 398

- Religious affairs of, 172

- Rivers of, 156

- Russian occupation of, 282

- Schools in, 172

- Statistics of, 164

- Taranchis in, 163,168

- Trade progress in, $29 \mathrm{I}$

Sepulchres at Khanki, ii. 249

Sergiopol, Antiquities of, 145

- Arrival of Author at, 143

- Beekeeping in, 185

- Climate of, 159

- Decline of, 145

- Departure of Author from, 174

- Distribution of books at, 143

- Foundation of, 288

- Minerals near, I45

- Remarkable skulls found near, 145

- Road to, 142

- Scien'ific discovery at, 288

- Situa ion of, 145

- Sund $2 y$ at, I43

Serpitzky. Col., Visit to, in camp at Tashkend, 468

Servant, A new, ii. 359

Servants' wages in Tashkend, 461

Seven Streams, Land of, 151

Severtsoff, M., Explorations of, 494

_ Fatal accident to, ii. 508

- on Turkistan animals, ii. 514

- - - zoology, 415

Sevier, Mr. A. H., as interpreter, 17

- Accident to, ii. 166

- - - horse of, ii. 209

- Attention to sick in Bokhara, ii. 163

- Farewell to, at Odessa, ii. 504

Shadman-Malik, Bridge of, $56_{3}$

Shah Murad, Death of, 510

- Zindeh mosque, 564,571

_ - Legends concerning, 572

- - Ormamentation of, 573

- Places of devotion in, 574

Shahr-i-sabz, Ak-Serai palace at, ii. 32

- Arrival of Author at, ii. 30

- Batchas at, ii. 34

- Bek of, Conversation with, ii. 33

_ - Presents from, ii. 30, 34

- - - to, ii. 30

- - Visit to, ii. 32

- Bokhariot rebels in, 625

- Departure of Author from, ii. 40

- Entertainment at, ii. 34 .

- Historical associations of, ii. 32

- Information from courtiers at, ii. 36

- Mosques and medresses, ii. 39

- Population of, ii. 39

- Torchlight procession at, ii. 34

- View of, ii. 9
Shakespear, Lieut., at Kunia Urgenj, if. $34 \mathrm{I}$

- - Merv, ii. 457

- Conduct of Russian slaves, ii. 278

- Route of, ii. $3^{85}$

Shalgin, M., on goitre disease, 547

Shamanism among the Kirghese, 343

Shavat, Dog-fighting at, ii. 320

- Farm-houses near, ii. 321

- Lodging at, ii. 319

- Ram-fighting at, ii. 320

- Shops of, ii. 320

- Town of, ii. 320

Sheep in Zarafshan province, 545

- of the Steppe, 317

- Thian Shan, 245

- - Yuldus, 247

- and cattle at Chirakchi, ii. 40

- - goats of the desert, ii. $3^{82}$

Sheibanid rulers of Bokhara, ii. 71

Sheikh-djeili mountains, 427 , ii. 241

Shepherd at Karategin wells, ii. 380

Ship-building at Orenburg, 409

Shir-Dar medresse, $5^{8} 5$

Shirabad bekship, ii. 40

- river, ii. 196

Shirish, a remarkable plant, 557

Shoemakers' street in Bokhara, ii. 133

Shopping at Petro-Alexandrovsk, ii, 235

Shops in Iliali, ii. 3.32

- Karshi, ii. 45

- Khiva, ii. 284

- Khojeili, ii. 349

- Kuldja, 240

_.. Kunia Urgenj, ii. 365

- Tashauz, î. 33 o

Shrine of a Samarkand butcher, 588

Shrines of Samarkand, 588

Shrubs of Turkistan, 480

Shurakaneh, Arrival of Author at, ii. 227

- Houses at, ii. 227

- Population of, ii. 227

- Taxes in, 436

Siberia, Bible work in, ii. 237

- Bibliography of, ii. 673

Siberia's one monument, 36

Siberian prisons, see "Prisons."

- steamer, 32

Sibo curiosities, 213

- encampment, Visit to a, 212, 222 superstition, $2 \mathrm{I}_{3}$

Sibos, Hospitality of, 214

- Household gods of the, 212

- Number of, 212

- of the Ili valley, $21 \mathrm{I}$

- Sickness among the, 213

Silk culture at Bokhara, ii. 144

- factory at Khiva, ii. 287

Silver-mining near Kuldja, 199 
Silversmith's shop in Khiva, ii. $\mathbf{2 8 7}$

Sin, Conviction of, from reading Scripture, ii. 240

Singing oarsmen on the Amu, ii. 221

- and dancing at Bokhara, ii. 89

Skin-dressing at Bokhara, ii. 144

Skobeleff at Zmukshir, ii. 332

- in Ferghana, 512 Turkmenia, ii. 464

Skulls found near Sergiopol, 145

Slaughter of Bokhariots, ii. 69

Slave-trade at Charjui, ii, 185

- - Karshi, ii. 45

- of the Turkomans, ii. $48 \mathrm{r}$

Slavery in Bolkara, ii. 185

- Kharezm, ii, 276

- Merv, ii. 479

Slaves in Central Asia, Cruelty to, ii. 329 - - - Former condition of, ii. 329

- - Release of, ii. 329

Sleep on horseback, ii. 379

Sleeping in the desert, ii. 173. 376

Slumbers disturbed at Bokhara, ii. 92

Snow bridges of Thian Shan range, 155

Social evening at Petro-Alezandruvsk, ii. 233

Society, Bible, Help of, 5

- Religious Tract, Help of, 5

Sogdiana, Capital of, 561

Soil of Bokhara khanate, ii. 50

- Khiva, Character of, ii. 254

Solomon, Throne of, 500

Solons at Jarkend, Ig6

- of the Ili valley, 211

Solsky on Turkistan beetles, ii. 552

Songs of the Kirghese, 342 , ii, 90

Sorcery among Kirghese, 359

Soup in the desert, ii. 420

Souvenirs of Khiva, ii, 287

Spastic paralysis at Samarkand, 599

Sphegidae of Turkistan, it. 568

Spiders of Turkistan, ii. 543

Spies in Emir's palace at Kitab, ii. 20

Spirit distilleries, 55

Sponge-plant at Tashkend, 456

Sports of Central Asiatics, ii. 320

Staff, Bek's official, ii. 186

Stalls in Bokhara, ii. 135

Starovers, Sect of, 665

Stations between Altyn-Immel and Kuldja, 190

_- Aulie-Ata and Tashkend, 414

- Bokhara and Charjui, ii. 177

- _ Katte-Kurgan, ii. 137

- Huzar and the Oxus, ii. 52

- Karshi and Bokhara. ii. 56

- Khojend and Khokand, 514

- - - Samarkand, 55I

- Khokand and Osh, 531
Stations between Semipolatinsk and Sergiopol, 14 I

- - Sergiopol and Vierny, 174

- Tashkend and Jizakh, 477

- - Khojend, 478

- Tiumen and Semipolatinsk, 37

- Vierny and Aulie-Ata, 353

Statistics of Central Asia, 117

- cotton, 195

- crime in Kuldja, 236

_ - - Semipolatinsk, 665

- crops in Turkistan, 484

- - domestic animals in Turkistan, 420

- - drink traffic in Turkistan, 607

- - education in Zarafshan prov., 600

- habitations, Amu-daria prov., 433

- Kuldja, 243

- - nomads, 192

- Semipolatinsk hospital, 116

- - - post-office, I39

- Semirechia, 164

- - prisons, 668

- Suidun, 258

- Tashkend hospital, 449

- - trade at Tashkend, 462

- Ura-Tiube, 553

- Vierny, 274

- Zarafshan province, 544

- Recruiting. II4

- Religious, of Kuldja, 234

- Russian provincial, 96

- Ureliability of native, 118

Stealing in the desert, ii. 396

Steam navigation of Upper Oxus, ii. 197

Steamboat, Church music on, 40

- passengers, 40

- Siberian, 32

Steamers on Amu ruver, ii. 242

- - Syr-daria river, 410

Steamship Samarkand on Upper Oxus, ii. 197

Stebnitzky's reconnaissances of old Oxus bed, ii. 407

Stephen, Mr. C.. in Turkmenia, ii. 440

- - on Balkan mountains, ii. 437

STEPPE, Boundaries of the, 43

- Cattle of, 316

- Climate of, 44

- Communications of, 46

- Dimensions of, 43

- "Ehbi" wind on, 181

- Fauna of, ii. 430

- Forts erected in, 408

- Government of, 411

- General of, 42

- Hydrography of, 44

- Inundations of. 88

- Kirghese, Administration of, 411

- Lakes in. 44 
Steppe, Mines of 74

- Population of, 43,45

- Rivers in, 44

- Russian annexation of, 287

- Sandstorm on, 181

- Sheep of, 317

- Summer appearance of, 69

- Surface of, 44

- Tortoises of, ii. 430

- Vegetation of, 45,486

Stewart, Col., Journey of, ii. 469

- - at Khorassan, ii. $47 \mathrm{I}$

- on slavery at Charjui, ii. 185

_ _ - Tekke Turkomans, ii. $47 \mathrm{I}$

Stoddart, Cul., at Bokhara, ii. 74

- compelled to embrace Islamism, ii. 75

- - imprisoned at Bokhara, ii. 75

- killed at Bokhara, ii. 76

Stone ornaments in Kiskilenskaia, 353

Stores at Krasnovodsk, ii. 498

Street-sleeping at Kara-Chukum, 549

Streets and lanes of Bokhara, ii. I35

- of Khokand, 517

- Russian Tashkend, 440

Stremoukhof's account of Emir, ii, 25

$-\frac{-}{-}$ slavery in Bokhara, ii. 185

Student's life at Khiva, ii. 290

Subterraneous sheds in the desert, ii. 394

Suburbs of Bokhara, ii. 165

Suidun, Bazaar at, 262

- Chinese p'ai fang at, 204

- Russian occupation of, 627

- Statistics of, $25^{8}$

- Visit to Chinese Governor at, 257

- Walls of, 259

Suigati, Author's arrival at, 356

- Election of judges at, 347

- Visit to Kirghese at, 333

Suili, Cemetery at, ii. 432

- Wells of, ii. 431

Sulpbur baths at Arasan, 186

Sultans in Syr-daria province, 407

Sumbul, a remarkable plant, 557

Summary of Author's journey, ii. 505

Stummer appearance of Steppe, 69

- heats of Turkistan, 373

Sun-worship, Remains of, ii. 413

Sunday in Kuldja, 221

- - Sergiopol, 143

- Tashkend, 448

Sundukli, Sands of, ii. 170

Sungaria, Atkinson's travels in, 290

Baikof's mission through, 124

- Extinction of, 130

- Kirghese occupation of, 285

- Rebellion in, 626

Sungarian Ala-Tau mountains, 185

Sunjur Shah, Tomb of, at Merv, ii. 465
Sunni law against pictures, ii. 37

- superstition, ii. 21

Sunrise at Khoja-Moburak, ii. 59

Superstition of the Kalmuks, 220

- regarding pictures. ii. 21

Surakhane, Fire-worshippers at, ii. 500

Surface of Akmolinsk, 47

- Turkistan, $37 \mathbf{I}$

Surkhab river, Crazy bridges over, ii. 53

Swimming horses on the Oxus, ii. 196

Sycamore forests in Zarafshan, 608

Synagogue at Bokbara, ii. rog

- Karshi, ii. 48

- Khokand, 519

- choristers, 592

- of Samarkand Jews, 592

SYR-DARIA, Area of, 42

- Khokandian advance to, 614

- Population of, 42

- - province, 383

- - Administrative failures, 406

- - Boundaries of, $38_{3}$

- - Caravan rontes, 390

- - Communications of, $3^{89}$

- - Deserts of, 384

- - Extent of, 383

- - Feuds of natives, 405

- - Forts erected in, 409

- Khans abolished in, 407

_ - Kirghese kibitkas in, 315

_ - Kuramas in, 394

_- Mountains of, $3^{84}$

_ - Population as to creeds. 395

_ - Classification of, 395

- - Post-roads of, 391

_ - Roads of, 389

_- Russian advance to, 400 - criminal laws, 411

_- - Scriptures for, 443

- - Sultans appointed in, 407

_ - Surface of, $3^{84}$

_ _ Town on Orenburg road, 389

- - Towns of, 398

- river, $3^{86}$

- - Affiuents of, 388

- - at Chinaz, 387

- - Khojend, 387

- - Banks of, 388

- Embouchure of, 388

- - Sources of, $3^{86}$

- - Steamers on, 410

TABLE-LANDS of Boroldai, 484

- perquisites, ii. 12, 479

Tailly, Dishonesty of, ii. 311

Tajik literature, î. 292

- sacred songs, ii. 9 I

- weavers at Samarkand, 606

Tajiks of Karategin, Strength of, ii. 54 . 
Tajiks of Zarafshan province, 54I Takhta-Karacha pass, ii. 7

Taldi-Kuduk, Sale of books at, 175

Taldyk river, Ruins on banks, ii. 242

Tambourine music at Khiva, ii. 309

Tamerlane, Birthplace of, ii. 32

- Camp of, ii. 4

- Campaigns of, 562

- Capital of, 562

- Conquests of, ii. 275

- Coronation stone of, 564

- Court splendour of, 562

- Gates of, 555

- Ishrat Khana palace of, 579

- Legend concerning, 570

- Library of, 582

- Manuscripts of, 583

- Siege of Urgenj by, ii. 340

- Summer palace of, $57 \mathrm{I}$

- Tomb of, 564,569 , ii. 3

_ - Enamel work of, 587

- - Wainscoting of, ii. I24

- Wife of, 564,575

Tanning at Bokhara, ii. 144

Tara, Arrival at, 39

- Cheapness of provisions at, 40

Taranchi amusements, 208

- bazaar in Kuldja, 223

- - Visit to, $23^{8}$

- gardens in Kuldja, 224

- Kuldja, $23^{8}$

- mosque in Kuldja, 232

- rebellion, 203, 626

- victory over Dungans, 203

Taranchis at Jarkand, 196

- Description of, 206

- Dress of, 207

- Habitations of, 208

- of Semirechia, 163,168

Tarantass abandoned in desert, ii, 172

- arrival at Petro-Alexandrovsk. ii. 236

- difficulty in desert, ii. 172

- Narrow escape of, ii. 241

- on fire, ii. $5^{8}$

- Purchase of a, 17

- Sale of, ii. 236

- Shipment of, ii. I91

Tarbagatai mountains, 84

Target practice of Turkistan troops, 604

Tashauz, Arrival of Author at, ii, 327

- Departure from, ii. 331

- from palace roof, ii. 330

- Houses at, ii. 330

- Iranian population of, ï. 330

- Lodgings at, ii. 330

- Medresse at, ii. 330

- Mosques at, ii. $33^{\circ}$

- Palace of Khan at, ii. 328

- Route to, ii. 327
Tashauz, Ruins near, ii. 331

- Shops of, ii. 330

- Temperature of, ii. 33 I

- Town of, ii. 330

- Trade of, ii. 330

TASHKEND, Alim Kul at, Death of, 511

- Arrival of Author at, 423

- Asylum for aged at, $45^{\circ}$

- Barracks at, 468

- Bazaars of, 458 , ii. 286

- Beklar Bek medresse at, $45^{8}$

- Bible Society at, 453

- Bokhariot entry into, 621

- Buildings of, 440

- Camp at, 468

- Characteristics of, 439

- Climate of, 449,467

- Death-rate in hospital, 450

- Departure of Author from, 475, 485

- Diseases in, 449

- Dispensary for natives. $45^{\circ}$

- Divisions of, 438

- Domestic expenses in, 461

- Earthquakes at, 468

- Fairs at, 462

- Fancy goods in bazaar, 459

- Fevers in, 449

- Furs at, Prices of, 523

- Gaieties at, $45^{2}$

- Gates of, 424

- German visitors at, 452

- Germans in, 448

- Granary of, 478

- Grave of Gen. Kaufmann at, 448

- Hospital at, 448,449

- Hotel at, 424

- House-rent in, 461

- Household commodities at, 461

- Imports and exports, 46I

- Jews' synagogue, 445

- Khokandian sortie from, 620

- March of Russians on, 620

- Meteorology of, 469

- Money arrangements at, 473

-. Museum, 455

- Antiquities in, 455

- Botanical specimens in, $45^{6}$

- Buddhist idols in, 456

- Curiosities in, 455

- Ethnographical specimens in, 455

- Hemiptera in, 455

- Sponge-plant in, 456

- Observatory at. 441,467

- Officers' club at, $45 \mathrm{I}$

- Population of, 399,440

- Prison at, 671

- Provisions at, 46t

- Public library, 470

- Russian, Creeds of, 441 
TASHKEND, Russian Gazette in, ii. 292

- - Houses of, 440

- Inhabitants, Ages of, 442

- Library in, 44I

- Museum in, 441

- Observatory in, 441

- Occupations in, 441

- Population of, 441

- Religious beliefs in, 441

- - repulse at, 620

- Streets of, 440

- Theatre in, 441

- Sart curiosities, 458

- Schools at, 466

- Scripture distribution at, 442, 443. 469 , ii. 239

- Seminary for training schoolmasters at, 465

- Servants' wages in, 461

- Situation of, 476

- Stations to Jizakh, 477

- - Khojend, 478

- Storming of, 620

- Sunday in, 448

- Surrender to Russians, 622

- Temperature of, 467

- Trade of, 462

- Treachery in, 621

- Visit to Governor-General, 442

- Wages in, 46r

- Wagonette disposal at, 473

- Walls of, 423

- and Aulie-Ata, Stations between, 414

Tashkendian turbulence, 5 Io

- wanderers, 357

Tatar yemstchik, Accident to, 363

Tatars of Kazan, 401

- Submission of, 123

Tax-gatherer of Kunia Urgenj, ii. 316

Taxation of Orenburg Kirghese, 4 10

Taxes in Amu-daria province, ii. 316

- Bokhara, ii. 58,187

- Khivan khanate, ii. 270

- Semipolatinsk, III

Tchampani in the Ili valley, 258

Tcherkassky's expedition to Khiva, ii. 276

Technicalities of Hebrew MSS., ii. II5

Tejend oasis in Turkmenia, ii. 453

_- Hydrography of, ii. 453

- Robbers in, ii. 455

Tekkes, Food of the, ii. 446

- of Merv, Atrocities of, it. 481

- - Distribution of, ii. $\$ 77$

_- Divisions of, ii. 477

- - Lawlessness of, ii. 480

_- Number of, ii. 477

- - Occupations of, ii. 478

_ - Unattractiveness of, ii. 480
Tekkes of Turkmenia, ii. 444

Temperature at Porsu, ii. 425

- of Amu-daria province, $43^{2}$

- Tashkend, 467

- - the desert, ii. 422

- Turkistan, 371

Temuchin, see Jinghiz Khan,

Tent lodging at Kara-Tiube, ii. 5

Tents of the Akhal oasis, ii. $45^{\circ}$

- - Kalmuk Geluns, 216

- - Kirghese, 333

- - Turkomans, ii. 445

Theatre at Russian Tashkend, 44I

Thian Shan mountains, Exploration of, 152, 294

- - Extent of, 153

- - Geology of, 155

- - Glaciers of, 155

- - Ranges of, 154

- - Snow bridges of, 155

- - Valleys of, 156

_ - Volcanoes (supposed) in, 156

- sheep, 245

- Valikhanoff's exploration, 296

Threshing and ploughing, ii. 7

Throne of Solomon, 500

"Through Siberia," Different estimates of, 630

Tiflis, Author's arrival at, ii. 501

- Bayern, Herr, of, ii. 502

- Bible distribution from, ii. 502

- Society at, ii. 501

- Departure of Author from, ii. 502

- Weather at, ii. 502

Tillah-Kari medresse, 586

Timbek's residence at Khokand, 518

Timber at Aulie-Ata, Dearness of, 365

- Khiva, ii. 269

Timur, sec Tamerlane.

Timurid sway in Central Asia, ii, 69

Timurids, Capital of the, 560

Tiumen, Acquaintances at, 27

- Arrival of Author at, 26

- Book distribution at, 29

- Introductions at. 30

- Purchase of a telega at, $3 I$

Tiurebek Khanim, Tomb of, it. 345

Tobacco cultivation at Khiva, ii, 268

- - in Akmolinsk, 52

- - Ferghana, 499

- near Karshi, ii. 44

Tobolsk, Archbishop of, Visit to, 36

- Books for exiles in, 29

- Cemetery at, 35

- Governor of, Interview with, 35

Togus-tepe hills, ii. 425

Tokmak, Prison at, 670

- Old road to, 356

- Ruins near, $35^{6}$ 
Tomb at Sary Baba, ii. 425

- of Abdullah Khan, ii. 71, r37

- - - Pilgrimages to, ii. I37

- Ak-rabat, ii. 207

- Aulie-Ata, 366

- Bibi Khanum, 577

- - Nedjm-ud-din-Kubera, ii. 347

- Sunjur Shah at Merv, ii. 456

- Tamerlane, ii. 3

- - Wainscoting of, ii. 124

- Tiurebek Khanim, ii. 345

Tombs at Khanki, ii. 248

- of Kirghese, 3II

- - royalty at Khiva, ii. 293

- on Butenau plateau, ii. $39 \mathrm{I}$

Torahs of Jews at Bokhara, ii. I ro

Torchlight procession at Shahr, ii. 34

Torgouts of the Ili valley, 214

Tortoises of the Steppe, ii. $43^{\circ}$

Torture of prisoners at Bokhara, ii. 75

Town of Gazavat, ii. 318

- Krasnovodsk, ii. 495

- Kungrad, ii. $35 \mathrm{I}$

- Omsk, 59

- Petro-Alexandrovsk, ii. 234

- Shavat, ii. 320

- Tashauz, ii. 330

Towns of Akmolinsk, 53

- Ferghana province, 398, 499

_- Kuldja province, 398

- Semipolatinsk, 95

- Semirechia, 398

- Syr-daria province, 398

- Zarafshan province, 398

- on Lower Oxus, ii. 24 I

- Orenburg road, 389

Tract distribution in Moscow Exhibition, ii. 238

_ on railway journey, 19

- Success of former efforts, 27

- Society. Help of, 5

Trade in a Chinese bazaar, 239

- Kuldja bazaars, 239

- of Bokhara, ii. I33

- Central Asia, ii. 286

- Karategin, if. 54

- Khiva, ii. 285

- Khojend, $55 \mathrm{I}$

- Khokand, 523

- Merv, ii. 479

- Samarkand, 604

- Semipolatinsk, 139

- Tashauz, ii. 330

- Tashkend, 462

_- Vierny, 278

- progress in Semirechia, 291

- statistics of Turkistan, 462

Tradesmen of Khiva, ii. 269

Tradition concerning Hazarasp, ii. $3 I_{3}$
Tradition of Khoja-Akhrar, $5^{\mathrm{S} 2}$ Tamerlane's library, $5^{82}$

Traditions of Jews in China, 594

Kirghese, I 57, 177, 357

Samarkand Jews, 594

Tragical end of a china basin, ii. $3^{80}$

Training of hawks, ii. 326

Trans-Ili mountains, 268 region, Russian advance to, 290

Translation work of Mr. W. H. Cromie, ii. 506

Travellers, Aralo-Caspian, ii. 404

- in Central Asia, ii. 457

- on the threshold of Turkmenia, ii. 465

Travelling in a horse-box, ii. $50 \mathrm{O}$

Travels of M. Fedchenko, ii. 509

Treaty between Khiva and Russia, ii. 282 Russia and Khan of Khokand, 511

Trees of Turkistan, 479

- Zarafshan province. 608

- on Kopet-dagh mountains, ii. $43^{8}$

Trials among the Kinghese, 346

Tribes of Khivan khanate, ii. 270 Samarkand Jews, 595

Troitzky, M., with the Kirghese, 344

Troops in Akhal oasis, ii. 494

- Petro-Alexandrovsk, ii. 234

- Turkistan, 74, 601 - Arms of, 602

Drunkenness among, 603

- Education of, 603

- Food of, 603

- Moral standard of, $60_{3}$

- Target Practice of, 604

- Uniforms of, 602

Troubetzkoy prison in Petersburg, ( 42 - Cells of, 642

- Diet of prisoners, 644

- Garden exercise, 645

- Occupants of, 643

- Visits from friends, 644

- Women's quarters, 645

Troubles with attendants in desert, ii. 414

Trousseau of a Kirghese bride, 326

Trumpets and drums at Charjui, ii. 181

Tuar, Arrival of Author at, ii. 424

Tugais on the Amu, ii. 215

Tura river, Voyage on, 33

Turco-Tatar races, 392

Turkish dialects, ii. 292

Turkistan: Ak-Mesjed captured by Russians, 617

- Animals of, ii. 514

- Ants of, ii. 576

- Archbishop of, Visit to. 280

- Aulie-Ata captured by Russians, 6 Ig

- Aurora Borealis in, 377

- Beershops in, 607

- Bees of, ii. 562 
Turkistan, Beetles of, ii. 552

- Bibliography of, 470 , ii. 674

- Birds of, i. 517

- Boundaries of, 37

- Breweries in, 607

- Butterflies of, ii. $5^{81}$

- Capture of, by Russians, 619

- Cattle of, 420

- Caucasians in, 392

- Cereals of, 483

- Chimkent captured, 6 r9

- Cholera in, 538

- Chrysidiformes of, ii. 579

- city, Population of, 391

- Climate of, 371, 372, 375

- Conquest of, 504

- Cossacks in, 6or

- Crops in, 484

- Crustacea of, ii. $54^{8}$

- Definition of, 369

- Dimensions of, 370

- Distilleries in. 607

- Domestic animals in, 420

- Drink traffic in, 607

- Dungans in, 209

- Dyeing plants in, 483

- Earthquakes in, 378

- English competition in, 464

- Fauna of, ii. 506

- Fedchenko on zoology of, it. 506

- Fish of, ii. 243, 530

- Flora of, ii. 618

- Fogs of, 377

- Fortified post-stations, 488

- Forts of, 601 captured by Russians, 6I8

- Fruit-trees in, 480

- General Government of, 369, 624

- Geology of, $37^{8}$

- Gold in, 381

- Government, Reorganization of, 629

- Governor's residence, 442

- Humidity, Want of, 373

- Ichthyology of, ii. $53^{\circ}$

... Inhabitants of, 370

- Iranians of, 392

- Karamazar mountains in, 515

- Kaufmann appointed Gov.-Gen., 624

- Khivan encroachments, 615

- Khokandian advance, 614

- - fortresses in, 6r5

- subjugation of Kirghese, 615

- Kibitkas in, 434

- Kirghese insurrections in, 617

- Kuramas in, 394

- Lepidoptera of, 248 , ii. $5^{81}$

- Leprosy in, 540

- Liquor traffic in, 607

- Mammalia of, ii. 515
Turkistan, Meteorological observations, 374

- - tables, 376

- Military affairs in, 601

- Minerals of, 379

- Mining operations, Decrease of, jSt

- Mollusks of, ii. 537

- Mongolians in, 392

- Mountains of, 534

- Mutillidae of, ii. 575

- Neuroptera of, ii. 609

- Officers, Moral standard of, $60_{3}$

- Ornithology of, $4^{1} 5$

- Orthoptera of, ii. 6I3

- Plants of, 482 , ii. 620

- Poppy fields in, 257

- Population of, 370

- according to races, 391

- Classification of, 394

- Density of, 396

- Locality of, 397

- Prostitution in, ii. 299

- Races, Settled and nomad, 396

- Rain, Scarcity of, 372

- Reptiles of, 1i. 528

rivers, Direction of, 386

- Peculiarities of, 385

- Russian advance, Consolidation of, 617 inhabitants of, 393

- - invasion of, 616 - on Syr-daria, 615 - occupation of, 614 - repulse at Tashkend, 620 - victory over Khokandians, 617

- Salt deposits in. 537

Scoliidae of, ii. 572

Scriptures for, 443

- Sheep of, 246

- Shrubs of, 480

- Sphegidae of, ii. 568

- Spiders of, if. 543

- Summer heats of, 373

- Surface of, 371. 479

- Surrender of Tashkend, 622

- Table-lands of, 484

- Temperature of, 371

- Trade statistics of, 462

- Tribes of, 479

- Troops in, 74, 601

- Arms of, 602

- Education of, 603

- Uniforms of, 602

- Turko-Tatar races in, 392

- Vegetation of, $374,478,487$

- Vermes of, ii. 6r5

- villages, Number of, 399

- Wine-cellars in, $60 \%$

- Zoology of, 415 

Turkmenta, Adventures on frontier, ii.
466

- Akhal oasis of, ii. 449

- Alielis of, ii. 445

- Alikhanoff, Lieut., in, ii. 471

- Area of, ii. 436

- Attek oasis of, ii. 450

- Bibliography of, ii. 677

- Boundaries of, ii. 435

- Chikishliar taken by Russians, ii. 46r

- Climate of, ii. 440

- Ersaris of, ii. 444

- Ethnology of, ii. 444

- Expeditions in, ii. 46 I

- Fauna of, ii, $44 \mathrm{I}$

- Flora of, ii. 440

- Frontier of, ii. 435

- Fruit-trees in, ii. 440

- Goklans of, ii. 445

- Heri Rud river, ii. 453

- Irrigation of, ii. 439

- Lack of water in, ii. $43^{8}$

- Lessar, M., in, ii. 472

$-\frac{\text { Revision of chapters by, ii. } 435}{2}$

- Lomakin, Gen., Defeats of, ii. 464

- Markozoff, Col.. Failures of, ii. 462

- Merv oasis in, ii. 454

- Meteorology of, ii, 440

- Mountains of, ii. 437

- Naziroff, Lieut., in, ii. 472

- Oases of, ii. 449

- O'Donovan, Mr., in, ii. 467

- Opposition to Russians in, ii. 461

- Rivers of, ii. 439

- Russian forts in, ii. 461

- - invasion of, ii. $46 \mathrm{r}$

- - maps of, ii. 435

- Salors of, ii. 445

- Saryks of, ii. 445

- Skobeleff's campaign in, ii. 464

- Slavery in, ii. $48 \mathrm{t}$

- Stephen, Mr. Condie, in, ii. 440

- Surface of, ii. 436

- Tejend oasis, ii. 453

- Tekkes of, ii. 444

- Travellers in, ii. 457

- - on the threshold of, ii. 465

- Unknown country in, ii. 455

- Vegetation of, $44^{\circ}$

- Winter in, ii. 440

- Yomuds of, ii. 444

Turkoman bandits, ii. 337

- boats on the Atrak, ii. 439

- - Upper Oxus, ii. 207

- Doctoring a, ii. 374

- farms, ii. 226

- horses, Value of, ii. 352

- opposition to Russian 352 - Divisions of, 553

- region, ii. 337

- Steppe, Desiccation of, ii. 405

- tent, Rest in, ii. 369

- tents at Krasnovodsk, ii. 496

- tribes, Distribution of, ii. 444

- - Divisions of, ii. 444

- women, ii. 448

Turkomans, Amulets of the, ii. 447

- Benoist-Méchin, Baron, on, ii. 444

- Bravery of, ii. 444

- Carpets of, ii. 447

- Characteristics of, ii. 444

- Chess-playing among, ii. 444

- Classes of, ii. 445

- Dress of, ii. 447

- Felts of. ii. 447

- Food of, ii. 446

-. Grodekoff on the, ii. 444

- Habitations of, ii. 445

- Idleness of, ii. 444

- Jewellery of, ii. 447,497

- Manufactures of, ii. 478

- Number of, ii. 444

- Occupation of, ii. 447

- of Gazavat, ii. 319

- Origin of, ii. 443

Ornaments of, ii. 447

- Petrusevitch on, ii. 444

- Physiology of, ii. 444

- Russian chastisement of, ii. 332

- Slave-trade of, ii. 48 r

- Tents of, ii. 445

-Truthfulness of, ii. 444

"Turning in" to camel cradles, ii. 375

out of bed in the desert, ii. 432 policeman in the desert, ii. 396

Turquoise in Ferghana, 497

"Twickenham Ferry" in Bokhara, ii.91

Uснuм, Bokhariot defeat at, 625

Uigur rulers of Bokhara, ii. 68

Ujlalvy, M., at Sergiopol, 145

-. on Kirghese mothers, 360

- - Samarkand antiquities, 564

Ulianin, V. N., on Turkistan Crustacea, ii. 548

Ulug Beg, College of, ii. 72

- Medresse of, 585

- Observatory of, $564,5^{85}$

Tomb of. 569

Unfaithfulness of Asiatic wives, ii. 354

"Unfurnished apartments" at Kakir. ii. $6 \mathrm{I}$

Uniforms of Turkistan troops, 602

Unnatural practices in Bokhara, ii. 158

Un Tiube. Buildings of. 553

_ Divisions of, 553

- Long stage-journey to, $55^{2}$ 
Ura Tiube, Russian occupation of, 623 Sacred places of, 553

Seriptures for, 443

Statistics of, 553

Traditions of, 553

Urgenj, Cossack raids on, ii. 274

Urumtsi, Massacre near, 203

Urun-daria at Dekche. ii. 393

Ushak-bent, Lakes of, ii. 390

Ushakoff, M., at Khokand, 518

Ust-Kamenogorsk, Corn stores in, 3 I6 Trading-place of, $\mathbf{1} 3 \mathbf{1}$

Ust Urt, Cliffs of the, ii. 392

Mounting the, ii. 410

Ustik, Journey to, ii. 205

- Toksaba of, ii. 205

Usury among Kirghese, 316

- at Khokand, ii. 100

Uyezds of Akmolinsk, 50

Uzbeg Khans of Kharezm, ii. 274.

- languages and kindred dialects, ii. 292

- literature, ii. 292

- notions of a future life. ii. 220

- occupation of Merv, ii. 456

- rulers of Bokhara, ii. 71

- servants hired by Author, ii. 3

- society at Manak, ii. 323 town of Kipchak, ii. 24I

Uzbegs in Khivan khanate, ii. 270

Uzun Kuyu, Gazelle captured at, ii. 4I3

- Well of, ii. 4 10

VAccrNatron in Semipolatinsk, 117

Valikhanoff at Kashgar, ii. 471

- crossing the Thian Shan, 296

Vambery at Kunia Urgenj, ii. 34 I

- Description of Emir by, ii. 24

Vardan Zigi, Silk eulture at, ii. 144

Vaulin, Col., Hospitality of, $55^{2}$

Vegetation at Bokhara, ii. 165

near Samarkand, ii. 8

- of Ferghana, 497

- Kuldja, 257

- Kurama, 478

- Merv oasis, ii. 476

- - the Steppe, 45

- Turkistan, $374,478.487$

- Turkmenia, ii. $44^{\circ}$

- on banks of Amu, ii. 223

Vehicles in Khiva, ii. 316

- of the Dungans, 210

Venison in the desert, ii. 382

Veniukoff, M, on Kirghese religion, 343 - - Survey of Issik-Kul country, 297

Vermes of Turkistan, ii. $6 \mathrm{I}_{5}$

Vertebrata of Kuldja, 247

Viands of Kunia Urgenj, ii. 364

Victoria lake, ii. 193

Victories of Jinghiz Khan, ii. 69
VIRRny, Agricultare of, 278

- Aliken's hotel at, $27 \mathrm{i}$

- Archbishop, Visit to, 280

- - Treasures of, 280

- Bazaar at. 278

- Beekeeping in, 185

- Book distribution at, 279,670

- Cattle market at, 276

- Chinese curiosities in, 275

- Climate of, 271

- Creeds in, 280

- Departure of Author from, 282, 352

- Droshky drive in, 272

- Eating-houses at, 278

- Education at, 279

- Fruit at, 277

- Hotel at, 275

- Houses in, 272

- Industries of, 278

- Kalmuk school in, 170

- Library at, 279

- Magistrate of, Visit to, 274

- Market, Prices in, 277

- Melons at, 277

- Mercantile introductions, 276

- Occupations in, 274

- Police-master, Visit of, 276

Population of. 274

- Prison at, 666

- Gardening in, 668

- Nationalities of prisoners, 666

- Provisions, Cheapness of, 668

- Races, Diversity of, 274

- Religions of, 280

- Schools at, 279

- Statistics of, 274

- Streets of, 273

- Thriving condition of, 272

- Town of, 272

- Trade at, 278

- Uninviting quarters in, 271

- Visiting in, 272

- and Aulie-Ata, Stations between, 353

Villages in Turkistan, Number of, 399

- near Altyn-Immel, 187

- on the Upper Oxus, ii. 202

Vishnu pictures at Khokand, ii. 100

Vodka distilleries in Turkistan, 607

Volcanoes (supposed) in Thian Shan, 156

Volga, Mennonites of the, ii. $35^{\circ}$

Voting by ballot among Kirghese, 349

WAGes at Petro-Alexandrovsk, ii. 235

- in Tashkend, 46r

Wairabad, Minerals near, ii, 141

Walls in Central Asia, ii. 124

- of Aulie-Ata, ii. 124

- - Bokhara, ii. 124

- Etchmiadzin, ii. 124 
Walls of Khiva, ii. 305

- Khokand, 524

- Suidun, 259

- Tashkend, 423

Wandering Tashkendians, 357

Wanderings of the Kirghese, 319

War expenses of Khan of Khiva, ii. 271

- with Khokandians, 298

Watch-towers of the Turkomans, ii. 452

Water distillation, Krasnovodsk, ii. 495

- in Turkmenia. Lack of. ii. 438

- of Bokhara, ii. 149

Weapons of the Kirghese. 313

Weariness of desert travelling, ii. 423

Weather at Petro-Alexandrovsk, ii. 233

Weavers of Samarkand, 606

Weaving in Bokhara, ii. 144

Wedding ceremonies in Central Asia, ii. 353

- ceremony of the Kirghese, 326

- festivities among the Kirghese, 327

Weights and Measures, Bokhara, ii. 36

W - of Central Asia, 682, ii. 285

Well of Demerdjan, ii. 429

- - Seikiz Khan, ii. 42 I

- - Uzun Kuyu, ii. 410

Wells at Ak-bugut, ii. 391

- of Igda, ii. 407

- Karategin, ii. 379

- Kazakhli, ii. 416

- Kum-sebshem, ii. 417, 419

- - Sary Kamish, ii. 394

- Suili, ii. 431

White asses at Bokhara, ii. 163

Wild Animals of Khiva, ii. 269

- boar at Porsu, ii. 426

- hens in the desert, ii. 422

Wine-cellars in Turkistan, $6 \mathrm{~m}$

Winter in Tukmenia, ii. 440

- palace at Khiva, ii. 306

- - of Khan, ii. $28 \mathrm{I}$

- Preparing for, ii. 233

Wives of Emir of Bokhara, ii. 156, 355

- - the Kinghese, 340

Wolf-hunting by Kirghese, ii. 211

- scare on the Amu, ii. 217

Wolff, Dr., at Merv, ii. 457

- Bravery of, ii. 77

- Perils of, in Bokhara, ii. 77

- Return of, to England, ii. 77

Wolves among sheep at Kabakhli, ii, 210

Women of Turkmenia, if. 448

Wood, Lieut., explorer of Oxus, ii. 193

Work, Carlyle on, 4

Worms of Turkistan, ii. 6r 5

Woven products of Samarkand, 606

YАKоOn as interpreter, ii. 3.

Yamyshef lake, Russian fortress at, 127
Yelenktosh, College of, ii. 72

Yemstchik, Accident to, 363

Yermak, Conquests of, 121, 402

- Death of, 122

Yomuds of the Khivan Khanate, ii. 337

- - Turkmenia, ii. 444

Yuldus sheep, M. Alpheraky on, 247

ZaISAn neighbourhood, Geology of, gr

- Mineral springs in, 92

- Pnblic corn stores in, 316

- lake, 89

- Chinese junks on. I3I

- Fauna of banks, 91

- Fish in, 90

- Fisheries on, 91

Zangs among the Kalmuks, 215

- Duties of, 217

Zarafshan oasis, End of, ii. 16.4

- province, 533

- Aborigines of, $54 \mathrm{I}$

Afghans of, 544

Agriculture of, 608

Arabs of, 544

Area of, 42

Cattle in, 545

- Crops of, 545, 608

Definition of, 534

Dimensions of, 533

Divisions of, 537

Education in, 600

- Epidemics in, $53^{8}$

- Ethnology of, 54I

Ferns of, 609

Flora of, 557

- Galtchas of, 541

Gipsies of, 543

- Hissar range, 535

- Inhabitants of, 544

- Irrigation of, 536

- Iskander-Kul lake, 535

- Kohistan district, 537

- Leprosy in. $53^{8}$

- Miankal island, 535

- Mountains of, 533

- Plants of, 557

- Population of, 42,544

- Public-houses in, 607

- Roads of, 545

- - Sheep in, 545

- Soil of. 608

- Statistics of, 544

- Sycamore forests in, 608

Tajiks of, 541

- - Towns of, 398,545

- Trees of, 608

- Turkistan range, 534

— river, 534

- Affluents of, 535 
Zarafshan river, Bridges of, 535

- Canals of, 535

- End of, ii. I69

- - Fish of, ii. 510

- Fording of, 559

- Source of, 534

Zenana work, Need of, ii. 356
Zerbulak, Bokhariot rout at, 625

Zindan prison at Bokhara, ii. 153

Zmukshir, Fortress of, ii. 332

- Skobeleff at, ii. 332

Zones, Climatic, of Turkistan, 375

Zoology of Turkistan, 4I5

_- Fedchenko, M., on, ii. 506

THE END. 



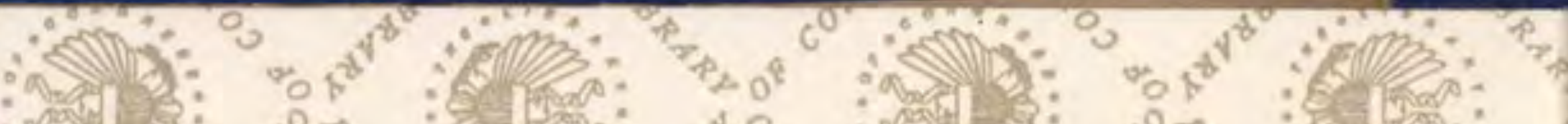

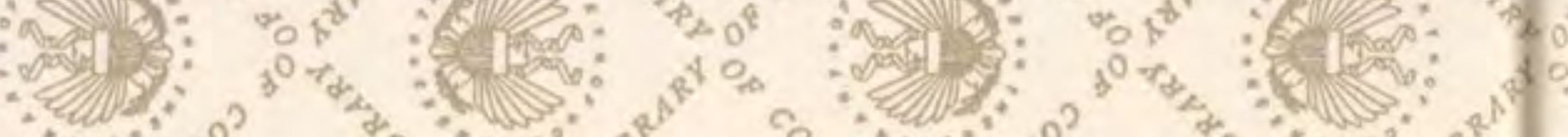

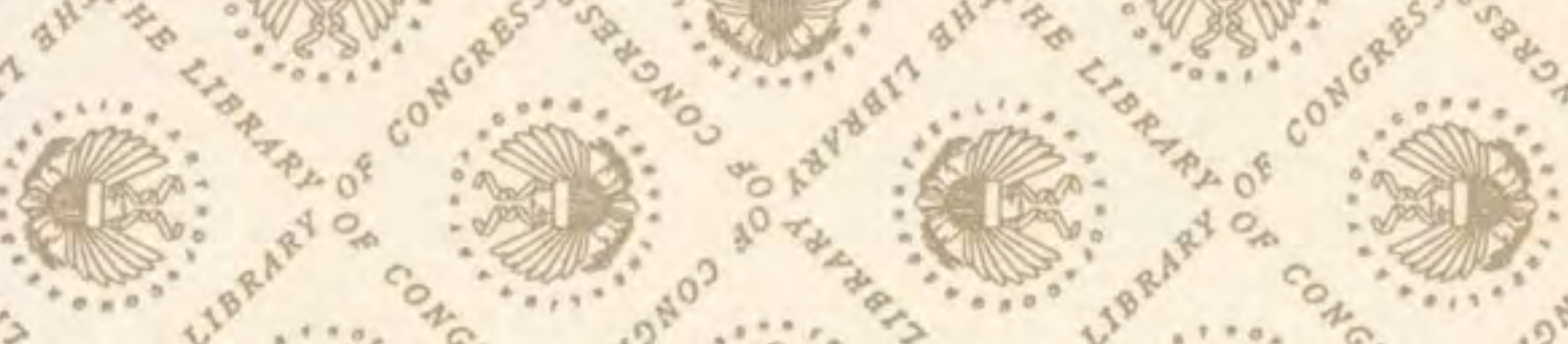

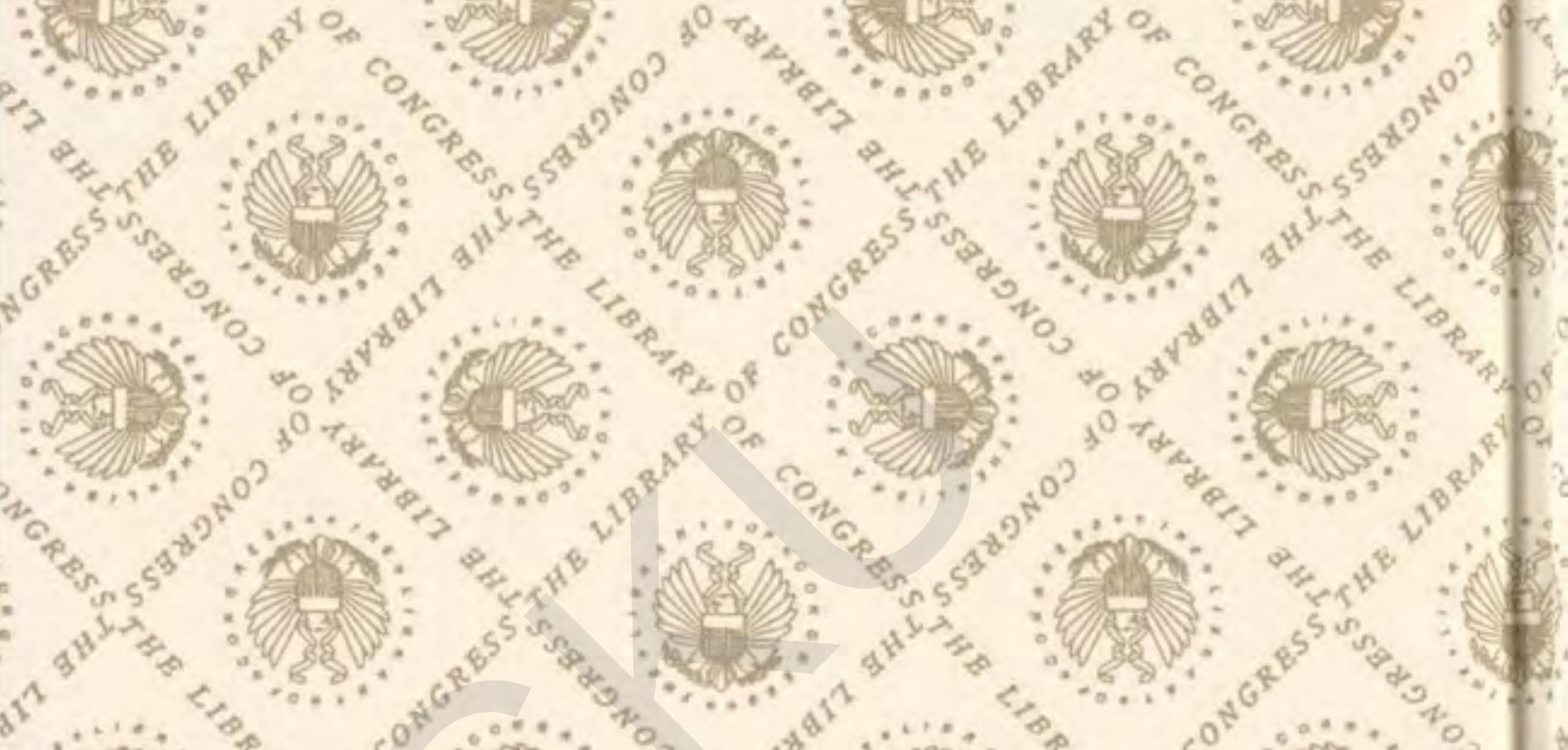
(

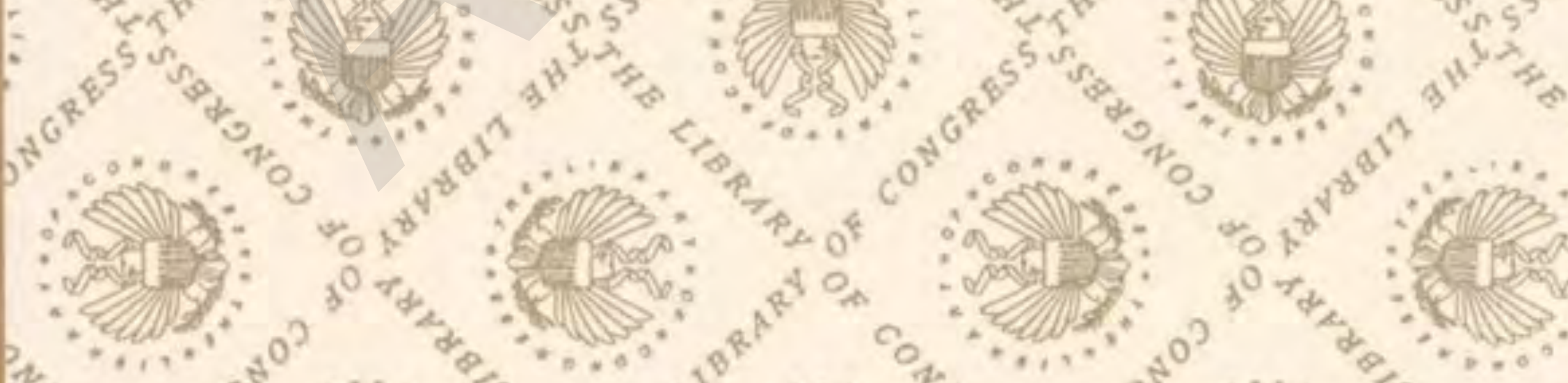
(n) (S)

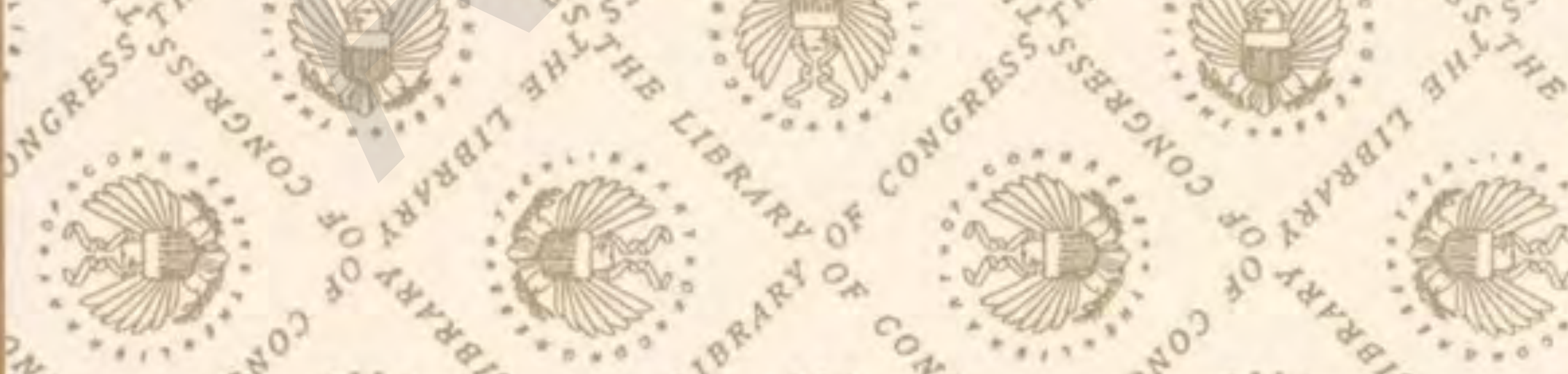

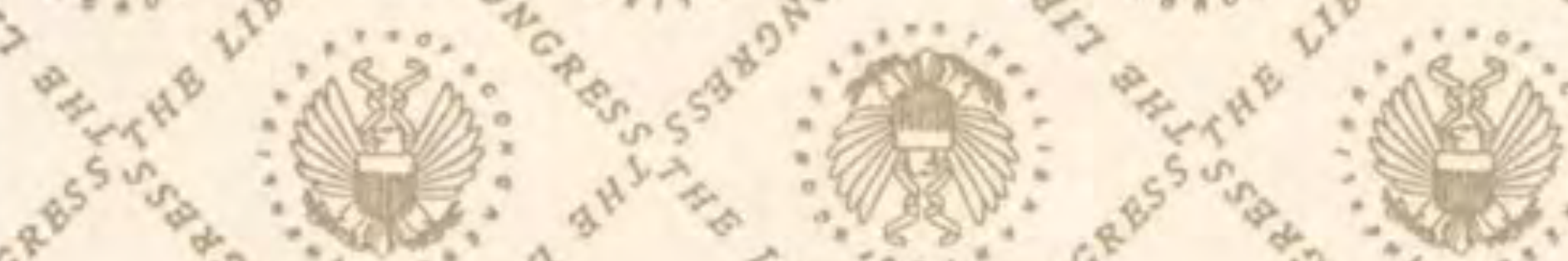




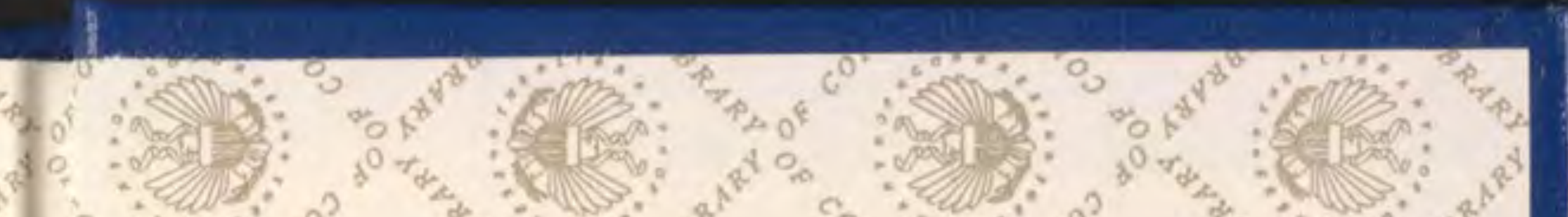

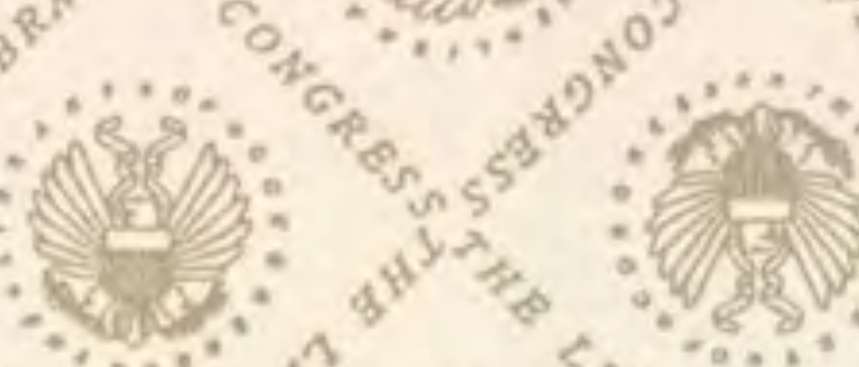
40 :

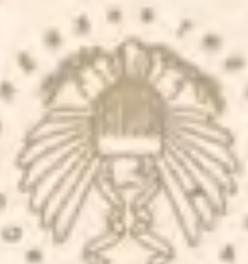

(1)

1

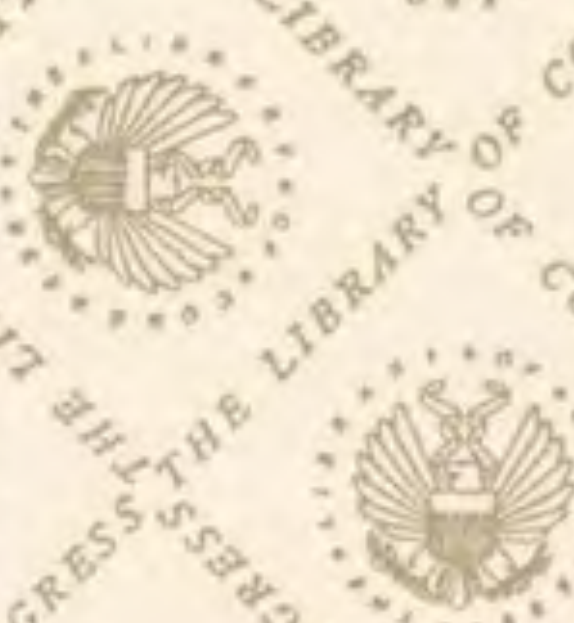
(Emp: 30<smiles></smiles>

Non:

Nes:

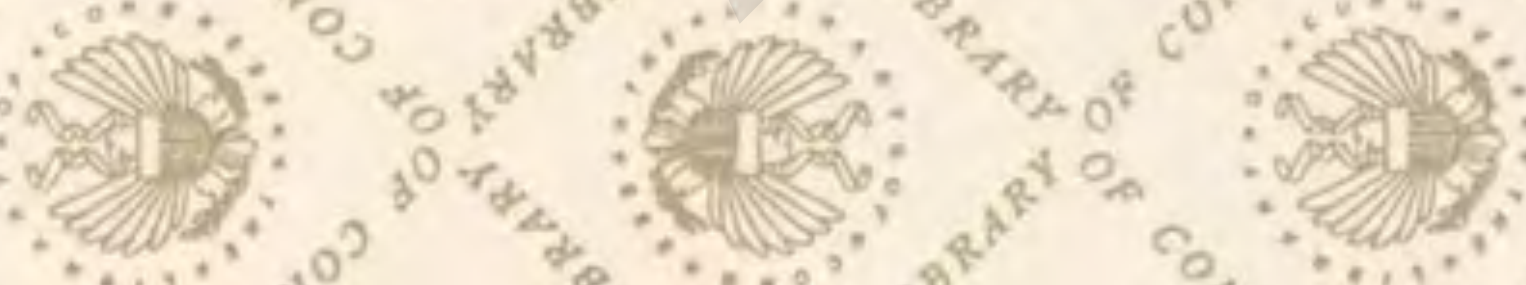

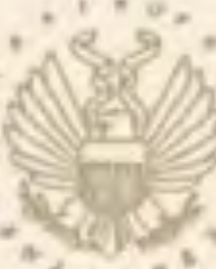

$\therefore$ in:

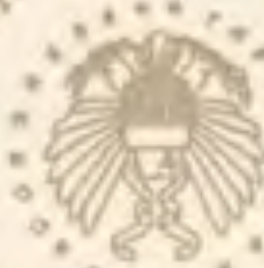

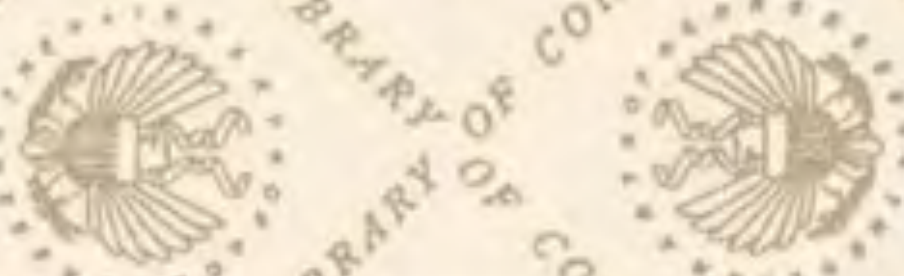
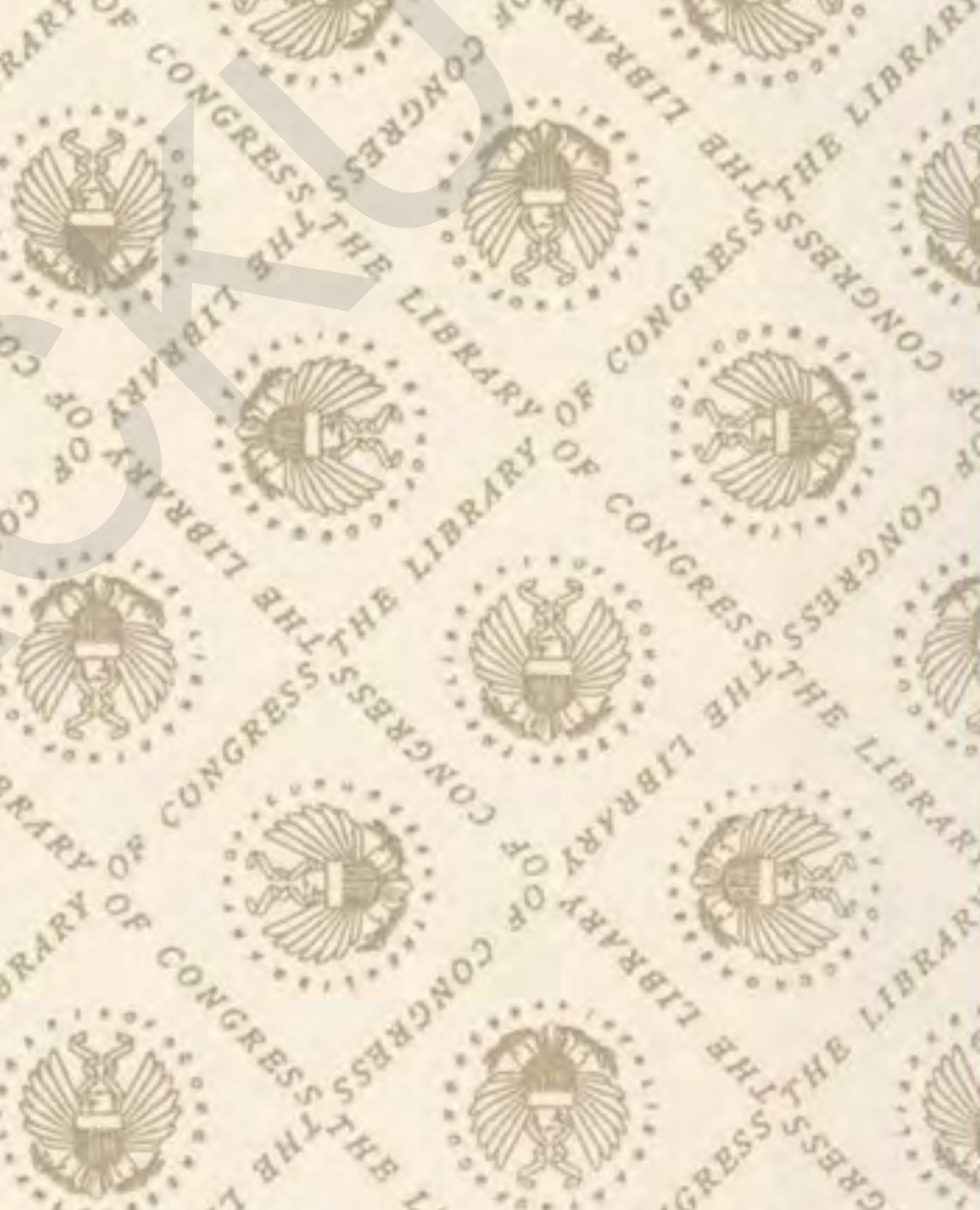
